ANL-7635

Biology and Medicine

\author{
Argonne National Laboratory \\ 9700 south Ciass Avenue \\ Argonne, Illinois 60139
}

\title{
Biological and Medical Research Division
}

\section{Annual Report \\ 1969}

Derember 1969

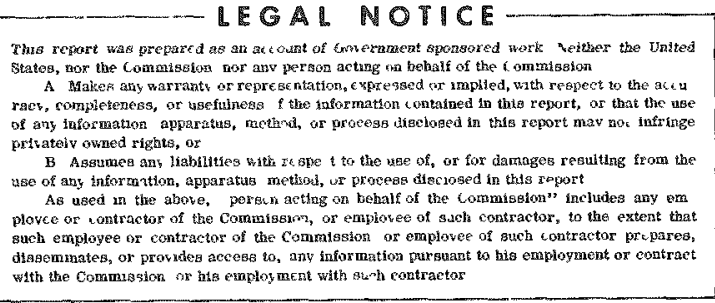

Preceding Report

ANL-7535, December 1968 


\section{DISCLAIMER}

This report was prepared as an account of work sponsored by an agency of the United States Government. Neither the United States Government nor any agency Thereof, nor any of their employees, makes any warranty, express or implied, or assumes any legal liability or responsibility for the accuracy, completeness, or usefulness of any information, apparatus, product, or process disclosed, or represents that its use would not infringe privately owned rights. Reference herein to any specific commercial product, process, or service by trade name, trademark, manufacturer, or otherwise does not necessarily constitute or imply its endorsement, recommendation, or favoring by the United States Government or any agency thereof. The views and opinions of authors expressed herein do not necessarily state or reflect those of the United States Government or any agency thereof. 


\section{DISCLAIMER}

Portions of this document may be illegible in electronic image products. Images are produced from the best available original document. 


\section{GENERAL RADIATION BIOLOGY}

1 Duration of life daily ${ }^{6 n}$ (o gamma irradiation: Report on survival and indence of tumors

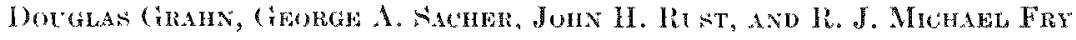

9 Long term effects of low doses of irradiation on immune responsiveness of $B 6 C^{\prime} F_{1}$ Anl[Anl biti mice with age

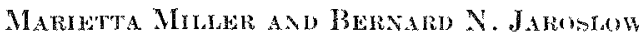

10 Studies: on the Corneal lipithelium

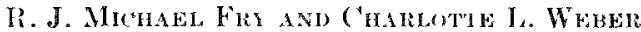

11 Some factors that influence the uptake of tritiated thymidine. I.

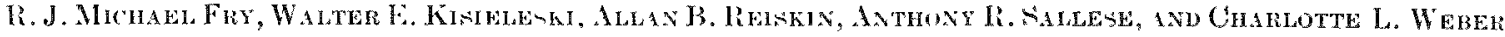

11 Some factors that influence the uptake of tritiated thymidine. II. R. J. Mich

16) Semsitivity of acatalasemic mice to radiation-induced motivation

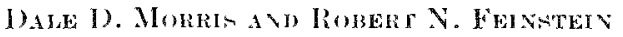

17 An enzymatically inactive catalase-anticatalase ROBER' N. FELATELA, JOAN T. FAULHABER, A \D BERNARD X. JAROSLOW

18 Organ and tissue weights and catalase activities in a species of wild duck. Powsible relationship to radiation sensitivity

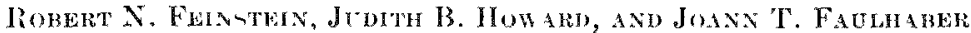

20 Effect of whole-body $X$ radiation on flavoprotein enzymes

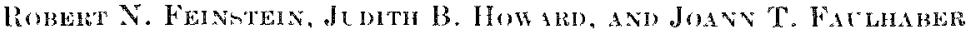

22. Mierovasculature and loose connective tissue of the chick mesentery. Frenze-eteh observations

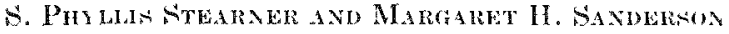

30 Protection against early radiation injury to the microvasenatature

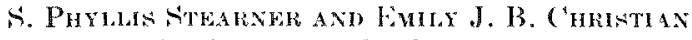

35 Resistance to early circulatory death in the irradiated chicken: Effect of split exposures A. PHY LISS STEARNER

39 Larly Radiation injury to the microcirenlation: Relation to mortality

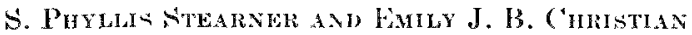

30 Radiosensitivity of intestinal crypt cells in grond squirrels during arousal from hibermation

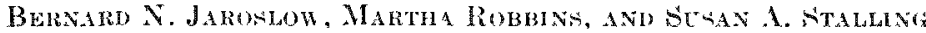

42 Kinetics of the immune response initiated in vitro

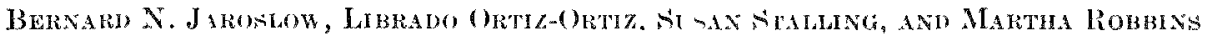

44 Modifications of antibody formation

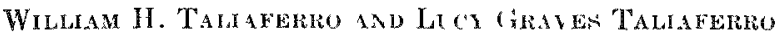

47 Developmental delay and lethality studies of X-irradiated Tribolium eastancum eggs:

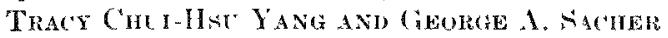

49 Effeets of $\mathrm{X}$ irradiation on some physieal properties of a developing Tribolium

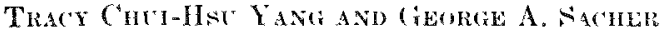

50 The lethal effects of monenergetic neutrons and "oC" gamma ravs on Tribolium castanenm Tracy Chei-Hse Yang, Nomuan A. Frigero, añ Matin J. Sampson

52 studies on the development of the mid gut of the l'ribolimm castaneum adult

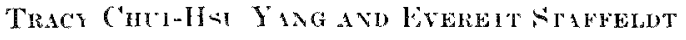

\section{LABORATORY ANIMAL MEDICINE}

55 Statement of program ohjeretives

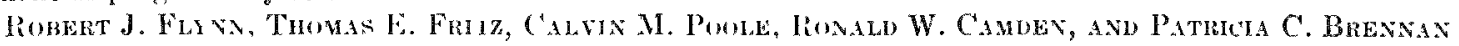

5.5 The supply and maintenance of defined animals for the livision is researeh program: Status of the enlony

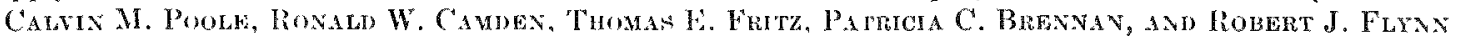

57 Age of lakoratory rodents at time of first fertile mating

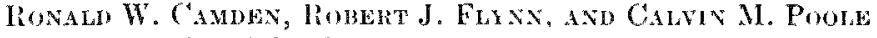

58 The development of an inbred acatalasemic monse

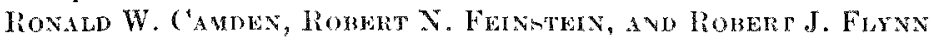

58 Rotus rottus as a research animal

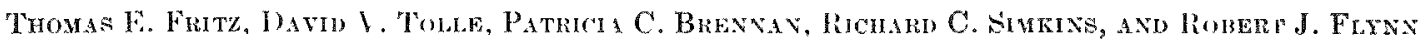

59 Genetic, nutritional, and environmental effects on syrian hamster production

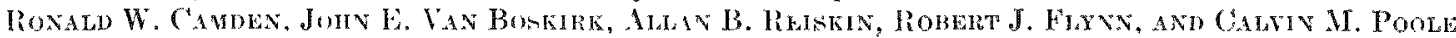

61 A coat color mutation in the Syrian hamster

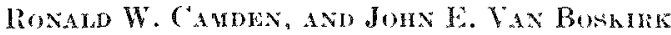

(12) Monogamous mating of Chinese hamsters

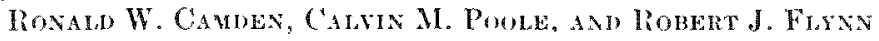


64 Frequency of eage cleaning and the survival of mice

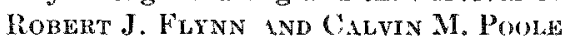

tit Hepatic and renal lesions in a hamster breeding colony

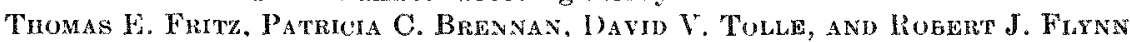

Thruat flora of a closed colony of beagle dogs

Patricla C. Brennan and Richami C. Simkins

\section{THEORETICAL BIOLOGY}

if Multifactorial analysis as a tool for the study of evolutionary and organizational aspects of mammalian structure and function

GEORCE A. SACHER

(69) Computer simulation of percent labeled mitoses eurves

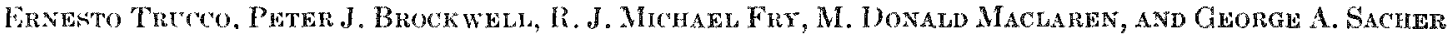

70 The area rule of cell kineties

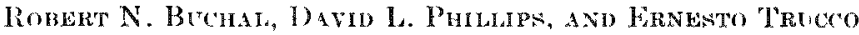

72. A note on Helmstetter and Cooper's model for bacterial replication and on related work by Marr, Painter, and Nilson ERNENTO TRTCOO

75 On the average cellular volume in synchronized cell populations Heneisto Thereo

80 The distribution of eellular volumes in exponentially growing populttions Brivesto Trucco

8i) Characterization of photoreactive processes in bacteria Sylyanus A. Tilen and Merian H. Mipent

8s A three-dimensional model for rhythmic flowering eyeles in Fanthium

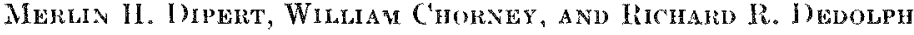

\section{JANUS}

89 JMN's: Status of the facility and technical considerations Frank S. Wilhamson

91 The JANUS radiobiology program I. JoHN AINsw onty

\section{TOXICITY AND METABOLISM OF RADIONUCLIDES}

STUDIES OF RADIATION-INDUCLD CHANGES

93 Toxicity and metabolism of radionuclides: Program objectives and introduction Wimitia u P. Noriers

The response of ANL beagles to protraeted exposure to $80 \mathrm{Co} \gamma$ rays at 5 to $35 \mathrm{~K} /$ day

94 1. Survival and clinical observations

Wrilia M P. Norris and Calsin M. Prole:

95 II. Estimation of the LD $)_{30}$ at $35 \mathrm{~L}$, day

Wrlliam P. Norkis and (alvin M. Poole

96 III. Henatology

Cart E. Rehfeld, Donald F. Doyle, Dorothy L. Chladek, Donald L. Pharson, ani Patrick H. Polok

99 IV. Bacteriologic findings Patricia (". Brennan and Richari) C. Smbiato

102 V. Pathology

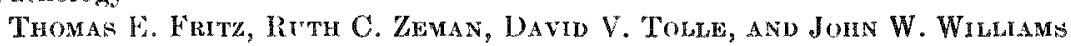

102 The dependence of ${ }^{17} \mathrm{C} s$ retention on age in the juvenile beagle dog Sylvanes A. Trler, Norbert D. Kretz, and William P. Niorims

('HARACTELIZATION OF THE ANL BEAGLE

Studies of the physiology of the beagle thyroid gland

104 Introduction

William P. Noreis

104 I. The cycle of accommodation to restricted dietary iodine in the thyroid gland of the ANL beagle dog Wiluam 1. Norris, Thomas G. Fritr, and James A. Taylor

107 II. Pathology and familial incidence of thyroiditis in a closed beagle colony Thomas E. Fritz, Ruth C. Zliman, and Max R. Zelole

108 III. Influence of thyroiditis on biological half-time of 1 in the ANL beagle dog Thomas E. Fritz, Whiliam P. Norris, Norbert D. Kugte, Ruth C. Zeman, and John W. Wildiams

110 skin graft survival in partially inbred beagles Carl E. Rehfeid, Gustave J. Damuin, and Willam J. Hesteri

110 Definition of relationships in a closed beagle colony Carl E. Rehfeli 
110 The ultrastructure of normal hemopoietic cells from dog bone marrow

Theodone N. Tammisian, Rogemarie L. Devine, Betty Jean Whight, William P. Noris, 'lhomas E. Fritz,

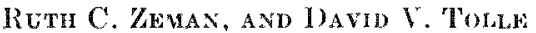

\section{MECHANISMS OF CARCINOGENESIS}

115 Mechanisms of carcinogenesis

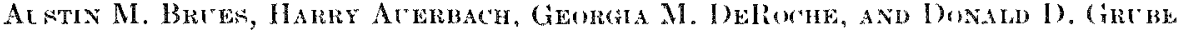

119 Retention of radiostrontium in soft tissues

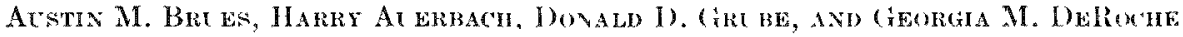

121 Cellular proliferation and earcinogenesis

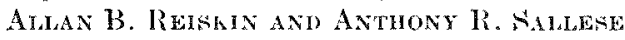

126 situdies of rat mammary gland growth

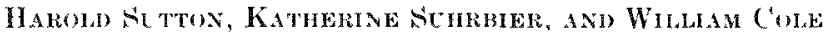

12x An at tempt to grow HeLa cells in an Fisler-Webb Nephelostat

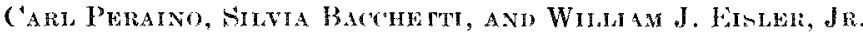

129 Enzyme regulation in rat liver: Functional properties of the ornithine aminot ranserase molecule (AarL Peration

131 Metaloolic and morphologire studies of hepatoeareinogenesis in the rat

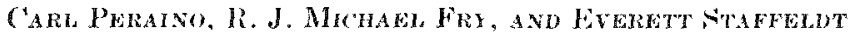

13.3 Immunofluoreseent localization of ornithine aminotransferase in rat liver

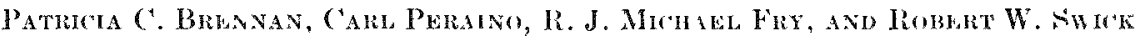

135 optimum beam energy and geometry for neutron capture theraps

Norman A. Frighiolo

138 Jepth dose romputations in slab, eylindrical and anthropomorphous phantoms

Norman A. Frigermo

130 Instruments and materials for studies of dept ho dose distributions

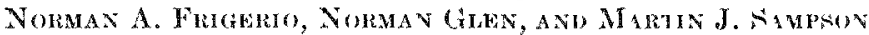

141 Tissue equivalent phantoms for Standard Man and musele

Norman A. Frigherio and Martin J. SAM Pron

14 I Dosimetry of small 252 ( $f$ sourees in a human phantom

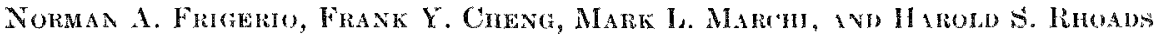

148 Quantitative determination of peroxide in tumor tissue

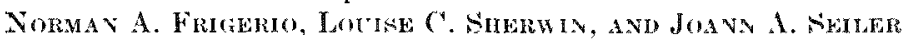

150 Least squares adjustment of hydrolywis data for antitumor compounds of platinum (II)

Ronatid F. (orey aNo Nomian A. Frigerio

152. ('erenkov radiation and liquid scintillation counting

WALTER I\% KISIELESTI

\section{MAMMALIAN GENETICS}

154 renetics of the "muttled" alleles on the X-chromosome of the mouse"

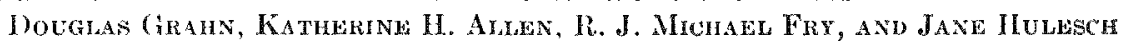

15 Tentative location of an $\mathrm{X}$-inactivation controller gene on the normal $\mathrm{X}$-chromosome of the mouse

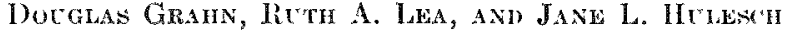

158 Inability to inhibit brain catalase completely in viro with aminot riazole

liobert N. Feinethin, Judth B. Howated, and Joand T. Faulahber

160 lisectrofocusing of purified beef liver patalase and of eatalase in mouse blond

Robert N. Feinstein and Carl Perano

\section{MICROBIAL GENETICS}

162 The growth-duplication eycle. X. Appearance of phage binding sites during the cell rycle of Excherichia coli Michael L. Frefimax and Herbert E. Kubitsonek

163 The growth-duplication cycle. XI. (krowth of nondividing cells deprived of thymine

Herbert E. Kubitisches

Mutation in continuous cultures

165 Int roduction

HERHERT L. KunThouek

165 I. Repair of UV-induced lethal and mutational lesions

Herebert F. Kubitsches

167 II. Spermine and cadaverine as antimutagens

Herisert E. KuntTa' Uak

168 1II. Nuclear selection

HeRBER r H. Kr:BITHCHEK

170 IV. Delayed expression of mutation to T5 resistance Herbert E. KuatrecheK

171 Changes in the mean cell volume of Escherichia coli after bacteriophage infection Mrohael L. Fregduan and Robert L. Krisch 
174 Effects of cell size and DN.A synthesis on padiation sensitivity of Escherichio coli

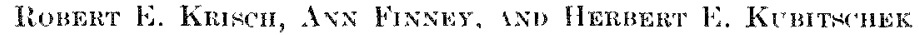

175 Lethal and genetic effects of radioisotope decay in bacteriophages and bacteria

Robert F. Krinch, Barbara A. Coonbs, añ Wayn T. Kiokels

176 The organization and function of the bacterial chromosome. Regulation of ehromosome replication in Bacillus aublilis. The effect of amino aed starvation in Strain los

JAMES ('. ('OPELAND

180 The organization and function of the hacterial chromosome. The chromosome in competent rells of Bacillas subtilis, Strain 168

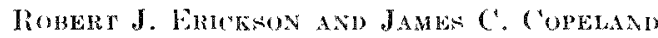

\section{RADIATION PROTECTION}

186 Metabolio and therapeutios studiss of plutonium. $V$.

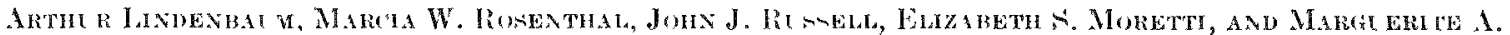
SМгтн

191 Bioghemistry and ion binding of comnextive tiswe. IV.

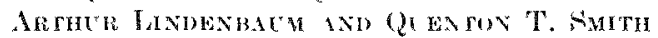

192 Restoration of lethally II - axposed and IN 2 treated amohae by transplantation

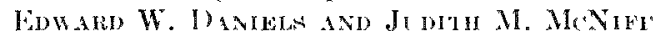

195 IItrastructure of oyster gametes

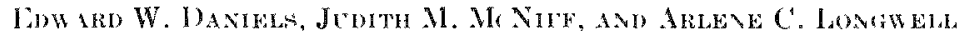

\section{BIOCHEMISTRY}

200 Enaymatic activity of yeast cell ghosts produed by protein action on the membranes

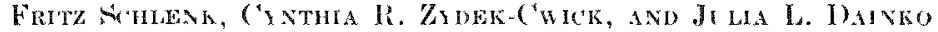

201 The stability of the glyeosidie bond of $s$ adenosvlsulfoninm eomponuds foward arid

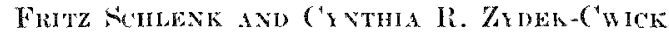

203 The speeifieity of s-adenosyl-L-methionine sulfonium steresisomers in some enzyme systems

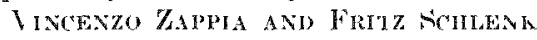

205 The metabolism of mituehondrial proteins

Robert W. SW tok and Carl. Peratio

zot The heteroenzymes of ornithine aminot ransferase

ROBERT W. SUICK AND DaN F. WOODLE

209 The homogeneous distribution of membrane-bound and soluble mitochondrial enzymes

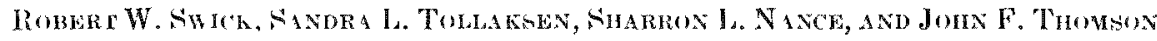

209 The sedimentation coefticient of ornithine aminot ransferase

LISE ( $\mathrm{r}$. BCNIILE

210 Ultraviolet microseopy of embryonating Toxasearis leonina ova

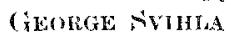

212 Vltravinet micrography of penetration of extraneous cytochrome e into the veast cell

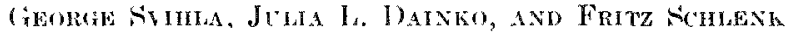

212 Estimation of component size and separation in fused caussian distributions

PETER D. KLEIN

214 Measurement of isotope ratios during combined gas chromatography-mass spectrometry

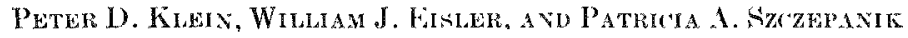

216 Examination of bet a spectra in a liquid scintillation eounter coupled to a multichaneel analyzer

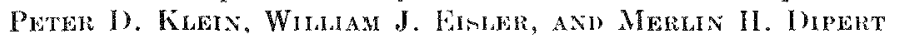

217 Combined gas chromatography -mass speet roseops of hacterial fatty acids

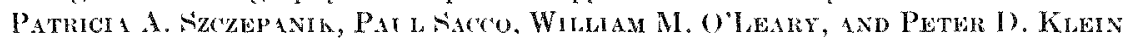

210 studies on rat liver ribonueleases. IV. Further studies on heterogeneity of liver lysosomes: Intracellular localization. of arid ribonucleases and acid phosphatase in rats of varions ages.

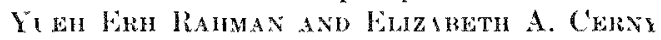

219 Studies on rut liver ribonucleases. I. Liver gibonucleases in developing, 2-acelylanimofluorine fed and partially hepatectomized rats.

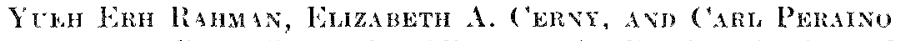

220 RXA turnover studies in livers of suckling rats. Applieation of polyacrylamide gel to RN. separations

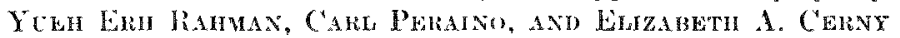

224 Phospholipases 1 in purified subcellular fruetions of rat liver. Evidence of a membrane bound phospholipase in lysosomes.

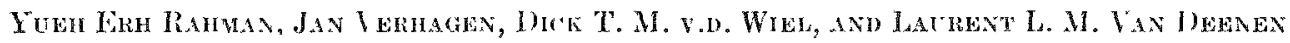

225 studies on liposomes (lipid spherules) prepared from mitochondrial and mierosomal phosploolipids. Their surface charge and their interactions with varions proteins

ITHH Lin Raman

226i Lipid analysis of purified subedlular fractions of rat liver

L̃en Gir R.AHM 


\section{BIOPHYSICS}

229 Cell generation cycle and radiation effects in mammalian cells in culture

Whanex K. Sinclath

229 The cell eycle distribution of ('hinese hamster cells in stationary phase cultures

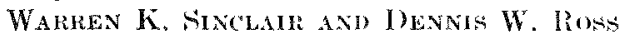

2,32 Recovery from sublethal damage induced by $\mathrm{X}$ irradiation in crsteanine protect ed ('hinese hamster cells

WARELN K. NIMTLAIR

2)3 Protection by evsteamine of rells sensitized by hydroxyurea to $\mathrm{X}$ irradiation

WARREN K. SINChAHR

234 Protective effects of eartain agents against $\mathrm{x}$ irradiation in manmalian cells

Warlex K. Ninc'hall

236 Sensitization of Chinese hamster cells to $X$ rays by $\lambda$-enthymaleimide

Whinix K. Sixchatr

23s cyeloheximide-and radiation-indued division delay in sychohonized ("hinese hamster cells

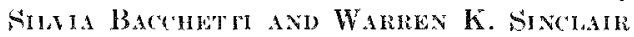

210 The effect of $\mathrm{X}$ rays on the uptake of $\mathrm{Jl}$-leucint in synchronized chinese hamster eells

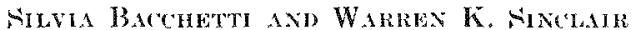

212 Thaviolet light-induced division delay in synehronized ('hinese hamster ecls

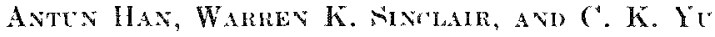

211 Interaction of $\mathrm{X}$ raws and ult raviolet light in mammalian cells

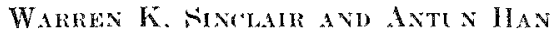

245 Cytological studies on eysteanine protected (hinese hamster cells in ritro C. K. YV ANo WaneN K. SinelatK

247 Polyploidy indueed by $\mathrm{X}$ rass during the generation cyele of synchronized chinese hamster eells

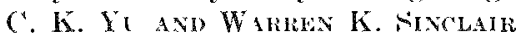

248 A nuelear magnetie resonaneestudy of the st rueture and interaetions of nueleic acid derivatives in sulution. C. Assignment and conformational properties of ribowe hydroxyl protons

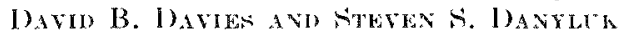

251 Theoretical calculations of nucleic acid ennformations. B. Conformational energies as a function of $\Phi_{C}-x^{x}$ and $\Phi_{C_{A}}-C_{5}$,

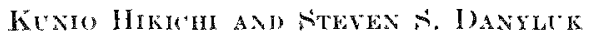

25:3 blectron spin resonanee studies of $\gamma-$ ray irradiated dinucleot idess at $77^{6} \mathrm{~K}$

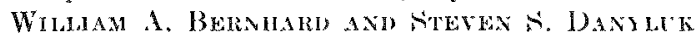

20) Molecular interactions of biologieally active molecules

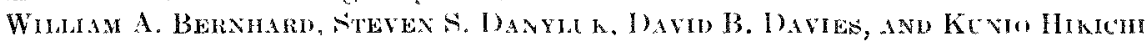

255) High-resolution magnetic resonamestudies of antibiotie struetures and interactions. Part. I. Aetinomyein D: Temperature and solvent effects upon the $\mathrm{N}-\mathrm{H}$ and $\mathrm{N} \mathrm{H}_{2}$ groups

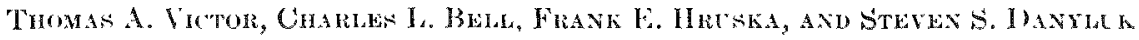

250 Mutagenesis by ultraviolet and visible light in continuous cultures

Rorent B. WEBB AND MICKEY S. BRUW

2 tri crowth and mutagenesis in the Nephelostat

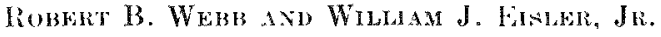

26.5 liffects of ultraviolet and visible light on a multiple repair deficient strain of Eseherichia coli

Mrokex A. Brow and Robrit B. Whibr

2ti) Lethal effects of long wavelength ultraviolet and visible light on reells

JOHN R. LOLWNZ AND ROBERT B. WhBH

272 A sequential repair model of photureactivation in bacteria

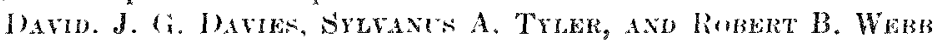

273 High intensity vapor are lamp for biologieal researeh

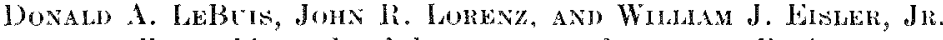

275 An X-ray crystallographic study of the strueture of conctantalin I

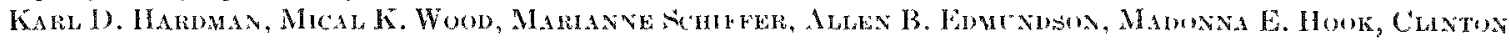
F. Answarth, axid Kathex li. JiLl

277 A chemical study of the hinding sites of coneanavalin 1

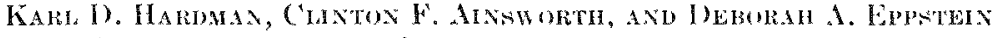

278 Chenical and enzymatic cleavage of concanavalin $A$

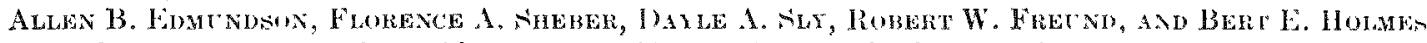

279 . I new procedure to compare amino acid sequences of Bence-Jones and other proteins

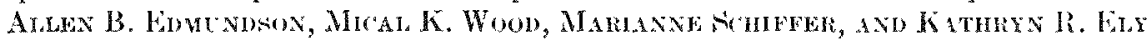

261 A crystallographic investigation of the Meg L-type Bence-Jones protein

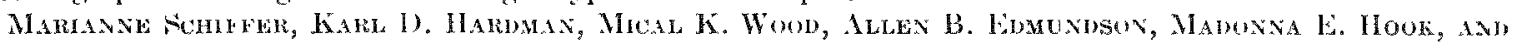
KATHRYA R. THY

28:3 A rystallographic investigation of the Meg myeloma protein

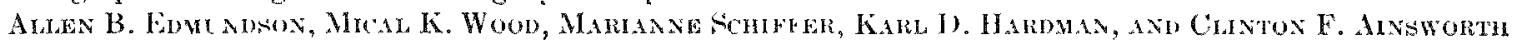

$2 \times 5$ Prediction of heliot segments in glueagin

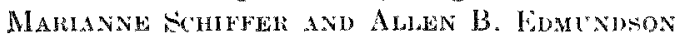


287 Amino acid sequencing of (atostomus clarki hemoglohin

I) ENNIS POWERs

288 Neutron-gamma response for leaf and roleoptile growth in barley

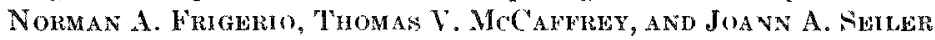

\section{CELLULAR FINE STRUCTURE}

292 Effects of antibiotics on differentiating cells. I. Sensitivity of grasshopper spermatogenesis to actinomyein D Theodore N. 'Tahmigian Rosemarie L. I Eving, and Betty J Jan Wright

298 Lipids in the liver pell nucleus

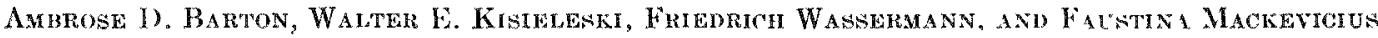

\section{PLANT RADIOBIOLOGY}

303 Further studies on the origin of auxin in the urine of the mouse Solon A. Gondon, R. J. Michatel Fri, and Susan Barr

306 Crowth and cytological effects of light on Haplopappus in suspension cultures

Philp Kremer, Solon A. Gordon, and Stiblamatiax Ventetenwaran

309 Light and ribulose-1,5-diphosphate carboxylase activity in etiolated plants

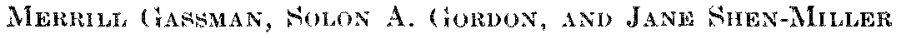

311 Respiration measurements during flower induction in Xanthium

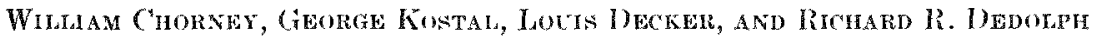

312 The souress of lead in perennial ryegrass and radishes

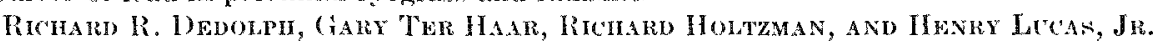

312 The concentration of radium, thorium, and uranium by tropical algac

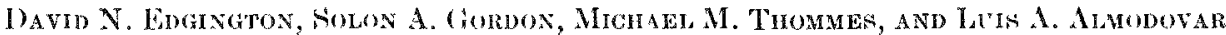

\section{GROWTH AND DEVELOPMENT OF PLANTS IN COMPENSATED GRAVITATIONAL, MAGNETIC, AND ELECTRICAL FIELDS}

313 Observations on the interaction of gravity and ionizing radiation on nuceli in the roots of licia faba

Solon A. Gorbon and Everax M. Bress

317 Reciproeity in the artivation of geotropism of oats grown on clinostats JANE SHEN-MILLER

320 Participation of Golgi apparatus in geotropism JANE SHEN-MILLER ANB RaY HINGMAN

323 Cytology of the young oat seedling

RAY HINYHMAN

327 Influence of audiofrequency sound on the growth of the oat shoot: Further observations

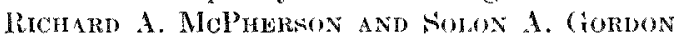

329 The effect of the length of the period of preplanting imbibition on subsequent growth and georesponse of out seedlings

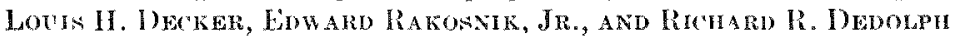

330 A note on growth rates of the Avena coleoptile Richard A. MaPuerion and solon A. Gordon

\section{EDUCATIONAL ACTIVITIES IN COOPERATION WITH THE ARGONNE CENTER FOR EDUCATIONAL AFFAIRS}

332 Summer Institute in Radiobiology, June 16-August 1, 1969

334 Symposium on the Evolution of the Immune Response Bernard N. Jaroslow, Chairman

335 PUBLICATIONS

338 STAFF OF THE BIOLOGICAL AND MEDICAL RESEARCH DIVISION

341 AUTHOR INDEX 


\title{
GENERAL RADIATION BIOLOGY
}

\section{DURATION OF LIFE DAILY "CO GAMMA IRRADIATION: REPORT ON SURVIVAL AND INCIDENCE OF TUMORS}

\author{
Douglas Grahn, Goorge' 1. Sacher, John H. Rust, ${ }^{*}$ and R. . . Michad Fry
}

This report is concerned with some of the analysis of the data ohtained from a study of chronic ratiation lethality of four strains of mice. The design and the experimental conditions have been previously described $d^{1-3)}$ and initial reports on the lethality data and incidence of tumor have been givent. Mire at 100 days of age were placed in a $\gamma$-radiation facility that automatically irratiater the animals during the night for a period of 7 to $10 \mathrm{hr}$. The animals were caged in group of three texeept at $0.3 \mathrm{~K}$ day and irradiated for the duration of life. Both sexes, in equal numbers, of three inbred strains. A Jaxt ih, BALB woth, and C.5BBL 6.th and one hybrid, the $B C \%$ ic $57 B L, 6 \times$ BALB e $F_{1}$ l were wed in the major part of this study. Additional information was ohtained on the (5) (ih strain at domes of $12 \mathrm{R}$ day and above.

Ten daily-tome levels were employed and are given in Table 1 along with the mean after-survival raluen. From $12 \mathrm{R}$ day and above, equal sample sizes were ured for all genetic groups; 48 sex and strain at 6 R diy, $12 \mathrm{R}$ day and $24 \mathrm{R}$ day; 24 sex and st rain at 32 R day, 43 R daty, and 56 R day. At 0 R day through of $R$ day, a double sample was uned for the $\mathrm{B}\left(\mathrm{F}_{1} ; 168\right.$ sex at $0 \mathrm{R}$ day and $1.3 \mathrm{R}$ day; 96 -ex at $2.6 \mathrm{R} d \mathrm{ay}$ and $6 \mathrm{R}$ day. The samples were 84 and 48 , respertively, for the three inbred strains.

The dose group at $0.3 \mathrm{R}$ day was an irregular sample. Thi- exposure condition is behind a bulk lead shield in one corner of the $\gamma$-radiation fucility and does not provide an irleally comparable environment to the balance of the exponure conditions. Caging was alko different and incolved groups of 12 . Originally, only the BCF $_{1}$ and BAIB e -trains were entered owing to space limitation. Sixty mice sex for the inbred and 120 rex for the hybrid were uned. Late in the study. the $A$ strain was added as spare became avalable, so there is a degree of discontinuity in time between the $0.3 \mathrm{R}$ day group in the $A$ strain and the balanes of the study. (aging and other microenvironmental

* Departments of Pharmacology and Radiology, Cniversity of Chicago. variables imduce a general diseontinuity for all animals at this dose. Thi is empha-ized beeause there are certain inconsintencies in the data at this level that eamnot be clearly interpreterl.

control miee were held in a maze corridor to the $\gamma$ room. (ienerally, the physical environment was comparable to that in the room itedf. but there was more ambient temperature variation and greater contact with the general animal facility anvironment. Here, woo, there is some reservation regarding the mo-t ricorou comparative analy-is. At any rate. for the dose group from $1.3 \mathrm{R}$ day through $56 \mathrm{R}$ day. the enxironment was- -ubstantially constant.

MORTALISY FBON ALL CALSE

The survival datat are given in Table 1 and Figure 1. In the latter, log MAs imean after-survivall is plotted against daily done, and a linear relationship is rearly demonstrated. This was seen earlier by sacher and (irahn':3 and has been substantiated in a half-

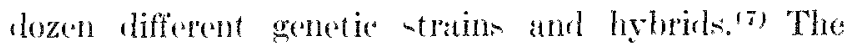
datat fit the equation

$$
M .1 s_{I}=M A x_{10} e^{-3 n} \text {. }
$$

The value of $\beta$ has only varied between -0.033 and -0.043 for different sexes, strains, and hybrids in nearly two dozen separate estimates over the pat 10 to 1.5 year's. The simple areruge for all trains and rexer is -0.038 ; that is -3.8 ; R day; -3.8 days/

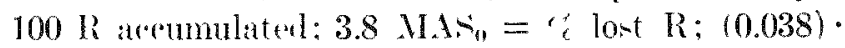
(Xlik, = daym lost R day.

Beratuse there is no significant genetie variation in this eonstant. nearly all genetie differences in longterm response atre ineorporated in the base differencer in life experetancy.

Figure 1 alon expands the weale at the lowere doen to demonstrate the increase in variation of response. Strain $A$ shows almont no respone differential below $6 \mathrm{R}$ day. Nitrain, B.ALB e and C57BL, show a steady progres,ion down to $0 \mathrm{R}$, while the $\mathrm{BCF}_{1}$ demonstrates a matl amount of orer-survival at $0.3 \mathrm{R}$, day. This is statistically significant for the males, but not the females. 


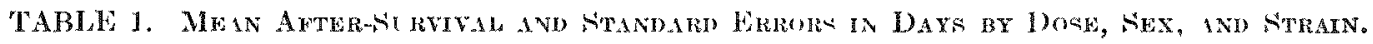
Age at Start of Exposure: 100 Days

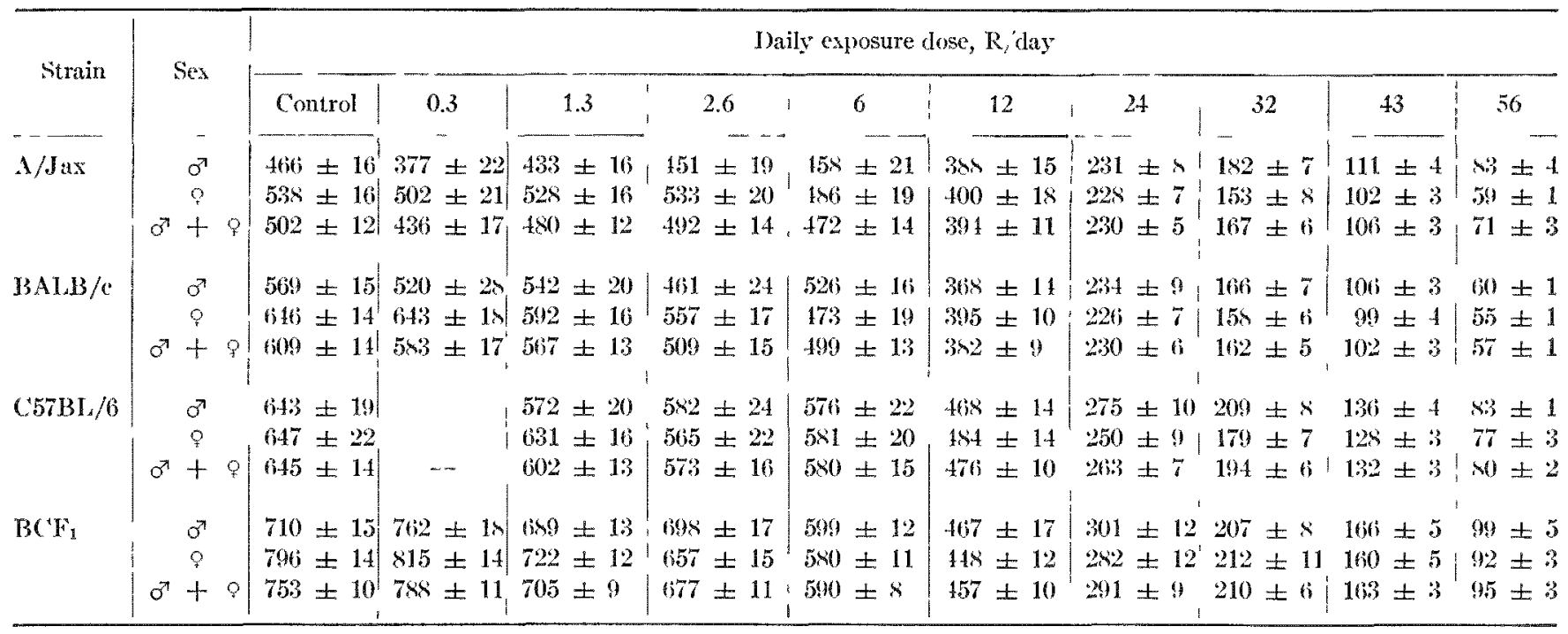

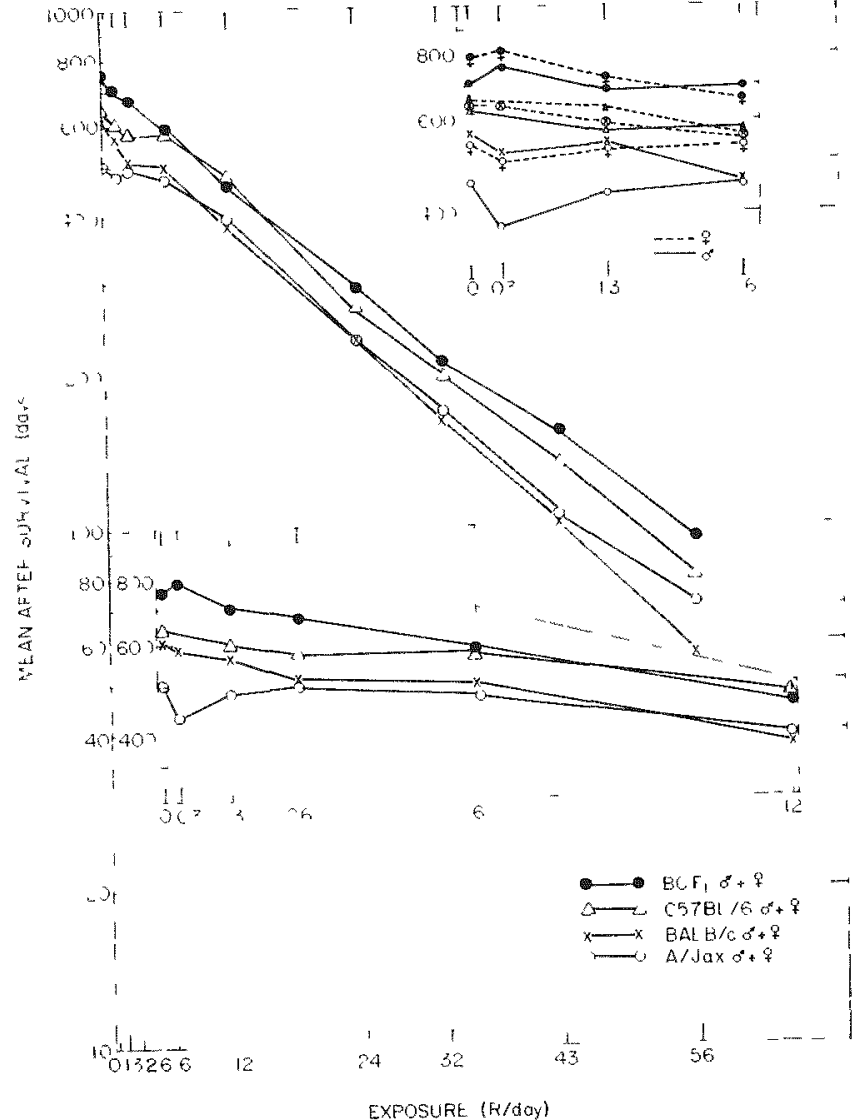

Fig. 1.- Logarithm of mean after-survival (MAs) vs. daily dose of $\mathrm{Co}^{60} \gamma$ radiation.

'The basic age-pereifie death rates for all cauren of death, the two rexes combined, are given in Figure 2 for the four genetic groups. The characteristic fan of mortality-rate slopen is evident in all strain though

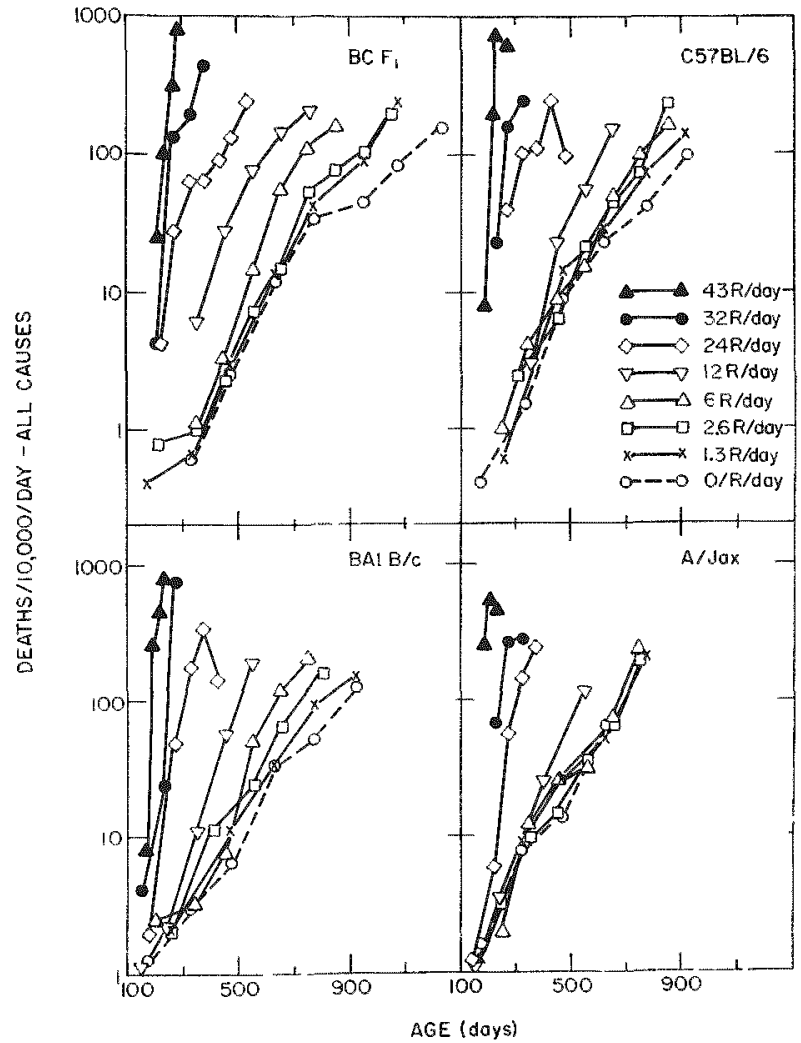

Fic: 2. Age-specific mortality rates for indicated strains and daily doses. Sexes rombined; all causes of death.

the 1 strain reveal an unchanging array for dowes $0 \mathrm{R}$ through $6 \mathrm{R}$ day. The pathological bavis for this spparent lack of radionemitivity in in the stiseceptibility of this strain to amyloidoris and kidney degeneration." A careful comparion among the strain indicates that all the 1 -train low done groups and the 
control have an accelerated mortality rate; the (sompert $z$ slopes for the $0 \mathrm{R}$ through $6 \mathrm{R}$, day groups are all roughly equal to that at $6 \mathrm{R}$ day for the BALB a. All radiation injury at dones below $6 \mathrm{R}$ day in strain $A$ is apparently orerwhelmed by the high incidences of degenerative diseare. It thould be noted that this suppression of monse affects nearly all upecific end point in the A strain at the low doeses, although the respones at $12 \mathrm{R}$ iday and above is quit typiral of the arerage mouse.

Figure 3 is a more detailed dimplay of the mortality rates for the $B(\mathrm{~F}$, for which more adequate sampling was arailable. The death-rate curves are nearly all substantially nonlinear. This has been discussed previously by sacher." It should also be noted here and in Figure 2 that in no care does one find at nonlinear relation that is concave upward at described by Neary'10" for the (BBA moune. The Harwell experienee for long-term gamma or neeutron irradiation is mont peculiar in this regard and in certainly not confirmed bx anything we or others have seen.

some of the nonlinearity of response (an be attributed to leukemia. which has a phasic nonlinear increment of it own. Mortality rates derived from the population decremented for leevemia mortality are given in Figure 13 and will be discured in a later seretion.

The control data are alo given for the full neonatal, infant, and juvenile period. Thene dat at are derived from our breeding record for the firnt 30 dat: and from tock rage experience for the perior 30 to 100 days. Between 200.000 and 1.000 .000 mouse-day of experience are now atrailable for the early part of the life table for this hybride as well an many of the inbreds. The preweaning death rates tend to be about 10-fold higher than thome in human experienee in the firt 30 days, a common feature in littering animals.

\section{MORTALTY WITH SPECIFIC PATHOLOG}

Autopsese were performed on almont 90 's of the miles. Major lesions were grossly defined and thout 25 to $500^{\circ}$ were studied hy microncopie examination. The pereentage examined microscopically was highwet in the control and low done groups. since the sime degres of detail wats not availahle for all miere we derided to andyze the data for leions for which both the marronepire and microneppir information sained could be ueed. Gur surrey concentrated on:

1. Tumors of the reticular tis we, whieh were -ubdivided into two groups, (a) thome with thrmic involvement and (b) thome with no apparent thymic involvement. This arhitrary subdivision was necessary because data obtained by materoscopic examination alone was used. This

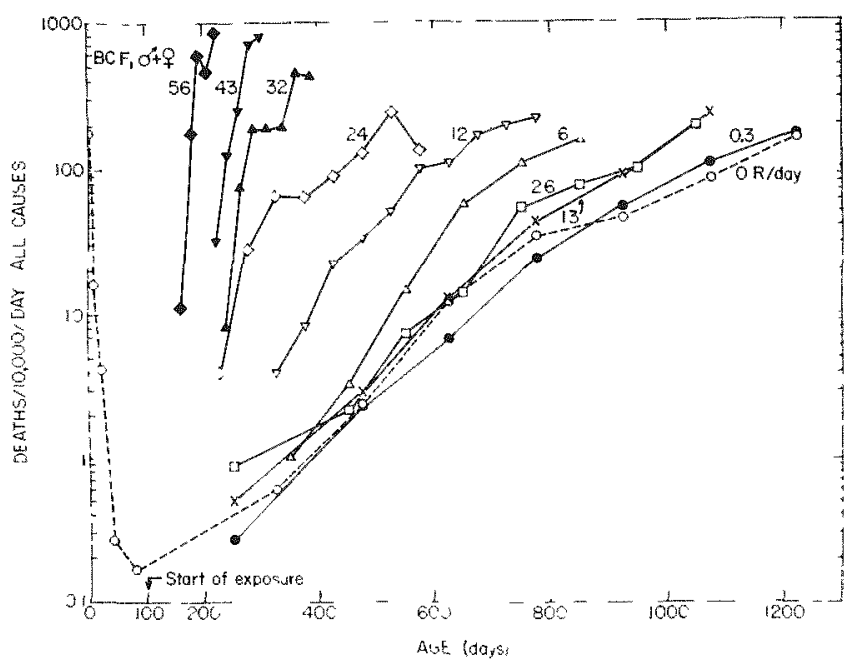

Fic. 3.--1ge-specific mortality rates for $\mathrm{BC} \mathrm{C}_{1}$ hybrid; sexes rombined, all causes of death.

-ublivision results in an underestimate of tumor of extrathymic origin which oceur late in the life-yan.

2. Mrarian tumors and crats.

3. Pulmonary tumor - (primarys.

4. Ilepatomas.

万. Total tumor incidence, which also includet misrellineour tumor. such as alrenal. skin and ronnective tisue, mammary gland, and hemangioman.

6. Renal lecions, often detered by cratir degeneration.

The final pereent incidenes for the major tumor "ategories is seen in Figure 4 . We wish to emphasize the extreme nonlinearity of the datat ho as to discourage the catsual reales and experimenter from attempting to draw grand ronclusion about dosta-reponse relation-hip- from such -imple expremion of data.

dil tumors do renpond to low done: the rather extreme response for ovarian tumors at $1.3 \mathrm{R}$ /ay is quite signifirant. The nearly exponential drop in incidenee above $1.3 \mathrm{R}$ day is apparently a function of two major opposing romponents- -induction by radiation but with little dose-perpone sensitivity cmore of an all-or-none type semponse; sere Figure 91 opponed by procresive life shortenine and truncation of the di-tribution period of expression.

Pulmonary tumors and hepatomat prenent a similat pireture of a rine at the 2 or 3 lower doese levels. then at -teady decline at life-shortening effects predominate. Reticular tiene tumor- hate a hiphasie re-pome: the first rise at $1.3 \mathrm{l}$ day is -ignificant by a chi-cpuare tent $1 \mathrm{P}<0.002$, and generally oecurs in both leukemia subtypen and in both sexen of all four 


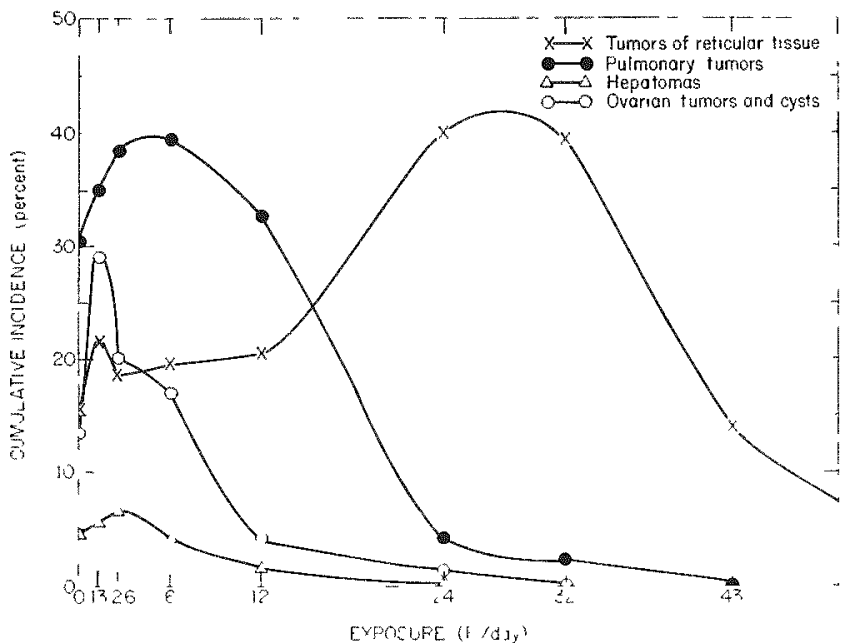

Fic. 4.- Cumulative indidence for reticular tissue 1 umors, hepatomas, and ovarian tumors for strains $\mathrm{A} / \mathrm{Jax}, \mathrm{B} . \mathrm{IJ} \mathrm{B} \mathrm{c}$, $\mathrm{C} 57 \mathrm{BT}_{1} / 6$ and the $\mathrm{BCF}_{1}$ hybrid eombined. Ihata for pulmonary tumors on $\mathrm{A}, \mathrm{BALB}$ and $\mathrm{BCF}_{1}$ only. Sexes combined.

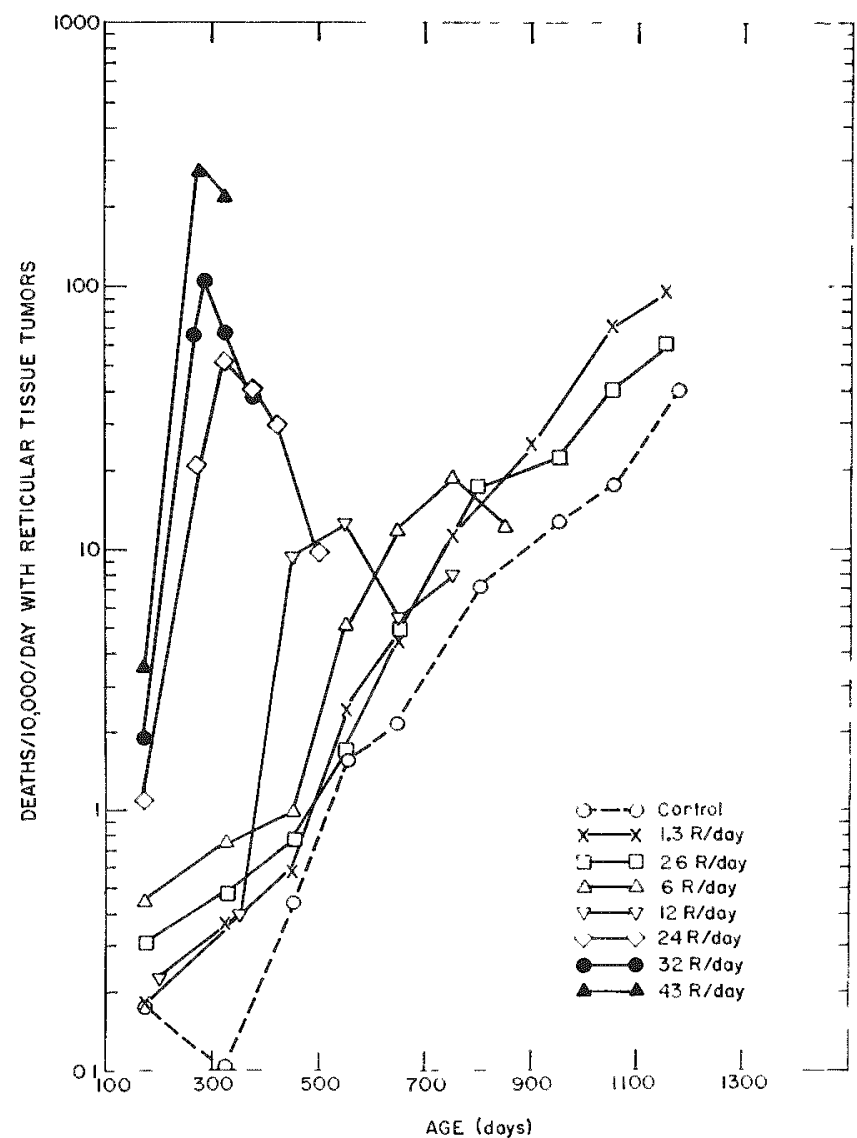

Fic. 5.-Age-specific mortality rates for reticular tissue tumors for combined sexes and strains $\mathrm{A} J a x$, BALB/e, $\mathrm{C}_{57 \mathrm{BL}_{2} 6} 6$ and $\mathrm{BCF}_{1}$.

strains. This is followed by a small drop-back and then a steady rise through $12 \mathrm{R}$ /day. Thymic tumors make up only one-fourth to one-third of the total until $12 \mathrm{R}$ /day, when these suddenly shift to about $70^{\circ}$;

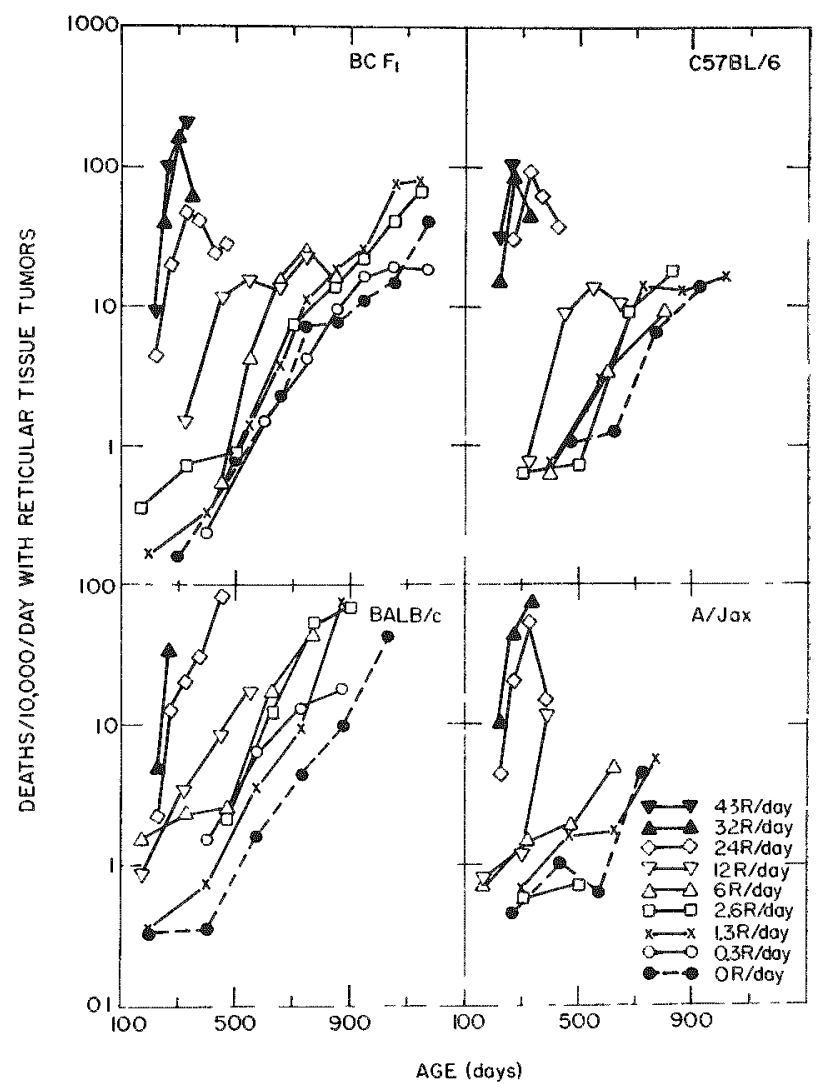

Frix ti. Age-specific mortality rates for reticular tissue tumors, sexes combined, for indieated strains and doses.

and thereafter produce the serond phanic response at $24 \mathrm{R}$ and $32 \mathrm{R}$ 'day.

\section{Reticular Tissue Tumors}

Figure s prenents the death-rate data for all strains and nexer combined. At the lowest doses the response is linear, and the doath rater are generally displaced upward and parallel to the control. This may be a kind of balanee hetween the early-life thymic tumors and the later increment from those not involving the thrmus. At $6 \mathrm{R}$ day the thymic component is beginning to have its effect. and at $12 \mathrm{R}$, day and above the sharp, but phatic, mortality inerement occurs from tumor involving the thymus. At the $6 \mathrm{R}, 12 \mathrm{R}$, and $24 \mathrm{R}$ day levels, there is at definite return to or near the underlying linear trend. The latter is commonly seen after single doren. (11-14)

The dat a for each strain are shown in ligure 6 and while the same geveral pattern is seen in all, there are some exceptions. Data from the $\mathrm{BCF}_{1}$ are much like thowe for all strains (this will be generally noted becauss they make up 40's of the total sample in the pooled datal, and the data at $0.3 \mathrm{R}$ show no response above control. The (57BL shows mostly a thymic tumor response component. The opposite is seen in the $B A L B / c$. Here the nonthymic component is predomi- 
ant in responne at $0.3 \mathrm{R}$ through $6 \mathrm{R}_{/}^{\prime} \mathrm{day}$. Although a definite thymic tumor response occurs at the upper dow levels, it is more linear and broadly distributed in time. The A strain show almost no response at o R through $2.6 \mathrm{R}$ day. A sharp thymic tumor respone does ultimately emerge at $12 \mathrm{R}$ day. As will be noted later, the total reticular timsue tumor response at the four lowest doses is apparently not independent of the pathology defined by degenerative renal lesions.

A detailed analynin of the nonthymie tumor in the $\mathrm{BC}^{\prime} \mathrm{F}_{1}$ at the 5 lower done levels reveals a family of linearly increasing death-rate sopen 1 Figure 71 . Theme originate from an apparent common intereept at about 400 day of age. Although $0.3 \mathrm{R}$ day haw no apparent influence on thi- type of leukemia, a -ignificant increase in death-rate sope is seen at $1.3 \mathrm{R}$. $2.6 \mathrm{R}$, and $6 \mathrm{R}$ day. The only comparable bit of information is Cpton' report on nomnyeloid, nonthymie tumors of the RF moune after single does of $\mathrm{X}$ ravs.' ${ }^{1+4}$ In that inciance, an upward, parallel diplacement occurred, which would be expereded after -ingle domes. in contrat to the present dat a that how a prosremsive slope potation and a common intereept.

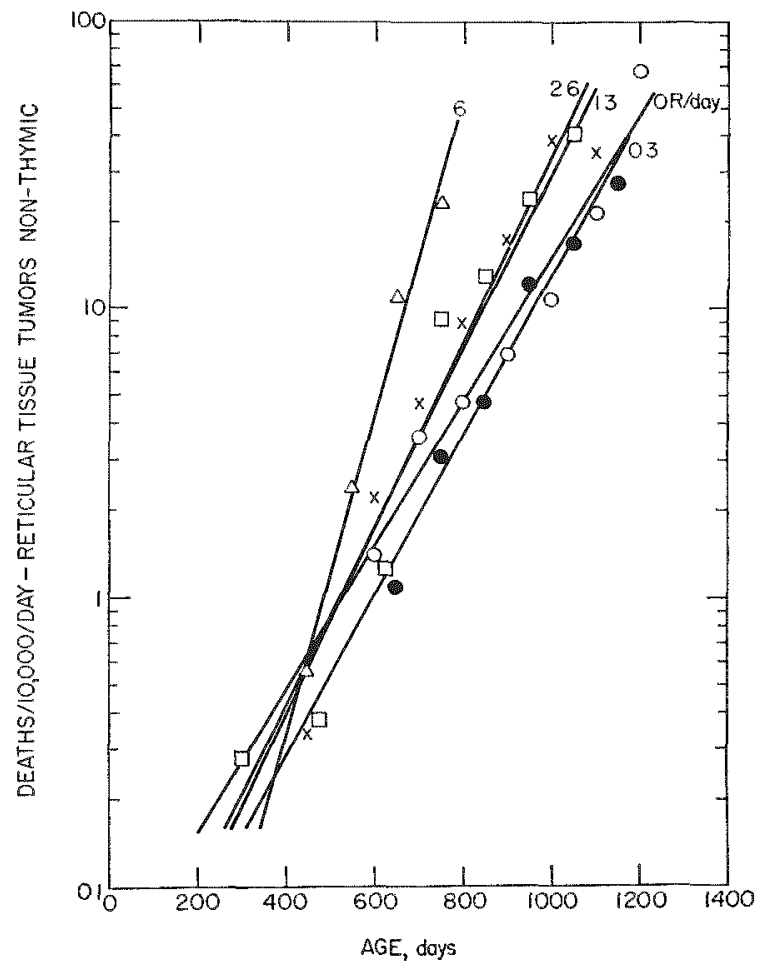

FrG. 7.-Age-specific mortality rates for non thymic retieular issue tumors in $\mathrm{BCF}_{1}$ mouse, sexes combined. Data fitted by east squares linear regressions; slopes are: $0 \mathrm{R}, 0.0058 \pm$ $0.0005 ; 0.3 \mathrm{R}, 0.0064 \pm 0.0005 ; 1.3 \mathrm{R}, 0.0072 \pm 0.0010 ; 2.6 \mathrm{R}$, $0.0074 \pm 0.007 ; 6 \mathrm{R}, 0.0127 \pm 0.0013$.

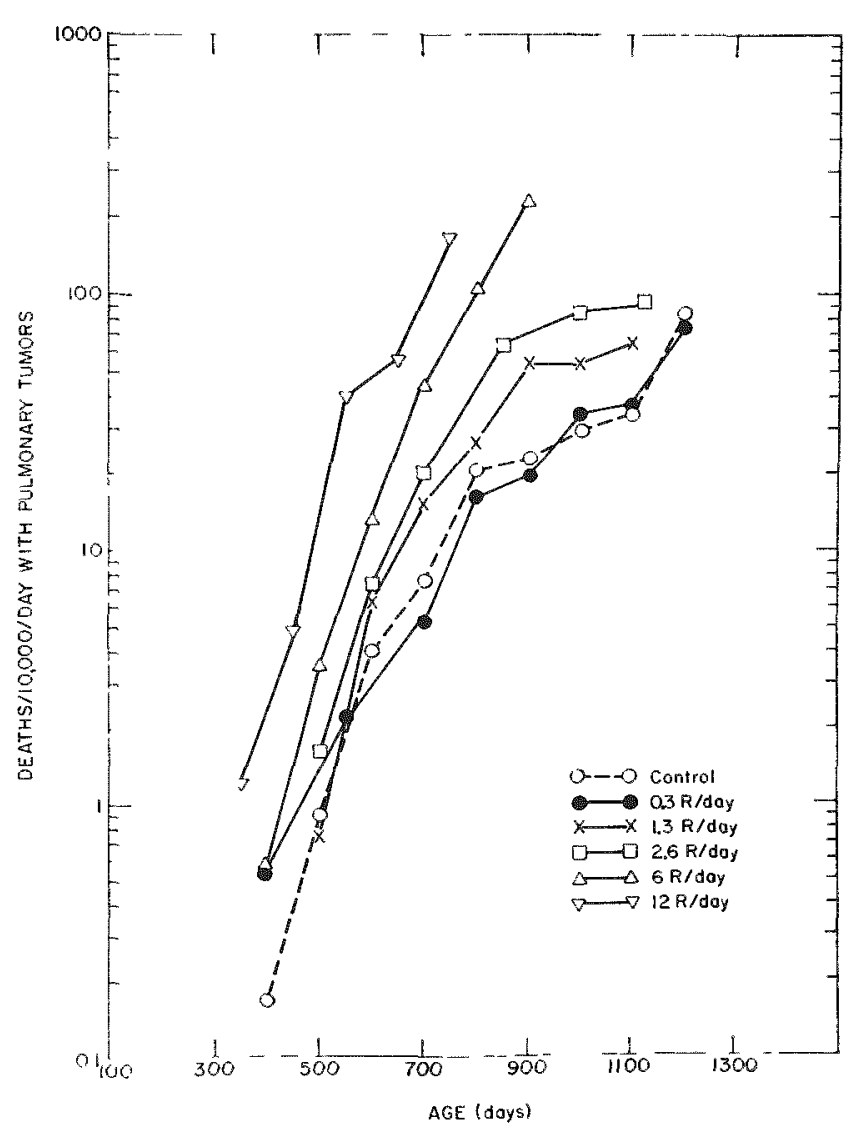

Finx $\&$ Age epecific mortality rates for primary pulmonary

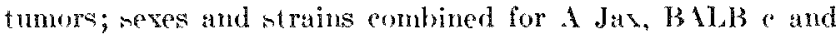
$B C F_{1}$.

\section{Pulmonary Tumors}

The rombined data for strains A. BALB ce, and BC'F atre presented in Figure 8. This tumor provideat good array of respones: none at $0.3 \mathrm{R}$, - come progremive divergence of mortality rate at $1.3 \mathrm{R}$ and $2.6 \mathrm{R}$, and both divergenee and displacement at $6 \mathrm{R}$ and $12 \mathrm{R}$ day.

"The three contributing strain are not remarkable. The A strain show the suppressed response through $6 \mathrm{R}$ day noted for other end points. The BALB a and $B C{ }^{4} F_{1}$ are individually -imilar to the combined re-pones. The respone in the (57BL 6 was generally below 3 to st's.

\section{Oraran Tumers and rysts}

Figure 9 present the combined dat: for the four strains. The characteristio to be noted here is in the -imilarity of respones at $1.3 \mathrm{R}, 2.6 \mathrm{R}$, and $6 \mathrm{R}$ 'day. The lack of dose' responsiveness and the minimal divergence through 600 days of age -uggeet that this tumor requires a long development period and that induction may require a comparatively low thre-hold of injury to be surtained. Because the female moune 
is particularly -ensitive to radiation-indured sterility ${ }^{15}$ ) the tumor respone may rice rather abruptly to be a potential maximum when -terility is induced. Death ratem could then be the ame for all doses, and yields would be a direct function of total time at rink beyond about 500 days of age.

The individual strain thow some interenting respones (Figure 10). The incidence in the $A$ strain, again. is -uppresed by degenerative diseave mortality while the (57BI, chow a tight cluster of death raten at all dow athove control. The BALB $a$ and $\mathrm{BCF}_{1}$ indirate some minor degree of doue responet, though this in -till -mall compared to the bavic difference between irratiated and unirradiated. The $0.3 \mathrm{R}$ day group of the $B C{ }^{\prime} F_{1}$ loem how an intermediate poition, but the total dose is only -everal hundred Rads 'ven after two year' exposure. The general conclu-ions noted from thene data confirm many of the obrervation-made on the $\mathrm{IAF}_{1}$ by Lorenz at doum below $8 \mathrm{R}$ dat ${ }^{(16)}$

\section{Hepatomas}

The data for thin tumor are quite meagre, and intdividual -train never yield more than $14^{r_{c}}$ incidence. The death rates are progres-ively divergent, linear,

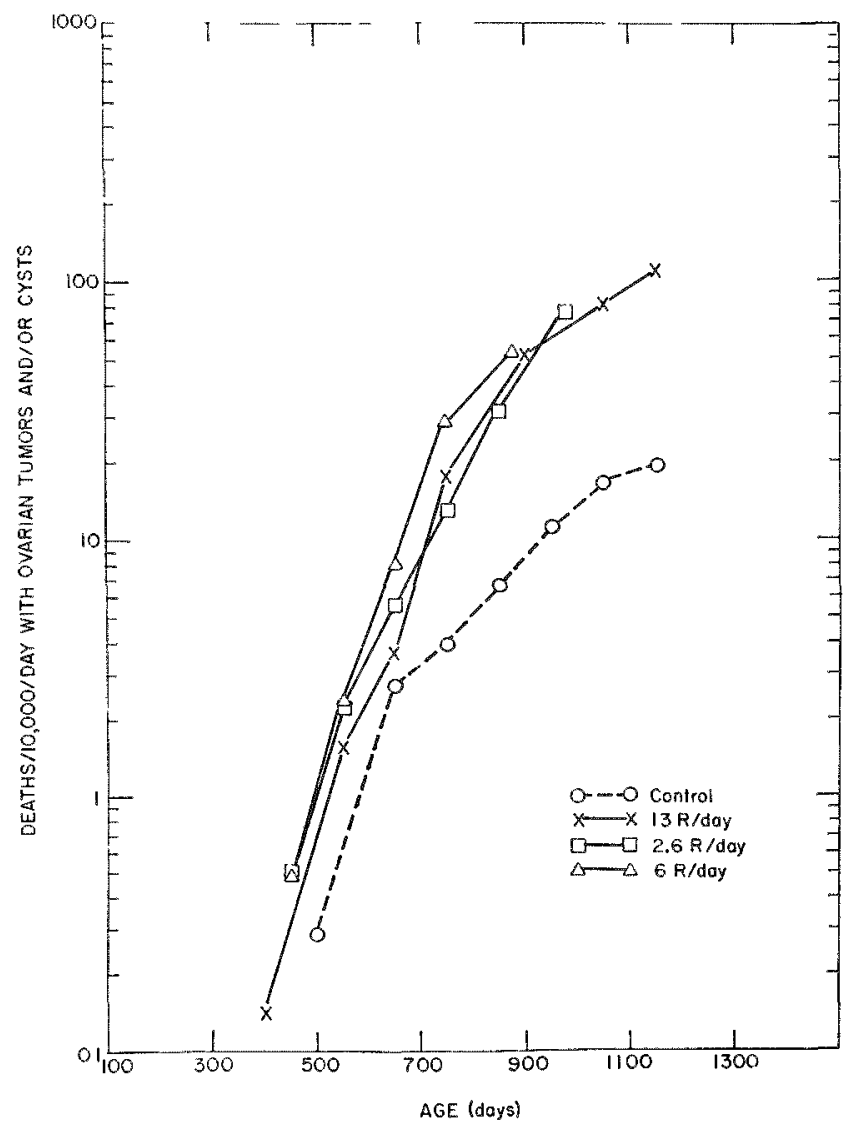

FIt. 9.- - Ige-sperific mortalits rates for ovarian tumors and

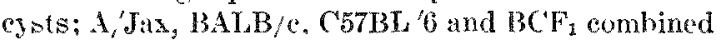

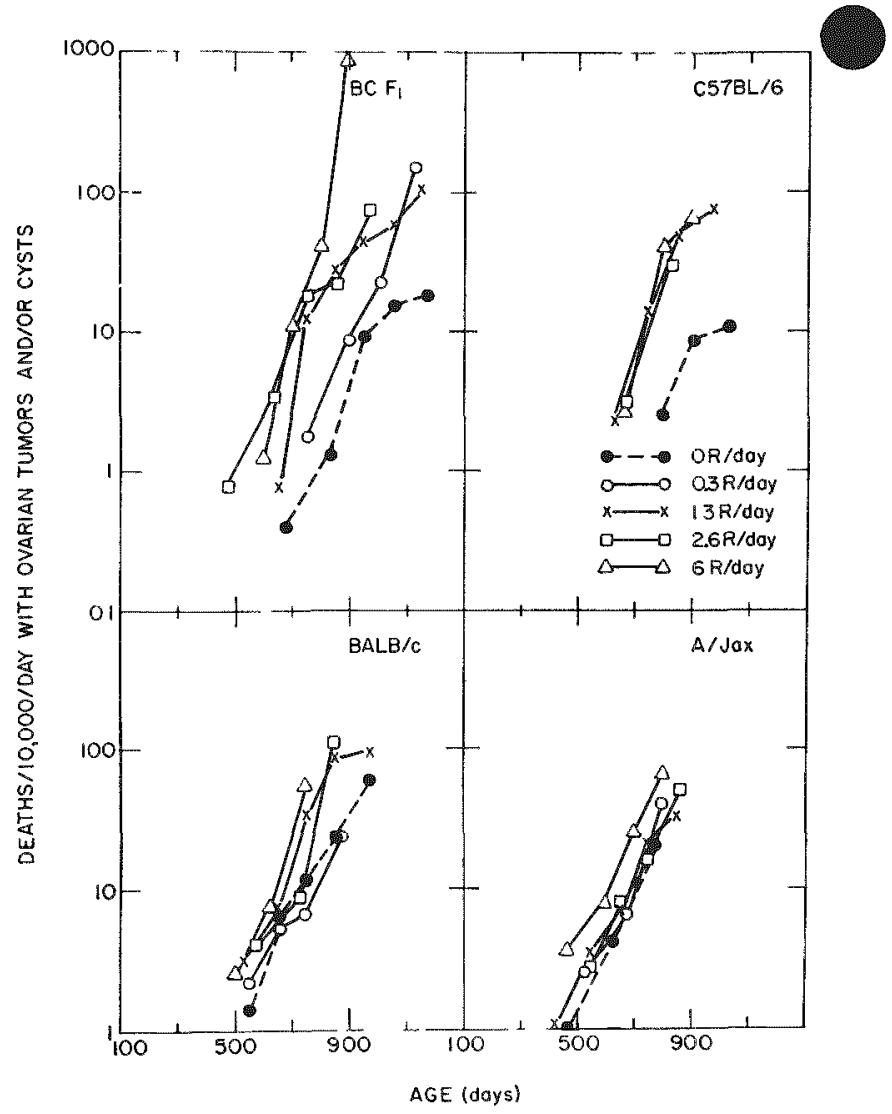

Fig. 10 -Age specife mortality rates for ovarian tumors and eysto for indeated strains and daily dose groups.

and rive from it common intereept of $2 \times 10^{-5}$ at 500 day of age. To -tudy the done respone of the incidence of hepatomat, the strain of choice in $\mathrm{C}^{3} \mathrm{H}_{\mathrm{f}}$, which will give yield up to 60 's.117)

\section{Miscellareons Tumor}

'The incidences of other true of tumors wa low. In generat, the remult on tumor incidence reporterd here are in subtantial agreement with those given hy Lorenz et al.'1n' for the LAF $_{1}$ exposerl daily to doses of $0.11,1.1,2.2,4.4$, and $8.8 \mathrm{R}$ day. Lenkemian, pulmonary tumors, hepatomit, and ovarian tumors all demonutrated qualitatively and quantitatively similar level of response. Finfortunately. earlier -tudien of our own on the $\mathrm{IAF}_{1}$ moune could not fully corroborate thone data. an our previoum studies did not go below in day, and it in obviou that much of the valuable tumor information leen at donen below that level. The prenent data at higher donen are all conistent with our previous peports. (1))

\section{litnal Lesoris}

A form of renal dereace often ero-ly characterize by crutie degenteration and moro-copieally by amyloid infiltration i- commonly oberred in mice and 


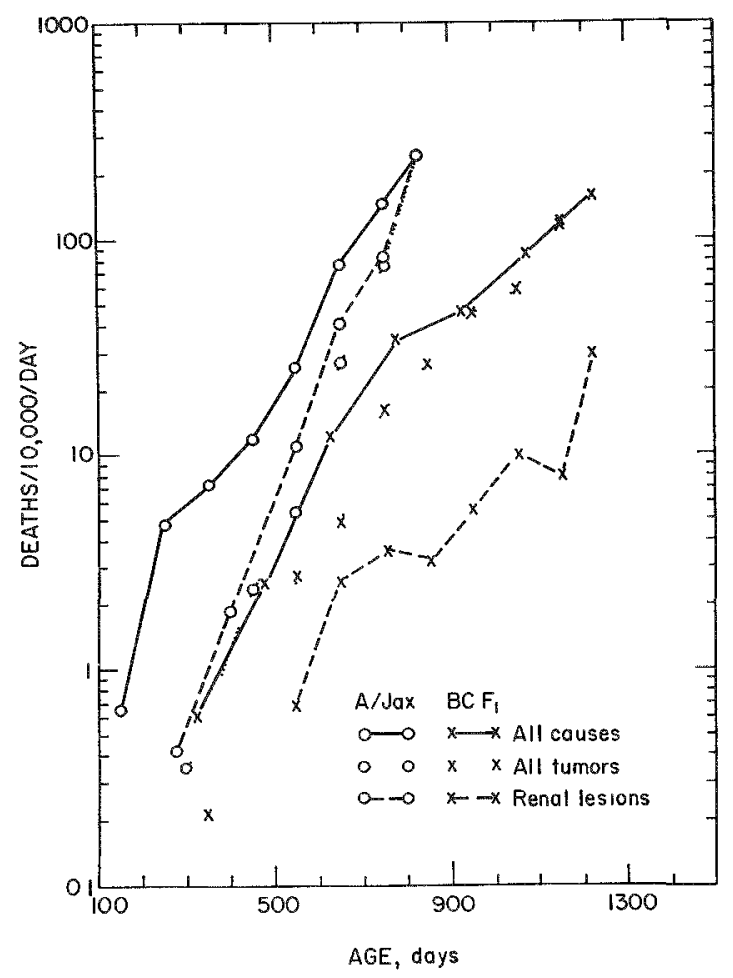

Fig. 11.-Age-specific mortality rates for $A$ Jax and $B\left({ }^{\prime} \mathrm{F}_{1}\right.$ control populations for indicated causes.

wat a common lesion. particularly, in the $A$ and ( $57 \mathrm{BL}$ strains. It reaches a total incidence of 30 to $50^{\circ}$, in the A strain, 15 to $35 \%^{\circ}$ in $(5.5 B \mathrm{~L}$, and 5 to $15{ }^{\prime} c$ in the $B C F_{1}$. In the irratiated group the highert incidence was in strain A, 60\% at $0.3 \mathrm{R}$ day. which acrompanied a disproportionately reduced life expectancy ITable 1 and Figure 11.

Figure 11 give a comparative analysis of death rate for the control- of trains $A$ and $B C F_{1}$, for all eatim, all tumor and renal lesions. The picture preconted ky -train $A$ is seen at all the do-m below $12 \mathrm{R}$ day with minor exception-. Death- from renal lesionoverwhelm all other cauren and would seem to foree the mortality rate upwatr. At $6 \mathrm{R}$ day. enough early lenkemia oceur to emerge from the renal lecion background for a ferw humdred day- between 1.50 and 4.50 day of age. In a senese, the renal lesion act a- a culline foree in train $A$ that producen a perfect set of cancer morbidity data. Becaure the death rate slove for renal lesions is con-tant between $0 \mathrm{R}$ and $6 \mathrm{R}$ day, a redundant serie of morbidity data are produced and no information emerge- on differential tumor remponse.

The $B C F_{1}$, on the other hand, exhibit no obriouimpairment due to the renal lesion. Death raten from all tumor clonely follow the death raten from all causes. This is generally -een in the other strains, though the $\mathrm{C} 5 \mathrm{~F} \mathrm{BL}$ is somewhat intermediate in its re-

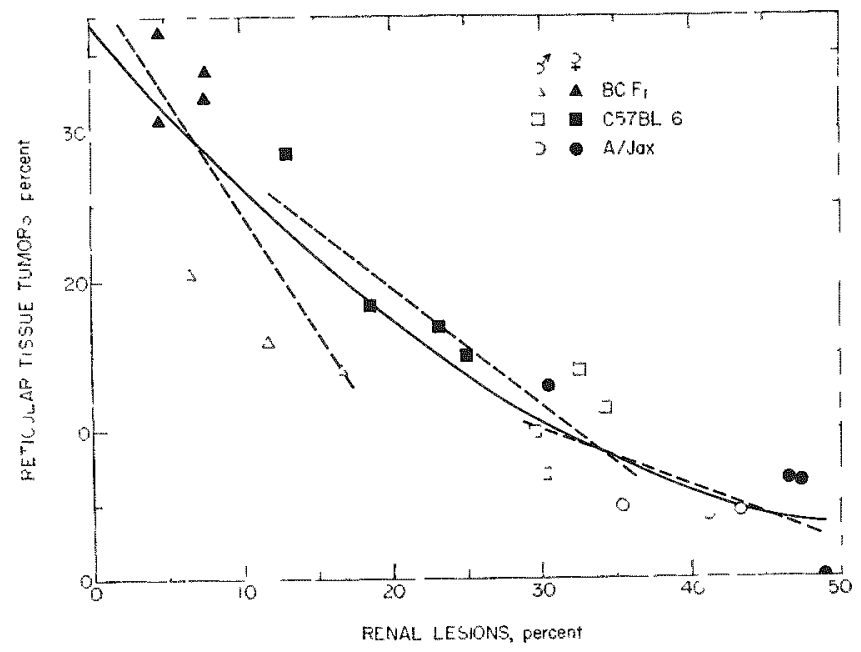

Fig. 12.-Final incidence of all reticular tisues tumors vs. final incidences of renal lesions for dose grompa $0 \mathrm{R}, 1: 3 \mathrm{R}, 2 \mathrm{f} \mathrm{R}$, and $6 \mathrm{R}$ iday. I ata fitted by least squares; whopes are $A$ dax, $-0.384 \pm 0170 ; \mathrm{C}_{57} \mathrm{BL}_{1},-0.780 \pm 017 \% \mathrm{BCF}_{1},-157.3 \pm$ 0 $55 \mathrm{~s}^{2}$. The combined data were fitted by the equation $y=a+$ $b x+\cdot x^{2} ; a=36,94 \pm 291 ; b=-118 \pm 0.27 ; r^{2}=0010 \pm 0005$.

lations betwern renal lexion and all-tumor death rate.

The extent of interetion between renal lesion and neespla-iat is reen in Figure 12. The find incistence of renal lenion and leukemian for don 0 R. 1.3 R. $2.6 \mathrm{R}$, and $6 \mathrm{R}$ day for the three indirated -train- show an individual and a combined negative correlation between tumor incidenes and kidney lewion. It would thu appear that the sy-temic or ba-ic netabolice erent that underly the renal degoneration also act upon reticular time tumors. At the four doe group employed in thi- relation-hip, there is no major doen repones for either lemion; the exond llegree polynomial that decribes the data is thu not an indirect function of radiation level.

Curiou-ly, no particular relation exi-t- between renal lesion and the all-tumor category or ovarian tumor. One is tempted to -ugge-t that thi- dogenerative dienese ha an autoimmune etiologe that also influence the hematopoietie sytem.

\section{Life Shortening Risk Estimates}

A leetailed appliestion of portion of thene data to the general quention of estimating the lifetime rink of low does radiation exposure has been given by (irahn."6) (One particularly attractive penult wa- derived from the anaty-i of all caune of death after the removal of all leukemia mortality. Thi proesen of derementing a population for leukemia death wa carricel out on the $\mathrm{BCF}$ hybrid, with rexe comhined. The resulting age-pereifie death rate data were fitted by firt ant -econd degres polvnomial and a 


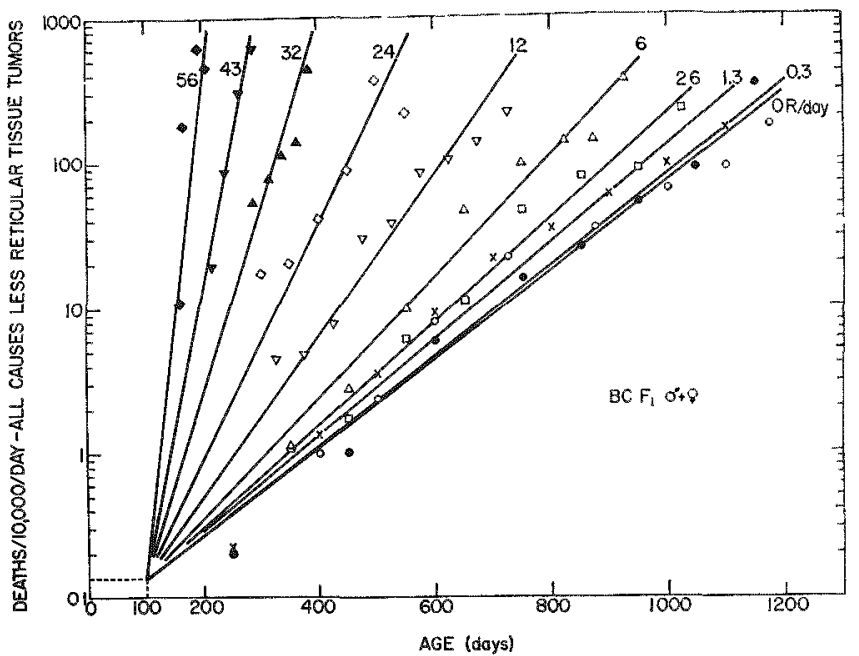

Fic. 13.-Aga-sperific mortality rates for leukemia decremented populations fitted by first-degree equations foreed through common 100 -day intercept of $13.5 \times 10^{-6}$. $\mathrm{BCF}_{1}$, sexes combined. See Table 2.

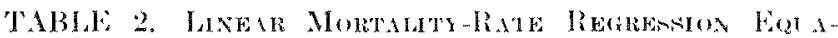

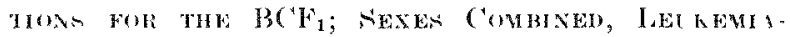

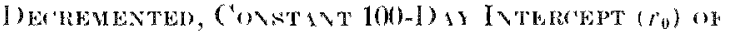
$13.5 \times 10^{-6} ; r=13.5 \times 10^{-6} \mathrm{~m}^{7 t}$

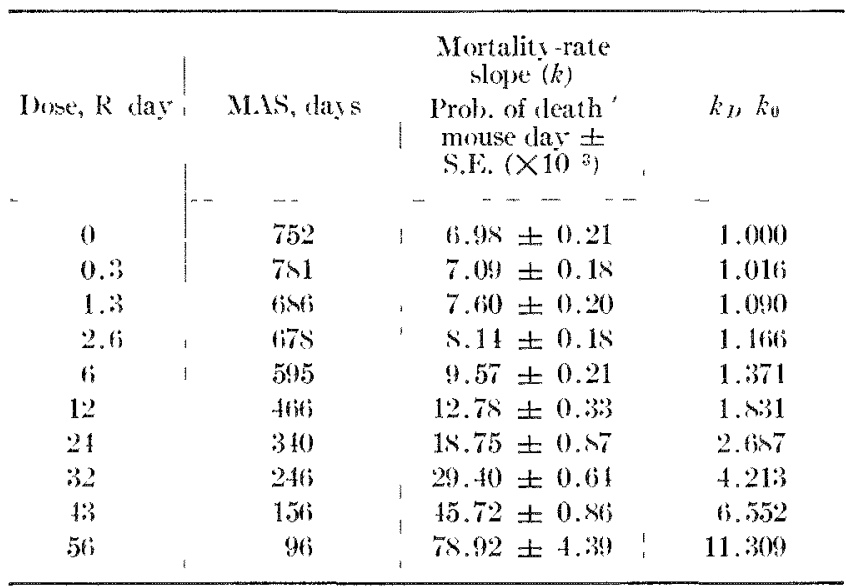

common intereept for the starting age, 100 days, wat estimated from these equations. The data were then refitterl, hut now all done groups were forcemfit through the eommon intereept. "The results of this lant analysis are shown in Table 2 and Figure 13. A later report will teal in more detail with the problem of antimation of not only life thortening rirk but also risk for sperific caures of death.

The data on life shortening and effects on tumor incidence in this report confirm some of those previously reported as well as adding rome new information. The result and the study of suitable methous of anatysis will be of particular value in the planning and execution of the Janus Program.
REFERFNC'ES

1. (Arahu, O)., (A. A. Sacher, and K. F. Hamilton. Survival of miee under daily gamma irradiation: Progress report. Argonne National Laboratory Biological and Nedical Ritsearch Division Annual Report, 1965. ANL-7136, pp. 18-20.

2. (xrahn, 1)., (4. A. Wacher, R. J. Michael Fry, J. H. Rust, F. M. Cooke, and F. Siaffeldt. Survival of mice under daily gamma irradiation: Progress report for incidence of some tumors. Argonne National Laboratory Biologiral and Medical lesearch Division Annual leport, 1968. ANL-7535, pp. $7+76$.

3. Nacher, (8. A. and D). (Arahn. Survival of miee under durattion-of-life exposure to gamma rays. T. The dosage-survival relation and the lethality funetion. $J$. Nat. ("ancer Inst. $32,27 \%-321$ (1964).

4. (irahn, I). late effects of external irradiations in animals and the prediction of low-dose effects. Biological Implications of the Nurlear Age. I.S. Atomic Energy tymposium Serien, (CONF-690393, in preparation.

5. Sacher, (x. A., D). (Aruhn, R. J. M. Fry, and J. H. Rust. Lipidemiological and cellular effects of chronic radiation exposure: A search for relationship. Proc. First Luropean Sympesium on Late Fffects of Radiations, Casaceia, Italy, April $22-23,1969$, in press.

6. (irahn, 1). Biolugical effecto of protracted low dose radiation exposure of man and animals. Prox. Colloquium on Late and subtle Efferets of Radiation on Man and Animals, Iniversity of ("hicago, May 15-17, 1969. Taylor and Franris. Itd., Isondon, in preparation.

7. Grahn, 1)., ( $x$. A. Sacher, and K. F. Hamilton. A uniformity of life shortening arnong genetically different mice under daily gammat radiation. Radiat. Res. 19, 239 (1963).

8. Humn, " $\mathrm{l}$. B. Relationship of amyloid infilt ration and renal disease in mire. J. Vat. ('aneer inst. 5, 17-28 (1914).

9. Aacher, ( $i .1$. The (iompertz transformation in the sturly of the injury-mortality relationship: Application to late radiation effects and aging. Radiation and Ageing, Wd. P.J. Lindop and ( :. A. Sacher. Taylor and Francis Latd., London, 1966, pp. $411-411$.

10. Neary, (i. Aging and radiation. Nuture 187, 10-18 (1960).

11. Brues, A. Ml and ( 4 . A. Sacher. Analysis of mammalian radiation injury and lethality. Symposium on Radiobiology, Kd. J. J. Nickson. J. Wiley \& Sons, New York, 1952, pp. 441465.

12. Inited Vations Seientific Committee on the Fiffects of Anatomic Radiation, (ieneral Assembly, Nineteenth Session, Suppl. Vo. 14 (A 5814), New York, 1964.

13. [pton, A. C., A. W. Kimball, J. Furth, K. W. Christenberry, and W. H. Benedict. Some delayed effects of atombomb radiations in mice. C'ancer lies. 20, 1-62 (1960).

11. Cpton, A.C., M. A. Kastenbaum, and J. W. Conklin. Agespecific death rates of mice exposed to ionizing radiation and radiomimetir agents. Cellular Basis and letiology of Late Somatic Effects of Ionizing Ladiation, Hd. R. J. (". Harris. Academic Press, New York, 1963, pp. 285297.

15. Rugh, R. and J. Wolff. X-irradiation sterilization of the female mouse. Fertility and Sterility 7, 516 (1956).

16. Iorenz, L., L. O. Jacohson, W. K. Heston, M. Shimkin, A. B. Lischenbrenner, M. $K$. Deringer, J. Doniger, and $R$. schweisthal. Heffects of long-continued total-body gamma 
irradiation on mice, guinea pigs and rabbits. III. Nffects on life-span, weight, blood pieture, and careinogenesis and the role of the intensity of radiation. Biological Efferts of External $\mathrm{X}$ and Gamma Radution, Fd. R. F. Zirkle. Mr. Graw-Hill, New Yorh, 1954, pp. 24-148.

17. (rahn, D) and K. F. Hamilton. Influenere of sex, envirnn- mont, and radiation factors on life shortening and tumor incidence in $\mathrm{C}^{3} \mathrm{H}_{\mathrm{g}}$ mire. Lirdiut Res. 21, $191(1964)$.

18. Lesher, S., (r. A. Sacher, D). (irahn, K. F. Ilamilton, and A. Sillese. Survival of nice under duration-of-life exposure to gamma rays. II. Pathologic effects. Radzat. Res. 24, 239276 (1965).

\title{
LONG TERM EFFECTS OF LOW DOSES OF IRRADIATION ON IMMUNE RESPONSIVENESS OF B6CF, AnI[Anl 66] MICE WITH AGE
}

\author{
Waritta Willer and Bemard N. Jarostom
}

PIRPOE AND MLTHOD

Thi- program will invertigate the changes in the immune repones with age and the efferet of nemtron and gamma irradiation upon this reqponat. "The primatry inmune response (19s and 7st is measured in term of it latent period. rate of development of antibody-forning cells and the number of antibody-forming rells. Thene factors will be determined for both rexes of the moune strain $1360^{\circ} F_{1}$ Anl[Anl 66$]$, which

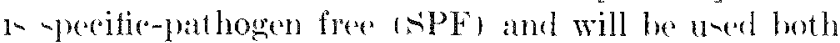
in the IANTS Program and in sudien of hone marrow reeovery from nentron and gamma irraliation. This stran is longe lived and has an L.D $)_{50}$ so after X irratiation of about 980 R.

At wath age rhomen for the tent, 4 mals and 4 female nice were given a single intraperitoneal injeretion of -hesel erythroevtem. The mire were the sherifired at different timen up to 14 days after the in-

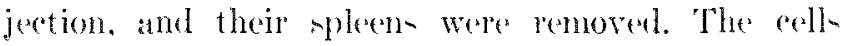
uned to examine the immune respones were freed by gentle tea-ing of the splerm- into bagle 2 medium. An aliquot of the splesen rell surpervion wa- then dispereed on a blood agar plate, and individual hemoly-in-forming cell were detereted by the clear plaguen (hemolyzed) they formed in the atgar. "This technique

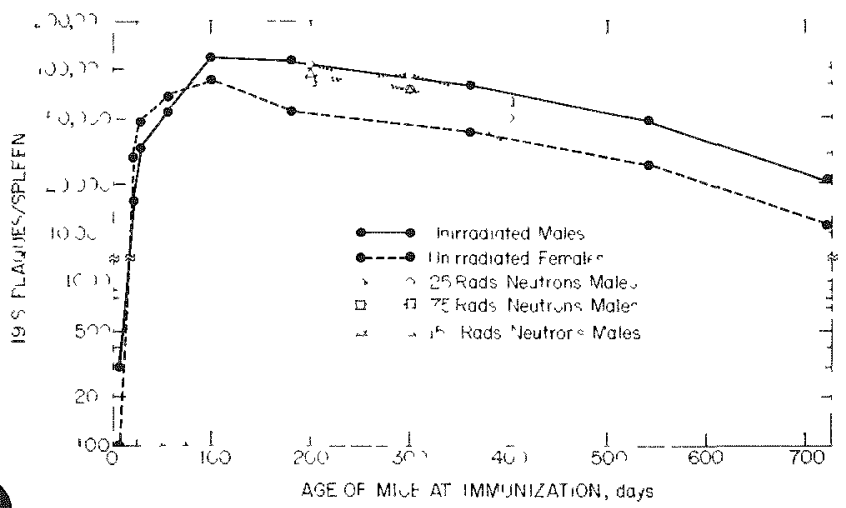

Fir. 14.-The peak number of 19 s plaque-forming cells per spleen in male and female BuC $\mathrm{F}_{1}$ Anl $[\mathrm{Anl}$ (6)] mice given a single injection of sheep erythrocytes at different ages. wa- adapted from that of .Jerne et al.'1 Almont all platpue produced are formed by exll-producing the himhly hemolytio 19s antibody. To detect red colls that are coated with the poorly hemolytio 7 antibouly, goat antimone sammat globulin is adlerd with thr romplement, as rleneribed by sterzl and Riha." This combination rewalts in hemoly-is and the appearance of plaques, where $7 x^{-}$antibody has been adorthed anto thes red exell-

PROMRLA REPOR I

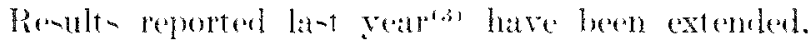
so that now we have a meantere of immunological rapacity for mate and female mies. 360. 540, and 720 day- ohl. The werlier data for mio 6, 21, 28. 56, 100. and 180 day-old, have been - mpplenented by retents of $56-$. 100-. and 180-day-old mice. so that they reprement 16, 12, and 12 nice, repertively. In addition. threes sets of 100-day-oll mies were given 2.5. 7.5. and 1.50 R of neutron radiation. renperetively. At 200, 300, and 400 days of ages 4 mine from each wet were immunized with heep $R B C$ ' and their antibody responate wat meatured.

The result in Figure 14 how that inmune respon-

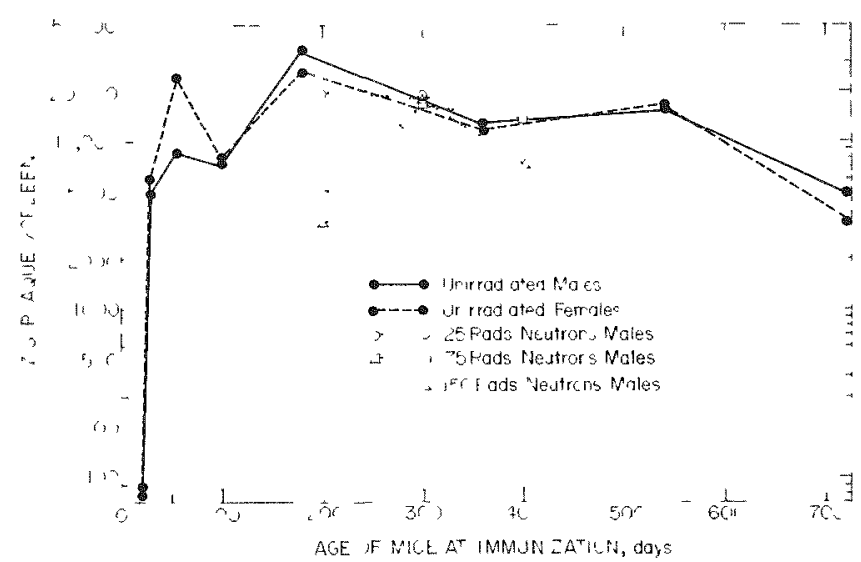

Fur. 15. - The peak number of 7 ts plaque forming cells per spleen in male and female $B 6\left({ }^{\prime} F_{1}\right.$ Anll Anl 66$]$ mice given a single injection of sheep ers throcytes at different ages. 
-ivenems, at meanured by the production of putative 19 s placues, reaches a peak between 100 to 180 days. The derline has a half-life of approximately 280 days. Males reach slightly higher peak reponiveness than females, and the rate of decline in the two groups is parallel up to 720 days. There is no significant difference between the wexe in their immunological renonsiveness at any specific age. The consintently higher number of placue-forming cells per splexn of males tented at 5) different ages from peak at 100 days gives a probability of approximately $3{ }^{c}$, that the two sexes rempond equally. There in no detectable difference between the sexes for the number of putative 75 plaques per spleen (Figure 15). At this time, wo cannot detect any late effects of any of the three doses of neatron radiation.

\section{CONCLTEION}

The number of 19 s placque-forming cells per spleen reaches a higher peak in males than in females. "The difference between them remains the same during the decline in immunological responsiveness to 720 days of age, the oldest mice tested. There is no differenco between the wexes for the 7 s plaque-forming cell- $\Delta t$ this time, no late effects (to 300 days of 25,75 , or 100 Rads of neutron irradiation have been deterted.

These experiments will be extended to include 109:dayy-old mice. We also will investigate the long term effects of different doses of neutron irradiation on the antibody reponsireness of mice that are immunologirally mature.

\section{REFERENCW}

1. Jerne, N. K., A. A. Norden, and C. Menry. The agar plate technirye for recognizing antibody-forming cells. CellBound Intibolies, Fd. F. B. Amos and H. Kaprowski. Wistar Inst. Press, Philadelphia, 1963, pp. 109-125.

2. Sterzl, J. and I. Riha. A localized haemolysis in gel method for the detection cells producing is antibody. Nature 208 , $858859(1969)$.

3. Miller, M. and B. Jaroslow. ('hanges in the immune response" of $\mathrm{BCF}_{1}$ /Anl mice with age. Argonne National Laboratory Biological and Medical Research Division Annual Report, 1968. ANL -7535 , pp. 101-102.

\section{STUDIES ON THE CORNEAL EPITHELIUM}

\section{R. J. . Wichael Fry and charlote L. Weber}

PERPOKE AND METHODS

We have continued our studies of the eell kineties of the corneal exithelium. Previously, we discused some of the reasons for choosing this timsue for call kinetic and radiation studies. ${ }^{11}$ The reason included. the accesibility which allow the cell population to be expowed to drugs, labeled DNA, RNA, and protein precurors, and altered environments in a manner similar to that used for in vitro cell systems. This atcesibility male posible the comparison of the re-ults for the entimate of IDNA synthesis by the perrent-mitones-labeled curve method in relation to the route of labeling. In lino cell kinetic studies are almont all carried out with sytemic labeling, but our previou result ${ }^{11.2}$ have rained the questions of whether the reutilization and prolonged availability of the label occurred with parenteral labeling.

The purpone of this report is to show the differences in the pereent-labeled mitores after topical and intraperitoneal labeling. Female (CF 1 Anl[Anl 66] mice, about 95 days old, were uned. Tritiated thymidine ("HTClR) 0.36 ('i mM was applied topirally and washed off with a solution containing comparable amounts of thymidine 10 min later; mice were acrificed at intervals between 2 and 18 hr. In the cane of mice sarrificed between 44 and $108 \mathrm{hr}$, the ${ }^{3}$ HTdR wan washed off with saline. Squash preparations were made, and the pereent of mitoses labeled was determined.

In a third group, label and ('oleemid were applied topirally, and nice were sacrificed hourly for $5 \mathrm{hr}$. and the labeling index of the total population was determined on sections.

PROARTES REPORT

The results for the pereent labeled mitones are shown in Table 3 and Figure 16. The ralues for 42. 48 , 5.), and $60 \mathrm{hr}$ were reported separately last yeatr. There time intervals were dome first, as it was clear that thene times were most germane to the question of "HTar reutilization. The results for the later time" intervals confirm and extend the conclusion that the differeneses in results for the estimater of cell cycles times are dependent on the route of labeling. Perhatps of more interest are the differences in the first part of the curve. The data point for the intraperitoneal group are not hown, as they were reported previously;'31 the curve has been ploted using the metin values for percent mitomes lakeled at the variou- times after labeling. The time claped between the soc; points on the first part of the curves or the areas under the curves given entimates of about 14.5 


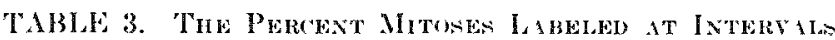
AFTER TOPICAL APPLICATION OF 'H'TdR

\begin{tabular}{|c|c|c|}
\hline Hours after labeling & $\begin{array}{c}\text { Percent mitoses laheled, } \\
\text { Mean } \pm \text { SD }\end{array}$ & Number of mice \\
\hline- & $1.1+0.6$ & $2^{-\cdots}$ \\
\hline 3 & $12.6 \pm 12.5$ & 3 \\
\hline 4 & $73.5 \pm 16.0$ & 3 \\
\hline 5 & $83.9 \pm 0.9$ & 2 \\
\hline 6 & $97.4 \pm 4.2$ & 3 \\
\hline$x$ & $99.8 \pm 0.4$ & 3 \\
\hline 10 & $99 . x \pm 0.4$ & 3 \\
\hline 12 & $92.6 \pm 6.3$ & ti \\
\hline 14 & $65.3 \pm 27.4$ & 3 \\
\hline 16 & $20.3 \pm 11.3$ & 3 \\
\hline $1 s$ & $2.3 \pm 2.7$ & : \\
\hline 44 & $0.4 \pm 0.6$ & 2 \\
\hline 55 & $1.1 \pm 1.3$ & 2 \\
\hline 6) & $1.5 \pm 0.7$ & 2 \\
\hline fis & $7.8 \pm 3.1$ & 3 \\
\hline 74 & $2.3 \pm 1.0$ & 3 \\
\hline 84 & $15.3 \pm 9.0$ & 3 \\
\hline 96 & $9.6 \pm 0.4$ & 3 \\
\hline $10 \%$ & $11.9 \pm 6.1$ & 3 \\
\hline
\end{tabular}

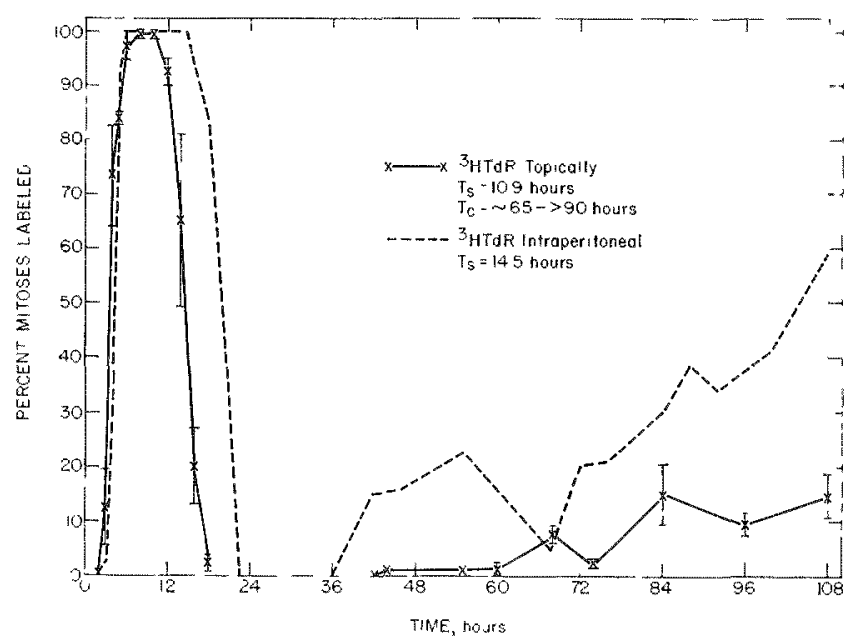

Ficx. 16.--Percent mitoses labeled in comest epithelium following topieal or intraperitoneal administration of ${ }^{3} \mathrm{HTdl}$.

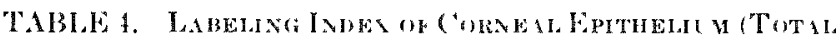

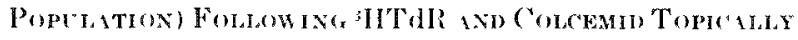

Time after label, hr
--
1
2
3
4
5

labeling inder \pm S.E.

$$
\begin{aligned}
& 3.4 \pm 0.2 \\
& 3.2 \pm 0.4 \\
& 3.0 \pm 0.5 \\
& 2.7 \pm 0.4 \\
& 2.5 \pm 0.3
\end{aligned}
$$

atnd 11 hr for the duration of DNA sytheris for the intraperitoneal- and topieal-labeling groups, respertively. Table 4 show the results for labeling index after topieal applieation of ${ }^{3}$ HThl and Colcemirl. colcemid prevents an increase in the labeling index due to cell divinion. No increate in labeling index $0^{\circ-}$ curred over the period of the experiment, which suggest: that the arailability of the label with topical administ ration wa- lem than one ler.

CONCLIMION

The results suggest that topical application can provide at satisfaretory pulse labeling method to study cell kineties in the comea. It appears that the estimate of the duration DNA sythesis with intraperitoneal injection is an orerentimate due at least in part. to the duration of the pulee of labeling. These results illustrate the importanee of determining the curation of the arailability of the label in in rive experiments.

\section{REF HRFNCL}

1. Fry, R. J. M., (". 1. Weber, and J. K. Newlin. Studies on the moneal epithelium. Argonne Nat ional Laboratory Biological and Medical Research Division Annual Report, 1968. ANL $7535, p p .76-77$.

2. Fry, R. J. M., C. Weher, and J. Newlin. Cell kinetios in the corneal epithelinm of the monse. liatiat. Res. 35, 485 tion (1978).

3. Fry, R. J. M. and ('. Weber. Studiess of the corneal epithelium of mice. I. and II. Argonne National Laboratory Biological and Medical Research Division Anmul Report, 1967. ANI -7409, pp. $1 \times 8-191$.

\title{
SOME FACTORS THAT INFLUENCE THE UPTAKE OF TRITIATED THYMIDINE. 1.
}

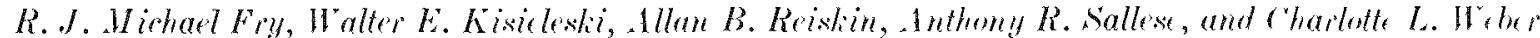

\section{PU RPOSE AND METHOD}

The finding, reported last year"1 on the radioaretivity in various tim-uen of two -pereses of ham-ter following injection of different dones of tritiated thymitine ( $\left.{ }^{3} \mathrm{HT} d \mathrm{R}\right)$ of three specific activities raised a number of questions. It wat clear that the labeling intex of the comeal epithelimm of the (chinese ham-ter increased between 1 and $3 \mathrm{hr}$ following intraperitoneal injertion. It wats also found that the total radioactivity in the intestine rose in the interval between 1 and $3 \mathrm{hr}$. These finding- -timulater at re-examination of the factor influencing the duration of availatility of 
3HTdR in in vive experiments. The gut and eye have again been chosen as the tissues for study, but the mouse wan used instead of the hameter because of the diffeculties in performing intravenous injections in the hamster. "Three quentions have been anked. (1) In the uptake of tritiated thymidine ("HTdR) into arypt cell of the jejunum influenced by the ronte of injection? (2) Does the uptake last only for a brief period (usually assumed to be about $1 / 2$ hr)? (3) Is the uptake of "HTdR by the gut affected by time of day independent of route of labeling? Male $B{ }^{~}{ }^{\circ} F_{1}$ Anl [Anl 66] mice, 120 days of age, 30-garerage weight, were und. The following experiments were done:

1. ${ }^{3} \mathrm{HTdR}, 0.5 \mu$ ('i, g, 0.36 ('i m.I, this done and -pecific activity was uned in all the experiments) wan injected either intraperitoneally or intravenously at 1200 and $2400 \mathrm{hr}$, and mice were aterified one hour later. Samples of the jejunum and the eyes were removed, and the ${ }^{3} \mathrm{H}$ content wan determined by a ligquid scintillation count ing method.' ${ }^{11}$

2. Mice were injerted as in Experiment 1 at 1400 hr and acrificed one hour later. squash preparations of jejunal erypt- were marle, and antoradiographwere prepared using Ilford $\mathrm{K} 2$ liquid emulsion and an exposure of 4 days. The mean grain eount per erypt cell was determinet.

3. Three type of determination were carried out: (a) the number of labeled cells per crypt squath and the ${ }^{3} \mathrm{H}$ content $3 \mathrm{hr}$ after intraperitoneal and intravenous injection of "ITTdR, (h) the number of labeled cells at $1 \mathrm{hr}$ after intraperitoneal injection of ${ }^{3} \mathrm{HTdR}$ and $6 \mathrm{hr}$ after "IITdR and colcemid $5 \mu \mathrm{g} g$ at 0 and $3 \mathrm{hr}$, and $1 \mathrm{c}$ the number of labeled Colecmid blocked-metaphase edls at $1,2,3,4$, and $6 \mathrm{hr}$ after intraperitoneal injection of ${ }^{3} \mathrm{HTdR}$ and Colemid. In experiment lat the number of labeled eclls wan the sum of cells in $S$ and progeny of initially labeled cells. In Experiment the if the colecmid block wan sati-

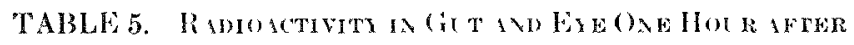

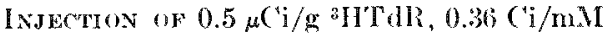

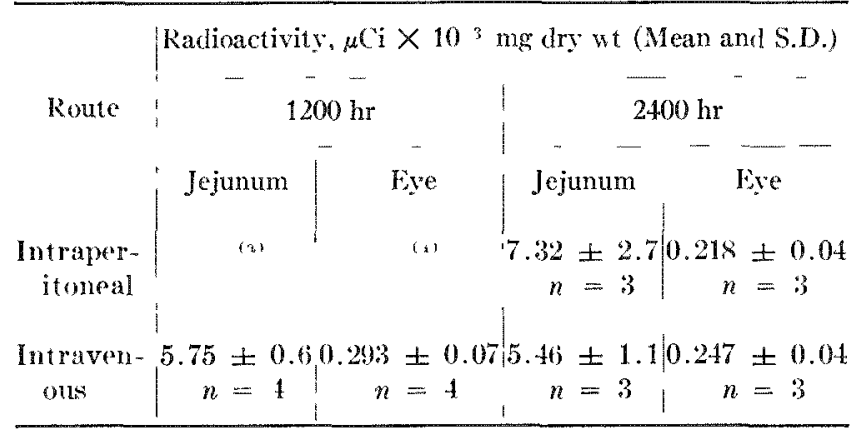

(b) 3 mice were injected IP; in 1 wo mice the values were very low, suggesting that the label was not injerted correctly.

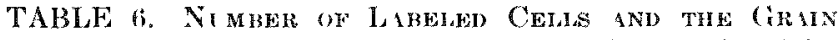
('UCNT ONE HOCR AFTER ${ }^{3} \mathrm{HTdR}^{\prime}, 0.5 \mu \mathrm{Ci} / \mathrm{g}, 0.36 \mathrm{Ci} / \mathrm{mM}$

\begin{tabular}{|c|c|c|}
\hline & $\begin{array}{l}\text { Mean No. of labeled } \\
\text { cells 'crypt } \\
\text { squash } \pm \text { S.F. }\end{array}$ & $\begin{array}{l}\text { Mean grain } \\
\text { count, crypt } \\
\text { cell } \pm \mathrm{S} . \mathrm{E} .\end{array}$ \\
\hline Intravenotus & $\begin{array}{c}19.7 \pm 1.7 \\
(3 \text { mice, } 69 \text { crypto })\end{array}$ & $\begin{array}{c}10.5 \pm 0.16(1) \\
(3 \text { mices } 1512 \text { cells })\end{array}$ \\
\hline Intraperitoneal & $\begin{array}{c}59.7 \pm 1.7 \\
\text { (3 mice, } 71 \text { (rrypts) }\end{array}$ & $\begin{array}{c}12.9 \pm 0.2 \\
\text { (3 mice, } 1340 \text { cells) }\end{array}$ \\
\hline
\end{tabular}

a The mean grain eounts of erupt cells from the two groups were different $(P>0.001)$.

factory, any increase in labeled cells over the 6-hr period would be due to flow of eclls into $x$ during the 1-to-6-hr period. In Experiment $(0)$ the following an-umption were made: (1) Coleemid does not alter the age distribution, c.g. hy altering flux into $S$. and it - teady state existed, 12 , the metaphase blocking action of colcemid was complete within a period equal to the minimum to plus.$M$ period and lasted $3 \mathrm{hr}$, (3) blocked lakbled motaphawes did not disappear in $3 \mathrm{hr}$. If the latter two as-umptions were not ralid the number of labeled motaphasen would be understimated by this method.

\section{PROMIRES REPORT}

The results of Experiment 1 are shown in Table .5 and can be summarized an follows. There is no signifieant difference in the "H content of the samples of jejunum and the eye injected at noon and midnight when the label in injected intravenourly. Due to the large variation in the values obtained following IP injection at $1200 \mathrm{hr}$ cperhaps due to incorrect injection in two mices the higher value of "II content in the intestine at $2400 \mathrm{hr}$ with IP injection war not significantly different from the value for the IV group. However, thene result raine the question whether reported diumal rariations determines $b y$ labeling experiment were influeneed by the route of injertion.

The result of Experiment 2 are shown in Table 6 and Figure 17. Both the number of labeled erypt cells and the mean number of grains per erypt eell were signifieantly higher following intraperitoneal injertion. These results could be due to a pulse of longer duration with the intraperitoneal injection, with or without local uptake from the peritoneal cavity occurring apart from uptake by systemic distribution. Skougaard and Stewart ${ }^{(2)}$ previously reported a similar difference in grain counts for crypt cells on sectioned material following intraperitoneal and intramuscular injertions. The magnitude of the difference in the mean number of labeled cells per crypt rqua-h 
is surprising, considering sacrifice was at one hour after injection. If the grain count distribution in the intravenously injected group resulted in false negatives, then the apparent difference in labeled cells per erypt squash would be increased. These results raise the question of the suitability of intraperitoneal injections for certain types of labeling experiment.

The results for Experiment $3(a)$ are shown in Table 7. There is an increase in the "II content at 3 hr, which is signifieant at the 0.01 level. The increase in number of labeled cells per crypt squash is not -ignificant.

In Experiment 3(b) the result for the number of labeled cells per erypt aquath are shown in Table 7 .

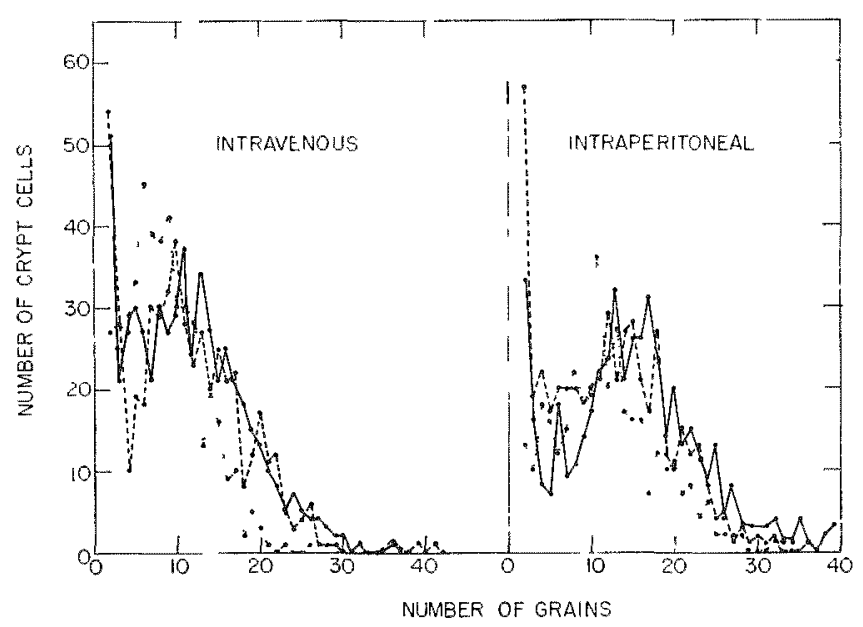

Fik. 17.- The frequeney distribution of number of grains per erypt cell following (a) intravenous and (b) int raperitoneal injection of ${ }^{3} \mathrm{HTdR}, 0.5 \mu\left({ }^{\prime} \mathrm{i} g, 0.36 \mathrm{C}^{\circ} \mathrm{i} \mathrm{mM}\right.$.

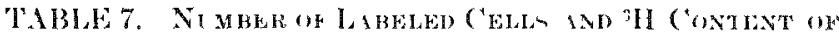
THE JHJ VI M

\begin{tabular}{l|l|l}
$\begin{array}{c}\text { Mean No of } \\
\text { cells crypt squash }\end{array}$ & $\begin{array}{c}\text { Radioactivity, } \\
\mu\left(\ddot{i} \times 10^{3}, \mathrm{mg}\right.\end{array}$ \\
\hline
\end{tabular}

$3 \mathrm{hr}$ after ${ }^{3} \mathrm{HTdR}, 0.5 \mu(\mathrm{i} / \mathrm{g}, 0.36 \mathrm{i}(\mathrm{i} / \mathrm{mM}$

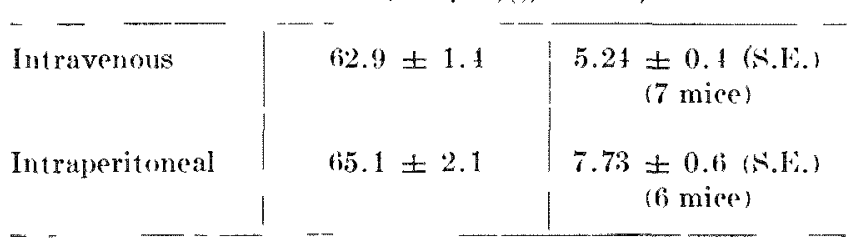

$6 \mathrm{hr}$ after ${ }^{31 \mathrm{~T} d \mathrm{R}}$ and colcemid

Intravenous

$42.0 \pm 2.6$

$39.7 \pm 1.8$

$50.6 \pm 2.9$

$54.3 \pm 3.7$

$53.1 \pm 2.8$

$53.1 \pm 2.6$

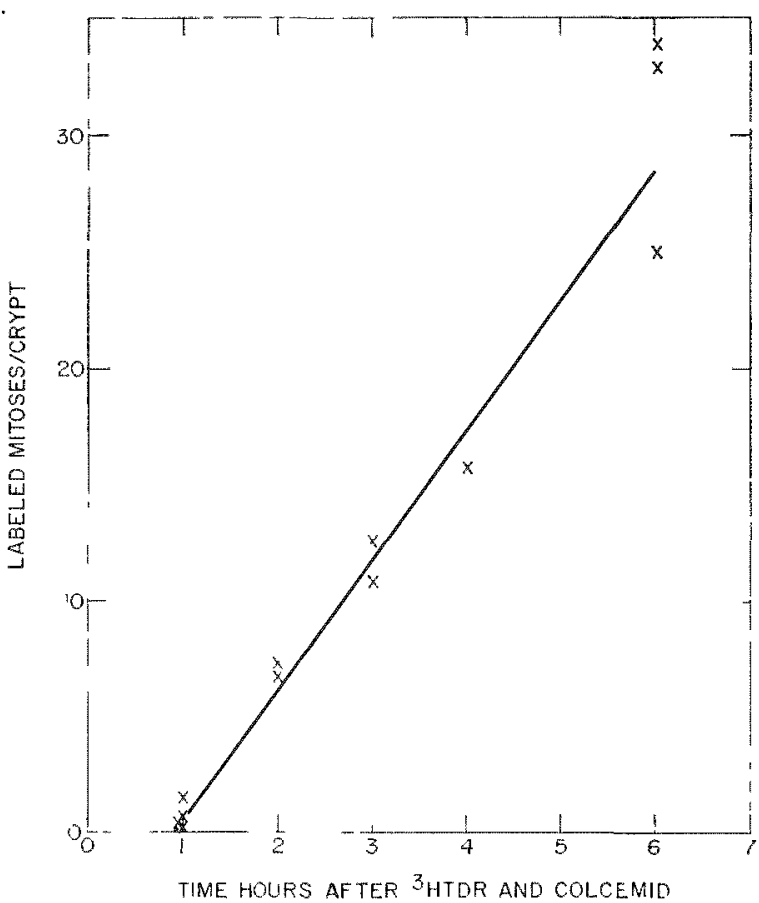

Firx. 18." The mean number of labeled blorked metaphatess per crypt squash as a funetion of time following injection of HThle at 0 hr and ('olcemid at 0 and $3 \mathrm{hr}$.

The metn number of labeled eells per crypt requash at $1 \mathrm{hr}$ was $43.4 \pm 1.5$ (s.E. of the mean) and the $.53 .5 \pm 1.7$ at $6 \mathrm{hr}$; there values are rignifirantly different at the 1': level.

In Experiment $3(\mathrm{c})$ an extimate of the duration of $\therefore$ wat obtained from determining the rate of flow of rells from $s$ to.$M$ and the number of cell initially in $\therefore$. If reptain asmumtions are made, for example, that a steardy state exists, then $T$, the mean time in $s$ of cello initially labeled ${ }_{*}$ may be obtained:

$$
T=V_{s} b
$$

inee $b=\Delta . I$ 't where $b$ is the rate of flow of cell from $S$ to $M$ and $\Delta . I I$ is the increment of latheled blocked metaphasen during a period $t$.

The number of labeled blocked metaphasen was plotted an a function of time (Figure 181 and the point were fitted with a regresion line. The slope was $7.2 \pm 0.6 \mathrm{hr}$. The nean number of labeled cell- pere erypt squash wat $54.4 \pm 1.5$ (3 mire. 60 crypt-1. Substitution of these raluen gives a value for $T$ of $6.03 \mathrm{hr}$. This reults in about $1 \mathrm{hr}$ less than the value obtained hy the pereent mitoser labeled methods. It should be pointed out that this method is dependent on the validity of the assumptions and the aceuracy, in particular, of the number of initially labeled cells. The results by this method are not afferted by protracted availability of label. 
DISCUSAION

The importance of the duration of the availability of injected ${ }^{3} \mathrm{HTdR}$ was recognized and investigated by a number of workers. ${ }^{13-6)}$ The effect of route of administration on uptaks has also been investigatted. (2, 3)

Skougaard and stewart'2) interpreted their result in the following way. If tritiated thymidine is injeeted intraperitoneally, a fration of the label may be absorbed directly across the intestinal wall into the intestinal blool supply, resulting in a higher effertive dose for the gut compared to other tissues outside the peritoneal earity. It is of little importanee, for in the direct route from peritoneal eavity to erypt cell the intestinal circulation probably plays a minor role. and direct diffusion is more important. The important point is that in some cell kinetic studien the uptake" of the label in dependent on the route of injection. and, therefore, the tisule-cell characterintice that one assumes are not the only factor influeneing the uptake. Of particular importance to many of the eell kinetic studies is whether the route of injertion influences the duration of arailability. Time was not a variable in the experiment of skongatard and stewart or of Potersen and Baserga. (3) Therefore. these studies did not reveal evidenere that the duration of arailahility might differ hetween intraperitoneal and intravenous administration. A great many of the cell kinetic studies in rodent, have been carried out with intraperitoneal injection. Studies on the cell kinetice of aseites tumor cells have been similarly inventigated. The results in this report raise the question of the appropriatenes of the intraperitoneal injertion in any experiment in which duration of availability in of importanee. It is alse po-xible that variation of local uptake of label in the gut may make interpretation of diumal variation in uptake by ti-sues outside the peritoneal "avity difficult.
CONCLTMONS

The results of thesese experiments show that:

1. The uptake of "IITilR by crypt cells of the jejunum is greater when this label in given intraperitoneally than intravenously.

2. The duration of availability may be longer when "IITdR is given intraperitoneally. Whether the stimate of the duration of DNA synthesis by the percent mitones labeled methor is influeneed by the route of injection is being inventigaterl.

3. When "HTilR was given intravenouly, there wan no difference in the total radioactivity in the gat or ere of group of mier injected at 1200 and $2400 \mathrm{hr}$. The uptake following injection by the two router as a function of time of day will be studied further by isolating the $1 \mathrm{NA}$ and determining specific activitien.

\section{RFH ERENCEN}

1. Reiskin, A. (4., A. R. Sallewe, W. K. Kisieleski, A. A. Tyler, J. L. Vewlin, and R. J. M. Fry. The effect of various dose levels and specific activities of tritiated thymidine in $t w 0$ species of hamster. Argonne National Laboratory Biologieal and Medieal Research Division Annual Report, $190 \mathrm{~s}$.

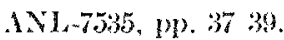

2. Hougaard, M. R. and P. A. Ntewart. Comparative effectiveness of intraperitoneal and intramuscular ${ }^{\prime} T d R$ injection routes in mices. Exp. ('ell Res. 45, 158-1665 (1967).

3. Petersen, R. O. and R. Baserga. Ronte of injection and uptake of tritiated precursurs. Arch. Path. 77, 582-586 (1961).

4. Blenkinsopp, W. K. Muration of availability of tritiated thymidine following intraperitoneal injection. $J$. ('ell. Sci. 3, $91-95$ (1968).

5. Starnscik, R. N., W. H. Jenkins, and M. I. Mendelsohn. Availability of tritiated thrmidine after intravenous administration. Fature 202, $456-458$ (1974).

6. Koburg. H. The use of grain eounts in the study of rell proliferation. Cell Proliferation, Ed. L. F. Iamerton and R. J. M. Fry. Blachwell serentific Publications, Oxford, 1943, pp. $62-76$.

\section{SOME FACTORS THAT INFLUENCE THE UPTAKE OF TRITIATED THYMIDINE. II.}

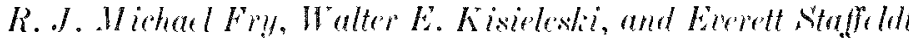 \\ P[RPONE AND METHODN \\ Studies dependent on the uptake of tritiated thy- \\ midine "IITrdR in Rattus natulensis Mantomvis \\ have been frustrating beeause of an inordinate num- \\ ber of atpparent failure in lebeling. Injeetions hatre \\ been given intraperitoneally, partly becalues of the \\ diffeculty in handling these animals for such proces- \\ dures as intrasenous injections. The purpose of this
}

report is to give the renult of an experiment to determine whether antesthetizing the animals reduced the number of unsatisfartory rewult in labeling and the interanimal variation in uptake. Two different typer of anterthetion were chonen, lat ether and (b) Xembutal.

Intraperitoneal injection- of ${ }^{3} \mathrm{HT}$ Th, $0.5 \mu \mathrm{c} \mathrm{i}$ 0.36 ( $\mathrm{i} \mathrm{mM}$. in $0.4 \mathrm{ml}$ saline were given to Mastomys 


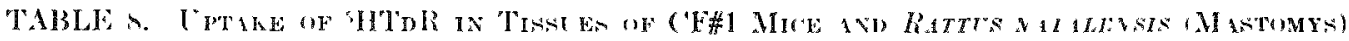

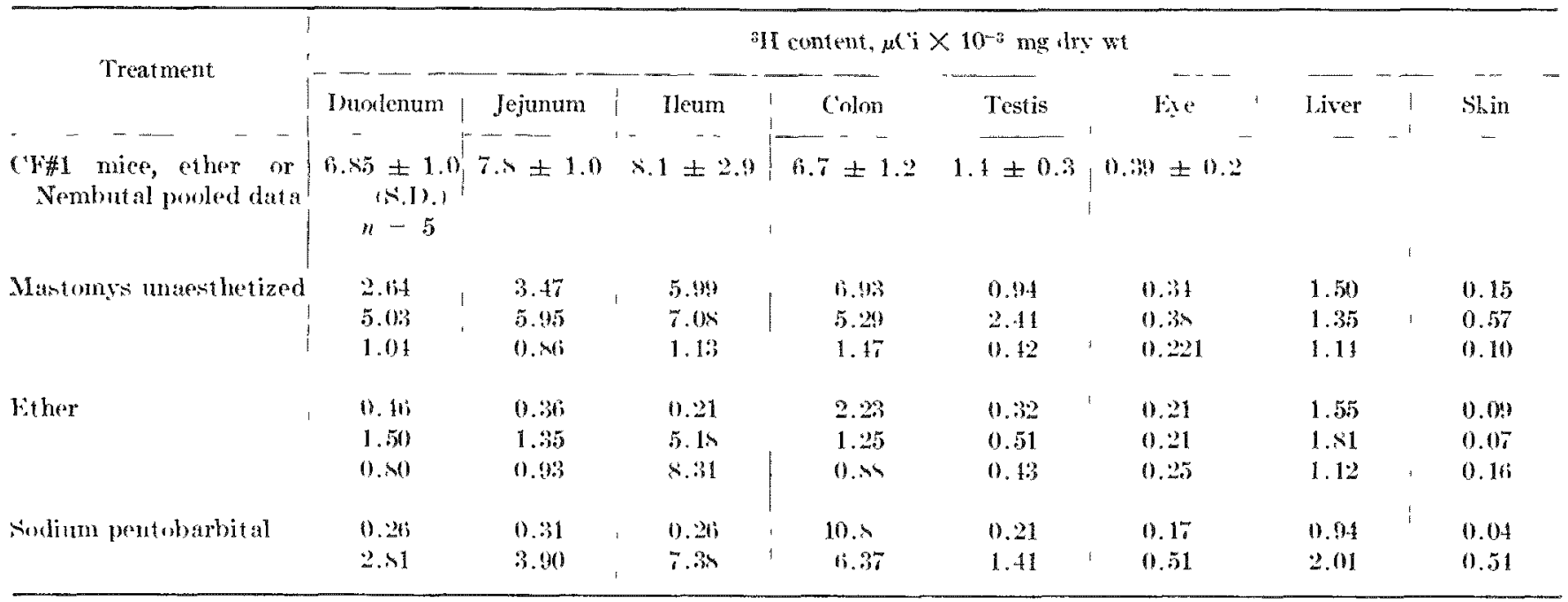

which were unathentized or anaththetizen with (a) ether or (b) sodium pentobarbital $10.4 \mathrm{mg} g$ ). "Two hours after injection the animals were sacrificel and -imples of 4 regions of the gitt, the testis, eve, liver, skin. and other tistuen were taken. The tritium eontent was determined be a scintillation counting methorl. (1) Results for anaesthetized C F 1 Anl Anl 66] mice treated similarly are given for romparion.

\section{PROMRES REPORT}

The results are shown in "Table 8. It was found that with CF 1 micesenther type of andesthestic had an apparent effect on the uptake so the results for is mier given either ether or nembutal prion to injection have hesen pooled.

In the Mastomys the she content of timones showed marked interanimal variation in the three groups. There is no evidenee that anathetizing the animal improver the reprodusibility of remlts. In fact, though perhap coincidentally, the intramimal variation increased. For exmple. the rexional differencon in the uptake of "HTdR hy the gut of individual animals was very marked in the groul) given (thex. In one animal the ileum had about ten times the amount in other regions of the gut but the levels of "H in the other orgats suggent that -5 -temic distribution of the label oceurreel. In one of the animals given Nembu- tal the "H content in the colon was over 30 times that in the other rexions of the gut. In this animal other tis-nes showed lower levels of "H than the arerage of that the injection may have heen into the colon. It is colear that intraperitoneal injertions in

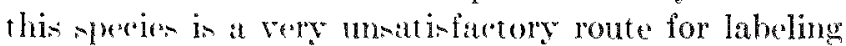
exporiments and that andesthetizing is of no help.

The generally lower "II content in the wall intertine of the Mastomys compated to that in the ( $\mathrm{F}]$ mire is comsintent with the significanty longer turnorer times in the jegunm of the Ma-tomys about $130 h \mathrm{r}^{12 \mathrm{t}}$

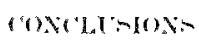

These results show that in the Matstomy the up1:ke of "HTdR following intraperitoneal injertion is ren more vitriable than in the mousc.

\section{REFTRFNCT-}

1. Kisieleski, W. F. and 1. (i. Inther. A combustion method

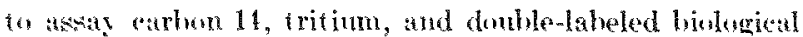
materials. Argonne National Laboratory Biological and Medical Researeh Division Annual Report, 1965. ANT,-709, pp. $70-72$.

2. Fry, R. J. Mehatul, A. B. Reishin, W. Kisieleski, A. Sallewe, and L. Staffeldt. Riadiation effeers and rell renewal in

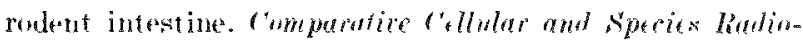
sensitivity, Ed. V. P. Bumd and T. Silguhara. Igakn shoin Lat., Tokyo. 1964, pp. 25.5-270. 


\section{SENSITIVITY OF ACATALASEMIC MICE TO RADIATION-INDUCED MOTIVATION}

Dale D. Worris and Robert I. Feinstein

PIRPOAE AND METHODS

A single exposure of ionizing radiation used to condition an aversion to saceharin-flavored water is well established in animal behavior reatarch.' ${ }^{2}$ No mechanism responsible for this postirndiation saccharin avoidance behavior hats been aceepted. A possible explanation is the humoral motivating farter that Hunt, carroll, and limeldorf postulated from bohavional antalyis, ung parabiont rat pairs with at skin-vareular andomonis.". "They suggest that this behavioral effect might reflect toxieity from products of cellular brealidown or the lowe from the vascular sistem of an unidentified substance. It allow hat been pestulated that hrodrogen peroxide (11.20), produced in irradiated atqueous solutions, may serve an al cole in postirradiation saceharin aversion in mice."

If rarliation-produced HeO is relereant to humoral mediation of radiation recognition. animals lows able fo degrade Het) should be abnomally resonsive to pestirradiation sacelatrin aroidance behavior. Such low catalase animals are now arailable: the "acatalasemie" mouse strain, $e^{b b}$, developed in this laboratory. This mouse trpically exhibits a blowd ratalake artivity 1 to $^{2} 2^{\prime}$, of normal, and catalane activity of it varions

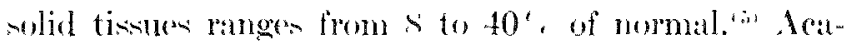
talasemice mice also are combiderably more sensitive to intraperitoneally injected $\mathrm{H}_{2}$ h. than are normal mire. Relatively high survival of the miere after acute whole body $x$ irradiation suggests that their low catalase level maty actually protect them from raliation injury.

In the 196s Annual lieport, ${ }^{77}$ we deseribed a test of 20 actatalaremise and 20 normal mies $\left.(6)^{\prime \prime}\right)$ of the struin from which the acatalasemic mutant was derived. There wis ne differenee between the initial saceharin

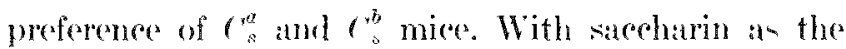
conditioned stimulus and X rays as the unconditioned stimulus, both strains showed an arersion to sacharin after conditioning. The ${ }^{\cdot b}$ mice exhibited aversion to a lemererextent than dide mice.

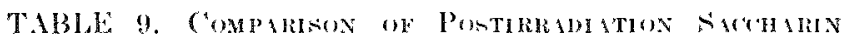

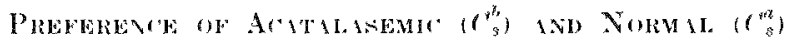

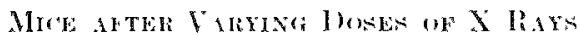

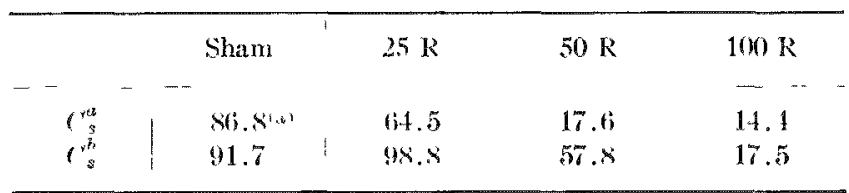

s.) The preference score is the pereentage of situreharin consumed of the cotal liquid comsumption.
PROMRESS REPORT

In a second test, postirradiation salceharin preference wis compared in $c_{s}^{b}$ and $c_{s}^{a b}$ mice after varying exposures of $X$ rays. liesults of this experiment ares presented in Table 9. Again, normal mice exhibited a greater aversion to satceharin than did acatalasemic mice. While the greater difference between these two strains was obtained at an exponure of no $\mathrm{h}(\mathrm{P}<0.001$, a cleat and signifirant $\left(P^{3}<0.01\right)$ differencese alow was obtained at 2.5 R. Revulte of this experiment are published in Nature is:

In later experiment w utilizing the saccharin aversion paraligm, we attempted to modify the postirradiation

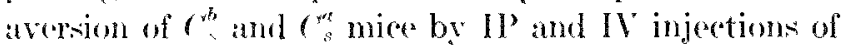
eatalase (Worthington ("TR, 0.02 $\mathrm{ml}$ g body weighti. Neither route of injertion modified the animal's aversion to saceharin in comparion to control animals. Tentatively, we concluded that the catalate molecule may be too large (o) afferet the receptor site involved in the humoral motivating factor when ardministered in this farhion.

foing a molification of the waceharin arexion paradigm, experiments in which e $e_{s}^{b}$ and $r_{s}^{\text {se mice received }}$ an injection of irmadiated blowd pla-mat in platere of the uatul $x$ ray expesure were performed. The blocd was drawn from donor $\left(c_{s}^{\prime \prime}\right.$ and $c_{s}^{\prime \prime}$ mice, was irradiated with 30 hR of gamma rays, was centrifuged, and the platma was injected Il' inte the experimental $e^{\text {ac }}$ and $\boldsymbol{r}^{b}$ miece. Ife were unable to endition statistically reliable aversion to saccharin with this techniques. Garciat, Ervin, and koelling previous ly hat reported saceharin aversion by injecting the werum from animals which harl been irradiated before the bleod was drawn. dithough further research is necessary for complete specification, the humoral motivating facetor may be due to a circulating by-produet of energy absorption with texin-like effects that are humorally mediated, but which recuires receptor cites other thatn humoral sites for generation.

In experiments currently in progress, IP injections

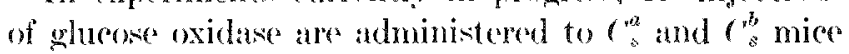
in place of the usual $X$-ray exposure used in the saccharin averion paradigm. The dove-response curve for gluesse oxidase which produces $\mathrm{H}_{\mathrm{o}} \mathrm{O}$, by enzymatic reatetion) is similar to that obtained after $X$ irradiation for both groups of animals.

CONGTISTON

The saceharin aversion behavior of normal and acutalasemic mice differs significantly. Becuume the 
only known difference between these two strains is their blood and tisue catalise, hydrogen peroxide must be involved in the aversion phenomenon. If $\mathrm{H}_{2} \mathrm{O}_{2}$ per os is remponsible for the aversion, one would, a priori. expect the acatalasemic strain to be more sensitive, because $\mathrm{H}_{2}\left(\mathrm{O}_{2}\right.$ will remain intact longer in these animals. This is not the eare; the acatalasemic mouse exhibits lese radiation-indued aversion. This implies that the actual aversive stimulus is dependent upon the presence 'f both $\left.\mathrm{H}_{2} \mathrm{O}\right)_{2}$ and catalase. Because the only products of the catalatic reaction are oxygen and water, neither of which appears a likely randidate, it is suggested that the arctual aversive stimulus is a product of the peroxidatice action of eatalase; the ehemiral identity of this product is monkown.

\section{REILREN 'ES}

1. Kimeldorf. D. J. and F. L. Hunt . Ionizing Radiation: . Leurel Function and Behavior. Academic Press, New York, 1965.

2. Hunt, L. L., II. W. Carroll, and 1). J. Kimeldorf. Humoral mediation of radiation-induced motivation in parabiont rats. Sicience $160,1717-1748$ (1965).

8. Lelan, H. and W. S. Mous. Possible efferts on radiationproduced hydrogen peroxide on postirradiation aversion in mice. Experientia 23, 719-751 (1967).

4. Feinstein, R. N.. J. B. Ifow ard, J. T. Braun, and J. F. Seaholm. Aratalasemic and hypocatalasemic mouse mutants. Gentirs 53, 923938 (1966i).

5. Feinstein, R. N., J. T. Braun, and J. B. Howard. Aratalasemic and hypocat alasenic mouse mutants. II. Mut at ional variations in blood solid tissue catalases. Arh. Biorhem. Biophys. 120, 165169 (196i).

6. Feinstein, R. N.. J. T. Faulhaber, and J. B. Howard. Sensitivity of acatalasemie mice to acute and chronic irradiation and related conditions. Radiat Res. 35, 311-319 (196s).

7. Morris, 1). D. and R. N. Feinstein. Sensitivity of acatalasemic mice to radiation induced motivation. Argnme National Laboratory I Division of Biological and Medical Research Annual Report, 1968. AN $\Gamma_{-}-7535, \mathrm{pp} .98-99$.

8. Morris, I). I). and R. X. Feinstein. Mechanism of monse awareness of X radiation. Lature 222, tis8-489 (1969).

9. Careia. J.. F. R. Frvin, and R. A. Kuelling. Tosienty of serum from irradiated donors. Nature 213, 682 6s:3 (1967).

\title{
AN ENZYMATICALLY INACTIVE CATALASE-ANTICATALASE
}

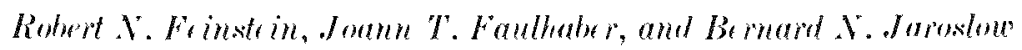

\section{PI RPOCE AND MLTHODS}

It has been known since 1939'1. 2) that if one speecien of animal the rabhit has been most ured) is immunized to atalawe prepared from liver or blood of another speries, the antibodies produen will complex with the relevant antigen to produces a complex which in catalatieally active. The presumption in that the primary antigenic site of the eatala-e molecule is -patially di-tinet from the enzyme active site.

An acatali-mire and four hyporatalianemir mutant trains of mire have been derelopeed in this laboratory.'31 We hates recently -hown's that the blood eatalase of nomal. acatalanemir, and hypocatalanemie mice all have apparently identical primary antigenic -ites and presumably differ only in the enzyme active site. The posibility has therefore been comistered that if one strain of miere is uned as blood donor, and another strain as recipient. the recipient mice may generate antibodies which would of necessity be directed to the enzyme active site and henee would produer an enzymatieally inartive catalane-anticatalane complex.

In the earlier paperen it was shown that if one -train of moure in "immunized" "against another strain on a shedule satisfactory for the produetion of rabbit-antimouse blood catalate antibodies, no antibodies are detertable. This is probably not surprising, since one would expeet a priori that any other area of the catalases molecule would prove les -trongly antigenic than that area which is the primary antigenic -ite. We have, howerer, attempted a very much more intensire inmunization of moune strain- against each other and hate obtained some evidence of the production of antibodie.

Antigens need were aponin-lyaed hemolyatem of pueked but not wahed erythroegten from $r s^{\prime \prime}$ mormale, (" $x^{\prime \prime}$ (atatalisemic), and ("se (hypocatala-mic) miee. The exact immunization sehedule is not provided in this hrief report, but uffiose to say that the process of inmmization extended orer at period of nine monthe, and was o intem-ive that fewer than sol, of the miere surviverl.

Terhniques emplowerl for the detection of anticatalatere were -tandard ouchterlony double diffu-ion. and inmunoelectrophorei- both performed with the LKB Produkter apparatus. In the "ase of mouse-antimoune sera. the mere appearanes of a precipitin line is con-idered presumptive evidenes of the production of anticatalase, berature "atalase i- considered to he the only molecule with revect to which theres strain rliffer. In the "ase of rabhit-antimoure sera, however, many precipitin lines are produced, because the immunizing antigen employed wa whole hemolysate of moune erythroevten. In this rane, the catalaseanticatalase line in easily identified by flooding the 


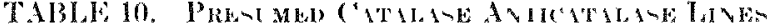

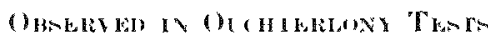

\begin{tabular}{|c|c|c|}
\hline $\begin{array}{l}\text { Antigen } \\
\text { (1) Wood souree)". }\end{array}$ & $\begin{array}{l}\text { Antiserum } \\
\text { (immunized mice) }\end{array}$ & Resulto \\
\hline$\ldots \ldots$ & (2) & \\
\hline Normal & Normal & Nogntive \\
\hline Normal & Aratalasemia & Positive \\
\hline Normal & Hypestalanemic & Positive \\
\hline Aratalanemic & Normal & Positiven: \\
\hline loatalanemic & Hy penestalatemice & Vegalive \\
\hline deatalanemic & Actilalanemio & Nogative \\
\hline Hy pueatalanemio & Normal & Positive \\
\hline Hivporat alatsemic & Aratalasemic & Negative \\
\hline
\end{tabular}

¿Antigen is blood lisate from stated mutants or normal unild tope, controli mice. Antiserum is from stated mutant or normal mice immunized with the desienated antigen.

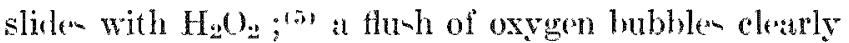
demomet raten the prenence of eatalatic activity.

PRUMBLAT REPURT

Table 10 indicaten the permutations of antigen donor and recipient und, and precipitin lines cpresumed to be ratalane--anticatalated observerl. All innmunization schedulen were islentical. It will be ohserved that normal mice evidently produced antibodien against acatalatemice and hyporatalatemio mou-e blood catalases, and acatalaremie and hyporatala-emic mice produred antibodies against normal moune blood cataliane, but acatalasemic and hypocatalasemic mice produced no detectable antibodies again-t the blood eatalase of each other. This is perhaps a predictable findiug, because it haw been -hown ${ }^{(6)}$ that the differences between the catalases of normal mice and those of all the mutant strains are probahly greater than differences between those of inutants.

It should be emphanized that the findinge des'ribed are not invariable. Even repeat tests of the identical antirera sometimes do. and sometimes do not, how preripitin lines. We have. however, reen clets and ummintakable lines for all those marked as ponitive in Table 10 . We conclude that the mousc-antimoure antiborly levels are near the threshold of vinual detectahility of precipitin lines, and slight, unknown variations in technique make the differenes between detertion and nondetection.

Although we asume that any moure-antimouse precipitin line that we sec mut represent ratalaseanticatalane, this is difficult to prove definitively. Flooding of a slide containing moune-antimouse preeipitin line with $\mathrm{I}_{2}\left(\mathrm{O}_{2}\right.$ doen not produce oxygen; this is to be expected if the antibody is directed to the "nzyme atetive site. A more definitive demonstration will have to be devined; we are now in the procem of attempting to do :o.

\section{$\cos C x-\operatorname{ION}$}

We have presented presumptive cridence of a catalatirally inartive eatala-e-anticatala-e. This was wehieved by immunizing normal mice with the bloor of catalace-mutant mice, or viee rersa. We are attempting to ohtain more definitive evidence that the precipitin lines we we are indeed catalane-anticatalate.

\section{MEFERENCLS}

1. Tria. E. Anticatalasse. J. Biol. (thm, 129, 376-38; (1939).

2. Campbell, I). H. and $I_{1}$. Fourt. Immunothenistry of catalane. J. Biol. ("hem. 129, :365-3192 (1939)).

3. Feinstein, R. N., J. B. How ard, J. T. Braun, and J. K. seaholm. Acatalasemic and hypocatalasemic mouse mutants. Genetics 53, 923-933, (1966).

4. Feinstein, R. N., II. Suter, aud B. N. Jaroslow. Blood catalase polymorphism: some immuntugieal aspects. Science 159, (Bes-640) (1968).

5. Micheli, A., F. Peetom, N. linse, S. Ruddy, and P. (irahar. lmmunochemieal studr of hemolysates of humatu red blood rells. III. Identifieation of erythroegte catalase. A $n n$. Inst. Pasteur 98, (69)-700) (1960).

6. Heiustein, R. N., J. T. Branu, and J. B. Howard. Acatalasemic and hypocat alasemic mouse mutants. II. Mutaidonal variations in hlond and solid tissue eatalasess. Areh. Biochem. Bimphys. 120, 165169 (1967).

\title{
ORGAN AND TISSUE WEIGHTS AND CATALASE ACTIVITIES IN A SPECIES OF WILD DUCK. POSSIBLE RELATIONSHIP TO RADIATION SENSITIVITY
}

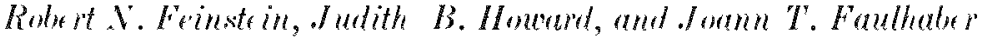

PIBPOF AND METHODS

In last rear's report, ${ }^{(2)}$ we listed organ and tissue weights and eatalasie activities in the blue-winged tcal Chnas discors) and the hoveler (A. clypeata). We intended to include comparable data for the green-winged teal (1. cetere). but at the time of the report we have not yet obtained the birds. They have since been obtained, and the data are now provided.

The original purpore of thi- work was to attempt to correlate catalise levels of a given -pecies of wild 


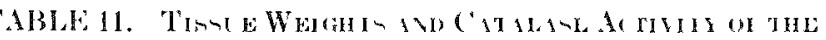

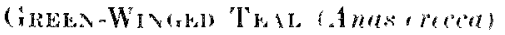

\begin{tabular}{|c|c|c|c|c|c|c|}
\hline Bird & 1 & 2 & 3 & 4 & 5 & Average \\
\hline- & - & & & & -1 & 1 \\
\hline W eight, gr & 298 & 282 & 321 & 300 & 306 & 301 \\
\hline sices & U & l & $M$ & M & $M$ & \\
\hline- & & & & & & - \\
\hline Liver & & & $t$ & & & \\
\hline Wright, g & 4.76 & 5.50 & 5.78 & $6.2 \%$ & 5.20 & 5.52 \\
\hline$P I^{\circ}$ & 104 & 2,50 & 31.5 & $14 \mathrm{~s}$ & $1: 321$ & Sant \\
\hline Total PL & 311 & $130 \times$ & $1 \times 1 \times$ & $2 \times 00$ & Itikit & $172 \pi$ \\
\hline Kidney & & & & 1 & & \\
\hline Weight, gr & $1 . x$ & 1.90 & $1.9 \mathrm{~s}^{\prime}$ & $1.9 \%$ & $1.5 \%$ & 1.46 \\
\hline$P[\cdot g$ & 1101 & $11: 3$ & 120 & 1 litio & litit & $1 ; 3 ;$ \\
\hline Total Pr & 1946 & 215 & 20342 & $: 14$ & 2131 & 265 \\
\hline Bloced & & & & & 1 & 1 \\
\hline Iolunes, ml & 30.4 & 24.2 & 396.0 & 33.60 & $: 31: 3$ & 33.1 \\
\hline$P l^{\circ} \mathrm{ml}$ & 1.8 & 1.5 & 1.5 & 1.4 & 16 & 1.5 \\
\hline Tutal PL" & 13 & 12 & 51 & 17 & 5.5 & is \\
\hline Lumg & & & & & & \\
\hline Weight, ex & 8.301 & $\therefore .50$ & :3. & 1.77 & 3.87 & $: B . t i t ;$ \\
\hline$P L$ & $\therefore$ & 5.1 & $3 .: 3$ & 3. & $3.6^{1}$ & 3.4 \\
\hline Total PL & 1.5 & I) & 10 & 17 & 12 & 11 \\
\hline dilzzard & & & & & & \\
\hline Weight, g & 9.64 & $\therefore .5$ & 7.37 & S. $\left.(6 .)^{3}\right)$ & $7.1 \%$ & $\times .32$ \\
\hline$P[: \mathrm{g}$ & 1.3 & $(i, 0$ & 3.01 & 4.5 & $: 3.7$ & 1.3 \\
\hline Total PI & $1: 3$ & 51 & $2 \cdot 2$ & 13 & 27 & 36 \\
\hline Breast muscle & & & & I & & \\
\hline Weight, g & (i1. 1 & 5.5 & 57.16 & (iin.ti & (it. 0 & (ii). \\
\hline$P T^{\prime} g$ & $x . y$ & $11 . \mathrm{s}$ & 11.4 & 10.8 & $1: 3.0$ & 11.7 \\
\hline Tutal P' & $546 i$ & $\$ 51$ & 6.57 & $4 . \tilde{5} .5$ & 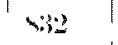 & $70 x$ \\
\hline Lexir muscle & & & & & & \\
\hline Weight, $g$ & 12.4 & 10.0 & 11.1 & 10.6 & 12.5 & 11.1 \\
\hline P' & 5.3 & 7.1 & 6.1 & 4.0 & 4.) & 3.9 \\
\hline 'Total P' & titi & 71 & ins & tit & til & ifit \\
\hline $\begin{array}{c}\text { Total mesasuree } \\
\text { P' }^{\prime}\end{array}$ & 1453 & 2616 & 24 til & $3: 10$ & 291.5 & $\operatorname{lom}_{2} \times 13$ \\
\hline $\begin{array}{c}\text { Total Pl', } \\
\text { body } \\
\text { weight }\end{array}$ & 6.2 & 9.1 & $\checkmark .9$ & $1: 1.1$ & 4.5 & 9.4 \\
\hline
\end{tabular}

"Total blowd volume estimated at $11.2 \mathrm{ml} / 100 \mathrm{~g}$ body weight. Pl $=$ perborate units of eatalase activits.

duck with the sen-itivity of the species to whole borly X radiation, and determined by Tenter at al. ${ }^{2 y}$ This powible correlation wan suggented hy the face that we have been ahle to demontrate such at relation-hip in mutant straim of mices. (3)

Methots are decribed in the carlier report.(1)

PROMRE- REPORT

Table 11 list weight and catala-e activity data for 1. crecea. These may be directly compared with the lat at of Tablen 42 to 44 of the earlier report. ${ }^{(1)}$

Table 12 combine- data from the previous reportin Fith data from the preent report and with data from Tater et al. ${ }^{\prime 2}$ It will be oberved that high catalase artirity show a positive correlation with

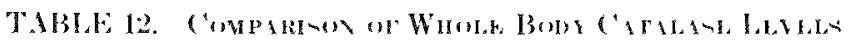

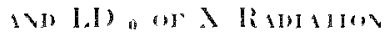

\begin{tabular}{|c|c|c|}
\hline spetits & $\begin{array}{l}\text { Total mea-ured } \\
\text { catalase," P'l g }\end{array}$ & 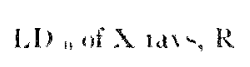 \\
\hline-- & - & $+\ldots$ \\
\hline A. plippatal & $1: 1$ & 49 \\
\hline 1. Jiwar & 10.7 & 715 \\
\hline 1. Arocou & 9.1 & in. \\
\hline
\end{tabular}

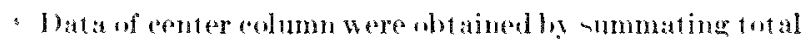

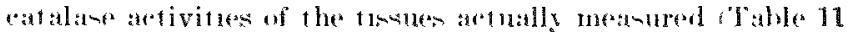
of present report and latales 13 and 14 of earlier raport ${ }^{2}$, and dividing by total bodk weight. $\mathrm{Pl}^{\circ}$ - perkorate unite of atalane arivita. I ras I.I) , data are tahen from Temere al. $x^{2}$

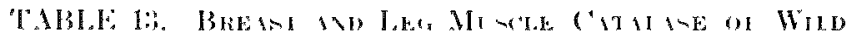

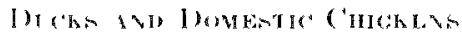

\begin{tabular}{|c|c|c|c|c|}
\hline \multirow{2}{*}{ ryecies } & \multicolumn{2}{|c|}{ Catalase activity, $P L$} & \multirow{2}{*}{$\begin{array}{c}\text { Catalase } \\
\text { batio, } \\
\text { breatot } \\
\text { lege }\end{array}$} & \multirow{2}{*}{ l' value } \\
\hline & Breast muscle & Lexg muxle & & \\
\hline 1. IIprata & 10.1 t. 2.3 & $6.4 \pm 2$. & 1.5 & $\therefore \approx$ \\
\hline A. destor & $9.1+2.0$ & $5.2 \pm 11$. & 1.6 & 4002 \\
\hline A. corecola & $117 \pm 2.3$ & $.5 .9 \pm 0.9$ & 2.0 & $<0001$ \\
\hline (8. dementione & $1.0 \pm 0.2$ & $1.2 \pm 10$ & 0.2 & $<0.0001$ \\
\hline
\end{tabular}

1):at a for the wild durehs are extrated from "Takle 11 of the prement report and from Tables 43 and 14 of the previons report. ("hichens were white leghoms. :3 monthe old, billed

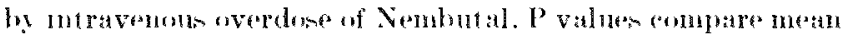

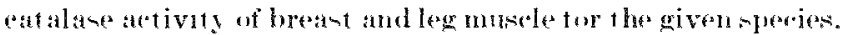
N.S. = not mignifionty different.

high retdiation resirtance. This is in contradistinction to the situation oberred in mutant momes strain, iss where high boly catalase correlated negatively with high radiation resistance. It should to pointen out, however, that in the cane of the duek, only three groups were involved, of that is differult to claim statiotical significaner for any "correlation."

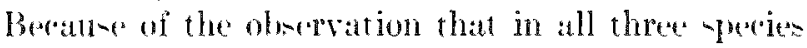
of wild duek. the catalane atetivity of breast muscle in higher thatn that of lege mu-cle, the possibility was com-inlered that muscle catalia- in in some way relatted to functional artivity. To add information on this point. We atsayed the catalare activity of leg and hreast musele of the chomentic ahicken. The result a together with comparable information for the three sperien of wild duck, are prenentest in Table 13. which augments the -uggertion that musele cataliate maty somehow be related to bunetional atetivity.

\section{CONLISTON}

The ratalase level of three -pecien of wile duck correlate puitively with the X-ray resistance of the three spereis. Thi is in contrast to the negative correlation of the same parameters carlier shown for 
mutant strains of mice. Aloo, whereas the cutalase activity is greater in the breant murcle tham in the leg muscle in all three species of wild duck, in the cane of the domentic chicken, the catalase activity is greater in the leg muscle than in the breast muscle. A relationship of muscle catalane level to functional activity is suggested.

It is a pleasure to acknowledge again the continued cooperation of Mr. Harvey $\mathbf{K}$. Nelson and Mr. ('harlem IV. Dane of the Northern Prairie Wildife Rerearch Center in providing the green-winged teal and rolevant information.

\section{REFERENT}

1. Feinstein, R. N.. J. B. Howard, and J. T. Faulhaber. Organ and tissue weights and eatalase activities in two species of wild duck. Argonne National Laboratory Biological and Medieal Research Division Annual lieport, 1968. ANL-7565, pp. 9294.

2. Tester, J. R.., F. MeKinney, and 1). B. Siniff. Mortality of three species of dueks- Anas discors, A. creced, and A. clypeata-exponed to imizing radiation. Ladiat. Res. 33, $36-370$ (1968).

3. Feinstein, R. N., J. T. Faulhaher, and J. B. Howard. Fensitivity of acatalasemic mice to aeute and chronic irradiation and related conditions. Rarliat. Res. 35, 341-349 (1968).

\title{
EFFECT OF WHOLE-BODY X RADIATION ON FLAVOPROTEIN ENZYMES
}

\author{
Robert N. Feinstein, Judith B. Howerd, and Joam 'T. Faulhaber
}

\section{PCRPOSE AND MFTHODN}

The literature of radiation biochemistry is replete with studies of the effect of whole-body $\mathrm{X}$ rarliation on tissue enzymes. One clits of enzrmen. huwever, which appears to have been largely ignored in this respect is that of the flavoprotein enzymes. At the time of writing, only four paper- ${ }^{(1-4)}$ and one abstract(5) have appeared touching on this subject. These ruports suggent increases in xanthine oxidase and o-hydroxy acid oxidase in liver after wholebody $x$ radiation, while no effect was observed on urieane or L-amino acid oxidane in liver. Dones, times and rodent species differ amongst these rurious reports.

It therefore appeared to $u_{n}$ to be worth while to attempt a systematic survey of the effect of wholehodr $X$ radiation at various times after various doses on the activity level of various flavoprotein enzymes in mouse liver and kidney. Rnzymer examined are listed in Table 14 with some details of assay. All ascays were done on whole homogenates of tiscle. All incubations were at $37^{\circ} \mathrm{C}$. In some instancer the assay method were sightly modified from the references cited.

Mire uned were male ( $\mathrm{F}$ 1/Anl[Anl 66] 10 to 14 week of age. Asisays were done on liver and kidney of unirradiated wice and mice $3 \mathrm{hr}, 6 \mathrm{hr}$, and $1,2,4$, and 7 days after 5,50 , or $500 \mathrm{R}$ of whole-body $\mathrm{X}$ radiation. Radiation wa obtained from a machine operating at $2.50 \mathrm{kVp}$ and $15 \mathrm{~mA}$, with a dose rate of approximately $40 \mathrm{R}$, min. 'Ten mice were used for earch enzyme asray at each time and done point, exrept that if it became evident that a particular enzyme activity was detectable at none of the timedose points, only 5 mice were used in each instance to establish this fact.

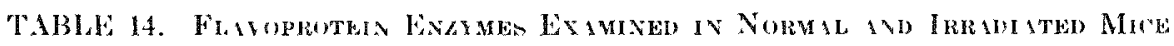

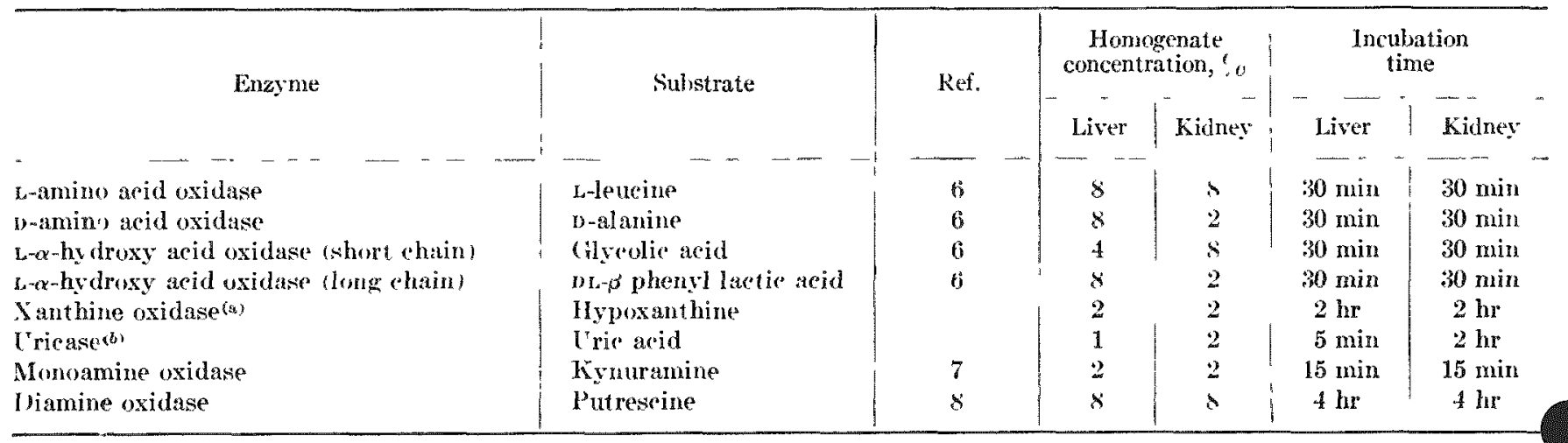

(a) Xanthine oxidase was assayed by following the increase in absorption at $295 \mathrm{~nm}$ in $0.1 \mathrm{M}$ borate buffer, pll 8.5 , in the presence of the uricase in hibitor 2,8 -dihydroxy-6-methylmereaptopurine at $10^{-4} M$.

(b) Cricase was assayed by following the decrease in uric acid absorption at $295 \mathrm{~nm}$ in the sane buffer. 


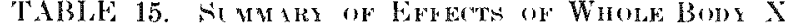
RidITION ON FLAVOPROTLIX ENLYMES

\footnotetext{
rlass 1. To activity detectable' at any time'

a. Liver L-amino arid oxidase

b. Kidney h-amino acid uxidase

c. Liver i)-amino acid oxidase

d. Kidney L- $\alpha$-hydroxy acid oxidase (short chain)

a. Liver t- $\alpha$-hydroxy acid oxidase (long ehain)

f. Kidney anthine oxidase

g. Kidney uricase

h. Liver diamine oxidase

i. Kidnta diamine oxidase

(law: II. Adtuity detertable but not modified by irradiation

a. Liver L- $\alpha$-hydroxy acid oxidase (short chain)

b. Liver xanthine oxidase

c. liver uricase (postirradiation inereases noted in mean level are not statistically significant)

d. Kidney monoamine oxidase.

Class 1Il. Postirnatiation changes in activity

a. Kidney b-anino acid oxidase (increased after most times and doses)

b. Kidney L-o-hydrox! acid oxidase (long rhain) increased after most times and dosses)

c. liver monoamine oxidase (early increases after low doses; late decreases after all doses)
}

At the proper time after a given $\mathrm{X}$-ray dose, mice were sacrificed, and liver and kidney were removed, frozen in dry ice-acetone, and maintained in liquid nitrogen until assay. In each day's asways, an attempt was made to include tissues from a variety of dosetime areas, rather than doing one whole series of comparable tissues as a group.

\section{IROGRENS REPORT}

(ieneral observations are summarized in Table 15. complete datal are too copious for the prenent brief report.

\section{CONCLCSIONS}

The eight flaroprotein enzymes studied in both the liver and the kidney of mice at various times after varying doses of whole-body $\mathrm{X}$ radiation do not behave as a homogeneous group. Four of the enzymes searched for in liver and five searched for in kidney were not detecter. (of the enzymes that did display detectable activity, three in liver and one in kidney were enentially unaffected by any done of $\mathrm{X}$ radiation at any time observed.

(only three enzymen were observed to be affected by whole-body X raliation:

a) The D-amino arid oxidase of kidney exhibited increased activity at most times after most doses. No ignificant correlation was apparent with either time or dore.

h) The 1.-ax-hydroxy atdid oxidase (long chain) of kidney similarly showed increased activity at mont times after mont doner. Agatin no significant correlations were observet.

c) Monoamine oxidane activity in liver showed the mon interesting and mo-t significant pattern of pontirradiation changes. significant increanes were reen early $16 \mathrm{hr}$ after 5 and after $50 \mathrm{R}$, and rignifieant deereasen were seen later 44 days after all doses. By 7 daym after all dones, activity had returned approximately to normal.

\section{REFHRENCES}

1. Roth, J. S., II. J. Fichel, A. Wase, C. Alper, and M. J. Boyd. Fiffect of total-body $x$ irradiation on some enzymes of rat tissues. A reh. Biochem. Biophys. 44, 95-101 (1953).

2. "Thomson, J. F. and Y. K. Rahman. Effect of $\mathrm{X}$ irradiation on distribution and properties of cytoplasmic particulates of rat liver. Radiat. Res. 17, 573-578 (1962).

3. Waldichmidt, M. Das Verhalten von 1-Aminosäurenoxydase und Acrl-('oA-Dehydrogenasen in den Mitochondrien sowie der (rehalt an Flavinadenindinukleot id in Leber und Mil von Ratten nach Bestrahlung in viro. Strahlentherapie 132, $4(63)-471(1967)$.

1. Waldschmidt, MI. and E. Arkenan. Das Verhalten einiger Enaym Aktivitäten und der Atmung der Nliuseleber narh Bestrahlung in viv. Strahlentherapie 136, 723738 (1968).

5. Kleinbergs, $A$ and I. A. Bernstein. The effeets of whole-body irradiation on enzymes in mouse liver peroxisomes. Radiat. Res. 35, $5: 37$ (1968).

6. Robinson, J. C., L. Keav, R. Molinari, and 1. W. Hizer. L- $\alpha$-hydroxy acid oxidase of hog renal cortex. J. Biol. Chem. 237, 2001-2010 (1902).

7. Weissbach, H., T. F. Simith, J. W. Dals, B. Witkop, and $\mathrm{S}$. Tdenfriend. A rapid spectrophotometric assay of monoamine oxidase based on the rate of disappearance of kynuramine. J. Biol. Chem. 235, 1160-1163 (1960).

8. Melwen, C. M. Nerum amine oxidases in pregnaney. J. Lab. (lin. Med. 64, 510-547 (1964). 


\section{MICROVASCULATURE AND LOOSE CONNECTIVE TISSUE OF THE CHICK MESENTERY. FREEZE-ETCH OBSERVATIONS}

\author{
S. P'hyllis Stearner and Margaret II. Sanderson \\ PIRPOCE AND METHODS
}

Cltrantructural ehangen in the microva-culature of the chick ambryo within one to two hour atter lethal X irradiation have been reported."1 A rapidly developing exlema accompanied the vascular injury and has been observed in the irradiated rlick as woll as the chick embryo. These effects nugest that there are signifiant arely alterations in the extracellular ground substance surrounding small blood rents. Study of the ground substance is diflecult. howerer, becane of its low density and solubility in the u-rat tisue fixative. Some year ago, the fine structure of ground substaner in frecze-dried tisme was describerl as a system of submicroseopic vacuoles 1600 to 1000 if of a colloid-poor material surrounded by a don-er colloid-rich phase."2) In light microscope studies, structures vinible in special preparations are believed to represent clusters $1>1 \mu$ of such submicroncopic varuoles.3) The freezenteh terhniquer. in provides a physical method of fixation that preserves the ultrastructure of extracellular as well a intracellular material with a minimum amount of fixation artifact. In addition, a three-dimensional representation of organelles and surface struetures is obtained. "The chick mesentery was selected for tudy with this technique becatus 11 it is similar histologically to the extraembryonic membrane of the chick embryo used in our previous studies and (2) the small mass reculired for rapid frevenge can be obtained without disturbing the relationship of the cells and ground substance. Preliminary observations of the microvasculature and loose connective tissue are reported here. Subsequent invertigation involving this technique will include study of the alterations that follow lethal ratiation exposure.

Chicks, two to three week of age, were lightly anesthetized with ether. Small pieces of mesentery were excised, placed in a slycerine phosphate huffer solution, pH 7.2, and cut into pieces of los than 1 mm". To prevent formation of ice erystals and permit vitrification of tissue water during freezing, these tissues were treated with two glycerine solution cone hour warh, in either 10 and $20^{\circ}$, or 20 and $30^{c}$ e vlycerine). The menentery is extremely thin when mpread: therefore, it was allowed to contract to ensure atdequate thicknes for fracturing after frezing. After elycerine tredtment, the sperimens were placed on aronified, degreated copper dises $13 \mathrm{~mm}$ in diameter), frozen in Freon $\left.121-150^{\circ} \mathrm{C}\right)$, and stored in liquid nitrogen $1-196^{\circ}(')$ until wed. The freezt-etch procerlure, carried out in a Balzers apparatus, employed a sperimen temperature of $-120^{\circ} \mathrm{C}$, a knife temperature of $-150^{\circ} \mathrm{C}$, a vacum at the time of fracturing of $10^{-6}$ torr, and a temperature at sharlowing of $-120^{\circ} \mathrm{C}$. The fractured surface was shatowed immerliately with platinum-earton at an angle of $45^{\circ}$, followed by a supporting film of carbon at an angle of $90^{\circ}$. The cold knife holder served as a cold trap to minimize contamination of the replica surface until the specimen rould be removed from the chamber. Commereial bleach was uned to free the replicas from the underlying ti-su" and to clean them. Replicas were rinned in several changes of distilled water, mounted on 200- or 300-mesh gold grids and riewed in a . IF.M-7.d electron microncope.

\section{PROMRLS' REPOIT}

The fine strueture of a small hlood vessel and the surrounding loose connective tisme, as observed in ultrathin sections of material taken from a chick, is -hown in Figure 19. The endothelium and an adjarent pericyte are surrounded by a well-developed basement lamina. Whereas the ground rubstance, in which collagen fibers and fibroblants occur, is a pale-staining material with little apparent structure. A small plammatflled blood vesmel, as displayed in a freezenteh replica, is shown in Figure 20. Collagen

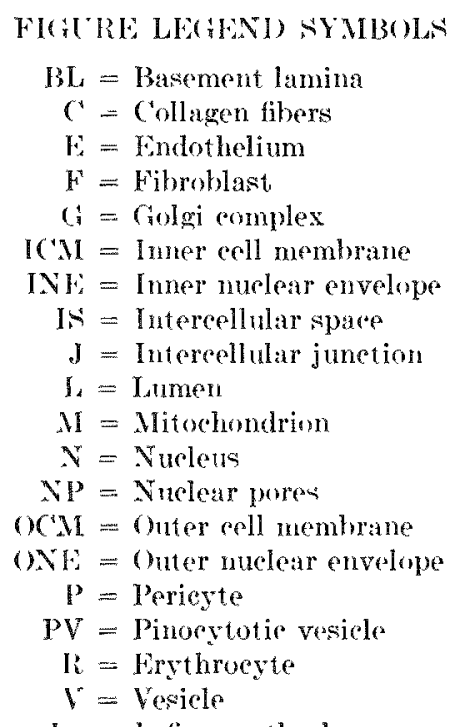

In each figure, the large arrow indicates the direction of shadowing. 


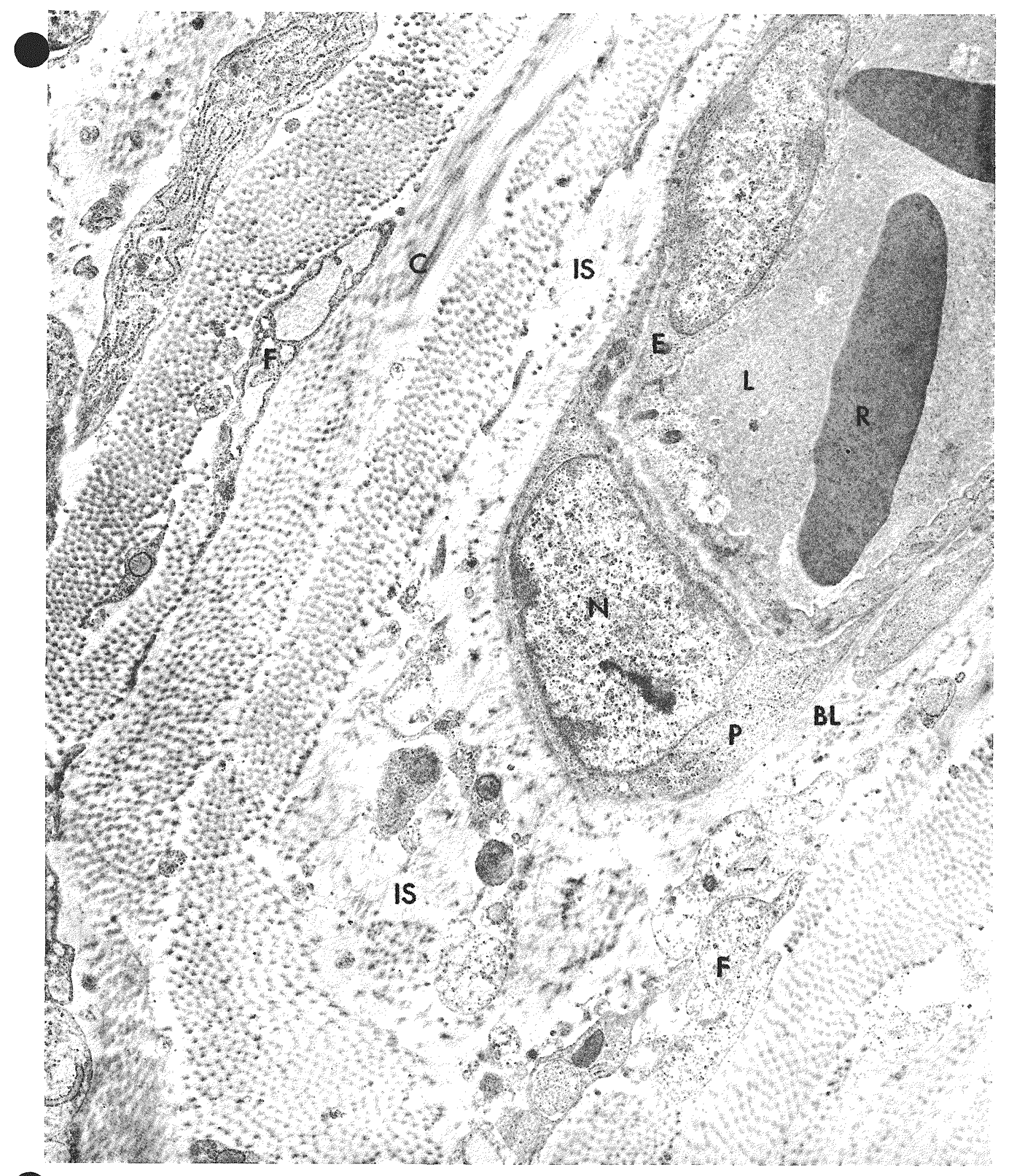

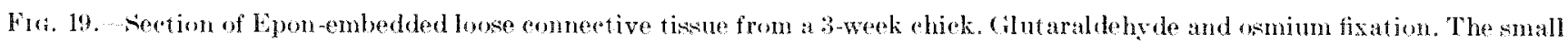

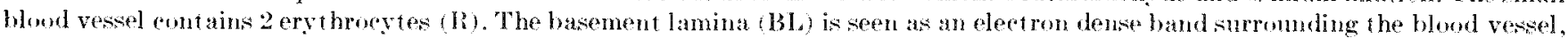

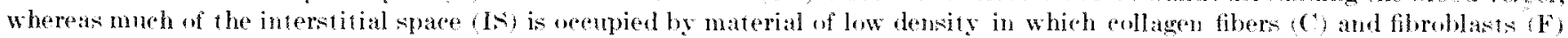
are present. $\times 10,000$. 


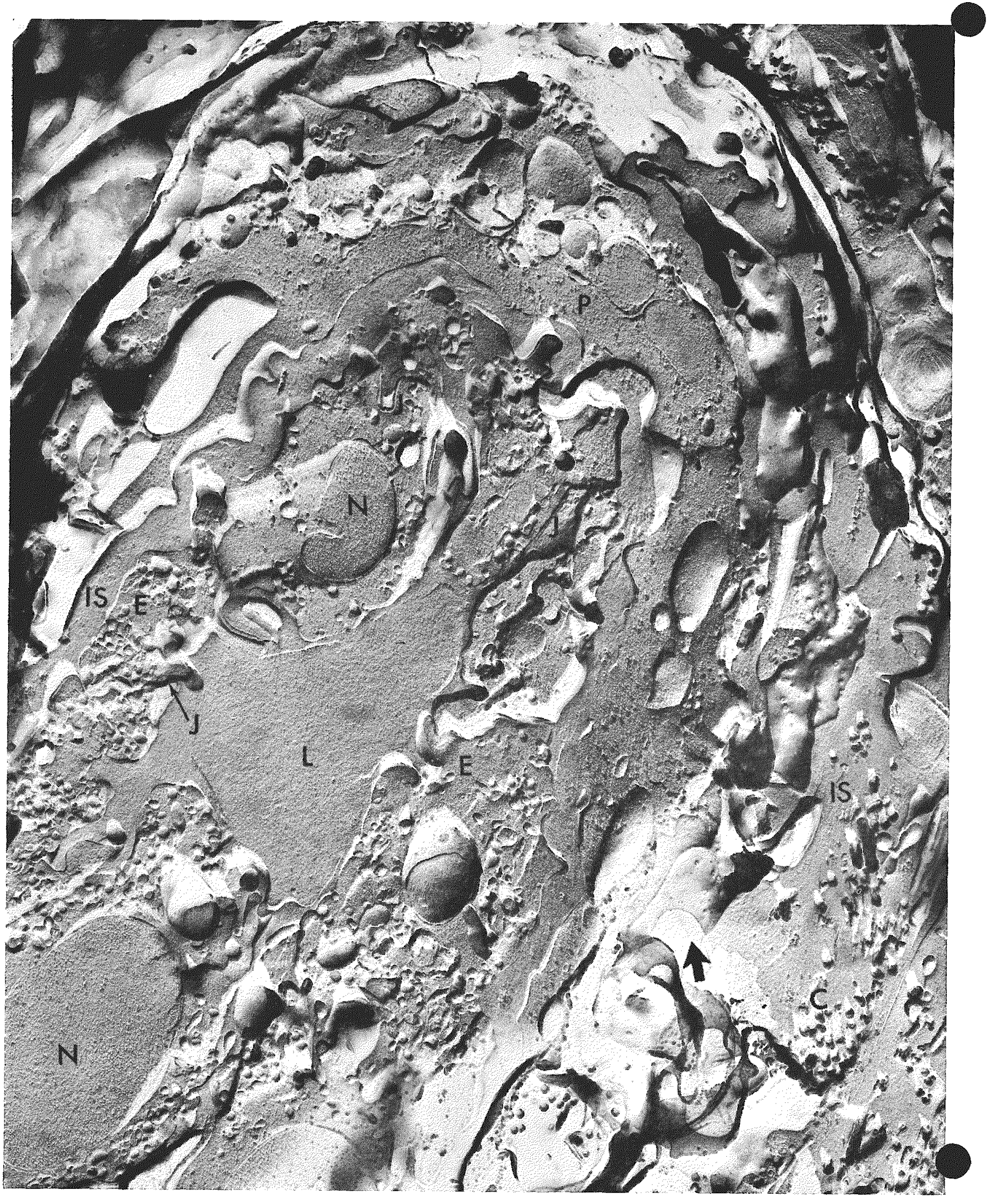

Fia. 20. Cross fracture of small blood vessel in the mesentery of a 3 -week chick, from a freeze-etch replica. The surrounding interstitial space (IF) contains fibroblasts and collagen fibers $(C)$ in the ground substance. $\times 19,000$ 


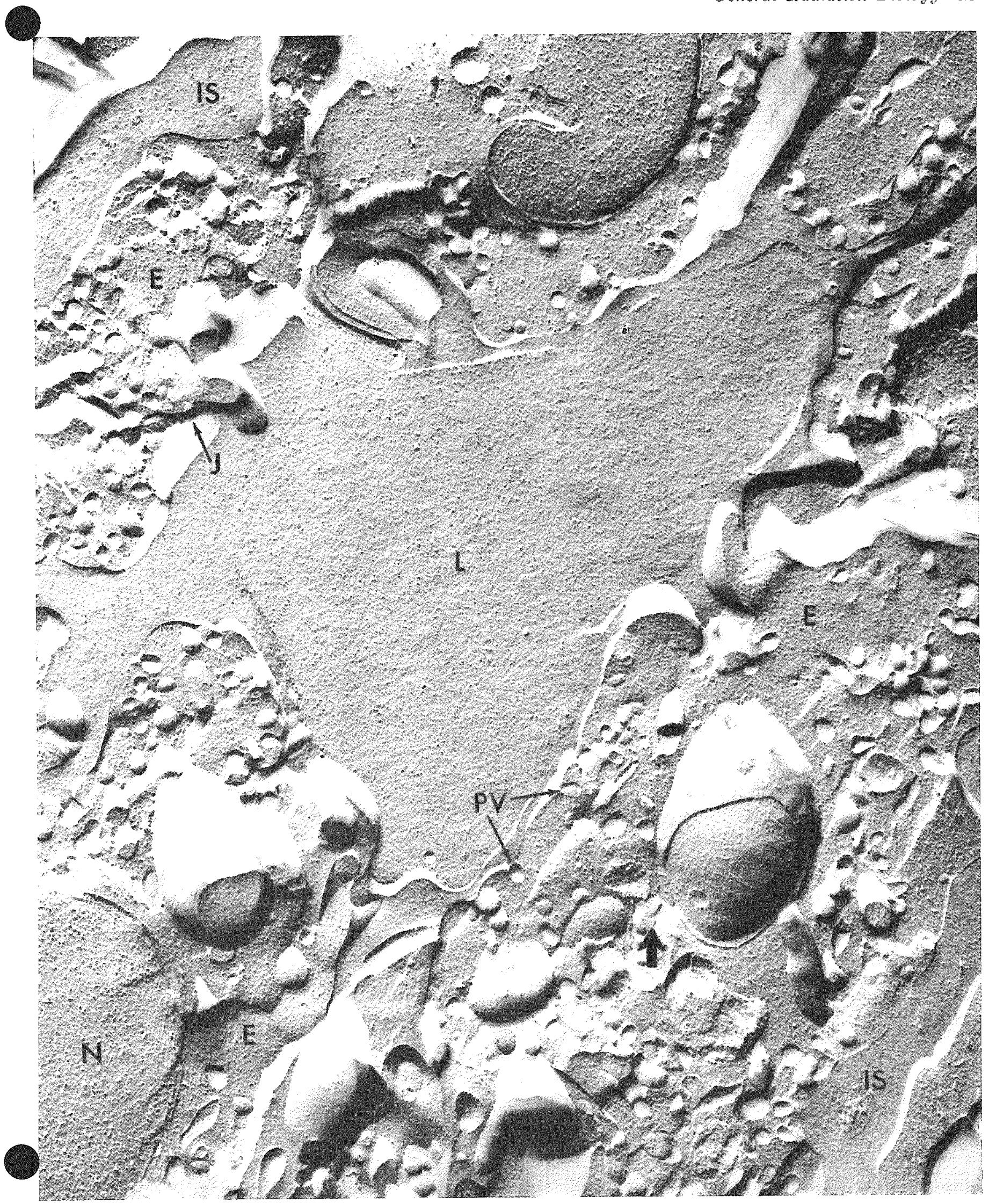

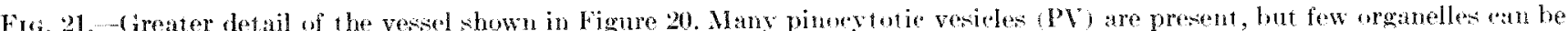
distinguished. $\times 43,000$. 


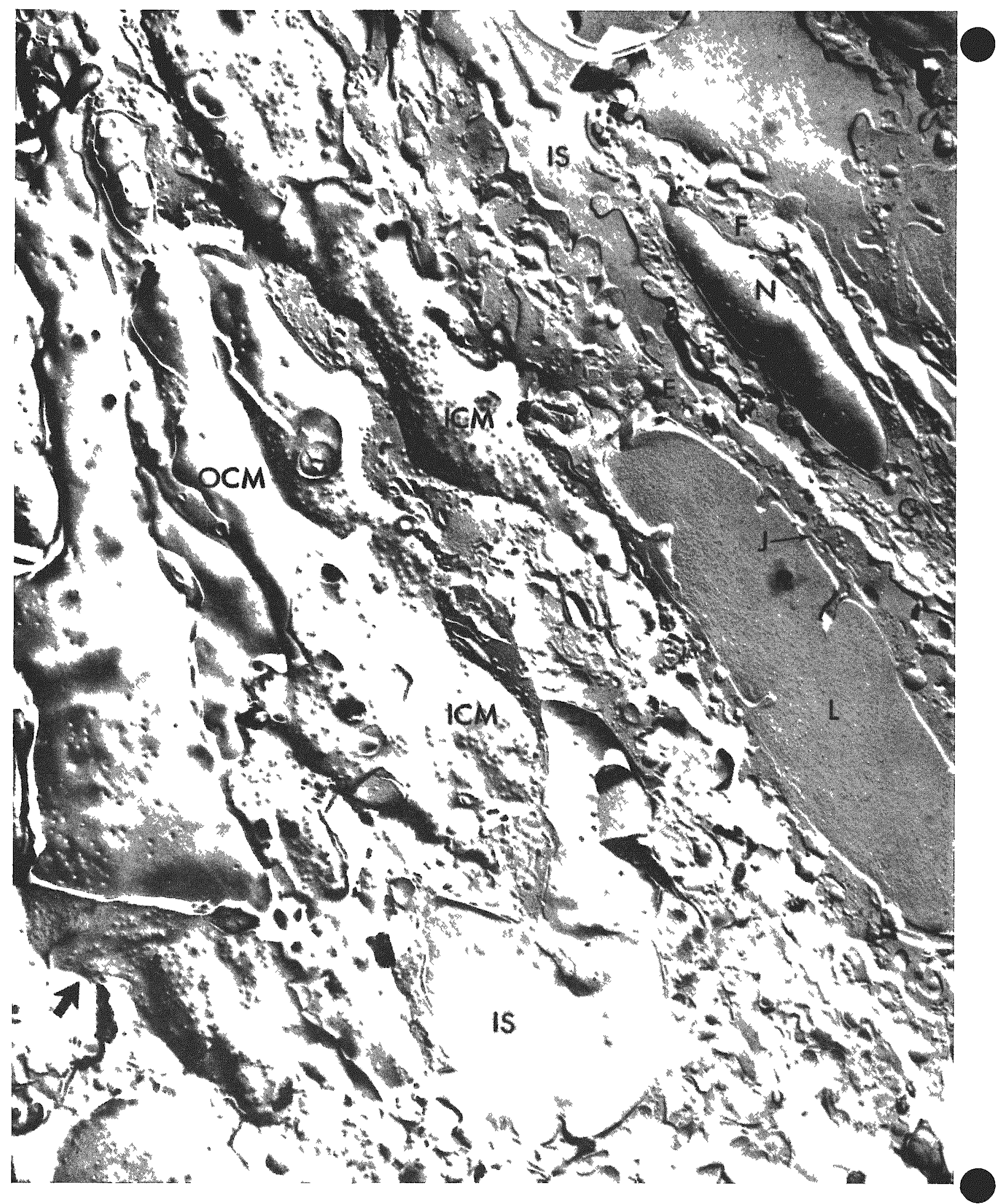

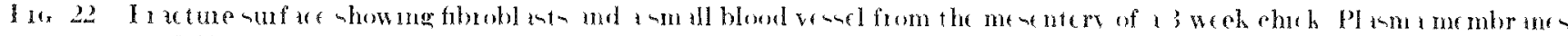

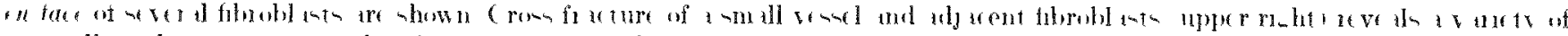

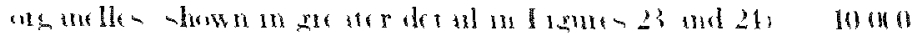




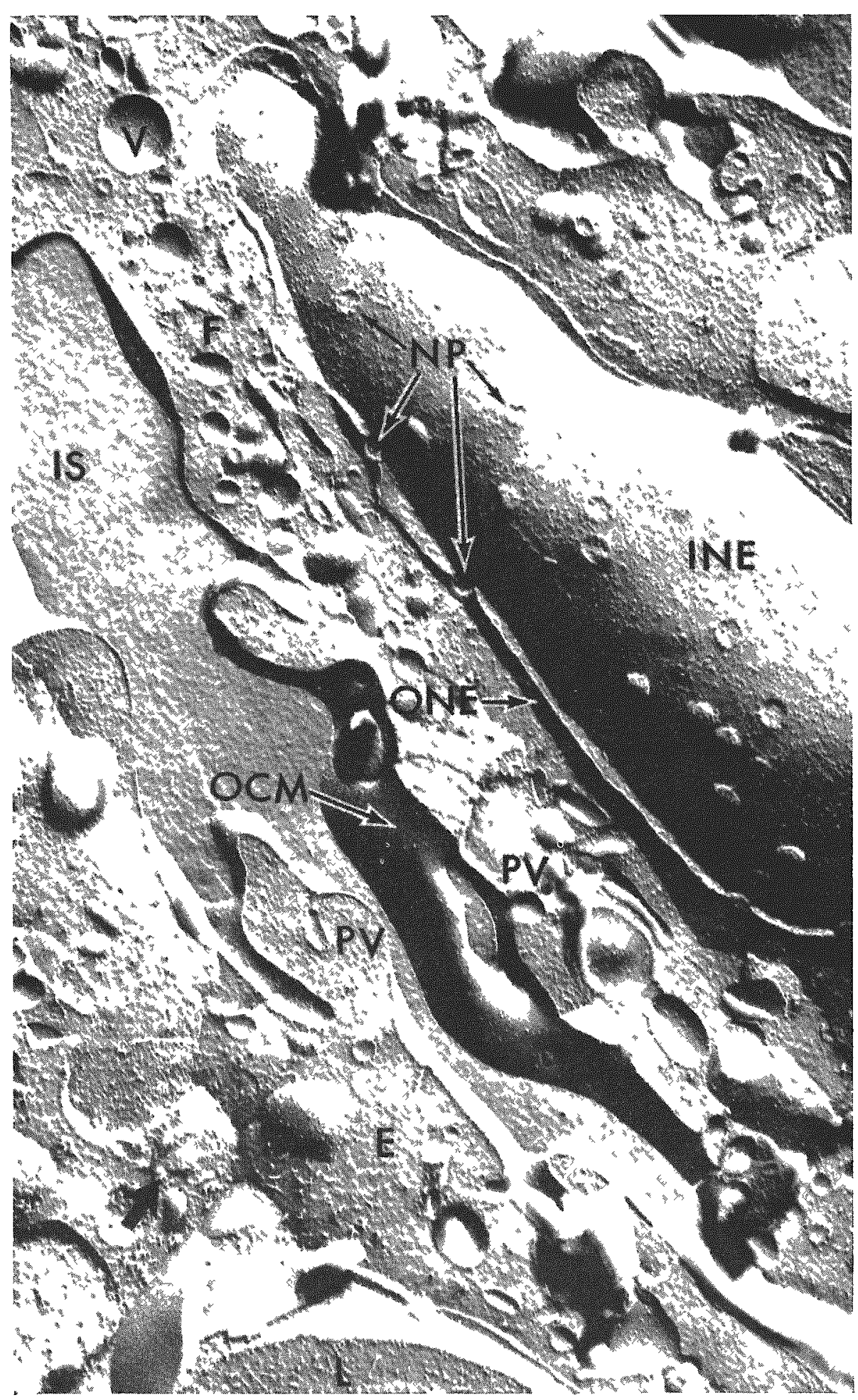

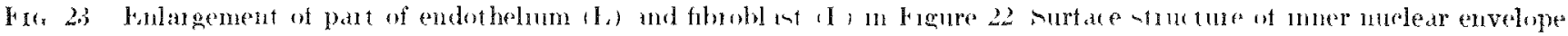

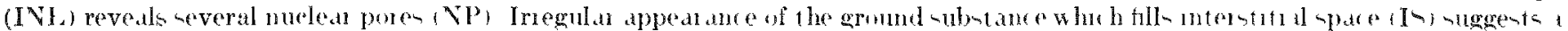
system of vacnolom $\times 37,500$. 


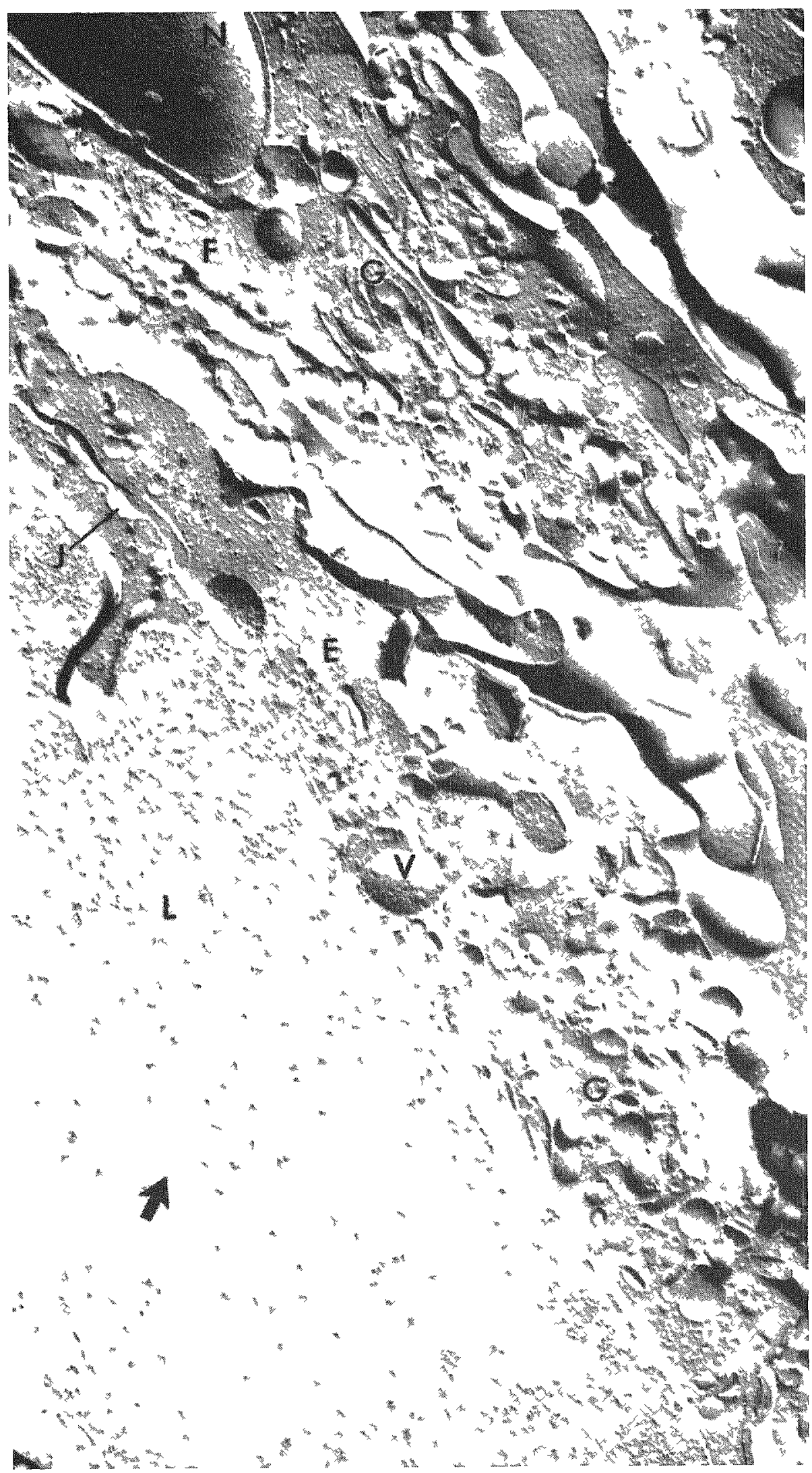

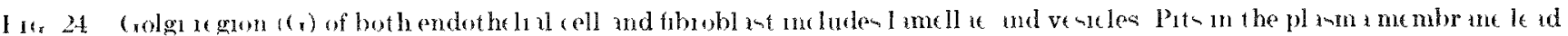
into pinoc vitotie vesile $\times 32000$ 


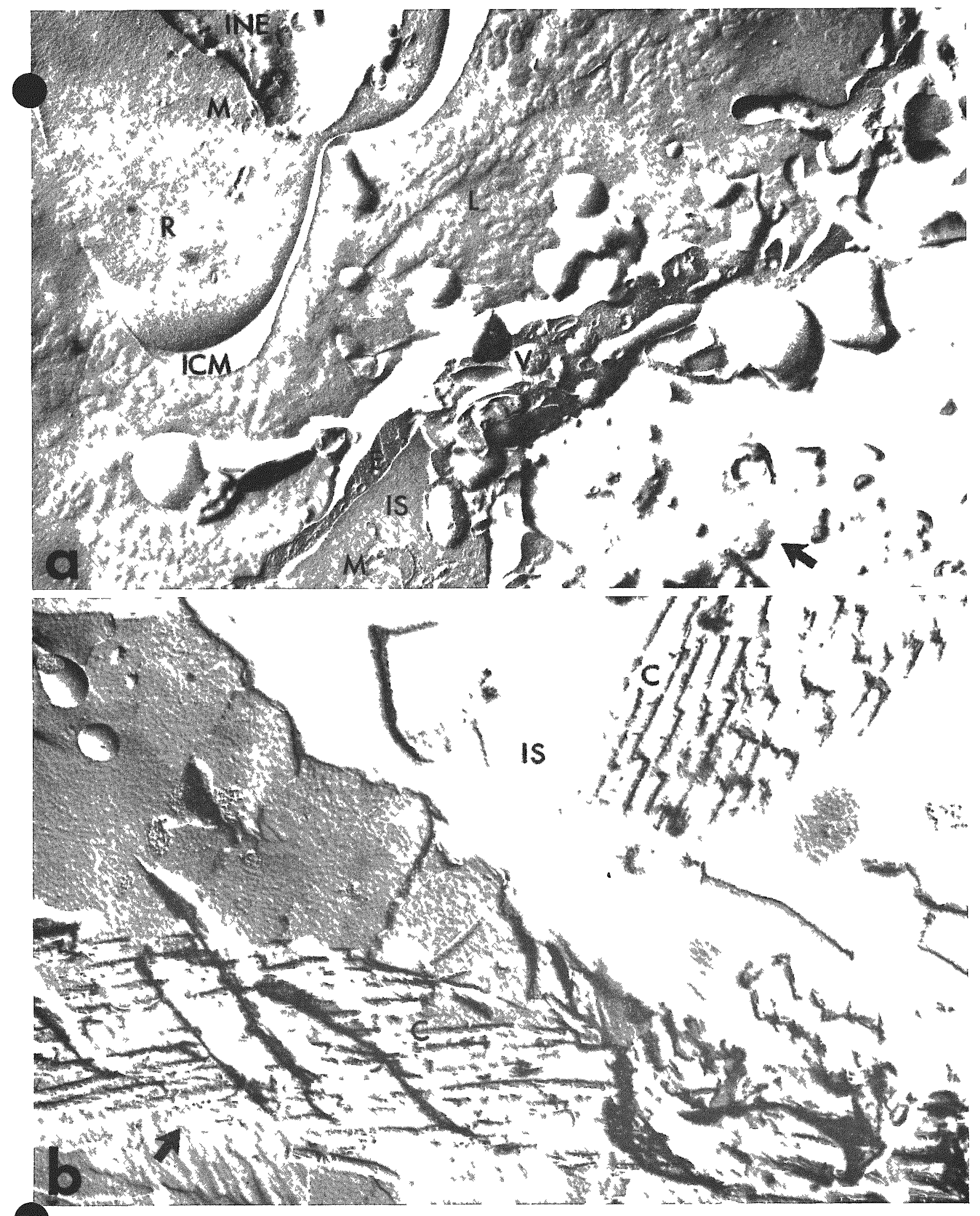

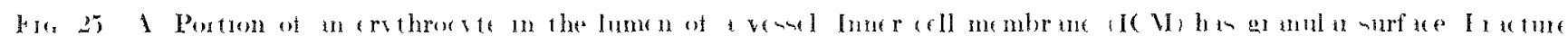

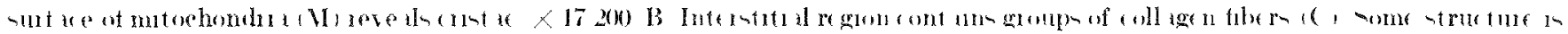

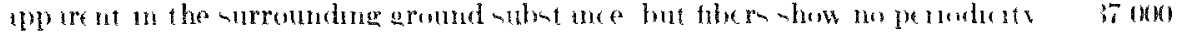


fiber and portion of fibroblant can be distinguirhed in the perivarcular region. The appearanes of the pla-ma in similat to that of the ground ulutance that fill the interstitial space (Figure 21). There is no eridence of a bavement lamina immediately surrounding the eudothelium. A larger areat of the connective tione adjatent to a -mall hlood venest is hown in Figure 22. Surface fractures of several fibroblant reveal detail of exten-ive areas of both the inner and outer -urface of the platmit membrane. A part of the endothelium and a fibroblant. (upper right) are -hown at hioher magnifiration in Figure 23 and 24 . The ground -ub-tance in the inter-titial space has a definite - truetural pattern that resembles the syatem of racuole 1600 to 1000 di deacribed by Bondareffes and by ("hane,'s) w-ing other methorl of timene preparation. Thi- vacuolated tructure can be eontratted with the inore granular appearane of the eytopla-mic matrix. A surfure fracture of a fibroblat nurleus (Figure 23) demon-trates the two layer of the nuclear envelope and nuclear pores. A frolgi complex, containing both resicles and lamellate. i- present in a fibroblat and aloo in an endothelial cell (Fienre 24). An endothelaul cedl junction is wown but tight junetions eannot be distingui-herd. In the attenuated endothelium of a larger venel (Figure 25a) there are few pinorytotic resicle. The exythrocete, hown in part, has a homogeneow- gramular eytopla-m and few organellen. At higher magnification the fibrillar -tructure of collagen fibers "an be seen, surrounded by ground subtances (Figure 2.361.

\section{CON'LA MON}

Three-dimensional repliean ohtained by the freezeeteh technique have provided information about the fine structure of small bloot reseds and the perivaneular loowe romnertive ti-sure of the mesentery of the young chick. This method is well-suited for the prenerration of connectire tim-le in a more normal tate than can be oltained in fixel material and will be und in connection with studien of radiation

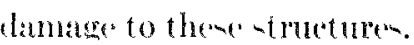

Wo thank (ieorge T. ('hubh) for invaluable adrice and an-i-tanes in applying the freeze-eteh method to our material, and butty Jean Wright for helpful information about speeimen preparation. We aho arknow lextge the effielent ervice of George T. Chubb and Patul W. Fillwanger in matintaining the Electron Mircromere cinter.

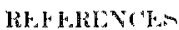

1. Stearner, S. P and M. II. Sanderon. Tarly vasolat injury in the irradiated chich ambryo. An electron micronospe study. J. Path., in prems.

2. Bondareff, William. Sibmicromeopic morphologs of connerotive tissue grund substance with particular regard to fibrillar genessis in aging. Crenontologia 1, 222-2393 (1957).

3. Chase, William H. Extracellular dist ribution of ferrocyanide in muscle. A rith l'ath. 67, 5:55-5032 (1950).

4. Monp, Nans. Freezectehing International Revice of "ytology, Vol. 25, Ed. (A. H. Bourne and J. F. I)anielli. Academic Press, Jew York, 1969, pp. 391-412, 等

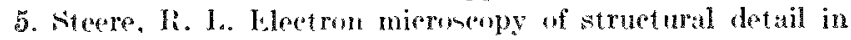

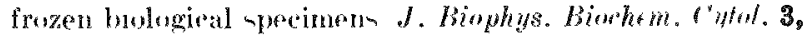
45-60) (1957).

\section{PROTECTION AGAINST EARLY RADIATION INJURY TO THE MICROVASCULATURE}

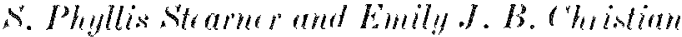

PCRPOL: AND MII LIOSD-

Vasular injury and terminal ripenlatory failure have been described in the ehick embryo following lethal irradiation."11 Thi early damage frecpuently remult, in mortalits within at few hour. not only in the chick embryo, but in the young chick and the adult rootere an well. Vancular damage han aho been lemontrated in a vatiety of mammalian preciem and is important in development of ti-nue damage that follow- exposure to ionizing radiation- Radionem-itivity in terms of does and time during or between exposure indicates that reversal or rewintive procesen oreur during a -ufficiently protracted expo-ure or during the interval between the two fraction of a -plit ryo-ure to reduce the radiation injury: therefore. the effects leading to raveular ilegeneration "ath be revered or prevented at an early stage. Early radiation injury can aloo be reduced by pretreatment wh the antiprotease, oybean trypin inhibitor

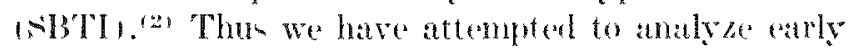
radiation injury mechani-me and the rapinl repair or

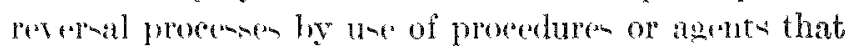

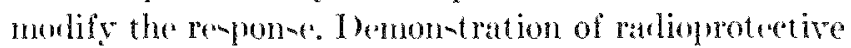
procedures are not only of practical ignificance, but ahe maty provide information eonerruing the nature of radiation injury merhani-me.

In studien of the microcirculation in the living

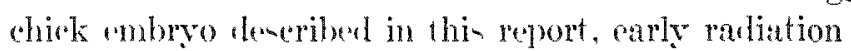




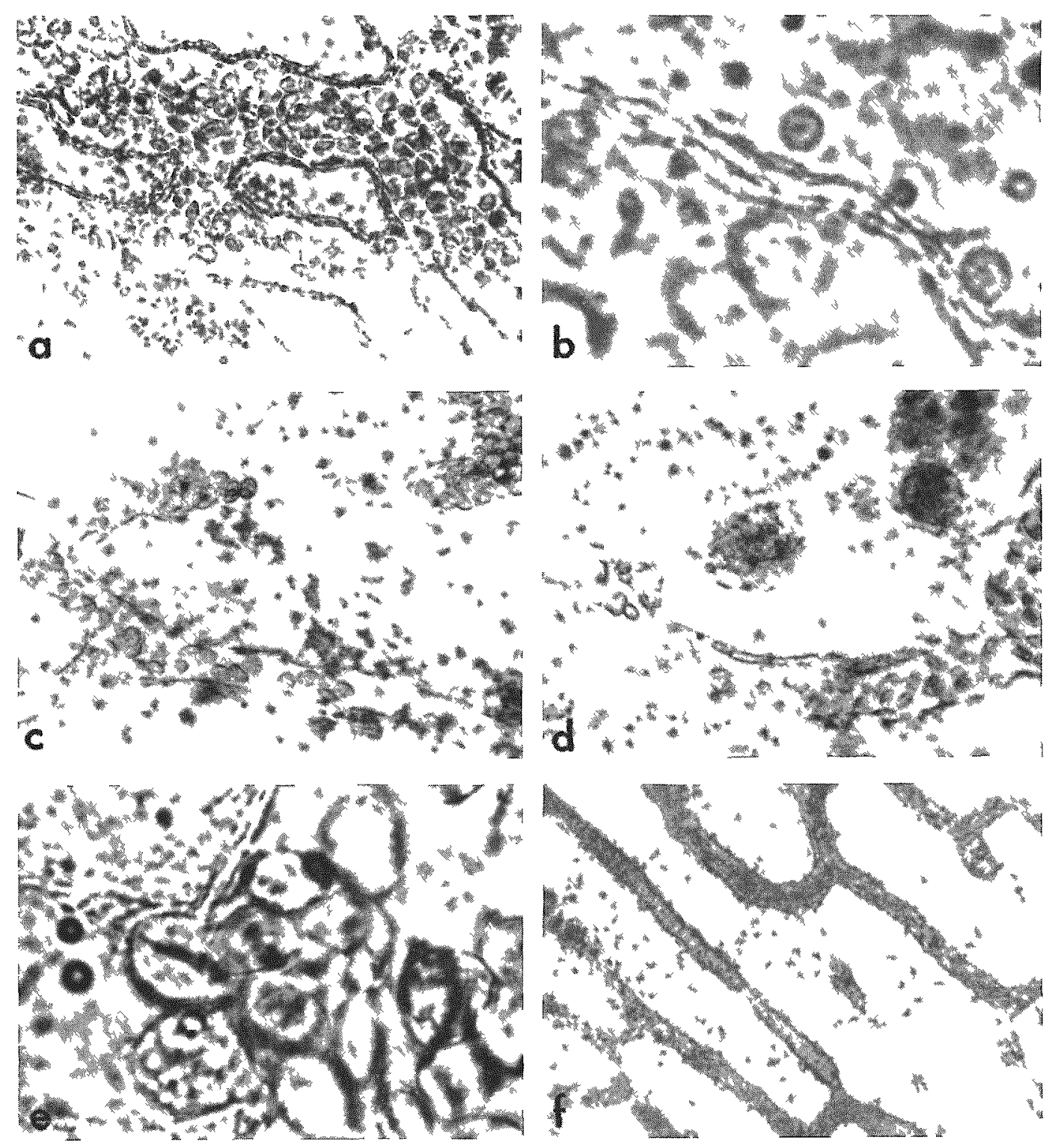

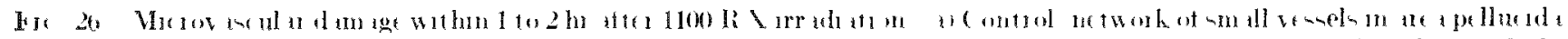

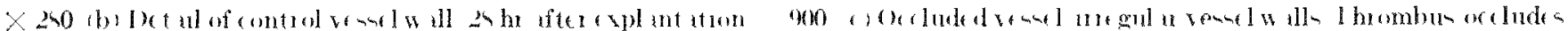

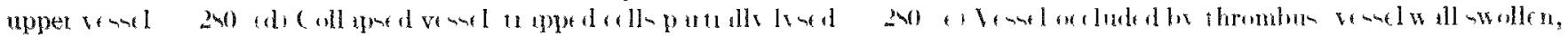

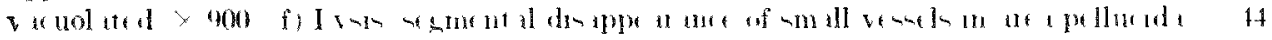

d.tm toe was -hown to be tedured in tmbrom pre-

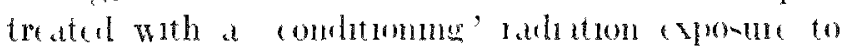
700 li of I lav 4 he betere the crond on thelleneme exposule 1 -mulde reduction in damteg to the

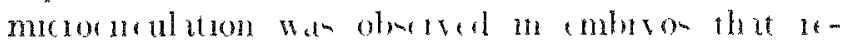

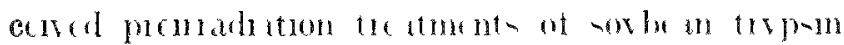
mhinitor

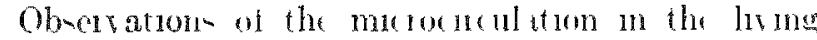

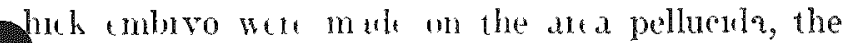

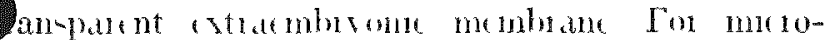

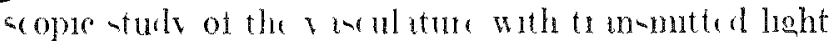
embruon were apluted onto a colul molum ac-

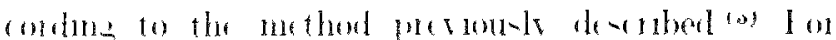

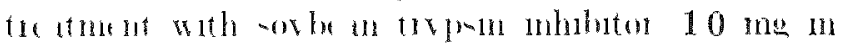

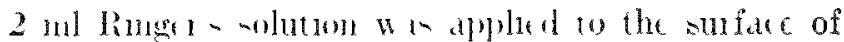
the esplent rentral expere of the ambirol leter 5

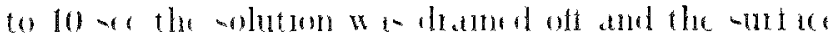

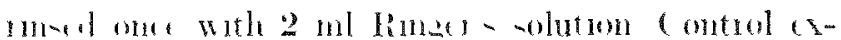

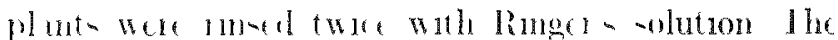

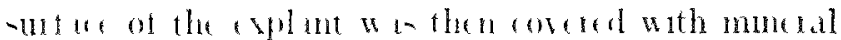

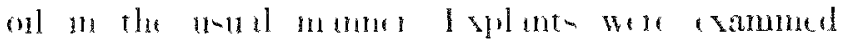

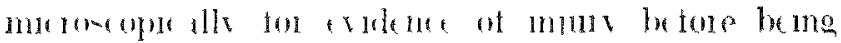

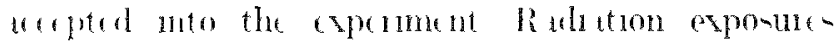
wit to $250 \mathrm{k} / \mathrm{P} \backslash \mathrm{w}$ - phe-14 al condit lons me luded 
$1.0 \mathrm{~mm}$ aluminum and $0.5 \mathrm{~mm}$ copper filtration; target distance and exposure time were varied. Each dose of the split exposure was delivered in $12 \mathrm{~min}$. SBTI-treated embryos received $1100 \mathrm{R}$, delivered at $95 \mathrm{R} / \mathrm{min}$ at 20 to $30 \mathrm{~min}$ after application of the drug. lxplants were irradiated in a revolving, heated Lucite chamber maintained at a temperature of $38^{\circ} \mathrm{C}$. Irradiation was carried ont in an atmosphere of $40 \%$ $\mathrm{O}_{2}, 5 \%\left(0,2\right.$, and $55 \% \mathrm{~N}_{2}$. Embryos were also incubated in this atmosphere after irradiation.

The protective effect of SBTI against early radiation mortality was not testerl on 3-day embryos in ovo, for at this stage of development specialized technigues for intravenous administration of the drug are required. Application to the ventral surface of
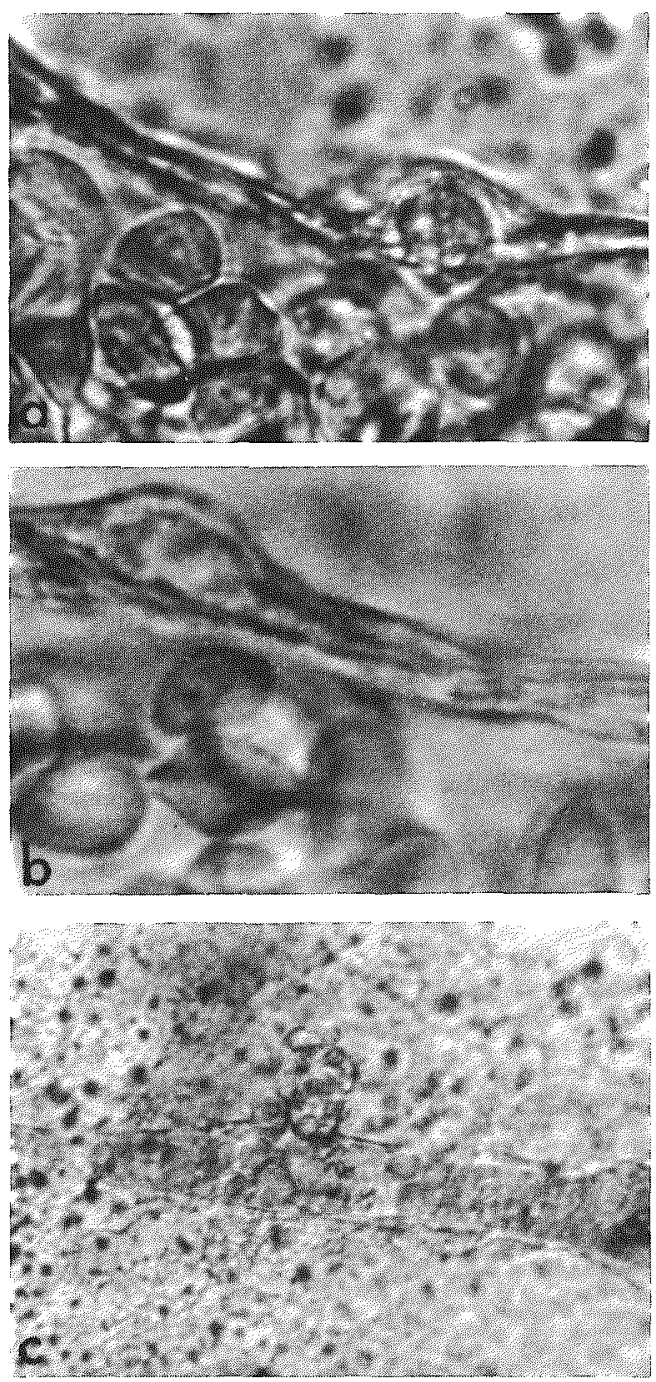

$F_{1 \in \dot{x}}, 27$, Dispedesis and formation ố small hemorthase after lethal radiation exposure $(100 \mathrm{R}$. (a) Penetration of circulating rell into vessel wall. $\times 900$. (b) Cell trapped be. tween layers of vessel wall. $x$ (90). (c) (roup of extrivasuted blood cells, vessel nocluded. $\times 280$.
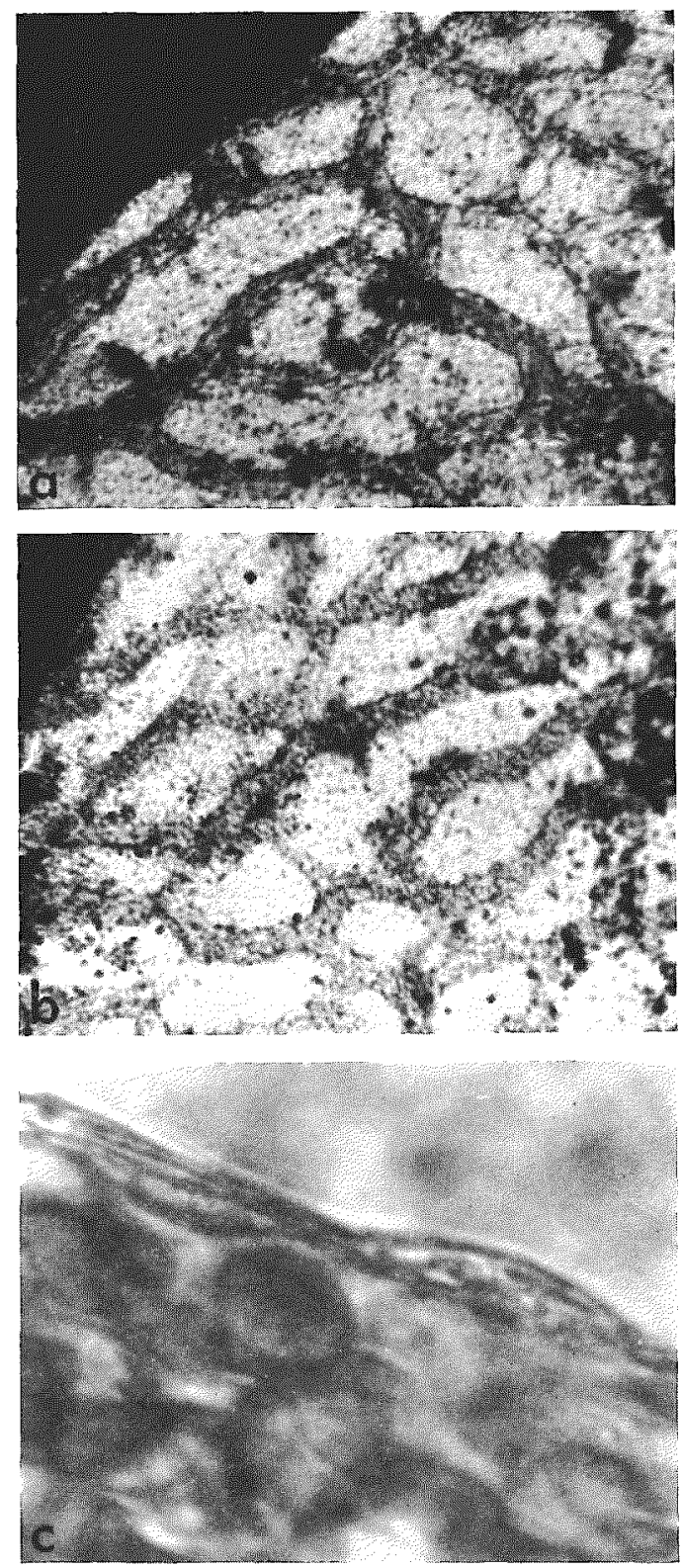

Fik. 28. "Protective" affect of a conditioning exposure on radiation injury to the microvaseulature. (a) No apparent damage at $1 \mathrm{hr}$ after first exposure $(700 \mathrm{R})$. $\times 44$. (b) At th hr affer second exposure of $1100 \mathrm{R}$ (10 hr after $700 \mathrm{~h}$ ), microvaseulature appears unchanged. $X+4$. (o) Normal vessel wall at $24 \mathrm{hr}(20 \mathrm{hr}$ after $1100 \mathrm{li})$. Compare to control after $28 \mathrm{hr}$ in explant (Figure 26b). $\times$ gno

the hastodem, howerer, is probably similar in effectiveness to intruvenous injection, for the rasenlature is readily accesible to a topically applied substance.

REMLTS

The 3-day tmbryo hat a well-dereloped rascul system; in explant the structural detail of small veswels in the area pellucila can be observed at 

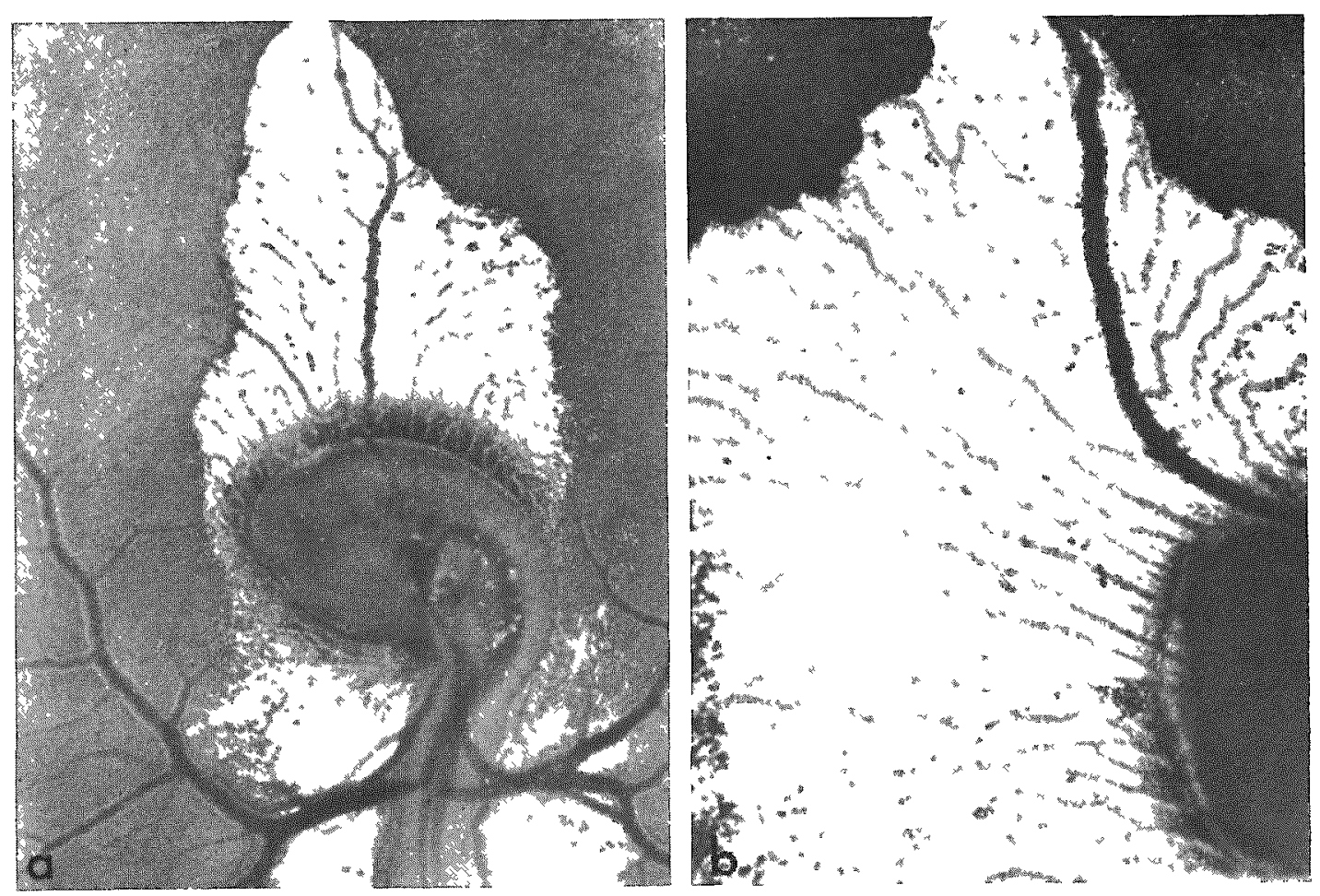

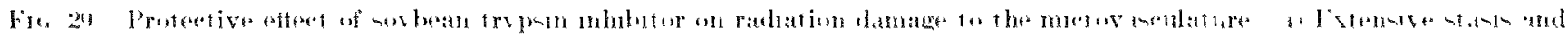

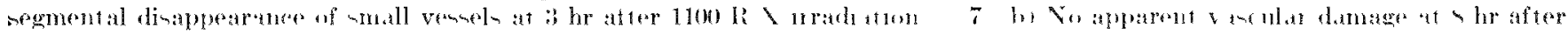

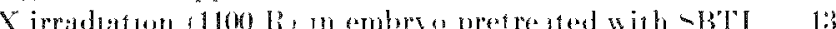

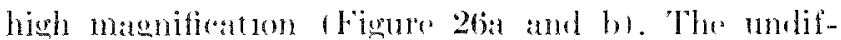

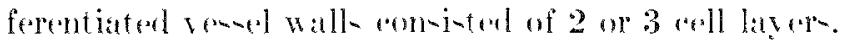
cirrulation wa maintained in explant for more than 24 hr. and there wan eontinued growth of the embryo: during this time the vened wath remained thin and hatrply out linest.

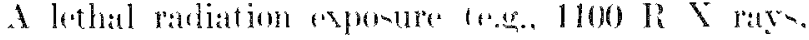
delivered in 12 mint pe-ulted in rapid degencration of the microvarentature. (Berlu-ion of individual remests developed within 1 or 2 hre and generalized ta-i- and death watly oecurred within 4 to 8 hr. Mirowenge whange oberved in the loving animal have been deoribed previou-ly. Brieffy, the major effects included wolling and racuolization of the remel wall, onelu-ion by thrombe and finally collaper and -res-

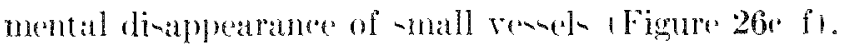
Penctration of a circulating ceell through the remed wall and a re-ulting small hemorrhage are -hown in Figure 27 . 1,y-i- of the venel and entrapped cells frectuently proceded rapidly. Mortality within $12 \mathrm{hr}$

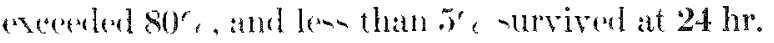

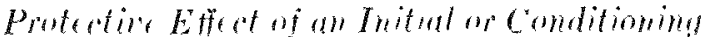

Exposure on Subsequent Ratiosensitinity

An initial or ronditioning expo-ne of the explanted 3-tlay enbryo to a minimal lethal deen of $x$ ray

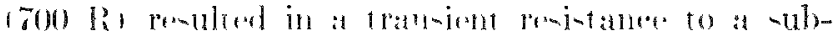

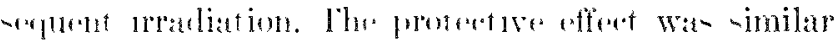

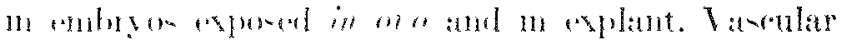

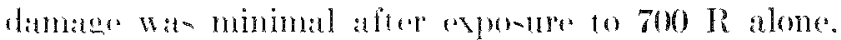
and mortality within 21 hr wa - low than st. Mo-t renel- remained funcrional, and only in a few in-

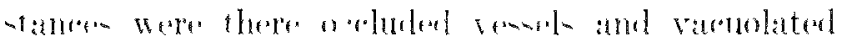

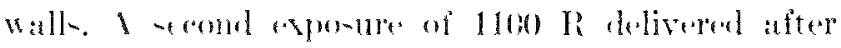
an intertal of 4 he remented in 40 , mortality within 12 hr complese to more than sor, in embryon ex-

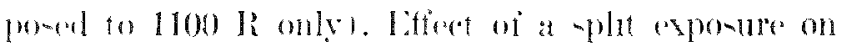

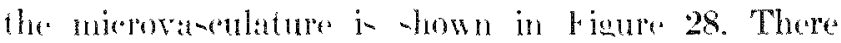

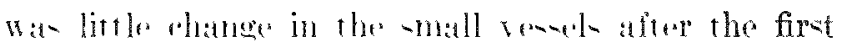
esponere, and little additional injury followed the -reond or ehallengine dow. A firw monfmetioning

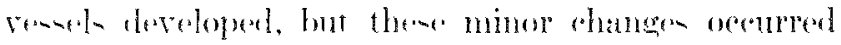
-lown ly wer mang hour and frepuently little ad-

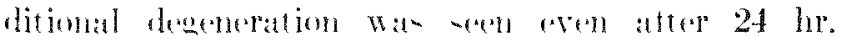
Matny renel wall- remained thin and datinetly out-

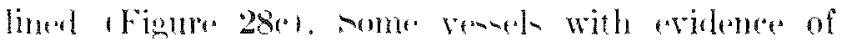
molury. a.e. - wollen benel wall and thromboryten arlherine to lowilizal ander. rontinuenl to function for the duration of the ohervation period. Fxamples of temporars orelu-ion ware oberved in other intamese. but after a thort time the acthering reals

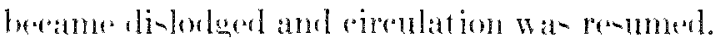




\section{Protective Effect of Soybean Trypsin Inhibitor (SBTT)}

In explanted embryom pretreated with SIBTl, 50\% -urvived at $12 \mathrm{hr}$ after $1100 \mathrm{R} \mathrm{X}$ irratiation; of these, mont had a strong regular pulse and good circulation at 24 hr. 'There was little' change in the mierocirculation; mout reusels were functional and appeared normal after $8 \mathrm{hr}$, compared to cxtensive vancular damage in unprotected irradiated embryon (Figure 29). In many embryon, the architerture of -nall vesech resmained unchanged at $24 \mathrm{hr}$. When a few degenerated or occluded resine we were seren within an hour or two after irradiation, entinued oberration for many hours frequently howed no further change, the remaining resols continuing to function. lisen in an oecluded versel, the arehitesture of the wall and entrapped ell was maintained with little or no change at $8 \mathrm{hr}$. and the mase of cell wa till vi-ible seceral hour later. Normal blood flow continued in the -nrrounding arest. Some animal developed atrythmia and, although eirculation beane poor, went rened wallo remained intact for many hour.

It was repeatedly noted that, in embryo- without a brating heart at 24 hr, the nomal strueture of ratall resele was maintained. This was in harp cont ra-t to untreated irradiated embryon, in which the $1 \mathrm{y}^{-} \mathrm{i}$ - and di-appearaned of verel- oceured rapidly after cirelllation ceaverl, freapuently within a few minuter.

\section{CONCLCLIONE}

The effect of a conditioning raliation expo-ure in pretenting breakitown of the microvaculature following suberquent lethal irradiation rembembed the proteretive effect of soybean trypin inhilitor. After either types of treatment, radiation frequently rewulted in little degeneration and dinappestrance of mall remels. and normal circulation continued in mo-t remels for $24 \mathrm{hr}$ and more. Early mortality was reduced by about 50 'r

Some vears ago we demontrated a radiation-indued ratiorenitance in the 3-divy chick after exposure to a sub- or minimal-lethal amount of ionizing raliation. ${ }^{21}$ This reistane persinted for ereral hours and was largent in conmention with the mor- tality expresned within one to two days after irradi tion. The nature of the radiation-induced radiorenintance has remained obscure. It was previounly suggerted that the initial radiation exposure resulted in liberation of a substance, the absence of which indueed at temporary resintance. It reformation wat then considered to be remponsible for the return of the organi-m toward its original son-itivity. ${ }^{(4)} R^{2}$ -ult of later experiments, -ome of which are reporter here, indieated that the action of lytic anzemu are important. "The suereifie artion of wybean trypin inhibitor again tarly radiation injury is assumed to be dependent on its inhibitory action againt proteolytire enz:men. In the explanted chick embryo, th well at in the older embryo and the young chick. pretreatment with SBTI reduced early radiation lethality. In embryo trated with sB'TI before irradiation, injury to the microviseulature was reduced: the venel wall frequently showed little or no rhange over many hour, eren in some indiriduals that dirl not survives to $24 \mathrm{hr}$. In other experiments we have demonstrated a rytochemieally detectahls increase in acid phomphatase at 90 min after a lethal irratiation, -uggesting a releare or activation of hound enzymes."5. In adlition, the increa-e in pla-ma acid phosphata-e aretivity that oredured at 2 or $3 \mathrm{hr}$ after at lethal irratiation of the young chick wik not seren in rhick treated before irradiation with SBTT. ${ }^{(2)}$

\section{RI I I. RE:NCHes}

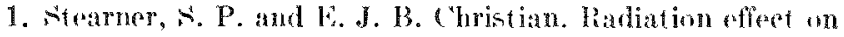
the mierocirculation: Relation to marly mortality in the chirk embryo. Radiat. Res.34, 13x 152 (1968).

2. Stearner, *. P. and $\$$. A. Acma larly radiation lethality. Fuzyme relesse and the protective artion of soxbean trypsin inhibitur. Proc Sur. Exp. Biol. Med.128, (13-91\% (19kis).

3. Christian, F. I. B. and $\$$. P. Stearner. A procedure for explanting the 2 horr chick rmbuyo. Pro. Soe. Exp. Biol. Mal. 125, 13:30-1392 (196\%).

4. Sitedrner. S. P., S. A. Tyler. MI. II. Standerson, and V. J. B. Chriatian. Mechanimme of resistance and reversal in the initial radiation responas in the ehick. Ratiat. Res. 14, $7932-747(1961)$

5. Stearner, \&. P. and M. H. Sandersom. "The nltrastrueturel localization of acid phosphatase in the ares pellucida of the chick embryo: Fiffect of $X$ radiation. Argonno Vational Laboratory Biolugical and Medical Receareh Diviaion

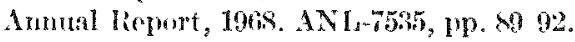


RESISTANCE TO EARLY CIRCULATORY DEATH IN THE IRRADIATED CHICKEN: EFFECT OF SPLIT EXPOSURES

\section{s. Phylles sto arner}

PLIPUM: ADB MITHOD

In obervation of early rarliation mortality (0) to 2 day- in the chick, the comparison of protracted and fractionated axponure 12 or 4 dones indicated that qualitatively different procemes were operating during and between irradiation. (1) The kinetice of injury accumulation during irradiation eprotracted esposuren was comintent with an empirioal model that motulated a con-tant or linear reversal of dose saffertivenem. There nat no evidence of a depatrture from a linear pelation for expoure periors up to 24 hr, and the time constant was comparable in the (i-d day rhick embryo, ${ }^{(2)}$ the 3 -rlay ehirk, ${ }^{(6)}$ and the 6-month rooster." With -plit domen, the kinetion of reduction in radiomemitivity to a sherguent irradiation. during the interval after the intial expoure. indieated a nonlinear procen. Thi radiationinduced proesen, under appropriate condition- (proper magnitude of firet dose and intervall, resulted in at ratiation tolerane above that of the untreated animal and wa- termed a "rewistives procen." (5) Unlike the receral operating during irradiation, the resintance appeared to depend on the magnitule of the initial expo-ures. Mlore reeent tudien reported heres rerealed other kinetic differences in the initial lethal remone: 11) Throushout derelopment, from the 3-day" chick embryo to the 6-month rooter, there wat little change in radionem-itir ity to -ingle-done exposure, and the time contant for reversal durine irradiation were comparable. 12 , The magnitude of the indured reintanes incerested during development of the rhichen. The resitance was relatively mentl in the 3-day ambro. but in the roo-ter a relativaly refractory ctate wa- produred on that the enrly mortality, a rapidly proere-ing circulatory failure, did not oceur ex an after a challengine feceond expo-ure of more than $7000 \mathrm{R} y$ rays.

The effect of the size of the firt ronditioninge) fraction of a yolit expo-ure to Co $0^{60} \gamma$ rate and duration of the interval between expouree on induced radionesistance in the roonter are deceribed in this report. In addition, comparisons are mato with chatratcteristice of the induced radiore-istance in the younc rhick and chick embryo after ionizing radiation.

Roo-ter (white leghorn) were reared in our animal ueilitier from rockerels received at 2 diam after hatehing. It 30 day of age, chick-were wing-clipped and tran-ferresl from brookers to cages. They were maintained 2 or 3 to a cuge until they were 5 to 6 month of aste. Roonter- were irrarliated in perforated aluminum boses that were arranged radially aromel the colvalt-60 source and were rotated at a rate of $0.5 \mathrm{rpm}$ during irradiation in order to equalize the distribution of the delivered done throughout the body. single-done expontre were given in $30 \mathrm{~min}$. The firs fraction of a -plit espo-ure wan given in $1.5 \mathrm{~min}$, the eromd fration in 30 to t.5 min. Interval ranget from $60 \mathrm{~min}$ to $24 \mathrm{hr}$. Hore than 800 rooster were. und in the srite of experimente reportad here $(600$ for -plit expowres and 26.3 -ingle dowe controls). Mrorlalit! wa- recorded daily; -urvivor after 30 daw

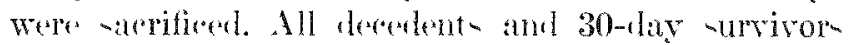
were neropeied for obervation of arom lesions. chick- white leghom corkepel-s were received at 2 day atter hatehing. At 3 day. they were exponed monder -tandard condition's, to colsalt-60 $y$ rays. Single-done eryosures were delivered in 10 to $12 \mathrm{~min}$. tach fraction of the -plit expo-ure wa delivered in 12 to $1.5 \mathrm{~min}$; intreval ranged from $60 \mathrm{~min}$ to 24 hr. Mortalits wa reerorded daily for 30 days. Approsmmately iono ehick-were included in thi- analyin.

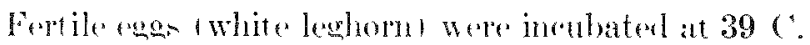
Embryo, after 3. 6, 12, or 14 day- incubation, were irradiated $n$ wo in eardboard hosen. Exposure time for each fraction was lew than $1.5 \mathrm{~min}$. Interval, ranged from $60 \mathrm{~mm}$ to $24 \mathrm{th}$. : $t$ nd tuge were returned to the ineubator during thi- period. Fog were eandled daily until hatrhine to determine -urvival. Approximately 3300 embryon mere irradiated; of those, the lareent-erien was that exponed at 14 ilay 123001.

PROMREST RLPORI

Analy-i of the influenere of dowe and duration of interval on rarly radiation death is bated on mortality within 24 hr after the challenging recombl expo-rure. although -urvival wat oberved in all groups for 30 dare. Vers lew deathe oceured on the serond dav. In all age eromp, the larenet firet dome 1600 to $7(0) \mathrm{R}$ ) wa- at the approximate lower limit of the lethal range $(<5,1$. Radion-mitivity of the roo-ter. chick, and embryo ape hown in Table 16.

The dependenes of radiation mortality in the rooster on -ize of the fir-t fration and duration of the interval is bown in Figure 30. After a conditioning exponde of $1.50 \mathrm{R}$, radiation ameitivity decreaned with an increase in interval /Figure $30 \mathrm{~A}$, and at $120 \mathrm{~min}$ a -mall rewi-tance hen-itivity lew than that 


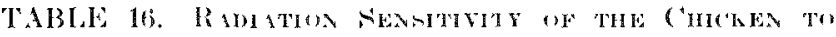
FARL C'TRCLLTORY DETTH

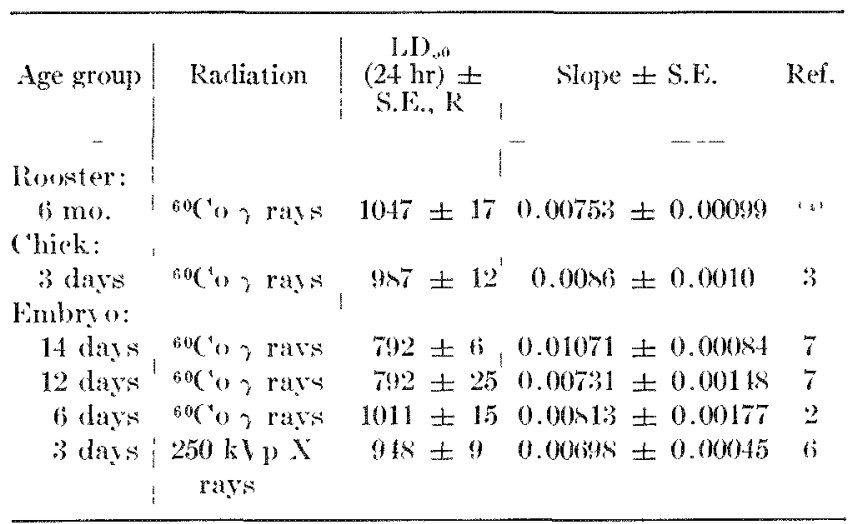

(2) This report.

of the unirradiated bird was present. The resistance was larger after an interval of 240 min, but after at 24-hr interval it had decreared to a level equivalent to that at 120 min. A larger resintance was induced by a first exponure of $300 \mathrm{R}$ (Figure $30 \mathrm{~B})$. This wat apparent after 120-240 min, but after 24 hr - en-itivity was similar to that seen after a first exposure of $1.50 \mathrm{R}$. After a conditioning expo-ure of $600 \mathrm{R}$, Figure 30(1) the resietance was very large at 240 min; a challenging txponre an high as $7400 \mathrm{R}$ resulted in no carly mortality. After an interval of 24 hr. however, onsitivity had returned to that oberved after the 120 -min interval, more than $1000 \mathrm{R}$ ereater than in groups that had pereived pither of the -maller conditioning dowes. Resistaner, as a function of interval for each of the three firstexposure groups, bined on estimated LDse values, is thown in frigure 31. Resistanee ergual on 0 indieated a sensitivity to the second expo-ure erpual to that in group not frervious ly irradiated, i.e. effect of the firt exposure had been completely nullified.

In the 3-day chick, the effert of a reonditioning exponure on subequent ralliation menstixity was -imilar to that in the rooster, although the induced peristance was -omewhat maller (Figure 32). Ratliosemsitivity returned to the preirruliation level ino effect of the first expo-upe remaining about $120 \mathrm{~min}$ after the initial expowure. With longer intervals radioaenitivity docreased further, and maximum resintane to early rarliation mortality $1 \geq 2000 \mathrm{l}$, was reached at 240 to $360 \mathrm{~min}$. After $24 \mathrm{hr}$ only a small renintance remained. erputl 10200 to $300 \mathrm{R}$. Wulike the rooter, the resistance at $24 \mathrm{hr}$ showed little relation to the size of the first dowe.

In the 14-day chick umbryo, a relatively small re-istance resulted from an initial expo-ure of either 300 or $600 \mathrm{R}$, expual to not more than ahout $600 \mathrm{R}$ (Figure 33 ). At 24 hr there was little loss of resistance,

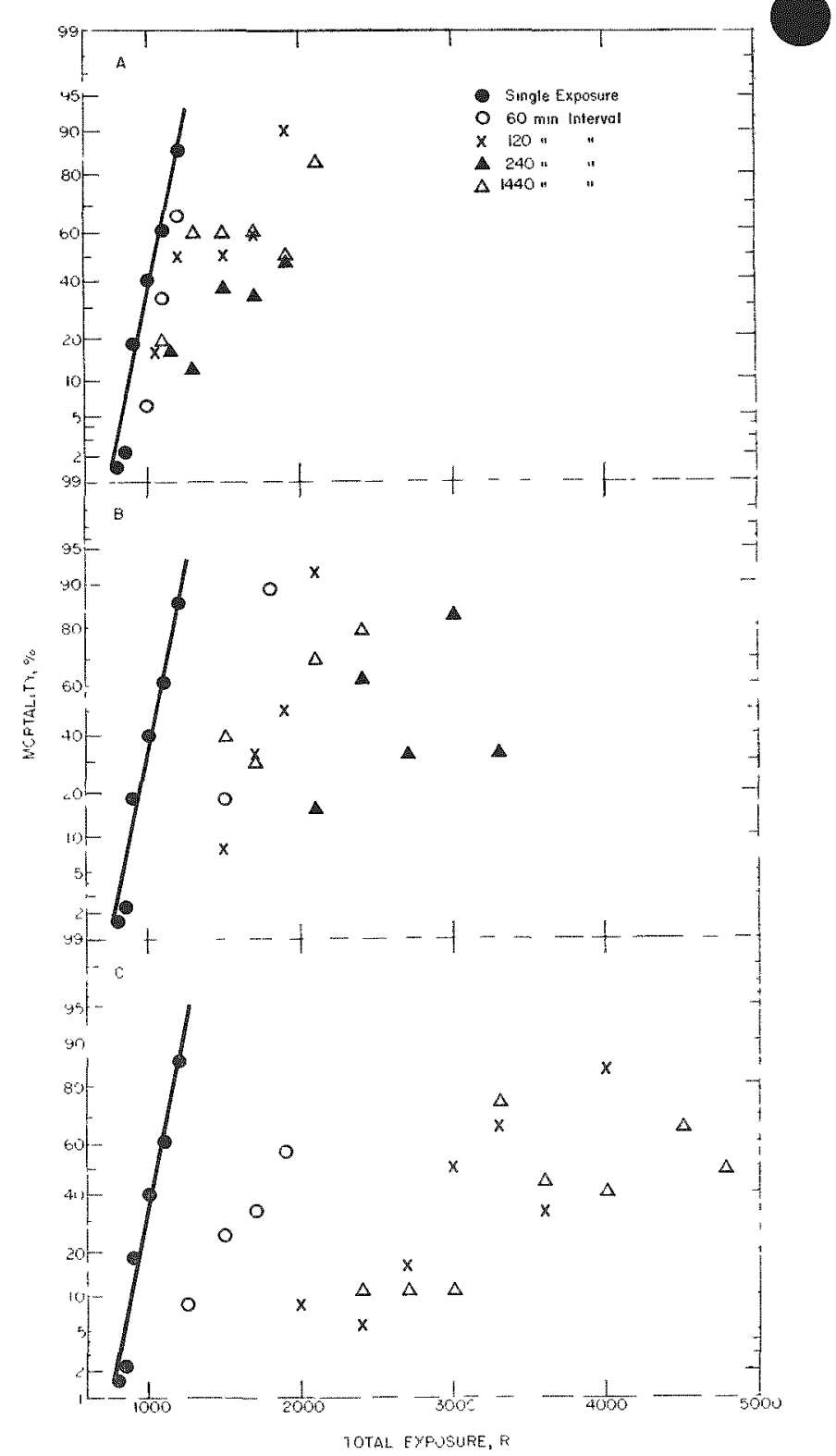

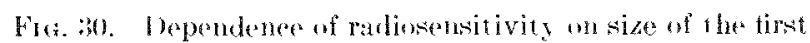
fraction and interval between fract inns of a split -dose revonsure

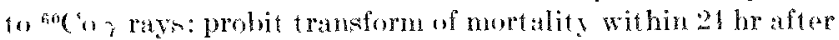

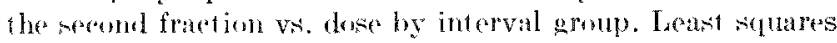
(onstants of the single-exposire gronp: $1.1 \%,=1017 \pm 17 \mathrm{l}$;

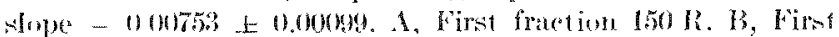
fraction :300 lR. (', First fration fon R. With 210-min interval to mortality was observed with total exposures up to kono $\mathrm{R}$.

so that the total amount remaining was sinilat to that in the ehick. In younger embryon 13 to 12 day' incubation maximuma resistanee did not exeede 300 to $400 \mathrm{R}$.

'The effect of age or stage of development on the ratiation-induced resintance is shown in Figure 30 Throughout the embryonie period the magnitude resintance was little changed; the maximum wis equal to 500 to $600 \mathrm{R}$ after a conditioning exposure near 


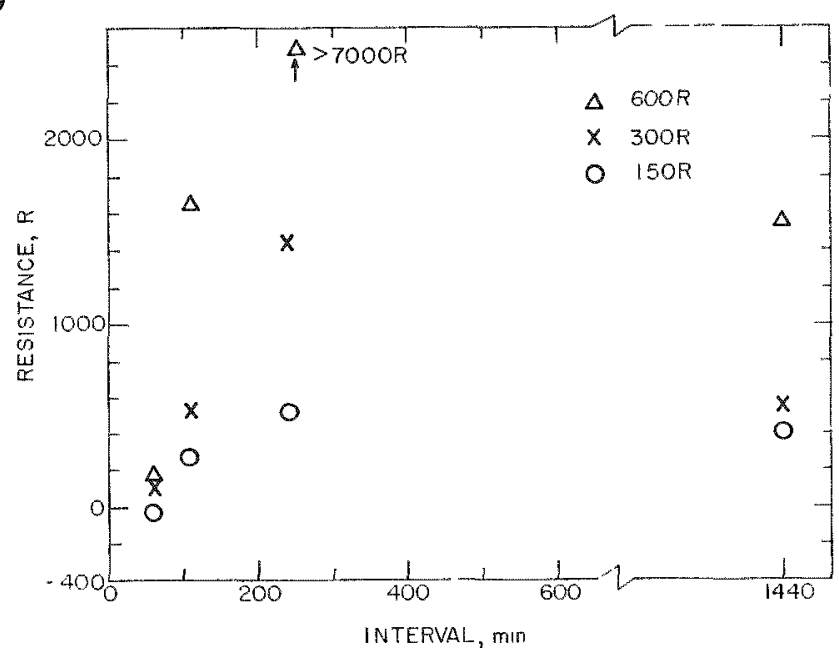

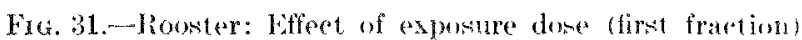
and duration of the interval on resistanee to early eirenlatory death following a second expowure (LI) values at imated from data in Figure 30). The radiosensitivity of the unirradiated chichen is represented by a resistance ectulal to deror.

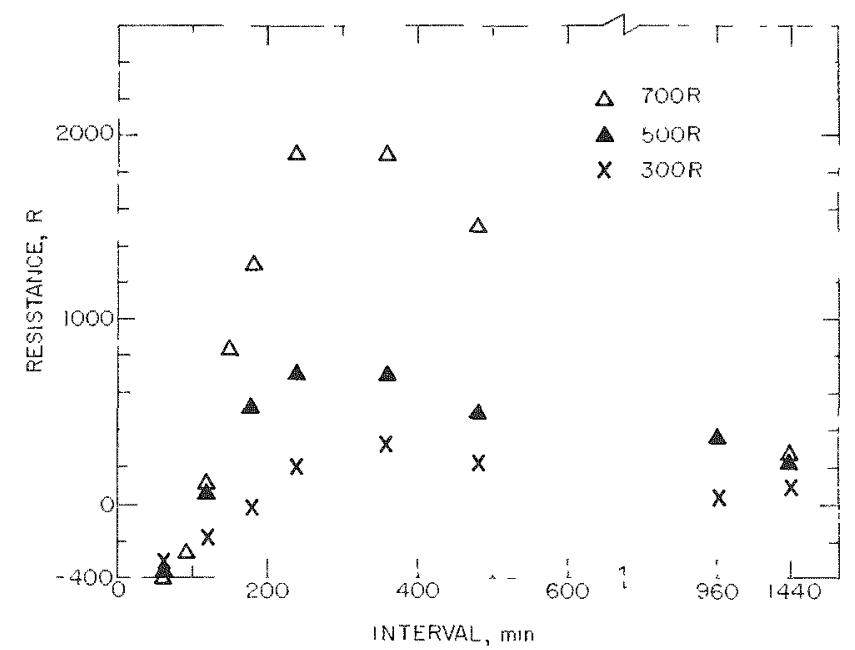

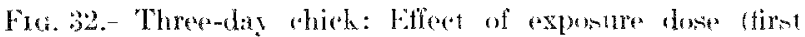
fruction) and duration of the inferval on resistance to carls

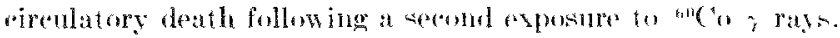

the lethal level 1600 to $700 \mathrm{R}$ and wat lategent between 240 and 480 min after the firsto dere. The 3-day dhick developerd a much greater radiorenintance after at conditioning exposure. The maximum revintaner was approximately $2000 \mathrm{R}$ for $5 \mathrm{O}^{\prime}$ of the population. (If the remaining $50 \%$, many survived after mueh hareer challenging expondres. In the rooster, the peristanes at $240 \mathrm{~min}$ after at lirs expoment of $600 \mathrm{R}$ wa- rery high, and no mortality wa obsereed eren after challenging exposure above $7000 \mathrm{R}$. The resistance was -till high $(1500 \mathrm{R})$ at $24 \mathrm{hr}$, in contrast to the chick and chick ambryo in which only about $300 \mathrm{R}$ remained. It is possible that resistanes is lost more

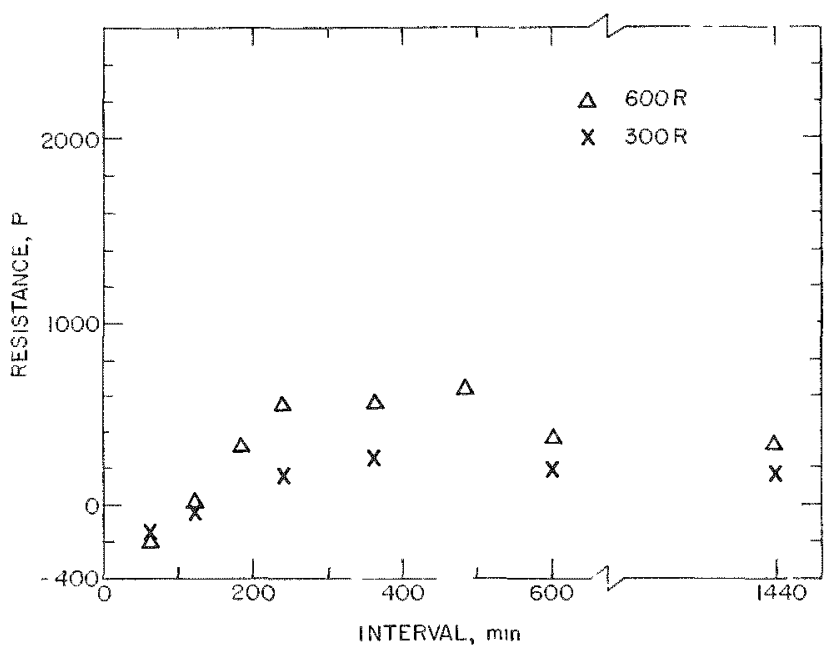

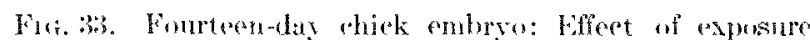
dime (first fraction) and duration of the interval on resist auce to farly circulatory death following at seend exposure to binco : rates.

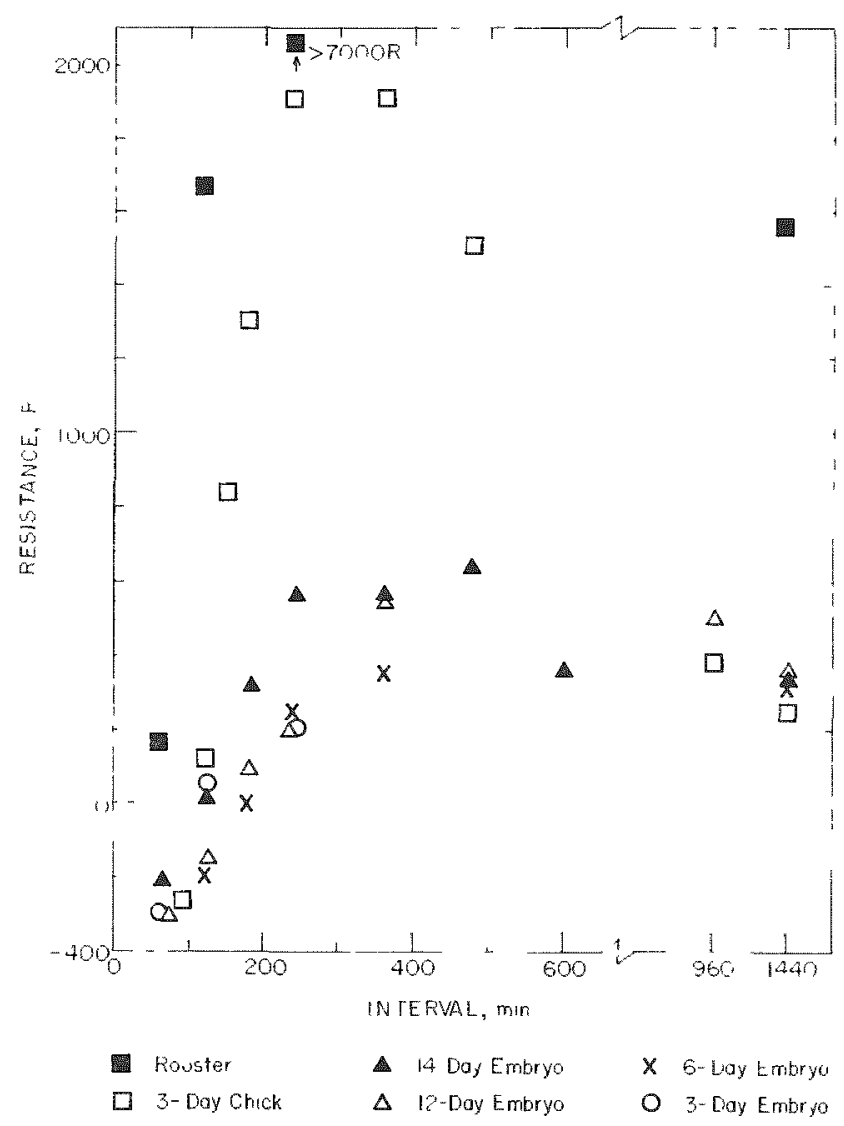

Fin. :3t Age offect on radiation indued radioresistanee to

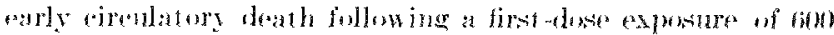

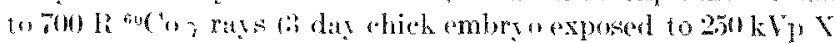
riont.

-lowly in the rooster and that it persists over sereral days. Tests after longer intervals are required to determine whether or not normal radiosen-itivity is ap- 


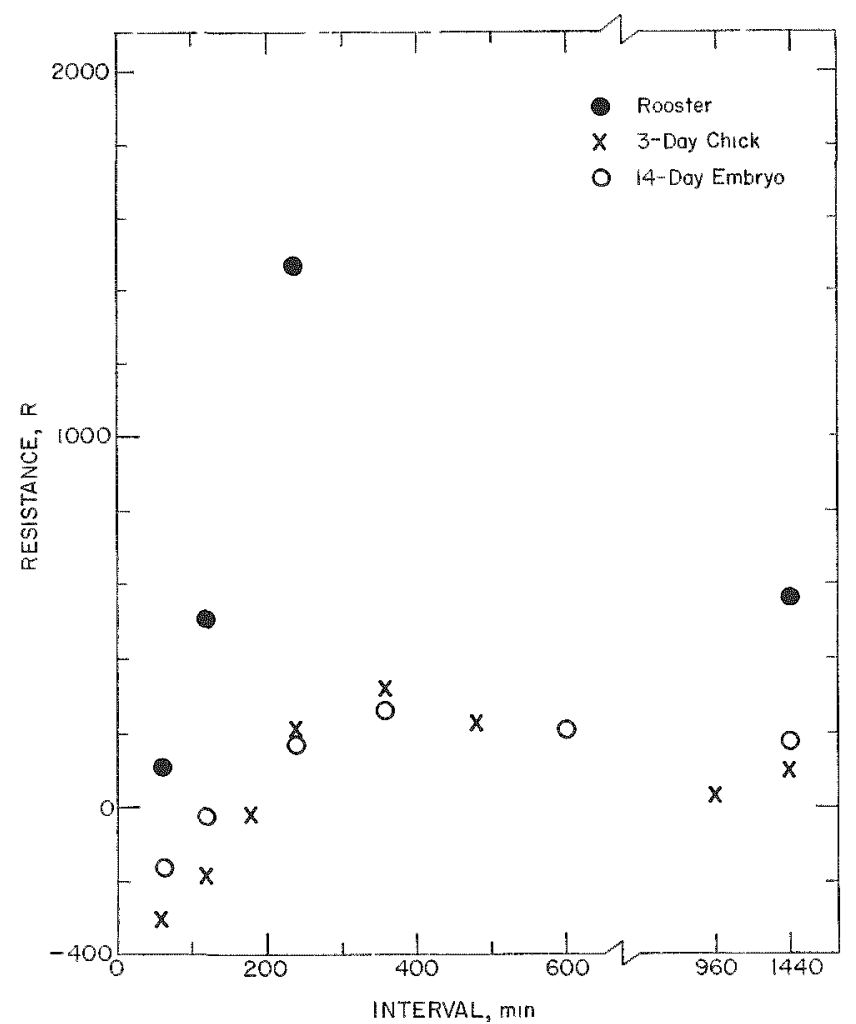

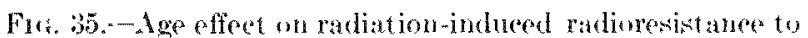
atrly cireulatory death following a first -dose exposire of $300 \mathrm{~K}$ 6nch raw.

proached after a longer period. Alter a smaller first fraction, well below the lethal level (300 Ri, the induced res-tanre wa approximately the same in the 14-day embryo and 3-day rhick, i.e., 200 to $300 \mathrm{R}$ 1Figure 33. In the rooster, however, the resitance wan large even after this relatively small firt dore. i.e., almost $1500 \mathrm{R}$ after $240 \mathrm{~min}$.

\section{COACLCDLNS}

Resintence that can be induced by a conditioning radiation exposure may be characterized as follow: 11) Resistance increase's with the magnitude of the first done. (2) Resistance increares with age after hatching 114-day embryo < 3-ray ahick < the roosterl, but is unchanged with embryo age (3- to 14-day embryol. (3) In all age group a resistance can be demonstrated within $180 \mathrm{~min}$ after irradiation, and a maximum is reached at 4 to $8 \mathrm{hr}$. (4) With one exception, an alnost identical level of radioresistance fapproximately $300 \mathrm{R}$ ) is reached at $24 \mathrm{hr}$ in all exposure and age groups; in the rooster. howerer, the resistance in eryual to almost $1500 \mathrm{R}$. (5) The rate of derelopment of the resistanee is nonline:ur. 16) There is no relation of the rexistance to the single exposurs L.1D) $)_{50}$.

The time effeets for re-istance and reversal proc-

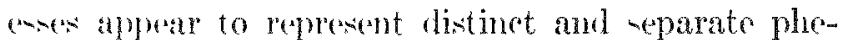
nomena. There is no quantitative difference in the reversal rate with age (the 3-day ambryo and the 6-rlay rooster are esentially the same), while the resistane is maximum in the rooster and at a similar low level in the 3- to 14-day cmbryo. Relation of the perersal and ren-tive proceneses to the microvaseular injury dereribed in living embryos is under investigation.

\section{RETERENCES}

1. Stearner, \$. I'. and I. J. 13. Christian. The effect of overall time of exposure on survival of young rhicks following roentgon irradiation. Am. I. Roentgenol. 65, 272-276 (1951).

2. Tyer, S. A. and Stearner, S. P. Modes of radiation death in the ehiek embryo. II. A model of lethal mechanisms. Radiat. lics. 12, 301:316 (1960).

3. Tyler, $\therefore$. A and $S$. P. Stearner. Diserimination between injury processes roflected in the acute radiation mortality. Irt. J. Ladiat. Res. 4, 194-509 (1962),

1. Statarner, S. B.. .M. H. Sauderson, and F. J. B. Christian. lelation of dose and exposure time for acute radiation mortality in the adult chicken. Aroome National Laboratory Biologieal and Mfodical lieseareh Division Ammual Re. port, 1\%6. AN1 -718ki, pp. 8233.

5. Stearner, S. P., S. A. 'Tyler, M. II. Sanderson, and F. J. Christian. Merhanism of resistance and reversal in the initial radiation responses in the wick. Rodiat. Res. 14, 7.92$747(1961)$.

6. Stearner, S. P'. and F. J. B. Christian. Warly vaseular injury in the irradiated ehich embryo: liffect of exposure time. Ratiat. Res. 38, 153-160 (1969).

7. Stearnes, s. P. and $\$$. A. Azuma. Coupublished data. 
EARLY RADIATION INJURY TO THE MICROCIRCULATION: RELATION TO MORTALITY**

S. Phyllis Steamer and Emily. J. B. christiun

The early response to lethal doses of ionizing radiation in the chicken and the chick embryo is characterized by rapid structural and functional changes in the microcirculation. Increased vaseular permeability and degenerative changes of the ressel walls lead to generalized circulatory stasis and death within a few hours after exposure. These effects were observed in the $\mathrm{X}$-irradiated, explanted 3-day chick embryo and were recorded cinemicrographically for subrequent study. Within 2 or $3 \mathrm{hr}$ after a lethal expo-ure delivered in a few minutes (1100 $\mathrm{R}$, exposure time $12 \mathrm{~min}$ ), the verel wall became -wollen. and circulating cells adhered to localized areas of the endothelium. Thrombi formed in such areas, and occlusion of -mall veswel and degeneration of the vesect wall occurred within 4 to $6 \mathrm{hr}$ after exposure.

\section{$-\ldots$}

* Abstract of a paper to be published in the Proceedings of the Symposium on Radiobiology of the Fotal and Juvenile Mammal, Battelle Memorial Institute, Pacific Northwest Laboratery, Richland, Washingtun, May 5-8, 1969.
Alterations of the ressel walls were rarely olmerved after radiation doses below the lethal range. Tnereasing the exporure time from a few minuter to a few hours decreaned the dowe effertiveness for this injury mechani-m; a larger amount of radiation was required to produce the same efferet. Degenerative changes in endotheliat cells appeared to be a direct efiect, and their incidence was reduced when expo-ure time. wats increanted.

Fatrly changen in raseular permeability and in the pernucability of extravincular structures, such at binement membrane and ground substance, aloo have been reported after moderate doess of ionizing radiation in mammalian species, including man; unally, these effect atre les nevere than in the chicken atm are not fatal. In newhorn rath, howerer. we hat. demonstrated an early mortality $1<48$ hri alter expo-nre- of 600 to $1000 \mathrm{R}$ of $\mathrm{X}$ radiation. The premence of detma, hyperemia, and hemorrhages in the rentral neprous sy-tem indirate that raseular injury wat a prominent factor in the lethal response.

\title{
RADIOSENSITIVITY OF INTESTINAL CRYPT CELLS IN GROUND SQUIRRELS DURING AROUSAL FROM HIBERNATION
}

\author{
Bernard X. Joroslow, Hatha Robbins, amd susan .1. Stalling
}

PIRPOME AND METHODM

Recent work has shown that irradiation of ground squirrels r'itellus tridecemlineatus) during hibernation or arousal from hibernation result in increased survival over nonhibernating control..1. $\because$ "To develop an understanding of what contributes to increaned -urvivat after irradiation at this time, we are studving survival of crypt cells in the ileum and colon of ground squirrels irradiated during and at different times after arounal from hibernation. Hibernating ground scuurels were removed from the cold room, thu initiating arousal. They were irradiated with $\mathrm{Co}^{60}$ ganma ray- from 0 to $48 \mathrm{hr}$ later, aml on the ninth day after irradiation, they were given an intraperitoneal injection of colchicine. Four hours after the colchicine injection, the animals were sacrificent, and pieces of ileum and colon were prepared for hi-tologieal examination. A sample of the number of surviving crypt- was made by counting the number "f erypt- in eareh rection that contained epithelial call blocked in mitos by the colchicine. This approach was baed on the idea of Withera's) for rounting colonies of erypt cells in the intestinal wall of irradiated mice.

PRO ${ }_{2} \mathrm{RK}$ - RE RORT

Hibernating ground apuirrel were removed from the rold room. and group of 10 were given 1500 . 1600,1700 , and $1800 \mathrm{R}$ at $0,1,3,7,12,24$, and 48 hr after remeral from the cold room. They were maintained at $22^{\circ}$ " until they were arrifiend 9 raylater. The timan were fixed, sectioned, and stained, and the numbers of reryet containing cells in metaphase were counted.

The number of crypt in animals irradiated at 0 and $1 \mathrm{hr}$ after removal from the cold room was higher. at all radiation howe, than their irradiated, nonhibernating control- and it was atho higher than in the unirradiated. nonhilernating control (Figure 

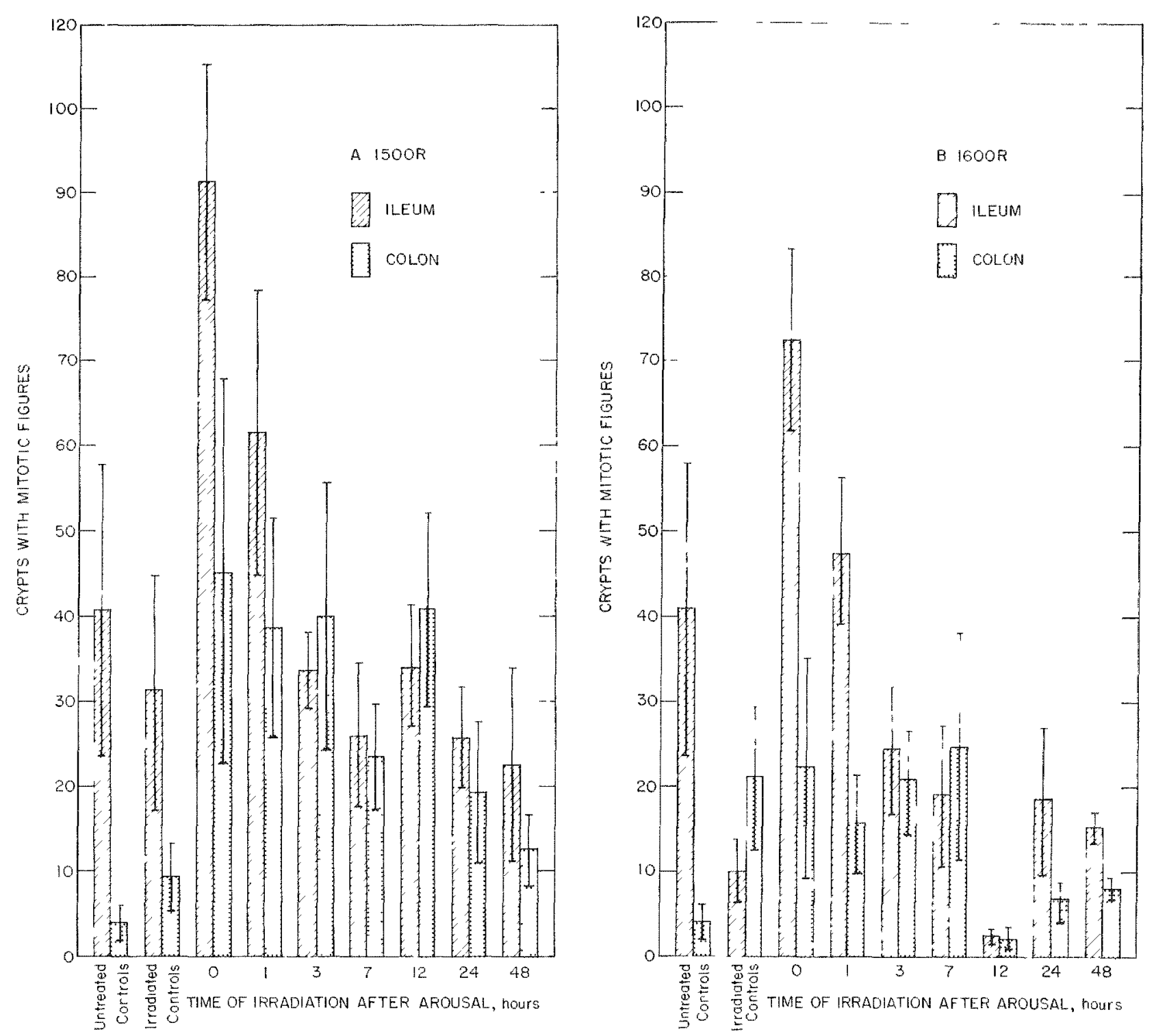

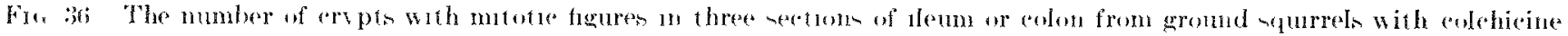

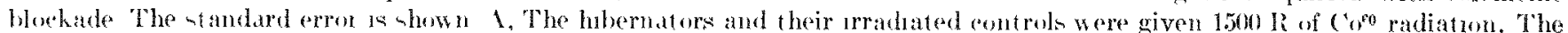

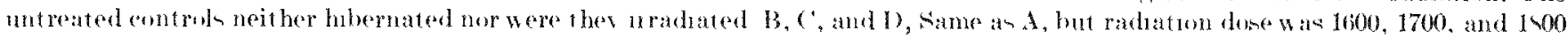
li, respesetivell. 

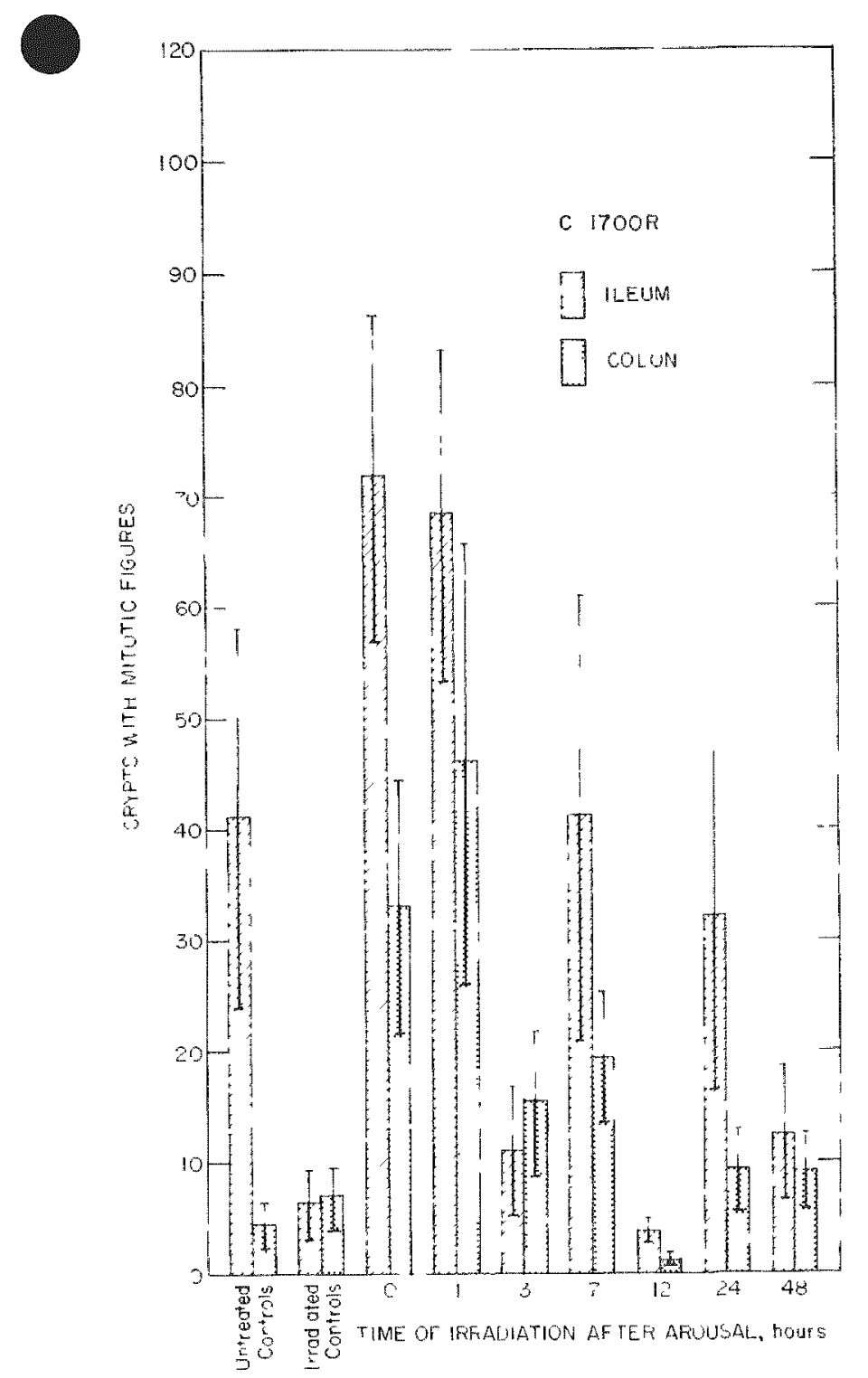

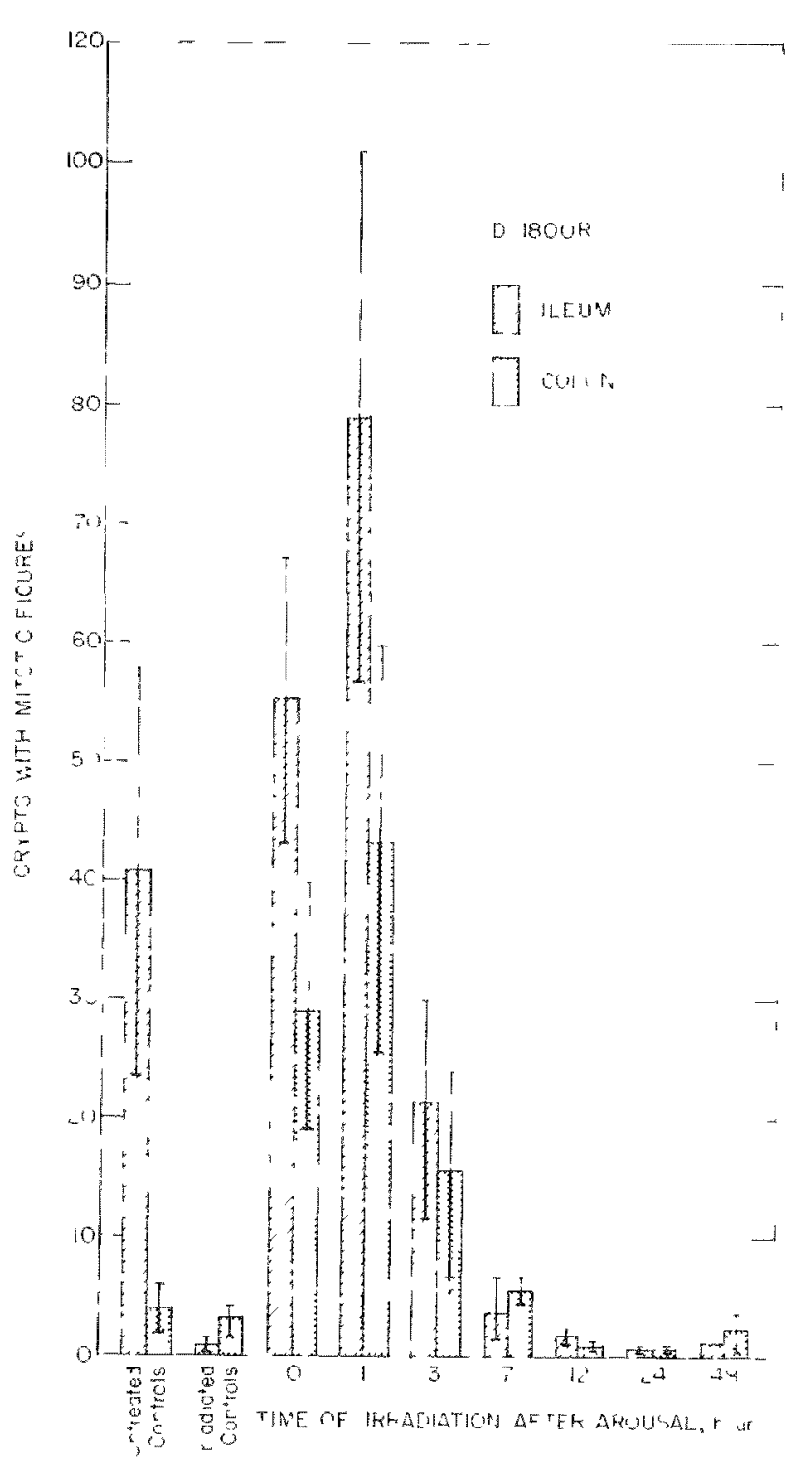

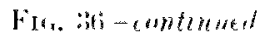

361. The atre no apparent differencen between the hibernator irradiated at the other time and their irradiated ront rols.

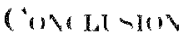

Thene perults clearly indicute a difference in the responet to irradiation during arou-al from hiberuafion, a compared to fully arotsen ground equirrel or the nonhibernating eontrol-. These differences are being inventigated.
RE1 LRLXCL

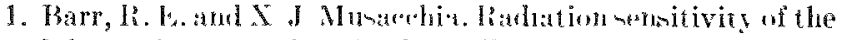

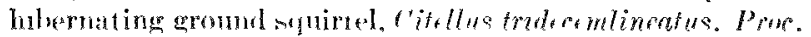
Sor Expell lizol. Wra. 124, 12014-1207 :1967).

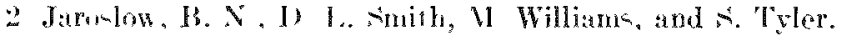
surival of hibernating around apuirrels fetellus bide-

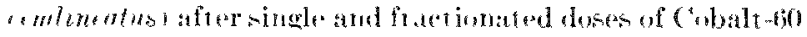

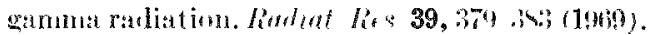

:3. Withers H. R. and M M lihind. Radrosenstivity and

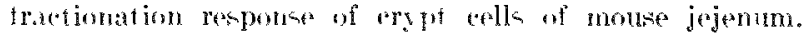
lindint. Rit 38, 59, $111: ; 11499)$. 


\section{KINETICS OF THE IMMUNE RESPONSE INITIATED IN VITRO}

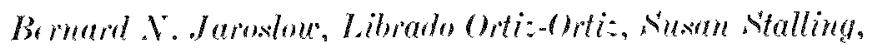
and Nartha Robbins:

PCRIOUl: AND METHODS

The -tudy of inturtion of the immune response has beren facilitated by techniquer for initiating the immune reponse in eito that have become geterally applicable within the lat five years. This breakthrough permit the study of cellular and molecular event-anociated with the induction and development of the immune response, free from the interaction with concurrent physiologieal processen in vivo. Thiinternetion is likely to become dominant when variou antimetabolite or stimulants are used. This becoms obrious in a sudy of the effesth of a drug uch a hydroxyurea feec report by the southwest. Cancer Chemotherapy Stuly Group'11).

Ifydroxyurea (HLi), as reported by sinclair,'2) killed DNA-nynthenizine Chinese hamster cells in vitre and blocked those in $\left(x_{1}\right.$ from beinning IDNat sonthemin. Thent blocked cell- eould renthesize RNA and protein. If the III wa- washed out hefore the blocked cells were due to divide. they continued their normal growth. If they were axponed to $\mathrm{HU}$ beyond their normat divinion time they died. On the other hand, Pfeiffer and Tolmach ${ }^{3 i}$ reported that HeI a cell were not killed by HU adderd during DNA

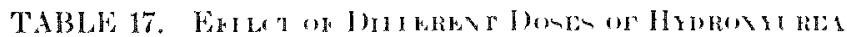

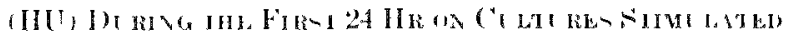

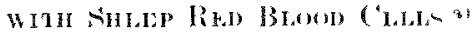

\begin{tabular}{|c|c|c|c|c|}
\hline $\begin{array}{l}\text { Group } \\
\text { vo. }\end{array}$ & Mouse splec na cells & $\begin{array}{l}\text { Mean vo' } \\
\text { viable } \\
\text { cells per } \\
\text { culture } \\
\times 10^{2} \\
\pm \$ \text { S.F. }\end{array}$ & 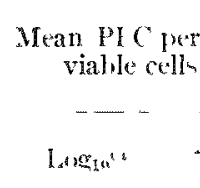 & $\begin{array}{l}\text { Sinti- } \\
\text { long }\end{array}$ \\
\hline 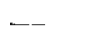 & $=$ & - & $-{ }_{-}-$ & \\
\hline 1 & alone & $19 \pm 1$ & $0 \times .3 \pm 0.3$ & i.s \\
\hline 2 & $+100 \mu \mathrm{VIII}$ & $10 \pm 3$ & 0.0 & 0.0 \\
\hline 3 & $+10 \mu \mathrm{VII}$ & $22 \pm+1$ & $096 \pm 0.26$ & 9.1 \\
\hline 1 & $+1.0 \mu V \mathrm{HC}^{\mathrm{L}}$ & $21 \pm 3$ & $0.4 \% \pm 0.26$ & 2.7 \\
\hline 5 & $+0.1 \mu V \|$ & $2 x \pm 4$ & $014 \pm 0: 31$ & 31 \\
\hline is & $+0.01 \mu .1 / \mathrm{HC}$ & $29 \pm 4$ & $0.50 \pm 0.32$ & $\because .2$ \\
\hline 7 & tSIIBC & $31 \pm 0$ & $2.615 \pm 017$ & 450.0 \\
\hline$\checkmark$ & $+N B B C+100 \mu . l l 11$ & $s \pm:$ & $2+2 \pm 0.1 \%$ & 2063.0 \\
\hline$y$ & tSRBBC $+10 \mu V$ HC $^{\circ}$ & $11 \pm 2$ & $3.11 \pm 0001$ & $1.3 \$ 0.0$ \\
\hline 10 & $+\mathrm{HRBC}+1 \mu \mathrm{H} \mathrm{HL}^{\circ}$ & $19 \pm 3$ & $3.15 \pm 0.111$ & 1.510 .0 \\
\hline 11 & +NIBC $+0.1 \mu v H C^{\circ}$ & $21 \pm 5$ & $3.15 \pm 01 \times 1$ & 1110.0 \\
\hline 12 & $+\operatorname{SiBC}+0.01_{\mu} / \mathrm{NT}^{\circ}$ & $10 \pm: 3$ & $302 \pm 00 i_{3} 1$ & 10.5010 \\
\hline
\end{tabular}

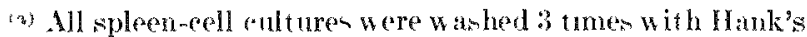
salt solution after 24 hr. The cultures were assaved for ylanueforming cells (P $\left.\mathrm{F}^{4}\right)$ after 6 dais

(b) Viach datum represents the arithmetice arerage of the

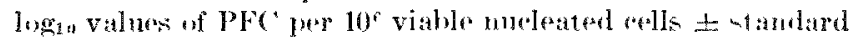
error for 5 enlturts.
Tnthesin or if they were blocked beyond their normal division time. This deviation from the resulte with Chinese hamster cells may reflect a difference in $\mathrm{HU}$ m-mitivity. Effects of $H C^{\circ}$ on the kinetirs of antibody-forming cells were inventigated in a dicsociated spleen cell rulture system from normal mice, aceording to the fechnique of Mi-hell and Dut ton. ${ }^{(4)}$

The immune response wan initiated in a cell suspension 120 million cells $\mathrm{ml}$ ) from spleen of unimmunized DBA $1 \mathrm{Jax}$ mice -timulated with $100 \mathrm{mil}-$ lion sheep red blood cells (SRBC). Tath culture rontained $1 \mathrm{ml}$ of cell su-pension. The number of antibody-forming celk in each culture was determined by the technique of Jerne et al. ${ }^{(5)}$ The cell -u-penion is plated on blood agar containine SRBC, and the antibory-forming cells are detected hy the appearancer of vivible cleatr spots (platquest in the ateatr, formed by the hemolytire action of the antibodien thar they produre. To remove IIU after treament, the eulture were pooled, wathed three times with Ilank is salt nolution, and divided again into aparate culturem. In the progeres report that follows, result of at rerien of experinente designed to investigate the time of onset of DNA rnthe is by the precursors of the placyue-forming "ell $1 \mathrm{PF}()$ and their generation time is meateured.

PRI) *RLM RLPORT

\section{Erperiment 1}

HU was arderd, at dowen from $100 \mu .1 /$ to 0.01 a.I (Table 17), to the cultures when they were started, and was wathed out after $24 \mathrm{hr}$. Its effect on cell viahility, the number of hackground plarpes, and the number oi plaque produred in enltures civen SRBC after 6 dave wa-mall, except perlup at 100 u.T (Group 8). ('ells treated with IIT for $48 \mathrm{hr}$ were killed.

\section{Experiment?}

IlU 10.5 p.IS wan added to anlures for the following intervale; 0 to 24,24 to 48,48 to 96,96 to 120, and 120 to $144 \mathrm{hr}$. The dowe chomen was the best rompromise: it allowed for the prorluetion of the maximum number of plarpu-forming cell and the minimum toxicity kee 'Table 17). When HU was wa-herd out. a set of control cultures was siven the same wash treatment.

The number of $\mathrm{PFC}$ - een on day 6 of culture without $S R B C$ are negligille (Table 18. Croup 1 ). 


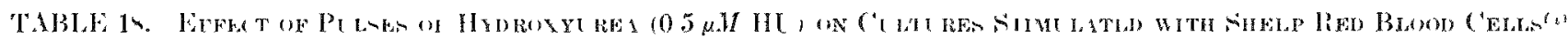

Mean P'L C per $10^{6}$ viable cells on day $6^{6}$.

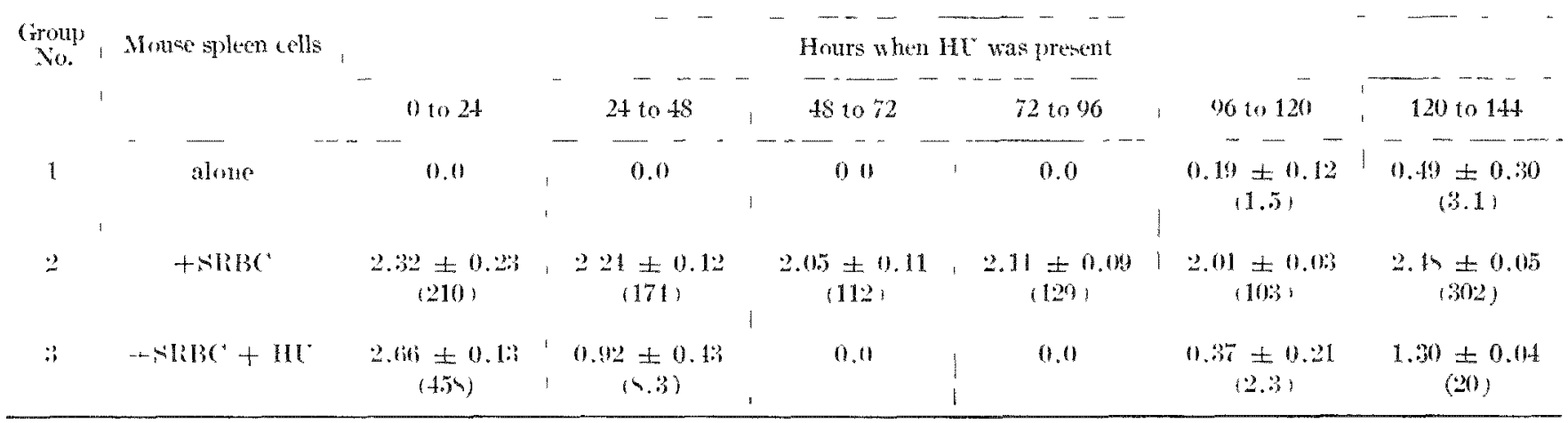

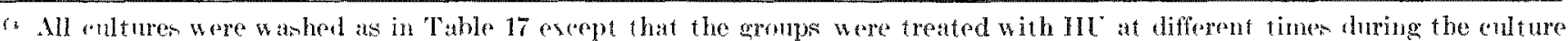
period.

(b) Far hatum reprementw the arithmetio average of the login valuen of $P F C$ per $10^{6}$ viable nucleated cello \pm standard error for

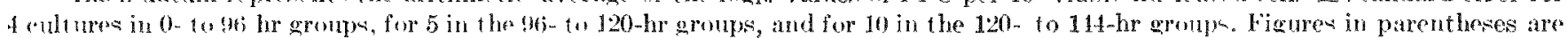
the gantilug of the neant.

The effect of washing the eultures at different times during the 6 day of eulture is small (Group 2). There is no -ignificant difference between the Group 3 cultures given IIt for 0 to $24 \mathrm{hr}$ and their washed control in ciroup 2. The differenen are sienificant between the $11 \mathrm{C}$ treated cultures of Group 3 and their respective Group 2 controk for ach of the other 24-hr periork.

It is noteworthy that $100 \mu . / \mathrm{HCr}$, when arded to the cell -m-pencion during the andy procedure, had no effeet on the number of plaques counted. i.e., it did not interfere with the synthemi- of antibody protein during a one-hour incubation.

\section{Eicperiment.3}

When IIC in added to a population of dividing antihody-forning cells in culture, the entire population is billed when the treatment is applied for 21 hr (Table 18), but only cell in the process of DNA synthe-i- are killed by a hori exposure to HU (Sinclair(")1. This experiment was de-igned to study the growth kinetice of antibndy-forming rells and their precuror.

Three dar after the cult ure were started and -timulated with $S \mathrm{RBC}$, wach group received $38 \mathrm{pg}$ 10.5) $\mu . h)$ of HC. After treatments of 2 to $24 \mathrm{hr}$, the culturew were washed free of $\mathrm{HU}$ and maintained as before. After 6 dars, the cultures were assayed for PFC. The antilog of the mean $\log _{10}$ PFC for each treatment aroup divided hy antilog for the control group, wa-calculated and the renulting mean fraction for each HU treatment interval from three experiments were plotted as shown in Figure 37.

IHU treatment from 2 to 7 hours hows a $70 \%$ doereave in PFC. The number of PFC falls rapidly

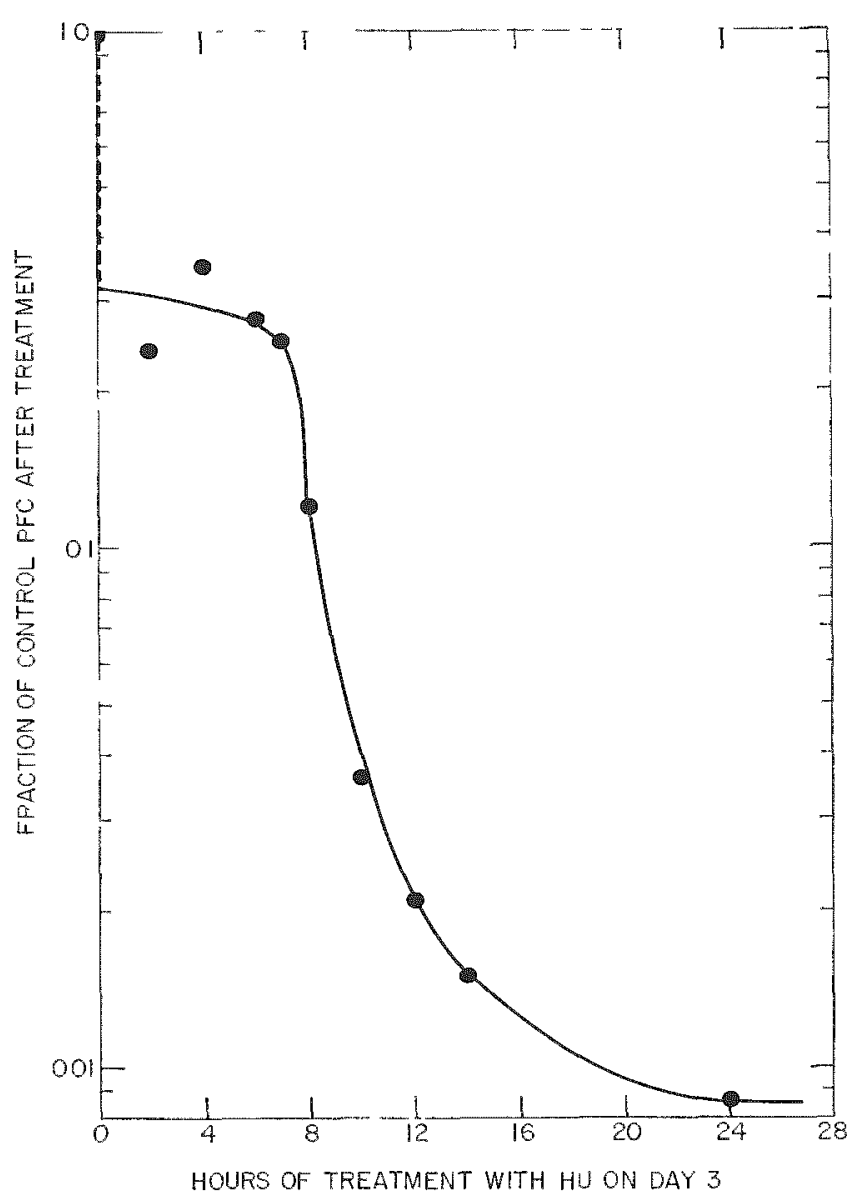

Fig. 37.-Survival of the precursors to plaque-forming cells (PFC) after different periods of inenbation with $0.5 \mu \mathrm{M}$ per culture of hydroxyurea (II). Earh point represents the antilog of the mean log $P F C$ per $I L$ treuted group divided by that for the contrul group. This curve is the composite of three experiments. 
and approaches zero as the period of incubation with HU increasen to $24 \mathrm{hr}$.

It in not yet clear whether the 2- to 7 -hr period should be flat or should have a negative slope.

\section{COYGLTMION}

We assume thit the fraction of PFC at the time of away is the same an the fraction of their precursor killed during treatment with IIU. We also assume that our results indicate the same effect of $\mathrm{HC}^{\mathrm{T}}$ on our eells ats on ('hinese hamster cell. (2) If these a-mumptions are correct, our findings indicate little or no 1)NA sunthes of precursor cells during the first day of eulture and active DNA synthesis from then on. At the time of active synthesis, after 3 days, allout $70^{\circ} n$ of the PFC and 'or their precursors were synthesizing DNA when IIL was added. The shoulder of the curve in Figure 37 indieate, according to Sinclair's interpretation of his lata, (2) that the be-

\section{MODIFICATIONS OF ANTIBODY FORMATION}

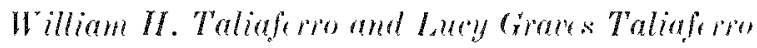

\section{P RPOME AV METHODS}

Previouly, modifications of the primatry ${ }^{-1}$ : and veondary ${ }^{3-11}$ For-man gamma 1 respones in rabbit were reported when sheep red hlood cell- ISIBBC were injected or reinjected from $t$ he to 2 montls ufter irradiation. The current -tudy, reported in part last year, ${ }^{(1)}$ death with modifieations of the same two reyonses when SRBC were injected or reinjeeted from 1 to 4 hour, to 2 month befort irradiation. Rathbit were exponed to either a single small 125 to $100 \mathrm{R}$ ) or large 1.500 to $700 \mathrm{R}$ ) dowe of totalbody $X$ rays, and reult were compared to unirradisted controls. The foregoing two stratematir studies of irradiation have not previous been undertaken for any immune remponet.'s 1"' Earlier reports on the hemolyin re-pone in pabhit hate mainly dealt with the effect of a large dowe of $\mathrm{X}$ rays at limited intervali on the primary rexponesere is and have pracetirally ignored the effect of a matl do-a on either reponce. (1:

In unirradiated rabhits after the intratenoum injection or peinjertion (1.5) to 2.5) monthe later of $2 x$ $10^{\circ}$ SRBC ${ }^{4}$ per $\mathrm{kg}$ rabhit, hemoly ${ }^{2}$ in formation 16-19) involves (1) induction during the first few hours, (2) elaboration of the r-rnthetic meehanism during a 2 - to 4-day latent poriod, (3) all arute rice to peak titer, which is attained in a week or two, (4) a rapid decline for sereral weeks after peak titer, and (5) it ginning of DNA synthesis to division involve slightly more than 7 hr. From the steep slope of the eurve, we estimate that the entire cycle ir approximately $8-9 \mathrm{hr}$. This study continues.

\section{REILRETC'}

1. Southwest cancer ("hemotherapy Study Cronp. A phane I study of hydroxyurea. C'ancer ('homotherepl lie ports 29 , 103107 (196i3).

2. Sinclair W. K. Hydroxyurea: Wfiects on Chinese hambler cells grown in colture. ('ancer Res. 27, 293-30s (19m7).

3. Pfeiffer, S. L. and L. J. Tolmach. Inhbition of INA s n thesis in Hela cells by hydroxyurea. ('aner Res. 27, 124 129) (196i).

4. Mishell. IR. I. and R. W. Dutton. Immunization of dissociated spleen cell cultures from normal mice. J. Exptl. Hed. 126, 123-412 (19ti7).

5. Jerne, N. K., A. A. Nordin, and C'. Ifenrt. The agar phatue technique for recognizing antibody-producing cells. C'tllo Bond Antibodies, Fel. B. Amos and II. Koprowski. Whatar Inst. Press, Philadelphia, 1963, pp. 109-130. much slower decline for a month or more feee cont rol graphe in Figure 38 and 391 . I Juring the lant three stages, protein sonthes takes place rapidly at firt and more slowly thereafter. T'o tent the effect of $X$ raye on these 5 stages, group of 9 or more rabbit, were exponed to a -mall dowe or a large dowe of $X$ rays at a appropriate interval during the primatry or secondary reponse. The individual rabbits in thene 20 -erien were blexl 3 or 4 times a week for at month or more, and serum from them were titrater for hermolyin in $50^{\prime}$ ' unit hy mearr of a colorim(tete. ${ }^{(15)}$

PHORRES RLPORT

Hemoly-in titer in individual rablit in the 20 -erien were graphed and vielded mean "- -tandard error-for peak titer and rarious other parameter of the inmmue repomes, including length of the latent period and length and raten of the rise and fall of hemolysin. Throe mean were compared to meane tandard exror in two unirradiated control serien, i.e. for the primary reyonec in 73 rabbit and for the - ereondary reyones in 48 rabbits.

The following reult were oltained in the rabits irmaliated at critioal timen during their hemolysin respones as compared to mirradiated controk. The -mall do of $\mathrm{X}$ ray during induetion of the primary repone timulated hemoly in formation, as evi- 


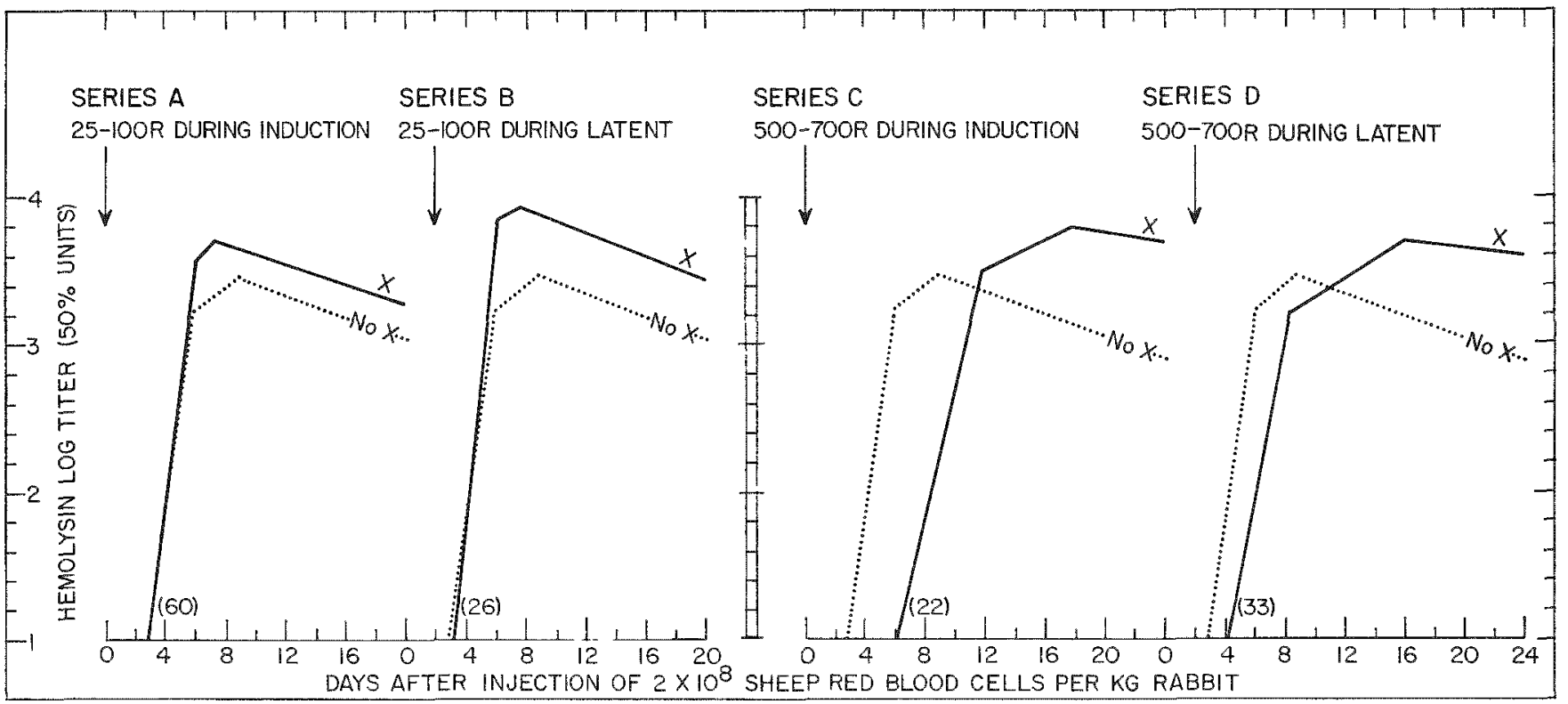

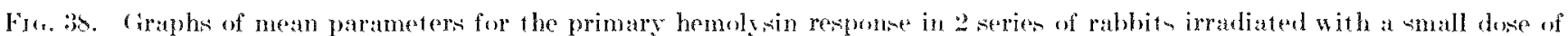

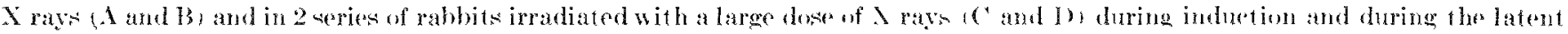
period. Arrews indieate the time of irraliation, and numbers in parentheses indieate the number of irvadiated rabbit- in each series. For comparative purposes, a control graph of mon parameters for the trimars hemolysin remponse in 73 unirradiated rabhits is repested in each seartion.

Note that the mean hemolysin responsess in irradiated rabbits are timulated in sedies 1 and $B$ and are at firnt depressed but teventually enhanded in serpies ("and I).

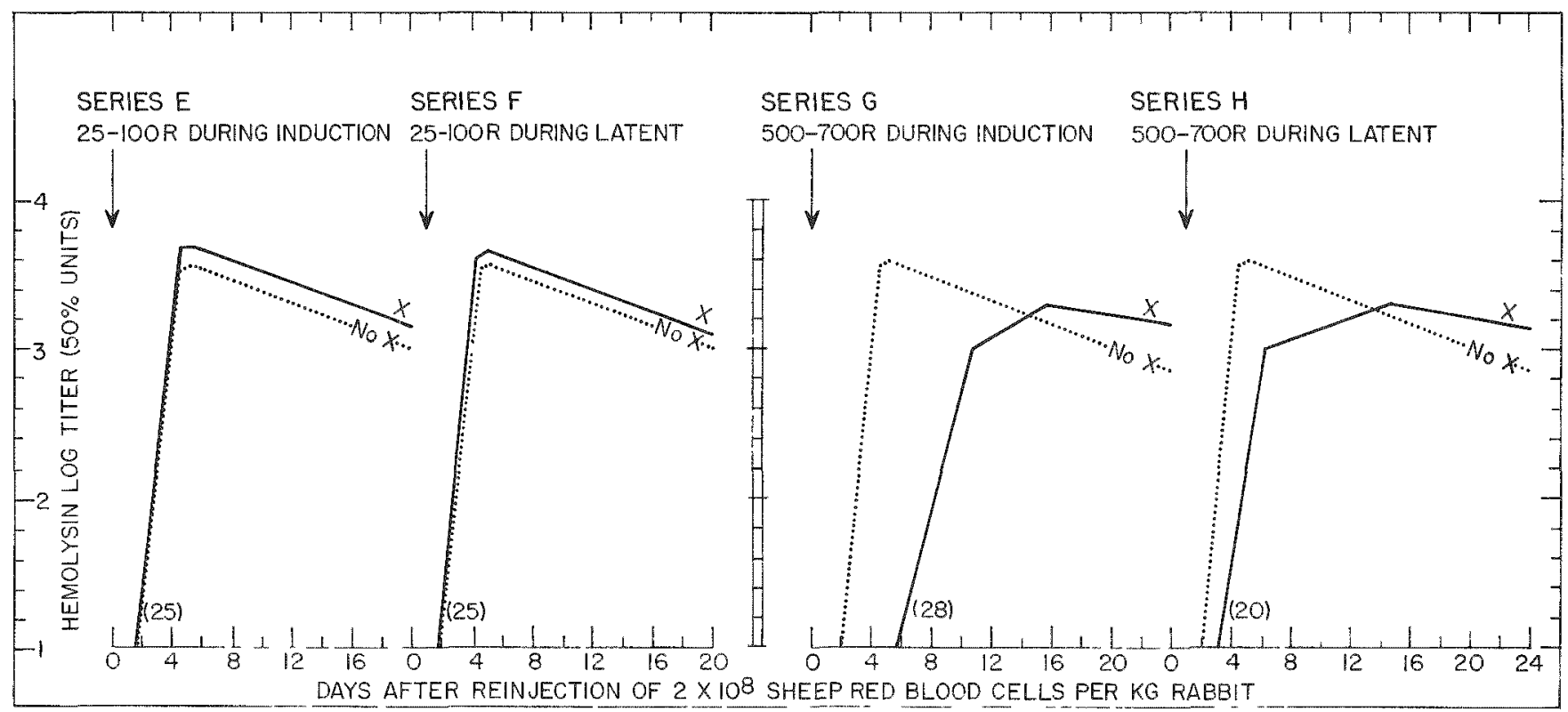

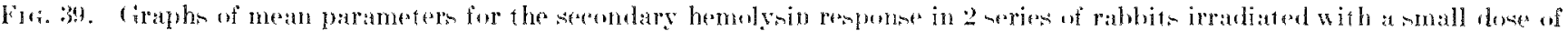

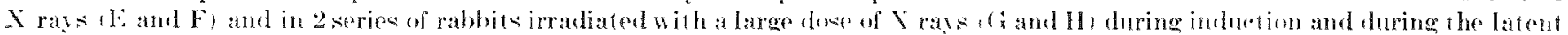

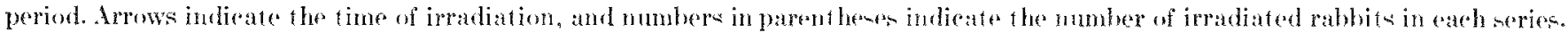

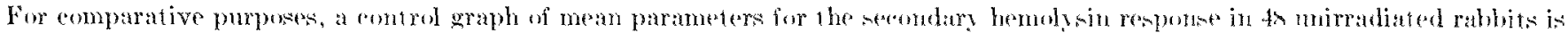
repested in each secotion.

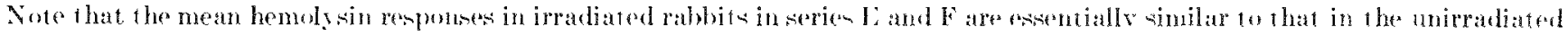

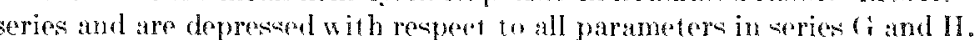


denced by significantly high peak titers attained whin nomal times and rates (Figure 38, serios A). It prodnced similar results when tested during the latent periol (Figure 38 , series $\mathrm{B}$ ), but failed to modify protein synthe is when tested during the rise and fall of hemolysin, i.c.. at 4,9 , and 21 days after the initial ingection of antiger. Different resulta, as might he expected, were ohtained with 500 to $700 \mathrm{R}$ of $X$ rays. 'This large dose of $X$ rays, when tented during induction of the primary response at first elepresied hut oventually enhanced homolyein formation, a evilenced by a longes latent period, a longer and slower rios to peak titer which culminated in a -ignificantly high peak titer and a slow decline after peak titer (Figure 38, serios C). It produed similar spertacular result when terted during the latent freriod (Figure 38, serien D). Subequenty, when this latre dose was tented at 4, 14, or 10 days after the injection of SRBC, deprexion mogresively overhiadowed enhancement. For axample, when rabbits were exposed to a large dose of $x$ rave 40 daty "after thry had received $S R B C$, hemolysin declined more harply and more erratically after than before irratiation and increased in titor only slightly and occa-ionally.

Irradiation effects on peak titer luring the areomtary response fell far short of those occurring during the primary remonas. I small dose during induction or during the latent perion of the secondary respones dis not produce any statisically significant stimulating effert (Figure 39, serie $E$ and $F$ ), wherea a large done luring the same early stages of the secondary rempone was prelominanty deprening as aridenced ho delayed and subnormal peak titer (Figure 39 , serie $\mathrm{C}$ and $11 \mathrm{l}$.

\section{CONCLCMIONS}

These data on immmuzation before irradiation, in agreement with our recent study on immunization after irradiation, sugge that the immunologically competent intial cell may be more casily stimulated and may rerorer from injury more casily than the activated memory call, which are present at the time of reinjecting SIBBC herance of prior initial antigenir stimulation.

\section{REFLRENCWS}

1. Taliaferro, W. H., I. A. Taliaferes, and B. N. Jaros Iow. Modifeations of antibody formation. Areone Xiational
Laboratory Biologieal and Medieal Research Division Amnual lieport, 1964. ANL-6971, p. 156.

2. Taliaferro, W. II. and L. G. Taliaferro. The relation of radiation dosage to enhancement, depressium, and recovery of the initial Forssman hemolysin response in rabbits. $f$. Infect. Dis. 114, 285:203 (1961).

3. Taliaferro, W. H. and L. C. Taliaferro. Effects of radiation on the initial and antmuestie IgXI hemolysin responses in rabbits: Antigen injection after X rays. J. Immunol.103(3), $55 \% 569(1969)$.

4. Taliaferro, W. I. and L. (A. Taliaferro. Modifications of antibody formation. Argomne National Laboratory Biological and Medical Researeh Division Annual Report, 1968. ANI -7535, pp, 99100.

5. Taliaferro, W. H. and L. G. Taliaferro. Fifeets of X-rays on immunity: A review. d. Immunol. 66, 181-212 (1951).

6. Taliaferro, W. H. Moditication of the immune response by radiation and cortisone. Anre. V. Y. Aral. Sori. 69, 745-764 (1957).

7. Makimolan, T. and X. Gengozian. Fffect of radiation on antibody formation. Radiation l'rotection and Recovery, Ed. A. Hollaender. Pergamon I'ress, New York, 1960, pp. 316301 .

S. Stoner, li. 1). and W. M. Hale. Radiation effects on primary and serondary antibod responses, The Effects of Ionizing Radiations on Immune Proresses, Ed. C. A. Tanone. Ciordon and Ireach, New York, 1962, pp. 183-219.

a. Taliaferro, W. II., L. (A. Taliaferro, and B. N. Jaroslow. Radiation and Immune Mechanisms. Academic Press, New lork, 1964.

11. Simie, M. M., V. S. Sljivie, M. $\breve{Z}$ Potrovie, and I). M. Cirkovic. Antibndy formation in irradiated rats. Bull. Buris Kidric Inst. A uel. Si. 16 (Siuppl. 1), 1965.

11. Taliaferen, W. H. and $t_{\text {. }}$. $x$. Taliaferro. Lefeet of $X$ irradiation on hemolysin dexeline. I. Infect. Dis. 87, 201-209 (1950).

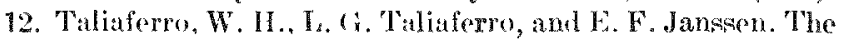
localizat ion of $X$ ray injury to the init tal phases of antibody response. J. Infect. Dis. 91, 105 121 (1952).

13. 'Taliaferm, W. H. and Is. (X. Taliaferro. kffect of $X$ rays on hemolssin formation following varions immunization and irradiation procedures. J. Infect. Dis. 95, 117-1.39 (1951).

11. Taliaferro, W. H. and I. C. Taliaferm. Further studies on the radiosensitivestages in hemolvsin formation. $J$. Infect. Dis. 95, 134141 (1951).

15. Taliaferro, W. H. and $L_{a}$. (i. Taliaferro. The effect of res peated doses of $X$ rays on the hernol vain response in rabbits. J. Infect. Ins. 101, $8599(1950)$.

16. Taliaferro W. H. (ieneral introduction: sithesis and degradation of antibody. J. Cellular l'omp. I'hysial. 50 (siuppl. 1), 126 (1957).

17. "Titlitferpe, W. H. and 1. (r. Thaliaferro. The dy uamies of hemoly sin formation in intact and spleneetumized rabbits. J. Infect. Dis. 87, :37-1i2 (19.5).

18. Taliaferro, H. H. and 1. (4. Taliaferro. The role of the spleen and the dynamies of hemolysin production in homologous anammois. J. Infect. Dis. 90, 205-232 (1952).

19. Taliaferro, W. If and L. C. Taliaferro. The effeet of antigen dosage on the Forsman hemoly sin response in rabbits. d. Infect. Dis. 113, 15\%-160 (1963). 
DEVELOPMENTAL DELAY AND LETHALITY STUDIES OF X-IRRADIATED TRIBOLIUM CASTANEUM EGGS

Tracy ('hui-Hsu Yang* and Grorye 1. Sacher

PI RPUSA AND MEIHOD

A mathematical theory of recovery in turning-over cell population after irradiation was proposed by Sacher and Truceo. (1) This theory in based on the anumption that the recovery rate is proportional to the number of proliferative cells that survive irradiation, and alo proportional to the amount of recorery still to he completed. i.e., to the difference between the existing population size and the set point. Thi- theory generate : an explicit mathematical model of recovery, wheh has the form of a logistic equation. One predietion of the mollel is that the time needed for the population to recover to a -peeified size is proportional to the radiation dove. The prediction of the model are in accord with data from -pht-done recovery tudie. The cell-recovery mordel tudien by sarher and Trucco contained no term for the delay of mitosis in the -nrviving proliferative eell population. Sacher cubecquently developed a model for division delay. (2) wheh vield a second-order kinetic model for the inactivation and regeneration of a -ubutanes cuntial for recovery in agrement with obervation on srehronized mammalian cells. This molel predict that division delay is proportional to doee. Hence, both of the major termo in recovery, that for intracellular perovey from divioion block and that for the rentoration of cell number, give ries to a proportionality of delay to do-e.

The insed egge is at cloerd ry-tem, so the hatehing delay will reflent the srowth delay of the embryo. Information on the hatchng delay of irraliated inseet eggs will, therefore, be valuable for testing the model an well an for undertanding the radiation effect on derelopment. Rarlionem-itivity of Tribolium egges at different agese was aloo-tudied.

Adult beetler, lew than one month from eclo-ion were put in a froh flour-yeat medium for 1 hr at $30^{\circ} \mathrm{C}$ and then were -ifted from the medium and egge. The time when the adult were remored was counted an zero hr for the age of eggm. After separation from medium by a finer sieve, the eggs were kept in tisue eulture lishes at $24^{\circ} \mathrm{C}$ until they hatehed. The number of larvae that hateher was checked every $8 \mathrm{hr}$ from the sixth to tenth day. Wog which failed to hatch before the tenth day were comidered to be dead. Irradiation was with a cieneral Electric

* Present address: I nivensity of (alifomna, Lawrence Radation Lahoratory, Berkeley, California, 9420. deep theraps X-ray unit at a dove rate of $10.5 \mathrm{~h} / \mathrm{min}$. Exponten were at $250 \mathrm{kT}, 1.5 \mathrm{~mA}$, and half-value layer of $1.5 \mathrm{~mm}$ of copper.

PIRUCRI - RFPORI

The hatehing delays for $T$. restaneum egen $\mathrm{X}$ irradiated at different ages are presented in Figure 40. The relative hatching time was calculated by the eyuation

$$
\frac{\left(\frac{\sum n_{2} t_{2}}{\sum n_{2}}\right)_{\text {mand }}}{\left(\frac{\sum n_{2} t_{2}}{\sum n_{2}}\right)_{\text {, wintel }}}
$$

where $n_{2}$ is the number of egen hatched at time $t_{2}$.

Rewnlt with 6-hr-old exge indicate that the development leelay is proportional to the dose. Acrording to Sacher and Truceo, the growth of an undivlurbed population proceeds at a constant rate, $\rho$, in the absence of external factors limiting growth. The stecumulated number of division at time, $t$, after dous $I), Q_{1 v}$ in giren by Sacher ${ }^{(2)}$ as

$$
\begin{aligned}
& Q_{\nu t}=\rho \int_{0}^{t} \overline{1}+\frac{1}{\left(c^{\operatorname{Ln} D}-1\right)} \overrightarrow{t^{-m t}} \\
& \left.Q_{D t}=\rho t-\frac{K D}{l_{i}}+\frac{1}{k_{i}} \ln \left[1+\left(e^{n \nu}-1\right) p^{-l t}\right]\right\} \text {, }
\end{aligned}
$$

where $k$ in a rate contant, and $K$ an inactivation con-tant.

The defieit of number of division, $\Delta_{n t}$, is

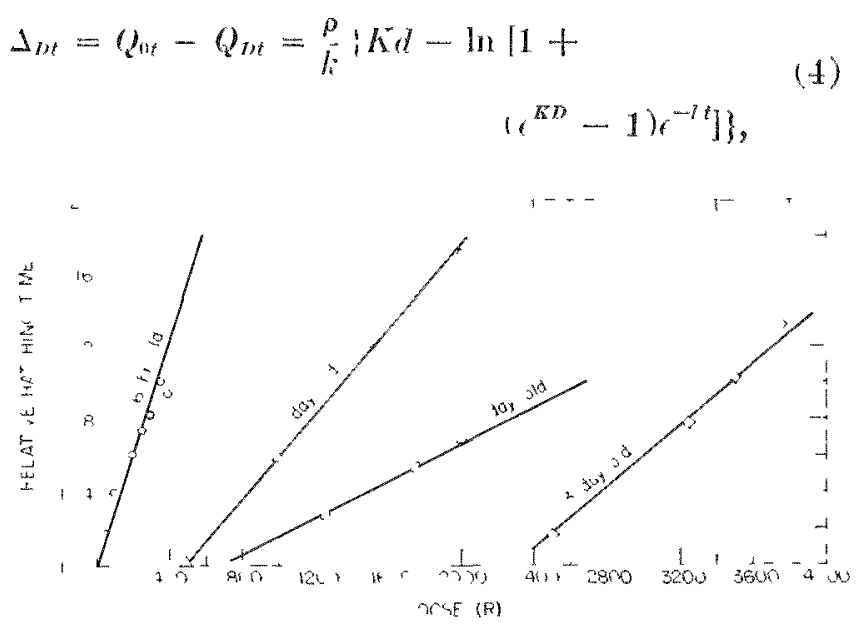

Fig. 10- Ilatohiug delay of Thbolium castancum eggs X irrudiated at different ages. 
and the delay in reaching an assigned number of divisions, $L_{D t}$, is calculated by

$$
L_{D t}=\frac{1}{\rho} \Delta_{D t}
$$

The interval between irradiation of Tribolizm egeand the hatching of larrae is sufficiently long so that the aymptotic form of Equation 4 can be used:

$$
\begin{aligned}
L_{A p c e} & =\frac{1}{\rho} \Delta_{n \infty t} \\
& =\frac{1}{\rho}\left(\frac{\rho K l}{k}\right) \\
& =\frac{K I}{k} .
\end{aligned}
$$

This rquation indieates that the hatching delay is proportional to the dowe. The relation of delay in done is linear at all ages, but a shoulder is oberved in the hatching delay of eggs 1 day old and older at irradiation. According to the ahove equation. theres should be no shoulder if cell killing is exponen-

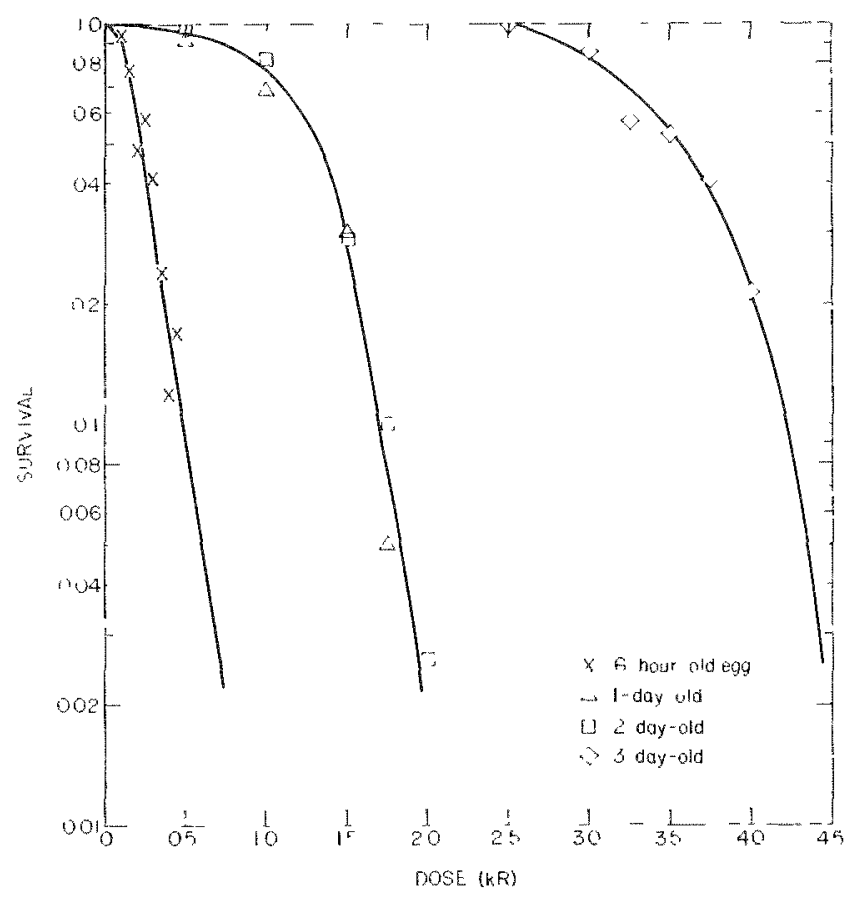

Fut. 41,- Survival curves of Tribolimm atstonezm eges $\mathrm{X}$ irradiated at different ages. tial. It is posible that the extrapolution number for the killing of embryonic cells. or nuelei, is near unity at early ages and increanes when elifferentiaterl embryonic cells appear.

The sacher-Truce theory in mo-t direetly applicable to sistems of undifferentiated cells, r.g. tissue culture erlls, unicellular orgmismm, ate. ()ur histologieal studies indicate that: lat the 6-hr T' castane'um egg is at clearage stage. after having had a series of endomitotic nuelear divisions; (b) the 1 day-old rgge ha parsed tha blantoderm stage; and (c) many organs have been formed in 3-day-old exgThe 6-herege is, therefore, a single eell with multiple nuelei, and the 1-day-old egg contains many difforentiated cells.

The re-ult atso show that the slope of the hatching delay function is not the same for exges of different ages. This difference maty be due to the fact that the inartivation con-tant, $K$, and the rate constant, $k$ may vary in rifferent typen of eell-

Figure 41 depiets the efferet of $\mathrm{X}$ irradiation on the survival of $T$. costene $u m$ roges. It was found that the 6-hrold eng is mont ensitive to radiation, that the 1-day- and 2-day-old egge are lem sensitive, and the 3-day-old egge are leant sensitive. The -lope at $L I)_{3}$ in about the same for egge of all agen, indi"ating that the number of targets that munt he de-troyed to kill the egg increanes with the age of the exger.

conctisions

Iratehing delay for T. cotetent um egges irradiated at age $6 \mathrm{hr}$ is directly proportional to the radiation dose. There in at shoulder for egge irradiated at later stages, and the slope of the curve aloo changes with the age of rger. X irrarliation is more effective in delaying or preventing hatching in the early, cleavage, stages than in the later, differentiation and growth, itager.

\section{REFTRENTES}

1. Sacher, (t. A. and k. Truece. Theory of radiation injury and recovery in self-renewing cell populations. Radiat. Res. 29, $236-256(1966)$.

2. Sacher, (4. A. Mathematical analysis of the division delay produced by ionicing radiation. Latiat. Les. $33,644-658$ (1968). 
EFFECTS OF X IRRADIATION ON SOME PHYSICAL PROPERTIES OF A DEVELOPING TRIBOLIUM

\author{
Tracy rhui-Hsu Yang* and Gorge 1. Sachro
}

\section{PLRPUNE AND METHODS}

The-e - tudies "xplored the mechani-m of the radiation effects on physical propertion of the developing flour beetle (Tribolium castame rme). ("hangen of body weight, elytrumt weight, and meshanical strength of elytra in relation to raliation, a well an the kinetice of recovery. were examined.

Two-wes old larvat, rained in 4 's flour-yeast medium at $30^{\circ} \mathrm{C}$ and a relative huminlity of 60 to $70^{\circ}$, were irradiated with a crenerel Filectric deep therapy X-ray unit at at dome rate of $4.50 \mathrm{ll}$ min. Physical condition of irradiation were $250 \mathrm{kV}$, $1.5 \mathrm{~mA}$, and half-value laver of $1.5 \mathrm{~mm}$ of coppex. (Ine week after the beetlen emerged as adult they were weighed alive on a mirrobalanes to obtain the wet body wight. Filyt ras disected from the bectles were weighed on the ame bilanes. In order to determine the menanieal - treneth of an elytrum, a material-tenting in-trument, the In-tron,t wat u-ed. In sytrum was placed, with it - indrde surface facing up, on an $\mathrm{I}_{\text {- }}$-hatped aluminum holder whose upper end was comnerted to a tem-ion-measuring load cell on the upper part of the inatrument. A thin $10.1336-\mathrm{mm}$ clianeters wire was placed ateros the midpoint of the long axis of the elytrum. With one end at weh sile of the clytrum. both end of the wire were pased through a sit $10.5 \mathrm{~mm}$ wite and $0.5 \mathrm{rm}$ lonel located under and at a $90^{\circ}$ angle to the long axis of the onter wing. "The wire then wat ronnected to the lower jaw of the in-trument which wa pulled away from the wytrum. can-ine the wire to -tretch, and erentually, break the elytrum. The fores alpolied to the elrtim before it hroke was automatically regisfrered on a recorder.

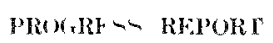

Figne 42 ,how the effect of $\mathrm{X}$ irradiation on the body wioht of adult $T$. cantanenm. The curve had a -houlder at $1 \mathrm{kR}$; hody weight decroater with an incroase in dowe up to $3 \mathrm{kR}$. In this study, adult - that emerged had a hody weight below $1.4 \mathrm{mg}$ when the X-raty does wan orer $3 \mathrm{kR}$. When the $3-\mathrm{k} R$, lose wa split inte two equal fractions and aiven to the 2werk-old larvat at different interval, there wa- a

* present addrens: Iniversity of ("alifornia. Iaw rence Raudiation Lathorators. Berheles. California, 91720

i Modified horny anterior wings.

f Instron Lnginpering Corportion. rapil recovery of hody weight of the arlult. The kinetien of recovery is similar to that in -urvival studien, il i.t., recovery of an oroaniom taken place rapilly during the first few hour, drops to a minimum at $6 \mathrm{hr}$, and then rises progrensively.

Hyllum weight hat the same type of repone to

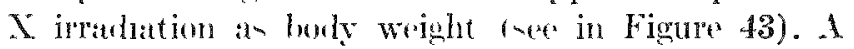
minimum of recorery at 6 he wath again obmererel. There was ditterenor in radionem-itivity between the lofit and right elytrum, and a lone of $3 \mathrm{hl}$ reulted in about a $28 \%$ : decrease in weight. Both the bodyweight and the elytrun-weight studiem indicato that radiation has an inhibitory effect on the development of adult oreans and tionter.

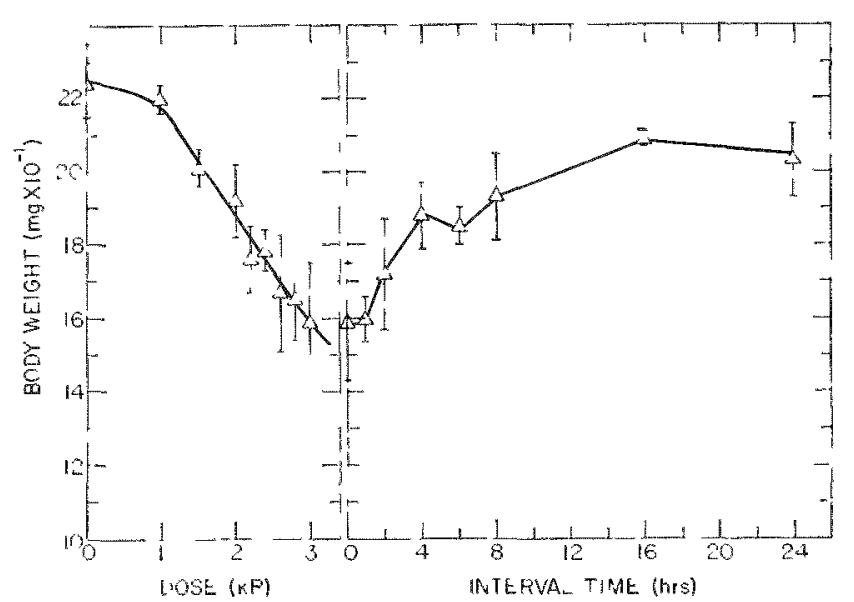

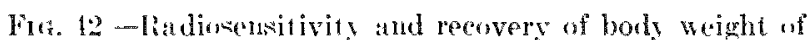
$\triangle$ ipradiated Trimlinm astarem adults. Standard arror is shrow tur each point.

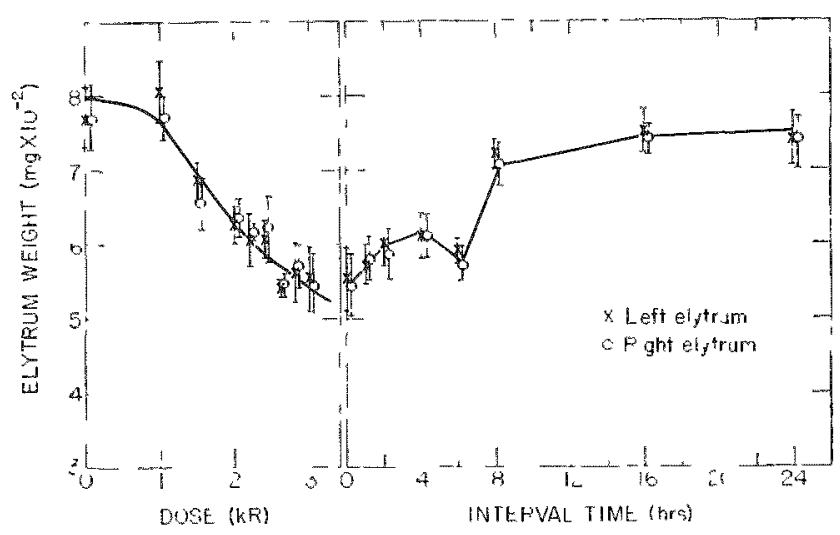

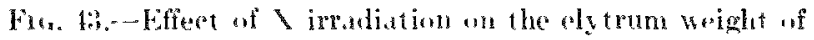
adults. 
Figure 44 depicts the change of mechanical strength of elytrum of an adult $X$ irradiated when it was a 14-day-old larra. A threshold was found at $1 \mathrm{kR}$, and the mechanical r.trength diminishes as the dose is

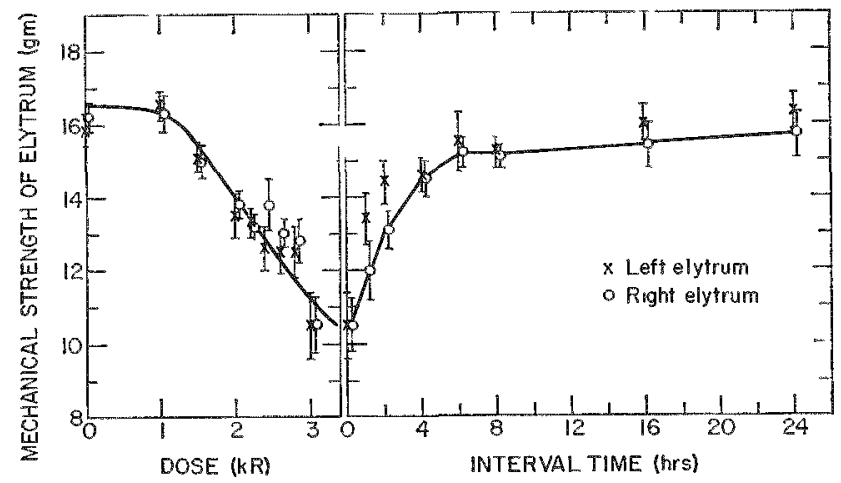

Fag. 14.-Fifect of $X$ irradiation on the mechanical strength of the elytrum, expressed as the total force, in grams, reunired for breakage. Lefi, duse effect relationship; right, split-dose recovery function.

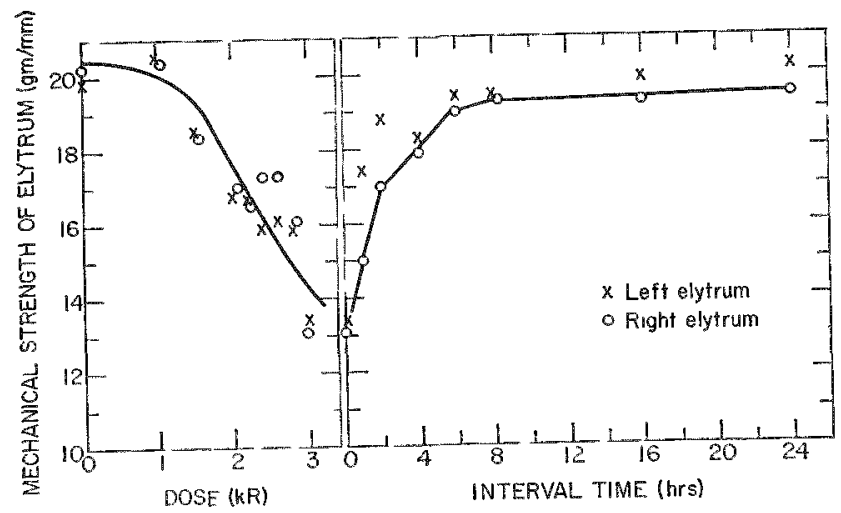

Fit. 15. - Lffect of $X$ irradiation on the machanical strength of the elytrum, expressed as $\mathrm{g}^{\prime} \mathrm{mm}$ of elytrum wilth. Lefi, dose-pffect relationship; right, split-dose recovery function. increaned. The kinetice of recovery of mechanical strength of elytrum, the mo-t interesting finding in this -tudy. was found to be an exponential type with no complieuted pattern, i.co, there was 10 minimum at $6 \mathrm{hr}$. When the mechanieal - trength of the elytrum is exprensed as $\mathrm{g} / \mathrm{mm}$, as hown in Figure 4.5 , no minimum wat found at $6 \mathrm{hr}$ in the time courne of recovery. although the left elytrum did exhibit a slight drop of recovery at + hr. The difference hetween the kineties of reeovery of survival, body weight, and elytrum weight and that of mechanical strength of dytrum may be due to the fact that survival, body weight. and elytrum weight are directly related to the number of cells in the organi-m. but the mechani"al strength of alytrum is related more elonely to the amount of cuticle rohitonl secreted by cells in the elytrum. The resovery minimum that aphear at $6 \mathrm{hr}$ is probably due to a phase of radiosensitivity in the eell mitotie cycles of the partly srnchronized cell population that emerges from mitotic block. (2) The exponential coure of recovery of mechanical strength of elytrum after $x$ irradiation is not incon-istent with the hypothesin that the lom of strength is due to rytoplamic injury. The present result- indicate that the radio exitivity of eytoplamm may not change meanurably during cell mitotic arele and that the recovery of ertoplarm follows first order kineties, i.e., $d S$ d $d t=-k$, , where $S$ is the amount of injury at time $t$.

\section{REFERLN('LS}

1. Yang, T. C. X rag response and recovery of Tribolom larvie. liadiat. lies. 35, 516 (19his).

2. Kallman, R. F. Recovery fron radiation injury: A proposed mechaniam. Voture 197, 557-560 (196:).

\title{
THE LETHAL EFFECTS OF MONOENERGETIC NEUTRONS AND "CO GAMMA RAYS ON TRIBOLIUM CASTANEUM
}

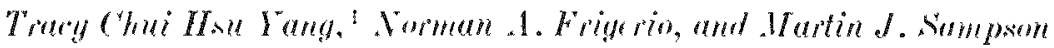

PLPOUE AND MTETHODS

As part of an ongoing program for determination of neutron toxicity and $\mathrm{RBE}$, the radion-itivity of Tribolium custantum larvate wa determined at several neutron energies. Current microdoimetry theory predicts that maximum neutron $\mathrm{RBE}$ will be found near $0.4 \mathrm{MeT}$. (1) 'l'hi predietion in difficult to verify for organism- much larger than a few grams

* Present address: Inivemity of California, Lawrence fiadiation Iaboratory, Berkeley, California, 91720. berane of the nentron energy degrarlation which oecurs in timese and the difficulty of obtaining uniform done and energy dintribution orer the entire holly. The larrat, however, are so small that the problem are eliminated; therefore. they necmed a cood rhoice for extmination of the variation of RBE with neutron knt regy.

Larvare were expored in thin-walled polyethylene vial containing 100 larvate wach in about 1 gram of upport media. ${ }^{(2)}$ Tials wer mounted, 12 at a time, 
on a thin aluminum plate which was rotated at 1 rpm during exposure in the monoenergetic neutron facility previously described. ${ }^{(3)}$ The vials were positioned symmetrically in a plane $51 \mathrm{~mm}$ from the cource, at a perpendicular dintance of $51 \mathrm{~mm}$ from the axis of the proton beam. Thus, viaks were located on a circle making a $45^{\circ}$ angle with the beam at a radial distance of $72 \mathrm{~mm}$ from the rouret. Target thicknemes ranged from 95 to $125 \mathrm{keV}$, and dose rates were about 3 Rads min ${ }^{-1}$. Conditions of growth, maintenanee, and lethality seoring were an previously deseribed.(2)

Larvae were also exposed to "Co $\gamma$ rays at different dose rates, and lethalities were scored as previously described. $\left.{ }^{2}\right)$

\section{PROGRESS REPORT}

Complete dose-effect curves were obtained at 663 keV and $439 \mathrm{keV}$, with two sets at the lower energy. These atre hown in Figure 46 and may be compared with the "Co $\gamma$ eurves of Figure 47. Preliminary re-ults have also been obtained for 104, 170 and 1319 $\mathrm{keV}$, and these are given in Table 19 along with computed RBE values.

\section{CONCITSON}

Dexpite the fragmentary data at 104 and 1360 $\mathrm{keV}$, the results obtained, combined with the Janus

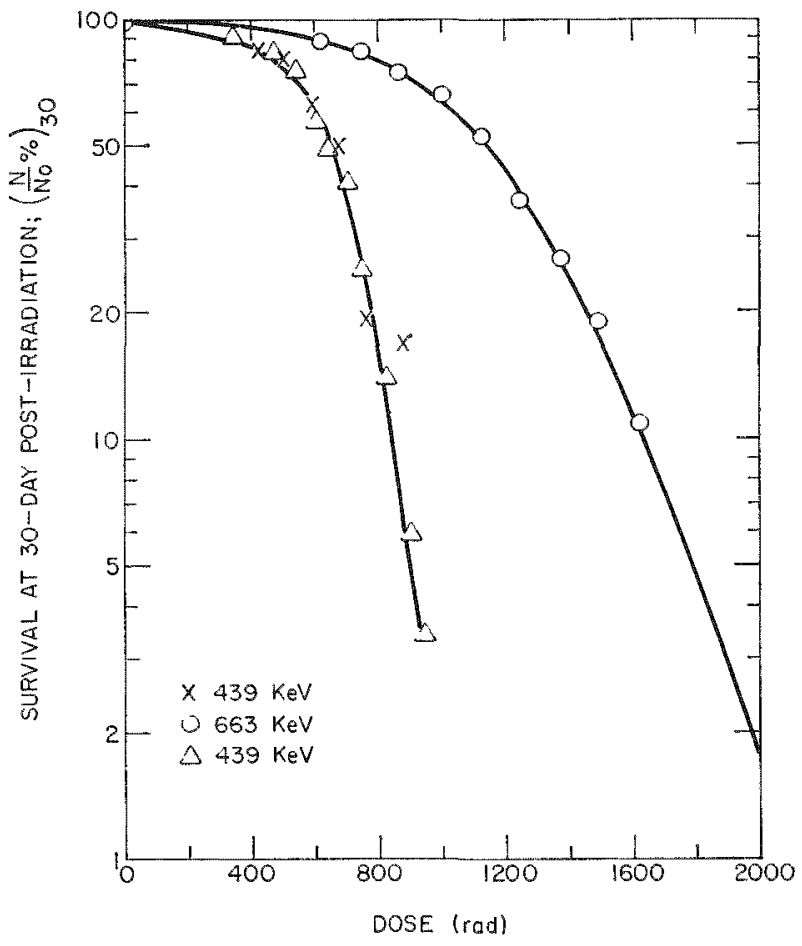

Fic: 4t.--I)ose-response curves of neutron-irradiated Tribolikm larvae. Each point represents the mean survival of 100 to 200 larvae. Two experiments were performed at to3 keV.

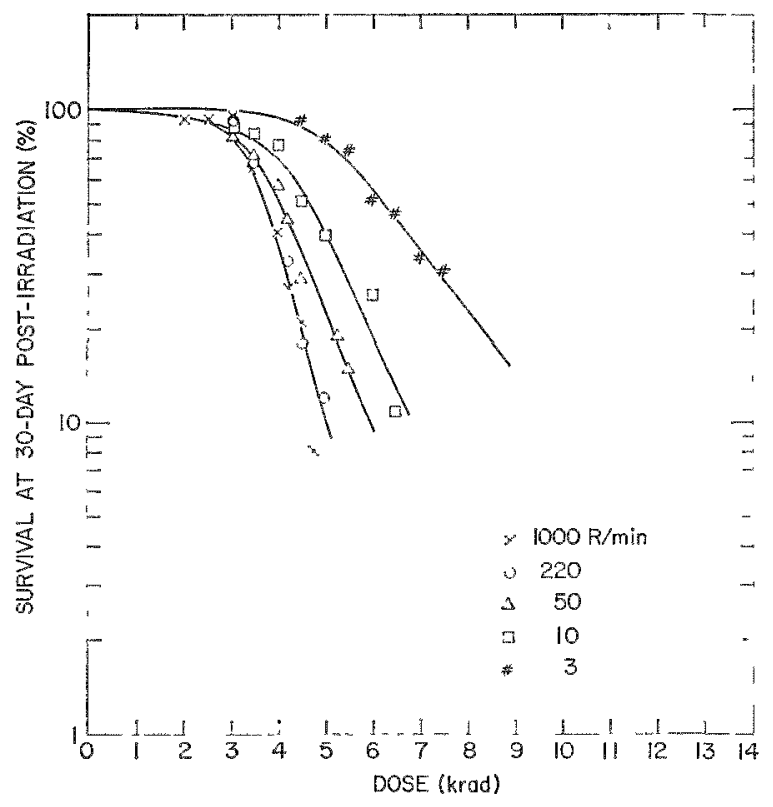

Fut. 47.-Dose-respunse curves of Tribolim larvae irradiated with ${ }^{60} \mathrm{Co}$ amma rays at various dose rates. Wach point represents the mean survival of 200 larvae.

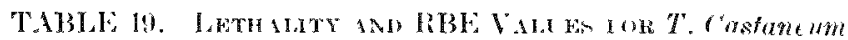

\begin{tabular}{|c|c|c|c|c|c|c|}
\hline \multirow{3}{*}{$\begin{array}{c}\text { Neutron energy, } \\
\mathrm{KeV}\end{array}$} & \multicolumn{4}{|c|}{ 30-day lethality } & \multirow{3}{*}{\multicolumn{2}{|c|}{$\mathrm{RIB}$}} \\
\hline & & & - & - & & \\
\hline & IÍ & 1 & $\begin{array}{l}\text { Dose, } \\
\text { Radis }\end{array}$ & $\begin{array}{l}\text { Dose rate, } \\
\text { Rate min }\end{array}$ & & \\
\hline$\ldots-$ & - & & $-m$ & $-\ldots$ & $-\ldots$ & - \\
\hline ל & 50 & & mis & 50 & 4.1 & \\
\hline 101 & 5 & & 900 & 0.3 & 5.0 & \\
\hline 170 & 50 & 1 & $\times 10$ & $:$ & T.t & \\
\hline 139 & 50 & & $1 ; 20$ & 3 & 111.0 & \\
\hline 4663 & 50 & & 1150 & 3 & 5.4 & \\
\hline $1: 319$ & 15 & & 1050 & 3 & 4.5 & \\
\hline
\end{tabular}

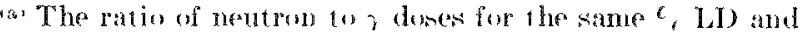

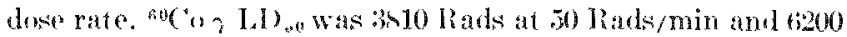
liads at 3 Radk, min. "Co liads are actually roent gern exposure values: neutron liads are herma to Ftandard Min.

neutron results previouly reported, show clearly that maximum RBE oceurs around $400 \mathrm{keT}$ as predicted. With the fortheoming arailability of a Dynamitron monoenergetic fucility of greatly increased doce rate, wo hope to examine the radiosenitivity of these larvac from 0.03 to $19.2 \mathrm{MeV}$ at various dose rates and to examine carefully response at the $\mathrm{N}$ and $\mathrm{O}$ neutron resonanes to verify or deny our hypothesis ${ }^{(3)}$ of -peeific ehemical effects there.

\section{REHERFACE}

1. Ihesi, II. H. Interpretation of biolngieal response in terms of micolosimetry. Ann. X. Y. Acod. Stci. 161, 260 (1969).

2. Yang, T. ('-H. Radiation exposure of flour beetles. I. The lethal effects of neutron or gamma irradiation on Tribulium 
castanezm. Argonne National Laboratory Biologieal and Medical Researeh Division Annual Report, 1968. $\mathrm{ANI}_{-}-7535$, pp. 109-112.

3. Frigerio, N. A. and D. L. Jordan. Patterns of lethality and alssorbed dose distributions in mice for monoenergetic neutrons. Biological Effects of Neutron and Proton Irradiation. Int. Atomic Energy Ageney, Vienna, 1963, Vol. 1, pp. $117-128$.

\section{STUDIES ON THE DEVELOPMENT OF MID-GUT OF THE TRIBOLIUM CASTANEUM ADULT}

Tracy Chui-Hsu Yang and Everett staffeldt

PURPOSE AND METHODS

Since Tribolium was used in nutritional studies by Chapman (1924), considerable attention has been given to the flour beetles by ecologists, geneticists, and radiobiologists. While ecological, genetic, and radiobiological information on Tribolium has increased rapidly in the past 20 years, developmental information has been limited to the external body structures.

The physiological eause of death of irradiated Tribolium has long puzzled radiobiologists. (1, :) Because this organism is small and has a hard cuticle, physiological and histological studies of Tribolium are very difficult.

Despite these difficulties, we studied the development and structure of Tribolizm castaneum mid-gut by histological methods and examined the effects of radiation on its development.

The general method of handing Tribolium castaneum has been reported before. ${ }^{(3)}$ When they reached late larval or pupal stage, they were fixed for 7 days in a mixture of a saturated solution of picric acid

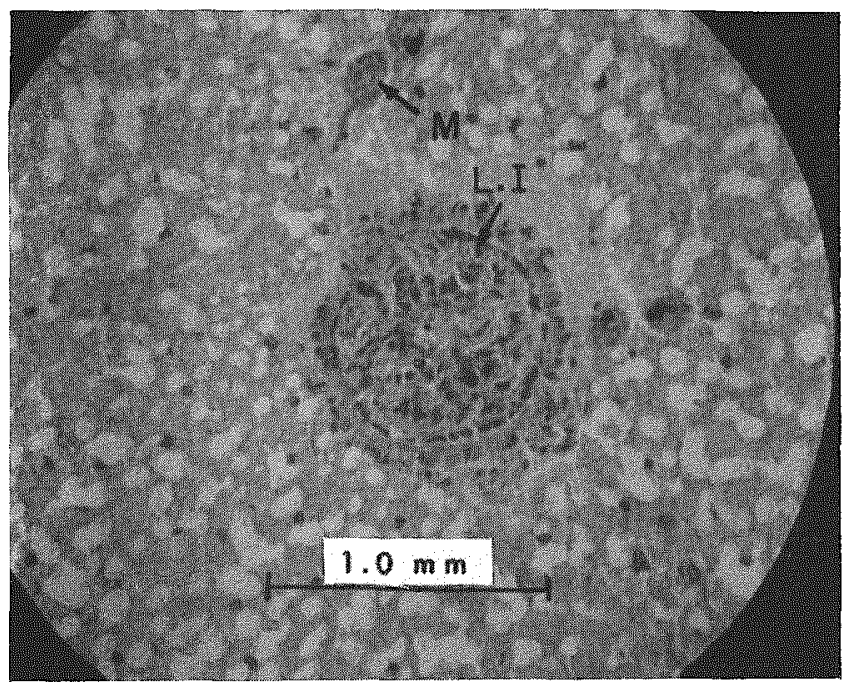

Fic. 48,- - A cross section through the mid-gut of 14-day-old Iarva. (M) malpighian tube, (L.I.) mid-gut of larval intestine. Fixation, nitric acid-picric acid; staining, Mayer's hematoxylin and eosin. in $90 \%$ ethyl alcohol, 75 parts; formalin, 25 parts; concentrated nitric acid, 8 parts. After fixation, the beetles were washed in warm $70 \%$ ethyl alcohol for several minutes. Dehydration was accomplished through a series of graded ethyl alcohols. Clearing was not necessary. They were then embedded in celloidin and paraffin with the conventional ether-alcohol-celloidin mixture for 7 days. The blocks were hardened overnight in chloroform. The block was trimmed into a small square with the beetles in the center. To insure proper infiltration of paraffin into celloidin, the blocks were promptly transferred to a suspension of 1 part paraffin, and 5 parts chloroform, in which they were kept orernight at room temperature $\left.\left(24^{\circ} \mathrm{C}\right) .4\right)$ Sections were cut at 5 and $10 \mu$ and were stained with Malloy's triple stain and Mayer's hematoxylin and eosin.

In order to investigate the effect of radiation on the development of the $T$. castaneum mid-gut, 2week-old larvae were irradiated with a General Electric, deep therapy X-ray unit, Maximar. Physical conditions of irradiation were $250 \mathrm{kV}, 15 \mathrm{~mA}$, and

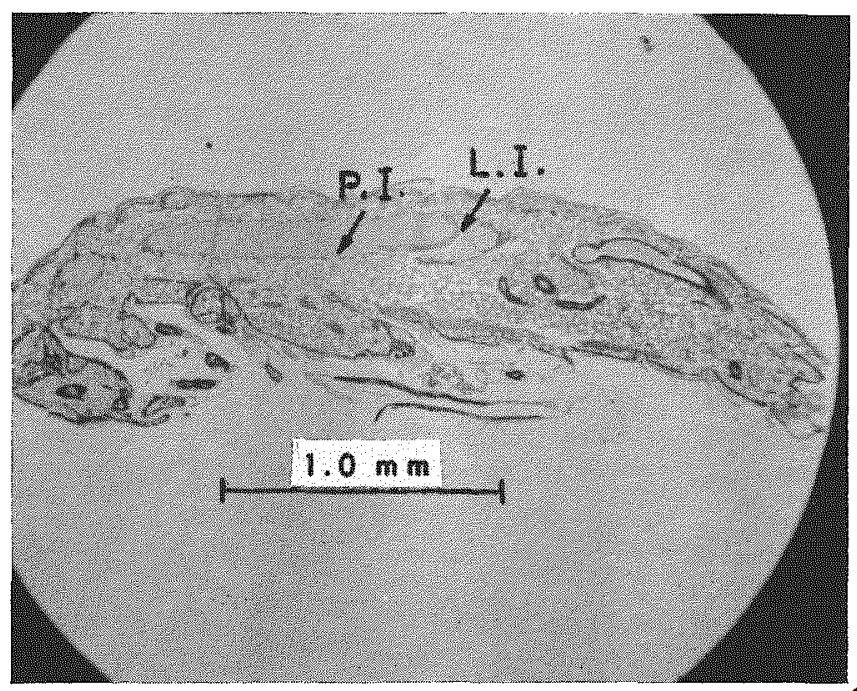

Fig. 49.-A longitudinal section of pupa. (P.I.) pupal intestine, (L.I.) undigested larval intestine. Fixation, nitric acid-pierie acid; staining, Mayer's hematoxylin and eosin. 
half-value layer of $1.5 \mathrm{~mm}$ of eopper. Ahout one week after emerging as adult-, the beetles were sacrificed for histologieal examination.

\section{PRUGRI in REPORT}

A crom seretion of mid-gut of a 14-rlay-old larva 1) hown in Figure 48. Epithelial rell are parcked together and appear to fill the intertinal lumen. The cellular arrangement may benefte the lanva by greatly merestemg the -urface areat of 1 th intertine. When $T^{\circ}$ castane um reacherd it pupal stage, there wat a rhange of tructure of mul-gut. While the

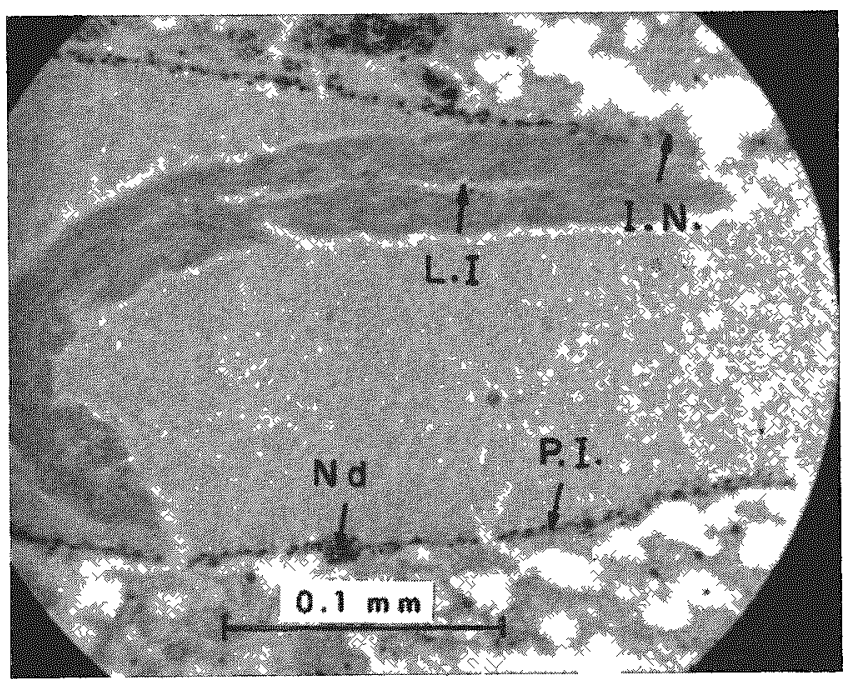

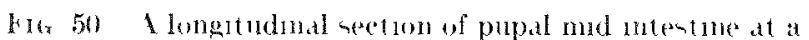
heher mionifation (L I ) a plece of undigested larval intestines, (Vd) nudue of pupd inid gut, (PI) pupal intentune,

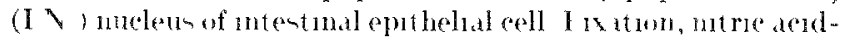

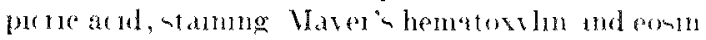

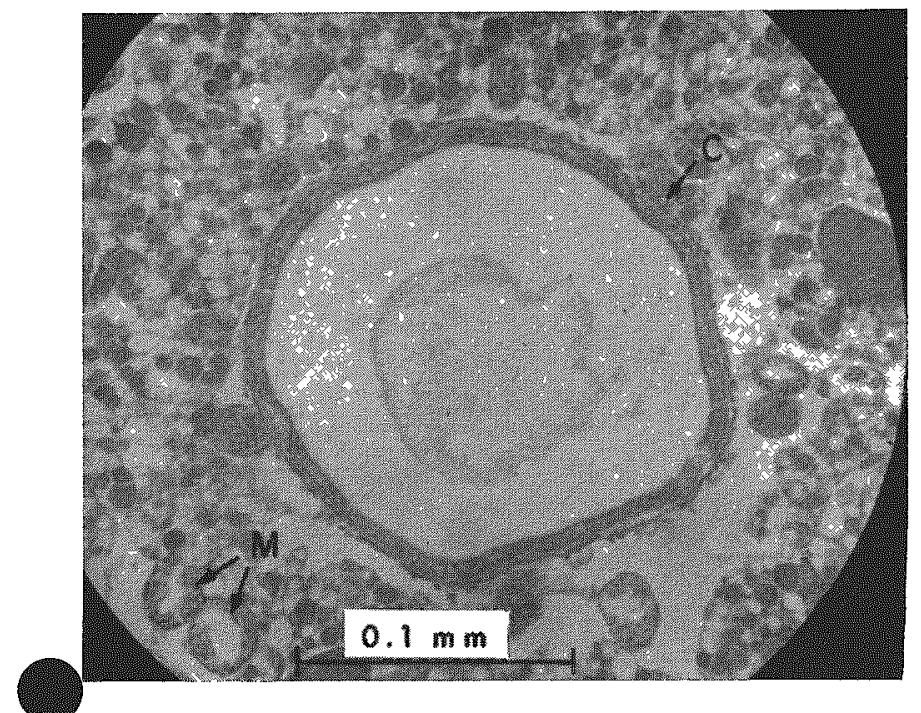

Iis 514 erms section of adult (C) ereum of mud gut, (V) malprghan tube Fixation, prere teul aleohol formalunitru acid, stamng, Malloss 's tuble st tun.

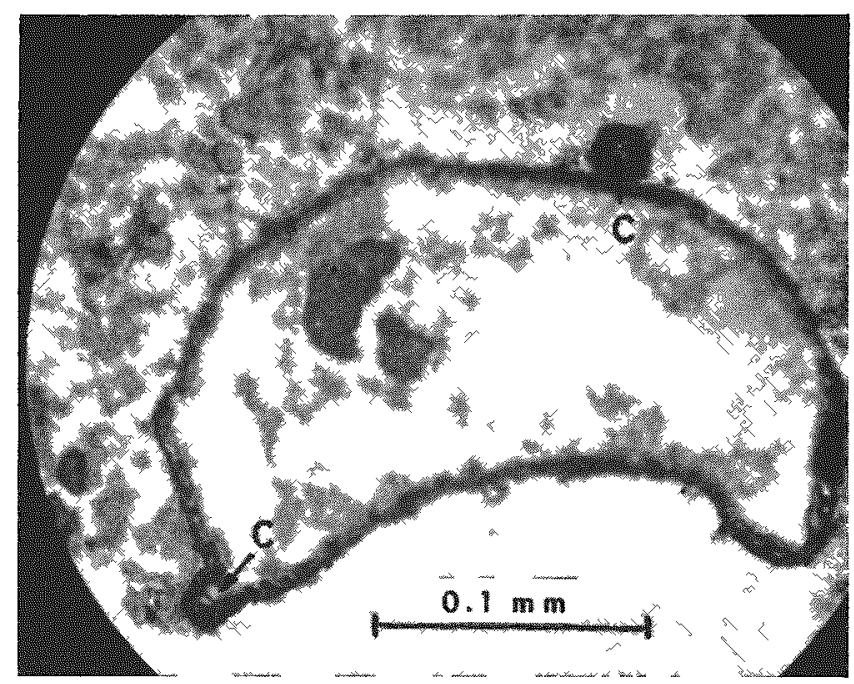

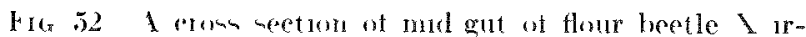

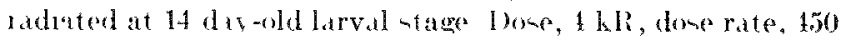

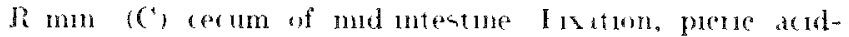

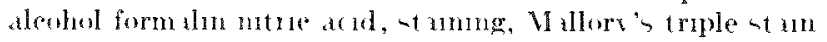

nutertune of the pupat wan formme. the latrval mutgat eppthelial cello were estuluded nito the lumen. where they recgenerated. in -lown in Figure 49 The newly tormed pupal intertine. contammin a prece of undigented litrval mid-gut, wh shown on Figute .50 at higher magnefration. The nueles in the pupal intertinal epthelial cello appeared to be small in -ize, and the reell form a continuou- latyer. Some mirl-gut exll- however, aggregated to form nuli In the adult these cello develop into raeca. A typieal crom section of adult morl-gut 1 - -hown in Figure 51. Epithelial cells in the mid-eut of the alult appeared to be ruboulal and have large nuclei. The cerum of $T$. cavancum appeared to be very -milar in -trueture to that found in Thanatophelue yepomeos, a Coleopteron. by shmola." Vito-1 in the cereum wat demon-trated by a -eyua-h preparation.

When the structure of the med-gut of a week-old T. retancum. X rrarlated with $4 \mathrm{kR}$ at the 14day-old larval thge wat exammed, the cecum wa-eeth to be almo-t demuled of epithelial celle, an hown in Figure 52 Although it appesure that radiation hillerl thene eputheliat rell- it mat not be completely re-pon-ible.

\section{covelatort}

The structure of the mirl-gut of Tribolium castant um wan tound to be different at different -tagen of it- development. The remm, not prevent in the larval -tage, was developed in arlult mid-gut, and come mitotir activity wa- oberred. $X$ urradiation given at the latral tage caured rome damage to the development of the adult mid-gut. 


\section{REHERENCES}

1. Grosch, D.S. Entomological aspects of radiation as related to genetics and physiology. Ann. Rev. Entomol. 7, 81-106 (1962).

2. Erdman, II. E. Fffects of X-rays on metamorphosis and adult life-span of flour beetles. Nature 211, 1427-1428 (1966).

3. Yang, $T$. C. Radiation exposure of flour beetles. I. The lethal effects of neutron or gamma irradiation on Tribolium casta- nerm. Argonne National Laboratory Biological and Medical Research Division Annual Report, 1968. ANL-7535, pp. 109112.

4. Sinha, IR. N. Sectioning insects with sclerotized euticle. Stain T'chnol. 28, 249-253 (1953).

5. Shinoda, 0 . Contributions to the knowledge of intestinal secretion in inserts. I1. A comparative histocytolog of midintestine in various orders of insects. $Z$. Zellforseh. $5,278-$ $242(1927)$. 
LABORATORY ANIMAL MEDICINE

\title{
STATEMENT OF PROGRAM OBJECTIVES
}

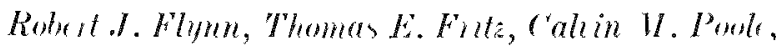 \\ Ronald I1. Camden, and Patrena (". Brennan
}

Prope $r$ are of laboratory anmal 1 both a humane and a rientifie requirement. Cufortunately, objective experimentally-obtained information in often larking on what contitutes proper eare. The Division's xeeareh program in lahoratory animal medicine w amed at meeting this need. This program develop- improved methods for the production and management of the animal used in the Divi-ion'- research programs. Research directed toward colving produrtion problem is illustrated hy reports of the age of lahoratory rodents at time of firt fertile mating; the development of an inbred acatalasemic mou-e: Rattus rattus as a resarch animal; genetic, nutritional and environmental effect on syrian hamster producion; a coat color mutation in the Syrian ham-ter; and monoganous mating of chinese hamster. Arlitional remearch coneern the refinement of controlled management. The phase i- illustrated by the report on frequency of caer cleanme and the -urviral of mice. A -pecial efiort in devoted to -tudying management of laboratory animal divea-e particularly tho-e dieanes that repre-ent hazard- to the Divison's reveareh program - involvng animal-. Thi, phate is illustrated by report on hepatic and renal lewion- in a ham-ter bresling colony and throat flora of a rlo-ed colony of beasle dog-.

Thi program alo provirlen cooperative, specialized profemional awitance (pathology, microbiology, roentexnography, ungery) to the Divi-ion- research program. This support in illu-trated in reports found elsewhere in this publication (ree the eections on Mechani-m of (arcinogene-i-, Radiation Protection. and. particularly, the Toxicity and Metaboli-m of Radionuclider).

\section{THE SUPPLY AND MAINTENANCE OF DEFINED ANIMALS FOR THE DIVISION'S RESEARCH PROGRAM: STATUS OF THE COLONY}

Calem U. Poole, Ronald H. C'amden, Thomer E. Fint,

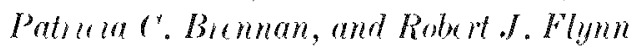

\section{PLRPOAE IND MLTHODS}

High quality animal are necenary for effective biomedical research. The -pecific animal requirement, for different reweareh projects is extremely divere and varuale. and the general trend in toward the use of animal that are more highly controlled and defined. It in the purpose of the animal facilities group to provide animals that are con-intent with thene requirement- through production or arquisition and to furni-h compatible maintenanee. The methork ucel to provide and maintain such animals have been reported." is

Roxatu- RFPORT

The June 30,1969 , animal inventory and the number and kinds of animal produced or arquired and maintained in the Divi-ion - animal farcilities during the pa-t fiveal yoar are premented in Table 20.

The stutien in which the-e animal, have been wed dunng thi- period mas he determined by reference to other part - of this report. Animals produced within the Dirision - faclitite are derignated with the suffix "Anl" ( for Argome Nitional Laboratory).

There have been no serious diveawe outhreak - in the pist year. Twolated epicoles of rolent lempiratory dienasem and definition of the raun of canine neonatal death appear to bo the mont important diesace prohlem- within the animal facilitie- at this time.

\section{RETEREY I-}

1 Hum, R I.T L, Futz, C U Ponlo R W Camulen, and

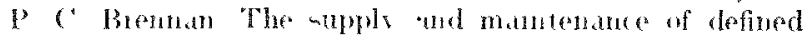


TABLE 20. ANIMAL INVENTORY

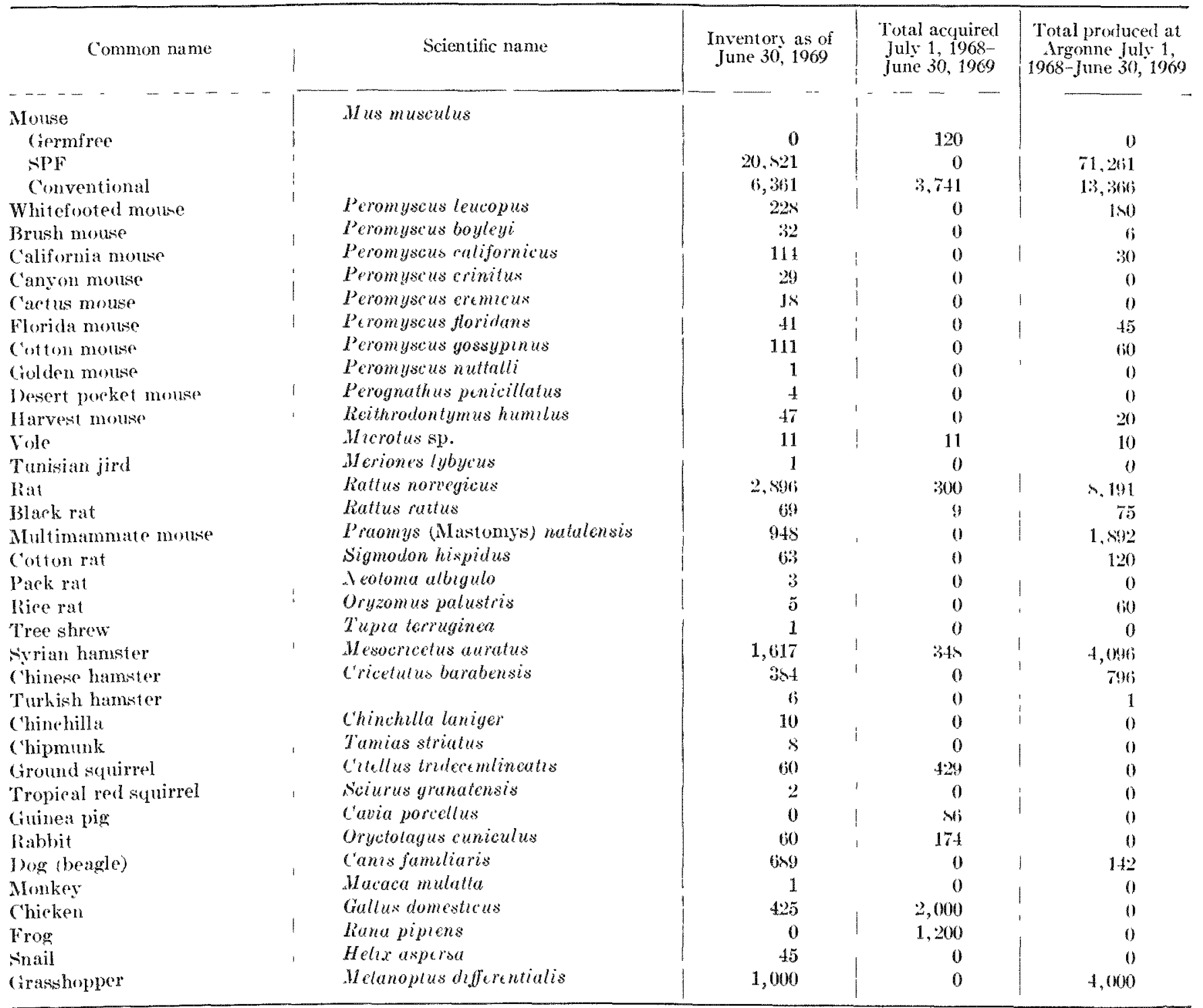

animals for the livision's research program: status of the colony. Argonne National Laboratory Biological and Medi"al Research Jivision Annual lieport, 1967. ANI $\mathbb{L}_{-7} 4098$ pp. $232-233$.

2. Flym, R. J., T. E. Fritz, C. M. Poole, Ji. W. Canden, and 1'. ( . Brennan. The eontrol of three disease outbreaks in laboratury rodents. Argonne National daboratery Biologi(al and Medical Research Jivision Annual Report, 1968. $A N L_{-}-7585$, p. 180

3. Fritz, T. E., P. ('. Brennan, 1. B. Reishin, D. V. Tolle, R. W. Canden, and R. J. Flym. Hepatic and renal lesions in a hamster breeding colony. Argonne vational Laboratory Biological and Medical Research Division Annual Report,

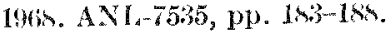

t. Brennan, P. C., C. M. Ponle, and IR. C. Simkins. "Throat flora of a clused colony of beagle digs. Argonne National Laboratory Biological and Medical hesearch Inivision Annual Report, 1964. ANL -7535 , pp. 188-1s9.

5. ("amden, R. W., R. J. Flyun, and R. N. Feinstein. The de- velopment of an inbred aratalasemic mouse. Argonne National Laboratory Biologiral and Medical Researeh bivision Annual Report, 1968. ANL-7535, pp. 189-190.

6. Camden, R. W., C. M. Poole, and R. J. Flynn. Mating systems for Chinese hamster production. Argonne National Laboratory Biological and Medical Meseareh Division Annual Report, 1968. ANT-i5:55, pp. 190191.

7. Canden, R.W., A. B. Reiskin, R.J. Flym, and C. M. Poole. Studies on siyrian hamster production. Aromme National Jahoratory Biological and Medical heseareh Division Annual Report, 1968. ANL, -75355, wp. 192193.

8. Flynn, R. J. Studies of transport of aged animals. Argunne National Laboratory Biological and Medical lieseareh I livision Annual Report, 1968. ANL-7535, pp. 19\%3-194.

9. Flynn, R. J. Ntudies of the effect of frequeney of rage cleat ing on survival of mice. Argonne National Laboratory Biological and Medical Research I Hivision Annual Report, 1968. $\triangle N I_{4}-75,35$, p. 194. 


\section{AGE OF LABORATORY RODENTS AT TIME OF FIRST FERTILE MATING}

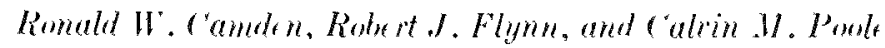

P(RPOME ANI) MFTHODS

These studien were initiated to dretemine the earlient ages at which fertile mating mav oceur in our

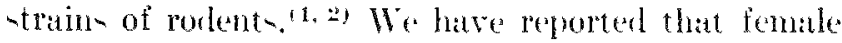
CF 1 , Anllatul 66] mice are capable of fertile mating as rarly an 26 days and the males as early a 40 days of age. Fertile mating oceurred a early as 23 days

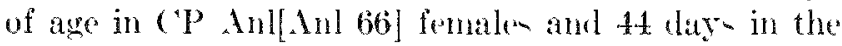

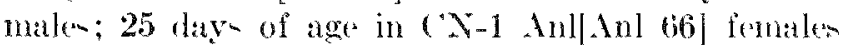
and 43 day in the males; and $3 t$ day of age in C.57BL, 6.Anl[Anl 66] fomales ame 41 dars in the mates. In ardition, a fertil. mating oceured at 19 day- of age in : CP Anl female and 20 day of and in a $\mathrm{C}-1$, ful feruale.

Reports in the literature of age at sexual maturity in mice are extremely variable. The earlient age of vasinal opening reported in the female in 24 days, in a $\left(5,5 \mathrm{BL}, 6 . .^{13}\right.$ Vaginal cornifiestion doen not oceur for 24 to 120 he after raginal openitug. and willingnes- to mate is sometime later. No report deal yem cifically with the age at firot fertilo mating in either sex. and litte in reported ahout sesual maturity in the male.

The age, in the literifure, of femele rat at asual maturity is quite variable." The youngem moan age reported for the srovacue-I awley female rat at time of raginal opening in 39.6 day-. The younge-t mean age reported for a fomale rat, of any -train, is 38 days. No report concern the male, weent that sexual maturity oceur - later than in the female."

During the period covered by this report. we tud-

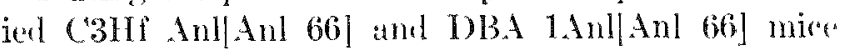
and SD Anl[Anl 66] rett-. Mating of 20- or 21-rlayold males of females with ardult of the opponita - ex were made, and the birth dite of the fir-t lites wat recorded. The adult- used were near 60 day- of age. In the cane of the rits, mating of young malen cuear 30 davs of age with femalen of a comparable age were alno marle.

The are of an individual animal at it firt fertile. mating wa- obtained by -uhtracting the mean length of the gentation period, determined in scparate studie to be 19 day in our micesis and to be $22 \mathrm{day}$ in our rats, ${ }^{(i)}$ from that individual's age when it wirt litter wa- horn.

\section{PROGRE- REPOR' ${ }^{*}$}

The age at firs fortile mating for (3Hi Anll.Mnl 66] and THA 1.Anl[Anl 66] mice are siven in Table
21. The earlient agen for the femiles are 23 and 25

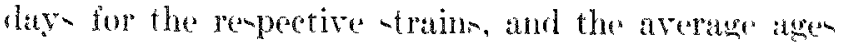
are 28.1 and 32.9 day, popectively. The tarlient ases for the males are 39 and 41 day- fenpotivels, and the "average agen are 48.0 and 47.9 dare.

Pable 21 alo given the agen at firt fertile mating for female and male si) Anl[Anl 6it rats. "Tho "atrliet ase for the fomale is 25 days, and the average age is 30.3 day. The arlient age for the malle in 49 ray. The arerage atge at first iertile mating for malks paired with 60-rlay-olel fermales is 73.5 day-, aml for males paired with $30-4$ lay-old femalem it is 63.4 dater. "The number of infertile matine, is hisher when an-ines

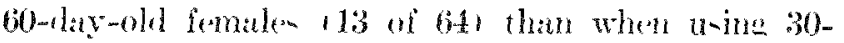

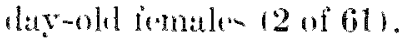

anchathe

The earlient age of the firt fertile mating of femal.

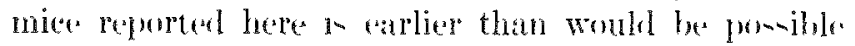
from the age of vaginal opening reported in the literature. There is a con-iderable differeme betwerenthe average ace of female from the two different otrain.

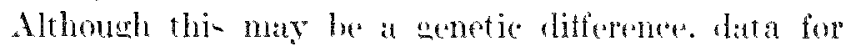
males of the two-train- are-imilar.

The earlient age and the arerage ates at fir-t fertile mating for female, - I) Anl[Anl 66] rate are nuch lowes than any reported in the literature. Mat le reth are more than twice a- oll a female at time of the ir fir-t tertile mating. Matins young malen with lemate of a comparable age 1 Male $B$ in 'lable 211 - tem- to provide a hetter tent ar-tem than matine with arlult formalen I Malte 11 .

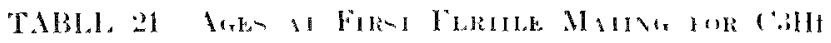

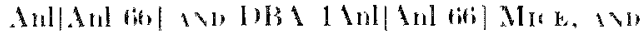
(1) Inldinl bifillim

\begin{tabular}{|c|c|c|c|c|c|}
\hline train & $-\longrightarrow-$ & $\begin{array}{c}\text { Yumb- } \\
\text { lot? } \\
\text { ol b- } \\
\text { served } \\
\text { ted }\end{array}$ & $\begin{array}{l}\text { Nutn- } \\
\text { ter } \\
\text { tedile }\end{array}$ & $\begin{array}{l}\text { lge } \\
\text { range, } \\
\text { labs }\end{array}$ & $\begin{array}{l}\text { ther } \\
\text { aepe } \\
\text { dygte } \\
\text { ald th }\end{array}$ \\
\hline (3HIf Anl| Ind (bil & Pomale & 20 & 24 & 20.39 & 21 \\
\hline 1)13.1 1 1ull.Anl 6in] & Fimale & 22 & 2 & $25.5 \%$ & .324 \\
\hline 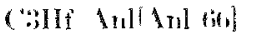 & M:Al\% & 41 & 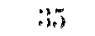 & $.39-42$ & 140 \\
\hline [MI I l.tul|Anl wil & Malo. & $2 *$ & 21 & $11-.78$ & 47 \\
\hline-11$)$ lnl $\ln (66]$ & I (monale* & (n) & (61) & 2.51 .5 & 30 \\
\hline (I) Anllatil tol & M:al* 1 & tit & 51 & 11) 1191 & 7.37 \\
\hline (1) Inl|xinl (iti] & Mala $13^{B}$ & $\$ 1$ & 50 & $\pi 2 \times 1$ & $4: B \quad 1$ \\
\hline
\end{tabular}

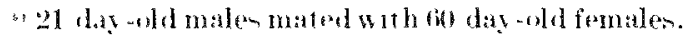

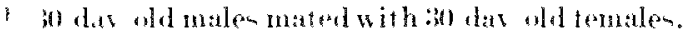




\section{REFLKI:YCE}

1. Camden, R. W. R. J. Flyun, and C'. M. Poole. Age of labora* tory mide at puberts. Argonne National Laboratory Biolugi"al and Medical Researeh loivision Annual Report, 19 ato. ANL, 7278, pp. 79 so.

2. Camden, R, W., R.J. Sivoboda, R.J. Fly mn, and ( . M. Ponle Age of laburatory mier at puberty. Argonne National Laboratory Biolngieal and Medical Researeh Division Anunal

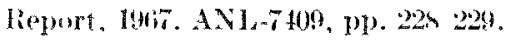

3. Bronson, F. II., ( . P. Dage, and (x. I). Snell. Reproduction. Biology of the Laborutory. Moust. Fd. W. L. Cireen. Med xam Hill Bowk (Company, Now York, lorit, pp. 145-149.
1. Robinson, R. Reproduction. Geneties of the Vorway liat Pergamon Press, New York, 1965, pp. 111-11s.

5. Camden, R. W., C.M. Poole, and R. J. Fly un. Medroxyprogesterone aretate to delas labor in gravid mice and the resultine effect on reproductive ability in cesarean derived progeny. Argonne National Laboratory Biological and Medial lieseareh l livision Annual Report, 1966. ANL.727s, pp. 717.

6. Camden, R. W.. L. O. Bibhs, ( . M. Poole, and R. J. Flym. Medruy progestarone acetate to delay parturition in gravid rats and the resulting effect on reproductive ability in cesarean-derived progeny. Argonne National Iaboratory Biologi"al and Medical Research Division Annual Report, 1906. ANL 7109 , pp. 229 $22 x$.

\title{
THE DEVELOPMENT OF AN INBRED ACATALASEMIC MOUSE
}

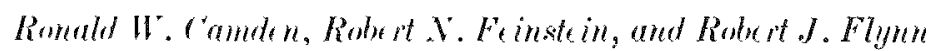

PLRPUE AND MEI IHOD:

The acatularemic mutant of the mouse $\left(\mathrm{C}^{\mathrm{b}}\right)$ is being introduced into the (3Hf Anl mouse in orler to provide an acatalanemic animal of uniform coat color, -ize, and growth rate with good reproductive performance. 1.2 ' This is being done by initial cromen between acataliaemie mutants and ( 3 Hf Anl mice and -uberuent backeromen between mutant carriers and the ("3Hf Inl stock. Only mutant carrier with low catalane levelo and from large litter 18 or 9 weanedl are used for further breeding. Wight generation of harkeromes and subsequent sibling matings between mutant carriters are required to produce an inbred acatalanemie moune (c 3 He Anl- $\left(x^{b}\right)$ that is genetically comparable to the normal catalaremic C3Hi Anl moune.

PRMAREA REPORT

The right backerom generation and one sibling mated generation have been completed and we have
24 breeding pairs in $F_{2}$ matings. The resultunt mice are uniform in body size and coat color and reproduce well.

\section{COXELL'S1OX}

We have introduced the $C^{b}$ locus into C3Hf Anl mice and have produred mice of uniform coat color and hody size that are acatalanemic and reproduce well.

\section{REI HRENCLS}

1. Flym. R.d., R.W. ('amden, R. N. Feintein, and I). (trahn. The development of an inbred acatalasemio mouse. Ar. gonne National Laboratory Biologieal and Medical Re. seareh llivision Annual lieport, 1967. ANL-7409, \%. 119.

2. Camden, R. W., R. J. Flynu, and R. X. Feinstein. The development of an inbred afatalasemie mouse. Argmme Sational Laboratory Biologieal and Medical Research Division Ammal Report, 1966x. ANL. 7535, pp. 199-190.

\section{RATTUS RATTUS AS A RESEARCH ANIMAL}

Thomas E. Frits, Dawid I. Tolle, Patrivia C. Breman, Richard '. Simkins, and Robert J. Flym

PLRPONE AND MFTHODS

Recent eriticiom of the albino rat (Rattus norecgicus) as a laboratory animal ${ }^{(1)}$ and confusing data on the relationships of the laboratory rats with wild strains of $R$. norvegicus and $R$. rattus's) prompted us. to e-tablinh a colony of the "roof" or "black" rat $1 R$. rattus and to compare it with the albino laboratory rat.

BRUI,RES REPORT

Initial attempt to acquire live specimens through commercial animal suppliers and laboratory animal raicer were frustrating. No supplier or raiser of 
odent listed in a comprehensive -oure direetory ${ }^{13}$ supplies either specimen- or information about where they could be obtained.

Through extensive personal communication and incuirie- we finally located a souree of $R$. rattus at the National Communicable Disease Center, Technical Development Laboratorie-, Saramnah, Georgia. This laboratory maintain an unraged, roof-rat colony in a shed. The original stock for this colony wan collected from sylvatic -ource.

A firt group of three trion 16 femalen and 3 maleof roof rat survived no longer than 10 dav in our laboratory. They were houned like our albino rate. individually, in plastic cages fitted with tainles steel top. Although they were given a variety of foor (including a standard laboratory rodent feed. fre-h fruit, and regetablen, canned dog food and dry powdered milk and water' none ate or drank, and all literally starved to death.

A econd group of 9 animal was caged a trio in large wire cager. apprxoimately $4 \times 3 \times 21_{2}$ feet. They had wooden ne-ting boxes, wood having for bedling and were fed a tandard laboratory rodent feed and eanned dog foorl, plu- water. Thene rats survived and were kept in thi- enviromment for approximately 9 month-, with 6 litter- horn during this time. After 9 months. all hut 2 pairs were put into plantic cages an monagomou- pair. During the past 4 month. 15 additional litter- have been horn for a total of 21 litter in 13 month. The 21 litters rontained 131 animals, 83 of which have been weaned. Twenty-eight animal are still -uckling and the re- mainder have died. Camnihali-m ha- heen the major caule of death.

This breeding colony now has 24 breeding pair in platic catgen, and two pairs are in wire cause. At this time. 3 litter of weanling have not been erouped as hreeding patir.

Death-among the artult and weanling animath have remulted from conuplication of cutaneou- lacerstions due to fighting or repiratory infection. Handling problems that have remited in fatal tramma are due to the particularly nervoum attitulte of the rat and their riolent attempte to encate from any true of

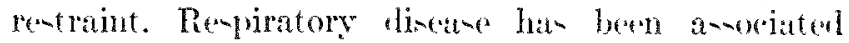
with infections of both Hucoplasma pulmonis as well as Peasteurella prewmotropica.

cove Litom

A production colony of $R$. rattus in featible. We hope that $R$. ruttes, particularly it-fir- and recondgenerution ofl-pring. will alapt to it new environenent well enough so that we can produce a number that will allow -tudien of it biologiral characteristire and permit romparion with the -tanelard albino laboratory rat.

\section{REI CRTY'H}

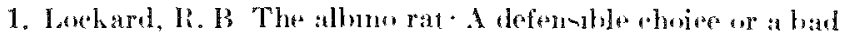
hable Am. Psuchol. 23, 731 712 (19mis).

2. Walker, F P. Mammals of the Hoold. Znd ed . Vul. 2. Juhne Hophin Press, Hallimeres. 19his

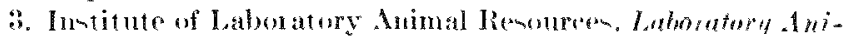

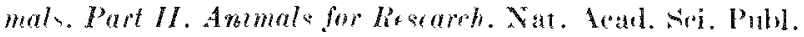
1413, Wanhington, I). ('. 19miti.

\section{GENETIC, NUTRITIONAL, AND ENVIRONMENTAL EFFECTS ON SYRIAN HAMSTER PRODUCTION}

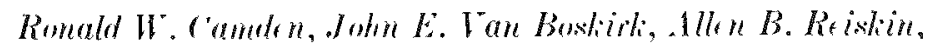
Rohert J. Flynn, and callin .T. Poole

\section{PL RPOSE AND METHODS}

To determine the reanon for lower proluction rates in the Divi-ion' Syrian ham-ter colonien compared with the rates reported by commercial breerler, -tudies of the effect of genetic, nutritional, and environmental variation- were initiated.(1) Invertigations tarted during 1968 were continued durine 1969. Thes include studies of the comparative productivity of a strain of ham-ter from Fngland and another train from the Tnited Staten; comparativo produrvity on pelleted diet- containing either 10r, fut. 4ro fat, or $4^{\prime \prime}$ fat =upplemented with apple three time- at week; and comparative productivity of syrian ham-

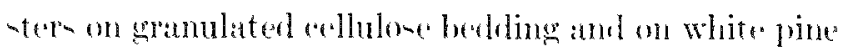
-hatring- New tudies initiated during 1969 include at romparion of producturity at $6.5,73$. and $80 \quad \mathrm{~F}$, and at comparion of produretivity under the [1-1:al andwhite thoresent light soures and the rexently developesd full -pectrum fluopereent lampe.

A morlified tent mating -ratem weed for aninat- in all -tudiem romsist of plating the fernale in the males cige for a seven-day period. The female is then weparated and oberved for pregnancy. If pregnant, she is not relored until her litter in weaned. If she is not pregnant after two weeks. he is placed with the malls atatin for another seren day. 
Partmeters used to determine productivity include the number of seven-ilay mating periods required to produce one fertile mating, the average number born and weaned per litter, the wraning percent, and the number of young weaned per female during her entire reproductive life.

\section{PROME- REPORT}

The reeults to date tre given in Tables 22 to 27.

\section{Stroin}

Table 22 compares the total productivity of the American and Engliwh strains. The American strain is superior to the Engli-h - rain in every category except its weaning percent. The total number of females observer in each strain included equal proportions of the two strains on the two different types of beding and at the three different ambient temperatures. There is a slight disparity in the diets given. Eighty-

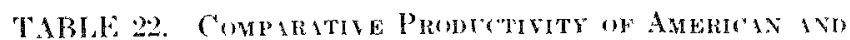

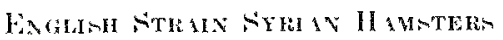

\begin{tabular}{|c|c|c|c|c|c|c|}
\hline Strain & $\begin{array}{l}\text { Number } \\
\text { of females } \\
\text { observed }\end{array}$ & $\begin{array}{l}\text { Matings } \\
\text { rerduired } \\
\text { for each } \\
\text { fertile } \\
\text { mating }\end{array}$ & $\begin{array}{c}\text { Average } \\
\text { number } \\
\text { born }\end{array}$ & $\begin{array}{l}\text { Average } \\
\text { number } \\
\text { weaned }\end{array}$ & $\begin{array}{l}\text { Wean- } \\
\text { ing } \\
\text { per- } \\
\text { cent }\end{array}$ & $\begin{array}{l}\text { Num- } \\
\text { ber } \\
\text { weaned } \\
\text { per } \\
\text { female. }\end{array}$ \\
\hline - - - - & - & - & -- & - & & - \\
\hline American & $x 1$ & $1 \ldots$ & $6.7 \%$ & 1.076 & (io) & 14.611 \\
\hline Fuglish & $14 x$ & 2.05 & 5.870 & $3.61 \%$ & is & $13.1 \%$ \\
\hline
\end{tabular}

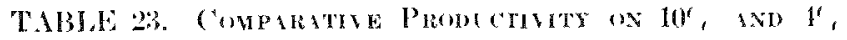

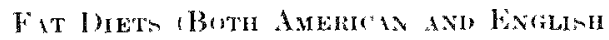

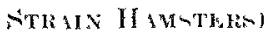

\begin{tabular}{|c|c|c|c|c|c|c|}
\hline I diet & $\begin{array}{c}\text { Number } \\
\text { of } \\
\text { females } \\
\text { observer }\end{array}$ & $\begin{array}{l}\text { Matings } \\
\text { required } \\
\text { for each } \\
\text { fertile } \\
\text { mating }\end{array}$ & $\begin{array}{l}\text { Average } \\
\text { number } \\
\text { born }\end{array}$ & $\begin{array}{l}\text { Average } \\
\text { number } \\
\text { weaned }\end{array}$ & $\begin{array}{l}\text { Wean } \\
\text { ing } \\
\text { per- } \\
\text { cent }\end{array}$ & $\begin{array}{c}\text { Number } \\
\text { weaned } \\
\text { per } \\
\text { female }\end{array}$ \\
\hline 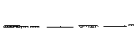 & $1-\ldots$ & - & -- & -- & - & - \\
\hline $10 \%$, fitt & 52 & $1 . x i$ & $6.62 x$ & 1.51 & 72 & $1 \times . t$ \\
\hline $1^{\prime}, \mathrm{f}: 11$ & 23 & 2.66 & ti.tit & 4.51 & $7: 3$ & 11.7 \\
\hline
\end{tabular}

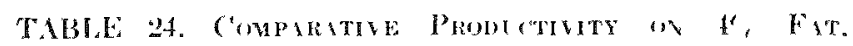

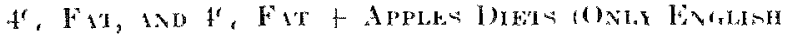
NIRIIVH HMTTERI

\begin{tabular}{|c|c|c|c|c|c|c|}
\hline Thiet & $\begin{array}{c}\text { Number } \\
\text { of } \\
\text { females } \\
\text { observed }\end{array}$ & $\begin{array}{l}\text { Matings } \\
\text { recpuired } \\
\text { for each } \\
\text { fertile } \\
\text { mating }\end{array}$ & $\begin{array}{l}\text { Average } \\
\text { number } \\
\text { born }\end{array}$ & $\begin{array}{l}\text { Average } \\
\text { number } \\
\text { weaned }\end{array}$ & $\begin{array}{l}\text { Wean- } \\
\text { ing } \\
\text { per- } \\
\text { cent }\end{array}$ & $\begin{array}{c}\text { Number } \\
\text { weaned } \\
\text { per } \\
\text { female }\end{array}$ \\
\hline 10, fat & 22 & 1.7 & 6.34 & $1 \overline{4.73}$ & $\int^{-}-5$ & 14.1 \\
\hline 4', fat & 10 & 4.3 & | $5.6 \%$ & 3.6 & 64 & 0.9 \\
\hline$t^{\prime}$, fuat + & 27 & 2.26 & 5.78 & $4.2 x$ & 73 & 17.4 \\
\hline & & 3 & 3 & & & \\
\hline
\end{tabular}

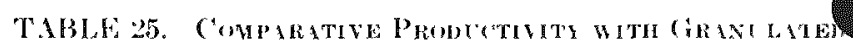

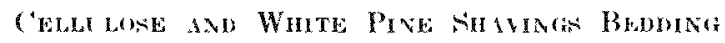

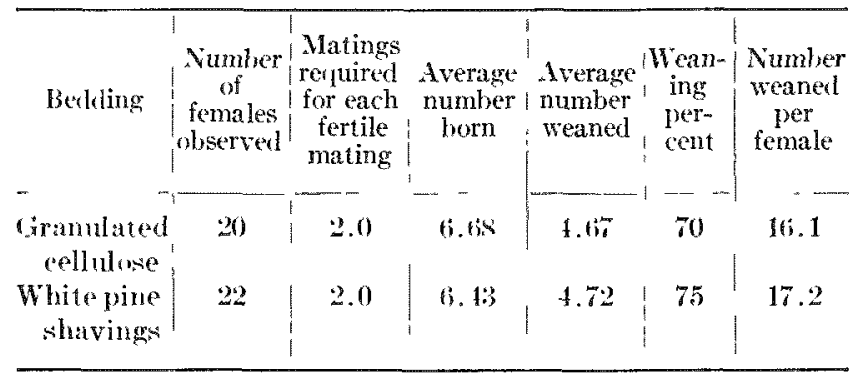

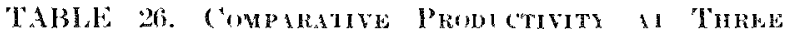

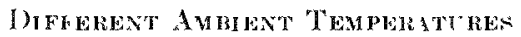

\begin{tabular}{|c|c|c|c|c|c|c|}
\hline $\begin{array}{l}\text { Temper- } \\
\text { ature }\end{array}$ & $\begin{array}{c}\text { Num- } \\
\text { ber of } \\
\text { females } \\
\text { ob- } \\
\text { served }\end{array}$ & $\begin{array}{l}\text { Matings } \\
\text { required } \\
\text { for each } \\
\text { fertile } \\
\text { mating }\end{array}$ & $\begin{array}{l}\text { Average } \\
\text { number } \\
\text { born }\end{array}$ & $\begin{array}{l}\text { Average } \\
\text { number } \\
\text { weaned }\end{array}$ & $\begin{array}{l}\text { Wean } \\
\text { ing } \\
\text { percent }\end{array}$ & $\begin{array}{l}\text { Number } \\
\text { weaned } \\
\text { per } \\
\text { fermale }\end{array}$ \\
\hline $65 \mathrm{~F}$ & 64 & $1 . \mathrm{st}$ & $5 . \times 1$ & 2.7 & $\mathrm{fti}$ & 9.70 \\
\hline $7 \times 1$ & 102 & 2.13 & 6.38 & 4.66 & $7: 3$ & 17.32 \\
\hline 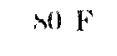 & (i) & 1.90 & 5.01 & 3.15 & 69 & 11.9 \\
\hline
\end{tabular}

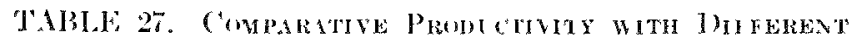

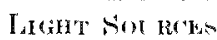

\begin{tabular}{|c|c|c|c|c|c|c|}
\hline $\begin{array}{l}\text { I.ight } \\
\text { source }\end{array}$ & $\begin{array}{c}\text { Num- } \\
\text { ber of } \\
\text { fe- } \\
\text { males } \\
\text { ob- } \\
\text { served }\end{array}$ & $\begin{array}{l}\text { Matings } \\
\text { requiret } \\
\text { for each } \\
\text { fertile } \\
\text { mating }\end{array}$ & $\begin{array}{l}\text { Aver- } \\
\text { agee } \\
\text { num- } \\
\text { ber } \\
\text { born }\end{array}$ & $\begin{array}{l}\text { Aver- } \\
\text { age } \\
\text { number } \\
\text { weaned }\end{array}$ & $\begin{array}{l}\text { Wtan- } \\
\text { ing } \\
\text { per- } \\
\text { cent }\end{array}$ & $\begin{array}{l}\text { Number } \\
\text { weaned } \\
\text { per } \\
\text { female }\end{array}$ \\
\hline-- & 1 & $\ldots$ & & & 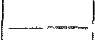 & $!-\ldots$ \\
\hline $\begin{array}{l}\text { Cool whites flu- } \\
\text { orescent }\end{array}$ & $1 \tilde{3}$ & s. 2 & 1.7 & 4.0 & $\therefore 5$ & 2.2 \\
\hline $\begin{array}{l}\text { Full spectrum } \\
\text { flumreseent }\end{array}$ & (1) & 6.0 & 1.42 & 2.1 & 49 & 1.50 \\
\hline
\end{tabular}

four percent of the American strain reedved the 10;0 fat diet and the remainder received the $4^{\circ}$ c fat diet. seventy-five pereent of the English females received the 10 ' fat diet, $7 r^{\prime}$ rereived the $4 \%$ fat diet, and the remaining $18^{\circ} n$ received $4{ }^{\prime} r$ fat and apples. All females in both strains were kept under a cool white Huoreserent light source.

\section{Diet}

Tables 23 and 24 show the diet comparisons. All animals were maintained at $73^{\circ} \mathrm{F}$, on both types of berding. and under cool white fluoresent light.. Table 23 contains data from both American and English strains, while Table 24 contains data only from the English strain. The two tables, therefore, canno be compared directly. The $10^{\circ}$; fat diet appears to b the most desirable, followed by the $4 \%$ fat and apples 
and then the $4 \%$ fat. The data for the $4 \%$ fat group in both tablen may be mirkading, however, bectuse both tables include the 10 fernales linted in Table 24 which gave data entirely out of line from all other.

\section{Bedding}

A comparion of the two typen of bedding (Table 25) Nhows slightly better reproduetive performance on white pine shavings. 'The number observed, howerer, is relatively small. All animals were kept at $73^{\circ} \mathrm{F}$ under cool white fluoreseent light and were giren a $10{ }^{\circ}$ fat diet. The Ameriean and Engli-h strain were requally distributed.

\section{Temperature}

Takble 26 show di-tinet differences among the three ambient temperutures. Highest production is at $73^{\circ} \mathrm{F}$, and lowest production is at $65^{\circ} \mathrm{F}$. Postnatal loss was extremely high $(54 \%)$ at $65^{\circ} \mathrm{F}$. American and Engli-h struin hamsters were di-tributed in relatively equal proportions in each temperature group. All those at both $65^{\circ} \mathrm{F}$ and $80^{\circ} \mathrm{F}$ were given a $10^{\circ}$ e lat diet and were kept on granulated cellulone bedding. All three diets and both types of bending were uned with hamster at $73^{\circ} \mathrm{F}$. All were kept under cool white fluorescent limps.

\section{Light}

Table 27 gives prelimintry data on animal houred under different light ources. All hamsters were hou-ed at $73^{\circ} \mathrm{F}$, given $4^{\circ}{ }_{0}$ fat diet. and kept on granulated cellulone bedding. The initial group gave very poor renult - with both light sourees, and little can be coneluded from the data obtained.

$\cos (\mathrm{Li}-10 \mathrm{~N})$

From the result obtaincel, there appears to be at genetic difference in productivity between the two strain of syrian hamsters. It aloo appears that an ambient temperature of $73^{\circ} \mathrm{F}$ and a diet containing $10 \%$ fat are nearest to optimum, but there is little difference between productivity on granulated cellulow and white pine thaving bedeling.

The rewult uning the different light -oureer are inconclu-ive, and these studins are continning. Studie on the efferts of other diets, - uch an pellets containing 10', iat -upplemented with apple are being mank.

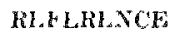

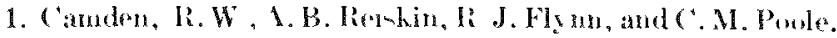

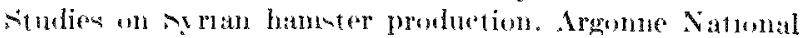
Lathoratory jovismo of Buolugeal and Medieal lieneareh

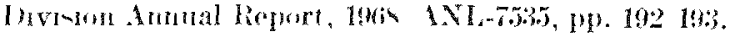

\title{
A COAT COLOR MUTATION IN THE SYRIAN HAMSTER
}

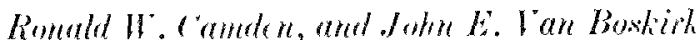

\section{PURPONE AND METHODS}

The purpose of this study is to define the phenotypic manifestations of a coat color mutation which appested spontaneous ly in our colony of golden syrian hamuters, English strain (1) and to determine the mole of genetic transmision. The phenotypic manifertations are needed to determine if there is any value in maintaining thi- nutant as a renearch animal. The mode of gentetic transmission is needed to entahlinh a breeding colony, if this is deemed deirable, and to eliminate the mutation from our colden colony.

The phenotypir manifertations are being determines by studying the pattern of pigment distribution and type of pigment in the hair and skin, both gromly and microncopically, and hy comparing thi- to similar information for the normal golden hamster. The effects of the mutation on other phenotypic characterinties such as eye color, hody size, and noonatal survival is also being -turlied and compared with thous of normal golden ham-ter'.

The genetis tran-mi<ion is being determines in several ways. The number of mutant and normal animal and the aex ration of each are being recorder for all litter in which the mutation appear. Mutant oftopring from normal parent - are being crowed and, if po-ible, a colony of pure breeding mutant w will be etathlished. Pure breeding mutants will then be cromed with normal golden and partial albino lanother cout color mutation maintained in the Divifion, animals to determine alleliom and involvement of rarioum loei. The finding will then be compared to thone reported in the literiture for other cont color mutant and, if pomible, matinge will be mate with phenotypirally similar animal to check for alleli-m.

In entimate of the proballe extent of the mutation in our prement golden colony i- alino heing marde. Thi is being done by making a sy-tematis search of pedigreen of golden hamerer mating which produce mu- 
tant progeny to determine if any common ancestor or ancetor exi-t.

PRO)rRTA REPORT

The pattern of pigment di-tribution in the mutant hair coat appear to be -imilar to that of the normal golden hameter with an obviou line of demareation between the domal and rentral coat. The pigmentation of the ventral coat, where phatomelanin predominate, is grossly the ame in mutant and normal animal. The dorsal coat, from the flank and lower chest on up over the barks, in much lighter in the mutant. The gros difference appear- to be lack oi enmelanin in the guard hair of the mutant with the underfur remaining the same a in the golden. No microseopic studice have been completed.

The pigment di-tribution in the -kin of the nutant animal in groms altered from that in the golden. The ears and secotum of the mutant - are light in rolor owing to an apparent lack of "umelanin. No microscopir observations have been completed.

The eye color, body -ize, and neonatal mortality among mutant appear similar to thone of the golden, but both the arerage litter -ize and arerage numbers wraned per litter are lower for the mutant than for the golden train: 4.9 as compared to 5.4 born and 3.2 a compared to $3.6^{\circ}$ weaned.

Twenty-one mutant animal with thirty normal golden ub have been produced be normal gollen parent. The sex ratio is 11 males to 10 females. ("rossen of mutant animals have produced only mutant offopring, sud a colony of pure-breseding inutants has been extablished. Ten litters from mutant parents have produced 1.5 malen and 17 fomalen. No cromes have been made between mutant animal and either nomal golden or partial allino animal.

$A$ search of the literature reveak numerow other cout color mutation in the syrian hamater. ${ }^{(2)}$ From available decription, it appears the present mutation may be a recurrence of the auto-omal recemive mutation cinnamon or brown $(b)$. No animal, from

\section{MONOGAMOUS MATING OF CHINESE HAMSTERS}

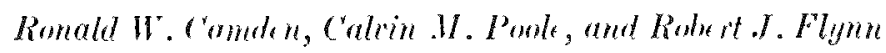

PL RPOSE AVD MLTUOHW

Present method of producing Chinese hamster require large amount - of time, labor, and spact. This study inventigates the prouluction of Chinese ham-ters stork in which this mutation oceurs have been obtained for crossing with our mutants.

Ancentral pedigree of mating producing mutant offinging have revealed the mutant was apparently present in at leat three of the 22 pairs of hamsters used to initiate our Fugli-h golden colony. None of these original paim produced mutant animals in their immerdiate progeny. Of 161 pairs currently in breedm ing in the English golden colony, 148 trace their ancestry to one or more of the three carrier pairs.

\section{CONCLUMION}

This coat color mutation in the syrian ham-ter appear to be the same a the previounly reported autosomal recensive brown 161 . The data we have obtained are compatable with auto-omal reesere inheritance.

W. have no indication that this mutant provides a useful research morel. We are, however, maintaining a pure breeding colony of mutant animals in order to carry out further -tudiess.

The mutant is probahly widespread in our golden lawater breeding colony. There is no indication that the presence of the mutant in the heterozygous st ate in a phenotypically golden animal is detrimental to the renearch u-culne's of that animal. It would, nevertheles, neem desiruble to eliminate the mutant from the golden breeding colony. At present we are attempting to une as replacements only progeny of the 13 pairs not tracing their ancestry to one or more of the three known carriers. Becanse of other criteria for selecting hreeder replacements. such a reproductive performance, we may need to use a sy-tem of test mating to mutant to select noncarries replacement - from progeny of the other 148 pair of breeders.

\section{REFERENGT}

1. Canden, R.W., A. B. liemken, R. d Flom, and C. M. Poole. Studier on sirian hamster produetion. Argonne Natiomal Laboratory Boblogieal and Medieal Remearch Division Anmual heport, 1968. ANL-7535, pp. 162-193.

2. Robinson, R. Genetien and haryology. The Golden Hameste -

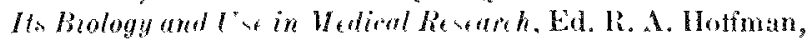
P.F. Robinom, and H. Magalhaes. Iow a state C'niversty

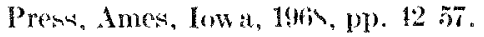

uing routine amount of time. labor, and space.(1) $W^{*}$ do this with a monogamou mating s.ytem by placing a mals and female together for their complete reprodurtive life under condition of controlled temperature. lighting, air "schange, and diet, similar to 
thone wed in our moune, rat, and other rodent-breesding colonies.

The -uceensful ure of monogamou mating for Chines hamster production has been peported recently by others, but with a small number of breederand with special procedures, including daily handling of animals until they herame doenile and supplementation of their diet with crushed oats. flaked matize. millet, sunflower seeds, and fresh apple. ${ }^{22} W^{2}$ are at templting to increase production and decreane aggrem sive tunlencies and cannabali-m by selection alone, and we are not supplementing the diet. Both sibling and nonsibling mating are employed. and we record the number of matinge (breeding pairel, the pereent of fertile matings, averages liter size, averagen number weaned per fertile mating. and the pereent adult mortality.

\section{PRU,REA RLPORT}

I large number of non-ibling mating and fire generations of -ibling mating have been completert. 'I able 28 show the total number of mating , the percent of uating fertile, the arerage weaned-litter size, and the arerage number of hamstern weaned per fortile mating. Also shown is the percent mating in which one adult ru-ually the male) wa- killerl.

The pereent of fertile mating declined to a low in the $F_{2}$-ibling mating but has increased in the later generations. Eight of the $19 \mathrm{~F}$, sibling mating have not vet produced a litter. but are in breeding statur. Later production by thene mating will increase the pereent of fertile mating - for the $\mathrm{F}_{5}$-iblings.

The average weaned litter size is lower for all generation of sibling matings than for nonsibling mating. Average litter size at bipth was ignifieantly lower than nowibling matings only with the $F_{4}$ and $F_{5}$-ibling mating. The increane in postnatal mortality with the sibling matings reflects a relative increase in lones of entire litter. The mode litter size at weaning is 4 for all type- of mating, exerept Fy, sibling matings, where the mode is 5.

The average number weaned per fertile mating in highes for the non-ihling matings. This number reflect-both litter size and arerage number of litter- pere breeding pair. Because some pairs are still in breesting status, enpecially in the $F_{1}$ and $F_{5}$ groups, the

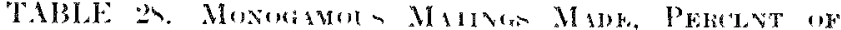

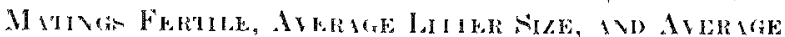

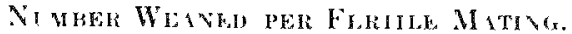

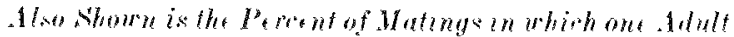
(l'sually Malt, wa Killed

\begin{tabular}{|c|c|c|c|c|c|c|}
\hline $\begin{array}{l}\text { A vee of } \\
\text { mating }\end{array}$ & $\begin{array}{l}\text { Vumber } \\
\text { of } \\
\text { matings } \\
\text { (loreed } \\
\text { ing } \\
\text { latirs }\end{array}$ & $\begin{array}{l}\text { Percent of } \\
\text { matings } \\
\text { fertile } \\
\text { (at least } \\
\text { one litter } \\
\text { lommi }\end{array}$ & $\begin{array}{r}\text { Av } \\
\text { Born } \\
\end{array}$ & $\begin{array}{l}\text { Crage } \\
\text { itter } \\
\text { iize } \\
\text { ineaned }\end{array}$ & $\begin{array}{l}\text { Arerage } \\
\text { number } \\
\text { weaned } \\
\text { per fertile } \\
\text { mating } \\
\text { 'breeding } \\
\text { pair) }\end{array}$ & $\begin{array}{l}\text { Per- } \\
\text { cent } \\
\text { adult } \\
\text { mor- } \\
\text { tality }\end{array}$ \\
\hline Nonsibling & & & & & & \\
\hline $\begin{array}{l}\text { Nollowhlong } \\
F_{1} \text { sbling }\end{array}$ & $\begin{array}{l}139 \\
151\end{array}$ & $\begin{array}{l}50 \\
11 i\end{array}$ & $\begin{array}{l}1.39 \\
1.39\end{array}$ & $\begin{array}{l}3.51 \\
3.24\end{array}$ & $\begin{array}{l}11.9 \\
9.24 i\end{array}$ & 21 \\
\hline $\mathrm{F}_{2}$-ibling & 9 & 35 & 1.54 & 30 & T.0.3 & 21 \\
\hline$\because$ whling & 26 & in & 4.:3\% & 3.55 & 9.17 & 1.3 \\
\hline$F_{1}$ - & 21 & 71 & 4.099 & 3.35 & 7.60 & 29 \\
\hline$F,-$ bling & 19 & 37 & $3 . .5$ & 3.1 & $3 .+i$ & .5 \\
\hline
\end{tabular}

number of hamster weaned per fertile pair will increate an nore litters are weaned.

The pereent of mating in which one adult cusually the male) was killed hy it mate is lighes in the nonsibling and hav generally derereated with each suecesive generation of shling mating. This give an incliration of the overall aggren-ive tendencies of adult Chinese hameters toward their own species. The female is u-ually the mont atgeren-ive and kills the male, although we have a fow examples of lethally agremivice maler.

\section{$\operatorname{CONCTA}$ SIONS}

The deereane of aggremivenem through inbreeding and section, as avidenced by the relative decreate in numbers of adult killed, i- encouraging, but a de-

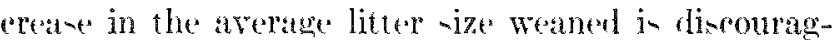
ing. Thi decrease is due to lonsen of entire litter prior to weaning and not to weaning of at large numher of -mall lifters or a dereahe in arerage number born.

\section{RH.HRLCE}

1. C'anden, li W.. ('. M. Pomle and H. J. Hlum. Mating smtemo for chinese hamenter produetion. Argonne National Laboratory Biological and dedieal Research loivision An-

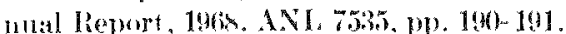

2. Porter, (B. and A. Latey. Breeding the ('hinese hameter

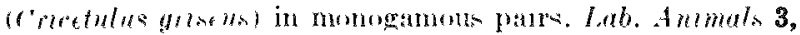
6 is 6 is 11969$)$ 


\title{
FREQUENCY OF CAGE CLEANING AND THE SURVIVAL OF MICE
}

Robert.J. Flynn and 'aluin .11. Powle'

\section{PCRPUNE AND METHOD:}

This study was initiated to determine if the frequency of cage cleaning influences the health and survival of laboratory mice. (1)

('F I Anl[Anl 60] femele mice were divided at Weaning into four grouls of $24.5 \mathrm{mire}$ each and two groups of 210 mire each. The cages of the firet four groups are cleaned three times a week. twice a week, once a week, or ance erery 2 weeks. Cagen of the other two group are cletued once erery 4 weeks or are never cleaned. Spontaneou death are recorded daily.

\section{PROXREA REPORT}

lontil the mire were 6 to 8 month of agen, no -ignifieant difference in their survival wan noted.(1) 1)uring the next month, when the mice were 7 to 9 month of age, screral died. ${ }^{22}$ While thenes death were thought to be due to Pasteur lla pneumotropied.

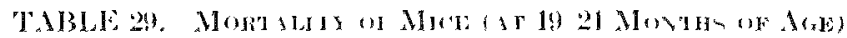

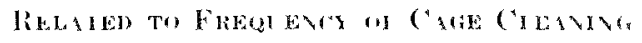

\begin{tabular}{|c|c|c|c|c|c|}
\hline \multicolumn{6}{|c|}{ Ireculency of cage clemings } \\
\hline - & & - & & & - \\
\hline $\begin{array}{l}\text { Ihree } \\
\text { times } \\
\text { nteb }\end{array}$ & $\begin{array}{r}\text { Tho } \\
\text { limes } \\
\text { week }\end{array}$ & $\begin{array}{l}\text { Once } \\
\text { I nect }\end{array}$ & $\begin{array}{c}\text { Fevery } \\
2 \text { weelss }\end{array}$ & $\begin{array}{l}\text { Evert } \\
\text { 4 wecks }\end{array}$ & Dever \\
\hline & - & & - & -- & - \\
\hline 92,245 & 82215 & $7,21.5$ & 84215 & $71 \cdot 210$ & 110,210 \\
\hline $37.5^{4}$ & $33.4^{\prime}$ & $31 . s^{\prime}$ & $34.2^{\prime}$ & 33.4 & $52: 36$ \\
\hline
\end{tabular}

$\because$ Number of deathototal mumber mice. this was not confirmed. Mont mice died in cages that were cleaned leant frequently (every four weeks or nerer).

The mice are now between 19 and 21 months of age. Although during the pant year no epizootien were recognized, the mortality han increased with the increared age of the mire (Table 29). Nice in the eages that were never cleuned have the highes mortality. The differenee in all the other group are slight, with the mice in ragen eleaned 3 times a week hatring the highe-t mortality.

\section{CONCLLTONA}

From the result obtained to date, it appears that the frecuency of atge cleaning has little effect on the health of young mice, unlers an infections pathogen is present. When this happens, decreaned frequency of cage cleaning seems to result in increased mortality. When the mice get older, poor sanitation, ansociated with never cleaming the eage-, appears to shorten the life-rpan; too frequent cleaning also may be detriinentul.

\section{REFCRLNCES}

1. Flynn, R. J. Studies of the effect of frequenes of cage cletaning on survival of mice. Argonne National laboratory lio-

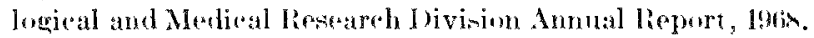
AN1.75:5, 1. 101.

2. Flynu, R. J.. T. L. Friz, ('. M. Ponle, R. W. ("anden, and P. (". Brennan. The aondrol of three diseatane outbreaks in laboratory rodente. Argonne National Laboratorg Biologio eal and Mledieal Rentateh llvinion Anmual Report, 1:mos. ANI.-75:35, p. 180.

\section{HEPATIC AND RENAL LESIONS IN A HAMSTER BREEDING COLONY}

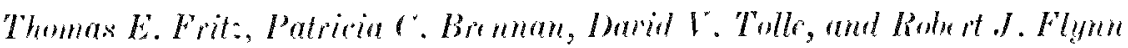

PL RPOE AND MECHOD

poor reproductive performance in as syrian lameter breerding colony stimulated the examination of culled hreeters and selected stock animals to determine dis(ate incirlencer and it-probable causes. (1)

PROMRES REPORT'

In litet rear's report we de-cribed the reult of pathologic, mierobiologic. and toxicologic examination conducted on animal from our breading colonien," with liver and kidney lesions the mot promi- nent pathologic finding. No bacteria of pathogenie significance were isolated nor were any toxic material foumd in food or bedding specimens examined by independent laboratorit's.

A cell-free filtrate and a cell suspen-ion prepared from livers and kidney from three afiected animals were inoculated intraperitoneally into litters of 2day-old ham-ters obtained from an out-ide souree. A third litter, which serverd ats a control, was inoculated only with the diluent I latgle hasal tissue cultur medium containing 200 unit of penicillin and $100 \mu \mathrm{g}$ 
treptomyein mle. A fourth litter sryed as uninorulated controk. Four littern of day-old C F 1 , Anl [Al 66) mice were inoeulated sirnilarly-one litter each was inoculated with the filtrate, cell suspension, and diluent, while the fourth litter served as uninoculated control.

At 3 months, 6 monthe and 13 monthe of age, at least two animals from each group of mice and hamsters were killed and nccrop-ied. No gross lesions were prenent in any of the animals, nor were any microscopic lexions oberred in hematoxylin and comin stained nections of liver and kidney prepared by the parafin method.

During the pant year, there have been no additional effort- to collect data on pathologic lesions in recently killed ham-ters. There have been no illnesner, other than tranmatir lesions from fighting and a few caseof diarrhea, and no hepatic or renal lenions have been olsoerved.

The eaune(s) of the liver and kidney lesions described in our previous report remain unidentified; animal inoculations have failed to reproduce the diseated Aderater reproductive performance and the ahsence of hepatic and renal lesions during the pant year have cau-ed un to abandon our search for the eause of the lesions.

RI THKLACL

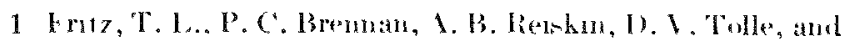

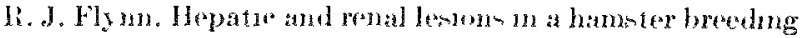
colong. Argome Natuonal Laburatory Bublogeal and Medo-

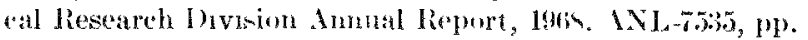
$1 \times: ; 14:$

\section{THROAT FLORA OF A CLOSED COLONY OF BEAGLE DOGS}

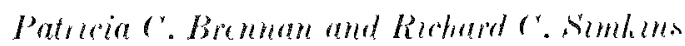

\section{PCRPOML AND MLILIODS}

In the 1968 Annual heport. we preented prelumenary data on the throat flora of 165 dogs in the purebred beagle colony in the Division of Biologieal and Merlicul Research.(1) We continued and expanded thi- survey in 1969 and now have re-ult for a oneyear period. four hundred sixty-seven dog- have been cultured.

Throst swab-were collected an before by swabling the left ton-illar area of each dog when it received its routine physical examination. In addition to the media uned previom-ly (blood agar platen, PPLO) agatr platen, and trypticise soy broth), phenylethyl alrohol agar for gram-ponitive cocci, Rogona agar for lactobacilli, Chapman Stone agar for staphylococci, eosin inethylente blue agar for coliform and siaharaudo, wyycophil and myconel agar for fungi aho were inoculated. The modia for fungi were incubated at $2.5^{\circ} \mathrm{C}$, and all others were incubated at $37^{\circ} \mathrm{C}$. Individual colonien of different typen were picked from each medium and identified by routine hiorhemical and serologic methods.

\section{PRORRL - REPOKT}

The kind of bateria and their incidence are preentul in Figure 53. Alpha - treptocoeri, nonhemolytic

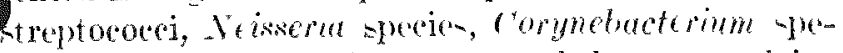
eies and Bacillus species are regarded as normal inhabitant of the throat of lloge and man. ${ }^{2}$ Myco- plasma specien were present in all the dogs cultured. serolugie tests show es that these strains are unrelated

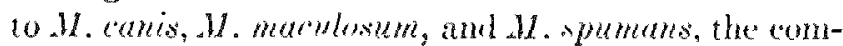
mon esmine strain- Beta hemolytic streptococed were catried by $41.8, c$ of the dogo, and all that were tested wore Laneefield group $G_{\text {. }}$ II $t$ found an incidence of almont 80, Pastentella mulloceda, in contra-t to our

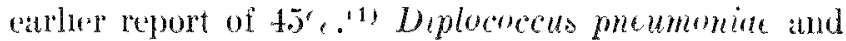
He mophelus - preeie- were not irolated.

Bexane of the relatively high incidenee of $\beta$ hemolytic-treptocoeci in the colony and beraune of its interent to $u$ an a cause of bacteremia in irrudiated dog $\left.,{ }^{\prime 3}, 4\right)$ we -tudied the incidence by age, - cex, stratin, kemel loration, and month in which the culture was obtained.

lounger doge, 1 to 4 year of age, had a significantly lower incidence than dog, 4 year old and older. The incidence of $\beta$ hemolytic treptoenced was similar for all month aseept (letoler and November, when an extremely low 120 c) incirlence wan noted. Antlyin of the incidence by kennel location showed that the locmes homing breeding adult and tock dog-hare a lower incirlence than thow in which experintental or control dog-are housed. Stock doge are rounger thin either the experimental or control dogs and, thu, the differencen noted are probably relat ed to age rather than to environment. No nex differences were noted in the incistenee, nor were differences observent between the two -train of heagle doge in the colong. 
BACTERIA

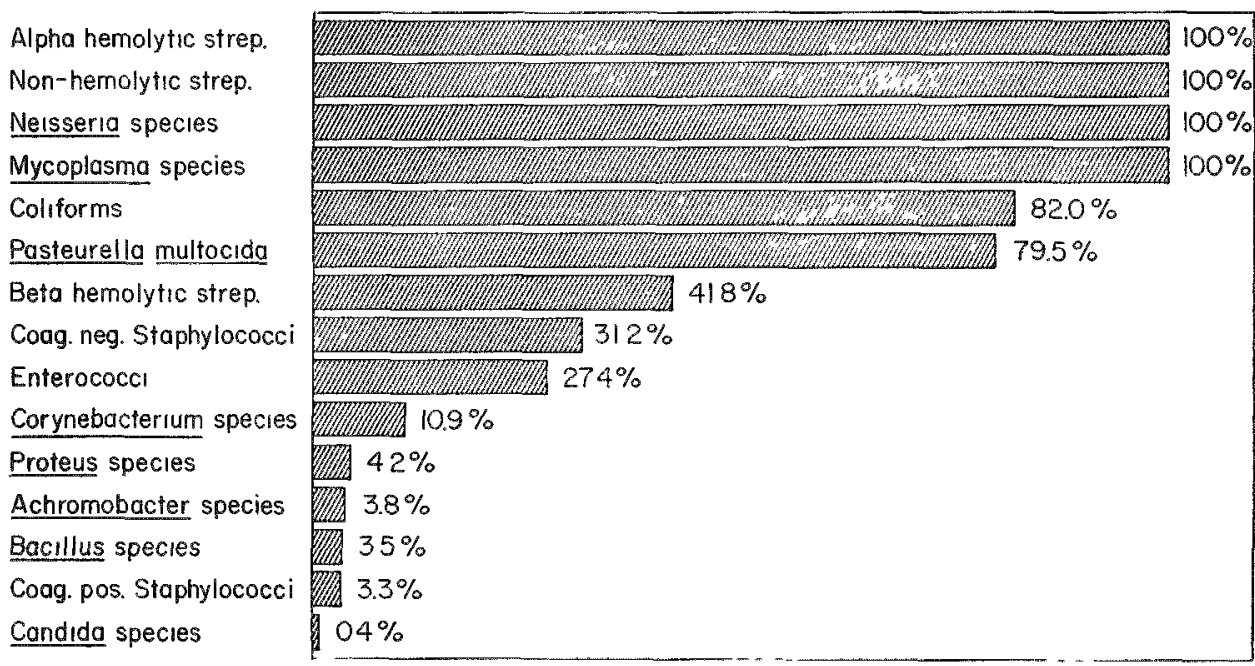

Fut. 53. - Kinds of bacteriat recovered from throat wabs and their incidence in a closed colony of beagle dogg

\section{CUNCLLTION}

Our results indicate that the throat flora of aloge is generally stable, tren when different methods are used to isolate bacteria and even when the dogs are subjected to different environmental conditions. Such stability of the flora was suggented before by Clapper and Meate ${ }^{(2)}$ from their experience with 25 dogs.

The significanses of the high incidence of $\mathrm{M} / \mathrm{H} \times \mathrm{O}-$ plasma species is not clear. Edward and Fitzgerald(5) found a high incidence of Myroplasma species in both the throat and ragina associated with infertility in dog. Possibly Mycoplasma species contribute to the low conception rate observed in our dog colony. ${ }^{(6)}$ but this has not been determined.

The incidence of $\beta$ hemolytic streptocoesi in of interest in terms of both its influence on radiation induexd repticemia and on the overall health status of the dogs. Group G, $\beta$ hemolytic streptoceoci have heen associated with ton-illitis and with neonatal deaths in $\log _{s}(7, y)$ and, rexeently, with an epidemic of pharyngitis in man. ${ }^{(9)}$ (Clearly, the wroup ( $x, \beta$ hemolytic streptococed in the dogs in thi- colony must be regarded as pathogenic rather than as harmless commensals.

Wr know of no tudies on the epidemiology of $\beta$ hemolytic streptocoeci in a closed colony of doge that allow direet comparisons with our results. Better conparisons will be powible when we have stulied the -ame colony another year.

\section{HEFERENCES}

1. Breman, P. C., C. M. Ponle, and R. C. Nimkins. 'Throat thora of a closed colong of heagle dogs. Argonne $N$ ational Laboratory Biologieal and Medical heseareh loivision $\mathrm{An}_{1}$. nual lifport. 1965. ANL-7535, pp. 1sis 1s\%.

2. Clapper, W. K. and (A. II. Meade. Normal florat of the nose, throat and lower intestine of dogs. I. Barteriol. 85, 613bits a 19633$)$.

3. Breman, P. C. and R. ('. Nimkin. The response of the beagle dogs to protracted exposure to ${ }^{60} \mathrm{C}^{\circ}$ z rays at 5 - 35 R/Aay. IV. Bacteriologie findings. Arome National Laboratory Biological and Medieal Ressarch Itivision Annal Report, 196s. ANL -75:35, pp. 159-160.

4. Norris, W. P., 'T. F. Fritz, (". W. Rehfeld, and C. Ml. Poule. The response of the beagle dog to cohalt-fol gamma radia-

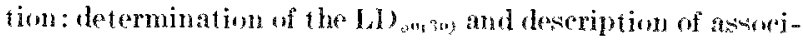
ated ehanges. Ratiat. Res. 35, fos $70 \mathrm{~s}$ (196s).

5. Fidward, D). (i. and W. A. Fitzgerald. The inolation of urganisms of the pleuropnenumonia grump from dogs. $J$. Gorn. Mirrobial. 5, 56ti-575 1051).

b. Prole, C. M., W. P. Norris and R. J. Flum. Colony stants: breeding program and evaluation. Irgonne National Iaboratory livision of Biological and Medical lieseareh Amual Report, 1967. AN1,-7103, pp. 27 s 290 .

7. Laughtom, N. Canine het a hemolytion st repturouci. d. Prathol. Bieveriol. 60, 471-476) (1918).

8. Pilot. I., ('. Buck, D). J. I)avis, and D). A. Eastman. Tronsillitis in dogs due to heamolytic streptocreci. Proce soce. Kxp. Biol. Med. 34, 493-502 (1934i).

9. Hill, H, R., ('. G. Caldwell, E. Wilson, D. Il ager, and h. A. Zimmerman. Cpidemic of pharrneitis due fo streptuencei of Lancefield gromp (x. Lomet 1, 371-37.4 (19m9). 


\section{THEORETICAL BIOLOGY}

\section{MULTIFACTORIAL ANALYSIS AS A TOOL FOR THE STUDY OF EVOLUTIONARY AND ORGANIZATIONAL ASPECTS OF MAMMALIAN STRUCTURE AND FUNCTION}

litarge d. Stacher

PLRPUNL AND MHAHOD

Previous reports and publipation have discuned the pretetical and theoretical reasons for our effort to derclop at comparative biology of longevity, aving, and radiation life thortening in Inammal. (1, $\because)$ The fundamental po-tulate underlying these effort is that all mammalian specie- are variation on at ingle bave plan of organization. To the extent that thi in true, the differencen between -peeien are expremible quantitatively as differences in the numerieal vilues of at common set of ystem paranteters. This pontulate is methodologieally valid, for it lead to the formulation of epecifie lakifialble hypothenen. It in important that the mplications of the portulate $b_{x}$ examined thoroughly. for a great deal of animal renearch on aging and late radiation effect is bared on the implicit a-umption that it hold-. The research prostum at Argonne -eck- to develop the hind of comparative biology of mimmals that in needed if inter-pecien inferencen are to be put on a reientific basis.

If all mammal are. by hypothen- charaterized by the posesion of common sytem propertier, then it becomen necenary to an-wer quention of the following form: how many distinet parameter an' reguired to characterize the performance of a -perified function by a particular perien in the clas? Two eomplementary approachen to thene quention mu-t be developed. One in the approach via the analy in of mechani-ms. The other in the approach viat the exhautive deneription of the structuren and functions concermed by appropriate technicule of multivarlate analy-i- The generic name for the latter approarch is factor amalysis. ${ }^{131}$

The basic po-tulate of factor analy-in is that each mea-urable trait or performane of an individual can be reprenented as a weighted linear combination of the underlying contributory determiner, or fartors. Each individual in characterized by a cet of coefficients, or ucights, for the set of factors. If individuats differ in the performaneen in quention, then they mut differe in their weight on -ome or all of the factor. The tak of factor analy-i is to determine how" many fartor are required to areount for the differences in performane in at -ample of individual, and to enti- mate the inlividual weight for those factor. The farctor problem can be solved if it is po-ible to meanure the -rores on at sufferently large -et of related functons, and if these meanrement- can be carried out on a -ufficiently large sample of individuals who vary - ennticantly and independently in their performance of the function. The inecpuality to be atr-fied in that the total number of independent meanurements cindivduals $x$ functions mu-t be severalfold largere than the total number of parametere to be entmated cindividual $x$ factor-. The number of modridual examined must al-o be ab-olutely large enough -6 that the -ampling error of the meanure of awerciation frovariander and correlations) are as - mall an newarkary.

Firtor analy is re-trieted to po-tulating linear morke becaue the general problem of multrariate nonlinear analy-is in -till intractible. If the linear morlel in accepted, then the relation between a cet of 1 variaten are completely eontained in the $n \times n$ matrix of rovariance or correlations, and the problem of discovering the factorial structure of the net of variaten ean be deatt with through the analysis of the matrix.

The reprementation of a matrix in term- of a - of of orthogonal factors in effected by mean of a clasical procerlure of matrix algehra known as diagonalisation. which romen-ts of performing a riged rotation that tran-form the original matrix into an equivalent matrx for which all the off-diagonal entrien are zero. "The sliagonal entrie- are the engendues, which are the varianem of the newly-formed factor. Fach fatctor hat a row of number, known a it eige meetor. which -perefien the facetor in term of the weight of the contribution of the original variaten to it.

(Ither important alofebraic manipulation are performed before the final et of areentablo factor in determined and the suaty-is ratehe at -topping point.

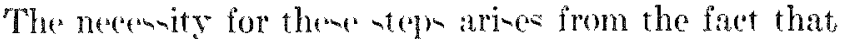
there are an infinite number of equivalent orthogonal factor demeriptions of a given covariance matrix. The farticular one found by the diagonalization procedure hat arlvantages as a tarting point. but it has zero probability of beines the desired and point. The proe- 
ex of tinding a best set of reference coordinates is dealt with by a process known as rotation. The purpose of rotation is to bring the factors into a configuration which sati-fies certain conditions of meaningful interpretation, and to do so by completely objectives procedures, which introduce no information about the substantire content of the variates or factors into

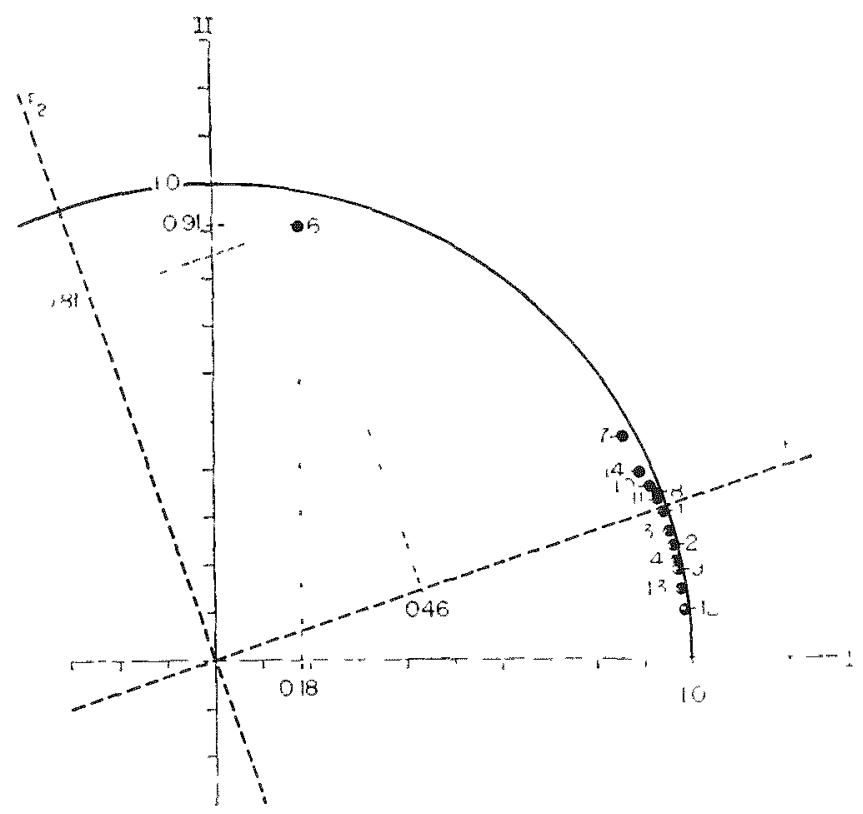

Fin. 54. 'lwo factors found in the analysio of a 14,1 correlation matrix of brain and body measurements listed below. The 14 variates were measured on each of fis specter of insectivoren inhrews, molent, prosinians demurs, galagos) and anthropoids (monkeys, apes, and man). The loadings of wach variate on fartor I are plotted on the absejasa va. the loadings on factor II plotted an the ordinate. The danhed coordinates are the anes of the eigenveretors of the initial diagonalization; the solid coordinate axes are the ases fomd by varimas rotation. "Varimas fantor I is interpreted as the resorticaliation factor besalus neorortex volume (variate 12) in the lowding vartate. Factor II is identified as the rhineneephalie, or paleocortical factor bectuse olfactory hulb (variate bi is the duminant variate. The angular relations between the variates are not altered by rotation. "Threes additional factors have been estracted from the 14,6 data natpis.

\begin{tabular}{|c|c|c|c|}
\hline \multirow[b]{2}{*}{ Nis. } & \multicolumn{3}{|c|}{ I ist of variates } \\
\hline & Nume & No. & Niame \\
\hline 1 & Medulla oblongetta & $\checkmark$ & Septum \\
\hline 2 & C'erebellum & 9 & Sitriatum \\
\hline 3 & Mesenrephalon & 10 & Shehizocostes \\
\hline 1 & liencephaton & 11 & Hipporantus \\
\hline 5 & Telencephaton & 12 & Neocortes \\
\hline ib & $\begin{array}{l}\text { Bulbus olf actorions + } \\
\text { bulbus accessorins }\end{array}$ & $1: 3$ & Brain weight \\
\hline 7 & $\begin{array}{l}\text { Paleocortex }+ \text { amyg- } \\
\text { dalat }\end{array}$ & 11 & Bordy weight \\
\hline
\end{tabular}

1 ariates 1 through 12 are volumes of the indicated regions in

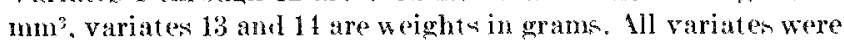
converted to logarithms before the correlations were computed. the proess. By the nature of the process, rotation can only be partially succersul, and the rotated factors must, therefore, be considered to be provisional and subject to further adjustment as more information, drawn from outside sources, is brought into the waluation by the invertigator. 'This is, however, an esential characteristic of all procedures for discovering meaning in natural phenomena. There is no branch of seience in which truth cmerges as the outcome of completely mechanieal manipulations.

PROR

Denpite some very deep problems still not solved, fuetor analysis in enomously surcesuful as a heuristic procedure. It ha- changed p-ychology, education, and vocational selection radically, and for the better. It is ured extensively in sorial wriences and warth soiences, and is rapidly coming into use in hiological noiences. The applications to be dencribed here are new. but at the same time typical. They are listed and briefly decribed below.

Relation of Longerity of Mammalian Species to Brim structure

Previous application of the ristem-theoretic approach had led to the discovery that life-span is highly correlated with brain weight, independent of bodr" weight and metabolic rate." The present study has produced a faeturial dencription of brain structure in mammala, and ha- led to tentative identifieation of a -pecifie brain factor an-ociated with longervity. (*) 'This in the factor for neacorticalisation. Four' other brain form factor have been isolated and tentatively inlentified (Figure 54t. The progres of thi- work was greatly farilitated by the cooperation of Dr. Heinz Stephan, of the Mas Planck In-titute for Brain Renearch, Frankfurt, Germany. Future work will be done with his continued collahoration and in collahoration with other neuroanatomist and neurophysiologirts.

$$
\begin{aligned}
& \text { Relation of Lift-xpan to Hupophysis siot amd } \\
& \text { Strutcture }
\end{aligned}
$$

No -pereifically livpophyesal factor wat fouml: the hypophysis ham a rematrkably alone allometric relattion to body size.

\section{Relation of Life-span to Metabolic Rate, Braine We ight, and Body Height}

Manmals have a wide range of homeothermic and heterothermic adaptation, so metabolic rate is not dependent on body size alone. Data on nine metabolic and related variates were tabulated for 89 mammalian species. Two metabolic factors were found. One relates to body size and overall metabolic rate and 
he other to the thermal conductivity parameter. life-span has relation only to the body size parameter.

Relation of Gestation Time to Brain and Body Weight at Birth, and to the Factors of Increase of These from Birth to Maturity

This -tudy shows that gestation time and, by implication, time to sexual maturity, is a most important limiting factor in the erolution of large-brainedness, for the duration of the developmental periods is clonely related to neonatal and adult brain weight, and this relation holds uniformly for the whole clars Mammalia. The relation of these development period to body weight is significant also, but considerathly weaker.

CONCLTSION

As a result of thene studies, we have attained, within a comparatively short time, a better qualita- tive and cuantitative conception of some important charteteristics of mammals qua mammals. Cognate studies are in view on the factors identifiable within the family Nuridae, and these will be relevant to our current and projected investigations of the comparative hiology of radiation life shortening, which are being c:trried out with murid rodents.

\section{RFHERENCLS}

1. Sacher, (A. A. Relation of life-span to brain weight and hodt weight in mammals. ('iba Foundation symposium on the life-span of Animals. Had. (i. H. W. Wolstenholme and M. o' comnor. Churehill, 1 andon. 1950, pp. 115133.

2. Sacher, 4 . A. The interspecies prediction of radiation life shortening. Argonne Xational Iaboratory Biological and

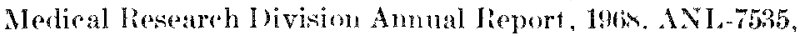
p). 11 is 120

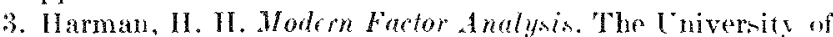
Chicago l'ress, Chicage, 1067.

4. Sacher, (s. A. Allometrie and factorial andysis of brain

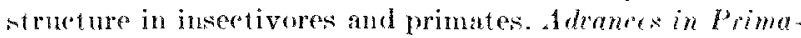
tology. kd. C. R. Soback and W. Montagna. Appletomc'ontury-C'rofto, New York, Iol, 1, in press.

\section{COMPUTER SIMULATION OF PERCENT LABELED MITOSES CURVES}

Einesto Trucco, Ieter .J. Brockwell, ${ }^{*}$ R. J. . Hichad Fry, M. Donald . Marlaren, ${ }^{*}$ and George' 1 . Sacher

\section{PURPOSE AND METHODS}

1 recent paper ${ }^{(1)}$ provides complete details on our theoretical model describing "pereent labeled mitosen" curves (Plali-curves). It alco explains why it is important to investigate from a theoretieal point of view this method of cell cyele analywis, wo frequently used in the laboratory. The main result in Reference 1 is an equation for the Laplace transform of the PLAl-eurve. In simple cases, the transform eat be inverted expliritly to give the PLAl-curve as a function of time, $P(t)$. Thus, we have been able to rederive an exuation previously obtained by Takahashi, ${ }^{12}$ and to eorrect an error in the work of Barrett. ${ }^{(3)}$ Furthermore, an algorithm for computar simulation of PLAI-curves by a Monte ('arlo technicque is briefly outlined.

\section{PROGRESS REPORT}

A second puper ${ }^{(4)}$ anatyzes the earlier work in greater detail. Two additional derivations are given for the main ecpuation found in Referenee 1. (ne of them, like Barrett's, ${ }^{31}$ based on renewal theory, and the second on the theory of branching procenses. By a simple argument, we are led to a natural decomposition of the

\footnotetext{
* Applied Mathematics IVivision.
}

Plall-curve inte a sequenere of "waven," $P(t)=$ $\sum_{(v)} P_{y}(t)$, each wave being produced by cells of a single generation. The area under the $y$ th wave, $\int_{t=0}^{\infty} P_{w}^{\prime}(t) d t$, is ver! nealy equal to the average duration of the S-period. Acourding to Mendekohn and Brescieni that areat should be exactly erual to the mean

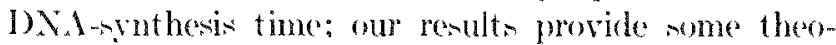
retical justifieation for this hy pothesis.

A second computer program for simulating Plallrurves, similar to Barrett' $\%$ has aloo been developed.

An interesting by-product of our -tudy ${ }^{14}$, 5t was the following. In a simple age-dependent branching proces, ${ }^{\text {fin }}$ charateterized by a probability density $f(\tau)$ for the distribution of interdivision times, $\tau$, the expected number of rells will eventually become proportional to $c^{t}$. where $t$ is time and $c$, the specific growth rate. is uniquely determined by the equation

$$
2 \int_{t=0}^{\infty} e r \tau(\tau) d \tau=1
$$

It can be shown that there exists an upper bound for the solution, $c$, of Equation 1 if the density $f(\tau)$ hat at sufficiently small cocfficient of variation, $r$. In fact.

$$
c \leq \bar{D}\left(\frac{1}{\left.1+v^{2}\right)} \ln \left(\frac{2}{1-v^{2}}\right),\right.
$$


provided that $e^{\prime}<1$. Here $D$ is the mean generation time. Moreover, $c$ is alwars $>(1 / D)$ ln 2 .

CONCLTHOX

One of the principal authors ( PJB $^{2}$ ) was on leave of absence for the past year, and therefore it is not certain at this point what direction future research on the PLAI-process will take. I possible extension of the model would include eorrelations between the rojourn times of cells in the four phases of the life ercle $\left(G_{1}\right.$, $s, G_{2}$, and.$\left.l l\right)$. These correlations are exeluded at present, but they certuinly exint in real systems. ${ }^{(7)}$ One could also study PLAll-eurves in cellular populations for which the number of eells (in particular the number of $\$$ sells) oscillates with a period of approximately $24 \mathrm{hr}$. such circadian rhythms have been observed in some systems.

In any case, a third paper will be written to give full detailis on the two computer programs now available.

\section{REFERENCES}

1. 'Truceo, F', and P', J. Brockwell. Pereent age labeled mitoses eurves in exponentially growing cell poplations. J. Theoret. Biol. 20, 321-337 (1968).

2. Takahashi, M. Theoretiral basis for cell cycle analysis. I. Labeled mitoses wave method. J. Theoret. Biol. 13, 202-211 (1966i).

3. Barrett, J. ('. A mathematical model of the mitotic cyele and its application to the interpretation of perentage labeled mitoses dat a. J. Nat. ('ancer Inst. 37, 443-150 (1966).

4. Brockwell, P. J. and E. Truceo. (nn the decomposition by generations of the PIAC-function. J. Theoret. Biol., in press.

5. Brokwell, P. J. Bounds for the asympt otic growth rate of an age-dependent branching process. I. Austral. Math. Soc. X, $231-235(1969)$.

6. Harris, T. F. A mathematical model for multiplication by binary fission. The Kinetics of (ellular Prolifertion, Ed. F. Stohiman, Jr. (irune and Stratton, New York 1959.

7. Nisken, J. K. and L. Morasea. Int rapopulation kinetics of the mitotir eycle. J. fell Biol. 25, 179-189 (1965).

\title{
THE AREA RULE OF CELL KINETICS
}

\author{
Robert V. Buchal, * Daud L. I'hillips, ${ }^{*}$ and Limesto Irucco
}

\section{PLRPOSE AND METHODS}

In studying certain steady state biological systems, it is common to assume that the system can be represented as a set of connected compartments. Faxch compartment has at least one input and one output through which some material flows. Usually the material consists of cells, but in other cases it may consist of molecules. ${ }^{(1)}$ For convenience, this material will be denoted by the torm "cells."

The properties of a compartment can be investigated by introducing some cells labeled with a radionetive isotope (e.g., tritium, administered in the form of tritiated thymidine). At any given time and for each compartment, the labeling index, $L$, is defined as the ratio $m, I$, where $m$ is the number of labeled cells and II the total number of cells in the compartment. Similarly, if.$T$ cells, of which $n$ are labeled, enter the compartment per unit of time through one of the inputs, the ratio $p=n^{\prime} N$ is the labeling index of that particular input. Labeling indices for all other inputs and outputs are defined in the same way. For a steady state system the quantities. $V$ and $N$ will be constant, but in general $m$ and $n$ are functions of time, and therefore $L$ and $p$ also vary with time.

The simplest form of the area rule (which may be

\footnotetext{
* Ipplied Mathematias Division.
}

called thr" "fundamental area rule") deals with a single compartment satisfying the following conditions:

(a) The compartment as a whole is in a steady state (but, as noted above, there is a transient flow of labeled cells).

(b) The compartment has only one input and may have any number, $k \geq 1$, of out puts ( e.g., if $k=2$, one of the outputs could be cell death, and the other a flow of cells into a following compartment).

(c) There is no uptake of label within the compartment. In the case of tritiated thymidine ('ITTdR), this applies to nonproliferative compartments which will acquire labeled cells only through inflow from prollferating precursors. It is also assumed that cells, once labeled, do not lowe their label.

(d) Exery cell has a tinite, though possibly very long, sojourn time in the compartment.

(e) Initially (at time zero) there are no labeled cells in the compartment. Furthermore, the influx of labeled cells should tend to zero for $t \rightarrow \infty$, in such a way that the integrals of Equation (1) below have a finite value. Both of thene conditions are met in nonproliferative compartments if the label used is ${ }^{3} \mathrm{HTdR}$ and if it is given for a limited period of time (e.g., ats a single pulse), because the number of cells labeled above background in the proliferative compartments will ultimately diminish to zero. 
(f) Biologically, labeled cells behave in exuctly the same way as unlabeled cells. Thus, the probability that a labeled cell will leave the compartment through wny one of the outputs should be the same as the corresponding probability for an unlabeled cell. Otherwise. that output would tend to favor either labeled or unlabeled cells, which is contrary to the assumption that the two types of cells are biologically indistinguishable.

Now, let $p(t)$ be the labeling index of the input flow and $p_{i}^{\prime}(t)$ the labeling index of the ith output flow $(i=1,2, \cdots l)$. If conditions (a) - (f) hold, it can asily be shown that

$$
\begin{aligned}
\int_{t=0}^{\infty} p(t) d t=\int_{t=0}^{\infty} p_{1}^{\prime}(t) d t & =\int_{t=0}^{\infty} p_{2}^{\prime}(t) d t \\
& =\cdots=\int_{t=0}^{\infty} p_{k}^{\prime}(t) d t,
\end{aligned}
$$

i.e., the total arests under the plots of the functions $p(t), p_{i}^{\prime}(t)$ vis. time must all be equal.

In practice, the quantities $p(t), p_{i}(t)$ are not eas. to measure, but the labeling index, $L(t)$, can be obtained without much trouble. This is done by taking small samples from the empartment at freciuent intervals and determining the ratio of labeled to unlabeled cells in each sample. Fxcept for statistical fluctuations, that ratio will be the same ats the labeling index of the whole compartment lassuming perfect mixing of labeled and unlabeled cells within the compartment). ('learly, then, the measurement of $L(t)$ is muivalent to an additional output that will not appreciably disturb the steady state situation. Therefore, Eyuation (1) can be extended as follows:

$$
\begin{aligned}
\int_{t \rightarrow 0}^{\infty} p(t) d t=\int_{t=0}^{\infty} p_{i}^{\prime}(t) d t=\int_{t \rightarrow 0}^{\infty} L(t) d t & \\
& (i=1,2, \cdots k) .
\end{aligned}
$$

Finally, suppose that there are two or more, sty $i$, compartments satisfying the conditions listed above; Jet them be arranged in seriess with one and only one output from euch compartment, except the last, serving as input to the following compartment. Hequation (2) Nows that

$\int_{t=0}^{\infty} L_{1}(t) d t=\int_{t=0}^{\infty} L_{2}(t) d t=\cdots=\int_{t=0}^{\infty} L_{L_{r}}(t) d t$,

where $L_{3}(t)$ is the labeling index of the $j$ th compartment $(j=1,2, \cdots r)$.

\section{PROMRESA REPOR'}

As a simple application of these result consider the curves published by Patt and Maloney ${ }^{(2)}$ for the labeling indices of nonprolferative compurtments in the granulopoiet ic system. There are four such compart-

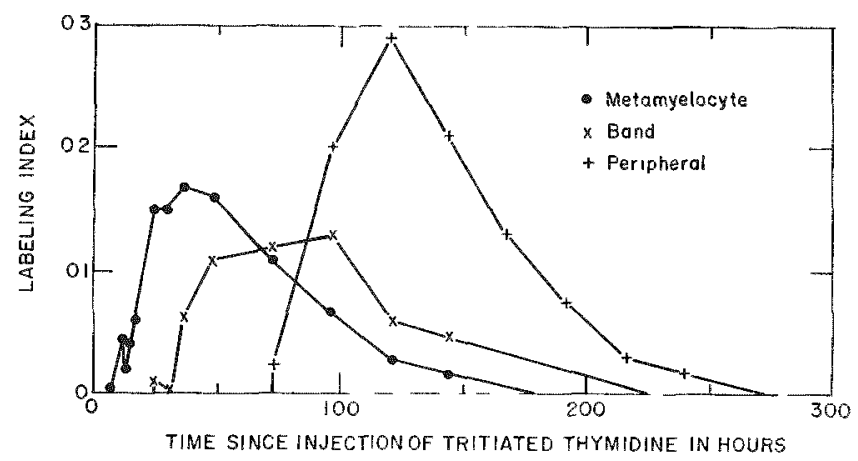

Fro. 55. Tabeling index vis. time for met amyelocy tes, band rells, and rireulating granulorytes (from Patt and Mlaloney).2:

ments: metamyelocytem, band cells, mature neut rophil in the marrow, and circulating rells; presumably they form at secuener of the type diseused in the last paragraph, so that each rell How through them in sueecssion.

The experiments were performed with doge (beagles) to which at single injertion of tritiated thrmidine had been given. Figure 5.5, redraw $n$ from ligures 2 and : of lieference 2 , show the functions $L(t)$ for threes of the four compartments (metamyelocytes, band cells, and circulating grmulocyter; the labeling index of mature cells in the marrow could not be meatured). 'The areas under the three curves are as follows: motamyeloreves, 12.6 hr, band cells, 13.5 hr. and circulating eells, 2:3.2 hr. * These were obtained by stratight line interpolattion and straight line extrapolation from the last two points, which obviously introducess some error. Neverttheles, the area of the curve from the blood is nearly twice as large as that of the metamyelocetes or of the band rells, while according to Equation (3) all three areas should be equal. 1 discrepaney by at factor of $t$ wo seems too large to be due to experimental error. It is thought that all the asumptions listed earlier art reasonably well fulfilled in the granulopoietic syotem, and a sitinfactory explanation for this surprising area discrepancy has not yet been found. ${ }^{\text {"3 }}$

Making appropriate asumptions, the area rule can be extended to include compartments with more than one input and also, in some cases, proliferative eompartments. Interesting results along these lines hare been obtained, but the! will not be reported here becalue complete detaik are given in a paper that is being published. ${ }^{\text {(4) }}$

Furthermore, there is a whole hierurehy of conservation law that can be derived for the higher moments of the functions $p(t)$ and $p_{i}^{\prime}(t)$. (The area, obviouly, is the zeroth moment. ) However, to be really useful in

* Votice that the integrals in Fapations (1), (2), and (3) hate the dimension of time bescause the labeling indices are pure numbers (with values ranging betwen zero and one). 
practice these equations would recpuire experimental data that are not available now with sufficient accuracy. The ealculations are presented in Reference 5.

\section{CONCLUTION}

('onservation laws have a unique place in the understanding of models, and the area rule is no exception. For one thing, it can be used to test the consistency of a model system, as shown by the analysis of patt and Maloney's labeling index eurves. In other cases, the area rule provides simple derivations of results that could otherwiene be obtained only by a rather complieated procedure. A typical example is its appliention to the system studied by Brues and Tyler (1) (of which a full discusion is given in Reference 4 \%. Also notice that results wach as licquation (:B) are completely independent of many detailed features that may be specified for a particular system (e.g., the distributions of cellular sojourn times within each compartment).
It is likely, therefore, that the area rule will turn out to be a useful tool in the study of eellular kineties.

\section{REFEREACH}

1. Brues, 1. M. and s. A. Tyler. On estimating 10 al radiation dosage from a compartmentalized isotope. Atompraxis 5 , $253256(1959)$.

2. Patt, H. M. and M. A. Maloney. Kineties of neutrophil balance. The Kineties of Cllular Proliferation, Ed. F. Stohlman, Jr. Cirune and stratton, New York, 1959, pp. 201207 .

3. Patt, H. M. and N. A. Maloney, Laboratory of Radio biolngy , Iniversity of California, School of Medieine, San Franciseo Nedieal center, San Franciseo. Private communication.

4. Buchal, R. N., D, L. Phillips, and E. Trueco. Area relations between labeling index curves from multicompartment cell kineties models. f'ell Tiss. Kinctics, in press.

5. Buchal, R. N., D. L. Phillips, M. A. Maloney, and E. Trueces. conservation latws in the equations of population dyramiess as applied to the tagging of white blood rells by tritiated thrmidine. Argonne Tational Laboratory, Applied Mathematics I ivision Terhnical Memorandum No. 90 (1966), umpublished.

\title{
A NOTE ON HELMSTETTER AND COOPER'S MODEL FOR BACTERIAL REPLICATION AND ON RELATED WORK BY MARR, PAINTER, AND NILSON
}

\author{
Ermesto Truero
}

PURPOSE A DD METHOD

Coing Escherichia coli B, r, S. ('ooper and (. E. Helmstetter ${ }^{11}$ have proposed that cell division oceur at a lixed time, $\left({ }^{r}+D\right.$, after each initiation of $D \mathrm{NA}$ replication. In rapidly growing cultures, when $\left(^{r}+D\right.$ is larger than the interdivision time, $\tau$, the bacterial chromosome will have multiple replication forks, at least for part of the cell's life ercle (for details sees lieference 1). 1. (1. Marr et al. ${ }^{\text {ai }}$ point out that the simple model of cooper and Helmstetter ignores variability in the frequency of times between initiations, as well as rariability of the time periods ${ }^{\prime}+D$. Then, they proced to derive an equation for the probability density of interdivision times, $f(\tau)$ [Ecpuation (14) of Reference 2 ]. I rigorou probabilistic treatment of the process described by Helmstetter and cooper in difficult (nee discussion below), but a reamonable first approximation follow: there is a (stationary) sequence of primary events, the initiations, eateh of which is followed by a recondary event (coll division) after a variable delicy, $(r+I)$. It is required to find the probability density, $f(\tau)$, for the time intervals between recondary events. This kind of stochastie process has been diseused in -ome detail by M. ten Hoopen and H. 1. Reuver, ${ }^{(3)}$
PROGRESA REPORT

Following Marr et al. ${ }^{(2)}$ we denote by $f_{i}$ the probability density function of interinitiation times and by $f_{d}$ the probability density function of the delay times. $("+D)$. We also assume that the two processess (initiations and delays) are statistically independent and, for simplicity, that the delay times, $C+D$, form a renewal process (cox and Lewis, Reference 4, p. 78 ). Then, aceorling to ten Hoopen and Reuver, ${ }^{(3)}$ the quantity $f(\tau)$ is given by

$$
f(\tau)=\int_{\xi \rightarrow 0}^{\infty} f_{i}(\xi) g_{1}(\tau-\xi) d \xi
$$

where $g_{1}(\eta)$ is the probability density for the difference between two suecessive delays. Thus.

$$
g_{1}(\eta)=\int_{x=-\infty}^{\infty} \int_{d}(x) f_{d}(x+\eta) d x .
$$

Inserting this axpresion into Equation (1) we obtain $f(\tau)=\int_{\xi=1}^{\infty} f_{i}(\xi) \int_{x-\infty}^{\infty} f_{j}(x) f_{d}(x+\tau-\xi) d x d \xi$.

Notice that in Equations (2) and (3) $f_{d}$ may characterize either the distribution of delay times or the deviations of delays from their mean, in which care the 
Thuments of $f_{d}$ may assume ponitive and negative values. For example, if $f_{d}$ is a Gaussian density with mean zero (or any other fixed mean, $m \geqslant 0$ ) and a (sufficiently small) standard deviation $\sigma$, Equation (3) giver

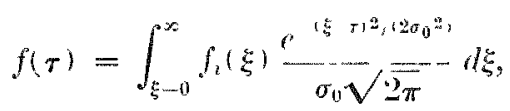

with $\sigma_{\|}=\sigma \sqrt{2}$.

In the following, however, we thall always take for $f_{1}$ the probability density of the artual delays, so that $f_{d}(y)=0$ for $y<0$. L sing this relation, and interchanging the order of the two integrations in Fapuation (3), we obtain

$f(\tau)=\int_{x \rightarrow 0}^{\infty} f_{d}(x) \int_{\xi=0}^{x+\tau} f_{2}(\xi) f_{d}(x+\tau-\xi) d \xi d x$.

This result whould be compared with Marr et all's expresion (which we denote by $f_{u}(\tau)$ ), namely,

$$
\begin{aligned}
f_{M}(\tau)=B \int_{x \rightarrow 0}^{\infty} e & { }^{l x} f_{d}(x) \\
& \cdot \int_{\xi=-1)}^{x+\tau} f_{d}(\xi) f_{d}(x+\tau-\xi) d \xi d x,
\end{aligned}
$$

where $k$ is the constant specifie growth rate for the cellular population when in steady state of exponential growth, and $B\left(=\left(B_{0} N_{0}\right)\right.$ in at constant $>1$ such that

$$
\left.B \int_{x-0}^{\infty} e^{-l x} f d x\right) d x=1
$$

W. have no ready explanation for the discrepancy between Equations (5) and (6). Powibly, this aries from the fact that Marr et al., in deriving their results, had to consider a population in steady state of exponential growth. Therefore, $B e^{-h x} f_{d}(x)$ might well bo the probability density of delay times for a sample taken from all extant cells in an exponentially growing mopulation. Howerer, it is not for such a sample that $f(\tau)$ is defined. ${ }^{(5)}$

In any ease, both liquations ( 5 ) and ( 6 ) can only be approximately correct. 'This is seen most easily by computing the integral, $\int_{\tau=0}^{\infty} f_{\mathcal{Y}}(\tau) d \tau$, which turns out to be $<1$. In fact, the Laplare transform of $f_{M}(\tau)$ is given by

$$
\begin{gathered}
{\left[I f_{M}\right](x)=B \int_{x=0}^{\infty} e^{-h x} f_{d}(x)} \\
\cdot \int_{\tau=0}^{\infty} e^{-s \tau} \phi(x+\tau) d \tau d x \\
=B \int_{x=0}^{\infty} e^{-h x} f_{d}(x) r^{-x} \int_{u=-x}^{\infty} e^{-s u} \phi(u) d u d x,
\end{gathered}
$$

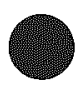

where $\phi(u)$ denotes the convolution of $f_{i}$ and $f_{d}$ :

$$
\phi(u)=\int_{\xi-0}^{u} f_{1}(\xi) f_{d}(u-\xi) d \xi .
$$

If $s=0$, the right hand side of bquation $(s)$ is maller than one. It follows from Equation (s), in particular, that Marr et al.'s Equation (1.5) for the variance of $f(\tau)$ is slightly ineorrect.

Special awes of the ineopulity $\int_{\tau=0}^{\infty} f_{M}(\tau) d \tau<1$ Lor $\left.\int_{\tau-1)}^{\infty} f(\tau) d \tau<1\right]$ can easily be worked out in detail and are quite instructive. Suppores, for example, that in Equation $(6)$ both $f_{2}$ and $f_{d}$ are negative exponential densities: $f_{d}(x)=\lambda e^{\lambda_{t}}$ and $f_{l}(\xi)=\mu e^{-\mu \xi}, \mu$ and $\lambda$ being two positive constants. Then $\lambda, B$, and $k$ must be related by the exuation

$$
\lambda B=\lambda+k
$$

in order to satisfy $(7)$, and one finds

$$
\begin{gathered}
f_{M}(\tau)=\left\{\begin{array}{c}
\frac{B \mu \lambda^{2}}{(\lambda-\mu)}\left[\frac{e^{-\mu \tau}}{(\mu+B \lambda)}-\frac{e^{\lambda r}}{(B+1) \lambda}\right] \text { if } \lambda=\mu \\
\frac{\mu B}{(B+1)^{2}}[1+(B+1) \mu \tau] e^{-\mu \tau}
\end{array} \text { if } \lambda=\mu,\right. \\
\int_{\tau-1}^{\infty} f_{M}(\tau) d \tau=\frac{B[\mu+\lambda+B \lambda]}{(B+1)(\mu+B \lambda)} \\
=1-\frac{\mu}{(B+1)(\mu+B \lambda)} .
\end{gathered}
$$

This latst expression will be eloue to one, if $\mu \lambda$ is -nffieiently -mall. similarly, integrating Equation (4) over $\tau$ from 0 to $x$, we have

$$
\begin{aligned}
\int_{\tau-0}^{\infty} f(\tau) d \tau=\int_{\xi=0}^{\infty} f_{i}(\xi) \int_{u--\xi}^{\infty} & \\
& \frac{\cdot u^{2}\left(2 \sigma_{u^{2}}{ }^{2}\right.}{\sigma_{11} \sqrt{2 \pi}} d u d \xi<1,
\end{aligned}
$$

and $\int_{\tau-1}^{\infty} f(\tau) d \tau=1$ if $\sigma$ is small compared to the mean of $f_{2}$.

As a last example consider the eane studied by Medill (cuoted in Reference :3) who towk a Dirue delta function for $f_{2}(x)$ and a negative exponential for $f_{d}(\xi)$. Thus, $f_{i}(x)=\delta(x-T)$ and $f_{d}(\xi)=\lambda e^{-\lambda \xi}$, where $T$ and $\lambda$ are positive constants. Fialition (.j) then given $f(\tau)=(\lambda 2) \exp [-\lambda|T-\tau|]$, and $\int_{r=0}^{\infty} f(\tau) d \tau=$ $1-\left(1_{2}\right) \exp (-\lambda T)$, which is nearly equal to 1 if $\lambda T$ is very large, i.e., if $1 \lambda \ll T$.

(ienerally speaking, the approxinate nature of Equations (5) and $(6)$ is due to the fact that we are restricted to order-pieserving time delays, in the sense explatined by ten Iloopen and Rouver. ${ }^{3}$ ' (onceivably, there might be a very long time delay after a first initiation and a very short subsequent time delay after the following initiation, so that the order in which the secondary event - oceur would be inverted with respect 


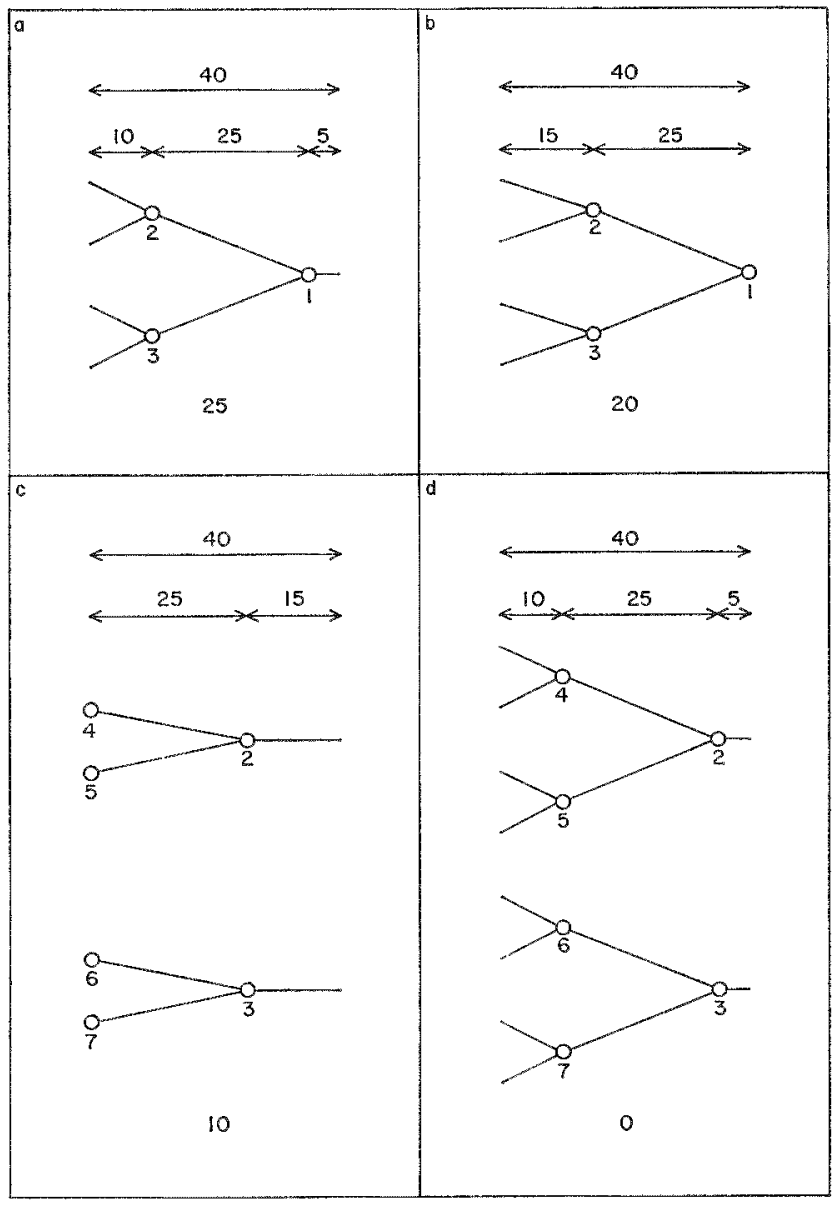

Fic. 50.- Melustetter and ('orper's model with $t^{\prime}=40 \mathrm{~min}$, $b=20 \mathrm{~min}$, and $I=25 \mathrm{~min}$. The numbers above each branch indicate its relative length, assuming that a branch point progresses at a constant rate along the chromosome. The number below earh figure is the time in minutes hefore cell division.

to the sequence of primary events. Such a situation, of course, must be avoided. It is diffieult to formulate this condition analytically, but a rough criterion is that the standard deviation of $f_{d}, \sigma_{d}$, should be small compared to the mean of $f_{i}, m_{i}$. [In Figure 13 of Reference 2 we find $\sigma_{d}=0.095 \mathrm{hr}, m_{\imath}=0.76 \mathrm{hr}$, and thus $\sigma_{d}{ }^{\prime} m_{i}=$ $0.125]$.

The opposite extreme of delays that are not onderpreserving has been studied by Govier and Lewis for the special case when the primary events oceur at fixed time intervals (sees pp. $204 \mathrm{ff}$. of Reference 4 and references given there). Obviously, their assumptions are not applicable for a generalization of the HelmstetterCooper model.

Finally, it should be pointed out that each delay, $\left({ }^{*}+D\right.$, is itself composed of two parts, namely, $C$ and $D$. This feature is also treated in the paper by ten Hoopen and heuver (Reference 3, pp. 604.605).

\section{CONCLISHONS}

In addition to being limited to order-preserving time delays, a further complication of the Helmstettercooper model is that one "event" must actually oceur almost simultaneously on different branches of at chromosome or possibly on two chromosomes. Is an illustration, consider the ideal case in which there is no variability of interinitiation times, $I$, or of delays, $C$ and $D$. Assume, as Helmstetter and Cooper did, that $C=40 \mathrm{~min}, D=20 \mathrm{~min}$, and take $l=\tau=2.) \mathrm{min}$. The sequence of chromosome configurations during the cell's life-span is shown in Figure 56 (taken from Figure 1 of Reference 1). At birth, i.c., 2.) min before the next division, the cell contains one chromosome with three branch points, 1, 2, and 3 (Figure 5 (ba). Five minutes after birth (Figure 56b) point 1 has reached the end of the chromosome. Ten minutes later (Figure 56c) the cell contains two separate ehromosomes, and four new initiations $(4,5,6$, and 7$)$ are started. Finally, at division (Figure 56d) the cell has two chromosomes, each of them equal to that of Figure 56 i.

If there is some variability in the sequence of events along each branch of a chromosome, it is no longer obvious exactly when cell division will occur. ('learly, a stchastic model, incorporating such features. would be extremely complicated.

R. H. Pritchard et al. ${ }^{(6)}$ and (C. N. Helmstetter ${ }^{(7)}$ have proposed models for the control of initiation. Esisentially, both of them assume that initiation starts when a certain substanee within the cell reaches a eritical amount or a critical concentration. We may postulate, then, that if this happens, four initiations, such as $4,5,6$, and 7 in Figure 56 e, will begin at the same time and thus can be regarded as a single event. If similar regulatory mechanisms are present for the delays ( $($ and $D$ ), then the model discussed might be valid because for all practical purposes we would have a simple sequence of initiations (with variable interinitiation times), each of them being followed by a variable delay period between initiation and cell division. liurther work will be necessary to establish if this is retlly the case.

\section{REFERE YCEN}

1. Couper, S. and C. E. Helmstetter. ("hromosome replication and the division cyele of $F$ scherichia roli B/r. J. Mol. Binl. $31,519-540(1968)$.

2. Marr, A. G., P. R. Painter, and H. H. Nilson. Growth and division of individual bacteria. Wicrobial Growth, 19 h Symp.. Soe. Gen. Microbiol., Cambridge University Jress, (ambridge, 1969, pp. 237-261.

3. ten Hoopen, M. and H, A. Reuver. Analssis of secuenees events with random displacements applied to biological systems. Wath. Biowci, 1, 599-617 (1967). 
(an, D). R. and P. A. W. Lew in. The Statistical Analgsis of Nerits of Events. Methuen \& (o. Lotd., London and John Wiley de sons Ine., Now Yort., 196it.

5. Painter. P'. I'. and A. (x. Marr. Mathematirs of micobial pepulations. Anm. Rev. Wirobiol. 22, 519-5 $1 \times$ (1968).

6. I'ritehard, R. H.. P. 'T. Barth, and J. Collins. Control of lNA synthesis in barteria. Wrobial Grouth. 19th symp. sore Gen. Mierobiol., ("ambridge lniversity Prens. ("ambridges. 14tit, pp. 2 tii3 297.

7. Helmstetter, C. E. Regulation of ehomomone replieation

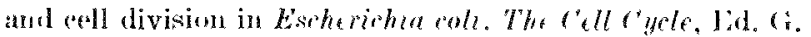
M. Padilla, (4. L. Whitwon, and I. I. Cameron. Acarlomic Press, New York, 19639, prp. 1.5.5.

\section{ON THE AVERAGE CELLULAR VOLUME IN SYNCHRONIZED CELL POPULATIONS}

Einesto Trucos

\section{I'URPOAL: IVD METHOD}

This inventigation arose in connection with as atudy of finclair and Ross, "who wore interested in the mean coll volume of a population that initially at time zorol consints of $I_{0}$ newborn cells, all with the same volume, $z_{1}$. It in a-iuned that cell division is determined only by the cell's age and not by its volume. The probability density function for the distribution of interdivision times, $\tau$. is denoted by $f(\tau)$. It is further supposed that cell death in negligible, so the population size will increase according to the laws of a simple age-dependent branching process. ${ }^{(2)}$ Let $V(t)$ be the expected number of cells at tme $t$ and put $V(t)=J^{n}(t) X_{0}$. The funcm tion .l/t) sitisfes Fquation 12 , of Reference 2 :

$$
. U(t)=\varphi(t)+2 h * h(t)
$$

where

$$
\varphi(t)=1-\int_{t \rightarrow-11}^{t} f(x) d x
$$

amel $: \| * f\}(t)$, the convolution of the two functions $I I$ and $f$, is defined by

$$
i, h * f(t)=\int_{x-0}^{t} f(x) . U(t-x) d x .
$$

The Nenmann series rolution of Futuation 11 is at follows:

$$
M(t)=\psi_{t}^{(t)}+\sum_{i=1}^{\infty} 2^{n} \mid \varphi * f_{n}(t)
$$

in which $f$ stand for the $\nu$-fold convolution of the function $f$, i.e.,$f_{1}(t)=f(t)$ and

$$
f_{z+1}(t)=\left\{f_{i} f_{3}(t) \text { for } \quad \nu=1,2,:\right\}, \cdots
$$

putting

$$
F_{v}(t)=\int_{v=0}^{t} f_{v}(x) d x=\left\{1 * f_{v}\right\}(t)
$$

me rex that

$$
\left.\left\{f * F_{\nu} \mid=i * 1 * i\right\}=\mid 1 * i_{v, 1}\right\}=F_{v\{1}
$$

and furthemore, since

$$
\begin{aligned}
\varphi(t) & =1-\{1 * f(t), \\
\left\{\varphi f_{b}\right\} & =\left\{1 * f_{l}\right\}-\left\{1 * f_{2+1}\right\}=F_{3}-F_{b+1} .
\end{aligned}
$$

Hence. Eyuation th an be written in the form

$$
M(t)=1+\sum_{v=1}^{\infty} 2^{\eta-1} F_{v}(t)
$$

from which it follows that

$$
\eta(t)=\sum_{z}^{\infty} 2^{z-1} f(t) .
$$

where $i l(t)=d . h(t), d t$. Also notice that in this model crery cell disappearing from the population at mitosiis immediately replaced by two new cello of age zeru and, therefore, the birth rate, $\alpha(t)$, must be equal to twice the net increan in number of exalls:

$$
\alpha(t)=2 V_{0} i(t)
$$

Sinclair and Ros " ured a special form of Equation (S). Let $\vec{\sigma}$ be the average generation time casumed to be finite):

$$
\tilde{\tau}=\int_{x \rightarrow 0}^{x} x f(x) d x
$$

Suppose that the probability density $f(\tau)$ has a relattively small coefficient of variation and that the time. $t$, is not too large, wh that no appreciable overlapping of generations oceurs. C'onsider values of the variable $t$ restricted to a sufficiently small meighborhood of $x \bar{\tau}$, where $x$ is a pontive integer. Then, in Equation ( 8$)$.

$$
F \cdot(t)=1 \text { for } \quad p<\therefore, \quad F_{3}(t)=0 \text { for } \quad v>x \text {, }
$$

and

$$
M(t)=1+\sum_{s=1}^{s-1} 2^{n-1}+2{ }^{1} F_{(t)}=2^{-1}\left[1+F_{s}(t)\right]
$$

or, uning the relation $F, s:=1$,

$X(t)=X_{1} \cdot 2-1\left\{2 \int_{x-1}^{t} f(x) d_{d}+\int_{x-t}^{\infty} f(x) d x\right\}$.

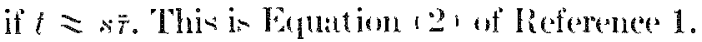


Two further assumptions are made regarding cellular volume:

(a) The rolume of each cell, $b$, is a given function of its age, $a$, and of its volume at birth, $c_{b}$ :

$$
v^{\prime}=\psi\left(a, v_{b}\right) \text {; }
$$

(b) When a cell divides, ach of the two daughters has the same birth volume. equal to one-half that of the mother eell.

special cases of liduation (13) considered by Sinclair and Rose are those of linear and exponential volume increase with age:

$$
r=r+r a(r=\text { constant }>0),
$$

and

$$
r=v_{b} e^{l n} \quad(k=\text { constant }>0) .
$$

Obriously in Equation (4, the number of cell is expressed in terms of generations. of $f$ represents the fraction of the original cells (zeroth generations that have not yot divided at time, t. 'The quantity.

$$
R_{y}(t, a) d a=\lambda_{12} z^{y}(a) f_{y}(t-a) d a
$$

is the experted number of cells present at time. $t$, belonging to the $y$ th generation $(\nu=1,2,3, \ldots)$, which have ages between a and $a+d a$. In fact, such cells will have undergone their $\nu$ th division at time, $t-a$, within $d a$ (or within $d t$, since $d t=d a$ ); this occurs with probability $f_{y}(t-a) d a$. Then, fial is the probability that a newborn ecell surviven to reach age, $a$, the facter 2 "account for cell doubling at earch division).

The life histor! of $p$ th generation ceell is specified by its $\nu$ interdivision times, $\tau_{1}, \tau_{2}, \cdots \tau_{\nu}$, and by its age, u. Alternatively, one maly use $a$ and the time period

$$
T_{\lambda}=\sum_{\mu=1}^{\lambda} \tau_{\mu}, \quad \lambda=1,2, \cdots \nu
$$

(a) that $T_{\lambda}$ is the time at which the $\lambda$ th division hat oceurred. These variables must sati-fy the conditions

$$
0<T_{\lambda}<T_{\lambda-11} \text { for } \lambda=1,2, \cdots(p-1) \text {, }
$$

and $T_{r}=t-a$ inee Figure 57 for $v=1$ ).

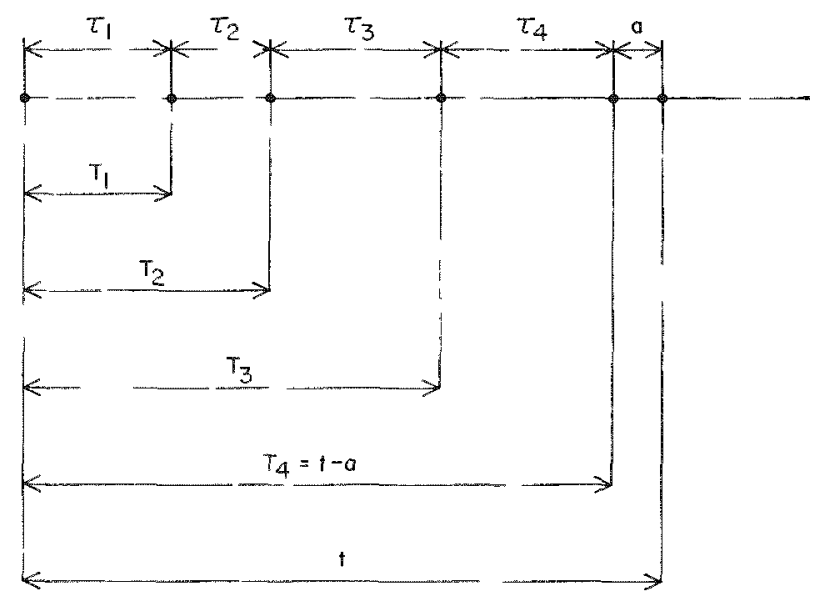

Fic. 57 -Illustration of the meaning of the variables $\tau_{2}$, $T_{3}, a$, and $t$.

Writing out the complete expression for the convolution integral, $f_{x} t-a$ ), in Equation (16), it beromess evident that the experted number of $p$ th generation cells present at time, $l$, which have age $a$ (within da) and which, for $\lambda=1,2, \cdots(p-1)$, have given values for the $T T_{\lambda}^{2}$ s ( within $d T_{\lambda}$ ) is equal to

$$
\begin{gathered}
N_{0} 2^{p} \varphi(a)\left[\pi_{\lambda-2}^{v} f\left(T_{\lambda}-T_{\lambda-1}\right)\right] f\left(T_{1}\right) d T_{1} d T_{2} \\
\ldots d T_{r-1} d l \quad(16) \\
\quad y=2,3,1, \cdots]
\end{gathered}
$$

where $T_{v}=t-a$. If $\nu=1$, thin expression redueses to $2 V_{0 p}(a) f(t-a) d a$. Now. uning Equation (1:3) and hatving the volume at each division, the volume of a th generation cell with a given life history ean be expreseded as a function of the quantities $l_{2}, T_{1}, T_{2}$, $\cdots T_{2-1}, t$, and $a$, say $\eta_{p}\left(t_{0}, t, a ; T_{1}, T_{2}, \ldots T_{\nu-1}\right)$. Therefore, the mean rolume as a function of time, (w) $(t)$, is obtained by multiplying the expresion (17) with $\eta_{2}$, integrating over $a . T_{1}, T_{2}, \cdots T_{r-1}$, summing over all generations, and finally dividing by $V(t)$. It is convenient to introduce $T_{x}=1-a$ as a new variable of integration instead of $a$. The resulting equation for $\langle(t)\rangle$ is

$$
\begin{aligned}
& \left(v(t)=\frac{1}{M(t)} \varphi(t) \psi\left(t, t_{0}\right)+2 \int_{\left.T_{1}-t\right)}^{t} \varphi\left(t-T_{1}\right) f\left(T_{1}\right) h_{1}\left(v_{t}, t, T_{1}\right) d T_{1}\right. \\
& +\sum_{v=2}^{\infty} 2^{v} \int_{T_{p}-0}^{t} \varphi\left(t-T_{v}\right) \int_{\left.T_{z-1}-1\right)}^{T_{\nu}} f\left(T_{v}-T_{2-1}\right) \int_{T_{v-2-1}}^{T_{v-3}} f\left(T_{2} 1-T_{z-2}\right) \\
& \cdots \int_{T_{3}=0}^{T_{3}} f\left(T_{4}-T_{3}\right) \int_{T_{2}-1}^{T_{3}} f\left(T_{3}-T_{2}\right) \int_{T_{1}=0}^{T_{2}} f\left(T_{2}-T_{1}\right) f\left(T_{1}\right) h_{y}\left(k_{10}, t ; T_{1}, T_{2}, \cdots T_{y}\right) \\
& \left.d T_{1} d T_{2} \cdots d T_{2}\right\},
\end{aligned}
$$


B. which $h_{y}$ is the same an $\eta_{v}$ with $t-T_{v}$ substituted for $\mu$.

To obtain the functions $h_{r}$, define the quantities i) recursively by the equation-

$$
\begin{aligned}
& r_{1}=1_{2} \psi\left(\tau_{1}, v_{10}\right), \\
& r_{j}=1_{2} \psi\left(\tau_{1}, v_{3}\right) \text { for } j \geq 2 .
\end{aligned}
$$

so that $" s$ is the cellular volume immediatels after the jth division. For a $p$ th generation exll present in the population at time $t=a+\sum_{\lambda=1}^{b} \tau_{\lambda}$, the volume will be $\psi\left(a, r_{v}\right)$. In this expresion replace each $\tau_{j}$ by $T_{3}-T_{3-1}$ (with $T_{11}=0$ ) and a by $t-T_{y}$; this gives $h_{t}\left(v_{v}, t ; T_{1}, T_{2}, \cdots T_{v}\right)$. In partieular, for $p=0,1$, and 2:

$$
h_{0}=\psi\left(a, i_{11}\right)=\psi\left(t, r_{u}\right)
$$

(time and age being the same for erells of the zeroth generation ),

$$
\begin{gathered}
h_{1}=\psi\left(a_{1}{ }_{2} \psi\left(\tau_{1}, l_{1}\right)\right)=\psi\left(t-T_{1}, 1_{2} \psi\left(T_{1}, r_{1}\right),\right. \\
0<T_{1}<t, \\
h_{2}=\psi\left(t-T_{2},{ }_{2} \psi\left(T_{0}-T_{1},{ }_{2} \psi\left(T_{1}, t_{1}\right)\right),\right. \\
0<T_{2}-t, 0<T_{1}<T_{2} .
\end{gathered}
$$

For example, in the ease of linestr volume increase with age [Equation 114$)]$ one finds

$$
\begin{aligned}
v_{y}=\frac{v_{0}}{2 v}+\frac{r}{2 y} \sum_{\lambda-1}^{p} 2^{\lambda}{ }^{3} \tau_{\lambda} & \\
& (\nu=1,2,3, \cdots)
\end{aligned}
$$

and, heneer.

$$
\begin{aligned}
& h_{0}=l_{0}+r t, \\
& h_{v}=\sum_{2}^{n}+i t-i \sum_{2}^{n} \sum_{\lambda-1}^{k} 2^{\lambda}{ }^{1} T_{\lambda} \\
& (y=1,2,3, \cdots) \text {. }
\end{aligned}
$$

PRorikLin' RHPORT

Fiquation (1) cam be written in a more compact form if the lunction $\psi\left(a, r_{b}\right)$ is of the "dieperionless" type, an defined by Anderom et al. "Reference? page 261). This means that

$$
\psi\left(a, v_{n}\right)=r_{b} \cdot g(a)
$$

$g$ being a function of age onla, with $g(0)=1$.

In that care, $h_{0}=l_{0} g(t), h_{1}=\left(r_{0} 2\right) g\left(T_{1}\right) g\left(t-T_{1}\right)$, and

$$
\begin{array}{r}
h_{v}=\frac{l_{0}^{\prime}}{2} g\left(t-T_{v}\right) g\left(T_{1}\right) g\left(T_{2}-T_{1}\right) \\
\cdots g\left(T_{v^{\prime}}-T_{v-1}^{\prime}\right) \text { for } \nu \geq 2
\end{array}
$$

Thus Equation a 18 i beeomes

$$
\langle n(t)\rangle=\frac{n_{0}}{\lambda l(t)}\left[\rho(t)+\sum_{v-1}^{\infty}\left\{\rho * m_{v}\right\}(t)\right] .
$$

where

$$
\begin{aligned}
& \rho(t)=y(t)(t), \\
& m t)=y(t) f(t) .
\end{aligned}
$$

and $m_{2}$ in the $y$-fold convolution of the function $m$.

The eare of exponential volume increase with age [Etutation (15)] is obtained by taking $g(a)=e^{k a}$ in Equation (2.5). Thi. give

$$
h_{p}={ }_{2 n}^{i_{n}} e^{k \ell}
$$

w) that the volume of at $y^{\text {th }}$ generation reell is come pletely independent of its life history. From Equation (1) or $(26)$ ane then find

$$
\left.\|(t)\rangle=\frac{i^{h t}}{\|(t)}\left[4(t)+\sum_{i-1}^{\infty} \mid \omega f_{i}\right\}(t)\right] .
$$

I ing layution 17 ), howerer, it is seen that the square bracket in this expression has the value 1 , and therefore

$$
s u(t)=\frac{r_{0}^{h t}}{\pi(t)},
$$

if $\psi\left(a, u_{1}\right)$ in given by Equation (1.)).

Now it is know that for large values of the funce tion $h(t)$ becomen approximately equal to $h_{\text {of }}$ ". where the nperifie growth rate. o, is unicuely determined b! the relation

$$
2 \int_{x \rightarrow 0}^{\infty}(" f(x) d x=1
$$

ind

$$
u_{n}=\frac{1}{2 a y}
$$

with

$$
y=2 \int_{x-0}^{\infty} x t{ }^{x} f(x) d x
$$

[Wigutions (5) and (6) of Reference 2$]$. These results follow from Fellers theorems on the renewal expution." Therefore, if $t \rightarrow \infty$, the right hand side of Equation (30) tomble to a tinite limit, ex $x$ ) $\%$ only if

$$
c=l_{i}
$$

In fard. Bell and Anderon have shown ${ }^{\text {s }}$ that $o$ must be equal to $k$ i $\alpha=f_{1}$ in their notations if there is no) cell death and if the rate of cellular volume increase with age is proportional to volume itself. 
However, even with $c=k$ there probably is instability, and one would expeet that no steady state of balanced exponential growth will be achieved, as was pointed out by Bell. ${ }^{(6)}$ Therefore, if Equation (1.5) holds, it is anrealistic to postulate that cell division depends only on eellular age and not on the volume attained by the cell this, too, is discussed by Bell ${ }^{\text {nis }}$. More generally, for "di-persionless" volume increase with age [Lquation (25)]. and still assuming that the occurrence of mitosis is not influenced by cellular volume, it is likely that a steaty state of balanced exponential growth will be reached, if at all, only for very special choices of the function $g(a)$.

Consider now the ease of linear rolume increase [Equation (14)]. From lifuation (15) one can obtain a simple expression for the liniting value of $\langle e(t)\rangle$ as $t \rightarrow \infty$. It will be assumed that the function $f(t)$ is sufficiently well behaved, so that Feller's theorems are applicable, which is a very mild restriction. In particular, $f(\tau)$ must be regular at the origin $\left[F_{1}(0)=\right.$ (0). [Actually, no cells divide at age zoro, and so $f(0)=0.1$

It an maly be shown that

$$
\begin{gathered}
\left.\sum_{\lambda=1}^{p} 2^{\lambda-1} T_{\lambda}=12^{p}-1\right) T_{1} \\
+\sum_{\lambda=2}^{p}\left(2^{p}-2^{\lambda-1}\right)\left(T_{\lambda}-T_{\lambda}\right)(3 ;, 3) \\
(\nu=2,3,4, \cdots) .
\end{gathered}
$$

Inserting the expresion given by Equation (21) for $h_{v}$ into Fquation (18) and using liquation (35.), one find $\hookrightarrow$, sinces

$$
\begin{aligned}
& \sum_{\lambda=1}^{z}\left(2^{y}-2^{\lambda}{ }^{1}\right)=1+(\nu-1) 2^{y}, \\
& \langle v(t)\rangle=\frac{1}{u(t)}\left\{v_{0}\left[\varphi(t)+\sum_{v=1}^{\infty}\left\{\omega * f_{p}\right\}(t)\right]\right. \\
& +\operatorname{sth}(t)-r(0 * t)(t) \\
& \left.-r \sum_{p=2}^{\infty}\left[\left(1+(\nu-1) 2^{p}\right)\left\{0 * f_{v} * q\right\}(t)\right]\right\}:
\end{aligned}
$$

here the function $q(t)$ is defined by

$$
q(t)=t \cdot f(t)
$$

With the leelp of Eyuations (6), (7), and (A) this beromes

$$
\begin{aligned}
& \langle v(t)\rangle=\frac{1}{M(t)}\left[u_{0}+r t h(t)\right. \\
& \left.-r \sum_{v=1}^{\infty} v 2^{p-1}\left[F_{v-1} * \alpha\right\}(t)\right] \\
& =\frac{1}{u(t)}\left[r_{1}+n+m(t)\right]
\end{aligned}
$$

where

$$
\left.S^{\prime}(t)=\sum_{\nu=1}^{\infty} 2^{*}\left[t F_{\nu}(t)-\nu_{i}^{\prime} F_{y-1} * \eta\right\}(t)\right]
$$

and

$$
F_{0}(t)=1 \text {. }
$$

Now. putting

$$
t F_{p}(t)=\gamma_{v}(t) .
$$

one has the simple identity

$$
\begin{aligned}
& \int_{u \rightarrow n}^{t} f(u)(t-u) F_{p}(t-u) d u \\
& =t \int_{u-1)}^{t} f(u) F_{v}(t-u) d u \\
& \quad-\int_{u=0}^{t} u f(u) F_{\nu}(t-u) d u
\end{aligned}
$$

or

$$
\left\{f * \gamma_{p}\right\}(t)=t F_{y+1}^{\prime}(t)-\left\{q * F_{y}\right\}(t)
$$

Therefore, eonvoluting both sides of Equation (38) with $2 f(t)$ :

$$
\begin{aligned}
& \left.\{2 f * S\}=\sum_{\nu=1}^{\infty} 2^{r}\left[1 f^{\prime} * \gamma_{\nu}\right\}-\nu_{i}\left\{F_{\nu} * q\right\}\right] \\
& =\sum_{\nu=1}^{\infty} 2^{v}\left[t F_{v+1}-(\nu+1) ! F_{v}^{*} * q^{\prime}\right] \\
& =N-\left[t F_{1}-\{1 * t /\}\right] .
\end{aligned}
$$

This shows that the function $S(t)$ satisfies the renewal equation

$$
S(t)=B(t)+21 ; * S(t)
$$

with

$$
B(t)=t F_{1}(t)-\int_{x=0}^{t} x f(x) d x=\int_{x-10}^{t} F_{1}(x) d x .
$$

It follows then from fieller's theorem that for large values of $t$

$$
S(t)=S_{B} e^{\prime c t} .
$$

Heres is again determined by Equation (331) and

$$
s_{0}=\frac{\int_{t-11}^{\infty} t^{-c t} B(t) d t}{\vartheta}=\frac{1}{2 c^{2} \vartheta} .
$$

Notice that for large values of $t, F_{1}(t) \geq 1, B(t)=t$, and the integral in lequation $(4.5)$ converges.l conserpuently,

$$
\lim _{t \rightarrow \infty}\left[\frac{N(t)}{M(t)}\right]=\frac{1}{c^{\prime}}
$$

and so 


$$
\lim _{t \rightarrow \infty}\langle u(t)\rangle \equiv\langle e(\infty)\rangle=\frac{r}{r} .
$$

This result is not unespeeteol because it can be shown ${ }^{(5,7)}$ that for a population in steady states of exponential growth the mean cellular volume is indeed equal to $r, c$ if Equation (1t) hold and if cell death is negligiblo.

The mean exllular volume at birth, $\left\langle l_{s}(t)\right.$, ean be calculated in much the same way as $x(t)\rangle$. The total number of newborn cell (colls with age between 0 and $d t$ present in the population at time $t$ is $\alpha(t) d t$, and the expected number of such colls belonging to the th generation is obtained from lisuation (16) by soxtting $a=0, \varphi(0)=1$. ("alls of the zeroth generation have age $>0$ if $t>0$, and the function $\alpha(t)$ is given by Equation (10). Procesding an in the derivation of Fquation (18) one lind, for $t>0$ :
Onece again, Equation 1.50$)$ can be obtained directly from Bell's theory for a cellular population in steady -tate of exponential growth." In the following, the notation of Reference 7 will be used, except that the quantity $\psi(v)$ of Ieoferences 7 is denoted herr by $\psi_{1}(r)$ to atvid confusion with the function $\psi$ of liduation $1 \mathrm{lib}$. Isume that there is no cell death and that cell volume increane linearly with age. Thus: $D(\alpha, v)=0$. $F(a, l)=r=$ comstant. $h(a, l)=l^{\prime}-r, H(a, l)=0$. A-mume further that the function $P(a, r)$ of lieforence 7 depends only on $a$ but not on $r^{\prime}: P(a, r)=P(a)$ (with $\left.\int_{x}^{x}{ }_{0} P_{1} a\right) d x \rightarrow \infty$ for $a \rightarrow \infty$ I. Then

$$
f(a)=P(a)(x)\left[-\int_{x-a}^{a} P(x) d x\right] \text {, }
$$

and liquation 1399$)$ of lioferenoe 7 becomes

$$
\beta(a, l)=L \psi_{1}(l-a) c^{a-a} f(a) l^{\prime}(a) .
$$

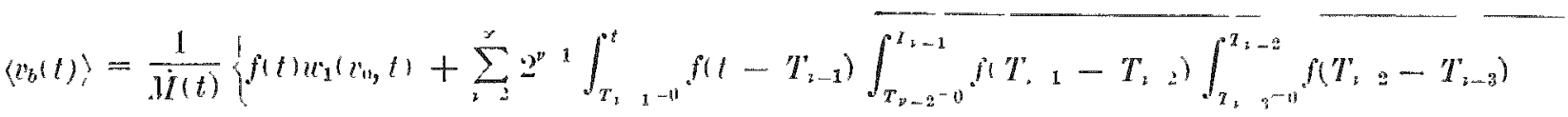

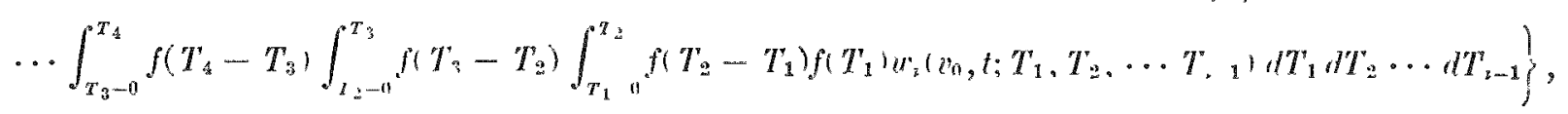

whore $u_{v} l=v_{z}$ ) in equal to $h_{1}$ with $T_{z}$ replaced by $t$.

for the exponential care [Fquation (1.5)] thin gives

$$
\left\langle u_{b}(t)\right\rangle=\frac{l^{\prime} e^{\prime} t}{2 \cdot \dot{H}(t)}(t)
$$

with

$$
f(t)=\sum_{i=1}^{\infty} f_{2}(t)
$$

The funetion $6(1)$ is a solution of the renewal rogution

$$
f(t)=f(t)+\{f * t\}(t)
$$

and theretore tends to the finite limit 1 for $l \rightarrow x$. Differentiating both siden of Equation (1) it is found that

$$
\dot{M}(t)=\dot{f}(t)+2 ! f * \dot{M}\} t
$$

and thus, for liarge $t, i h(t)=t^{\circ t}(2 v)=c M_{0 e^{2 t}}$.

In the linear cave (Equation 11 , one has

$$
\begin{aligned}
& u_{1}=\frac{v_{0}}{2}+\frac{r}{2} t, \\
& u_{\nu}=\frac{v_{1}}{2}+\frac{r l}{2}-\frac{r}{2} \sum_{\lambda=1}^{p=1} 2^{1}{ }_{v}, \quad \text { for } \nu=2,: i, 4, \cdots,
\end{aligned}
$$

and it is easy to see that $\left\langle b_{b}(t)\right\rangle$ tond to a finite value. $\left(b_{b}(s)\right\rangle_{1} a s t \rightarrow \infty$. The calculations are very nimilar to those used in deriving layation (46); the renult is

$$
\left\langle b_{b}(x)\right\rangle=2 \gamma \int_{x-0}^{\infty} d t t^{n} f(x) d x=m .
$$

Inserting this axpremion into Equation (44) of Reforence 7 given

$$
\left.\psi_{1}(v)=4 \int_{a-11}^{2 a t r} \psi_{1}(2)-r a\right) t^{\prime \prime c} f(a) d a
$$

Mult iplying both siden of this equation with $r$, integrat ing ofer $v$, from $v=0$ to $v=x$, and interchanging the corler of the two integrateons, one finds

$$
\begin{aligned}
& \left\langle u_{n}(\infty)\right\rangle=\int_{v-0}^{\infty} v \psi_{1}(v) d v
\end{aligned}
$$

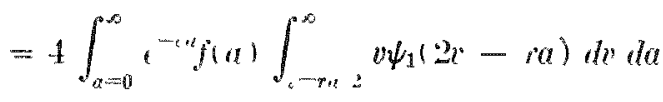

$$
\begin{aligned}
& =\int_{a-0}^{\infty} \sigma^{-1} f(a) \int_{u-1}^{\infty}(u+i a) \psi_{1}(u) d u d u \\
& =\frac{1}{2}\left\langle v_{b}(\alpha)+\frac{r \theta}{2}\right.
\end{aligned}
$$

or $\left\{r_{n}(<)=r \%\right.$.

Ilere the redetions $\int_{z \rightarrow+\infty}^{\infty}$ "fialda $=1_{2}$ and $\int_{i-n}^{\infty} \psi_{1}(u) d u=1$ hatre beenued.

The cuantity $y$ is the first moment of the "currier dencity" $20 " f(\tau)$. It can be shown that, in steady -tate of exponential growth without coll death, $\vartheta$ is the arerage age at which the cells divide. Also, $\theta$ is -lightly maller than the doubling time, $T$. of the population $[T=(1 \mathrm{c}) \mathrm{ln} 2]$. $T$ it-elf is smaller than the 
average generation time, $\tau$. Thun: $y<T<\tau$ (lieference 8 , page -1691."

Equation (.00) says that, as $t \rightarrow x$, the mean rolume. at hirth becomes equal to the volume increment during the time interval $y$, a result which is intuitively very plausible. Notice that acourding to byuation (14) the average eedl volume of the zeroth generation will be increased by approximately $r \vec{\tau}$, which could be much more or much less than $v^{\prime}$ (of courses in real populations there maty not be any cells with extremely large or extremely small volumes, but this is irrelevant for at discussion of the mathematical mordel). Subsedutently", however, the mean volumes, $\left\langle(v i)\right.$ and $\left\langle e_{b}(t)\right\}$, will spradually reach their asymptotir values. Hequations (46) and $(.50)$ show that these limiting values do not depend on $r_{\mathrm{it}}{ }^{\circ}$

The ansumption that all the cells in the population hatve age zero initially is fulfilled with good approximation if the ceells are synehronized by sedecting those in mitoris. On the other hand, it will certainly not be true that every cell has the same initial volume, $c^{\circ}$. If $\epsilon\left(l_{10}\right) d v_{0}$ is the fraction of cells with initial volumes

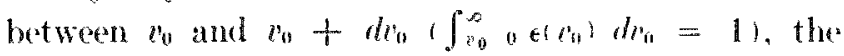
act ual mean cellular volume will bes

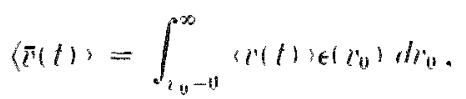

where $\langle(1)\rangle$, which depends on $t^{\prime}$, is given by Equat-

\footnotetext{
*In lieferenese sthe probability density of interdivision times is denoted by $\delta$ and the "earrier density" by f. Also, the fuantities $T$ and $D$ of lieferences sorrespond, respectivels, fo $\theta$ and $\vec{\tau}$.

f It would appear from sinclair and lioss Eulation 5 that the chose $r=l_{0} / \bar{r}$. In that ease, of courses, the right band sides of Finutions $(16)$ and $\{50\}$ wonld be proportional to $r$ :

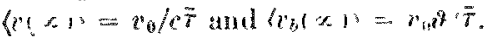

tion (18). For "dispersionlens" growth. Hoquation (20i)

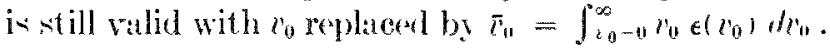

CONCLESTS)

The result a derived here sem to differ from those of Sinchir and lioss, eren though the bavic asimptions are the same in both theories. It might be of interest to repeat Sinclair and Ross' calculations using Equation (15), with either (14) or (15), and see which of the two alternatives gives a clomer fit to their excollent experimental curves. Perhaps an even better method would be to simulate the life histories of individual cells cincluding volume changes) with a Monte ('arlo program and extimate the mean collular rolune by taking arerages over sufficiently large numbers of eells.

\section{REF WRENCES}

1. Ninelair, W. K. and I). W. Rass. Modes of grow th in mannmalian cells. Biophys. d. 9, $10561070(1969)$.

2. Harris, T. E. I mathemation moles for multiplieation by binary tission. The Kint ir of r llular Proliferation. Fid. F. Stohlman, Jr. (Grune and Stratton, New York, 1954, pp. ins 3\$.

:3. Anderson, F. ('., C. I. Bell, I). F. Petersen, and R. A. Tohey. Cell growth and division. IV. I) termination of volume grow th rate and division probability. Biophlys. J. 9, 24ti$26: 3(1969)$.

1. Faller, W. On the integral pquation of renewal thenery. Ann. Hath, Sit. 12, 213 267 , 19111 .

5. Bell, C. I. and E. ('. Anderson. Cell growth and division. I. A mathematioal model with applications to cell volume

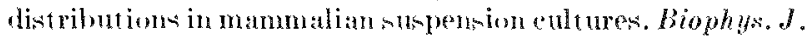

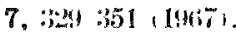

i. Bell, (i. I. Cell grow th and division. III. Conditions for balaneed exponential growth in a mathematisal model. Biophys. J. 8, 181-111, 1!36s.

7. Trueser, E. The distrihution of rellular volumes in es. ponentially growing populations. Thio report.

$\therefore$ Trupon, E. Mathematical models for cellular ststems; the Von Foerster equation, Part II. Bull. Math. Biophyse. 27, H.) $171+1965 \%$.

\title{
THE DISTRIBUTION OF CELLULAR VOLUMES IN EXPONENTIALLY GROWING POPULATIONS
}

\author{
Ermesto Trureo
}

\section{DURPOSE IND METHODS}

Iuch work has ben done at this laboratery on the volume speetrum of growing eell propulations. One ruestion of interest in these investigations wits whether the volume increase of individual cells with age conforms more closely to the exponential or to the linear mode. (1) Recently, Kubitiched, who favors the latter view, has derived aguations for the probability dencity of rolume distribution, $\lambda\left(r^{\prime}\right)$, in the can of linear and of exponential single cell gronth law (appendix of Reforence 2). Sinclair and lioss state that the were un"able to distinguish clearly between the two altematives. On the of her hand, Painter and Marr believe that "Most of the microse(o) ic measurements of the growth of bacteria are consistent with the hypothenis of an exponential increase in volume with age." (Reference 4. page $5.3 \% .3$

Eatrier atudies along the simes lines include the re- 
arhable papex by scherbaum and liasch, but it wats only the subseruent improvement in coulter counter techniques that made it possible to obtain acourate volume spect ra.'

For a cell population in steady state of exponential growth, the quantity $\lambda\left(t^{\prime}\right)$ can be calculated from the fulution of Collins and Richmond," lo" provided that the volume distributions of newborn cells and of dividing colls are hnown. Collins and lichmond's result, in turn, may be obtained from the formaliom developed by Bell ${ }^{42,}$ or from similar equations. ${ }^{23 *}$ For simplicity, the theory of Bell and Anderson will be used.

In Bell's tratement the state of a single cell is determined by two parameters, it age, a, and its volume. $r$. "The densily function for cells of age $a$ and volume $r$ is denoted by $n(t, a, b)$, meaning that $n\left(t, a, v^{\prime}\right)$ da de repressents the expected number of cells prexent at time, $t$, with ages in the range $(a, a+d a)$ and volumes in $(v$, $v+d v)$. The notation used here differs from that of

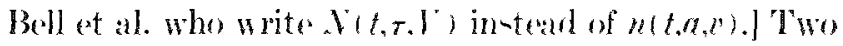
further funetions characterizing the cell population are

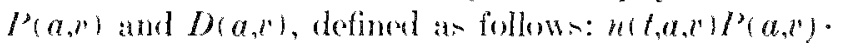

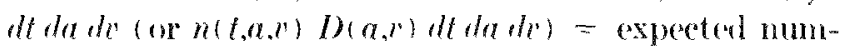
ber of cells dividing or dringe durine the times interval It with ages in $(a, a+d a)$ and volumes in $(b, t+d v)$.

It is also assumed that a dividing cell gives two daughterm of exactly equal , iat', and that the volume of each rell, $c$, is a well defined function of its age. a, and of its volume at birth, $r_{0}$. Thus, $r=b\left(a, r_{1}\right)$. "Th" rate of in

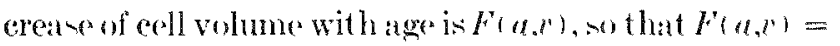
$\partial h\left(a, m_{n}\right)$ ga, where, after differentiation, ro on the right side must be expressed in terme of a and $r$. "Ihe function $b\left(a, r_{0}\right)$ is taken to be strictly increasing with its two arguments, $a$ and on. This amomption is probably too restrictive in mome cases for cell volume nay well res main stationary of eren hrink over certain age ranges), but mathematically it is eomenient becane it makes the transformations of variables introduced below unambiguous. For the simple casom of linear and exponen. tial volume increace with age, $b\left(a, b_{0}\right)$ is indeal a momotonic function of a aml of $x^{\circ}$.

More generally, one maty think of the thres variables a. $r$. and $c_{0}$, as being related by an equation of the form

$$
\text { fir } \left.a, r_{0}\right)=0 \text {. }
$$

where the function, $t$, must be such that

$$
(x, 0, u, u)=0
$$

Finder the andal mild rentrictions made in deriving theorem on implicit functions, each of the quantities , e, and en can then be written in terms of thes other wo:

$$
r=b\left(a, r_{n}\right)
$$

$$
\begin{aligned}
& r_{n}=h(a, n) . \\
& a=\mu\left(u^{\prime}, u_{1}\right) .
\end{aligned}
$$

Clearly, it mu-t be trute that

$$
b(0, u)=n \text {, }
$$

i.t.., cellular rohme at age zero acquah the initial volume. Alio

$$
h(1) . y)=y
$$

and

$$
\mu(y, y)=0
$$

(a cell whose volume is the ame as the initial rolume" hat age zerou. Furthermors,

$$
h(x \cdot b(x, u))=u \text {, }
$$

that i- to saty, the initial volume of a eell that has age $x$ and volume $h(x, u)$ is $u$. Similarly, $h(\mu(y, u), y)-u$ and $\left.b a_{a}, h(x, y)\right)=b(\mu(y, \|), u)=y$.

The expution for the special care of linear volume incrates with age ars

$$
\begin{aligned}
& u=h\left(a, r_{0}\right)=v_{u}+r a \\
& r_{0}=h(a, r)=r-r a \\
& a=\mu\left(r_{1}, r_{0}\right)=\left(n-v_{0}\right) r,
\end{aligned}
$$

Where $r$ is a poniture constant, and for exponential vol-

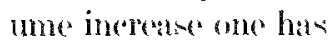

$$
\begin{aligned}
& r=b\left(a_{v}{ }_{n}\right)=r_{n} c^{l t}, \\
& r_{b}=h(a, r)=u^{-\lambda_{n} x} \text {. } \\
& a=\mu\left(r_{n, 1}\right)=(\mathbb{l} l i) \ln \left(r r_{11}\right) \text {. }
\end{aligned}
$$

le being another positive ronstant.

Boll's equation for the age density, ntt,a,v), is as follow:

$$
\begin{aligned}
& \frac{\partial n\left(t, a, v^{\prime}\right)}{\partial t}+\frac{\partial n\left(t, a, r^{\prime}\right)}{\partial a}+\frac{\partial}{\partial v^{3}}[F(a, n) n(t, a, n)] \\
& =-\| P\left(a, r^{\prime}+\|\right)\left(a, y^{n} \mid u\left(t, a, r^{\prime}\right)\right. \text {. }
\end{aligned}
$$

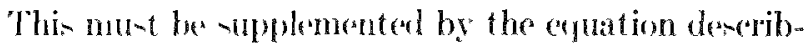
ing how cells of age zero are adeled to the population throlugh cell divi-ion, namely

$$
n(t, 0, n)=4 \int_{a, a}^{x} P(a, 2, n) n(t, a, 2 n) d u .
$$

It has been it-enmed up to this point that all ceels with given a and ohange therir volume at the same rate, $I^{*}(a, r)$. Letually, the quantity $F(a, n)$ must be understood as the nean rate of volume increase for such colls. In fitet. Fredrichion of al. ${ }^{.14}$ have shown that atthough the true rate of change may vary from cell 
to cell, it is only the average rate that appears in the final equations. A similar remark was made by Harvey et al. (Reference 7 , page 616 ) after their derivation of the Collins-Richnond erquation.

PROGRESS REPOR'P

Some useful relations between the various derivatives of the functions $h, h$, and $\mu$ can be obtained from liquation (1). According to well-known rules of the calculus

$$
\frac{\partial b\left(a, r_{1}\right)}{\partial a} \equiv b_{1}\left(a, r_{11}\right)=-\frac{G_{a}}{G_{v}^{b}},
$$

where the subscrint $a$ and $l$ denote differentiation of $b$ with respect to $a$ or $e$, and the right hand side of licquation (1S) must be written an a function of $a$ and $2_{0}$. In the same way,

$$
\begin{aligned}
& \frac{\partial b\left(a, p_{10}\right)}{\partial v_{0}} \equiv b_{2}\left(a, y_{11}\right)=-\frac{c_{v_{0}}}{c_{i_{v}}^{\prime}}, \\
& \frac{\partial h(a, b)}{\partial a} \equiv h_{1}(a, z)=-\frac{G_{a}}{G_{q_{0}}}, \\
& \frac{\partial h\left(a, v^{\prime \prime}\right)}{\partial v} \equiv h_{2}\left(a, v^{\prime}\right)=-\frac{G_{0}}{g_{z_{0}}}, \\
& \frac{\partial \mu\left(v, r_{0}\right)}{\partial v} \equiv \mu_{1}\left(v, r_{v}\right)=-\frac{G_{v}}{G_{a}^{r}}, \\
& \frac{\partial \mu\left(v_{2}, v_{0}\right)}{\partial v_{0}}=\mu_{2}\left(v_{2}, v_{0}\right)=-\frac{G_{v_{0}}}{G_{a}} .
\end{aligned}
$$

Becaune

$$
F(a, v)=b_{1}\left(a, h\left(a, l^{\prime}\right)\right),
$$

it follows from lquations (15), (20), (21), and (22) that

$$
F^{\prime}\left(a, v^{\prime}\right) h_{2}\left(a, v^{2}\right)+h_{1}\left(a, v^{\prime}\right)=0
$$

and

$$
F\left(\mu\left(c^{\prime}, v_{0}\right), v\right) \cdot \mu_{1}\left(v_{,}, v_{0}\right)=1 .
$$

Similarly,

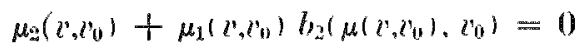

and

$$
b_{2}\left(a, h\left(a, l^{\prime}\right)\right) \cdot h_{\mathrm{a}}\left(a, l^{\prime}\right)=1 .
$$

It is convenient to define

$$
H\left(a, v^{\prime}\right)=\frac{\partial H^{\prime}\left(a, v^{\prime}\right)}{\partial v} .
$$

Putting

$$
b_{12}\left(a, r_{10}\right)=\frac{\partial^{2} b\left(a, r_{0}\right)}{\partial a \partial v_{0}}=\frac{\partial b_{1}\left(a, v_{0}\right)}{\partial v_{0}}=\frac{\partial b_{2}\left(a, r_{0}\right)}{\partial a},
$$

and uning Lquation (2S) this becomes
$H\left(a, v^{\prime}\right)=b_{12}\left(a, h\left(a, v^{\prime}\right)\right) \cdot h_{2}(a, v)=\frac{b_{12}(a, h(a, v))}{b_{2}(a, h(a, v))}$.

Comsider now the quantity $\int_{x-0}^{s} H(x, b(x, u)) d x$, where $s$ and $u$ are independent of $x$. From Equation (31) one has

$$
\begin{aligned}
& \int_{x \rightarrow u}^{s} U(x, b(x, u)) d x \\
& =\int_{x \rightarrow n}^{s} \frac{b_{12}(x, u)}{b_{2}(x, u)} d x=\ln b_{2}(s, u)-\ln b_{2}(0, u) .
\end{aligned}
$$

1 little reflection show shat $b_{2}(0, u)=1$ ( since $r=v^{\prime} 0$ for $a=0)$, and thus

$$
\int_{2}, H\left(x+b u, u, d x=b_{2}(s, u) .\right.
$$

This result, which is the same as Fafuation (14) of Reference 12, will be ured below.

Returning now to Equation (16), it can be written as follows:

$$
\begin{aligned}
& \frac{\partial n\left(t, a, p^{2}\right)}{\partial t}+\frac{\partial n\left(t, a, r^{\prime \prime}\right)}{\partial a} \\
& +F\left(a, v^{2}\right) \frac{\partial n\left(t, u, v^{\prime}\right)}{\partial v^{\prime}}=-Z\left(a, v^{*}\right) n\left(t, a, v^{\prime}\right),
\end{aligned}
$$

with

$$
Z\left(a, z^{2}\right)=P\left(a, v^{\prime}\right)+\nu\left(a, p^{\prime}\right)+H\left(a, v^{2}\right) .
$$

For a cell population in steady state of exponential growth $n\left(t, a, t^{\prime}\right)$ will be of the form

$$
n\left(l, a, n^{\prime}\right)=e^{e t} \beta\left(a, n^{\prime}\right),
$$

where $c$ (a positive comstant) is the specific growth rate. From Equation (3:3) one find for $\beta(\alpha, v)$

$$
\begin{aligned}
c \beta(a, v)+ & \frac{\partial \beta(a, y)}{\partial a} \\
& +l(a, v) \frac{\partial \beta\left(a, v^{\prime}\right)}{\partial v^{\prime}}=-Z(a, v) \beta(a, v) .
\end{aligned}
$$

This equation an be solved by introducing two new independent variables, $\eta(=a)$ and $\xi\left(=v_{0}=h(a, r)\right)$ instead of $a$ and $v$. Let $\eta=a$ and $\xi=h\left(a, v^{\circ}\right)$, of which the inverse equations are $a=\eta, r=b(\eta, \zeta)$. Also put $\beta\left(a, v^{\prime}\right)=\beta\left(\eta, b\left(\eta, \zeta^{\circ}\right) ! \equiv \gamma\left(\eta, \zeta^{\circ}\right)\right.$, and similarly $Z\left(a, v^{\prime}\right)=$ $Z(\eta, b(\eta, \xi)) \equiv Y(\eta, \xi)$. Since

$$
\begin{gathered}
\frac{\partial \beta\left(a, v^{\prime}\right)}{\partial a}=\frac{\partial \gamma\left(\eta, \zeta^{\circ}\right)}{\partial \eta}+\frac{\partial \gamma\left(\eta, \zeta^{\circ}\right)}{\partial \zeta} \cdot h_{1}(\eta, b(\eta, \zeta)), \\
F^{\prime}\left(a, l^{\prime}\right) \frac{\partial \beta\left(a, v^{\prime}\right)}{\partial v}=\frac{\partial \gamma(\eta, \zeta)}{\partial \zeta} h_{2}(\eta, b(\eta, \zeta)) \cdot F(\eta, b(\eta, \zeta)),
\end{gathered}
$$

one obtains from (:66), asing Equation (2.5):

$$
\left(\gamma(\eta, \zeta)+\frac{\partial \gamma(\eta, \zeta)}{\partial \eta}+Y(\eta, \zeta) \cdot \gamma(\eta, \zeta)=0,\right.
$$


which gives

$$
\gamma(\eta, \xi)=f(\xi) \psi^{n} \exp \left[-\int_{x-0}^{\eta} Y(x, \xi) d x\right]
$$

or

$$
\begin{aligned}
& \beta\left(a, x^{\prime}\right)=K \psi(h(a, m)) e^{-m} \\
& \cdot \exp \left[-\int_{x \rightarrow 0}^{a} Z\left(x, b\left(x, h\left(a, v^{\prime}\right)\right) d x\right],\right.
\end{aligned}
$$

where $K$ is a positive constant and $f(\xi) \equiv k \psi(\xi)$ is, so far, an arbitrary function of $\zeta$. Inowever, putting $a=$ 0 in Equations (3.5) and (39) it can be sexen that

$$
m(t, 0, v)=e^{e t} \cdot K \psi(v),
$$

and therefore $\psi(n)$ must charapterize the dist ribut ion of birth volumes in the cell population. Hence, it is natural to chooses $\psi(v)$ in such a way that

$$
\int_{\left(n^{2}\right.} \psi\left(x^{\prime}\right) d v^{\prime}=1
$$

The constant, $K$, is then determined from the recuirement that the integral of $\beta\left(\alpha, v^{\prime}\right)$, Foyuation (39), over all ages and all volumes must give the initial number of cells in the population. $\nu_{0}$ :

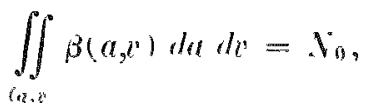

and thus

$$
\iint_{(a, v i)} n(t, a, n) d a d n=N_{n r^{\prime}} \text {. }
$$

Combining Equations (17), (39), and (40) it is seen that

$$
\psi\left(v^{\prime}\right)=\frac{4}{K} \int_{(a)} P(a, 2, n) \beta\left(a, 2 n^{\prime}\right) d a .
$$

The probability density for the volume distribution of dividing rells, $s(v)$, is related of $\psi\left(l^{\prime}\right)$ br the equation

$$
\varphi(v)=\frac{1}{2} \psi\left(\frac{v}{2}\right)
$$

Henee, it follows from ( 14 ) that

$$
\varphi(v)=\frac{2}{\bar{K}} \int_{(a)} P\left(a, r^{\prime}\right) \beta\left(a, p^{n}\right) d a,
$$

which is intuitively obvious cexept for the faetor of normalization, $2, K$ ) from the meaning of $P$ and $p$.

The expression for $\beta\left(a, v^{\prime}\right)$ derived in Equation (39) is valid only if $a$ and $"$ are such that the function $(a, v)$ remains $\geqslant 0$ (or perhitps $\geqslant \epsilon$, atsiming that cells Cannot have an initial volume smaller than $t)$. ()therwise $\beta(a, b)$ must be set aqual to zero. For example. in the case of linear volume increane [Fquations (10)-
(12) there can be no cell with a given volume, $v$, and age larger than $r$, $r$.

The probability density for the stationary distribution of cellular volumes, i.e., $\lambda\left(w^{\prime}\right)$, can now be found by integrating $\left(1 N_{0}\right) \beta\left(a, x^{\prime}\right)$ orer all ages (the factor 1 . To being introduced to normalize $\lambda(v)$ ). Thus,

$$
\begin{aligned}
& \lambda(v)=2 m \int_{(a)} e^{-c u} \psi\left(h\left(a, v^{j}\right)\right)
\end{aligned}
$$

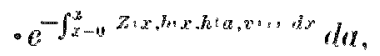

where $m$ is a constant equal to $K_{,}\left(2 N_{0}\right)$. If $u=h(a, v)$ is introduced as a new variable of integration (with constant $(x)$ instead of $a$, kquation (47) beromess

$\lambda(v)=-2 m \int_{u-1}^{v} e^{-c a t r, u} \psi(u) B(u, u) \mu_{2}(u, u) d u . \quad(4 s)$

Here, $B(u, n)$ is given by the equation

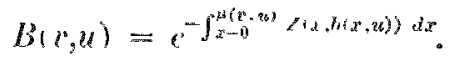

linitlly, putting

$$
\begin{aligned}
S(r), u)=(\mathrm{x} p) & {\left[-\int_{x=0}^{\mu(u, u)}[P(x, b(x, u))\right.} \\
& +D(x, b(x, u)], d x] .
\end{aligned}
$$

one hats, with the help of Equations (27), (:82), (344), $(40)$, and $(.50)$

$$
\begin{aligned}
& -B(u, u) \mu_{2}(u, u) \\
& \quad=-S(u \mid u) \frac{\mu_{2}(l, u)}{b_{2}(\mu(u, u), u)}=S(v \mid u) \mu_{1}(v, u) .
\end{aligned}
$$

Therefore,

$$
\lambda(u)=2 m \int_{u=0}^{c} e^{-c \mu(u, w} \psi(u) S(u \mid u) \mu_{1}(u, u) d u .
$$

Fidently, $S(r \mid u)$ is the probability that a cell with volume $u$ at birth will grow to reach volume $"$ without dying or dividing. On this basis, a simple derivation of Equation ( 47 ) has been given by 1. ( . Matr (porwonal communication) for the secial cate of negligible cell death (i.e., $D\left(a, x^{\prime}\right)=0$ ). Then, every all disappearing from the population is immediately replared by two new eclls, and the birth rate, $\alpha(t)$, must be equal to twice the net increase in number of cells: $\alpha(t)=$ $2 d N(t), d t=2 c . V_{0} e^{t}$. A rell present at time, $t$, with volume. $"$, and age, $a$, wats born at time, $t-a$, with volume $h\left(a, r^{\circ}\right)$. The number of ecels found at time, $t$, with volume between $v$ and $v+d v^{2}$, which is $N_{\text {or }}$. $\lambda(m, d r$, must also be obtained by taking the birth rate at tame $f-a$, multiplying it by $\psi(h(a, r)) \cdot h_{2}(a, r) d r$. sit $\left.l^{\prime} \mid h\left(a, v^{\prime}\right)\right)\left[\left(h_{s}\left(a, v^{\prime}\right) d l^{\prime}\right.\right.$ being the volume element that (orresponds to $d$ for cells of age zero ) and integrating over all agen. Thus 


$$
\begin{aligned}
& V_{0 e^{c t}} \lambda(v) d v=\int_{(a)} 2 c V_{0} f^{c(t} u \\
& \psi\left(h\left(a, v^{\prime}\right)\right) h_{2}\left(a, v^{\prime}\right) d l^{\prime} \times\left(v \mid h\left(a, v^{\prime}\right)\right) \text { del }
\end{aligned}
$$

or

$\lambda(c)=2 c \int_{(\alpha)} e^{-c a} \psi(h(a, v))$

$$
\cdot h y\left(a, r^{\prime}\right) S(v \mid h(a, v)) d a .
$$

It is readily seen that

$$
\begin{aligned}
& h_{\mathrm{g}}(a, n)=\left[b_{2}\left(a, h\left(a, x^{\prime}\right)\right)\right]^{1} \\
& \quad=\exp \left[-\int_{x=0}^{u} H\left(x \cdot h\left(x, h\left(a, v^{\prime}\right)\right) d x\right],\right.
\end{aligned}
$$

and it will be shown below that $m$ must be equal to $c$ if $D\left(a, n^{\prime}\right)=0$; hence Giluation (5i3) is the same as Equation (47) for the ease of no cell death.

The equation of ('ollins and Richmond will be obtained using a methor suggested by Bell (private communication). First, two functions, $f(v)$ and $d\left(v^{\prime}\right)$, are defined by the equation

$$
\begin{aligned}
& f\left(v^{\prime}\right) \lambda\left(x^{\prime}\right)=\frac{1}{N_{0}} \int_{(a)} F\left(a, v^{\prime}\right) \beta\left(a, y^{\prime}\right) d a, \\
& d(v) \lambda\left(v^{\prime}\right)=\frac{1}{\Gamma_{0}} \int_{(a)} D\left(a, v^{\prime}\right) \beta\left(a, b^{\prime}\right) d a .
\end{aligned}
$$

Proceeding as in the derivation of Equation (.52), one find * from Equation (46), (.54), and (5.5):

$$
\begin{gathered}
f\left(u^{\prime}\right) \lambda(v)=2 m \int_{u=0}^{u} \psi(u) Q(u, u) d u, \\
\left.d(v) \lambda(v)=2 m \int_{u=0}^{u} \psi(u) Q(u, u) l\right)(\mu(u, u), v) \\
\cdot \mu_{1}(v, u) d u, \\
\varphi(v)=2 \int_{u \rightarrow 0}^{v} \psi(u) Q(u, u) P^{2}\left(\mu(u, u), v^{\prime}\right) \\
\cdot \mu_{1}(u, u) d u,
\end{gathered}
$$

where

$$
Q(u, u)=e^{c \mu(x, u)} S(u \mid u)
$$

and bruation (26) has beren used to simplify the integrand in Liuation $(.56)$.

Consider now the expresion $-\int_{y-0}^{p}[r,(y)+$ $d(y) \lambda(y)+m \varphi(y) \mid d y$ which is equal to

\footnotetext{
* Similarly, Equation $(4 h$ is transformed into $\psi(v) \rightleftharpoons$ $1 \int^{2 w} \psi(u) Q(2 n, u) P(\mu(2 v, u), 2 u) \mu_{1}(2 r, u) d u=2 \varphi(2 u)$. This is Bell's integral equation [Lquation (26) of lieference 12] which must be satisfied by the function $\psi(v)$ in order that at steaty -tate of exponential growth may be at ained.
}

$$
\begin{aligned}
-2 m \int_{y-v}^{v} \int_{u-v}^{y} \psi(u) \mid c+D(\mu(y, u), y) \\
\quad+P(\mu(y, u), y)]_{\mu_{1}}(y, u) Q(y, u) d u d y .
\end{aligned}
$$

liemembering that

$$
\begin{aligned}
& \frac{\partial(y(y, u)}{\partial y}=-[c+I)(\mu(y, u), y) \\
& \quad+P(\mu(y, u), y)] \mu_{1}(y, u) Q(y, u)
\end{aligned}
$$

and interchanging the order of the two integrations. (60) becomes

$$
2 m \int_{u-0}^{u} \psi(u) \int_{u=u}^{n} \frac{\partial(u(y, u)}{\partial y} d y d u
$$

$\theta r^{\circ}$

$$
\because m \int_{u=10}^{v} \psi(u)[Q(u, u)-1] d u
$$

since $Q(u, u)=1$. It has been shown, therefore, that

$$
\begin{aligned}
f(p) \lambda(p)=m \int_{y-10}^{2}[2 \psi(y)-\varphi(y)] d y \\
\\
\quad-\int_{y-n}^{c}[r+d(y)] \lambda(y) d y .
\end{aligned}
$$

Letting $u$ tend to infinity in Liquation (61), and assuming $\lim _{v \rightarrow \infty}\left[f\left(c^{\prime}\right) \lambda\left(l^{\prime}\right)\right]=0$, it can be seen that

$$
m=c+\int_{y-y}^{\infty} d(y) \lambda(y) d y
$$

becaune $\lambda, \varphi$, and $\psi$ are normalized to unity. In particular, if there is no cell death $\left(D\left(a, l^{\prime}\right)=d\left(v^{\prime}\right)=0\right), m$ is equal to $e$ and

$$
f(l) \lambda(u)=c \int_{y-0}^{v}[2 \psi(y)-\varphi(y)-\lambda(y)] d y .
$$

This is the collins-Richmond ruation which was originally derived in another manner. $\left.{ }^{(4,}, 8,10\right)$

Differentiating both sides of Equation (61) with rempect to $e$ one finds

$$
\frac{d g(v)}{d(v)}=m[2 \psi(v)-\varphi(v)]-\frac{[c+d(v)]}{f(v)} g(v),
$$

where $g(u)=f\left(u^{\prime}\right) \lambda\left(u^{\prime}\right)$. This equation can be integrated to give $g(c)$, taking $g(0)=0$ an initial condition. The rescult is

$$
\lambda(v)=\frac{m e^{-x w 1}}{f(v)} \int_{x^{-0}}^{x}[2 \psi(x)-\varphi(x)] e^{R(x)} d x,
$$

with

$$
R(v)=\int \frac{[c+d(v)]}{f(v)} d v
$$


The right hand sides of Equations (.52) and (6.5) are two different expressions for the same function, $\lambda\left(z^{\prime}\right)$. It whould be pointed out that Equation (64) ean be obtained directly by integrating both sides of Equation (Bib) over a (ef. Bell and Anderson, Equation $(R)$ of Reference 11 ).

\section{CONCLLEION}

1. For the special case of linear volume increase with age [Equations $(10)-(12)]$, and as suming that $I)(a, v)=$ $d\left(r^{\circ}\right)=0$, no that $m=c$. one obtain from Equation (.)2)

$$
\lambda(x)=2 b e^{b u} \int_{u=0}^{c} \psi\left(u \sin (n) u e^{b u} d u\right.
$$

where

$$
b=\frac{c}{r} .
$$

Notice that $b$ is also equal to $\left[\int_{c-11}^{\infty} l \lambda(v) d y\right]^{-1}$. To sees this. multiply both sides of liquation (64) by $k$, and integrate over $r$ from $v=0$ to $v=x$. The left side is integrated by parto, asuming that $f^{\prime}(0) \lambda(m)$ tends to zero for $r \rightarrow x$. Furthermore, it in cleatr that

$\int_{v=0}^{\infty} r\left[2 \psi\left(r^{2}\right)-\varphi\left(v^{2}\right)\right] d t=0$, from Equation $(45)$, and so one in left with

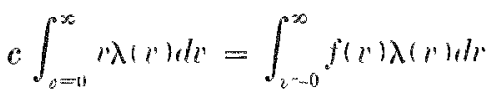

$$
-\int_{i n+1}^{\infty} i d(l) \lambda(v) d v
$$

[of. Equation (11) of Reference 11]. If $d(n)=0$ and

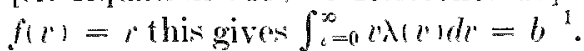

The mean volume at birth, $z$, can be defined by the cquation ${ }^{*}:=r T=\left(\begin{array}{ll}1 & b\end{array}\right) \ln 2$, where $T=(1 ; c) \ln 2$ is the doubling time of the population 6 so that $z$ is also the volume increment in time $T$ ). Thu, Equation (tio) beecomes, replacing $\psi(u)$ by $20(2 u)$ :

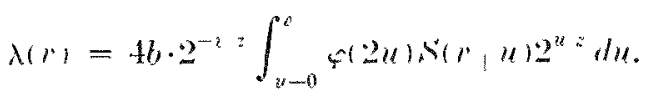

If $S(u \mid u)$ were independent of $u$ (which in general is not trues, it could be written in the form

$$
1-\int_{x \rightarrow \pi}^{0} \phi_{b}(x) d x
$$

and Equation 70 would agree with Kubitochek's result (A-7) of Reference 2 if $\int_{u=0}^{z} \varphi(2 u) 2^{x z} d u$ were expual tor $\int^{\prime} \int_{u-0}^{z} \phi_{b}(2 u) 2^{-u z} d u$ (where ${ }^{2}$ is a constant) for all

* This is only approximately true. For example, if there is nu cell death and if the function $P(a, v)$ does not depend on $v$, the correct expression for $\approx$ is Equation (50) of Reference 15 (in which $(2, x)$, is the same as $z)$.
Values of $l$; hence for $x 2^{2}=\left(\phi_{b} t x\right)$. This, however, seems to differ from laquation (2.) of lieforence $t$ in which the notation $\phi_{m}(x)$ in usel for pit $\left.x\right)$.

On the other hand, still assuming linear volume increare with age and no roll death, Equation (fi.) gives

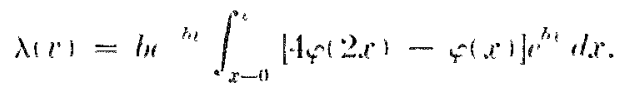

2 . ('onsider now the care of exponential volume inarease with age [Eepuation- 1 1:3, (1.5)] and assume $D\left(a, l^{\prime}\right)=d\left(x^{n}\right)=0$. It ean readily be seen that $l_{:}$must be coual to $a$. Thi concluwion is reached by putting $d(r)=0$ and $f(u)=k x$ in Equation (tia). Thus, one has from Equation (5i2)

$$
\lambda(r)={ }_{l}^{4} \int_{n-0}^{e} u \in(2 u) x(r \mid u) d u,
$$

which again differ from Kubitschek sesult $(A-S)$ of Reference 2 , even if $S^{\prime}(u)$ is replaced by

$$
1-\int_{x=01}^{x} \phi_{k}(x) d x \text {. }
$$

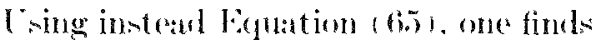

$$
\lambda(\nu)=\frac{1}{v^{2}} \int_{x-0}^{e}\left[4 \varphi\left(2 x^{2}\right)-\varphi(x)\right] x^{2} d x
$$

for the case of exponential volume inerease with age and no cell death.

In general, the expresions obtained by the method of ('ollins and Richmond [Lquations $(71)$ and 173$)$ above] are eanier to use in practice, particularly if cell death is neggligible. This is becanses $S(v \mid u)$ in an unknown function. for all practical purposen. whereas $s\left(l^{\prime}\right)$ can be determined experimentally - a faret that has been brilliantly exploited by Anderem at al. ${ }^{19}$

It would be interesting to try to fit liubitschek's re-ult ${ }^{\prime 2}$ using Equations $(71)$ and $(7 ; 3)$ in place of his

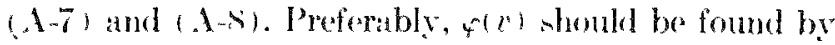
means of suitable experiments; otherwise it would be necesiry to mathe a specifie asumption on the shape of of $2 \%$. For example it might be supposed that reciprocal volumes at division are nomally distributed, which is analogou- to what Kubit schek did for his function $\phi_{b}(x)$.

I am much obliged to Drs. (:. I. Beell, H. E. Kubitschek, and A. (i. Marr for helpful diseu-ions and correspondence.

\section{RETLRE VC'ES}

1. Kubitschek, II. F. Linear cetl grew th in Escherichia roli. Biophly. J. 8, 792-x01 (1963).

2. Kubitsehek, H. F. ( Analy sis of eell sizo distribution. Biophy. .J. 9, 792,909 (1969).

3. Sinclair, W. K. and I). W. Rows. Modes of growth in mammalians cells Biophys. J. 9, $105 \mathrm{fi} 1070$ (13069). 
4. Painter, P. R. and A. C. Marr. Mathematies of micential populations. Ann. Ret. Mirrobiol. 22, 519-548 (1968).

5. Scherbaum, 0. and (a. Rasch. Cell size distribution and single cell growth in Tetrahymena pyriformis (it. Aleto Pathol. Mirrobiol. Asand. 41, 161-182 (1957).

6. Harvey, R. J. and A. ('. Marr. Measurement of size distributions of bacterial cells. J. Barturiol. 92, s05-811 (1966).

7. Harvey. R. J., A. ( 4 . Marr, and P. R. Painter. Kineties of growth of individual cells of Escherirhia roli and $A$ zotobacter agilis. J. Bacteriol. 93, 605-617 (1967).

s. Andersom, E. (. and I). R. Petersen. Cell growth and division. II. Hxperiment al sudies of cell volume distributions in mammalian suspension cultures. Biophys. J.7, $353-3644(1967)$.

9. Anderson, E. ('., (.. I. Bell, D). R. Petersen, and li. A. Tobey. Cell growth and division. IV. Determination of volume grow th rate and division probability. Biophys. d.9, $246-263)(1969)$.

10. Collins, J. F. and M. H. Richmond. Rate of growth of batillus aereus between divisions. I. Gen. Miorobiol. $15-393(1962)$.

11. Bell, G. I. and F. C'. Anderson. ('ell growth and division. I. A mathernatical model with applications to cell volume dist ributions in mammalian suspension cult ures. Bioplyzs. J. 7, 329-351 (1967).

12. Bell, (i. I. ('ell growth and division. 111. Conditions for balanced exponential growth in a mathematioal model. Biophys. J. 8, 431-44.4 (194k).

13. Ramkrishna, 1).. A. (8. Fredrickson, and H. M. Tsuchiy On relationships between varions distribution functions in halanced unicellular growth. Bull. Hath. biophys. 30, 314:328) (1968).

14. Fredrickon, A. (4., D). Ramkrishna, and II. M. Tsuchiya. Statistics and dymamios of procaryotic cell populations. Math. Biossi. 1, 327-374 (1967).

15. Truces, E. On the average cellular volume in syochronized cell populations. This report.

\section{CHARACTERIZATION OF PHOTOREACTIVE PROCESSES IN BACTERIA}

Syleames A. Tyler and Merlin H. Dipert

\section{PLRPOSE AND METHODS}

A model of the kinetics of photoreactivation in CV-irradiated bacteria was presented in the previous annual report. (1) The underlying postulate of this model states that UV-irradiation of the eall produces events (among other lesions) within the cell with the following propertion: 1) A single event can inactivate the cell; 21 sent are sequentially reversed* by exposure to visible light; 3 ) the cell in reactivated if, and only if, all events sustained are revered. The event are called mersible cecots to distinguish them from other induced lesions that also may influence and contribute to the total surviving fraction of the population. The proportion $\left(Q_{r}\right)$ of rever-ible event that contributen to the total proportion $\left(Q_{T}\right)$ of inactirated calls must be independent of all other inactivating events (proportion $=Q_{2}$ ). This condition establishes the relationship

$$
P_{T}=P_{r} \cdot P_{i} \text { for } P=1-Q \text {. }
$$

The description. based on the above postulation, was called "a sequential model." $T$ In addition, it was assumed that the events produced by a dose $d$ of UV irrudiation are Poison-distributed; i.e.,

* By reversal we mean any counter-action that unllifies, repairs, or circumventis the effect of an indured lesion that meas= urably contributes to the end point considered.

f Dr. David J. G. lavies, Nichool of Pharmary, Bath Cniversity of Technelogi. Bath, England originally proposed the sequential model of photoreactivation and supplied the experimental data upon which this report is based.

$$
\text { Prob. }[x: \mu(d)]=\frac{\mid \mu(d)]^{x^{-}-\mu, d,}}{x !},
$$

where $x^{2}$ and $\mu(d)$ are the number and expected value of events produced, respectively. We refer to this model, together with the assumption of Poisson-distributed crents, as the Poisson-siequential Wodel. The observed total surviving fraction, $[S(d, t)]$, after an exposure for time, $t$. to visible light follows a dose, $d$, of UV irradiation is"

$$
S(d, t)=P_{T^{\prime}}(d)\left\{\sum_{i=0}^{k} \frac{[\mu(d)]^{i}}{i !}+\frac{\left.\gamma[\mu(d)]^{k+1}\right\}}{(k+1) !},\right.
$$

where $P_{T}(d)$ is the surviving proportion atter zero photoreactivation, $\mu(d)=-\ln \left[P_{r}(d)\right], \gamma$ is a positive constant (less than 1 ), and $L=k+\gamma$ is the number of reactivated erents. This model is compatible with the survival data ${ }^{(2)}$ accumulated over a range of $t$ and $d$ values for cell of $E$. coli WP2 her- in stationary phase at photoreactivating irradiances of 60,4000 , and $6000 \mathrm{erg} \times \mathrm{mm}^{-2} \mathrm{sec}^{-1}$. It was found that at each irrarliance not more than approximately 20 events could be reversed. This suggests that only a prescribed number (say, 20) of reversible events are produced by UV irradiation and that a Binomial-Sequential Morlel may serve as a more appropriate description of the kinetics of photoreactivation.

* In leference $1, P_{i}(d)$ should be changed to $P_{z}(d)$ in Fiquations (5) and (ii). 
OGRESS REPORT

\section{The Binomial-Sequential Model}

Let un substitute for the Poison arsumption [Hquattion (1)] that, at most, $n$ reversible events are produced $b y$ the irradiation and are binomially distributed within the cell with probability $(1-\rho)$. Then,

$$
\text { Prob. }[x: n, 1-\rho]=\left(\begin{array}{l}
n \\
x
\end{array}\right)(1-\rho)^{x} \rho^{n} x,
$$

where $x$ is the number of events produced, and

$$
\left(\begin{array}{l}
n \\
x
\end{array}\right) \equiv \frac{n !}{x !(n-x) !} .
$$

The oberved total surviving fraction is expressed by

$$
\begin{aligned}
& S(d, l)=P_{i}(d)\left\{\sum_{x \sim 0}^{h}\left(\begin{array}{l}
n \\
x
\end{array}\right)(1-\rho)^{x} \rho^{n-x}\right. \\
& \left.+\gamma\left(\begin{array}{c}
n \\
k+1
\end{array}\right)(1-\rho)^{h+1} \rho^{n+k} 1\right\},
\end{aligned}
$$

where $\rho$ is ergual to the $n$th root of $P_{r}$ and $k$ is the largest integer for which the first term on the right of (4) does not exceed $S(d, t)$. With $n=20$, the Binomial-sequential Model was indistinguishable stati-tically from the Poisson-Sequential Model when the same data from the experiment with $E$. coli WP2 her- were used. ${ }^{2)}$ Howerer, this model requires the a priori determination of $n$ for processing. Thus, an iterative numerical procedure based on some eriterion of goodnens of fit must be employed to estimate $n$. Several criteria are under study currently.

\section{Random .Models}

The efficiency of two random models as descriptions of the kineties of photoreactivation was tested. The structure of these models rests on the postulation that events are randomly reactivated rather than sequentially reactivated by light. The Poison-Random model depicts the change in total surviving fraction with I"V dore and photoreactivation time by the following expression:

$$
\begin{array}{rl}
S(d, t)=P_{i}(d) \sum_{x=0}^{\infty}[\mu(d)]^{x} e^{-\mu(d)} P_{h}^{x} & x ! \\
& =P_{i}(d)\left\{e^{-\mu(d)\left\{1-P_{h}\right]}\right\},
\end{array}
$$

where $P_{h}$ is the probability of reactivating an erent and $\mu(d)=-\ln \left[P_{r}(d)\right]$. The Binomial-Random Moclel is s.ymbolically described by

$$
\begin{array}{r}
S(d, t)=P_{i}(d) \sum_{x=0}^{n}\left(\begin{array}{l}
n \\
x
\end{array}\right)(1-\rho)^{n} \rho^{n-x} P_{h}^{x} \\
=P_{i}(d)\left\{(1-\rho) P_{h}+\rho\right\}^{n},
\end{array}
$$

where $\rho$ is the $n$th root of $P_{r}$.

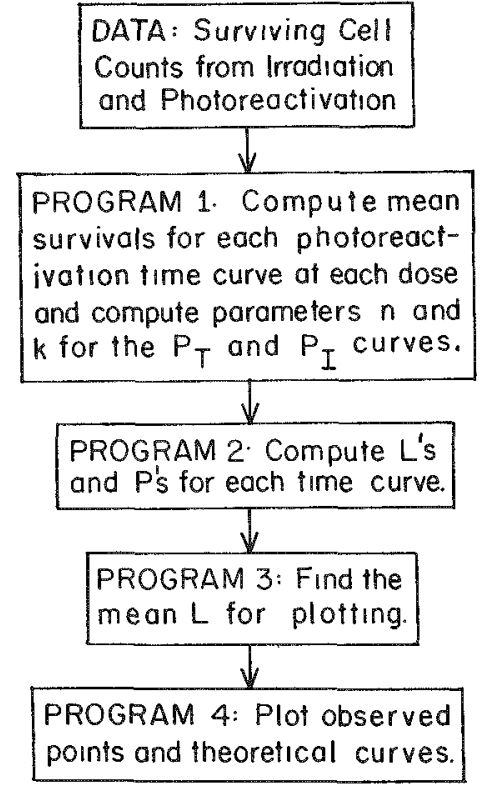

Fit. 5x,-FIow ehart for the coustruetion of survival curves

With several different strains of $E$. coli, the Binomial-Sequential Model seems to provide the best description of the oberved surviving fractions. We have noticed. howerer, that if a random model dereribes the data well, the Binomial-secuential morlel will fit even better provided $n$ is -mall (i.e., $n \approx 51$. Future effort will be directed toward a more systernatic investigation of the impressions.

The clueidation of a model for which empirical validation is sought is not practically described until the computational algorithms that make the necessary statistical testing feasible are established. Thus, along with the construction of there models, the numerical analy-is and coding of supporting computer programs have proceeded.

The computer algorithms for letermining the constants of the model are summarized in the flow chart (Figure 581. Although the detailed procerlures represented by each box will change as the particulars of the moled are further develoned, the exential tements will rentain.

Thesteps are:

1. (ompute the base line parameters for no photoreartivation and maximum photoreactivation. ('ompute the surviving arerages.

2. Compute the number of events reversed $(L)$ and the probabilities $\left(P_{h}\right)$ using either Equations (2), $(4),(5)$, and $(6)$.

3. Find the mean $I_{s}$ and $P_{h}$ for plotting.

4. Plot the theoretical surviral curres and the observed points.

The present algorithms will be extended to permit the -tatistical estimation of the characterizing con- 
stants of the models by minimum variance, least square procedures.

REFEREXCE

1. Tyler, S. A., M. H. Dipert, and I).J. G. Davies, A hinetic model of photoreactivation in LV-irradiated bacteria. A gonne National Laboratory Biological and Medical Researeh Division Annual Report, 1968. ANL -7535 , pp. 122-123.

2. Davies, I).J. (4., S. A. Tyler, and R. B. Webb. A sequential repair nodel of photoreactivation in bacteria. Photoch m. Photobiol., in press.

\section{A THREE-DIMENSIONAL MODEL FOR RHYTHMIC FLOWERING CYCLES IN XANTHIUM}

Merlin H. Dipert, William Chorney, and Richard R. Dedolph

PURPOGE AND METHODS

The development of a mathematical model to obtain a quantitutive description of the flowering cycle of Xanthium was outlined in the last report.(1)

\section{PROGRESS REPORT}

New data were obtained from carefully replicated experiments with light interruption time at $0,4,8$, 12, 16, 20, and $24 \mathrm{hr}$. Analysis and plotting, using the two-dimen-ional model [Equation (1), Reference 1] -howed the 0 - and 4-hr interruption data were significantly different from the 8- to 24-hr data, and they trere not uned in the three dimensional analyses.

Three-dimensional analysis [Equation (2), Reference 1] of the 8- to 24-hr data showed that parameters $P_{7}, P_{5}, P_{9}$ and $P_{11}$ wore not significantly different from 0 . The rewlts of fitting a surface to these data are shown in Figure 59. Thin surface reduced the sums of squares of the data set by 79r., which well deseribes the data trend of Howering with respect to the $x$ (time) and $\approx$ (light interruption treatments) axes.

The response surface is a clamped sine wave with a -mall negative slope in the $x$ direction, with ridges and troughe when hoth rive in the $x$ a direction and are uniformly displaced an a function of $a$.

To cotablish the location and direction of these

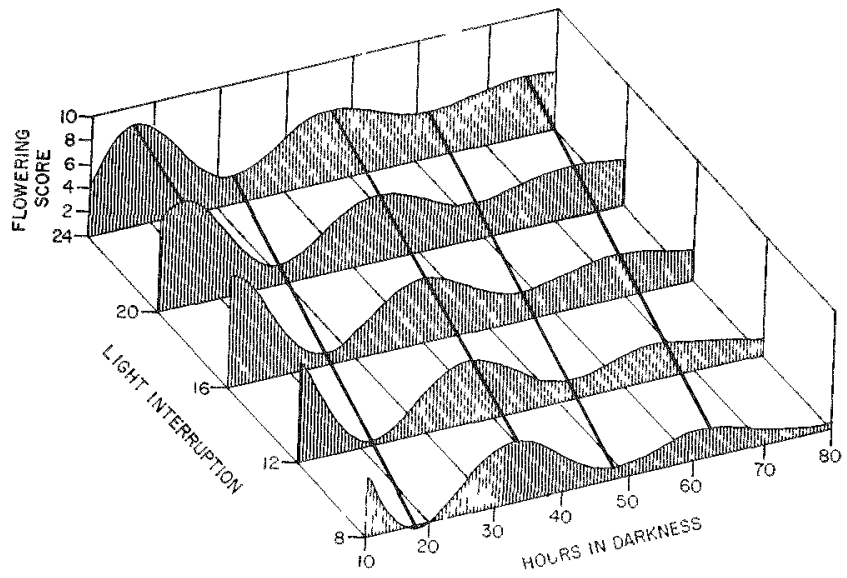

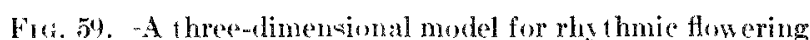
ercles in Xanthium.
TABLE 30. ('OEFFITENTS ND NTINIARD FRBORS

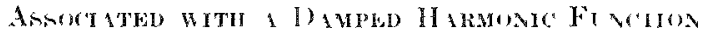

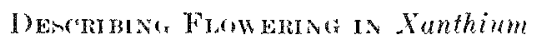

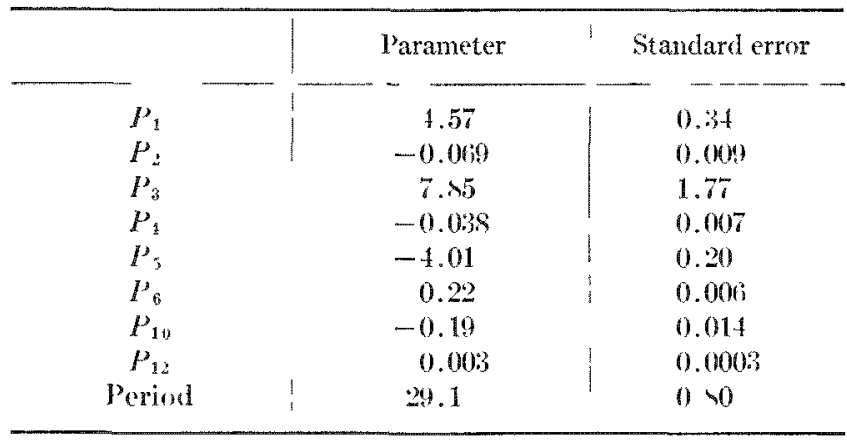

ridges (maxima) and troughs (minima), the $x$ and $z$ coordinates were calculated from an approximation formula.

Given any value :

$$
\begin{array}{r}
x=\left[n \pi+\tan ^{-1}\left(\frac{-P_{6}}{P_{1}}\right)-P_{5}-P_{10} \dot{0}\right] / P_{6}, \\
n=-1,0,1,2,3^{\circ}
\end{array}
$$

The parameters of the surface and their standard error are shown in Table 30. These values are in full agreement with the corresponding values calculated for the two-dimensional model of these data.

CONCLL-ION

We have described techniques making possible the valid interpretation of the combined effect of light interruption and darkness duration on the flowering of Xanthium. This repones surface form the basis for critical interpretation of the phrsiology of these treatments in inducing this long-studied phenomenon. These techniques have worked well in deccribing this complex response and have great utility investigating other rhythmic data of either a two- or the threedimensional nature.

\section{REFERENCE}

1. Iipert, M. A., W. (horney, and IR. R. I)edolph. A three-r mensional model for rhythmic flow ering rycles in Xanthium. Argonne National Taboratory Biological and Medical Research IDivinion Annual Report, 19fis. ANL-7530, pp. 123-125. 
JANUS

\section{JANUS: STATUS OF THE FACILITY AND TECHNICAL CONSIDERATIONS}

Erank S. Hilliamson

PURPOM AND MFLHOD

Previou report have traced the history of the JANL's irradiation facility, the operational problem encountered, and the rentual thutdown for modification on October 18, 1968.1. : Fxperimental evaluation of the propored shielding changes to the shutter and the walls, floor and ceiling of the High Flux Room have been de-cribed..$^{3}$ *

These modifieations include a) constructing new shutter and chutter-pede-tals of optimum hielding design and maximum allowable thickness, bi fabricating a new $\mathrm{U}^{235}$ converter plate and installing it on the High Flux Room side of the hutter location, primarily to relea- space for a thicker shutter, and e) lining the High Flux Room itcelf with a laver of lead 4 in thick, hacked $b y+$ in of a neutron absorbing material.

\section{PROTREA RE REORT}

\section{The dinl's Hinh Flux Rom}

Detailed design for the modifiution have been prepared by peromel of Reactor Operation and Plant Engineering Divi-ion-, under the guidance of a committee con-isting of indivilual from thene, and

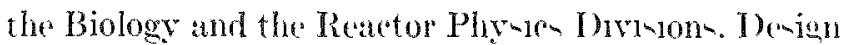
improvements have been introduced ince the modification- began. The original plan(4) involved a 4 -in layer of borobauxite concrete behind the lead room liner. Accele rated curing teet were carred ont on amplen of thic material in a vacuum chamber in order to determine the residual water content. The final vitue of approximately $2.9 \times 10^{22}$ atom of $H$ ce was whout ${ }^{1} 3$ of that originally sought for hydrogen concentration $\left(8 \times 10^{22}\right.$ atom of $\left.\mathrm{H} / \mathrm{co}\right)$.

At this time, diecu-nom, whth the Ma-onite ('orporation indicated that a boron-impregnated hardboard could be produced with the decired characteri-tice, and samples of hardboard -tock were te-ted for neutron actiration. The best result were obained from a hardboard made from redwood fiber. and the final prorluct, Benelex 207. consinted of such a board impregnated with ammonium biborate. This material ha-2.5\% borou by weight with only 125 part- per million of -odium, and $6 \%$ by weight, or $36 \times 10^{2}$ atom- ere of hydrogen.

Tent- of actiration by thermal neutron-indiested a factor of momprovement over borobstuxite concrete of approximately 30. In addition to -ome -uperiority over the borobauxite concrete a- regart- hydrogen concentrations and neutron activation, the Benelex $207 . \mathrm{m}$ the form of plank- 1 in thick and 16 in wile, in much easier to erect an a wall liner.

A denign difficulty which had been appreciated trom the inception of the modifieation propo-al wit that of -upporting the 4-in lead cerlnge without preenting ne utron-actratable material on the in-idle of the Ingh Flux Room. The poblem wa- olved by making the ceslung of 12-m vpuare "thle" of 4 -in thechne-. each weghing 240 pounch and hatring fout ${ }_{4}$-1n daameter aluminum stude cast in to aet an hanger. Thene tiles are en-pended from an aluminum gridwork. which in turn is -upported by the bottom flange of ateel Iheam- The stegl wat -pecified for low mangantere and cobalt content. The -pace above the leard tre- i- filled with borobaurite concrete which, while quentionable in a 4-in layer. 1 - aderpuate in the 8 -in thiekne-.."

Thi- concrete, which in loarled with boron carbide, minimize the thermal-neutron activation of -teel and alunmum -upport -tructures. except for the bottom flangm of the -terl I-beam, which are immediately adlacent to the leard ceiling. In order to correct thi-ituation the flanges were coated with a paint. mende in the laboratory. consinting of gardolinimm oxirle in a vehicle of polyurethane rarni-h.

Delay have oceur red due to difficultie experienced by the contractor in in-talling the lear ceiling, and hy the Cintral shop- Department in maxchining the horon-loarded polvethylene block w-ed in the shutter, and -hutter pede-tah. At the date of this report, (betober 1969, the lead wall and ceiling are completed. The floor will he left until heavy traftic in the room ha- reand at revined -cherdule projects -tartup of the reater for low-power teuting in early Desember, at wheh time the nentron flux dintribution acrom the converter plate will be mea-ured so that a grated attemator can be designed. It is important not to proluce inconvenient activation of the converter plate 
before thi- attenuator in installed, tested, and if necensary, rorreeted. Initially, therefore, all spectrometry, do-inetry studies and other testing which require the une of the converter plate must be carried out at low power and cin begin early in 1970.

It is intended to hou " mice, during irradiation, in di-ponable polyethylene containers loaded into removable thelve in a modular frame which will then be hung in the High Flux Room and identifies by the data-acquicition rotem. Calculations by shaftman and Medrthy's indieate that the thermal neutron flux in the modified High Flux Room during irraliation will be greaty reduced. If this flux is taken as unity, then the presence of .500 mice in polyethylene container will raise the thermal neutron flux by a fiactor of 28 and 1000 mice by a factor of 56 . The 500 mice are expected to produce approximately the ame thermal neutron flux an there was in the old, unmodified room without an animal loatling.

In order to further minimize hazards to perron hamdling these irradiated frames the material have been chowell so as to combine minimum activation with rapid decay. A prototype is under construction, u-ing magneium-aluminum alloy. It is not expecterl that artivation due to neutron eapture will present a froblem, hut, hould this a-ped require attention. the offending material can be treated with gardolinium paint. Although the polyethylene rehicle forms a cough, pliable film, an epoxy resin vehicle might be wren better.

\section{Automation and Datu Processing}

Becaune of a series of bukgetary difficultien, it has not seet been powible to ohtain the data acquisition $-F+t e m$ necemary for a large throughput of mice.

Experinent, have been carried out on file manageneent. using data rollected in another reneareh program. The most promising file organization is Indexed secpuential, supported by the IB.M 360 50-75 operating -ystem in the ANL Computing Center. In this type of file, the record are arranged by a collating sequence of jdentification keys and indexed. Adrlitions and retrieral may be made at random with reasonahle efficieney, but sexuential -earch of the entire file in very efficient. With Release 17 of the operating ratem. it became powible to have arcen an entire group of records by -peeifying that part of the irtentification key common to the group. There fram ture en-ure the flexibility necessary if the data procening goal is to be achiered. Thin goal is to create only general programs which ean be controlled or modified at execution time in order to achieve the de-ired remult.

Cie of expert programming -taff to write -pecial program whenever datia must be updated or retriered and routine statistics and plotting operations are neerded is not accoptuble. There functions should be carried out hy the cientist, using simple commands approximating normal languatge.

The PL 1 language is our standard higher language for all JANC's programming, with some asi-tance from subroutines written in $0 \mathrm{~s}, 360$ Assemblex langutuge, where this in justified hr an improvement in execution efficiency or the objective is otherwive unattainable.

A teletype remote terminal, linked by telephone to the REAClE interactive yotem on the 36050 , is now in une, and an IBM 2741 terminal is on order. The 2741 remblen a selectric typewriter and will be appropriate for use by a secetary to enter data into the eomputer directly.

JANC's data files will he maintained on dink or data eell -torage by the 3607.7 and updated through the RESCTE - r vitem and a batch computing job. Retrievals, if brief. can be read back at the 2741 terminal, or if more voluminous, directed to the local printer cacheduled for in-tallation in building 202 in -pring 1970 ) or main printer- in the Computing (conter.

A Hexible automatic graph plotting system i- under development. Eventually, it will he po-ible to produce plot on paper or film whenever data are retrieven from the filen, or computed, without any - peeeial attention. A firt rer-ion, remtrieted to cilcomp plotting, is now operating from commumls and data entered into RFCCE by teletype.

\section{CONCLLEION}

The JANCS reactor is expected to be in operation early in Ineember 1969. Evaluations of the flux ditribution will begin immediately thereafter. Spertrometry and dosimetry will be carried out in parallel with the initial radiobiology studie early in 1970.

\section{REF ERINCL}

1. Whlliamon, F. s. Janus reaceror: I tatus report. Argonne National Laboratory Division of Biological and Medieal heseareh Annual Report. 1966. ANL-727s, p 6 is.

2. Wulliamson. F. S. Janiw reator: 1 status report. Argonne National Laboratory Jivision of Biological and Medical Researeh Aunual Report, 1964. ANL 7535, p 130.

3. Schumacher, M. (" and F. W. lisha. The effect of shuter extemsion on neutron dose equivalent rates in the Janus High Flux Lxposure Room. Argone National Laboratory Division of Biologieal and Medical lesearch Annual lifo port, 1964. ANL-7535, pp. 133-134.

4. Williamson, F. S. Wall shiflding atudies on the Janu High Flus Room. Argonne National Laboratory I Division of Bio logieal and Medieal lieseareh Anmal Report, 1968. ANI. 7535, p. 131.

5. Whaftman, I), and 1. F. Mr.drthy. Conpublished. 


\author{
L. John dinsworth
}

The IANTS program is an integrated experimental approach to the eraluation of hazards a-ociated with short- and long-term cxposure to fi-ion spertrum neutrons or gamma radiations. The objective is to define ratiation remponsen that include both acute lethality and late effects, such an neoplasia and degenerative di-anes. in terms of radiation damage to cell-, alteration in the functional integrity of ti-sues and organ sy-tems, and decrement in physiological rapacity. In thin way, it will be pomible to predict more meaningfully and compare the consequences of human exposure, oceupational or otherwine, to fision spectrum neutrons or gamma radiation. The pre-ent experimental plaming for the first year concerns mice and, to a limited extent. dog. The main thrust of the program focusen on late effect of irradiation, but acute lethality studien munt he performed to provide mential haneline information. Fxperiment are planned to evaluate the extent to which repair and recovery phenomena influence both late effect- and the hort-term -urvival hazard attendant to repeated low level expo-ures.

The initial range-finding experiment in the late offeret- -ector of thi- program secks ensential batseline data concerning life-man shortening produced by a single acute "xposure to gamma or neutron radiation; graded expo-ure will be usad to provide donem repouse relation-hip. A directly comparable fractionation experiment is planned in which a high total exponure, viz., 300 Radh of neut row and 900 Rads of gamma radiation, is protracted from several days to approximately 180 day. From thene experiments, cortain late effect of radiation, viz., life-yan thortening. death rate, tumor incidenes and type can be "valuated at a function of total dor', the extent of do-s fractionation, and radiation-fres time. Morbidity group must be included so that, by -rial arerifice, information can be obtained about the derelopment of raliation le-ion and funrtional impairments, the ultimate mechani-me that produce deleteriou- late wifercts of inradiation.

A -mall initial effort in directer to acute lethality tudies in sereral mouse strains to characterize the relative contribution of hemstopoietic and inte-tinal damage to the meutron radiation -molrone and to $\mathrm{cx}-$ - Jore don-rate texpo-ure-time) effects. Comparable. helien are planned for doge. Improverl techninguen to evaluate dimage to tem rell- in the moune marrow and intertinal cryptot is and a thorough examination of cell population kinetion in the intertine sas should provide at heter definition of the neutron -rudrome emential to the interpretation of reult from other -turlies of fractionated or chronic exposures.

Resorery in mire after -ingle or multiple acoute exporurem will be meatured hy -plit-rlo-e letemination of the LI) is as and I.D), The The acommulation of injury during fractionated "xpo-ure will he evaluated

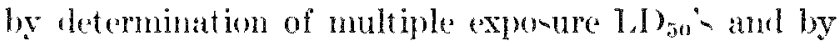

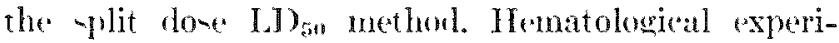
ment - in support of multiple expo-nese -tudite will contribute better undertanding of the continum of sydromen ocenring unler condition of loneterm "xpo-nre, and the extent to which the multiple expo-

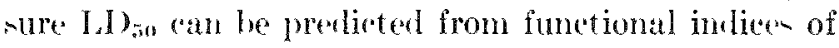
ratiation injury to the hematopoietic - In-tem.

"The current -tatu of the modification of the Ligh Ievel Esponere Room are described in an aceompanying report. Although the time rexuired to ats-omble and test the varions reartor componest- and oltain full sanction for unlimited operation of the furility cannot be preslicted at this writing. critical doimetric experiment - will be conducted coincilental to tents of the facility. The more extensive do-imetry in to he coordinated with the initial radiobiology effort to determine the influenes of spectral rariations on survival of Chinese hameter cell- exposed in ritro, wright lom in mous' te-ter, and survival of mice and their hematopoietic -tem cells. These hiological do-imetry experiments, to be completel within a few month of reactor operation, are desimed to lefine expoure com traint within the Iigh Level Room im-

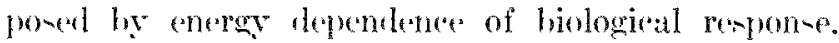
Tnitiation of all other experiment described above is planned for the firm year.

Farlier ANL toxicity program, concerned primarily with duration-of-life expo-upen, have gemerated ba-ia radiobiological prineiples. tertahle hypotheren, and extrapolation pertinent 10 the hazard of human (xpo-ure. ${ }^{(5-6)}$ The oNTT' raliobiologs program, which is expally anbitious in it objertiven, in the rexipient of this earlier experience and a peropetive which rexognizes that only by an integrated approach, involving both inortality and comprehensive studis of cellular and tisue injury, can the hazard of ne tron and gamma irraliation be evaluated and meaningrully prodiroted. 


\section{REHTRENCES}

1. Till, J. L. and E. A. Mc 'ulloch. A direct measurement of the radiation sensitivity" of bone marrow cells. Radiat. Rts. 14, 21:3-2222 (1961).

2. Withers, H. R. and M. M. Flkind. Radiosensitivity and fractionation response of arypt cells of monse jejunum. Radiat. les. 38, 59x-119) (1969).

3. Fry, R. J. M., A. B. Reiskin, W. Kisieleski, A. Nallese, and F. Atafeldt. Radiation effects on cell renewal in rodent intestine. Comparative rellular and speres Radiosensitivity, Igaku shoin Istd., 'Tokyo, Japan 1969. pp. 255-270.

4. Williamson, F. S. JANUS: Stat of the facility and techncal considerations. This report.
5. Sarher, G. A. and L. Trueco. Theory of radiation injury self renewing cell populations. Radiat. Ros. 29, 236-259 (1966).

6. Grahn, D. and (A. A. Sacher. Fractionation and protraction factors and the late effects of radiation in small mammals. Pror. Symp. on Jose Rate in Mammalian Radiation Biolugy, Agricultural Research Laboratory, lak Ridge, "Tenn. C. S. Atomie Energy Commission, Washington, D. ('., 196\%, pp. $2.1-2.27$.

7. Grahn. 1). Biological effects of protracted low dose radiation exposure of man and animals. Proc. Colloquium on Late and subtle Fffects of Liadiation on Man and Animals, 1969. Taylor and Frances, Ltd., London, in press. 


\section{TOXICITY AND METABOLISM OF RADIONUCLIDES}

\section{Studies of Radiation-Induced Changes}

\section{TOXICITY AND METABOLISM OF RADIONUCLIDES: PROGRAM OBJECTIVES AND INTRODUCTION}

\author{
Illliam I'. Nonrix
}

For a long time it has been recognized that reactor accidents and nuclear detonations are potential soureen of radiation exposure to large -egments of the population. A dosimetric recontruction of such an expo-ure would obviouly be rery complex. ince there will be contribution- from many -ources, ineluding inhaled and ingested fi-sion products. In spite of the concern exprened over our lack of information in thiarea, there have been no direet experimental attackon the problem. While there are data to deseribe radiation damage resulting from experimental exponure to single radionucliden. thene are not directly, or neeas-arily, applicalble to fi-wion mixtures.

Some perons have -upported the straight-away approach to the finion mixture problem-that in, a study of animal treated with raw mixtures of fission product. However, we rejected this suggeetion on the ground that such a complex nixture is imponible to deal with either analytically, or conceptually. Furthermore, it is impractical to attempt to reproduce the componition of a given fi-ion mixture, becau-e it depends so heavily on the fut source, time in the reactor. and pontirradiation cooling time. Therefore, we deri-ed an alternative, technically feasible approach, which hould contribute to the definition of the biologieal problem anociated with finion mixtures.

The firsion mixture problem can be restated to ank what will happen if different portion of the body are unequally, but more or les simultaneou-ly, irradiated. Beceture radioactive inotopen are involved. both the total doses and the done rates to areas of the body may vary. 1 practical example exist in the native of Rongelap, who received whole-hory irradiation from ground depoit of fision product - together with signifieant doses to the thyroir gland from metaboJized ${ }^{131} \mathrm{I}$.

The radiation dowe delivered to the body from a radioactive isotope deposited internally is intimately related to the metabolic characteristics of the isotone and the quality of it emitted radiations. The total done to the body is protrated, but the done rute decreane- with time, depending upon the biologic rate of ercretion and the phrical rate of decay of the isotope in quention.

Some elements, wch as cenium, maintain an esemtially "ontant relative distribution between the orgam of the hody: other-, weh an cerium, may show high initial concentration in one organ with subequent translocation to another.

It i- powible to selent a few ti-ion product, pow st--ing markedly different metabolir characteristios. which typify the biochemical propertien of the majority of radionurlide in a fision mixture. For our im-

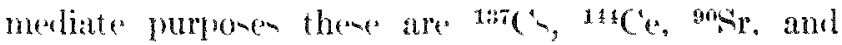
1:1. Thene radionudiden must firnt be studied reparately to determine their acute lethality, and the biological remone to dones below thou which are acutely lethat. Such data for sts will be obtained from work of other laborat orien.

In ardition to the above group of internal enitters. whols- or partial-body irraliation from calibrated external coures will be ued to provide bate-line information on the reppone of doge under known do-imetry. Such expo-ure will include whole-hody irradiation to determine the single-do-e I.D, protracted irradiation at both con-tant and decrementing dowe rates. Such studie- hould do much to relate the repronse of the dog to the latrger volume of work alrealy lone in rolent- A comparison of these data should determine whether a simple ratio of radiosen-itivity ean be used to axtrapolate between operiom under variou expo-ure ronditions.

A- implied above, the next step would he to invertigate the effects of simple combinations of thene radiation exponuren-for example, protracted wholehorly irradiation combined with 1"1I administration. The hiologir rationale underlying -uch exposures appears to be evident.

In aderuate under-tanding of radiation effect 
from a grven fision proluet must incluele at detailed knowledge of the dynamice of its metabolism, together with the capability to convert this information into meaningful e-timate of radiation dose rate and integrated radiation dose to significant organs and ti-ues. The latter is a difficult problem, in which limited uceess has been reported to date. INowerer, the application of a combination of arailable tlo-imetrie techniguen-some of which have alreaty been explored here-hould contribute significantly in this mot important area. Tnlem the importance of dosimetry in recognzed, the problem ansociated with internally depo-ited isotopes will nerer be artequately remolved.

One great advantage of the dog lim in it -ize, which allow it to be examined repeatedly and in detail. However, interpretation of results requires a comprehenere know ledge of the normal, unirradiated animal. and alo of the rhange- which occur as the animal matures and ages. Thu, a study of all aspects of the normal dog is equally an important as a sturly of the irradiated animal.

The rollection of such information-if it is to be me:mingful after many year-must be highly systematized to allow for continuity of ob-ervations entered in a comparable manner. The only fea-ible method of retrieral in through a computer. 'Thu, computer eompatible data cutry ystems were regarded an necenary from the begiming.

\section{THE RESPONSE OF ANL BEAGLES TO PROTRACTED EXPOSURE TO ${ }^{\text {"CO }} \mathrm{Co} \gamma$ RAYS AT 5 TO $35 R$ DAY. I. SURVIVAL AND CLINICAL OBSERVATIONS}

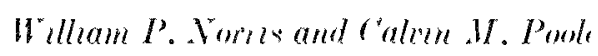

PLRPOLE AND METHOD

Our Annual Report for $1968^{(1)}$ deseribed the initiution of atr experiment in which young adult beagle doge are maintained in a ${ }^{60} \mathrm{Co} \gamma$-ray field until cleath. The daily exposure rates are either $35,17,10$, or 5 R 22-hr exposur' day. Thene exponures are entimated to be equivalent to either 25.40, 12.34, 7.26, or $3.63 \mathrm{Rad}-/ \mathrm{dtay}$, re-pectively.

The eapacty of the "'o $\gamma$-ray facility, a arranged for this experment, is 52 dog - 4 at $35 \mathrm{R} / \mathrm{d}$ lay, 8 at

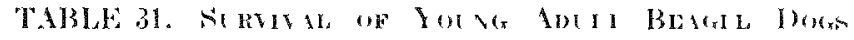

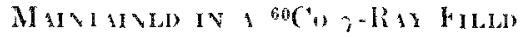

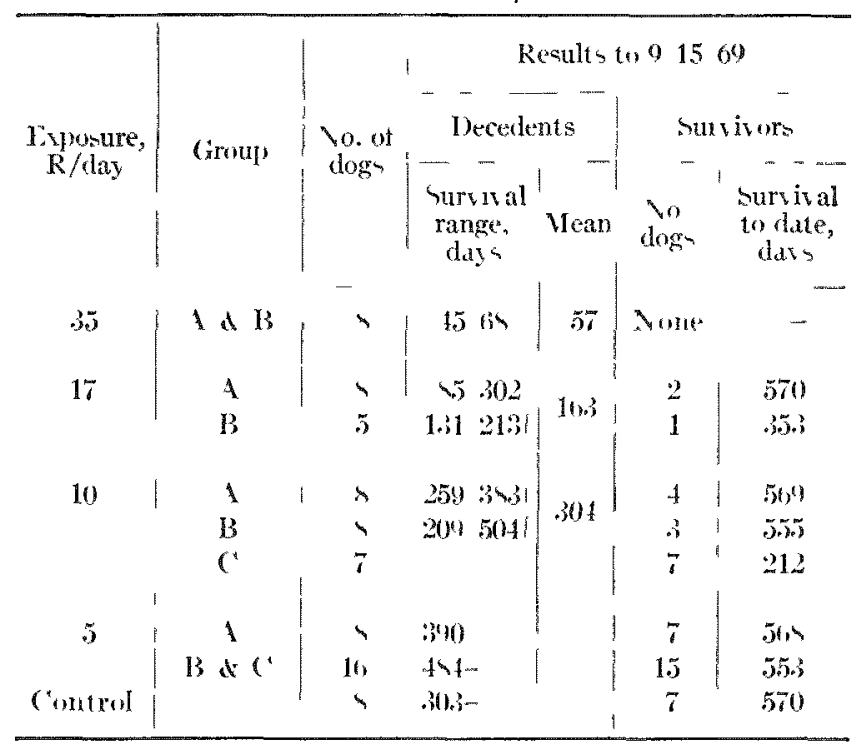

$17 \mathrm{R}$ day. 16 at $10 \mathrm{R}$ day, and 21 at $5 \mathrm{R}$, ilay. A- the dog died, they were replaced by other, so the total number of dogs irradiated to date is in excem of 52 .

Each dog in examined regularly for clinical abnormalitie, with special attention to the eyes (for sions of retinal pathology and lens opacition and hody temperature (for indication of septicemial.(2) A complete hematologic work-up, including a differential white cell count, enumeration of platelet- and reticulocyto, and measurement of rertain biochemical parameters, is done routinely on each animal. Bacteriologic examinations are performed at intervals on blood -perimem from living dogs, as well as on postmortem -pecimen, to define the significance of bactermia in the overall response. All decedents are necropied, and ti-nute are collected for micro-copic -tudy.

PROTHI $\rightarrow$ RJPORT

A -ummary of survival data obtained to date is presented in Table 31. At 3.5 R day, death oceurred after an average of 57 day' exposure-a total of 199.) R. At $17 \mathrm{R}$ daty, about $3 / 1$ of the dogs died after the average of 163 day expo-ure (2771 R), but 2 animals are - till -urviving in apparent good health after .50 dars $(9690 \mathrm{R})$ at thic expoure rate. Thu, based on -urviral time. the $17 \mathrm{R}$ day group has segregated into two -ubpopulation, one being -ignificantly more radiormi-tant than the other. A -imilar pattern appeatr to be deviloping in the dog exponed to $10 \mathrm{R}$ diy. Ahout 1 's of these doge died after an average of 


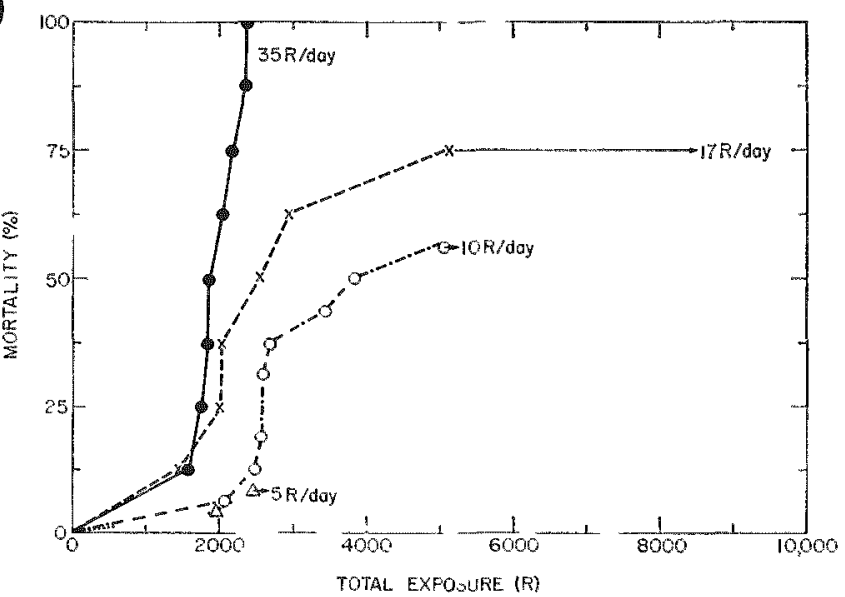

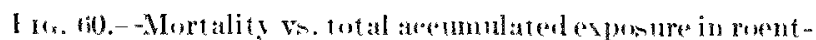
gens in dogs mantained continumbly antil deth in a ${ }^{\circ}$ (') ruray fiold at exponure rates of either 35, 17, 10 , or 5 lidar. The arrow indicate the mortalitg-total axponure relation ships at the time this chat was prepared fafter 510 days of expoulure\%. The exponuren are heing eontinued

304 days' exponure $(3040 \mathrm{R})$. The ret are still alive after ahout 560 days.
Exposure of doge to $5 \mathrm{R}$ 'hay has not proceeded to the wint where mort ality lata are meaningful.

\section{(1)}

The relatiom hip between mortality and total accumulated exposure at each of thene $t$ daily exposure ratem is premented in Figure 60 . We conclude that there are inherent differenem in marrow rell regen"rative and repair capahilitie among individual dogexpund rontinuou-ly to irratiat10n. Thene apahilitien berome laredy inopertable when the expon-ure rate in appreciably in exees of $17 \mathrm{R}$ 'day.

RLET RT VCH

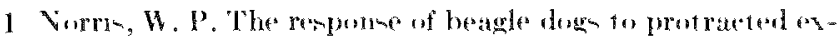

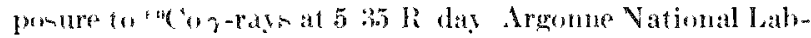

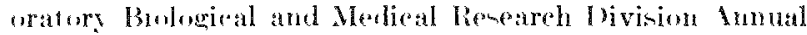

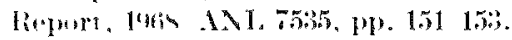

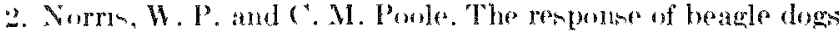

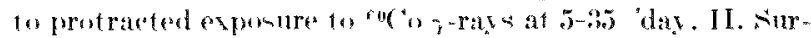
rival and clumeal whervation. Argome Natmoal Labora-

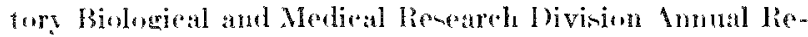

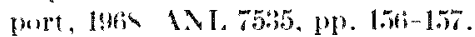

\section{THE RESPONSE OF ANL BEAGLES TO PROTRACTED EXPOSURE TO "CO $\gamma$ RAYS AT 5 TO 35 R DAY. II. ESTIMATION OF THE LD}

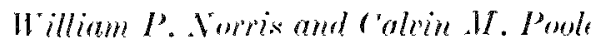

\section{PLRPOE AND MHELOD}

The -tuity of the effect of continuons expo-ure of animal to ionizing radiations is complicated. becusue it is undally necensary to regard come terminal portion of the exponure as "wanted"- that is, not contributing to the effect oberved. It is useful. therefore, to etimate the $L_{50}$ in experiments where continuous expo-ures are terminated at the appropriate time. such an estimate wan attempted for beagle dogs exponed to $3.5 \mathrm{R}$ dely.

I tudy of the rempones of beagles to unterminated exponure to 3.5ll day suggented that the CD $_{5}$ in reathed after 40 day in wch a $\gamma$-ray field. Foung adult beagles were given such an exposure in groum of 4. A total of 40 doge ham been treated in thi manner to date.

PROMUR-A RIPOR L

The mortality and survical data are presented in T:ible 32. Thirty percent of the dogs failed to -urvire. the 40-day period of continuour exposure to $3.3 \mathrm{R}$ ilay. Of the 28 dogs that did survive the 40-day exponure period (a total of $1400 \mathrm{R}$ ), 1.5 are still -urviring. Thi

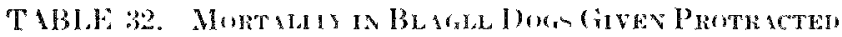

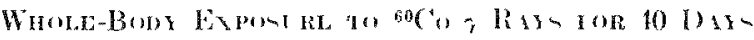

\begin{tabular}{|c|c|c|c|}
\hline & \multirow{3}{*}{ No. dogs } & \multicolumn{2}{|c|}{$\begin{array}{l}\text { Survival } \\
\text { time : }\end{array}$} \\
\hline & & $-\quad-$ & - \\
\hline & & Range & Mean \\
\hline Total llogm Cospowed & 40 & & \\
\hline $\begin{array}{l}\text { 1. I ailed tomurvive the forday ex- } \\
\text { penture period }\end{array}$ & 12 & $31-10$ & 38 \\
\hline 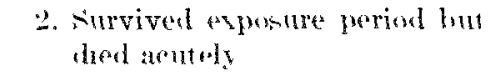 & 13 & 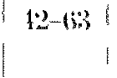 & 51 \\
\hline$\because$ Surviving & $\begin{array}{l}15 \\
163.59\end{array}$ & & \\
\hline
\end{tabular}

- All times are computed from beginzing of esponsure. Dat at tabulated to $4-15-64$.

expo-ure is a clo-e approximation of the $\mathrm{LD}_{50}$ without "wa-tel" radiation under the conditions studied. In alno-t every in-tance the prime eau-e of death was reptitemia. 


\title{
THE RESPONSE OF ANL BEAGLES TO PROTRACTED EXPOSURE TO "Co $\gamma$ RAYS AT 5 TO 35 R DAY. III. HEMATOLOGY
}

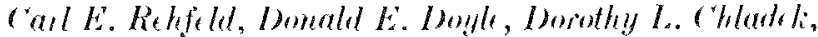 \\ Donald L. I'rarsum, and l'atrok H. I'olh
}

PLRPUNE AND MLIHOD

The respon-e of the heagle hemopoictic -ytem to continuous ${ }^{60} \mathrm{Co}$ rudiation has been recorded for 590 day- by -y-tematically onumerating the venous blood cell. The exponure rate are 3.), 17,10 , and $5 \mathrm{R} / \mathrm{day}$. Blool -amplen were obtained at either 7 - or 14-day interval depending upon dowe level and rate of

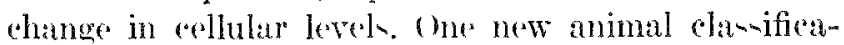
tion has been added within the last rear: this is the group of dog recovering from exposture to $3.5 \mathrm{R}$ ray for 40 days. The erythroryte and lakocyte count were obtained by clectronic rounting procelures. Thrombocytes are counted by hemocytometry, and reticulocyto are conmerated in a conventional, ritalstaining technique.

The dog irradiated at the rate of $17 \mathrm{R}$ day hav" a broud range in urvival tine and leukopoictic rem -pon-e. Failure to survive con-tant exposure at thin level of irradiation is charactorized by gradual despletion of verous cell- The two log that have survived nearly 600 days at $17 \mathrm{R}$ day have cell levels approximately equivalent to the dog expo-ed at ratem of 10 and $5 \mathrm{R}$, day.

PROARF- RIPORT

A number of -tudies hare beren conducted with mice and rat that include the -ame dose rates with an expowure time of 23 to 24 hour day." ${ }^{4}$ One of these report-11 includes the effert of 16 Rarl- day llifetime) on the hemopoidic reponse in hybrid rats. There was a transitory decreane in mononuclear cells between 1.) and 20 day and a leoser effect in the -ame period for polymorphomelear cell- In general, cell number were little changed at a dose rate of 16 Raul day orer a perion of 320 day-

The beagle is more rationensitive, in -ome reypects. than the rat and ha bown a marked hemopoietio rempone to a llowe rate of $17 \mathrm{R}$ 'day ( Figure 611 . The total leuberovte count slowly declined to a 10' nevel after 115 day of continuon radiation. The number of renou- leukoryte increa-ed gradually from a $28 \%$ to a 40 ' level between 220 and 440 days. The curve for $17 \mathrm{R}$ log- after about 170 day, is the nean value of only two dogs that have -unvived the entire period. Then two dog have maintained essentially normal red cell numbers, - o the period of decline in the mean value (Figure 62) wat cauned primarily by the non- mrviving doge.

Letukoryte in the dog-given o $R$ 'day gradually decreared in number from a $705_{0}$ level at 30 days to a $40^{\circ} ;$ level at 340 day, and have maintained at the latter pount, or somewhat higher. for about the last 250 day- 1)og sumitted to $10 \mathrm{R}$ 'day were gradnally depleted to a $20^{\circ}$ revel in about 200 days but have gradually recovered to the $40 c_{0}^{\circ}$ to $50{ }^{\circ}$ level, -tartine at 450 lay- A number of dog- have recovered atter 40 dity expo-nes at the rate of $35 \mathrm{R}$ day; 180 dar after removal from the radiation field these dogs have an atrorage of 8500 leukorytes $m^{3}$, and the trend is -till upwarel.

There in a direst relation between depression of leukocyte and dowe level- until about 115 day-; at that time, the $17 \mathrm{R}$ doge began recovery no that by 190 dav the number in both $17 \mathrm{R}$ and $10 \mathrm{R}$ dog began a parallel cours. In the period from 3.50 to 590 days, there have been approsimately equivalent number of venous leukoryter in the dog given $17 \mathrm{R}, 10 \mathrm{R}$, and ¿ $\mathrm{R}$.

Number of leukocyte- in recovery or maintenance periok have been rencribed above as percentagen of pre-irradiation lovel. Theme percentile figures must be regatrded an con-evative becaune of the rather remarkable and persiatent low normal values found in the rontrul dog. In the period from 100 days to 590 days the control ralue have varied around a level of $8,500 \mathrm{~mm}^{*}$. althoweh they had an average of over 12.000 ("all prior to caging. One would axpect that the doge in the irradiation field would also demon-trate this anvirommental effect. If allowituce is made for environmental influence, the rogs given $17 \mathrm{R}, 10 \mathrm{R}$, and 5 L all hate $50 \%^{\prime}$ to $60^{\prime}$ ' of the normal number of venou-lukorytes during the lant 200 days.

In Fieur: 62, a in Figure 61, there are two group of does at 3.5 $\mathrm{P}$ day; -ome remained in the radiation ficld to death, and other-were removed atier 40 day-; romment will be limited to thoue removed after 40 dars. The number of wythrocytes in control dogs was $8.5 \times 10^{6} \mathrm{~mm}^{3}$ before caging and have romained at $8.0 \times 10^{6} / \mathrm{mm}^{3}$-ince 100 days. Erythrocyte numbers wore mentially unohanger in log exponed at $5 \mathrm{R}^{\prime}$ day. There was a long, gradual decline and recovery period between 100 and 400 dax in dogs expored at $10 \mathrm{P}$ lay; the low point of $5.3 \times 10^{\circ} \mathrm{mm}^{3}$ was ob- 


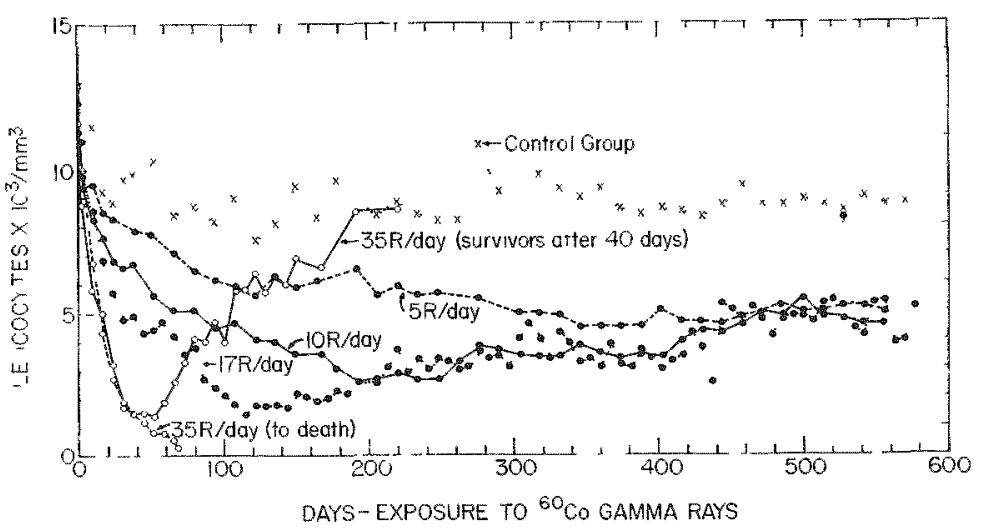

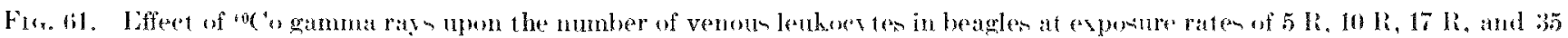

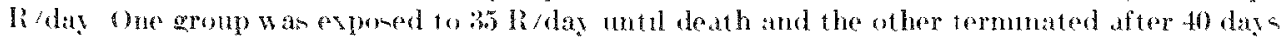

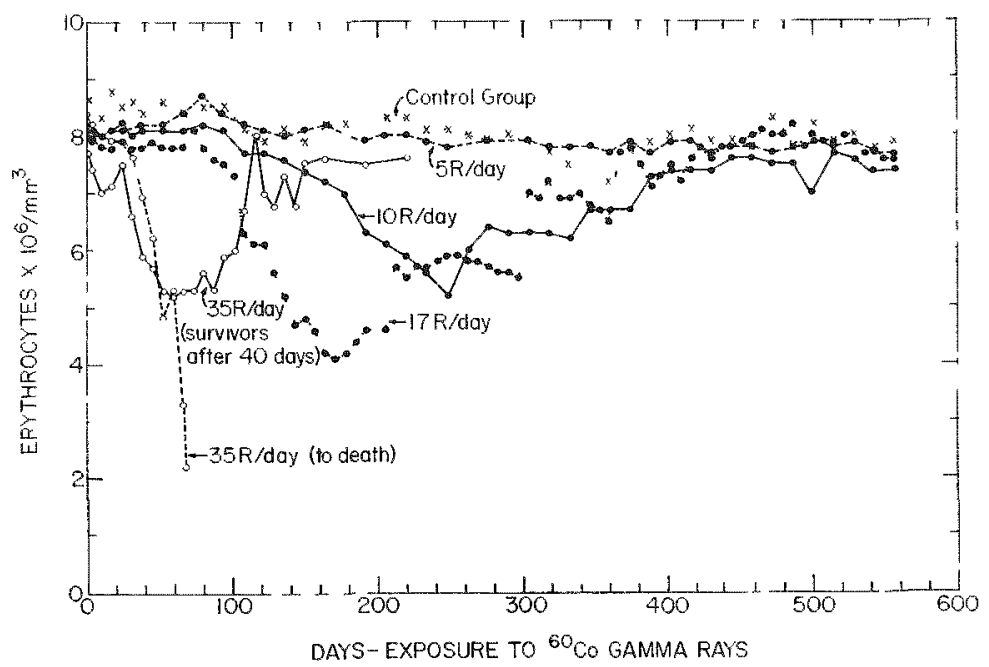

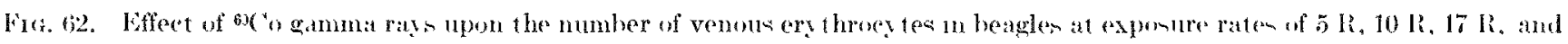

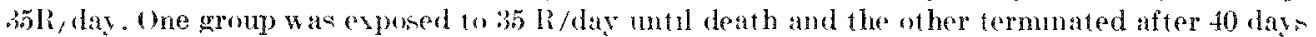

served at about 250 days. The $17 \mathrm{R}$ dogs reached at low point of 4 million cells at 170 days in a decline and rerovery period from 100 days to 370 days. The $35 \mathrm{R}$ dogs made a rapid recovery after their removal from the irradiation field and have maintained the normal range from 110 to 180 days sinee the ir removal.

Tran-ient macrocytosis (erythrocytes) was observed in three groups of dog ( Figure 63). In the $35 R$ doge, where exposure wan terminated at 40 days, thare wa- a significant increase in mean cell rolume AIC $\mathrm{Y}$ in the period 20 to 120 days after the end of expo-ure. The $17 \mathrm{R}$ doge had an increased MICV from 140 to 300 days, and the $10 \mathrm{R}$ dogs were affected between 220 and 340 days. Increaned MCV and reticulocyte rounts were not nece-arily related (Figure 63). Reticulocyte numbers raried considerably within hort periods of time (Figure 63); however, the $10 \mathrm{R}$ and is $\mathrm{R}$ dog- were quite similar in reponse. The $17 \mathrm{R}$ dog had a 100-day period at the $0.02^{\circ} \circ$ level starting about 8.5 days followed by a 1.00r, lreel between 200 and 300 days, with a repetition of this eycle during the pant year. During the first 300 day- the control valuen were generally above or equal to thowe of irradliated doga. but during the last 300 days the controls have been below or equal to the lowest values for irradiated doge.

The production of thrombocytes wits surpriningly gool by the rlog- contantly expored to level of $17 \mathrm{R}$, $10 \mathrm{R}$, and $5 \mathrm{R}$, day (Figure 64). There was a wellexpremed done re-pon-e during the first 160 lays; from that time to 320 day the production by the $17 \mathrm{R}$ and $10 \mathrm{R}$ doge wan closely parallel. In the period from 320 to 570 daty the value by $17 \mathrm{R}, 10 \mathrm{R}$, and $5 \mathrm{R}$ dog- have been parallel and steadily increasing so that they now arerage nearly 200,000 cells $/ \mathrm{mm}^{3}$. 


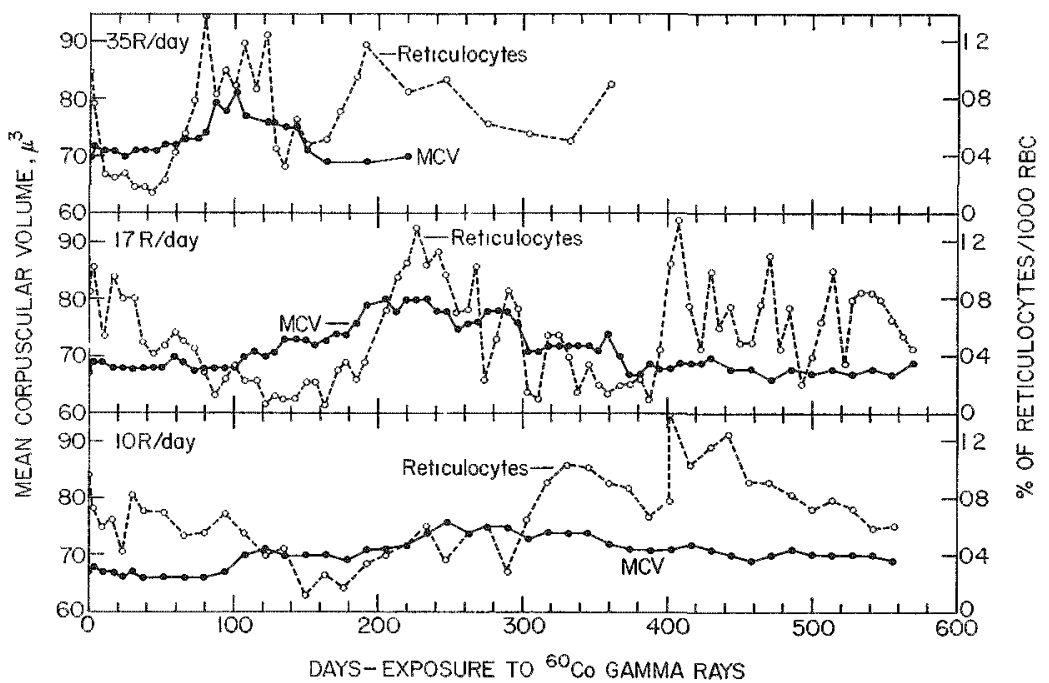

FiG. 63.- Effect of ${ }^{80} \mathrm{Co}$ gamma rays upon mean corpuseular volume (MCV) of erythroevtes and the number of retie uloeytes in venous blood in beagles surviving 10 davs exposure at $35 \mathrm{R} / \mathrm{day}$, and in other groups exposed continnously at rates of $17 \mathrm{R}$ and 10 li/day.

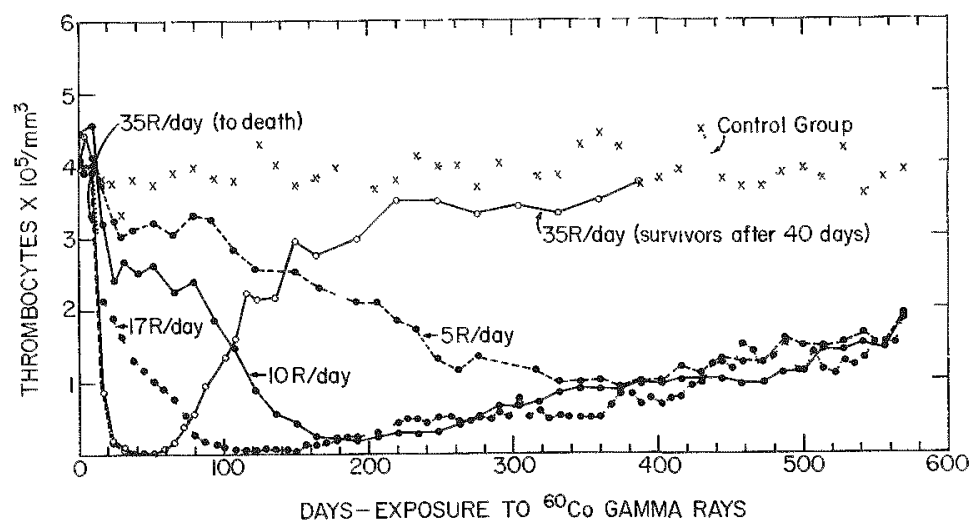

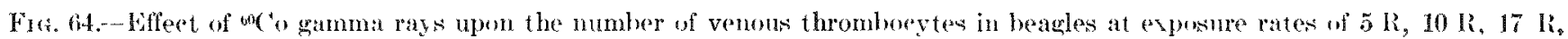
and $35 \mathrm{~L} / \mathrm{day}$. One group was expeced to.35 $\mathrm{R} / \mathrm{day}$ unt death and the ot her terminated af ter 40 dass.

The dogs exposed at the rate of $17 \mathrm{R} /$ day have a highly indivirlualistic respon-e to protracted rarliation judging from variation in subpopulations of venour leukocytes. A dog that died at 85 days had the lowest initial number of nature neutrophils $\left(.5500 \mathrm{~mm}^{3}\right)$ and an uninterrupted decline of all types of cells to death. The two dogs that dier at 115) and 122 days had more mature neutrophils initially, abortive increases in these cells and eosinophils, and a somewhat betier lymphoryte produetion. The two dogs that died at 135 and 170 days maintained mature neutrophil production at a ligher level for a longer period; both started to produce large number of atypical lymphocytes around 90 days, and one had an early abortive co-inophilia. The dog that survived for 300 day- started with les than 5000 mature neutrophils; these slowly sropped to 1000 at 11:) dar- and remained at that level until leath; it had large numbers of atypical lymphocytes initially and persistently. The two dogs -urviving through 590 days have persistently maintained comparatively high leukocyte numbers made up largely of mature and immature neutrophils.

\section{CONCLCMLN}

Protracted expowure 1590 days, $22 \mathrm{hr} /$ day $)$ of beaglen to "Co radiation at rates of $35 \mathrm{R}, 17 \mathrm{R}, 10 \mathrm{R}$, and $.5 \mathrm{R}$ 'day resulted in marked dose-responsive reduction in venous cell population during the first 200 days. During the second half of the 090 -day period the done response effect disappeared; the dogs surviving at the $17 \mathrm{R}, 10 \mathrm{R}$, and $5 \mathrm{R}$ levels produced nearly equivalent numbers of leukocytes, erythro cytes, and thrombocyter in the venous blood. In the most interesting groups, the dogs at the $17 \mathrm{R} /$ day 
level. there is a persistent, comparatively high level of neut rophilis.

\section{REFERENC'F"}

1. Lamerton, L. F.. A. H. Pontifex, N. M. Blackett, and K. Adams. Liffects of protracted irradiation on the blond forming organs of the rat. Part I: ('ontinuous exposure. Brit. $J$. Radiol. 33, 247-301 (1960).

2. Spalding, J. F., T. T. Trujillo, and P. Mr.Williams. Doses rate effect on survival of mice durine continuous $(23-24 \mathrm{hr} / \mathrm{day})$ gammatray exposures. Health Hhy. 10, 700-713 (1974).

3. Thomson, J. F., W. W. Tourtellotte, M. S. (carttar, I. S. ('os, Jr., and J. E. Wilisn. Studies on the effects of continu. ous exposure of animals to gamma radiation from cobalt tio plane sourees. $1 \mathrm{~m}$. J. Roentgenol. $69, \times 30$ sis (1953).

4. Fipton, A. C., MI. L. Randelph. and J. W. Conklin. Late of ferets of fast uentrons and gamma rays in mice as influenced by the dose rate of irradiation: Life shortening. Ratiat. Rem. 32, $493509(196 \mathrm{it})$.

\title{
THE RESPONSE OF ANL BEAGLES TO PROTRACTED EXPOSURE TO "Co $~$ RAYS AT 5 TO 35 R'DAY. IV. BACTERIOLOGIC FINDINGS
}

\author{
Patricia ('. Broman and Rirhard ('. S'imbins.
}

\section{PURPONF AND METHODS}

We have continued to colleret blood and tissues for culture from dogs exposed to continuous ${ }^{60} \mathrm{Co}$ radiation. The methods used were reported previously. (1)

\section{PROGRLA RFPORT}

All eultures of blood collecter from dogs at the time their WBC count reached either approximately $5 \times$ $10^{3}, \mathrm{~mm}^{3}$ (stage 2 ) or $2.5 \times 10^{3} \mathrm{~mm}^{3}$ lstage 3 , have been nexative. Pre-irradiation blood cultures (stage 1 ) were discont inued.

The bacteriologic findings on blood cultures collected when the IVBC count fell below $1 \times 10^{3} \mathrm{~mm}^{3}$ and or the $\operatorname{dog}$ had a trmperature $\geq 40^{\circ}$ (' listage 4), and on eultures from moribund or decedent animals (stage 5 ) are shown in Table 33 . Dogs receiving $35 \mathrm{R} /$ day generally died with bacteremia. One dog, No. 1603 , irratiated at this dose rate, was not septicemic. Blood cultures collected from this dog when its temperature was elevated were negative, and blood cultures and tissue samples collected at necropsy failed to grow hacteria. Five more dogs at the $17 \mathrm{R} /$ day exposure rate have died since our last report. Three of these were septicemic; two were not. At the $10 \mathrm{R} /$ day exposure rate, two of the nine dogs that died were septicemic, and at the $5 \mathrm{R} / \mathrm{day}$ expowre rate one of two that died was septicemic.

Is before,"11 Pasteurella multocida and $\beta$-hemolytic -treptocorei were the usual causes of bacteremia. The recovery of Escherichia coli and Clostridium perfringens from the tisunes of dearl dogs may be the result of postmortem decomposition. We suggested that the $\beta$-hemolytic streptocoeci and Pasteurella multocida orginate from the upper respiratory tract of the dogu, rather than the intestine. (1) This suggestion is strengthened by our finding that $41.8 \%$ of apparently healthy dog carry $\beta$-hemolytic streptococei in their throat $\therefore$ and 79.5$)^{\circ}$ carry $P$. multocida. ${ }^{(2)}$

\section{RFFERENCES}

1. Brennan, P. C. and R. C. Simkins. The response of heagle dogs to protracted exposure to $60 \mathrm{C}$ o $\gamma$-rays at $5.35 \mathrm{~L} / \mathrm{day}$. IV. Bacteriologir findings. Argone National Laboratory Biological and Medical liesearch Division Annual leeport, 1968. ANL-7535, pp. $15 \% 160$.

2. Brennan, P.C. and R. C. Simkins. Throat flora of a closed colony of beagle dogs. "lhis report. 


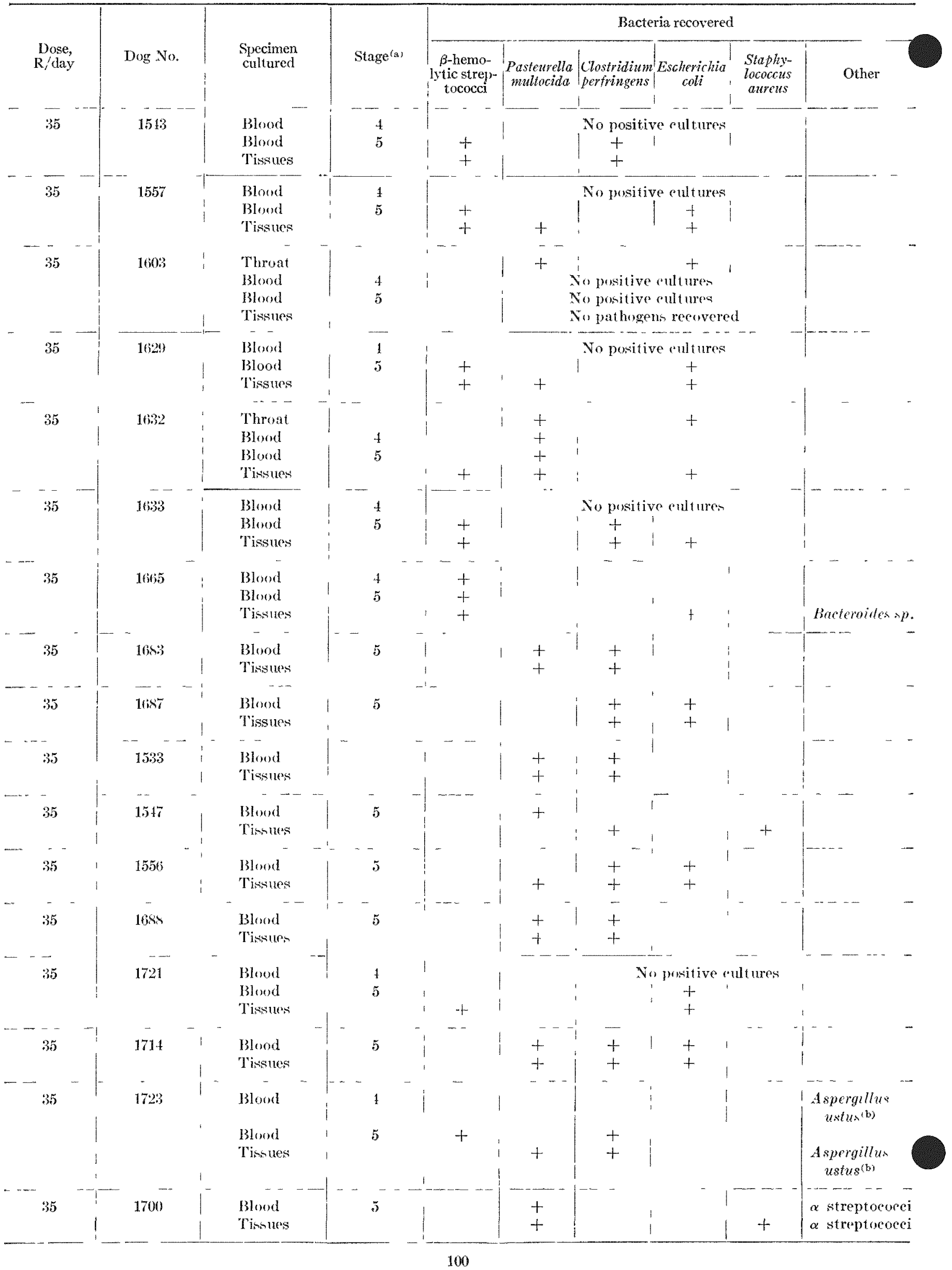


TABLL $33-$ Continut

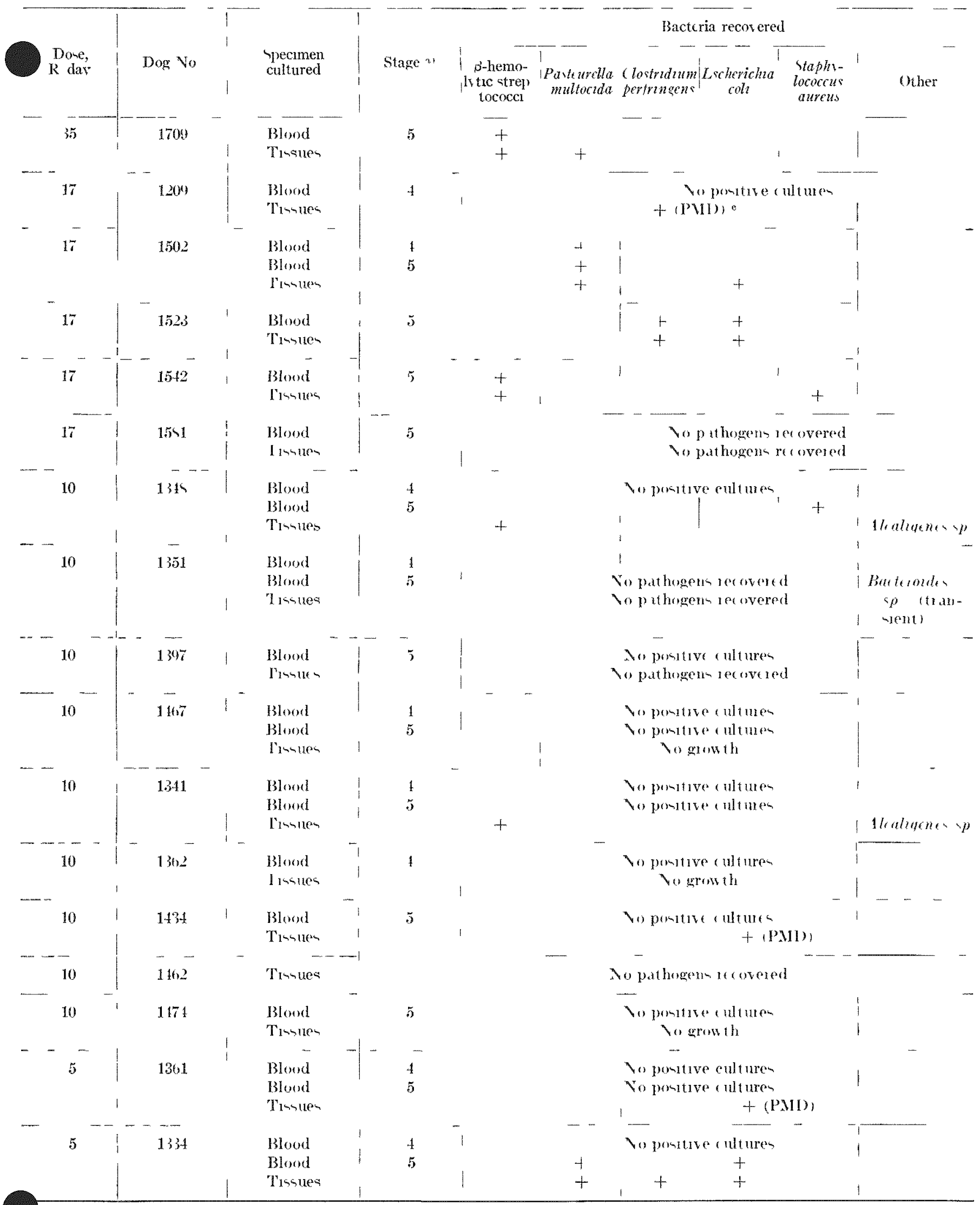

(a) Stage 1 Prenradiation blood culture Stage 2 Blood eulture taken when the WBC wa thoth $5 \times 10^{3}, \mathrm{~mm}^{3}$ stage 3 Bloud cultures taken when the $W B C^{4}$ was about $25 \times 10^{\circ} / \mathrm{mm}^{3}$, itage 4 Blood cultures then when the WBC was less than $1 \times 10 /$ inm ${ }^{3}$ and/or the temperature was $10^{\circ} \mathrm{C}$ stage 5 Blood cultures t aken when the dog was moribund or dead

(b) Assomaled with decomporng organe nat tar

(b) Postmortem decomposition 


\section{THE RESPONSE OF ANL BEAGLES TO PROTRACTED EXPOSURE TO ${ }^{\circ 0} \mathrm{Co} \gamma$ RAYS AT 5 TO 35 R DAY. V. PATHOLOGY}

Thomas E. Frits, Ruth ('. Zeman, David V. Tollt, and John W'. Hilliams:

PLRPO

During the past year, we have continued examinations and collection of specimens and data according to protocols described previonsly. (1)

PROGRESS REPORT

The death of dogs in the experiment during the past year has supported our previous prognosis, that main cause of death after protracted irradiation would fall into two categories: septicemia and anemia." septicemia is the main cause of the earlier death which occur at the higher doses, while anemia accounts for deaths at longer times in the lower dose group . The incidence of septicemic deaths is discused in another portion of this report. ${ }^{(2)}$

The most important finding during the past year has been two cases of myeloproliferative disease in log irradiated at $10 \mathrm{R} /$ day. These dogs died after 383 and 504 days of $\gamma$-ray exposure. The lesions were imilar in both dogs, and included splenomegaly, hemorrhagic lymphadenopathy, and edema of rarious tisuen, including the lungs and hody cavities. There were also seattered petechial and ecchymotic hemorrhages of the gastrointestinal ract. Both decedents showed a progressive anemia before death but had neither leukemia nor leukocytosis. Preliminary examination of postmortem marrow samples revealed a marked increase in the juvenile, or undifferentiated, forms of the myeloid element. The microscopic timsue changes in these two dogs included proliferation of jurenile or undifferentiated myeloid cells in the liver, spleen, and lymph nodes. These histopathologic changes are similar to thome previously described in dogs with developing myeloproliferative disorders after intravenous single doses of ${ }^{444} \mathrm{Ce}$ or protracted whole-body irrarliation given for 100 days. ${ }^{(3,4)}$

\section{REFLRENCES}

1. Fritz, T. E., R. ('. Zeman, I). V. 'Trulle, and J. W. Williams. "The response of beagle dogs to protracted exposure to "oc'o $\gamma$-rays at 5 to $35 \mathrm{R} / \mathrm{day} \mathrm{V}$. Pathology. Argonne National Isaboratory Biological and Medical Research Division Annual Report, 196s. ANL.7535, p. 161.

2. Brennan, P. C. and R. C. Simkins. The response of beagle dogs to protracted exposure to boco $\gamma$-rays at 5 to $35 \mathrm{li} / \mathrm{day}$. IV. Bareteriologic findings. This report.

3. Fritz, T. H., W. I'. Norris, C. F. Rehfeld, and C. M. Poole. Myeloproliferative disease in beagle dogs given protracted whole-body irradiation or single doses of cerium-144. Argonne National Laboratory Biological and Medieal Researeh Division Amnual theport, 1968. ANT,-7535, pp. 162-163.

4. Frit $z$, T. E.. W. P. Norris, C. E. Rehfeld, and C. M. Poole. Myeloproliferative diseane in beagle dogs given protrarted whole-bods irradiation or single doses of cerium-144. 1 y yeloproliferative Disorders of Animals and Man, Ed. W. J. Clarke and E. B. How ard. I. S. Atomic Energy Commission. Washington, D. ("., in press.

\section{THE DEPENDENCE OF ${ }^{137} \mathrm{C} s$ RETENTION ON AGE IN THE JUVENILE BEAGLE DOG}

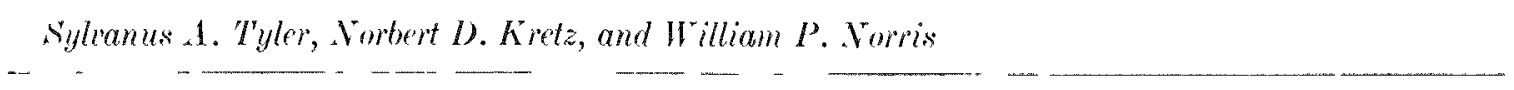

PL RPOSE ANI) METHODS

The retention of ${ }^{137} \mathrm{C} s$ by various mammals is reported to be related to body size.(1) Other studies ${ }^{(2)}$ of 137 ( 1 - retention lead to the conclusion that young mice excrete ${ }^{137}$ C's faster than old mice. We have inrestigated this dependency on age by selecting, at experimental subject, young, growing dogs from our colon of beagles. Our specific objective is to determine and cuantitatively ansess the influence of the gros weight of the dog on the retention of 137 ( $x$. Then we propose to attempt an answer to the question: which is the dominant factor in the retention of ${ }^{137} \mathrm{C}$ 's-age or body weight?

Cesium-137 retention at various times after injection was determined for individual dogs ranging from 61 to 5xis day of age at injection. These determinationm were made by periodic measurements of whole-body gammaray activity.

PROGRESA REPORT

The retention of ${ }^{137} \mathrm{C} / \mathrm{s}$ has bren followed in dogs injected at 133 different ages. Representative portions of this data are presented in Figure 65. These data show 1) that the specific rate of change in retention, $(1 R) \cdot(d R d t)$, decreases in absolute value as the age of the dog increases; and 2) that the specific rate of change in ${ }^{137} \mathrm{C}$ s retention approachen a constant val $(p)$ as the dog reaches maturity.

It is known from descriptions of grow th based on the Gompertz function as a model:(3) that 1) the specific 
atte of change in weight, $\left(1, W^{\circ}\right) \cdot\left(d H^{\circ}, d t\right)$, decreites an the age of the animal increases and 2 ) the specific rate of change in weight approaches zero as the animal reaches maturity. These qualitative similarities led to the development of a model ${ }^{(4)}$ for ${ }^{137}$ ( $s$ retention based on the (iompertz function. The retention of ${ }^{137} \mathrm{C} S \mathrm{~s}$ in a doginjected at age $a, R_{a} t$, is mathematically expmered ati

$R_{n, i}=R_{u, 0} \operatorname{Exp}\left\{-p t-\frac{1_{a, 0}}{\alpha}[1-\operatorname{Exp}(-\alpha t)\}\right.$,

where $d_{a, 0}+p=(1 R) \cdot(d R d t)$, the specific rate of change in retention at time of injection;

$p=$ The constant value to which the speecific rate of change in retention decars;

$d_{n, 1}=$ That part of the specific rate of change in retention at injection which is decaving:

$\alpha=$ The constant, proportional rate at which $1_{1,0}$ is decaying with age;

$R_{u, 11}=$ seale furtor:

$t=$ Time after injection.

As -tated, the rate $p$ is approached when the dog reaches maturity. From a practical point of view, maturity is reached at about :300 days of agese. The retention data post-300 das of age was fit with a cingle exponential function and the rate constant $p$ was determined. With $p$ determined, the parametern $A_{a, n}, \alpha$, and $R_{n, \text { n }}$ of Equation (1) were estimated by an iterative least cquaren procedure for the retention data at each age. The eompatibility of the model with retention datit in exhibited in IFigure 6.;.

With a mathematical dencription of 1 (n) ( retention in goung growing dogs, it is posible to determine whether grow th eorrelates with 137 ( 5 retention. In a previous report by Tyler and Norrio, was used to deseribe the areretion of weight by growing doge in this colony. The model uned for this analysio is mathematically expremed an:

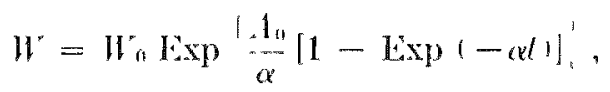

where $\|^{*}=$ Borls weight,

$W_{n}=$ Body weight at birth,

$s_{11}=\left(1 W^{*}\right) \cdot\left(d W^{*}, d t\right) \mid$, the serecilic rate of change in weright at birth,

$\alpha=$ The contant proportional rate at whioh $I_{1}$ is decan ing with age,

$t=$ The age of the animal.

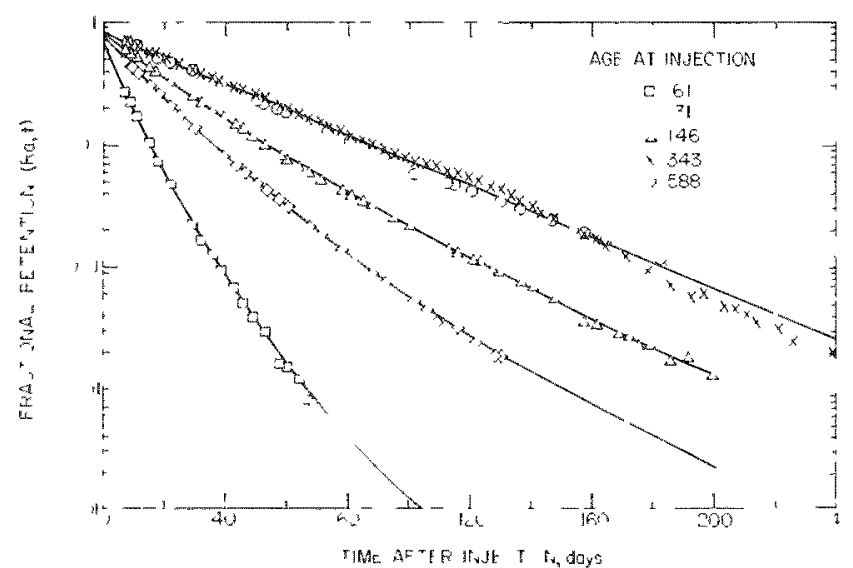

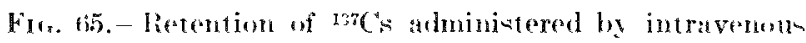
injection to beagles of different agess. ("urves are draw $n$ baned

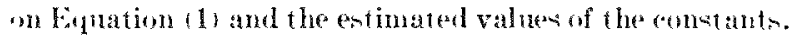

A comparion of the values of the 13 (a) ${ }^{2}$ retention parameter with the values of the eorreponding grow the parameters thows that the value of $\alpha$ for tat (") retention is the sames as the value of $\alpha$ for grow th. The comparison alos shows that the values for $I_{a, 0}$ and $f_{u}$ maintain a com-tant ratio at all agen.

GonThision

Contants of the model, derived from ${ }^{1.77}$ ( $)$ retention, reveal that the -pecitic rate of change of retention is at continuously decrea-ing function of age and is not influenced by the particular age at injection. ('omparian of the retention model and the gron th model demon-trates the high degree of correlation between

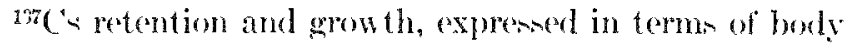
weight.

\section{BHA LREMCES}

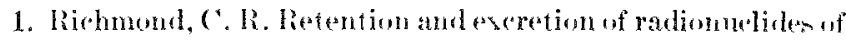
the alkali metals by five mammalian species. Lam Mamom

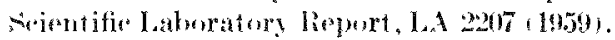

2. Miller, C. li. A.J. Finkel, and X. B. Wright wat selention in mice of different ages. Proe. Soe. Exp. Biol. Ved. 128,

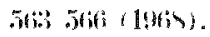

3. Laird, A. K., S. A. Tyler, and A. H. Batapon. H) namia ai

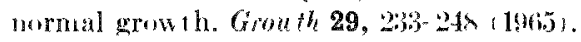

4. Tyler, s. A.. N. D. Kretz, and W. P. Norris. The dependence uf ${ }^{37} \mathrm{Cs}$ retent ion on atge in the fet al and juvenile beagle dog. Proe. Ninth Ann. Hanford semp. on Radiation Boologe, 1969 , in press.

5. Tyler, s. A. and W. P. Norris, An algorithm for selereling aceeptable animals from a colong of heagles. firowth 32 , $20.5-50 \% 3$, $1941 \times 1$. 


\title{
Characterization of the ANL Beagle
}

\section{STUDIES OF THE PHYSIOLOGY OF THE BEAGLE THYROID GLAND. INTRODUCTION}

\author{
$\|^{\circ}$ lllam IP. Sorris
}

Bufore -tulying the ruponse of the beagle thyroid gland to ionizing radiation, we have mide preliminary "xploration - f the physiologic properties of the gland. Thi work has resulted in certain olpervations and roncluslom. cither new or previounly only partially underatood:

1. The hesele thyroid in highly responsive to change- in dietary iodine. Such re-ponse is accompanied by large changes in all aspects of ${ }^{131} \mathrm{I}$ metaboliom lif the thyroid. 'The reponse maty proceed for a long a one year before a new -tearly state is reached.

2. Irmphocytic thyroiditio in an inherited dinca-e of the thyroid in the beagle, much as it seems to be in mian.

3. Traces tudien using 131 allow nondentruetive irlentification of colony heagles with and without lymphorytic thy roiditis.

Thi- work is dencribed in more detail in the thres report that follow. Beraus they illentify a large, notmal repon-ivenem to a simple timulu-change in dietary indine-ihey provide a strong basis for furthex -tudy of thyroin phy-iology and aho for work with the irradiated thrroid gland. Further, they allow the work to be done using dog with either normal or ahnomal thypoirl tisulte.

\section{STUDIES OF THE PHYSIOLOGY OF THE BEAGLE THYROID GLAND. I. THE CYCLE OF ACCOMMODATION TO RESTRICTED DIETARY IODINE IN THE THYROID GLAND OF THE ANL BEAGLE DOG}

\author{
Willume P. Sorris, Thoman E. Fhts, and Jame" 1. Taylor"
}

PL RPUL A AD MHIHOD

Publi-hed recommendation for adequate dietary allowances in doges' include, -eemingly, unnecenarily large amount of iodine. Becaune such recommendatum-influence the componition of commercial dog food. the arerage dog maintained on commercial diet exhibit a very low $\left(\sim 1\right.$ to $\left.s^{\prime}\right)$ thyroirlal uptake of tent dowes of ${ }^{131}$ T. Such low thyroidal uptake make certain experimental work with ${ }^{13 t} \mathrm{I}$ diffienlt or impractial.

Young arlult beagles, previously fed a commercial diet entimaterl to provide at least $500 \mathrm{mg} \mathrm{I}^{-} /$/ $10 \mathrm{~g}$ 'day, were -witched to at semi-ynthetic diet (made of casein, -ucrowe cotton ered oil, and purified vitamins and mintral-s containing $25 \mu \mathrm{g} \mathrm{I}^{-} 100 \mathrm{~g}$. Mea-urementof food intake showed the total dietary intake of iodiele to range from 50 to $75 \mu \mathrm{g}$ ' $\mathrm{dog}$ 'day.

These dog- were given test dose of ${ }^{131} \mathrm{I}$ at interval over a period of 6.51 days to mea-ure thyroidal uptake of ${ }^{131} I$ and its suberuent rate of los from the gland. After thene meanurement, the doge were killed repially to examine thyroid, pituitary, and adrenal tinene. Weight of the endocrine gland were re-

\footnotetext{
* Cham. Pfizer a Co, Groton, Comn
}

corded. Result of thene obervation were compared with -milar data from dog in the regular colony eating either the standard commereial diet or the -ame -mi-ynthetic diet rontaining $\mathrm{I}^{-}$equivalent to a dintary intake of $450 \mu \mathrm{g} \mathrm{I} \mathrm{I}^{-}$'log dar.

PROMRES REPOHT

The mieronopic appestrance of the normal beate thyrois gland is shown in Figure 66. During the firt 268 day of restricted iodide intake, the thyroid gland became increa-ingly hyperplastic and hypertrophic (Figure 67). Hyperpla-ia and hypertrophy were correlated with a large increase in the thyroidal uptake of test do-e of ${ }^{131}$ I. During the period of hyperplatia, the rate of low of ${ }^{131} \mathrm{I}$ from the thyroid gland herame increa-ingly more rapid. By 268 dayafter initiation of the low iodide diet, the biological half-time $\left(\mathrm{BT}_{1} \mathrm{2}^{2}\right)$ of iodine in the thyroid gland had deeceated to 3.9 day-from the pre-experimental ralue of 12.5 day- These data are presented in Table 34 and graphically demon-trated in Figure 68.

After 368 dity of restricted iodile intake, the thyroid glands were inroluted and had an ementially normal hi-tologic appearanee. The size and weight of the thyroids were, by this time, about three times 


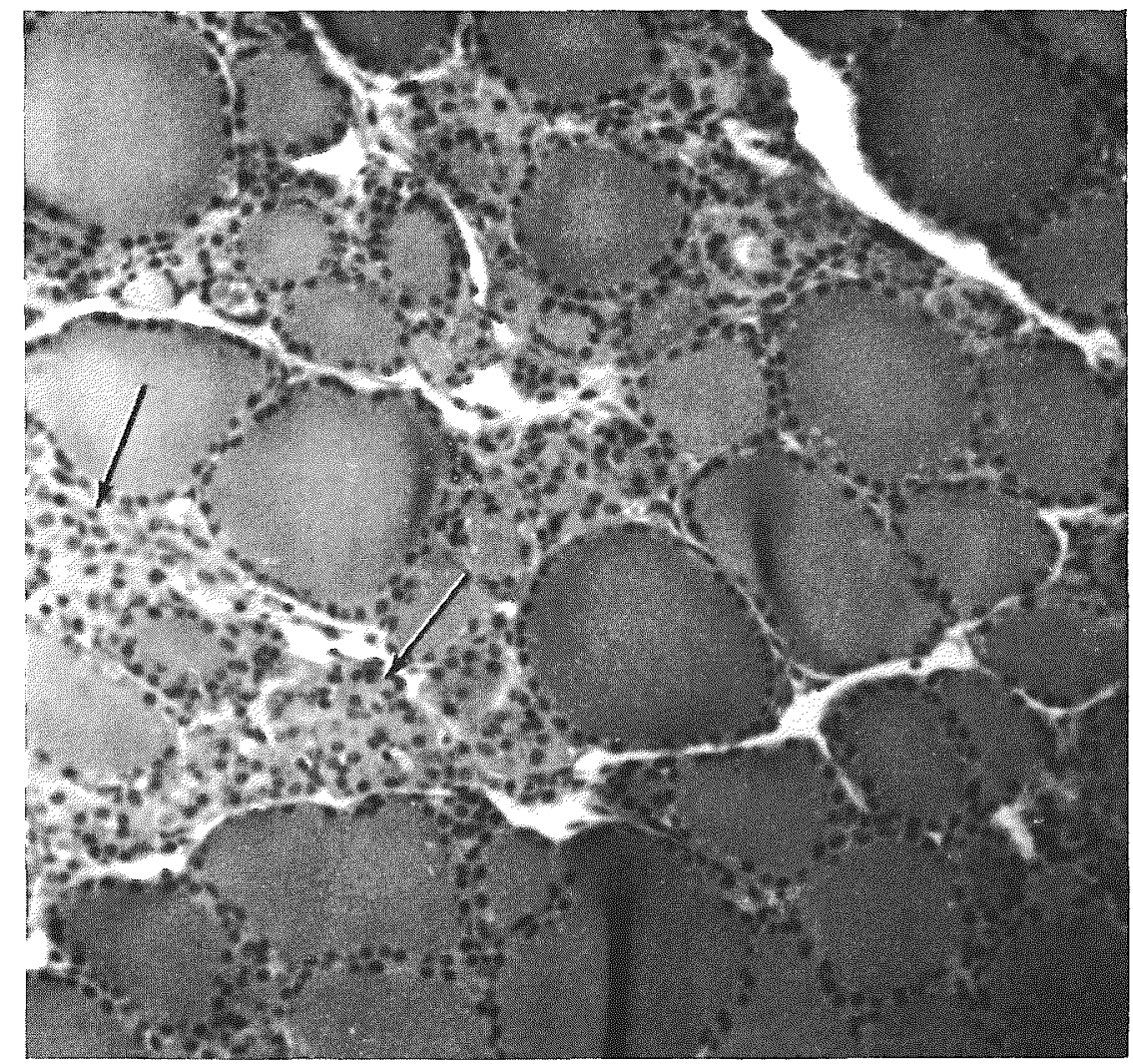

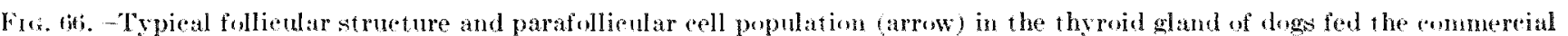
ration. Hematoxylin and eosin strain.

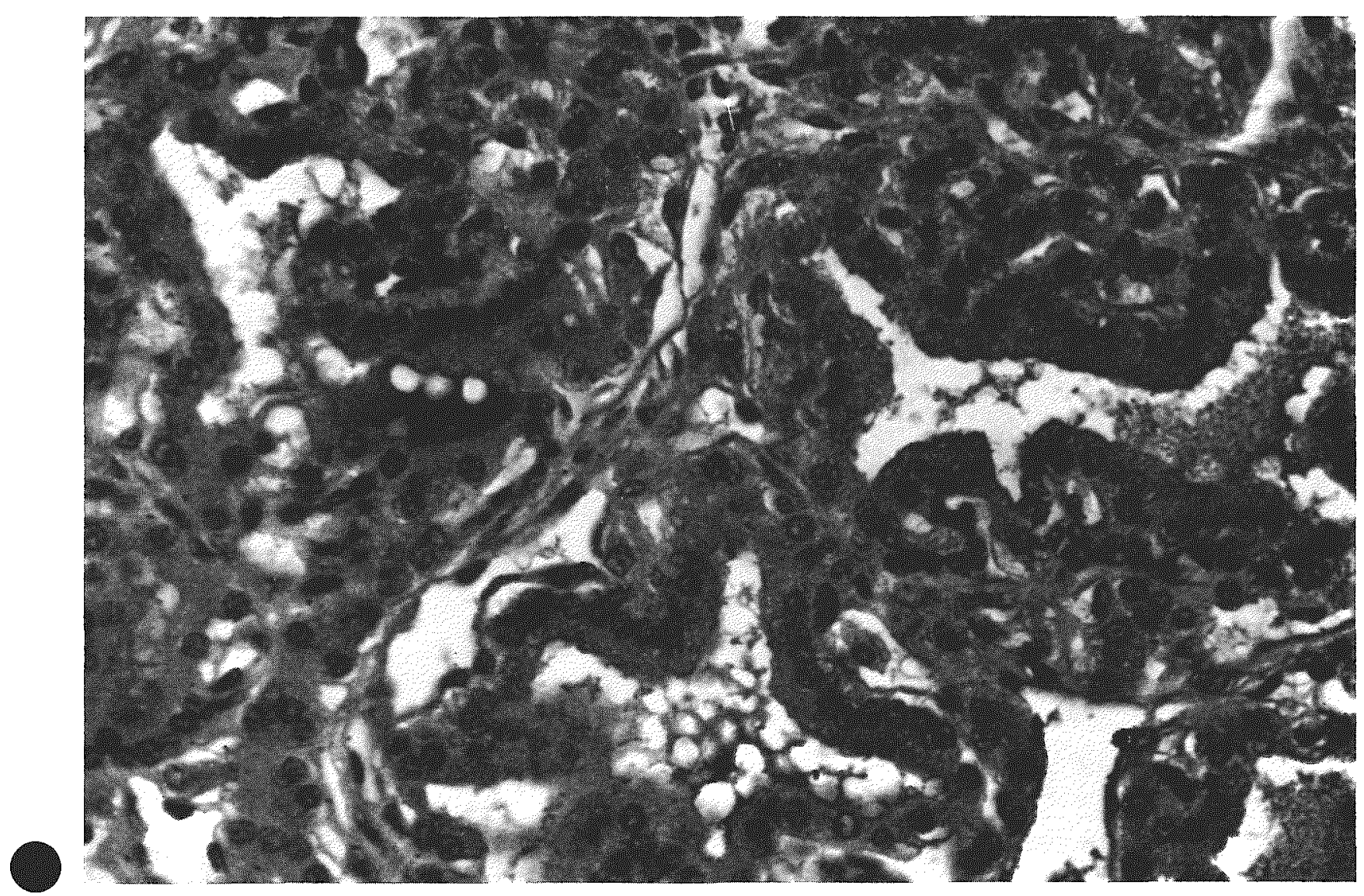

Fra. 67. - Thyroid gland of a beagle dog given the low-iodide diet for $26 \mathrm{~s}$ days. Nearly complete loss of colloid and severe folding of the follieular epithelium are shown. Hematoxylin and eosin stain. 


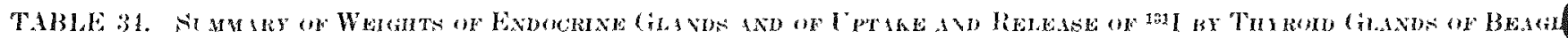

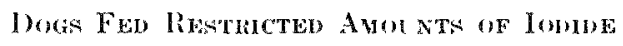

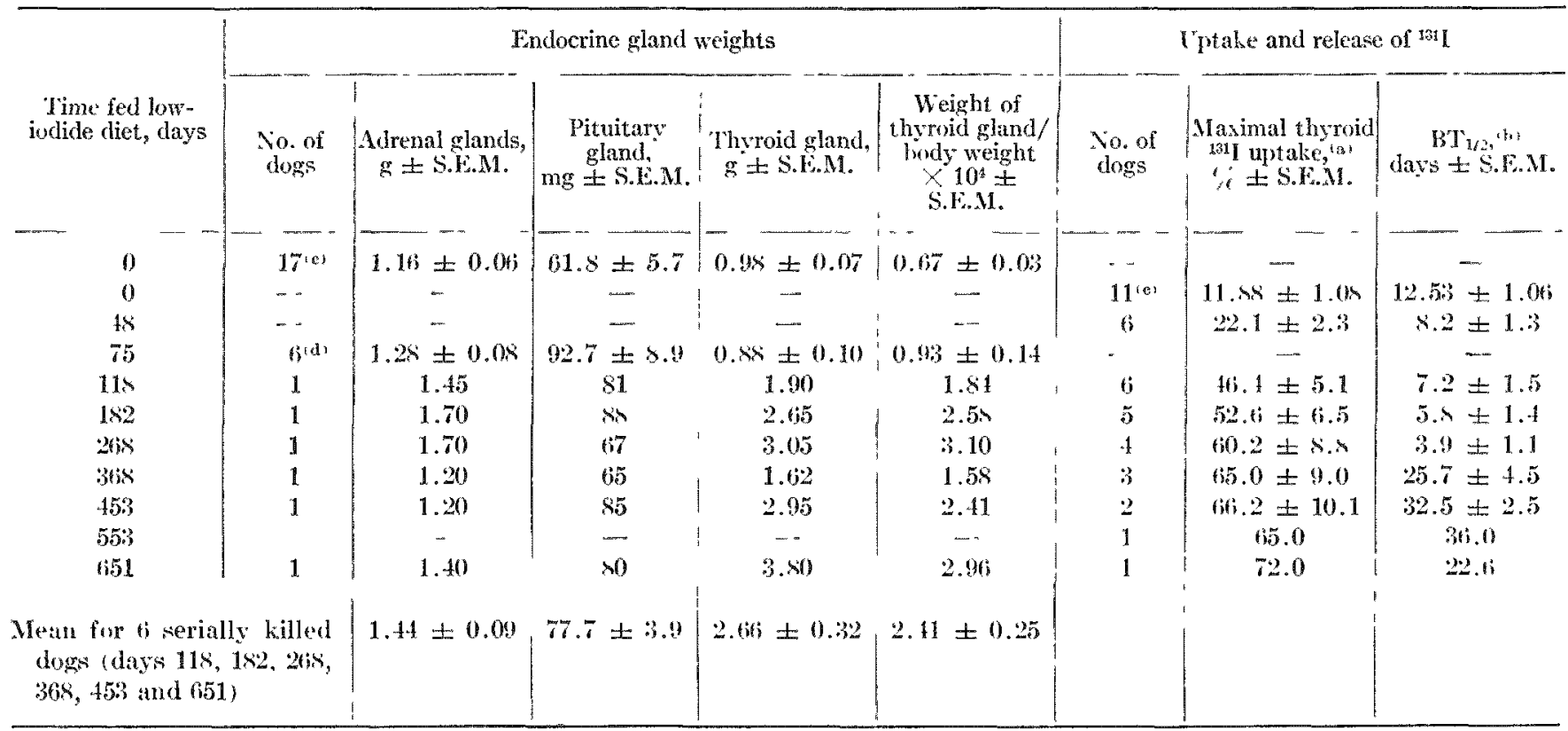

is Where dogs were serially killed, ${ }^{131}$ I for this test was administered 14 dats before they were hilled.

ab Biologieal half time of $\mathrm{j}$ dine in thyoid glands computed from serial measurements of 131 in the gland between 1 and 11 days after ${ }^{31}$ I was intravenously administered.

ies These data are from untreated dogs in this colong fed the pommereial ration. Woights of enderine glands were from 17 dogs averaging 475 (befweren 322 and 550 ) dars of age. See lieference 2 for ${ }^{171}$ I uptahe dat a in colony dogs.

sh These dogs were totally thyroidectomized after being given the diet with restricted indide content for 75 dars.

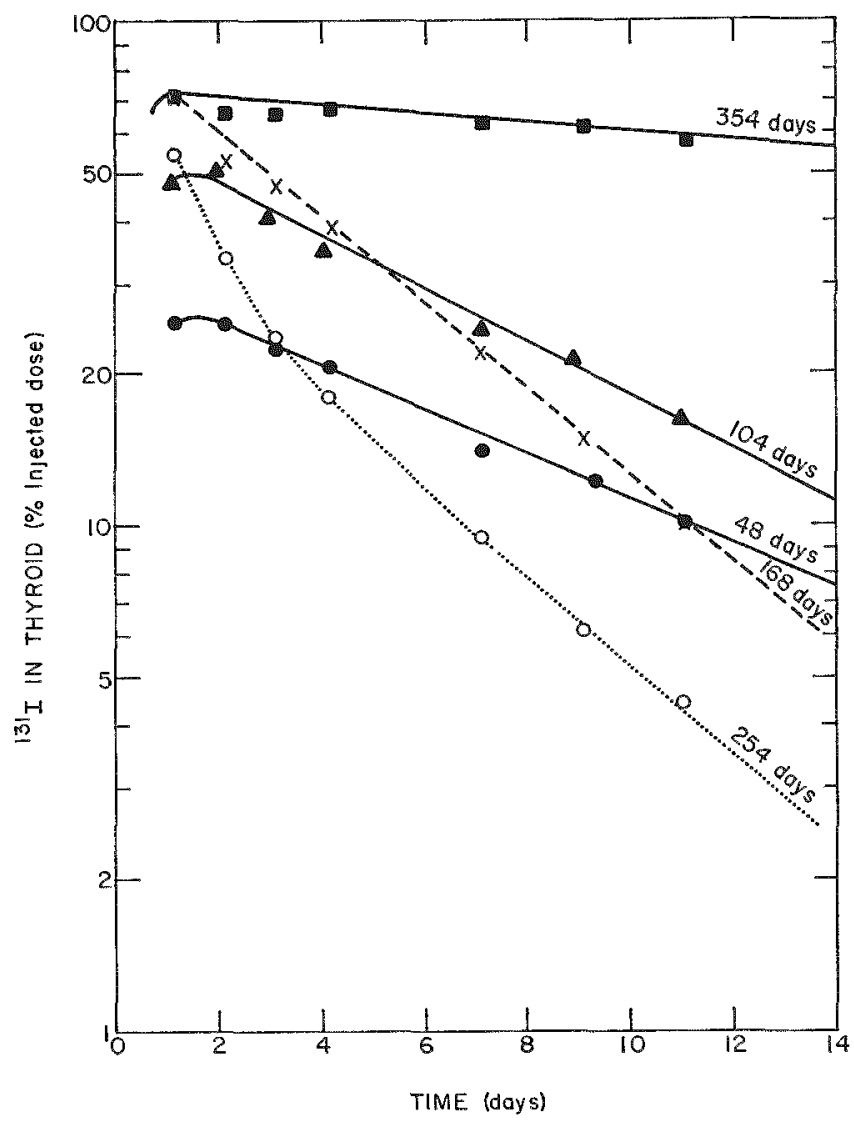

normal. No changes in the pituitary or adrenal glands wert" noted. Thyroid involution correlated with an abrupt increase in the $\mathrm{BT}_{1 / 2}$ of iodine in the gland to ahout 30 days.

This is the first report of the experimental demonstration of the complete eycle of thyroid accommodation to reduced iodine intake. During this evele, there are major changes in all a-pects of thyroidal iodine metabolism measured by test doses of ${ }^{131} \mathrm{I}$, as well as in hi-tologir strueture of the gland. In this instance the rycle was rompleted in about one year.

\section{REFLHEN'TS}

1. National liesearch Conneil: Resommended loetary . Allowances, Th Revised Fil. Fond and Nutrition Board, Natl. lead. Ni., Natl, Res. Conme. Puh. No. 1hit, Washingtom, 1). (.. 1968.

2. Toft, R. J., W. P. Norris, and S. A. Ty ler. Retention of radinartive iodine in dogs. Arenne National Laburatory Bion logieal and Mledieal Researeh bivision Aunual Report. 196h.

Frr. tix. Progressive changes in k,1 metalodism of an 11monthold beagle dog after a large reduetion in the iodide content of the diet. Measurements are of the in rico content of the thyroid gland vs. lime after intravenous adninistration o trarer doses. Repetitive tests nere initiated in the same do

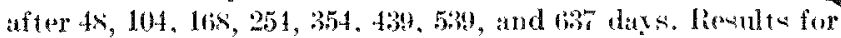
139, 539, and 637 dass were very similar to those for 354 dats and are omited for the sake of elarity. 

FAMILIAL INCIDENCE OF THYROIDITIS IN A CLOSED BEAGLE COLONY

\author{
Thomas: E. Evits, Ruthr'. Zeman, and Ilar R. Zelle
}

\section{PIRPOSE A MD METHOD}

The orecurrence of thyroiditi, in the Argonme besule colony ha- betu reported."1, a) During thr past year, our effort- to refine the incitlence, pathology, and heredity arpects of the disea-e have continued. Specimen- of thyroid timene from 401 log of all age and their perligrees have been examined.

\section{PROMRE- RI PORE AND CONCLUGIONS}

"lhyroiditis occurs spontaneously in the colony with an incidence approaching $20 \%$ in untreated animal orer one year of age (Table 351. The disease in dog over 400 iars of age in genetically influenced as determinel by chi-cquare test of the ancest ral componition of each animal (Table 36 ). The incidence inreane, with increasing degres of relatednes to thres -ibline progenitor of a partially inbred line. A l'Table 36 ), which comprives a major portion of the colony. 'The pathologie changes in the thyroids eanes neither' clinieal signs nor enlargement of the gland, and the - verity of the lesions is not related to age. 'Th's lesion do not appear to be progrensive in severity or to reult in atrophy or fibro-is of the gland. Althongh the hi-tologic feature and total incidence of thyroiditis in arbult dog given lethal or near-lethal dowe of ionizing raliation i- di-tinctly different from thyodidti in unirrarliated log wable 3.51 , its incillence in aendirally influenced in the amo manuer as in unirradiated adult Tablo 36). Ixmphocytic lenion aho orecur in the throvin of $5.5 \%$ of stillborn puppies (Table 3.5), but are difierent from tho-e in adult dogIn stillborn puppien, the incidence is not genetirally influences as it is in the arlult dogs.

I report deneribing thi- work is in prese. 63

\section{RCH FRENCLS}

1. Frit/, T. L., W. P'. Vorrin, and R. (" Zeman, Ths roidit in in at (a)eded colony of beaglem. Ireonne National Laboratory Bio-

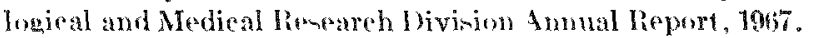
ANI. $7004,1 p \mathrm{p}, 271-2 \% 4$.

2. Fritz, T. F, W. P. Norrio, N. D. Kret $/$, R. C. Ztman, E. Witebmy, and J. II. Kite. "Thy roiditis in at closed colongy of beagle dogs: Nondestruet ive methods for diagnosis. Argonne Natonal Laboratory Biological and Medieal leweareh I livision Anumal heport, 19m 1N1-7595. pp. 173-174.

3. Fritz, T' L., R. C. Zeman, and M. li. Zelle. Pathologa and familial incidence of throiditis in alowed beagle collons. Exp. Hol. Pathol, in press.

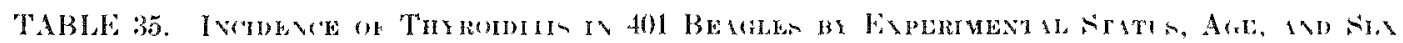

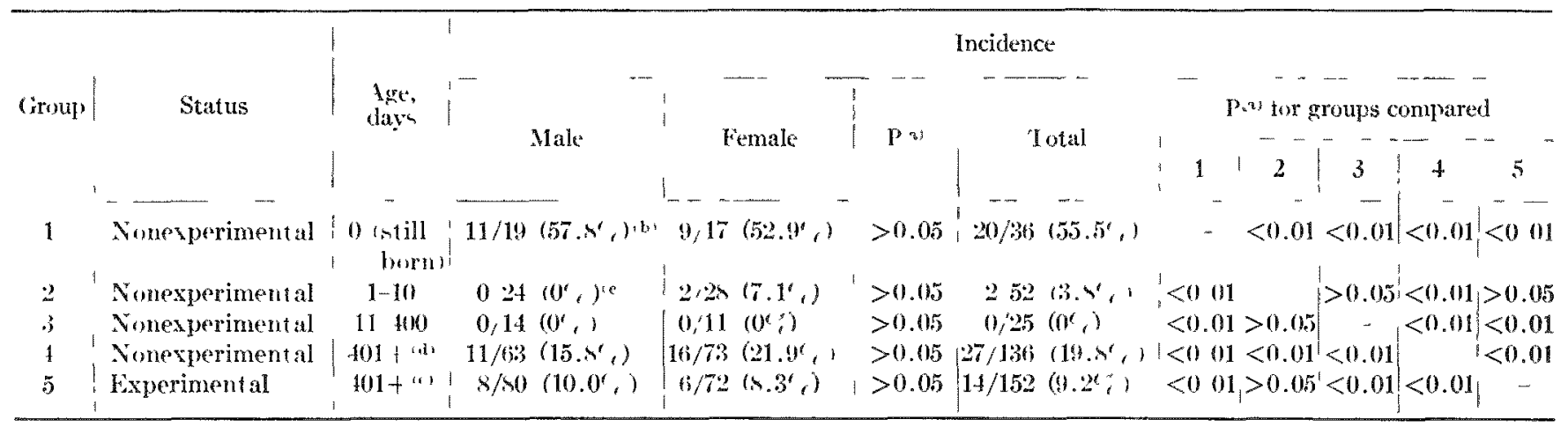

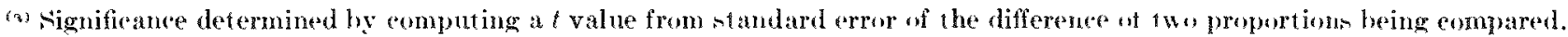

(b. No. positive No. examined.

"For statistical analssis 0 incilence was replaced by 0.5 .

a) $M e a n+S . E,=130 k \pm \$ 2$

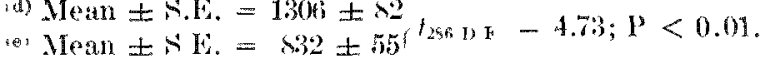




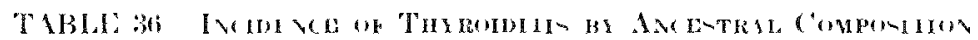

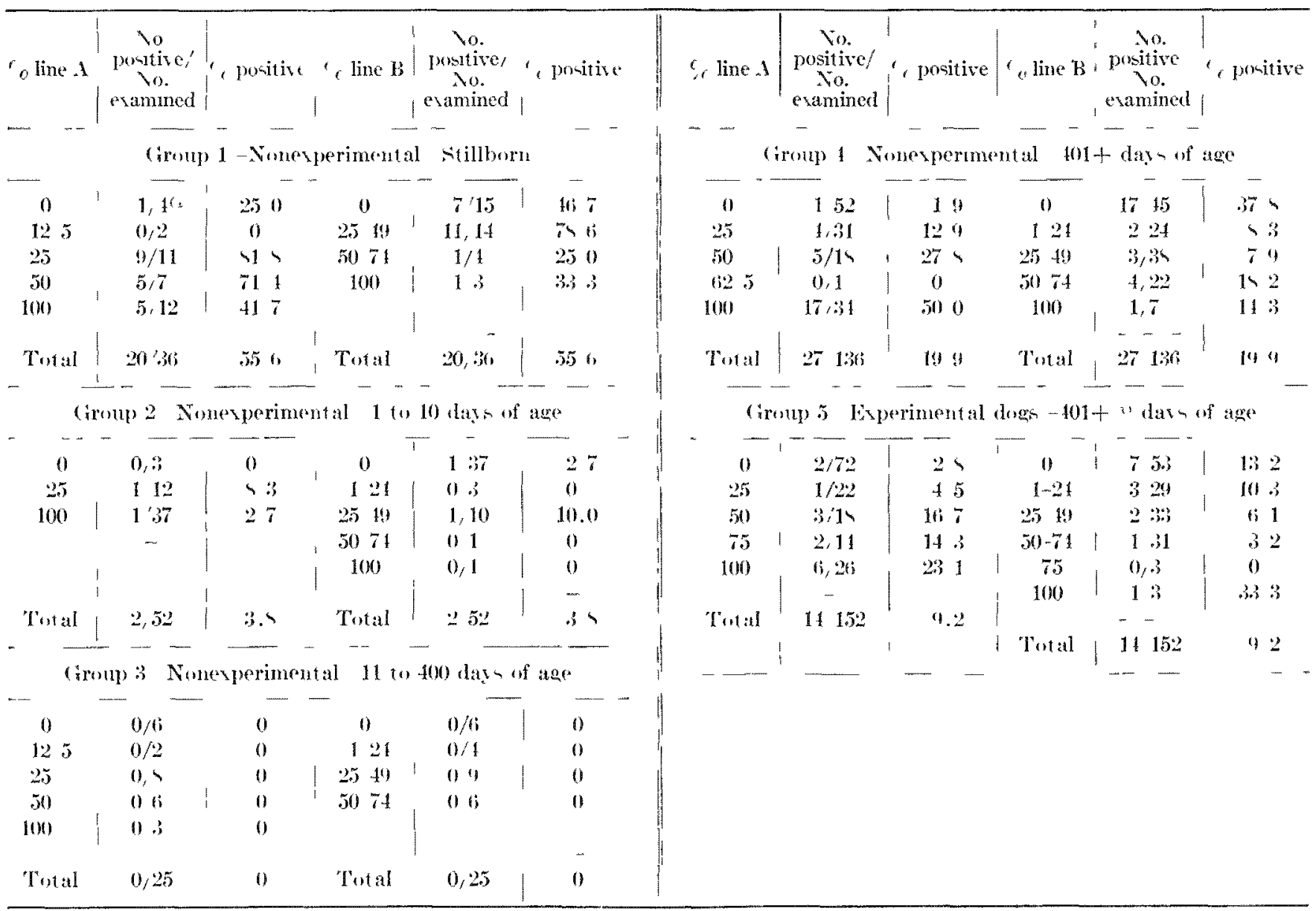

" Fileven doges were between its and sig days of age

\section{STUDIES OF THE PHYSIOLOGY OF THE BEAGLE THYROID GLAND. III. INFLUENCE OF THYROIDITIS ON BIOLOGICAL HALF-TIME OF 131/ IN THE ANL BEAGLE DOG}

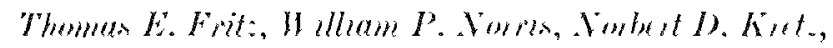
Ruth t'. Zeman, and ohotive II Illatm.

$-\cdots$

PI RPUL ADD METHOD-

Thyroiditi- recognized an at diseane entity in our beasle colony, han been -tudied in thi- laboratory for two year-i" " Becaute this drease producen no clinieal sigur, a nondestructive methor of diasnowis in highly de-irable. Thi- culject wan treated in lant year's report.'21

Sis dos- were selected for examination on the basis of their pedigree a being likely eandidate for thyroilitis and were injected with $20 \mu \mathrm{Ci}$ of ${ }^{131} \mathrm{I}$. Their thyroid artivity wan measured for 30 days, or until it could no longer be detected.

-imilarly, the six dog reporterl lat year, each of which had had one thyroid removed 13 months earlier.

were alo injected with $20 \mu \mathrm{C}$ ' $\mathrm{i}$ of ${ }^{131} \mathrm{I}$, and the thyroid aretivity wan followed. At the end of the 30-day perionl. one thyroid gland wa removed from each of the 12 dog-: in the care of the second 6 , the second lobe wa- removed. Section, were prepared by the paraffin methor for microrcopic cxamination. When changes of thyroilliti- were olnerved they were scored an to their neverity aceorling to the method of Beierwaltes and Nishiyama. ${ }^{(3)}$

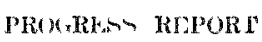

Table 37 summarizen the renult of tests conducted on the twelve dog- The results of the first te-t on 6 of the doge were reported lant year, ${ }^{(2)}$ but are included 


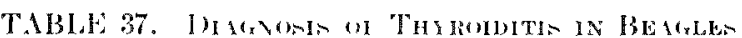

\begin{tabular}{|c|c|c|c|c|c|c|}
\hline $\begin{array}{l}\text { Dog } \\
\text { No. }\end{array}$ & Sex & Age & $\begin{array}{l}\text { I hyrruid } \\
\text { weight. g }\end{array}$ & $\begin{array}{l}\operatorname{Hist}(01- \\
\operatorname{ogg} y^{(8)}\end{array}$ & $\begin{array}{l}\text { Mas. } \\
\text { uptalee, } \\
\text { inj. dose? }\end{array}$ & $\begin{array}{c}B T_{12,} \\
\text { days }\end{array}$ \\
\hline
\end{tabular}

First $1^{21}$ I tracer f(est (left thyroid gland)

\begin{tabular}{|c|c|c|c|c|c|c|c|c|}
\hline \multirow[b]{2}{*}{0193} & -1 & -.. & & & $-\cdots$ & \multirow[b]{2}{*}{1} & \multirow[b]{2}{*}{$1 . x$} & \multirow[b]{2}{*}{1311} \\
\hline & $\mathrm{M}$ & $2 \pi 75$ & $0 . \ln i$ & & 0 & & & \\
\hline 0215 & $\mathrm{M}$ & 2759 & 0.101 & & 0 & & 20 & 13.6 \\
\hline 10:31 & $M I$ & $\$ 1.51$ & $0.200)$ & & $x+$ & & & 1.2 \\
\hline 0 & F & 30000 & 0.370 & & $3+$ & & 0.1 & 1.0 \\
\hline $010 \%$ & $\mathrm{MI}$ & 2780 & 01.432 & & 0 & & 1.V & 7.7 \\
\hline 049.5 & $\mathrm{~F}$ & 2552 & 1.90 & & $3+$ & i & 0.9 & 4.4 \\
\hline $10 \backslash 4$ & $\mathrm{~F}$ & $10 \%$ & 0.520 & & $3+$ & 1 & 1.1 & 3.0 \\
\hline $112 !$ & $\mathbb{F}$ & $101: 3$ & 0.1400 & t & $3+$ & & 0.7 & 5.4 \\
\hline 1131 & $M$ & 1013 & 0.520 & & 31 & 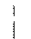 & 0.2 & 3.4 \\
\hline $117 i$ & F & 1397 & 10211 & & $3+$ & & 0.1 & 20 \\
\hline 1291 & $M$ & 4.52 & 0 tifi & & 0 & & 2.0 & 14.0 \\
\hline \multirow[t]{3}{*}{1719} & $M$ & 540 & $(1:: 80$ & & 0 & & 1.07 & 11.2 \\
\hline & \multicolumn{8}{|l|}{ - } \\
\hline & \multicolumn{8}{|c|}{ 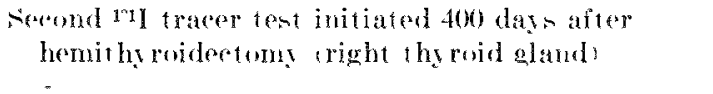 } \\
\hline $019: 3$ & $M$ & 32005 & 0.375 & & $1+$ & & 1.6 & $\therefore .0$ \\
\hline 0215 & $\mathrm{M}$ & 3146 & 0.3019 & & $1+$ & 1 & 1.3 & is 0 \\
\hline $10 \times 1$ & $\mathrm{~F}$ & $1.50 \%$ & (1) 194 & & $3+$ & & 0.2 & $: 3.0$ \\
\hline 1124 & $\mathrm{~F}$ & 1770 & 2.500 & & $3+$ & & 0.8 & 2.11 \\
\hline 1131 & $\mathrm{M}$ & 1180 & 0.151 & & $3+$ & & 02 & 24 \\
\hline 1231 & $\mathrm{M}$ & $1: 29$ & $0.15 \%$ & & 0 & 1 & 1.2 & $\therefore . .3$ \\
\hline
\end{tabular}

$\left({ }^{2}\right) 0=$ noo evidence of disane:

$1+=$ foral lymphoestio nufiltratess with me epithelial involveruent;

$2 t=$ grade $1+$, plus epithelial involvement. i.e., arinar atrophy, divintegration of folliendar rells and precence of macrophages:

$3+$ - erade $2+$, phus Hurthe eell changess of the follirular rpithelium.

here for purpone of comparion with this year'- doge. The result of the first teet of all 12 dog-support our conclu-ion of lis gear. The rate at which the thyroids lost ${ }^{13}$ I after the point of maximum uptake in diagnostic for thy roiditis. The mean $\mathrm{BT}_{1 / 2}$ (hiological half-time) for doge without thyroiditis wa- 12.5) days $\therefore \therefore \mathrm{F}_{0}=1.19$ and that of doge with thyroditio wa $\left.3.34+0.541 t_{11}=7.74 ; \mathrm{P}<0.005\right)$.

Although the $3^{\prime} \mathrm{l}_{1}$ : in this intance doen relate to thyroditis. it is more valid to say the $\mathrm{B}^{\prime} \mathrm{T}_{1,2}$ correlate- with the presence or abenee of normal thyroid follicular -trueture and the amount of colloid. This is

\footnotetext{
* (11) - degrees of freodom.
}

dememetrated by the result of the exeond teet of 6 dog which previou-ly had been teeted and had one erand removed. Two of then dogn were comidered histolocically negation after the first test, but po-itive $1+1$ after the surond te-t. Gren though they had milut thyrodititin, the $\mathrm{BT}_{1}$ a was similar to that in dogwithont thyroiditi. I oge without thyroiditis and log. with mild $(1+1$ thyroiditis have gland that are hi-tologirally -imilatr, expept for the prenencese of -mall

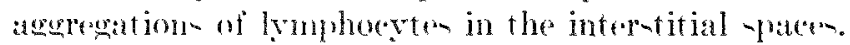
Thyroid with evere thyroiditis $(3+)$, on the other hand. com-inted largely of nonfollicular sheets of parafollicular-type cell-, and rolloit is ereatly rehured or, in some, virtually abent.

To vorify further the relation-hip between relative proportion- of colloit and epithelial component and the $13 \mathrm{~T}_{1}$ a of ${ }^{1: 1} \mathrm{I}$ in the cland we intesh to $\mathrm{u}-\mathrm{e}$ the terchnigue of Cotila and Kinnas" to guantitute the proportion of the eomponent of the thyroid gland.

coneritur

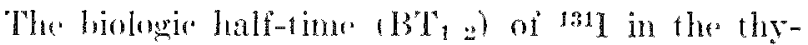
roil, determined by ealoulating the rate at which ${ }^{131}$ I ativity decrease following maximum uptake. in a practical method for entablishing the prenene of thyroid lemion in a berele colony with a high incidence of thyroiditi- Dose with erere thyroiditio have a significantly shortened BT $_{1} 2$ rompared to dogs with no thyroiditi or doge with mild lymphoirl cell infiltration of the chland. This tert ran be used without rigidly ront rolling the dietary iodide intake.

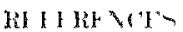

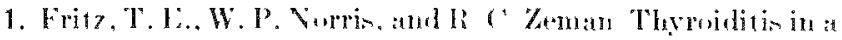
closed onlong of beagles. Argome National Laboratory Bion

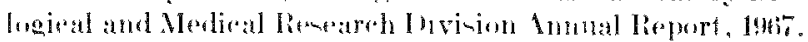
N1.-76m. PU 281254

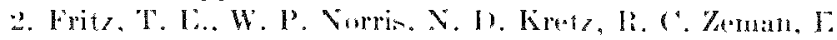

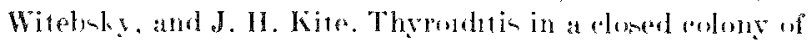

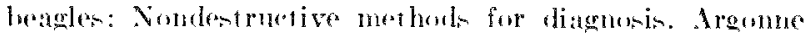
Vational Laboratorn Biolegeral ame Medieal heseareh Divi-

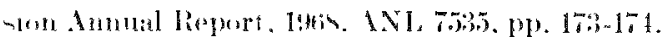

:. Beierwaltem, W. H. and IR II. Vinhisama. Jog thy roiditis:

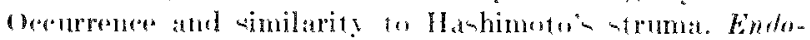

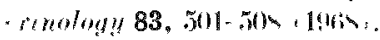

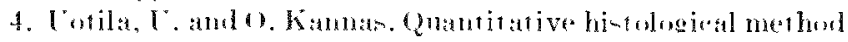
of determining the propurtion of the principal components

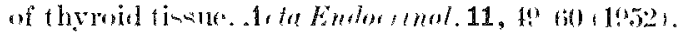




\title{
SKIN GRAFT SURVIVAL IN PARTIALLY INBRED BEAGLES*
}

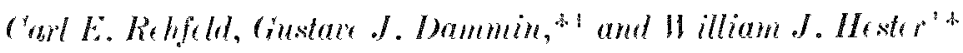

Skin gralts were exchanged betweten nember of 22 pairs of inbred and cou-in-related beaglen. The averagr. time from implantation to -lough in allograft control was 11.7 days and ranged from 9 to 48 days for all other allograft. Eleven allograft- eurvived 22 or more day- suggenting a donor-recipient relation-hip which approximates that between fraternal twins. All grafts were oberesed for contraction, healing, thres phase of

* Abstrat of a paper heng prepared for publication.

* This is a collaboratuve -tudy betwent Argonne National Laboratory and the Department of Pathologx, Iarvard Medi"al schmol, Peter Beni Brigham Hompital, Bomton, Masachulsettor. rejertion. aml mode of rejection; thene factor were correlated with coefficient of inbreding and relationthip. Gratt contraction appeared to have -one predictive value, becaune if graft continued to contract after 17 dave they did eventually slongh. The rate and degree of healing at inci-ed edge of donor and recipient skin appeated to be a sem-itice indicator of histocompatibility. (Araft that soughed before 17 days were usually intact, in the sense that, the epidermal, and perhape the dermat, later were till present. Cirats that -urvived more than 17 dar usually sloughed by lytic atetion. There was a bether correlation between coefficient of relation-hip and graft-urvival than there wat for the inbreeding coefficient and -urvival.

\section{DEFINITION OF RELATIONSHIPS IN A CLOSED BEAGLE COLONY*}

('arl L. Rehfeld

A comprehensive programu is dereribed for definition of inbreeding, relationships, and ance-tral composition within an animal population. Inbreeding coefficient may be ured to evaluate breeding history and to control inbreeding level. Coefficient- of relationship are mont uneful for accurate pairing of animals with respect to fumilial relationships. Ancestral comporition may be ued to define familial subpopulations within a colony -o that iuherited physiological and biochemical variation may be included in the evaluation of experimentally produced changes. A rloved beagle colony of $1690 \mathrm{dog}$ is ured to illuntrate both the application and value of the three eriteria

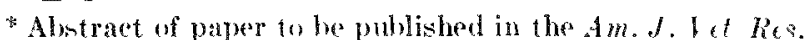

of breeling and relation-hip. Twelve humbed and one $\left(71.1^{\circ}\right)$ of thene dogs have some legrete of inbreeding. The coefficient of relationship is dependent upon how clomely animak are related, a value that may be anhanced if the dogs are inbred: it is a means of selecting pair with equivalent relationship for histocompatibility and other studien where accurate pairing is important. Ancestral compo-ition defines the two inbred subpopulation within this colony and the extent of their outbreeding with the other two subpopulation. Neonatal survival is uned to illustrate inbreeding effect, and the effect of outbrecting between the -ubpopulation are arusened by weanling survivil.

\section{THE ULTRASTRUCTURE OF NORMAL HEMOPOIETIC CELLS FROM DOG BONE MARROW}

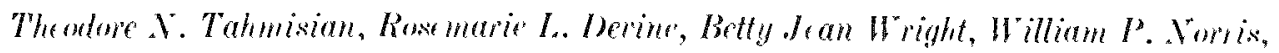
Thomas E. Frit:, Ruth ('. Ze man and David I'. Tollt

\section{I'T RPU A A MD MELITOD}

Dependent upon dose rate. acute and chronic irrudiation by $y$ rays from a cobalt souree reveals a differential su-ceptibility of hemopoietic cells in the hone marrow of dogs. In another section of this report. ${ }^{11}$ it is demom-trated that bone marrow cell pro- liferation in the beagle dog enentially ceawes when the animal are subjered to continuous exposure to " $\mathrm{Co} \gamma$ rarliation at $3 . \mathrm{R}$ 'day. At half this expo-ure rate, $17 \mathrm{R}$ day, or below, howerer, marrow cell mu tiply -uecenfully, and animal may survive for extended perios of time. It in desirable, therefore. to 


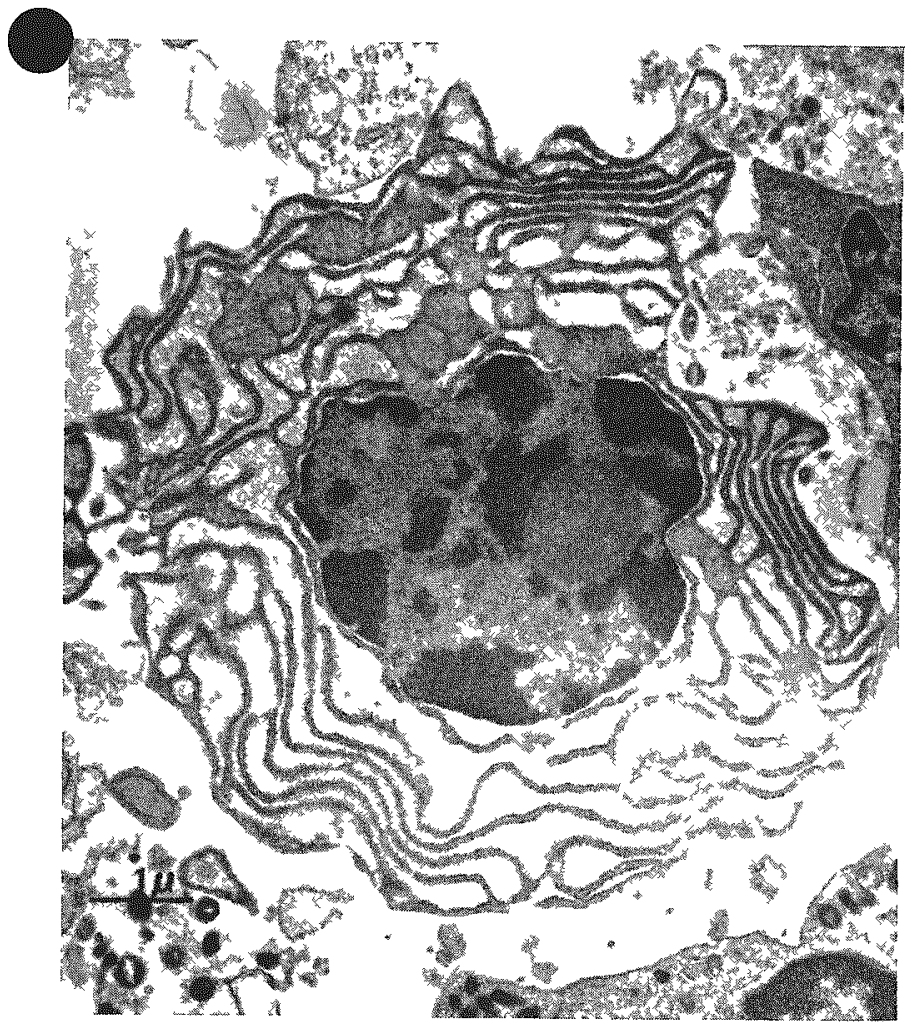

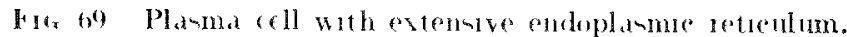

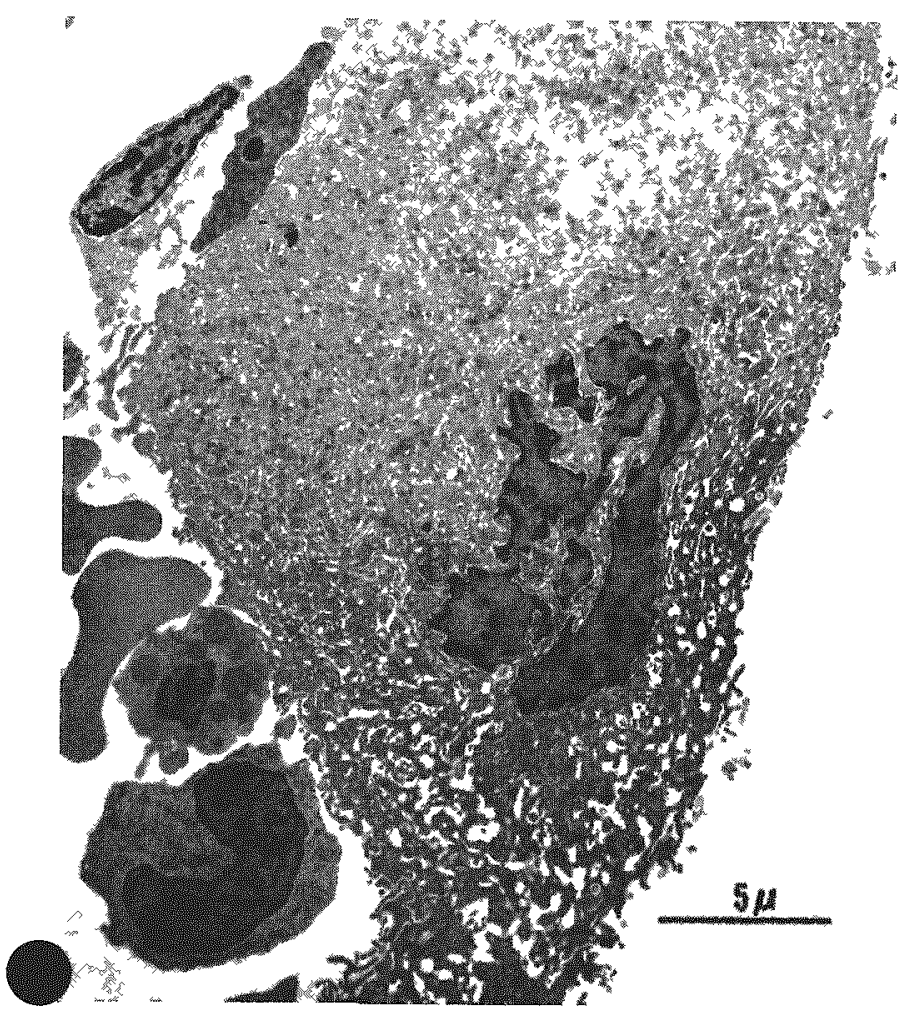

Fier 70 Megakarwerte, whe h tormo blood platelets

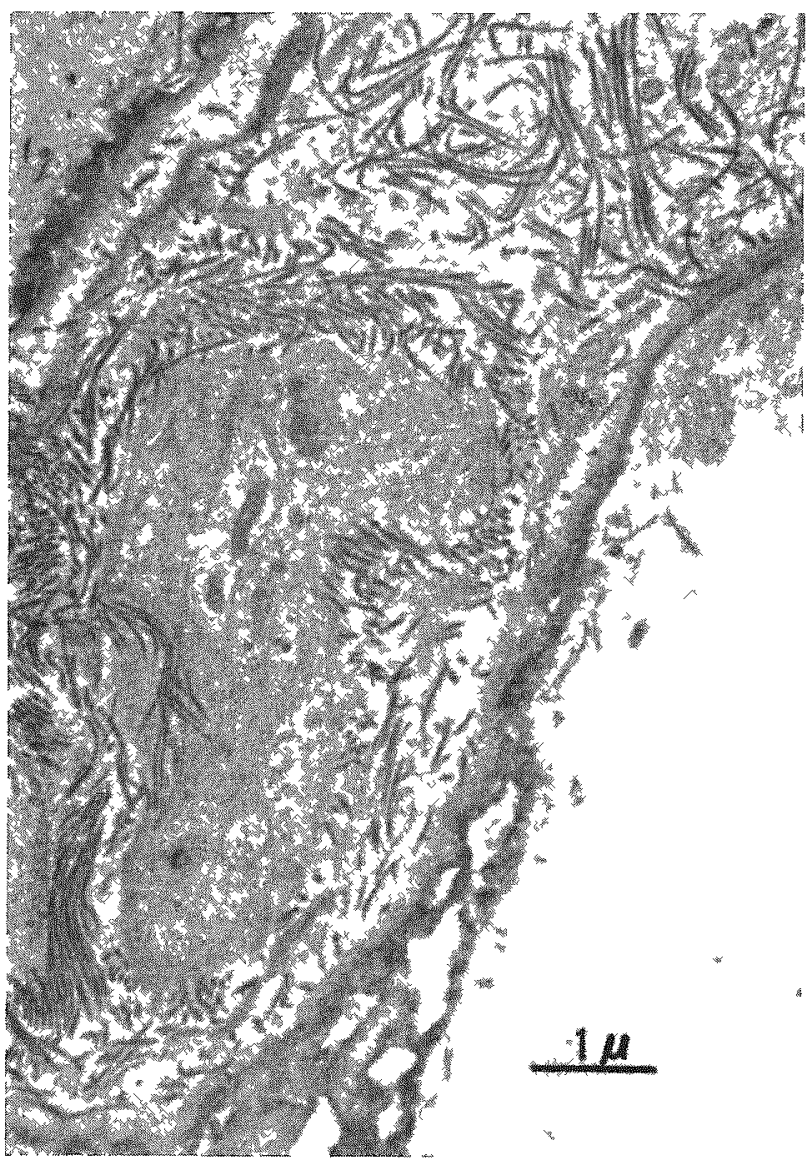

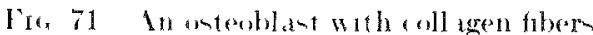

"samine the ultratruetule of matrow aell from dogs

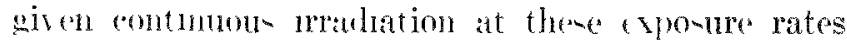
that are criteal for continuted marrow cell -urvival. A. at furet -tepe it became nece-sary to esamine and delentify nomal marrow cell- for comparion at a future tume with -imilar nradiated cell.

We preant the ultrantrueture of the varion types of normal bone marrow e llo identified with the aid of the elect ron micro-eope. The renult may be compared with the work of B(suls.'

Inmerliately following tuthana-id, bone marrow wat remosed trom the femur of a beagle and fived in Kitnor-kys's glutaraldehyde-par aformaldehy de solution buffered with phombate. "The tiwuen were fixed at 0 to 5 ("for' 3 to 5 hr. then wainhed oremoht with -roval chatnge of phoyhute buffered -alme and po-t-

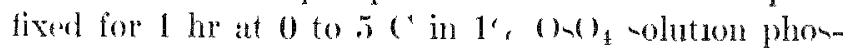
phate buffered to pH 7.4. They were then dellyolrated with alcohol, followed by propylene oxide, and embediled in eposy re-in- as deceribed by Luft. (4)

The block, were sectioned with a Reichert Om $\mathrm{U} 2$ ultramerotome. The sections were stained with urangl aretate and lead citrate a- deocmbed be lena- 


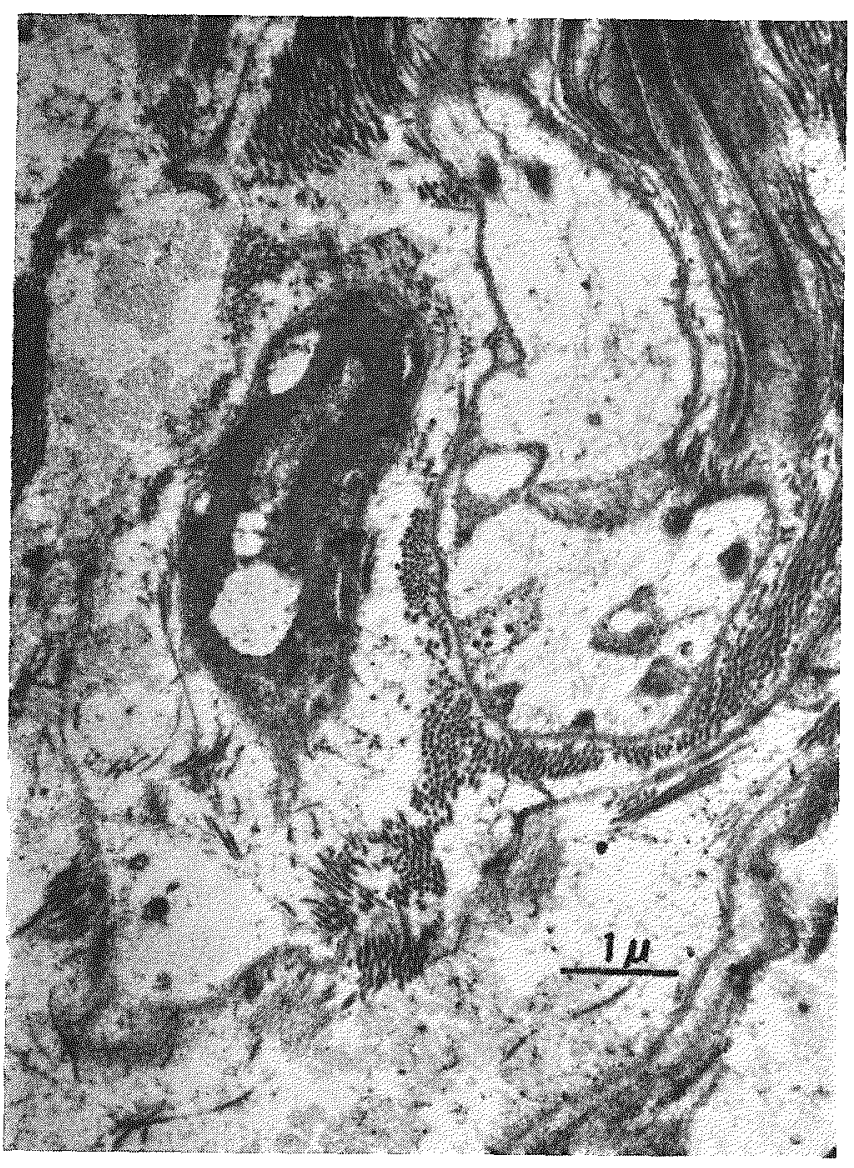

Fra. 72. Collagen fibers in longitudinal and ross section.

Fit. 7. Retienar rell uper left, two motarubrievtes upper and central right and two neut rophilic myelerytes at the lower end of the plate.

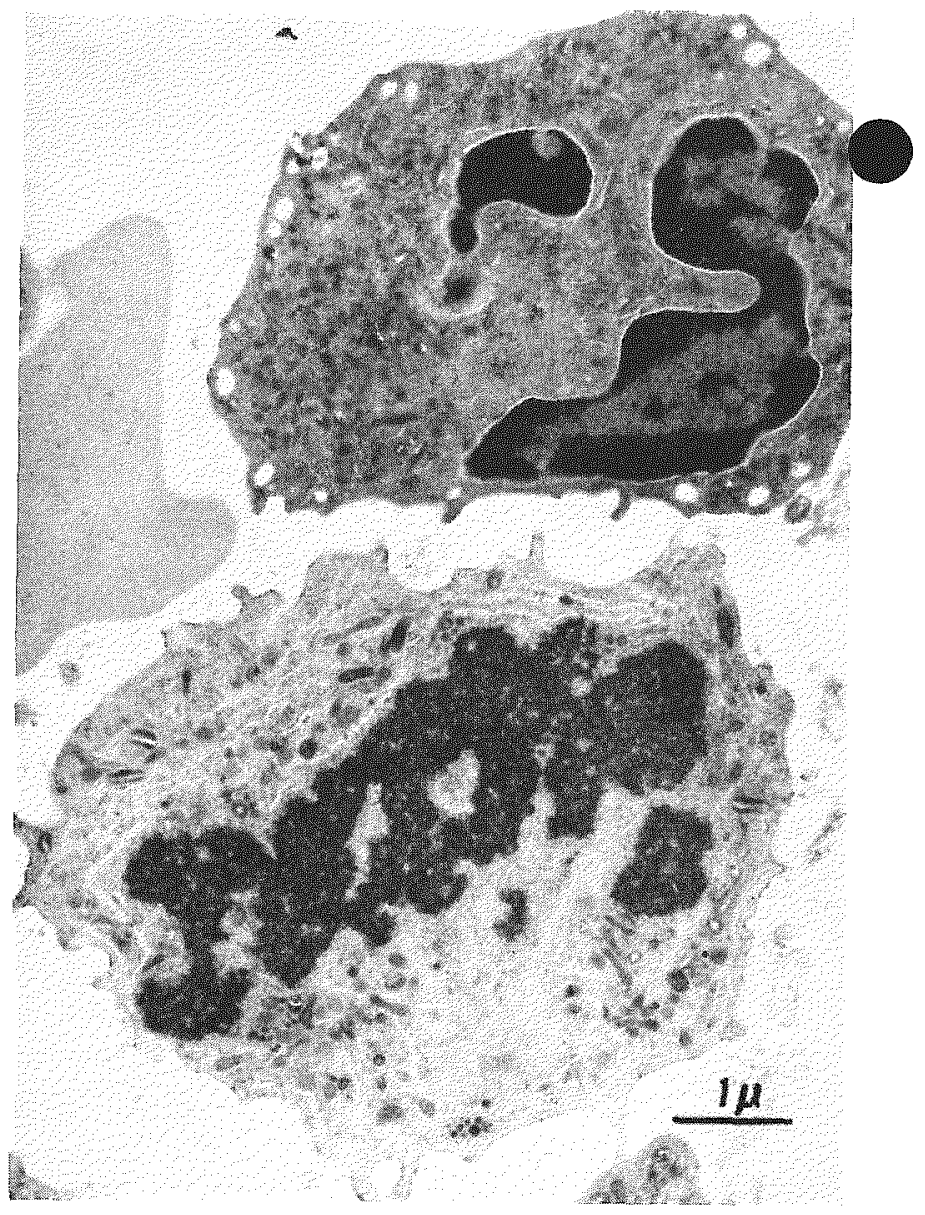

Fia. 73. - Mature nentrophil at upper right, portion of a red blood corpuscle at lef tenter, and an ensinophilic myeloryte in metaphase. This cell shows croplasmic e ranules within which erystals are formed.

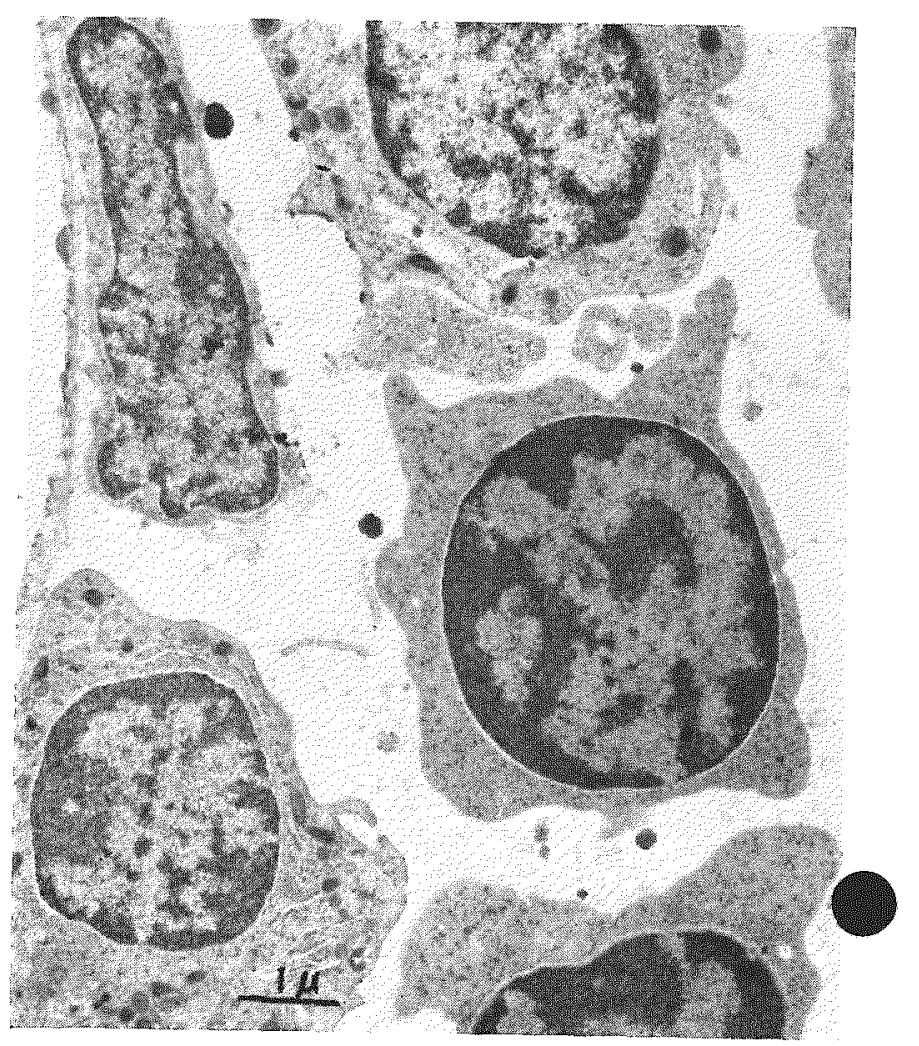




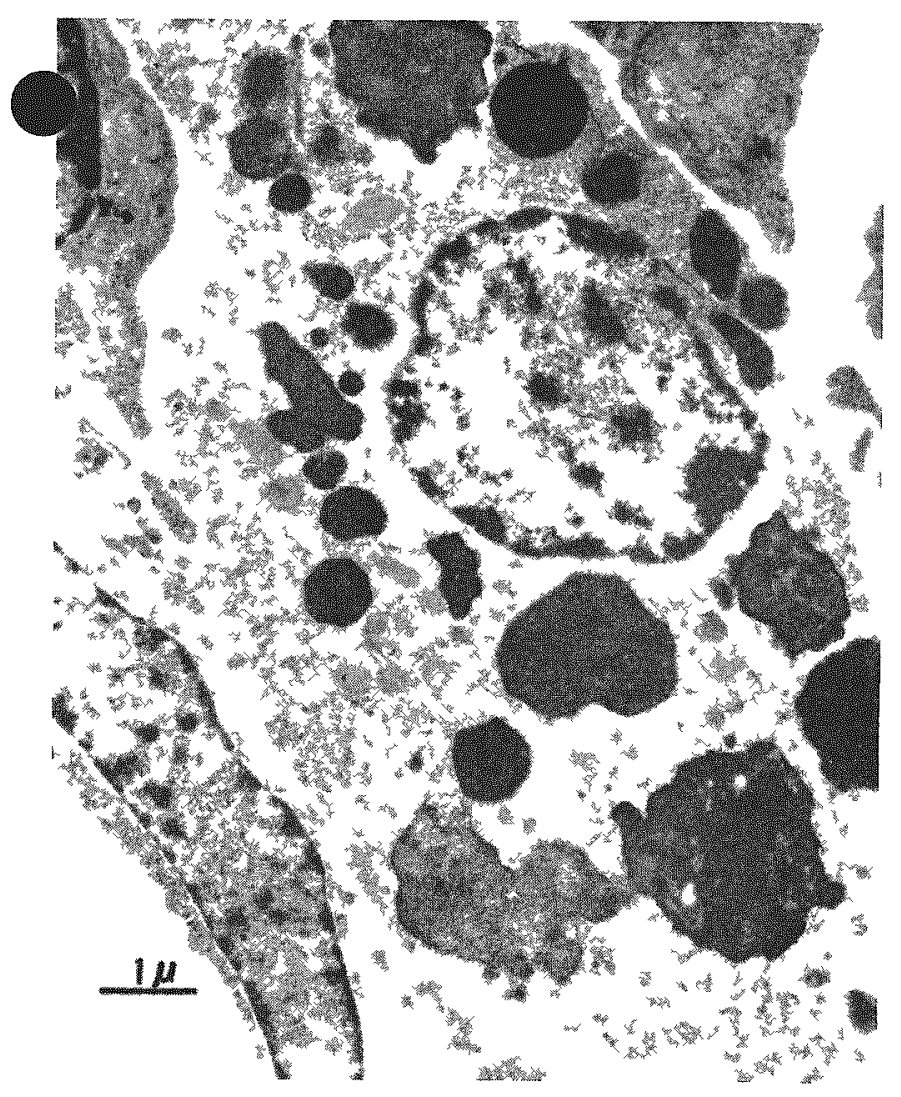

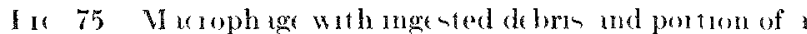
reticulal all al lower loft

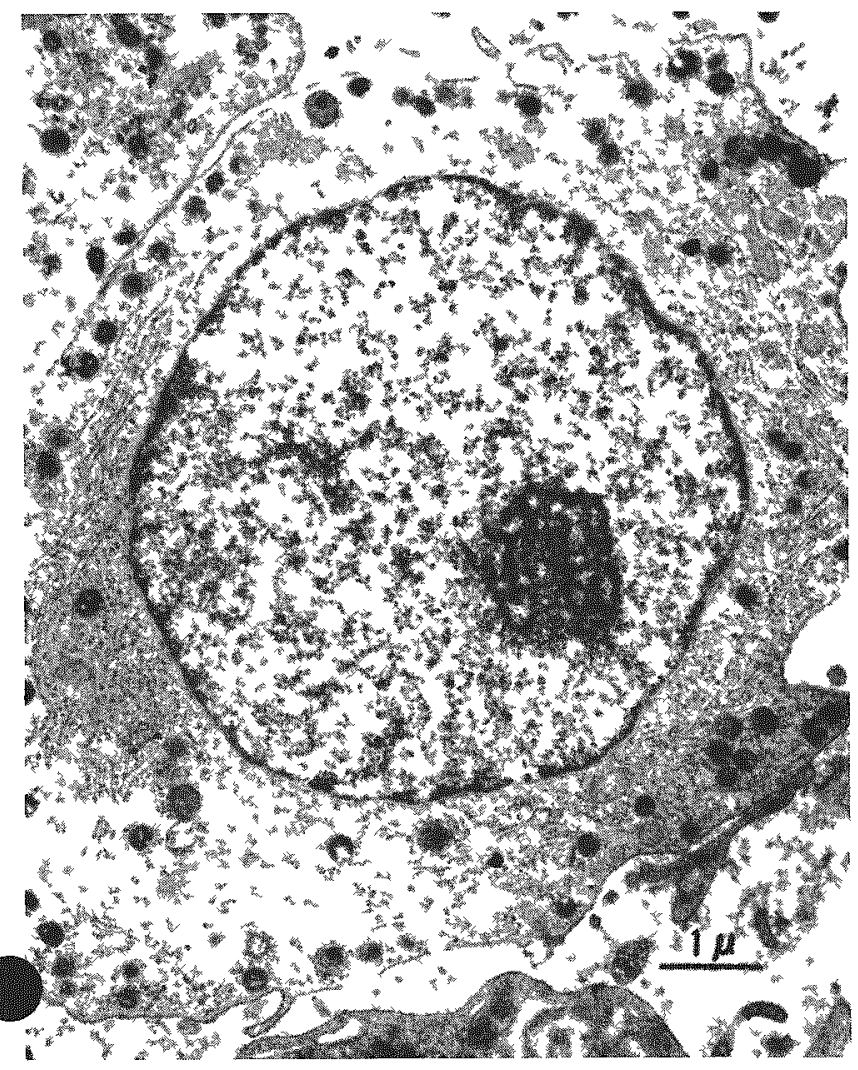

Ita 76 vecuophin promrelocte

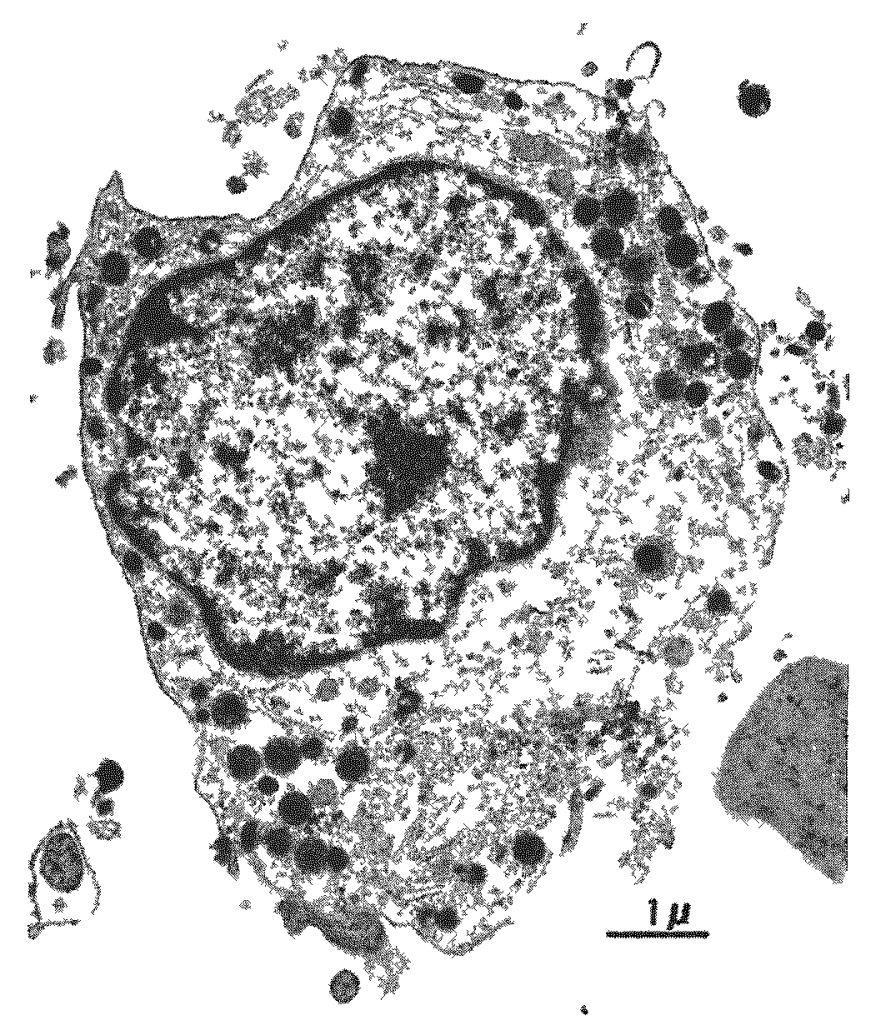

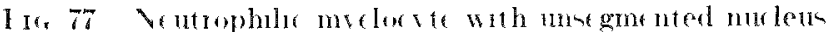

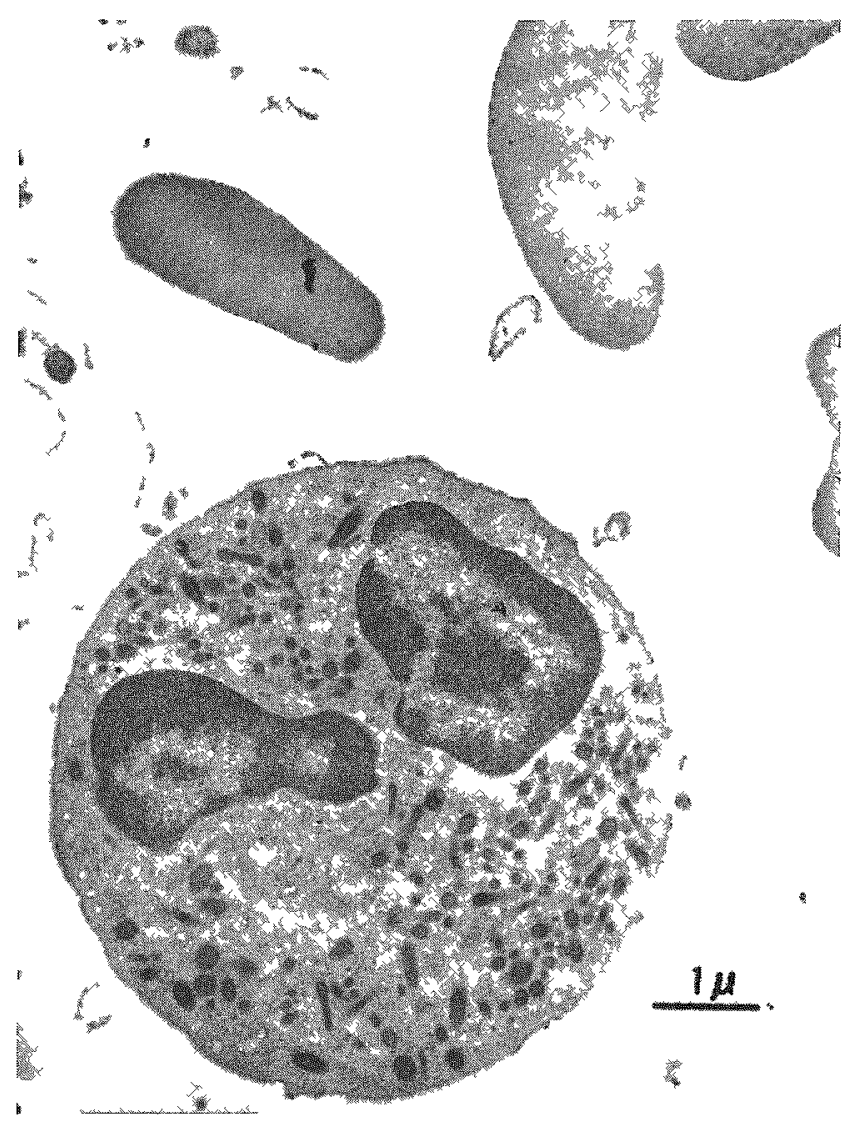

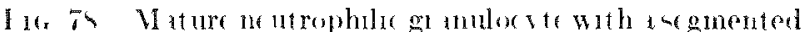

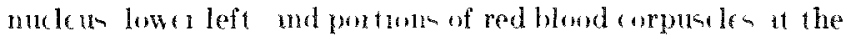
upper portion of the fol at 
ble et al.(5) and observed with the aid of a Siemens Elmiskop 1A. Photomicrographs were obtained at a constant original magnitication of $6,000 \times$, except where large cell such as megakaryocytes required a lower magnification to include the whole cell in the photographic plate. A point source Durst enlarger was uned for printing the electron photomicrograph.

PROGRLS REPORT

In this preliminary work we will only identify the different types of cells found in the bone marrow. Figure 69 shows a pla‘ma cell with its typical branched endoplarmic reticulum. Figure 70 shows a mature, platelet-forming megakaryoeyte. In order to include mout of the cell on one plate it was photographed at a low magnification. Cytoplasmic detail is not well represented; azurophilic granules and mitochondria are easily visible when higher magnification photographs are obtained. Figure 71 whows collagen fibers, an ostcoblast, some bone and the brush border between the bone and cell ti-ue. Figure 72 shows some collagen fibers. Figure 73 shows a mature neutrophil, an erinophilie myelocyte in mito-is (note granul with "crystals"), and portions of red blood corpuseles. Figure 74 shows two metarubricytes, two neutrophilic myelocytes and a reticular cell. Figure 75 shows a macrophage with ingested debris and a reticular cell. Figures 76,77 , and 78 show developmental stages of neutrophilic granulocytos.

REFERENCLS

1. Rehfeld, ('. F, I). E. I)oyle, I). L. ('hadek, D). I. Pearom, and P H. Polk. The responss of beagle dogs fo protrarted exposure to $60 \mathrm{Co} \gamma \mathrm{rays}$ at 5 to $35 \mathrm{l} / \mathrm{day}$. III. Hematology" This report.

2. Bessis, M. Hemopoietio tissue and blond. Elactron Vieroscopic Inatomy, Ed. Stanley M. Kurty. Academic Press, New York, 1964, pp. $14: 1 \mathrm{~s} 1$.

3. Karnovshy, M. J. A formaldehyde-glutaraldehyde fixative of high osmolality for use in electron mieroscopy. $J$. Cell Biol. 25, 407-40\% (1365).

1. Luft, J. II. Improvements in epony resin methods. J. Biophys. Biochem. ('ytol. 9, 409411 (1961).

5. Venable, J. Il. and R. (oggeshall. A simplified lead citrate st ain for use in electron microserny. J. Cell Biol. 25, 107-408 (19ti5). 


\section{MECHANISMS OF CARCINOGENESIS}

\section{MECHANISMS OF CARCINOGENESIS}

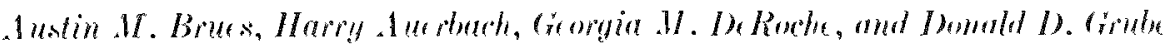

PLRPOE- IVD METHOD

This project has been concerned with the mechanims of tumor induction by local irrudiation of ti-uen and by the implantation of nonradioactive plation tien and other foreign materials. The hi-tologic respomes that preseden the induction of tumor by superficial irradiation of the -kin are being studied through the changen in cell dymamic of the exposed epirlermal population. The methol of double-isotope autoradiography ha bern modified to permit simultancous deteminations of the rates of cells flowing into and out of I NA ynthei- The une of chemical co-rarcinogen and tumor promoters after local irradiation of the -kin allow an as-em-ment of the afficacy and nature of irradiation as an indueing agent in tumor production. Interipereice comparion of thene effect are alo under -tudy. Previons reports (1-3) have dealt with a number of thene problems and include detail of some of the method- employed. The method devined for cell kinction studion are dencribed under the appropriate sertion. This report details frogeres on: 1$)$ aell kinetic tudien on mon-a epidermi-; 2) preliminary reult - of attempt- to demon-trate promotion of -kin carrinogenes by croton oil extracts after external beta irradiation; 31 a twily to deternine whether" ca-tration changes the distribution of -uheutaneou-ly injected plutonium-239, and it relation to the producetion of bone tumor ; 4) the artion of implant - containing radioactive material in does and 5) nonradioactive material heine ferted for tumor production. Conclu-ion are included with each project progrem at atcment.

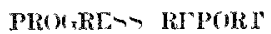

\section{cell Kinetwe studie on Wouse Epidermis}

Dexvribonucleic acid wnthe-is in the dor-al epi-

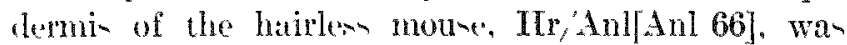
-tudieal during different periot of the dar uning labeled thymidine. "The s-indiren for the interfollicular

(1) a d of mon-e epidermis, illu-trated in Fignre 79 , bllow a predictable day-to-dacy diumal whythm and are not unlike thone reported by other."t is "This apparent change in the number of cells in DN. synthe-i over a $24-h r$ period could be the rewlt of any of the following: 11 a continuous change in the duration of the DNA - vonthe-i- (S) period; 2) a changing influx of rell into the $s$-compartment of the milotic cycle: $\mathrm{or}^{\circ} 31$ change in both parameter. For use in clarifyins thi-problem, we have besm looking eritically at the rasical method of double-label autoradography."(s) Theoretioally, autoradiography after separate injection of differently labeled thymiline hould make it po-ible to entimate, -imultuneon-ly, changen in the raten at which proliferating cell move into and through the compartment of the mitotic "ycle. T"-llal method do not diflerentiat" between nu"Itei labeled with earbon-1t and tho- which have incorporated thymidine laluled with both earbon-14. and tritim. 'Iherefore, at best, the nethod can give a relative mea-urement of only one flow parameter, i.t., the flow rate of "ell wher into wr ont of the $x$ compartment, and will not simultaneounly show both rute in the ame esperiment. Determination of the duration of DNA ynthesis hy such method are valid only with comsant flow rates in the cell cyele. Becaure an indieated above, the diumal cycle may rewlt from rhanges in flow rate, the methork do not erve to inventigate thi- po-ibility.

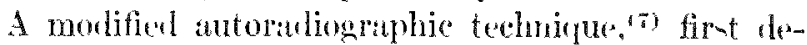

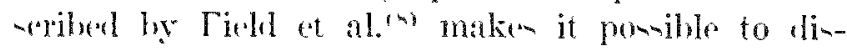
tingui-h hetween nurele labeled with tritium or carbon-14 hy the une of two overying emmlaion-. In the tirst the urain are dre-coupled, and in the sacond -ilver grains are -een. 'lhis has allowed us to moaure, -imultanew-ly, the pelative flus of roll- into and out of the s-comparturent, wings the - anne animal during an identical perion of the diumal evele. "Th" distincetion made betwe'n nuclei labeled with one or both iotopen cledrly demon-trited for the fir-t time an incepulity in the rate of pa-aige of cell- inte and out of DNI ynthei- Table 38 -how-two period of the diumal ryele -tudied, "it where there was a decteane in the pereent of ecllo contering $s$ ifl only) at compared to the percent of cell leaving the S-rompantment $1^{11}$ " only). The lact that hoth flow rates are 


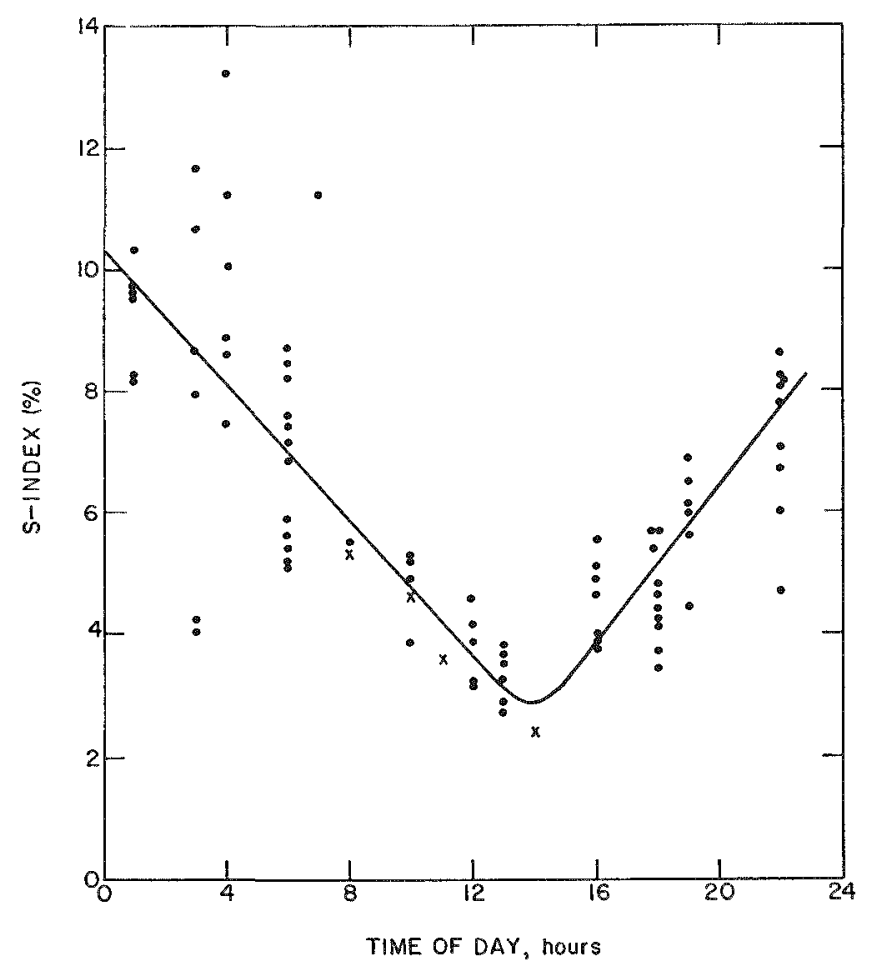

Fitr. 79. The pereent of DNA sy nhesizing labeled basal arells. ats determined by antoradiography, in the epidermio of hairless mice during a $24 \mathrm{hr}$ period. points in present experiment, $X$ mean values from previnum experiment.

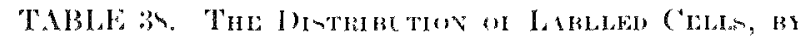

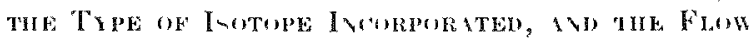

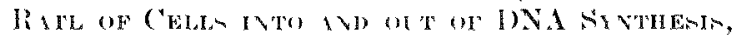
I

\begin{tabular}{|c|c|c|c|c|}
\hline \multirow[b]{2}{*}{$\begin{array}{c}\text { Olserved population } \\
\text { of cells }\end{array}$} & \multicolumn{2}{|c|}{10 a.m. series } & $2 \mathrm{p} \cdot \mathrm{m}$ & series \\
\hline & Number & , $\mathrm{hr}$ & Number & , , hr \\
\hline-- & & & & - \\
\hline Labeled basal cells & $16 \cdot 47$ & & $\left.455^{5}\right)$ & - \\
\hline $1: 4$ ondy & 179 & 0.94 & 257 & $0.5 \%$ \\
\hline 14(" and ${ }^{2} / 1$ & 120 & & $206 i$ & - \\
\hline -Hanly & 24 & 0.19 & 110 & 0.24 \\
\hline lubabeled basal cell & $23 \times(15$ & & 146.12 & 1 \\
\hline
\end{tabular}

decreasing from one period to the other is con-istent with a continuous decrease in the s-indices during these periods. Difference observed in the number of cell in the categories of labeled cell types in the two serien are due to the fact that in the first series the time interval between the thymidine $-2-{ }^{14} \mathrm{C}$ and the ${ }^{3} \mathrm{H}-1$ hymidine was $2 \mathrm{hr}$ (8 a.m. to 10 a.m.), and $3 \mathrm{hr}$ in the -econd series of mire (11 a.m. to 2 p.m.).

Theoretical models of the flow of cells into and through DNA s.vntheris are shown for a steady state in Figure 80 and during changing flow rates in Figure 81. A graphic analysis is presented to facilitate an eraluation of the changes expected in the numb and the categories of labeled eell typen with ehanging parameter, u-ing double-label autoratiography. The pelative values oberved in Table 38 are consintent with the model on the a-sumption that the duration of DNA synthesis is constant and the flux of rell into $x$ is changing terereasingl. Theoretieal morkes which asume a change in the duration of DNA -rntheis have been ronstructed, and the obnerved data in Table 38 are not conci-tent with such an as-umption.

The data in Figure 79 have been derived from a 24-hr experiment using double-label antoradiography. which was denigned to study flow rates throughout the diumal cycle. Preliminary data from this experiment, during a period of inereasing labeling indices, hate thown ration of the catcgorien of labeled cell typen con-istent with the experted ratios, an -hown in Figure 81 (b) lincreaning flow raten). T'ndtre the arsumption of a fixed DNA-rnthe-is period, the relative number of ceth entering synthenis should be equal to the number of cells leaving synthesis. at a time period later and cqual to the duration of the

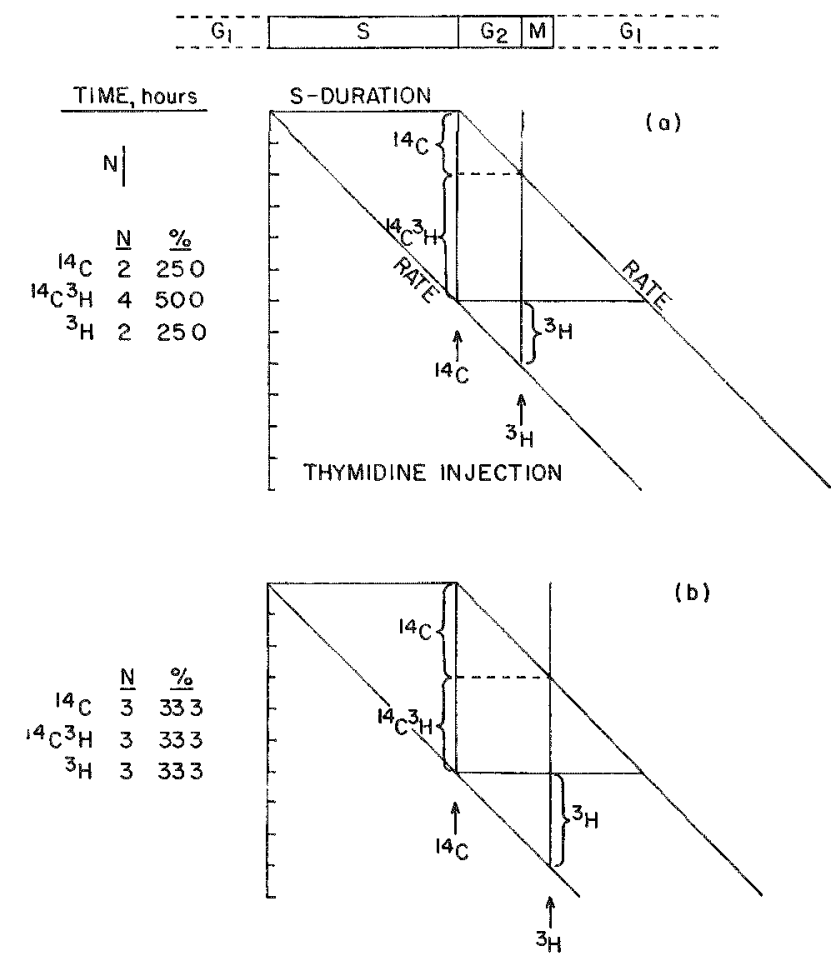

Fits. so. Two dimensional diagram of the flus of cells inte and unt of the $S$ compartment, uning double-label autoradiography (abseissa, the edl cycle; ordinate, the relative sumber of cells in a compartment during a point in time). (a) The distri bution of labeled cells in INA sy thesis during steads st at $t_{t s}-6 \mathrm{hr}, t_{a}-2 \mathrm{hr}$. (b) The distribution of labeled cells when: $t_{1}=6$ his, $t_{1,61}=3 \mathrm{hr} \cdot{ }^{67}$ 
nthetic procens. In the present experiment, preliminary calculation of two sets of flow data which were taken 7 hr apart, have shown good correlation between the cell flowing into ynthe-i- and later flowing out of synthesin.

From all of the presently arailable data in the 24hr experiment, the correlation - between labeling indices and flow rate- are uffichently good to confirm our working hypothe-is that, during the $24-\mathrm{hr}$ period studied in the epidermin, the flux of eell- from $\left(x_{1}\right.$ into $s$ wan actually changing, and that thi- change, mitself, in -nfficient to cauns the diurnal rhythmicity in the number of cells in DNA cynthenis and in subequent rompartments of the mitotie revele. Wre plan to une thi- terhnirgue in examining the effect on the cell crele of the poctirradiation reppone.

\section{Shin Carcinogenesis from Beta Lradintion}

Thi - tudy wan designexd to tent whether our observed low ckin tumor incidence after beta irradiation'si might be enhanced by the we of a vitable promoter, as has been demonstrated for a variety of

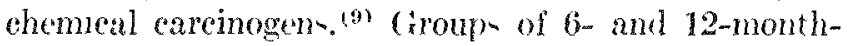
old female hairlem mice and haired sibling- IIr'Anl [Anl 66]. were irradiated with 2500 Rad or .0000 Rado
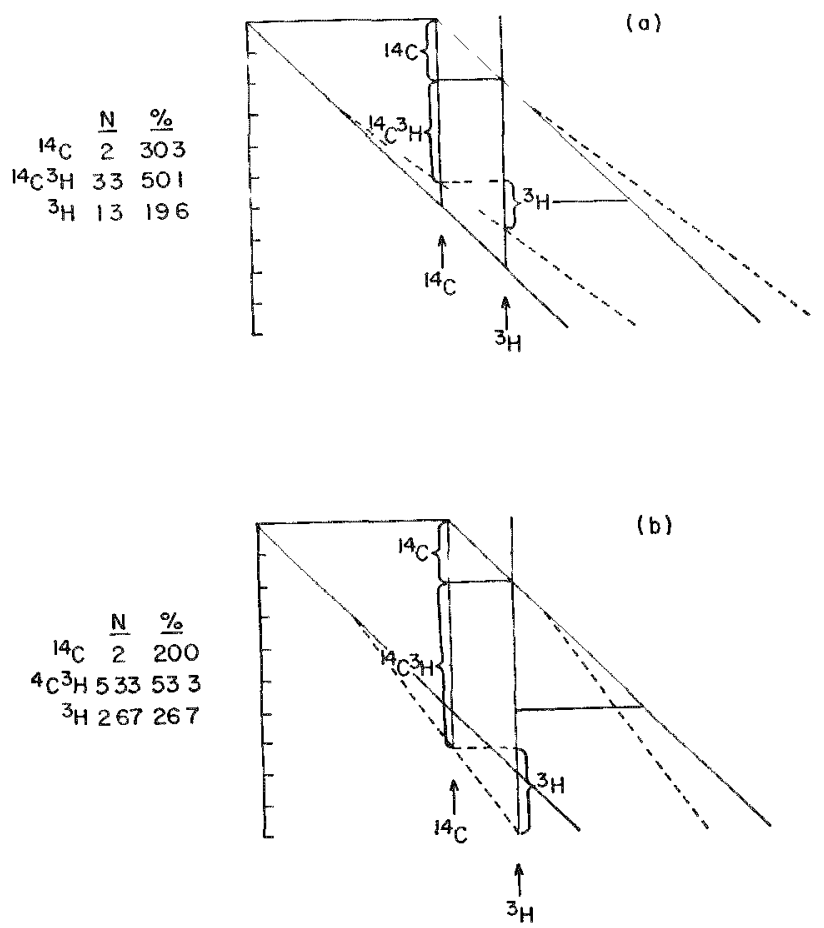

Fir y Two dimensional dhagam of the flus of eelle trits and out of the stecompartment, using double-label autoradogaphy. (a) The duration of I) NA st nthesis remanning countant hile the flux of cells into the compartment decreases at at peint in time, $t_{(0)}=t \mathrm{hr}, t_{t a}=2 \mathrm{hr}$. (b) The same as above, except the flux of cells into the compartment inereases $\left.{ }^{7}\right)$

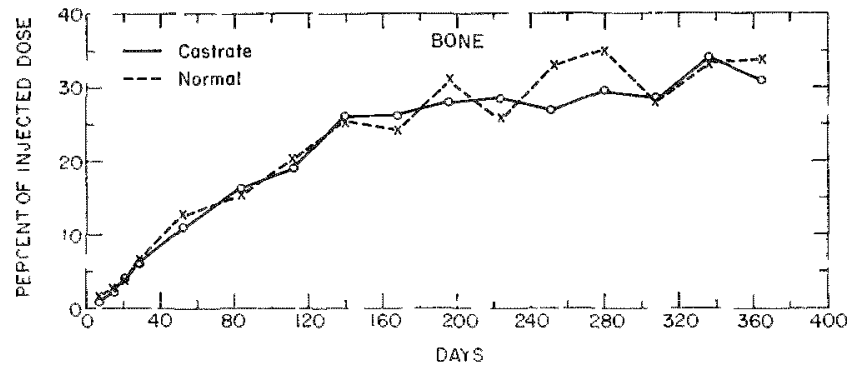

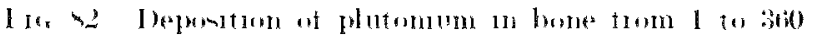

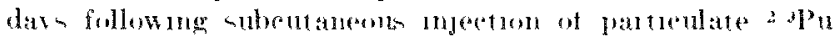
Fiprague lowleg female rath. cantrate and nonedatrate.

at a dowe rate of 7.5 Rad- min, in a whole-hody, heta

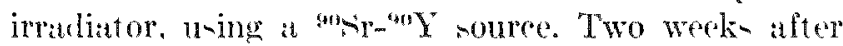
irradiation, 3 painting per week were begum on the doral -kin with a highly potent eroton oil extract athe promoter.'1"1 both the rontrol and painted group, within 2 month after irradiation, howed -ome epilation in the 2.500-Rad group and marked epilation in the s000-Rat group. The group have been under the painting regime for from 6 month to 1 rair, and no incrane in kin tumor induction ha. at yet, been -exth in any group. Thi is in markel contrat to the shervation with the $u$ es of ehemieal careinogen- where up to $80^{\circ}$ ' of the experiment al aninath revelop tumor within 6 montle of the start of fainting with croton oil extract.. ${ }^{101}$ This recult aloo secm- to be at varitnee with an early report in which a lower tone of a lem penetrating beta ray was 114ed:"111 further experiment are plamned to try to remolve this di-crepaney.

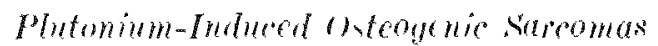

(at rate Sprugue-Dawley female rats injertel wh"utaneously with a particulate su-pen-ion of $2{ }^{9} \mathrm{Pu}$ have a higher incinlenee of o-tegenic sareoma than normal rat- with the -ame plutonium loce. 11 The preant andy wa unlertaken to establish the time pattern of di-tribution of plutonimon in the bone, liver. and pleen, under the -ame condition. Female rats were cat rated at 90 day of age and injected at 130 day of age. Catrate and noneantrate SpragueDawley rats received -imilar dose of particulate $23 \mathrm{Pu}$, and the animal were killed at predetermined interval for andly-i. Figure 8284 ,how the depo-ition of the radionuclide in hone. liver, and spleen from 1 week to 1 year after injection as determined lix athing analy-e. The depo-ition patterns of castrate and normal animal- are not distinguishahle. The loneer perior of cell proliferation and bone growth in the ca-trate animal in the prenence of imilar levels of deposited $239 \mathrm{Pu}$, may account for the observed hiwhes incidence of bone tumor in the cantrate rat 


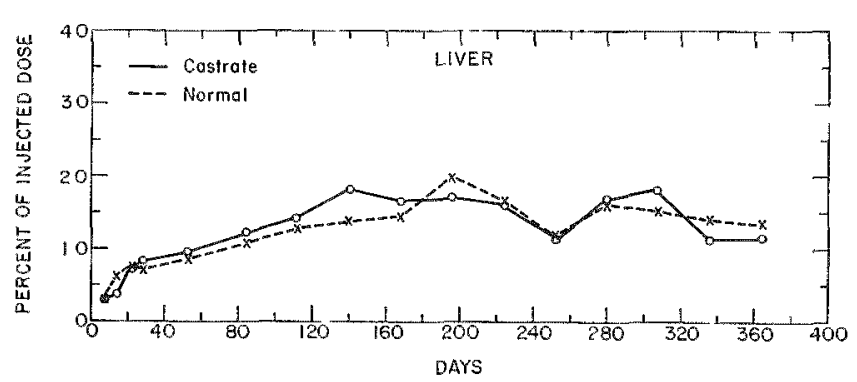

Fuc. \&3 Deposition of plut oni um in liver from 160360 days following subeut aneous injertion of particulate ${ }^{2}{ }^{9} \mathrm{P}_{\mathrm{u}}$. Sprague Dawley female rats, cantrate and noneastrate.

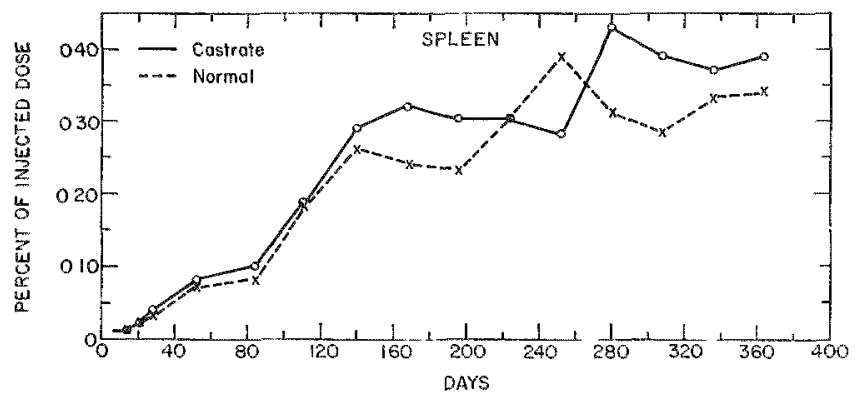

Fly. At. Deposition of plutonium in splecte from 1 to: 360 dats following subeut antous injections of particulate $2^{*}$ pu injections of particulate ${ }^{239} \mathrm{p}$ u. Sprague l haw les female rats, castrate and noneastrate.

as compared to the normal rats. Studies are continuing on the long-term effect $=$ of low doces of particulate ${ }^{* 39} \mathrm{Pu}$ in intact and catrate rats, as well as the pattern of deposition in the femur of the animal as determined by assily and antoradiographically.

\section{Siarcoma Production by Subcutanesus Implants.}

subcutaneou disce of Teflon, Mylar, silamice, and Mylar-laminated nource containing $5 \% \mathrm{Ci}$ of ${ }^{80 \mathrm{~S}-{ }^{201} \mathrm{Y}}$ have been implanted in 5 dogs for from 36 to 42 month. No tumor, as yet, have been observed with any of these implants. Similar dises in spragueDawley rats, in the cane of the nonradioative implants, have a probability of sareoma production of from $15{ }^{\prime}$; to $30^{\circ}$, per dise with a mean time to tumor production of 18 month. Radioactive dises of $5 \mu \mathrm{Ci}$ "str-9" implanted in rats have producel tumor in $95 ?$; of the animal with a mean time to tumor production of 10 month, ${ }^{(3)}$ and all tumors were produced by 18 monthe. In the care of the radioactive implant, the etimated proximal beta dove rate is 300 Rads/day or about 100.000 Rad, year. In the 36 month that they have heen implanted in the loge, the sites have accumulated a done of 300,000 Rads, and the only visible effect have been the complete epilation of skin over the implant beginning at 5 month after implantation, and the formation of fibrou sear over the souree. No skin eareinoma or other local tunom have, an yet, been oberverd at any site. Thi inter-pecies difierence is being further studied by the implantation of lower dose rate. laminated cource in alditional dog.

\section{Tumar Induction by Nonradioactive Materials:}

As previounly reported,,$^{3)}$ all typen of impermeable plastic and other material that have been implanted subcutaneou-ly in the sprague-I awley rat have produced -areoman in the animal with tumor probabilitien of from $15^{\prime} \%$ to $30^{\prime} ;$ per dire. In adlition Millipore filters show an almow exact inverse relationship between pore size and the tumor incidence. The tumor probabilitien range from $33{ }^{\circ}$ per diec at $0.1-\mu$ pore size to $5 c^{c}$, at $0.45-\mu$ pore size. with only

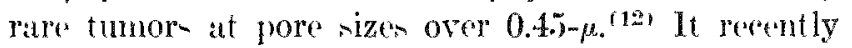
has been learned that the Millipore filter ured in these experiments contained the nonionis surfuctant, Triton X-100 (an alkylated aryl polyether alcohol, ${ }^{113)}$ which may, in some way, contribute to this effect since studies in vitro(13) and in vivo'14t have -hown Triton X-100 to have marked inhibitory effects on cell growth and differentiation. Aquapel la hydrophobir Millipore filter which repels fluid owing to a sperial treatment proces), an well as Duralon la nylon Millipores, Solvinert (a solvent-resistant Millipore), and Mitex (a Teflon Millipore), are being implanted in rats to stuly further thi- inverse relation hip with pore size and to look for any contributing effects from surfactants on tumor incidence. The po-ibility that the filters selectively absorb some growth or tram-forming sub-tances are alo umler invertigution.

\section{REF FRLACR}

1. Bruen, A. M., H. Auerbach, (i. M. Deliowe, and I), D. (irube. Mechanisma of carcinogenesis. Argonne National I aboratorv Biologieal and Medical Research I livision An-

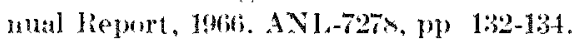

2. Brues, A. M., H. Anerbach, (4. M. Welkwhe and D. D. Grube. Mesohaniom of carcinogenesis. Areonne National Lathoratory Biological and Mediral Remeareh Divicion Annual heport, 1967. ANL.7409, pp. 151-155.

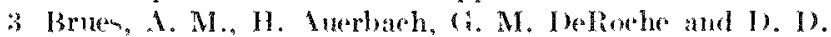
(trube. Mechanisms of rarcinogenesis. Argomne National Caborator Biologieal and Medical Tesearch Divinion ta. unal Repurt, 146x. AN1,-75:35, pp. 24 31.

1. Pilgrim, C., W. Firb, and W Matrer. Diurnal theruations in the sumbers of INA sythesiringe nucled in varions monse tisquen. Iature 199 , stis (1963).

5. Kregherg, L., A. Evenen. and O. Iversen. Influeneen of stress on the diurnal rhy thm in the mitotio artivity in the epidermis of hairless nice. Ata. Path. Wientiol. Scart. 64 176181 (1965)

6. Wimber, D. F, and 11. Quantler. A ${ }^{11} \mathrm{C}$ and II-thymidine 
double labeling technique in the study of eall proliferation

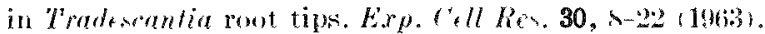

7. Grube, 1). I). A double-label aluoradiographic study of the interrelationship of the flom rate of cells and the duration of INA synthesis on the diurnal eycle in the epidermis of the hairless molace. Dissertation, Northern Illinois I'niversity $(1969)$

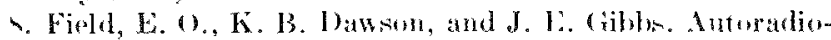
graphic differentiation of ritium and another beta-emitter by a combined oonlour conpling and double stripping film

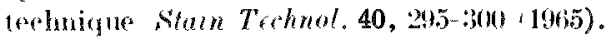

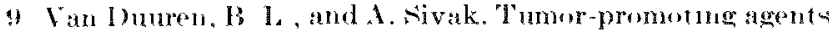

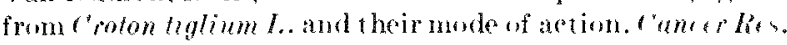
28, $2319+28,24 i(1966)$.
10. I an Duurekn, B. I... I. Langseth, A. Sivak and L. Orris The tumor enhaneing prindiples of roton tiglium $\mathrm{I}$. Ir.

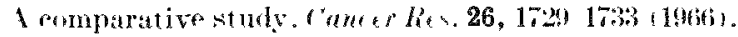

11. Shubik, P., A. R. Coldfarh, A. C. litwhie, and H. Liser. latent careinogentic action of beta irradiation on monse

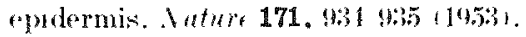

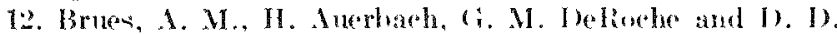
(ipule. Influenefe of porsity on sareoma preduetion by sut-

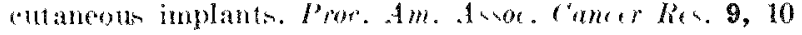
$11 \% 691$.

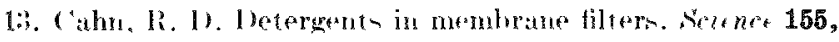
19.5 $10(4)(13+5)$.

14. Goldhammer, II. and W. R. MeManus. Fefferts of nonionic

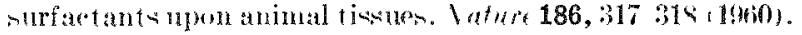

\title{
RETENTION OF RADIOSTRONTIUM IN SOFT TISSUES
}

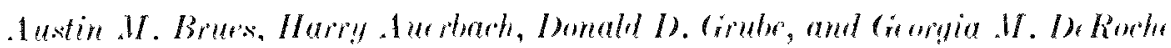

\section{PIRPUA AND MISHODS}

(our previous reports ${ }^{\text {(1-3) }}$ have indieated that radiostrontium in mont soft tissuen, including testis, romen rapidly into equilitrium with blood planna, after which the concentration ration remain essentially routant for long periorl. For these timsues, the plasma concentration curve, therefore, provides a sati-factory indes of the ti-ne concentration integrated through time. Fpecies and age differrores in early deponition in the "exchangeable" fraction of bone and in excretory rates pesult in very marked differences in the pla-na curve which, in turn. reflect radiation donage levels in thone organ that are not very close to mineralized tisue of the skeleton. We have made a preliminary -urvey of published plasma levels of radiontrontium and radiocaleium after single injection. Becalle quentions are still being raised regarding the po-sible genetic effects of tran-mutation of radiuntrontium that may the deponited in spermatozoa (pre-umathly bound to nucleoprotein at the time of meio-is and mitosic) we have also undertaken to makr moasurentents of sisp binding in sperm. Sperm ramples have been collected from dogs at intervals after injection. while pla-ma samples were aloo assired. and the wanhed -permatozou have been counted and the level of ralioactivity measured.

PROGRE- REPORT

Table 39 show representative values for a series of rat ti-such which appear to reach a constant ratio of - pereific artivity to that of plama. These are mean alues, reached after 1 to $5 \mathrm{hr}$, from animals sacrim ficed at interval- up to a month after injection. It wa noted previon-ly $y^{\text {(3) }}$ that in mice. the seminal rocicles with rontents dirl not reach maximum pation to pla-ma until bater fratio of 2 10 3 on the secoud day). Ti-ues containing cartilage, including trachea, show increa-ing ration up to several weeks, and the degres of retention in these ti-stues is murh greater in older

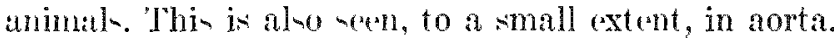

In a previou reportiz we demonstrater a marked difference between -pecies, and with age, in the pla-mat retention curver. We are rollecting adlitional data from the literature, where the mearurement and condition, have been given in weh a way as to make "alculation po-ible fin mo-t tracer studies the data are rxpressed in uch a way that the waight of the sulpect mut be civen in orler to make meaningful (ompari-ons of ti-ue mecific activity). These values are reduced to a common base, i.t., $\mu$ Ci ig of tisule per ${ }_{1}$ ('i g body weight administered. and these dimexionles values are integratel through time to give a value in day from which may be derived an approximation of ti-suc dome resulting from a given almini-tured amount. An acoptable integration for the firt week or two ran usually be obtained by graphical analy-is. some selected values are given in "Table' 40.

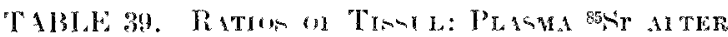

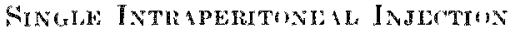

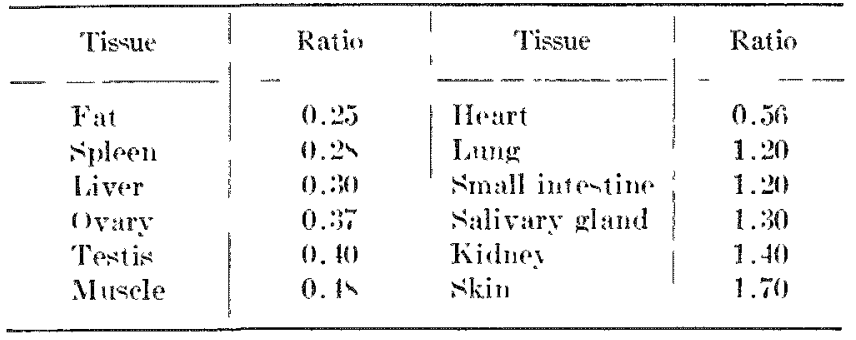




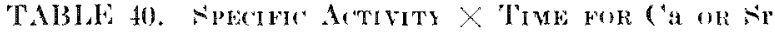

\begin{tabular}{|c|c|c|}
\hline Sipecies & $\mu\left({ }^{\circ} \mathrm{i}\right.$ days $/ \mu\left({ }^{\circ} \mathrm{i}\right.$ & Reference \\
\hline$-[-\quad-$ & .. & - - \\
\hline Youngerat $r a t)$ & 0.15 & 4 \\
\hline ()ld rat & 0.59 & 4 \\
\hline$: 3100-9$ rat & 0.80 & 5 \\
\hline Voung arlult mabbit & 0.54 & (i) \\
\hline liat (intratracheal) & 0.611 & 7 \\
\hline f-month beilgle & 0.37 & 8 \\
\hline $11_{2}$-year beagle & 2.9 & 8 \\
\hline Adult mongerel & 1.9 & 6 \\
\hline Womañal & 5.07 & 4 \\
\hline Masuras & 7.70 & 9 \\
\hline IIuman pationts & & Me:alt valuest \\
\hline Euthyroid & 10.8 & from lefer. \\
\hline Thyrotoxiromist & 3.5 & encess 10 and \\
\hline Mrsedema & 20.3 & 11. \\
\hline Paget s disease & 2.5 & \\
\hline Hypoparst hy roid ${ }^{h}$ & 11.7 & \\
\hline Hyperparat horoid & 5.5 & \\
\hline Osteopuromis & 9.1 & \\
\hline
\end{tabular}

“47 a injerted

on Including values for calcium tis well at strontium.

Plarmat levelo are influenerd, during the time when they are high, almont entirely by the rapidly exchangable calcium pool in hone and by excretion rates. It hould be powible, therefore, to use relatively simple data to make an approximation of soft-tisene dosage during the carly periods after injection. $A$ theoretical basis for this approximation has been given by Marhall. ${ }^{(12)}$

Where human intake of "ser is by way of the alimentary route, at in the "ates of fallout, the daughter ${ }^{\text {se }} Y$ is effectively not absorbed. We showed pre-

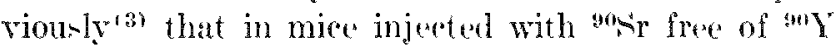
the tram-location to te-tin wa-in-ignificant, although liver wa found to have ahout four times as much

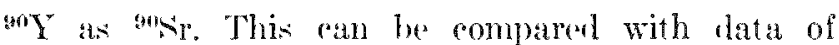

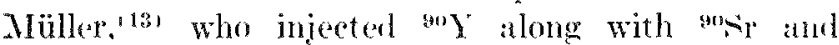
found evidenee of greater retention of yttrium and some acerumulation in the texti-.

We have attempled to mea-ure setention in dog spermatozoa. Aberge and Gillnere ${ }^{14}$ peported mearurathle value 10.1 atom of "sr per cell, in ramm given injection in the acute lethat rangel. () the few sperm samples we have collected so far in ardult beagles, one sample taken at two werelks howed a mea-urable amount. A ample of $1.5 \times 10^{8} \mathrm{~Np}(\mathrm{rm}$. after wathinge to a constant level, contained $2.8=0.8$ eount-min following a total injertion of $7.4 \times 10^{7}$ counts min, each sperm cell containing about $2.5 \times 10^{-16}$ of the total amount injected. This agrees well with Aberg's mesururement (1t) on the ram.

It sem-clear from preliminary estimates ba-ed on these data that the deposition of radiostrontium in sperm cannot be a significant factor in the fallout hazard. Further experiments on this and on retrium translocation are being carried out in order to make more precise calculations.

\section{REFTRLNCES}

1. Brues, A. M., H. Auerbath. 1). 1). (Erube, and (1. M. Delooche. Retention of radiostrontium in soft tiselues. Argonne National laboratory Biological and Nedieal Research Dlivision Annual Report, 1967. ANI-7409, pp. 15ti$15 \%$.

2. Brufs, A. M.. H. Alterbarh, I). D). (arube, and (*. M. Delioche. Restention of radiostrontium in soft tissues. Argone National Laboratory Biological and Medieal Reneareh Hivision Ammal Report, 19m. AN1-7585. p. 59.

3. Brues, A. M., H. Auerbach, 1). I). (irube, and (a. M. Ihe Rowhe. Studies on soft tissue domage from strontium 90. Strontium Metobolism, Hd. J. H. A. Lenihan, J. F. Loutit, and J. II. Martin. Academic Press, New York, 19tit, pp. 207212 .

t. Bronner, F. and R. Lemaire. (omparison of adeinn kinet -

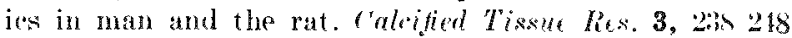
i 19699$)$.

5. Donamaki, T., J. Liniechi, and 1). Withownka Kineties of calcium, stroutium, barium, and radium in rats. Delayed Efferts of Bone-seeking Ralionuclides, Fd. C. W. Mavs, Cniversit! of I tah Press, Salt Lake City, 19t69, pl. 74-94.

b. Lowland, L. E. Exelungeable bone calcium. Argonue Na tional Lakoratory Radiologioal Physios lovision .Antual lieport, 1966. ANL -7220 , pl. $68-80$.

7. Korolev, A. K. Distribution and Biological Effeds of hidedioartive Ixotopers. Ed. lu I. Moskalev, 196it. C. S. Aromie

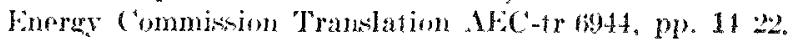

B. Brues, A. M. . et al. Inpublished data.

9. Jovanevie, V., S. Popovic, I. Latkovie, and I. Simonovic. kineties of ${ }^{3}$ ( $a$ in Man. Arh. Hig. Rada i lugulavial 19, $11-23$ (19tis),

10. How, C. ('. and J. B. Stanbury. Strontium and calcium metabolism in metaholic bone diseases. d. rline. Inest. 39,

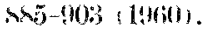

11. Krane, S. M., (. I. Brownell. J. B. Ftanhury, and IT. Corrigan. The effect of thy roid disease on "alcium metab-

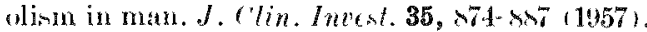

12. Marshall, J. II. Theory of alkaliue earth metabolism. d. Thoret. Biol. 6, Sx+t 412 (1964).

13. Nüller, W. A. Cronad dose in mate mice after incorporation of strontium-10. Tature 214, 431933 (196it).

11. Aberg, B. and M. Cilluer. Jadiostrontimn, stable strontium, stable ralcium, and phosphorus in sperm I) NA. Strontium .Hetabolism, Ed. J. M. A. Lenihan, J. F. Lontit, and J. H. Martin. Arademic Press, New York, 1967, pl].

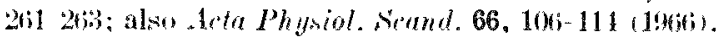




\section{Cellular proliferation and carcinogenesis}

dllon B. Rethlin and a luthony R. Sallene

PL RPOLE AVD METHODS

Thi program in part of a continuing effort to deseribe and compare the proliferation kinetice of normal and tumor tinue. Normal tissue kinetion are mea-ured under different functional and phryiological condition - -0 that the effect of proliferative behavior on tumor induction can be exaluated. The kinetic of tumor are compared to the kinetien of normal tisuen. including the ti-nut of orign, to help elitrify de-.velopmental mechani-m. Finally, growth parameter of histologically nimilar tumor induced by different agents will be examined to eraluate the relution-hip of tumor cell kinetion to the indueing agent. In atsociation with these long-term objectiven. methods uned in meacuring proliferation kinetice and indueing tumor- are being reevaluated. ${ }^{(1)}$

PROMRIA M RI PORT

In earlier communication, (2:, 3) autoradiographic (atimaten of the cell cycle in the cheek pouch epithelium of adult and wanling ham-ters and preliminary data from neonatal anmals were prenented. Additional data on neonatal animals are prenented in Figure 85. The percent of mitome labeled by of $\mu \mathrm{Ci}$ of tritiated thymidine ( ${ }^{3} \mathrm{HTdR}$ ) is ploted against time after I.P. injection. The tran-it time through DNA synthesin $\left|T_{s}\right|$ entimated from the firt ware of labeled mitose is about $6 \mathrm{hr}$. In weanling and adult animislo, $T_{s}$ wan between 9 and $10 \mathrm{hr}$. The mean transit time through the generation eycle $(T, \mid$ in entimaterl to be approximately $26 \mathrm{hr}$ in neonatal animal, compared to about $60 \mathrm{hr}$ in weanling and $150 \mathrm{hr}$ in adults. Although there appear to be changes in $T_{\text {s }}$ with aging, the most significant changes orcur in

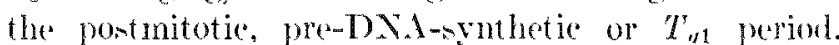
The change in shape and subequent di-appleatrance of the second wave of labeled mitonen is consistent with a molel in which $t_{1}$ cell randomly hegin DNA synthemis at a rate baned on the local demand for cell production. In the growing animal, where the demand is high, variability between cells should be reduced and a recoml wave reaconably well defined. In adult . where the demand for cell production in reduced and the variability increaned. a -econd wave is difficult 10 demonstrate. Figure 86 in a photomirnoraph of the dereloping clece pouch in a dav-old ham-ter. An epithelial anlage is formed at the junction between the skin of the eheek and the bucal muteo-a. The onter portion of thi- anlage are formed by batal cell w wh differentiation progrewing toward the center. On about the etenth day a separition orcur, resulting in the formation of the ponch, Figure 87.

The result of experiment- deriened to look for phythme in phy-iologic artivity were reported last year." Preliminary data howerl poorly defined patterm of activity and indicated that under our normal laboratory conditions rconstant light a activity was neurly random throughout the day. Additional experiment- hase been carried out or are in progrem to leteret rhythm in activity, body temperature, mitotic index. and labeling index.

Trmperature-encitive. miniature radio tran-mitters were inplanted in the aldomen of two ham-ters. Temperature changen aller the tran-mi-sion frequeney, and changer in the orientation of the transmitter with repect to the rereiving antenua produce periodice sgnal low. It i- pounible to the the -ignal lom to entimate the frepueney and time di-tribution of artivaty in allition to obtaining the meanurement of temperature. Figure 88 illustraten a typical recording. I data olstained in thi way are "lowely correlated with thone obtained from surpen-ion eager. At this time, it hat not been po-ible to demon-trate ry-temat ir changes in bodr temperature nor to correlate temperaturs change with activity.

In another experiment, 24 ham-ters were injected wilh $0.5 \mu \mathrm{Ci} g$ of ${ }^{3} \mathrm{ITHR}$ at different time during the day and killed one hour later. Six thou and randomly -elected ba-al cell per animal were crored in rheed pouch autoraliogreph a labeled or unlabelerd. mitotic or interphase. The data are hown in Table 41. No -imnificant differeneen have been

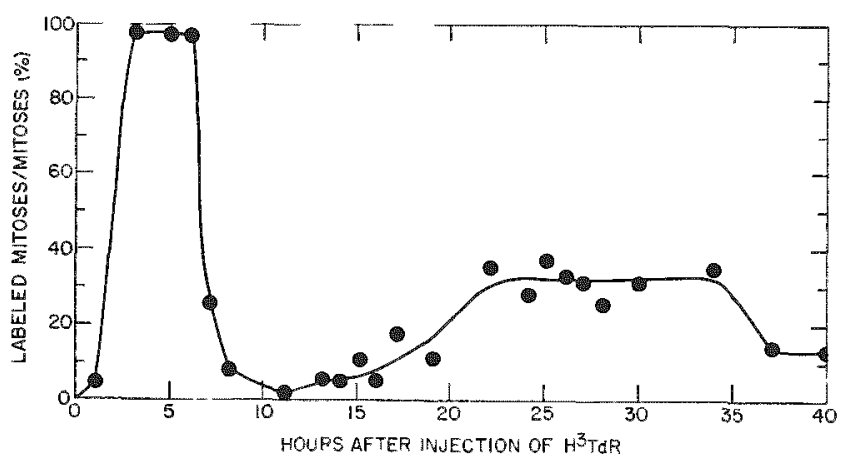

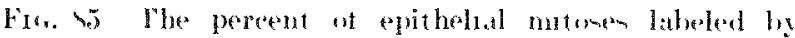
-HTdR in the developine sherk pourh of new boun hamsters 


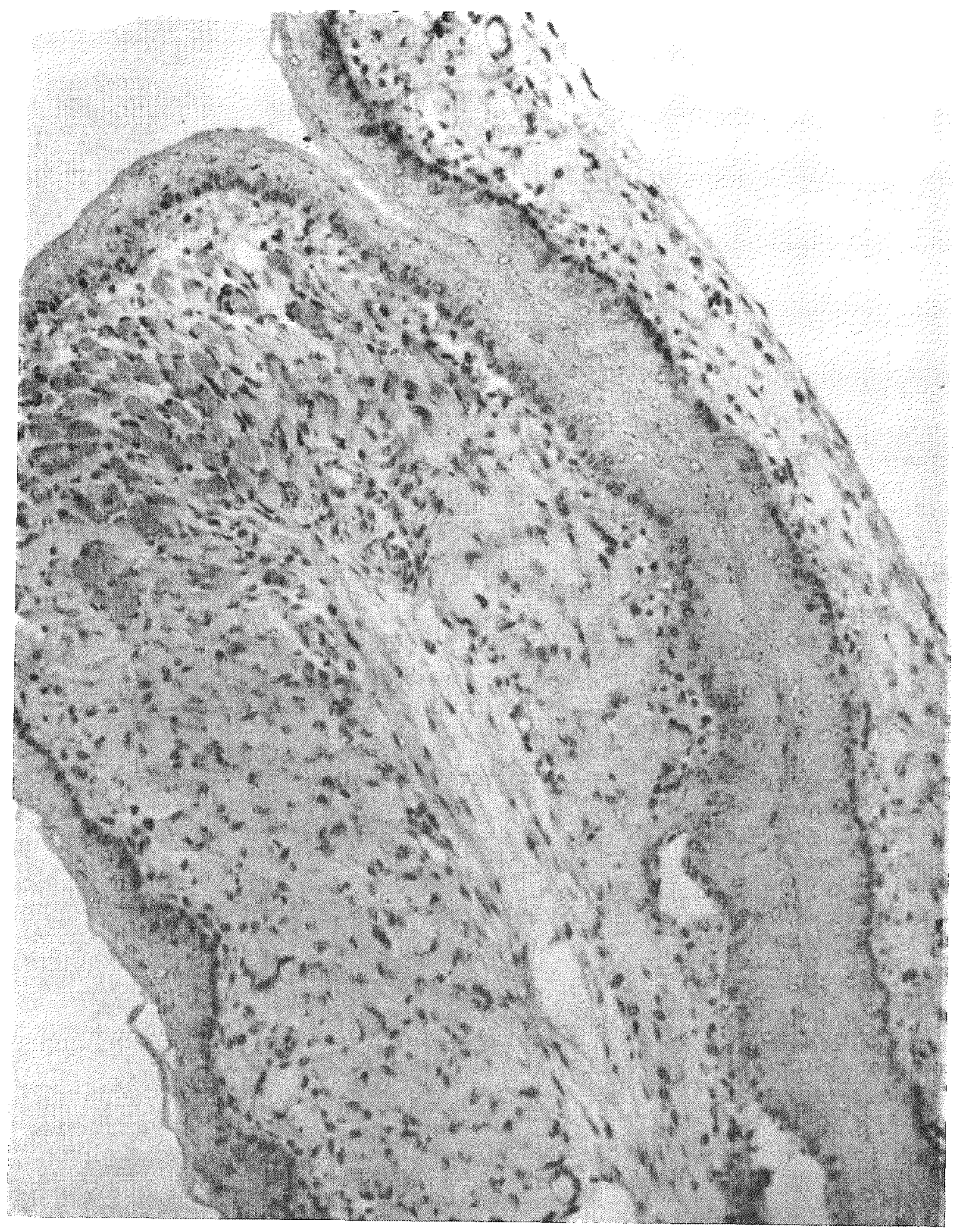

Fia. 86. Histugenesis of the eheok pouch, $1 \mathrm{day}, \times 100$.

found as a function of time of day. Rhythms may exist, but the level of interanimal variation is so high that extremely large samples will be required to demonstrate them. Preliminary estimates of thymi- dine uptake, measured by mean grain counts, suggest that peak incorporation occurs in mid-after noon. It is not clear why there are more conspicuous changes in uptake than in percent of cells labeled. 


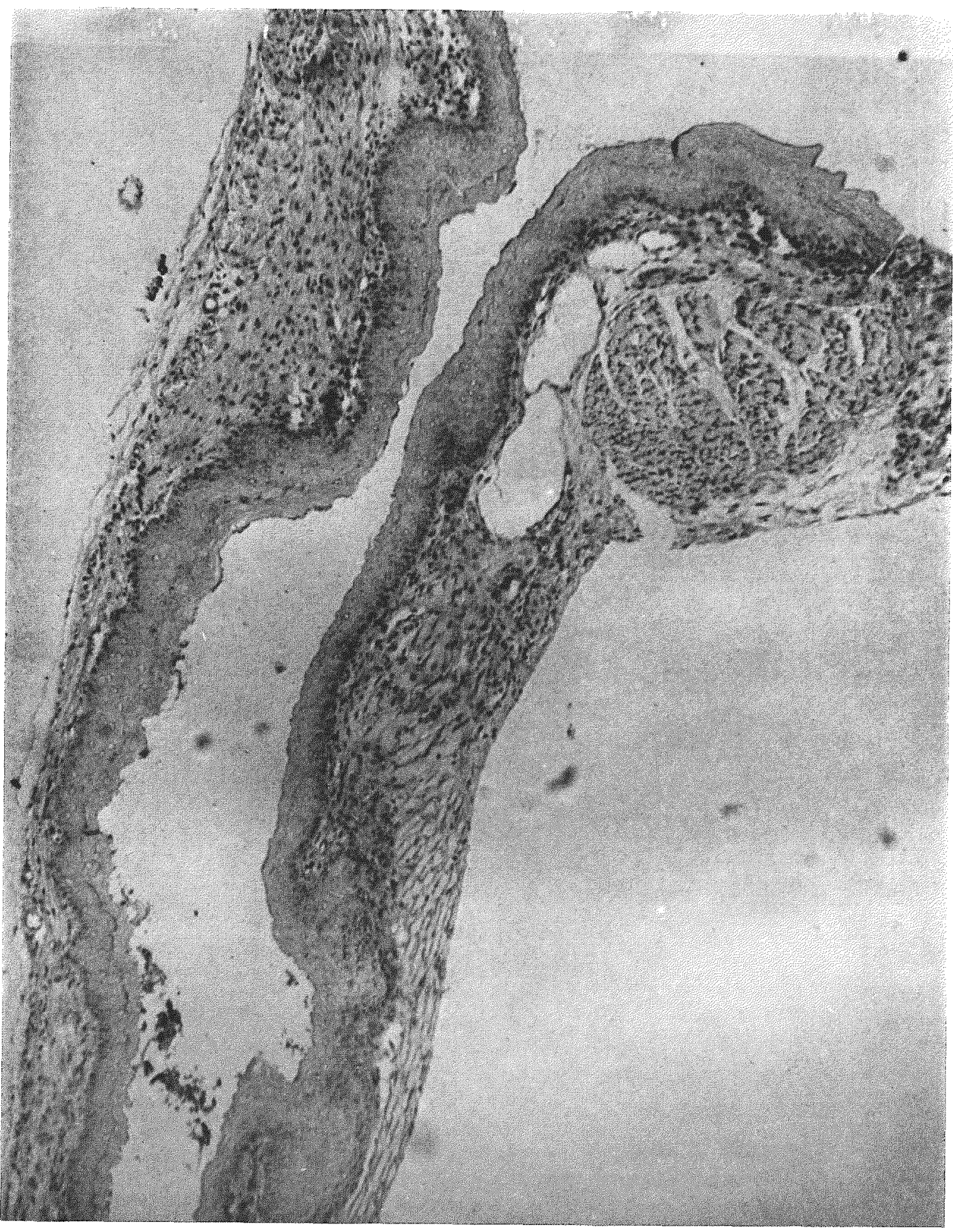

Fra. 87. - Histugenesis of the cheek pouch, 11 days after hirth.

Attempts have been made to induce tumors in the leek pouch with several different agents. In the previous report, (3) it was observed that irradiation of a 1-cm diameter field (2,500 to 10,000 Rads) was ineffective within the first three postirradiation months. Animals have now been observed for a total of 15 months, and the tumor incidence is zero. Because tumor induction may be affected by the size 


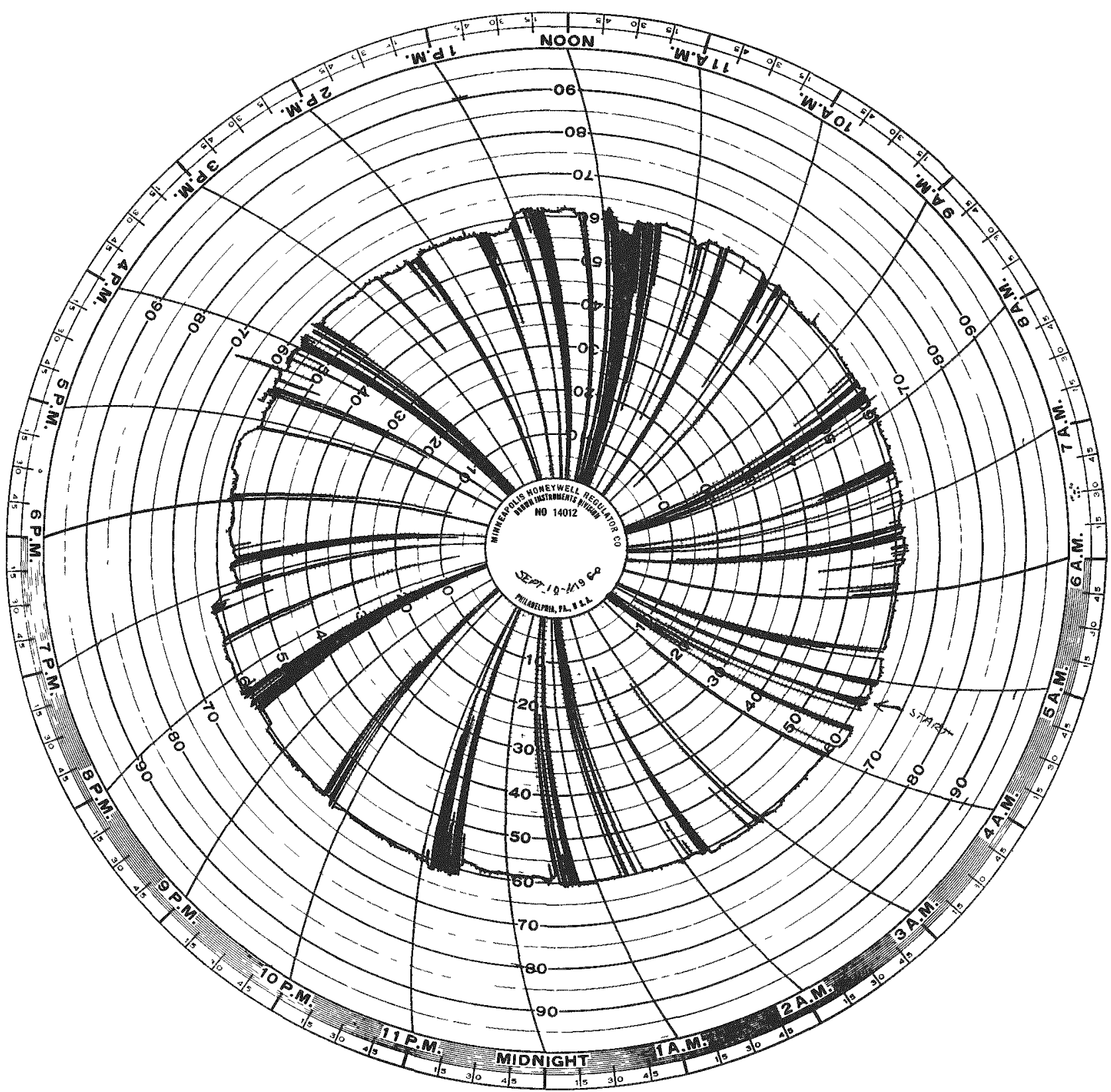

Fur. ss. - Telemetric recording from implanted transmit ter. ("irenlar tracing indicates frectueney of tratsismission, which in temperature dependent Radial lines indieate periodie signal losm.

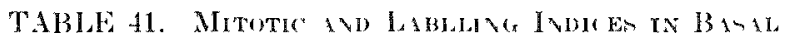

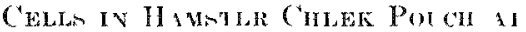
DIFFERL 1 TIMLS (OI 1$)_{1 Y^{(3)}}$

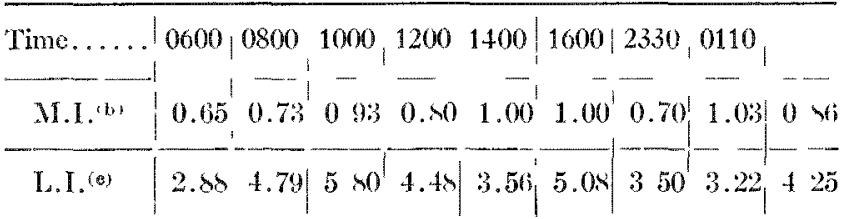

"Counts are based on 6,000 randomly selected cells per animal and $: 3$ animals per group.

(b) MI.I., mitoses per 100 cells.

(c) L.I., labeled cells per 100 cells. of the irradiated field, a second experiment was undertaken in which the entire pouch was irradiated $(50$ $\mathrm{kV}_{\mathrm{p}} \times \mathrm{X}$ raym, 2,500 to 7,000 Rads). Two hundred and four animals or 408 pouches have produced no tumor within the first 6 months. Aside from early erythema and edema, the only change noted has been moderate deep fibrowis.

In addition to the previously described attempts to intluee cheek pouch tumor by irradiation, 44 net horn hamster had SY-40 inoculated into the area of the dereloping cheek pouch. One of these ham- 


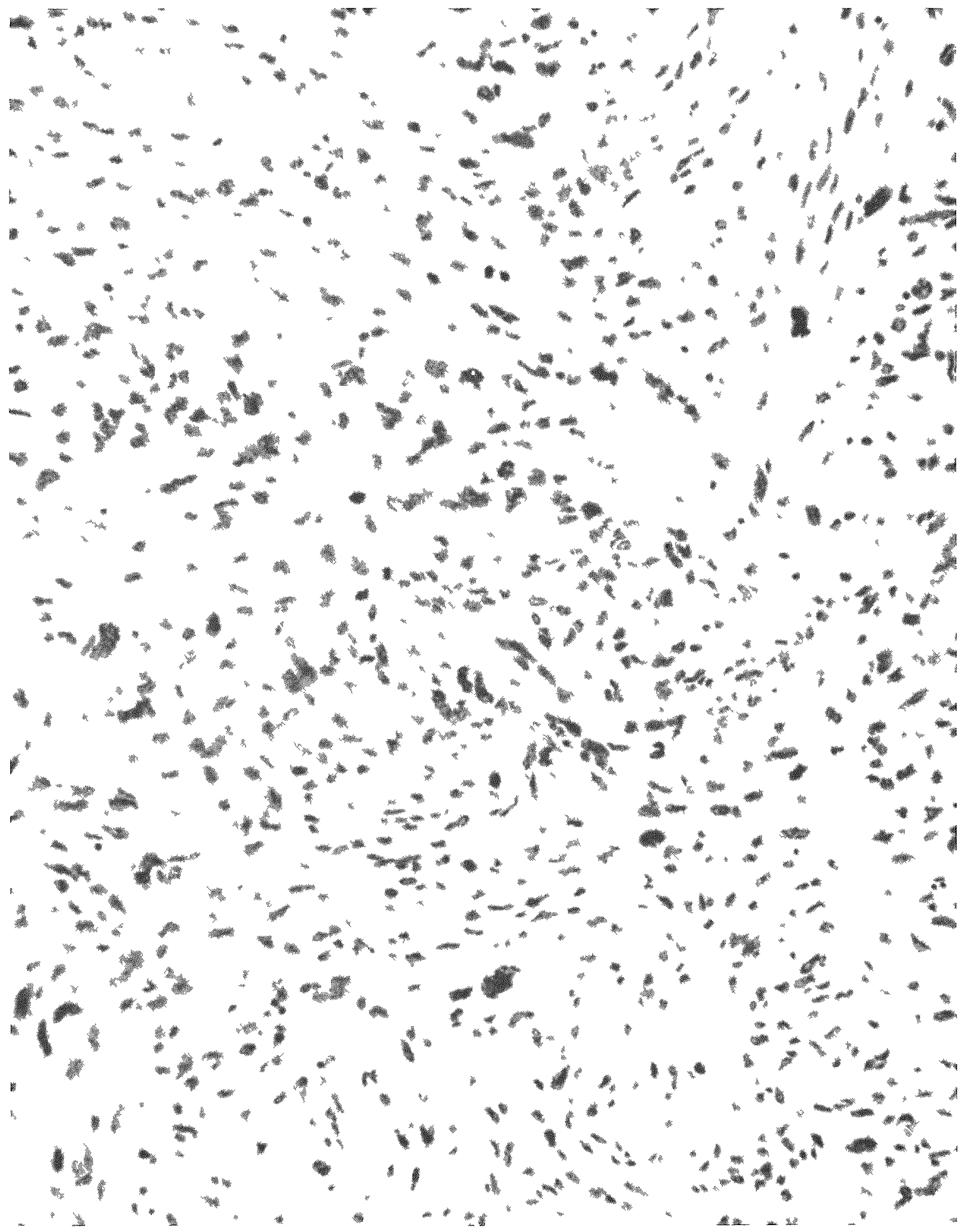

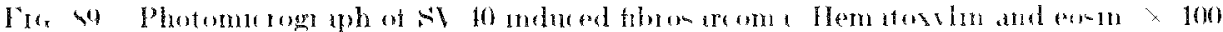

sters developed a lipoma at a distant site and two othern -ub-equently developed anaplastic fibronarcoma of the cheek pouch (Flgure 89). These tumors are beang carried by transplantation in the strain of origin ( $\mathrm{x}$ (') Anl) and in an mbred tram (PD4, Anli. No trancplant into ham-ter moculated with $S F-40$ at birth have been sucem-ful, - -uggenting that the tumors carry sV-40 antigen. Anmals with aecond 


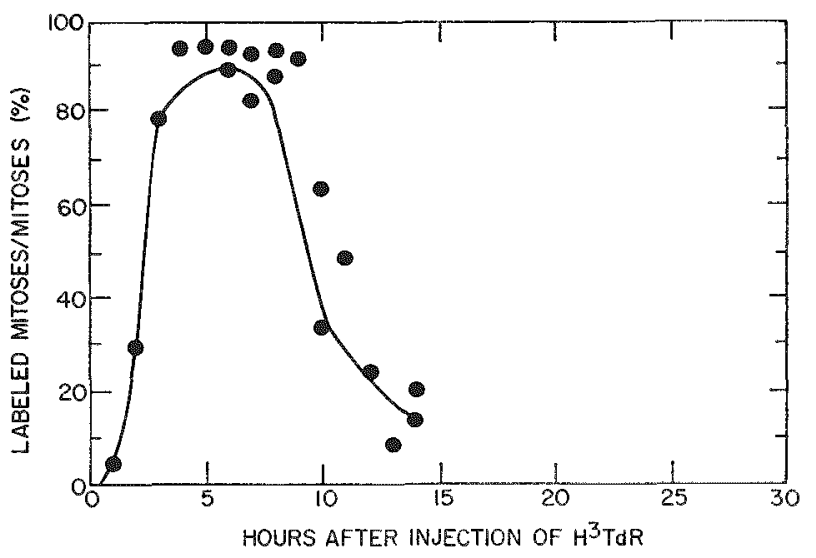

Fiti. 90.- The pereent of mitoses labeled in Si-40 tumors at different times after injertion of ${ }^{3} H \mathrm{TdR}$.

generation transplants were injected with ${ }^{3} \mathrm{H}$ TdR and killed at various times thereafter. Figure 90 is a preliminury plot of labeled mitoses obtained from these animals. When these data are compared to those shown in Figure 91, which are derived from connective tissle cells in newborn hamsters, it appears that $T_{\mathrm{s}}$ of normal connective tissue cells is shorter than it counterpart in the riral induced tumors.

\section{STUDIES OF RAT MAMMARY GLAND GROWTH}

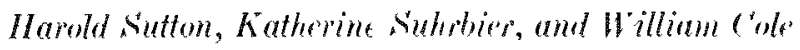

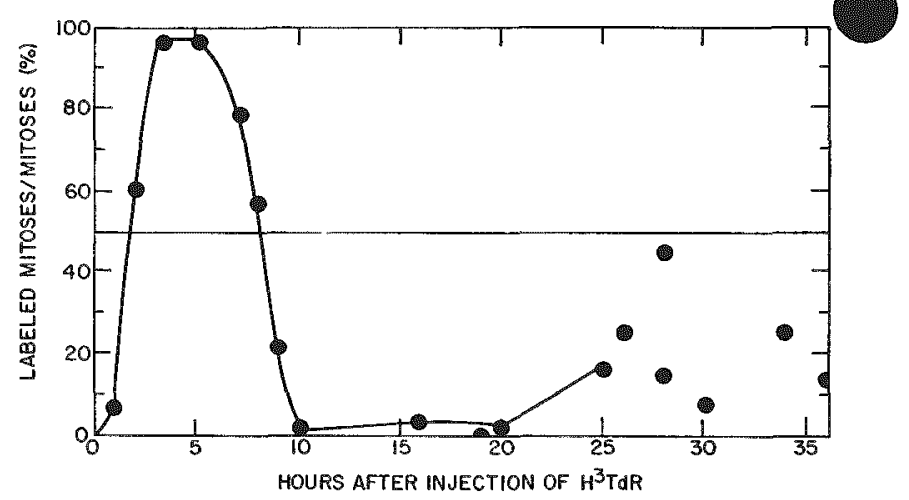

Fur. 91. The percent of mitosen labeled in the connective tissue of the developing eheek pouch as a function of time after injertion of aTTII:

\section{REFERENCES}

1. Fry, R.J. M., W. Kinioleski, A. Reiskin, A. R. Fallere, and C. L. Weber. Some factors that influence the uptak" of tritiated thr midine. This report.

2. Reishin, A. B. and A. R. Fallene. Careinogenesis and cellular proliferation. Argonne National Laboratory Biological and Medical Researeh livision Innual Repert, 1067. 1 NC-7 304, pp. $162-163$.

3. Reiskin, A. (A. and A. R. Sallece. ('ellular proliferation and rareinogenesis. Argome National l,aboratory Biologieal and

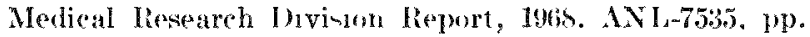
353.

\section{PT RPOME AND MEIHODS}

The purpose of these stulien is to define growth patterm of the rat mammary gland and to explore their relationships with careinogen sen-itivity.

We report here 1) a brief dencription of a method to prepare broad-section autoraliographs that gives more representative histological sampling of all structural divisions of the gland, and facilitates recognition of powible regional differenee in the proliferatire activity and differentiation of the gland: 2 ) a rorrelation of labeling index meaurement of rell proliferation ohtained from autoradingrapls of the gland with more eavily obtained indirect paramoters of gland growth.

Wo ank thene question: In a cycling female ral given tritiated thymidine, how do the labeling indices of the -everal cell subpopulation correlate with the gland DNI sperific activity? Does the extent of occupancy of the fat pad by the expanding glindepithelial structures (duct, alveolus, and end bud) correlate with the sperific artivity of the manmary gland INA? (The index of gland oceupancy i- approximated by the ratio of fat pad gland DNN/fat pad aland wet weight.

Earlier, we reported the determination of specifie activity of mammary glanil DNA in ereling female rat given tritiated thymidine. ${ }^{(1)}$ The specific activity of the DNA is a -ingle index of the arerage proliferative artivity of the entire gland epithelium. Now we report a methor for preparing broaluretion autorarliograph of the mammary gland which "an provide information about proliferative activitise of each of the neveral cell subpopulation over a wide area. Durt, alveolu, and end bud are not etually di-tributed throughout the abdominal-inguinal glend. Instear of preparing multiple biopsies whon aggregate area may be quite limited. where structure may be mi-ed. and the orientation is awk wated to recontruct, we have derined a method to obtain broal, $4-\mu$-thick scetions. Autoradiographs of 
uch broad sections contain arlequate representation of all structures and preserve their anatomical relation-hips. The labeling index of rpithelial cell subpopulations from the gland exposed to isotopes is u-ed an a firt approxmation of their comparative proliferative activities.

In bricf, broad-section autoradiograph- of a Sprague-Dawley derived rat mammary gland are prepared from rats given $1 \mu$ ('i $i$ hody weight of 0.36 $\mathrm{Cl} \mathrm{mM}$ of tritiated thymidine intravenous ly. (Tne hour litter, the abdominal-inguinal fat pad, containing the gland proper, is exci-ed, stretched out on glam, and fixed in cold acetone. After formaldehyde fixation, the specimen is delyodrated through graded alcohols and cleared with fat colvent-. The gland, at this tage, in hroal and thin with wriukled contour. A final planar orientation of the gland in an embeding medium is required to obtain a broad section. The perimen in placed between two layer of fine monofilament polve-ter ereen fabrie held taut like two superimposed drumbeads over the end of a cylindrical Teflon molt. The gland in this planar tate in embedred in a methacrylate block after a method dercribed hy Norrive(2) Aftex polymerization, the block in removed from the Teflon mold and is machined to that the ide- are perpendicular to the plane of the tinue. The -perimen lie- llat punt beneath, and parallel to, the top -urface of the block. The block is po-itioned in a Jung motorized lerleg. microtome and arddrewesl precinely to the blade -0 that hroad extum of the ti-ne ran be cut. Section, $4 \mathrm{~cm}$ in diameter and $4 \mu$ thick, are mounter on 3- 2-in -lide- Antoradiograph-are prepared by the dipping technique in the u-ual manner. and finally, the ecetion are tained with hematosylin and romin.

The labeling indes of rell are found in three genteeral zonem of the -ertion under 1000 ' masnification. 'Thes' are a superior lateral zone. a zone at the level of the inguinal lymph node, and a zone intermediate to the former zones. The end bud are concentrated in the superior lateral zonen. Where po-ible, at lea- 2000 epithelial cell are counted in w"uch zont, for each rell -ubpopulation, so that approsimately 18,000 cell- are counted per lide.

\section{PROARE- REPORT}

Wo have correlated average breat proliferative activity data obtained by two methods. "The labeling index data obtained from autoradiograph are cor-

Prelated with the specifie artivity of mammary gland Dxd obtained by a biochemical and liquid cintillation counting methor. Table 42 shows the DNA specific activity for four phane of the entru crele

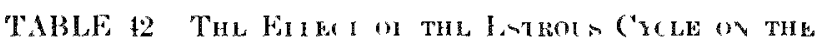

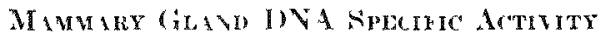

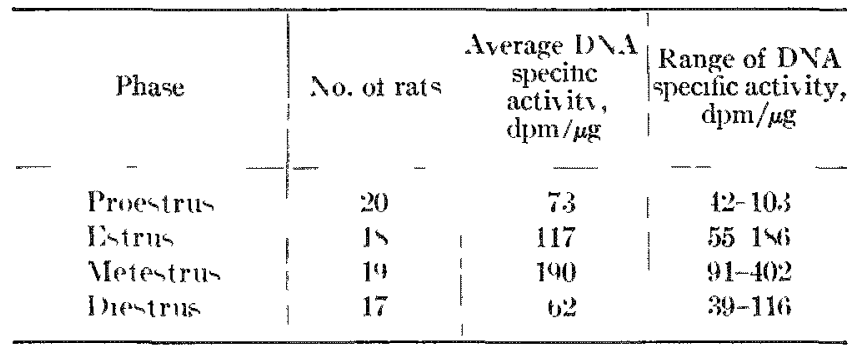

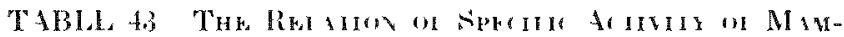

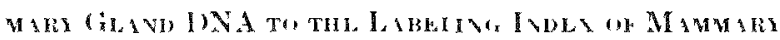

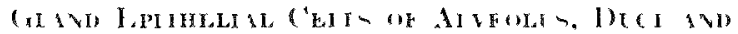

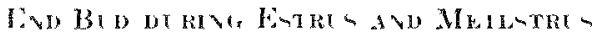

\begin{tabular}{|c|c|c|c|c|c|c|c|c|c|}
\hline \multirow{5}{*}{ 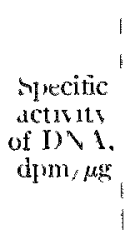 } & \multicolumn{3}{|c|}{$\begin{array}{l}\text { Number } \\
\text { of rate }\end{array}$} & \multicolumn{6}{|c|}{ Percentage of labeled cell- } \\
\hline & - & & - & . & - & & & - & - \\
\hline & & & & Alv & colus & In & & Lnd & bud \\
\hline & $I Y-$ & & Vet- & & - & & $\bar{x}$ & & $\cdots$ \\
\hline & & & & $I$ strus & $\begin{array}{c}\text { Hot } \\
\text { tsêtrs }\end{array}$ & burus & $\begin{array}{l}\text { Het- } \\
\text { ostras }\end{array}$ & $y \operatorname{str} u$ & $\begin{array}{l}\text { Het- } \\
\text { estrus }\end{array}$ \\
\hline- & - & & - & & & - & & 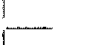 & $\ldots$ \\
\hline $50-75$ & 3 & & & 063 & - & $|a r|$ & - & $132 \theta$ & - \\
\hline $\begin{array}{lll}7+125 \\
\end{array}$ & ; & & 5 & $\therefore$ & $1.36^{\circ}$ & 45 & 551 & $13,3.3$ & 1.531 \\
\hline $120-175$ & b & & 1 & 192 & +47 & .516 & h 9 & $15+1$ & 1354 \\
\hline $17(j-2,25$ & 2 & & 2 & 54 & 521 & 7.39 & 767 & 1790 & $1 \times 7$ \\
\hline $226,12.7$ & & & 1 & & 15.74 & - & 70 & & $16 i 00$ \\
\hline
\end{tabular}

in 60-duy-old rats given tritiated thymidine. Diestrus and proetru are lowe-t, metestrus is highest and entru-is intermediate. Note the wide range of variation, partlcularly for estru- and metertru, and how the pecific activity value for the two phases have a lares reon of overlap. In Table 43 are the renults for the 14 entrus and the 15 metestrum ratcho-en for intial analy-1 becaue their DNA specific artivity value are distributed orer the complete raner.

Rat- m borh e-tru- and motentrun phasen were grouped by the -perific activity lerd indicated. The arerage labeling inder for duct, alreolur and end bud wa calculated for etach animal by aroraging data rollecter from three anatomical zones of the eland The labeling indires recorded are the average of individual rats of the -ame cycle phane and rpecific activity lorel. There in a correlation of ascending DNI -perifie activity ralues and the ringe labeling indien of alvoolus, duct, and and bud. In those levels of IDNA yeecifie activity in which entru- and metentru-overlap. 75 to 125,126 to 175 , and 176 to 225 don pg, duet labeling inders value are slightly higher than alveolat valur. Fitru- and mots-tru- valuen are quite -imilar for hoth of the re rell -ubpopulations. Unly metertru, rate are found in the highes yerific aletivity leverl, (226 to $425 \mathrm{~d} / \mathrm{m} / \mathrm{g})$. Al-o of interent 


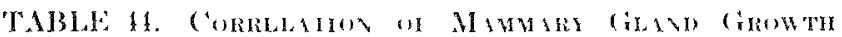

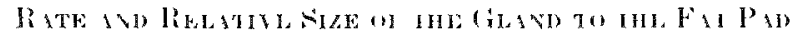

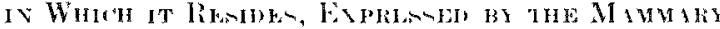

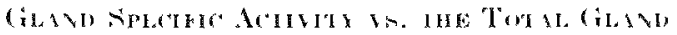

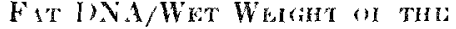
(iLIDI) Fil l'll)

\begin{tabular}{|c|c|c|c|c|}
\hline \multirow[t]{2}{*}{$\begin{array}{l}\text { Specific activity } \\
\text { of }[N \mathrm{~N}, \mathrm{~d} \mathrm{~m} / \mu \mathrm{g}\end{array}$} & \multicolumn{2}{|c|}{ Aumber of rats } & \multicolumn{2}{|c|}{$\begin{array}{l}\text { Gland fat pard INA } \\
\text { gland fat pad net } \\
\text { weight } \mu \mathrm{g} / \mathrm{mg}\end{array}$} \\
\hline & Fstrus & Metesirus & lostu & Hetestrus \\
\hline 5075 & 3 & & $1.2 \% 5$ & - \\
\hline 76125 & 3 & 5 & $142 \pi$ & $1.71 \mathrm{~s}$ \\
\hline $124: 175$ & ii & 4 & $1.20 \%$ & $1.3 .5 t$ \\
\hline $176 \quad 225$ & 2 & 2 & $0.4 \times 9$ & 1150 \\
\hline $236 \quad 45$ & 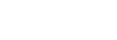 & 4 & & $0 \times 5 \%$ \\
\hline
\end{tabular}

in thi-group is a sharp rise in the alvoolar labeling while the duct value drops slightly. In contrust, at the low end of the -perifie atetivity range, only entru rats are represented and the labeling index of both duct and alveolu are very low. Labeling indice of end bud rorrenponding to the lowent level of DNA -precific activity are relatively high and how only an average increase up to 40 '; as the specific artivity level rises more than threefold. For the end bud, also, the average labeling inde $\mathrm{x}$ is similar for both estrus and metentru at any given DNA sperifie activity level.

An index of gland occupaney of the fat pard is ajproxinated by the ratio of fat poul gland DNA/ fat pard gland wet weight. In thi fat pad gland, a single fat cell is much lareer than a single epithelial cell. Chanese in the number of the epithelial cells sharply affect the total DNA but do not proportionately affect the wet werght of the gland fat par. In Table 44, the ration of fat pard gland DNA fat parl gland wet weight are correlated with the a-centing lerels of mammary gland DNA specific activity for entru and metentrus. For the higher specific activity leveln thigher gland growth rate) the values of the ratio are lower. That is. the fat pat is currently lem oceupied by the epithelial struetures of the gland, which are now growing more rapidly. For the lower specifie activity valuen the ratio is higher, inclicating the fat pat in relatively more oecupied by the gland epithelial structures which are currently growing at a lower rate. Thi- relation-hip of gland oredupaney to growth rate warrants further study.

rovelol Don

1. A method has been devised to prepare autoradiograph of broat areas of rat mammary gland -uitable for study of eell kinetices of all three struetural divisions: duet, alveolus, and end but. The andtomical interelation-hips of these structure in a given broad plane is prenerved, and comparisons of latge areas are pomible.

2. In 60-day-old female rat-, the average ineorporation of tritiated thymidine in mammary gland DNA varien with the phan of the "strus aycle and is reflected in yeedife activity of $10 \times \mathrm{A}$ and labeling index. E-tru and metentru- labeling indices of duct, alverlus, and rond bud ran be correlated with DNA -peeifie activity levels.

3. The relative size of the mammary gland to the fat par in which it renides ean be correlated with the average growth rate of the gland in estrus and metentrur.

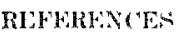

1. Sutton, H. G. and K. Subrbier. Pat terms of breast INN A ththesis and eaneer induretion. Argonue National I aboratury, lBiological and Medical Remearch llivision Annual leport, 196it. ANL $-727 \%$, pp. 131138

2. Woudruff, L. A. and W. P. Norris, Sertioning of underaleified boue, with opecial references to radioantographe appli(ations. Stain Torhnol 30, 179-1ss (1954).

\section{AN ATTEMPT TO GROW HeLa CELLS IN AN EISLER-WEBB NEPHELOSTAT}

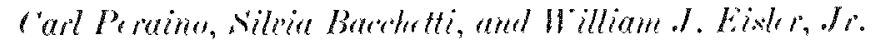

\section{PI RPOA A NU METHWD-}

The Nephelowat is a photocell-controlled rontinuou--ulture derieg for the automatir maintenance of bacteria in balaneed srowth."1, It should be" porible to atapt thi devioe for the continuoun aulture of mammalian cellin.

HeLat rells growing in -unpension were obtained from MeArdle latboratory at the Enivenity of Wiscon-in and were platerl in a lightly modified Nephrolowat growth tube. ("ulture medium was added and remosed with 1-mm diameter 'Teflon tubing connected. to a prer-talt ic pump that had silicone rubber pump ing tuber. Cell growth was reeorded automatically by the Nephelostat and by counting samples in the Conlter rounter. 
PRORIS RLPORT

The cells grew quite well in this swatem for alpproximately seven weeks, at which time the -ystem became rontaminated with mold. Thi, experiment showed, therefore, that the procedure in feasible.

Beraune the standard Nephelostat growth tube has a volune of only 2.) mul. subsequent experiment, have involved attempt, to enlarge the capacity of the ratem to $500 \mathrm{ml}$ o that sufficient cells can be obtaine for biorhemieal studien. Two major difficultien have been eneountered in these experiments.

First. latrger diameter tubing wa- needed to supply medium to the latrese growth renervoir. Latex rubber tubing allegedly -uitable for intrarenous feeding was ued and wa found to contain cubstances which were extracted into the medium and which were highly toxic to the cell-. Thi- problem wat orereme through the une of medical arade cilirone mbber tubing, which wa- nontoxic to the corlh.

serond, relk are normally mintained in a -ingle cell -urpen-ion in the Nephelostat by bubbling a mixture of air and $5 ", \mathrm{CO}_{2}$ through the reservoir. With the larger remervoir, incresced bubbling wan required, ratusing an unaceptable amount of foaming. An attempt was made to suppren the foaming by adding a silicone antifoam preparation. Prior addition of the antifoam to Petri-di-h cultures of Ileta cell monolayer had reulted in no visible effects on cell morphology and rate of growth. When the antifoam wa added to the su-pen-ion culture, howerer, it mised more exten-ively with the medium berane of the agitation provided by the bubbling. The cells then ingereed the antifoam droplets twhich appeared at ertopla-mie granules), and con-equently failed to srow. When thene cell were removed from the Nephelo-at and ruturned to Petri-di-h attures they betan to regureitate the antifoam. This was indicated by the -teady decrease in the granularity of the rell and by the appearanee of antifoam iroplet in the medium. This proren continued for several lays, through soveral rhanges of medium, after which the cell reacyuired their normal appearance and renmed a nomal rate of growth. It is clear. therefore. that the antifoam wat not chemically toxie to the eoll- but rather interfered with their function throush a proes- of phy-ical engorgement. In

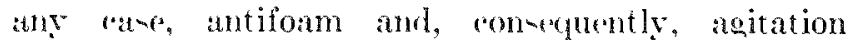
by bubbling, rannot be uned. Future experiments will at tempt to determine whether stirring can be uned where the rello in -unpenaion.

(o) $20-101$

IIelat cell man be spown in continuou culture in the Nephelo-tat, hut further study is recuired to detrmine the best condition for maintaining the cell- in an anlarged Nephelo-tat growth whamber.

RLHLINCI.

1. Finler, W.J , dr and R. B. Webb. Cleetroneally eontrolled

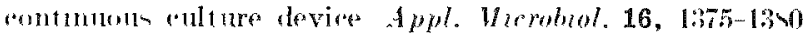
alitivi.

\section{ENZYME REGULATION IN RAT LIVER: FUNCTIONAL PROPERTIES OF THE ORNITHINE AMINOTRANSFERASE MOLECULE}

('arl l'erainu

\section{PI RPONE IND METHOD}

(ornithine aminotranferane, an amine acid catabolizing enzyme, is located in rat liver mitochondria." It is strongly regulated in rive both by feedbach inhibition and bx dietary and hormonal alteration of its turnover. ${ }^{(2)}$ 'There wharacteristien render ornithine aminotransferane a ureful tool for studien of the mechanism of enzyme regulation. 'The enzyme was purified, and neveral of it - chemieal, phy$\mathrm{i}(\mathrm{al}$, and struetural properties were -tudied.(6) This report dencribes an extension of this inventigation and includes an examination of functional propertien of the enzyme under a variety of experimental condition. This study in still preliminary becaune much time is resuired to perfect or develop techniquen. Howerer the recult, obtained are encouraging.
The ornithine aninotran-ferted retuetion was examined in two half-praction. Each half-reaction is invertigated under a variety of condition. The overall ornithine aminotranserane reaction in an follow:

\section{First half-itaction}

onithine + ornithine aninotranserant-pyridoxal phopphate $\rightarrow$ prroline carboxylate + ornithine aminotransfera-mpridoxamine pho-phat"

\section{Sicond half-reaction}

alpha ketoglutarate + ornithine aminotran-fera-p-proridoxamine pho-plate $\rightarrow$ glutamate + ornithine aminotran-feranc-pyridosal phomphate.

The first half-reaction is studied by reacting ${ }^{11} \mathrm{C}$ - 
ornithine with the enzyme, removing the enzyme, and resolving the resultant mixture of ornithine and pyrroline carboxylate on a Dowex 50 cation exchange column. The second half-reaction is studied by treating the enzyme with ornithine, removing the ornithine and pyrroline carboxylate by Sephadex treatment, and reacting the pyridoxamine form of the enzyme with ${ }^{1} \mathrm{C}-\alpha$-ketoglutarate. The mixture of $\alpha$-ketoglutarate and glutamate ohtained are again resolved by ion exchanga chromat ography.

\section{PROGRESS REPORT}

Figure 92 shows the stoichiometry of each halfreartion. These rexults indicate that one mole of enzyme (assuming a molecular weight of $132,000-$ see Reference 9) reacts with two moles of ornithine. This relationship is not strictly observed in the second half-reaction, in which one mole of enzyme reacts with 1.5 moles of a-ketoglutarate. The reason for this lower value is not known at present, but it may represent a partial low in the functional capacity of the enzyme after its conversion to the pyridoxamine form or it may indicate a change in the molecular weight of the enzyme during the reaction.

Figure 93 indicates activity $\mathrm{rs}$. $\mathrm{pH}$ for the complete enzyme reaction. The curve is symmetrical, with an optimum at approximately pH 8.2 .

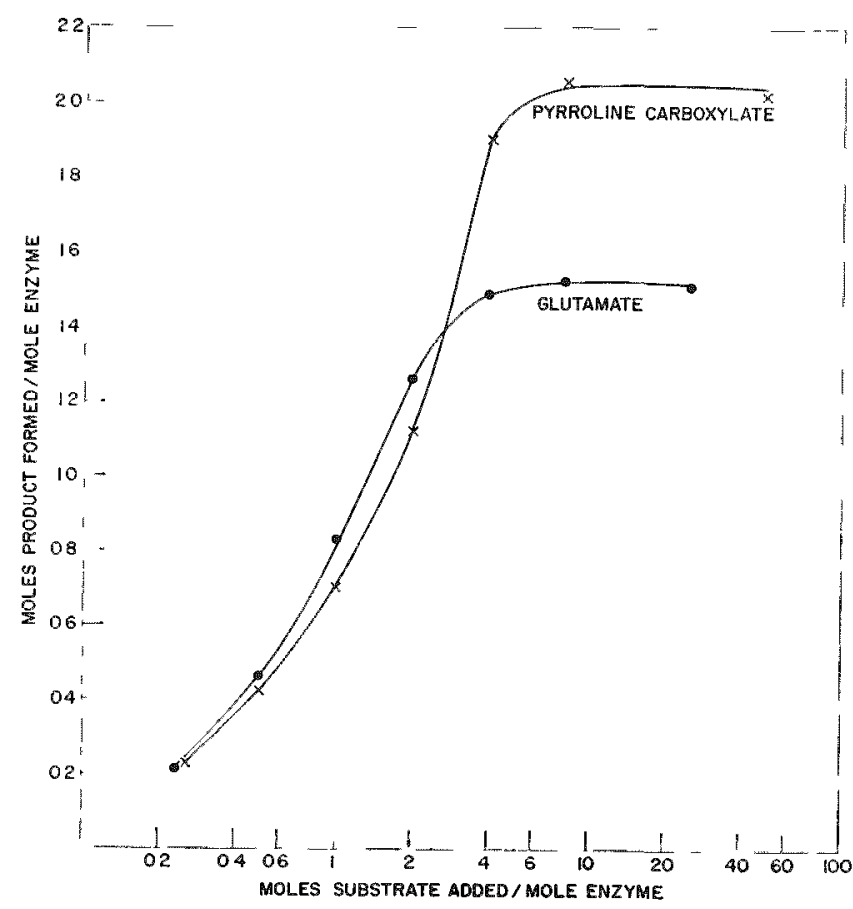

FIG. 92.- Stoichiometry of the ornithine aming transerase half-reartions.

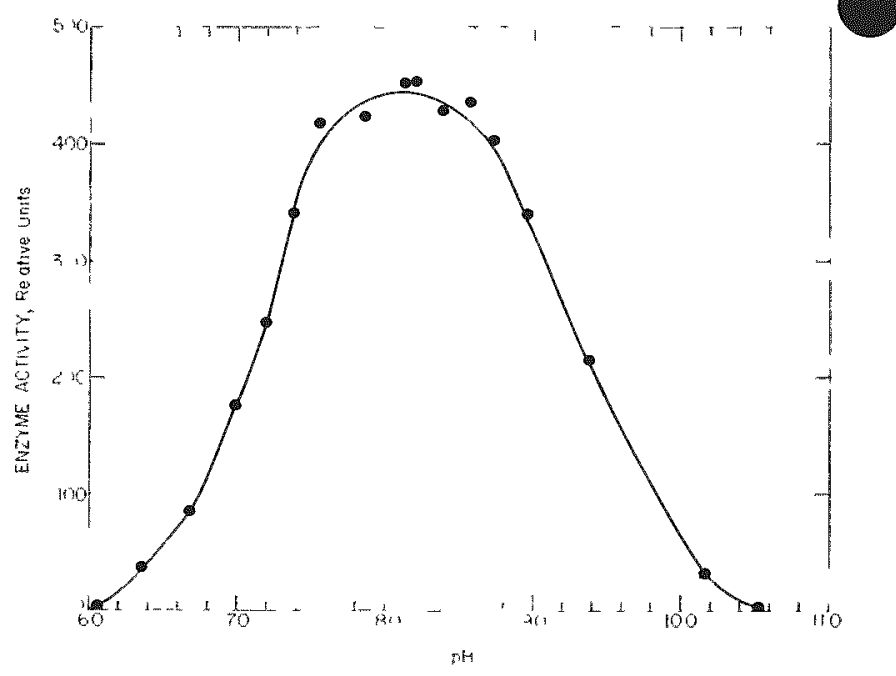

Fig. 93. - keffects of pll an the complete ornithine aminotransforase reaction.

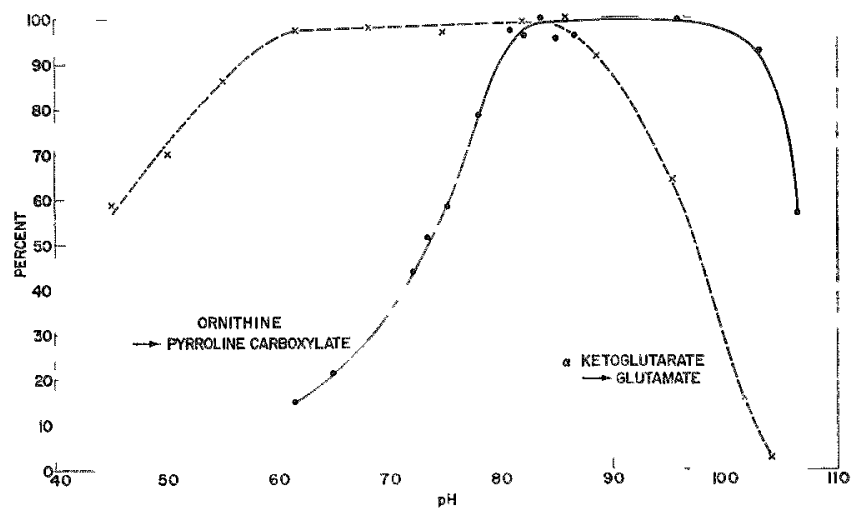

Fis. 91.-Effects of $p H$ on the ornithine aminotransforase half-reactions.

Figure 94 shows the effects of $\mathrm{pH}$ on each half reaction. The responses of the two half-reactions to $\mathrm{pH}$ changes differ markedly, both from each other and from the response of the complete reaction. Combining these results for the half-reactions (Figure 94) and proceeding from low to high $\mathrm{pH}$ reveals that the ancending limb of the $\mathrm{pH}$ eurve for the whole reaction (Figure 93) corresponds to that of the first half-reaction (Tigure 94), and the descending limh for the whole reaction (Figure 93) corresponds to that of the second half-reaction (Figure 94). The compositc $\mathrm{pH}$ curve obtained when the curves from the two half-reactions (Figure 94) are combined, however, is displaced to the right (higher $\mathrm{pH}$ ) of the pH curve for the whole reaction (Figure 93). The significance of this difference is under investigation. 


\section{(M)I.I-IUN}

A procedure was devined to stuly the two halfreation of ornithine aminotran-lerare. The results obtained indicate that: 11 Two molecules of each subtrate react with one molecule of enzyme. 2 ) The response of each half-reaction to changes in pII difier from each other and from that of the complete reaction. 3) The pII curve for the complete reaction apparently is a composite of the curves for the halfreartions. The general approach dencribed in these experiments appears to be well-suited to further inten-ive inve-tigation of the functional propertie of the ornithine aminotransferite molecule.

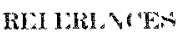

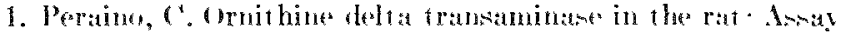

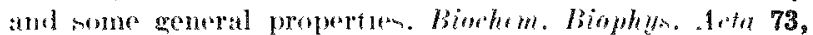
2022231 (1963).

2. Pitot, M. C. and ('. Paraino. Carbohydrate represmion of

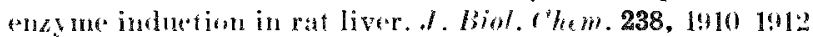
$1963)$.

$\therefore$ Pitot, M. (. and C. Peraine. Studies on the induetion and

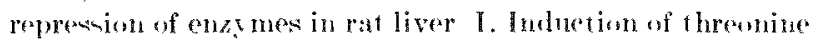

dehylrant and ornithine-delta-transaminase by oral in-

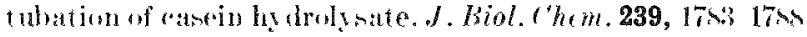
1901,

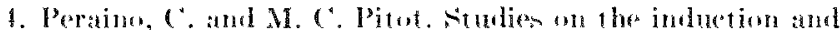
repression of ensymes in rat liver. 11. Caphohydrate repression of dietart and hormonal induction of threonine de-

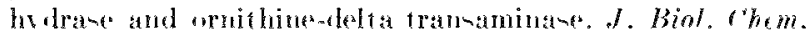
239, 1304 t31:; 196:1:

5. Peraim, (C.. R. 1. Blake, and M. C. Pitot. Studies wh the induction and pepreseion of eng mes in rat liver. III. Indurtion of oruthine delta-transaninase and threonines dehy

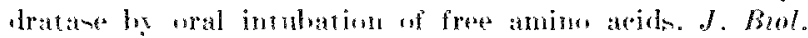

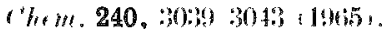

(i) Perain, ('., C. Iamar, Jr., and M. ('. Pitort. Studies on the molnetion and represuion of enas mes in rat liver. IV. Hefferets of cortisone" and phentherbital. I. Biol. chem. 241, 2914-

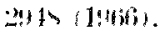

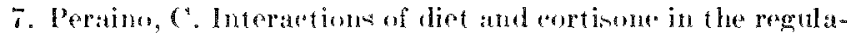

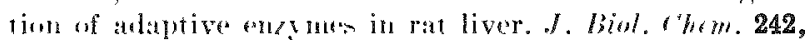

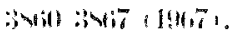

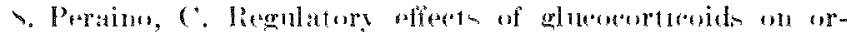
tol hine aminotranserase and serine dehy dratase in rat liver. Biwhim. Biophy. At to 165, 10s-112, 196is).

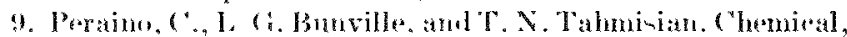
phy ateal, and morphologiest prepertion of ornithine amino-

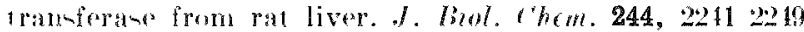
(19m?!).

\section{METABOLIC AND MORPHOLOGIC STUDIES OF HEPATOCARCINOGENESIS IN THE RAT}

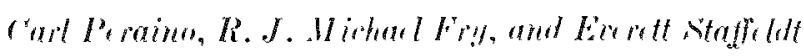

PCRPOML AND METHOUS

In previou studies we demombtated that the produetion of hepatomas in rat - by the feeding of acetylaminofluorene (AAF) was subtantially decreased if phenobarbital was aloo included in the diet."11 Thi protertive effect of phenobarbital probably resulted from a stimulation of detoxifying systems in the liver.' ${ }^{(2)}$ In a subsequent -tudy $(\dot{ })$ an investigation was made of the effect of varying the time of exposure to a given level of dietary $\Lambda \mathrm{AF}$ on the production of hepatic tumor. In thi- experiment the effect of phenoharbital were alo studien, but the phenobarbital wa- fed after the rat had been exposed to AAF rather than simultaneously with the A.AF an in the previous experiment.(1) The survival of rat fed AIF followed by phenobarbital was lens than that of rats fed $A \mathrm{AF}$ followed $\mathrm{b}$ a diet not containing phenobarbital.(3) This suggests that the dimage produced by AAF wa amplified by the su-b-quent administration of phenobarbital. Now we report further results of the experiment involving the equential feeding of $\mathrm{ALF}$ and phenobarbital.(3)

While the end point in the previou experiment wan the survival time of the rats, the end point in the present experiment was the incirlence of hepato- mis. In order to obtain the data, at leant 3 rats from each group were killed at intervals throughout the experiment. These intervals were $56,84,98,113$, 127. 161, 190, 232, and 282 days after the beginning of the experiment. At autopy, the animals wore examined for tumors and other lesions. In the najority of eanen where hepatoman were obrious or where careful examination of all lober revertled no ahnomality, no tis-uen were taken for histologiral examination. Where an abnormal appearance was found, and in a number of apparently normal or tumorous livers, tissues were taken for preparation of reetion. The incillence of hepatoma was compiled from the pooled data from macro- and mieroseppic examination. (ther detail of the experimental

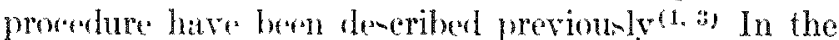
experiments involving maintenance of rats on diets containing $1 . \mathrm{F}^{2}$ and $\mathrm{AAF}$ phe phenoharbital, the proliferative antivity of cell in the liver has been invertiguted. ${ }^{3} \mathrm{HTdR}, 0.5 \mu \mathrm{Ci}$ g. $0.36 \mathrm{Ci}, \mathrm{mM}$, was injected intraperitoneally and the rats were acrified 1 hr later. 'The latheling index of hepatocytes and littoral cells was determined for the 6 treatment eroup -hown in Table 4.5.

In order to tudy whether phenobarbital had an 


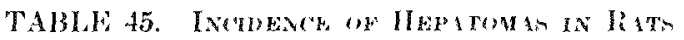

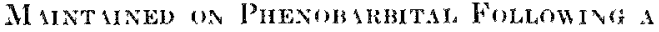

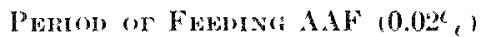

\begin{tabular}{|c|c|c|c|}
\hline Treatment & $\begin{array}{l}\text { Time on } A \perp F, \\
\text { weeks }\end{array}$ & No. of rats & $\begin{array}{c}\text { No. of rats with } \\
\text { hepatomas }\end{array}$ \\
\hline$A A F$ & 2 & 26 & 2 \\
\hline $\begin{array}{l}\text { A.tF followed by } \\
\text { phenobarbital }\end{array}$ & 2 & 26 & $x$ \\
\hline$\triangle A F$ & 4 & $26 ;$ & is \\
\hline $\begin{array}{l}\text { A AF followed by } \\
\text { phenobarbital }\end{array}$ & 4 & 26 & 25 \\
\hline $\mathrm{AAF}$ & 6 & $20^{2}$ & $2 ; 3$ \\
\hline $\begin{array}{l}\text { AAF followed by } \\
\text { phenobarbital }\end{array}$ & 6 & $2 t i$ & $26 i$ \\
\hline
\end{tabular}

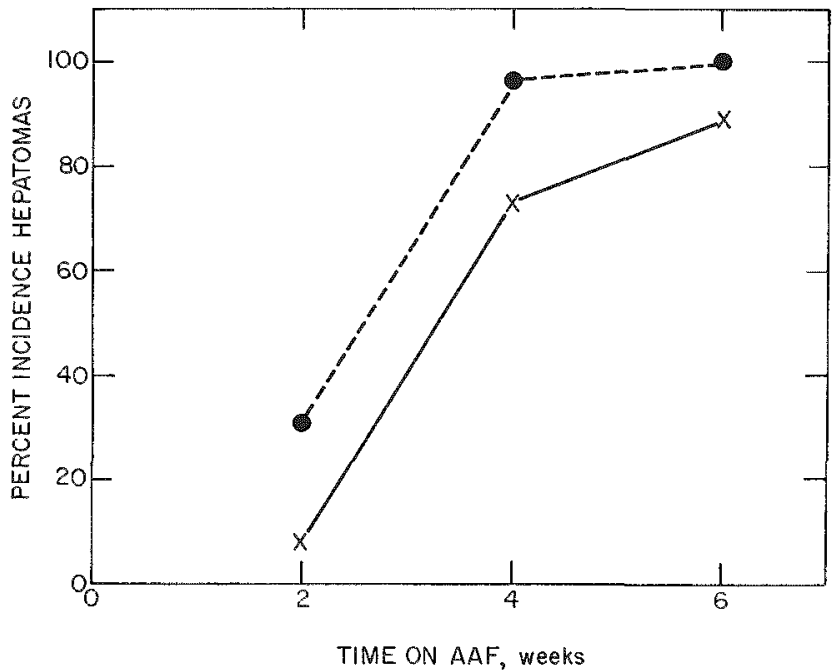

Fus. 95. The incidence of hepatomas in rats treated with A.AF for 2,1 , and ti weeks and then given a dien containing phenobarbital. Dashed line, AAF followed by phemobrhital; solid line, AAF.

"arly, and perhapm temporary" effect on proliferation of hepatocytes, 6-week-old male SD/Anl [Anl 66] rate were maintained for 3 days on control diet plus 0.5 's phenoharbital and injecter with "IITili and sacrificed $1 \mathrm{hr}$ later. In opder to entablish the labeling index of both binucleate and mononueleats hepatocyten, muear were prepared. The liver were perfu-ed with calcium and glucome-free Hank's solution containing collagenane and hyaluronidase, slicerd, agitated in a water bath, cieved, and spread on slike. Autoradiographs were prepared in the standard way, and the labeling index wan determined on amplen of 1000 to 2000 heputocyte.

PROKREAT REPUR'T

The exferet of the AAF in the diet for 2, 4, and 6 weeks, followed by a return to control diet with and without whenobarbital alkel, is shown in Tabl 45 and Figure 95. The incidence of hepatomas is higher in the ruts maintained on the diet containing phenobarbital in all the groups, though the difference is very small in the 6-week group owing to the high incidence of hepatomas, irrepective of the po-t-AAF treatment. An analysi of rariance showed that the incidence of hepatomas was different in the two treatment groups at the 5 ', level.

It was also found that the hepatomas oceurred somewhat earlier in the rate maintained on control diet plus phenobarbital subsequent to a 2-week $A . \mathrm{F}$ treatment. In the group of rats receiving only $A \mathrm{AF}$ for 2 week, only two tumor- were found: the tir orecurred at 190 days and the other at 282 days. In the counterpart group tive' phenobarbital tumors were found on day 113 , and five rat had tumor by 282 day. It in now clear that the deeign of the experiment is not the most suitable to show the signifieane of the differenee in the two treatments.

The result of the autoradiographic experiments on ('RL:CDISC) rats are shown in Table 46. Beratue these rats are only 6 week old, the labeling indices are high. The labeling indices of the hepatocytes and littoral rells of the AAF 10.019$)$ plus phenobathital $\left.10.0 \tilde{n}^{\prime}\right)$ were signifieantly different from the eontrol value at the $2^{\prime} ;$ and $5^{2}$ levels renpectively. It is likely that thene determinations will be more informative in the two older age groups now under tudy. The ahove experiment also did not eliminate the po-ibility that the addition of phenobarbital to the diet might result in an early and temporary effect on proliferative activity. This question and whether there was any difference in the labeling index of mononucleate and binueleate hepatoryten wa- inventiguted. It was important to extablish whether phenobarbital did increase DNA swnthetic activity, as has been reporterl, but not documented, ${ }^{(-1)}$

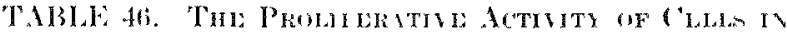

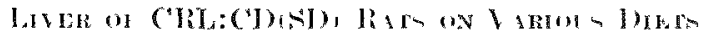
nol 'Tho Whas

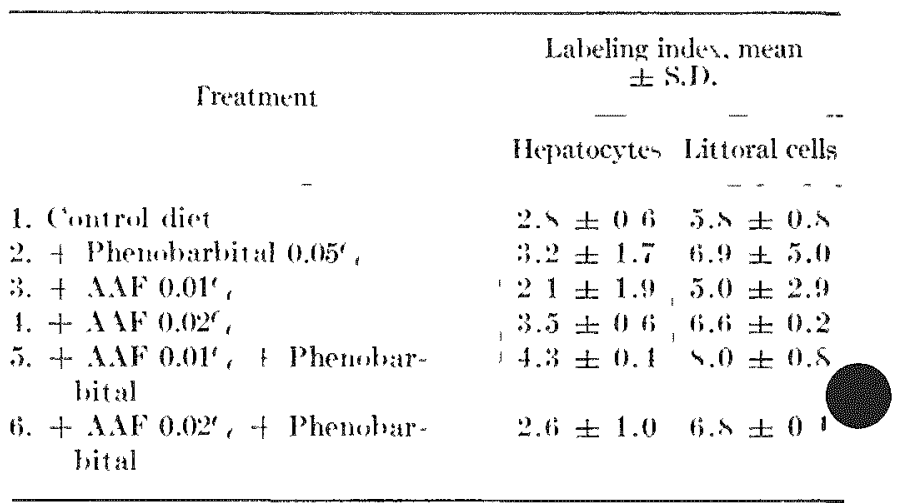


ecause of importance in the porsible relationship of DNA synthetic activity and the neoplastie transformation.

In the SD Anl[Anl 66] rats, on the control diet, the labeling index of the hepatocytes was $0.36 \pm$ 0.26 ; it was $1.45 \pm 0.53$ for thone given 0.05 C $^{\prime}$ p phenobarbital in the diet for 3 days. These values are ignificantly different at the $5{ }^{\prime} "$ level. The percentage of binucleate hepatocytes was $23.8=0.5$ and the labeling index for binucleate parenchymal cello was not greaier than for mononucleate cells. There appears to be a surprisingly large strain difference in the labeling index of hepatorytes, namely, $0.36 \pm$ 0.3 in the SD/Anl[Anl 66] rat and $2.8 \pm 0.6$ in the CRL:CD(SD) rats, although the ages of the rats and the diet were the same in both groups.

CONCLENION

The indieation that phenobarbital influence the carcinogenetic effect of $A A T$ when given after the treatment with carcinogen must be subtantiatenl. If the finding is confirmed it will open up powibilitic for invertigating the biochemical event, ar-ociated with neopla-tic tran-formation.

\section{REFFRENCTS}

1. Peraine, (". Metaholie and morphologie mudies of hepatocarcinogenesis in the rat Argunne National daborator Biological and Medical heseareh Divi-ion Annad Report. $146 \mathrm{~A}$ ANL 7109, p. 165.

2 Kato, H , H. Nhoji, and 1. Takanaka Metaboliom of car-

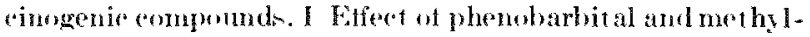
"holanthrene on the activites of $x^{-}$-demethylation of ear cinogenic eomponds by liver microsmes of male and female rath (iann 58, 1678 169: 1967).

3 Peraino, C. and R. J. M. Frs. Metabolie and morphologu* studies of hepatocarcinogenesis $n$ the rat. Argonne $X_{a-}$ timal Iaboratory Biologieal and Medieal liosearch I livision Annual Report, 196. AXY.-7535, p 39.

4. Japundzic. M., B Knezevir. V Injordjevie, and I. Japund ine. The influences of phemobabital $\mathrm{Na}$ or the mitutie are tivity of parenehomal hiver estls during rat liver regenera tion. Exp. ${ }^{\prime} t$ ll Res. 48,163$)^{-167}$ (1967)

\section{IMMUNOFLUORESCENT LOCALIZATION OF ORNITHINE AMINOTRANSFERASE IN RAT LIVER}

Patricia C. Brennan, ('anl P'eraine, R. I. Michat Fry, and Robert II". Suick"

\section{PL RPONE AND METHODS}

Ornithine aminotransferase (L-ornithine:2-oxoacid aminotransferase) can be used to study the nature of enzyme regulation because it is regulated in vivo by feedback inhibition 11 and by dietary and hormonal regulation of its turnover. ${ }^{(2-s)}$ Activity al-o varien among different transplantable hepatomas $(\tau, s)$ and among different clasmes of mitochondria.(9) For thene reanons, it was of interest to determine whether the di-tribution of the enzyme could be studied by histochemical methods. This report derribe the localization of ornithine aminotransferase in rat liver by an indirect fluorecent antibodr terhinique.

Crystalline omithine aminotransferane from rat liverion wat emulifier with an equal rolume of Freund's complete adjurant and injected into rabhitfor antiborly production. Another group of rabhitwas injected with Freund s adjuvant alone to produce a control serum. The specificity of the antiserum for ornithine aminotran-ferara wa verifed by Ouchter-

trophoreis, wing both crude timue extructs and pure enzyme a- sources of antigen. Single precipitin band were obared in all caces.

Male .7-week-old, $5 \mathrm{D}$ Anl[Anl 66] rat were fed either a pelleted diet containing $00^{\prime}$ protein or $60 \%$ protein ad libitum. In addition some rats were fed at -tundard laboratory diet containing $24 c^{c}$ protein. The efferet of these diet on the level of hepatic onithine aminotranserans in rats has been reported. ${ }^{(5.6)}$ The $60^{\prime}$ \% protein diet induem high level- of thi- enzyme, whereas rats fed the 0 , diet have little or no hepatic ornithine aminotransferase. Liver- of rat- fed the -tantard laboratory diet have ahout ones-fifth as much ornithine aminotran-ferane wot ix ity at thow fed the 60 , protein diet.

After 4 lars on thene two diet the rats were killed and frozen eetions of liver were prepared and fixed in methanol. In one experiment, pellet of mitochondria from liver of rat- fext the $60 c^{c}$ diet and the $o_{c}$ diet were prepared by difterential centrifugation and eectioned. The fixed -eetions were stained by the indiret fluorement antihody procedure previously deocribed,"11) except that Firionthome black was uned as the counter-tain. The sides were 


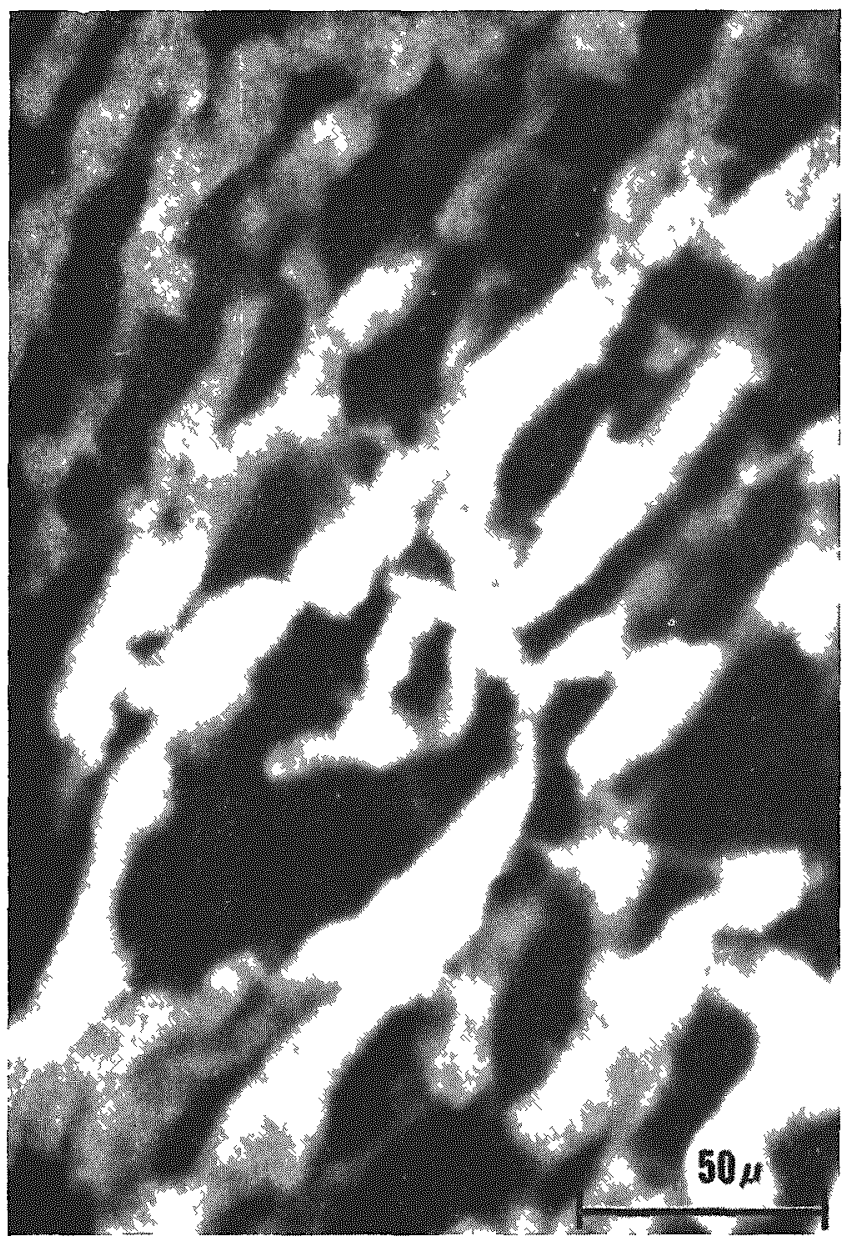

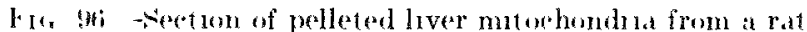
ted the wor, protem diet. The section was treated with or nithue ammotransferase anther um and then with fluorearem labeled antirabbit goat globuln

"xannined with a Leitz Ortholux microscope equipued for Huoreserent microscopy.

PRY, RI - RTPOR I

Brilliant fluorencence (Figure 96) wits ob-erved in section of pelleted rat liver mitochondria from rate fed the $60^{\prime}{ }_{c}$ protein diet treated with anti-erum and then with fluorecein labeled antirabbit goat globulin. No -pecifir fluorencence wa seen in similar sestion- treated with control rabbit serum. Sections of rat liver mitochondria from rat fed the o's protein diet and treated either with antinerum or with control serum did not fluore-ce.

The ornithine aminotransferane specific fluoresenence in livers from rats fed the $60 c_{c}^{\circ}$ protein diet wan diffu-ely distributed throughout the eytoplasm, but not in the nuclei of lepatic cell- (Figure 97). Fluoresence wa absent in section- from the same liver

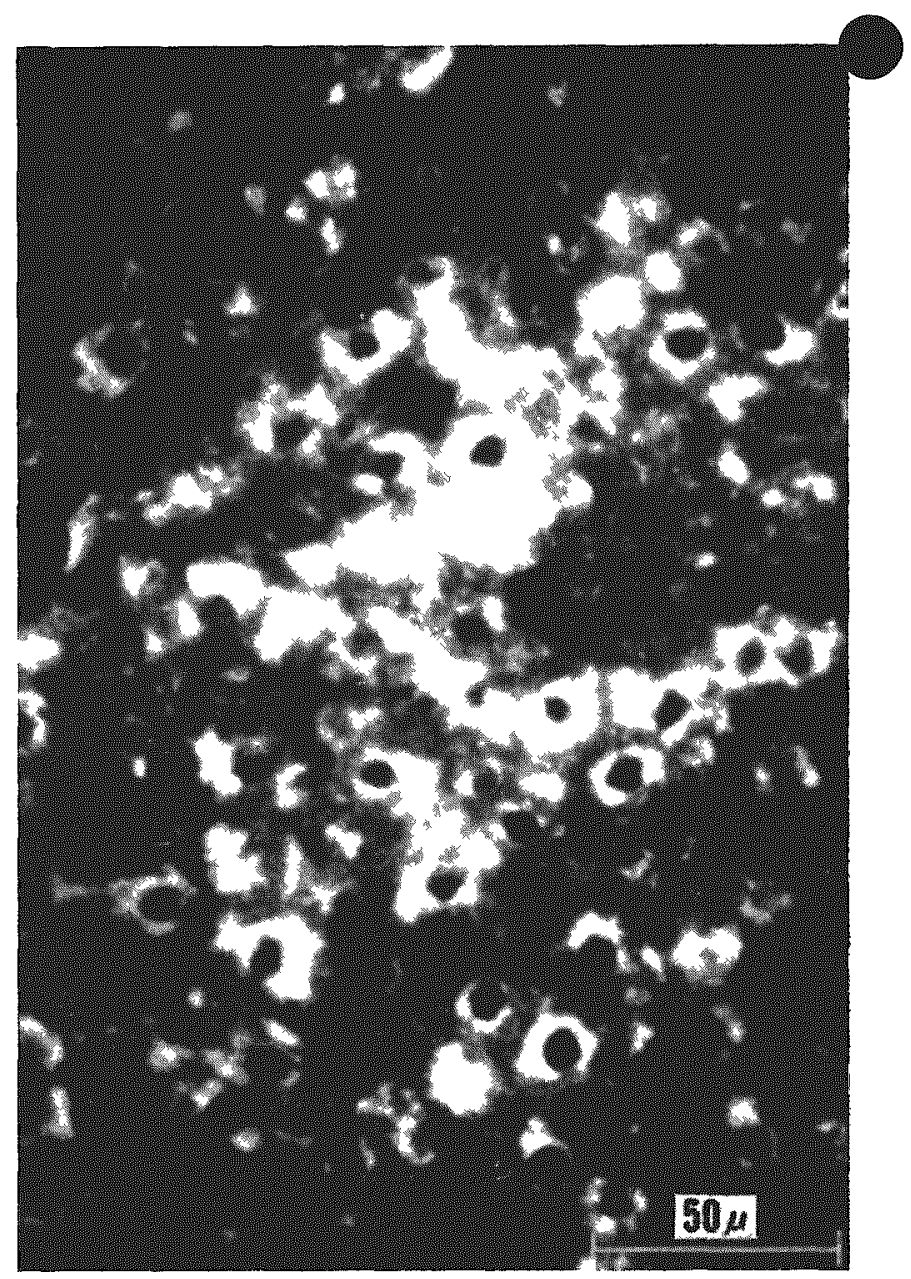

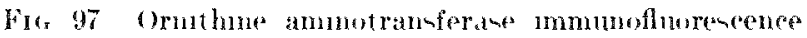

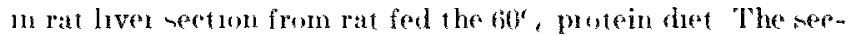
thon was treated with antiserum and fluoreceen lakeled antirabbit glubulm

treated with control erum. When -pecifically -tained nertion- from rat fed the $60^{\prime}$, protein diet were examined with low power. patchen of fluoreseent cells appeited to fill the entire lobule. In contrast, Huoresent cells in sections of livers of rate fed the tandayd det containing $24{ }^{r}$; protein were lem numerou and more randomly distriluted throughout the lobule. The hreps of rat fed the $a^{\prime}$, protein diet and treated with antierum howed no specific fluoreserences.

coN LACIOT

The fluoresent antibody renults reported here correlate well with mea-urement of ornithine aminotran-ferane activaty in extract- of liver from rats fed sinilar dict. 6,6$)$ The technique should prove uneful in further studiee of the loralization of orne thine ammotran-ferane in normal and dieaned liver. 


\section{EFERLANCES}

1. Katumuma, X.. M. Okata, and Y. Nishi. Retgulation of the urea eycle and 'T 'A recle by ammonia. ddedness in Enzyme Regulation, Vol. 4, kd. G. Weber. Perganon Press, New York, 19titi, pp. 317335.

2. Peraino, C. and H. ('. Pitut. Studies on the induetion and repression of enzymes in rat liver. II. Carbohydrate re pression of dietary and hormonal induetion of threonine? dehydrase and ornithine $\delta$-transaminase. $J$. Biol. $1 \mathrm{hom}$. $239,4305-4: 313(19464)$.

3. Paraino, C., R. I. Blake, and H. C'. Pitot. Studies on the induction and repression of enzymes in rat liver. III. Induetion of ornithine $\delta$-transaminase and thromine dehydrase by oral intubation of free amino ardds. J. Brol. ("hem. 240, 3039-304\$)(1915).

4. Peraino, C., ('. I amar, Jr.. and H. C. Pitot. Studies on the induetion and repression of enzymes in rat liver. IV. Feffects of cortisone and phenobarbital. J. Brol. rhem. 241,

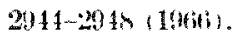

5. Peraine, C. Interantions of diet and cortisone in the regulation of adaptive enzy mes in rat liver. J. Biol. them. 242, $3 \times 60-3 \times 47(1966)$.

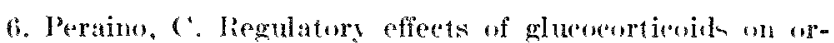
nithine aminotransferase and serine dehydratase in rat

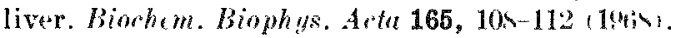

7. Poirier, 1. A. and II. C. Pitot. Het ary induetion of some enzymes of amino aeid metabulism during azo dye foesting. cancer lits. 29, 175-180 (1969).

s. Potter, V. R., R. A. Ciebert, II. C. Pitot, C. Peraino, C".

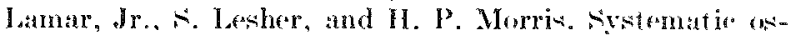
reillations in metabolie activity in rat livers and in hepatomas. I. Morris hepatoma No. T783. C'aner the 26, 1517-

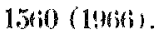

9. Nwick, I. W., J. I. Stange, S. I. Nanee, and J. F. Thom son. The heterogenesus distribution of mitochundrial rncymes in normal rat liver. Biochemistry 6, 737-71t (196r).

11. Peraino, (., L. (Y. Bunville, and T. N. Tahmisian. (hemiral, physical, and morphologieal propertien of urnithine aminotranserase from rat liver. $J$. Biol. $1 \mathrm{~h} h \mathrm{~m} .244,2211$ $2: 249$; 1949 !.

11. Brennan, P. (., T. F. Fritz, and R. J. Flynu, Roluc of L'ase

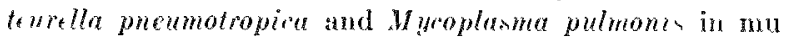
rine pnetmonia. J. Bustertol.97, 337 319 (1969).

\section{OPTIMUM BEAM ENERGY AND GEOMETRY FOR NEUTRON CAPTURE THERAPY}

Norman A. Frigerio

\section{PLRPOSE AND METHODS}

In a recent diffusion treatment of the penetration of neutrons into tissue, Ryabukhin (1) concluded that the optimum neutron entergy depended only on tumor depth, rising from $100 \mathrm{eV}$ for a tumor at the surface to $2.5 \mathrm{MeV}$ at $14 \mathrm{~cm}$. Infortunately, this treatment ignores the neutron-gamma dose to the patient from the beam it-elf. This effect is rery marked and, unless carefully controlled, would lead to demise of the patient from radiation at a beam level still too low to significantly affect the tumor. (2)

We have continued our previous examination of this question, ${ }^{(2)}$ using both theoretical and experimental methods. For theoretical computations program BIM-130 wan uned(2) and dose-space-energy distributions computed for a cubical phantom 16.35 $\mathrm{cm}$ on each side at various neutron energies and for rarious betam areas. Beam, were taken to be plane collimated and normal to the $\mathrm{X}=0$ plane of the phantom. Composition and density were thore of tissue equivalent liquid.(3) and temperature wataken as $293^{\circ} \mathrm{K}$.

The experimental phantom was of the same size, composition, temperature, and orientation as above, except that it was contained in a tank of $0.03 \mathrm{~cm}$ iainless steel type SK-304. The beam- used were the $2 \mathrm{keV}$ se filtered beam, and the $25 \mathrm{keV}$ Fe filtered heam, of the Idaho Divisions Alaterials Teuting Reartor I.llTR1. Suectrometry of thene beam was acompli-hes with proton recoil and ${ }^{3} \mathrm{H}$ e spectrometer. The 2 hel bean proved to be contaminated with 30 ' or more of neutrons orer $100 \mathrm{kel}$, so that no further examination was attempted. The $2.5 \mathrm{keV}$ be:m contained les. than $1 c_{c}^{s}$ of neutrom over 40 kell, so that it wan neel without moditication for lepth dose studies. Measurements were malle with timsue equivalent chambers, $\mathrm{BF}_{3}$, $\mathrm{He}$, and ${ }^{3} \mathrm{C}$ countern in in earlier work. For some measurements, a norlel human head was used" with organ- and direues filled with tis-ue-equivalent gel-, ${ }^{(4)}$ skull and other bones filled with an aqueous slurry of $\mathrm{Ca}_{3}\left(\mathrm{PO}_{4}\right)_{2}$, made into a gel by addition of agar.

PROMREM- REPORT

A- our previous computations had indicated that optimum energien would lie around a few $\mathrm{ket}$ and optimum cource areas around $50 \mathrm{~cm}^{2}$, this region wa- explored in greater detail. Result are presented in 'Pable 47 for the tumor-to-skin ratio ITSR at 6.5) cm. This is the ratio of the total dons to a tumor located at a denth of $6.5 \mathrm{~cm}$ and containing $3.5 \times$ $10^{-3}$ moles $\mathrm{kg}^{-1}$ of ${ }^{11} \mathrm{I} 3$ to the total dowe near the -kin. TSR taken in this way yield a "worst "ine" 


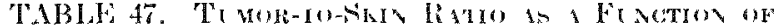

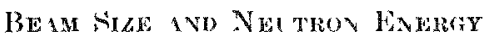

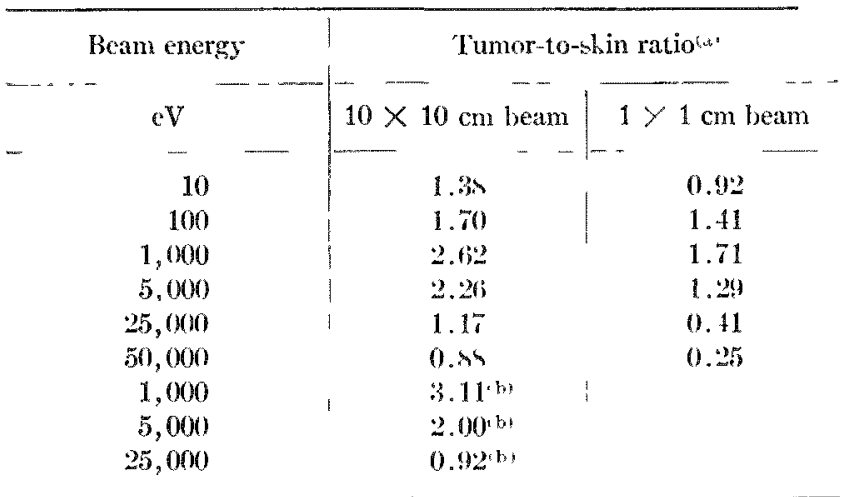

"Tumor taken as $1 \mathrm{~cm}^{3}$ in volume at a depth of $t .5 \mathrm{~cm}$ and cont aining $3.5 \times 10^{-3}$ moles ${ }^{10} \mathrm{~B} / \mathrm{hg}$ tumor. Nkin taken as a 1 'm' rube of normal tissue, frese of 1 "B, located at a depth of $0.5 \mathrm{~cm}$. Beam plane collimated, square in cross section, entrant perpendieular 10 the $X=0$ fare of a eubieal phantom of equivalent liquid 16.35 ("m on earh side.

"h. TSR here taken with shin reference an infinitesimal volume at $\mathrm{X}=0$. Beam at $25 \mathrm{~h}+\mathrm{l}$ was a circle of area $15.5 \mathrm{~cm}^{2}$.

figure of merit for brain tumors, as $6.5 \mathrm{~cm}$ depth in the phantom ued is equivalent to the center of a human brain.

From Table 47, it is clear that the larger beam invariably gives a higher TSR than the smaller. although tha difference decrea-e, somewhat with decreaning energy. Computations were also marle for beams of intermediate sizes but, as TSR increased monotonically with beam area, only the extremes are hown here. Becaune $10 \times 10 \mathrm{~cm}$ is ahout the area of the front of a human head, a much larger beam in impracticable.

It is also clear from Table 47 that the optimum energy in about $1 \mathrm{keV}$. Unfortunately, a reasonables do-e rate for therapy, about $100 \mathrm{Rad}_{\mathrm{m}} \mathrm{min}^{-1}$, would rerpuire a thux of about $10^{11} n \mathrm{~cm}^{-2}$ sec-1, and no $1 \mathrm{keV}$-ource is known that even approaches this figure. Some hope may be held for a $2 \mathrm{keV}$ beam via sic filtration of a reactor spectrum. The $2 \mathrm{keT}$ beam available at present (see above) has a flux of only $2 \times 10^{6} \mathrm{n} \mathrm{cm}^{-2} \mathrm{sec}^{-1}$ and a completely unaceeptable contamination by high energy neutrons. The powibility exists. how'ver, that these objections can be orercome by appropriate engineering maneurers. The available $25 \mathrm{kel}$ beam, while adequately monoenergetic. has an available flux of only $2.2 \times$ $10^{5} n \mathrm{~cm}^{-2}$ sece-1, although this, too, may be amenahle to engineering improvement. In either case, reenginesing can hardly take the form of a $10^{t} \mathrm{in}$ creane in resctor power wince the present power at the 2 and $25 \mathrm{keV}$ facilities is already 40 MIW. Rather, the output spectrum must be modified to increane the fraction in the 2 to $2.5 \mathrm{keV}$ region. Thus, an intermediate energy reactor must be designed, or found, with an adequate neutron output in the 2 to $25 \mathrm{keV}$ region. We examined this question at the epithermal neutron facility of the Medical Research Reactor (MRR) at Brookhaven National Laboratory, using foil, " $\mathrm{He},{ }^{6} \mathrm{Li}$, and proton recoil spectrometry. $A$, predicted theoretically, the flux in the $25 \mathrm{keV}$ region was $3.2 \times 10^{7} n \mathrm{~cm}^{-2} \mathrm{sec}^{-1}$ per $\mathrm{MW}$, requiring a somewhat unralistic $300 \mathrm{MW}$ in reactor power for an output flux of $10^{10}{\mathrm{n} \mathrm{cm}^{-2}}^{-2} \mathrm{sec}^{-1}$. This does reprenent an improvement over the 10,000 MW required at the more highly thermalized IITR facility, however, suggesting that a facility can be designed or found which is sufficiently high in epithermal neutrons to provide the recuired flux at nome reasonable reactor power.

The patteru of tumor done gamma dose, and total lowe at 1,5 and $25 \mathrm{kel}$ are shown in Figures 98 100. A neutron energy increases above $1 \mathrm{keV}$, the proton recoil dose near the surface increases rapidly. while the tumor and gamma doses slowly decrease. This results in a monotonically decreasing TSR above

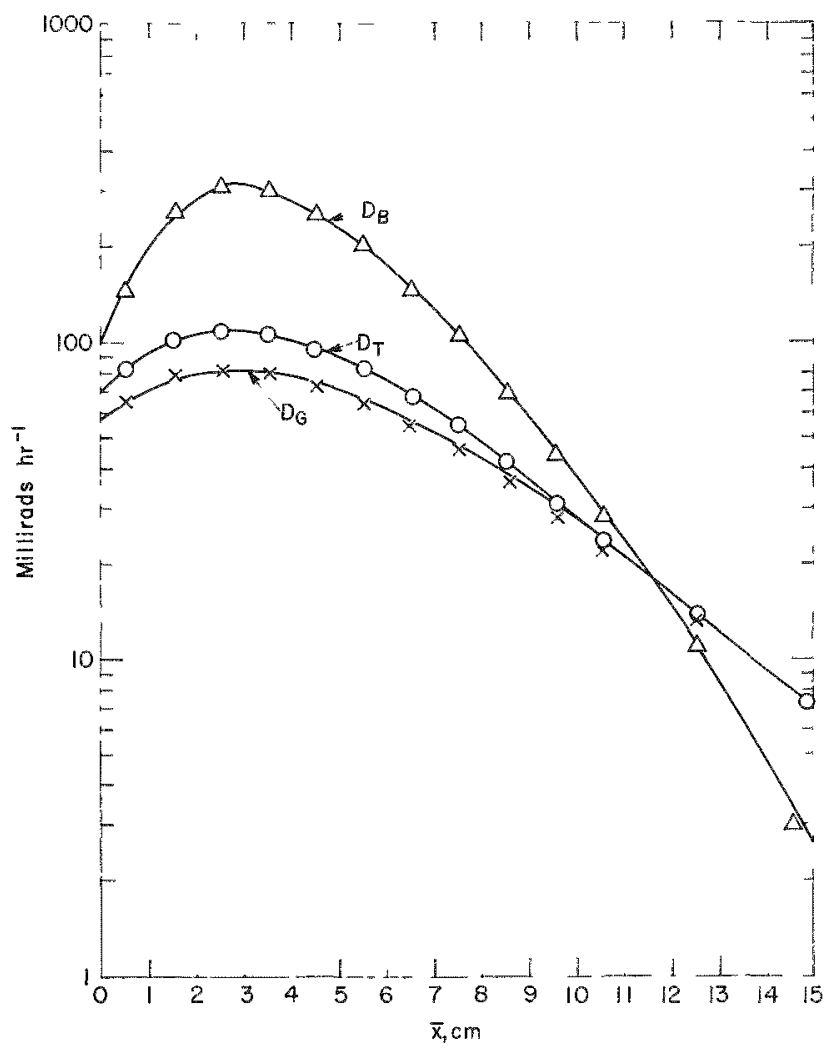

Fra. ah. Depth dose distributions in head phantom irradi ated hy a $10 \times 10 \mathrm{~cm}$ heam as computed with BIII-130. $/ b_{\mathrm{B}}$ dose to tumor onntaining $3.5 \times 10^{3}$ moles $\mathrm{kg}^{-1}{ }^{101} \mathrm{~B} ; L_{\mathrm{i}}$ gamma dose to normal tiscue; $D_{I}=$ total dowe to normal tisolft. 1 kel neutron energy. 


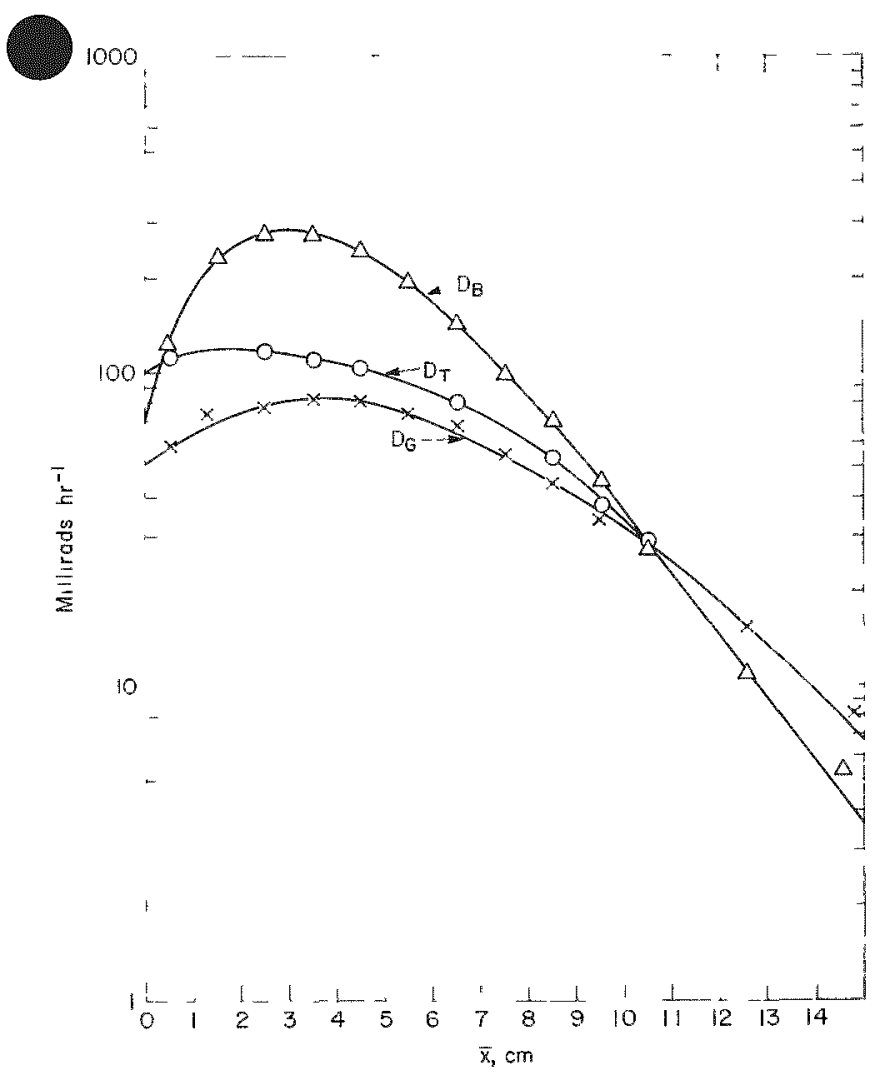

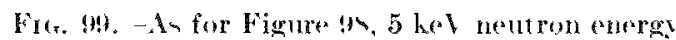

1 kel. Below $100 \mathrm{er}$, although not shown, the gamma and total doses remain nearly constant, but the tumor dose begin a fairly rapid drop, epecially at penetrations greater than $3 \mathrm{~cm}$, depresing TSR values. Between $100 \mathrm{eV}$ and $1 \mathrm{keV}$ a fairly broarl optimum region exist, wherein a rhoice of energy would be dictated by the precise chape, size, ${ }^{10} \mathrm{~B}$ concentration and po-ition of the tumor. Figure 100 indicate- the excellent agreement to be obtained in romparions hetween experiment and BIMI-130 computation.

Included in lable 47 are the $6.5 \mathrm{~cm}$ TSR value referred to the epidermi i.e.e at $x=0$. As skin is a critical tissue in radiotherapy, thene TSR values are comewhat more relevant to actual therayy. For reference the $12 \mathrm{~cm}$ TSR values from Figures 98, 99, and 100 are $0.43,0.32$, and 0.14 , re-pectively. Thus, $1 \mathrm{kel}$ is the better energy, even at depths equivalent to a tumor in the center of a human torso.

Theoretieal studien will continue to explore the relation hip of beam energy, beam geometry, tumor geometry, and rompo-ition until we are able to de-

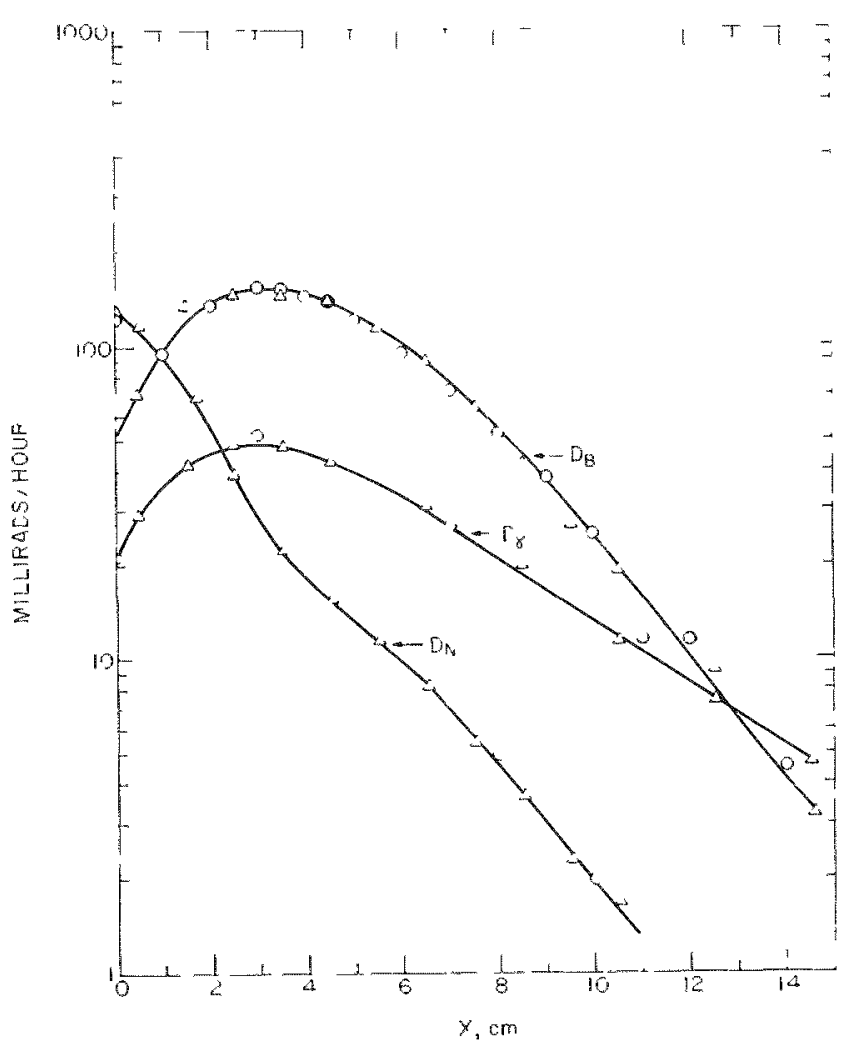

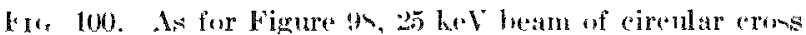

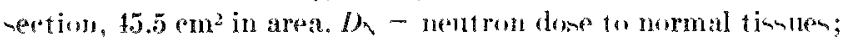

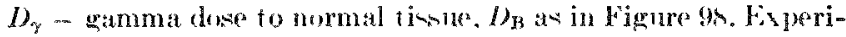
mental points (aireles) are compared with these (omputed viat BIM 130 :triangles.

fine optimum conditions for all feashle tumor in heal and body for different-rized humans, from infont- to ardult. Thene, in turn, will guide our detailed moninesering de-ign of therupeutically useful neutron fucilities. In any ease, the information now available make a strong cane for intermediate pectrum reactor as a type of facility, regardles of the eventual detail of construction and operation, so that feasibility - tudiem of such reactors are under way.

\section{REF FIRLACES}

1. Risulshin, Y. A. Optimal eneregies of incident neutrons in nextron rapture therapr. Wetinthana Radiol. 11, 913 ilfiti?.

2. Frigerio, N. A, M. J Shaw, atnd J. 1. Seiler. Neutron therapt of cancer: Physical aspeets Argomes National laboratory Biologieal and Medieal Remeareh Division Annual liepurt, 19H6. ANL-7.5is. pop. 15-14.

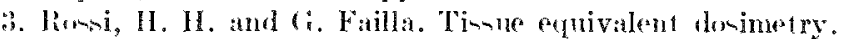

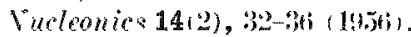

1. Frigerio, N. A. Neutron penet ration during neutron eapture therupv. Phys. Ved. Binl. 6. $511-549(1962)$. 


\section{DEPTH DOSE COMPUTATIONS IN SLAB, CYLINDRICAL AND ANTHROPOMORPHOUS PHANTOMS}

Norman A. Frigerio

\section{PURPOSE AND METHODN}

Computations of the neutron dowe and LFT distributions have been published for a semi-infinite slab $30 \mathrm{~cm}$ thick and for a right cireular cylinder $30 \mathrm{~cm}$ in diameter and $60 \mathrm{~cm}$ high. ${ }^{1,2}$ The differences between these two were quite large, so that the question arose as to whether even the evlinder provided an aderuate phantom for Standard Man. We have attacked this problem with our BLAr-130 program, ${ }^{(3)}$ examining the dose and LWT distributions in finite slabs and in an eleven-region anthropomorphous phantomi ${ }^{(4)}$ under nongeometric computational conditions as near as fousible to those used previously.

\section{PROGRFAS REPORT}

('omputations were performed at a number of representative neutron energies incident on the phantoms as plane collimated beams parallel to the $x$ axis. The slab phantom was $24 \mathrm{~cm}$ in $x,: 2 \mathrm{~cm}$ in $y$, and $160 \mathrm{~cm}$ in $:$, with composition 6.216 in $11,0.1789$ in $\mathrm{N}, 2.89 \mathrm{~s}$ in 0 ,
0.626 in $C, 0.0093$ in $\times$ a. and $0.009: 3$ in (1. all given in atoms $\mathrm{em}^{-3} \times 10^{2: 2}$. The Standard Man, described elosewhere in this report. ${ }^{\text {(4) }}$ was filled with standard soft tissue of $H, x, O,{ }^{(12)}$ in all eleven regions, at unit density. 'Temperature wa taken as $293^{\circ} \mathrm{K}$ throughout. It leant $2 \times 10^{5}$ interactions were recorded at each energy, wo that each energy run recguired about:300 min on the IBM-360; 7.5.

\section{CONCLUSTON}

Results are shown in tables 48 and 49 in emparion with semi-infinite slab and right eireular eylinder results published previously. It is evident thit significant differences exist even bet ween the right circular eylinder and the anthropomorphic Standard Man. Thu, not only is the eylinder inadequate, but even the anthropomorphic phantom may not be adequate. We will test. this proposition in future work, using geometric phantoms yet more closely resembling the Standard Man until a representation is obtained whose results ares essentially unaffected by further refinement.

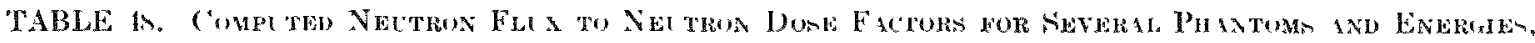
Then Aloni thi Midine of the Pilntom

\begin{tabular}{|c|c|c|c|c|c|}
\hline 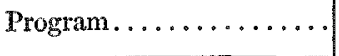 & $05 R$ & BI.M 130 & $05 \mathrm{R}$ & BIM 130 & $B I M 130$ \\
\hline Size $(x, y, \ldots) \mathrm{cm} \ldots \ldots \ldots$ & $(30, \infty, \infty)$ & $(24,30,160)$ & $(30,30,60)$ & $(30,30,60)$ & - \\
\hline $\begin{array}{r}2.5 \mathrm{MoV}, \quad 0 \mathrm{~cm} \\
6 \mathrm{~cm} \\
12 \mathrm{~cm} \\
18 \mathrm{~cm} \\
24 \mathrm{~cm} \\
30 \mathrm{~cm}\end{array}$ & $\begin{array}{r}4.1 \times 10^{-9} \\
2.1 \times 10^{-9} \\
1.1 \times 10^{-9} \\
0.15 \times 10^{-9} \\
0.19 \times 10^{-9} \\
0.065 \times 10^{-9}\end{array}$ & $\begin{array}{c}3.69 \times 10^{-3} \\
2.5 \times \times 10^{-9} \\
1.17 \times 10^{-3} \\
0.534 \times 10^{-9} \\
0.181 \times 10^{-9} \\
-\end{array}$ & $\begin{array}{l}3.7 \times 10^{-9} \\
2.0 \times 10^{-9} \\
0.95 \times 10^{-9} \\
0.50 \times 10^{-9} \\
0.22 \times 10^{-9} \\
0.04 \times 10^{-9}\end{array}$ & $\begin{array}{l}3.67 \times 10^{-9} \\
3.02 \times 10^{-9} \\
1.52 \times 10^{-9} \\
0.67 \times 10^{-9} \\
0.28 \times 10^{-9} \\
0.086 \times 10^{-9}\end{array}$ & $\begin{array}{c}1.22 \times 10^{-9} \\
2.72 \times 10^{-9} \\
1.36 \times 10^{-9} \\
0.622 \times 10^{-9} \\
= \\
=\end{array}$ \\
\hline $\begin{array}{r}0.5 \mathrm{MeV}, 0 \mathrm{~cm} \\
6 \mathrm{~cm} \\
12 \mathrm{~cm} \\
18 \mathrm{~cm} \\
21 \mathrm{~cm} \\
30 \mathrm{~cm}\end{array}$ & $\begin{array}{l}1.9 \times 10^{-9} \\
3.8 \times 10^{-10} \\
1.2 \times 10^{-11} \\
4.2 \times 10^{-12} \\
\cdots \\
=\end{array}$ & $\begin{array}{l}1.92 \times 10^{-3} \\
3.84 \times 10^{-10} \\
5.01 \times 10^{-11} \\
6.19 \times 10^{-12} \\
7.11 \times 10^{-13} \\
\end{array}$ & $\begin{array}{l}1.4 \times 10^{-9} \\
1.1 \times 10^{-10} \\
6.0 \times 10^{-11} \\
.0 \times 10^{-12} \\
8.0 \times 10^{-13} \\
1.0 \times 10^{-13}\end{array}$ & $\begin{array}{l}1.64 \times 10^{-3} \\
5.93 \times 10^{-10} \\
0.15 \times 10^{-11} \\
1.41 \times 10^{-11} \\
2.26 \times 10^{-12} \\
3.50 \times 10^{-13}\end{array}$ & $\begin{array}{c}2.19 \times 10^{9} \\
7.75 \times 10^{-10} \\
1.19 \times 10^{-10} \\
3.43 \times 10^{-10} \\
- \\
-\end{array}$ \\
\hline
\end{tabular}

(a) Standard Man described elsew here, ${ }^{(4)}$ as are the parameters for eomputation of phantom \#1(1) and ${ }^{3} 3^{(2)}$. Phantoms 1 and 2 contained $\mathrm{H}, \mathrm{N}, \mathrm{O}, \mathrm{C}$ in Standard Man proportions, ${ }^{13}$ ' 3,1 , and 5 in standard muscle proportions. (2) Phantoms were irradiated with infinite area, plane collinated beams parallel to the $x$ axis. Cylinders had ases parallel to the $z$ axis. Factors are given in lia. $n^{-1} \cdot \mathrm{m}^{2}$. 


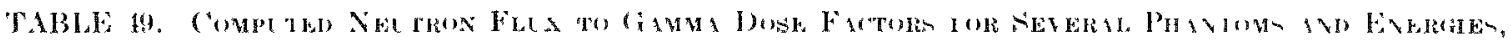

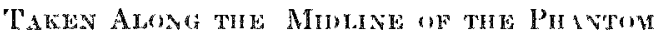

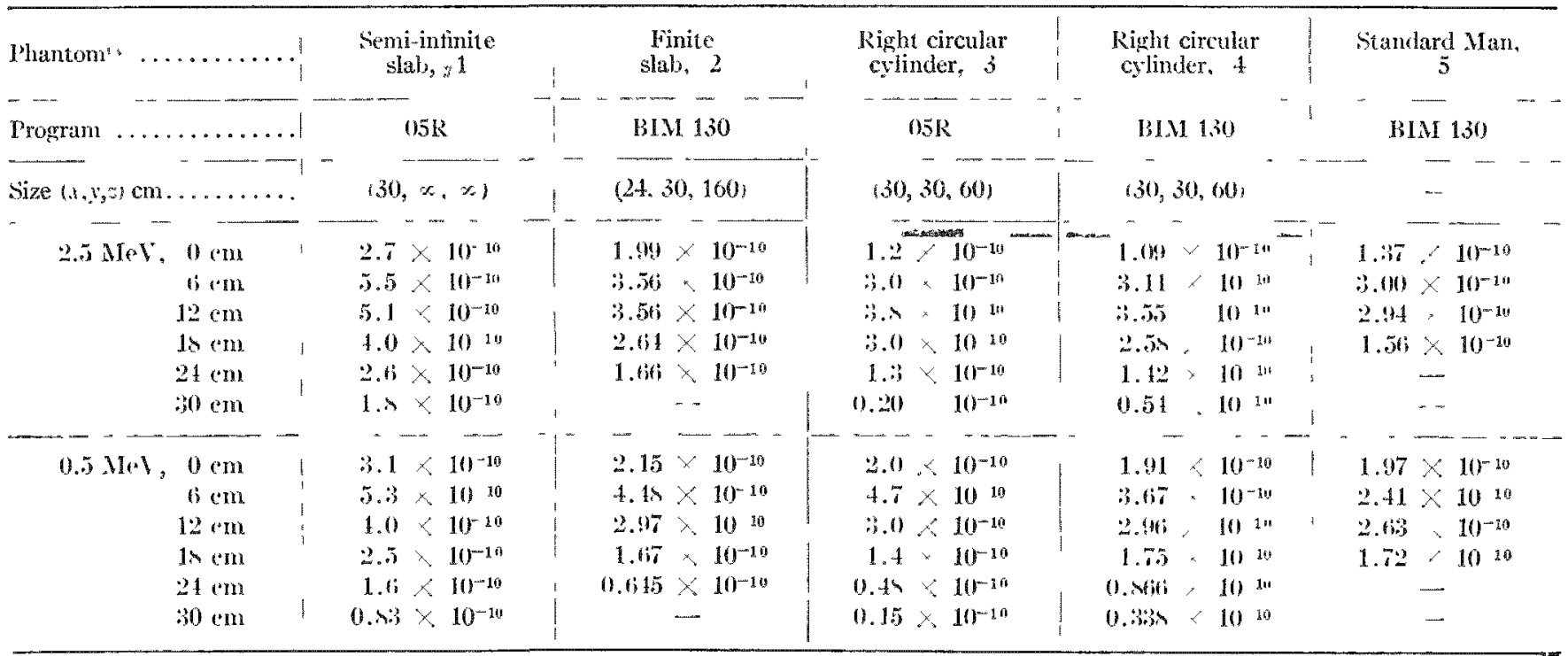

(a) Conditions as for Table is.

\section{TEFHLENCE-}

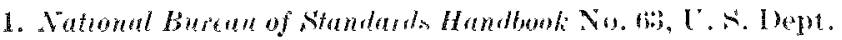
Commere, Washington, 1).C"., 1957.

2. Sing der, W. S. Distribution of dose and dose equivalent in an anthropomorphic phantom. Cnited states Atomio Knergy

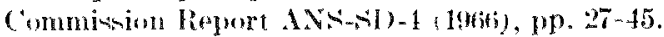

3. Frigerio. N. A. Nonte ( arlo complutation of dime parameters in neetron radiobiologe. Argontes National Latooratorg Bio-

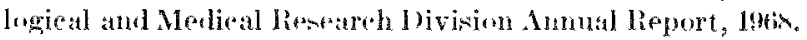
ANL-75,35, pp. 1:31 1:37.

4. Frigerio. N. A. and M. J. Sampono T'isue equivalent phanfoma for Standard Mlan and mulacle. Thi peport.

\title{
INSTRUMENTS AND MATERIALS FOR STUDIES OF DEPTH DOSE DISTRIBUTIONS
}

\author{
Normen .1. Frigerio, Norman Gilen," and Martin J. Sirmponon
}

\section{I'LRPOAE AND METYODN}

Determination of neutron-gamma done levels at various depth- in animal and human phantoms is a necensary adjunet to radiobiological studies, to studies of radiation foxicity, and to the ure of neut ron sourees for radiotherapv. Such measurements require small, semitive, timue equivalent dosimeters, as well as at knowledge of the phrsical and chenical parameters defining the tissuen to be represented by the phantom. We have begun here by examining the applicability of some commercial dosimeters to the problems of neutron depth dosimetry, using various standard neutron and gamma souress to determine their accuracy, precision, encergy response, and dose rate response. In addition, we have measured the densities and componitions of some of the tisues of radiobiological interest, using -

* AC*A-ANL Summer Binenginearing sitndent.
For combustion analysis, ti- -ue were dried to constant mins at room temperature over $\operatorname{Mg}(1)_{4}$. Dried samples were then subjected to the usual (C, II, N combustion, and ath residuen were weighed and saved.

\section{PROARESS REPORT}

In connection with their neutron dosimetry, ${ }^{\prime \prime} T$. erastuneum larvase were analyzed. as well at the flour media in which they are irradiated. Results are incluled in 'Table 50. Whole-body den-ities were measured by miarencopic volumetrie analy is for each of 13 weighed larvae, and a value of $0.949 \pm 0.00 \mathrm{~s} \mathrm{~g} \mathrm{~cm}^{-3}$ obtained.

Igur is used in compounding tisue equivalent gels for docimetry phantome, and is usually the only component whose composition in not known exactly from formula. Samples of the eommonly used Bacto-Agar (1)ifer Inc.. Detroit, Wich.) were analyzod and results are alou included in Table $.0 .14^{\prime \prime} \mathrm{w}$ w gel of BatetoAgar gave a measured dernsity of $0.9466 \mathrm{~g} \mathrm{~cm}^{-3}$ at $2.5^{\circ}$. 


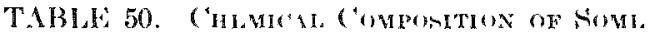
M I TERI \I OF DWIUET BIC INTEREST

\begin{tabular}{|c|c|c|c|c|c|c|c|}
\hline Material t' & $\mathrm{H}$ & $N$ & $0^{\text {the }}$ & $r^{\circ}$ & $\mathrm{Cl}$ & P & s Ash \\
\hline$\ldots \ldots$ & $-\quad \cdots$ & & $-\quad-1$ & & & & $1 \ldots$ \\
\hline $\begin{array}{l}\text { T. castanem, } \\
\text { larvae }\end{array}$ & 9.36 & 3.15 & 60.24 & 25.90 & 0.06 & 0.330 & 0.110 .82 \\
\hline $\begin{array}{l}\text { T. castanoum, } \\
\text { medium }\end{array}$ & 4.71 & 2.25 & 50.10 & 40.17 & $0.0 \%$ & 0.171 & $1 3 \longdiv { 0 . 1 0 }$ \\
\hline Bacto-Agar(e) & 5.77 & 0.21 & 44.51 & 45.25 & 0.19 & 0.000 & 0.903 .17 \\
\hline Bone marrow & 10.15 & 3.41 & & 13.11 & & & \\
\hline I) $\mathrm{spot}$ fat & $12.27^{1}$ & 0.02 & & 61.33 & & & \\
\hline Large intestine & 10.29 & 2.83 & & 11.01 & & & \\
\hline Small intestine, & 10.96 & $2.8 \$$ & & 13.05 & & & 1 \\
\hline Kidney & $10.37^{1}$ & 2.79 & & 11.49 & & & \\
\hline Liver & 10.13 & 3.02 & & 12.42 & & & \\
\hline Skelet:al muscle & 10.24 & 3.29 & & 11.98 & & & \\
\hline
\end{tabular}

(a) Analyses reported in weight perent. Analytical methods were precise to $\pm 0.02 \%$

(b) $\mathrm{By}$ difference without allowance for () in ash.

(e) Analysis reported on dry weight hasis, Ho() was $19.50 \pm$ $0.70 \%$

(d) All tissues pooled from a rats. Only ( $, \mathrm{H}, \mathrm{N}$ analyses iompleted to date.

TABLE 51. DENATILO OF RIT AND MOYSE Oreans at $25^{\circ} \mathrm{C}$

\begin{tabular}{|c|c|c|}
\hline Organ & Mouse(v), $\mathrm{g} \mathrm{cm}^{-3}$ & $\mathrm{Rat}^{(b)}, \mathrm{g} \mathrm{cm}^{-3}$ \\
\hline--- & - & $-\longrightarrow$ \\
\hline Brain & $1.0475 \pm 0.009$ & $1.0442 \pm 0.0019$ \\
\hline Fikeletal muscle & $1.05 \times 3 \pm 0.0012$ & $1.0562 \pm 0.0013$ \\
\hline spleen & $1.0 \times 26 \pm 0.0011$ & $1.0 \times 00 \pm 0.0024$ \\
\hline Kidney & $1.0547 \pm 0.0008$ & $1.0566 \pm 0.0010$ \\
\hline liver & $1.08 \times 7 \pm 0.00066$ & $1.0725 \pm 0.0013$ \\
\hline
\end{tabular}

(2) Mean $\pm \sigma$ for 15 mire, reported previously. ${ }^{(2)}$

(b) Mean $\pm \sigma$ for $5 N I /$ AnllAnl-(bi) rats.

equivalent to a partial wolution densits, ${ }^{2} \rho_{a}$, of $0.7 \mathrm{sig}$ en ${ }^{-3}$ for the agar.

Tisues from five female sprague-Dawley rats, 3:00 diss old and littermates w eighing $200 \pm 4 \mathrm{~g}$, wore subjected to analysis and to denity meaturement s. Liewalt: are presented in Tables .50 and 51.

In addition, samples of -keletal museles from the rats and from 15 ("F 1 mice were meatured for fat-iree denvity by previously reported methods. ${ }^{(3)}$ The rats qave 1.06 .5 and the mice $1.06 \mathrm{c}$, both in $\mathrm{g} \mathrm{cm}^{-3}$ at $: 37^{\circ} \mathrm{C}$.

Four other mice and one rat, taken randomly from the ANI Facility animal population and differing in age, strain, and -ex were -ubjected to organ density measurement in a preliminary attempt to acrertain the probable spread of such values in a laboratory restent population. Result are preented in Table .i2.

In addition to the phy sirochemical studies above, wa examined the suitability of some small, paired, commereial* ion ehambers for depth dosimetry. lateh pair

\footnotetext{
* Bendix Corp., ('ineinnati s, ohio.
}

TABLE 52. DLNATIES OP VARIOU RAT AND MOLSE ORTBNS

\begin{tabular}{|c|c|c|c|c|c|}
\hline ()rgan $(a)$ & $\begin{array}{c}\text { Mouse } \\
\text { I } \\
27^{\circ}\end{array}$ & $\begin{array}{c}\text { Mouse } \\
\text { II } \\
27^{\circ}\end{array}$ & $\begin{array}{l}\text { Mouse } \\
\text { III } \\
26^{\circ}\end{array}$ & $\begin{array}{l}\text { Mouse } \\
\text { IV } \\
25^{\circ}\end{array}$ & $\begin{array}{l}\text { Rat, } \\
3 \sigma^{\circ}\end{array}$ \\
\hline Liver & $1.0 \mathrm{~N} 13$ & 1.0874 & $1.0 \times 10$ & 1.0679 & 1.06114 \\
\hline Femur & $1 . \$ 715$ & & & 1.6660 & 1.5. 123 \\
\hline Ovary & & & & & 1.06665 \\
\hline Theriss & $1.06 \times 5$ & & 0.0627 & $1.06 \times 4$ & $1.059 \%$ \\
\hline He lens & 1.2216 & & & 1.2083 & 1.3170 \\
\hline Iloart & $1.0 \div 30$ & 1.0515 & 1.0615 & 1.0736 & 1.0595 \\
\hline Small intestine & 1.0417 & $1.031 \%$ & 1.0254 & 1.0342 & 1.0 .855 \\
\hline Large intestine & 1.0290 & 1.0432 & 1.0252 & 1.0289 & $1.03 \times 9$ \\
\hline Stomateh & 1.0411 & & 1.0442 & & 1.0524 \\
\hline Limgs & 0.6143 & $0 . \times 243$ & 0.8030 & $0.6 \times 4 x$ & $0 . \times 447$ \\
\hline Pancreas & 1.0668 & 1.3081 & & & \\
\hline Skin (shaved) & 0.9501 & 1.0029 & & & 1.0715 \\
\hline Lymphatios & 0.9736 & & & $1.0: 392$ & \\
\hline Salivary glands & 1.0538 & & & & \\
\hline Whole aye & & & & 1.0748 & \\
\hline Bladder & 0.97938 & & & 1.0338 & \\
\hline Thymus & & & $1.038 \times 1$ & & \\
\hline Tumor (fibroma) & & & & & 1.0515 \\
\hline
\end{tabular}

(2) Densities given in $g \mathrm{~cm}^{-3}$ at the temperature noted.

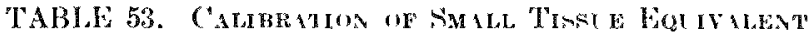
ION ('HA UBER PAIRS

\begin{tabular}{|c|c|c|c|c|}
\hline Source (a) & Pair 1 & Pair II & Pair III & Pair IV \\
\hline $\begin{array}{l}\text { La } \gamma \text {, tissue } \\
\text { equivalent } \\
\text { chambers }\end{array}$ & $\begin{array}{l}1.021 \\
\pm 0.013\end{array}$ & $\begin{array}{l}1.196 \\
\quad \pm 0.009\end{array}$ & $\begin{array}{l}1.110 \\
\pm 0.016\end{array}$ & $\begin{array}{l}0.945 \\
\pm 0.011\end{array}$ \\
\hline $\begin{array}{c}\text { ha } 2\left(\mathrm{CO}_{2}\right. \\
\text { chumbers }\end{array}$ & $\begin{array}{l}1.000 \\
\pm 0.010\end{array}$ & $\begin{array}{l}1.202 \\
\quad \pm 0.012\end{array}$ & $\begin{array}{l}1.103 \\
\pm 0.000\end{array}$ & $\begin{array}{l}0.915 \\
\quad \pm 0.000\end{array}$ \\
\hline $252 \mathrm{Cf}$ & 0.97 & 0.90 & 1.02 & 0.07 \\
\hline Pu-be & 1.01 & 1.02 & 0.99 & 1.01 \\
\hline $84 \mathrm{k}: \mathrm{l}$ & 1.04 & 1.09 & 1.00 & 1.07 \\
\hline $39 \mathrm{~s}$ hel & 1.05 & 1.06 & 1.00 & 1,04 \\
\hline $663 \mathrm{keV}$ & 1.05 & 1.07 & $1.0 \mathrm{~s}$ & 1.0 .5 \\
\hline $391 \mathrm{kel}$ & $1.0 \%$ & 1.05 & 1.06 & $1.0 \%$ \\
\hline $1: 321 \mathrm{keV}$ & 1.01 & 1.03 & 0.98 & 1.02 \\
\hline
\end{tabular}

(a) Values are given as fraction of the known dose from the calibration standard. Standard deviations for soures other than lia were all about \pm 0.02 .

comsinted of a tirsue efuivalent chamber and a graphite(Y) chamber, both of the Romi trpe. " I ull-reale reading was about 0.2 Rads and sen-itive volume was $1 \mathrm{~cm}^{3}$.

light pair were-elected and cross calibrated against a National Bureau of Standards rudium $\gamma$ couree. (alibration was also effected by using the monoenergetic neutron facility previounly decribed, a plutonium bervllium neutron sondee calibated for us by NBS

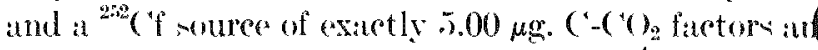
equations were tahen from the literature. ${ }^{(1)}$ Re-ult-are presented in Table is. 


\section{GFLEN'ES}

1. Yang, T. C.-H., N. A. Frigerio, and M. J. Sampson. The lethal effects of monoenergetic neutrons and "n 'o gamma rays on Tribolium rastareum. This report.

2. Frigerio, N. A. and M. J. Nampson. Tissue equivalent phantoms for Standard Man and muscle. This report.
3. Frigerio, X. A., H. IA. Frigerio, ৯. Bink, and L. Barhors. 'The density of mammalian tisules. Argonne National Laho uratory Biological and Medical lieseareh livision Semiinmulal lieport, July-1)ecember 1959. ANL-6264, pp. 2:3 24.

4. National Burean of Standards II andbook No.75, T.S. I lept. Commeret. Washington, D.C.. 1!ni1.

\section{TISSUE EQUIVALENT PHANTOMS FOR STANDARD MAN AND MUSCLE}

Noman 1. Frign rio and Martin . . Sampwon

PURPOSE AND METHOD

Although tisue equivalent chambers are widely used in experimental neutron dosimetry, ${ }^{1}$ depth dome measurements require tisucerequivalent phantoms as well. Such phantoms impose more stringent requirements than do chambers with respeet to elemental composition, chemieal composition, density, and geometry. ${ }^{2 \prime}$ As phantoms meeting these requirements are not at present available, we endeavored to fill this need by using eommon phyiecochemical methods, taling the needed biological data from standard references.3 ('urrently, we have rest ricted ourselves to the two best characterized sistems, Standard Man and lean, mammalian muscle.

\section{PROGRLAS REPORT}

In addition to the recuirements above, a tissueequivalent liquid for use in phantoms should be moderate in cost, transparent, colorless, compounded of readily available substances, neither corrosive, toxic, volatile, nor unpleasant, and stables to radiation; also over a period of time it should not be subject to growth of microorganisms, to internal chemical reaction, or to absorption of $\mathrm{C}_{2}$ ete. from the air. Satisfuing thene requirements is quite an exereise in applied ehemistry and that process is too eomplex to deseribe in detail here. However. Table ot list s the properties of a number of useful eompounds, nearly any mixture of which will meet the requirements above solong as the sistem is chiefly arpueour. The only conspicuous exeeptions are mixtures of the salts. enpecially (at and Mg phemphateand -ulfates. Where their enerentrations are fairly low, as in muscle, one can resort to a mildly aridic medium or to the addition of a chelating agent (e.g. EITT) to hold the ions in solution. It high concentrations, as in Standard Man, even chelatem are insufficiently soluble, and we have been unable to avoid acidie solutions. We were alos unable to avoid the use of at fen uncommon mpound st though we were able to rentrict ourselven to thone both inexpenive and commercially arailable. With the exception of the fairly low pH of some of the mixture, then, they satisfy all of the recuirements pre. sented above.

Volatility is proportional to total erguilibrium vapor presure. This ean be estimated by Raloult's Law ;

$$
P=\sum_{i} X_{i} P_{i} \text {. }
$$

where $I^{\prime}$ is the total vature pressure at a given temperature, $X_{2}$ the mole fraction of the ith romponent and $P_{i}$ its vapor premure at the given temperature. In eoncentrated aqueous solutions. I' will generally be lower than given by Eicuation 11 , becatuse of ionic and molecular interaction. For all of the mixtures given in this report, the totul vapor presure at $25^{\circ}$ will be lower than that of pure water, even for mixtures contuining some higher vapor-pressure components, becaluse of the combined effeets of Raoult's Law and of chemical interaction. Nonetheler, mixtures should be kept orvered, both in wese and in storage, to prevent slow ehanges in their componition and den-ity through evaporation.

Similarly, density ean be ext imated froma ${ }^{(2)}$

$$
(\vec{\rho})^{-1}=\sum_{i} U_{2} \bar{\rho}_{a, i} .
$$

where $\bar{\rho}$ is the mean deneity of the mixture, $H_{i}$ is the weight Pration of the ith component, and $\bar{p}_{a r i}$ is it apparent -perific density in solution.

Values of $\bar{\rho}_{n}$ are included in 'Table 5 , th ome computed from literature datat and rome measured by u- With there and Eafution (2) an estimate of $\bar{p}$ can be made to +1 ' or $*$. In principle, the mothed of partial den-itim can be uned to prediet $\bar{p}$ to a few hundrethe of at pereent. In practice, however. thi- would rectuire that $\bar{\rho}_{a g}$ values be known for the exact concentrations and milien uned so that it is more pract icable to une bquation (2) only for preliminary estimaten. and take $\bar{\rho}$ by acetual mea-urement on the final mixture. Where it i- necessary to obtain a partieular den-its, the amount of trial and crere can be greatly redueed by making up two wolutions, one of $\bar{\rho}$ slightly higher and one with $\bar{\rho}$ slightly. lower thatn desired. These can then be combined lineatry to wive the $\bar{\rho}$ desired, as the error introduced by non- 


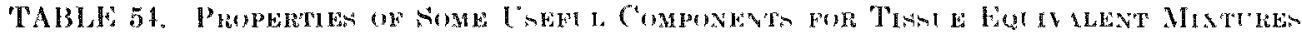

\begin{tabular}{|c|c|c|c|c|c|c|c|c|c|}
\hline \multirow{2}{*}{\multicolumn{2}{|c|}{ Compound }} & \multicolumn{2}{|l|}{ Canonical formula } & \multicolumn{3}{|c|}{ Apparent solvated density } & & \multicolumn{2}{|l|}{1} \\
\hline & & $-m$ & & $\begin{array}{l}\bar{\rho}_{c 2}(\hat{r g}) \\
\mathrm{g} \mathrm{cm}\end{array}$ & $\begin{array}{l}\text { Tempera- } \\
\text { turt, "f }\end{array}$ & $\begin{array}{l}\text { Concen- } \\
\text { tration, } \\
\text { moles } / \mathrm{kg} g\end{array}$ & $\begin{array}{c}\text { Vapor prensure } \\
\text { at } 25^{\circ} \mathrm{C}, \mathrm{mm} \\
\mathrm{IIg}\end{array}$ & $\begin{array}{l}\text { Solubility in } \\
140 \text { at } 25 ? \\
\text { moles/hg }\end{array}$ & $\begin{array}{l}\text { Formula wt, } \\
\mathrm{g} / \mathrm{mole}\end{array}$ \\
\hline Water & & $\mathrm{II}_{2} \mathrm{O}$ & & $0.94 \%$ & 25 & 55.5 & $29.76 i$ & s. & 15.016 \\
\hline Propandel 1 & $\vdots$ & $\mathrm{C}_{3} \mathrm{H}_{6}\left(\mathrm{H} \mathrm{H}_{2} \mathrm{C}\right)$ & & $0 . x 23(0)$ & 23 & 2.5 & 20.1 & $\infty$ & 40.091 \\
\hline $\begin{array}{l}\text { Et hylenediaminetetratcetio } \\
\text { arid, (EIST) }\end{array}$ & & $\left({ }_{10} \mathrm{~N}_{2}\left(1 I_{2}(1)\right)_{5}\right.$ & 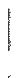 & $1.1900^{\circ}$ & 25 & $0.1^{b}$ & (f) & 0.1 in & 202.24 \\
\hline Glyeerol & 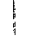 & $\left({ }_{3} H \cdot\left(\mathrm{H}_{2} \mathrm{O}\right) \mathrm{H}_{3}\right.$ & & 1.300 & 20 & 2.1 & $3 r$ & $\infty$ & 92.091 \\
\hline $\begin{array}{l}\text { Xris (hydrosymethyl) aminu- } \\
\text { methane. (ThIs) }\end{array}$ & $:$ & $\left({ }_{4} \mathrm{H}_{5} \mathrm{~N}, \mathrm{H}_{2}\left(\mathrm{H}_{3}\right.\right.$ & & $1 .: 316^{*}$ & 21 & $: 1$ & 'f & 2.9.8: & $121.1 !$ \\
\hline l'reat & ; & $\left.\mathrm{CH}_{2} \mathrm{~N}_{2}, \mathrm{H}_{2} \mathrm{O}\right)$ & & 1.301 & 20 & 1.6 & (f) & $\therefore .: B$ & 60.058 \\
\hline KHNO: & & $\mathrm{KHNO}$ & 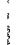 & 3.13 & 20 & 0.2 & (f) & 4.1 & 136.17 \\
\hline Siall & ' & $\mathrm{NaCl}$ & 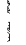 & 3.34 & 20 & 0.1 & (5) & $1.5 \%$ & 58.45 \\
\hline $\mathrm{NaH} / \mathrm{P}\left(\mathrm{O}_{1}: \mathrm{H}_{\mathrm{S}} \mathrm{O}\right)$ & & $\mathrm{N}_{3} \mathrm{Pl}^{\mathrm{P}} \mathrm{O}_{3}\left(\mathrm{HLO}_{2}\right.$ & 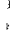 & $3 . x: 3$ & 25 & 0.1 & if & 1.2 & $13 \times .01$ \\
\hline $\left.\mathrm{H}_{2} \mathrm{PO} \mathrm{P}_{1}: \mathrm{H}_{2} \mathrm{O}\right) \mathrm{d}$ & & \|\|$^{P}\left(0 H_{g}(0)=\right.$ & 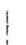 & 2.719 & 20 & 0.2 & $\ddot{z}$ & 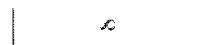 & 116.020 \\
\hline $\mathrm{Ca}\left(\mathrm{H}_{2} \mathrm{P}\left(\mathrm{O}_{2}\right)_{2}\right.$ & $!$ & $(\mathrm{aPa})(\mathrm{HoO}))_{2}$ & & $: 3.18$ & 25 & 0.5 & if & $0.7 x$ & 170.06 \\
\hline 1,5 Pentanediol & & $\left(\mathrm{CH}_{\mathrm{s}}\left(\mathrm{H} \mathrm{CO}_{2}\right.\right.$ & & $1.012 \cdots$ & 24 & 1.5 & if & $\infty$ & 104.146 \\
\hline (Gat $\left.\mathrm{NO})_{3}: 4 \mathrm{H}_{2} \mathrm{O}\right)$ & 1 & $\left(\mathrm{aO}_{6} \mathrm{~N}_{2}\left(\mathrm{H} \mathrm{H}_{\mathrm{g}}(\mathrm{)})\right.\right.$ & ' & 3.614 & 2.5 & 0.8 & in & 3.8 & 236.160 \\
\hline $\operatorname{Mg}\left(\operatorname{lo}_{2}: H_{2}()\right.$ & & $\mathrm{MgCl}\left(\mathrm{H}_{2} \mathrm{O}\right)_{\mathrm{B}}$ & 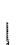 & 5.17 & 25 & 0.02 & 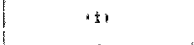 & 3.1 & 203.330 \\
\hline Vacoll & & $\mathrm{NaOH}$ & & $\therefore .93$ & 15 & 0.1 & (f) & 12.7 & 40.005 \\
\hline Iń()ll & & KuH & & $x .4$ & 15 & 0.1 & if & 12.5 & 50.101 \\
\hline$H\left(1: 3.3 \mathrm{Hu}_{\mathrm{u}} \mathrm{O}^{\mathrm{id}}\right.$ & 1 & $11\left(\mathrm{l}\left(\mathrm{H}_{8}\left(\mathrm{O}_{3.3}\right.\right.\right.$ & & $1.9 \mathrm{x}$ & 25 & $0 .: 3$ & 14 & $s$ & $95.91 \mathrm{~s}$ \\
\hline Dimethyl sulfoside & 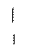 & $\mathrm{C}_{2} \mathrm{H}_{2} \mathrm{~N}\left(\mathrm{H}_{2}(\mathrm{O})\right.$ & 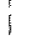 & 1.107tes & 21 & 0.1 & 0.5 & $\therefore$ & 78.1834 \\
\hline $\mathrm{IINO} \mathrm{O}_{3}: 1.5 \mathrm{H}_{2} \mathrm{O}^{(\mathrm{a})}$ & 1 & $\mathrm{NO}_{2} \mathrm{~S}_{(\mathrm{H}}\left(\mathrm{H}_{2}()_{2}\right.$ & & 2.11 & 25 & 1.0 & 13 & $\approx$ & 90.040 \\
\hline
\end{tabular}

(a) Moles solute per lig solution. ('oncentrations for $p_{a}$ were chosen to be close to expectations for tissue equivalent mixtures.

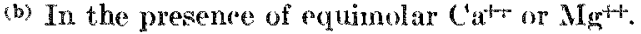

- Although these solutions are somew hat alkaline, they will not absurb ( $\mathrm{O}_{2}$.

(d) The composition of the usual commereial acid, i.e. $\mathrm{x} 5^{\prime}, \mathrm{H}_{3} \mathrm{P}_{4}, 7 \mathrm{O}^{4}, \mathrm{HNO} \mathrm{O}_{3}, 38^{\prime}, \mathrm{HCl}$.

(a) Values so matred were measured by us. The rost were obtained from the literature.

(1) Murh less than $0.1 \mathrm{~mm}$ IIg.

' Values are per gram parent compound, not per gram hy drated form.

(a) Values given in acid solution; the free base is nearly insoluble in water.

linear combination of $(\bar{\rho})^{1}$ values for the two will seldom execed $0.01^{c} i$.

The difficulty in obtaining elemental compositions exactly matching their target values ${ }^{(1,2)}$ experienced by previous workers suggests that a general method would be weleome. We, therefore, developed a simplified rersion of the (ribbs Method of ('anonical Components, using water as an obligatory component with the individual elements the remaining canonical components. for solution of the problems of tissue equivalent conposition.

This is illustrated in Table 5. for the simplest care -it ti-sue composition expressed in simple integers. T'aking the well-known tissue approximation formuli, ${ }^{1)}$ ${ }_{6}{ }_{5} \mathrm{H}_{40} \mathrm{O}_{1 \times N} \mathrm{~N}$, we first transfer the canonically required component $\mathrm{H}_{2} \mathrm{O}$, to rield $\mathrm{C}_{5} \mathrm{H}_{2} \mathrm{~N}\left(\mathrm{H}_{2} \mathrm{O}\right)_{1 \times}$. ('ompounds of empirical formula ${ }_{5}{ }_{5} \mathrm{H}_{4} \mathrm{~N}$ exist, but they meet few, if any, of the eriteria presented above. Thus, we transfer sufficient moless of ureat, a common compound that meets these requirements, to satisfy the needed one mole of $X$. By writing urea in canonical form, $\mathrm{CH}_{2} \mathrm{~N}_{2}\left(\mathrm{H}_{2} \mathrm{O}\right)$, it is evident that 0.5 moles are needed. This vields $\left({ }^{1.5} \mathrm{H}_{3.0}+0.5\left(\mathrm{CH}_{2} \mathrm{~N}_{2}\left(\mathrm{H}_{2} \mathrm{O}\right)\right)+17.5 \mathrm{H}_{2} \mathrm{O}\right.$. We now need a simple compound of $\mathrm{C} / \mathrm{II}=3,2$, or. as $H_{g}()$ is a canonically permitted component, $\left(\mathrm{C}_{3} \mathrm{H}_{2}\right)_{m_{3}}\left(\mathrm{H}_{2} \mathrm{O}\right)_{n}$. (Alycerol is $\left(\mathrm{C}_{3} \mathrm{H}_{2}\left(\mathrm{H}_{2} \mathrm{O}\right)_{3}\right.$ so that tranfer of 1.5 moles of glycerol rields $1.5\left({ }_{3} \mathrm{H}_{2}\left(\mathrm{H}_{2} \mathrm{O}\right)_{3}\right)+$ $0.5\left(\left(\mathrm{CH}_{2} \mathrm{~N}_{2}\left(\mathrm{H}_{2}(\mathrm{l})\right)+18.0 \mathrm{H}_{2} \mathrm{O}=\mathrm{C}_{6} \mathrm{H}_{40} \mathrm{O}_{18} \mathrm{~N}\right.\right.$. The fo mula weight is $402.37 \mathrm{~s} \mathrm{so}$, to make $1 \mathrm{~kg}$ of mixture, we take 1000,402.37s times as many moles of each com- 


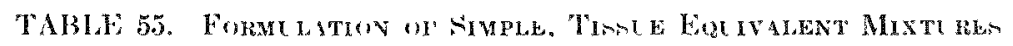

\begin{tabular}{|c|c|c|c|c|c|c|c|c|c|}
\hline Component & $c^{\circ}$ & H & 0 & 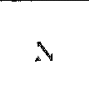 & 1 & $\mathrm{H}_{2} \mathrm{O}$ & Creal & Glycerol & $\begin{array}{l}\text { Ethylene } \\
\text { glycol }\end{array}$ \\
\hline$-\cdots \quad-$ & - & $1-\quad-\quad-$ & -- & - & 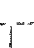 & -- & --- & -- & - - - \\
\hline $\mathrm{C}_{3} \mathrm{H}_{40} \mathrm{O}_{142} \mathrm{~N}, \mathrm{wt} \mathrm{C}_{0}$ & 14.9 & 10.0 & 71.6 & $: 3.5$ & & & & 1 & \\
\hline Transfer $\left.18 \mathrm{H}_{2} \mathrm{O}\right)$ & 5 & 1 & 0 & 1 & & 1s & & & \\
\hline Trancfer $0.5\left(H_{2} N_{2}\left(H_{2}()\right)\right.$ & 1.5 & 3.0 & 0) & 0 & & 17.5 & 0.5 & & \\
\hline Transfer $1.5 \mathrm{C}_{3} \mathrm{H}_{2}\left(\mathrm{H}_{2} \mathrm{O}\right)_{3}$ & 0 & 0 & 0 & 0 & & 13.0 & 0.5 & 1.5 & \\
\hline Final wt'c & 14.90 & 10.00 & 71.60 & 8.50 & & & & & \\
\hline Earlier wt & 15.6 & 9.8 & 71.0 & 3.6 & ' & & & & \\
\hline Muscle equivalent, wt', & 12.3 & 10.2 & 71.0 & 8.5 & i & & & & \\
\hline Moles/lig & 10.211 .5 & 101.1905 & 40.250 & 2. 190 & & & & & \\
\hline Transfer $4\left(6.2500 \mathrm{H}_{2} \mathrm{l}\right)$ & 10.2415 & $\times .6005$ & 0.0 & 2. 199 & 1 & 46.2500 & & & \\
\hline Transfer $1.2495 \mathrm{CH}_{2} \mathrm{~N}_{2}\left(\mathrm{H}_{2} \mathrm{O}\right)$ & $\$ .492$ & 4.1919 & 0.0 & 0.0 & t & $15.000 \%$ & $1.219 \mathrm{z}$ & & \\
\hline Final we $c_{i}$ & 12.30 & 10.20 & 71.00 & 3.50 & ; & & & & \\
\hline Farlier we $\frac{\text { o }}{2}$ & 12.0 & 10.2 & 71.2 & $3.6 \mathrm{i}$ & & & & & \\
\hline
\end{tabular}

ponent as indicated atbove. This riedds a mixture of exaet composition and, interentingly enough, of one les chemical component as well. The earlier mixture" utilized $569 \mathrm{~g} \mathrm{H}_{2} \mathrm{O}$, $284 \mathrm{~g}$ glycerol, $76 \mathrm{~g}$ urea, and $7 \mathrm{I} \mathrm{g}$. $\mathrm{su}-$ crove. For the density of the sarlier mixture we obtained $1.112 \mathrm{~g} \mathrm{~cm}^{-3}$ at 2.5 . For the three-component mixture of Table 5.5, we estimated $1.0966 \mathrm{~g} \mathrm{~cm}^{-3}$ by Equation (2) and measured $1.1048 \mathrm{~g} \mathrm{~cm}^{-3}$, both at $25^{\circ}$.

Whesl, ar is usually the case, mole ratios stre not integers, the first ttep is the reduction of the weight percent composition given to moles/kg. In Table s.. this is illustrated with a simplified muscle equivalent liquid prevously described elsewhere. ${ }^{(6)}$ Again, water is first transferred; then 1.249 mole of urea are added to complete the $\mathrm{N}$ requirement. The $\mathrm{C}$ - II ratio remaining lies between 3,2 and $1,2 . g$., between glverol $(G)$ at $\left({ }_{3} \mathrm{H}_{2}\left(\mathrm{H}_{2} \mathrm{O}\right)_{3}\right.$ and ethylene glycol $(E)$ at $\mathrm{C}_{2} \mathrm{H}_{2}\left(\mathrm{H}_{2} \mathrm{O}\right)_{2}$. Setting up the simultanesus equations for carbon, $3 G+2 E=8.9922$ and for hydrogen, $2 G+2 E=$ 6.1919, we obtain $a^{\prime}=2 .>00 \%$ and $E^{\prime}=0.29 .46$. Latimated $\bar{\rho}=1.0776$, measured $\bar{\rho}=1.0797$ at $2.4^{\circ}$, earlier $\bar{\rho}=1.07$ at room temperature, all in $\mathrm{g} \mathrm{cm}^{-3}$.

for more complex mixtures, the same procedure is applicable, provided that one first transfers components containing minor elements (e.g., inorganic compounds), then $\mathrm{H}_{2}(), \mathrm{N}, \mathrm{H}, \mathrm{C}$, in that order. Where a high density mixt ure is desired, it is best to nolve for $\mathrm{H}$ and $\mathrm{N}$ simultaneously, using high density components, then to satisfy ( via transfer of glueone or acetic acid. This is becaune both $\left({ }_{6}\left(\mathrm{H}_{2}\right)\right)_{2}$ and $\left({ }_{2}\left(\mathrm{H}_{2}\right)_{2}\right)_{2}$ are camonically equivalent to pure (', and high in density as well. For low denity mixtures it is best to molve $(, H, N$ simultanemaly, using low density romponents, so as to leave only $C^{\prime}+$ II in ratio 1:2. Thin is becaune the lowent density components are generally of composition $\left(\left(\mathrm{H}_{2}\right)_{m}\left(\mathrm{H}_{2} \mathrm{C}\right)_{n}\right.$, e.g. p propanol-1.

The componition of Standard Man has the force of an I.C.R.P. quantity, on that we have used it as given with only one small change, as shown in Table 56 , increasing the oxygen by $0 .{ }^{\circ} \%$ to bring the total to $100.00 \%$.

Taking density, sizes, whapes, volumen, etc. from literat ure ${ }^{(3-3)}$ we have also arrived at a geometric representation of the Standard Man shown in Figure 101 and described in Table $\overline{7}$. This phantom, filled with the Standard Man liquid of Table is, should provide a useful simulacrum for either computation or experiment.

In compounding the mixtures of 'Table os the components thould be added in the order indicated in the

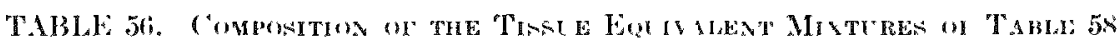

\begin{tabular}{|c|c|c|c|c|c|c|c|c|c|c|c|}
\hline Element & $\mathrm{C}$ & $\mathrm{H}$ & 0 & $X$ & Ca & P & 8 & $\mathbf{K}$ & $\lambda a$ & $\mathrm{Cl}$ & $\mathrm{Mg}$ \\
\hline Standard Man, we & 18 & 10 & 69.7 & 3 & 1.5 & 1 & 0.25 & 0.20 & 0.15 & 0.15 & 0.05 \\
\hline Mandard Man, moles $k \mathrm{r}^{-1}$ & $14.9 \times 75$ & 99.206 .3 & 11.0625 & 2.1116 & 0.2713 & $0.32 \times 3$ & $0.07 \times 0$ & 0.0512 & 0.0652 & 0.0423 & $0.020 \mathrm{i}$ \\
\hline discle, wt $\%$ & 12.3 & 10.2 & 72.91 & 3.5 & 0.01 & 0.20 & 0.32 & 0.30 & 0.07 & $0.0 \mathrm{~s}$ & 0.02 \\
\hline Muscle, moles $\mathrm{kg}^{-1}$ & 10.241 & 101.190 & 45.653 & 2.499 & 0.0025 & $0.06+45$ & 0.1000 & 0.1000 & 0.0301 & 0.0226 & 0.0082 \\
\hline
\end{tabular}




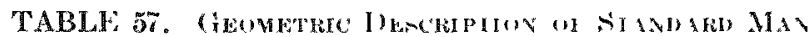

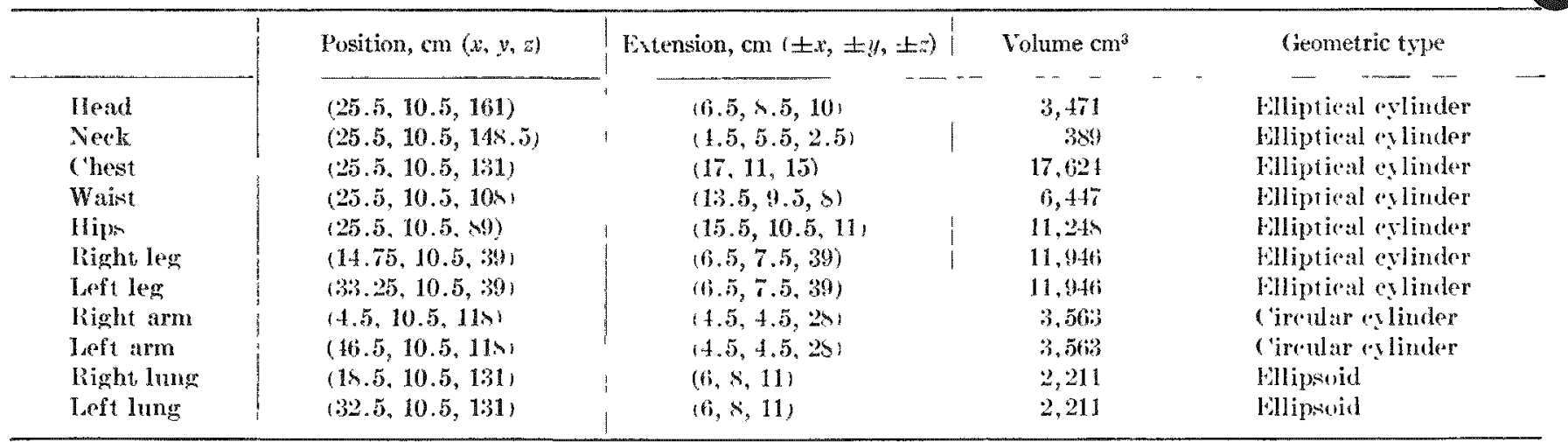

Phantom coordinates are Cartesian, dimensions are in $\mathrm{cm}$, and cylinders are right with ayes parallel to the $\approx$ dirediun. Total volume is 70.20 liters, inclusive of lung voids totalling 4.42 liters. Surface ares is $1.45 \mathrm{~m}^{2}$. ("artesian origin taken at lower left front "orner of indusive eube so that tigure is entirely" in the positive octant (ses rigure 101$)$.

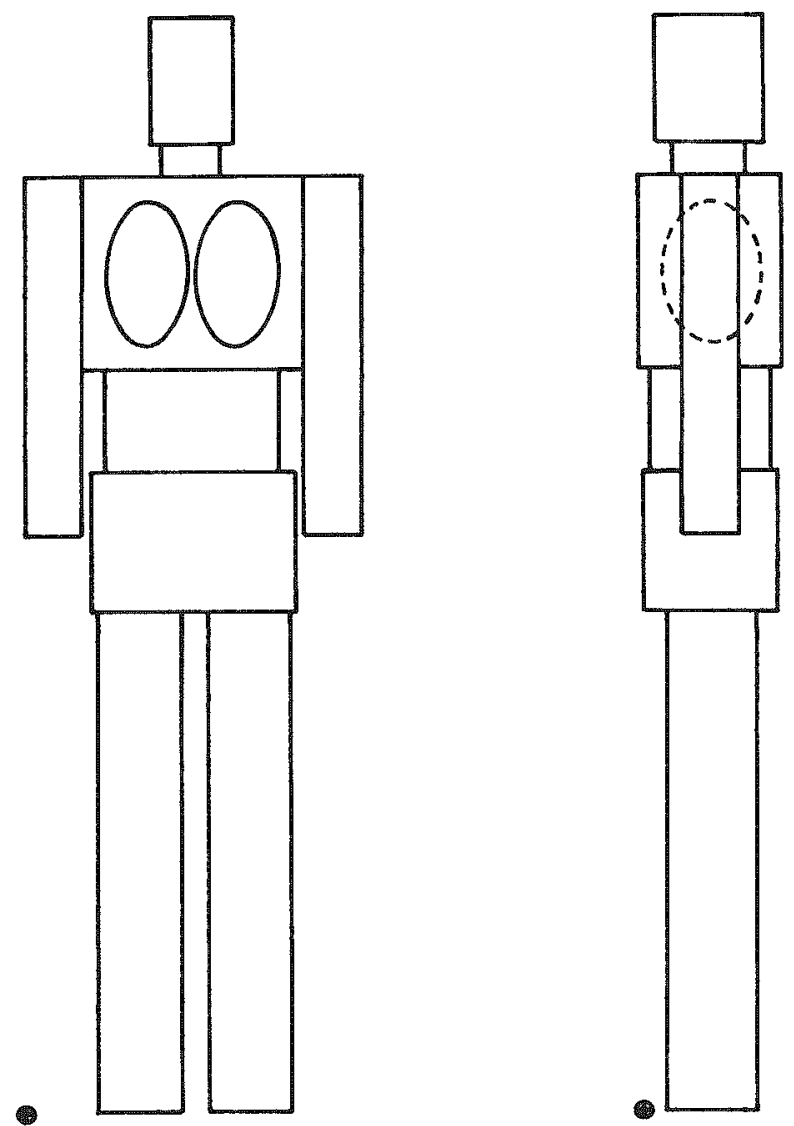

Fuli. 101. Front and side views of an eleven-region standard Man. Coordinate origin is indieated by the circled eross. lomensions and positions are given in l'able 57.

table, each component stirred into solution without heat before the next is added. In this way, it will be found that all components enter solution rapidly and completely at room temperature. Otherwise, intermediate precipitates may form, and these are often very difficult to bring back into solution.
In Table of a -tandard demsity mixt ure is given, along with mixtures of higher and lower demity for those who might desire to obtain vone ot her value by linear combination. Alternatively, innection of the three mixtures indieates how other densities maty be obtained at constant composition. by suitable choice of components from Table .74. Thus, increasing the ratio of triethylamine to $H N()_{3}$ at eonstant percent $N$, decreasen the II (' rationeeded in the final addition from 2.00 to 1.60 . This shifts the requirement from the lower density compound of $\mathrm{H} / \mathrm{C}^{\prime} \supseteq 2$, e.g., propinol, to the higher dennity compounds of $H$ (" lewe than 2, (2.g., pentanediol at If $C^{\prime}=1.60$. The other components are held constint becalues of the difficulty of obtaining an alternative salt system which is equally soluble and atable.

With few exceptions, the component of Table of are commonly available at -uch high purity and stability that no thought need be taken to their atsaty. For highest accuracy, howaver, assay values supplied with purchased IINO, $\mathrm{O}_{3}$. $\mathrm{Cl}$ and $\mathrm{H}_{3} \mathrm{PO} \mathrm{O}_{4}$, hould be cheched. If

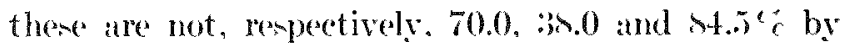
weight, correction should be applied. Some samples of triet hylamine of of malonomononitrile contain traces of water, as well as colored impuritios which impart a vellow tinge to the final mixture. "These may be removed by simple distillation for the triethylamine. and by recrystallization followed by in cacue drying to constant weight for the somewhat hygroseopic malonomononitrile.

Elemental composition of lean muscle was taken from

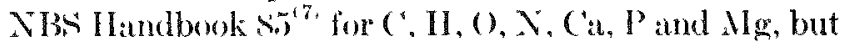
K, $X$ a and $s$ were readjusted slightly $y^{\text {ss }}$ to allow for the ('l omitted by Handbook 8.). From theos values three tissue equivalent mixture of different density were formulated, as for Standard Man, and thess are describe in Tables 56, 58, and 59 . The comments mide for Standard Man apply, exeept that, though the EDTA 


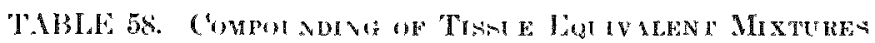

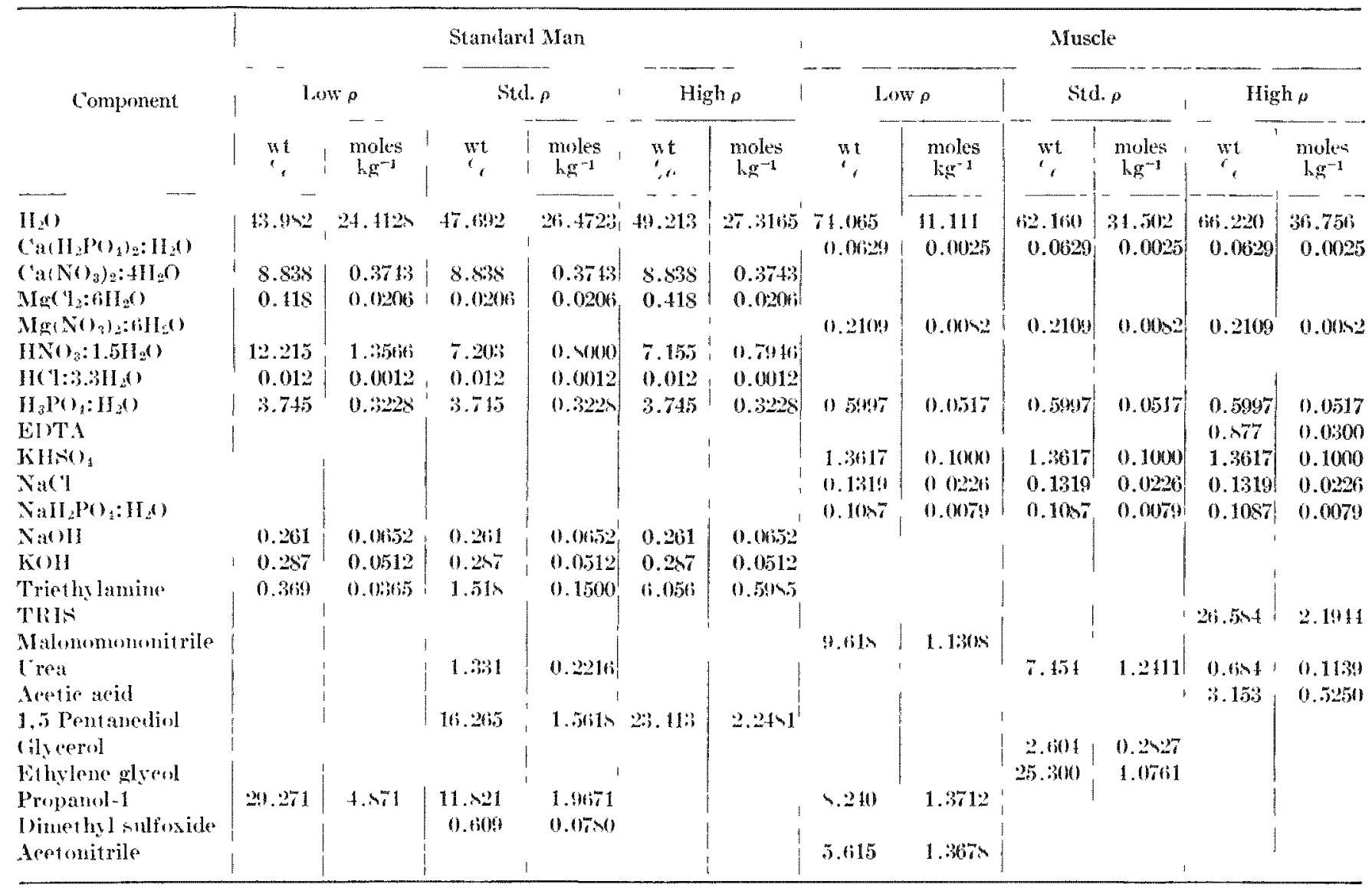

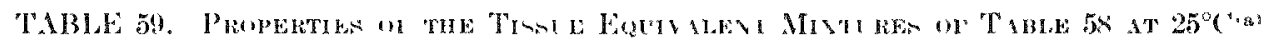

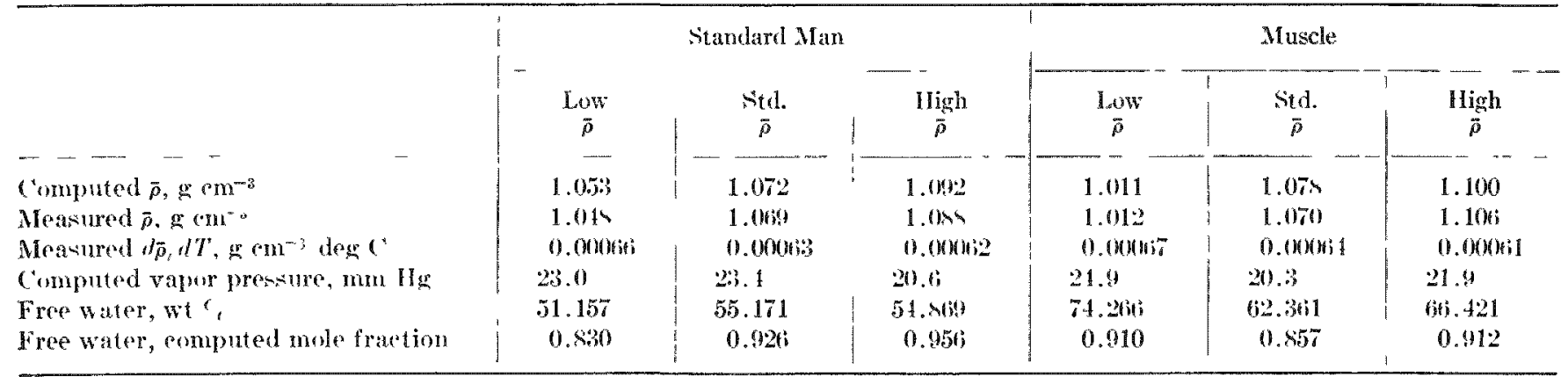

(a) Computed values of $\bar{p}$, vapor pressure and mole fraction made without regard for ionizat ion.

must be added before the 'TRIs, it will not disolve completely until after 'Tlis addition. In the muscle. mixtures density increane wa cobtained by thifting from a trio of compounds of low combined den-ity acetonitrile, malonomononitrile, propanol t, to a syetem bared almont entirel on a single high density, alhaline comGound (TRIs'. The chelating agent Elol'l was added counter the salt precipitation effect of the increaned alhalinity, and arectic acid in uned ats a canonical carbon component to lower the pll to s..).

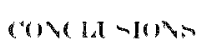

Is the masinum range of soft timsue densitien and rompentions lies well within the range of uneful compounds given in Tables $i 1$, it appears that any real ti-ne can be matehed by tissue equivalent liquid, using the methods outlined above. It now beemen necessiry (1) obtain composition, dem-ity, and geometry data for

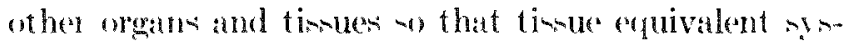
teme can be devired for them an well. This requires a combination of literature evaluation and experiment, 
both of which are under way in our laboratories. Not all experimental requirements can be met by liquids, however, so that efforts are also being made to provide tissue equivalent gels and plasties of appropriate mechanieal properties for phantoms and ion chambers, using previously proposed chemical systems and reactions. Measurements of chemical binding and neutron optical effect in tiswues are also under way. Thus, it appears probable that systems which are macroscopically tissue equivalent for neutrons of all energies will son become available.

\section{REFELENCES}

1. Rusi. H. II. and ('. Failla. 'liswe equivalent dosimetry. Iuclonics 14(2), 322-31 (1956).
2. Frigerio, N. A. and M.J. Sampon. Tissue equivalent phan toms for neutron studies, standard Man and muscle. To be published.

3. Speetor, W. S. Hand Book of Biological Data. W. B. Saunders, Philadelphia, 1956.

4. Altman, P. Growth. Federation of American Sncieties for Experimental Biology, Washingtom, 1962.

5. Malina, R. M. Quantification of fat, muscle, and hone in man. ('lin. Orthoped.65, 9 3r (1969).

6. Goodmau, L. J. A modified tissue equivalent liquid. Health Phys. 16, $763(1969)$.

7. Physical Aspects of Irratiation, Int. Comm. Lad. Cuits Report 10b, NBS Hand Book No. S5. I\%. S. Govt. Printing (Afices, Washington, J).C. (196) $\})$.

8. Rauen, H. M. Biochemische 'laschenbueh. Springer Verlag, Berlin, 196 it.

\title{
DOSIMETRY OF SMALL ${ }^{250}$ CF SOURCES IN A HUMAN PHANTOM
}

\author{
Norman 1. Frigerio, Frank 1. Cheng, ${ }^{*}$,Tark L. Marchi, and Harold s. Rhoads*
}

\section{PLRPOSE AND METHODS}

Interest in use of implantable " fast neutron therapy of rancer has increased. ${ }^{1,2}$ Bes cause precise knowledge of the nir dose distribution from -uch sources is a prerepuisite to therapentic trials. we attempted to sat isf this need as part of our program on the application of neutrons to cancer therapy. Although a similar study has been published, "he respon-se of si diode and foil detectors used woreso different from tissue equivalence," "and the probability of considerable error was so large, that a redetermination of dowe distributions with tisme equivalent yotems seemed narranted.

To make these measurements, the central 2.5 cm of a commercial human phantomt was replaced with a Jucite-walled tank of the same shatpe, filled with the timare equivalent liquid ured previounly." A $5.00-\mu \mathrm{g}$ ${ }^{252}$ " $f$ source was positioned in the center of this section, and tissue equivalent and gamma sensitive chambers were arronged about it af various distaneen. Sonress, chambers, and calibration methods were the same as thone dencribed for other done measurenients."

Program BSII-1:30 was lased to compute the $n \gamma$ dose distribution in a homogenous volume of the same elemental composition, densits, and hape at the experimental tank. This program provides much more information about the space-energy distributions of the $n \gamma$ interactions and of LF" spectrat than can be obtained by experiment. Because of this, it was hoped that agresement between computation and experiment would

* AUA-ANL Biuengineering Student Program, ANI. Center for lidueational Affairs.

† Alderston Pando, Long Island ( it $\mathrm{N}, \mathrm{N}$. Y. justify the $\mathrm{u} \times$ of the program to interpolate and extrapolate dose and L.MT distributions in regions where these cannot be measured; such agresment has been obtuined in other comparisons of $3 \mathrm{M}$ - 130 with experiment. ${ }^{(5,6)}$ In computing the dose, the ${ }^{252}$ (f $n$ and prompt $\gamma$ spectra uned were taken from the literature, ${ }^{t, s+}$ and the ficion product spectrum was assumed to be the same as that of ${ }^{258}[$ at equilibrium.

PROTHEMS REPORT

ligures $102-104$ prescent results obtained for $1.00 \mu \mathrm{g}$ "fo (f compared with the dita of (Oliver and Wright." A mestsurable diserepancy betwent theory and reatis was axpected from the simplified computation cmployed, i.e., without regurd for the presence of the donimeters themostves. Fome mechanical ditheulty was alow cneountered in ponitioning the dosimeters to the $\pm 0.1 \mathrm{~mm}$ needed for precise dosimetry; therefore, the experimental figures are less preaise than the computed oner. 1)espite this problem, goud agrement was obtained between our experiments and the BIJI-1:30 computations.

J)ifferences betwern our results and these of Oliver and Wright ${ }^{(1)}$ are probibly related to their une of the non-timue-equivalent si diodes. These diodes were calibrated against a bare reactor spectrum and then ured with a quite different moderated ${ }^{25 \%} \mathrm{Co}$ spectrum. They show an uncertainty exceeling $\pm .50 \%$ in this energy region, ${ }^{(3)}$ so that the discrepaney observed is not surprising. Is to the $\gamma$ difforences, we note that the previous workers obtained a $n / \gamma$ dose ratio of 1.4.5 for the barr source, while ours was 2.36. As the $n / \gamma$ ratio for $a^{25 z}$ ( $\mathrm{f}$ sonrce will increase with time after preparation 


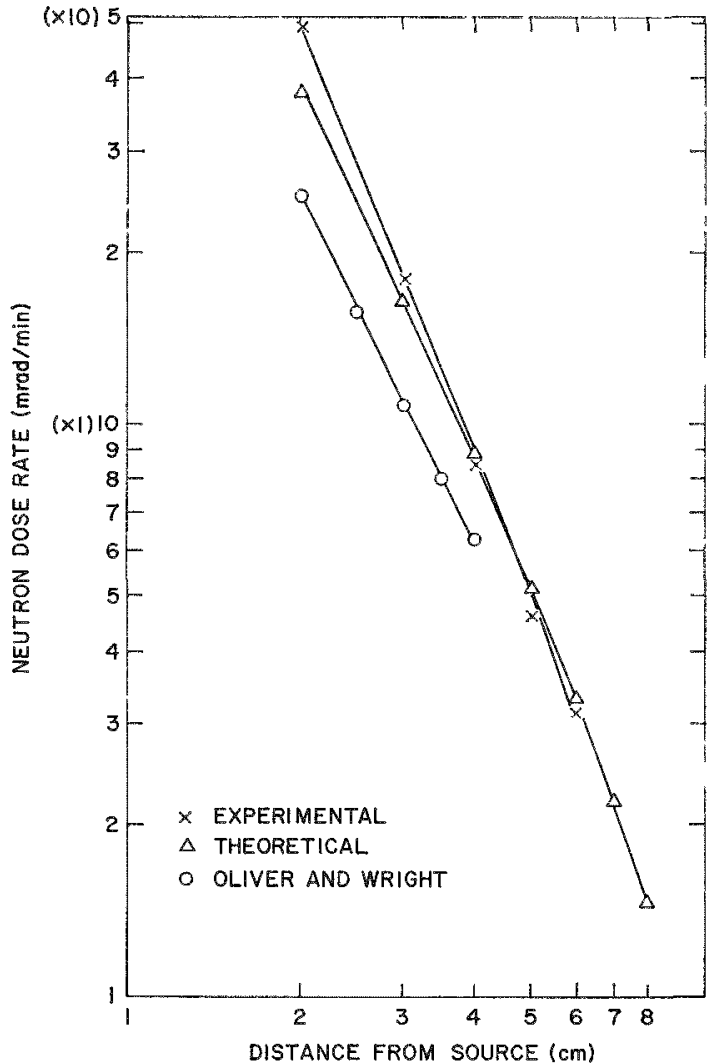

Fici. 102. Neutron dose rate as a function of distance from the souree.

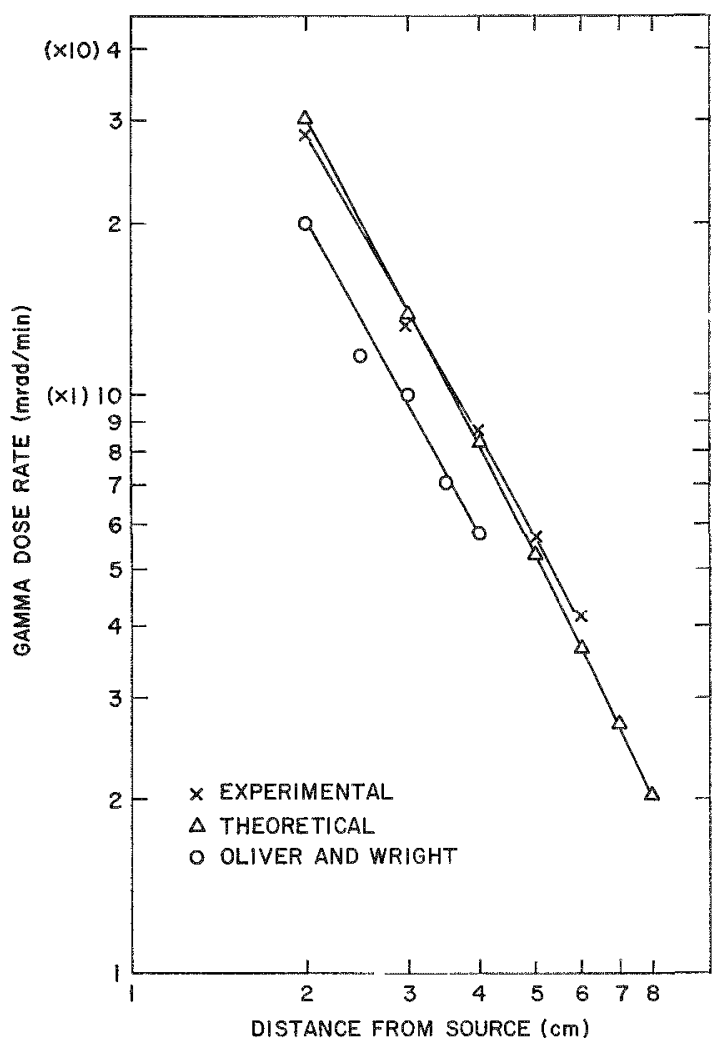

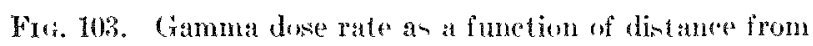
the source.

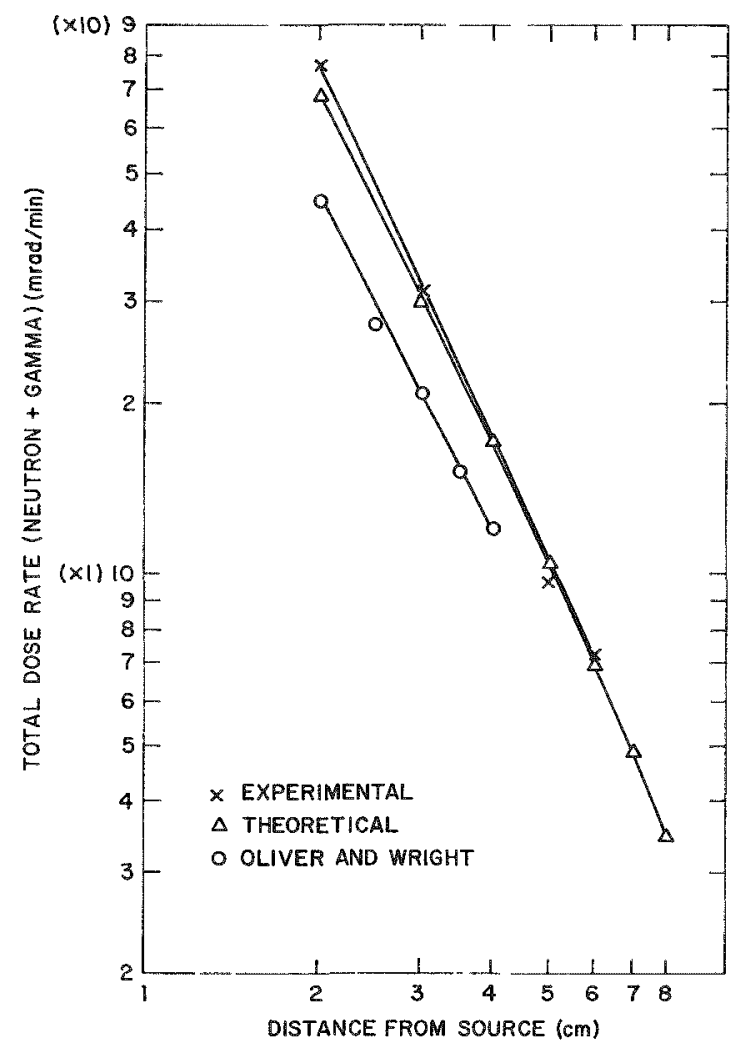

Fic, 104. Total dose rate as at function of distance from the source.

becetuse of the approach to fission product equilibrium, their souree probably had not attained pquilibrium when their measurements were made. In support of this, ${ }^{252}$ ('f measurements made at another laboratory ${ }^{\text {(2) }}$ using Si diodes calibrated against a tissue equivalent chamber gave dose rates intermediate between our and thowe of Oliver and Wright.

\section{COMCLUSIONG}

It appears that even at relatively simple we-m will give good agreement between experimental ${ }^{2}$ (1) dosimetry and the prediet ions of the BI,M-1:30 program. Thus, we are encouraged to extend our meatsurements, uing at more precise mechanical positioning system which we have recently completed to greater penetrations and to more complex organ, bone, and of timule phantoms. If there continue to shon good agreement with BSISI-1:00 computations, the latter will be uned to describe completely the dome-spale-particle energe-LET dintribu-

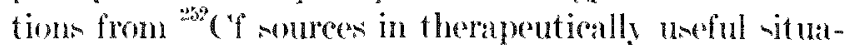
tions, wo that the potential of such sourees for enncer theraps ean he fully utilized.

REFELECL'

1. ()iver, (A. L). and (". N. Wright. I)owimet ry of an implantable 252 (1) suluree. Radiology 92, $113-117$ (1969).

2. Fair hild, R. (x. Soures of fission neutpons and their dusim- 
etry. U. A. Atomic Energy Commission Report BN L.-12452 (1968).

3. "Thurston, M. O. A ki fast-neutron domimetere of wide sensitivity range. Viefron Vonitoring. International Atomic Energy Ageney, Vienna, 1967, pp. 245-252.

4. Frigerio, N. A. N. (flen, and M. J. Sampson. Instruments and matorials for studies of depth dose distributions. This report.

5. Frigerio, N. A. and M. H. Bransom. BIM-130, a computor program for neutrou-gamma radiobiologl. Argunne $\mathrm{Na}$ timnal Laboratory Biologieal and Medieal liestearch Div vion Annual Report, 1967. ANL 7409 , pp. 213-247.

6. Frigerio, N. 1. Optimum beam energy and geometry for ue utron capt ure theraps. 'This report.

7. Smith, 1. H. Prompt gammat rass during fission of $252 \mathrm{Cf}$. Phys. Ree. 104, b99-702 (1956).

8. Meadows, J. W. 2 agc tission neutrou speetrum from 0.003 to 15 MeV. Phys. Ret. 157, 107 t $10 \times 2$ (1967).

9. Reater Physics constants. Argonte National latboratory lieport ANT,-5K00, and Fad. (19titi).

\title{
QUANTITATIVE DETERMINATION OF PEROXIDE IN TUMOR TISSUE
}

\author{
Vorman 1. Frigerio, Louise ('. Sherwin, and Jnann 1. Seiler
}

PLPPOSES AND METHODS

Several lines of evidence have suggested an abnormally high concentration of peroxide in tumor tissue. In teuting boronic arids for possible use in neutron capture therapy, ${ }^{(1)}$ it was noted that borono Evans blue was oxidatively hydrolyzed in wive to free $\mathrm{H}_{3} \mathrm{BO}_{3}{ }^{(2)}$. Adlitional investigation showed that this hydrolysis only vecurred in the tumor-beuring mice and could not be confirmed for other laboratory mammals or for humans." This reaction could have been catalyzed enzrmatically, and a search for such an enzyme began. ${ }^{(2)}$ A second posible explanation for the above reaction is the presence of peroxide, for it in known that benzeneboronic acids are oxidized to borate esters by $\mathrm{H}_{2} \mathrm{O}_{2}$ and the esters sub*requently hydrolyzed to phenol and $\mathrm{H}_{2} \mathrm{BO}_{3}:{ }^{(4)}$

$$
\begin{aligned}
& \mathrm{H}_{2} \mathrm{O}_{2}+\mathrm{C}_{6} \mathrm{H}_{5} \mathrm{BB}\left(\mathrm{OH}_{2}\right) \rightarrow \mathrm{H}_{2} \mathrm{O}+\mathrm{C}_{6} \mathrm{H}_{5} \mathrm{OB}(\mathrm{OH})_{2} \\
& \mathrm{C}_{6} \mathrm{H}_{5} \mathrm{OH}(1) \\
& \left.(\mathrm{OH})_{2}+\mathrm{H}_{2} \mathrm{O} \stackrel{\mathrm{OH}^{-}}{\longrightarrow} \mathrm{C}_{6} \mathrm{H}_{5} \mathrm{OH}+\mathrm{H}_{3} \mathrm{BO}\right)_{3} .
\end{aligned}
$$

In normal tistue, the concentration of $\mathrm{H}_{2} \mathrm{O}_{2}$ never reaches a level high enough to promote the above reaction because of the presence of eatalare. Tumor tissues, how ever, are generally known to have a reduced activity of eatalase, ${ }^{(5)}$ and so there is the possibility of a high $\mathrm{H}_{2} \mathrm{O}_{2}$ concentration. Subsequently, two other investigations have been made of the interrelationships of peroxide and boronic acid in tisue systems.

The first was a study of the hydrolysis of a benzeneboronic acid in plant and animal tissue homogenates by measurement of the amount of phenol produced. ${ }^{(f)}$ No oxidative hydrolysis of benzeneboronic acids was found in the normal tisues tested. But such activity was found in all three of the spontaneous tumor homogenates tested at a level equivalent to $10^{-4} .7 / \mathrm{I}_{2} \mathrm{O}_{2}$, which is at least a hundred times that in other tissues.

In the second study, ${ }^{(7)}$ a colorimetrie mieromethod for the determination of $\mathrm{H}_{2} \mathrm{O}_{2}$ and similar peroxides was developed, using mata-nitrophenylboronic acid (NPBA), and the method was applied directly to tissue systems." (Qualitatively, the renults confirmed the previous investigation, but a quantitative determination could not be obtained because of the difficulty in elarifying the tissue extracts. As a continuation of theses preliminary studies, a more extensive -tudy was undertaken to work out an NPBA method that could be applied to tiscue serstems in a quantitative mamner, and to test a larger number of neoplastir tissues for their :bility to hydrolyza NPB.1.

The NPBA method wat developed by using various normal tisues containing known coneentrations of added $\mathrm{H}_{2} \mathrm{O}_{2}$ and by motsuring the amount recovered by the NPBA reaction. ('entrifugation and precipitation techniques produced turbid, red to yellow solutions. Dialysis, on the other hand, produced clear solutions with no color from extrancous tisue compounds. We also found that completing the process at low temperature $\left(1^{\circ}\right.$ to $: 3^{\circ}()$ and uwing sand, mortar, and pertle instead of a homogenizer helped to avoid denaturation of the proteins which seemed to destroy most of the $\mathrm{H}_{2} \mathrm{O}_{2}$, probably by ummasking of - $\mathrm{SH}$ grouns.

Wrighed samples of normal or tumor tissues were sonked in a solution of $\mathrm{NaN}_{3}\left(+\times 10^{-2}, \mathrm{H}, 0.5 \mathrm{ml}\right)$ to inhibit any catalase and then ground in a mortar and pestle with sand until the tiscues were thoroughly homogenized (about is min). NPBS $\left(10^{-2} . /, 1.0 \mathrm{mI}\right.$ ) was then added to the tissue homogenate, and the mixture was dialyzed against $12 \mathrm{ml}$ distilled water for $s$ to $10 \mathrm{hr}$. After dialysis, $0.1 \mathrm{ml}$ of $19.1 / \mathrm{NaOH}(2$ drops) was added to the dials sate to produce the yellow color that is characteristic of the nitrophenoxide ion:

$$
\begin{gathered}
\left.\mathrm{NO}_{2} \mathrm{C}_{6} \mathrm{H}_{5} \mathrm{OH}+\mathrm{OH}^{-} \rightleftarrows \mathrm{H}_{2} \mathrm{O}+\mathrm{NO}_{2} \mathrm{C}_{6} \mathrm{H}_{5} \mathrm{O}\right) \\
\text { colorless } \\
\text { yellow }
\end{gathered}
$$

The absorbances of the olutions were read at $400 \mathrm{~m} \mu$ in $5.0 \mathrm{~cm}$ cuvettes on a Berkman DI' spectrophotometer. 
- ti-ue mass, dialyzing volume, dialvite volume, and absorptivity eoefficient were known, the initial $\mathrm{H}_{2} \mathrm{O}_{2}$ concentration in the tisine could be calculated.

\section{PloGREA REPOR'T}

I number of normal tisues and pontaneous tumor from rate and mice were tested by the above method, and the results are thomn in lable 60. Liver, plecen, brain, intestine, lung, kidney, skin, muscle, and heart from each of $1 \mathrm{~s}$ control animals were tested but gave no suggestion of $\mathrm{H}_{2} \mathrm{O}_{2}$. Iowever, as seren from Table 60 , seemingly normal tissues from tumor bearing animals gave some indication of $\mathrm{H}_{2} \mathrm{O}_{2}$, and tumors gave very high concentrations of $\mathrm{H}_{2}()_{2}$. 'That the reatetant was $\mathrm{H}_{2} \mathrm{O}_{2}$ is shown by the experiment of Table 61. Here, tumor dialysates obtained in the presence of $\mathrm{NaN}_{3}$ but absence of NPBA gave reaction characteristic of $\mathrm{H}_{2} \mathrm{O}_{2}$," including the specific " $\mathrm{Ti}$ complex. ${ }^{(3)}$ Fven though oxidation of $\mathrm{Fe}^{+-}$or $\mathrm{I}^{-}$in trong acid is not strictly -pecific for $\mathrm{H}_{2} \mathrm{O}_{2}$, it is difficult to imagine any tiosue axidants other than peroxides strong enough to bring about these reactions. ('ertainly no biochemical svitems are known whose oxidation potentials equal those of the fee $\left(0.777\right.$ volts or $\mathrm{I}^{-}(0.540$ rolts) syatemin.

Tumor dialysites obtaned in the abence of both Naxs and NelBd gave little $\mathrm{H}_{2} \mathrm{O}_{2}$, suggesting the aretion of, e.g., blood catalane. Tumor dialvates obtained in the presence of NPBA but absence of Na Na gave about half the $\mathrm{H}_{2} \mathrm{O}_{2}$ yield of dialyates from other samples of the sume tumor tested by the complete method. "lhis suggest the NDBA competes fairly suecessfully with catala a for $\mathrm{H}_{2} \mathrm{O}_{2}$, powibly by inhibition of the enzyme.

The fact that the oxidant was dialyzable and gave tests for $\mathrm{H}_{2} \mathrm{O}_{\mathrm{a}}$ rules out the ponsibility of an enzymatic hydrolysis of the NPBA. The fact that NPBA and $\mathrm{NaX}_{3}$ are strong bacteriocides, ${ }^{(10)}$ along with the low temperaiture, rules out the possibility of a bueterial action specific to tumor tissue. Two other posibilities exist: 1) a high $\mathrm{H}_{2} \mathrm{O}_{2}$ concentration, in viw, in tumors; 2) : chemical system unicule to tumors and capable of producing $\mathrm{H}_{2}()_{2}$ on reatction with air leither enzymatic (e.g., flavoenzymes) or autocatalytic (e.g., ersteine)]. Tratments which denatured tissue proteins (e.g., heat, extremes of, $\mathrm{H})$ not only prevented detection of $\mathrm{H}_{2} \mathrm{O}_{2}$ but even destroved added $\mathrm{H}_{2} \mathrm{O}_{2}$. Thus, the autoxidation of cysteine, etc., is ruled out because such reactions are promoted by heat and by high pH rather than inhibited.

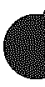

A series of spontaneous rat and mouse tumor homogenates have all shown $\mathrm{H}_{2} \mathrm{O}_{2}$ concentrations two to three orders of magnitude greater than tissues from

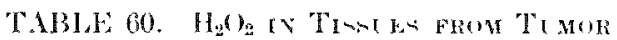

BHARINir dNIULA

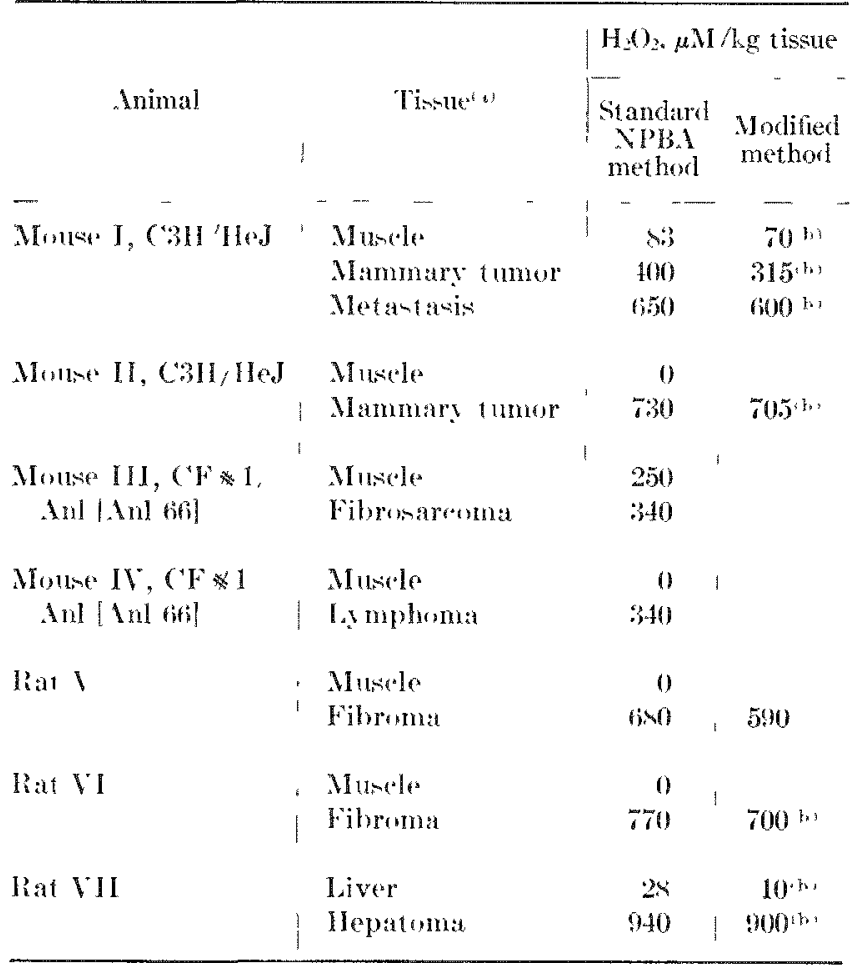

- *3 Non tumor tisenes taken from near the tumor.

"NoBA added to dialisate after dialysis.

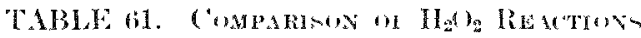

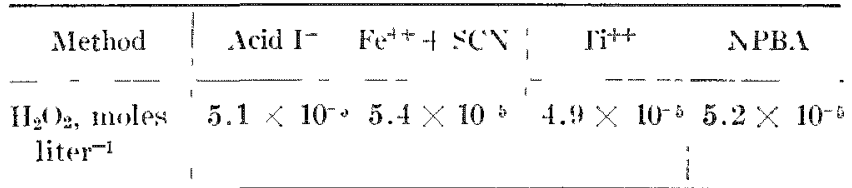

Tunor dialyate from hat VI of Table bo used for all determinations; $\mathrm{NaN} \mathrm{N}_{3}$ only present during dialysis.

healthy animak. If this truly reflects a high in cire tumor concentration of $\mathrm{H}_{2}()_{2}$, a number of new chemotherapentic arenues are onened. For example, an alkylating anent could be held in sterically hindered form by carbon--boron earbon bond. The latter would cleave only in the presence of $\mathrm{H}_{2} \mathrm{O}_{2}$, releaning the cytotoxic alkylating groupsin, and only in, the tumor. If, on the other hamd, the high $\mathrm{H}_{2}\left(\mathrm{O}_{2}\right.$ eneentrations found are due to an in citro oxidation peculiar to tumor tisues. elucidation will be necessary before the possible therapeutic implications can be formulated. Work is currently under way to resolve this question. As an aid in this work we were recently able to -rnthesize the para antog of the meta-NPBA used above. This react in the same way as meta-NPBA but gives a seventeen-fold increase in sensitivity as a consequence of the much 
higher absorptivity of the para-nitrophenoxide ion produced.

\section{REFERENCES}

1. Frigerio, N. A. Reeent developments in the theory of neutron capture therapy and Systems for neutron capture therapy-general considerations. Argonne Natiunal Laboratory lieport ANI,-6910 (1964).

2. Frigerio, N.A. and N. Bink. The localization of boronic acids in mouse neoplasm. Argonne National Laboratory Biological and Medical Research Division Semianumal Report, January through June, 1959, ANL-6200, pp. 60-62.

3. Soloway, A. H. Boron compounds in cancer therapy. Progr. Boron ('hem. 1, 203-231 (1964).

4. Kuivila, II. (A. and A. (i. Armour. Electrophilie displacement reactions. $\mathrm{LX}$. Effects of substituents on the rate of reaction between hydrogen peroxide and phenylboric acid. J. Am. ('hem. Sor. 79, 5650 56662 (1957).
5. Feinstein, R. N. and J. I) ainko. Cse of 3 -amino-1, $2,4-\operatorname{tr}$ azole to reduce body catalase activity in cancer studies. Cancer hes. 19, 612-617 (1959).

6. Frigerio, N. A. and M. Brummel. Benzeneboronic acids. I. Interactions with tissue and use for eatalase visualization on solid matrices. Argonne $\mathrm{N}$ ational Laboratory Biological and Medical Research Division Annual Report, 1965. $\mathrm{ANI}_{2}-$ 7136, pp. 184-195.

7. Frigerio, N. A. and M. R. Neiler. Benzeneboronic acids. II. Use of meta-nitrobenzeneboronic arid for the determination of $\mathrm{H}_{2} \mathrm{O}_{2}$ and $\mathrm{H}_{2} \mathrm{O}_{2}$-enzyme srstems. Argonne $\mathrm{N}$ ational $\mathrm{I}_{\Delta} \mathrm{ab}$ oratory Biological and Medical Research Division Annual Report, 1965. ANL-7136, pp. 185-187.

8. Frigerio, N. A. and J. A. Seiler. Work in progress.

9. Charlot, (A. C'olorimetric Determinations of the Eltments, Halsevier, Amsterdam, 1964.

10. Seaman, W. and J. R. Johnson. Derivatives of phenylboric acid, preparations and action on hacteria. $J$. A $m$. Them. Soc. 53, 711-723 (1931).

\section{LEAST SQUARES ADJUSTMENT OF HYDROLYSIS DATA FOR ANTITUMOR COMPOUNDS OF PLATINUM (II)}

Ronald F. Coley and Norman A. Frigerio

\section{PURPONE AND MECHODN}

The recent utilization of certain chloroammine and chloroamine complexes of platinum(II) as antitumor agents ${ }^{(1)}$ stimulated our interest in the aquation equilibria of such compounds. In acpucous solutions at $p H$ values of biochemical interest, such compounds undergo successive aquation reactions as indicated by Lquations (1) and (2):

$$
\begin{aligned}
& {\left[\mathrm{Pt}\left(\mathrm{C}_{2} \mathrm{\Lambda}_{2}\right]+\mathrm{H}_{2} \mathrm{O}=\left[\mathrm{PtC}\left(\mathrm{H}_{2} \mathrm{O}\right) \mathrm{A}_{2}\right]^{+}+\mathrm{C}^{\prime} \mathrm{I}^{-},\right.} \\
& {\left[\mathrm{Pt}\left(\mathrm{Cl}\left(\mathrm{H}_{2} \mathrm{O}\right) \mathrm{\Lambda}_{2}\right]^{r}+\mathrm{H}_{2} \mathrm{O}=\left[\mathrm{Pt}\left(\mathrm{H}_{2} \mathrm{O}\right)_{2} \mathrm{\Lambda}_{2}\right]^{2+}+\mathrm{C}^{\prime} \mathrm{l},\right.}
\end{aligned}
$$

where $\lambda_{2}$ is two ammine ligands, two amine ligands, or the bidentate ligand ethrlenedimine (en). The concentration equilibrium quotients for the above reactions, $K_{1}$ and $K_{2}$, are related to the total complex concentration, 1 , and to the equilibrium chloride ion concentration, $T$, by the expression ${ }^{12}$

$$
T^{3}+K_{1} T^{2}+\left(K_{1} K_{2}-1 K_{1}\right) T-21 K_{1} K_{2}=0 .
$$

The aquo eomplexes of the reactions of Liquations (1) and (2) are weak acids, titratable with $\mathrm{Xa}$ ()H. Becaluse it is generally only possible to titrute one proton of each water ligand, the equilibrium arid concentration is equal to the equilibrium chloride ion concentration. Thus, titrations of equilibrium solutions provide a basis for the evaluation of $K_{1}$ and $K_{2}$.

Although Equation (3) can be solved for $K_{1}$ and $K_{2}$ from titration data for equilibrium solutions of any two different total complex concentrations, the leat scuares method outlined in this report, when applied to data from solutions of six different concentrations over at tenfold total complex concentration range, provided values for $K_{1}$ and $K_{2}$ with an order of magnitude increatse in accuracy.

Equation (:3) is linear in the two parameters, $\alpha=K_{\mathbb{1}}$ and $\beta=K_{1} K_{2}$, and could be treated as a function of the form $Y=\beta X+\alpha$. Such treatment. however, would involve variables of little physical significance. Furthermore, both variables would be functions of $T$. which would foree one to consider both $X$ and $Y$ subject to error. For the treatment described in this report, a generalized least squares adjuntment, such as that dencribed by Doming, ${ }^{(3)}$ has been applied to Equation (:3) directly. The 1 variable has been assumed to be exact, a simplification well justified beouse the error in total complex eoncentrations, $A$, determined by diswolving weighed (quantities of solid compound) were at leant an order of magnitude smaller than the errors in the $T^{2}$ variable.

\section{PROTRESS REPORT}

I computer program was written to perform the demired least squares adjuntment. The quantity that was minimized was the sum of the weighted squares of the differences between the experimentally determined and the least squares adjusted values for $T$, i.e...

$$
S=\sum_{i} W^{*}\left(T_{i}^{\text {exptl. }}-T_{i}^{\text {ralre. }}\right)^{2}
$$

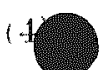

The program was written to output the values of $K_{1}$ and $K_{2}$ with their associated standard deviations. dloo, 
TABLE 62. TITRATION I) AT FOR THE DETERMINATION OF $K_{1}$ AND $K_{2}$ FOR $\left[\mathrm{P}^{2} \mathrm{Cl}_{2}(e n)\right]$, IONIC STRENGTH $=0.318$

\begin{tabular}{|c|c|c|c|}
\hline \multirow{2}{*}{$\begin{array}{c}\text { Initial } \\
{[\text { PtClian)], }} \\
\text { millimolar }\end{array}$} & \multirow{2}{*}{$\mathrm{T}^{\circ} \mathrm{C}$} & \multicolumn{2}{|c|}{$\begin{array}{l}\text { Equilib. acid concentration, } \\
\text { millimolar }\end{array}$} \\
\hline & & Exptl. $\pm \sigma$ & Calcd. \\
\hline 1.0014 & 35.0 & $0.8913 \pm 0.0054$ & 0.8909 \\
\hline 0.80152 & & $0.7536 \pm 0.0031$ & 0.7544 \\
\hline 0.60114 & & $0.6093 \pm 0.0033$ & 0.6066 \\
\hline $0.1007 t^{2}$ & & $0.440 \pm 0.004$ & 0.4435 \\
\hline $0.2003 \mathrm{x}$ & & $0.257 \pm 0.002$ & 0.2562 \\
\hline 0.10019 & & $0.145 \pm 0.002$ & 0.1456 \\
\hline 1.0060 & 30.0 & $0 . \times 742 \pm 0.0041$ & $0.872 \times$ \\
\hline $0.80+83$ & & $0.7426 \pm 0.0043$ & 0.7424 \\
\hline 0.603312 & & $0.5994 \pm 0.0038$ & 0.6003 \\
\hline 0.40242 & & $0.439 \pm 0.003$ & 0.4119 \\
\hline 0.20121 & & $0.25 x \pm 0.001$ & 0.2576 \\
\hline 0.10060 & & $0.147 \pm 0.002$ & 0.1470 \\
\hline 1.0008 & 25.0 & $0.8580 \pm 0.0015$ & 0.8572 \\
\hline 0.50064 & & $0.72 \times 7 \pm 0.0062$ & 0.7249 \\
\hline 0.60048 & & $0.5882 \pm 0.0043$ & 0.5909 \\
\hline 0.10032 & & $0.436 \pm 0.003$ & 0.4357 \\
\hline 0.20016 & & $0.255 \pm 0.003$ & 0.2545 \\
\hline $0.1000 x$ & & $0.116 \pm 0.002$ & 0.1455 \\
\hline
\end{tabular}

by utilization of a subroutine that employs a NewtonRaph-on iterative technique, ${ }^{\mid 4}$ the program solves the cubic equation for the values of $T$ at each experimental value of $A$, using the least equares values of $K_{1}$ and $K_{2}$. The pereent differences between such calculated values for $T$ and the experimentally determined $T$ values were less than one pereent of the calculited values in most canes. The program also generates a plot of ealculited $T$ values $r .1$ values and superimposes the $(1, T)$ datat points. The required input information consists of the $(A, T)$ data points. the experimental tandard deviation of each $T$ value, and initial estimates for $K_{1}$ and $K_{2}$.

Trpical titration data for the dichlororethylenediamine platinum (II) complex are presented in Table 62 . Fach solution was titrated ten times, and the experimental standard deviation, $\sigma$, has been included. The calculated values in this table are the least stuares adjusted values obtained by minimization of the summition of Equation (4). A typical least squares plot appears in lïgure 10\%.

\section{CONCLT-ION}

From these resulti, together with the results of similar adjustments at the same temperatures, the values of able 6:3 were obtained for the concentration equilib-

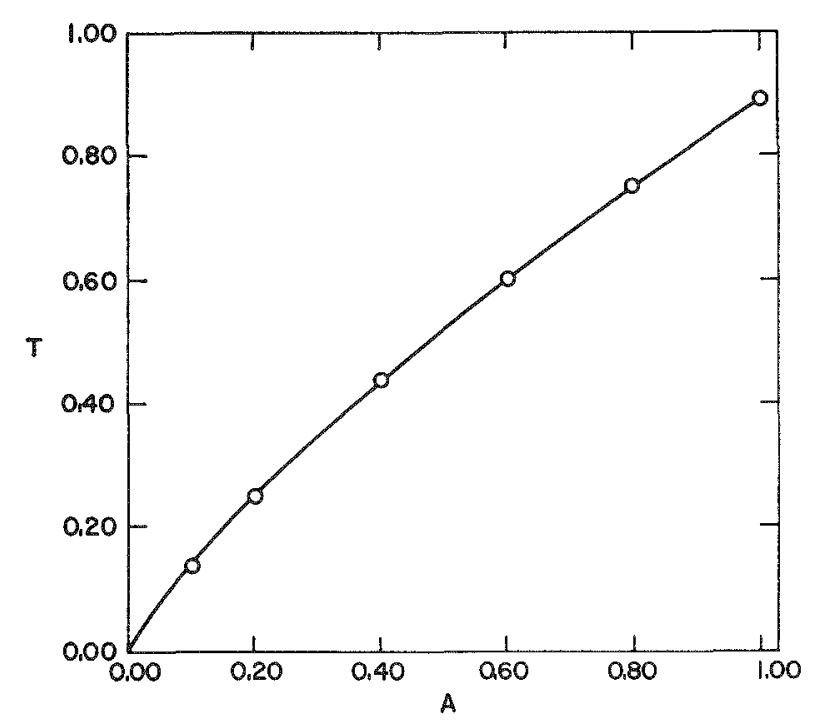

Fit;. 105.- Least squares plof of Equation (3) with the $(A, T)$ data points superimposed for the $35.0^{\circ} \mathrm{C}^{\circ}$ dat a of $\mathrm{T}$ able 62 . A and $T$ are in millimolar mits.

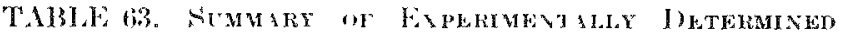

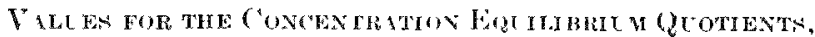

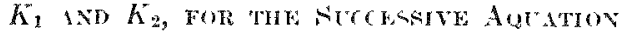

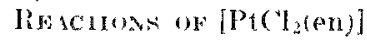

\begin{tabular}{|c|c|c|}
\hline Constant & Valus & Temperature \\
\hline$K_{1} \times 10^{3} M$ & $\begin{array}{l}2.76 \pm 0.05 \\
2.33 \pm 0.09 \\
2.19 \pm 0.11\end{array}$ & $\begin{array}{l}35.0^{\circ} \mathrm{C} \\
30.00^{\circ} \\
25.0^{\circ} \mathrm{C}\end{array}$ \\
\hline$K: \times 10^{ \pm}=$ & $\begin{array}{l}1.3 x \pm 0.05 \\
1.4 s \pm 0.05 \\
1.43 \pm 0.11\end{array}$ & $\begin{array}{l}35.0^{\circ} \mathrm{C} \\
30.0^{\circ} \mathrm{C} \\
25.0^{\circ} \mathrm{C}\end{array}$ \\
\hline
\end{tabular}

$\Delta H^{n}=4 \mathrm{keal} \mathrm{mollow} ; \Delta H^{r}:=-1 \mathrm{k} \cdot \mathrm{al}$ mole $\mathrm{e}^{-1}$.

rium quotients associated with the suceseive aquation reactions of [P't ( $\mathrm{l}_{2}$ ( en) ]. It is clear that this complex is largely arpuated in aquerus solution, so that the nature of the anionic moiety ( $11 . \mathrm{Br}$, ete.) will probably have little influence on antit umore activity.

\section{RFF WREVCH}

1. lisenberg, B., I. Vancamp, J. F. Trosko, and V. H. Nansour. Plat inum eompounds: I new olass of potent antitumour

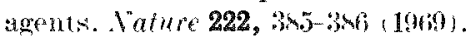

2. Sanders, ('. I. and 1). S. Martin. Jr. Arid hydrolysis of

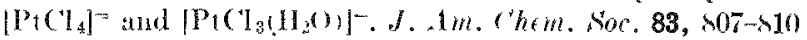
(1961).

3. Dening. W. H. statistical Adjutment of Datr. John Wiley and sons, Inc. New Fork, 194?.

1. Macdonald, P. Muthernaties and Statistion for secientists and Enginetr. Van Nostrand, Princetur, 1966. 


\section{CERENKOV RADIATION AND LIQUID SCINTILLATION COUNTING}

Walter E. Kisieleshi

PLRPOSE AND METHODS

Counting Cerenkov radiation to measure energetic $\beta$ emitters commonly used in biology and medicine $\left({ }^{32} \mathrm{P},{ }^{131} \mathrm{I},{ }^{21} \mathrm{Na},{ }^{90} \mathrm{Y},{ }^{42} \mathrm{~K}\right.$, and $\left.{ }^{47} \mathrm{Ca}\right)$ is a recent derelopment in liquid scintillation methodology. (1-3) Cerenkov radiation is produced when a charged particle (e.g., $\beta$ particle) passes through a transparent medium at a velocity greater than the speed of light in the same medium. It is characterized by a bluishwhite light emission that is directional, relatively weak in intensity, and has a continuous spectrum whose energy is concentrated mainly in the ultraviolet, but extend into the visible and becomes negligible in the infrared and microwave region. In water, which is an optically denser medium than air. the lower energy limit of electrons for the simulation of Cerenkov radiation has been determined to be 0.26.5 MeV. ${ }^{(4)}$

Compared to conventional liquid scintillation procedures, sample preparation is relatively simple becaluse completely aqueous ystems can be counted without the addition of organic fluor. The counting efficiency is unaffected by chemical quenching; however, color and ultrariolet quenching are still a major problem.

TABLF, 64, ESPERIMENTIL ("HRENKO

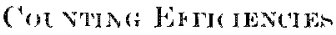

\begin{tabular}{|c|c|c|}
\hline Nuclide & $\mathrm{E}_{\max }(\mathrm{MeV})$ & $\begin{array}{l}\text { Counting } \\
\text { efficiencs ( of } \\
\text { disintegration) }\end{array}$ \\
\hline$-\ldots-\cdots-\cdots$ & - & $\ldots$ \\
\hline Calcium-47 & $0.66\left(83^{r}\right), 1.94\left(17^{r}\right)$ & 8.0 \\
\hline Potassium-10 & $1.32(8 \%)$, & 16.0 \\
\hline Sodium-24 & $1.39(1004)$ & 21.0 \\
\hline Phosphorus-32 & $1.71\left(100^{r}\right)$ & 30.7 \\
\hline Potassium-42 & $2.0\left(1 x^{6}, 3,3.6(82)\right.$, & 64.0 \\
\hline
\end{tabular}

TABLF 65. HFFICUN OF COC mon rn Vimoum Medi

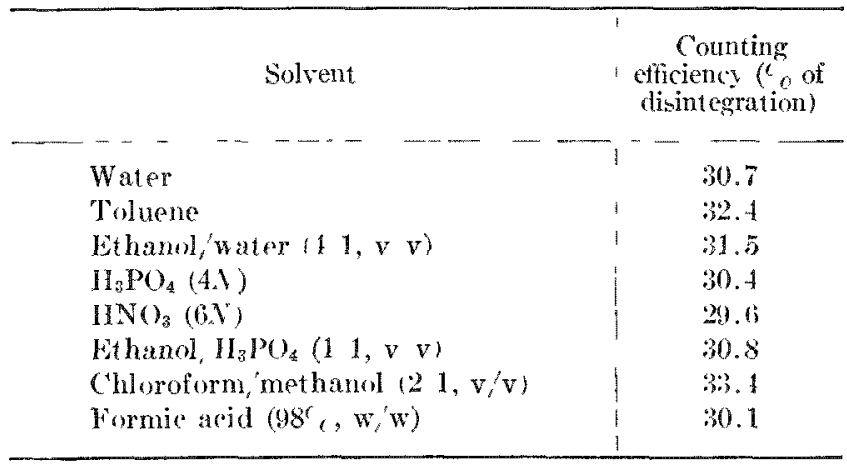

The purpose of this inve-tigation was to cxamine selected experimental parameters that determine cerenkor respone to $\beta$-emitting radionuclide in liquid counting syntems and to assess their application to biologieal and medical researeh.

Major interest was that Cerenkor terhniques might be uned in combination with liquirl scintillation counting methods(5) to measure and deted chergetic $\beta$ emitters $\left({ }^{32} \mathrm{P},{ }^{131} \mathrm{I}\right.$, and $\left.{ }^{42} \mathrm{~K}\right)$ in the presence of low energy $\beta$ emitters $\left({ }^{3} \mathrm{P},{ }^{3} \mathrm{H}\right.$, and $\left.{ }^{14} \mathrm{C}\right)$.

PROGREAS REPORT

1 mo-t important criterion in the utilization of Cerenkor radiation for radionuclide assay is $\beta$ detection efficiency. In Table 64 experimental Cerenkov counting efficiencies are presented for a number of $\beta$ emitters of different energy. To obtain these measurements, a Beckman ISS-100 ambient temperature spectrophotometer was used and the counter was optimized to give maximum counting performance. Samples were prepared in glass scintillation counting viak, and appropriate aliquot- of each radionuclide were adder to $10 \mathrm{ml}$ of di-tilled water. The rexults indicate that the Cerenkor detection efficieney for $\beta$ particles is a direct function of their energy.

We then incestigated the counting efficiency of ${ }^{2} \mathrm{P}\left(\mathrm{Na}_{3}{ }^{32} \mathrm{PO}_{4}\right)$ by Cerenkov radiation in the pressnce of varioum solution of salts, acids, and hases (media). These results are shown in Table 6.5. Cerenkor radiation in aqueous samples is not dimini-hed hy colorles acids, alkalin, or salts. The decrease in counting efficieney with nitric arid is due entirely to rolor quenching.

In acidity studie (Figure 106) phomphorie acid, regardless of pH value, gave stable counting rates; this was not true of nitric acid. A decrease in counting efficiency was noted at higher molarities, again, att ributed to color quenching.

Result of the effect of sample volume on Cerenkov counting efficiency, determined for solutions of phosphoric and nitrie acid in our system, are shown in Figure 107. The efficieney of Cerenkor detection as ween in Figure 107 is a function of the total sample volume. In the system used in this study, efficiency is maximum at a sumple volume of $10 \mathrm{ml}$. Identical counting rolumes must be used to obtain reproducit counting efficiencies when various samples are to be compared.

Measurements were also made to determine and 


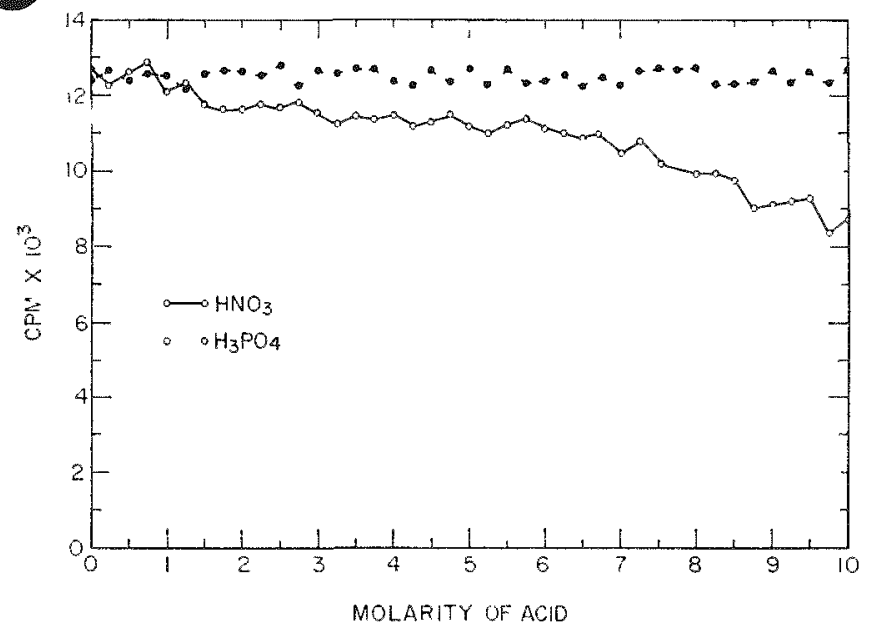

FItr. 106. The measurement of ('arenkov rudiation as at funetion of the acidity of $\mathrm{H}_{3} \mathrm{PO}_{4}$ and $\mathrm{HNO}_{3}$.

compare counting efficiencies for ${ }^{32} \mathrm{P},{ }^{33} \mathrm{P}$, and ${ }^{3} \mathrm{H}$ by Cerenkor detection and liquid sintillation counting with organic fluors.' ${ }^{61}$ Various coneentrations $(\mathrm{dpm} /$ $\mathrm{ml}$ ) of ${ }^{32} \mathrm{P},{ }^{33} \mathrm{P}$, and ${ }^{3} \mathrm{H}$ were added to counting vial containing $4.0 \mathrm{ml}$ of phomphoric acid in alcohol solution. Lach sample wa firnt counted directly bo the Cerenkor technique, after which $1.5 \mathrm{ml}$ of a dioxanebased liquid scintillation fluor was added to each vial, which wat recounted by the standard proceslure for liquid seintillation measurement. The results shown in Table 66 clearly indicate that in duallabeled experiment thi- combined method of analysis allows the quantitative measurement of energet is $\beta$ emitter in the presence of low energy $\beta$ emitters as ${ }^{3} \mathrm{H},{ }^{14} \mathrm{C}$, and ${ }^{33} \mathrm{P}$.

\section{CONCISOSIONS}

1. From the experimental result obtained, the most direct adrantage of Cerenkov counting in the simplicity of sample preparation.

2. Samples ran be counted in a completely aqueous sy-tem without adding scintillating fluors.

3. The eronomy, bared on both simplicity of procedure and cost of fluor reagent, favor acceptance for large-sale analycer. Although chemical quenchine appears to be completely eliminated, color and ultraviolet quenching is a problem.

4. Of prime importance: dual-labeling experiments that rerquire energetic $\beta$ cmitters $\left({ }^{32} \mathrm{P}\right)$ in the presence of lower energy $\beta$ emitters $\left({ }^{3} \mathrm{H},{ }^{11} \mathrm{C}\right.$, and $\left.{ }^{33} \mathrm{P}\right)$ now can be successfully undertaken without rerourse to adiorhemical separation.

Cerenkor rounting can be a uneful methor for the

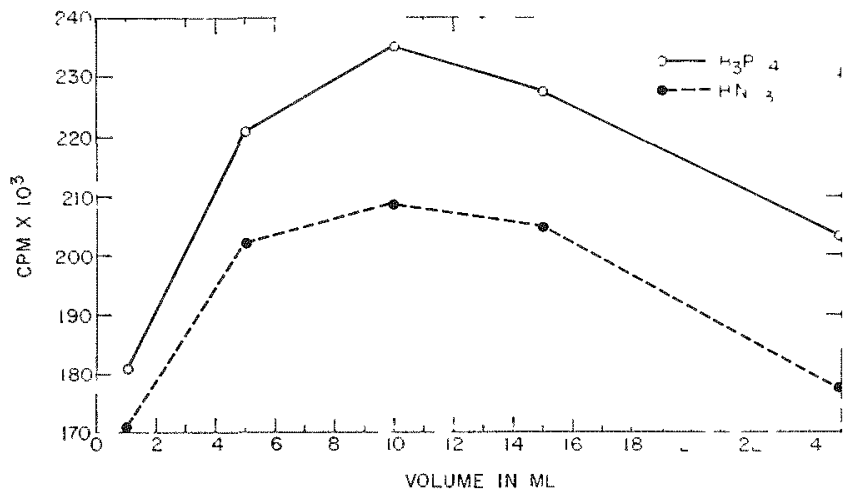

Fin. 107 The meanurement of Cerenkev radiation ats a function of the volume of twa acidie media

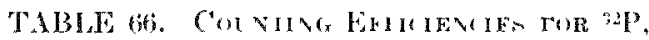
3 ? $12 \mathrm{I})^{3} \mathrm{H}$

\begin{tabular}{|c|c|c|c|c|c|c|}
\hline \multirow{2}{*}{$\begin{array}{l}\text { Volume of each } \\
\text { nuc lirle } a r\end{array}$} & ('erekor & countin & cpm & \multicolumn{3}{|c|}{$\begin{array}{l}\text { Liquid scintillation } \\
\text { counting, cpm }\end{array}$} \\
\hline & $\overline{82 p}$ & $\mathrm{~m}{ }^{2}$ & $\sqrt{11}$ & ${ }^{22} \mathrm{P}$ & $-\overline{s p}$ & 3H \\
\hline & & $\ldots$ & $\ldots$ & & + & - \\
\hline 50) $\mu 1$ & $30,11: 3$ & 135 & bogg & 65,931 & 23,713 & $22,1: 34$ \\
\hline $100 \mu \mathrm{l}$ & $58,08 \mathrm{si}$ & 2336 & 55 & 1126,710 & 15,571 & 10,017 \\
\hline $200 \mu \mu$ & 120,261 & 371 & 121 & 12612,372 & 91,672 & $7 x, 3<0$ \\
\hline $\begin{array}{l}\text { Counting effi } \\
\text { denes, ' }\end{array}$ & 307 & 033 & $002 !$ & 10.3 & 87.4 & 221 \\
\hline
\end{tabular}

(a) $100 \mu \mathrm{l}$ of $\cdot 2 \mathrm{P}=192,974 \mathrm{dpm}$

$100 \mu \mathrm{l}$ of $\mathrm{s} P=53.151 \mathrm{dpm}$.

$100 \mu \mathrm{l}$ of ${ }^{3} \mathrm{H}=191,000 \mathrm{dpm}$

bkg $=$ hackgromind $=30 \mathrm{ipm}$.

mea-urement of entergetic $\beta$ einiting radionuclidenspecially in biologieal samplen. Cerenkor counting technique in combination with conventional liquid eintillation procedures offers a new dimension in liquirl seintillation methodology.

\section{REY ERENCES}

1. Haberer, K. Ther die deneontinierliehe Mensung der Radioaltivitat in Wasser. Atomw irthehaft 7, 192497 (1962).

2. Eirick, R. Il. and li. P. Parker. The use of Cerenkov radiation in the mesturement of $\beta$-emitting radionucliden. Int. J. Appl. Raduat. Isotopes 19,2 tis (19tis).

3. Roms, H. H. Measurement of of emuting nuclides unng ('erenkov radiation. J. Anal. chem 41, 1260 1265) 19669$)$

1. Jelley, J. V. C'erenhor liedution and it, Applacation Pergamoni Preso, (Bxfort, 195\%.

5. Kinielesk1, W. L. and I. (4. Huehner. Evaluation of combuntion methodo for measurement of tritium. Arconne National Lahorators Biolugical and Medieal Researeh Division Annual lieport, 1968. ANI. 7535. pp. 2\$5-267.

i. Robiuson, J. R. ${ }^{3 s P}$ : I muperior rarliotracer for phouphorus. Int. J. Appl. Ratlat I sotopes 20, 531-510 (1969). 


\section{GENETICS OF THE "MOTTLED" ALleLES ON THE X-CHROMOSOME OF THE MOUSE}

Douglas Grahn, Katherine II. Allen, R. J. Michael Fry, and Jane Mulesch

\section{PL RPUAE AND METHODS}

Wte have been studving the geneties of the "mottledl" allelen as an adjunct to incestigations of the radiation induced mutation rate for sex-linked detrimental gene- 1,21 several genes in the allelic serien are being uned in those experiments as marker genes. The allelen under investigation are: blotehy, Blo; brindled. $M o^{b r}$; dappled, $M 0^{d p}$; tortoise, To. Thene genes vary in their lethal effects, both before and after birth. in their pathologic manifentation, and in their phenotypic expression of mosaic coat color.

The data are derived from stock maintenanee recork, from breding records, from the mutation-rate studies. and from sperial matings to test interallelic behavior. All animals are rexed at birth and phenotypically classified at that time, if posible, or as soon ats derelopinent permits.

\section{PHO ${ }_{\text {RLSA }}$ REPORT}

\section{Phenotupic Variation}

The mottled genes act on coat color by an interference in pigment production. Affected hairs are grey to white but some collection of black pigment gramules will often be seen in the tips of the long guard hair. This reducen the intensity of depigmented areas and, in viable males, as blotehy and occasionally brindled, and otherwine near-white coat will have a -tippled dark orereast.

Brindled, dappled, and tortoise have nearly identical phenotypen; only dappled is differentiated by depigmented spots in the ear and tail. The monaic depigmentations in the coat of these three alleles are similar. The rumbom mosaic expression is attributed to the random inactivation of one or the other X-chromonome, and all the genes contained thereon, early in development. ${ }^{(3)}$ When the X-chromonome carrying the will-type allele is inactivated, the mutant phenotype is scen.

The gene blotchy is much less expressive than the other. A carrier female is sometimes indistinguishable from the wild-type.

The genes vary in viability effect, but only Blo is normally viable in the male or homozygous female.

\section{Reproductive Performance}

The hasic reproductive capabilities of these alleles atre presented in Table 67. The upper half of the data is derived from standurd mating of the carrier dam with a wild-type ire and data in the lower half of the table are from carrier dams top-crossed with $B l o$ males. The important features to be noted are the normal viability of all Blo genotypes, the po-tuatal male lethality for $M o^{b r}$ along with nearly normal viability for the females, the complete prenatal male lethality for Mo $\mathrm{O}^{d p}$ and To accompanied by some reduced prenatal and postnatal viability in there carrier females. of the allelie combinations with Blo, Blo $\mathrm{Wo}^{\text {br }}$ is sublethal postnatally, but Blo $M \mathrm{o}^{d p}$ and Blo To are essentially postuatal lethals. One Blo To female survived to 10 ) days of age. A point worth noting in all of these data is the genetically predictable behavior of the rex ratio; it drops from 0.5 to 0.33 for the prenatal male lethals. This anherence to expectation is not always seen, as among the progeny of XO dams, (4) and it confirms the lethal gene effect as a zygotic lethal, not a gametic lethal.

We also have been breeding the Blo Mo Wo $^{\text {br }}$ female on the long shot that a recombinant wild-type might oceur. herause this locus seems to be a complex one with considerable intraallelic differentiation. None has occurred in over 500 offspring. The data indirate, however, a normal freundity but a reduced survival among the progeny suggestive of a deficiency in milk production.

\section{Relutive riability}

Table 68 defines the relative viability among the four alleles and the arailable combinations according to reven classes of pre- and postnatal lethality, sublethality, and viability. The arailability of a fortile To male, reported earlier, ${ }^{(5)}$ permitted some otherwine forbidden allelic tests although To/To was, itself. not tested. Although this classification usd -omewhat categorical subclasification, it should be noted that the time of death is actually a continuously distribut ed property between conception and 


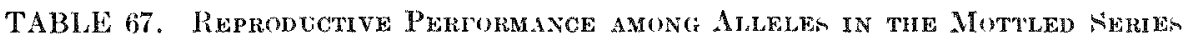

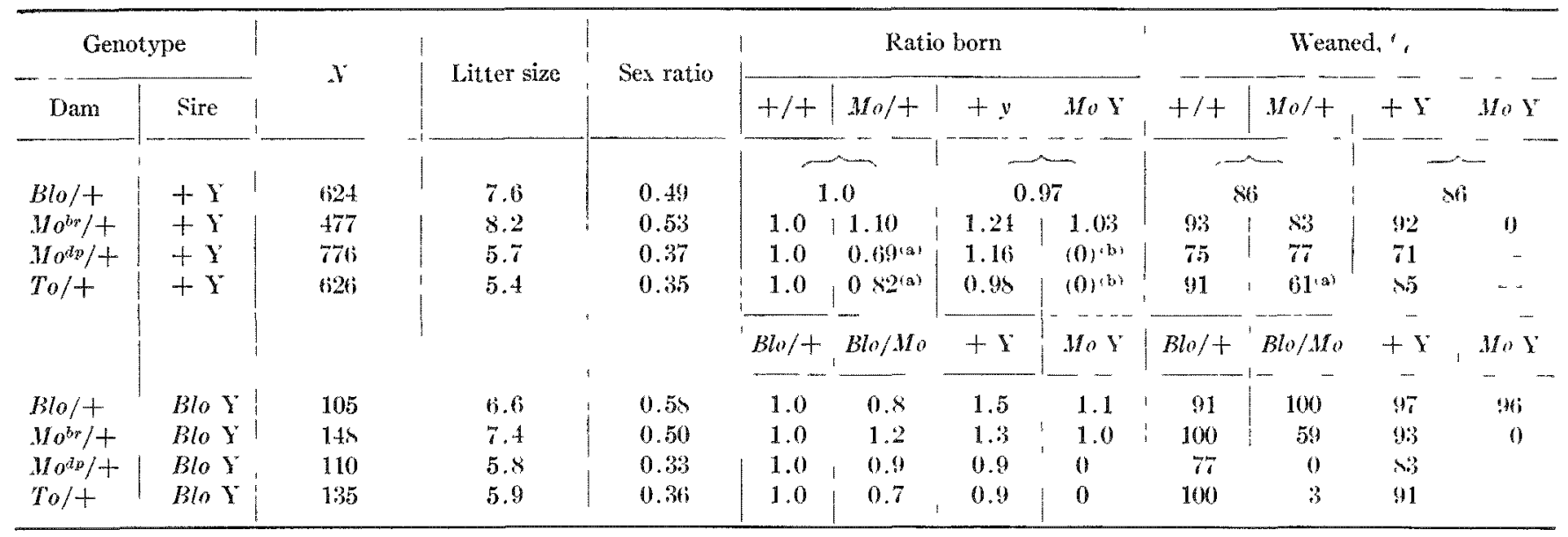

(a) Difference from $+/+$ class significant at $P<0.05>0.01$.

(b) These classes of males normally die in utero, but oreasional individuals are stillhoru.

TABIAE f8. Rentive Viabilty or Mottled (ihanotipes

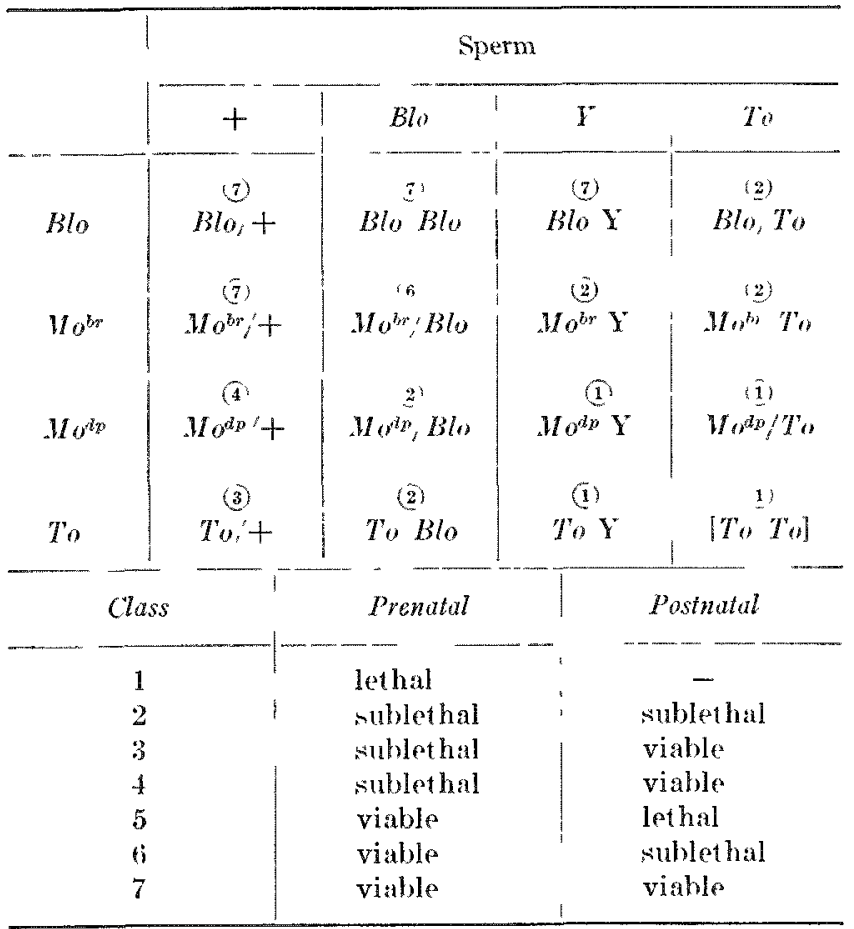

30 day - of age or beyond. The birth event is only a milestone in this continuum. Most deaths occur by about 21 days of age and oceur in neonatal $(0-5$ days) and infant (8-20 days) time period clusters. The distribution of deaths varies a bit among alleles, but the major difference involves blo malen. Many of these die with cardiovarcular lesions between 50 -nd 250 days of age, normally a period of minium death rate.

The prenatal deaths are both preimplantation and postimplantation. For the To gene, death of To males appear to be equally before and after implantation. No data are now available on the other atllelen.

\section{Pathologic Manifestations}

The effect of $T$ to on the clastic laminae of the

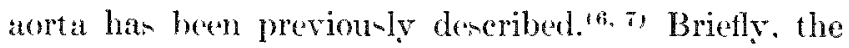
elastic laminate are irregular and the intralaminar -race appear increased along with dioruption of the laminate. Aneurym, rupture, and hemorrhage are secen. Sometimes aneurym is accompanied by a defined s-curve in the thoracio sorta or an s-curve may be seen alone. A summary of the ineilenee of aortic lenions is given in Table 69.

Curiously, the mont viable allele, Blo, and the most lethal, To, have similar frequencien of aortic lenions. Although many Blo males die of ruptured aneurym-

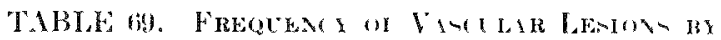

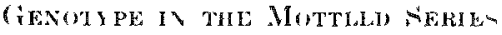

\begin{tabular}{|c|c|c|c|c|c|c|}
\hline \multirow{2}{*}{-} & \multirow{2}{*}{ Genotrye } & 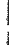 & \multirow{2}{*}{$x$} & \multirow{2}{*}{ Normal's } & \multicolumn{2}{|c|}{ Co Aortic lesion } \\
\hline & & & & & $\begin{array}{l}\text { Aneu- } \\
\text { rysm }\end{array}$ & IS-curse \\
\hline & $B l o+$ & 1 & $1 !$ & (6is) & 32 & 5 \\
\hline & Ho, Blo & & 13 & 15 & \$ร̃ & \\
\hline & $B \% \mathrm{Y}$ & & 63 & 2 & 98 & \\
\hline & BHo . . $10^{l_{2}}$ & & 12 & 100 & & \\
\hline & $M n^{z_{2}}+$ & & 32 & 100 & & \\
\hline & $1 / \omega^{3} x \mathrm{Y}$ & & 13 & 100 & & 1 \\
\hline & $M o^{t y}+$ & & 47 & 90 & 1 & ti \\
\hline & $T w+$ & 1 & $32 x$ & 58 & 25 & 17 \\
\hline & $T a \&$ & 1 & $2 i$ & 19 & 81 & 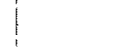 \\
\hline
\end{tabular}


an have been seen in stillborn To males this lesion is obviously not the primary cause of the lethal action. The vascular lesions have not yet been found in $M o^{b r}$ or $B l o, H o^{b r}$, and the incidenee is low in $H o^{d p}$, ret the lethal action is clearly similar in time to that in To. This distinct difference in rascular lesions encouraged our tents for possible recombination between Blo and $M 0^{b r}$.

One additional feature coneerning the posible genetic basis of mosaic pattern variation is discussed in a separate report. ${ }^{(8)}$

\section{CONCLALIONE}

The genetic and pathologic analysis of the mottled alleles on the sex chromorome of the moune reveals the complex nature of this genetic locus. The alleles vary in prenatal and postnatal viability, but not in direct relation to the severity of grossly observable lecions of the aorta. The clarity of monic coat color patterns also varies among the alleles from distinct patches of depigmentation in both hair and skin of the ears and tail (.1\%odp) to barely discernible blotches of light hair (Blo).

\section{REF ERENCTS}

1. (arahn, 1)., R. ('rages, W. P'. Leslie, and J. Liebel. Nammalian genetics: Ietermination of the radiation indued muta- tion rate for sex-linked refessive lethats in the monse. A wonne National Laboratory Biological and Medical Research Jivision Anuual Report, 1968. ANI -7535, pp. 17-19.

2. (arahn, I), W. P. Leslie, and R. ('raggs. Estimation of the radiation indueed mutation rate for sex-linked detrimentals in monse spermatogonia. Proc. XII Intern. Congr. Genctics $1,96(1968)$.

3. Lyon, Mary F. ('hromosomal and subehromosomal inaetivation. Annual Revitu of Genetios, Ed. H. L. Rimman. Annual Reviews, Inc., l'alo Alto, ('alifornia, 196x, Vol. 2, pp. 31-52.

4. Russell, W. L., L. B. Ruswell, and J. S. (rower. Lxceptional inheritance of a sex-linked gene in the mouspe explained on the basis that the $\mathrm{X} / \mathrm{O}$ sex-chromosome constitution is female. Proce. Nat. Alad. sei. 45, 554560 (1959)。

5. (irahn, D). and R. (Tragg. Mammalian (heneties: An unusual cecurrence of $X X Y$ fortoise males and presumed $X Y / X Y$ mosaic. Argome National Laboratory Biological and Medi(al Researeh Division Annual Report, 1967. ANL-7409, pp. 111113.

6. Grahn, 1)., F. A. Verley, R. J. Michael Fry, B. Slaughter, L. Staffeldt, and $K$. F. Hamilton. Inherited connective tissue defect in tortoise mice. Argonne National laboratory Biological and Medical Research Division Annual Report, 1966f. $1 \times 1,-727 \%, p p .145-146$.

7. Fry, R. J. M., B. Nlaughter, 1). Grahn, F. Wassermann, F. Manelis, K. F. Iamilton, and E. Staffeldt. Inherited connective tissue defect in tortoise mice. Argonne National Laboratory Biological and Medieal Research Division Annual Report, 1967. ANL $-7-109$, pp. 11t-11\%.

x. (Grahn, I)., R. A. Lea, and J. L. Hulesch. Tent ative loeation of an $X$-inactivation controller gene on the normal $X$-chromosome of the monse. This report.

\title{
TENTATIVE LOCATION OF AN X-INACTIVATION CONTROLLER GENE ON THE NORMAL X-CHROMOSOME OF THE MOUSE
}

\author{
Donglas Grahn, Ruth A. Lea, and Jane L. Hulesch
}

PIRPOCE AND METHODS

In the manmalian female, only one of the two $\mathrm{X}$-chromosomes is considered to be functional in the cells and tirsues of the adult individual; the other $\mathrm{X}$ is heteropyknotic and believed to be metabolically inactive. (1) The choies of which chromosome will be inactive is apparently a random one, and it oceurs early in development, probably at or before the definition of the notochord and neural erest.

Melanoblasts are derived from neural crest cells and these migrate laterally to their ultimate location in the skin and hair follicles. ${ }^{(2)}$ If one of the X-chromosomes carries a gene that inhibits pigment formation, then an unpigmented area will appear in the coat in thowe regions where the mutant-bearing $\mathrm{X}$ is active. When this $\mathrm{X}$ is inactive, the normal coat color will prevail. One allelic series on the murine X-chromoxome, the "mottled" series, has this type of phenotypic expremsion in the fur.' $\left.{ }^{2}, 3\right)$ Females carrying any one of the genes blotehy (Blo), brindled $\left(M o^{b r}\right)$, dappled $\left(M o^{d p}\right)$, or tortoise $\left(T^{\prime}\right)$ ) have a mo-aic coat color. The pattern often shows mediolateral striation that reflects the migration of melanoblasts.

It in expected that if the choice of inactivation is -trictly random, then the arerage mouse would be 50 c greyi-h-white and 50 , full color. Variation around the mean would be esentially binomial and the ralue of $n$ in the expansion to approximate the observed variance would be an estimate of the melanoblast cell population size at the time of X-inactivation.

There is. however, a nonrandom component. The (xtent of mutant gene expression can be shifted to high or low degrees of expression through ordinar genetic selection procedures. ${ }^{(4)}$ Lines differentiated by 
Hertion have light coat color areas that make up about $55^{\prime} \%$ and $25 \%$, of the total roat for high and low etected linem, remeetively. Thi- nonrantom component ha been deceribed by cattanah an attributed to an inactivation "controlling element" $"$ and by Rurell an an inatetivation center from which inactivation spread distally. ${ }^{\text {br }}$ To date, all critical publiched data have been based upon the variegation or mo-aiciom meen in X-auto-omal tran-location -tocks, wherein inactivation of the automomal recoment doem -eem to be -ubjeet to a -preadunger effect, or at leat to -ome dexpres of vatriation in inativation not explainable by smple binomial variation.

While this interpretation is certainly valid for the stoek wed, it - validity concerning the normal $\mathrm{X}$ (an be quentioned. '7) ['Itimately, it comes down to the que-tion of whether the inactive $X$ is completely inactive or whether it might have a low lex el of genetir. action, a "leaky" effect, that would only be detected in thoue metalolie reytems that have a low threnold of responsiveness. A controlling gene could act to increave or decreane thi- "leaky" artion of the chromo-ome upon which it is borne. Thus, if a controller that enhances activaty is on the $\mathrm{X}$ (arlying the mottled mutant. the mutant geme effeet will predominate so that the arerage moure will have in ardlition to the unual 50c, liuht area- an additional amount due to this low level of gene action from the ineompletely inactive $X$. Converely, when an enhancing controller gene is on the will-type $X$, then nonmutant areas will be added to the expected 50? value, an now the wild-type allele would be irpegularly expresing itself in otherwise mutant arrat.

This type of gene interaction recuiren that a type of codominanee prevail among the allele involved. Although strictly -peaking, codominance requires both gene effects to be manifest, the interaction we devribe is not compatible with partial or complete dominance, either. In this eave, we asume that codominance exists to the extent that the gene product of each of the two competing allele are produced independently of the action of the other $\mathrm{X}$, and the choice of which gene artion prevails is random when the phenotypic respon-e threshold has been reached or exceeded.

We, therefore, do not awume that the controlling gene is an "inactivation center" from which a complete inactivating offect will -pread with rarying extent along the chromosome. Our hypothemis is that all inactive X-chromosome have some metabolic arvity. and the level of this activity is under the genetic control of the controlling element or gene which may be ynonymoun with the inactivation center).

Thi hypotheris differ from the aggregate of other conreptr, as reviewed by Lyon.'11 in a-suming that a), inital S-chromo-ome inactix ation is random but never truly completer regarding gene activity for all ex-linker aenes: b), the nonrandom component of ratresation is a function of a rontrolling genes a that exert - it - affect on the whole chromonome uniformly;

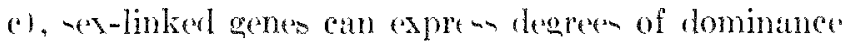
and corlominanes on the heterozgeom female smilar to antormal genen, though nolifien by the level of controlled -uppremion of artivity of the hetropytnotir (inartives $\mathrm{X}$ : d). phenotypire expren-ion- with low threwhold of rewone can thow a wide range of phenotyle variegation along with ome rempone to -election prewure in the heterozygou female; ("), tixo X-chomo-omen must be present to produce a completely nomal female in all mammals; deviationfrom thi will alway leal to abnomality due to

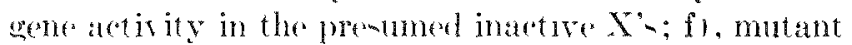
heterozyoten ran show different degress of mutant expenion-the mutant gene may be expresed in the whole animal, but whow variegation in the degree of ererity; variegated normal verus mutant. uniformly normil, or uniformly mutant-depending upon dominituce and threshold of respone.

Sex-chromo-me genet ic behavior, according to thene concent, is then merely" an extension of the u-ual auto-omal chromowme and gene behavior, and dom not really tren- clacical genetle roncepts an seriourly as con-idered by Grïneberg. ${ }^{(4)}$ Proof of the existence of the above conviderations is admittedly difficult and may depend mo-tly upon the coninteney of oberves phenotypir detail and their interpretation. Data of our own on a premumed thret-point linkage inrolving $M_{0}{ }^{b_{n}}$, $(r s$, and a controllng gene are briefly prewented an evidence in partial -uppont of our theis. Obriou-ly, no single genetic tent r.rtem coukl araluate all the concept Provicionally. we will rodes the rontrolling gene a ro; the uppereane ymbol indicaten enhancement of gene al iraty in the heteropyknotic $\mathrm{X}$.

The data ste derived from the $\mathrm{F}_{2}$ progeny of our prement we-linked mutation rate study. This teet tmploy the $+M 0^{b},++$ dam and $C+Y^{2}-i r e$ to produre an $\mathrm{F}_{1}+\mathrm{Ho}^{\text {br }} \mathrm{F}_{\mathrm{s}}+$ that in outerosed to ('BA malem that would be clated as $t+\mathrm{Y}$. Extreme variation in the variegation of brindled. greasy, and brindled-greay recombinant ha permitted a rea-onable dichotomization of the brindled and greany clasues that retro-peretively suggent that the cromen are as follows: 


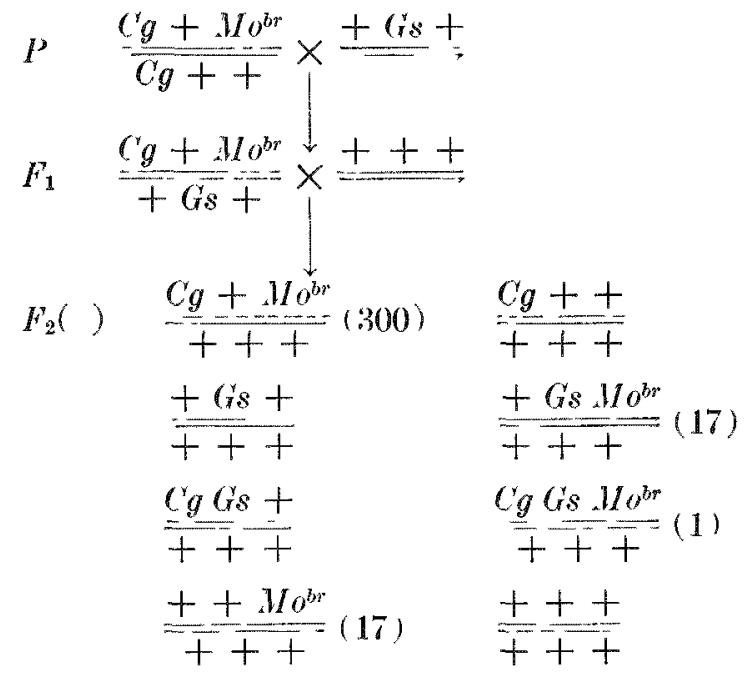

The frequency of phenotypic classes involving.$M 0^{\text {tr }}$ are given in parentheses. These figures suggent about a $5_{i c}^{c}$ recombination for each of the regions. The different greasy classes have been more difficult to define, but quite recently we have attempted this classification in mice that are several months old rather than making the determinations at 20 to 30 days as for the other types. At present we detect a class of greasy females that would meet the genotype, $\mathrm{Cg}$ Gs $+!+++$. The patches of $G$ s on these females are distinctly larger and cover more total coat area than for a female we would class as + is $+i+t+$ The ratio of these two types is at present 4:83.

Probably the most distinctive feature among these mice is the persistent occurrence of minimum $\mathrm{Mo}^{\text {br }}$ rariegation in the $G s-M o^{b r}$ recombinants-they are a categorically dark class. The one proumed double recombinant is also distinetive and was discernible before weaning as a rery light colored, greasy-brindled moure.

Data collection is continuing, and progeny tenting of the Fis segregants is also under way. The basic genetic test is also being reconstituted, separately from the mutation rate study, with the original stock presumed to carry the cy gene.

\section{CONCLUSIONS}

The genetic control of mammalian sex-ehromosome inactivation is discussed with the suggested hypothesis that the inactive $\mathrm{X}$ is never fully inactive and the level of residual activity may be under definable genetic control. Some of the consequences of our thesis are discussed and preliminary data from a three-point linkage are presented to partially support our contentions. Although different interpretations can certainly be applicd to our data as they stand, the genetic behavior of the $C y$ gene can be tested in combination with other sex-linked genes. The hypothesis presented here provides a genetically ronsistent interpretation of most available data and in, itself, susceptible to genetic test.

\section{REFERENCES}

1. Lyon, M. F. Chromosomal and subehromosomal inartivation. Annual Revitu of Geneties, Ed. H. I. Roman. Annual Reviews, Inc., Palo dito, ('alifornia, 1968, Vol. 2, pp. 31-52.

2. Snell, (, . 1). and L. ('. Stevens. Early embryology, Biology of the Laboratory Mouse, Ed. Larl 1. Green. Me( Graw-Mill, Inc., 1966, 2nd Fd, pp. 205245.

3. Grahn, I., K. F. Hamilton, R, J. M. Fry, and J. Hulesch. Genetics of the "motlled" alleles on the X-chromosome of the mouse. "This report.

4. Cat anach, B. M. and J. H. Isaarson. Genetio control over the inactivation of autosomal genes at tarhed to the X-chromosome. Z. Vererbungsl. 96, 313-323) (1965).

5. Cattanach, B. M. and J. II. Isaarson. Controlling elements in the mouse $\mathrm{X}$-chromosome. Genetios 57, 331-346 (1967).

6. Russell, L. B. Another lonk at the single-active-X hy pothexis. Trans. N. Y.uAcad. Aci. 26, 726 . 736 (1964).

7. Lyon, M. F. Lack of evidence that inactivation of the mouse X-chromosome is incomplete. Genet. Res. 8, 197-203 (1960).

S. (iruneberg, Hans. More about the tabby mouse and about the Iyyon hypothesis. J. Embryol. Exp. Morph. 16, 569590 (1966).

\title{
INABILITY TO INHIBIT BRAIN CATALASE COMPLETELY IN VIVO WITH AMINOTRIAZOLE
}

\author{
Robert X. Feinstein, Judith B. Howan, and Joann T. Faulhaber
}

\section{PCLRPOH AND METIODS}

Hill et al. ${ }^{\prime \prime}$ recently demonstrated a considerable variation in the sensitivity of various inbred strains of mice to hyperbaric oxvgen. These authors were unable, however, to identify the biochemical parameter(s) responsible for the variation, although they did conclude that deathis were due to central nervous system failure. The enzyme, catalare, eemed to us to be a rather likely andidate for the remonsible parameter becanse of its involvement in oxroenperoxide metabolism. Two approaches appeared promi-ing to test this possibility: a) obtain number of inbred mouse strains. measure brain catalase, and try to correlate the results with the lethal- 
Y lata of Hill of al.: ${ }^{11}$ or b $^{\prime}$ inhibit brain catalase with 3-amino-1,2.4-triazole (AT) and measure the re-i-tance to hyperbaric oxygen of animal so treated.

The decision to use the lattere approach wat band on three considerations: at we would be able to proceed immediately: bl we were, in any cive, interested in eomparing the effect of $\triangle T$ on brain catalite with it effect on the eataliane of other tissuen: and ol mo-t importantly, if it dereloped that low brain ratala-e wat protertive actain-t the toxicity of hyperharic oxyen. we would have available a tested technigue for the restuetion of the catallatic activity of brain. Before mea-uring the resistance of AT treated mice to hyperbaric oxveren, it wan neeenrary to a-more that AT war inderd rapable of inhibitinge bratin ratalise me rivo, and it in to this question that thene experiments wetere ardidrened.

Mise ured were CF 1 Anl[Anl 66$]$ of age and rex specified in each experiment. All injection were intraperitoneal: dom are -tated with each axperiment. Animal- were -ilcrificed by breaking the neck. The brain rand sometime aloo other oroms for comprarisond wat removed and trozen in dry ire-acetome. Frozen tisuen were sored over liguid nitrogen and eventually thawed, homosenized in cold 18 : Triton, ${ }^{\prime}$ and andyed for atatlane artivity by the perhorate technicque.'s)

Some experiments were performed in which $\mathrm{AT}$ inhibition of catalane activity in vitro wa- mestured. In thene experiment-, A'T effect-were mes-ured both in the prenence and the almenee of ascorbic acid. The arcorbate wat anded in order to an-ure the traces of $\mathrm{H}_{2}\left(\mathrm{l}_{2}\right.$ neecematy for $\mathrm{A} \mathrm{T}$ inhlibition. ${ }^{(4)}$

\section{PlROGLLA REPURT}

\section{In Vitro Inhibition Eiperiments}

Thres experiment were performed with normal brain homogenates. u-ing liver" and heart homogenater as comparison tisues. Time and $\mathrm{AT}$ concentration were varied, and the effect of arcorbate was tested. In brief, we have found that brain and heart are inhibited in retro by $\mathrm{IT}$ an completely a- and more raplidly than, the more thoroughly studied liver. The extent of ultimate inhibition of all timsuen was, as commonly found for liver, 92 to $98^{\prime} \%$. It i- further to be noted that although the presence of ancorbate slightly atcelerated the inhibition of liver homogenate, it was without positive effect on the inhibition

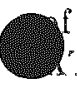

heart or hrain homogenates. Actually, maximal $\Gamma$ inhibition of brain homogenates was slightly delayed by the presence of ancorbate; we have no explanation of this observation. It is, in any care, rvident that there is nothing about brain or heart catalase that make them inherently noninhibitable ly. AT.

\section{In Vivo Inhilition fopperiments}

1. Arlult malen were given a single injection of 2000 me $\mathrm{AT}$ ke borly weight, then sarrified at

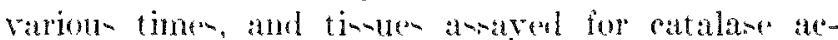
tivity. Maximal inhibition attained at any time were liver and kudney. 95\%: - tomach, 80\%: hoart. 70\%; and brain. of, . Naximal inhihition wa genterally oberered at about 1 he after injection.

2. Ailut mater were given daty injections of 2000 ma dT kg for 5 days, and groups were sacrified 1 hr alter wath injertion. Inhibition- oberved were: liver, 90 to $95^{\prime} r$ : heart, 60 to $70^{\prime},:$ and brain. 40

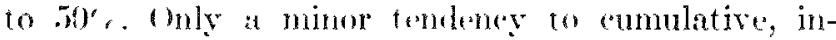
crea-mes inhibition was oberved.

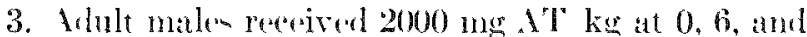
$12 \mathrm{hr}$, and group were marrificed at 1,7 , and $13 \mathrm{hr}$. Inhibition obetervel were: liver, 90 to $95, \%$; heart, (i.) to 70r ; and britu, 40 to bore. The brain appeaded to be acromulating inhibition, but the re was-o much valiation that thi- rannot be ronsidered significunt

4. Arlut malen peceived $2000 \mathrm{mg} \mathrm{AT} \mathrm{kg}$ at $0,2.4$, 6, 8, 10, 12, athl 24 hr, and group were sacrificed 1 hr after rach injection. Inhibition observed were: hestr. 70 to $80 \%$; brain, 30 to $600^{\circ}$. Cumulative inhibition wan not elearly evident.

5. Becaure of the po-ibility that a "blool-brain barrier" is not entabli-hed in young animals, 1t-dayold femalem were given $2000 \mathrm{mg}$ A T $\mathrm{kg}$, and blood, liver, and brain were anayed 1 hr later. Inhibition found were: blood, $0^{e}$, CAT is known not to inhibit blood eatalane in rivo in adult animalss: liver.

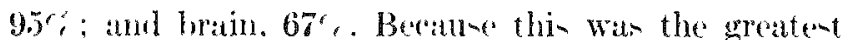
inhibition obervenl of brain cataline activity after wither -ingle or multiple injections of aminotriazole. it is -luggented that the blood-brain barrier may indered play at role in the control of AT reaching the bratin.

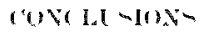

Although in ritro tent- demonstrate that 3-amino1,2.4-triazole (AT) ean inhibit the eatalase activity

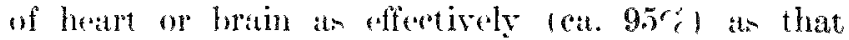
of liver, it hat not been po-ible to achieve an spreat an inhibition of the brain or heart ratalase in rive. Althongh the blood-brain barrier probably playe a role in cuatrding brain atalane againet $\mathrm{AT}$ inhibition, thi rannot be the whole -tory, becaue stomach and heart ratalises ars atho lem inhibited in rivo 
that atre the liver and kidney enzymes. Howerer, brain is inhibited leant of all.

\section{RETTRENQ⿻}

1. Ilill, (A. B., S. Moterhout, and W. M. O'Fallon. Variation in response to hypertharic osg gen among inbred strains of

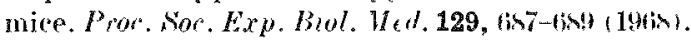

2. Feinmtein, R. N. Solubilization of particulate "atalane" with nuninie detergent. Arh. Riok km. Biophys. 79, 3nn 100 $11953)$.

3. Feinstein, R. N. Perborate as mubtrate in a new astas of ratalase. J. Brol. ("hem. 180, $119712(02$ (1949).

4. Feinstein, R. N., J. H. Teaholm, and J. B. Ballomoff. Fiffect of compounds related to aminotriazole on calalase in vivo and in vetro. Enazmologia 27, 30 10 (1961).

\title{
ELECTROFOCUSING OF PURIFIED BEEF LIVER CATALASE AND OF CATALASE IN MOUSE BLOOD
}

\author{
Rebert . F. Feinstein and Carl Perainen
}

\section{P(RP(ME ANI) METHOH)}

Although catalase has been crystallized from blood and liver of exceral of the larger mammals, and from rodent liver, it has not ret been greatly purified from the blood of either normal or genetically hyporatalasemic miee." This in presumably due largely to the lability of normal moune bloot ratalase, which lability is even grester in the eane of the hypocatalisemic mutant.' LKB P'rodukter lstockholm. sweden) has recently developed a eries of ampholyte compound for electrofocusing, and equipment and techniques for their une, with which it should theoretically be pomible to fractionate protein mixtures fairly quickly and cleanly on the bacis of indiridual isoeleetric points. The initial purpose of this projert was an attempt to separate cataluse from mouse blood rapilly and with a minimum of degradation. Preliminary re-ults were so unexpected that we have enlarged the problem to include a study of the electrofocusing of purified beef liver catalate. When our understanding of the electrofocusing technigue, and of the demonstrated polymorphism of catalace, are more complete, we expect to return to the original attempt at a quick smaration of catalare from blood.

Apparatu used wa the commercial LKB aruipment, and ampholvtes of various pH ranges. The ampholyte. with test material incorporated, war placed on a water coolet solumn in areord with natur facturer': instructions: electric current was applied; and approximately 30 har later the column wat thed into at -tandird refrigerated fraction collector. Generally. 50 2-ml fraetion were collected. A portion of each fraction wa a-ayed for eatala-r aretivity by the perborate technique, ${ }^{31}$ and the pll of each fraction war individually determined.

Materiak that have been examined are beef liver catalate Northington Biorhemical Corporation,
("TS'), and saponin-lysed hemoly-ates of packed erythrocyter obtained from normal mice.

\section{PROGRESS REPORT}

Our first well-defined experiment with mouse blood produred two surprises: al we found not one, but two peak of "alalare activity, and b) the isoelectric point of hoth peak- was unexpectedly high, namely, pHI 8.1 and 8.9. (The literature'th gives an i-oelectrie point for beef liver catalase of 5.7 ; we are not atware of any -tatement regarding the $\mathrm{N}$ of any blood eatala-e preparation.)

Berane of thene finding, we decided to confirm the validity of our terhniques with a purified bees liver eatalare (Forthington, CTS). We have now performed some eight electrofocusing experiments with this material and almost invariably have deterted three di-tinet fractions of active ratalase. The rangen of inoelectric points are: Peak I, pH 5.6 to 6.0; Peak II, pH 6.6 to 6.8; and Peak II1, pH 7.2 to 7.4. Peak III genterally represents only a very -mall fratetion of the total and, in faret, does not al ways appear. Peak- I and II contain the bulk of the ratalatic activity, but the relative proportions in the two peak- vary from experinent to experiment. We have tented the suggention of Heidrich" ${ }^{(5,}$ " of "oxidizing" "atalase" with oxygen and "reducing" it with cleland"s reagent dithiothreitols. Our firs experiment-uggested that Peak I reprented a reduesd form of catalawe and Peak II an oxidized form, hut luter experiments have not heen consistent on this point. We are -till umahle to prediet the relative proportion of "atalare that will appear in the two major peaks.

It should be noted that heterogeneity of liver catalare is not a new ol-ervation. Recent mentior of this phenomenon will $b$, found in the paper of

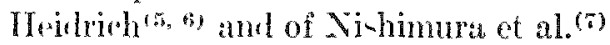




\section{UNC LISEION}

Iroclecetric heterogentity is shown by both the eatalawe in whole lysates of mouse erythrocyter, and also by a purified commercial beef liver catalase. The inoelectric points obmerved for moune blood catalase are approximately three pII units higher than for beef liver catalise.

\section{RHE IARLACLS}

1. Feintein, R. N., J. B. How ard, J. 'T'. Braun, and J. E. Seaholm. Aeatalasemic and hr poratalasemic mouse mutants.

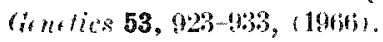

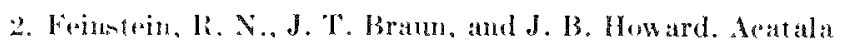
emic and hypocatalasemic mouse mutants. II. Mutational variat ions in blood and solid tishne toat alakes. A roh. Biochem. Blophys. 120, 167\%-16h) (1067).

3. Feinmein, R. N. Perborate as substrate in at new assag of ratalase. J. Biol. ('hem. 180, 1197-1202 (1949).

4. Silnuer. J. B. and A. L. Donnere C'rustalline catalase. $J$. biol: Chem. 121, 117-121:1937).

5. Heidrich. H. (4. Xew aspects on the heterogeneity of beef liver catalase. $Z$. phy $y 20 l$. ('htm. 349, $873-880)(1968)$.

t. Heidrich. H. (i. and $K$. Hannig. The native form of heas liver watalave. Biorhem. Biophus. Acto 168, 380-3\%2 (19kis).

7. Nishimara, L. T.. S. N. C"arsum, and T. Y. Kobara. Isozy men of human and rat eatalasen. Anh. Biochom. Biophys. 108, $452450+(964)$. 


\section{MICROBIAL GENETICS}

\section{THE GROWTH-DUPLICATION CYCLE. X. APPEARANCE OF PHAGE BINDING SITES DURING THE CELL CYCLE OF ESCHERICHIA COLI}

Michael L. Freedman and Herbert E. Kubitsihd

\section{PLRPOSE AND METHOOS}

If cell grow linearly becaune the number of siten for uptake of nutrients remains fixed, then the rate of accumulation of nutrient during most of the coll rycle should be contant. Such a re-pone wan found in Escherichia coli strain- $\mathrm{B}_{s-1}$, WP' her-, and 15 THI for the metabolites glycine, leucine, glucose, ulfate, phonphute, and thymidine.(1) Becau-e the uptake loci for there subtance may lie in the cell membrane, the study ha been extended to the hacterial cell wall through the ue of isotopically law beled bacteriophage. ${ }^{2}$. We have examined $E$. coli $15 \mathrm{THC}^{\mathrm{r}}$ and $\mathrm{B} \mathrm{r}$ to see whether or not the number of phage attachment sites is constant during mo-t of the eell growth cycle.

\section{Prepuration of Radionctire Bact riophage}

We used coliphage T4I), which requires thymidine, and host strain B3 or 15 THL, whirh are thymidylate -ynthetane negative. $1, x \rightarrow$ in oceurred in -upplemented minimal medium with methyl-3H H-thymidine an the ole thrmiline source. The lyaten were extracted with deoxyribonucleas. I and dia-

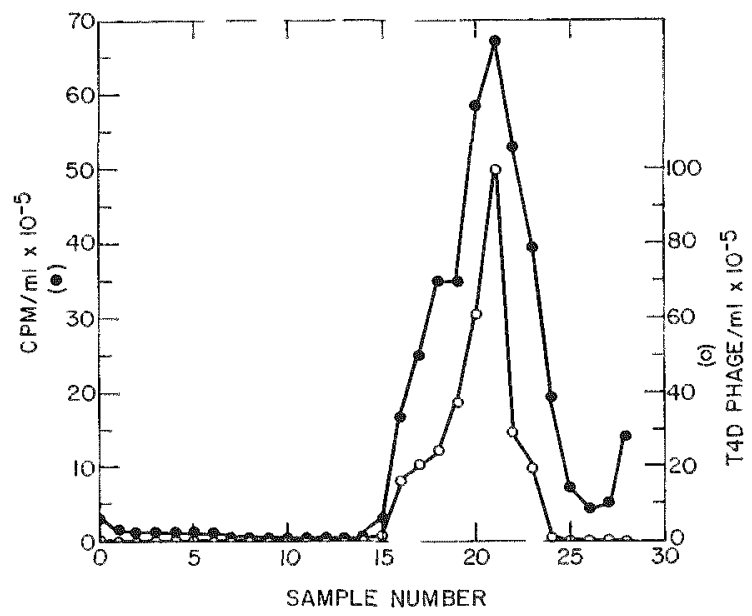

Fis $10 \%$. - Distribution of htic activity and radioatavity in a preparation of colphage $T+1)$ banded in a cesium chloride density gradient. Sample densitues diminish toward the right. lyzed against basal salt- medium to remove tritium count- not associated with phage. The phages were concentrated by acid precipitation, and an aliquot wa- banded in a cesium chloride gradient using an analytical ultracentrifuge. The re-ult - of such a phatese purification procedure are shown in Figure 108. Less thatn $9^{c}$ of the radioactivity lie outside the phageront aining samples.

\section{Lisuly of Phage Bonding Litt:s}

To follow the appearance of phage adsorption siten during the cell evele, -hake eulture of $E$. coll 15 THI and B r were matintained at cell titer characteri-tic of steady state growth by repeated backculture. These growing culturen were exponed to phage at different multiplicitien of infection for 3 to $4 \mathrm{~min}$, after which time formalin wan added to kill the cell. In af $f(x)$ experiments the cell were concentrated $10-$ to 1,i-fold prior to infection. Tnadnorbed phage were removes br centrifuging and resu-pending in fresh merlium. Figure 109 show the effect of repeated wash cyele at several cell concentrations and phage multiplicities. (Ince binding ha- occurred (measured after

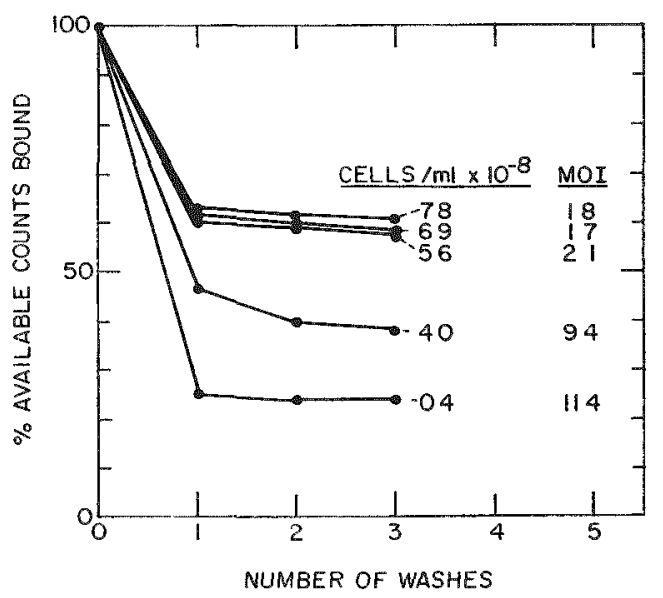

lic. 109.- Comparison of radioartivity bound to cello af tejo several w unhen following infeetuon of $E$. cols strains with phad 'I4D) Several (all denkites and phage multiplecities of infertun MOI) wore used. 


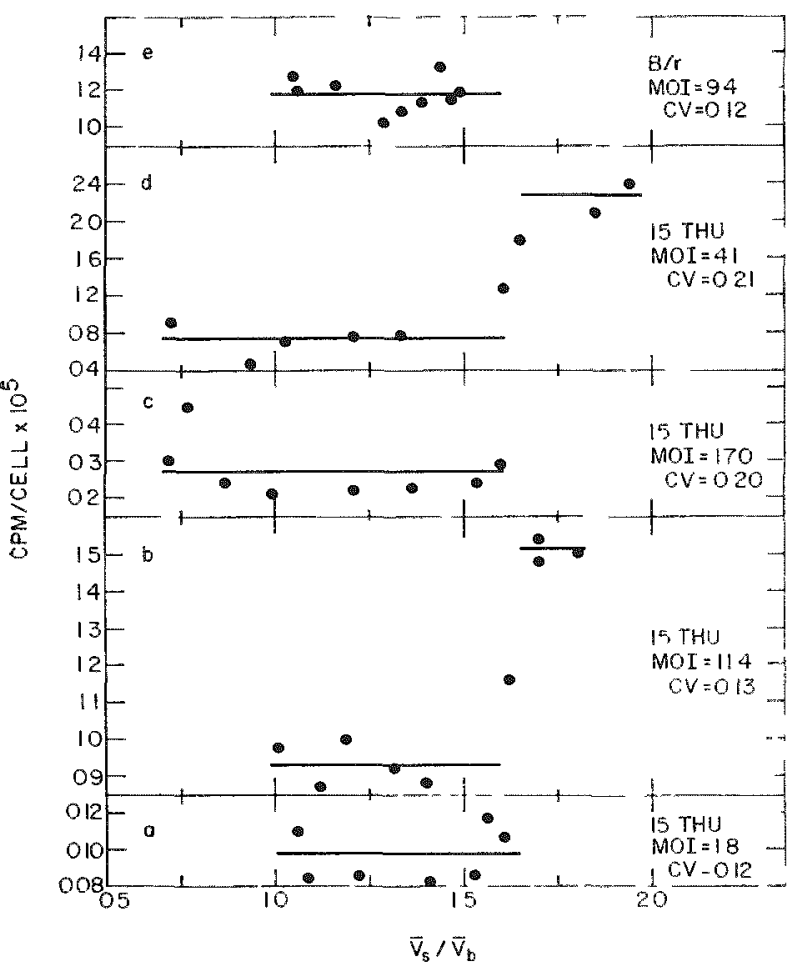

Fis. 110. Radionetivity per cell as a function of the ratio af the mean cell size, $V_{s}$, to the mean birth size, $V_{k} K$. coli strains 15 THC and b/r were infected with T4I) phage at sev. *ral multiplicities of infection, MoI. $C \mathrm{C}$ is the average coeffirient of variation of the samplest tahen from the sucresese gratdient.

the firt washy little artirity in lost. As expected, the lower the cell titer, the -mallere is the percentage of the available tritium count- bound. This appears true "ven when high phage multiplicities were uned with low rell concentrations.

Finally, the formalin killed rells with their bound

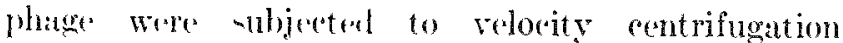
through a is to lise gradient. (ell simples from the gradicnt were counted and sized with a coulter rounter-multichannel analyzer, and their radioactivities were medsured. Radioartivity per cell was exprewered at a function of average cell size.

PROMERES RIPURT

Figure 110 - how the pult of fire phitge-bindine experiments. The specitie activity of the T41) phage ued in experiment- hown in Figure $110 \mathrm{c}$ and d wat 2.1 . $10^{*}$ "pm phage and in experiments a, b, and ", $0.6 \times 10^{-4}$ cpm phagr. Regarllem of the host cell strain of the nultiplicity of infertion, the phage-ate-

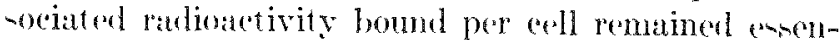
tially constint for approximately the first two-third of the rell crele. In Figure 110 b and al, where mean eell -ize, $\dot{l}_{s}^{*}$, were larger than 1.6 times the metan birth size, $r_{b}$, there was an abrupt increase in the amount of ratlioartivity bound pere cell.

\section{(I)}

From these experinents, it appears that the number of rerepter sites for the attatehment of bacteriophage T41) in $E$. coll strain- 15 THC and $\mathrm{B}$ r remain- ron-

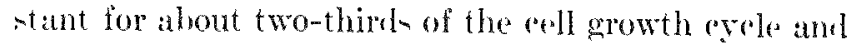
then incereates abruptly. The results are in good agresment with me:anrement of the mumber of uptake siten for metabolite. Also, the result suggent that phage attarhment -ite atre either formed or activated ronparatively late in the cell growth ayele.

\section{RFFEREN $\mathrm{R}$ -}

1. Kubitsehek. H. E. ('onstancs of the uptake during the rell "Yele in Exherchin roli. Biophys. of 8, 11011112 (1!tfis).

2. Weidel, W. Bacterial virunes dnn Rer. Mirrobiol. 12, 27 is (195).

\section{THE GROWTH-DUPLICATION CYCLE.XI. GROWTH OF NONDIVIDING CELLS DEPRIVED OF THYMINE}

Herbert L. Kubitschel:

PI RPOL AND METHOD

Exidence for linear growth of bacteria was presented earlier in this serie. Iinear growth requiren that the rate of increase in rell mass is constant. In turn, this implien that during most of the cell cycle there are a constant number of surfare sites for the ptake of each growth factor. Measurements of the rate of uptake of a rariety of growth factors support this interpretation. ${ }^{11}$
Thi interpretation pretliets that nondividing cells would grow indefinitely at the same rate as long as the number of uptake sites remained constant. It might al-o be neeereary to prevent DNA synthesi- to maintain a constant number of ites. Fortunately, both DNA sythesis and cell divion are prevented in thymine-recquiring bacteria that are starved for thibate. These thymine-starvel cells become inviables ("thymineles death") it ther have not completed a 


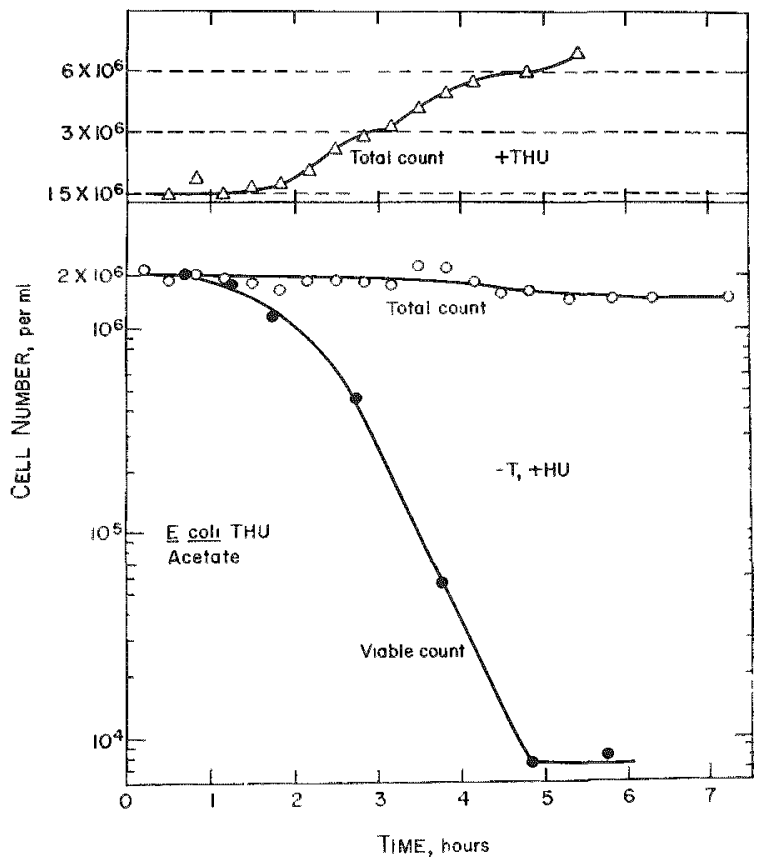

FIs. 111. - Total and viable comuts of a rolture of Evherechia roli THI deprived of thymindine and of a sont rol eult ure.

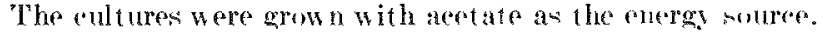
Total rounts were metasured with a coulter munter. Viable comuts were determined by plating cells upon nutrient agar. $O$, without thr midine: $\triangle$, with the midine.

round of DNA replication. Fevertheles, if an energy cource in present, the cells should continue to increatises in size, and their rate of increane would then provide a measure of the number of uptake sites.

\section{PRERES REPORT}

A suchronous "ulture of Escherichia coll THT, requiring thymine for thymidine), histiline, and urate wa- prepared by banding cello in a surome gradient in a centrifuge tube and seleeting small cells from the top of the band. The culture was divided inte two parts. one of which wa- deprived of thymidine. As shown in Figure 111 the cells in the control rulture divided completely after about $3 \mathrm{hr}$, and again after about 5 hr. The number of cell in the thrmidinedeprived culture did not increase and, in fact, decreased -lightly after about $4 \mathrm{hr}$. The viable count in thi- culture decreaned by a fuctor of more than 200 during the experiment.

The mean eell volume of the control culture inretened linearly before divinion i Figure 1121, and after division was completed (by the third hour) the

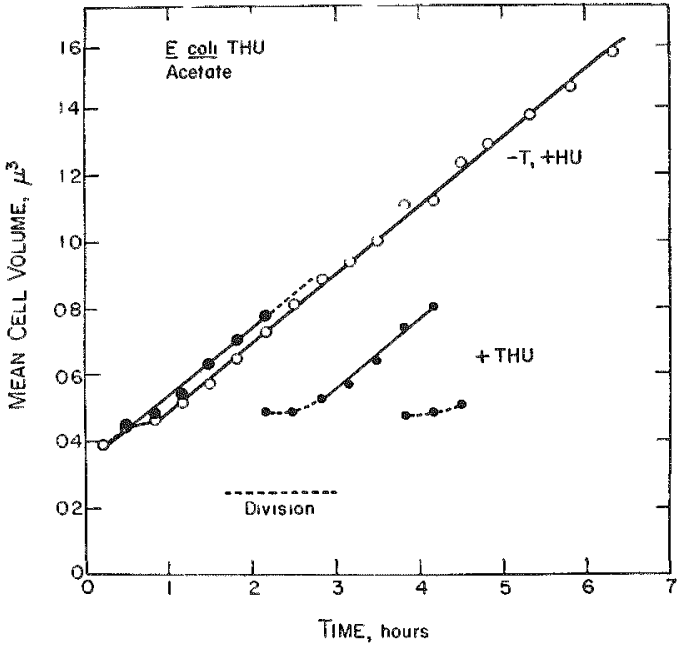

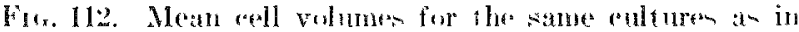
Figure 111.

growth of the progeny wat andin linetr and had the same rate as the parental generution. In the thymidinelem culture the growth rate was reduced temporutrily, an unu-ual orcurrence probably due to a hamdling accident. After this tinke, mean cell volume in thene cells increaned at the ame rate as in the control culture. The cells deprived of thrmidine maintained the same growth rate as the control during the remainder of the wereriment, as cell volumes increased through more than two suceensive doublings.

From microsepir examination, thyminelem cells were irregular in shate and length, with pronouned rhanges in demity in different areas. Even though these cells were aberrant and inviable, their growth rate wa unaffected, indicating that the number of uptake, iter remained constant.

\section{CONCLT - ION}

Further -upport for at ron-tant number of uptake siten (for trath-port of growth factor into the celly during the cell cycle is provided by the obearvation that growth rates remain constant for at leant two generation timen in cells that are prevented from DNA - rnthei- and cell division by thymine -tarvation. and that thes growth rate are equal to those of "ells in the steady state growth-duplication crele.

\section{RHFHREVCES}

1. Kubitsehek, H. F. Constam! of uphate during the coll eye

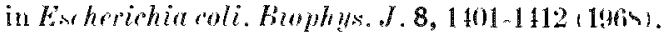




\title{
MUTATION IN CONTINUOUS CULTURES: INTRODUCTION
}

\author{
Herbert E. Kubitschek
}

Continuous culture techniques allow the study of mutation in viro under carefully cont rolled conditions and present many advantages over batch cultures. Cell death and physiologiral perturbations are minimized. Effect of toxic mutagen can be examined by maintaining concentrations of these compounds at very low levels. Bacteria in slowly growing culture contain a minimum anount of DNA, presumably a single genome, desirable for studies of mutation. In addition, accurate data are more easily obtained in continuous eultures than in batch cultures, because the technique provides a tran-formation from the $\mathrm{ex}-$ ponential increane of cell numbers in flasks to the linear increase of cells in continuous eultures. This transformation is both an experimental arlvantage, providing contant numbers of cells, and a conceptual advantage, allowing the investigator to think more directly about his resareh problem.

Most of our effort has been devoted to studiem of the kineties of accumulation of mutants that are re- -intant to barteriophage Ton in chemo-tat cultures of Esccherichie coli. This is a forward mutation with the advantage that this mutant character is not under relection. As at result, there is no need to determine the value of a eleetion factor for each experiment. concentration- of phenotypically expresed mutants were measured by exposing culture samplem to bacteriophage T5 upon nutrient agar platen; ennitive cell ad orb the bacteriophage and are lyed, while mutant cello do not arkorb the phage and generste visible colonies after a lav's growth at $37^{\circ} \mathrm{C}$. ('onerentrations of latent mutants (cell- with the wild phenotype, remitive to T5 and giving rine to mutant dercendant resitant to Thy were measured by -prealing rulture samples upon plates, and incubating there at $37^{\circ}$ ( for 3 hr before spraying with batereriophage. I huring this period, each cell generated a mierocolony of about 100 eclls, allowing expremion of the mutation in one or more of the progeny of a newly mutated reell.

\section{MUTATION IN CONTINUOUS CULTURES. I. REPAIR OF UV-INDUCED LETHAL AND MUTATIONAL LESIONS}

Herbert E. Kubitschel:

PLRPUS AND METHONS

Although we have obserered repatir of mutational lesions in discontinuous cultures, present evidence support the abenee of repair of mutational lecions for Th resistance in continuous, glucose limited chemostat cultures, even in bacterial strain known to produce repair enzymes under other growth conclitions." This abence of repair of mutational lesionled un to ank 1) Are lethal lesions repaired in chemostat cultures? and 2 , Are lethal lesions basically" different from mutational lesions?

To examine the first que-tion, bacteria from chemostat culture were exposed to ultraviolet light $(\mathrm{CV}$ and plated on chemostat-like media. The surviral of thene cells was compred with that for the same strain grown in mutrient broth, irradiated, and plated on nutrient agar. The strain u-ed, Escherichin coli B, i, known to repair lethal lesions when grown on nutrient gar. Thu, if survival of the chemostat cells is equal to that for nutrient-grown cells repair must oceur as extensively for hoth. Minimal plate- for the chemo- -tat cells rontaned grlucose at a concentration of 10 $\mu \mathrm{g}$ ml. Thi- low coneentration is approximately that foumd in ehemostat eultures, -0 the growth of cells on thene "rhemontat" platen minice the growth in chemo-tat coultures.

Alternatively, LV-irradiated bacteriophage T1 wits plated with cells under the two wowth eomelition- Lethal lesion in phase T1 ran be repaired by host cell reativation; anzymes protuced by the hont barterium renair the lesion in the phage. Igain, repair must be as exten-ive in chemontat rultures a- if is on nutrient agar platen if phage survive ergually well under both condition.

To examine the second question, cell- from irraliated "hemo-tat culture- were exposed to visihle light. which is known to repair pyrimidine dimer that are produced in IDNA by CIV. If thene dimer's are the mutational lerion, or if they are the sonere of some of them, axposure to vi-ible light should redure mutant frequencies. A corresponding experiment, meaturing cell -urvival would examine the pomibility that dimers are the source of lethal lesions. 


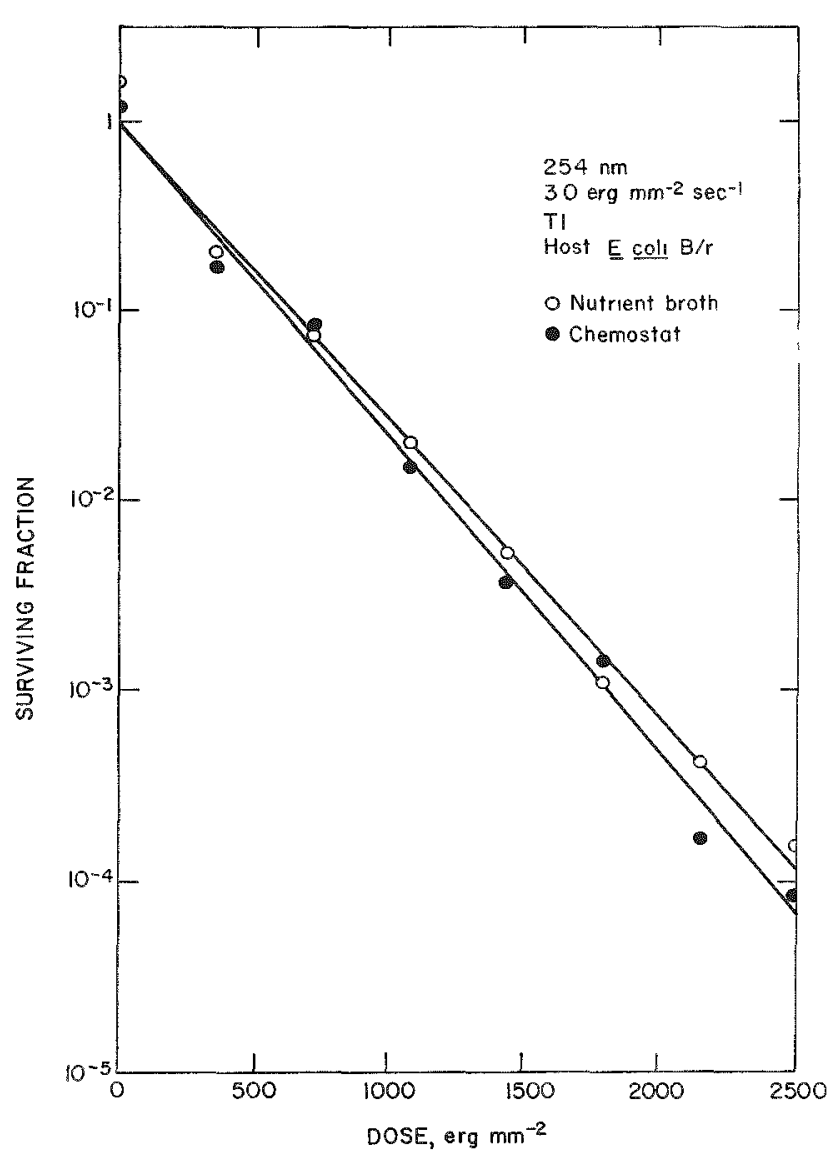

Fir .113. Survival of $E$. coli $B$ after exposure to ultraviolet light for two different conditions of growth. 0 , grown in nutrient both, irradiated, and plated on nutrient agar; grown in glueose limited chemost at culture, irradiated, and plated on "rhemostat plates."

\section{PROIRFAS REPORT}

(ells of $E$. coli B were grown upon nutrient broth, exposed to $\mathrm{CV}$, and plated upon nutrient agar. The survival curve for this culture tas experimentally indistingui-hable from cells grown in chemostat cultures and plated upon "chemostat plates," Figure 113. Sinee cell surviral under nutrient conditions involves extensive repair of lethal lesions, the similar survival under condition. of chemostat culture requires that repair processes occur to about the same extent.

In a second comparison, UV-irraliated bacteriophage T1 were mixed with cells of $E$. coli B r grown in nutrient broth or in chemostat cultures, and plated upon corresponding media. Again, survival curves were experimentally indistinguishable, Figure 114. Since extensive host cell reactivation of T1 occurs with these broth-grown cells, repair must also have occurred under chemostat conditions.

To examine the nature of the mutational lesions, a chemontat culture of $E$. coli WP2 try her was ex-

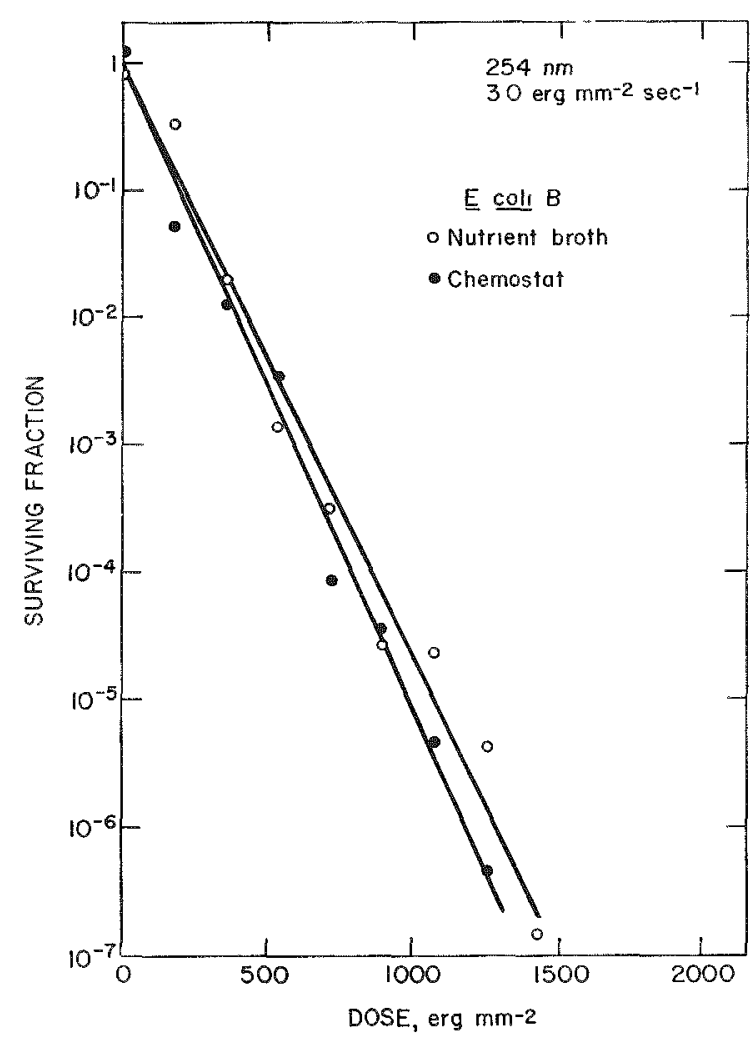

Far. 114. Siurvival of bacteriophage to after expesure to ultraviolet light on $E$. coli $B / r$ grown under two different culture oonditions. $O$. grown in nutrient broth, irradiated, and plated on nutrient agar; grown in glucose limited chemostat cult ure. irradiated, and plated on "chemostat plates."

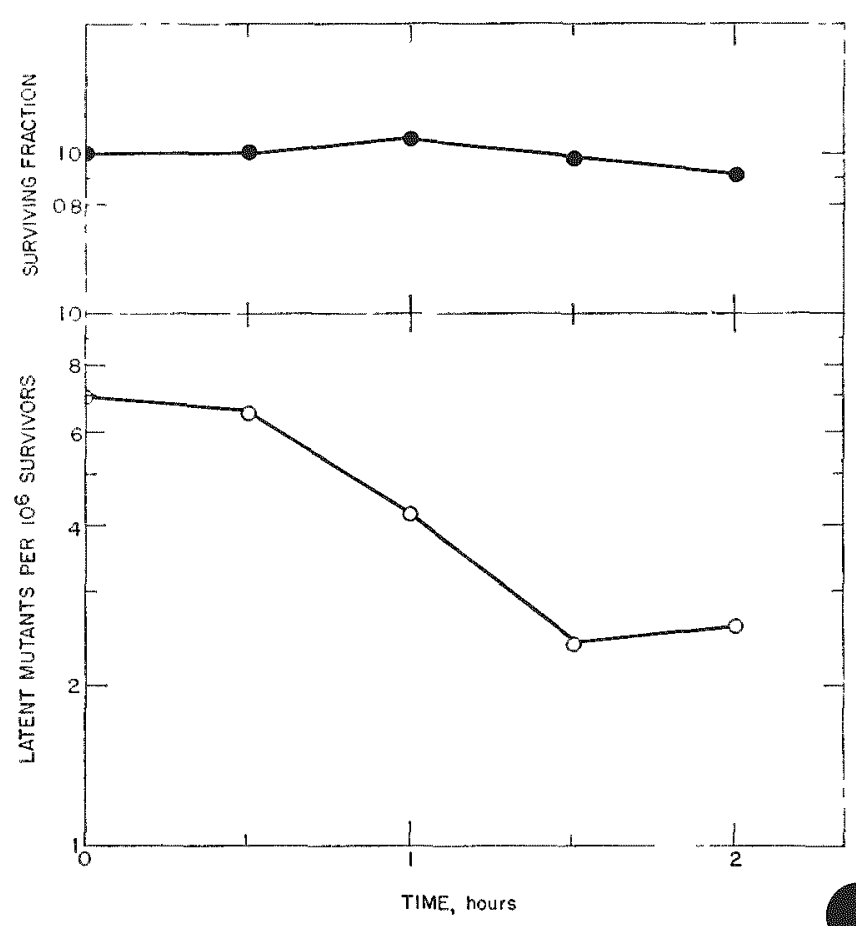

Fifr. 115,--C'ell survival and photoreversal of latent mut ants in a chemostat culture of $E$. coli WP2 her exposed to visible light. 


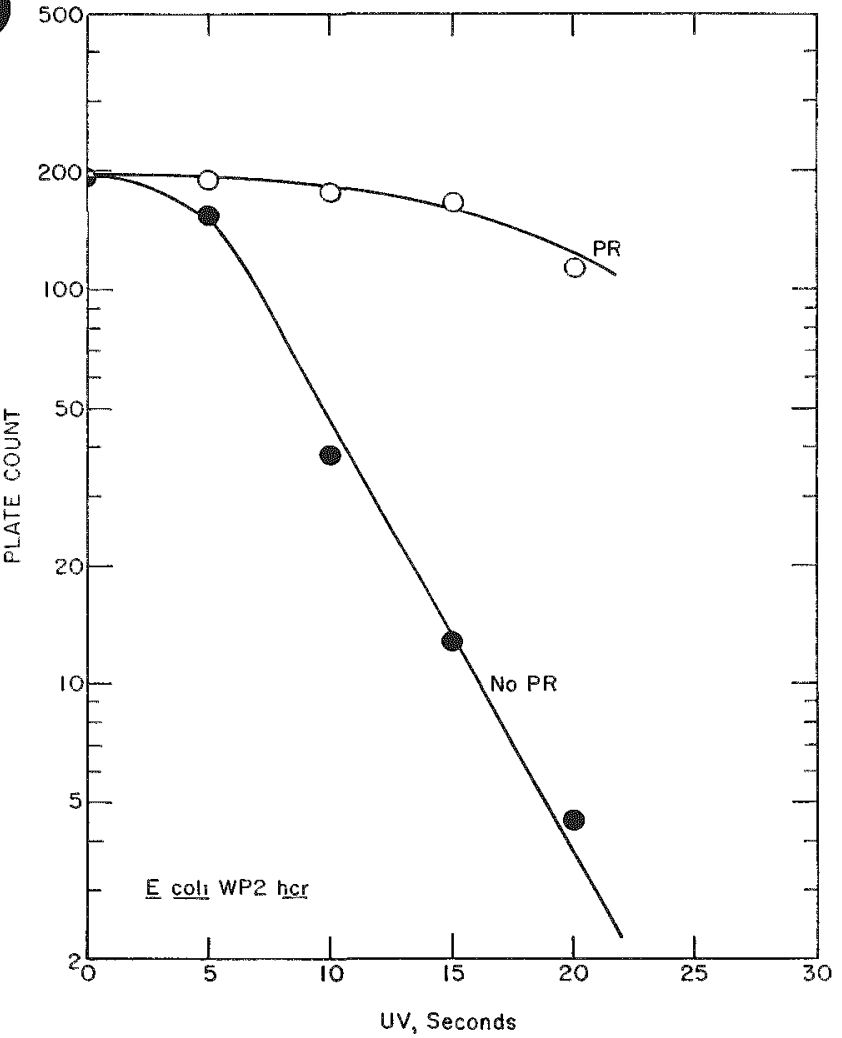

Fitr. 11ti. Photoreactivation of cells from a ehemostat eulture of $E$. coll WP's her by expmure to visible light af ter a posure to [' Visible light expomure (Pli) approximatels $10^{\circ} \mathrm{erg}$ $\mathrm{mm}^{-2}$.

posed to CV, and a generation later, samples from this culture were exposed to risible light (100-W tungsten projection lamp; Kodak Tratten filter $\$ 85$ to remove wavelength below $380 \mathrm{~nm}$; do- $t^{2}$ rate. sp- proximately of $\times 10^{\text {ti }} \mathrm{erg} \mathrm{mm}^{-2} \mathrm{hr}^{-1}$ ). As shown in Figure 115, mutant frecluencien were decredsed by ahout 6.5; at expo-ure that killed only small fractiom of thene cells. Thi decrease provides evidence for the photoreversal of pyrimidine dimers that act an mutational lesions, or an the nource of thene leion-

Finally, lethal lesions produced in UV-irratiated all- from chemontat cultures of $E$. coli $\mathrm{B} r$ were photoreactivated with visible light, Figure 116.

CONCIAT-ION

After exponure to UV, both lethal lesions and mutational lesion were repaired when ehemo-tat cellwere axposed to visible light. Beeaue repair hy visble light is thought to involve only pyrimidine dimer. it appear that these dimers are reponsible both for death and mutation.

Neverthelese, repair system for death and mutat tion munt be different, becaune lethal lesiom were repaired in continuou- chemostat culturen while muta-

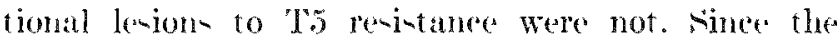
-anne cells are known to repair mutational le-ion- under other growth condition, the corresponding repair sy-tem mu-t be inative in chemontat enltures. Thi. may be due to the limited (neregy -upply in thene cultures. If $-o$, there can be no repair of other mutational lesions. This powibility is under investigation.

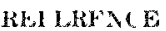

1 Fubituchek, H. F: lienatir of latent T5 resistant mutant in rhementat rulturess. Prou. (chat Foundation Meeting, I ondon, 1969. C"zba Foumlation simposium on Hutatom as a rellular Prosess, Ld (4. K W. Wolstenholme and M. WConnur. S. \& A Churchbill, Itd., Iandon, 190:1, pu). $22-101$

\section{MUTATION IN CONTINUOUS CULTURES. II. SPERMINE AND CADAVERINE AS ANTIMUTAGENS}

\section{Herbert E. Kubitseheli}

\section{PTRPOSE AND METHODS}

Antimutagens reduce spontaneous or induced mutation rates, without reacting or complexing with the mutagen. A knowledge of the antimutagen spectrum for a given mutagen is of importance in determining the mode of artion of the mutagen in viz'o. Spermine was claimed to be antimutagenic by Johnson and Bach, ${ }^{11}$ who found that this compound reduced both pontaneous and caffeine induced mutation rates to streptomycin resistance in batch cultures of bacteria and that spermine complexed with the bacterial
DN.1. ${ }^{21}$ Their experiment, however, did not rule out the posibility that streptomycin resistant hacteria had a -elective advantage in the prenence of spermine. Mutation to $T 5$ resistance in chemontat cultures avoids this problem because $T$ s resitant bacteria grow at the ame rate a their sensitive parental struins.

PRO,RLS REPURT

Spermine was found to be antimutagenic for caffeine inducesl mutations to $T$. resistance in glueose 
limited chemostat cultures of $E$. coli $\mathrm{B} / \mathrm{x}, 1, t r y$. At a concentration of $40 \mu \mathrm{L}$, spermine decreased mutation rates ly a factor of four. The related diamine, cadaverine was less efficient. At a concentration of 110 $\mu i l$, cudarerine decreased mutation rates by about a factor of three.

CUCLI $-1 O N$

The diamines, spermine and cadarerine, were found to be antimutagenie against eaffeine induced mutation in chemostat cultures. Thene diamines are believed to complex with DNA as do other antimutagenc. If, at Puglisi has suggested, ${ }^{3)}$ antimutagenic compounds art through inhibition of nueleotide re moval of some portion of the DNA, we may expect mont rompounds that complex with DNA to be antimutagenic.

\section{REH HRFNCES}

1. Johnson, H. A. and M. K. Bath. Apparent suppression of mut at ion rates in baeteria by spermine. . ature 208, tos 404 (19615).

2. Johnson, H. (i, and M. K. Bach. Cptake and subecllular lewalisation of tritiated spermine in Esherichia coli. A rob. Biwhem. Biophy. 128, 113) 12\% (1968).

3. Puglisi, P. P. Ant imut agenic act ivify of actinomy rin 1 and

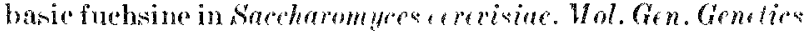
$103,2(x-252(196)$ s $)$.

\section{MUTATION IN CONTINUOUS CULTURES. III. NUCLEAR SELECTION}

\section{Herbert li. Kubitwehel:}

PLRPOA: AND METHODS

Cells in tryptophan limited chemostat cultures of E. coli $\mathrm{B} 1$.try and $\mathrm{B} \times 1$, try are filamentous." $\mathrm{At}$ generation time longer than 2 hr, the average volume and DNA content of these multinueleate, filamentous rull is proportional to the generation time of the culture. "2t When surh cell are exposed briefly to the mutagenie action of acridine orange and risible light. mutant frequencies (to T. resintance) are increared immedistely and then remain almost constant there-

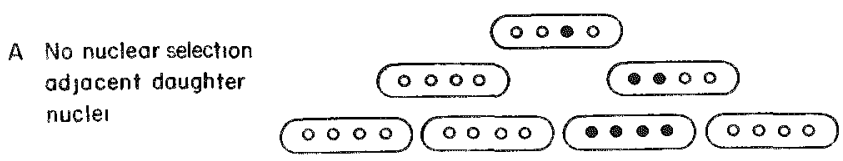

A All nuclei mutated

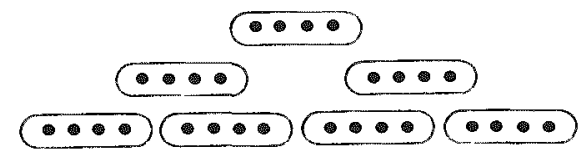

C Segregation of one daughter nucleus to each cell
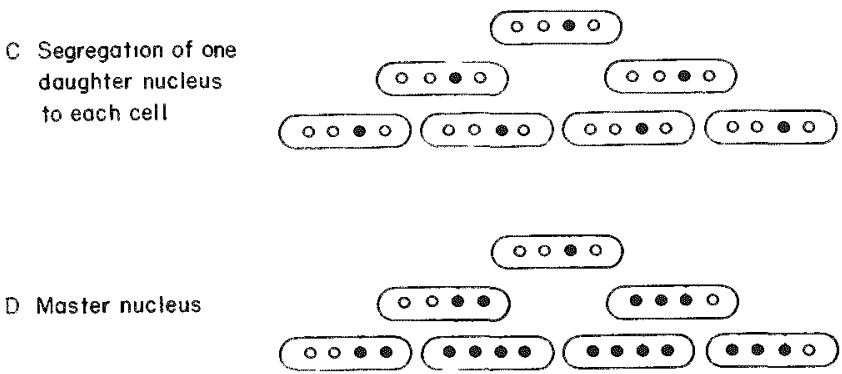

Fia. 117. Models for mutation, melection, and segresgation of melei in filamentons bacteri: after. This ronstancy recpuires the expression of To re-irtance in the progeny of almost every newly induces mutant.

Howerer, T5 resistance is a recessive character, and therefore should not be expressed unless all nuclei are mutant. Bersuluse mutation is a very rape erent, it is unlikely that more than one mucleus was mutated in any rell. Thun, most of the nuelei in nutated cells shoukd have been wild type, and consequently, now progeny rello were expected to be unmutated. In-tead, mont or all of the progeny of newly mutated cell ultimately were oberved to express the mutant character.

The length of these filamentour colls and the number of nucles they contain both depend upon generation time. The filamentous cells can be fractured to individual cells, each containing a single replicating nucleu- by derereating the gentration time of the culture. When nuelei are "repackaged" into individual rell in this way, the phenotype of the nucleus is exprewed. Thus, a reparkaging experiment (by a shift to more rapid growth ratel makes it possible to determine the number of mutant nuclei originally presm thit in the filamentous cells.

Four powible molels of nuclear replication and segregation are illustrated in Figure 117, for cells containing four nuelei. Thene are:

1. All nucle replicate at the ame rate and produce daughter nuclei that remain adjacent to each other. As hown in the figure, this model reduires exprestion of progeny in 25, of these multimucleate cells. Since final mutant frequencies were almost expal to fre quencies initially induest, this model is ruled out immediately. The other three models are consistent 


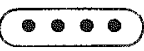

(6) (-)

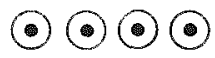

C

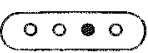

(0)6(0)

(0) (0)
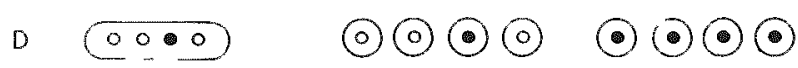

Fis lis Predietions of mut ant frecueneies after "repack aging" nuclel nuto nondividual cellh.

with complete exprention of mutation in all progeny of newly mutated cells.

13. All nuclei in a cell are mutated by a single mutational event.

( . Resintance to bacteriophage T.5 in a dominant character in the eultures, and pair of mutant nuclei are regularly segregat cel.

1). (Inly the mutated nucleun is replipated and transeriberl.

Worle- B, C. and D differ in their prediction- of mutant irecquercies for repackaging experiment-immediately after mutagenteris and at much later timen. Theme prediction- are illu-trated in Figure 118.

\section{PROGRE- RLPURT}

A - lowly growing culture with at generation time of $8.3 \mathrm{hr}$ wat expo-ed to arridine orange and rivible light to produre mutants for the repackaging experiment. When cells were taken from this culture immediately after mutation and hifted to a generation time of $2.1 \mathrm{hr}$, the mutant frecuency dropped to a much lower stealy state value, as hown in Figure 119. Thi result rules out model $B$, the mutation of all nuclej.

When cell wore taken from this culture after 6.2 generation time-, mutant frequencien were unchanged. Thi- how that almost all nuclei in the filamentouprogeny of mutant cells wre mutant, ruling out model C. The only model that explains these results, therefore, is the final model. D. of a "matter nu-

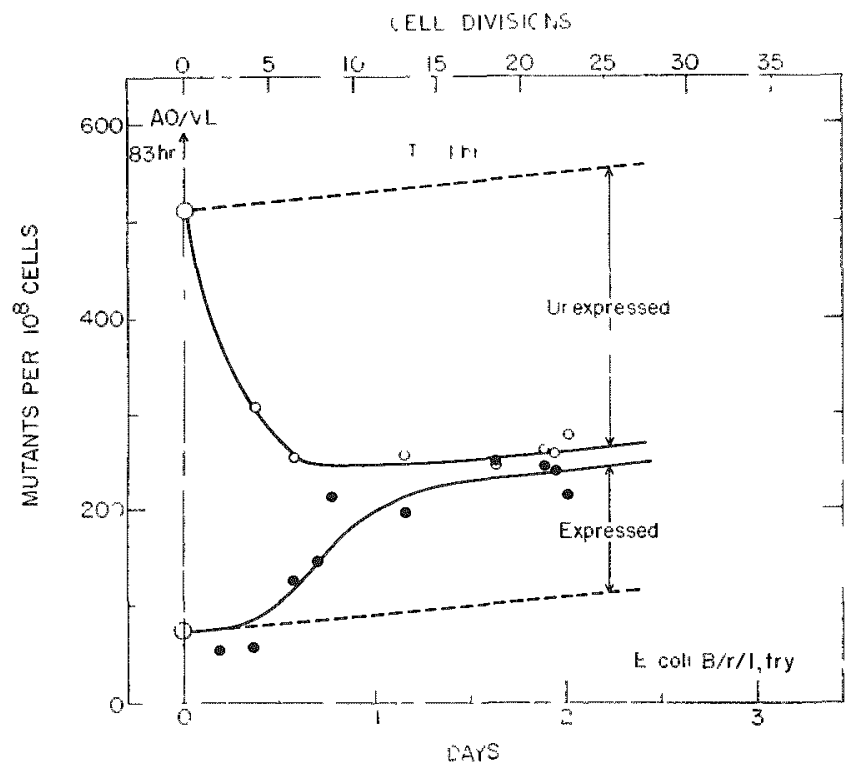

I Ir. 119. I "reparchagng" experiment performed inmedsately after brief pxposure of a glurome limiterl cult ure of $E$. owl

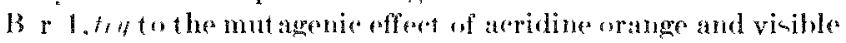
light

"leu": only one uucleur in the rell that is tran-cribed and replicated. Master nurlei of subsequent ceneration are the deucendant of the original master nueleu.

\section{conctertions}

The fil:mentou - bate eriat formed in tryptophan linit ed culture of the tryptophan requiring strains of

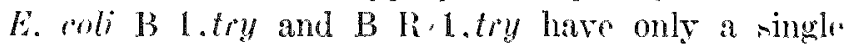
functional, or "ma-ter" nurleus. All other nuclei are lormant. The phenotype of the eell in determined by the genetir contitution of this nuclesta, even for reces-ive characters. The matere nucleus is the progenitor" of all nuclei formed in thene cells, including the manter nuclei of -uecestive seneration- This extreme selection probably recpuires that replication or initiation of replication of DNA i limited he thr supply of the recpuired amino acid under thenge growth conditions.

\section{REFERL NCF}

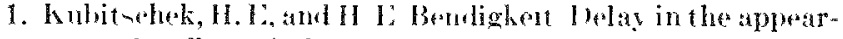

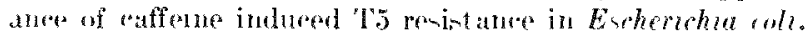
(itentle, 43, titi-bitil (195)

2. Bendigheit, H. li ("affeinfe indued mut at oun in Escherishin wh Ph.D). Thomis, Illinois Institute of Tephmology (1068). 


\section{MUTATION IN CONTINUOUS CULTURES. IV. DELAYED EXPRESSION OF MUTATION TO T5 RESISTANCE}

\author{
Herbert Li: Kubitschek
}

PURPOSE AND METHODS

Expression of mutation cannot occur instantaneously. Mutant proteins or enzymes must be made, or wilk-type enzyme's must be diluted out by growth and division. If the character is recessive, nuclear segregation may be required for expression. Furthermore, mutation may involve only a single strand of the DNA duplex, and transcription and expression may be delayed until the muiant locus is replicated to the second strand. These, and other factors, may add to the period of time required for expremion of the multant phenotype.

Delay period found for expresion of azide resistance $^{(x)}$ and for reversion to independence of amino acids(2) generally have been rather short, about a generation time or less. Far longer delays occur in the apresion of resi-tance to bacteriophage $\mathrm{T} 5$ and other phages, with mean delay periods that approach five generation time. (3) The long delay in the expression of rasistance to T5 and other bacteriophages has been a perplexing problem for over a decade.

Sensitivity to bacteriophage $T .5$ is a dominant elarraeter. and it is due to the presence of active receptor sites on the bacterial surface. Working with phage T5, Weidel and his coworkem extracted active receptor sites from bacteria. The extracted site were mucopolysacharide spheroid, and a single phage could attach to each.'" Receptor siten extracted from resittant bacteria had the same chemical, morphological, and immunologieal properties, but phage were not able to attach. ${ }^{(5,6)}$

An early proposal for the long delay period for phage resistance wat that, after mutation, functional receptor sites were diluted out to progeny cells by growth and division. Ultimately, some progeny would arise that had inherited no actives sites, and therefore would be sensitive to the phage. Although this model was attractive, it is ruled out by the finding that the delay period for '15 rexistanee depend upon the mutagen to which the eclls are exposed: with eaffeine the mean delay period is almost 5 generations, but with acridine orange and vi-ible light as the mutagen, the delay is only half at long. (7) The same number of receptor sites are present on these cells before either mutagen is adder, and the same number of generations would be required in sach cave to dilute them out. In addition, the mean delay of 2.5 generation- for acridine orange also rules out the site-dilution molel, since the average number of receptor wites per cell could not be greater than 10 , if these are to be diluted away in 2.5 generations. On the contrary, meacurements of the number of recentor sites always give much larger number, from 200 to 1000 per cell.

It is interesting that other mutagens also appear to give delays that fall into one or the other of the two classen. For example, similar long mean delay periods were found for visible light mutagenesis, 4.4 generation times IR. B. Webb of this Divisionl and for rapilly growing cultures exposed to UV or to 2 aminopurine, approximately 5 generations. Shorter delays of approximately 2.5 generation timex were obverved with visible light in conjunction with any of reveral other dye, proflarine, s-aminoacridine, methylene blue, and aloo in very slowly growing chemostat cult ure cxponed to UT or 2-aminopurine.

Becaune the cells in these cultures were minurleate, these rewults are not explained by nuclear segregation, nor are they explained loy any simple models of additive delay.

PROMREST REPURT

Motels to dencribe the observed delays in phenotypic expremion of T5 re-istance were constructed on the basis of results reported earlier for acridine orange visible light as the mutagen.(') At each division, a latent mutant cell gives rive to one laughter that remains senitive to the phage and one daughter that wapreseses resintance. schematically,

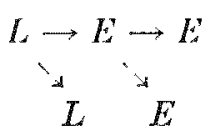

where $L$ represents a latent mutant cell and $E$ reprenents a cell that has expressed the mutant phenotype. The mean delay for this sequence is 2 generations. In addition, assuming that mutation only occur's or is fixed at replication of the gene, the average period before the gene is replicated in cells distributed throughout the cell cycle in continuous rultures is approximately 0.5 generations. Thus the value of the mean delay period for this model is approximately 2.5 generations in continuous cultures 'This value is in excellent agreement with the thort delay values oberved experimentally. 
A-reond model assumen that a newly formed latent mutant $\left\{L_{1}\right\}$ must go through a sccond latent step $\left(L_{2}\right)$ before the mutation can be expresed $(E)$. Schermatically,

$$
\begin{aligned}
& L_{1} \rightarrow L_{2} \rightarrow E \rightarrow E \\
& { }^{4} L_{1}{ }^{4} I_{\alpha 2}{ }^{\star} \mathrm{L}:
\end{aligned}
$$

The metn delay period of this seduence is 1 generation. Adkling the period of 0.5 generations for cells in continuous cultures, the mean delay period for this mollel in 4.5 generations. This ralue is in good agresment with the longer delar value oherved experimentally.

Neither of theme morlel- for phenotypic expression agrees with the ronventional Wation-Crick model for replieation of IDNA. becaune all the progeny of each latent mutant give rise to expresued mutanto. Both sehemat predict abence of segregation after mutation, and ale in agreement with observerl result, ${ }^{18}$ 9) quantitatively an well an qualitatively. Thene delay model- support the manter strand model of DNA repliration proponed earlier. ${ }^{(10)}$

\section{(ONCLAL $-10 N$}

Two models were proposed for expression of mutation to T., renistance. The delay periods predicted by there models are in agreement with experimental result . Both of the delay morlels require that INNA replicate from a manter strand, and not from both -trand as in the Wat con-C rick model.

\section{REH HRLNCES}

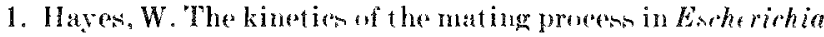

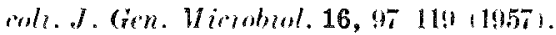

2. Within, ls. M. "Time, temperat ture, and protein synthesis: a thaly of ultraviolet indured mutation in bacteria. Fold spring Larber Symp. Quant. Buology 21, 12\%) 140 (1956).

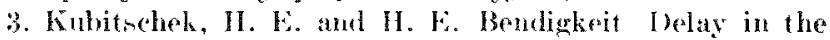

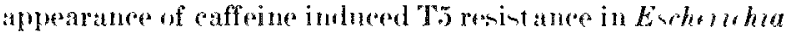

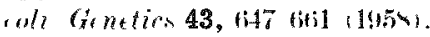

1. Weidel, W. and $\mathbf{F}$. Kellenberger. The $E$. roli B-recept or for

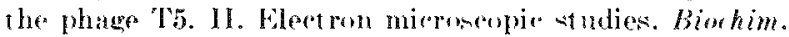
Bwohys. Arta 7, 1 ? (1955).

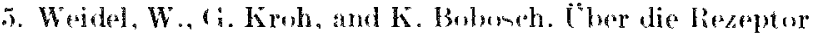
subetanz fur den Phagen T. I. Fitraktion und Reindarstellung ans $E$. coli B. Physikalinche, dhemische, und funh. tionelle ('hartateri-ierung. $Z$. Latuforerh. 9h, 573 55t (10.54).

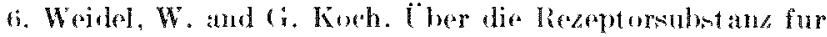
den Phagen T5. III. Seroluginche I'ntemeluhungent. $Z$. Iaterforste. 10h, 69t 69s i 1955).

․ Webb. R. B. and H. K. Kubitsehek. Photody namie mut ation an cont inuons cultures. Argonne National Laboratory Biological and Medieal lieseareh I ivision Anmual Report, 1!H5. ANI. 7136, pp. $11514 \mathrm{~s}$

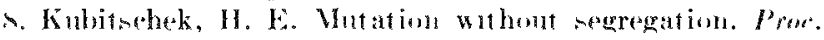
let . A red sici. 52, 137-1381 (194i1).

9. Kubitschek, H. K. Mutation without segregation in bae

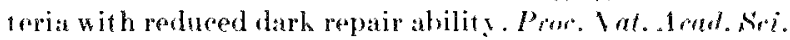
$55,26927619660)$.

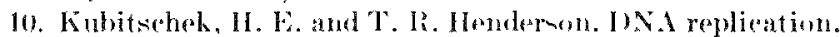
I'roe. Iat, .1cad. St 55,512519 (1966).

\section{CHANGES IN THE MEAN CELL VOLUME OF ESCHERICHIA COLI AFTER BACTERIOPHAGE INFECTION}

Micharl L. Freedman and Robert E. Krisch

\section{PI RPUAL AND METYKODN}

There have been a very limited number of studies of the effect of bacteriophage infection on bacterial cell -ize. Using motion photomierography, BayneJones and Sandholzer'1) (1933) ,howed an apparent swelling of individual Bacterium coli cells which had beten exponed to lytic principle. (ell sizes increased as much a 900 'c prior to lysi- when compared to uninfected control of similar age. In 1948, Doermann'(2) reported at decrease in turbidity after infection of Escherichia coli by wild type and by rapid lysis mutants of phages $\mathrm{T} 2, \mathrm{~T} 4$, and $\mathrm{T} 6$. The recovery of the culture from the drop in turbidity was slower at

- Wigher multiplicities of infection (MOI). More reently, indirect evidence has appeared that suggests physical swelling of phage infeeted $E$. coli cells. Con- comitant with infection and dependent on phage multiplicity, ion fluxer, optical density decreases, and parched cell rolume increase oecur in $E$. coli $\mathrm{K} 12(\lambda)$ infected with T4rII mutant- and in $E$. coli $\mathrm{B}$ infected with 'T'-ren phage. '3, 4'

In the present study, we have used a Coulter counter-multichannel andlyzer to inventigate directly the rexponse of host cell ize to phage infection. Changes in cell number and meatn cell volume were followed for cultures of $E$. coli $\mathrm{B} r$ and $B_{s-1}$ infected with phase T1 or T2r. Shate cultures in Canamino acidssupplemented basal salt medium were maintained by repeated back-culture at low cell titer" characteristic of balaneed growth. Bacteriophage were aded at MOI' from $<0.1$ to $>520$. Call aliquots from inferted and from uninfected control cultures were re- 


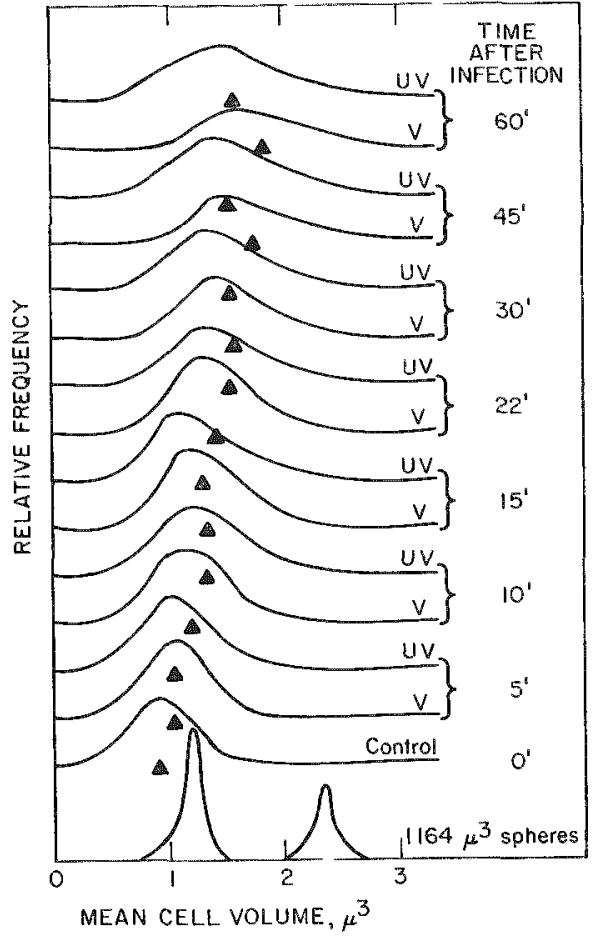

Futr. 1:20-Cell volume distributions of cont rol and phage infered colt ures of $E$. woli $\mathrm{B}$ 'r. $V$, culture infect ed with viable phage; IV, enlture nuferter with ult raviolet hilled phage. Multiplicity of phage "Tor was 4.0. Arrows denote mean cenll mizes.

moved every few minutes, and hoth titered and sized (lecetronically. Both virulent and ultraviolet light ( $(T)$ killed phage were u-ed in mo-t experiments.

\section{PHOCRLA REPORT}

The result from a typiesl experiment are shown in Figures 120 and 121. Figure 120 presents the eall rolume distribution from eontrol and phage infected ture and the volume distribution of $1.305-\mu$ diameter standard micropheres. A marked shift to at larger mean cell volume is seen with time in cultures infected with either viable or with $\lceil Y$ killed phage. Figure 121 a gives the change in Coulter count forrected to true coll count- $\mathrm{ml}$ ) and rereals, characterintically, a slight increane in cell number in both infered cultures. The control curve translates to a -traight line on a remilogarithmic plot.) The mean cell volumen in Figure $121 \mathrm{~b}$ reveal teady state con-tancy for the control and increanes for the experimental group. The total volume of cellular material per milliliter of culture, Figure 121e, in obtained from the product of Figures 121 a and $b$. It shows an immediate deviation from exponential increase in the infected "ultures.

The dependenee of swelling upon MOL is presented in Figure 122. The percent increase in the mean cel volume, after $20 \mathrm{~min}$, of $E$. coli infected with riable phage was arbitrarily nelected as the basis for comparion. At MIOI $>4$, the cell' ability to swell reaches a plateau. Figure 122 indicates that swelling in not influenced by the phenomenon of "lysis from without," which haw been dercribed for high titer of phaget.

A pomible explanation for the above renult is that phage infection immediately bloekel cell division without inhibiting the increase in cell rolume and mats anociated with normal cell growth, i.e., that phage infection permitted cell growth without division. If this were the case, the mean try weight pere rell should increase with time after phage infection. In order to tent thin po-sibility, large aliquots of infeeted cultures were trapped on membrane filter. wahed. and dried in vacuo at $80^{\circ} \mathrm{C}$. The result of stch an experiment are presented in Figure 123. The mean dry weight per cell remains constant, $a=$ anticipated if the size increane were due to physical enlargement of the infected cell without concomitant

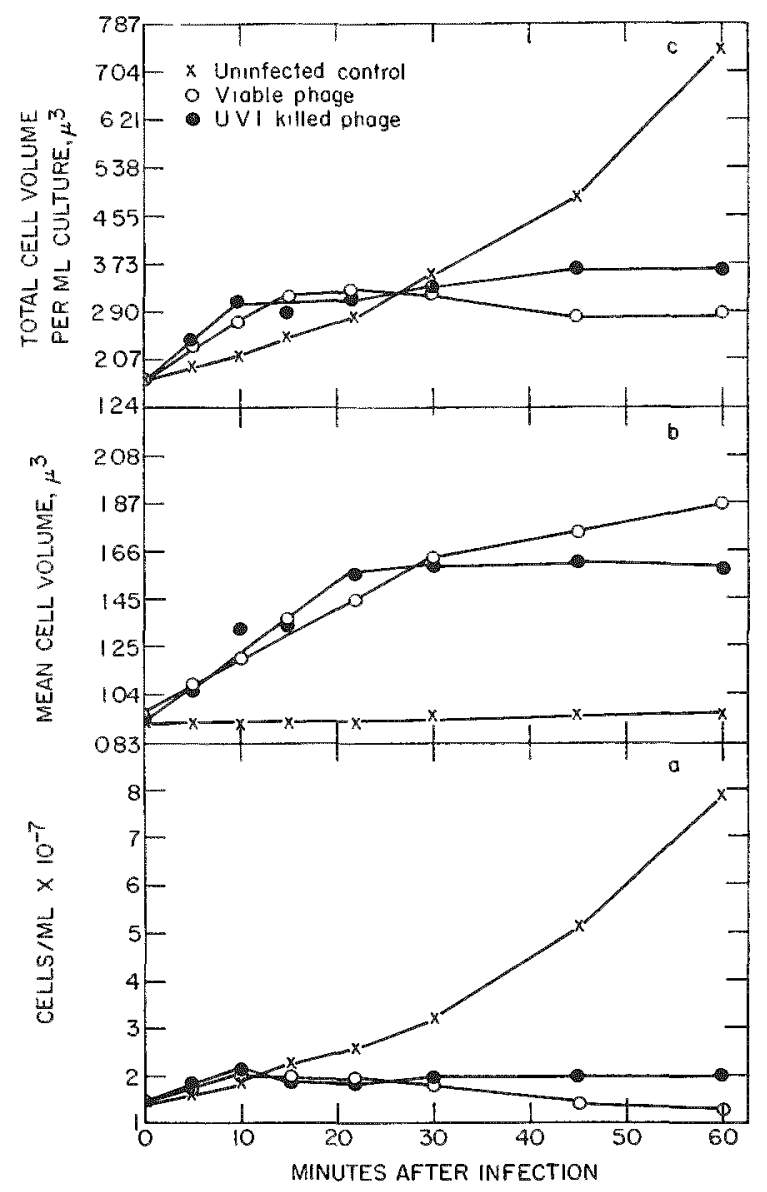

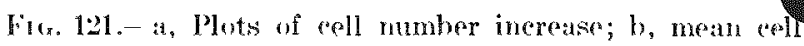
volume thanges; and e, tof al rell volume changes per mullilit er of culture. Same rell, phage, and Mo 1 as in Figure 120. 


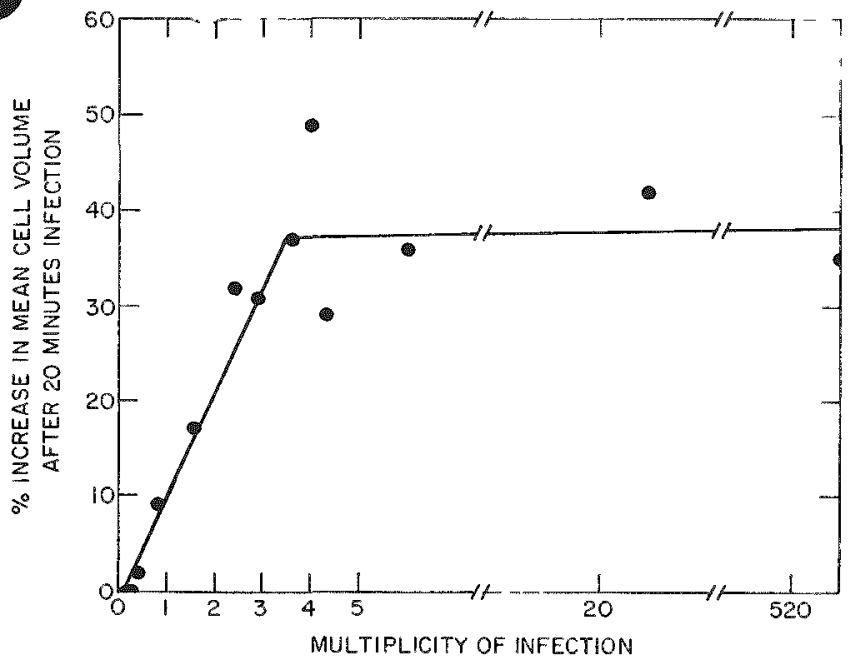

Fig. 122. Inependence of isnereane in mean cell volume after 20 min of infection. [ bat a are eombined from experiments ning

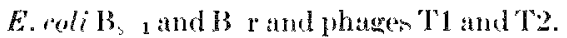

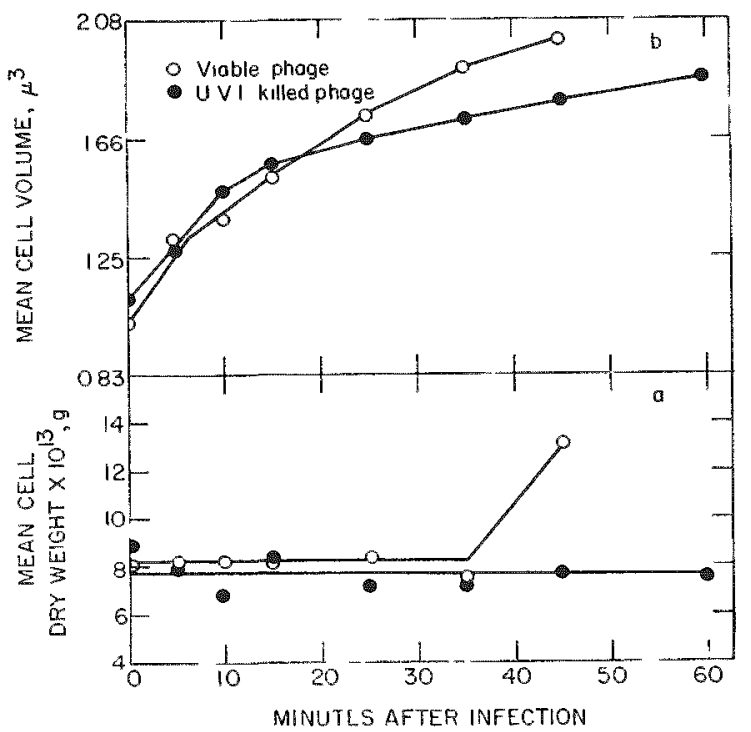

Fitr. 12: a. (constanes of mean aenll dry weight; and b.

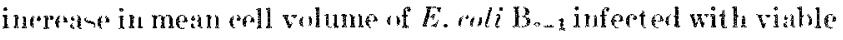
or T T-hilled T2r phatese at an MIII of 2.6 . matcromolecular synthenis. The abrupt increase in the mean cell rolume, 4.5 min after infection with viahle phatere, is thought to redfect lysis of the bacterial culture, which bexin abmet 30 min after infection. Iysi"onle! ratu- this imereste in the mean dry weight per rell, hecture the oell titer drops considerably, while murh of the reulting debris is retained on the filter and rontributen to the total dry weight. Ultraviolet light killed phage nould not he expected to cause ly-ito the -ame extent at virulent phage.

\section{AONILTSIOS}

swelline of the baterial hont eell appears to be at roal and ignificant atage in the infective cycle of $E$. roli hacteriophage. It occurs atrly during the infective "ycle. dow not sem to be reversible, requires very low multiplicites of infection, and doen not, in furt, depend on the artion of a viable phage. It dom not reflecet anty incrane in dry weight per cell. "There pe-ult atre all compatible. with the reeent suggention of $\therefore$. . (ohen's) that such swelling in an osmotir phenomenon catered by the phage's puncturing the basterial cell wall and membrane. ()ur preent data do not di-tingui-h whether or not this -welling plays at vital role in the phatate life "gele as postulated by rohen. Further experiment are planned along this line.

\section{KI, FHERU L}

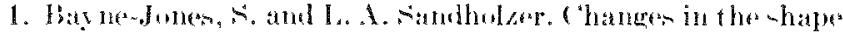

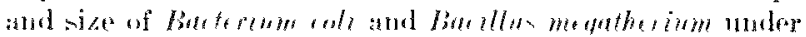
the influene of batelerionhage a mot ion photomiarographio

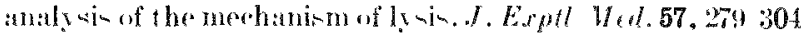
$(19393)$.

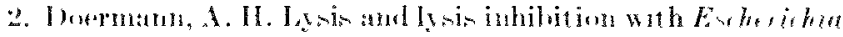

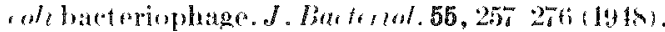

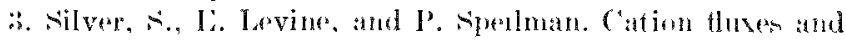

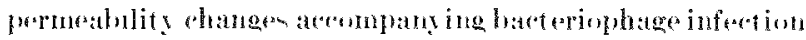

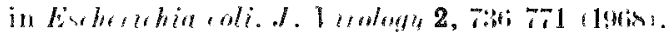

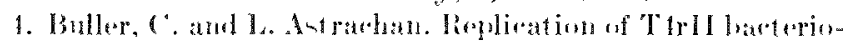

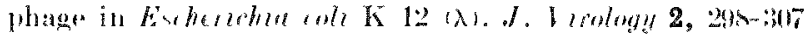
(19;6).

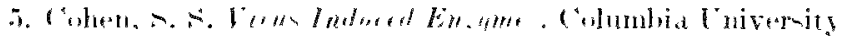
Prest, New York, lmix. 


\section{EFFECTS OF CELL SIZE AND DNA SYNTHESIS ON RADIATION SENSITIVITY OF ESCHERICHIA COUI}

Robert E. Krisch, Inn Finney, ${ }^{*}$ and Herbert E. Kubitschel

PLRPOSE AND MHTHODS

Studies of ultrariolet sensitivity in synchronously dividing population. of Escherichia coli have demonstrated differences among cells of different ages after division, (1, 2, In these experiments cells with relatively short generation times, continuous DNA $-\mathrm{yn}-$ thesis, and varying numbers of nuclei per cell were uned. The studien demonstrated an increase in the number of survivor in the lat ter part of the cell cycle, illentified by an increase in the initial shoulder of the -urvival curve but with no change in its final -lope.

The goal of the experiments presented here was to letermine correlation between radiation sen-itivity and either "ell size or INA. synthesin in unsynchronized, slowly growing. largely uninucleate cell populations, obtained hy growing $E$. coli in steadr tate chemontat cultures. (Growth wan limited with $100 \mu \mathrm{g}$ ' ml glucone, and the generation time was varied from 2 to $12 \mathrm{hr}$ by regulating the rate at which frem medium was introduced. (cell samples with different mean volume were prepared by velocity sedimentation of the entire ceell population in a suerore gratient. ${ }^{13)}$ ('ell volume dist ributions for each sample were determined in a coulter counter coupled to a multirhannel analyzer.

Thene techniques allow the study of differences in radiation sensitivity among reell populations of different mean volumen. Beciurs the size of individual cells of $E$. coli increases with their age after division, these techniques alo permit the study of differences in radiation sensitivity among cell populations of different mean ages. Experinental results obtained from un-ynchronized cell populations thus ean be compared directly with results obtained from mechanieally or chemically sychronized cell populations.

It had been shown previously that DNA syntheris in slowly growing chemostat cultures of $K$. coli 15 THC is restricted to the larger cells at generation times greater than $2 h^{\prime}{ }^{33}$ Radiation sensitivity in either the prenence or absenee of DNA synthesis is -tudied by irradiating samples containing cell populations of mean rolumes both above and below the critical value at the onset of DNA $-y n$ thesin.

\section{PROGRESS REPORT}

Fxperiments were carried out with both $E$. coli $13_{s-1}$, which is deffeient in dark repair and is very UF

\footnotetext{
* ACM st udent. Lawrener l'niversity, Appleton, Wisconsin.
}

- renitive, and $E$. coli 15 'THU, which has normal dark repair and is TV resistant. The bacteria had generation time of 6 to $7 \%$ hr, incuring a single nucletus at birth and the abrence of DNA synthesis until late in the cell eycle. Cell samples of four different mean rolumes were uned in each experiment. In a single experiment, the mean cell volume for the sample with the largent cells was, on the arerage, about 65'? greater than the mean cell volume of the ample with the smallent esolls. Survival curven were obtained for these cell fraction by irratiating them with a range of $\mathrm{CV}$ doser.

Within experimental arror, the survival curves for repair defirient $E$. coli 13,1 cells of different sizen were the same. (1) the other hand, small, but significant, differences were obtained with $E$. coli 15 THIC cells of different sizes: the lareere cells had more survivors at low dones. Furthermore, $\mathrm{CV}^{r}$ survival curves for $R$. coli $B_{,}$were exponential. but those for $E$. coli 15 THC hat an initial shoulder. For both strains, however, an analyis of the data using least squares fits indiested that the final slopen of the survival curves were independent of mean cell size.

\section{(c)}

Cell size, age, and the prenence or abence of IDA synthesis hatre no apparent effect on the UV survival curver $E$. coll $B_{s}$ i a repair deficient strainl. nor upon the final -lope of $E$. coli 15 THU (a strain capable of repair). The magnitude of the initial shoulder on the -urvival curve of 15 THC, which has a dark repair mechtnism. inceatuen with cell volume.

The underlying mechanim for the increased resistance of 15 THI is not identified. Because it is seen only at low IX dones in eclls with a repair capacity, we suppoes that thi- differential sencitivity may reflect ereater repair capacity in larger cells, possibly lue 10 a greater number of repair enzymes in these rell. Our rentis are in general agreement. with the previously eited reports of differential UV sensitivity in synchronoun ly dividing bacterial population that have normal repair capability.

\section{REFTRENC LS}

1. Yanagita, T.. Y. Maruryma, and I. Takebe. Cellul response to deleterious agento during the eoume of syuchr nous growth of Escherichia wh. J. Bacteriol. 75, 523 529 $(1058)$. 
Ilelmstetter, C. E. and R. P. Iret $z$. X-ray and ultraviolet sensitivity of synehronomsly dividing Escherichia colt. Biophys. I. 3, 35-47 (1966).
3. Kubitseheh, H. E., H. F. Bendigkeit, and M. R. Lahen. (Mnest of I)DA synthesis during the cell eycle in ehemostato

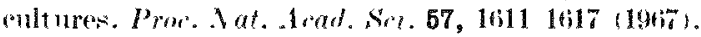

\title{
LETHAL AND GENETIC EFFECTS OF RADIOISOTOPE DECAY IN BACTERIOPHAGES AND BACTERIA
}

\author{
Robert E. Krisch, Barbara 1. ('ombs, and Wayne' T. Kidiels"
}

PURPOME AND METHODS

Various radioirotopes incorporated into viable cells cause death or genetic damage in an increasing fraction of the cell as decay orcurs. These effects have been most extensively studied for ${ }^{3} \mathrm{H}$ and ${ }^{32} \mathrm{P} .(1,2) \mathrm{It}$ is generally difficult to relate olmerred biological effect in such experiments to sperifie physical and chemical changes in decaving atoms. ${ }^{3}$ ") In fact, it often is imposible even to distinguish effects due to there loral changer in the decaving atom from those due to irradiation of the rest of the cell.

In the study reported here, the effects of radioinotope decay in bacteriophage are inventigated and compared with the effects of decay in bacteriat. By wing hacteriophage, the smallest available microorganism, it is hoped that the role of radiation effects in comparion to local decay effect can be minimized. Studies of the lethal and genetic effects of the beta emitters ${ }^{32} \mathrm{P},{ }^{33} \mathrm{P}$, and ${ }^{11}\left({ }^{\prime}\right.$. as well as ${ }^{129} \mathrm{I}$, which dem "ats by electron captur", are included. Each isotope is incorporated into the INA of the microorganimms to be studied.

${ }^{32} \mathrm{P}$ and ${ }^{33} \mathrm{P}$ emit heta particles with mean energies of $0.70 \mathrm{MIC}$ and $0.093 \mathrm{MeY}$, rempectively, and mean ranges in water of $2600 \mu$ and $120 \mu$; and the daughter nuclei acquire mean recoil energien of $20 \mathrm{eV}$ and 1.7 eV. Decay schemes otherwise are identical. It has been proposed that the lethal effect of $32 \mathrm{P}$ in cells are primarily due to double-strand breaks in DNA cau-ed by the high recoil energr. (1) If this were true, the lethal effects of ${ }^{3} \mathrm{P}$ decay would be much less than those of ${ }^{32} \mathrm{P}$ decay. (nnly two experiments are reported that tested this idest, and their results are contradictory. (") By incorporating purified ${ }^{25} \mathrm{P}$ or ${ }^{33} \mathrm{P}$ into bacteria and bacteriophage and comparing lethal efficiencies, it is propowes to tent this hypothese regarding the lethal mechani-m of $: 2 \mathrm{P}$ decay.

${ }^{11}$ ( decays by emitting a beta particle of relatively low energy (mean 0.05 MeV). Its lethal effects have been studied by others using bacteria and various gher organisms. ${ }^{(4,5)}$ With our present test $-\mathrm{v}$, tem, the' difficulty of distinguishing between local decay effects and radiation effect should be greatly de- creaned becaure of the small ize of the T1 phage particle $(0.05 \mu)$ compared with the mean range of ${ }^{14} \mathrm{C}$ beta particles in water $(33 \mu)$.

12.I decays by electron eapture, with a subsequent vacuncy cascalle and probable electrostatic disruption of the molecule harhoring the decaving atom. ${ }^{(6)}{ }^{125} \mathrm{I}$ i- being incorporated into phage DNA in the form of labeled iododeoxyuridine, a thymidine analog. Although the hiologieal effects of ${ }^{125} \mathrm{I}$ decay have not been studied, the disruptive local physical events known to accompany it decay lead to the expectation of a high lethal efficiency for decays in DNA. perhap $100 \%$.

\section{PROGRLAS REPORT}

Experiments have been undertaken to compare the effect of ${ }^{32} \mathrm{P}$ and ${ }^{3} \mathrm{P}$ decay in hacteriophage $\mathrm{T}_{4}$ and in several strains of $E$. coli: two wild-type radiation re-istant strains, 15 THC and $\mathrm{K}-12 \mathrm{AB} 1157$ as well as two mutant radiation sensitives -trains, $B_{5-1}$, which iv deficient in dark repair of DNA damage, and K-12 AB 2463. Which is recombination deficient. Preliminary result indicate that the lethal effects of ${ }^{33} \mathrm{P}$ duplicate thome of ${ }^{32} \mathrm{P}$ in the phage and in the four bacterial strains. When storage during decay is at $-196^{\circ} \mathrm{C}$. approximately $5^{\circ} c$ of all decays in DNA are lethat to phage $T_{k}$ or to either radiation rensitive -train of $E$. coll, whether the isotope is ${ }^{22} \mathrm{P}$ or ${ }^{33} \mathrm{P}$. Approximately $2 \%$ of ${ }^{32} \mathrm{P}$ or ${ }^{33} \mathrm{P}$ decay in DNA are lethal to either of the radiation resistant strains of E. coli.

In other experiments, the lethal effects of ${ }^{125} \mathrm{I}$ de(ay in hacteriophage and bacteria are being sturlied. (bur renlts indicate that, ats -uggested by the disuptive local physical event accompanying electron captur', ${ }^{125} \mathrm{I}$ decear in DNA is much more highly lethal to phage and hacteria than sep decay under similar -torage contition. When ${ }^{125} \mathrm{I}$ is incorporated specifically into the DNA of E. coli $15 \mathrm{TH}$ T and the cells are stored at $-196^{\circ} \mathrm{C}$ during decay, approximately $20^{\circ}$ of all decays are lethal, compared with 2 , for ${ }^{32} \mathrm{P}$ deray. When ${ }^{12} \mathrm{I} \mathrm{I}$ in incormorated into the DNA of harteriophage $\mathrm{T} 1$ under the same storage condi- 
tions, at least 35e, of all decays are lethal compared with $5 \%$ for $32 \mathrm{P}$ decay. The lethal efficiency of ${ }^{125}$ decay in bacteriophage may actually be even higher than $35^{2}$, becaune this figure a-sumes nondiscriminatory uptake of iododeoxyuridine and thymidine, and there in a porsibility that the phage actually discriminate in faror of thymidine. Experiment are under way to measure directly the 12er content of radioactive phage particles. Our results also indicate that the lethal effects of ${ }^{125}$ I decay in phage are much lens dependent upon storage temperature than are the lethal effects of sap decay. If the storage temperature is increated from $196^{\circ} \mathrm{C}$ to $+4^{\circ} \mathrm{C}$, the lethal efficieney of an 1:25 decay changen from about 3.5\% to firer but that of a ${ }^{32} \mathrm{P}$ ideray more than doubles, from $5 ?$ to $12 \%$.

\section{(1)NCICHION}

Our preliminary comparison of the lethal effect of $\therefore \mathrm{P}$ and ${ }^{33} \mathrm{P}$ decay in bacteria and bacteriophage how no difference between the two isotopes. This strongly suggests that murlear recoil doen not play a major role in cauning lethalities from ${ }^{2} \mathrm{P}$ decay an propoued by stent and linerst. "1) because ${ }^{23} \mathrm{P}$ decay involver much lower recoil energies, incapuble of breaking chemical bonds. The lethal effects must be due, instead, largely to loral decay effects which the two inotopen hatre in rommon. Likely pomibilitier are atomic excitation or local production of free radieals.
The study of the lethal efferet of $125 \mathrm{~T}$ decay in 11 DNA of bateteria and bacteriophage now that 125 deatave are approximately 10 times more efficient in killing microorganimo than are $32 \mathrm{P}$ decays. Theme result are compatible with the destructive effect ob-erverd from decay by electron rapture in small orwanie molecule compared with very milel molecular effect oberved from beta deray. ${ }^{6)}$ The relative temperature independence of the lethal effieieney of 12 in decay alow fit in with the concept of direct phy-iral disruption of the I N.I molerule in which the deear occurs.

\section{REF BREACE}

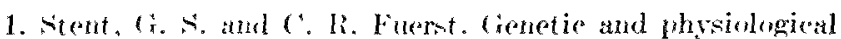
effects of the deray of incorporated radionetive phosphorus

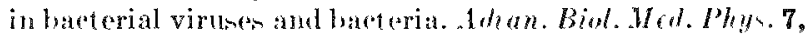
$175(1960)$.

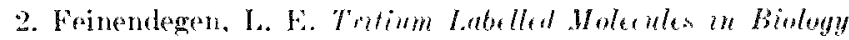
and Vedirine. Academic Prens. New York, 1967.

3. Stratks, B. S. The genetio effert of incorporated ratiolinen

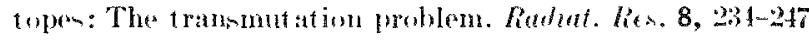
$(1958)$.

1. Krisch, R. L. and M. R. Zeelle. Biological affects of radio

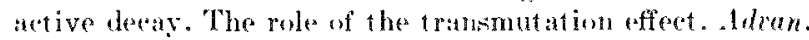
Restat. Binil. 3, 177 21:3 11969).

5. Ipelgot. S. and R. Iaterjet. Marquage d'un acide deox ribonucleicuc bacterien par le radiophophose, le radiocarbose, of le tritiom: Comparinen des effets letaux. Brochim.

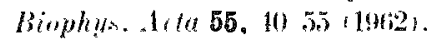

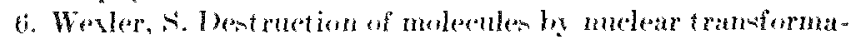
tion. Sit nie 156, 90190\% (1946).

\section{THE ORGANIZATION AND FUNCTION OF THE BACTERIAL CHROMOSOME. REGULATION OF CHROMOSOME REPLICATION IN BACILLUS SUBTILIS. THE EFFECT OF AMINO ACID STARVATION IN STRAIN 168}

\section{Iame C. ropeland \\ PI RP(ME AND MFTHOD-}

Regulation of chronosonte replication has been - tudied mo-t textensively in Escherichia coli." "st starvation of erells for an emential amino acid result in chromonomen alioned at their terminu. ${ }^{(2,4-6)}$ This. has been interpreted to mean that each suceesive round of chromo-ome replication is triggered (-witched on) by an initiation arent which reguires a protein to be cffected. Once initiated, chromosome replication continue- until that round is completed at the terminus of the chromonome. ${ }^{(7,8)}$ Thu the essential control point for chromo-ome replication is at the the initiation step of replication. (s) Recently, conflieting reports concerning the effect of amino arid starvation on chromosome replieation in $E$. coli have appeared. ${ }^{(9)}$
It is the purpose of thi- report to show that regulattion of chromosome replication in $B$. subtilis, Strain $168.11+1$ in respone to starvation for a required anino acid, differs from that in $E$. coli. This difference allow examination of another regulatory circuit that affect DNA synthe-ie, and may involve the ratio of DN.I to cell mata.

Bectune I3. subtilis is trunsformable, it is ponible to stuly chromonome replication and organization at the molecular level in a direct way. The method involve transfering etls in balanced growth in a defined, minimal mextium to the same medium lacking an enential amino arill. Samples are taken and viability, the amount of IDNA and RNA, as determind by the diphenylamine and oreinol texts respectively, is meacured. To specifically obtain that DNA marle 
after a given treatment, such as that made following amino atcid -tarvation, cells are transferred to a medium made up in D,O. "The isolated DNA is ractionated in a Cscl gradient and the fractions are -uberuently analyzed, by tran-formation, for yecitic genetic marker aretivity. In this wat the narker atetivity anociated with the new ly replicated IDNA ran he measued and the configuration of the chromosome after the treatment inferred.

PROMRLA REPORT

Cells of $B$. sultiles, strain $13 \mathrm{C} 200$, which has requirement - for thymine, leurine, and methionine, have a nuas-doubling time of 60 to 70 min when grown in a minimal medium at $34 \mathrm{C}$. Figure 124 shows that rell in balancerl growth are not disturbad appreciably by filtering and wathing. The rulturen deprived of leweine increase slightly in optical density and then stop growing. Ledeine starved cells remain viable. The kinetien of macromolerular synthe-i during amino acid starvation are shown in Figure 125. In this analysis, the change in optical density is cruated with rhange in total protein. The kinetice of DNA -rnthe-i- are unlike thon' appeterl if only rounds in progres are allowed to complete, and subsequent round are blockel. During amino acid sarvation, DNA rnthe-is rontinue until 3.) to $40^{c}$, more in

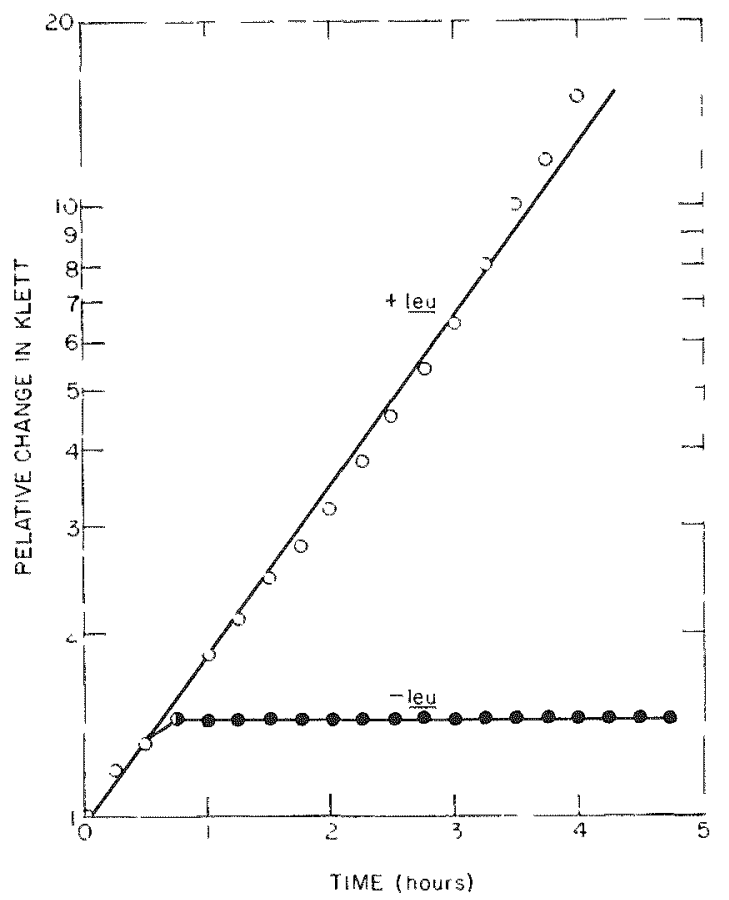

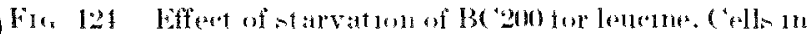
laned growth fillered and wathed with minimal medium minus leneine. The amino acid wa added bavk to the eont rol, and it was hept below 1 × 10 aell $\mathrm{ml}$ by periode dulution. O. Control and eellantarved fur lemeine

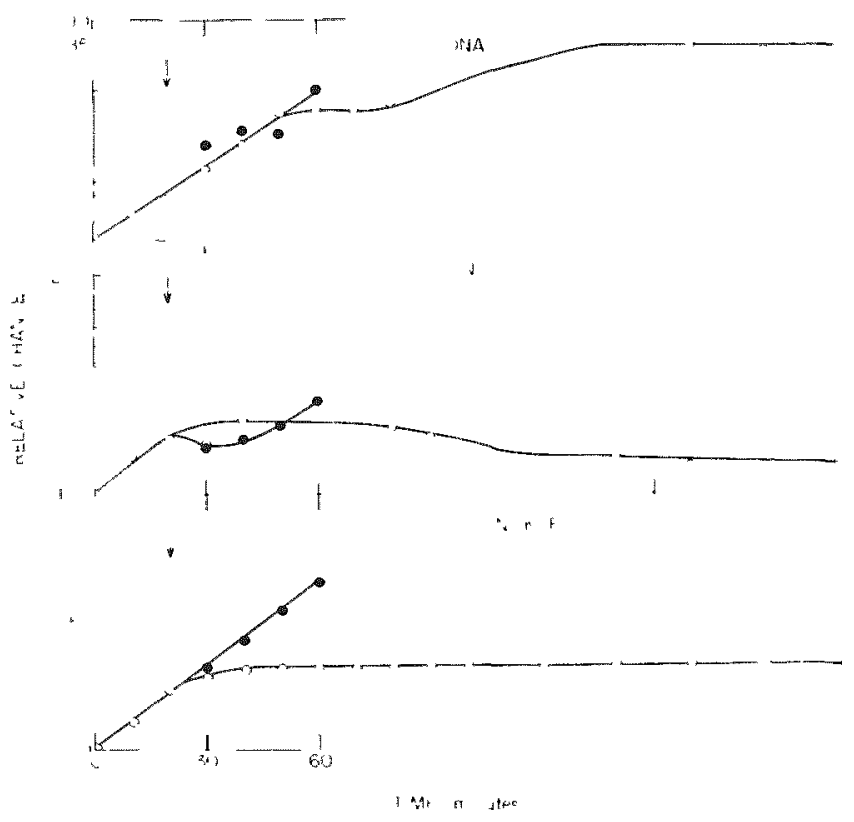

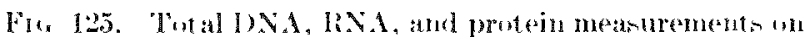

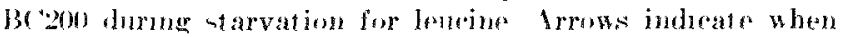

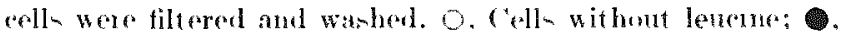

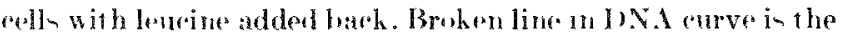

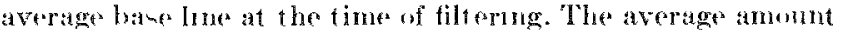

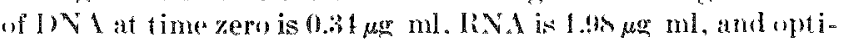
ral dermat! for protein is 0014.

mate. There follow a temporary platean, after which there is a -eondary rise in total DNA by an average increse of 70 , s to a second anl permanent platesu.

Frandition of leucine after $1.50 \mathrm{~min}$ of starvation leak to an immerdiate increat in cell growth parallelled by a imilar increane in viable cell number. The kinetion for IONA, RNI, and protein -ynthesis upon restart are hown in Figure 126. To DNA is made for the firs 40 to 50 min. whereas PNA and protein senthe- i- hein immediately upon rentart. ONA syn-

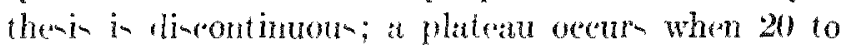
25: more IDNA is mald". This amount, added to the amount of I NA made during anino acin -tarration. io requivalent to a doubline. rexative to that quantity prement at the onet of amino acid starvation. DNA. -ynthe-i- begins again at about that time when RNA and protrin have doubled alter remlart.

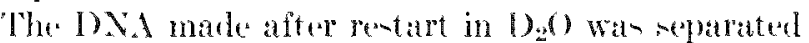
in a (") density gradient. The fractionated gradient wa and lyzed genetioally by tran-formation to identify the replicating patre uf the ehromonome. In this analyis. twelve lifferent markers were andyed (Fioure 127) in each of four different eratients. The sratient- wert derivel from amplem taken when DN.1 increaced 10, 13,22 , and 5is pereent after re-tart. In Figure 128 is repremented the pereent pepliration per grationt for wath genetio mapker $v$, the 


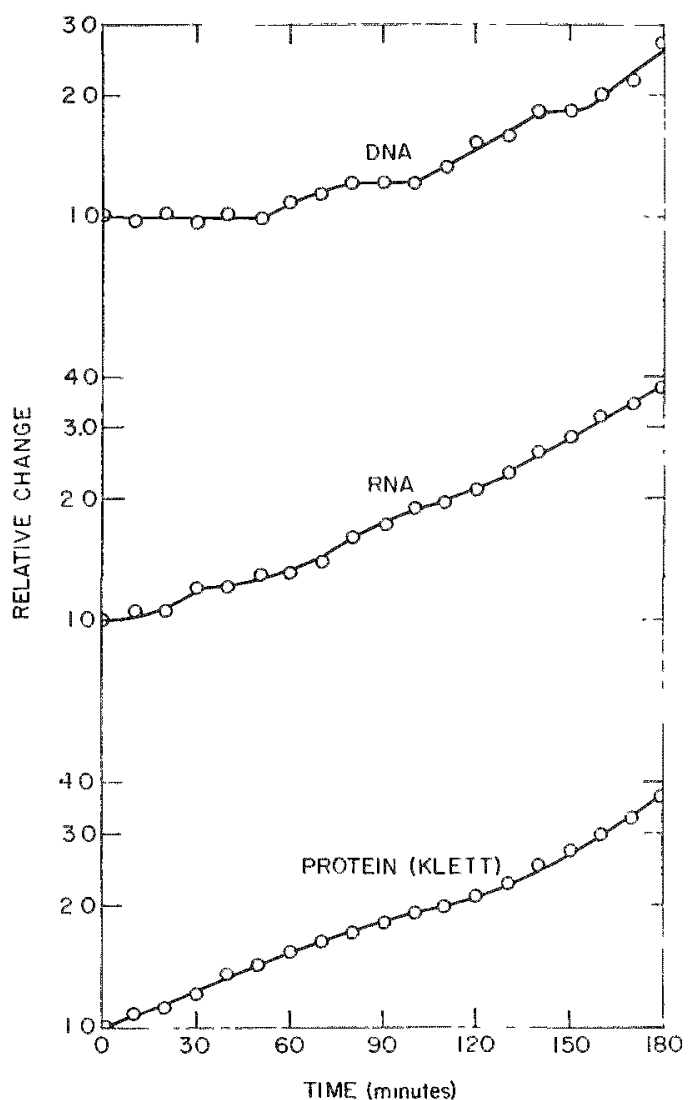

Fite 126.- Restart kineties for DNA, RAd, and protein. BC200 starved for leucine for $150 \mathrm{~min}$, as indicated in Figure 125, at which time lencine was added back to a final concent rattion of $50 \mu \mathrm{g}$ ml. The average amount of INA at time zero is $0.6 \% \mu \mathrm{gml}$, RN. is $2.20 \mu \mathrm{g} \mathrm{ml}$, and optioal density for protein is 0.05 .

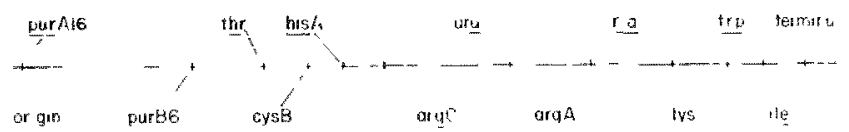

Fic. 127.- Representation of genetir matp for $B$. subtilis adapted from Dubnati of al.11

amount of DNA synthesized when the sample was taken. It is readily apparent that upon restart all of the markers assayed were actively replicating. The amount of replicating activity for each marker differs quantitatively in a particular way which will be discussed later. Another characteristic property of all markers is that their replicating activity falls toward zero after about 20 , more DNA has been made. This is consistent with the kinetic results obtained on restart of DNA syuthesis, i.e., there is a plateau in I) NA synthesis when 20 to $25 \% 0$ DNA is made.

Another observation made from these data, but better illustrated in Figure 129, is that the markers appear to be replicating but not in the sequence ex-

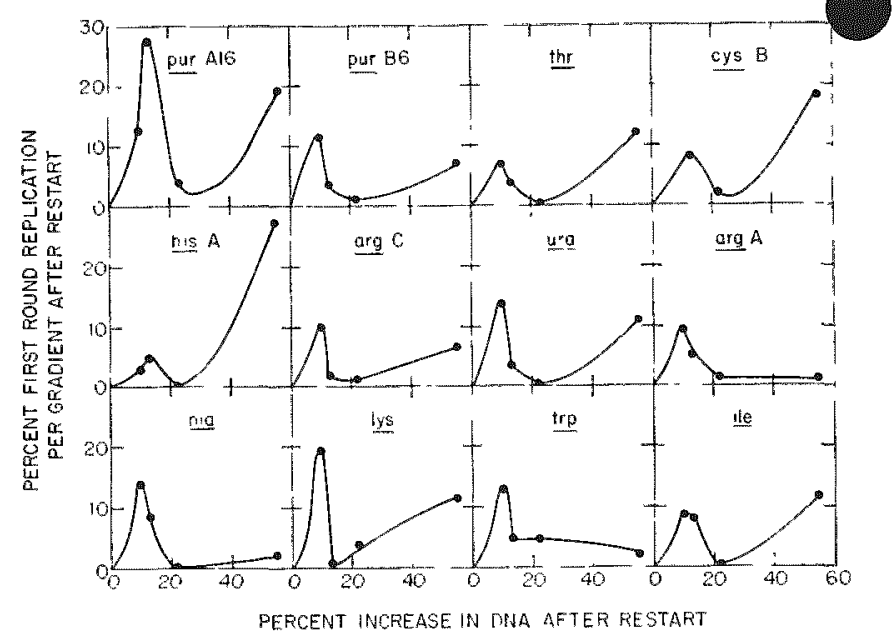

Fla. 12x.- Replieation antivity expresed as pereent of tot al first ronnd repliation per genetie marker per gradient after addition of leucine 10 amino acid starved BC"200. This is enmputed from gradients assayed by transformation as illust rated in Figure 1:2\%. The first round after rest art is defined as transfer of tratsforming antivity to the hybrid region. When the wum of activity under the arve equals $100 f^{\prime}$, it would indieate that all copies of a given genetic marker prosent at restart have repliated once. The relationship is expressed simply as:

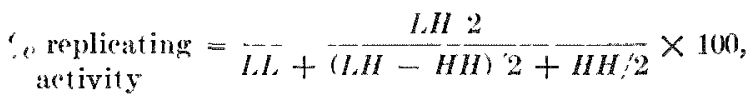

where $L . L$ is equivalent to the transforming act ivity in the light frat ion, $L H$ with that in the hybrid fract ion, and $H H$ wit h that in the heavy fraction, each expressed as pereent of total transforming aretivity in the gradient.

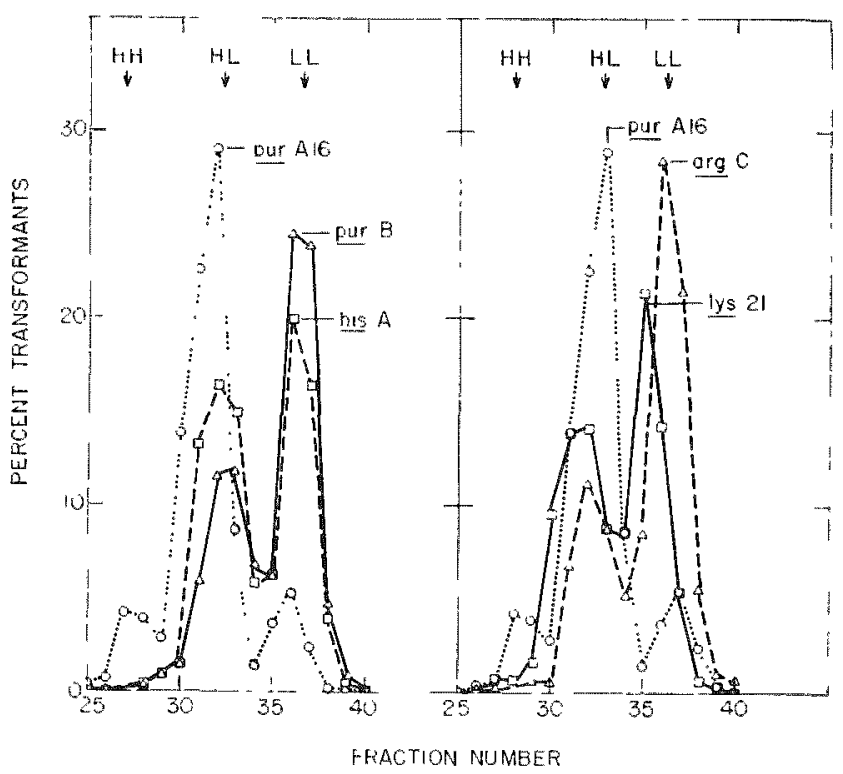

Fitr. 129. - Transformation assay of gradient taken when $55^{\circ}$, IN 1 hats been synthesized after restart. Cells of $B C 2$ were previously st arved of leucine for $150 \mathrm{~min}$. $l_{A} L_{A}$ indicat peak of light fraction, $H I$. that for the hybrid fraction, and $H H$ for the heavy fraction. 
ected from their map position. For example, the his A marker has been replieated more than the pur B matrete. The known map order is pur $\mathrm{A}$, pur $\mathrm{B}$, then his A (see Figure 127), but the apparent order of replication after amino acid starvation is pur $\mathrm{A}$, his A, then pur B. Also, the map order is pur A. wrg $\mathrm{C}$, then $l y s$, but the apparent order of repliration after amino acid -tarvation is pur A, lys, then arg ('. Other misordering ean be sen in tigure 128.

To demonstrate that replication is not proceeding in a random order after restart, replinating activity for each marker after $22 \%$ DNA has been oyntheiized is compared to activity when between 22 and 5.) INNA has been synthesized, as shown in Figuro 130. Initially, replicating activity is greatent on the last half of the chromomome. The noticeable exception is at the pur A marker, near the known origin. This artivity represents newly initiated chromonomes. Later, replicating activity is lowent on the lant half of the chromosome and highent on the first half. These data indicate that replication after amino acid starvation is ordered, and reflect the state the chromosome romer to an at rewult of the amino aldil starvittion.

\section{CONCLIBIONA}

Regulation of ehromonome replication in $l B$. subtilis, Strain 168 in response to amino arid starvation is different from that in Escherichia coli. In 13. subtilis 168, chromosomen appear to complete their replieation in the abenee of the amino acid if one ansumes that the near 40 r more IDNA made to the first plateau is the amount neederl to complete rounds in progrem." some of the completed chromosomes, howerer. then initiate a new roumd of replication that appears to stop with a broad distribution of resting site located mainly over the la-t half of the ehromorome. This account for the additional DNA made beyond that needed to just complete round in progres. This arrangement would best aceount for the pattem of gene replication found upon restart.

The observed minorker of markers, when arranged aceording to their replicating activity compared to their map order, might be accounted for in at lesat two way. It could indieate that there are preferred -topping sites for repplication fork not able to proceed to the nomal terminus. The other posibility is that new round of replication can be initiated at siten other than the normal origin of the chromosome, recently demon-traterl in $F$. colion

One striking feature of these data stems from consideration of the ration of INA to RXA and protein before, during, and after amino acid starration.

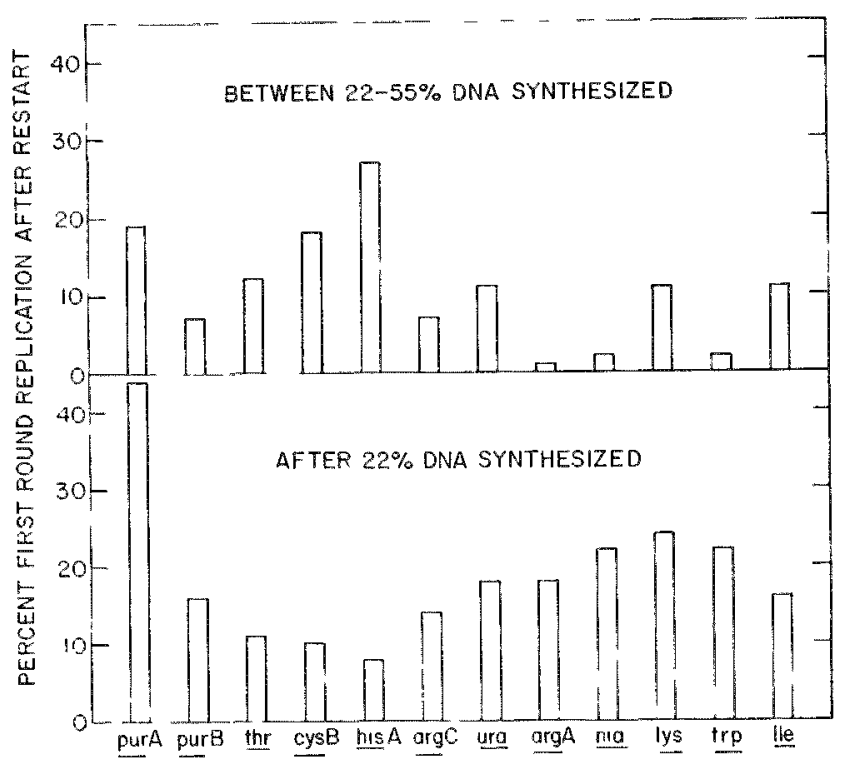

Fit. 130. Bar graph illus rat ing the dint ribution of replication ard ivity for genet io markers acrording to their order on the genetite maty of $B$. subtilis. The lower seetion represents the dintribution after $22 \%$ INNA synthesis, which is aquivalent to the first platean upon rent art. The upper seotion represento the

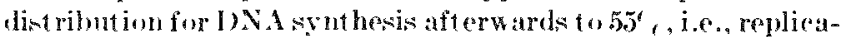
tion artivit at $55^{4}$, IDNA mints replieation arotivity at $22 \%$ 1)N.1-ruthesized.

Inring amino arid starvation, the amount of RNA drop -lightly and protein changes little, or not at all. But 1)X.1 in made unt il there is about 70'r more. creating an imbalance in the ration of DNA to liNA and protein, relative to the amount prenent in cells during balanced growth. Tpon restart, the complementary -ituation result in RNA and protein being male in the absence of DNA synthesis. 1 s more RNA and protein are marke. and normal ration are approuched, DNA s rnthe-is is switched on again. Genetic analy is indieaten that those rounds that were in progrems contimes at the same time as new round are bewan. Then I)NA sythesis and replieating artivity thut of when cxactly a doubling in amount of DNA is reached, relative to that present at the time amino acill starration began. It does not begin again until the nomit ratios are ohtained by continued RNA and protein synthe-in. INA synthesis, thereafter, appear to be continuou and, together with RNA and protein synthes- the cells appear to be back in balanced growth. Thene obervations are taken a- support for a coneept first uggested by Maalge (5. 13) and more recently extended by Donachie, ${ }^{11,12}$ that IN) sonthen is is regulated by it relationship to RNA. protein, rell mass, or other factors that contain -ome or all of the former. (For conreniener this relation-hip will he referred to as the $10 \mathrm{~N} / \mathrm{mass}$ 
ratio. (One particular proposal relates the initiation (rent to at definite DNA mass ratio or a multiple of that mas..111

It is evident rom these results that the regulatory circuit involving the DNA mass ratio can operate independently of the initiation event which controls the onet of replieation. New rounds of replication. startell by addition of the amino acid. are stopped, as shown by the platealu in amount of DNA male and the concurrent shurp decreane in replicating aetivity, particularly for the pur A marker. DNA synthe-ie dow not hegin again until the normal DNA mass ratio in attained.

It should be smpha-ized that ehromosome replicaltion, once begun. need not go to completion in an uninterrupted sequence. This is clearly shown during annino acid starvation, when newly initiated rounds erentually stop before reaching the terminus. Also, upon restart. newly initiated rounds stop replicating activity until a balanced ratio of DNA/mas is reachel. Furthermore, initiation events occur when colls are in an unbalaneed condition. This happenduring amino acid starvation after rounds in progress come to completion. during which time total RNA and protein has changed only slightly. Again, new initiations oreur upon restart before the balanced ratio of DNA to mas is reacherl. It max be this uncoupling of the initiation event from the control cireuit, involving the ratio of DNA to mass, that makes $B$. subtilis 168 different from $E$. coli in its response to amino seid starvation.

The result of this study nuggest there are at least two regulatory circuits that affeet chromosome replication, and affect it lifferently. Initiation of replication in an all or none event; it acts only once during a round of replication. Once initiated, a given round of replication tends toward completion to its terminus. The second eircuit is operitive during chromosome replication and modulaten replication activity by tuming it on and off relative to other cellular factors that involve enll mass or correlate with it. This second cireuit could serve to entrain chromoson replieation to other cellular events, such as cell growth and division.

\section{REF GRLNOE}

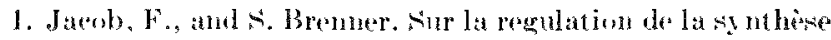
du livi thes les bateteries: 1, hypothese du replion.

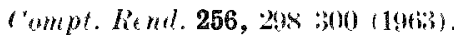

2. Lark, K. (i.. T. Hepko, and F. J. Iloffman. The efferet of

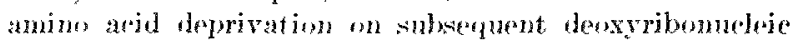
arid replication. Biorhim. Biopleys. a det 26, y-24 (1960\%).

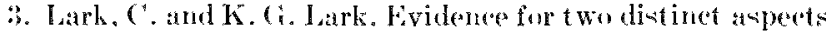
of the merhanism regulating chromosome replication in

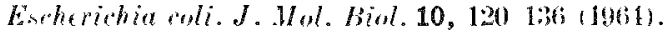

4. Mataloe, O., and P. (". Hanawalt. Thymine defieieney and the normal DNA replication eycle. I. J. Mol. Biol. 3, 1Ht $15.5(1961)$.

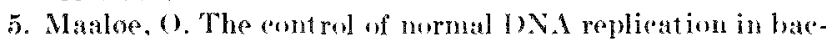

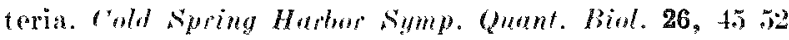
(10)il).

t. Forro, fr., F. Autoradiographic studies of hactorial chomo some repliontion in amino acid dedicient Escherichia foll $15 \mathrm{~T}^{-}$. Binphys. J. 5, 62:1-619 (19t5)

7. Cerda-Gmedo, L., P. ('. Hanawalt, and X. Cillerola. Mutagenesis of the replication point by nitrosonganidine. Map and pattern of replication of the Escheridhic roli chromosome. J. 110l. Biol. 33, 705 719 (19m8).

8. Wolf, B., A. Newman, and I). L. (ilaser. On the origin and direction of replication of the Esele rischia coli K 12 chromosumes.d. 17ol. Biol.32, 611-629 (1968).

9. Caro, L. Ci.. and ('. M. Bere. (hromesome replication in some strains of Escherichid coli Kl2. Cold Spring Harbor Symp. Quant. Biol. 33, 559563 (19)

10. (opeland, J. ('. Regnlatjon of thromoseme replication in Burilles subtilis. Effeet of amino acid starvation in strain 1tis. J. Bacteriol. 99, 730 7386 (1966).

11. Wonachie, W. I). Relationship bet ween cell size and time of initiat ion of DNA replication. Vature 219, $107 \%$ 1078 (1968).

12. Bunache, W. D., D. (4. Hobls, and M. Masters. Chromo-

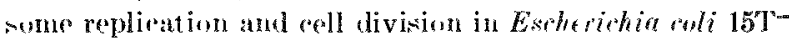
after growth in the absence of 1 N.1 synthesis. Vature 219 , $10 \% 1080(1968)$.

13. Mataloe, (1. On the role of protein syuthesis in the 1 )N.1 replication excle in bateria. J. Collulat comp. Physiol. 62, suppl. 2, s1 $44(1963)$.

14. Dubran, D)., ('. Goldhwite, J. Smith, and J. Marmur.

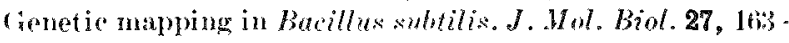
$185(1967)$.

\section{THE ORGANIZATION AND FUNCTION OF THE BACTERIAL CHROMOSOME. THE CHROMOSOME IN COMPETENT CELLS OF BACILLUS SUBTILIS, STRAIN 168}

\section{Robert I. Erichsom and James C. Coppelanel}

\section{PIRPONL AND METHODS}

Colls that can take up exogenous DNA are said to be competent. Under appropriate conditions, this uptake results in the formation of genetic recombinants. In a competent population of Bacillus subtilis. cell that are competent comprive a minority component. Recently, it was discovered that competent cell are lew dense than noncompetent cells, ${ }^{(1)}$ and cou be selectively enriched on a step gradient of Renografin. (z) This process makes possible a direct studv 
competent cells separated from the more numerous noncompetent cells. Studien with mixud population of competent and noncompetent redh have sugge-ted that the competent population in physiologirally retive. In thi study we want to determine the -tate of the chromosome in this ppulation, i.e., is it in a complete form. at hat bets poutulated for the chror mo-ome in yores?

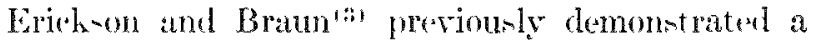
correlation between the eflicieney of tram formation of a siven marker and chromo-ome replication. The $y$ found that the maximum efficiency of transformation oceurred at different tinse- for different markeps in a competent population treated or an to have aligned or sychonized rhromonome replieation. Furthermore, the order in which genetio marker were maximally tran-formed was the ane an the equence in which the markers are known to replicate. It is the purpone of this -tudy to determine the configurstion of the rhromo-ome in the competent popralation and to further examine the relation-hip between tran-formation efficiency and replication.

PROMRI - HEPORT

The eoncentration of Renogratin is eritioal to the relative purity of the lighter competent fraction of "ell- The data illu-trated in Figure 131 show that, an the demeity of the eeparating layer of Renografin $\mathrm{j}$ - in creaned, more cells remain at the top of the gradient; at the -ame time, DNA hinding per cell decreaten sharply. Thus, in the experiments to be deneribed. Renografin solutions diluted to a refractive index of $3.3680 \pm 0.000 .5$ were uned an the neparating laver.

The conmerival preparation of Renogratin used in these -tudies contained two preservatives (methyl paraben and propyl parahen) a well as inhibitory concentration of dinodium EDTA dihydrate. To obtain a physiologirally active cell population after separation on Renografin recpured a vigorous. yet nonlethal, wa-hing procedure. Thi involved collecting the cell- on a Millipore filter (pore diameter $0.45 / \mu$ ) and whing them in growth medium containing $0.002 . / \mathrm{Mg}$. 5 , followed by a wath in $0.02 . / \mathrm{Mg}+\mathrm{Mg}^{+}$ in $I_{2}\left(1\right.$ and a final wath in the $\mathrm{D}_{2}(\mathrm{O}$ merlium containing $0.002 .1 / \mathrm{Mg}++$ and $10^{\circ} \mathrm{o}$ glycerol. The cells were then fast-frozen and stored at $-70^{\circ} \mathrm{C}$. Individual preparations of competent rell- were pooled to provide a sufficient concentration of cells for further examination.

To analyze relative rate of DNA -vnthenis in mpetent and noncompetent cells during the incubanon period required to produce a competent population. the rells were exposed to ${ }^{3} \mathrm{H}$-labeled thymidine at different timen before separation on Renografin. The

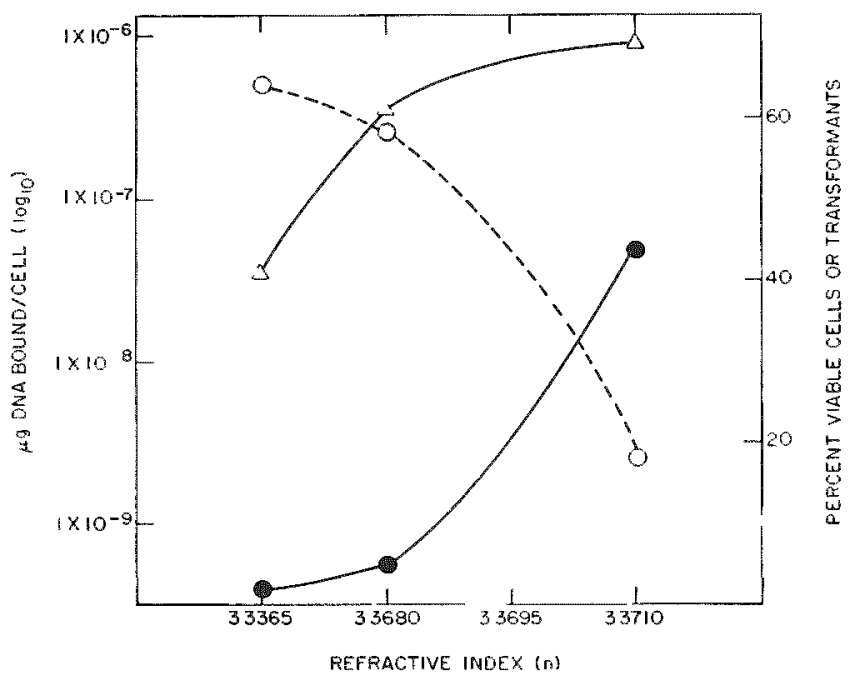

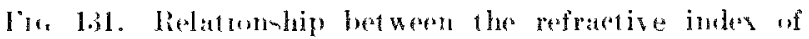
Renugratun and the effichory of eparation of competent $b$.

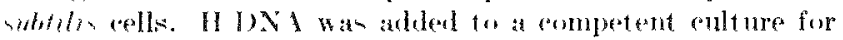

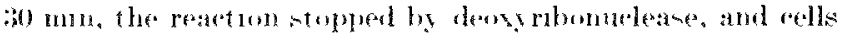

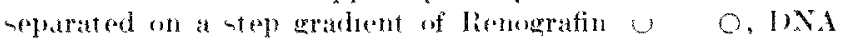
bunud to vells; - percent vable rellh; and $\triangle \Delta$,

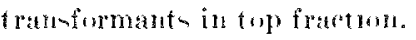

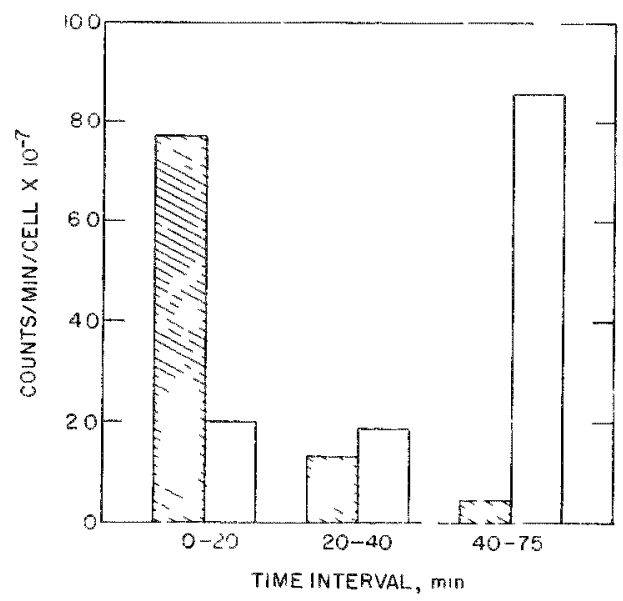

Fex. 1:32 The monporation of 11 thymidne into top (wompetent) and bottom enonempetent) rell fractions. Solid bar represent the enmpetent coll fration. Open bars represent the nonempetent reall fractions.

(eell- were then frartionated, and the distribution of lithel in the two cell fraction tcompetent and noncompetent 1 wan determiner. The revaltis, illustrated in Fioure 132. show that DNA synthesin is decreasing in the competent cells but increasing in the noncompetent cells during thi- incubation period. This implien that rompetent and noncompetent cells are physiologically different, in agreement with published resport-."

The kineties of DNA, RNA, and protein synthesis in the frartionated competent cell-grown in an enrichenl $D_{2}(1$ merlium are illu-trated in Figure 133. As 


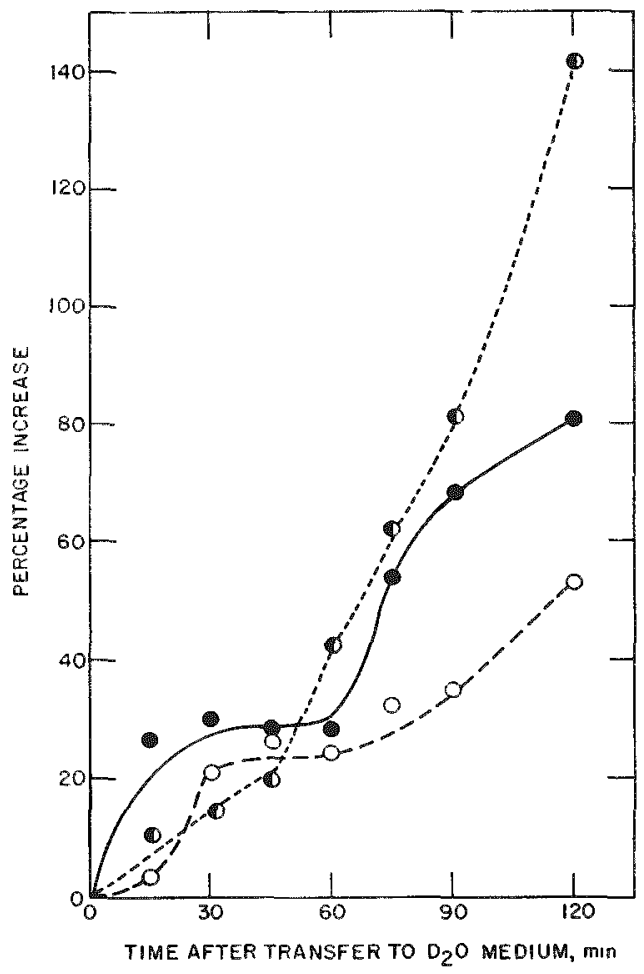

Fig. 13\%. -Kineties of macromolecular stathesis in competent cells grown in enriched 1$) \mathrm{A}$ medium at $31^{\circ} \mathrm{C} .11 \mathrm{NA} ; \mathrm{O}$, IRNA; and protein at tot al miss.

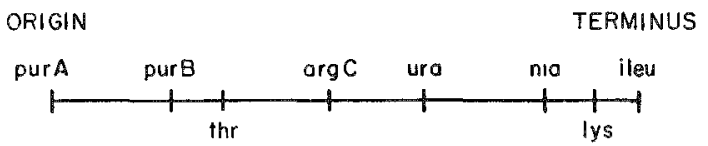

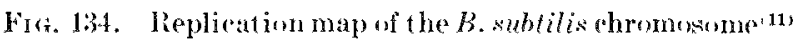

hats been found by others, (1) DNA and RNA synthesis is low, relative to the increase in mass of the culture. INA does not appear to increase continuously during this growt heriod.

The newly replicated DNA made in the $10_{2} \mathrm{O}$ medium was isolated and fractionated on the $\mathrm{CsCl}$ density gradient. The gradients were then assayed for transforming activity. (5) Genetic activity associated with replicated DNA is found in the fractions that contain hybrid density DN.1 and that associated with unreplicated DNA is found in the fractions that contain the light-density IDNA (Figures 134-136). According to this analysis, the terminal half of the chromosome is replicating most actively. Thus chromosome replication is aligned in competent cells. but not at a defined replication origin (near the purA16 locus). The majority of chromosomes appear to have replication points distributed between ura and lys when the competent cells were separated. It is interexting to note that this pattern of alignment is like that ohtained when cells of Strain 168 are starved for an (sicential amino acid."(i) What significance this observation has concerning competence and/or regulation of chromosome replication is highly speculative at this time.

The pattern of replication observed could be explained by competent cells having half-completed chromosomes which continue replication when the cells are placed in a fresh growth medium, or by new initiations oecurring on the terminal half of the chromosome. The gradient method does not allow a choice between these alternatives, but the marker frequency

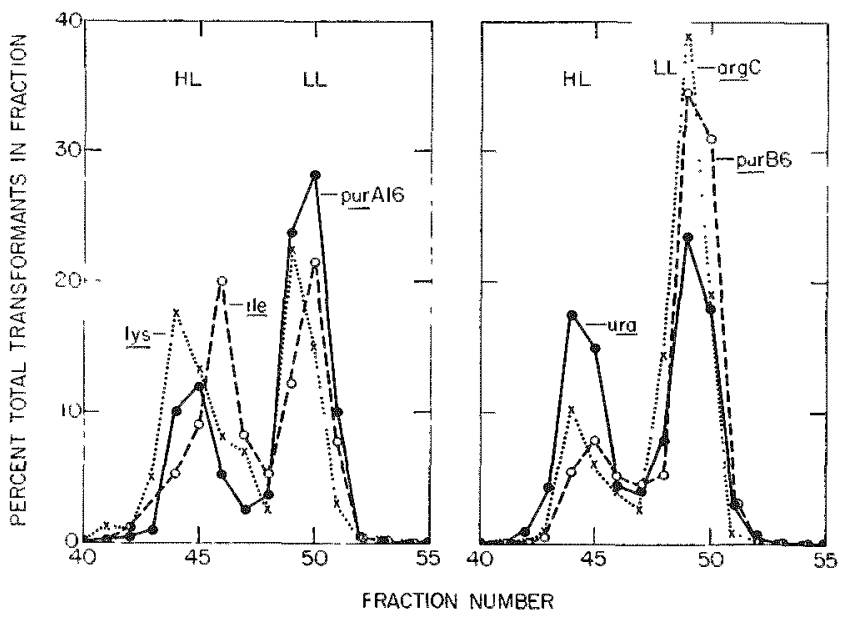

Fit. 135.- I ist ribution of transforming activity for different markers in fractions of $(\mathrm{CCl}$ gradient. I) NA obtained from compet ent cell fraction isolat ed from $I_{z}()$ medium and transio ferred to 1), medium. Total increase in 1)NA synthesized at sampling time was 22 , 2 . Hl. indicates hrbrid density and $L . L$ indieates light density fractions.

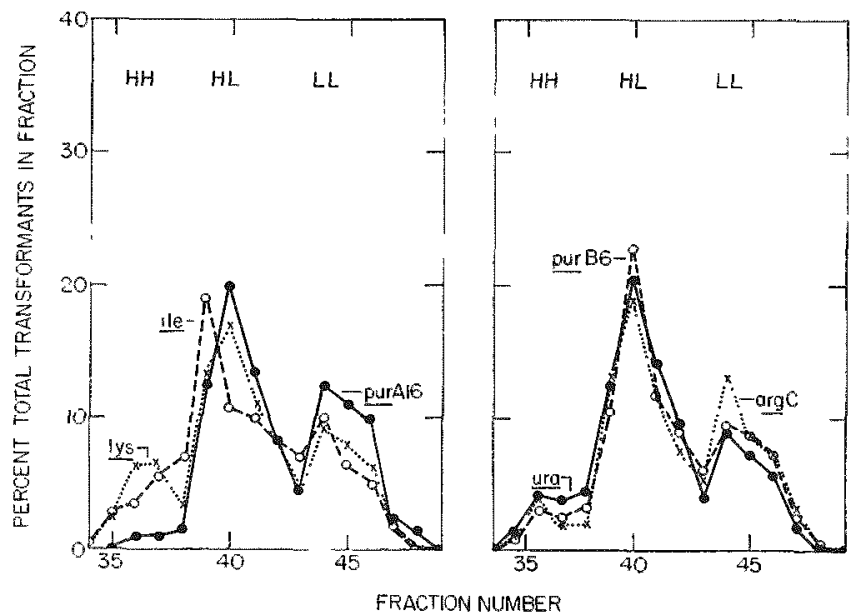

Fra, 136.- Distribution of transforming activity for differ. ent markers in fractions of ('sC'I gradient. T)NA obt ained from eompetent cell fraction isolated from $\mathrm{H}_{2} \mathrm{O}$ medium and tran

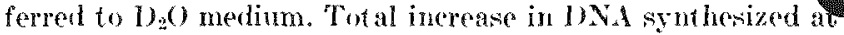
sampling time was 51 ,. HH indeates heavy density, $H L$ indicates hybrid density, and $/ . L$ indieates light density fraetions. 


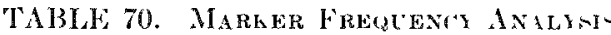

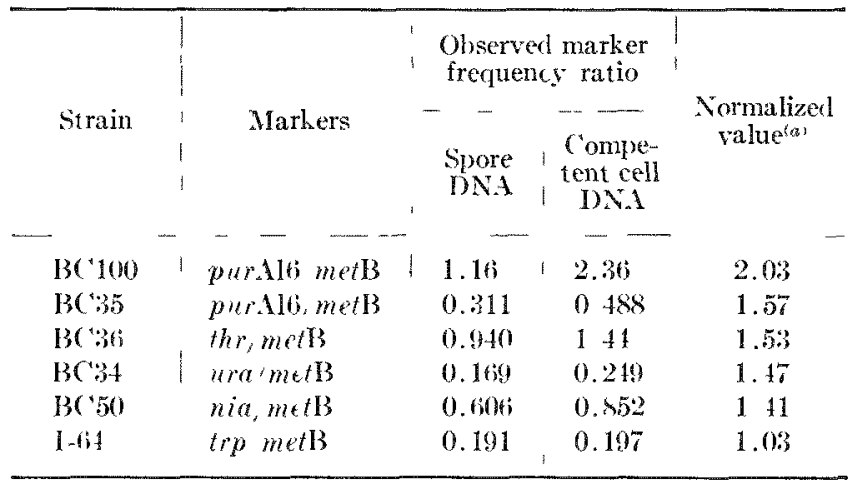

"f1.00) Marker frequency ratio ohtained with spore I) NAI] X [Marker frequeney rat io obtained with competent cell [NA] $=[$ Normalized value $]$.

analy-i doen. ${ }^{(7)}$ In this analysis the frequency of genetic markers in a DNA preparation is determined relative to a reference marker. To correct for differences in efficieney of trans formation between markers these relative values must be compared to a sample with equal frequencies for all marker', i.e., spore DNA. (s) To apply this technique successfully, all genetic markers must be inolatel without preference. Thus, a DNA preparation was used where no part of the sample was dincarded. Removel of low molecular weight breakdown product was accomplished by dialysis. As an additional precaution, the DNA con- centration from the cell sample and that of the spore DNA preparation were adjusted to give approximately equal numbers of tramformant for a given genetic marker. It was observed that unequal DNA concentrations produced anomalous marker frequency ratios, prewumably becatue the sopes of the plots of DNA concentration $r$. frecueney of tram-formation are not equal for the different markers. In fact, thi- relationthip maty not be linear for some genetic markers.

Renlt of the marker frecueney analysin, shown in Table 70 agree with the gradient analy is and confirm that the competent B. subtilis cell po-mesece at partially completed chromomome which ha initiated replication from the defined origin. This in indicated by the oburration that the normalized pur.16 met $\mathrm{B}$ ratio is highent with no normalized marker ratio excoteding that of a marker preceeding it on the replication matp (Figure 134). The very alrupt drop in the normalized marker ratio, between purA 16 'metB and purbi metB, suggeste the initiation of a new round of replication, perhaps during the wa-hing and separation proceduren. In addition, the rery gradual deeline in the normalized marker frerueney, between puris6 met $B$ and nite met $B$, and the second abrupt drop. between nis 'met $\mathrm{B}$ and trp 'met $\mathrm{B}$, indicate that the majority of chromo-ome have been replicated at lea-t as far ac ura and nia.

As demonstrated in the gradient analy-is, the ter-
0

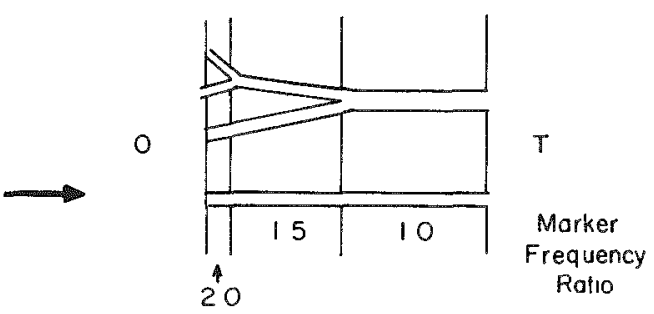

Competent cell

After Separation on Renografın
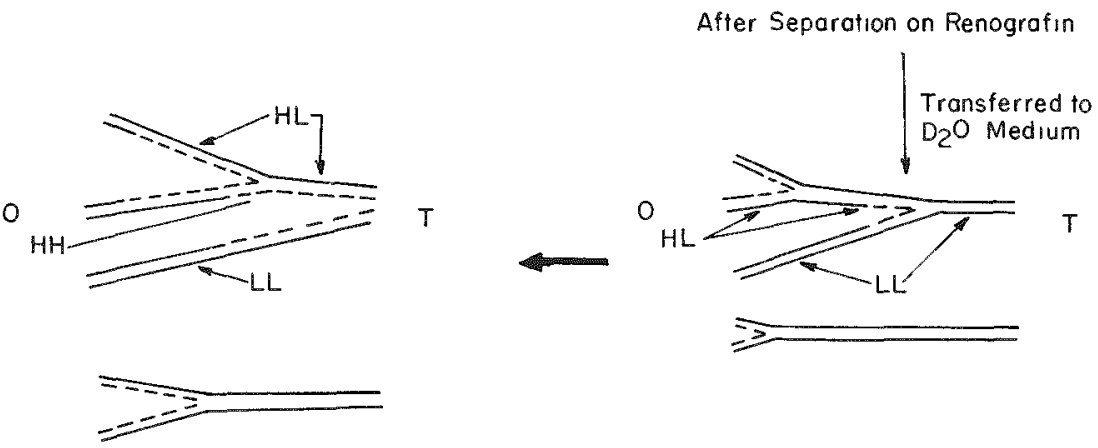

Fir. 13i. Nodel for chromusome replication in competent Is of $B$. subtilis 168 . $L L$ designates I) NA synthesized in $\mathrm{H}_{2} \mathrm{O}$ ) medium- both strands of light density. $H L$ designates IDN.t sy nthesized onfe in $\mathrm{D}_{2} \mathrm{O}$ medium parental strand of light density and daughter strand of heavy density. $H H$ designates
DNA swnthesized twice in Mo M medium both strands of heavg densit $\mathrm{V} . \quad-$, DNA made in $H_{2}$ ) medium and - - DNA made in 1$)_{2}(3$ medium. $(1$, origin of thromomome replication; 'T, terminun of chromosome repliation. 
minal portion of the chromosome replicates first and then the proximal part, to the extent that all markers are equally represented in the once-replicated DNA (see Figure 136) when DNA synthesis has increaned by approximately $50 \%$. It is important to note that the genetic marker replicated first are now beginning to replicate a second time (their activity is apparent in the heavy fractions). This is true for all markers but the purA16 marker, in accord with a marker frequency analysis, which indicates that some chromosomes have replicated during the separation procedure and before transfer to the $\mathrm{D}_{2} \mathrm{O}$ medium. All of these observations, taken together, suggest that the competent cell contains one half-replicated and one fully replicated chromosome. During the separation procedure, one arm of the partially replicated chromosome initiates and replicates at least to the purA16 site. Cpon trunsfer to the $\mathrm{D}_{2}(\mathrm{O})$ medium, the halfreplicated chromosome is completed, followed closely by the completion of the alrealy initiated sister chromosome, before subsequent initiations and replication from the origin occur (which accounts for the murA16 marker activity in the hybrid density fractions). This in represented diagramatically in Figure 137 and forms part of a proposed model to explain competence in B. subtilis. ${ }^{9}$

The joint tran-formation of two umlinked genetic markers ham been taken as a measure of the fraction of the total population that is competent, since it is asumed to be a function of two, random independent events. (10) Howerer, if transformation is inHuenced by replication, as shown in an earlier -tudy, ${ }^{(3)}$ this anumption would be invalid. This rela-

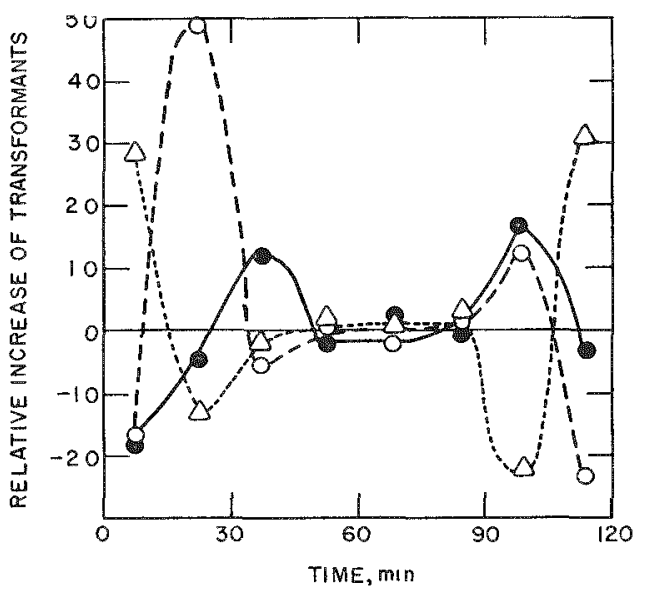

Fiti. 138.- ('hanging efficiencies of tran formation in competent rell fraction during incubation with dome INA. Relative values obtained be subtracting relative increase of all classes of transformants from relative increase for a given marker. $\triangle$, met transformants; 0 . thrt transformants; and $-l e u^{t}$ transformants.

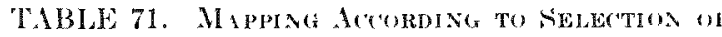
DOI BLE TRINGIORMAN IS

\begin{tabular}{|c|c|c|c|c|c|}
\hline Genetic markers & $\begin{array}{l}\text { Frequency } \\
\text { of single } \\
\text { transfor- } \\
\text { mations }\end{array}$ & $\begin{array}{l}\text { Frecyuency } \\
\text { of double } \\
\text { transfor- } \\
\text { mations }\end{array}$ & $\frac{f(a) f(b)^{(a)}}{f(a b)}$ & & $\begin{array}{l}\text { Rela- } \\
\text { tive } \\
\text { map } \\
\text { distance }\end{array}$ \\
\hline$-\quad \ldots+\ldots$ & $\ldots$ & $-\quad-\infty$ & $-\ldots$ & & - \\
\hline$(t m s-12)$ & 0.00161 & & & & \\
\hline$(l e u)$ & 0001232 & ' & & & \\
\hline$(m e / B)$ & 0.00333 & & & 1 & \\
\hline$(m s-12)(l e u)$ & 1 & 0.00000442 & 0.0391 & & 9.2 \\
\hline$(\operatorname{tms}-12)(\operatorname{mct} B)$ & & 00000461 & 0.0550 & & 13.0 \\
\hline$($ leu $)(\operatorname{met} \mathrm{B})$ & 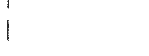 & 0.0000900 & 0.01843 & & 20.0 \\
\hline$(\arg C)$ & 0.00184 & & & & \\
\hline (leu) & 0.000979 & & & & \\
\hline$(m e t \mathrm{~B})$ & 0.00140 & I & 1 & & \\
\hline$(\arg C)(\operatorname{le} u)$ & I & 0.000115 & $10.015 t i$ & 1 & 43.0 \\
\hline$(\arg C)(m e t B)$ & ! & 0.000171 & 0.0151 & : & 11.6 \\
\hline$(l e x)(\operatorname{met} B)$ & I & 0.000189 & 0.00725 & & 20.0 \\
\hline (purAli) & 0.05360 & i & & & \\
\hline$(l e u)$ & 10.01215 & & & & \\
\hline$(m e t l i)$ & 0.0273 & 1 & & t & \\
\hline$(p u r A l b)(l t u)$ & 1 & 0.00149 & 0.772 & & 31.4 \\
\hline (purAl6) (metB) & T & 0.001413 & 0.354 & & 14.4 \\
\hline$(l \in u)($ met $B)$ & 1 & 0.00119 & 0.493 & & 20.0 \\
\hline$(i l e)$ & 0.010522 & 1 & & & \\
\hline$(l e v i)$ & 0.00654 & & & & \\
\hline (metls) & 0.00532 & & & 1 & \\
\hline (ile) $(l+u)$ & & 0.000254 & 0.134 & 1 & 24.6 \\
\hline (ile) (met $\mathrm{B})$ & & 0.00135 & 0.0206 & & 3.8 \\
\hline$(l e u)($ met $\mathrm{B})$ & 1 & 10000320 & 0.109 & & 20.0 \\
\hline$(p u r B(0)$ & 0.00277 & 3 & & 1 & \\
\hline$(l e u)$ & 0.00173 & ! & & & \\
\hline$(m e t 3)$ & 0.00241 & & & & \\
\hline (purBib) (len) & 1 & $0.0000 \times 06$ & 0.0594 & 1 & 37.0 \\
\hline$($ purB(i) $(m e t \mathrm{~B})$ & & 0.0100255 & 0.0262 & & $16 . .3$ \\
\hline$(l \circ l l)(m \in t \mathbf{B})$ & I & 0.000130 & $0(1321$ & 1 & 20.0 \\
\hline$(h r)$ & 0.0517 & & & & \\
\hline (leu) & 0.0239 & i & & & \\
\hline$($ metB) & 0.0167 & 1 & & & \\
\hline$(t h r)\left(l_{t} u\right)$ & & 0.00257 & 0.482 & 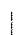 & 39.2 \\
\hline$(t h r)(l, u)$ & 1 & if 000278 & 0.310 & & 25.2 \\
\hline (leu) (molB) & 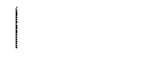 & $1^{0.00162}$ & 0.216 & 1 & 200.0 \\
\hline$(n i a)$ & 0.0232 & ? & & 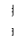 & \\
\hline$(t e u)$ & 0.0137 & i & & & \\
\hline$(m e t l B)$ & 0.0227 & 1 & & t & \\
\hline$(m u l)(l+n)$ & & 0.00170 & 0.0187 & i & 9.6 \\
\hline (nal) (metB) & 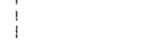 & 0.00178 & 0.0296 & & 15.2 \\
\hline$(l e u)($ met $\mathrm{B})$ & $i$ & 0.0000800 & 0.0389 & 1 & 20.0 \\
\hline$(u r a)$ & 0.001633 & 1 & & & \\
\hline (len) & 0.00215 & i & & & \\
\hline (metlis) & 0.00273 & & 1 & & \\
\hline (ura) (leu) & & 0.001007891 & $0.0+42$ & & 17.9 \\
\hline$($ ma $)(m e t \mathrm{~B})$ & 1 & $0.0000 \times 79$ & 0.0506 & & 21.0 \\
\hline$(l \in a)(m \in t B)$ & 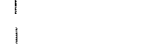 & 0.0000119 & 0.01963 & 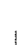 & 20.0 \\
\hline
\end{tabular}

a $f(a)$ and $f(b)$ are the frequeneies obtained for single marker transformations for markers $a$ and $b$ selected independently. $f(a b)$ is the frequenes obtained for double mark transformation for markers $a$ and $b$ selected simultaneousis

(b) Total genetic map taken as 100 units; the distance be tween leu and met $\mathrm{B}$ taken as 20 units (from I) ubnau et al.'11). All other genetic markers assigned map unit values relative to leu or metB. 
conship wat examined again, but with the i-olated competent fraction of eells in which the sub-equent order of chromosome replication has been determined, as already described. It is to be emphasized that these cell were in no way manipulated purporefully to align ehromosomes, other than to make them eompetent. The reults are repremented in Figure 138 and clearly whow that efficiency of transformation for a given marker changes with time and that the sequence in which they reach their maximal efficiency for transormation is the same as the order they replicate in the competent cell. Thus, the probability of a ruces-ful rouble-transforming erent hould increane as a function of the proximity of the two loci to an approaching replication fork. This relationship would then reflect the order in which the genctic markerm replicate and could be used to generate a genetic map. Table 71 presents the data for all posible clasiess of double tran-formants among the markers -elected. It is obvious that the value of clouble trannformants varien-ignificantly in relation to the markers chosen. If this relation-hip is used to generate a genetic map relative to two arhitrarily chonen standard markers, the remaining genctic loci are located in an order that agrees with the order found in already publiwhed genetio maps for B. subtilis (Figure 139)."111 ('enetic mape derigned as at function of double tranformantdo not reflect accurate linkage relationships, but do

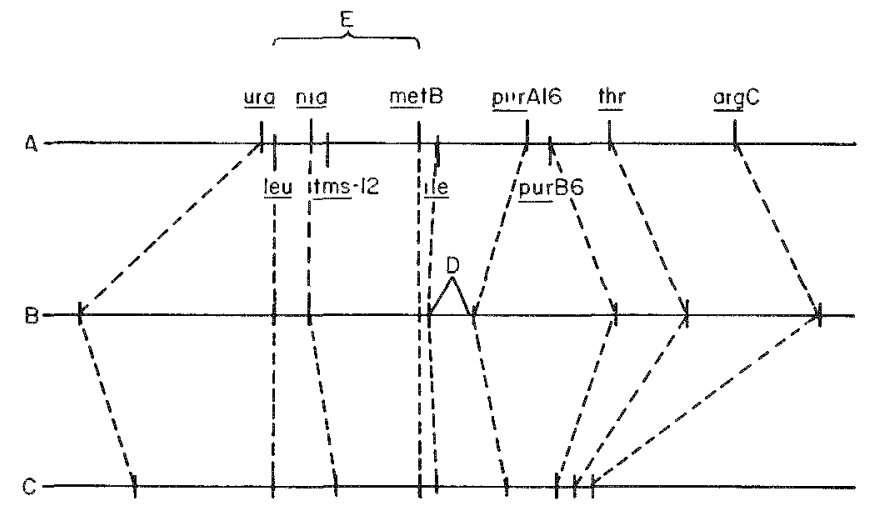

Fict. 139. (ienetic maps of 1 . subtilis chromesome. A. transformatun map based on estimated distances from me $B$; $B$, linkage map of Inbuan et al."11, arranged in the order determined by the transformat ion mapping function; $C$, truns formation map based on estinated distanees from lou; I), map distance based on calculations of ONullivan and suevkat ${ }^{12} ; \mathrm{E}$, all maps hased on assumption that distance from lou to met $\mathrm{B}$ is equal to 20 map units. preent the orler in which the markers replicate. Thene rewlts clearly show that the afficiency of tran-formation in influenced by the replication procem and ronfirm and extend the earlier oberration.

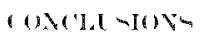

Competent cell- of B. subtilis contain one chromo-one that is half-replicated and another that in fully replieated. The replication pattern produced by placing competent cell in a medium for growth is strikingly sinilar to that obtained when amino acid-starved rells of strain 168 are released from starvation. An anoriation betwen transformation and replication has been eonfirmerl.

REH FHEN 'FS

1. Ningh, 13. N. and 11. P. Pitale. Euriohnent of But illus subtilis transformants by anal centrifugation. I ature 213 ,

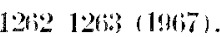

2. Hadden, C'. and F. W. Nester. P'urifeation of competent

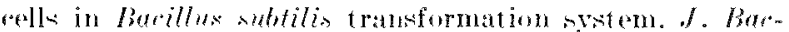
to iol. 95, s7ti 8xis (19)6is).

3. Eriekson, R. J. and W. Brann, Apparent dependenese of

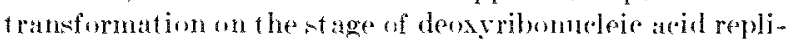

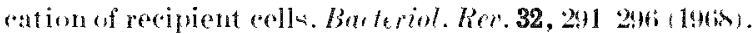

1. Mecarthy, Cand k;. W. Nester. Materomolecular-ynthosis

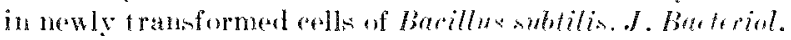

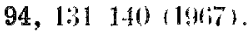

5. Yoshibawa, H. and X. Fuboka. Frequential repliation of barillus subtilis chromosome. Il. Isotopie tramater experi-

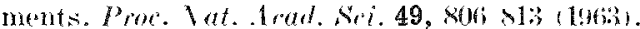

6. Copeland. J. C. The organization and funetion of the bato terial chromosome. Regulation of chromesome replication in Barillue subtilis. The off $e^{2} e^{\circ}$ of amine acod sarvation in Strain 168. "This report.

7. Yowhikawa, H. and N. Suenkat. Sequential replicetion of Bar illas subtilis chromosome. I. Comparion of marker frefuency ratios in exponential and stationary phase eclls.

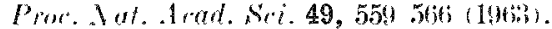

s. l'akahashi, I. The isolation of nuclede awd from haterial

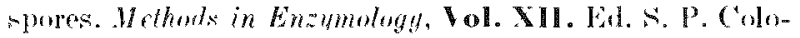
wick and $\mathrm{N}$. O. Kaplan, Arademic Press, Dew Furk, 196is, pp. $109+100$

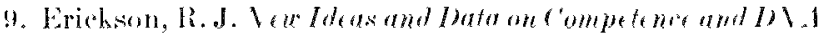
Entry in Transformation of bacollas subtilis. Mipringor Verlage, Barlin, in press.

10. Nester, F. W. and B. 1. D. Stooker. Bios nt hetio lateney

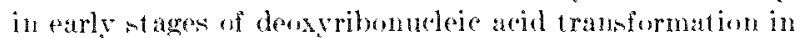

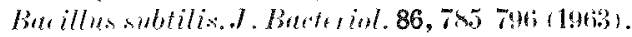

11. I)ubuate, I).. ('. Coldthwaite, J. Simith, and J. Marmuro cionetie mapping in Barllas subtilis transformation syo-

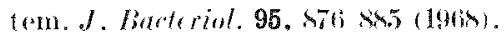

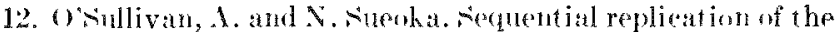

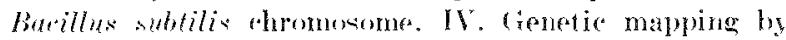
den-ity transferexperiment.J. Mol. Biol. 27, 340 :3tio. 


\title{
RADIATION PROTECTION
}

\section{METABOLIC AND THERAPEUTIC STUDIES OF PLUTONIUM. $V$.}

\author{
Irthur Lindenbaum, Marcia II. Rosenthal, John .J. Russell, \\ Elizabeth \$. Morett, and Marquerite 1. Simyth
}

PI RPOCE AND METHODS

The broad objective of this program is the development of new approaches to the therapy of poinoning by radioactive and nonradioactive metals." Plutonium-239 han received increasing emphasis in this work during the lant several years, (2) becaune its growing use in public power reactors and it high radiotoxicity in hone make it an important radiological health hazard. The varying tendency of compoume of plutonium (as well as other polyvalent heatry metaln to hydrolyze and polymerize, both in solution and in vivo, result in restiable particulate characteristics which influence the deposition, retention, effectivenem of therapy, and delayed pathologixal effect of the plutonium. Thun, information obrained with plutonium aids in understanding the beharior of other nucliden of the actinide, lanthanide, and ratre earth serie- in living tisuce. In addition, plutonium rompound provide uneful information regarding the tran-location and deposition of colloids and materomolecule in tisutes.

Following the demontration of the effectiventess of chelating agent such as diethylenetriaminepentaalestic acid (DTPA) for removal of plutonium and related element from blood, bone, and soft tirulues, resent attention has been directed toward the development of additional therapeutic approachen to the remoral of the plutonium not readily removed from liver and bone by IOTPA.

Irelated to the plutonium program is a concomitant investigation ${ }^{(3,4)}$ concerned with the nommal procsures of raleium uptake and depletion and the biochemical transformation in the calcifying matrix of prooscous cartilage. Thi-study is designed to provide a better understanding of the uptake of metal cation, including -uch divere radionuclides as plutonium and strontium, in cartilage and bone.

Thin report describes recent -tudien of the efferets of the physical form of administered plutonium on distribution and retention in tissues and on longterm effect, the estimation of plutonium deposited in bone marrow and in cellular and subcellular ele- ment in the liver, and adjunct therapy with glucan to remove hepatic plutonium not accesible to the artion of DTPA.

PROGRE AS RTPORT

Eiffects of Physiral Form of Plutominem on Tisalt Distribution and Retention and on Lang-Term Effects

The -tudy of the influence of the physical-chemical propertite of injected plutonium on the long-term effeet of deposited plutonium in a continuing project. Previous work has shown that, with equal amount in the moure skeleton, polymeric plutonium is lems areinogenic than monomeric plutonium, premumaby breause the smaller fraction deposited on bone surfaces reduce the amount of radiation delivered to endorteal cells.'5) To explore thene relationship further, an experiment is in progres in which equal initial skeletal burden were achieved in two series of mires given a -ingle intravenous injection of ${ }^{239} \mathrm{Pu}$. The first eries received graded polymeric plutonium of narrow particle -ize range prepared by a differential precipitation technique;'(2) the second series reresed monomeric plutonium of $<0.01-\mu \mathrm{m}$ particulate diameter (Table 72). Although only one-fourth of the miee were dead by 400 day, a summary of the results obtained "no far is of interest. The tissue distribution and retention of the two forms of plutonium have been determined in miec designated for the purpone and selected at random for serial sacrifice at $1,3,6,20,44,90,181$ and 350 days.

After injection of the monomeric form, distribution and retention of the plutonium were generally comparable to those deneribed carlier for an unfiltered monomeric plutonium, ${ }^{5}$ except for a slightly higher initial bone hurden. At 6 days, $455^{\prime} \circ$ of the injected dose wa in the bone. It in extimated from studies with iron-59 (reported below) that less than $1 / 20$ of the total bone burden was in the marrow.

After injertion of the polymeric plutonium, high uptake in liver and spleen to be expected with thi- form'21 was observed. At 6 days, these organs 
ontained $84{ }^{\prime}$, and $6^{\prime} c$ of the amount injected, renpectively, while the total skeletal burden was $3 \%$. Almost two-thirds of this bone burden is estimated from the iron-59 studies to be in the marrow. In the group with the highest level, at 6 days, the specific activity of plutonium in the liver and spleen was about 0.14 and $0.12 \mu \mathrm{C} i$ ge pepectively, but in the marrow it was stimated to be lesw than $0.01 \mu$ ("i $g$ in spite of the high relative concentration of plutonium in marrow compared to hard bone. Between 6 and 350 days, the -pleen burlen did not rhange, although the liver burden dereased by about one-third, and the bone burden, as represented by the femurs, increased about fiveloll. This tranklocition to bone confirm- earlier obmervations. (2)

In the dose rangen uned for this experiment, the amount of either form of plutonium injered did not influence the fraction deposited in any tissue.

The serially-sacrificel mice also were uned for hi-topathologie, antorarliographic and limited hematologic studies." The remainder of the mices were maintained for duration-of-life studies and sacrificed when death appeared imminent. At 400 days. survival of these long-term miere was either the same as, or higher than, the controls, exeept in the two groups that received the highest levels of plutonium.

The 52 duration-of-life mice that recesved the highext level of polymeric plutonium $(7.8 \mu \mathrm{C} i \mathrm{~kg})$ died between 128 and 254 days; the primary eause of death in all mices apparently was anemia. Breause death meecifiestly attributel to anemia is most unu-ual after plutonium alministration, ${ }^{\text {(n) }}$ the results to date from this group will he summarized in more detail. Included are ob-ervations on 47 mice a acrificed from 1 to 181 divis and on the 52 duration-of-life mice.

Evidence of possible hematopoietic damage was fors suggerted by the white ecll count at 90 dars, which was about one-third of the control ralue. Leibopenia wa- prenent in all mice at the end of lifta as indirated by the almont complete absenes of white cells in blood smears and by the "xtremely thin buffy cout. There was no evidenes of septicemia. Hemoglobin and hematocrit valuen in individual serially-sarifiesd miee at 181 days ranged from normal to about one-half normal. All longeterm mire were markedly anemic at end of life: in the 17 nires sampled from 128 to 254 days, the mean hemoglobin was $1.9 \mathrm{~g} 100 \mathrm{ml}$, compared to $17 \mathrm{~g} 100 \mathrm{ml}$ in controls, and the mean hematocrit was o.4.; , compared to $46^{\circ}$ ' in control.

liver degeneration occurred in all mice of this group

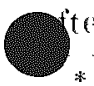

* We grat ofully atchowledge the adviee and remeneration of Dr. Thomas L. Frit $z$ and I)r. (arl li. Rehfeld in thene phases of the work.

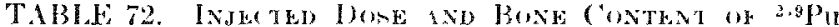

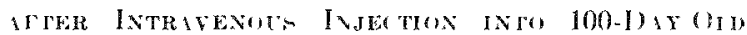
CF1/Anl Fena Mice

\begin{tabular}{|c|c|c|c|c|c|c|c|}
\hline & & $\begin{array}{l}\text { Polymeric } \\
\text { plutonium }\end{array}$ & & Monon & acric $p$ & troniun & \\
\hline- & - & & & & & - & - \\
\hline $\begin{array}{l}\mu(\text { 'i kg in- } \\
\text { jected }\end{array}$ & 1.1 & $2.2: 3 . x$ & $7.80 .0 \%$ & 0.14 & 0.27 & 0.47 & $0.96 \mathrm{~s}$ \\
\hline $\begin{array}{l}\text { u'i in bone } \\
\text { at th dayss }\end{array}$ & 0.9 & $1.7: 3$ & $60 . x$ & 1.6 & 3 & 5.3 & 10.8 \\
\hline
\end{tabular}

"rative chatngen were noted hi-tologiodly. The denenteration wan mainly in the entrolobular regions, but in more severely damaged livers there was difiune degenteration and coagulation neeromi- At 90 and 181 days, and in all duration-of-life mice examined, there leion- were of the same nature but more-evere: the s.velity was not roprelated with time. No regenterative ti-sue was noted at any time.

Atrophy of the spleen wat a comeintent rhange. At 6 dites the spleen weight was slight le reduced. and by 20 days it was one-half of the rontrol weight. The mean spleen weight of the duration-of-life nice was $8.7 \mathrm{mg}$, compatred with a control woight of 100 mg. Atrophy. with ome low of the lymploid follicles, was wen at 44 day- By 90 and 181 day-, there was almo-t complete aplesia of the lemphoid timene, but -inuroilal and reticular timenes were retained. I few

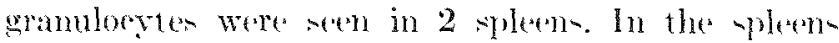
of duration-of-life miere, lymphoid elements were ats-

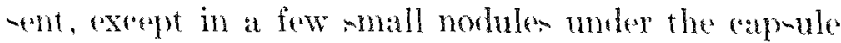
in some mice. Thene nolulen were probably the sames a- those -een in varying numbers in half of these miets at antoper. Whether theme nodules represent resilual or regenerative lymphatic timse is not clear.

Alhough the lymph nodes and thrmus of many of the duration-of-life miee were mall. fairly lape

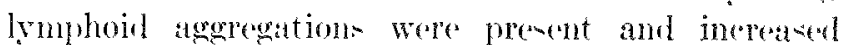
number of plitema erells were seen in some niece. Hemorrhage or hyperemia with dilated rescels or sindarids congented with orythroryten were often wen in the nodes. Eetopir hematopoiesis. involving

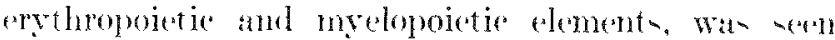
in the node of 7 of the 16 mice eximined; thin wa nore common in mice that -urrived 200 dares ar more. The myelopoiesin i- eon-idered compensatory rather than neoplastic herause of the presence of both erreth-

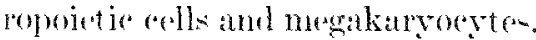

The kidney- Were comparible to thome of eontrol mice, exeept for ereppic hematopoies in one kidney irmo a duration-of-life mone at 196 datr.

Other charateristir finding in this group inrluded enlatrged, sometimes hemorthagic hearts and peterehical hemorrhagen, u-nally in the skin. 
The bone marrow wa- everely damaged after 7.8 $\mu$ Ci he of polymeric plutonium, as shown by blood -tude and by the death of all duration-of-life mice with anemia. Bone eetions and marrow prints of a terminal mone at 133 day - howed general aplavid of marrow, but there wan con-iderable variahility anong indivilual bonem.

Marked increase in skeletal demity, hown by incereases rallio-opacity on the roentgenogram, wat chararterintic of thene mice. Hintologically, increased number am thicknem of traberulae and thickened cortical hone were obrious.

No bone tumor were obuerered in the mice of this group; most had died before the expected latent period wa- over.

With lower levels of polymeric plutonium, lens hematoporetic damage wa seen. From about 300 days, hematopointic death dil occur, mont commonly in the mice that receiver $3.8 \mu \mathrm{Ci}$, kg. Howerer, they aho died from other caune, including onteogenic atrooma.

After monomeric plutonium, outeogenic sarcomas aho have been oberved. The hortent interval to death with an identified bone tumor was 283 dayafter plutonium injection. The limited data available andirate that there was probably 10 -ignifieant hematologle effect of the monomerie plutonium through 2.50 day . No histopathologic lesion- were oberved during this period.

\section{Localization of Plutonium in Bone and Liver}

Ifeavurement of plutonium in marrou and intact bone.-The fraction of plutonium in the marrow of a

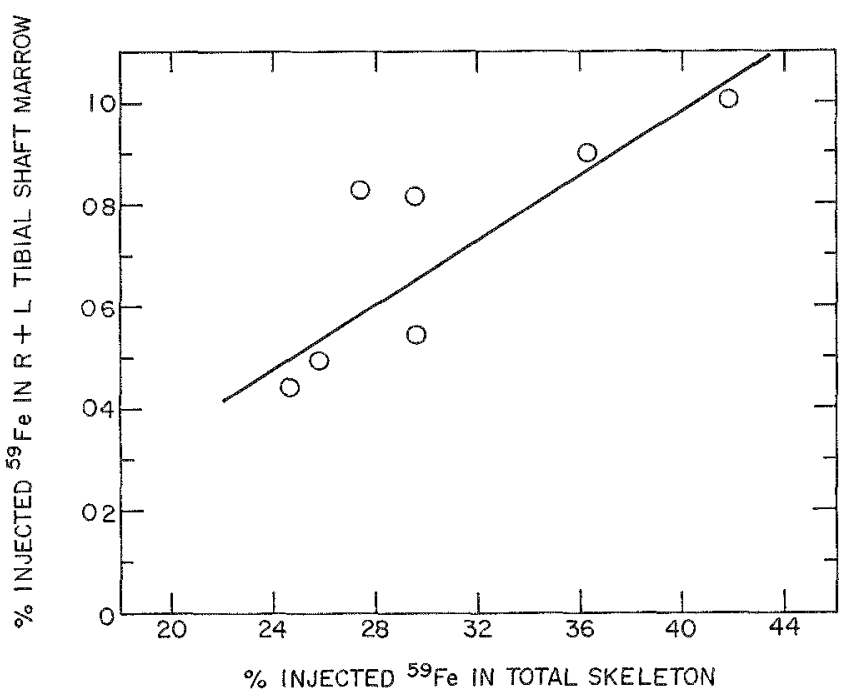

Fit 140 Relatomshop of mon-59 uptahe in monse tibial shaft marrow to total skeletal uptake at $5 \mathrm{hr}$ after intravenous injertion tandard 9.0-1nm segment of the mouse tibia has bec ured an one measure of tissue dintribution after the injection of different form of plutonium. ${ }^{17}$ A marrow index has been propo-ed, ba-ed on the estimation that the amount of plutonum in the marrow of thiregment is $z_{3}$ of the total tibial marrow. (2) Meanurement of the plutonium in the total marrow and in individual hones are atho needed to asmess more exactly the role of hone surface and hone marrow plutonum in the induction of bone tumor. Pending the development of a satisfactory chemical eparation of marrow and bone (nee below), a method baned on the uptake of "Fe by erythropoletic tisste is being uned to obtan this information nderectly.

Ifter intravenou- injection of ${ }^{59} \mathrm{Fe}$ in $1^{\circ}$ c citrate, mice were sacrificed at $5 \mathrm{hr}$ and perfuned with -aline to remove the blood. Radio-iron uptake wa determined in all keletal parts, including the separated marrow and bone of 9 -1nm tibial shaft regment. Although the total akeletal uptake of ${ }^{59} \mathrm{Fe}$ (assumed to $b^{2}$ equiralent to the marrow uptakel varied wudely among individual mice (Figure 140), there was a rearonably constant relationship between the uptake of "Fe in any one bone and that in the total slieleton. "The sample of marrow an the tibias was as reliable an larger -amples for calculation of total skeletal iron. Bared on the data to date, therefore. an average factor of 43 in uned in the mouse for conrersion of the marrow in two tibial cegmente to total-body marrow. The work with radio-iron has aloo hown that the tibial regment contains about $\because$ of the total tibial marrow, rather than $\%_{3}^{\prime}$, as estimated earlier. (2) To asmem the value of radio-iron in computing the distribution of plutonium, further work will include double-tracer experiments with ${ }^{59} \mathrm{Fe}$ and $239 \mathrm{Pu}$.

Becaune extrapolation to man iv a long-range objextive of this program, it is important to compare the metaholism of different form of plutonium in larger -pecies (rabbit and (log) with that in the mouse and rat. In the rabbit, phy-ical separation of marrow from bone for plutonium analy is is simplified in the long bones, particularly in the tibias, which have a minimum of spongy bone. The more extensive traheculation in the long bones of the dog, and in the rpine of both specien, however, prevents complete phyical removal of marrow. A continuing search for an effective chemical procedure for marrow removal in therefore in progress. "NCS" INuclear Chicago ( $\mathrm{C}$. ), a quaternary amine dissolved in toluene, is a promising compound for removal of the organi material from halved bones of both rabbit and doc To determine condition that will insure minimum removal of plutonium bound to bone surfaces, a com- 
parison is being male of rhemical and physical removal technigues, using plutonium-injected rabbits.

The liquid reintillation method for plutonium analysis is complicated in the case of large amounts of tissue le.g. dog femur or liver) by exees amount of interfering inorganic remilues. To avoid this problem, a liguicl-liguid extraction technigue has been developed, in cooperation with MI. M. D). Fairman, that unes the oreanir solvent TIOA (triimootyl amine) and permits recovery of $90 \%$ to $100 \%$ of the plutonium adderd to large massen of synthetic hone a-h."

Microlistribution of Plutonimm in Lirer.-Autoradiographic -tudies "s airned at the quantitative estimation of plutonium deposits associated with tissue strueture at the cellular and subcellular level are continuing. To stablish the validity of conversion of alpha track rount - in a histological setion to mecific tisue actirity. cortain geometrical assumptions are being tested. If these asmumptions are correct, autoradiograms prepared from equivalent sections of the same time hould give the same value for the amount of deposited plutonium. whother determined at different exposure times or whether track are counted at optical microsopic or alectron microseopic levels. Thene valuen should agree with the value for timsuc plutonium obtained by gromi radiochemical analysis. In preliminary comparison of autoradiograns of liver, the variance from the gross radiochemical ralue after 2 or 6 day exposure was one to twofold at the ontical microsopic level, and two- to fourfold at the electron mieroncopic level after 3 or 6 month: exponure.

The retention of polvmeric plutonium in rat lires is known to involve uptake by at least one intracellular organelle, the lromome. ${ }^{20)}$ Further efforts are being made to learn more about the deposition sites and transport of radiotetive macromolecules. In particular, the effects of colloidal and particulate properties upon their partition among cellular and extracellular structures and among different cell types in the liver are being studied. A compari- on of the rex- $^{-}$ tention of monomeric and polynerie plutonium in mouse liver homogenatent indicates that the frational dimtribution of injected monomeric plutonium is nearly irlentical to that of polymeric plutonium. Thus, lysosomal asociation is indicated for both forms of plutonium. However, ahout $46^{\circ}$, of the total liver (oontent of the monomeric plutonim was accounted for in all the intracellulat components mea-ured, whereats only

* This work was performed by Raymond K. Hert $\%$, who was a articipant in the 1969 ANL Summer student Training Pro ram.

† This work was performed with the assistance of Johannat Janephon during her tenure as an . IC'M semester st udent. about $\bar{\sigma}^{\prime}$, of the polymerie plutonium was similarly identified; most of the polyneric plutonium was ar-ociated with liver component renser than mitochonIriat.

Attempts have been made to jolate intact parenchrmal and littoral cell types from rat and mouse liver and to further inolate cell membranes from each of these cell types. These have not been entirely succestul beraun of inaderuate techniques. Howerer, the inolation of mall numbers of cells of each type amb of parenchymal rell membrane has been achieved of Athough groses radiochemieal analy-i of asoociated plutonium is not feasible. it is hoped that autoradiography of isolated component, will yitel useful information for application to the problem of transport merhanisms and therapeutio lemoral.

\section{Therapentio Studie with Glucan}

In aceordane with the long-range objective of this program, which is the development of more effective therapeutic procedure, attempts are being made to ramove deponited plutonium from tisive sites not accenible to rhelating agents weh as DTPA. Recent work has demonstrated the effectiveness of glucan, a purified poly-accharide oltained from brewer's yeast Gacheromyles cerevisial, in acelerating the removal of polymeric plutonium repo-ited in mouse liver."1. 11 Both the chemiral and physical properties of gluean, including particle size, are now considered to be important parameters in it therapentic effect. It is, therefore important to invertigate the relation between these properties and the effectiveness of wollcharacterized gluoun obtained from reast and other soureos.

Several batches of brewer's veast glucan were prepared $b x$ a methol emploving alkaline hydrolysis followed hy whanol-ether extraction.s Microscopic "xamination indicates that the product obtained con-ist nearly uxclusively of smooth oroid particles of approximately 3-pm diameter. In addition, we have recently received samples of glucans irolated from another organism, the fungu, sclerotinea, from Prof. I. Satomura of Onaka City Cniverity, Japan. The toxicity and efferetivenem of these sulstances will be testerl in mice injected with plutonium.

\section{other Related Activities}

The problems of distribution, retention and removal from living tis-ues presented hy plutonium are prototrice of a large group of rarlionuclirles which include the actindes. lanthanides. and rare earths. The highly

$\$$ We thank Eizabeth cerny for valuable assistance in this phase of the work.

"lhis work was orried ont hy Ratamond $k$. Hertz. 
variable tendency of these clements to hydrolyze and polymerize under physiologieal conditions has resulted in large uncertainties in the estimation of hody burdens, determination of eritical organs, and dosimetry of indiridual tissues, both in animals and in human subjects. Accordingly, in 1967 ICRP Committee 2 activated a task group charged with the responsibility of gathering pertinent chemical and biological data on the effect of physicochemical properties on the metabolism of these radionuclides. "Two Argonne staff members, Drs. A. Iindernbaum (Chairmam and M. W. Ronenthat are members of this task group. The first draft of a report, entitled "Mretabolism of Plutonium and Related Elements, and their compounds," is now in preparation.

In aldition to ICRP activities, one of Us (A. Is.) is also a member of NCRP scientific Commitee 30 , whone task is to prepare a report on the pleysical and biological properties of rationucliden.

\section{CONCLLTONM}

Protracted hematopoietic leaths oceur in miere after injection of $7.8{ }_{\mu} \mathrm{C} \mathrm{i}_{/} \mathrm{kg}$ of polymeric plutonium of narrow particle size range which is deposited heavily in the reticuloendothelial organ. The concentration in the marrow was estimated to be less than that in the liver and spleen by an order of magnitude. All mire died of anemia between 4 and 9 months. This anemia was characterized by marrow aplaria and hy hematorit and hemoglohin levels almost 1/1n of control. Ectopic myelopoiesis occurred in lymphatic tirsues in the later deaths. Leukopenia. hydropir degeneration of the liver, inarked splenic atrophy, peterhial hemorrhages. and increaned bone density were atho observed. After lower dones of this polymeric plutonium, hematopoietic deaths oceurred at longer intervals, but some miee died from onteogenie sareomas and other conditions.

'l'ranslocation of plutonium from liver to bone' after injection of polymerie plutonium has been confirmed.

By une of radio-iron as a tracere for bone marrow in mice, a factor of 43 was obtained for conversion of the marrow of a standard tilial segment to total body marrow. Based on this fartor, almont two-thirds of the - Keletal burden of this polvmeric plutonium is in the marrow, as compared to len than ${ }^{1}: 0$ with monomerie plutonium.

\section{REFERFNCES}

1. Lindenbaum, A. and M. W. liosent hal. General objectives of the program on therapy of poisoning by radiesetive and nomradiostetive metals. Argonne National Laboratory Biologieal and Jedieal Leseareh Division Annual Report, 1965. ANL-7136, py. 19) 192 .

2. Lindenbaum, A., M. W. Rowent hal, C. J. Lund, J. J. Russell, M. H. Smoler, E.S. Moretti, and H. Brown. Met abulic and therapeutic studies of plutonium. Ir. Argonne National Laboratory Biologieal and Medieal lesearch Division Anmual leport, 196is. ANL-7535, pp. 60 tis.

3. Lindenbaum, A., A. O. Jibril, and W. M. Westall. Biochemistry and ion binding of connective tissue. Argonne National Laboratory Biological and Medieal Research Division Annual Report, 1964. ANL fort, pp. 1115.

4. Lindenbaum, A., M. H. Smoler, and Q. T. Smith. Wiochenistry and ion binding of connective tissue. III. Argonne National Laboratory Biolngical and Medieal liesearch Division Annual Report, 1968. $\$ N \mathrm{I}_{4}-7535, \mathrm{pp} .67-6 \mathrm{~s}$.

5. Rosenthal, M. W. and A. Lindenbann. Osteosareomas as redated to tissue distribution of monomeric and pols merie plutonium in mice. Delayed Effertor of Bom Secheng ladiomeclides, Proc. Symp., Sun Valley, Idahe, Sept. 11-14, 19ki, Hd. ('. W. Mags et al. The Cniversity of [tah Press. Salt Lake (it y, 1969, pp. 371 38t.

ti. Prosser, ('. I. The clinical sequenere of physiologialeal effects of ionizing radiation in animals. Ratiolog! 49, 240:313 (1917).

7. liosenthal, M. W. J. H. Marshall, and 1. Lindenbaum. Autoradiographic and radiochemial studies of the effect of colloidal state of intravenonsly injected plutoninm on its distribution in bonfe and marrow. Diagnomis and Treatment of Deposited liadionuclides, Proe. Symp., Richland, Waskingtom, May 15 17, 1967. Excerpta Medica Founda. tion, Amsterdam, 1968, pp. 7380 .

\&. Lindenbaum, A., M. W. Rosent hal, and M. H. Smoler. In an oradiographic study of the changess in distribution of polymerie plufonium in mouse tissues. Diagnes is and Tratment of Deposited Rodionuctides, Proe. Symp., Richland, Washingtom, May 15-17, 1967. Excerpta Medica Fondadation, Amsterdam, 19068 , pp. 6.572.

9. Lindenhaum, A. and M. H. Smoler. High-resolution antoradiography of intracellular plutonium. Seitnef 165, 192$194(196))$.

10. Rahman, Y. R. and A, Lindenbanm. Idrosome particles and subeallalar distributions of polvmeric tetravalent plutonium-230. Radiat. Res. 21, 575 583 (1961).

11. Rosenthal, M. W., M. H. Snoler, and A. Lindenhaum. combined reticulofendothelial stimulation and long-term, intermittent IDTPA therasy in poisoning by polymeric plutonium. Diagnomis and Tratment of Depesifed liationulides, Proce. Symp., Richland. Washington, May 1517 , 1967. Fererpta Medica Fondation, Amsterdam. 1968, pp. $40,412$. 
BIOCHEMISTRY AND ION BINDING OF CONNECTIVE TISSUE. IV.

\section{Irthur Linderbaum and Quereton T. Smith}

PIRPONE AND METHOD

In the removal from the horly of many toxie radioelement, including the polyvalent, heavy metals, such as plutonium, bone is the critical tineue. $A$ better under-tanding of normal atud abnormal physiological procenes in bone, therefore, in of practical an well at fundamental importance. The overall objectiven of thi- project are to investigate the biochemieal rhangese taking place in rartilage during caleification and onsification, particularly with regard to changem in the muropolyacharide and mucoprotein componento, and to determine the involvement of such -ubtarees. in the areunulation of normat and ahomat metals such as calcium and plutonium. The ohjectiven of present experiment- are 1$)$ to determine whether there are differences between the mueoprotein rompoition of bovite natal cartilage a tim- that doen not omify and the empo-ition of different resion of calf sapular

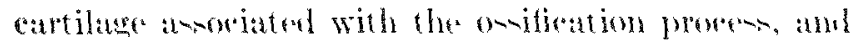
21 to measure the hinding of intient artilage and of irolated muroprotein components with caleium and other metal ions.

PRORKRTS REPORT

Previous worken hat heen deroted to the inolittion of mucoprotein sulferaction- from bovine na-al septum catrtilage and from pressucom cartilage of the resting and hypertrophe zonen of ralf scapulat. using modifications of the extrattion method of sibubert and an-ociate. (2) These inolated mucoprotein subfraction have now been analyzed with rempect to yield. ecpuivalent weight, uronir acid. hexo-amine, sulfate, sialic acid, atcium, we. Except for vield, few difierencers have been noted.

Po-ibly -ignifieant rariation in vield have heen foumd in the PP-I.4 and PP-I.6 -nbfractions. Calculated at the fraction of total PP-1, extracted, in nawal reptum ahout 10; of the PP-I, was PP-L4, a compared with 0.7 to 0.9 , in the resting and hypertrophic zone: of calf acapular cartilage. Fimilarly, over twice a much of the PP-I.6-ubfraction was foumd in the hypert rophice zone as in the resting zone of calf sapula. There variation in vield are not anociated with appreciable differencen in the other malytical raluen obtaineel.

In prelinimary work conterned with the meaturement of affinity rontant between rartilage components and metal ions, a comparion hat been mate between the ion exphange and erguilibrium dialy-io method for mea-uring the binding of calcium to PP-L -ubfactions of nasal wptum and calf scapular "altiliare. Problem related to riconity and coneentration appear to by lew tromblemene with the ion exchange methor. liarly results, although inemplete, -how a low order of binding with ral lium $(\log K \sim 2)$, with lifferenees of no more than an order of masnilute among all PP-I, -ubfraetion. (On the hasis of prement evidenese the ameunt of retleium bound at eache region of (a-ifying cartilage would appeat to despend on the amount of oreanir ligand available for binding.

Thi- work is being supplemented by paralled sidedis w ith plutonium in small animals, u-ing autoradiographe to localize the radionuclinle at specifie siten in ratrilage and bone.

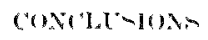

Invertigation of the differences in the composition of wifying and nonomifying rartilage. and the rignifieance of such differencen, will be continued. both for at better undertanding of metal ion uptake in bone formation and for therapeatic manipulation of ardionuclide- ineurpurated in bone.

\section{RHF CREVICH}

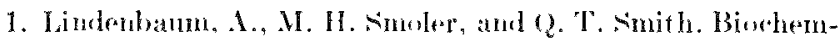
istry and ion binding of rounective timste. III. Argonne vafional Iaburatort Biologioul and Medieal lieneareh

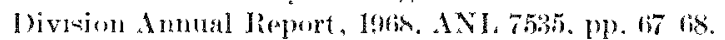

2. Pal, s.. P. T. I haganges, and M. Sehubert. The separation of new forme of the proteingelysalecharides of bovine natsal

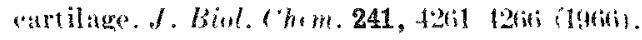




\section{RESTORATION OF LETHALLY UV-EXPOSED AND HN2-TREATED AMOEBAE BY TRANSPLANTATION}

Eduard H. Danicls and Judith .M. Ma Viff

PURPUL AND NR'HHOD

Recently, a large amoeba found in Colorado was identified a a new strain of P'clomyxa carolincnsis. (1) We determined it senmitivity to ultraviolet radiation (IV) $22.74 \mathrm{~mm}$ and nitrogen mustard IIN2) with a riew toward using it in studies of radiorestoration and recosery after lethal do-e of HN2. It is well known that IV damager I) NA in cells, and that nitrogen mustard react primarily at the $N-7$ powition of the guanine ring in 1DNA. ${ }^{(2)}$ Thi exploratory -tudy invertigaten way to resue cell- from lethal IT and HN2 injurien. Additional intracellular [T and $\mathrm{H}_{\mathrm{N}} \mathrm{2}$ damage is also sought. as this knowlerge may permit the development of improved therapeutic trestment of radiation injury.

Amoebate were exposed to $\mathrm{C} Y$ in groups of 10 per $0.5 \mathrm{ml}$ open glam vials, $7 \mathrm{~mm}$ in height containing 6

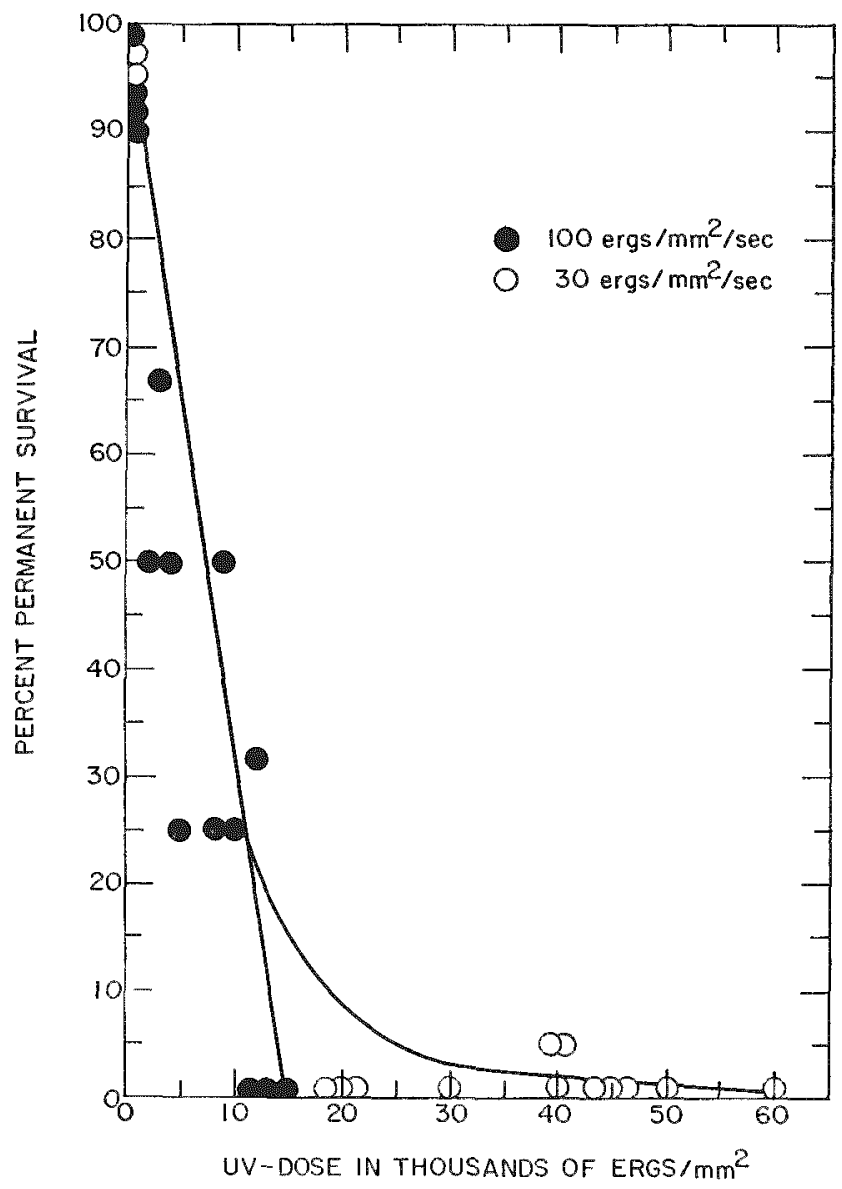

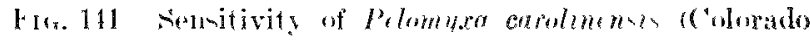
strain to ult ravoulat radiation 1254 nm): mon glaw-dintilled water. The amothar lay on the

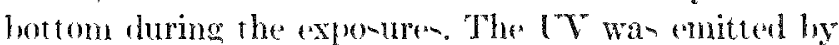
a pen-ray quartz lamp at 2.54 nm (Cltra Violet Product, Inr., San (xah)ritel, ('alif.; Model No. NCT1; 11.5 volt 60 eyele; 0.22 anm-1. "Two done ratten were uned 1100 arg $^{2} \mathrm{~mm}^{*}$ uece and 30 erge $\mathrm{mm}^{2}$, nee at target lintancen of $6.5 \mathrm{~cm}$ and $12.5 \mathrm{~cm}$, respectively). All C $Y$-exponed anowate were kept in similar vi-ible light throughout the experiment- to erualize photoreactivattion effeets.

The nitrogen mutard $1 \mathrm{H} \times 2$, was purchaned from Merck, sharp, and Dohme" an a trituration of Mustargen HC'l amedhlorethamine-H('l) in 10-ml muber-toppered vial-, each containing $10 \mathrm{mg}$ of the drug with solium (hloride (1.). $100 \mathrm{mg}$. Amoeba buffer"s) (pH 6.9 ) was uned both as a solvent and a culture medium. The time betwere the addition of the rolvent to the drug and the beginning of the treatment wam $2.5 \pm 0.5$ min. The total treatment time was $1 \mathrm{hr}$, after which the anoebate were watshed in buffer and fed hy adding food organi-m fparamecia and ehilomonias.

Whole unirradiated, untreated $P^{3}$. carolime resis (colorato strain), or portions thalves, thirds, quarters cut from them, were nicrosurgically tram-fermed (funed) into [V-exponed and IIN2-treated recipient amoebar. (Other amoshae exponed to lethal dones of ['T, or portion at from them, were combined by microfu-ion into whole amoebte or amoehat portions lethally treated with $H \times 2$. The micro-urgical operation-were unally done within a daty or two after $U V_{\text {- }}$ exponde and or HN2-treatment. All experimentally furd amochas" were indated, a were rome of the I'V-xposed and HN2-treated control cells. Off-pring from inolaten were kept tugether in the same culture. Wher control, i.e., Y T-exposed, HA2-treated, and stock (untreated) amoebae were kept in man culturen.

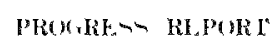

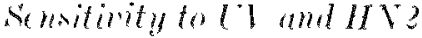

The en-itivity of the Coloralo strain of $P$. correlimensis to TV at two dowe raten is shown in Fiente 141. Expocure 112 amoebae per point l to a total done of $1 ., 000$ ero- mm² at 100 eres $\mathrm{mm}^{2}$ see resulted in 100' lethality. None of the total domes of UT radia tion enited at 30 arow $\mathrm{mm}^{2}$ ree 120 amoebae per

\footnotetext{
" Hivision of Merek a Ca, Went Prine, Pa.
} 


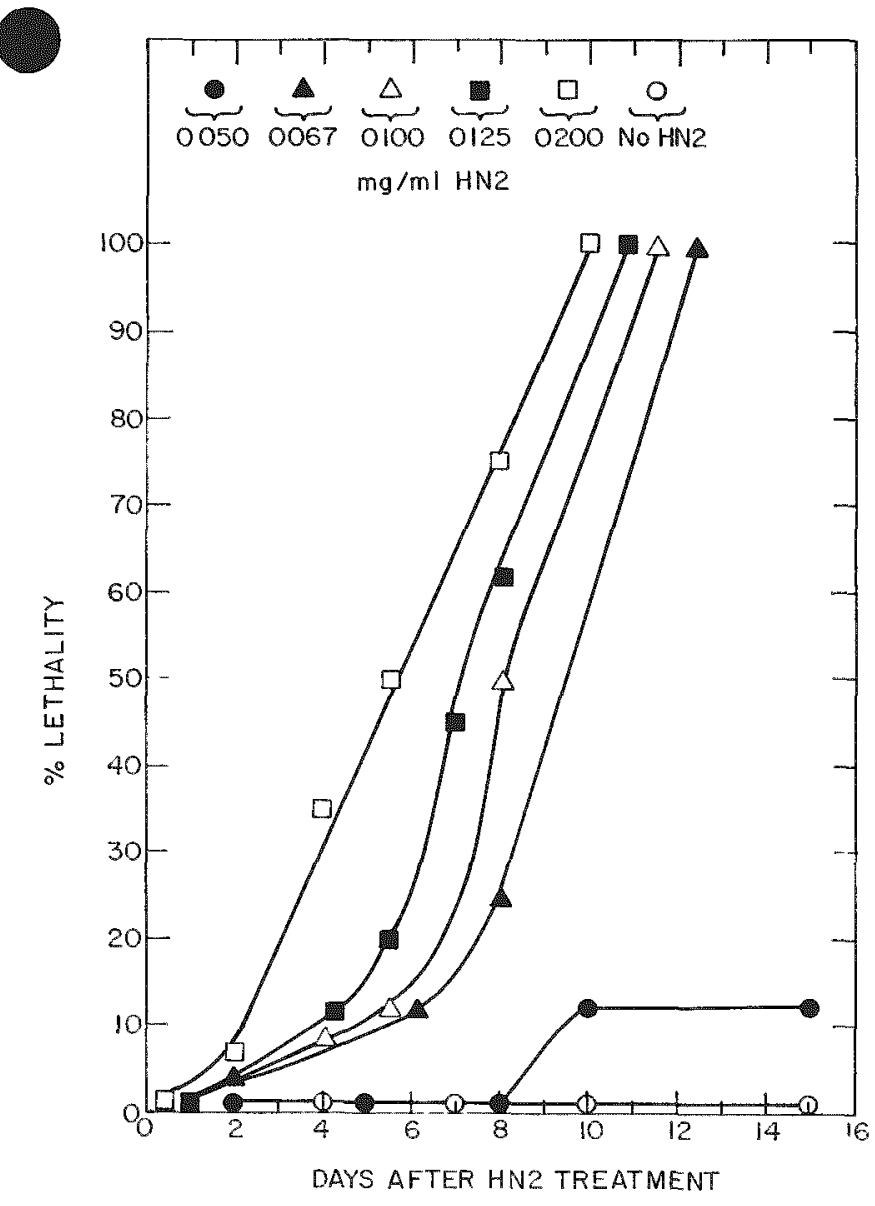

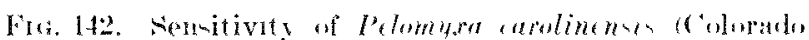
itrinin 1 . IIN2.

point, was an low an thoe given at the more rapid rate, hut dowe of 20 , 30, and 40 kiloergs $\mathrm{mm}^{2}$ were lethal to 100 ; of exponed amoebar, except for a $x^{2}$, recocery in two 40-kilocrge mm² groups (Figure 141 ). All dowes greater than this were consistently lethal to all texpo-ed amodbate.

'The enstivity of thi -train to HN2 i- hown in Figure 142. We were primarily interested in lethal dorem and in death rate. All of the dose-hown in Figure 142 were lethal, but the majority of amoebae treaterl with the lightent dose $60.05 \mathrm{mg} / \mathrm{ml}$, did not die until 3 week - or longer from the time of treatment. $A$ few of the amoebat in the latter group divided. but all of the offinprine exentutlly dierl. Mont of the amoebate treated with $0.0 .0 \mathrm{mg}$ ml $\mathrm{HN2}$ appeared to grow ahmormally laree in size without undergoing division. Amorebste that receiver the higher do-en of HN2 did not divide, and none apleseded to inereane in size.

\section{Mirrotrunsplantation}

The microsurgiet procedure have been described previmaly. ${ }^{11}$ The volume ratio of unirraliated, untreated tock protoplam to UV-expond and HN2- treated recipient s was entimated by visual comparion of donor to recipient cells at magnifications of 40 to 80 diameter. Complete tranfer of protoplam was oberred in mont of the fusions.

\section{Therapeutio tratment of lethally IT-exposed amolbae by microtiansplentation}

Amoebare exposed to 4.5 kiloergs $\mathrm{mm}^{2}$ at 30 erese mon ${ }^{2}$ sec received protopla-m from unirradiated $P$. curolinensis of the same -train. Seren amoebae were treated in this manner. and each produred a mass culture' (Figure 1431. All I"T"-irradiated control amoebate that were not injected with unirraliated donor protoplar $-m$ died without cell rivi-ion. All fusion ratios ivolume for volume of protopla-me of the unirradiated-to-irradiated anochae were approximately $1: 1$; in other work, each experimentally fu-erl organism had neaty exual anoum of irratiated and unirradiated protoplasm.

Fath furend amouba wa- i-olated. ('ell division was inhilites for about 3 daye irom the time of UV ex-

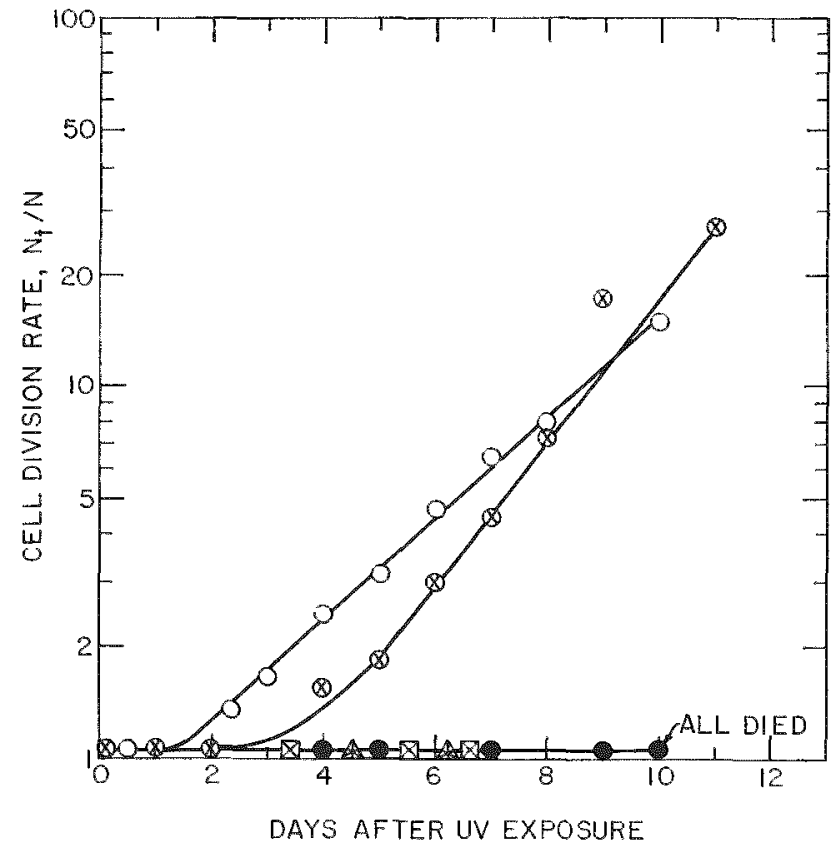

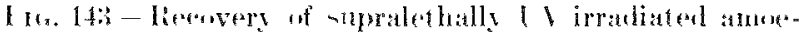

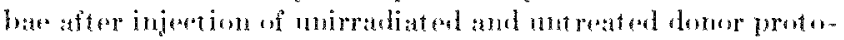

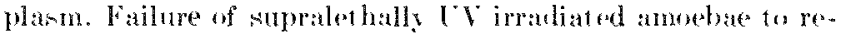
aver following injertion of HAz treated protoplasm. 1 Nimber of elones: $1 z-$ mumber of annelbate at tima $t$.

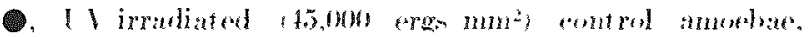

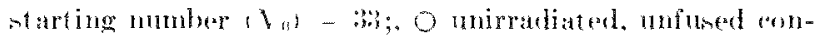

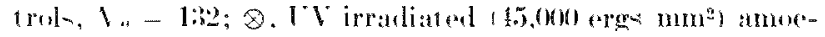

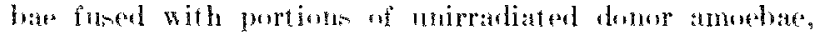

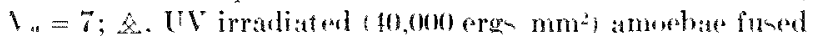

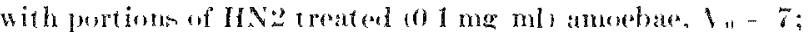

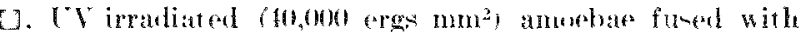

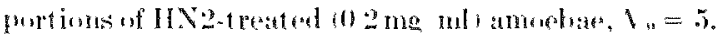


posure (Figure 143). Cell division occurred on the th and 5th days, then exceested the control division rate for about 5 days (Figure 143). Offopring from a ingle amoeba were kept together as a separate clone, eultured for a month, then discarded.

Therapentic treatment of lethally $H \times 2$-treated $(0.125 \mathrm{mg} / \mathrm{ml}$ ) amoebae by microtransplantation

Cutrested stock protoplam, transplanted into supralethally HN2-treated amoebae, prevented death and promoted rell division as shown in Figure 144. The fusion ration (rolume-for-volume of untreated - tock protoplasm to IHN2-treated recipients ranged from 1:15 (one part untreated to 15 parts treated), to $9: 1$. Forty-seven perent of the fused amoebae had either equal amount of untreated and HN2treated protoplamm. or a slight excess of HIN2-treated protoplasm. The remainder of the fured amoebat (53,c) had an exeess of untreated protoplasm, exi-ting primarily in ration of $2: 1$ and $3: 1$. The morapid recovery was seen in HN2-treated amochae that received about an equal amount of donor untreated protoplasm. The HN2-treated amotbae that received less than an cqual volume of protoplanm

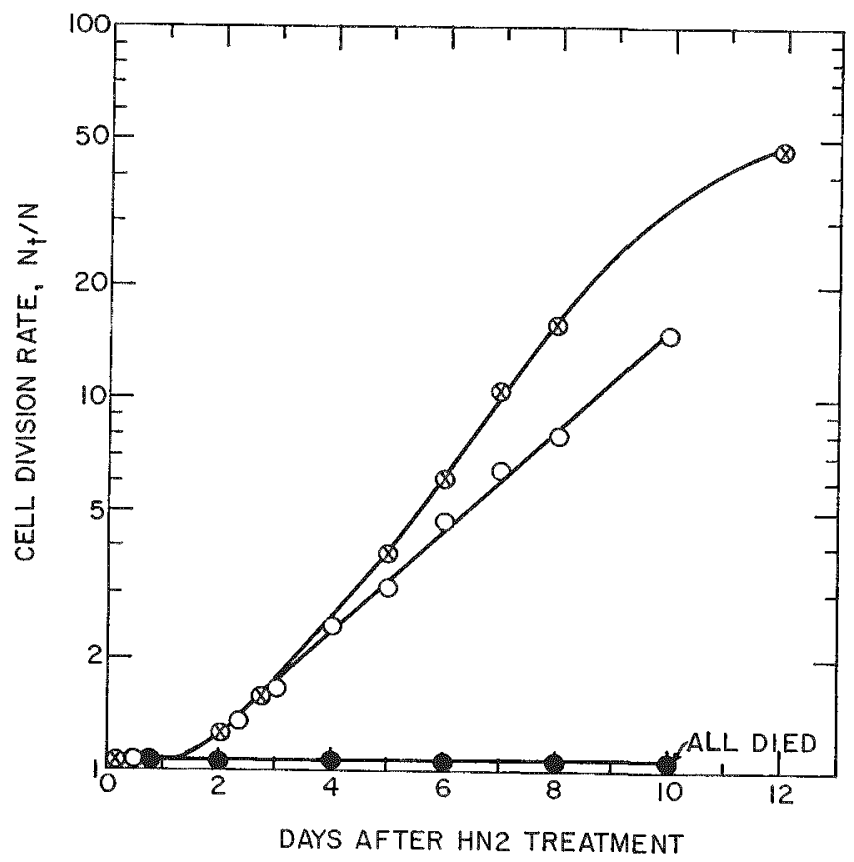

Fir. 144. Recovery of supralethally $11 \mathrm{~N} 2$-t teat ed amoehaf following injection of unirradiated and untreat ed donor protoplasm.

$\Lambda=$ Number of clones; $\lambda_{t}=$ number of amolya at time $t$.

- $0.125 \mathrm{mg} \mathrm{ml}$ HN2-treated control amoebae, starting number $\left(N_{i}\right)=40 ; 0$. untreated. unfused controls, $\lambda_{0}=$ $132 ; 0,0.125 \mathrm{mg}$ ml HN2-treated amoebae fused with untreated amoeba portions. Io -19 . from an untreated donor rearhed their firt cell dir sions more lowly. All of the $0.125 \mathrm{mg} / \mathrm{ml} \mathrm{HN2-}$ treated control, died without dividing (Figure 144). A. shown in Figure 142, this dose is 2.5 timen the lethal done.

Lethally L'T-exposed amotate injected with protoplesm from lethally $11 \mathrm{X}$ s-treated donors

Amochate that received 50 kiloergs ' $\mathrm{mm}^{2}$ of $\mathrm{Cl}^{2}$ at $30 \mathrm{crom} / \mathrm{mm}^{2}$, sec were injected with protoplasm from amoehae lethally treuted with $\mathrm{HN}_{2}$ (0.1 and 0.2 $\mathrm{mg}$ mll. Most $\left(70, \mathrm{C}^{\circ}\right)$ of the transer ratios were $1: 1$ with approximately equal amount of UV-texpoud and HN2-treated protopla-m in the fused amoebia. None of the efured eell- -urvived longer than IIN2treated controls, or [V-exponed controls ifigures 142 and 143). Furthermore, none of these fused amoebate divided. Thu, protoplan from HN2treated amoebae did not promote radiorestoration in the lethally LV-exponed amophas. Conversely. the protoplasm from amochate exponed to a lethal dove of CV was ineffective in preventing death in supralethally HN2-treated amookat.

\section{CONCLTHIOS:}

Wr have explored the I"V and $\mathrm{HN} 2$-ensitivitien of a new train 1 (Colorado) of Pelomyxa carolinensis. Trumplantation experiment, have shown that recosery is posible after an amoeba han received more than a lethal do-e of either TV or HN2. Presumably, death occurred after exponure to thene agents bescause of damage to nuclear DNA. Because of its extensive nature, this damage was not repaired by the cell without proper therapy. Transplantation (injection) of umexposed, untreated protoplasm from donor amoebate replaced the damaged nuclei and, presumably, repaired DNA damage in exposed nuclei. Eridence from the work prenented in this report is not adequate to demontrate DNA repair, but previous investigations of a -imilar nature on a different species of amoeba showed that the nuclei of amoebae that were exposed to 2.5 timen the lethal UV-radiation. doue recovered and divided normally after transplantation therapy. ${ }^{(4)}$

It i- clear from the work reported here that ITradiation irreparably damages restorative agents normally present in unirradiated protoplaim needed by lethally IIN2-treated amoebae for recorery, and vice versa. Howerer, -upralethally HN2-treated amoeba protoplasm is a very strong rectorative agent for supralethally $\mathrm{X}$ irradiated amoebae. ${ }^{(5)}$ Thus. of leant in lethally $X$ irradiated amoebae, critical dan age causing death ean be repaired, or the damaged 
trueture replaced, by protoplasm from supralethally IIN2-treated donor amoebae. Presumably thi is not INA, because the primary site of damage by nit rogen mustard is in DNA. ${ }^{(2)}$ Furthermore, nucleus-free 'ytoplarm from untreated, unirradiated donor amoehat is restorative. (5)

Lethally $\mathrm{X}$ irradiated amoebae are not restored by protoplasm from lethally UV-irradiated donor amoelbae. ${ }^{(4)}$ UV radiation is absorbed by both DNA. and RNA, and it would appear from transplintation studies that lethally $\mathrm{X}$ irradiated amocbae recover if given protoplam defieient in DNA, but fail to re"orer when the protoplasm is deficient in both DNA and RNA. From this, it may be postulated that an RNA species is eswentitl for radiorestoration of supralethally $\mathrm{X}$ irradiated cells.

\section{REFERENCES}

1. Haniels, F. W., P. A. Fustarsie, and J. F. Meclellan. (Giant amoehae from ("ulorado identified by transplant ation tolerance. J. Protozonl. 16, 182181 (1969).

2. Browken, P. and P. I). Lawley. The reaction of mone- and difunctional alkylating agents with mucleic arids. Binchem. J. 30, 446i-503 (1961).

3. Pare, I). M. and B. W. MrCashland. Hffects of low roncentrations of cyanide on growth and respiration in Palomyxa 'arolinensis Wilson. I'wer'. Sor. Exp. Biol. Med. 76, 165 168 $1951)$.

4. Ianiels, H. W. Micrurgieal studies on irradiated Pelomyxa. Ann. A. Y. Acall. Sri. 78, 662 67t (1959).

5. Daniels, L. W. Recovery of reproductive function in supralet hally $\mathrm{X}$-irradiated amoehae follow ing eytoplasmic microtransfer. Progress in Protozoulogy, Proc. 1st Intern. Congr. on Protozology, Prague, Ed. J. Ludvik, J. lom, and J. Vavra. ic zerh. Hoad. Sci. Publishing House, Prague, 1961, pp. 258$2 ; 34$.

\section{ULTRASTRUCTURE OF OYSTER GAMETES}

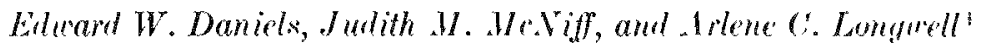

\section{PURPUNE AND METHODS}

The Amerion oyster ICrassostrea virginica (imelint in a commercially valuable bivalve mollu-k whone sexer nomally are separate. Fertilization is external at the time of spawning. This is a report of the ultrastruetural anatomy of the ooeytes and spermatozoa of this -percies. Galtsoff'11 wrote a book on this specien and preented numerous detail of its biology. He dereribed the gametes. published two electron miarograph of oyster sperm rells, but presented no information on the ultrantructure of the oocyte. He dis"unned the need for additional ultrantruetural work on the gatmetes of this species.

Wo have studied $C$. virginior nerm cell- and oocyten with the electron microsepe in an effort to provide a more complete baseline of rytologiral information on it miture gameten. Thi information is addrensed to future fine-structure, stulies, research on the genetion, studies of the fertilization and embryological derelopment. and to the potential effect- of environmental pollutant - on oxingers.

\section{MATMRAL, AND METHLON}

There oysters were shipped in moist plastic container by air from Milford to Chicago and picked up on arrival. The bivalves were opened, and the go-

* I. S. Department of the Interior, Finh and Wildlife Serwce. Bureau of commereial Fishories, Biolngieal Laboratory, Melford. Comnecticut oritio. nats were exposed. A bionsy sample was examined in the phane microncope to letermine the sex type and quality of gametes. The gimetes (nperm or ooertent were pinetted directly from the moist gonad into 4': ghlutaraldehyde (Polyscieneen. Ine., Philadelphia, Pa.l buffered in $0.15 M$ phomphate $\left(\mathrm{Na}_{2} \mathrm{HP}()_{4}\right.$; KII.P( $\left.)_{4}\right)$ at pll 7.0 in $0.9^{\prime} ; \mathrm{NaC}^{\prime} \mathrm{l}$ for $2 \mathrm{hr}$. They were rined for sereral hour or overnight in 3 changes of the saline phosphate buffer and post-fixed in 1\%: ()-1) made up in the saline phorphate buffer at pII 7.0. Fixation in onmium was from 1 to $2 \mathrm{hr}$. The swerimens were dehydrated in graded ethanols, and from pronylene oxide they were embedded in Epon 812. The blocks were rectioned with a DuPont diamond knife in a Fuxley microtome and stained with uranyl acetate (-aturated methanol solution) and lead citrate. They were studied in an RCA-LAMU 34 electron mieroscope.

PRMARLAS REPORT

\section{Cltrastructure of Oyster Spe imatrina}

'Typiral longitudinal sections through the spermarozoa are -hown in Figures 14.) and 146. As in other -perm cell- the nuelew- is the largent structure in the herdflerese and the acrosome in the most anterior, except for the platmalemma and the occasional vesicle of plismalemma (blebl a Figure 145). The axial bonly'11) a Figure 145. $\mathrm{X}$ i i- eupped into the anterior portion of the nucleus and capped by the arrome; 


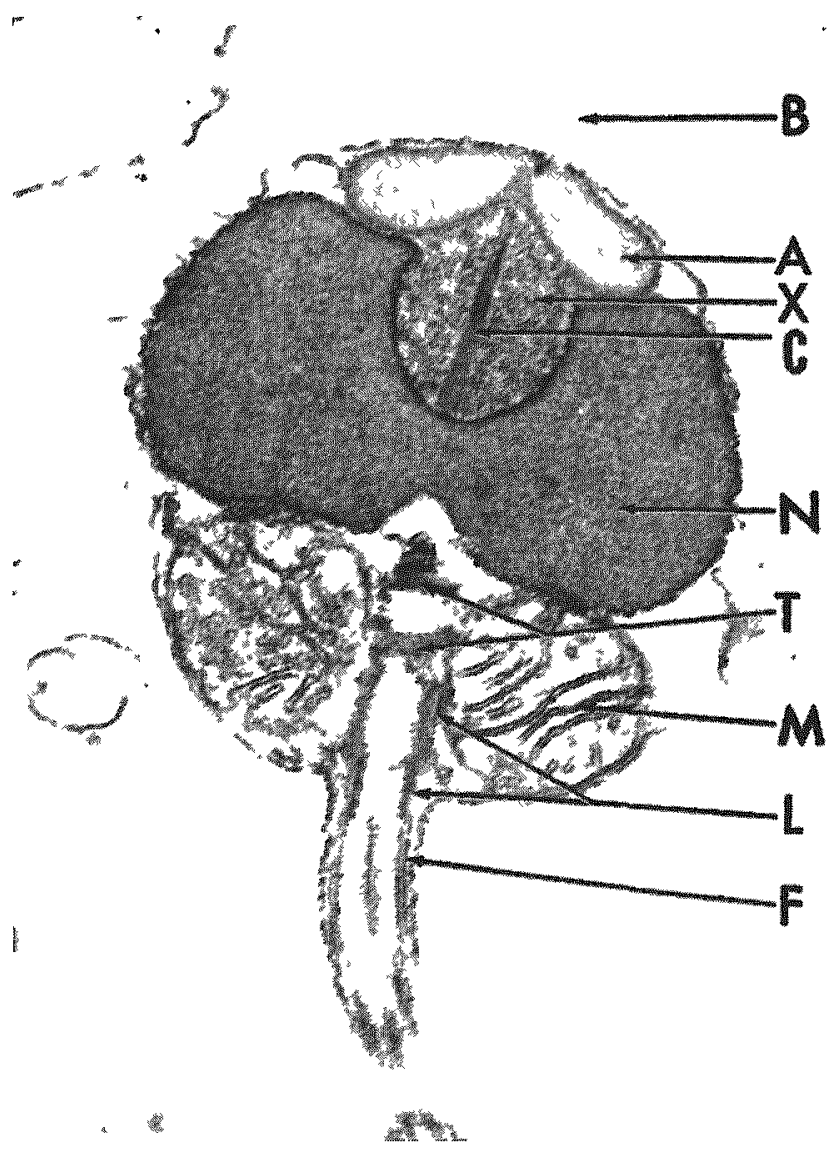

Fiti. 115. Jomgit udinal mexet ion through oenter of spermato-

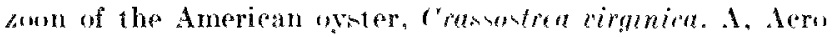
some; B, anterior bleb: (', core of axial boudy; filament in proximal portion of tail-piece; $I$, longitudinal (distal) erentriale; M, miturhondrion; $\mathcal{X}$, nurlens: 'T, trankvarse (proximal) rentriole; $\mathrm{X}$, axial bondr. 34,000

the axial corete (Figure 145, () lien longitulinally in the middle of the axial body.

The middle piese of the ornter sperm is compresed anterioposteriorly and contains 4 mitochondria, two of which are seen in a typical longiturlinal seretion of the -lorm; there are two centrioles. The distal longitudinall centriole is continuous with the anterior end of the tail-piece of the sperm (Figures 14.5 and 146). In our figures, the proximal itranseres centriole is "ut lengthwise (Figure 145), and obliguely I Figure 146).

Filament in the tail-piece were previon-ly de-ribed and demontrated loy Galtoffich as follows: "The tail consist of a pair of axial filament surrounderl by a ring of nine double filament spaced at expal intervals alone the periphery." Figure 1.45 and 146 of thi- report show longitudinal sections of these filanents.

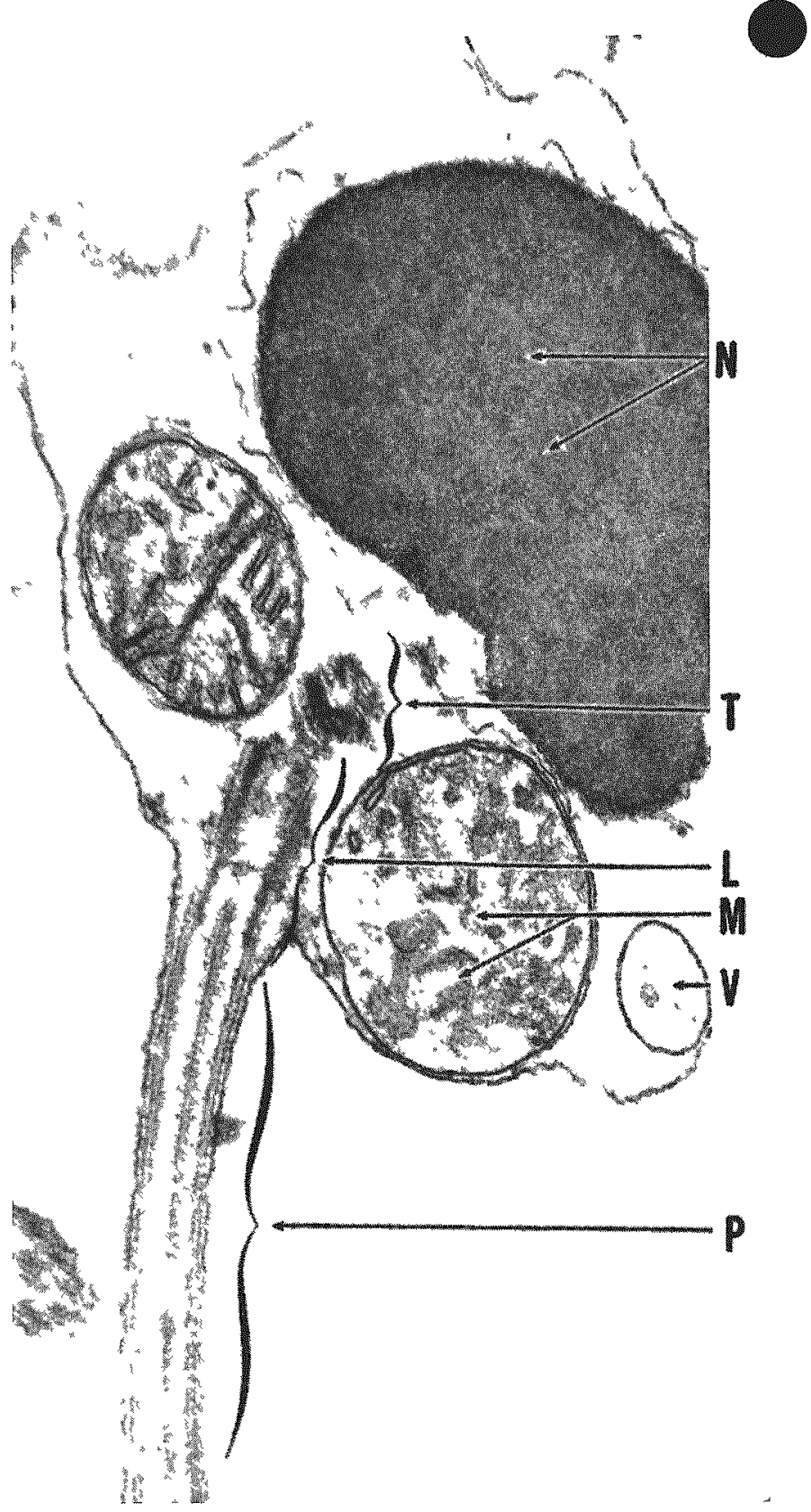

Fer. 14t. Longitudinal sectinn through a monewhat immat-

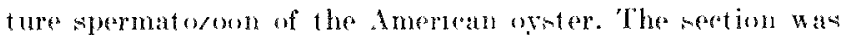
made at nearly a right angle to that hown in Figure $14.5 \mathrm{~L}$,

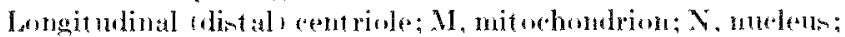

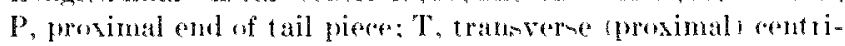
ale: I, vesicle in the estoplasm. 4ti,500 X.

\section{Cltrastructure of Gyster mocytes}

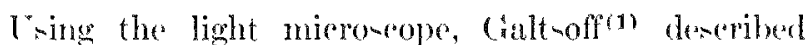
the hape, size. and cotoplasmic inclusions of the mature oocyte of $C$ rirginica. Our -tudies with thr electron microneope how the surface of the oocyt to be eharacterized by -mall villi on the periphery of the oocyte (Figure 147. VI). A coating of amorphom- 


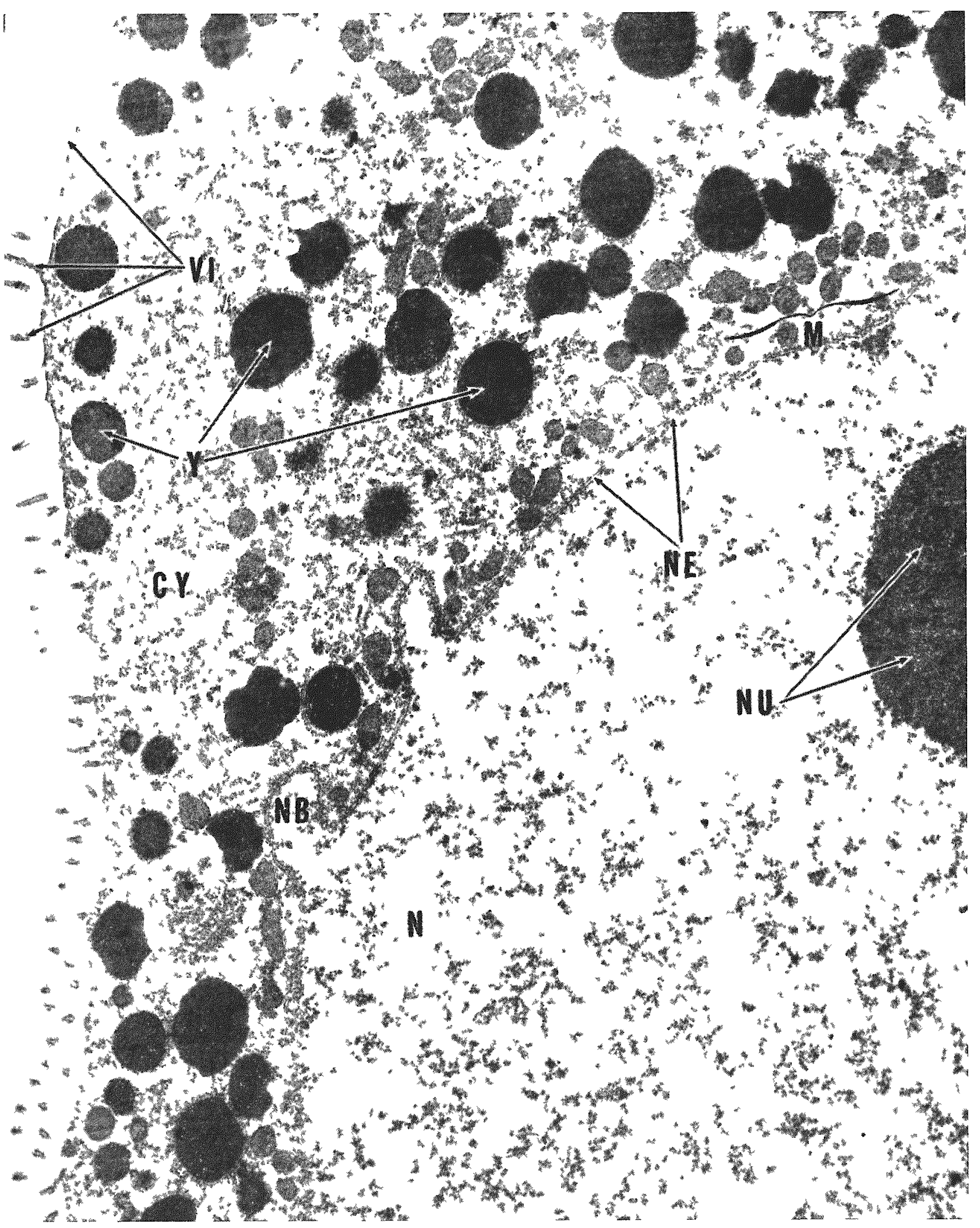

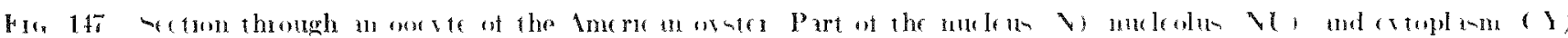

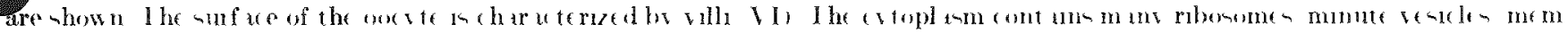

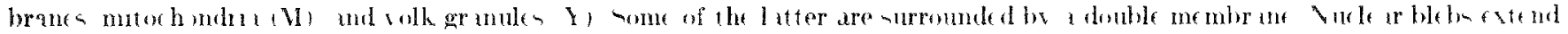

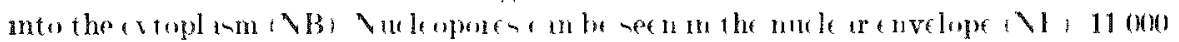


(4)

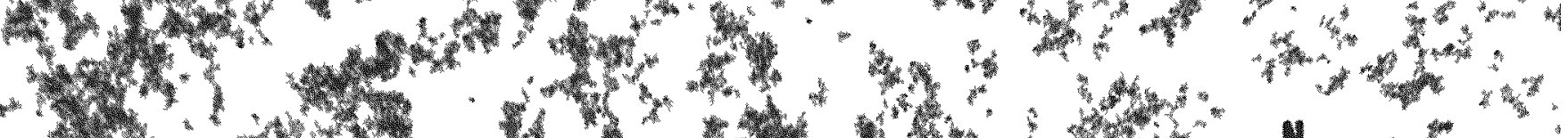
(3)

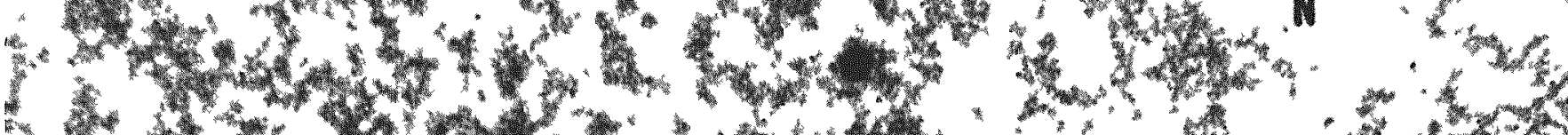
4. 1.t. 1. H.

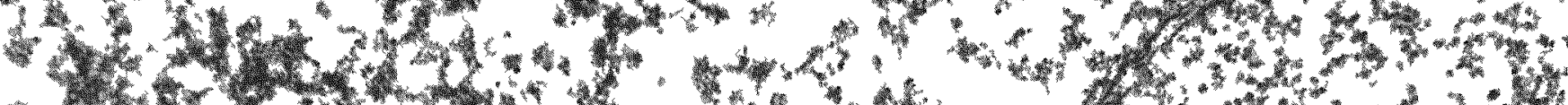
6.

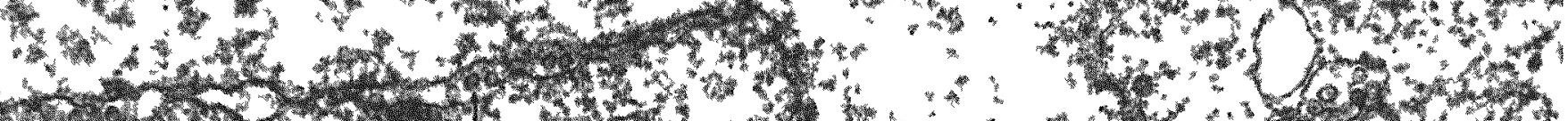

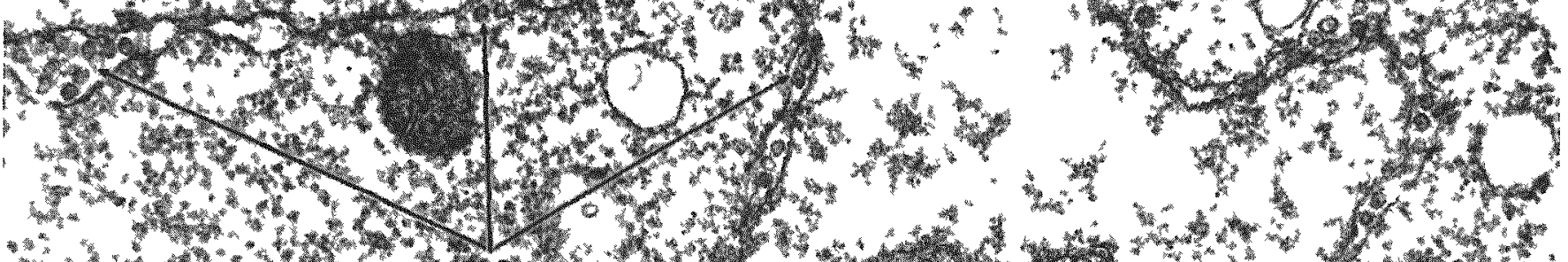

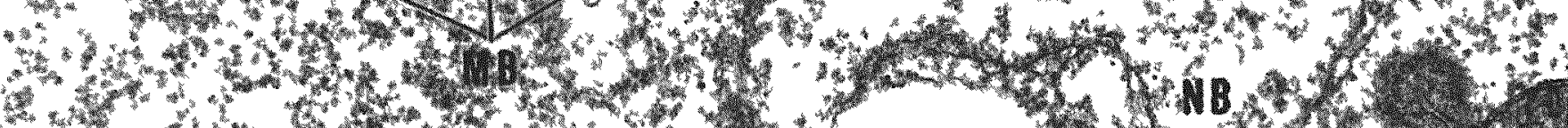

(n) 6. 2.".

tom

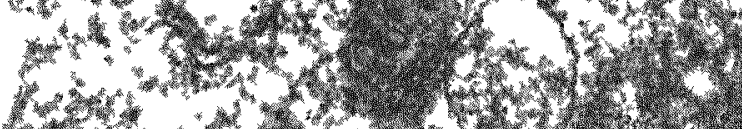

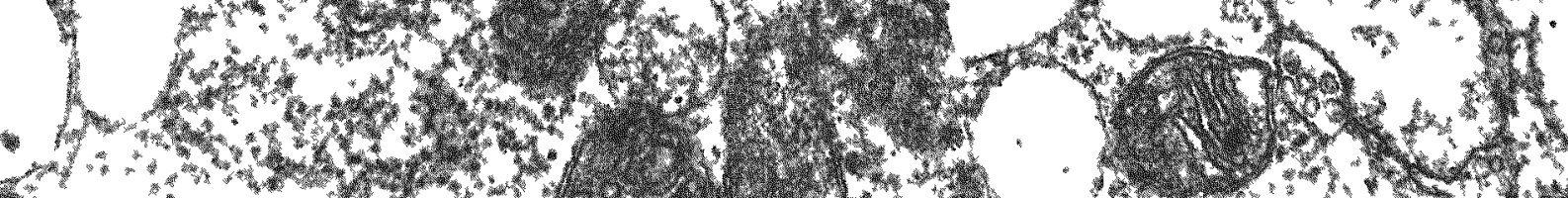

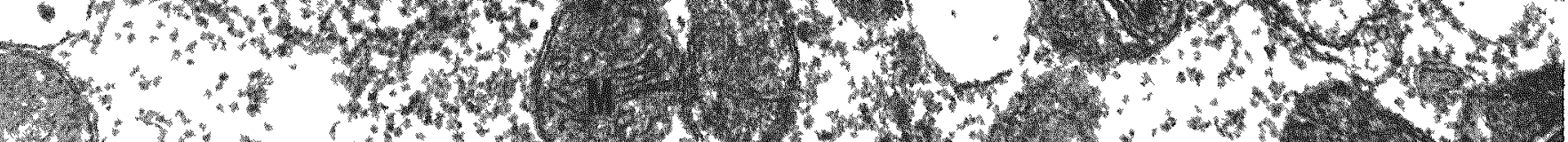
-2.7:

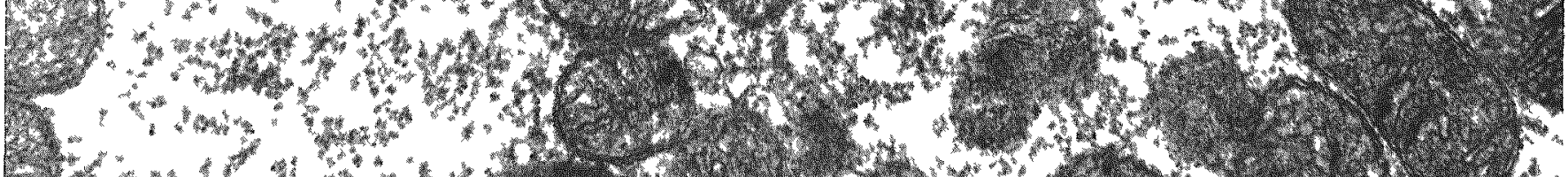
(2) (6) H. (t) 4. 19. 


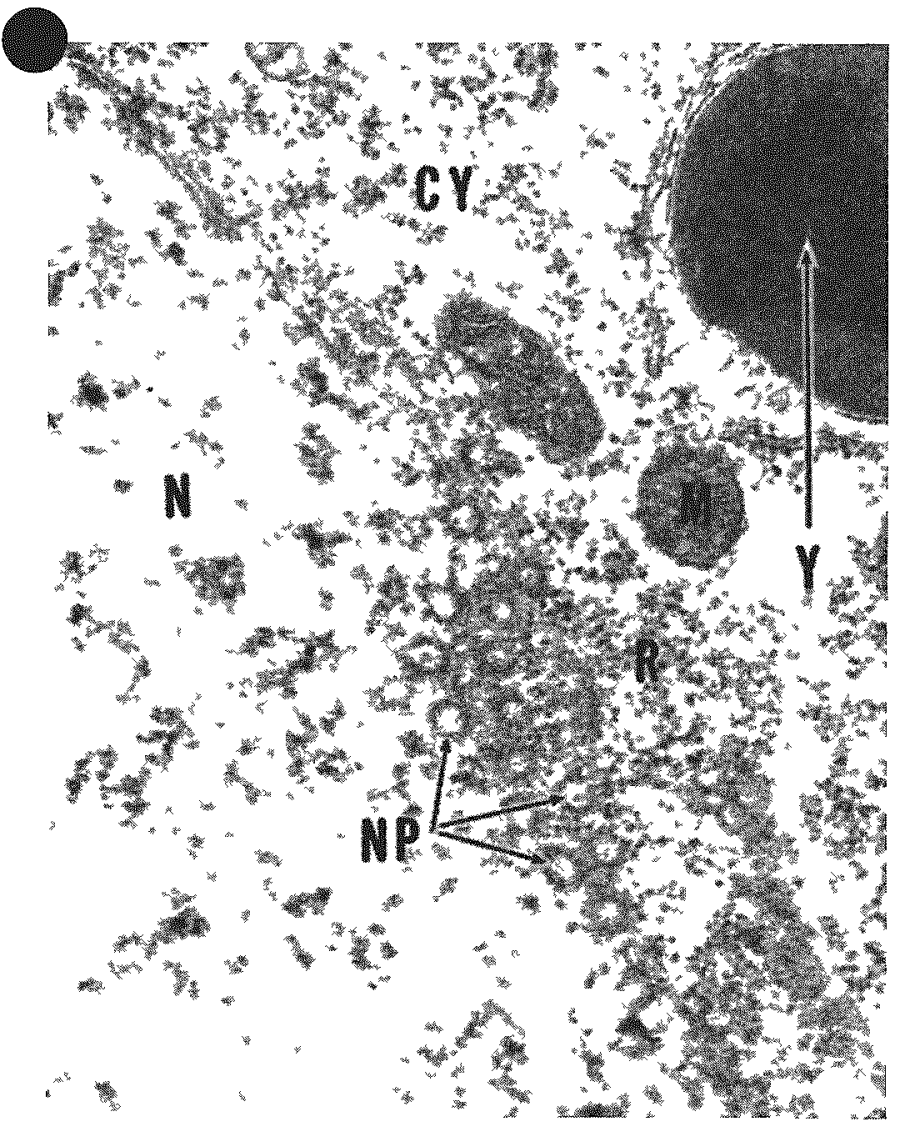

Fis 149 Oocrte of American or ster showing nucle ppores (VP) 1 mass of rlbosomes (R) les on the ertoplamic (CY side of the nucleus (N) Mitochondrid (N) and a whlk globule (Y) are also in view $33,000 \times$

material orer the oocyte extends from the planmalemma to the tip of the ville (Figure 147)

The nucleu of the oocyte is large, 25 to $40 \mu$ arcording to Galtoff, ${ }^{(1)}$ and has an acentrie nucleolu- (Figure $147, N^{*}$. Nuclear bleks, come of which are branched, extend into the eytoplam IFigures 147 and 148, NB). The nuclear envelope (Figure 147, NE) has nucleopore that are demonotrated in tangential (Flgure 149, NP) and cross section (Figure 150, NPl. A diaphragm may extend acros the pores (Figure 150, NP). Numerou ribosome are shown in the cytoplasm (Figure 149, R) but appear to be exeluded from the nuclew by the nuclear envelope.

Mitorhondria are demonstrated in the cytoplasm (Figures 147-149, 2I). Yolk globulen (Figures 147149, X) are also hown in the eytoplasm. Galt-off(x) reported the stratification or rolk granules of $C$.

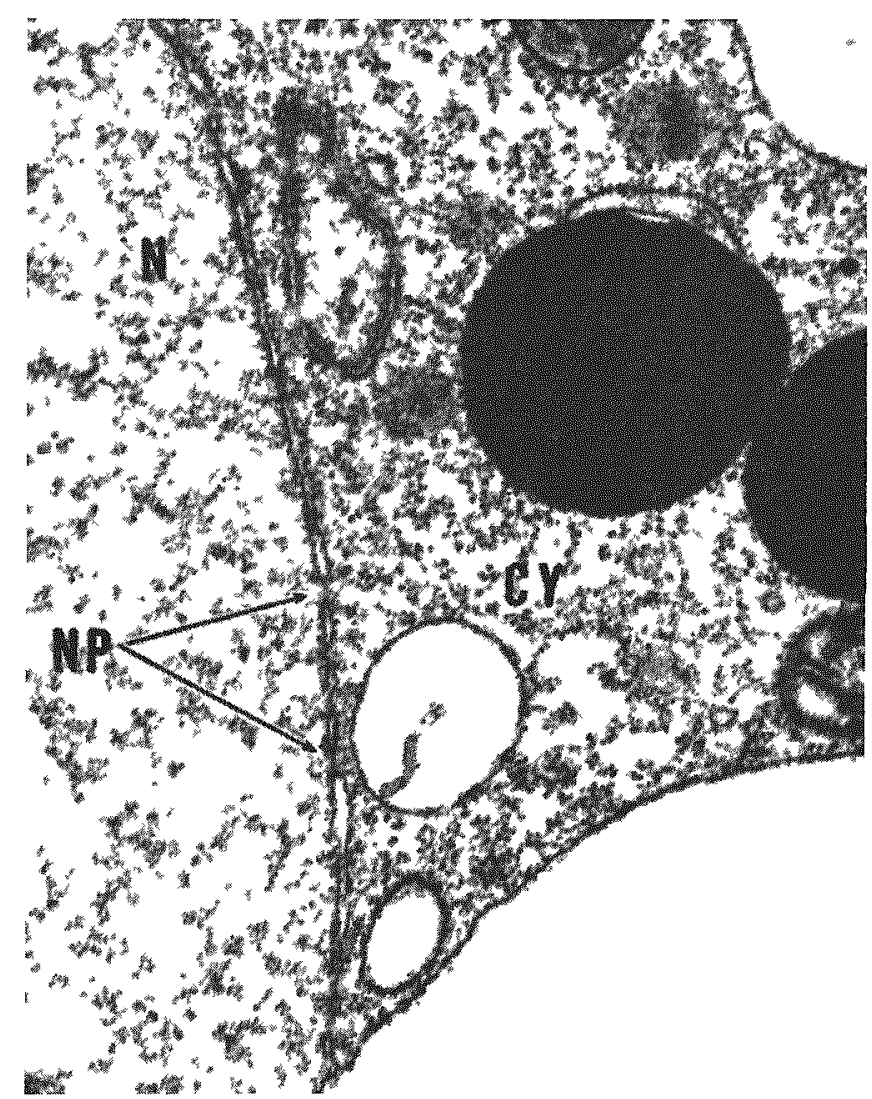

His 150 Side view of nueleopores (NP) in ooct te of the Ameila an orter Apparentls, d daphragm dowe each pore $N$, Vucleun, ('), crtoplasm $30,000 x$

rerymere egg- by centufugation 14,000 times gravity for $10 \mathrm{mml}$. We centrituged oocytes removed from the gonath of (". errumica at 2,500 times gravity for $10 \mathrm{~mm}$ and obtained -ome but not complete separatron of lipul from protem yolk globules.

CONLI-ION

Prelmmary electron microscopic studies have been made on both sperm and oocytes from Crassostrea raramer some new information has been obtained which can be used in a contmuing -tudy of this commerrial oy-ter.

RLFI RENCE

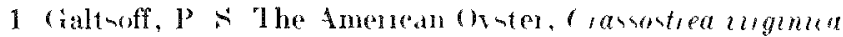
Gmeln $F^{\circ}$ - Dept Interior Fl hery Bulleten of the Fish

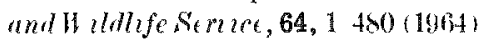




\title{
ENZYMATIC ACTIVITY OF YEAST CELL GHOSTS PRODUCED BY PROTEIN ACTION ON THE MEMBRANES
}

\author{
Frita Schlenk, Cynthia R. Zydelin'('uich, and Julia L. Dainlio
}

\section{PLRLOSE AND METHODS}

By the action of small basic protein molecules on yeant cell in water suspension at low clectrolyte concentration, the membrane is rendered permeable, viability is lost, and cytoplasmic constituents diffuse into the surrounding medium. (1) The cell ghosts obtained in this way retain the cytoplasmic proteins. The wanhed ghosts were examined for enzymatic activity by adding substrates and ob-erving the enzyme reaction by analyzing the product that diffused into the medium. This procedure appeared particularly important for the tudy of substrates and coenzymes which do not penetrate into intact cell. The preparation and -ome of the properties of the ghosts have been deurribed earlier. ${ }^{(2)}$ This report deals with their enzymology.

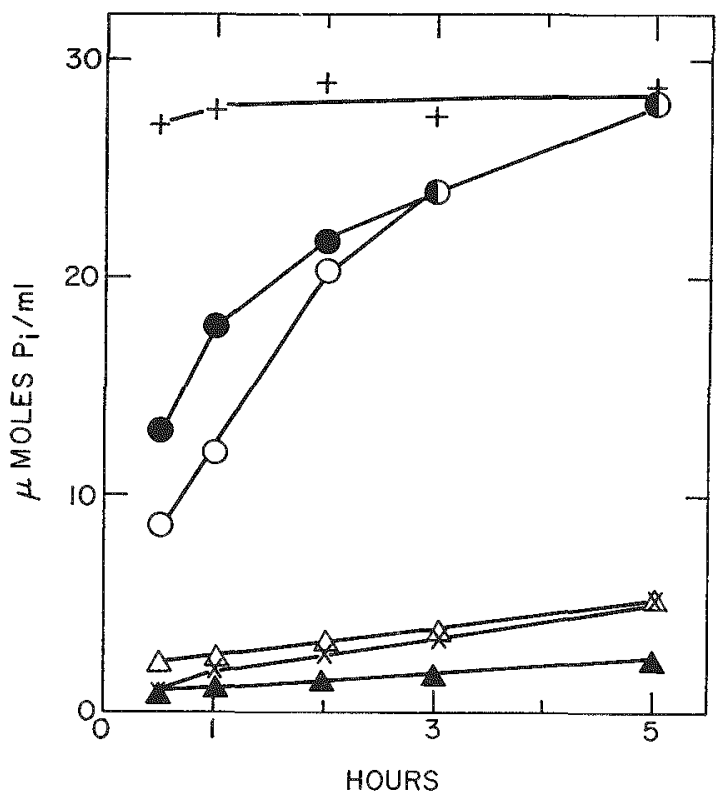

Fis 151. Formation of $P_{2}$ from ATP and PPi hy ghosts of candula utule. The substrates (15 $\mathrm{m} n$ ) were incubated with $150 \mathrm{mg}$ of ghosts per ml. PP, $+; \Lambda T P, O$; ghests only, $\Delta$. Fiperiments with ghosts prepared in (isotonic) $1.0 \mathrm{Vl}$ mannitol, then transferred into o $6 . / 7 \mathrm{KCl}$ : ATP, ; ghosts only, Intact cellowith $1 \mathrm{TP}$ or $\mathrm{PP}_{2}, \mathrm{X}$.
The ghosts were sumpended in suitable buffer nolutions and mixed with the substrates. After incubation, the $u<p e n<i o n s$ were cleared by centrifugation, and the supernatant fluid was analyzed for the reaction products.

\section{PROGRF $S$ REPORT}

A complete survey of yeant enzymes with the present ghosts was beyond realization, and the investigation was restricted to a few examples, mainly from the realm of carbohydrate metabolism. The penetrability of the membrane after protein action is illustrated in Figure 1.51, which compares the formation of $P_{2}$ from ITP and $P_{P_{i}}$ by ghosts with that by intact eells. The spernatant fluid of the ghost preparation was without effect. (Alucose-6-phosphate dehydrogenare (Figure 152) is another example that contrant the urcfulne- of ghonts with the inefficiency of cells in the metaboli-m of external substrate and coenzyme. The progres of the reaction, glurowe-6monophoyhate + N.AI)P $\stackrel{\text { gahout encmes }}{\longrightarrow} 6$-phosphowluconate + NADPII, wan meatsured by clearing samples by rentrifugation, followed by assay of the reduced roenzyme by observing it alsorbance at $340 \mathrm{~m} \mu$. In a -imilar experiment (Figure 153) the artivity of aconita-e and isocitrate dehydrogena-e could be demon-trated by incubation of the ghosts with citrate and NADP-. Intact cells did not permit the uptake of substrate and coenzyme. Glutamate dehdrogenase also was active in the gho-t.

(Bther enzyme ryntem- found active in the ghosts included the oxidation of $\mathrm{NADH}$ to $\mathrm{NAD}^{+}$, hexokinase, the principal amino acid tran-aminases, uracil riho-ide hydrolare, $\beta$-glucosidive, and L-homocy-teine methyltran-ferane. Multienzyme systems, however, apparently are dirupted in the ghost. Oxidation of gluco-e to $\mathrm{CO}_{2}$ and $\mathrm{H}_{2} \mathrm{O}$ was slow and incomplete. Thi- failure may be explained by the extencive intracellular disorganization in the process of convert ing eells to ghost which ha- heen demontrated earlier by electron micro-coly. ${ }^{(3)}$ 


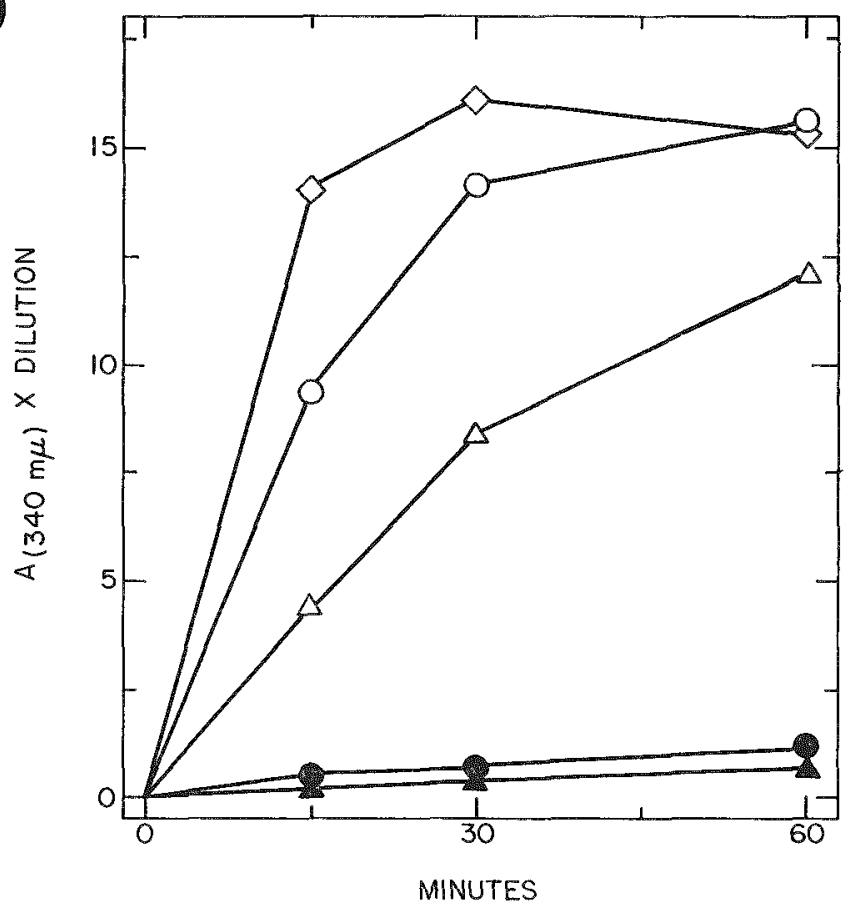

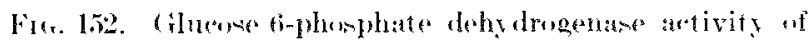

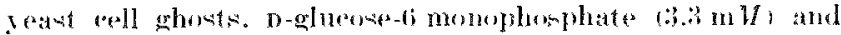
NADP $63.0 \mathrm{~m} V /$, were incubated in 0 o: $1 /$ potassium phosphat abuffer, pH 7.5 , with ghomts in a coneent ration of $16.5 \mathrm{mg}$.

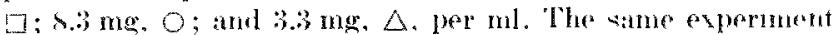

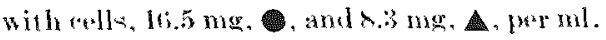

\section{CONCLI HION}

The prenent procodure supplement the earlice methoi of youst enzemology which inchule sonic and mechanical disintegration of the cell wall, freering and thawing. pla-moly-i with toluene or ethylacetate, or partial autoly-is by macuration. In gentlenem and afficiency, the present method is not rivaled by any of thene procedures. The aces-ibility of the enaymen in the ghost suggest sheir application in all experiments in which -ub-trates and cotactorn fail to penetrate into the intact rea-t cell.

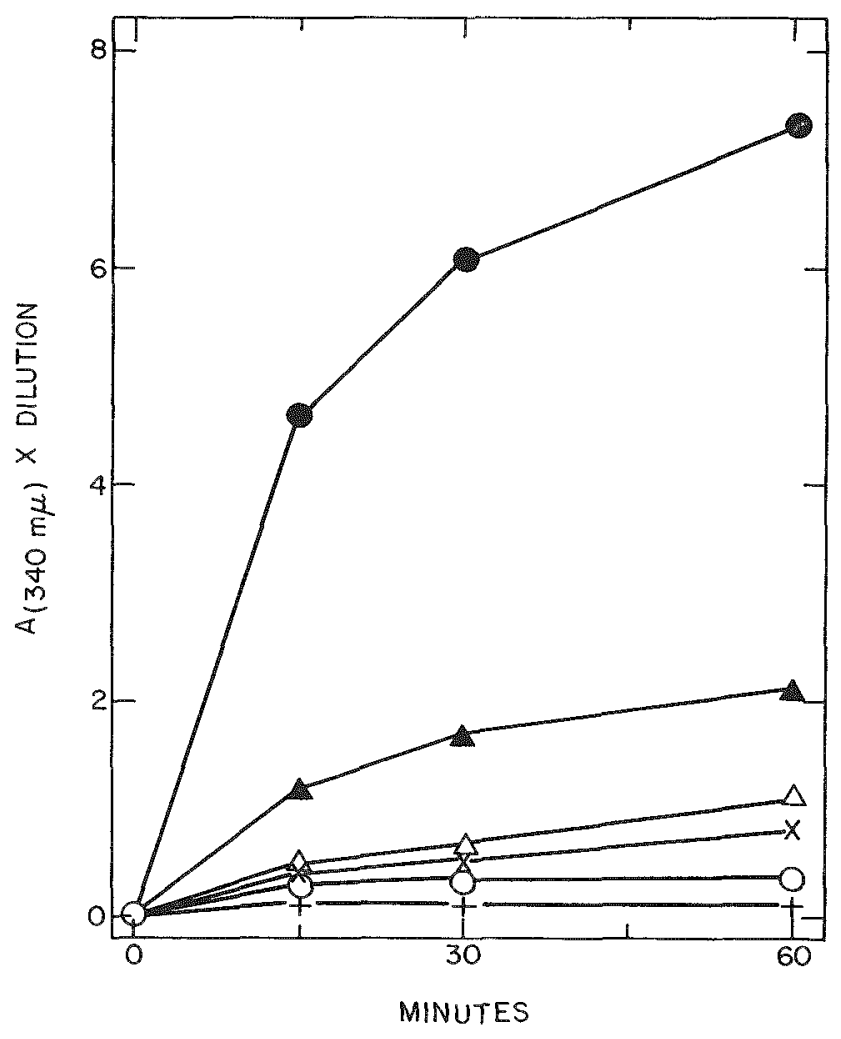

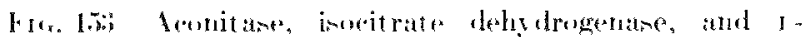

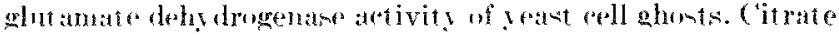

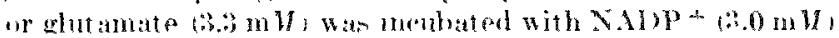
and $333 \mathrm{mg}$ of ghose pere $\mathrm{ml}$ of $0.003 \mathrm{~V}$ potansium phosphate

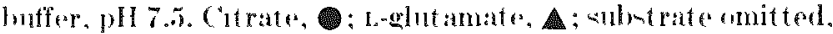

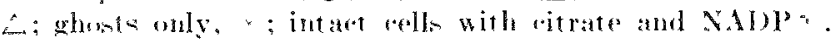
o; int aed colls onlt, to

\section{REEERENCES}

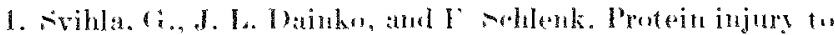
the reast esell membrame. Iromene Vational Laboratory

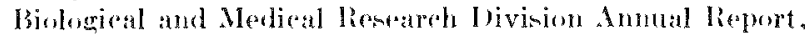

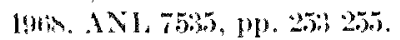

2. Sphantio, I). A.. J. L. Wainko, and F. Sohlenk. Fitferel of

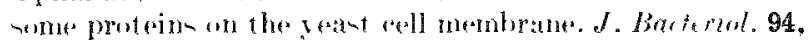
$1.509-1515)(1946)$.

3 Mlper. R. F., J. L. Dainke, and F. Sebllenk. Propertien of

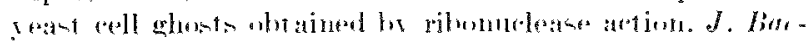
t*16\%. 93, 759 $765,16463$.

\section{THE STABILITY OF THE GLYCOSIDIC BOND OF S-ADENOSYLSULFONIUM COMPOUNDS TOWARD ACID}

Frit: sohlenli and Cyuthia h. Zurleli-Cwirle

I'LRPOAL AND METHODM

In experimentation with the biological methyl donor s-arlenosylmethionine (Formula I) high stability toward acid was oberred.(1) In rontrant hereto, the demethylated compound, s-adenony thomorysteine (Formula II was found to be lahile at the glrcosilic bond to the same deagree a- other biologiral adeno-ine rompounds, including ANP. ADP, ATL, IOPN, and TPX. A s.retrmatic exploration of this phenomenon 

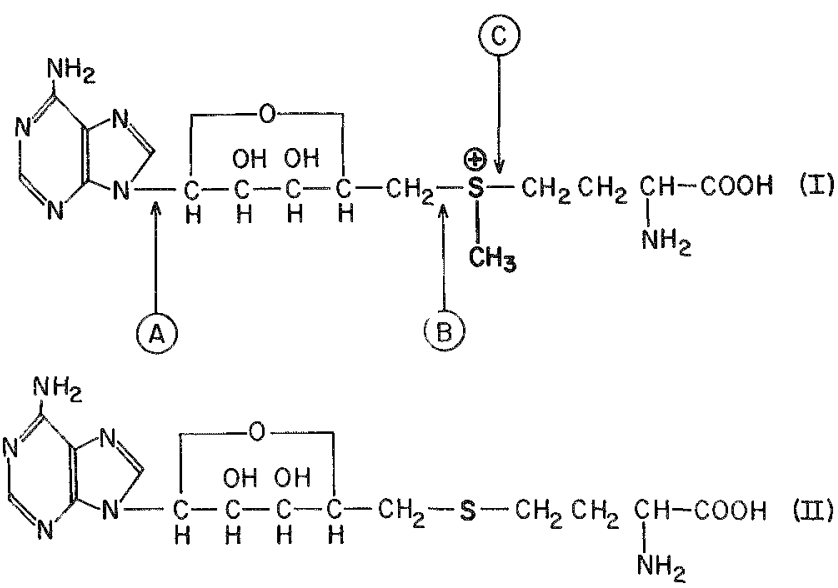

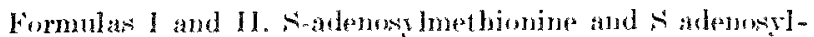
homoersteine. The principal sites of acid hydrolysis are indirated by letters.

appeared to be of interest in relation to nucleoside rhemistry, and practical procedures for the separation of S-adenosylhomocysteine from s-adenosylmethionine were indicated. The acid resistance of the sulfonium compound was studied in detail, and the products obtained were analyzed.

\section{PHOMRESA REPORT}

The hydrolvsis of the glyrosidie bond of s-ateno-ylmothionine (Formula I, bond A) and of the corresponding linkage in s-adenosylhomoersteine (Formula II) was determined by chromatographic ansay

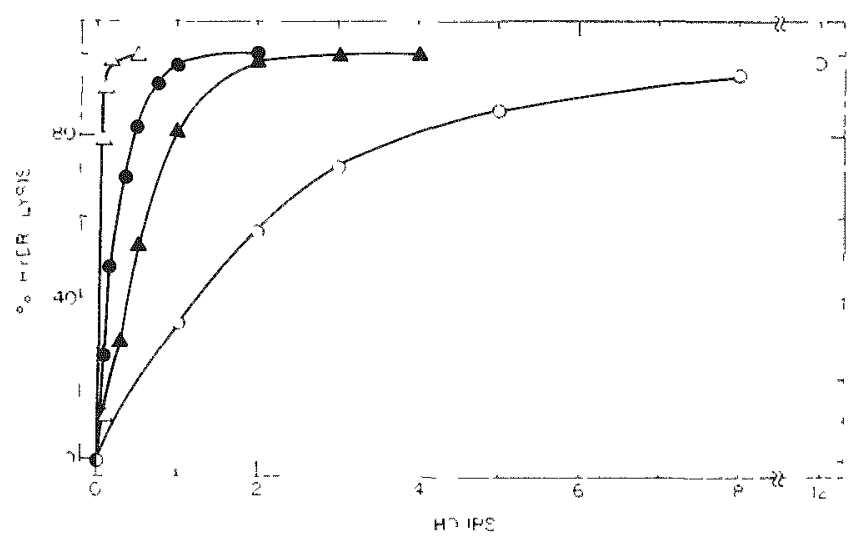

Fix. 154.- Acid hydrolysis of Ś-adenosylmethinnine and s-adenosylhomoryteine. The samples of $\mathrm{r}$-adenosymethionine $(5 \mathrm{~m} . \mathrm{h})$ in $1.0 \mathrm{NHCl} 1 \mathrm{O})$ and in $0.1 \mathrm{~N} \mathrm{HCl}$ iO were heated at $100^{\circ}$. The decrease in the eoncentration of the sulfonium rompound and the enincident formation of adenine were determined by ion exchange ehromatography and spectrophotometry. S-adenosylhomoessteine (5 m.H) was hydrolyzed in the same way in $1.0 \mathrm{~N}$ HC $(\Delta)$ and in $0.1 \mathrm{~N}$ HCl ( 1 ). The residual si-adenosthomoryteine was determined by deamination and spect rophofomet ry ${ }^{(2)}$ of the aldenine which is formed in the process (Figure 154). It may be seen that the reaction constants for the hydrolysis of these rompounds in $1.0 \mathrm{~N} \mathrm{HCl}$ differ hy two orders of magnitude. In $0.1 \mathrm{NHCl}$, the difference is much less, which suggested that the hydrolysis taken a different coures. By paper chromatography and asmat with adenosine deaminase $e^{(2)}$ it was found that in dilute acid, scission $C$ (Formula $I$ ) is the first step; this leads to 5 -methylthioadenosine, which undergoes scission 1 very rapidly. In $2 \mathrm{X}$ and $6 \mathrm{~N} \mathrm{H(1,}$ bond $\mathrm{B}$ (Formula I) is broken in preference to hond C.

The difference between S-adenosylmethionine and s-atenowylhomocysteine in their sensitivity toward acid can be used to adrantage for selective destruction of S-ardenosylhomoeysteine in acid extracts of cell material. S-adenosylmethionine preparations are sometimes contaminated by up to 20 , r of S-adenosylhomocysteine, and the elution peaks of the two compounds from Dowex $50 \mathrm{H}^{+}$eolumns unually merge or orerlaty. S-adenoylhomocyteine conld he dentroyed by heating the initial 1.5 $\mathrm{N}$ perchloric acid extract of yeant hy hereting to $100^{\circ}$ for 5 min. The loss of s-arkenosylmethionine was less than $5 \%$, while s-adenosylhomorysteine was reduced to an insignificant level. Figure 155 how the chromatographic analysis. As a control the same experiment was performed without heating of the extract from another sample of the same yeast.

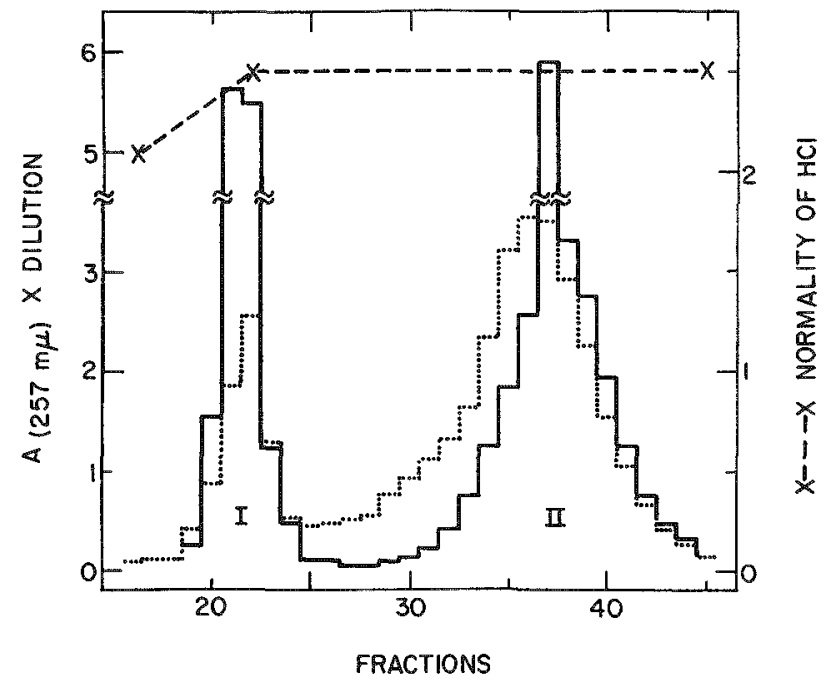

Fici. 155.- fon exchange chromatography of adenine. Sadenosylhomocysteine. and stademosvimethionine in yeant extract. A Dowex $50 \mathrm{H}+$ column was used. Nuclemides and nucleotides appeared in the early fractions, followed by adenine (peak 1) and a mixt ure of s-adenosylhomoeysteine and s-adenosylmethionine (peak II), dotted line. The same pxperi. ment with previously heated extract $15 \mathrm{~min}, 100^{\circ}$, is repred sented by the solid line; only $S$-adenosylmethionine was foum under these circumstances in peak II. 
In the latter, S-adenosylhomocysteine preceded s-adenosylmethionine and merged with it in the elution as judged by paper chromatography and enzymatio analysis. ${ }^{(2)}$

\section{CONCLLSION}

The stahilizing effect of the sulfonium group on the glycosidic bond is of great importance. Current conrepts of the acid hydrolysis of nucleosides suggest that a proton is attached initially to nitrogen atom 3 or 7 of the purine and then transferred to the carbohydrate to open the furanoid ring. Difficulty in the initial attachment of the proton or in its transfer to the carbohydrate moiety may account for sluggish hydrolysis. The purine moiety of S-adenosylmethionine should offer the same chance for protonation as in other purine nueleosides. However, the proximity of the sulfonium pole to the purine ring may be inhibitory. As an alternative, the sulfonium group may stabilize the furanoid ring and thus prevent transfer of the proton to the ring oxygen. Perhaps a combination of both effects is responsible for the low rate of acid hydrolysis of the glycosidic hond of S-arlenosylmethionine.

\section{REFERINCLS}

1. Schlenk, F., (. R. Zydek-(wich, I). J. Ehninger, and J. I. bainko. The production of s-adenosyl-L-methionine and s-adenosyl-toethionine by yeast. Enzymologia $29,283-389$ $(1965)$.

2. Hohlenk, F. and C. R. Zrdek ('wick. The action of adenosine deaminase on S-adenosylhonocysteine and related compounds. Biochem. Biophys. Res. (ommun. 31, 427-4322 (1968).

\section{THE SPECIFICITY OF S-ADENOSYL-L-METHIONINE SULFONIUM STEREOISOMERS IN SOME ENZYME SYSTEMS}

rinerenzo Zappia and Frita Schlenk

\section{PCRPOSE AND METHONS}

Linzymes weually show high specificity toward the D- or L-form of compound containing an asymmetric carbon atom, particularly if the action involves the center of asymmetry. Similar stereoisomerism is observel at the sulfur atom of sulfonium compounds:

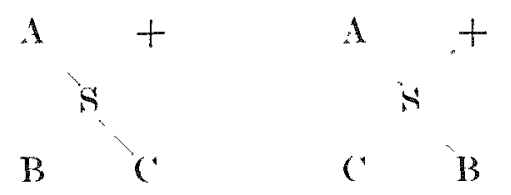

On the hasis of polarimetry, the two stereoisomers are deignated as $1+$ ) and $1-1$ sulfonium form, besaluse the absolute configurations have not yet been clueidated, ${ }^{(1)}$ and no basin exists for the relation to the D- and L-series of carbon stereoinomers. There has been only one investigation to this date which deals with the enzymatic specificity of sulfonium stereoisomer, $1+1$-adenosyl-L-methionine and $(-)$ s-ardenosyl-r-methionine; only the latter was found active in enzyme sytem..' It appeared rewarding to explore this stereoisomerism in more detail. For this, (tisadenosyl-L-methionine was sytherized by methylation of s-adenosyl-L-homocysteine; the activity of the ratemic form was compared with that of biosnthetic, hatural 1-is-adenosyl-L-methionine in several enzyme sytems. For analytical convenience, all methyl donors were ${ }^{14} \mathrm{CH}_{3}$-labelest; the material for the decarhoxylation experiments was ${ }^{1 *}(\mathrm{C})(\mathrm{H}$-labeled.

PROGREA REPORT

For the tests, histamine $N$-methyltransferase, acetylierotonin methyltransferase, L-homocysteine methyltransferase, and S-adenosyl-L-methionine decarboxvlase were employed. In the methylation of histamine (Figure 156) twice as murh of the synthetic ( 1 sulfonium rompound was neederl as of the biologieal $1-1$ form to achieve identical speed of the reaction. Inartivity of the $1+$ setereoisomer is indieated hereby. The same observation wa- made with the acetylserotonin methyltransferase system. In contrast to this specificity, both stereoi-omers were found altire in the methylation of $\mathrm{I}$-homocysteine to L-methionine (Figure 157). The transmethylation with the ( \pm ) stercoiromer went beyond the eritical ralue of $50 \%$, which show that the $(+)$ form is active. The higher speed of reaction with the racumic methyl donor as compared with the $(-1$ form indieates that the $(+)$ stereoisomer react, faster than the biological (-) form.

In the decarboxylation of s-adenowyl-L-methionine to si-alenosyl-15')-3-methylthiopropylamine (Figure 158), only the biosynthetic $1-1$ sulfonium compound reacted. The progress of the reaction with the racemic compound was virtually the same as that observed with half the coneentration of the $1-i$ form; the de- 


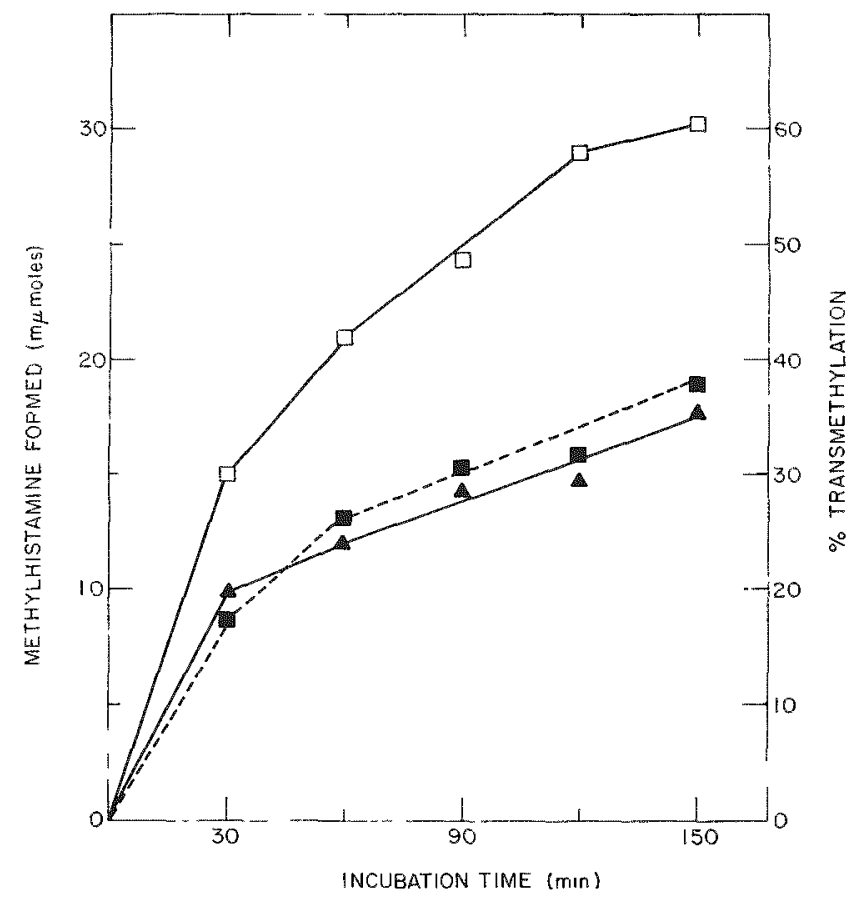

Fic: 156.- Sulfonium stereoisomers of s-adenosyl-ra methionine as methyl donors in the methylation of histamine.(3) Purified enzrme was incubated with 0.2 mole of hist amine

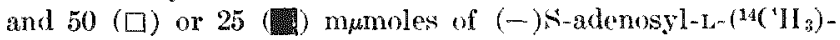

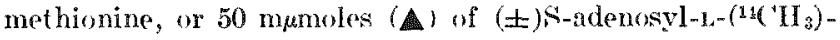
methionine.

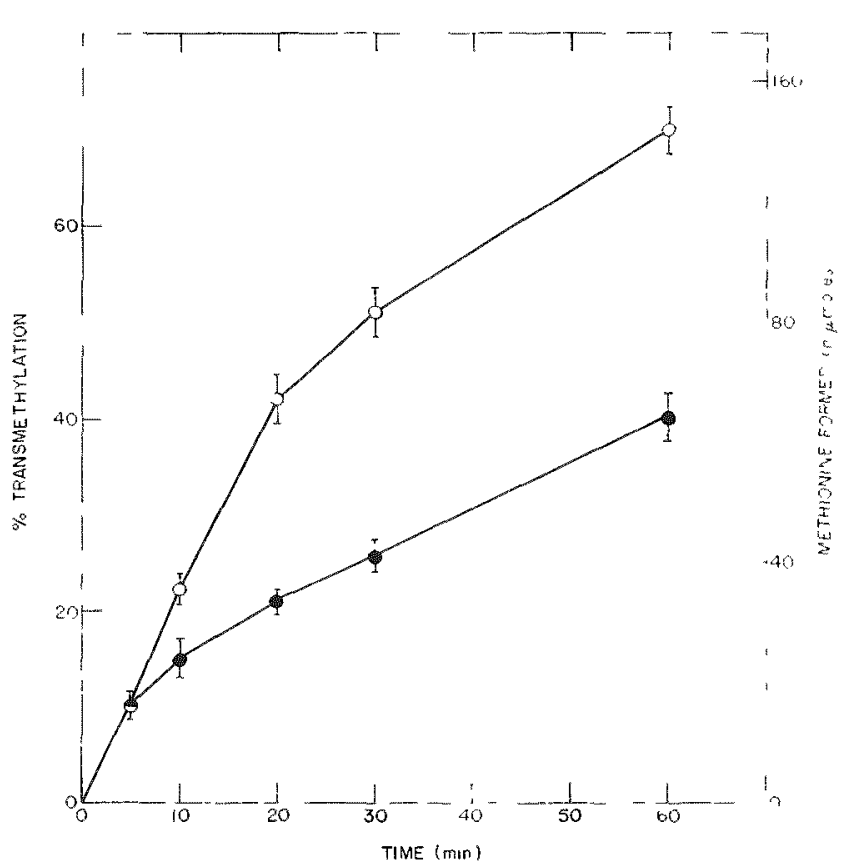

Fig. 157. The methylation of L-homocysteine by sulfonium stereoisomers of S-adenosy l-I -methionine. The enayme was

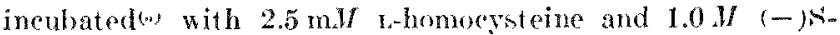

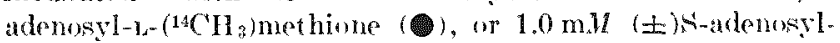
1.- $\left.{ }^{14} \mathrm{C}^{4} \mathrm{I}_{3}\right)$ methionine 10$)$.

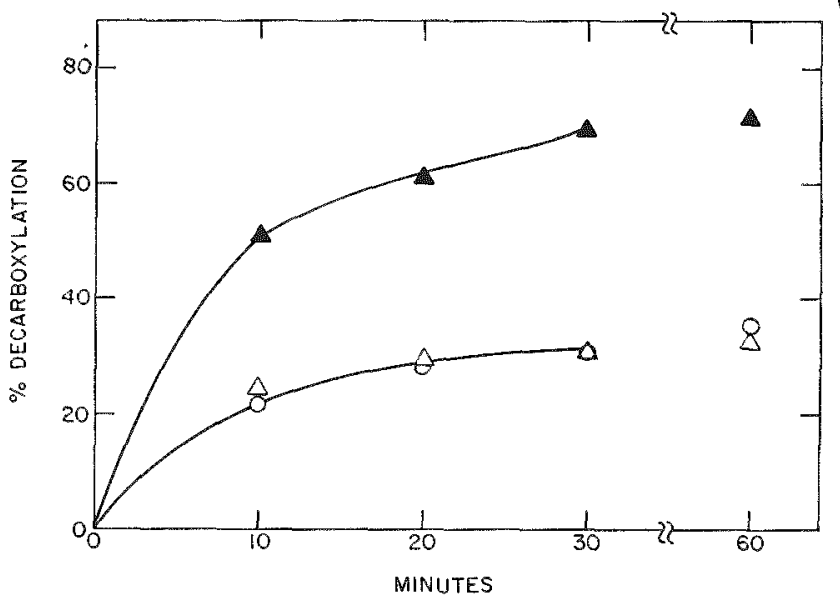

Fit. 158.- Decarbuxylation of the sulfonium steredisomers of S-adenosyl-L-methionine. The decarboxylase from Escher ichia roli was used ${ }^{(4)}$ for incubation with ${ }^{14} \mathrm{C}$-carboxyl-labeled

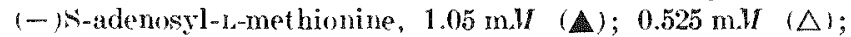
under the same ronditions, ${ }^{1}\left(\mathrm{C}^{\prime}\right.$-arboxyl-labeled $( \pm)$-adennsyl-t-methionine was testrd, $1.05 \mathrm{~m} M(0)$.

carboxylation of the racemic product did not exceed $50 \%$.

\section{CONCLUSIONS}

The activity of both sulfonium stereoisomers of Sadenosyl-L-methionine in the L-homocysteine methyltransferase system is an exception to the usual requirement for the (-) sulfonium donor in transmethylation. The biological implications of this remain to he explored. The sulfonium stereospecificity of propylamino group transfer from S-adenosyl- $\left(5^{f}\right)-$ 3-methylthiopropylamine in the formation of spermidine and spermine from putreseine has not yet been tested. However, the present observation that only $1-1$ S-adenosyl- $\mathrm{t}$-methionine is decarboxylated, maker: it improbable that the $(+)$ propylaminowulfonium compound plays a part in this process.

\section{RLFERENCEN}

1. Nohlenk, $F$. The rheminty of biologieal sulfoninm eompounds. Aflances of the rhemistry of Organie Natrul t'omponndw, Vol. 23, Ed. L. Kechmeister. Springer, Vienna, 19tit, pp. (il 112 .

2. 1)e la Haba. (i., G. A. Jamieson, S. H. Mudd, and H. II. Richards. S-Adenosylmethionine: The relation of eonfiguration at the sulfonium center to encymatic reactivity. J. Amer. rhem. Sor. 81, 3975-8980 (1959).

3. Zappia, V., ('. R. Zrdek-C w ick, and F. Sehlenk. "I he' specifieity of S adenosyl-L-methionine sulfonium steresoisomers in some enzyme systems. Biochem. Biophys. Arta. 178, $185-187(1968)$

4. Zappia, V., R. Cortese, C. R. Zydek-Cwick, and F. Sohlenk The specificity of S-adenosylmethionine decarboxy lase. Att Acead. Van dei lancei (Rome) 46, 191-195 (1969). 


\section{THE METABOLISM OF MITOCHONDRIAL PROTEINS}

Robert $\mathrm{H}^{*}$. Surich* and Carl Peraino

\section{PTHPONF AND METHOD-}

An elucidation of the pattern of turnover of the variou, protein components of the mitochondria should lead to a better understanding of the normal dynamies of this organelle. Fleteher and sanadic estimated the renewal rate of liver mitochondria from the kinetic of the decay in radioartivity of a labeled amino acid with no correction for the posibible effects of reutilization of the irotope. Because the rate of decay in activity in the lipid fraction labeled with acetate was similar, they suggested that the mitochondria are renewed as entities with a half-life of about 10 days. Subrequent studie's by a number of invertigators have tended to confirm an 8- to lo-dity half-life for a number of crude mitochondrial protein fractions.

In the present stuly, rats were exponed continu-

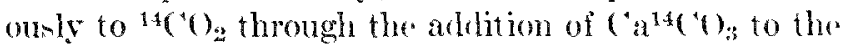
diet, which was then foed fraetionally 24 times a day. The turnover rates of the variou liver protein fraction were ralculated from the specific radioactivities of the guanidine rarbon of protein arginine and of excreted urea after variou leriod of exposure. Mitochondria were separated into six operational fructions, all of which appeared to have about the same turnovere rate: 0.13 to 0.16 days $^{-1}$. (3) The tumover rate- were aloo eximated from enzyme activity kineties by asaving alanine atminotran-ferase ${ }^{13)}$ and ornithine ketoacid aminotransferases at intervalafter rhanging the rate from a nomed diet to at diet high in protein (and the rereres) or atter the injection of the corticasteroid, predni-olone. Th contrat to the re-ult obtained from i-otope incorporation. the renewal rates of the enzymes were very rapid in all rane 0.67 to 0.95 dary 1.31 Additional experiments have been rarried out in an attempt to renolve this differeneer.

\section{PROMRES REIORT}

The lat and mont significant step in the stuly of the metabolic turnover of mitochondrial proteins is the rivere meanurement of the renewal of a pure prom tein from this particle. Ornithine aminotranfarave wa chosen because of our experience with it, the ease of it - purification, ${ }^{6)}$ and the arailability of estimater of its turnover from the kinetien of it induetion.(3)

Confislence in the validity of the latter method would

* Prosemt address: Department of Nutritional Mrences, Eniversity of Wiseonsin, Madion, Wisconsin. be enhanced if similar value could be obtained from inotope incorporation experiment.

We first attempted to isolate ornithine aminotransferane from rat liver mitochondria with the aid of the antilondy to the enzyme, which had been prepared earlier.' (i) An unaceeptably large amount of non-pecific protein wa- however, alway, precipitated with the enzyme-antiborly complex, rendering the technique unders for this purpose. Next. we attempted to inolate the "nzyme from a single liver after the addition of about a 10-fold exeen of pure, carrier ornithine aminot rumserase. While this procedure provided suffienent qutntitien of protein for inotope analysis, the additional aror introduced by the isotope dilution made interpretation of the results difficult. Finally, the purification technique was perfected to the point that amounts of omithine aminot rannferane -uffieient for inotope analysis could be isolated directly from the livers of as few as 4 rats 12 rats, when indured). Although thene experiment - have been frought with methodological diffienltien. ateceptable result were obtained in one txperiment. Table 73 gives a comparison of the renewal rate of ornithine aminotram-fertas as determined by enzyme induction and inotope incorporation. The values agrese equite well. The renewal rates of the other (nonenzyme) fractions are shown for compurison and are similar to those obtained for uch fractions previously. ${ }^{(3)}$ Thus, there seem- to be no douht that this enzyme i- renewed rapidly in the mitochondria and at a rate ahout 5 timen greater than that of the other protein fractions.

It haw been shown that there is a limited but significant sythe-is of protein in the mitochondrion cope Referenese 8); however, it has alno been hown that most of this protein is asoociated with the inner membrane." Becalne ornithine aminotrams ferate is earily colubilized, it is undoubtedly a matrix cuzyme and its

TABHL:

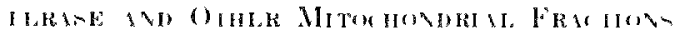

\begin{tabular}{|c|c|c|}
\hline \multirow{2}{*}{ Comploment } & \multicolumn{2}{|c|}{$k$ in $\operatorname{las}^{-1}$} \\
\hline & $\begin{array}{l}\text { En/nie } \\
\text { induction }\end{array}$ & $\begin{array}{c}\text { Isotuget } \\
\text { incopporation }\end{array}$ \\
\hline$=$ & & \\
\hline 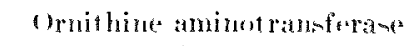 & $0 . \times 1$ & $1 .(10)$ \\
\hline 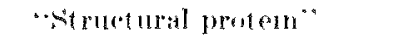 & & 0.15 \\
\hline Remillue & & $0.10 i$ \\
\hline phl 5 preteipitate & & $0.1: 3$ \\
\hline 5.) prequpitate & & 0. 12 \\
\hline
\end{tabular}




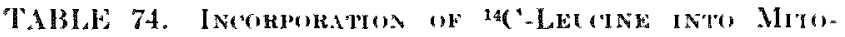
'HONDHA IACT BTED in Vitro

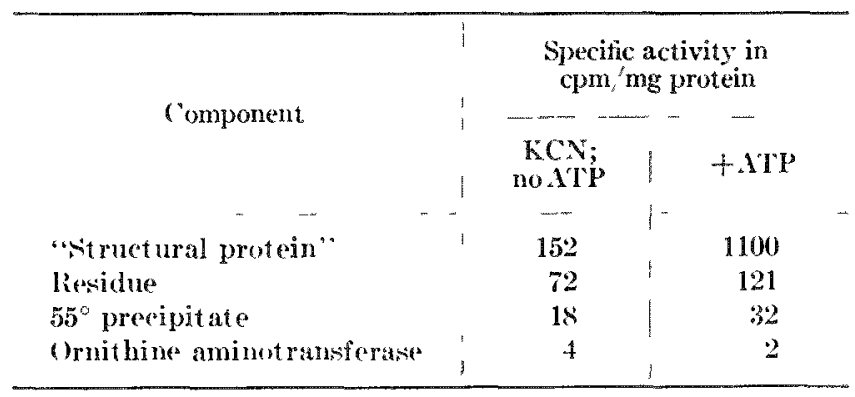

synthexis in situ is unlikely. Its very rapid renewal rate, the speed of its induction, and the speed of its disappearance after removal of an inducing agent could be explained, however, by the in situ synthesis of the enzyme. To test this posibility, mitochondria were incubated with 1 te-leucine and the other components known to be required for in vitro protein -ynthesis. $(x)$ As a control, a parallel incubation was carried out under conditions which preclude protein -ynthesis, i.t., no ATP was adderl, while $\left(\mathrm{CN}^{-}\right.$was included. The results are given in Table 74 . It would reem that while there was incorporation of isotope into the "structural proteins" of the mitochondria under these conditions, no synthes- of omithine aminotranserane occurresl.

\section{CUNCLCSION}

Ornithine aninotransferase has been shown hoth by inotope incorporation and the kineties of enzyme induetion to have a renewal rate of about once per day. a rate 5 times as rapid as that for other mitochondrial protein. This rapid rute apparenty is independent of mitochondrial generation; this independence might be explained by the in situs synthesis of ornithine aminotransfertse. Cinder the conditions employed in these experiments, howerer, no labeled amino acid was incorporated into ornithine aminotransferase in vitro although significant amounts of isotope were incorporated into the "structural protein." Our previous conclusions are confirmed that the mitochondria are in a dynamic state and alteration of the enzyme composition does not depend on the formation of new mitochondria.

\section{RLFERENCES}

1. Fleteher, M. J. and I), R. Fanadi. Turnover of rat-liver mitochondria. Biochim. Biophys. 1etn 51, 356)360 (1961).

2. Snick, R. W. Measurement of protein turnover in rat liver. J. Biol. ('hem. 213, 751 7til 11958).

3. Swick, R. W., A. K. Rexroth, and J. I. Stange. The met abolism of mitohondrial proteins. III. The dynamic state of rat liver mitochondria. $J$. Biol. them. 243, 3581-3587 (1968).

4. Swick, R. W., P. L. Barnstein, and J. L. Stange. The met abolism of mitochondrial proteins. I. Distribution and characterization of the isozymes of alanine aminotransferase in rat liver. J. Biol. ('hem. 240, $33384-33840(19+15)$.

5. Peraine ( ${ }^{\circ}$ and H. ('. Pitot. Ornithine- $\delta$-transaminase in the rat. I. Assay and some general properties. Biochim. Biophys. L lota. 73, 2222-231 $\{19663\}$.

i. Peraino, (.., L. C. Bunville, and T. N. Tahmisian. Chemial, physical, and morphologieal properties of urnithine aminotransferase from rat liver. J. Binl. ("hem. 244, 2241-2210 (19i9).

7. Peraino, ( $\triangle$ Lnzyme regulation in rat liver: purification and properties of ornithine aminotransferase from rat liver. Argonne National Laboratory Biologieal and Medieal liesetareh I ivision Annual heport, 1948. AN1-7535, pp.43-45.

8. Whesdom, I. W. and A. 1. Lehninger. Protein synthesis in isolated rat liver mitechondria. Bionhemeistry $5,35 \% 38,3545$ (19titi).

9. Beattit, D). S., R. L. Basford. and S. B. Korit/. "The inner nembrane as the site of the in eitro ineorporation of $\mathrm{L}^{-14} \mathrm{C}^{4}$. leucine, into mitochondrial protein. Biochementry 6, 30m$3106)(1946)$.

\section{THE HETEROENZYMES OF ORNITHINE AMINOTRANSFERASE}

Robert 11 . Sarde* and lom L. Hoollet

PI RPONF: AND METHOHO

Enzymes from different soures which eatalyze the same reaction and have similar substrate specificities and kinetic propertits are termed heteroenzymes. Heteroenzymes almost certainly have similar arrangements of amino acids about the eatalytic sites, but their anino acid serpuence in other parts of the molem

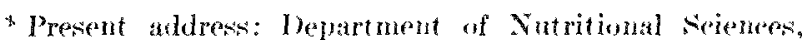
Iniversity of Wiseonsin, Matisen, Wisconsin.

I. IC M student.
}

cule may differ, reulting in differencen in conformation, electrophoretic mobility, solubility characteristics, and immunologieal properties.

The purnose of this project was to characterize a number of the heteroenzymes of ornithine aminotransferan through a comparion of their electrophoretic and immunological properties. The heteromzymes were prepared from mitorhondria isolated from the ti-suen of a large number of species of rodents and other animals available in this Division, using the 
first four steps of the procedure described by Peraino. Bunville, and Tahmisian. "1) Because we started with mitochondria, the specifie activity of ornithine aminotransferase was quite high at this point. Electrophoretic mobility is of interest because of the implications regarding the structural relation hips, both three-dimenrional and chemical; it was investigated wing disc electrophoresis. After migration, the sel plugs were cut into 4-mm lengths and assayed for the enzerme. The comparative immunology of the heteroenzarmes is of interest besaunes of the impliestions rexarding the taxonomic relationships of the sources of the enzyme. The immunologieal cross reactivity of the heteroenzymes was studienl by titration of the enzymes with antiwera obtained from rabbits which had been injected with pure rat liver omithine aminotranserase. Inhibition of the cnzyme activity by the antibody was also investigated.

\section{PROKARES RKPORT}

An analy-is of the activity of each preparation revealed a wide spreal in the amount of enzyme among the different species (Table 75 ). The activity of onithine aminotranferase was expresed in units per gram of tis-ale: the limit of enensitivity was 0.05 unit- ge. Peromyscus leneopus had the highest level of engrme in the liver axumined with 0.72 unit g. Spe(1)e of the families (ricetidae and Muridate also hat high levels of enzyme, and crallus galles was just below these amounts. Although the amomt of enzyme in ('anis familaris liver and kidney, Bos taums kidney,

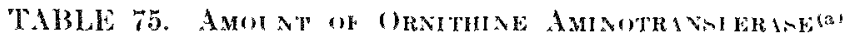

\begin{tabular}{|c|c|c|c|c|}
\hline \multirow[b]{2}{*}{ Organism } & \multicolumn{2}{|l|}{1} & \multirow{2}{*}{\multicolumn{2}{|c|}{$\begin{array}{l}\text { Ornithine ami- } \\
\text { motransferase, } \\
\text { units f } f \\
\text { tissue }\end{array}$}} \\
\hline & & Organ & & \\
\hline$-\ldots \quad-$ & & - & & $\ldots$ \\
\hline Pcromysers leuropus & i & liver & 1 & 0.72 \\
\hline Peromysons alifornirus & & 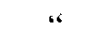 & & 0.45 \\
\hline Rattus norvgimes & & " & & 0.36 \\
\hline Oryzomys paluatri. & & "6 & 1 & 0.16 \\
\hline Rattus ratius & & " & & 0.13 \\
\hline Wierotus pennsylvanirm & & " & 1 & 0.10 \\
\hline Wus musculuss & & “ & & 0.09 \\
\hline Meriones: & t & Kidney & 1 & 0.08 \\
\hline Gallus gallus: & & Liver & 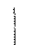 & 0.08 \\
\hline Sigmodon hispidus & & liver & 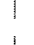 & 0.06 \\
\hline ranis familiaris & & Liver & & $<0.05$ \\
\hline Canis familianss & & Kidney & ! & $<0.05$ \\
\hline
\end{tabular}

(w) The following species were folud to have an amonnt of ornithine aminotransferase signifieanty less than 0.05 units' tissue: Bos taumes liver and kidney, 'itellus tridersmlineatus iver and kideny, ('aria porellus liver and kidney, $M_{u s}$ muse'ues kidney, Syluilagus liver, Mastomys natelensis liver, Meriones liver, Perognathus perillatu, liver and kidney, Mirtohs pernsylvanirus kidney, and Ranu pipiens liver.

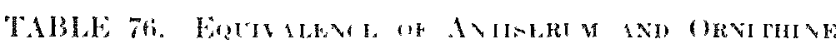

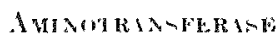

\begin{tabular}{|c|c|c|c|}
\hline Organi-m & Organ & $\begin{array}{c}\text { Calculated, } \\
\text { units } 0.01 \\
\text { ml }\end{array}$ & $\begin{array}{c}\text { slope }=1 \\
\text { units } 0.01 \\
\text { ml } l^{63}\end{array}$ \\
\hline$-\cdots$ & $\alpha-\infty$ & $-\infty$ & - \\
\hline Kathes nored ghems & $\operatorname{liver}$ & 0.076 & 0.078 \\
\hline Ascites tumor aells & & $0.0 \% 0$ & 0.081 \\
\hline Litiltus intian & I livin & $0.06 \mathrm{it}$ & $0.06 i 4$ \\
\hline lus musoluses & Liver & $0.16 \% 3$ & $0.0 \% 60$ \\
\hline I'toml!ystus raliformle'lls & liver & $0.05 \%$ & $0.0 \% 5$ \\
\hline 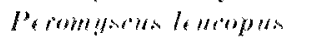 & liver & 0.05 & 0.05 \\
\hline Herionts & Kiding & 0.03 & 0.05 \\
\hline "anis fambliaris & Liver & $0.10: 32$ & $0.02+i$ \\
\hline bos tribitus & Kidnes & $0.02 \times$ & 0.0 .11 \\
\hline Gallus qullim: & Liver & 0.00 & 0.00 \\
\hline
\end{tabular}

"Volumes of ant is:runu diluted $1: 3 \%$

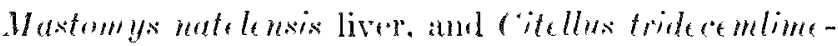
ates liver wa- low, concentration of the preparations marte possible characterization of these enzvmes.

The hereroenzymes of ornithine aminotransferane showed rery similar clectrophoretic mobilities. Purified Ruttus norvegicus liver and kiduey ornithine aminot ran-ferate and the partially purified heteroenzyme preparations moved about $32 \mathrm{~mm}$ under the conditions chosen. Enzyme aetivity was usually found in two adjarent seetions of the gel, although it sometimes ranged from 1 to 5 sections of the gel. When the purified samples were stained, a leading band of enzyme was well defined, but a trailing edge diffuned to clearnes. This was not surprising because the enzyme is known to agugregate.'11 A stained protein bant. however, did not always correspond to the section showing enzyme actirity; apparently, the amount of protein at the site of enzrme activity was inadequate to produce a visible stain.

The immunological tit ration of the enzyme preparation- was next performed to obtain a quantitative measure of the cross reactivity of the heteroenzymes. When eruivalence was calculated, some of the slopes varied slightly from the theoretical value of 1. Thus, equivalenes was estimated hoth from the calculater -lope as well as the theoretical slope (Table 76). A comparison of equivalemes showed that 4 groups were formed (Figure 159). Froup) 1, which consisted of those species in the family Muridae, i.e., Rattus norecyicus, Rattus rattus, Wus musculus, and ascites tumor relk, reacted with the highest equivalence 0.07 units $0.01 \mathrm{ml}$ antiseruml. Group 2, which was from the closely related family Cricetidae, i.e., Peromyscus californicus, Peromyseus leuropus, and Meriones had a lower equivalence point $(0.05$ units, $0.01 \mathrm{ml}$ antiserum). The animals from a different order formed group 3, i.t., Canis familiaris and Bos taums, and 
these had equivalence at a still lower value 10.03 unit $0.01 \mathrm{ml}$ antiserum). Gallus gallus, which in in a different clas, formed group 4. This enzyme wan wither nonreactive, or the extent of reactivity was too low to meaure. Thus, it i- readily seen that equivalence depended on the taxonomie relationship of the different mecien.

The inhibition of Rattes norvegiens liver ornithine aminotranserase by it antirerum was determined. Various amount of antiverum were incubated overnight at $0^{\circ}$ to $4^{\circ} \mathrm{C}$ with a constant antount of enzyme. The -amples were stirred, and an aliquot wa- removed and anaved for conzyme activity. The remaining sample wa- centrifuged, and the supernatant solution was assityed. The amount of anti-erum added plotted against the enzyme units recovered before centrifugation reulted in a two component curve / Figure 160) which wa- renolved he computer analyin. The firnt component reprenented the inactivation of the enzyme by small amounts of antibody. The suppen-ion wan a mixture of free enzyme and antibody-enzyme complex. Complete a-ropiation of the enzyme with the antiboly orcurrel ahout at the breakpoint of the curve, a confirmed hy the lower curve which -hows that all of the enzyme acticity was -edimentable at that point. The second component reprenented the further inhibition of the antihorlv-enzyme complex by larger amount of antibody. Fixtrapolation of thi- line to the ordinate indieated that the antibodyenzyme complex wan $68^{\circ}$ : a active as the free enzyme. 'The antiborly-enzyme complex was also inhibited by

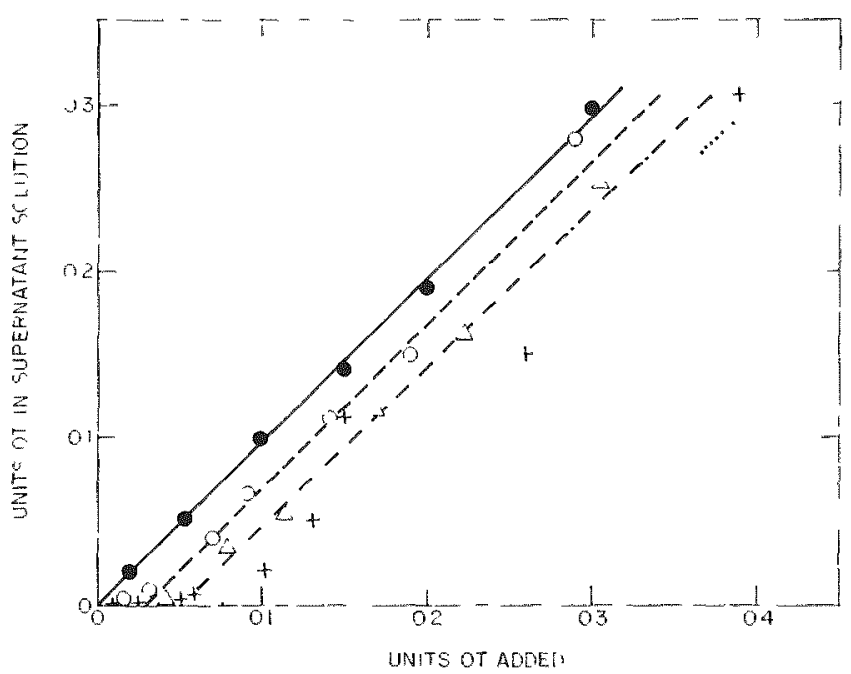

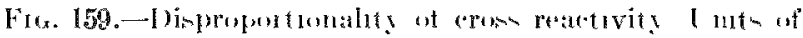
ornithine aminotranferase (c) ald aded $0.01 \mathrm{ml}$ antiserum ploted against unte of ensane in supernatant solution after incubation $001 \mathrm{ml}$ antimerum. $t$, hathes nemlegerm lover; $\triangle$.

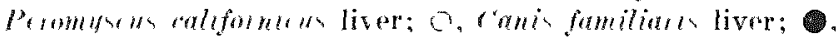
Gullu, gullu, liver.

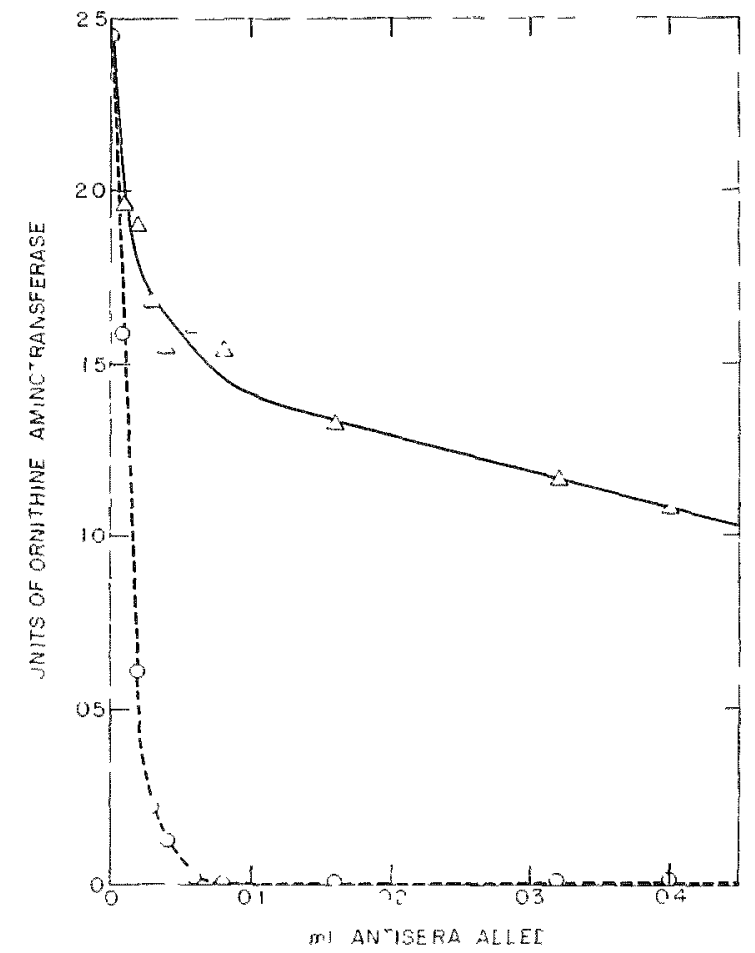

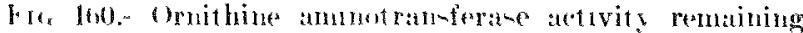

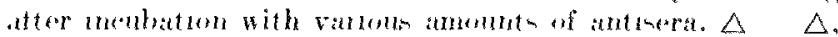
after incubation but before centrifugation; $0 \quad 0$, after inwhation and after coutrifugation.

increasing amount of antibody: ach $0.1 \mathrm{ml}$ of antibody removed 0.107 units of ornithine aminotranferase. This providen evidence that the antibody does not react with the catalytice site, and that the inllibition produced was probably caused hy alloweric efferts.

$\operatorname{cove} L 1-10 \mathrm{~N}$

Flewe tophorefic characterization in based on the net charese of the protein. 'The internal groups of the protein hold the conformation of the molecule; the exfernal sroup, however, determine the net charge, beralue they are not involved with other eharged group. The clectrophoretic molility of all of the prepartion wa- similat. Thus, apparently all of the enzymes, rexardles of source. atre cuite similar in the amino ateid whirh affect the charge on the molerule.

Immunochemical terhnirgues are uned an a basis for taxonomic clasification. The antierum to Rattus normericus liver oruthine aminotran-forane in this stuly reacted dieproportionally with the heteroenzames of ornithine aminotran-ferase. Thus, it is readily - een that the greater the taxonomic difference, the leser the equivalinee value between antiserum and :nzyme.

The estent of the cron-reactivity of ornithine 


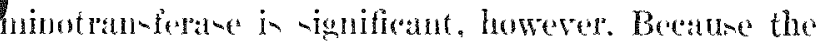
determinant are componed of mall chemical groups in a vecific arrangement, both the groum and the conformation of the heteruenzymes at the determining siten nutet be similar. Apparently the Gallus galles enzyme is -ignificantly different in either one or both rexpecets, bexau-e there was no cromo reaction.

Further characterization will involve the -tuly of

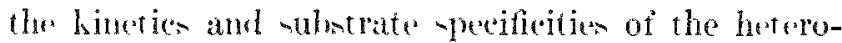
rnzyme and their precipitation and inhibition by the anti-era.

REIERTNCE

1. Peraino, (c, I. C. Bunviles, and T. N. Tahmisan Cheme*al, phrseral, and morphologioal propertion of ornuthine amino tramferase form rat liver $f$. But. ('hem 244, 2241 (1969).

\section{THE HOMOGENEOUS DISTRIBUTION OF MEMBRANE-BOUND AND SOLUBLE MITOCHONDRIAL ENZ̈YMES*}

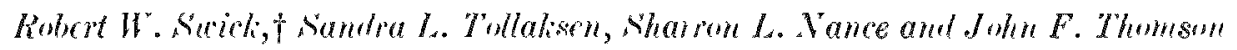

Mitorhondria were i-olated from normal rat liver, kidney, and heart and from molse liver and andites tumor cell-. The mitorhondria were then dintributed through a linear sucroue dencity gradient in a zonal centrifuge. The distribution of the activitien of eteveral enzymen known to be anociated with either the outer or inner membranen were eompared with the distribution of the soluble mitorhondrial enzymen. The millesint of the di-t ribution appeared to be sienificantly different when the two clanes of enzemen were ploted againt the mean particle diameters of the fractions an recovered. (In the other hand, when the distributions of the outer membrune enzemes were calculated an a function of the area of the particle

4. Almetract of papese in preparation.

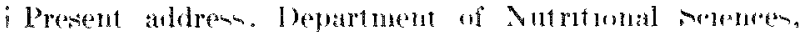

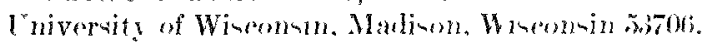

and the dintribution of the soluble enzymes wat ixpreaned a a function of the volume of the mitochondria. the particle diametern corresponding to the respere ive midpoints were quite similar. This congruence ruggent that mitochondria are, after all, homogeneous with remeet to the enzsmat atrivitien examined. Furthermore, the distribution of the inner membrane activitien were like those of the outer membrane enzymon. If the anzyme compo-ition of the membrane is homogeneou, the area of the imer menblane appears to be proportional. not to the rolume of the mitorhondria, but to the area of the onter membrane.

The exeellent congruenee of the di-tribution of rotenone inemitive NAD-cytochrome c reductane and other membrane-bound enzymes is strong evidences that the redurtare is a normal cometituent of one of the mitowhondrial membrane sytem.

\section{THE SEDIMENTATION COEFFICIENT OF ORNITHINE AMINOTRANSFERASE}

\section{layle cr. Bumill}

PI RPQL" AND METHOH

The apparent moleculur weight of ornithine aminotramerant, an determined by equilibrium ultracentrigufation. has been hown to vary from 1322.000 in very dilute -olution up to approximately 200,000 at concentrations of the order of $0.3 \mathrm{me}$ 'ml. ${ }^{(1.2)}$ From information arailable at that time if could not be ascertained whether this rariation in molecular weight was due to the presence of noninteracting preciem theterogeneityl, or a romecuence of the annociation i the enzyme. In order to atabli-h the origin of the Concentration dependenere of the apparent molecular weight, particular emphas- ha- been placed upon its ardimentation behatvior. utilizing the fechnique of band extimentation. ${ }^{\text {s.s }}$ In this techniqute, a thin lamellat of the enzyme -olution is layered onto a dermere-edintentation solvent in an ult rasentrifuge coll. The -uberguent tran-port of the narrow hand of enzyme macromoleculen through thi colvent in ob-reverl -peetrophotometrically an a function of time. The principle adrantage of this technique are 11 ex-

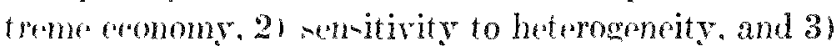
ardaptability to treatment of the enzyms with a wide varity of reagents. In the latter inctanere, sediment ation of the enzyme in a -olvent containing the sulsstate for the enzyme allow- the lles of enzyme ron- 


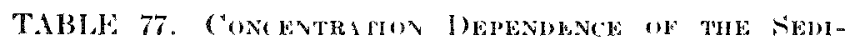

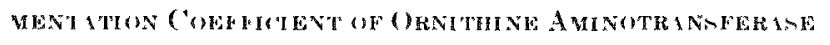

\begin{tabular}{c|c}
\hline Initial conc., mg, ml & $s_{25,2} . \mathrm{s}$ \\
$0.020^{(\alpha)}$ & 5.35 \\
$0.038^{\circ}$ & 5.50 \\
$0.052^{\circ}$ & 5.45 \\
0.26 & 8.43 \\
0.51 & 9.09 \\
1.0 & 9.78 \\
2.1 & 10.0 \\
6.3 & 10.4 \\
\hline
\end{tabular}

'a Solimentation in prenenee of wubstrate.

centrations an orler of magniturle lower than fea-ible when the enzyme is ob erred directly. ${ }^{(4)}$

PROMREST REPURT

As reen from the representative results presented in Table 77, the sedimentation coeflicient, s.s.s, form rected to a rolvent viscosity and density corresponding to water at $25^{\circ} \mathrm{Cl}$, of ornithine aminotransferase is strongly dependent upon the concentration of the enzyme.

By combining the sedimentation coefficient of $5.13 \mathrm{~s}$ and molecular weight of 132.000 obtained at extreme dilution, it may be estimated that the molecular weight correponrling to a selimentation coefficient of 10.4 s is approximately $350 \times 10^{8}$.
From the sedimentation profiles of the enzyme high concentrations, it may be inferred that the high molecular weight species is substantially asymmetric in shape and that the rate constant for it- disociation is small.

OONCLT $-10 N$

From an inve-tigation of the concentration dependence of the sedimentation eoetficient of ornithine aminotransferase, it has been concluded that the variation of apparent molecular weight with concentration't' is the renult of the -elf-ar-ociation of the enzarme.

\section{REFEREVI'ES}

1. Praraino, ("., L. A. Bunville, and T. N. 'Tahmisian. Chemieral, physical and morpholngieal properties of ortithine aminotransferase from rat liver. $J$. Biol. $(' h+m .244,22112249$ 11969).

2. Bunville, I. r. The molecular weight of ornithine amino. transferase. Areonne Dational Laboratory Biological and

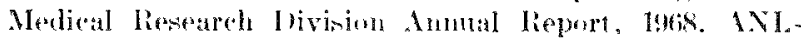
7675, pp. $27: 274$.

3. Vinograd, J., R. Brumer, R. Kent and J. Weigle. Bandrent rifugation of macromolferules and viruses in self gener-

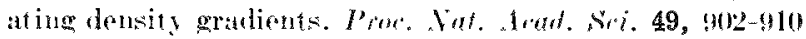
(1:Hii, ).

4. Cohen, R.. P. Giratud, and 1. Meniah. Theory and practice of the analytiral centrifugation of an aretive substrate-

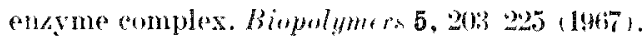

\section{ULTRAVIOLET MICROSCOPY OF EMBRYONATING TOXASCARIS LEONINA OVA}

\section{George Srihla}

\section{PTRPOSE AND METHODS}

C'ursory examination of an veraional nematode or rotifer during the course of ultraviolet microscopy studies in the lat decade has revealed that the distribution and concentration of materials which ab-orb monochromatic energy in these organisms seems to differ from what is observed in yea-t, ${ }^{(1-4)}$ protozoan. ${ }^{(5.6)}$ or mammalian cells. Toxescarix leonina (Ascaridae) egg- isolated from feces of Argonne beagles, or from adult worms obtained hy treatment of the dogs with piperazine hydrochloride, furnished an opportunity to examine the aborption pattern of emhryonating engss of this -pecies. The eggen had been obtained in an investigation, with Dr. Calvin Poole, of the incidence and identity of ascarids in beagles in the Argonne rolony by Latura Harde-ter, a risiting faculty investigator.
The nematode ege in noturiously resistant to chemiraks ued as killing and fixing agents in conventional and elestron microscopy. A method that would permit study of the living organism and rield information about rertain biochemical proseseses of development of the embryo suemed worth intestigating. At the rery least it would provile information about the location and roneentration of materials ahorbing at specific wavelengths that would be useful for stulies of $\mathrm{CY}^{2}$ irradiation effects. Leads to information useful for the elimination or control of $T$. leonina as a speeific parasite, or nematodes in general, could be of considerable economic importance.

Embryonating ova in various stages of development. mounted in water on cuartz slides under quartz covers, were photographed at 297 and $265 \mathrm{~nm}$. A $32 \times$ C'ltrafluar objective was used in conjunction with ap paratus already described. (i) 

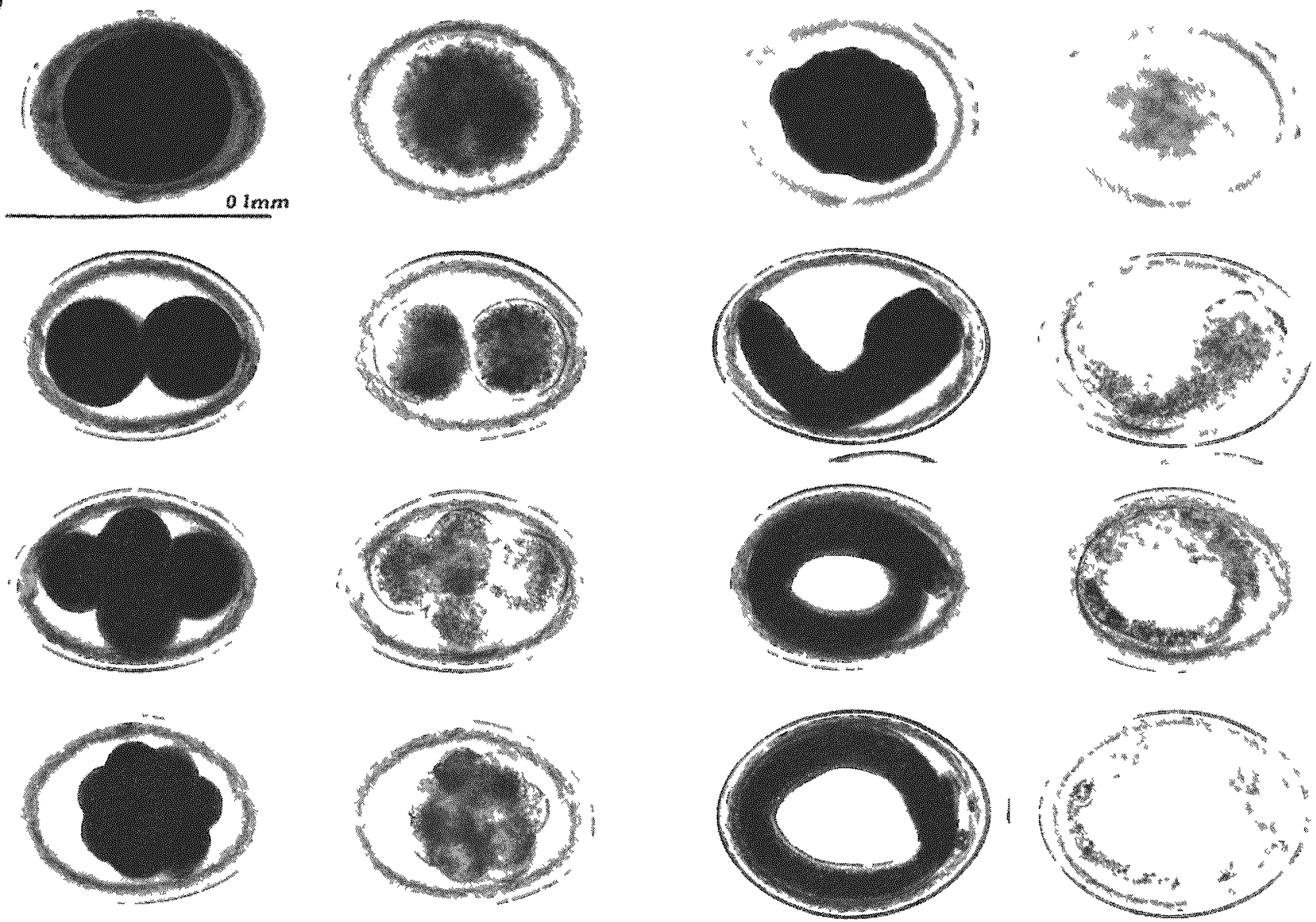

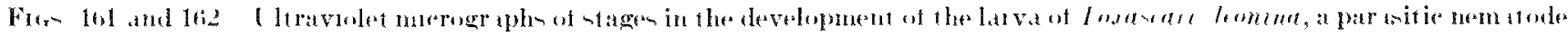

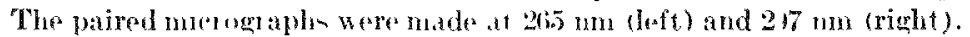

PHOKRKA RLP(ORI

Clt ravelet micrograph- of embryonat ind 2 . lconina ege- made at 297 and 26.5 um restealed - trone aborphtion at 26,5 nm t Figure- 161 and 1621. The al-orption pattern is smikar to that observent in erest of Entometa medem ju-t before exertation:"r) the ultraviolet-aborling material iv uniformly ditributed throughout the reytopla-m of the erell- rather than concentrated in the nuclese, an, for example, icommon for mammalian cell- or in the ehromatoid bouly of $k$. imedene ryote durine early tage of encyatation. While the chromatoil hody of $\mathbf{k}$. en-

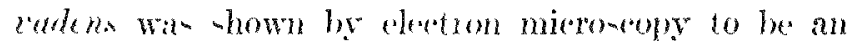
agerenation of ribo-ome-like particken that diepered in the mature cy-t, the UV-ithorhing material of $T$. Ienina egg- ha not been identified. Aborption at $26.5 \mathrm{~mm}$ and focation in the rytoplatm mogent Lat it may be ribonueleoprotein.

Nematodes belonger to the phylum A-rhelminthes, which meludes the rotifere and have a "fixel" -0matice coll number reathed at about the first lasval -tage. No acell division taken place later than their catly embroblogy. Cotil hatching, there is no uptahe of meterial from the environment coxecpt ganeomet. Aiter hatching. growth in hy increate in cell -ize. Becune of there perouliaritien, the dietribution of the IT-ab-orbing material during resll divinion wat of partienlar interent. The serien of ultraviolet mirrograph- I Fisure 161 and 162 , whow that the $[Y$-abcorbing material present in the one-cedled tatere is -hated about afually at "areh aell divi-ion. Infortunately. the -ize and movement of the larval tatge has interfered with obervation of the dietribution of the [T-aborbing material during lifferentiation.

rench-10)

The embryonatine ova of $T$. lemine contain an ablumbares of a more or len homogeneomely din- 
tributed ultraviolet-ahorhing $(265 \mathrm{~nm})$ material. Since aboorption of encrgy in necesary for an eflect, the egg of $T$. lconina should be interesting material for ultraviolet irradiation studies. Some time-lapse motion picture tudies of the effects of irradiation with $253.7 \mathrm{~nm}$ ('nergy on dividing eggs and on larvae have been initiated.

\section{REFERENCTS}

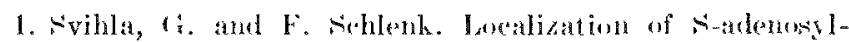

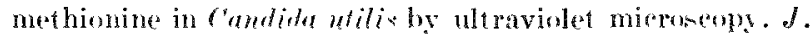
Butertiol. 78, 500 505 (198)

2. Nvihla, (i., J. L. I)ainko, and F, sehlenk. IItraviolet miorose

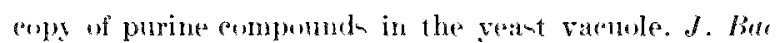
Iot. 85, 349 409 (19tios).

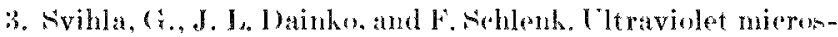

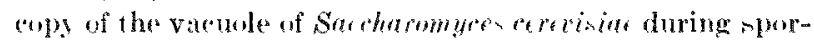
ulation. d. Buteriol. 88, 449 15a a 19tid).

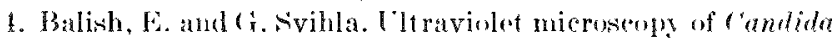

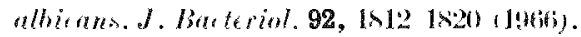

5. Barker. 1). ('. and (;. Svihlat. Lasealization of eytoplannie nuclese arod during growth and eneystment of Entamotha

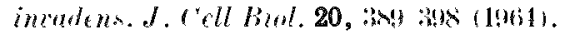

fi. Fehuster, F. and a, Svihlat. Ribonuclemprotein-ront atining venicles in eyots of Vagheria gruberi. J. I'rotonol. 15, 752758 (19)

7. Janiceh. L. and (i. Svihla. I litaviolet mierography in biolociral reseatreh. d. Biol. Ihotog. alswor. 36, 59 (66 (1968).

\title{
ULTRAVIOLET MICROGRAPHY OF PENETRATION OF EXTRANEOUS CYTOCHROME C INTO THE YEAST CEL**
}

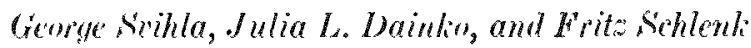

Candida utitis and Saccharomyces cerevisiat in water suspension were found to be very semitive to exogenou- cytorhrome $c$. The protein was taken up by the cells, and the viable count was reduced to it few percent of the initial value. Mierography at 405 $n$ m revealed penetration of cytochrome $c$ into the

\footnotetext{
* Abstract of a paper publishesl in d. Barteriol. 100, 198 jor (19mis).
}

interior of the cell. The rytoplamic membrane lost it capacity to retain intracellular com-ituents; ultraviolet-ahsorbing compound were released into the medium. When budding cell were subjerted to treatment with eytochrome $c$, the mother cells were found more sureeptible than the buds. Phosphate bufer protected the cells and spheroplast against evtoehrome e.

\section{ESTIMATION OF COMPONENT SIZE AND SEPARATION IN FUSED GAUSSIAN DISTRIBUTIONS}

I'ter D. Kleir

PIRPOLE AND METHODS

It is of general interent to be able to detect the presence of two components in a distribution when these components are not visibly resolved in the enveloping peak form. Previous work in this area(1) achieved the renolution of multiplet gatlusian distributions when it was asumed that each component was identical in size and dispersion to the others. As uneful as this is, it would be helpful if it could be appliet to components of unequal size. Ching the computer-generated distributions employed in previous studies, ${ }^{(2-4)}$ I have exanined the higher monuent of the compound di-tribution and found a relationship betwen thene moments, the relative sizes of two unequal components and the soparation hetween them.

\section{PROGRF- REPORT}

Two populations, $n_{1}$ and $n_{2}$, having the same disper-ion $\sigma$, but whose means are separated by an increment, $د, h$, are combined, interval by interval, to give a compound peak with mean $I I$, and dispersion $\sigma$. The monents from firt to sixth are computed as shown in Table 78, which also lists their accepted statintical -ignificance.

A series of populations ranging from proportions of 59.5 to 9.55 , and separated ha di-tances of $د . / 1$ or from 0.8 to 2.6 were syuthesized, combined, and the higher stanlurd moments generated from the compound distribution. Examination of the value for these standard moments showed a relationship be tween the fifth and sixth moments, as illustrated i Figure 163. In each compound peak whose com- 


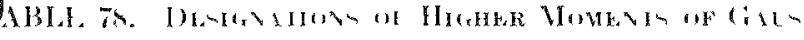

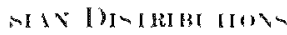

Moment: $\quad \Sigma\left(\mu-x_{i}\right)^{\text {se }}$

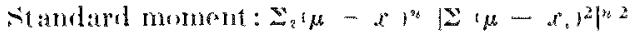

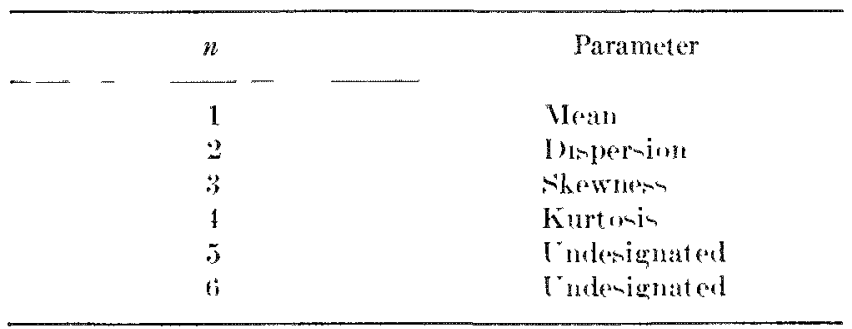

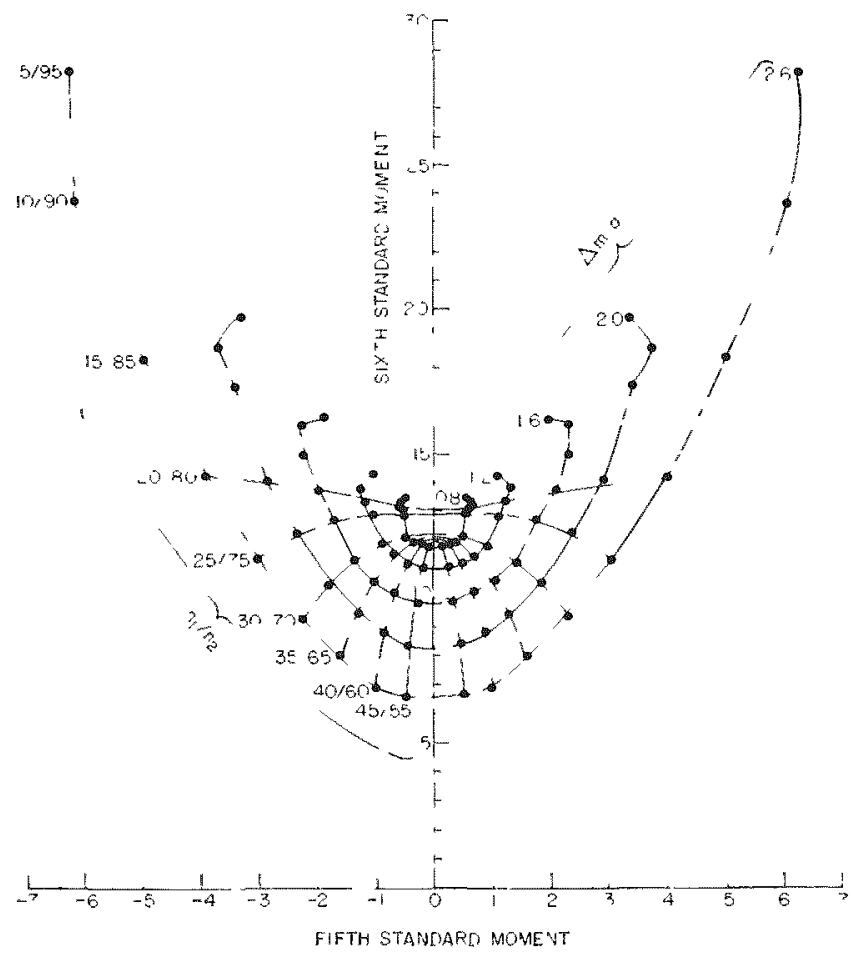

Fit 1tis. Fifth and ant at andard moment of eomponum peah- grouped by peak heparatom and amponent size.

ponents were separated by the same $\Delta .1 /$ or, the vilues for the fifth and sixth standard moments formed a parabola that was concave ubward from the origin and symmetrical about the axis. The value of the fith moment increased in proportion to the imbalance of the two component populations, and parabolas reprenenting larger and larger values of $\Delta . M \sigma$ were concentric in shape.

Through the same points, one can also draw a serim of parabolas which begin as narrow cone, concave rlownwards, progresively broaden and finally berome convex or inverted. These reprenent the value Por a single proportion, e.g., 40,60 lidentical and quiralent in magnitude exerept for sign to 6040 , at progrenively larger values of $\Delta . I T$. Thur, a given fifth and ixth moment uniquely shatracterias the composition of a romponurl peatk.

The cocfficient of the two interecting trien of pratublan were evaluated and their relationship to $\Delta l^{\circ} \sigma$ and $n_{1} n_{2}$ was determined. The eppatration between components could be expresed hy the equation

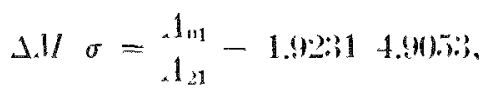

where $1_{21}$ in obtained from the fifth and -ixth - tandard moments $(x, y)$ irom the relation-hip

$$
d_{21}=\left(y-5.23081\left(4.1517+x^{2}\right),\right.
$$

and $t_{101}$ is given by

$$
A_{011}=4.1517 .1_{2}+.0 .2308 .
$$

The proportion $n_{1_{s}} n_{22}$ was obtained from the somewhat more complicated expre-ion

$$
n_{1}{ }_{2}=\frac{\log [13.93310 .500-.42)]+1.5097}{2.856 i},
$$

where

$$
\left.1_{22}=(!)-13.132\right) r^{2}
$$

It is ponible to determine the separation and comporition of two component from these equations. relying solely upon the fifth and -ixth standard moment of the distribution. How well the equationwill determine the parameters is shown in Tables 79 and 80 . Here, the actual moments of the pure, rnthetio distributions were re-inserted in the ecputtions derived. and both parameters were computed orer the entire range -tudiet. Certain limitation are erident in the two tables; for example, the determination of component size is probably unreliable when

\begin{tabular}{|c|c|c|c|c|c|c|c|c|}
\hline$n_{1}$ & 0.100 & 0.150 & 0.200 & 0.250 & 0.30010 & 0.350 & $0.100^{\prime}$ & 0.450 \\
\hline$U_{\sigma}$ & & & & $n_{2} \mathrm{f}_{\mathrm{l}}$ & numl & & & \\
\hline 1.00 & 0275 & 0.292 & 0.316 & 0.344 & $0: 371$ & 0109 & $0+52$ & 0511 \\
\hline 1.20 & $\left|\begin{array}{ll}\mid l & 16 b_{0}\end{array}\right|$ & $0 \begin{array}{c}0 \\
211\end{array}$ & 0254 & 0.300 & $03.5 \%$ & 0.3408 & 0.438 & 0.501 \\
\hline 1.40 & $0181^{8}$ & 0.200 & $024 x$ & 0240 & $0: 3$ & 0.378 & 0422 & (1) 48 \\
\hline $1 \mathrm{ln}, 1$ & $0.028 \mathrm{it}^{2}$ & 0.159 & 0.220 & 0.269 & $0.323,3$ & 0.8867 & 0.418 & $0.1 \mathrm{k}$ \\
\hline 1.80 & $0.01 \times 5$ & 0164 & (1) $2211^{1}$ & 0.267 & $0: 112$ & $0.358 \mathrm{~s}$ & $0.410^{\circ}$ & 0.47 \\
\hline 2.00 & 0084 & $0.15 \mathrm{t}$ & () 210 & 0 & 0.310 & 113,357 & 0110 & 0179 \\
\hline 2.20 & 0.112 & $\begin{array}{lll}0 & 167\end{array}$ & 0.213 & () 258 & $0: 50.8$ & (1):35\% & $0.407^{-1}$ & 0.47 \\
\hline 2. 10 & 0.119 & 0.165 & 0209 & 0.255 & $0.301 \mathrm{i}$ & $0: 301$ & 0.409 & 1) 17 ! \\
\hline 2.60 & 0.186 & 0.171 & 0.211 & 0256 & 0.308 & 0.3583 & 0.410 & 0.45 \\
\hline
\end{tabular}
the -eparation between prak i- low and the components are of ero-ly different proportions. At -epa-

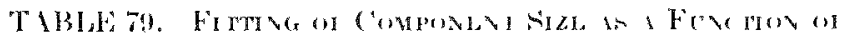

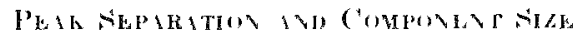




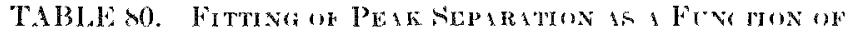
COMPUAENT GIZE IND PELK FEPIRIION

\begin{tabular}{|c|c|c|c|c|c|c|c|c|}
\hline$n_{1}$ & 0.100 & 0.150 & 0.200 & $\begin{array}{c}0.250 \\
-\end{array}$ & 0.300 & 0.350 & 0.400 & 0.450 \\
\hline$\| \sigma$ & \multicolumn{8}{|c|}{$\Delta U \sigma$ found } \\
\hline 1.00 & 1.11 & 1 & 1.14 & 1.14 & 1.1 & 3 & 1. & 12 \\
\hline 1.2 & 1.18 & 1.19 & 1.19 & 1.19 & & 1.21 & 1.22 & 1.21 \\
\hline 1.40 & 1.28 & 1.383 & 1.35 & 1.31 & $1 . \therefore 2$ & 1.30 & $1.2 x$ & $1.26 \mathrm{i}$ \\
\hline 1.60 & 1.39 & 1.17 & 1. 19 & 1.17 & 1.52 & 1.48 & 1.15 & $1.4 \%$ \\
\hline 1.80 & 1.65 & 1.71 & 1.75 & 1.72 & 1.67 & 1.622 & 1.58 & 1.56 \\
\hline 2.00 & 186 & 1.95 & 1.95 & 1.91 & $1.96 \mathrm{i}$ & 1.92 & 1.89 & 1.88 \\
\hline 2.20 & 2.20 & 2.27 & 2.25 & 2.21 & 2.17 & 2.15 & 2.15 & 2.16 \\
\hline 2.10 & 2.17 & 12.5 & $2.1 \mathrm{k}$ & $24:$ & 2.5 & 2.60 & 2.73 & 2.86 \\
\hline 2.60 & 2.8 .5 & 2.45 & 2.70 & 276 & 2.8 & 2.94 & 3.63 & 3.61 \\
\hline
\end{tabular}

rations of $\Delta . / \% \sigma$ of 1.0 , it in not pomible to distinguish differenes in component proportions, and, genterally, components smaller than $15 \%$ are correctly listinguinher only in term of magnitude. A similar interdependene is evident between the value of $\Delta .11 \sigma$ and $n_{1}$ in the measurement of $\Delta . I$ r. Below values of $n_{1}$ equal to 0.150 , values for $\Delta . Y$ or are far more inaceurate than above thim proportion. The relation-hip is mon inaceurate at very low or high valuese ior $\Delta M$ o.

Choice of the constunts und in Fquation 111 to (5) wan made on the bu-in of least square fitting of the data point compromine between the extreme of composition. Tndoubtedly, the inclu-ion of higher order terms in these equations would improve the elo-eness of fit orer wider range, but this would make their solution considerably more difficult. Nevertheless. this first approximation makes powible the resolution of two populations to an acceptable degree without anuming that they are of equal size and without a prior knowledge of the dirtance between their means.

\section{CONCLLSELON}

Two overlapping population. in a compound di-tribution can be dintingui-hed and their relative size and the distance between their mean- may he wimated from the values for the fifth and sixth standard moments of the compound distribution. These relationships apply to any system in which romponents of the ame dispersion and guassian characteristic are present.

\section{RKE FREVCFS}

1. Cejka, V., M. H. Dipert, S. A. Tyler, and P. I Klein. betertion of unresolved multiplet chromategraphis peaks. 1 nal. them. 40, 16141620 (1) 1 (tis).

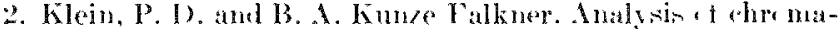
tographic peak displatement and band brotdening be inpurities. Anal. ("hem. 37, 12 t5 124t (19tia).

3. Klein, P. I). Criteria of identits and purity in chromatem graphic separations. St paration si $i 1,511-529$ (196t).

4. Klein, P. K.. 1). W. Simborg, and P. A. Szezepanih. 1)etedtion and eomputation of inotope frationation in the adnorption chromatographe of dual labeled componuls. Pure

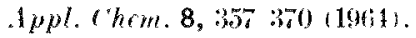

\title{
MEASUREMENT OF ISOTOPE RATIOS DURING COMBINED GAS CHROMATOGRAPHY-MASS SPECTROMETRY
}

\author{
I'ter D. Klein, William .I. Eisker, and P'atricia A. Sicotpanili
}

\section{PI RPOA AND MLIHUD}

There are a number of attractive reanom for using stable irotopes for labeling in place of radioative inotopes. Thene include a greater "ase of handling, the une of conventional synthetic procemen, a creater variety of isotopice posibilities and. mo-t important, their inherent safety and abence of toxicity. Nevertheles, only a small proportion of metabolic and clinical studies makt' $u_{-2}^{2}$ of stable inotopie labeling. At least part of the reanon for surh negleet is the lack of mea-urement techniquen with the sen-ilivity, convenience and speed of liquid reint illation counting, proportional counting, or garnmal spestroscops. Inotoper ratio mea-urement - by conventional mass speetro-enpy unually require the sumple to be in the form of a get, such an $\mathrm{CO}_{2}$ or $\mathrm{NH}_{3}$, which is blend into the ion sourer orer a period of exveral minuter; the ratio is determines from the proportion of jons falling on two fixed collector plates. Such a sy-tem require extencive sample preparation, a far greater quantity of sample than is conventionally uned for radioactive measurements, and the adoption of a fixed collect or plate configuration.

Allany of the problems as ociated with -ample preparation and introduction have been overcome by the we of combined gan chromatographr-mans spectrometre. (1) The gan chromatograph serves to fractimate mixtures into individual component which are introduced requentially into the ion souree of the mass spectrometer. This delivery system permits tho use of exceedingly small quantities of material. prod rided only that they have been made volatile through derivative formation. The problem thus concerns the mean of measuring the irotope ratio of a gas chro- 
- Matographic peak during it trannit through the ion source.

\section{PROGREEY REPORT}

The principle which appears to have the greatent potential for isotope ratio mea-urements is shown in Figure 164. The mass -pectrometer ion heam is adju-ted to bring the lighter ion into focus on the dem tector electron multiplier. Thi ion may he the molecular ion peak or any other fragment expereted to contain the i-otopically mbstituted position. Next. an increncental change in the areclerating field or in the magnetic field is introduced in order to brine the heavier ion of the same type into fore on the detector. Thi inerement is protuced by a sparate power supply to the aceelerating roltaws or magnet voltater and when it is di-ronnected, the fores of the instrument revert to the point of focu for the lighter ion. Thus, ath alternate ardelition and withlrawal of this inerement will produce alternate -ampling of the intermity of heary and light ioms. surh a device. hat already boen dencribed be sweeley ot al., for for u- in the -ingle-focusing LAB gav chromatographmats peretromeder, in which the accelerating voltage wan werd to rhange focus. 'The output from tho veretrometer was simultaneounly switehed between two pert of a dual pen recorder to provide a record of the parasege of the lieht and heary molecular speren through the ion wurce. Becaune of the sight, but pereeptible, degree of inotope fractionation occurring during gas chromatography, the light molerular sperite emerges from the column aluead of the inotopie molecular speries and the true i-otope ratio cannot he obtained from a single in-tantaneous moaurement. ${ }^{3}$ Instead, the individual meanurements of ion intensity must be stored separately and integrated to olitain two integral inten-ities which reprem sent the true inotope ratio.

He have leen concerned with the adaptation of the peak-switching concept to the Perkin-Finer GC-MIs 270, a double-focusing instrument in which the electrostatic sector provide- beam alignment and foeusing and the mathetic field is raried to provide seaming of the mass spectrum. Three questions must be answered to achieve the adaptation: How should the peak switching be carried out? How can the signal he converted to digital ralues and stored? How can the storage of data be coupled to the peakswituhing system? Some of the operational consideration. are: the gas ehromatographic peak may - it ar long as $30 \mathrm{sec}$ or be an whort as 2 to 3 seco and ideally, each ion peak thould be sampled 20 to 30 times during the passage of the gas chromatosraphic peak. This requires a peak-switching rate of
MEASUREMENT OF ISOTOPE RATIOS DURING GAS CHROMATOGRAPHY MASS SPECTROSCOPY
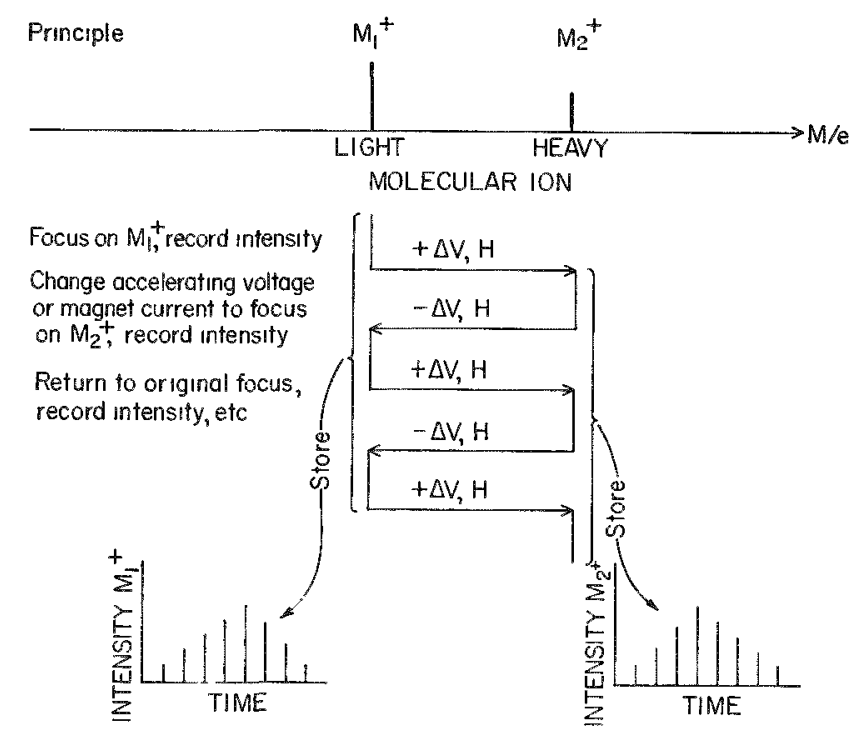

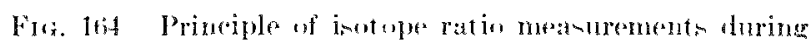

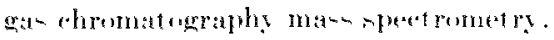

0.5 to $1.0 \mathrm{~Hz}$ variable up to $2011 \%$. This. in turn. rerguiren that the in-trument respond to a change in focus and tablize at the new level with settling time of 5 mose or les. lixten-ive rom-ultation with the denen chemere of Perkin-Eluner has indieated that the magnet voldege sharacteristion are better wited to -uch rapid switehing than the arocklerating voltage. The latter riruitry was derigned with an mpha-i on long-term sability and sacrifices the short-time ronstant- required for -witching in faver of drift-fres lexformance; magnetic peik switching modifiation of the magnet roltage has bech carried out and appeare to be fouble. Wre arto premently constructing the calibrated roltage supply and the flip-flop circuit peruired to and and withdraw the incremental magnet voltage.

Control of the witching frepueney is achiever by the use of a time base generator which simultaneouly switches the voltage and rontes the detretor signal to an adrlers in a multichannel analyzer. The logic of the addres alvance ha been specially modified to permit seruential storage in alternate halves of the momory. Thus, the address sequence in the modified mode of operation is typically 001, 201, 002, 202, 003,203 , re. In this mamner, the two ion peale are stored in separate halves of the andyzer and may be read out in individual fractions, or integrated and read out as two sum. The time bave generator is also used to provide conversion of the analou signal from the clectron multiplier of the detector to a digital form. The voltage from the letector signal is sampled and charges a condemor in the gate eir- 
cuitry. Pulse- from a $1 \mathrm{MIIz}$ oncillator are aceumulated in the addresent channel for a time proportional to the charge on the condensor. This system of analog to digital conversion in lem aceurate than conventional weighing eircuits, but ha- the advantage of being an integral part of the analyzer sy-tem. The digitization and storage of test signals has been -atiofactorily achieverl, an well as subequent readout in soft ropy and puncheel card format. Coupling of the analyzer to the $026 \mathrm{kr} y$ punch ha- been sucess-fully carried out and is operating satisfactorily.

\section{CONCLISION}

It in our inmediate objective to complete the remaining linkage between the time ba-e generator and peak switehing circuitry and extablish the performthee of this concept on known mixtures of deuterated compounds.

\section{REFERENCES}

1. Kilein, P. 1)., F. Mannine and P. A. Szezepanih. (Aan dhromatographe as a method of introducing amimo acid -amples into a mass spectrometer. Argonne Nat ional Iaboratory Bio-

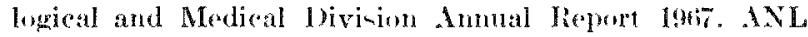

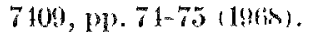

2. Smeeley, ('., F. Filliott, W. H. Ian, and Li. Lyhage. Mans speet rometrid determination of unresslved components in gas chromatugraphore effluenta. Anal. ('hem. 38, 1510150 $16090)$.

3. Latagh, J. H.. J. E. Sealey, and P. IJ. Klein 'The presence and effect of inesope fractionation in lostope dulution anal rein: A factor in the measurement of aldusterome secretory

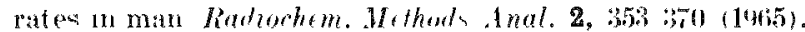

\section{EXAMINATION OF BETA SPECTRA IN A LIQUID SCINTILLATION COUNTER COUPLED TO A MULTICHANNEL ANALYZER}

Peter D. Klein, William J. Eisler, and Merlin M. Dipent

PLRPOAE AYD METHODS

The mea-urement of beta inotopes in biological material by liquid scintillation counting has one major drawback: the weaker the energy of the irotope. the greater the likelihoor that not all of the radiation will be detected. Two factor intervene: 'The solvent molecules excited by the pasage of the beta particle may, in-tead of tran-mitting their excitation to the fluor molerulem which give rine to photons, give up their energy to a eceondary species of molecule. Additionally, before they reach the photomultiplier tube the photon produced may be absorhed and degraded by colored subatances in the ecintillation fluid. There two procesuen renult in a reduction in the average photon energy and in a dintortion of the entergy distribution characterizing the isotope. The degrese to which a given distribution in di-placed or di-torted is related to its mean energy and to the predominance of one or the other quenching mechani-ms. The conrentional mean of determining the efficieney with which a sample is being counted is to irradiate the -ample with a gamma source ("external standard") held agatinst the sample vial. The gamma radiation produce secondary dectron within the simple, whieh behate exactly like the beta particles being counted, i.e., they produce excited -olvent molecules and photons and are ubjected to the same quenching factor as the sample. They are sufficiently energetic, howerer, to rewult in photon production under the most adverne comlition and the effect of quench- ing is almost cutirely limited to a reduction in the average energy of the photons. If the proportion of photons with an encrgy exceeling some mean value is compared to the proportion helow this value, the ratio will reflect changes in quenching within the sanuple. Thi "external standard ratio" can be plotted against counting efficiency for an isotope under known contition, and the resulting calibration curve may be wed to obtain disintegrations per minute from count per minute and the external standard ratio. Infortunately, the beta neectrum of the sample may not repond exactly the ame way to all factors reducing the external standard ratio by the came amount, i.e., different calibration curven may be required for the two type of quenching. A clearer under-tanding of the behavior of beta cpectra under variou- quenching conditions may permit a more explicit formulation of correction factor.

PROMFES RLPUR'

The gan chromatograph-mans yectrometer sintem currently being awembled has provicions for recortind spectra in the multichamel analyzer. This ana-

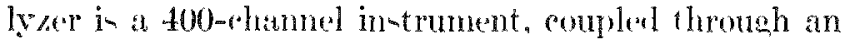
interfuce to an IBM troewriter and $026 \mathrm{k} \cdot \mathrm{y}$ punch. The output of phototuber, through the -umming amplifiers of the Beckman Ts 200 linuid seintillatic comuter, has been connected to the Packard analyze through a conventional gating eircuit. This combination permits the entire beta spectrum a he -tored in 


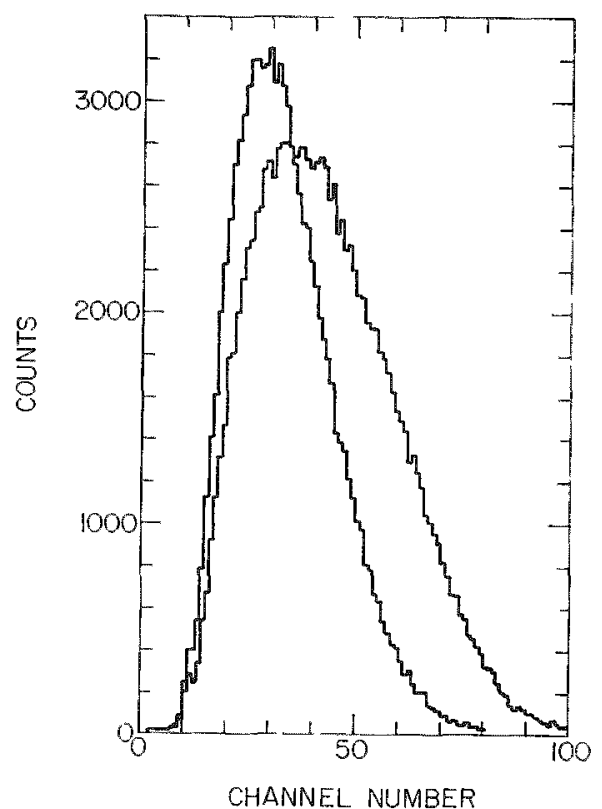

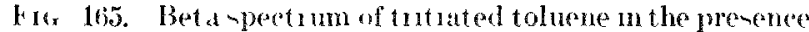
(lett) and absence (right) of origen dissolved on the anditil lator olution

the analyzer memory in far greater detail than the two or three channel- available in the liquid scintillation counter. This was done long ago in the care of gamma isotopes but characterization of beta spertra as statistical populations seem to have lagged behind the treatment of discrete gamma spectra. (Thi appears to be a general novelty to other uner of liquid scintillation counter. We have found that the di-play of beta spectra in thin manner -uecerd- in conveying to student an immediate comprehen-ion of the relationship of the tritium -pectrum to the carbon spectrum. window selection for dual label counting, effects of quenching, etc.l The advantage of this instrument configuration in that the data may be handled by exi-ting computer routine for -tati-tical analy in and on-line plotting of spectra.

In the short time that thi-configuration has been in

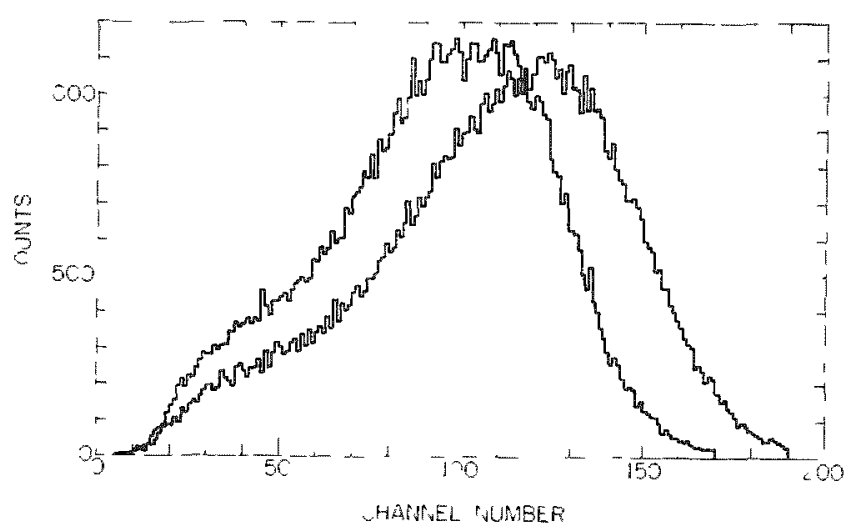

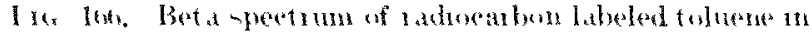

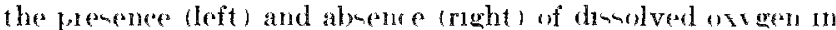
the sentillat or solution

operation, no exten-ive analysi of peak hapes hats been po-ible. A striking qualitative change of known

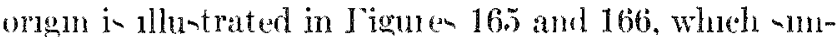
ply represent the pectra of tritium and radiocarbon in -tundard scintillation olvents me presenes and ab-ence of dimolved oxyern. The reduction of atverage photon energy in rivid and graphically exilent. curve-fitting. using normal and log normal di-tribution functions, has heen suecesful in describing -amplen with moderate lo-ser in radiocarbon efficiency and exten-ive locae in tritium. It is further apparent that the present sy-tem of liquil scintillation couming. in which sector of the neetra are examined through a limited number of channel, may be more sen-itrete to effect generated by a nurrow experimental pont of view than the multichannel analyzer. Certianly, one ran di-tingui-h between low in efficieney as repurewnted by count falling within a specifie energes range and the failure of tho-e photons to reach the photomultiplier. The exoml procen, as ween in the analyzer, applar to be lew wevere than the former. Thin may nedieate that yestalt ham at role to play in the phrereal an well an the biolocieal reienem.

\section{COMBINED GAS CHROMATOGRAPHY-MASS SPECTROSCOPY OF BACTERIAL FATTY ACIDS}

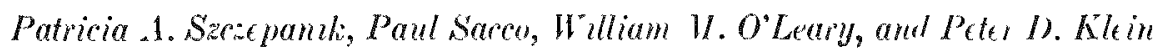

PLRPOLE AND METHOD-

There is growing interent in the pomibility of a-ifying closely related organisms on the ba-is of heir chemical composition. Such efforts at chemical taxonomy are particularly concerned with diringuinhing members of the same species of microorga- ni-m, now clanified at the same variety, which may hate been inolated from different sources. Becalne the componition of hacteria, particularly the lipic fraction, ean be dra-tically altered by culture condition of medium and time of harvent, it in nerenary to conduct such studies under elosely similar 
conditions for all varietien. Two laboratorien, one in the Department of Pharmaey of Xavier Cnirersity, New Orleans, and the other in the Department of Microhiology, Cornell Medical College, New York, have been concerned with this classification process an it applies to species of Preudomonas. At Xavier University, there are three varieties of plant nathogen that infect tobacco and at Cornell, there are four culturem of Pseudomonas aenumosa, esach irolated from a different source. Drs. Aareo and O'Leary have dereloped culture conditions for their organisms that are reproducible and comparable within each set. Preliminary characterization of the fatty acid methyl ester has been done in both laboratorics, but the alsence of definitive standards in several casen has delayed the clawification of types of fatty acid. Moreover, the quantitative analysis of compo-ition requires a volume of data handling not available in thene laboratories.

\section{PROCRESA REPORT}

We have established gas chromatographic and mass -peetrometric conditions for the separation and analysis of fatty acid mixtures as their methyl ester, using the Varian Aerograph instrument for quantitative comporition and the Perkin Elmer-270 for mass spectra determination. Although it is likely that quantitative analysis of the components can be made from

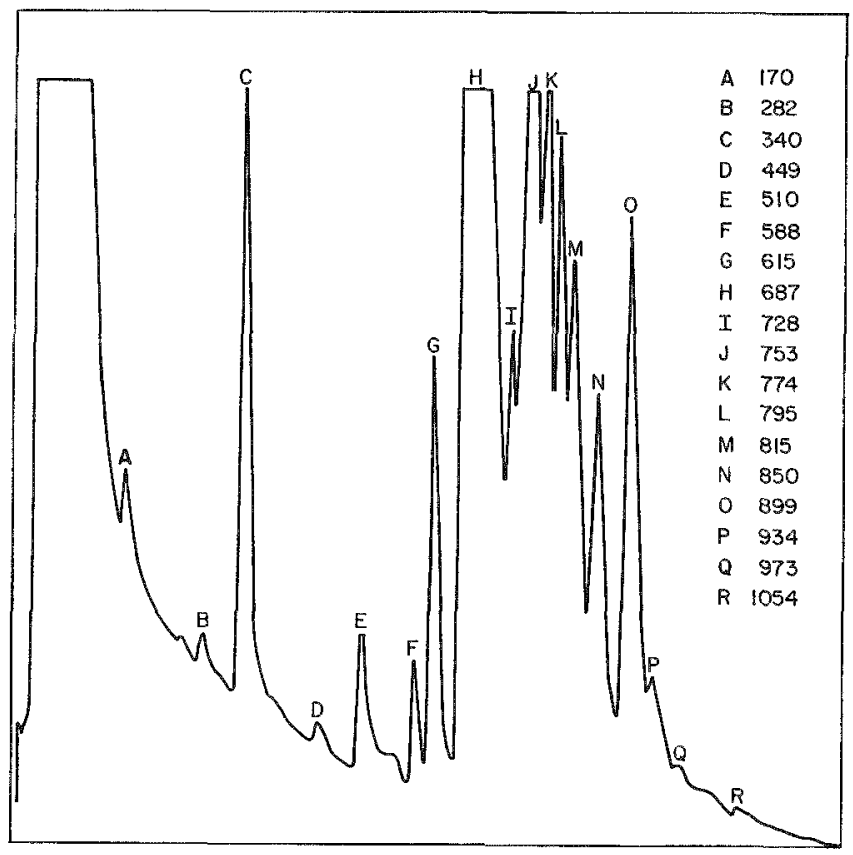

Fys. 167. Cras chromatogram of the fatty acid methyl asters of Pscudomonas aerugmosa \#352. Conditions: Column ${ }^{s}$ in $\times$ ift, $10^{c}$, diethylene glycol suceinate on Chromosorb Q, 80-100 mesh; temperature 90 to $185^{\circ} \mathrm{C}^{\circ} 10^{\circ} \mathrm{per}$ min; gas, helium, $10 \mathrm{ml}$, min.

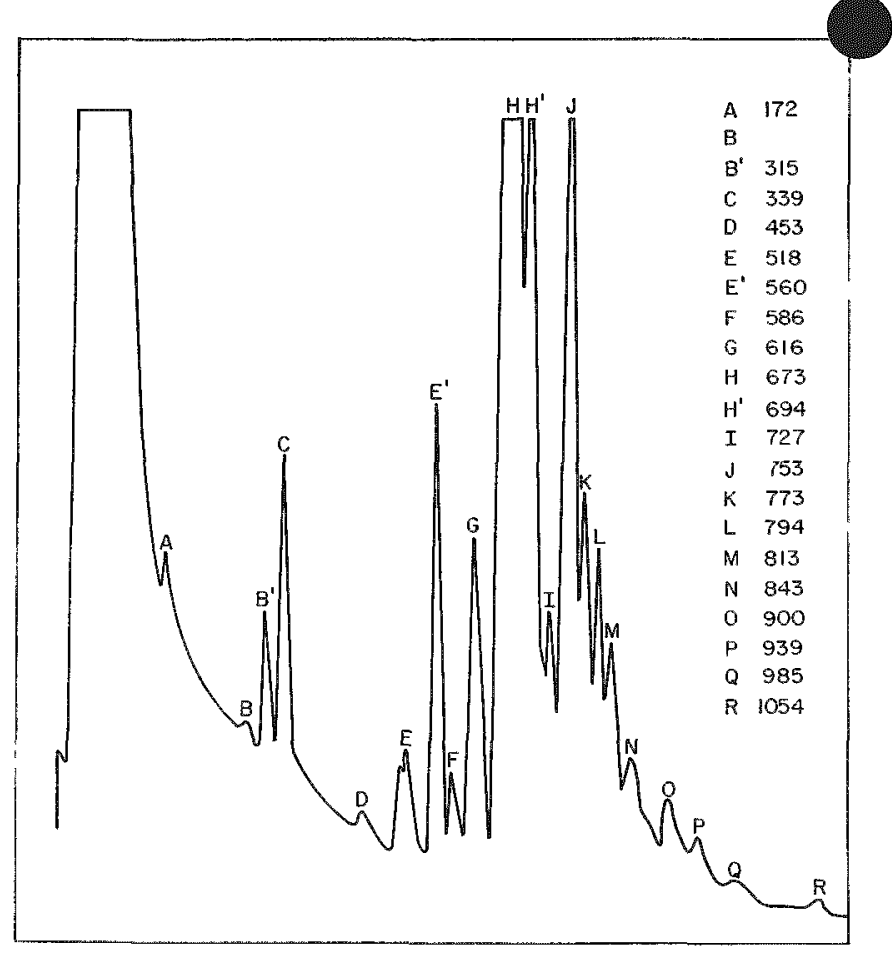

Fict. 168 Conditions as in Figure 167. Sample of fatty acid methyl esters treated with trifuroaretic anhydride.

the total ion current records of the gas chromatograph in the 270 , we have not yet established the efficiency with which individual fatty acids are transferred through the molecular separator to the ion source. This has required running all studies on both instruments to obtain both qualitative and quantitative analyses. The previously established gas chromatograph-digital peak integrator system, coupled through a multiplexer to the IBM 026 card punch has yermitted calculation of relative retention times and percent composition from the output of the digital peak integrator. This hav proved to be an enormou-aving of time and the only feasible way of combining replicate runs to obtain averaged values for the romposition.

The Perkin Elmer-270, after an extended period of thake down. ham produced high quality spectra, which we are claswifying and interpreting on the basis of known standards and published speetra. The high degree of reproducibility is shown in Figures 167 and 168 , which represent two gas chromatographic records of the same fatly arid mixture; in Figure 167 as the simple methyl enters and in Figure 168 as the trifluoroacetate (TFA) derivatives of the methyl esters. The latter derivative modifies any substitutent on the hydrocarbon chain, e.g., an amino or hydrox. group, and reduces its retention time. The letters on the peaks of the chromatograms represent points at which mass spectra were taken, and the listing of 
eak indicates the retention time in seconds. When the two chromatograms are compared, the clone agreement between retention timen is clearly evident and the appearance of three now peaks, rewulting from the TFA derivatization, can be ascertained. Thene are indicuted in Figure 168 by prime marks. These chromatograms al-o illu-trate the complexity of the char- acterization problem: eighteen component, can be distingui-hed in thi chromatogram, and each -pectrum mu-t be andlyzed at least once in each series. Neverthelom, the veratility and potential of this in-trument system in the analysis of complex mixtures in clearly evident in the short time it hav been operating.

\section{STUDIES ON RAT LIVER RIBONUCLEASES. IV. FURTHER STUDIES ON HETEROGENEITY OF LIVER LYSOSOMES: INTRACELLULAR LOCALIZATION OF ACID RIBONUCLEASES AND ACID PHOSPHATASE IN RATS OF VARIOUS AGES*}

Iuch Erh Rahman and Eliabeth A. C'crmy

In adult rat liver, by the we of sucrove gradient centrifugation, the intracellular distribution pattern of acid ribonucleare was found to be different from that

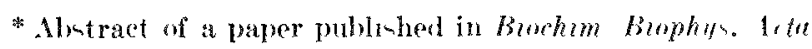
178, $4167(1969)$. of acid pho-phatase. This finding further confirmour previou-reults obtained by zonal centrifugation.

An arditional gromp of subcellular particles in the top few fractions of the gradient wan reported in young rat. The biological significance of this new group of particles is discussed.

\section{STUDIES ON RAT LIVER RIBONUCLEASES. V. LIVER RIBONUCLEASES IN DEVELOPING, 2-ACETYLAMINOFLUORINE FED AND PARTIALLY HEPATECTOMIZED RATS*}

Yueh Erh Rahman, Elisabeth .1. C'erny, and r'arl Peraino

A relationship was found between the activity of three ribonucleane and liver growth.

111 threc liver ribonucleaves ,howed high activity in fetuses 3 days before birth, in new-born, and in suckling ratc; these enzyme activities decreaued gradually and attained the adult level between 30 and 40 days of age. Acid phosphatase was relatively constant during the developing stage of the rat.

Acid ribonuclease (i.e., ribonucleane I) increased soon after feeding 2-acetylaminofluorene while acid phosphatase decreased. Ribonuclease II and ribonu-

* Summars of a paper puhlinhed in Blowhem biophis. Alete $178,(18-73,(1964)$. clease III increased during the first 5 to 6 week and decreaner sub-equently for approximately 10 weeks before returning to the control level.

In regenerating liver, all three ribonucleases were increaned roon after partial hepatectomy with a maximal increase at about $4 \mathrm{hr}$ after the operation. Pibonucleare II activity was significantly decreased from $8 \mathrm{hr}$ to $24 \mathrm{hr}$. Ribonuclease I and ribonuclease III remained increased up to $72 \mathrm{hr}$ after partial hepatertomy.

The possible implications of the relationship between ribonuclease activities and phenomena of liver growth in discussed. 


\section{RNA TURNOVER STUDIES IN LIVERS OF SUCKLING RATS. APPLICATION OF POLYACRYLAMIDE GEL TO RNA SEPARATIONS}

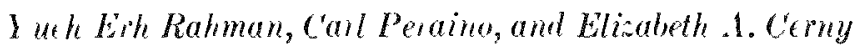

PLRPOA AND MLYHODY

High activity of liver rubonucleanes was found in fetu-e three days before birth. in new-boms, and in suckling rat. (1) This finding -uggests that the RNA in young rat may be turning over more rapidly than in adult rats. Therefore, experments were conducted to tent the valudity of this hypothesis.

Four- to six-day-old suckling rats were injected intruperitoneally with ${ }^{14} \mathrm{C}$-orotic acid at a dore of 10 $\mu \mathrm{C} 1100 \mathrm{~g}$ body weight. Groups of 16 rats were then killed at different tome intervals after the ${ }^{17}$ '-orotic arel injection; their livers were remored at one and pooled for homogenization in ice rold $0.25 . I I$ cucrone. The nuclei were purified according to the methor deseribed by Blobel and Potter. ${ }^{(2)}$ After the centrifugation. the nuclei were collected from the pellet at the botton of the tuber; the supernatant, which con-ivted of the bulk of cytoplam and cellular membranen, was recovered quantitatively and centrifuged again in the spunco 30 rotor at $30,000 \mathrm{rpm}$ for $1 \mathrm{hr}$. This material wa- ued a eytoplam of the liver. Total RNA was extracted from both the cytopla-m and the nuclei in the presenee of sodium dodecrl sulfate, according to

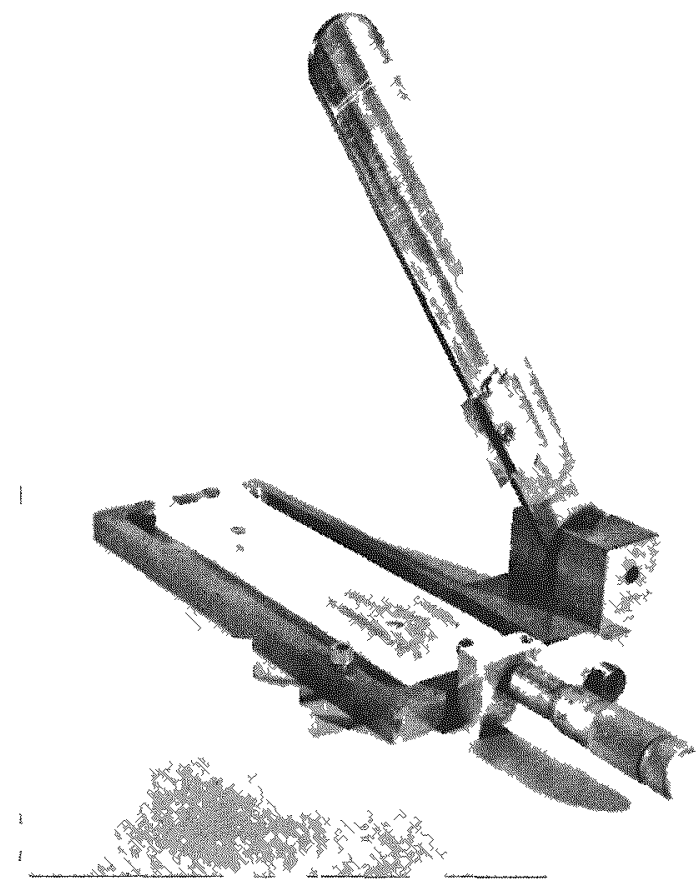

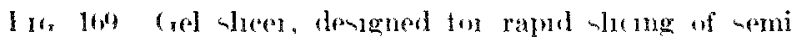
fro/ongel $g$ trip
Hyatt, ${ }^{(3)}$ and the mucleic acids obtained from both fraction were treated with deoxyrihonucleace as dencribed by Di Girolamo et al. ${ }^{(4)}$ before being precipitated overnight at $-20^{\circ} \mathrm{C}$ from ethanol containing $2 c^{\circ}$ potassium acetate. The precipitated RNA was then dicolved in 0.01 .4 Tris buffer, $\mathrm{pH} 7.4$.

Aliquots of RN.1 colution were determined at $260 \mathrm{mp}$ in a Beckman DU spectrophotometer. A concentrition of $10 \mu \mathrm{g} \mathrm{ml} \mathrm{i-asimed} \mathrm{to} \mathrm{give} \mathrm{an} \mathrm{absorb-}$ ance of 0.24 at $260 \mathrm{~m} \mu$. The radioactivity was determmed in a Beckman liquid scintillation counter.

RNA was further separated by gel electrophoresis, which wa performed at pll 9.2 on a $3 \%$ polyacrylamide gel rCyanogum $\mathrm{kab}$ in an $\mathrm{EC}$ apparatus. Sample containing $200 \mu \mathrm{g}$ of $\mathrm{RN} \Lambda$ in a final volume between $0.2 \mathrm{ml}$ and $0.6 \mathrm{ml}$ were placed in the sample slot- Migration wa- toward the anode, and the running time was approximately $2 \mathrm{hr}$ at $300 \mathrm{~V}$ and 140 m. The gel lab was then removed from the apparatus and cut longitudinally into strips, each of which encompassed one sumple slot and the migration path of that sample. The strips were then placed in a tray lined with Saran wrap, and the tray wan placed on a slab of dry ice to freeze the strip as quickly a po-ible. Quick fretzing was enential to maintain the integrity of the gel structure. Each frozen strip was placed in a specially devi-ed gel slicer (see Figure 1691, which was lying on a bed of crubled ice. The frozen -trip wat then allowed to warm lightly to a whipetively determined optimum ron-1-teney for licing, and slices $(1.8 \mathrm{~mm})$ were made as rapidly as po-ible. Fach slice wa placed in $2 \mathrm{ml}$ of double distilled water in a test tube, and the tubes were allowed to stand at room temperature for $48 \mathrm{hr}$. This procenture consi-tently eluted all the radioactivity from the gel slices and enabled $u=$ to obtain highly reproducible radioactivity patterns. The procedure wan umativfactory with regard to chemical measurements of RNA, however, sinces variable amounts of extraneous $260 \mathrm{~m}_{\mu}$ ab-orbing material was eluted from the gel, which also interfered with the orcinol anay for RNA. It was not posible, therefore, to determine the specific activity of the RNA in each gel -leet. The distribution of the RNA in the gal prior to elution was vi-ualized qualitatively in the following mannere.

After electrophoresis the gel slab was remove from the electrophorewis chamber and taken to a dark room where it was placed on a Vycor plate (1/8" thick) 


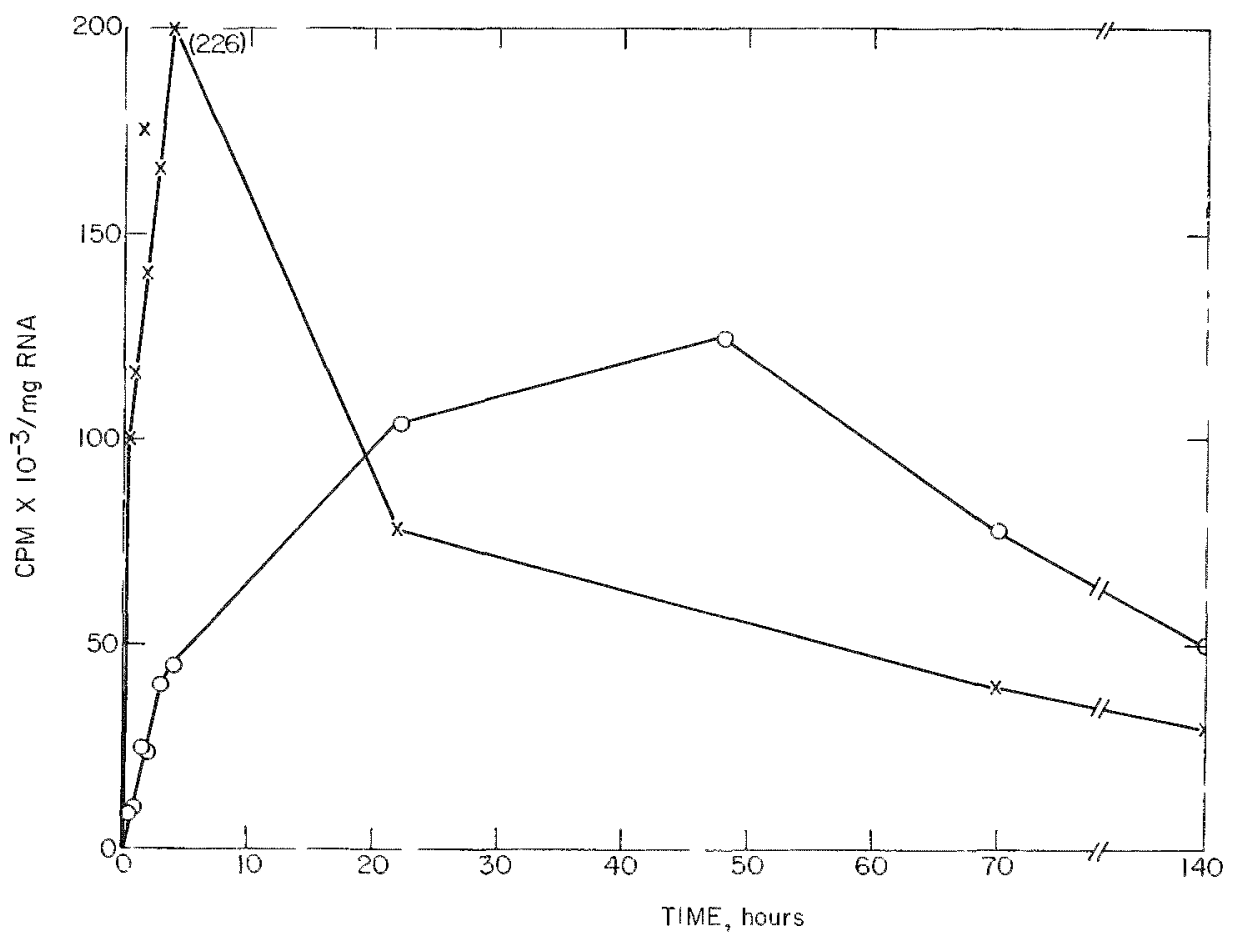

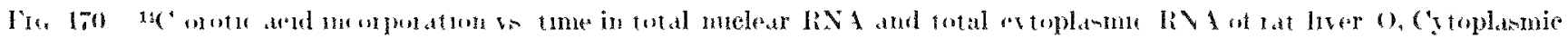
IRXI; ג, nuclear IRNA

which wan overlying a theet of UV-sen-itive film. A $2.56 \mathrm{ma} \mu$ light -ource wan positioned above the gel and turned on briefly after which the film wan removed from beneath the Fycor plate and developed. The poition of the Uf lisht -ource and the time of expo-ure were varied to produce optimum remult

\section{PROGRL}

Figure 170 show the incorporation of ${ }^{14} \mathrm{C}$-orotic acil into the nuclear RNA on one hand and into the cytopla-mic RNA on the other. The nuclei incorporated high radioactivity $30 \mathrm{~min}$ after the ${ }^{11} \mathrm{C}$-orotic acid injection, and this incorporation increaned rapidly up to 4 hr and then decreased subsequently. Twenty-two hourn after the injection, only about onethird of the radioactivity found at $4 \mathrm{hr}$ remained in the muclei. The cytopla $-\mathrm{m}$, on the other hand. incorporater at a much slower rate, with a maximum after $48 \mathrm{hr}$, and then decreated ateadily up to $140 \mathrm{hr}$.

Tahle 81 shows the same revults as Figure 170 , but they are expressed as percentagen calculated from the total radioactivity recovered from the nuclear and the cytoplasmic RNA. Up to $4 \mathrm{hr}$ after the injection of ${ }^{11} \mathrm{C}$-orotic acid, 80 to $90 \%$ of the radioactivity wan calized in the nuclei, and thi- radioactivity was then rapidly reduced to a level of $43 \% 22 \mathrm{hr}$ after the injection; and it was further decreaned to $32 \%$ after

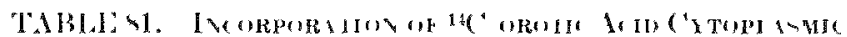

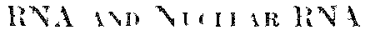

\begin{tabular}{|c|c|c|c|c|c|}
\hline \multirow{12}{*}{--} & Time & \multicolumn{2}{|c|}{ 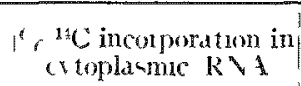 } & \multicolumn{2}{|r|}{$\begin{array}{l}\text { "1" incorporation } \\
\text { m nuclear } R \vee A\end{array}$} \\
\hline & $\underline{-}$ & 1 & $\underline{-}$ & & {[} \\
\hline & 30 min & . & $\bar{i}$ & & 9.8 \\
\hline & $100 \mathrm{~min}$ & & 9 & & 91 \\
\hline & 90 zकnu & 1 & 1.3 & & 87 \\
\hline & $120 \mathrm{mm11}$ & & 16 & 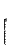 & $s i$ \\
\hline & $1 \times 0 \mathrm{~mm}$ & 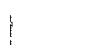 & 14 & & $\Delta 1$ \\
\hline & 210) min & & $1 \%$ & 1 & $x_{0} 3$ \\
\hline & $22 \mathrm{hr}$ & 1 & 5 & 1 & 1.3 \\
\hline & Ix hr & & (n) & 1 & 32 \\
\hline & $70 \mathrm{hi}$ & & 67 & & $M$ \\
\hline & $110 \mathrm{hr}$ & & $6:$ & & 37 \\
\hline
\end{tabular}

$48 \mathrm{hr}$. Thi percentage of radioativity in the nuclei remained almost unchanged thereafter up to $140 \mathrm{hr}$.

The ahove results .how verr clearly that the mont rapidly labeled RNA in mainly localized in the nuclei, and this labeled IRNA was ubequently transferred to the cytoplasm. Whether the labeled nuclear RNA was tramferren an intact RNA molerules or an degraded material into the cytoplarm is not known. Thi- point raises the question of whether or not there are RNA degrading enzymes within the nuelei. Experiments are under way in order to clarify this point.

Figure 171 shows the radioactivity found in nuclear tRNA and in cytopla-mic tRNA at different time 


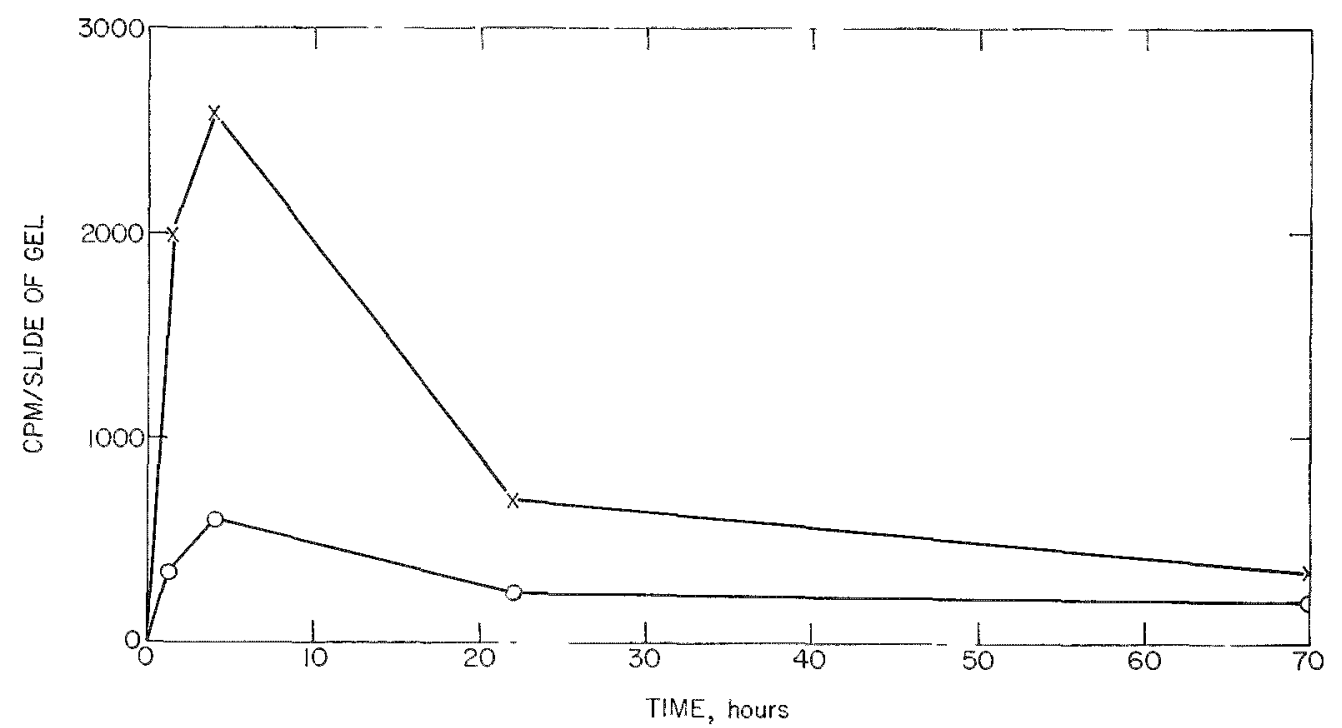

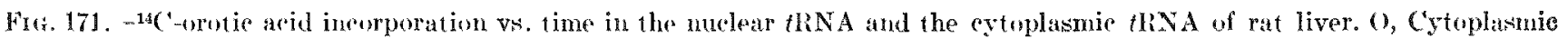
tRNA; X. nuclear $t$ RNA.

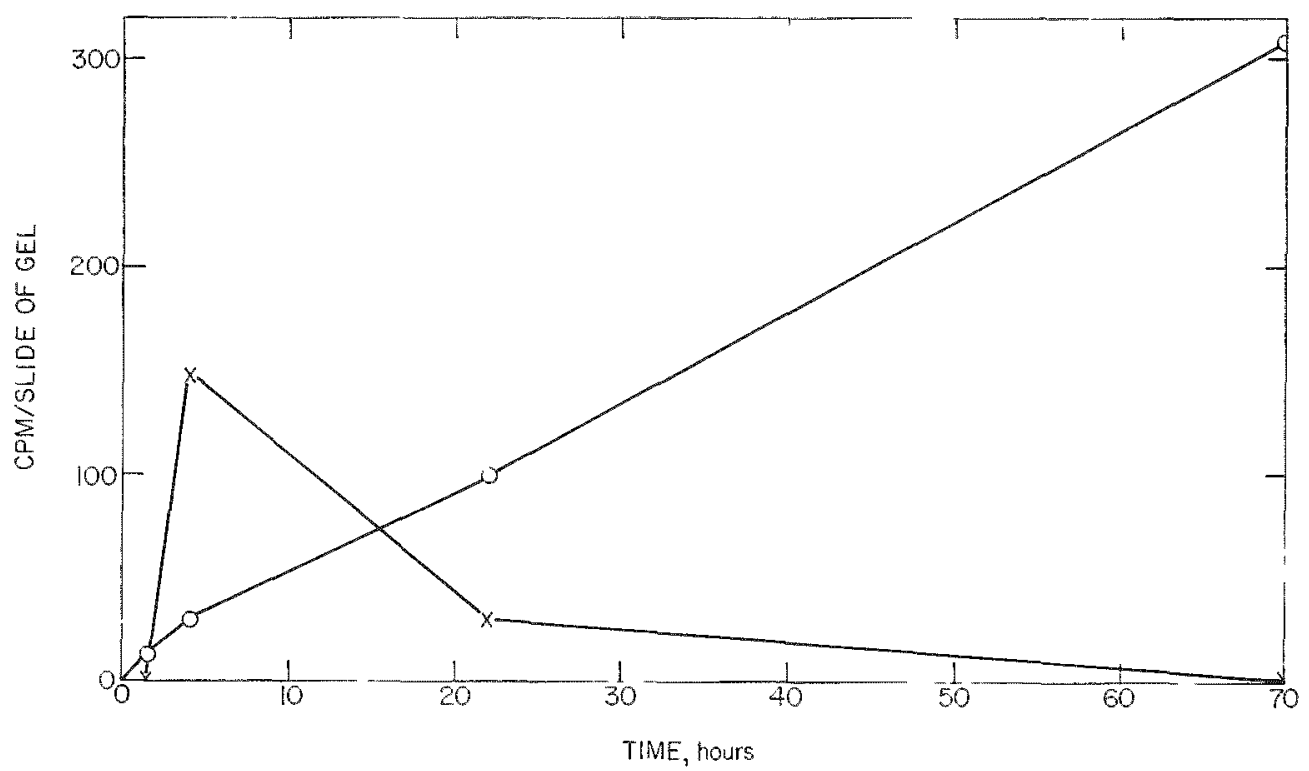

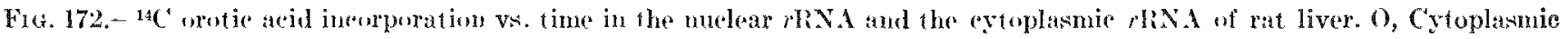
rRNA; Xielear rISNA.

intervals after the ${ }^{14} \mathrm{C}$-orotic acid injection. Both showed maximal activity $4 \mathrm{hr}$ after injection, but the nuclear $t \mathrm{RNA}$ has a radioactivity 4 times higher than that of the cytoplasmic RNA.

Figure 172 shows the radioactivity found in nuclear $r \mathrm{RNA}$ and in cytoplasmic rRNA at different time intervals after the ${ }^{14} \mathrm{C}$-orotic acid injection. The nuclear $r$ RNA shows maximal activity $4 \mathrm{hr}$ after injection, but the cytoplasmic rRNA shows a continuous increase in its incorporation up to at least $70 \mathrm{hr}$ after the injection.

Figures 173 and 174 are radioactivity pattern: in
RNA obtained from two representative gel strips. The electrophoresis procedure was run as described in Method Section. Each figure shows the patterns of a duplicated run. In both figures, a peak activity can be seen between fractions No. 70 and 80 , which rorresponded to the two low molecular weight RNA bands (see UV absorption patterns Figure 175), but between fractions 20 and 70 , radionetivity was found rather uniformly distributed with few small peaks in the midale section of the gels.

The turnover of the total cytoplasmic RNA was found to be around $76 \mathrm{hr}$. while that of the total nu- 


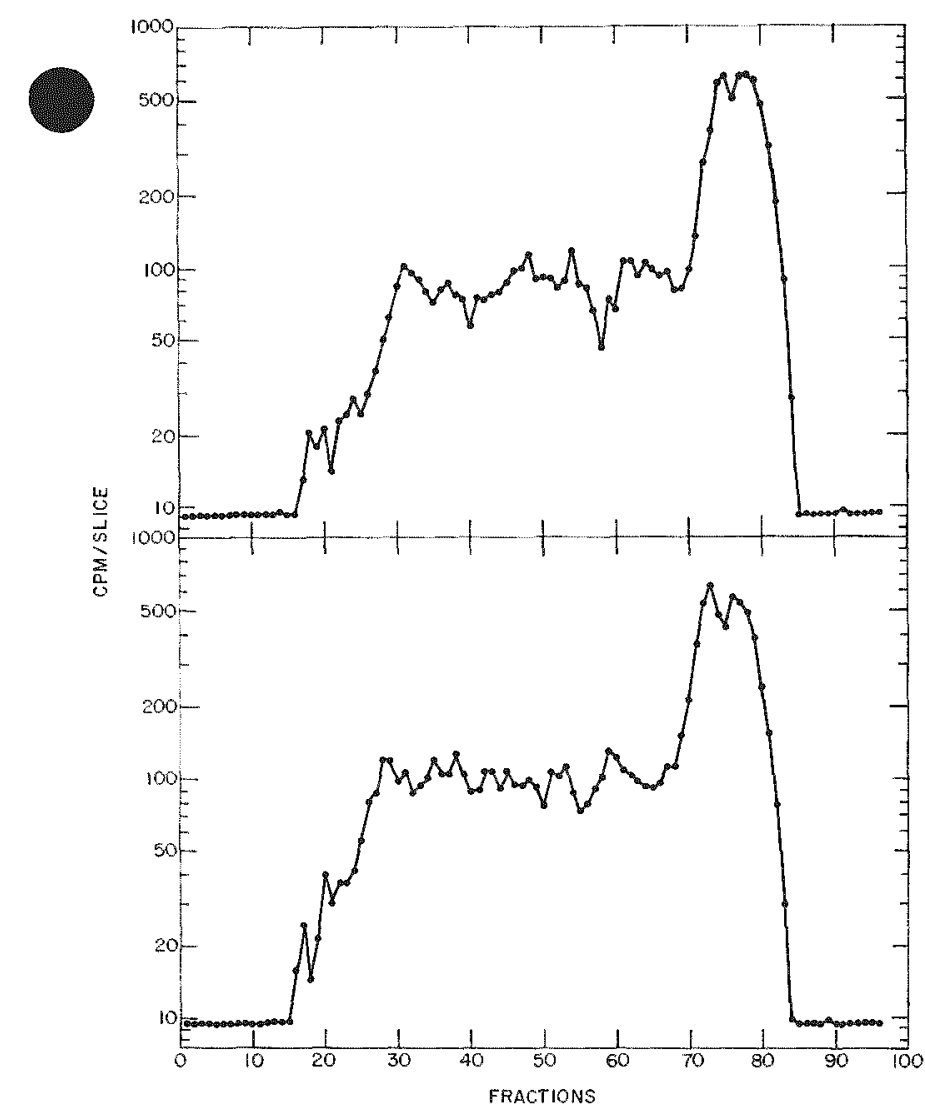

Fis. 173.-A representative radioactivity pattern from the total cytoplasmic RNA after subjection to gel electrophoresis procedure.

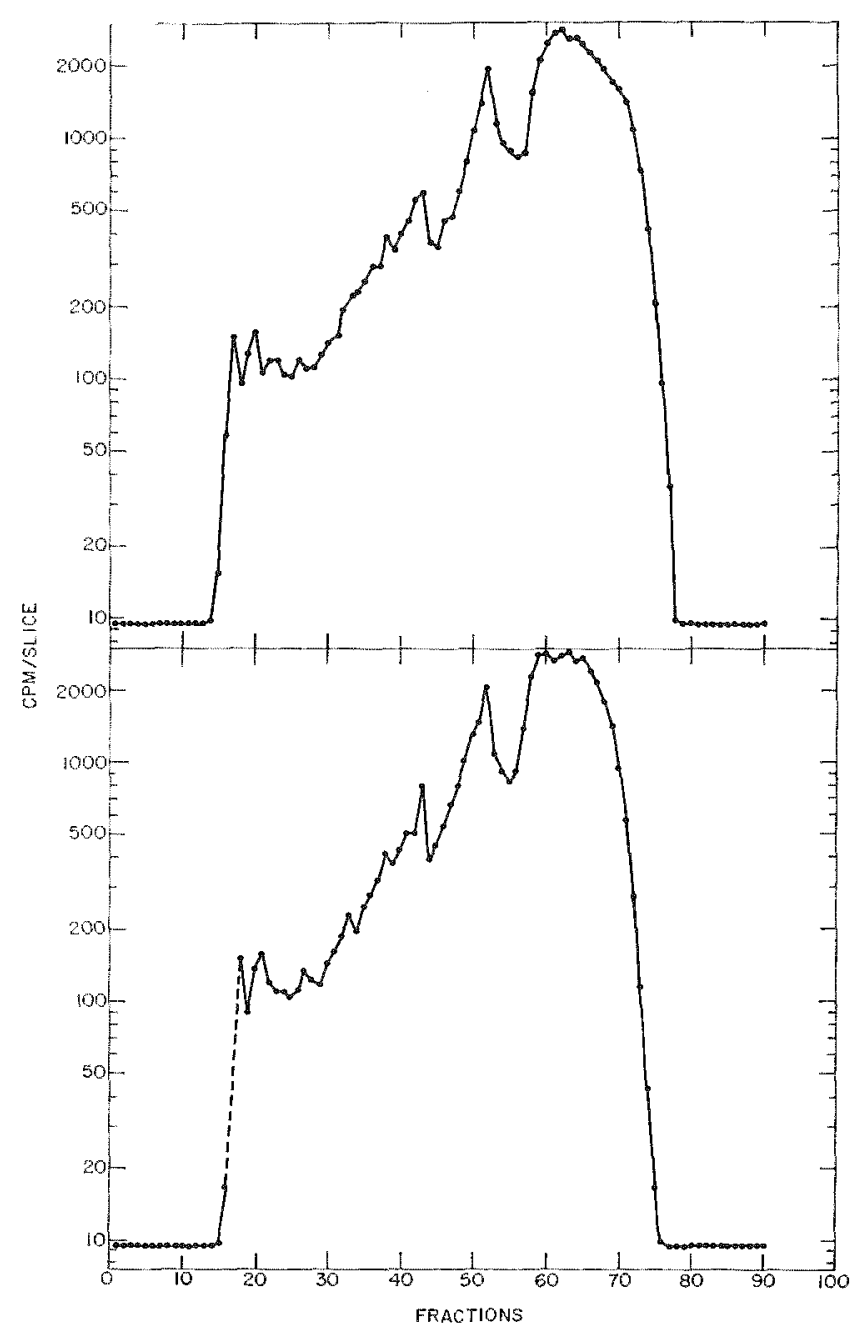

Fig. 17t.- A representative radioativity pattern from the total nuelear RNA after subjection to gel electrophoresis pro. cedure.

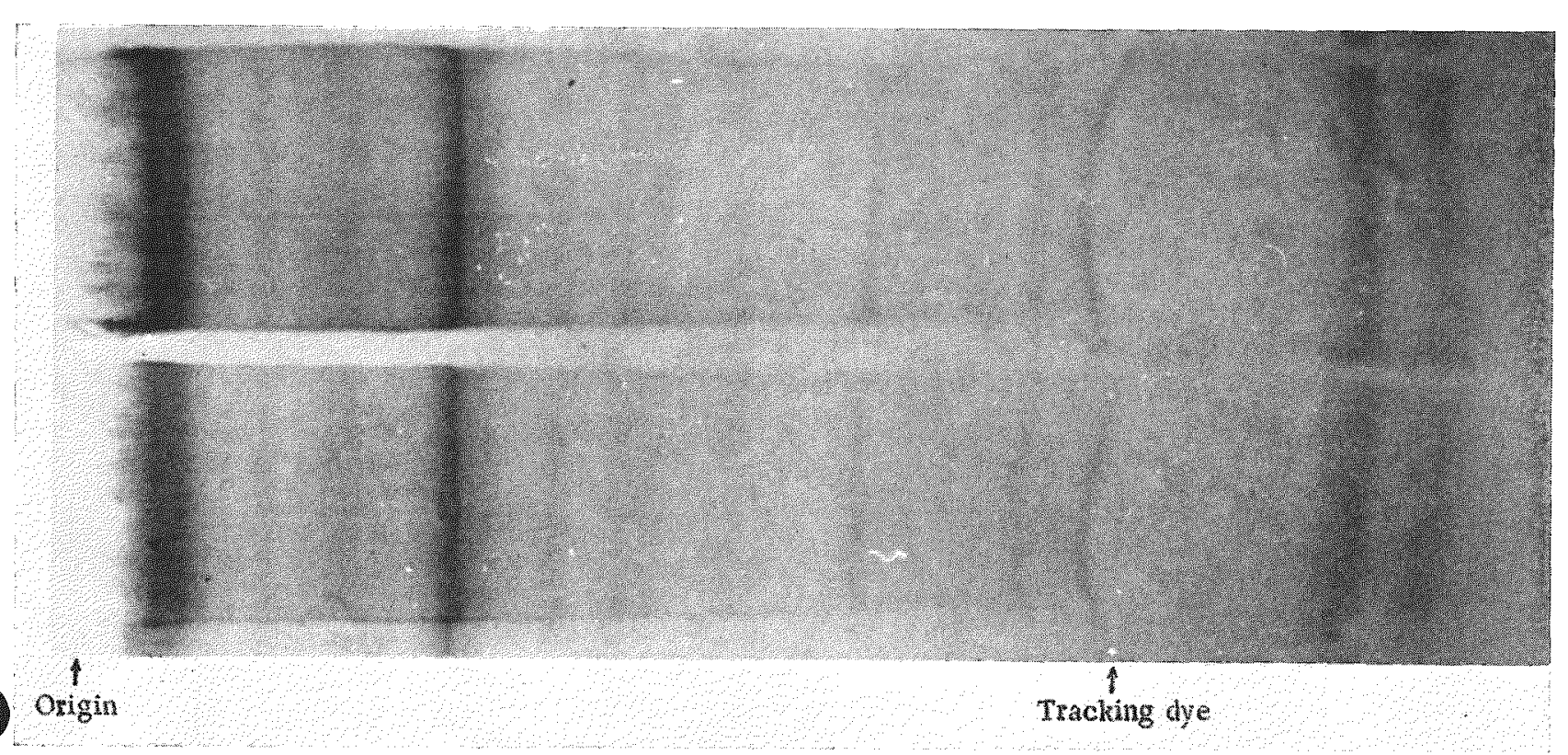

Fig. 175.-.-. UV absorption pattern of a gel strip after subjection to gel electrophoresis procedure 
clear RNA was only $11.5 \mathrm{hr}$. The fraction of $t \mathrm{RNA}$ in cytoplasm was however found to have a faster turnover, around $15 \mathrm{hr}$, whereas both fractions $t \mathrm{RNA}$ and $r$ RNA from the nuclei showed a turnover of 10 and $11 \mathrm{hr}$ respectively; these times are very similar to that of the total RNA.

\section{CONCLUAIONS}

The RNA turnover in suckling rats was found to be faster than that of adult rats as reported by other authors. (5, 6) Loeb et al. (5) found the turnover of cytoplasmic RNA in arlult rat liver to be $\mathbf{5}$ days, although Revel and Hiatt found the rapidly labeled RNA in cytoplasm to hare a turnover time of $40 \mathrm{hr}$. However, in order to ascertain that our findings with suckling rats are indeed due to the difference in their RNA turnover when compared to that of adult rats and not simply due to difference caused by experimental methods, experiments should also be done with adult rats under our own experimental conditions.
The gel electrophorenis is a more sensitive method for RNA separation when compared to the classical sucrose gradient method. The unsuccessful elution of RNA from the gel for spectrophotometric determina tions is, however, a serious drawback.

\section{REFERENCES}

1. Rahman, Y. F., E. A. Cerny, and C. Peraine. Studies on rat liver ribonucleases. IV. hiver ribonucleases in developing 2-acetylumino-fluorene fed and partially hepatectomized rats. Biochim. Biophys. A1 10 178, 68-78) (1969).

2. Blohel, A and V. R. Potter. Nurlei from raf liver: Isolution method that combines purity with high yield. Sciener 154, 16621665 (1966).

3. Hiatt, HI. II. A rapidly labeled IRNA in rat liver nuclei. $J$. Hol. Biol. 5, $217(19 t 2)$

4. Di Girnlamo, A., F. C. Henshaw, and H. H. Hiatt. Messenger RNA in rat liver nuclei and eytoplasm. J. Wol. Riol. $8,479488(1969)$.

5. Loeb, J., R. R. Howell, and (a. Romkins. Turnover of ribosomal RNA in rat liver. Seiene 149, 1093-1095 (1965).

ti. Revel, M. and H. II. Hiatt. The stability of liver messenger HN.1. Proc. Nat. Ared. Sti. 51, 810-818 (1909).

\section{PHOSPHOLIPASES A IN PURIFIED SUBCELLULAR FRACTIONS OF RAT LIVER. EVIDENCE OF A MEMBRANE-BOUND PHOSPHOLIPASE IN LYSOSOMES*}

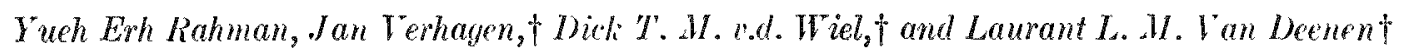

The phospholipases $A$ werc investigated in purified mitochondria, lysosomes, plasma membranes, and nuclei of rat liver.

1. Mitochondria showed very low activities of phospholipase A. The enzyme found in this fraction has an optimal activity between $\mathrm{pH} 6.5$ and 7.0 , is activated by $\mathrm{Ca}^{++}$, and is specific for the fatty acid at the 2-position $\left(\mathrm{A}_{2}\right)$. It cannot be ascertained whether or not the presence of this enzyme in the mitochondria is due to a small contamination by the plasma membranes.

2. Two phospholipases A were found in lysosomes: 1) an acid phospholipase with a pHI optimum at 3.5, inhibited by $\mathrm{Ca}+{ }^{+}$and Triton $\mathrm{X}-100$, mainly localized in the soluble fraction. and found capable of hydrolyzing the fatty acids at both poritions

\footnotetext{
* Abstract of a paper to be submitted for publieation. † From the Laboratory of Biochemistry, State lniversity of lit recht, The Netherlands.
}

$\left(A_{1}\right.$ and $\left.A_{2}\right) ; 2$ ) an alkaline phospholipase with a pH optimum at 7.5 , activated by $\mathrm{Ca}^{++}$, also inhibited by Triton $\mathrm{X}-100$, and found mainly localized in the membrane of the lysosomes. This mzvme was found to be -pecific for the fatty atcid at the 2-position $\left(\mathrm{A}_{2}\right)$.

3. Two phospholipanes were also found in the plasma membranes: 1) one with a pII optimum at 6.5 , specific for the fatty acid at the 2-position $\left(A_{2}\right)$; 2 ) one with a pH optimum at 8.0 , specific for the fatty acid at the 1-position $\left(A_{1}\right)$. Both enzymes required $\mathrm{Ca}+\mathrm{f}$ for their activities. The presence of these two enzymen in the plarma menibranes was not due either to contamination by mitochondria or to contamination by microsomes.

4. Purified ntclei were found to have very low phospholipid hydrolyzing activities.

The po-sible function of the lysosomal membrane phospholipase in the initial binding between lysosomes and membranen of other subcellular particles is discussed. 


\author{
Yuch Erh Rahman
}

PCRPUL AND MELHOD

The important role surface-active propertie of lnid play in the transport phenomena of various blological membranes has become well recosnized in the rerent vear. Hodel sy-tem (e.g., monolayer and bilaver lipul membranes have been developed and studred. Recently, a method was described for obtaining lipid pherule for liyo-ome-1 from -ruthetic pho-pholipids in the presenes of water and alt olutions." The structure and sizes of thene lipowome were found to be very -imilar to variun membranes of biolocical particle- they are de-cribed a roncentrae bimolecular lamellae eparated from each other by water compartments. ${ }^{21}$ Diffu-ion of varioun jon- arrom thene leponomen were alo -tudled. $\left.{ }^{2}\right)$ The ion transport. a well as lipid-protein interastion, in membrano of ubeellular particles is an important phenomenon in cell phyiology. and a -mple model rytem, such an the liporomes, obriou-ly -eem of interent for such studies; therefore. preparations of lyo-ome were made from phospholipid of -pecific -ubcellular particles, i.e., mitochondria and microsomen, and turlies of their wurface propertee and their interation with ome protein were conducted.

Mitochondria were inolated from rat liver in a 25 to 4.5. surrone gradient; the uradient was centrifugen! at $3,500 \times g$ for $2 \mathrm{hr}$ in the International Centrifuge Model PR-6. Purified mitorhondria were collected at the level of the $40{ }^{\prime}$ : -ucrous layer. Mironomes were prepared from a $10^{\circ}$ o rat liver homogenate; the nuclei, mitochondria, lyomomen and microbodien were first removed by a centrifugation at 15,000 $\times g$ for 10 min, and the -upernatant obtained wat then centrifuged at $100,000 \times q$ for 60 minutes. The micronome at the bottom of the tubes were wahled onee before they were used for lipid extraction.

Total lipids from purified mitochondria and microsome were extracted according to Bligh and 1)yer: phopholipids were separated from the total lipid by silicic acid column chromatography, as described by Sheltaw $y^{\text {(t) }}$

Egg-yolk lecithin wa purified by 3 subsequent precipitation as $\mathrm{CdCl}_{2}$ adducts and chromatooraphy on ilicic acid. Phosphatidic acid wa oltained by enaymic lydrolysis of the egg lecethin with a phoyhollpase 1) prepared from extract - of silvoy cabbage. ("ardiolipin was obtained commercially.
Liponomen wert prepared according to De Gier (t al.'") Therr birefringent pattern were examined under phane microsopy. The electrophoretic mobilities of the liponome were incasured in a cell clectrophoretic apparatur. Mea-urement were made by direst observation of the particle movement in the tatumaty latyer of the cylindrical tuhe Mobilitien were converter to zeta potential. u-ing the following equation:

$$
\therefore-12.9 \frac{k}{k}
$$

in which $t$ equal relocity and $E$ in the field -trength. (6)

Protein with i-orlectric point- ranging from acid to alkaline range were choren: they were bovine serum albumin, ribonucleave, and lyozme. These proteins were in highly purified form and obtained commerrially.

$P R(N \times R I$ T REPURI

\section{Whtochondriul Liposomes}

The formations of mitochondrial liposomes prerented no major difficulty: howerer, addition of $7 \mathrm{mall}$ of $\mathrm{CaCl}_{2}$ facilitated their formation, and they had more unform sizes, when oberred under phase micro-copy. Zeta potential of liposomes from separate preparations of phopholipid were an follows: - 40.0 , $-38.2,-49.5,-38.7,-45.4 \mathrm{mV}$, with an average of $-42.2 \mathrm{mV}$. Change of zeta potentials of mitochondrial liposome in the prevence of variou proteins are prenented in Figure 176.

\section{Hicrosumal Liposomes}

The formations of lipo-omes by microwomal phospholipids were rapid, and no $\mathrm{CaCl}_{2}$ wan needed. Zeta potentials of liponomes from 4 separate preparations of microsomal pho-pholipids were an follows: -32.4 , $-32.1,-38.9,-40.2 \mathrm{~m} V^{*}$, with an average of -3.5 .9$ mV. Their interactions with protein, were similar to thoue obtained with mitochondrial linosomes.

\section{Liposomes Pitpared with . Iirtures}

Lipo-ome of comparable zeta potential to mitochondrial and micronomal liponomes can be obtained by the following mixture of lipids: a) $85 \%$ egg lecithin $+15 \%$ cardiolipin, and b) $70 \%$ egg lecithin + 


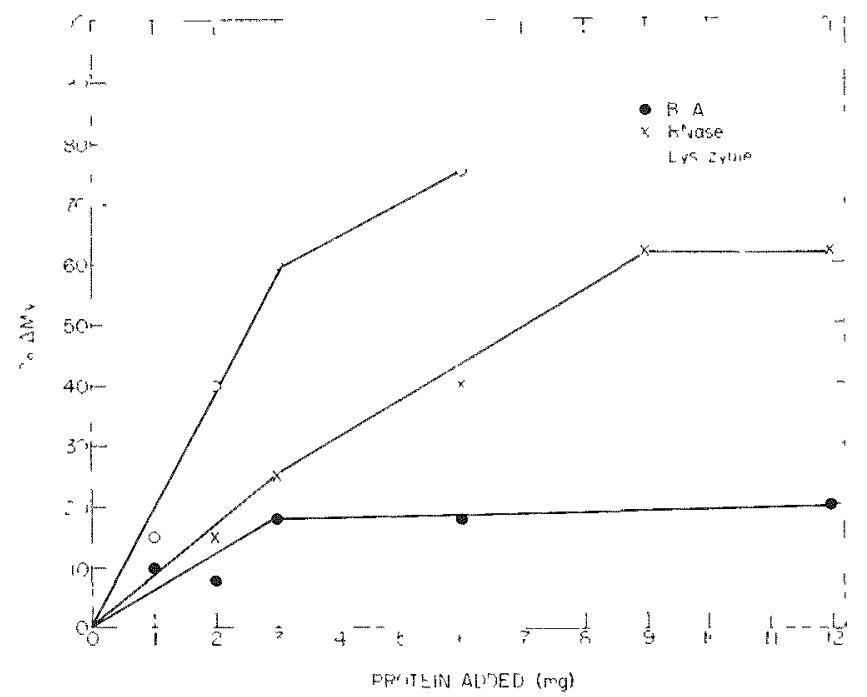

Fit. 176. The changen of zet a potentials of mitorhendrial liposomes in the presence of B,A ribunuclease, and lysozyme.

$30 \%$ phosphatidic acid. In the presence of proteins, changes of zeta potentials of these liposomes were similar to those shown with mitochondrial and microsomal liposomes. In the presence of proteins, zeta potentials of various liposomes prepared by mixtures of lipids showed significant changes only when their starting potentials were higher than $-30.0 \mathrm{mV}$.

CONCLUSIONS

Successful preparations of liposomes from lipids of mitochondria and microsomes were demonstrated.
This membrane model is a valuable tool to study simple interactions between lipids and proteins. Studies of their internctions with other' substances, e.g., carbohydrates or metal ions, can also be extended.

Two interesting facts can be concluded from the experimental results: 1) Tipids from intracellular particles, e.g., mitochondria and microsomes, showed surprisingly high negative charges. 2) A threshold of $-30.0 \mathrm{mV}$ in the surface charge of liposomes is needed for measurable ionic interactions with proteins. A physicochemical explanation for this phenomenon is lacking, however. 3) The degree of interactions between the liposomes and protein appears to be determined by the difference of the inelectric point of the proteins.

\section{REFERFNCES}

1. Derviohian, 1). (4. The phrsien ehemist ty of phospholipids. Biophys. Hol. Biol. 14, 2ti, $312(1961)$.

2. Bangham. 1. 1), . M. M. Ntandish, and J. ('. Wat kins. I) iffusion of univalent ions arrose the lamellate of swollen phospholipids. J. Mol. Biol. 13, $2382922(1945)$.

3. Bligh, E. C. and W.J. Iyer. A rapid methon of total lipid estraction and purification. ('an.J. Biomem. Physiol. 37, $411 ! 17(19549)$.

1. Sheltawy, A. Dietary alterations of the mitochomdrial lipid pattern. Biocherm. J. 95, 561-56is (19tia).

5. De (Hier, J., J. (t. Mandersloot, and I. L. M. Van Deener. lipid composition and permeability of lipesomes. Bion him. Biophys. Arta 150, hitit hos (1968).

(t. Davies, J. T. and E. K. Rideal. Interfarial Phemomene. Arademia Press, Landon, 1961, p. 134.

\section{LIPID ANALYSIS OF PURIFIED SUBCELLULAR FRACTIONS OF RAT IIVER}

Yueh Enh Rahman

\section{PLRPONE AND METIODS}

Lipids other than those in adipose tisue are located primarily in biological membranes locaterl at the surface of the cells (plasma membranes), and in subcellular particles (mitochondria, microsomes, Golgi apparatus, lyso:omes, mierobodies, nuclei, etc.).

Analysis of lipid composition of subcellular particles has been reported by many authors (see review paper $\left.^{(1)}\right)$. The values reported in the literature for liver subcellular particles, enpecially those of the nuclei, are quite variable and contradictory in many cascs. The main reasons for this confusion are that a) different methods were used for subcellular frictionations, and a critical evaluation of the purity of these particles was not appljed, and b) the methods used to analyze lipid composition often were not en- tirely reliable. Therefore, this problem was re-examinet using well-characterized subcellular particles, and more recently developed or improved techni(ques, such as thin-layer chromatography (TLC), column chromatography, and gas-liquid chromatography.

Purified mitochondria, microsomes, and nuclei were used. The preparations of mitochondria and microm somes are the same as those described previously. ${ }^{(2)}$ Nuelei were isolated according to the method of Blobyel and Potter. ${ }^{(3)}$

Total lipid was extracted according to a method deveribed by Bligh and Dyer. ${ }^{(4)}$ Column chromatography was carried out according to Vorbeck and Marinetti's(5) method. Fatty acid composition of various lipids were analyzed after esterification by gas-liquid chromatography. 
Separation of phospholipids was done with TLC on silica gel $\mathrm{G}$, using a chloroform-methanol-water $(65: 35: 4, \mathrm{v} / \mathrm{v})$ solvent system. Separation of neutral lipids on TLC was done according to the method of Skipski et $a l .^{(6)}$

Total lipid phosphorus was determined by the method of Fiske and Subbarow, ${ }^{(7)}$ and the cholesterol determination was made with Ijieberman and Burchard reagent.

\section{PROGRESS REPORT}

Data obtained for nuclei, mitochondria and microsomes are summarized in Tables 82-85. Phospholipids from nuclei, mitochondria, and microsomes were analyzed by TLC; the results were comparable to those published previously. ${ }^{(1)}$ Electron microscopy of purified nuclei showed that their outer membranes remained intact.

\section{CONCLUSION}

Mitochondria and microsomes contained high percentage of phospholipids. This finding is consistent with recently published data. ${ }^{(8)}$

The fatty acid composition of phospholipids in all three subeellular fractions was similar to various puhlished data. (1) However, the fatty acid composition of the neutral lipids from purified nuclei was not reported by other authors. The interesting features of thi- composition are 11 high percentages of palmitic

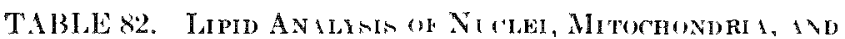
Microsumes or Rith hiver

\begin{tabular}{|c|c|c|c|}
\hline & $\underset{\text { protein }}{\mathrm{Mg} \text { lipid }}$ & $\begin{array}{l}\text { Phospholipid } \\
\text { ro of total } \\
\text { lipid }\end{array}$ & $\begin{array}{l}\text { Cholesterol. } \\
\text { of total } \\
\text { lipid }\end{array}$ \\
\hline & $-\cdots$ & $\ldots-$ & - \\
\hline Nuclei & 0.019 & 50.6 & 2.973 \\
\hline Mitochondria & 021 & 88.4 & 280 \\
\hline Microsomes & 0.35 & 78.6 & 5.30 \\
\hline
\end{tabular}

(x) Averages from 3 to 7 separate determinations.

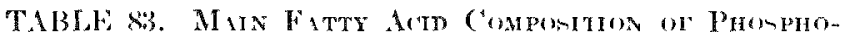
IIPIDS OF RAT LIVER SCOBCLLITLAR FRACTIONS

\begin{tabular}{c|r|c|c}
\hline I atty acid & Nuclei & Mitochondria & Microsomes \\
\hline $16: 0$ & 20.23 & -18.74 & 13.27 \\
$16: 1$ & 0.50 & 1.05 & 2.78 \\
$18: 0$ & 25.12 & 20.23 & 19.11 \\
$18: 1$ & 13.11 & 1529 & 12.05 \\
$18: 2$ & 13.70 & 20.52 & 16.58 \\
$20: 1$ & 21.80 & 23.15 & 28.82 \\
$22: 0$ & 3.20 & 0.63 & 5.46 \\
\hline
\end{tabular}
tions.

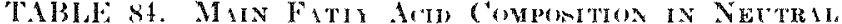
LIPIDS OF lit LIVER NUTLEI(z)

\begin{tabular}{cc}
\hline Fatty acid & Area percentage \\
\hline $16: 0$ & -1 \\
$16: 1$ & 30.06 \\
$18: 0$ & 4.36 \\
$18: 1$ & 2.24 \\
$18: 2$ & 21.46 \\
$20: 4$ & 34.15 \\
$2: 0: 6$ & 5.15 \\
& 1.06
\end{tabular}
tions.

TABLE 85. LIPID COMPOSIIOM OF RI' LIVHR NTCLEI

Phospholipids: 50.b' c (mainly phosphatidyl choline and phosphatidyl ethanolamine)

Nent ral lipids: 28.3, (triglycerides: $654, ; 1,2$ diglycerides: 5-10', monoglycerides: 25-30r,

Lnidentified: 21.1'; (phosphorus, hexose, and ninhydrin test negative)

acid (16:0) and linoleic acid (18:2), and 2) very low perentage of stearic acid $(18: 0)$.

The percentage of total phospholipids in nuclei was lower than in most previous reports; ${ }^{(1)}$ this difference can be explained as due entirely to the contamination of the nuclear preparations by other subcellular particles because the conventional differential centrifugation method was the popular choice throughout these studies.

Nuclei isolated under the procedures used in this study conserved their outer membranes, but no conclu-ion can be drawn concerning the localization of the nuclear lipids.

The cholesterol contents in nuclei were much lower than previous reports, ${ }^{(9,10)}$ this undoubtedly is due to the contamination by plasma membranes in the preparations. Cholesterol found in mitochondria and microsomes was comparable to Thines-Sempoux's results; ${ }^{(10)}$ in both their and our studies, however, a small contamination in mitochondria as well as microsomes by plasma memlinanes cannot be ruled out entirely because no ideal marker for the plasma menbranes is arailable. This important point should be clarified in further experiments.

Two interesting conclusions can be drawn from this report.

(1) Neutral lipid in purified nuclei were in greater concentration than in other subcellular particles. The major fatty acids in the neutral lipids are palmitic and linoleic acids.

(2) There are indications that cholesterol might be unirue to the plasma membranes. 


\section{REFERENCES}

1. Heischer, $s$. Lipids of subcellular particles. $d$. Am. Oil Chem. Soc. 42, 326-607 (1965).

2. Rahman, Y. F. Studies on liposomes (lipid spherules) prepared from mitochondrial and microsomal phospholipids. Their surface charge and their interaetions with varions proteins. This report.

3. Blobel, $\mathrm{x}$. and $V$. R. Potter. Nuclei from rat liver: Isolation method that combines purity with high yield. Science 154, 1662-1665 (1966).

4. Bligh, H. (H. and W. J. I)yer. A rapid method of total lipid extraction and purification. Can. l. Biochem. Physiol. 37, 911-917 (1959).

5. Vorbeck, MI. L. and (x. V. Marinetti. Separation of glyeosyl diglycerides from phosphatides using silicic acid column chromatography. J. Lipid Res. 6, 3-6 (1965).
6. Skipski, V., A. F. Smolowe, R. C. Sullivan, and M. Bar clay. Separation of lipid classes by thin-layer chromatography. Biochim. Biophys. Acta 106, 197-199 (1965).

7. Fiske, C. and Y. Subbarow. A method for phosphorus determination. J. Biol. Chcm. 66, 375-379 (1925).

8. Rouser, G., G. J. Nelson, $A$. Fleischer, and C. Simon. Lipid composition of animal rell membranes, organelles, and organs. Biological Membranes: Physical Fact and Function, Hd. D. Chapman. Academic Press, London, 1968, p. 488.

9. (Gurr, M. I., J. B. Finean, and J. N. Haw thorne. The phospholipid of liver cell fractions. I. The phospholipid composition of the liver-cell nucleus. Biochim. Biophys. Acta $70,406-416$ (1963).

10. Thines-Sempoux, D. Les Lipides des Lyosomes et d'autres Constituants Subcellulaires. Ph.D). Thesis, Iniversity ("atholique de Iouvain (1968). 


\section{BIOPHYSICS}

\section{CELL GENERATION CYCLE AND RADIATION EFFECTS IN MAMMALIAN CELLS IN CULTURE}

Warren K. Sinclarr

Techniques with cultured mammalian cells in vitro have been widely employed to investigate mammalian cell responses to ionizing and other radiations and agents, as well as to explore regulatory and control mechanisms in mammalian cells. In particular, the u৬e of sunchronized populations has permitted these renonses to be investigated in relation to the changing biochemistry of the manmalian cell as it progressen through its generation eycle. This program is concerned particularly with relationshiph between ratdration effects and their cell cycle stage and the biochemical factors concerned with thene stagen.

The following eleven reports embrace the progren made during the past year in studies in mammalian cell with agents wheh protect or sensitize cells to ionizing radiation, or inhibit particular biochemical proceses and the dependence of thene upon cell cycle stage. Similar studies have been conducted with ultraviolet light, and other are in progress upon the interaction between ultraviolet light and $X$ radiation. In addition studies have been carried out on the timing of events in the cell cycle just prior to divi-ion. There studies have betn confined so far to a -ingle line of Chinem ham-ter lung cells grown in culture and to some of its derivative sublines. The radiation effectexamined include lethal damage, recovery from -ublethal damage, divinion delar, cytological effects. biochemeal modifications, and effect- upon growth. In mont cane population-synchronized by the mitotis selection method, sometimes with the addition of Colcemid to improve vield or hydroxyureat to improve ynchrony, form the ba-i of the experimental prorexdures.

\section{THE CELL CYCLE DISTRIBUTION OF CHINESE HAMSTER CELLS IN STATIONARY PHASE CULTURES}

Warren K. Senclar and Dennts Wh. Ross

PLRPOC AND MCTHOD

Investigations of the -tationary phase of growth in mammalian cell (ultures after the partial depletion of the culture medium have been less complete than tho-e of steudy tate rexponentiall gronth. Nonproliferating, tationary phase mammalian cell culture- max represent a closer analog to certain situations in wivo (e.g., tumor) than exponential phase rell. The preent tudy was de-igned to determine the distribution of cells within the metaholic compartments of the cell cycle $\left(I T, C_{1}, S, G_{2}\right)$ after cell proliferation has apparently ceaned in the culture.

The cell cultures were started at a low cell concenration in fresh medium. Cell concentration and average cell volume were monitored during the exponential and stationary phane, uning the electronic rolume -pectroneopy "quipment demeribed previou-ly." (hine-e ham-ter eell of the V79-S171-ubline were maintaineel in two different rulture media (HUT-15 and LU-151'2, for this cudy, because there were indication- from cell rolume distribution that the cell "ycle distribution wa- likely to differ in the two media. In atdition to cell number and arerage volume, mitotic inder, percent of cells ynthe-izing DNA (by uptalie of ${ }^{3}$ HTelR) and plating efficiency were examined. The di-tribution of rell within the cycle during early, mid, and late stationary phisen was determined hy allowing the cell to reume growth in frew medium containing Colcomid an a mitotic blocking agent. A plot of rumulative mitotic index verou- time was obtained which, in adition to a plot of cell- labeled with "HTill as a function of tmes. allowed the di-tribution of the population w then the cedl 


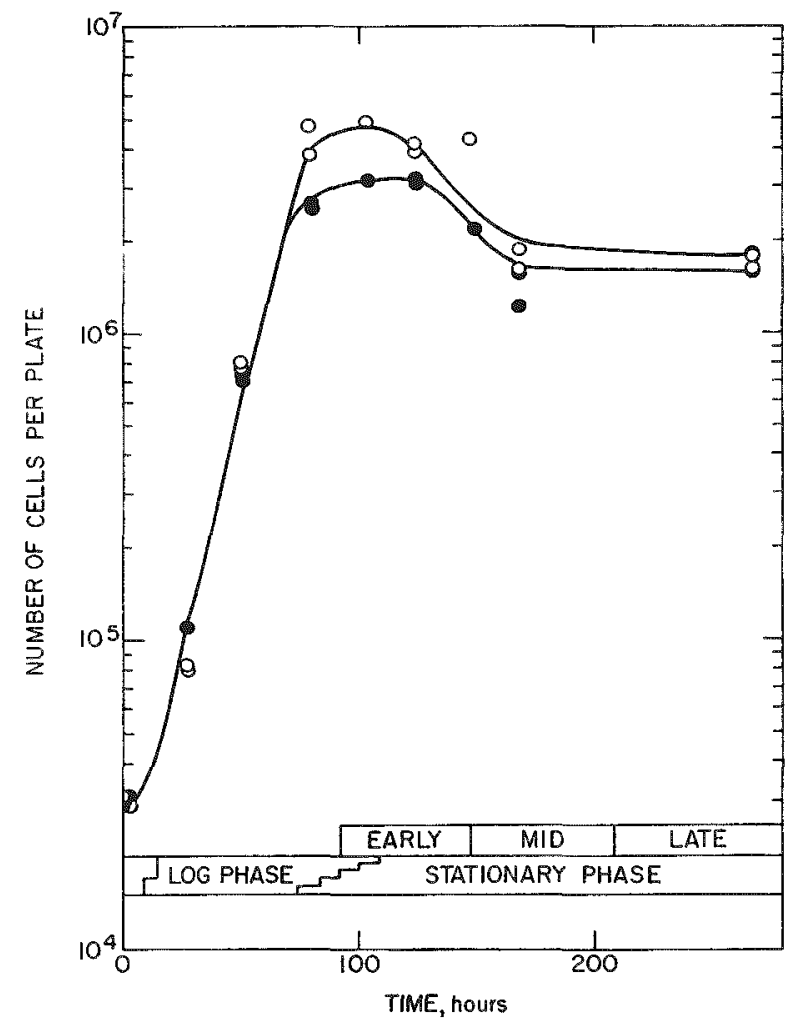

Ficr. 177. (irowth curve, cell number per culture vs. time, for ("hinese hamster rells V7y-s171. Spen rircles for cultures grown in HIT-15 medium, solid rircles for E.M1-15. Divisions of the growth curve into log and stationary phases and the stases of stationary phase are shown above the lime axis.

cycle compartments and the length of the ccll cycle when growth resumed to be determined.

\section{PROGRESA REPORT}

The growth eurve, number of cells per culture dinh (50 mn diameter) versus time for a typical experiment, is shown in Figure 177. The lengths of $\log$ and tationary phases are shown along the time axis. The H UT-15 medium has a composition nearly identical to EM-15, except for an additional cnrichment of $2.5^{\circ} \mathrm{r} / \mathrm{v}$ of NCTC 109 vitamin and amino acid mixture ${ }^{(3)}$ and $2 \% \mathrm{v} / \mathrm{v}$ of trypsin. The HUT-15 (enriched) medium supports a final concentration of $4 \times 10^{6}$ cells/dish, and EMI-15 medium supports $2 \times 10^{6}$ cells/dish. A parameter for describing the amount of cell growth that a particular volume of growth medium can support on these dishes was formulated by the authors. The empirically determined growth curve, cell number versus time, $N(t)$, is integrated from the start $\left(t_{0}\right)$ to the end $\left(t_{i}\right)$ of the $\log$ phase of growth. The value of the integral

$$
\int_{\varepsilon_{0}}^{t_{i}} N(t) d t=N_{\text {witax }} \text { (cell-hours) }
$$

is the maximum, $N_{\text {max }}$, of cell-hours of steady state growth that the given volume of the medium can support. If $\nu_{\max }$ in exceeded, the culture ceases log-phase growth and enters stationary phase. For the media used here, these numbers are:

$$
\begin{aligned}
& \text { HUT'15) } N_{\max }^{\mathrm{T}}=\AA \times 10^{6} \text { (ell-hours } / \mathrm{or}^{\circ} \\
& \text { EXI-1.) } N_{\max }=4 \times 10^{6} \text { (ell-hours/ce. }
\end{aligned}
$$

This concept of supportive cell-hours/ce of medium was verified by repeated feeding of dense cultures at increased frequency. If $N_{\max }$ was never exceeded, cell cultures could be maintained in log phase to coneentrations of at least $2 \times 10^{7}$ cells/plate.

After the cell medium is depleted to a point where exponential increase in cell number ceases, the cell number remains approximately constant for a period of about $40 \mathrm{hr}$ and then begins to drop slowly. We have divided the stationary phase of cell growth into early, mid, and late stages as indicated on Figure 177. The distribution of cells within the cell cycle was studied in each of these stages.

Figure 178 a hows the average cell volume as a function of time for a culture in HUT-15 medium proceeding from log to stationary phase. The average volume drops sharply after inoculation, remains nearly constant during $\log$ phase, and then decreases by about $20 \%$ to a new low value in stationary phase. Figure

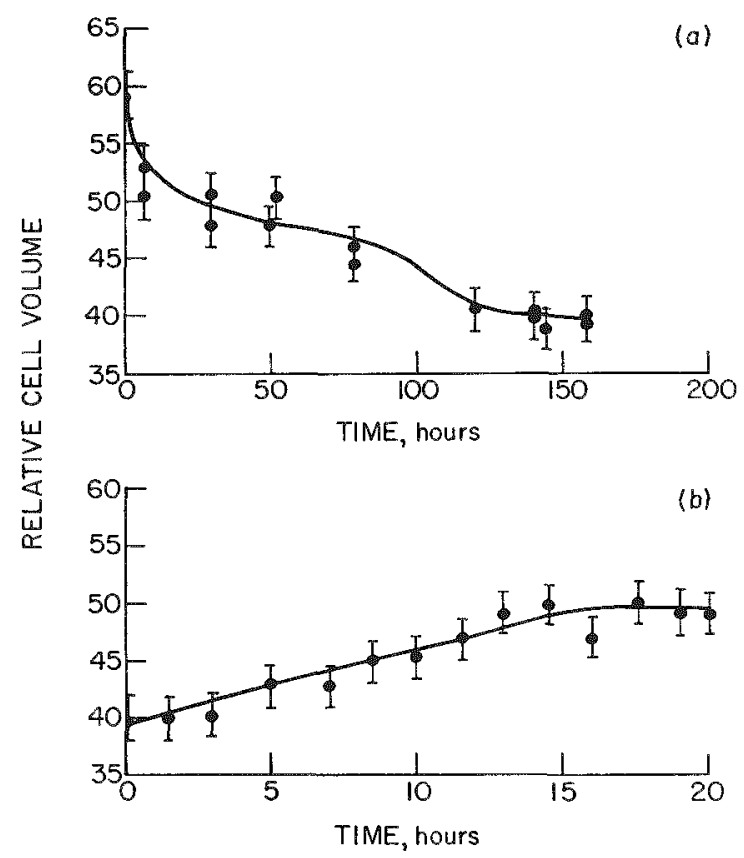

Fir: 178. Average cell volume (relative seale) va time for Chinese hamster cells, V79-\$171, in IIT T-15 modium. (a) (cel vilume changes from log to st ationary phase; (b) cell volume changes for cells in st at ionary phase resuming growth in fresh medium. 
178b show the return to log-phise volume within one generation time after cells from a stutionary phase population are diluted in fre-h medium and resume growth. The volume changes in EM-15 medium followed a somewhat different pattern, ponibly indicative of a different di-tribution of cells in carly stationary phase.

The mitotic index of a stationary phase population declined stearlily with time after cells left log phase; in EM-15 medium it was about $1 c^{\prime}$ in early, $0.5 \%$ in mid, and $0.2 \%$ in late stationary phase. Thus, cell proliferation was greatly reduced throughout, but did not ccase entirely. Figure 179 shows the result of a growth-resumption experiment from early stationary phase: percent labeled cells and cumulative mitotic index rersus time. The cumulative mitotic index curve shows an initial increase after growth resumption. which is interpreted as a burst of cells previou-ly in $G_{2}$ now coming into mitosis. A plateau region in the curve follows, lasting 10 to $12 \mathrm{hr}$, during which time the labeling index (percent of cells in $S$ ) rises sharply. The second increase in the cumulative mi-

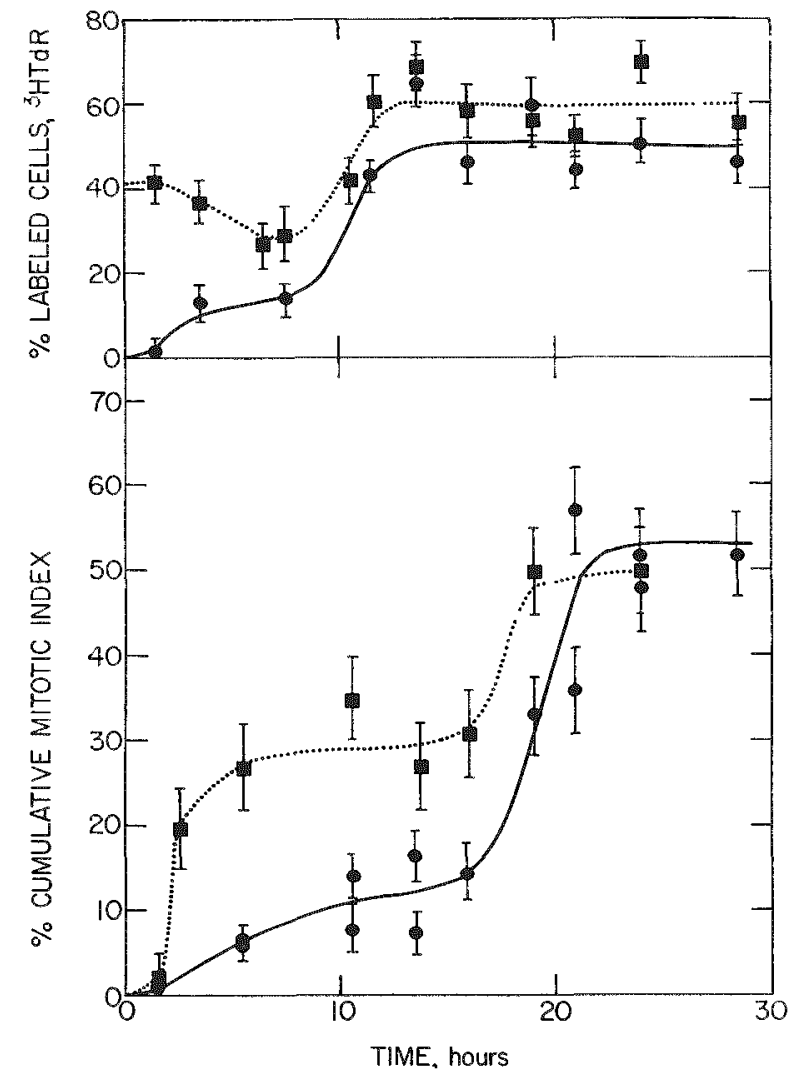

Fin. 179.-A growth resumption experiment for ('hiness hamster cells V79-\$171 in stationary phase diluted into fresh medium. Circles and solid line for HI'T'-15 medium; squares and dotted line for EM-15. Percent labeled cells and cumulative mitotic index vs. time.
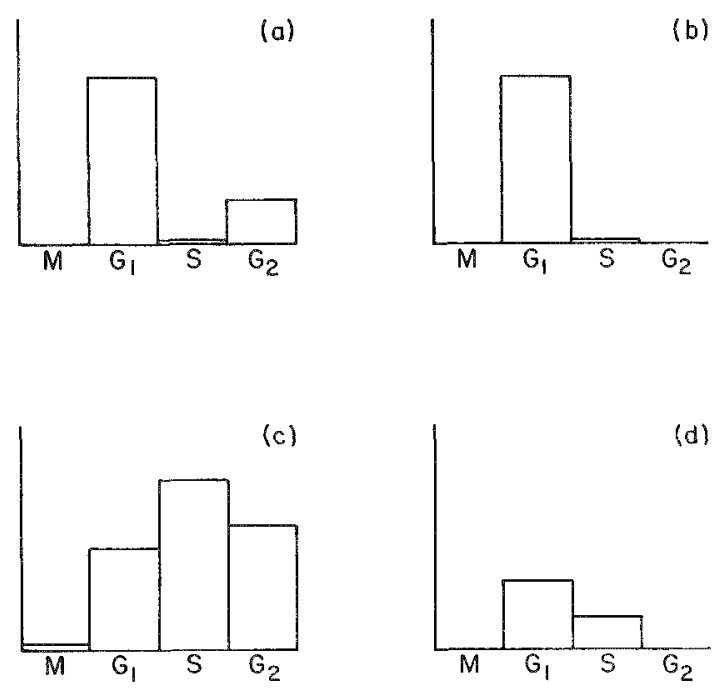

Fir. 180. A rohemative reprenentation of cell erele diat ri butions within the metabolue compartments of the rell raclo.

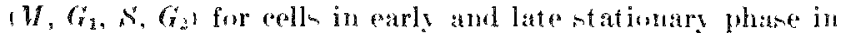
two media, He T-15 (enriched) and Fill-15 unenrehed), (a) Earla stationary phase, He T-15 medium; (b) late -taticuars

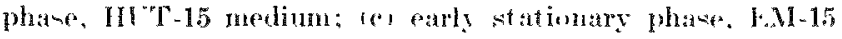

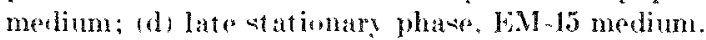

totic index is presumably duc to $G_{1}$ cells which, after a very much prolonged $G_{1}$ period, reach mitosi-. Few "sells are stopped in S (DNA synthesis) for cells grown in IIUT'-15 medium. However, in EMI-15 medium, many cells are arrectel in $S$ but appear to be nonviable and to not reach the next mitosis when providel with freh medium (note platean in Figure 179). This observation wats confirmed by the we of cultures treated with hydroxyurea.

The dintribution of the cell population in each compartment of the cell cycle, as revealed by these growth resumption experiments is shown schematically in Figure 180 for early and late stages of stationary phase. In HUT-15 medium, the cells are initially arrested in primarily the $G_{1}$ and $G_{2}$ portions of the cycle. The viability drops rapidly as the time in stationary phame increases. In late stationary phase, all cell- are in $G_{1}$ but very fow are viable. That is, the cells when provided with frenh medium will. after a lag, enter a DNA swnthetic period and then proceed through $G_{2}$ and form a mitotic figure in a culture blorked with Colcemid. However, these cells will not divirle continuously in an unblocked culture and will not give rise to colonies. In EMI-15 medium, in addition to cells in $G_{1}$ and $G_{2}$, a large fraction is in $S$. Cells arrested in $S$ are nearly all nonviable and noncycling when provided with fresh medium as discussed earlier. Note that the distribution of stationary phase cell in the $G_{1}$ and $G_{2}$ eycle compartments has also 
been noted in a mouse lymphoma line.) (4) Plating efficiency decreases less rapidly in E.M-15 medium. There is a -teady decline with time in the $G_{2}$ and later in the $s$ component in favor of $G_{1}$. In late stationary phase. although only a small portion of the cells were viable. as determined by their inability to form colonice, nearly $50 \%$ were able to contiuue the cycle and reach mitosis when provided with fresh medium. Further studies are needed to illentify whether these cell die at mito-i or in some later interphase.
RFFERFNCES

1. Sinclair, W. K. and I). W. Ihoss. Modes of grow th in mammalitu cells. Biophys. $d .9,10$ ori-1070 (1968) .

2. Hhind, M. MT. and H. Sitton. liadiation response of mammalian cells grow $n$ in culture. I. Repair of $\mathbf{S}$-ray damage in surviving ('hinesse hamster cells. Radiat. Res. 13, 55t-593 (19)(o).

3. Iifon Laboratories, Detroit, Michigan. Reagents Media, and Cell Lines for Tisste ("ulture and lirus Propagation, 1964.

1. Watanabe, I. and $\therefore$. Oladat. Nationary phase of eultured

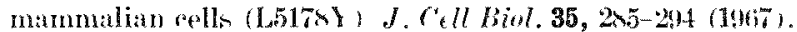

\section{RECOVERY FROM SUBLETHAL DAMAGE INDUCED BY X IRRADIATION IN CYSTEAMINE PROTECTED CHINESE HAMSTER CELLS}

Haren K. Sinclair

\section{PURIOSE AND METHODS}

Recovery from sublethal damage after $\mathbb{X}$ irradiation is now a well-known phenomenon in mammalian cells, provinled a shoulder exists in the single dose survival curve. ${ }^{(1)}$ It is also known that thiols, such as cysteamine (MEA), protect some mammalian cells differentially at different stages of the cell evele, $(2,3)$

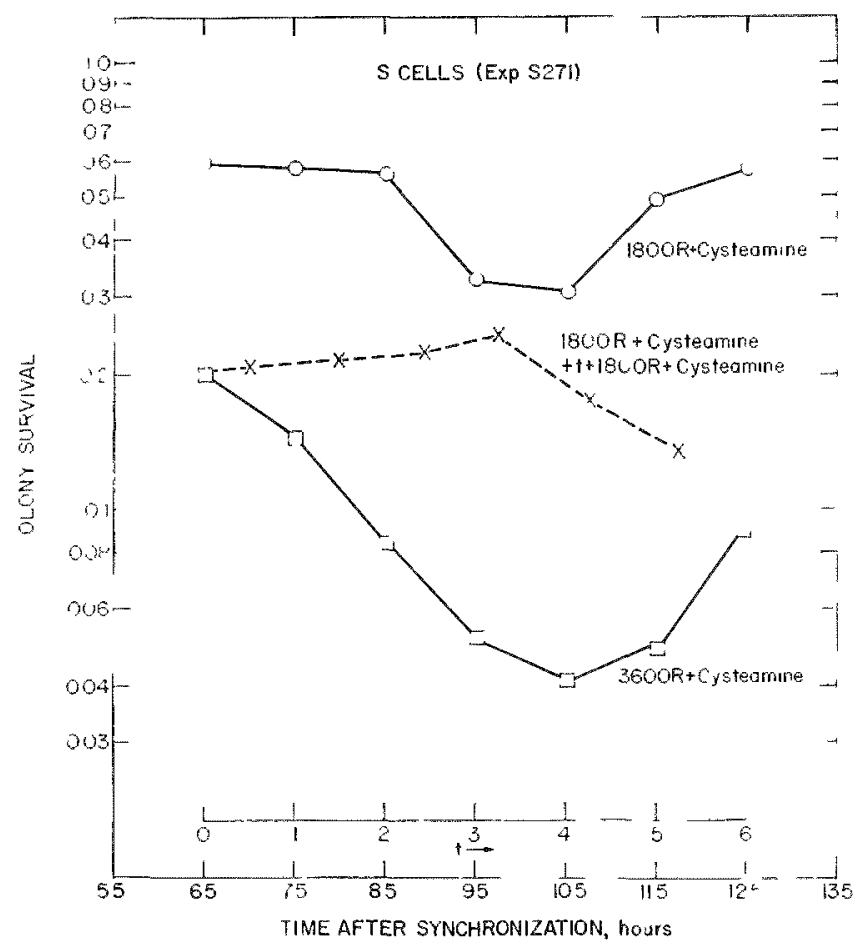

Fin. 1K1.--The responme of synchromols ('hinese hamster cells irradiated at $6.5 \mathrm{hr}$ (late $\mathrm{s}$ phase) with $(1800 \mathrm{R}+50 \mathrm{~m}$ I/ Mr.d) followed by an interval, $t$, without MEd, then a second $(1800 \mathrm{R}+50 \mathrm{~m} \cdot \mathrm{i}$.MLA). The reyponse of cells from $6.5 \mathrm{hr}$ onwards $61800 \mathrm{R}+50 \mathrm{~m} / \mathrm{MKA}$ and $3000 \mathrm{R}+50 \mathrm{ml} / \mathrm{MLA}$ is also, whown. indicating some form of interaction between the thiol and the biochemistry of the cell. It is, therefore, important to investigate whether thiol-protected cells can alo recover from sublethal damage.

It already has been noted that in Chinese hamster cells the shoulder is largest during late $S$ and resistance is maximum there; consequently, recovery is most aasily demonstrated in late $S$ phase cells.(4) Thus, the method is to use synchronous Chinese hamster cells in late $S$ phase, irradiate with a first dose in the presence of MEA, remove the agent and, at varjou time intervals thereafter, add MEA again, irra-

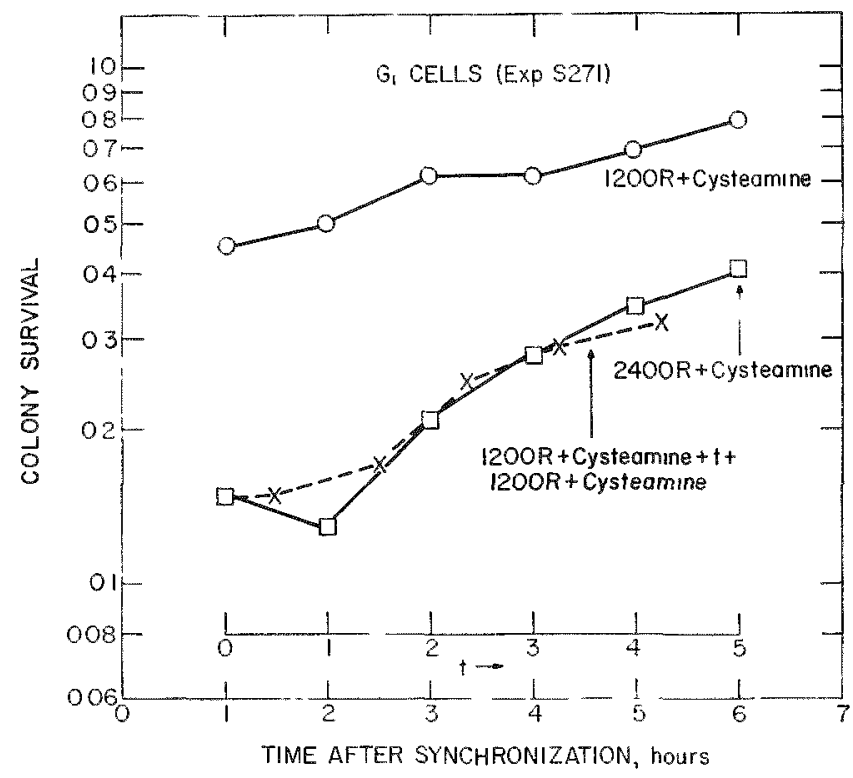

Fig. 182. The responses of ynchromons chinese ham-ter cells irradiated at $1 \mathrm{hr}\left(G_{1}\right.$ phase $)$ with $1200 \mathrm{l}+50 \mathrm{~m} . \mathrm{MLF}$; followed by an interval, $t$, without MEA, then a seeond dose of (1200 li +50 m.17 Ml.d. "The response of cells from $1 \mathrm{hr}$ on-

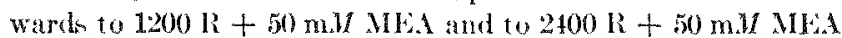
is also whown. 
diate with a recond done, then removes ME L. Survival is scored by the subequent formation of colonips. $250 \mathrm{kTp} \mathrm{X}$ radiation, HVT, $0.9 \mathrm{~mm} \mathrm{Cu}$. at about 160 $\mathrm{R} / \mathrm{min}$ is employed.

PROGREMA RFPORT

The toxicity of two applications of $50 \mathrm{~m} . /$ MEA was tected in $G_{1}$ and $S$ cells and found to be no different from a single appliration, which usually ,hows only very slight toxicity. ${ }^{(3)}$ Cells in $S$ phase were then irradiated with two doses of $1800 \mathrm{R}$ in the presence of $50 \mathrm{~m} . I I$ MEA with different intervals between the doses. In thin interval, no MEA was present. The result are compared with the result of exposure to a single dose of $1800 \mathrm{R}$ in the presence of MEA and a single dove of $3600 \mathrm{R}$ in the presenee of MFA (Figure 181). Fridently, marked recovery occur in the cell- irradiated with two doses with an interval between. Thus, recovery from thiol-protected cell in ss phave doen occur.

I further experiment was condurted to determine the rewonse in tis cells. U-ing smaller dowe of 1200 $R, 2400 R$, and $1200 \mathrm{R}+1200 \mathrm{R}$ respectively. The result in ,hown in Figure 182. A small amount of recovery may have occurred. However, in both the thiolprotected and the unprotected cell. survival curve shoulder are small and recovery is difficult to prove in $G_{1}$ cells. More definitive experiments are needed to wathli-h whether thiol-protected $G_{1}$ cells recorer an do s cells.

\section{RH.FERENCEA}

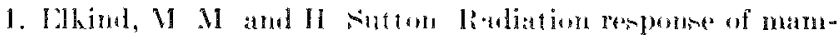
malian reells grown in culture. I liepair of 1 ray damage in

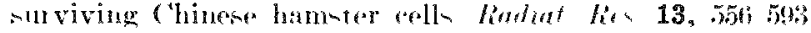
(1960).

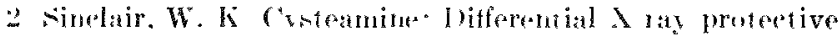

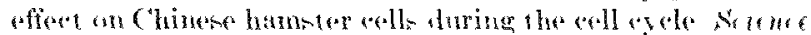
$159,142,414(194 \mathrm{~S})$

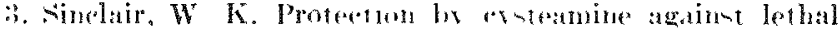

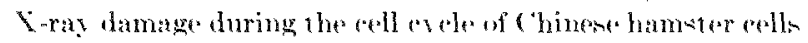

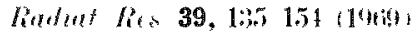

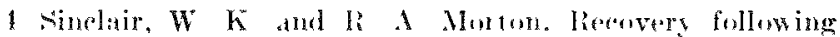
Yirradiation of sidurhroneded chineme hamater rells. Vatur 203, 217-200 (11!14)

\section{PROTECTION BY CYSTEAMINE OF CELLS SENSITIZED BY HYDROXYUREA TO X IRRADIATION}

\author{
Harren K. Nindair \\ PIRPONE AND METHOD
}

Cristeamine (MEA) protects cells most effectively at their most sensitive stage in the cell cycle, i.c. mitosi-1 2) Cells blocked at the $G_{1}-S$ transition with hydroxyurea (HU) can be rendered as rensitive as cell in mitosis, but this sensitivity develops only over a few hours of blocking with the agent. (3) It is of interest to examine whether crsteamine can reverse the sensitizing effects of hydroxyurea when it is added just prior to irradiation.

Synchronous populations of Chinese hamster cells selected at mitosis are employed. Cells are exposed to $I U$ arded in $G_{1}$ for varying periods, and just prior to $250 \mathrm{kTp} X$ irradiation $M E \mathrm{~A}$ is anded. Both agents are rin-ed of immediately after irradiation. In some cases. HU is replaced again in order to examine the postirradiation effect of HU upon MEA treated cells. Surviving cells are incubated and grow into risible colonies in 8 to 10 days.

PROM RENA REPORT

The results of eysteamine treatment on $\mathrm{HL}$-sensitized $G_{1}$ cells are shown in Figure 183. Cysteamine protects these cell [Done Modifying Factor (DMF)
7.).] at least as well an mitotic cells but not quite to the level of un-en-itized cells. Likewise, the portirruliation effect of HU in MEA-treated cells shown in Figure 184 is reduced, comprared with that of untreated cells (Nhown in Chart 4, Ref. 4). The modified responses indicate that, although cysteamine does not completely erase the effects of $\mathrm{HC}$, there is interaction between the cellular effects of the two agent Thin is additional evidence (if it were needed) that MEA is not simply a dose-modifying agent acting via a merhanism such as the suppression of free radicals, but that it interact directly with cellular constituent, even in the brief time between addition of the agent and irrarliation.

In a practical way, it empha-izes the remarkable capacity of eysteamine to protect sen-itive cells more thin resistant cells and thus tends to level of variations in sensitivity due not only to cell cycle modifications but also due to intluction by hydroxyurea.

\section{RFI EREN( $\mathrm{ES}$}

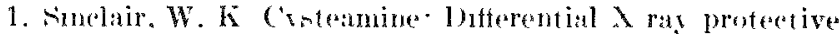

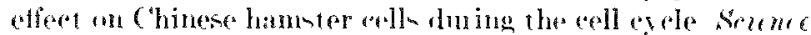
$159,112+11(196 \mathrm{~s})$

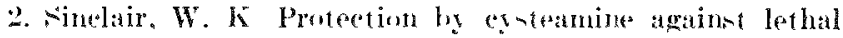




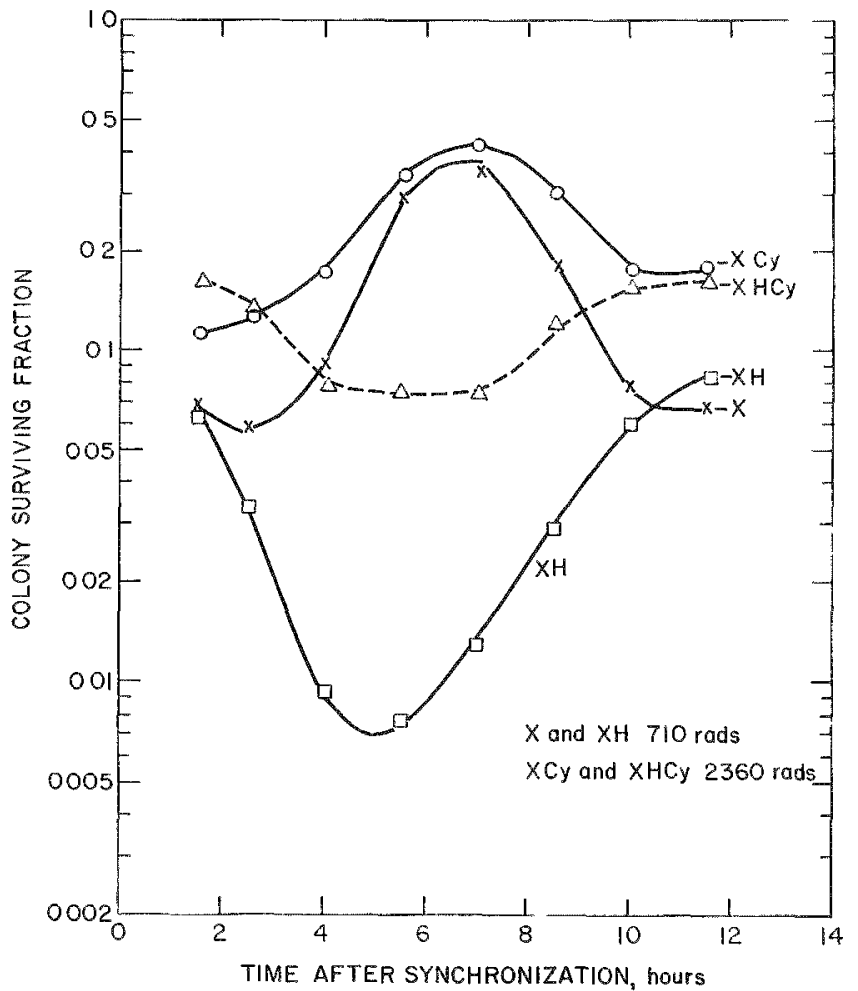

FIr. 183. Crsteamine protection of $G_{1}$ cells inhibitad with hydroxyurea. ('urve $X$, normal age response after 710 liads. Curve XII, age response of rells treated with $1 \mathrm{~m} / \mathrm{HL}$ at $1.5 \mathrm{hr}$ and given 710 Rads at times indicated. HI removed inmediately after irradiation. ("urve $\mathrm{XC} r$, age response of cells trested with $75 \mathrm{~m} . /$ crstemine during irradiation with 2340 liads. ("urve XIICY, age pespontise of cells treated with 1 m. $/ U$ II ${ }^{\mathrm{r}}$ at $1.5 \mathrm{hr}$, then with $75 \mathrm{~m} . /$ cysteanine during irradia tion with 2360 hads.

X-ray damage during the cell cycle of ('hinese hamster cells. Radiat. Res. 39, 135-154 (1909).

3. Sinclair, W. K. X-ray survival and I) NA synthesis in Chinese hamster cells. I. The effect of inhibitors added before $\mathrm{X}$ irradiation. Proc. Sat. Acad. Sei. 58, 115-122 (1967).

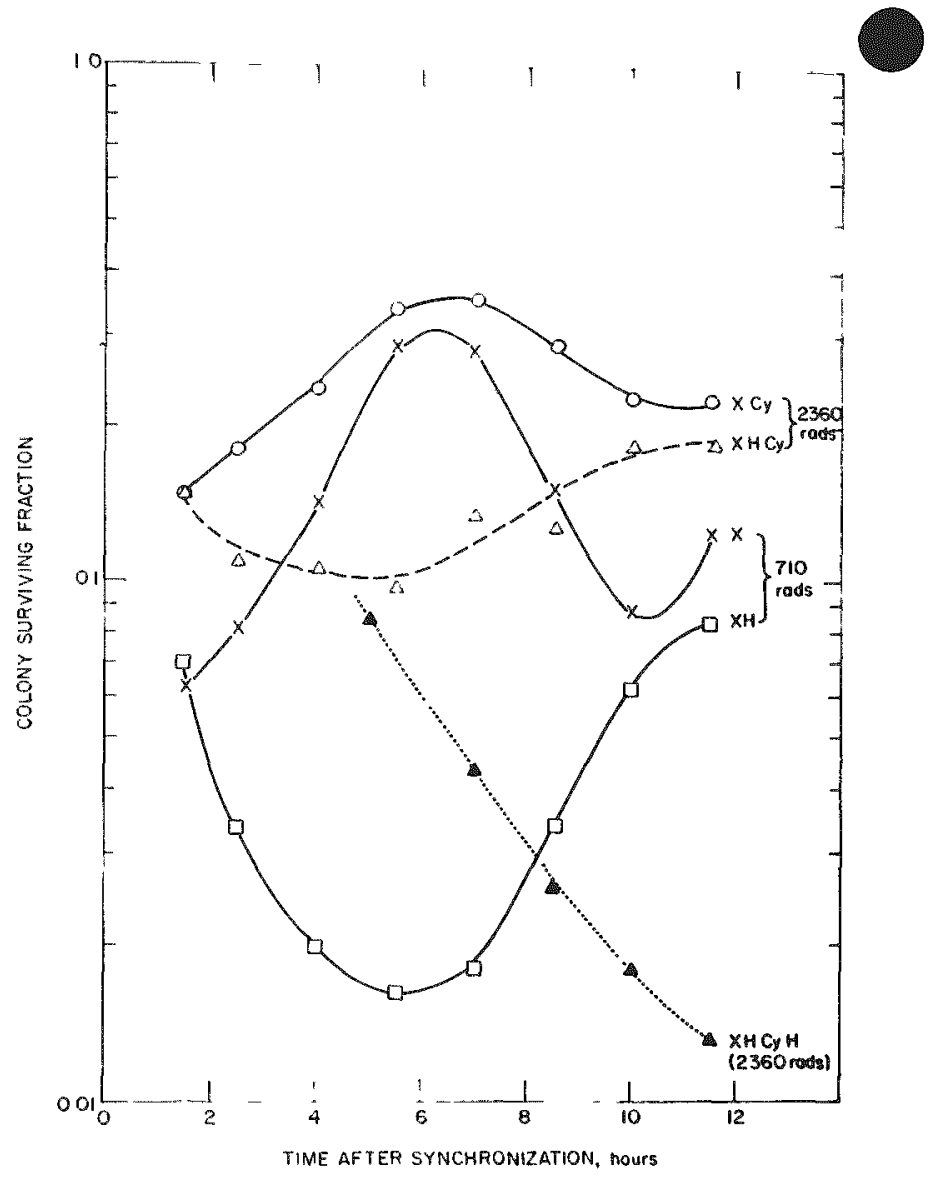

Fics. 181. ('vatesmine protection of $G_{1}$ cells inhibited with hydroxyurea showing postirradiation effeet of hydroxyurea on cysteamine prot ected cells. The dat a are for a different esperiment from these of Figure 183, but curves X, XII, XC $\mathrm{y}, \mathrm{XIICy}$ are for the same ponditions and doses as in Figure 18\%. Curve XHC $\mathrm{y}$ II shows the response of eells treated with $1 \mathrm{~m} . \mathrm{h} \mathrm{HT}$ at 1.5 he, then with $75 \mathrm{ml} /$ cysteamine during irradiation at -4 $\mathrm{hr}$, then with $1 \mathrm{~m} . / \mathrm{II}^{\circ}$ present subsequently.

4. Ninclair, W. K. The eombined exfeet of hydroxyureat and $\lambda$ rays on Chinese hamster cells in vitro. ("aver hes. $28,190-$ 206 (1968).

\section{PROTECTIVE EFFECTS OF CERTAIN AGENTS AGAINST $X$ IRRADIATION IN MAMMALIAN CELLS}

ITarren K. Sinclair.

\section{PLRPOSE AND METHODS}

Crsteamine (MEA) protects differentially during the cell cycle. ${ }^{(1,2)}$ However, even up to almost toxic levels, MEA does not completely level of the cell cycle response. ${ }^{(2)}$ Possibly, a more effective sulfhydryl protective agent could completely level off the response. Alternatively, other types of agents (e.g., disulfide protectors), if they have or do not have a differential action, may cast light on the differential effect observed for MEA.

The method employ: asynchronous cells to establish, first, toxicity and, then, DMF's (dose modifying factor) for the agent before testing for differential action during the cell cycle, using synchronous cells. The agents are added just prior to irradiation and rinsed off after $30 \mathrm{~min}$, and the surviving cells are al- 


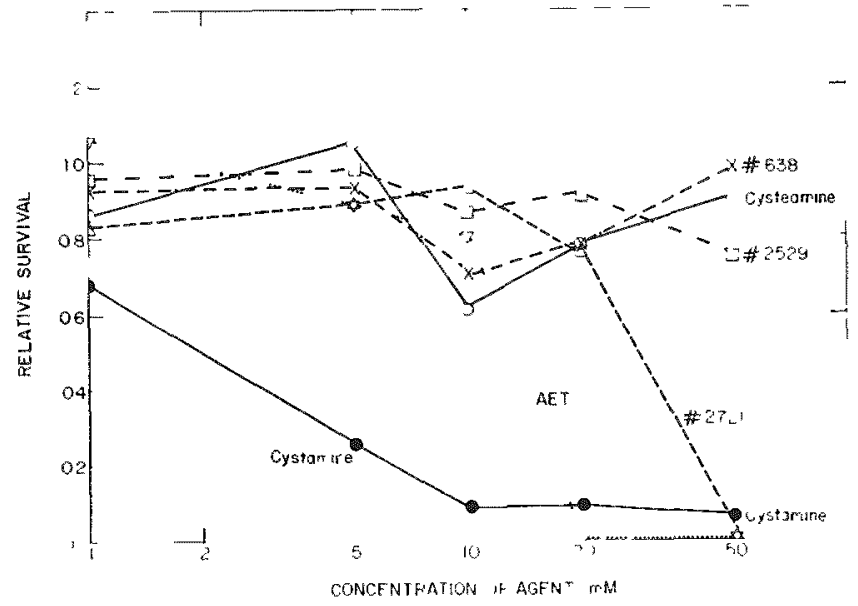

- Fira. 185. Survival (colony formation) of (hinese hamster V79 cell (anynohronous) after 30-min exposures to various concentrations of radioprotective compoumds. (H)p. 338. .)

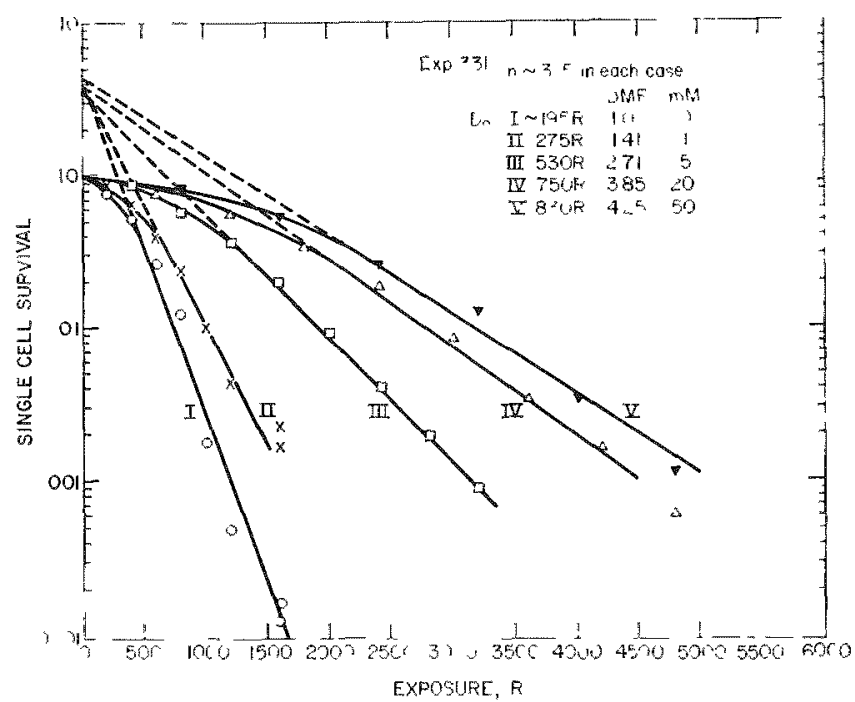

Fig. 186.- - Survival foolong formation) of (hinese hamster rells irradiated in the presene of varions concentrations of anteamme.

lower to grow into colonies during the next 8 to 10 days. $2.50 \mathrm{kVp} \times$ rays, HVL $0.9 \mathrm{~mm} \mathrm{Cu}$, are used at about $100 \mathrm{R} / \mathrm{min}$, absorbed dose rate $0.945 \mathrm{Rads} / \mathrm{R}$.

PRUTRESA REPURT

The agents investigated so far include MEA, cystamine (already known to be ineffective in cultured cells), (2) AET (aminoethylisothiurea), (3) and three compounds (identified as $\$ 638,2529$, and 2721 ) which had shown promise in screening tests in animals at the Walter Reed Army Research In-titute."

The renults of toxicity studies on these 6 agents are shown in Figure 185. AFT was toxic above $\sim 10$

* I am indebted to Dr. David P. Jacohns of the Ilivision of Medicinal chemistry, Walter Reed Army lustitute of Rosearch. for samples of these compounds.

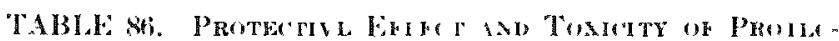

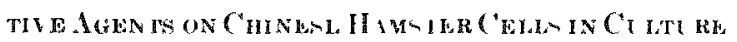

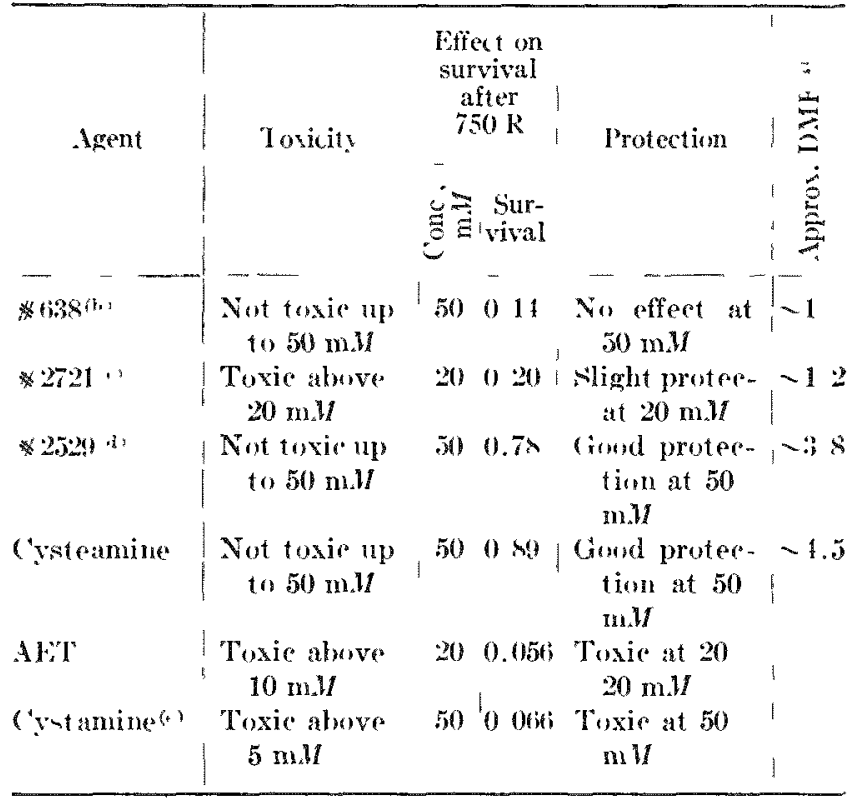

"2. Derived from a test after 750 lh only and using survival

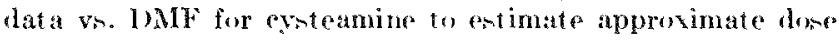
modifring factor (DMF).

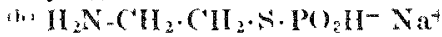

is $\mathrm{H}_{2} \mathrm{~N}\left(\mathrm{CH}_{2}\right) \mathrm{NH} \cdot\left(\mathrm{CH}_{2} \cdot\left(\mathrm{CH}_{+} \mathrm{A} \cdot \mathrm{P}\left(\mathrm{O}_{3} \mathrm{H}_{2}\right.\right.\right.$

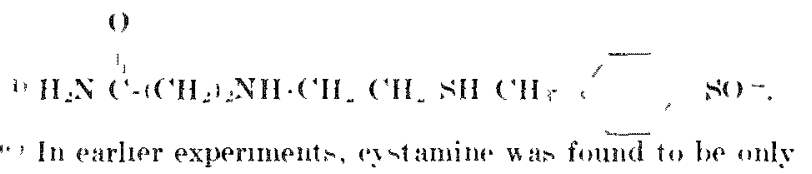
mlightly toxic $(-0.8)$ above $5 \mathrm{~m} / \mathrm{l}$.

m.II even when the pH was adju-ted (other experiment, not shown herel. Thus, it could he used only at comparatively ineffective levels in these colls. It will be noted that in this experiment eystamine was toxic at almost all levels whereas, previously, (2) toxicity was not a serious problem. Tariability, possilly. from batch to batch, in ehararterintic of nome of thene agents!

As an index of protective effect against concentration of the agent, result of $\mathrm{X}$-ray experiments for different concentration of MEA in aynchronous cells are whown in Figure 186.

The approximate D.MF': of the other compounds are shown in Table 86. Also, by way of example, the effect of compound 2.529, with a DMIF of $\sim 3$ on synchronous cells is shown in Figure 187. There may be a slight differential effect, similar to that for cy-teamine, but much smaller.

It is suspected that unless the DNF in asynchronous cell is high, no differential effect in likely to be ob-erverl. Prospects of finding an agent superior to ME. in this regard, do not appear high. In animal, however, compound 2721, a thiophoyphate, han been very effective. ${ }^{(k)}$ That it is ineffective in culture may 


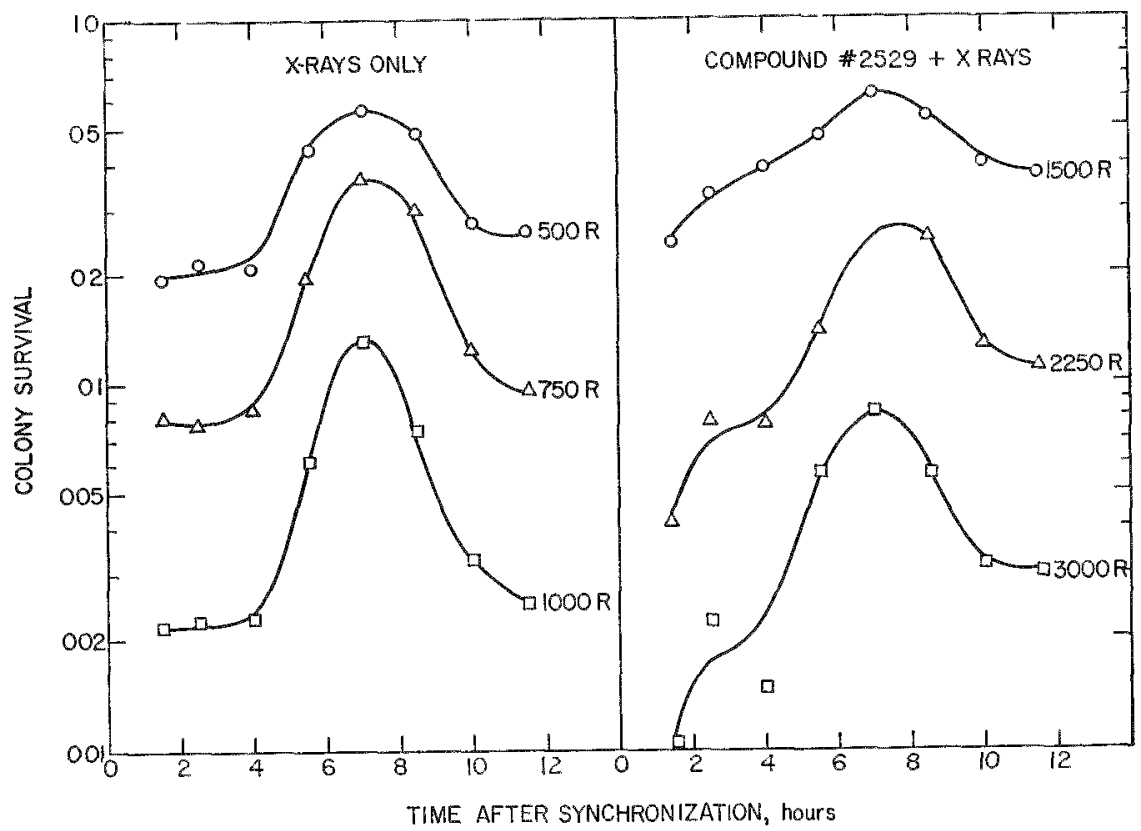

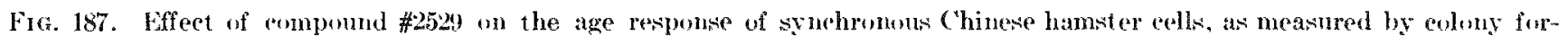
mation. The age response of untreated cells at three dose levels is shown on the left panel. There may be slight evidence of differential protection.

result from the inability of the culture system to liberate thiols from these cells. Thus, the thiol counterpart of the thiophosphate may be a much more useful compound in cell eulture.

\title{
REX FREXTCES
}

1. Sinelair, W. K. CInteamine: Hifferential $\mathrm{A}$ ray protedive effert on Chinese hanster cells during the cell cycle. Seitree $159,442-144(1968)$.

\section{SENSITIZATION OF CHINESE HAMSTER CELLS TO $X$-RAYS BY N-ETHYLMALEIMIDE}

\author{
Warren $K$. Sinclair
}

\section{PCRPU AE AND METHOD}

The observation $(1,2)$ that cysteamine protects Chinese hamater cells differentially at different stages of the cell cycle has led to various investigations concerning the role of thiols in modifying radiation damage. It is also known that thiol-blocking agents, such as $\lambda$-ethyl malcimide or iodoncetic acid, sensitize mammalian cells to $\mathrm{X}$ radiation. ${ }^{(3)}$ Thus, if these agents sensitize cells differentially during the cell cycle, thiols would be further implicated in the radiation damage process, and alditional clues as to the nature of this damage should be derived.
2. Simelair, W. K. Protertion by crsteamine against lethal X-pay damage during the cell "yele of (hiness hammer cells. Ladiat. Rex. 39, 135-154 (19469).

3. Doherty, 1). (i. and W. T. Burmett, Jr. Protective effeet of $\therefore \beta$-aminoethylisothiuronium $\mathrm{Br} \cdot \mathrm{HBr}$ and related compounds against $\mathrm{X}$ radiation death in mice. Pror. Sur. Exp. Biol. Mtd. 89, 312 (1955).

4. Luhas, J. M.. and J. B. Storer. Differential chemoprotection of normal and malignant tissues. $\%$. Nat. Cancer Inst. $\mathbf{4 2}$, $331-336(1969)$.
The method employs both asynchronous and stnchronous mammalian cells grown on plastic petri dishes in EII15 medium. Treatments with $250 \mathrm{kVp}$ $X$ rays are performed with and without the agents Nethylmaleimide (NEM) or iodoacetic acid (IAA) during irradiation. The agent is rinsed of immediately after exposure, and the cells are incubated for 8 to 10 days to form visible colonies.

PRU, RFAS REPORT

Treatments with a range of doses of both NEM and IAt have been performed with asynchronous 


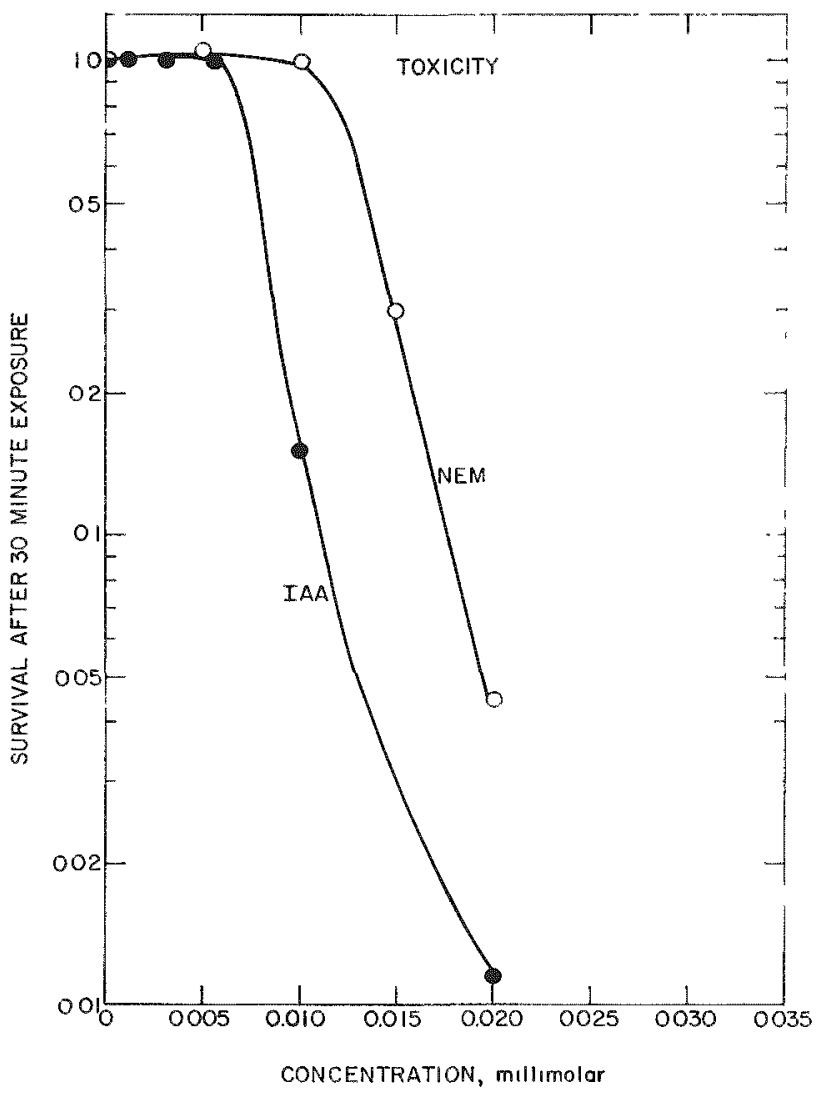

Fiti. 185. -Toxicity of NKA and IAA in ('hinese hamster (ells sxposed to the indicated concentration for $30 \mathrm{~min}$. Nurvival measured by colony formation.

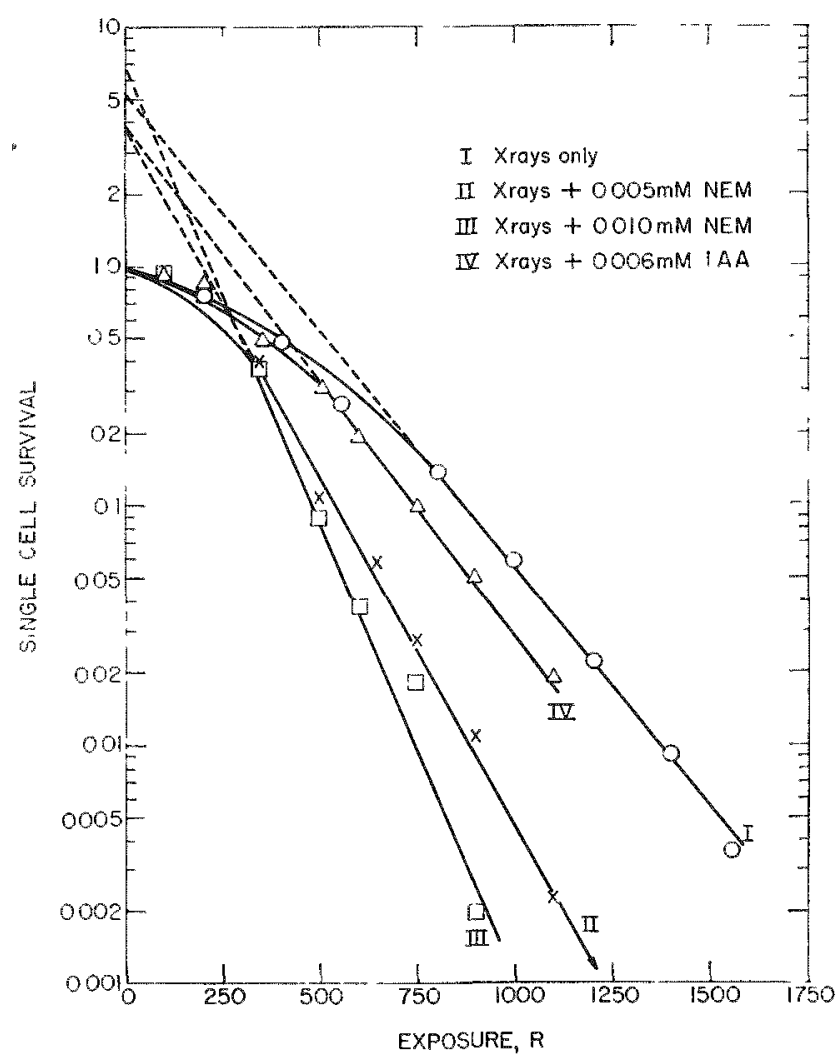

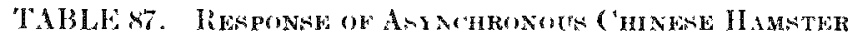

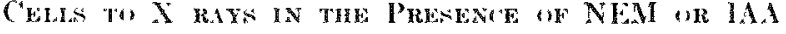

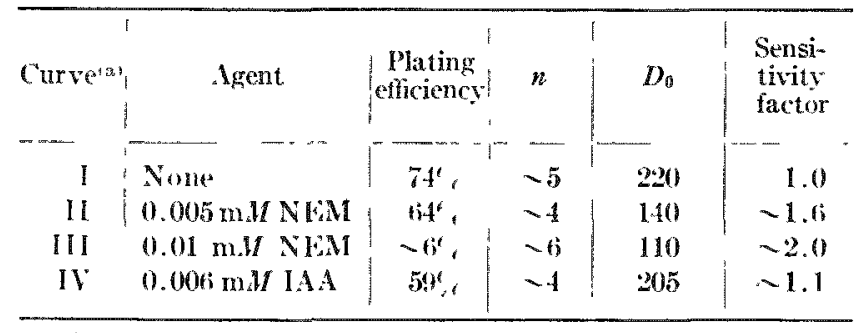

(a) Seter Figure 189.

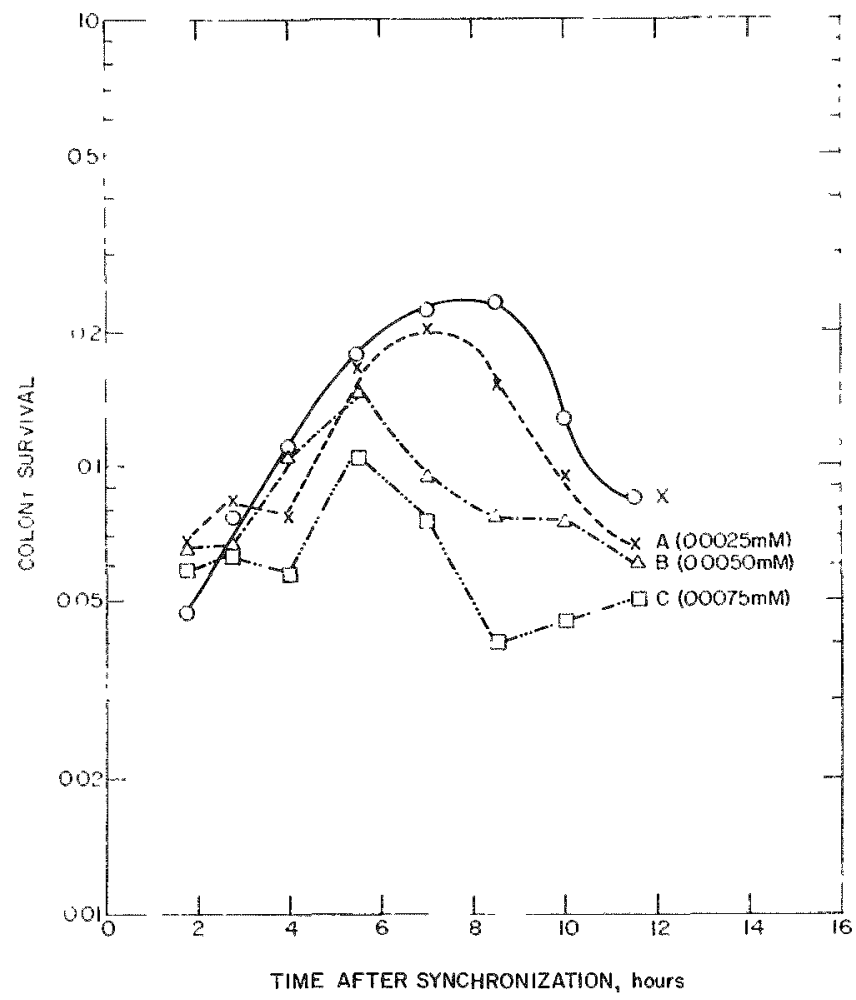

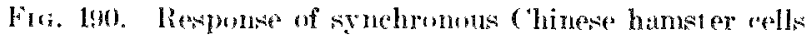
to 70 lials A radiation in the presenes of NEM for $: 30$ nuin. $X$,

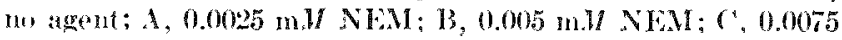
m.H XEM

cells to establish the concentration at which these agents sensitize without undue toxicity. At levels often employed with bacteria $(0.1$ to $10 \mathrm{~mm})$, both agents were quite toxic after only a 30 -min exposure. lior sensitization studies, the agent must be relatively nontuxic; thus, the borderline of toxicity for 30-min exposures was established at much lower levels within a relatively narrow range, as shown in Figure 188.

The agents were then used at close to the toxic level. and their sensitization properties were determined in X-irradiated anynchronous cells. Survival data for $\mathrm{X}$-irradiated cells with and without these agents is

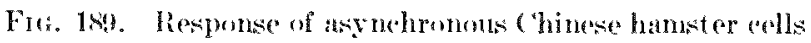

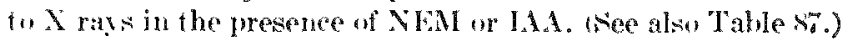


shown in Figure 189. NEM had a sensitization factor of 1.60 at $0.005 \mathrm{~mm}$ (very slight toxieity), and this factor was not improved greatly at $0.01 \mathrm{~m} M$ when only $8 \%$ of the cells survived the drug alone. At 0.006 $\mathrm{m} M$, IAA had a sensitization factor of only 1.10 . (See Table 87.)

It is proposed to investigate the cell cycle dependance of the sensitization factor for NEM, using synchronous Chinese hamster cells. To date, preliminary experiments have been carried out, and one of thene is shown in Figure 190. Evidently, a very dramatic difference exists in the sensitization properties of NE.I in late $S$ compared with early $S$ cells.

\section{REFEREACES}

1. Ninclair, W. K. Crsteamine: Differential X-ray protedive effect on (hinese hanster pells during the cell cycle. Sicitere $159,442444(1968)$

2. Sinclair, W. K. Protection by crsteamine against lethal X-ray damage during the cell eycle of Chinesse hamster cells. Iisudiat. Res. 39, 135154 (1969).

3. Myers, D. K. and I). F. Nlade. Radionensitization of manmalian cells by iodoaretamide and related componuds. Riadiat. Res. 30, 186in-203 (1967).

\section{CYCLOHEXIMIDE- AND RADIATION-INDUCED DIVISION DELAY IN SYNCHRONIZED CHINESE HAMSTER CELLS}

Silvia Bacchetti and Warren $K$. Sinclair

\section{PURPOSE AND METHODS}

Ionizing radiation delivered to mammalian cells in culture induces, among other effects, a delay in cell division. This delay occurs in cells irradiated at evrry stage of the cycle $\left(G_{1}, S, G_{2}, M\right)$ but it matgnitude is dependent upon the cell $\operatorname{stage}^{(1,2)}$ as well as upon the dose of radiation. ${ }^{(2-4)}$ The division delay is due to two factors, a block of the cells in $G_{2}$ and a prolongation of the IDNA synthetir period. $(1,5)$ The latter results only for cells irradiated in $S$. 'The universal nature of the $i_{2}$ block has prompted more detailed studies of this phase with synchronized cells, ${ }^{(6-10)}$ and the results obtained have suggested that the block could be due to an inhibition in the synthesis of proteins required for division. In support of this hypothesis are the observations that: 1) $G_{2}$ cells have already duplicated their I)NA; 2) the mean lifetime of RNA coding for protein ensential for division in Chinese hamster cells is about $2.9 \mathrm{hr}$ (i.e., longer than the ( ${ }^{\circ}$, phase in this cell line and longer than the delays induced by $\mathrm{X}$-ray doves below $1000 \mathrm{Rads})$ (7) $^{(7)}$ ionizing radiation and inhibitors of protein synthesis both induce a block in division, and their last points of action in $f_{2}$ roincide; ${ }^{(6-9)}$ 4) protein synthesis is required during the period of delay for cells to resume division, while DNA and RNA synthesis are not. ${ }^{(6)}$ However, the observation that both $\mathrm{X}$ ravs and protein inhibitors have the same point of action in $\dot{G}_{\mathrm{s}}$ does not allow us to conclude that both agents damage the same target in the cell. Similarly, the observation that protein synthesis is required during the delay indicates only that proteins are necessary for the repair of the damage induced by $\mathrm{X}$ rays. 'The purpone of the experiments presented in this report is to stully further the nature of the $G_{2}$ block in our cell system by determining the last points of action in $(i .2$ of both $X$ rays and a protein inhibitor (cycloheximide) and by establishing whether the effect of the two agents is -ynergintic or additive.

In our studies, we used synchronous population of ("hinesse ham-ter cells selected at mitosis after" a 2-hr incubation with Colcemid $(0.1 \mu \mathrm{g} / \mathrm{ml})$. The division delay was determined by counting the cells at hourly intervals during 1 or 2 cveles and by comparing the times of dirision in the treated populations and in the control. Protein synthesis was determined by pulse labeling the cells with "II-leucine $122.6 \mathrm{Ci} \mathrm{maI;} 4 \mu \mathrm{Ci} \mathrm{ml}$ ) for $1.5 \mathrm{~min}$ and by counting, after antoradiography, the number of labeled cells as well as the number of grains per labeled cell. All the other details of the methods have been reported elnewhere. (11)

\section{PROGRRSS REPORT}

The effect of the protein inhibitor eycloheximide (CH) on the progression of eells toward division was investigated after addition of three different concentrations of the $\operatorname{drug}(2,5$, and $50 \mu \mathrm{g} / \mathrm{ml})$ at various times in the cell cycle, beginning in mid-s pha-e. In the first series of experiments. the cells were exposed continously to the drug, and the time and extent of cell division, if any, was determined. We obnerved that when division occurred in these circumstances it was not delayed, compared to the control population and, also, that the rate of division did not differ from that of the control. However", the number of cells dividing was dependent upon the 
lime of addition of the drug and upon the concentration used. Addition of $\mathrm{CH}$ at any concentration during the $S$ phase resulted in no division at all, but addition of the drug in very late $S$ and through $G_{2}$ allowed more and more cells to divide. An example of this for $5 \mu \mathrm{g} / \mathrm{ml}$ of CH is shown in Figure 191. By relating the number of cells dividing to the time of addition of the drug, we were able to map a last point of action in $G_{2}$. All the pells prior to this point in the cycle at the time of treatment are inhibited in their progression toward division, but all the cells past this point divide normally. In Figure 192 are summarized the results of the experiments for the three concentrations of CH used, as well as for a dose of $\mathrm{X}$ rays (600 Rads). The experiments with ionizing radiation were performed by irradiating the cell at different times in the last part of their cycle, and the dose of 600 Rads was chosen initially as one inducing an appreciable division delay ( 2 to $3 \mathrm{hr}$ ). ${ }^{(2)}$ [This dose, however, reduced the survival

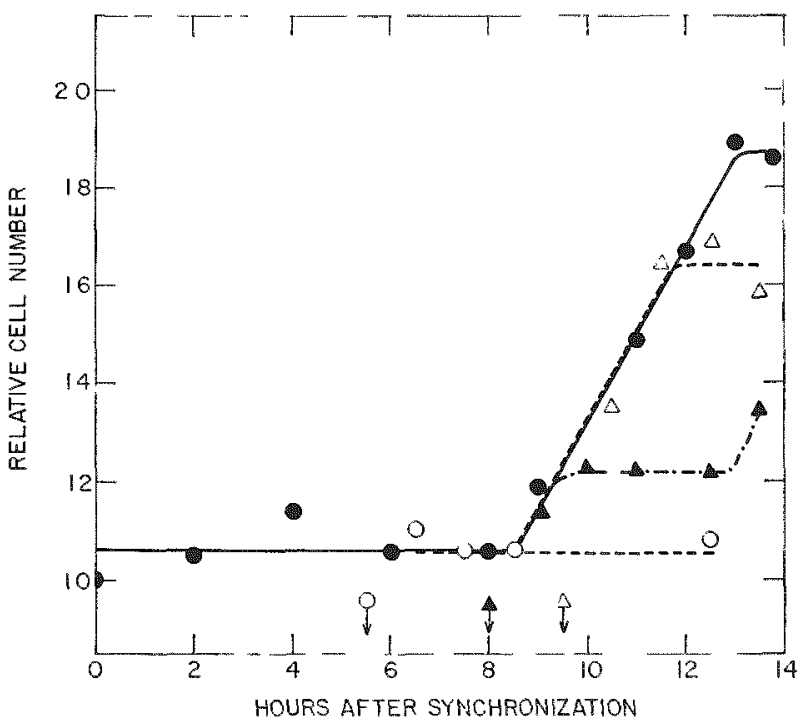

Fig. 191.-Heffects of $5 \mu \mathrm{g} \mathrm{mll}$ of CH on cell division. 'The times of addition of the drug are indieated by the arrows. control, $\mathrm{O}, \mathbb{A}, \triangle$, CH added at $55 \mathrm{hr}(\mathrm{S}$ phase $), 8 \mathrm{hr}\left(G_{2}\right)$ and 9.5 hr $\left(G_{2} / M\right)$ after synchroniation.

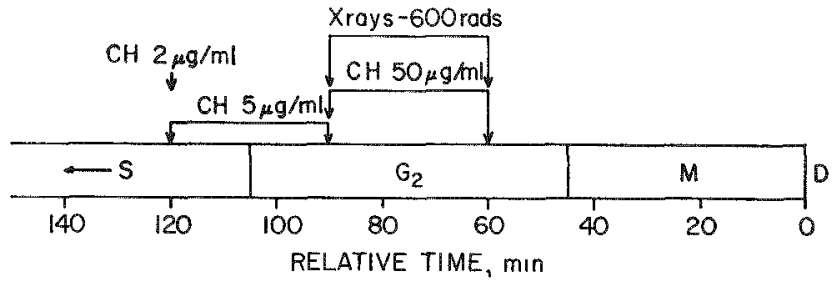

Fis. 192,-Mapping of the last points of action for $\mathrm{CH}(2,5$, hd $50 \mu \mathrm{g}, ' \mathrm{ml}$ ) and $\mathrm{X}$ rays (600 Rads) in inducing a block in cell division. The relative tines in minutes indicate the time before division $(D)$ at which the blocks ocem and also the length of mitosis $(M)$ and $G_{2}$.

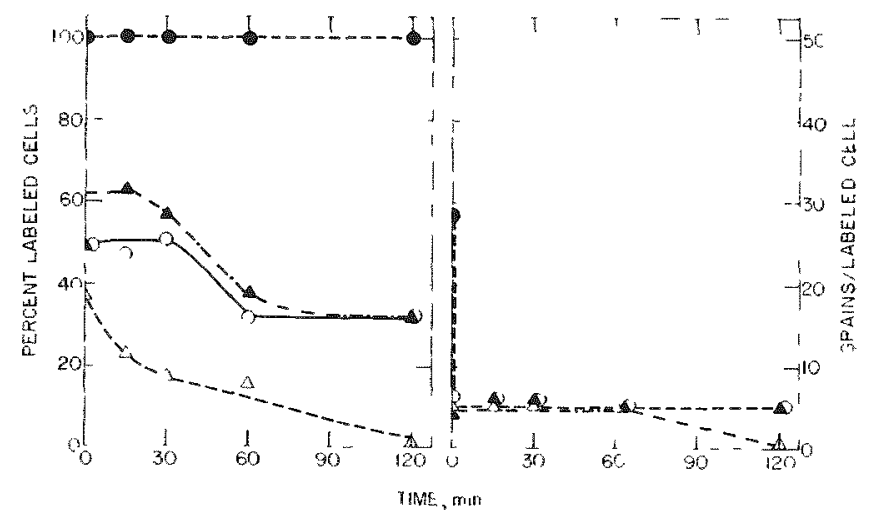

Fitx. 193. Fffert of different concentrations of ('H on the number of labeled cells and the number of grain per labeled cell during a pulse with IItencine The drug was added at time zero and the uptake of "H-leurne was determined after a 1.5 min pulse. Fach experimental point is plotted at the be ginning of the pulse 0 control; $0,2 \mu \mathrm{g}, \mathrm{ml} ; 5 \mu \mathrm{g} \mathrm{ml} ; \Delta, 50$ $\mu \mathrm{g} ' \mathrm{ml}$.

of $\left(i_{2}\right.$ cells to about $\left.0.1,{ }^{12}\right)$ while the dones of $\mathrm{CH}$ uned did not aftect cell survival for the duration of the experiment..] The results shown in Figure 192, indeed, indicate a coincidence in the last point of action for 600 Rads and $50 \mu \mathrm{g} / \mathrm{ml}$ of $\mathrm{CH}$. However, they also showed that different doves of $\mathrm{CH}$ have different times of action in $G_{2}$. This dose-dependent rffect is apparently due to the fact the 2,5, and $50 \mu \mathrm{g}$ inl of $\mathrm{CH}$ reduce to a different extent the number of cells synthesizing proteins, although they may affect equally the rate of synthesis (Figure 193). Further axperiments will be devoted to investigating the last points of action for several $\mathrm{X}$-ray doses (200 to $1000 \mathrm{Rads}$ ) to determine if the similarity observed between 600 Rads and $50 \mu \mathrm{g} / \mathrm{ml}$ occurs orer a wide range of doses.

A comparison between a continuous exposure to CII and an exposure to $X$ rays may not be valid, because $\mathrm{X}$ rays are delivered to the cells in a short pulse; therefore, we have performed experiments in which a short pulse of CH was given to $G_{2}$ cells. Although no division delay was observed at the first post reatment division, there may have been experimental reasons for this.

Finally, although we have confirmed a coincidence in the last points of action of at least one dose of CII and one dose of $\mathrm{X}$ rays, we do not think this olverration is enough to establish the hypothesis that both agents act on the same cellular target. In fact, while CH reduces appreciably and rapidly the amount of protein synthesis (Figure 193), no similar effect is found after irradiation. On the contrary, in the latter case a stimulation of protein synthesis at early times after treatment has been observed. ${ }^{(13)}$ Further 
studies are in progress to investigate whether treatment of $i_{2}$ cells with $\mathrm{CH}$ prior to irradiation results in a synergistic or additive offect on the division delay.

\section{RFFERFNCES}

1. Terasima, T. and L. J. Tolmach. (Arowth and nucleice acid synthesis in sychehronols ly dividing populations of Helat (rells. Exp. Cell Res. 30, 341-3030 (1963).

2. Yu, C. K. and W. K. Sinclair. Mitotie delay and chrome somal aherrations indured by $X$ rays in synehronized (hinese hamster cells. J. Viat. ('ancer Irest. 39, 619 632) $(13467)$.

3. Whitmore, (4. F., C. P. Stamers. J. W. Till, and S. (ruly as. Nucleic acid syuthesis and the division eycle in $\mathrm{X}$-irradiated L-strain mouse cells. Biochim. Biophys. Acta 47 , $6 t^{2}-77(1901)$.

4. Elkind, M. M., A. Han, and K. W. VolL. Radiation response of mammalian cells grown in eulture. IV. Dose dependences of division delay and postirradiation growth of surviving and non-surviving, ('hinese hamster cells. J. Nat. Cancte Inst. 30, 705-721 (196i3).

5. Sinelair, W. K. Cy clie X-ray responses in mammalian eells in vitro. Ratiat. hes. 33, (i20 tit:3 (1968).
6. Boidat, Y. and si. Okada. Radiation-induced mitotic delat

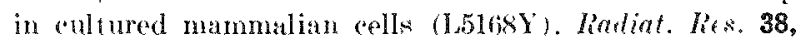
$513529(196 \%)$.

7. Tobey, R. A., F. (C. Anderson, and 1), F. Petersen. IRNA stability and profein synthesis in relation to the division of mammalian cells. Prose. Lat A card. Sci.56, 15201527 (1966).

8. Walters. R. A. and I). F. Petersen. Radiosensitivity of mammalian cells. I. Timing and dose dependence of radiation-indueed division delay. Biophys. $/ .8,1475-1486$ (19his).

9. Walters, R. A. and D). F. Petersen. Radiosensitivity of mammalian rells. 11. Radiation effects on macemolecular synthesis. Biophys. J. 8, 1487 1501 (1968).

10. Ruatad, R. ('. and B. R. Burchill. Radiation-induceal mitotic delay in sea urchin egges treated with puromycoin and actinomyein 1). Radiat. Le's. 29, 2013-210 (196it).

11. Ninclair, W. K. and R. A Morton. X-ray and ultraviolet sensitivity of synchronized (hinese hamster cells at varions stages in the cell eycle. Biophlys. J. 5, 1-25 (19ti5).

12. Ninclair, W. K. Radiation effests on mammalian cell populations in ritro. Rediation Restarch, Ed. G. Silini. North-Holland Publ. ('o.. Amsterdam, 1967, p. 607.

13. Bacehet $i, 2$. and $W$. K. Ninclair. The effeet of $X$ rays on the uptake of "H-leueine in synehronized Chinese hamster eells. This report.

\title{
THE EFFECT OF $X$ RAYS ON THE UPTAKE OF ${ }^{3} H$-LEUCINE IN SYNCHRONIZED CHINESE HAMSTER CELLS
}

\author{
Silvia Bacchetti and Warren $K$. Sinclair
}

PIRPOSE AND METIIODS

In a previous report ${ }^{(1)}$ observations on the changes in DNA, RNA, and protein synthesis after irradiation of synchronized cells were reported. After irradiation of $S$ phase eclls with 710 Rads, the uptake of ${ }^{3} \mathrm{H}$-leucine continued at its maximal rate during the whole period of dirision delay (i.e., for longer than the period of retention of cells in $x$ phames, instead of decreasing as in the control population. Because of the relevance of these data to the studies presented in the previous report, ${ }^{(2)}$ we have started a series of experiments to investigate the uptake of "If-leucine during two postirradiation cycles of cells given 710 Rads in different phases. Some of these experiments are reported here.

The method used to obtain synchronized cells and the labeling procedure have been deseribed previously. (2) In the present experiments, the concentration of ${ }^{3}$ Il-leucine used was either 2 or $4 \mu \mathrm{C} i \mathrm{i}, \mathrm{ml}$ (specific activity $22.6 \mathrm{Ci} / \mathrm{mM}$ ). Iabeling of st phase cells to determine the cell age in the cycle was obtained by pulsing the cells with ${ }^{3} \mathrm{HTdR}$ (specific activity $14 \mathrm{Ci} / \mathrm{mM}, 0.16 \mu \mathrm{Ci} / \mathrm{ml}$ ) for $15 \mathrm{~min}$.

\section{PROGRESS REPORT}

Figure 194 shows the results of two experiments in which the cells were irradiated in late $S$ phase. In the first instance, uptake of ${ }^{3} \mathrm{H}$-leucine in both control and irradiated cells was followed for part of the next cycle, and in the second experiment into the third evcle after synchronization. The percent of cells labeled with HTdR irlentifies the position in the cycle of the population at the time of treatment. The results show that when 710 Rads are delivered in $S$ phase (when the rate of leucine uptake is nearly maximal) the irradiated cells continue to incorporate the labeled precursor at a maximal rate or are stimulated to incorporate it at an even higher rate. This confirms the previous observation. ${ }^{(1)}$ The difference between the two experiments in Figure 194 is probably not due to the amount of leucine employed but conld be due to the fact that the cells were irradiated at two different times relative to their cycle of protein synthesis, that is, either immediately before or after they had reached the maximum rate of uptake.

The experiment illustrated in Figure 195 shows the results of 710 Rads delivered when most cells are in late $G_{2}, U$ las determined by sIITdR labeling and by mensurements of cell divicion). At this time, the uptake of leucine in the control is elose to its $\mathrm{min}$ ( mal value and the irradiated cells are, indeed, stimulated in their uptake in the 2 to $3 \mathrm{hr}$ immediately after irradiation. At later times, the control cells in- 

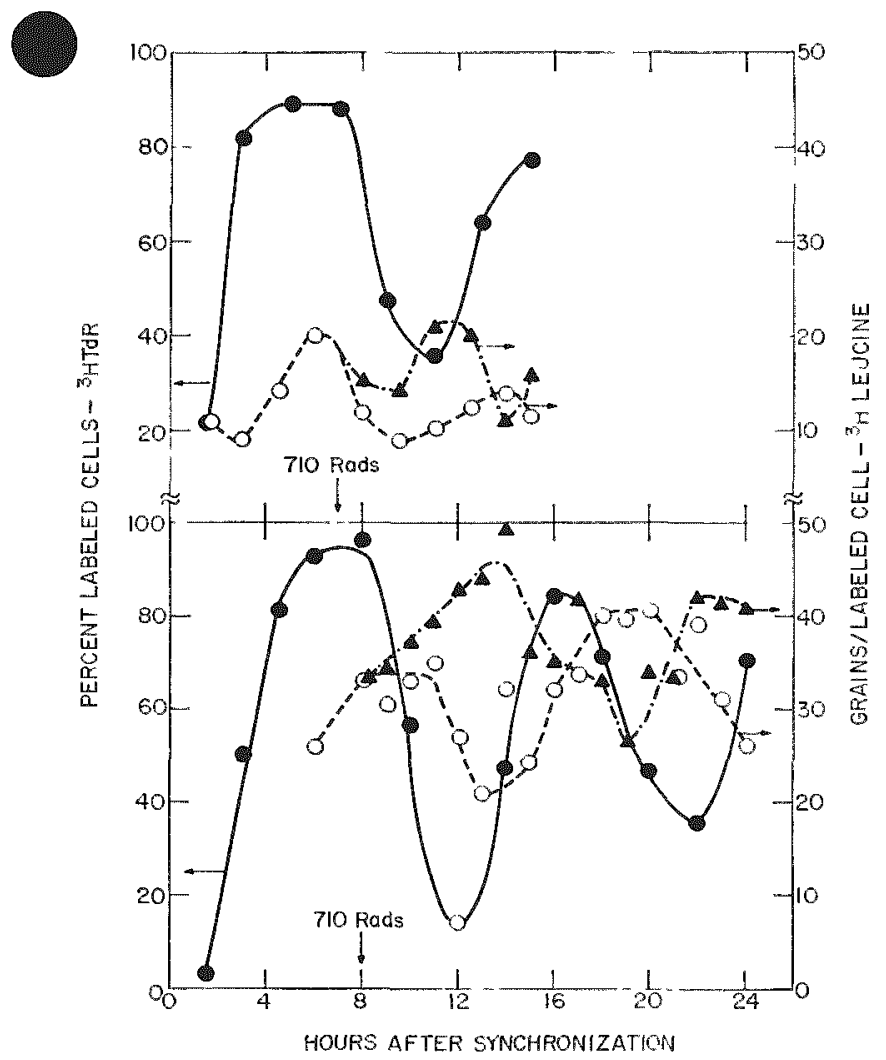

Fes. 194. Feffects on protein srothenis of 710 hads de livered in late $s$ phase. The exacet times of irradiation are indieated in the figures. ', of cells labeled with "HTdL in the eontrol; $O$, number of grains per labeled eell after if leneine labeling in the ent rol; $\mathbf{A}$. number of grains per labeled eell after "Hleneine labeling in the irradiated population. Buth control and irradiated ponulation have almost look, of the cells labeled with alleweine at all times. In the top figure $2 \mu \mathrm{Ci} \mathrm{ml}$ of "Il leueine were nsed: in the bottom figure the concentration of sh-lencine was $1 \mu$ ('i ml.

crease their letcine uptake, reaching the high level characteristic of $s$ phase; the irradiated cells, however. Show this increase 3 to $4 \mathrm{hr}$ later (they also suffer a division delay of the same length).

These preliminary experiments indicate that $X$ rays stimulate the uptake of leurine. Whether this -timulation occurs only in 8 cells, which is a pomible explanation of all three experiments, or occurs also in $f_{2} . I I$ cells remains to be determined. Although the stimulation of leucine uptake presumably means a higher rate of protein $-y$ ynthesis. alteration in aninoacid pool size, due to irradiation, can not be climinated as a posible explanation.

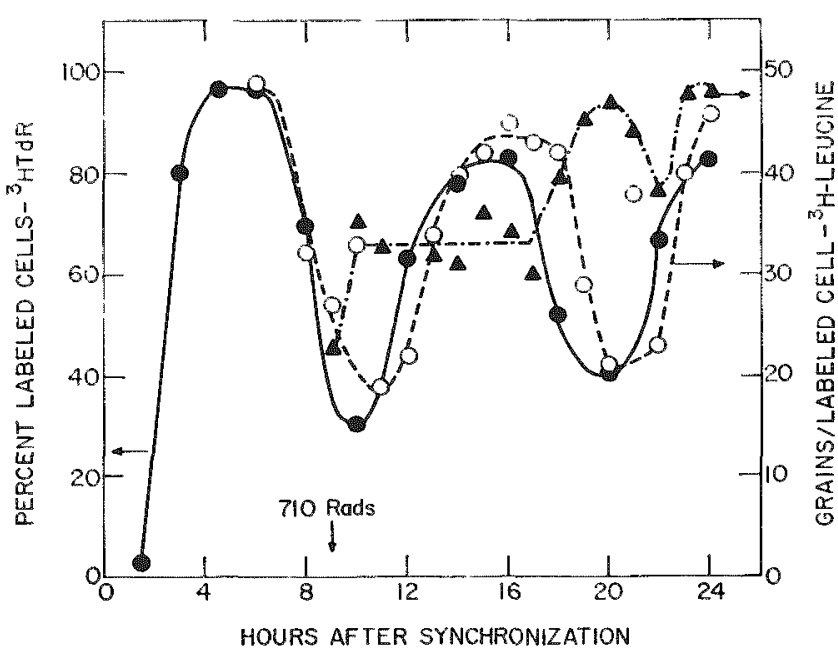

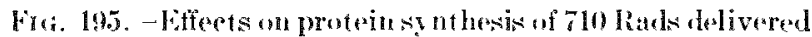

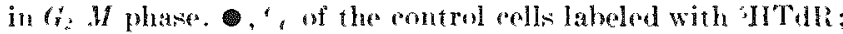
O. number of grains per labeled eontrol reell coll-leurints, 1 $\mu(\mathrm{i} \mathrm{ml})$; number of grains por labeled irradiated coll

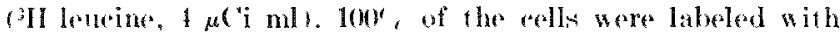
II lenerine at all times both in eontrol and irradiated poundations.

Stimulation of protein synthesis may bo disadvantageous to the irradiated cell. and preventing synthenis with a protein inhibitor ie.g., eveloheximide) may therefore increare cell survival, ats has been observed in Hola cells, ${ }^{\text {(3) }}$ whereas in Chinese hamster collo survival is only slightly affected.(4)

Further experiments will be devoted to the sturly of this phenomenon in other phases of the ryele and also to the investigation of the rate of protein synthesis and the survival of cells treated with cyclohesimide after irradiation.

\section{RWFERENCES}

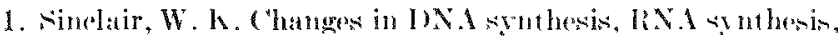
and protein sruthesis following $\mathrm{X}$ irradiation. Argontue National Laburatory Biologieal and Medieal liemeareh

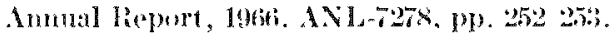

2. Batedeti. S. and W. K. Finelair. Cyelohesimide-and radiation-indered division delay in sychronized chineste ham store cells. This report.

ॐ. Phillips, Ii, A, and 1. J. Tolmach. Hepair of potentially lethal damage in X-irradiated Hela cells. Rodiat. Ros. 29 , $11340282(19666)$.

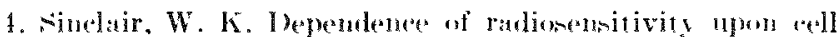
atere. Presented at carmel, california, conferenece on Thint atud Dosa lielationships in Radiation BBology as Applied to Radiotheraps. To be published in a mongeraph by the National cander lustitute. 


\section{ULTRAVIOLET LIGHT-INDUCED DIVISION DELAY IN} SYNCHRONIZED CHINESE HAMSTER CELLS

Intun Han, Warren K. Sinclair, and C.K. Iu

PURPOSE AND METHODS

Previous studies $(1,2)$ have established the fluctuations in lethal response of Chinese hamster cells to ultraviolet light (UVL) as they age between one division and the next. These cells were found to be most sensitive in $S$, less sensitive in $G_{1}$ and $G_{2}$, and least sensitive in mitosis. A complete description of the kinetics of cell populations irradiated with

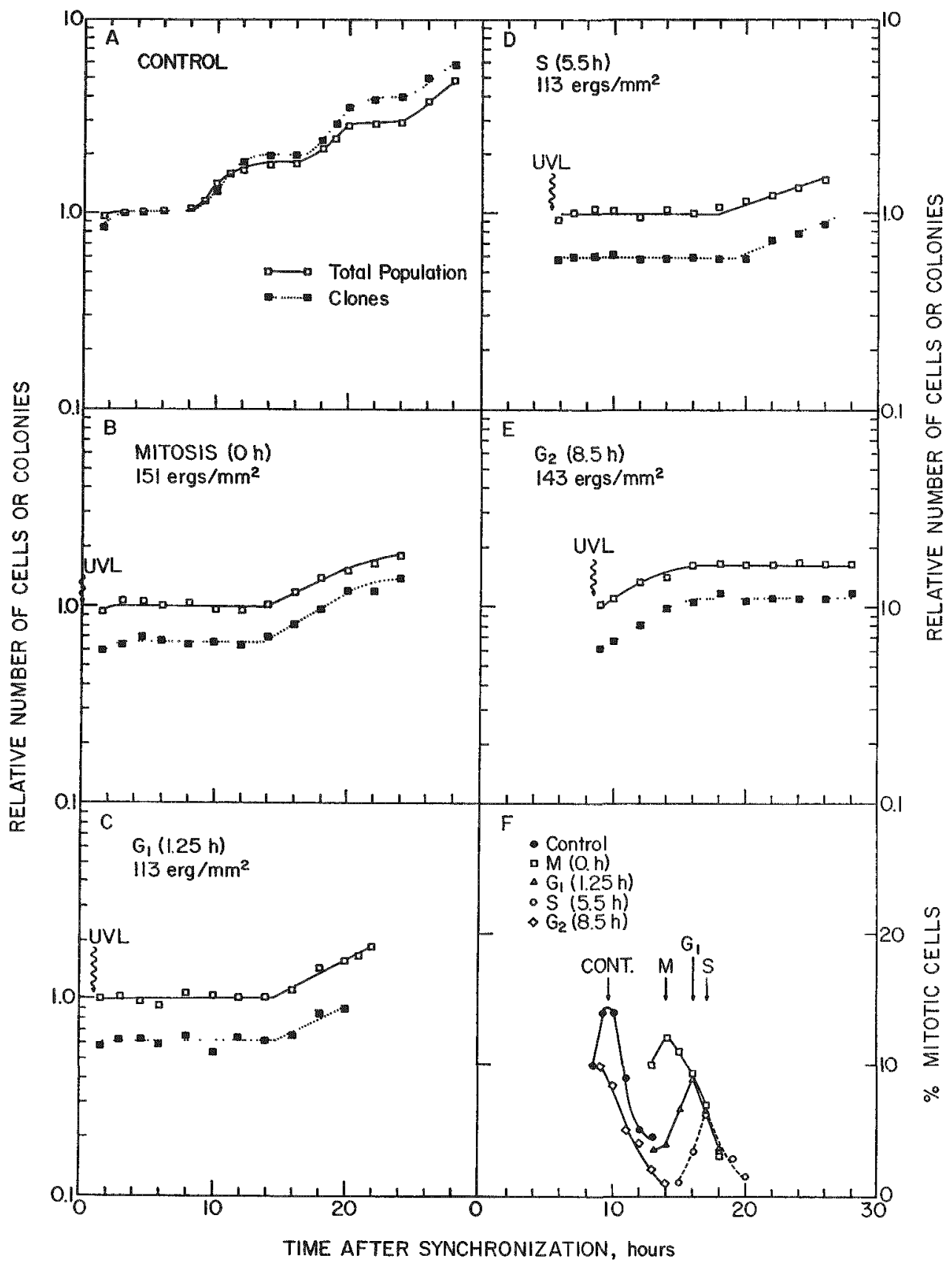

Fra. 196.- Division delay in synchronous Chinese hamster cells irradiated with CVL to levels which result in about 0.6 survival. Open symbols, total cells; closed symbols, survivors. A, Grow th of controls. B, Growth of cells irratiated in mitosis (151 ergs, mm2). (. Growth of cells irradiated in $G_{1}\left(113 \mathrm{ergs} / \mathrm{mm}^{2}\right)$. I), (4rowth of cells irradiated in mid-s (113 $\mathrm{ergs}$, $\mathrm{mm}^{2}$ ). E, (Growth of cells irradiated in $G_{2}\left(143 \mathrm{prgs} / \mathrm{mm}^{2}\right) . F$, Mitotie index vs. time for cells irradiated in $1 I, G_{1}, S$, and $G_{2}$ with the same UV doses as alhove. 


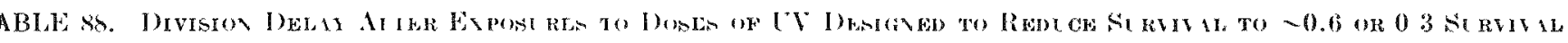

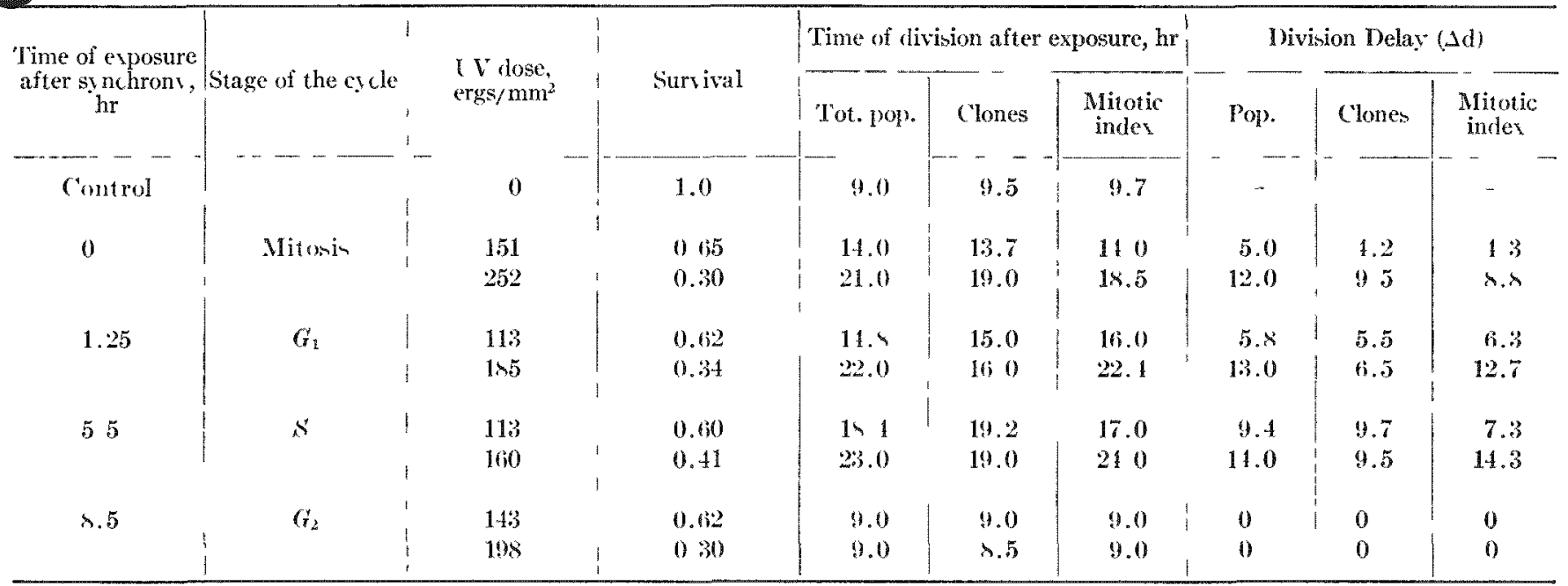

UVL requires, in addition to lethality, a knowledge of the age dependent effects of UVL upon division delay. This report is concerned with UVLminduced division delay and its relation to the cell age at the time of irradiation.

The harvesting procedure for synchronized Chinese hamster cells has been described in detail elsewhere. $(1,2)$ However, division delay experiments require a large number of cells per sample to ensure a reasonable number of cell counts. Therefore, the method of synchronization was slightly modified; harventing platen were incubated for $2 \mathrm{hr}$ in Colcemid before synchronization $(0.1 \mu \mathrm{g} / \mathrm{ml})$ to increase the yicld of mitotic cells. This change in synchronization has increased the yicld by about 2.5 times. Synchronized Chinese hamster cells, subline V79-\$171, were exposed to UVL from a GE germicidal lamp, $8.7 \mathrm{ergs} / \mathrm{mm}^{2} / \mathrm{sec}$, at different stages of the cell cycle. Two methods of assaying delay were used.

The first measure division delay by counting the increase in cell number with time. As a function of time after irradiation, single-cell suspensions were made by trypsinization. The contents of two plates were pooled to form one sample, and this was counted electronically to determine the growth of the total population. From this, the suspension was diluted, as needed, and plated into three di-her for colony formation to determine the growth of the viable fraction in the population. 'The procedures used for the growth of controls were the same, except for the absence of UVL exposure.

The sereond method determines the arerage mitotic clay by scoring mitotic index as a function of time after synchronization and by comparing control and irradiated cells. The method has been employed pre- viou-ly with $\mathrm{X}$ rays.(3) Lxposures were performed with cells attached to the bottom of the dish and with the melium removed. UVL exposures were adjusted. to yield approximately the same survival levels at different stages of the cycle, and the induced division delay was examined after exposures which yielded 0.6 or 0.3 survival level.

\section{PROGREA REPORT}

Figure 196 shows the length of the division delay after exposures which yielded about a 0.6 survival level. The increase in the number of surviving cells is chown relative to the total number of cells in the population at the time of exposure (normalized to 1.0). The results presented in Figure 196 show that cells irradiated in the middle of $S$ suffered the longe-t division delay, cells irrudiated in $G_{1}$ or mitosis have about the same delay in division, and cells exposed in $i_{2}$ were not delayed. The results of the sccond methor, in which the mitotic index is scored an a function of time, are shown in Panel $F$ (Figure 196). These results show delays similar to those shown in the other panels.

Growth data presented in Figure 196 indicate that total population and riable cells suffer about the same division delay.

A further experiment was conducted in which the exposures were increased to reduce the survival level to $\sim 0.3$ at each stage. The patterns produced are similar to those shown in Figure 196, except that the magnitude of the delays was increased. The re-ults for both 0.6 and 0.3 survival are summarized in Table 88.

At 0.3 survival, the results for mitotic index ver-us time agree best with those for the total population, 
whereas the delay for viable cells is somewhat shorter than these. This suggests that all cells reach mitosis. However, all of the cell increase can be accounted for by the increase in size of the viable cell population; thun, the nonsurviving cells presumably are present during most of the experiment and apparently are stopped at mitosis and do not divide.

Evidently, divirion and mitotic delay are much larger in magnitude than after X-ray doses that reduce cells to about the same survival, (1) but, as in the case of $\mathrm{X}$ rays, division delay is age dependent and the largest delays occur when cells are irradiated in 5. The absence of delay in $G_{2}$ is an interesti feature of this study.

\section{REFHRENCWS}

1. Sindair, W. K. and IR. A. Morton. X-ray and ultraviolet sensitivity of syuchronized ("hiness hamster cells at various stages of the cell cy cle. Biophys. J. 5, 1-25 (1965).

2. Han, A. and W. K. Ninclair. Sensitivity of synchronized Chinese hamster cells to ultraviolet light. Biophys. J.9, 1171-1192 (1969).

3. Yu, C. K. and W. K. Sinclair. Mitotic delay and chromssumal aberrations induced by $X$ rays in synehronized Chinese hamster cells in vitro. J. Nat. ('ancer Inst. 39, $610-631(1966)$.

\title{
INTERACTION OF X RAYS AND ULTRAVIOLET LIGHT IN MAMMALIAN CELLS
}

\author{
Warren $K$. Sinclair and Antun Han
}

\section{PURPOSE AND METHODS}

$\mathrm{X}$ radiation and $\mathrm{UV}$ light cause lethal damage in mammalian cells, and the shape of the survival curves with dose in the two cases is similar. Is the nature of the lesion induced by both agents the same or different, or is there an intermediate degree of interaction between them? Various pieces of ovidence

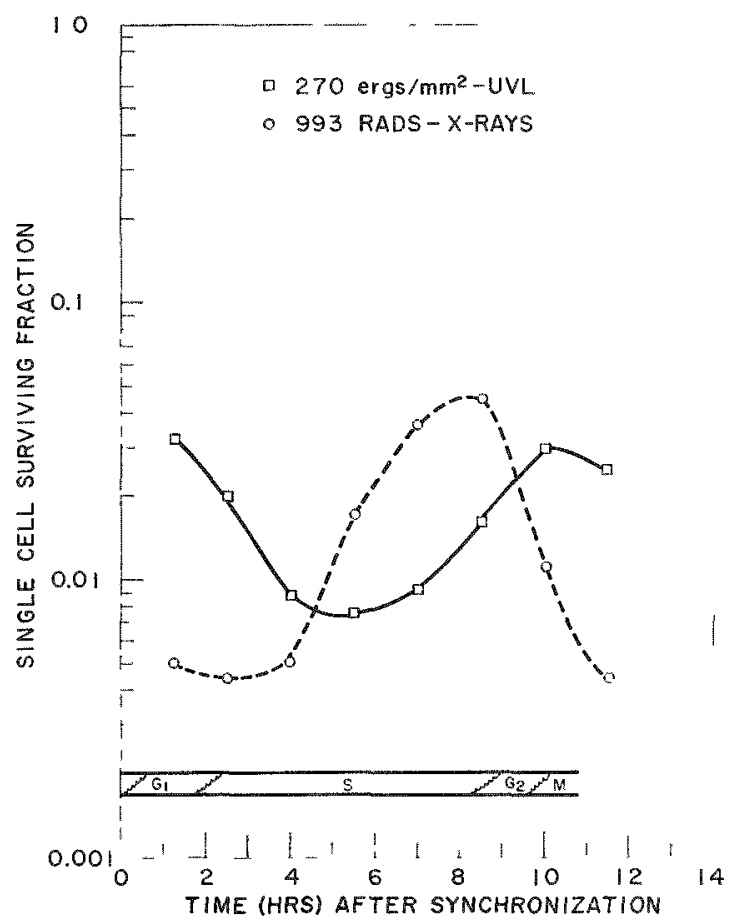

Firr. 197.-The age response of synchronous ('hinese hamster cells measured by colony formation after ultraviolet light and after $250 \mathrm{kVp} \times \mathrm{X}$ radiation. The approximate distribution of stages of the cell crole is show nat the foot of the graph. indicate differences as well as similarities between these two types of radiation, a notable difference being in their capacity to repair sublethal damage, well known for $\mathrm{X}$ rays(1) and not observed after UV irradiation. ${ }^{(2)}$

The question of interaction between these two types of radiation is difficult to explore and interpret if asynchronous cells are used because of the marked difference in the age response for these two radiation. ${ }^{3,}$ * The method reported here, therefore, consists in using synchronous Chinese hamster cells in vitro, selected at milosis, and irradiating them with combinations of UV and $\mathrm{X}$ radiation at known stages of the cell cycle, with only a small interval between them, and then incubating the cells until visible colonics are formed by the survivors. 250 $\mathrm{kVp}_{\mathrm{p}} \mathrm{X}$ radiation, HVL $0.9 \mathrm{~mm} \mathrm{Cu}, \sim 100 \mathrm{R} / \mathrm{min}$, absorbed done 0.945 Rads $/ R$, and a germicidal $\mathrm{TV}$ lamp (G.E.) with mainly $254 \mathrm{~nm}$ radiation at 8.7 $\mathrm{ergs} / \mathrm{mm}^{2} / \mathrm{sec}$ were used.

\section{PROARWS REPORT}

The age response for $\mathrm{X}$ and UV radiation in synchronous Chinese hamster cells is shown in Figure 197.

Doses of $X$ or UV radiation were then selected so that the survival was reduced to $\sim 0.2$ with the first dose ( $\mathrm{X}$ or UV) and by about a further 0.2 with the second dose (UV or $\mathrm{X}$ ). This required careful selection of doses at all points in the cell cycle. The result of an experiment of this type are shown i Figure 198. Full interaction between the two radia tions is taken to mean that if an irradiation with $\mathrm{X}$ ray, is given at some point on the survival curve 
below its shoulder, irradiation with UV with various different doses therefore will vield a survival curve that has no shoulder. No interaction is taken to mean that the full shoulder appears in the TIV survival curve irrespective of the $X$ radiation dose. Experiment of this type are difficult to reproduce precisely, but the result obtained so far show an intermediate lerel of interaction at mont cell ages. Furthermore, in come experiments more interaction appeared to oecur when the UV was given firs, rather than $\mathrm{X}$ ravs. Indeed in the example shown, there may be full interaction between UV and $X$ radiation when the $\mathrm{CV}$ in given firt in $G_{1}$ and $G_{2}$ thut not in $x$, but not when the $\mathrm{X}$ rays are given first.

More refined experiments will be necessary to establish whether the degree of interaction is determined by the stage of the cell cycle, whether the order of delivering the exposures affects the result, and the effects of timing between exposures. The remolution of these question may be very useful in our future understanding of the nature of $\mathrm{CT}^{\mathrm{V}}$ - and $X$-ray-induced lesions.

\section{REILRENCES}

1. Elhind, M. II and H. Sufton. Radiation response of mammalian cells grown in culture. I. Repair of $X$ ray damate in surviving Chinese hamster enllh. Lutut. Lis. 13, 5.36-50? (ligtion.

2. Man, A., B. Miletic and I). Petrovie. The action of ultraviolet light on repair of $x-r a y$ damage in $L$ cells grow $n$ in

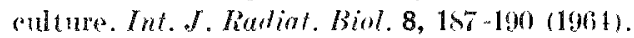

3. Ninclair, W. K. and R. A. Morton. X-ray and altaviolet sernitivity of anchronized Chinese hamster pells at various stages of the eell cyele. Biophys . I. 5, 1-25 (19,5).

4. Han, A. and W. K. Ninclair. Sensitivity of syohronized Chinese hambter cells to ultraviolet light. Biophys. I.9, $11711192(100(4,4)$.

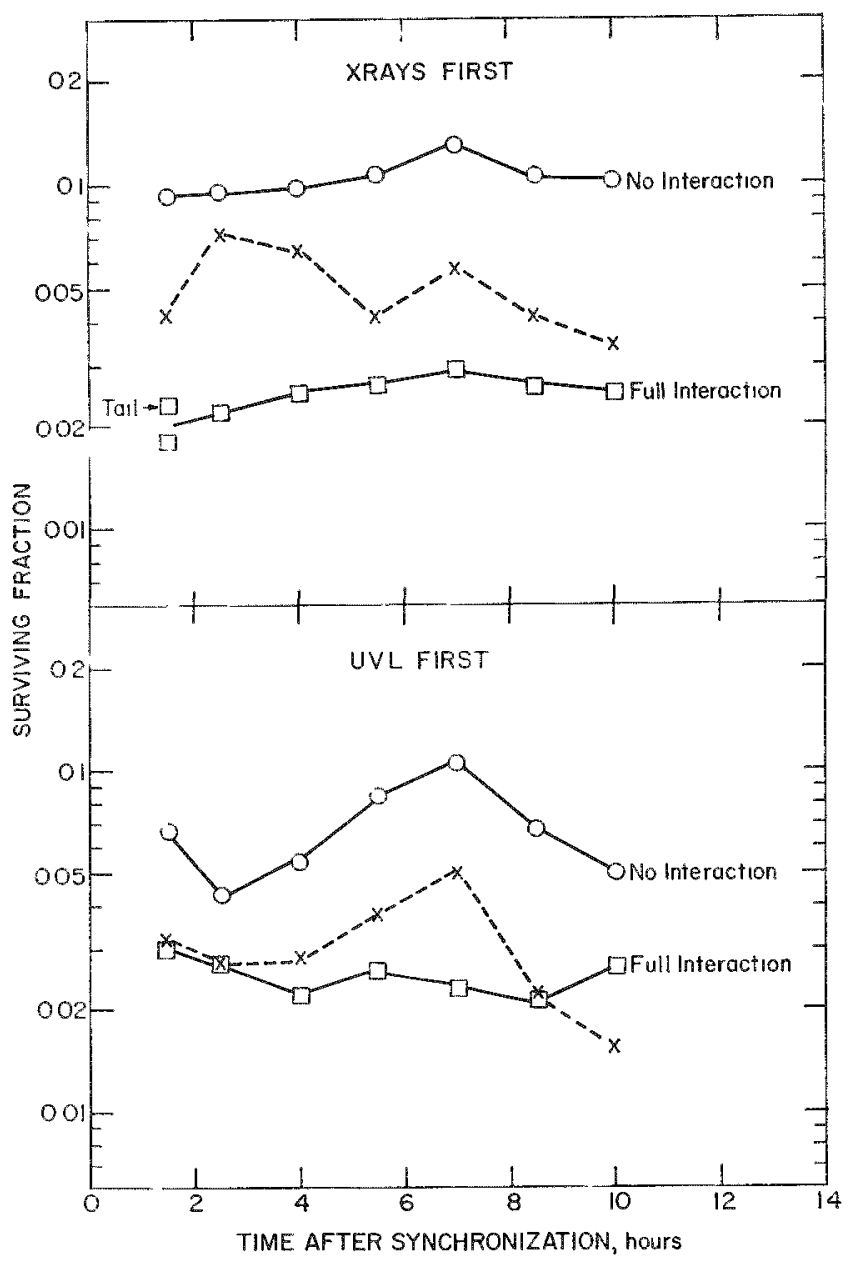

Fitr. 194. - Interaetion of $\mathrm{Cl}$ and $\mathrm{X}$ rats given within 3 min of each other, with demes adjusted to give approsimatel the same survival at each stage of the ecll rele. Top, X rays given first: bottom, IVI, given first. In ateh patnel the full lines repremetet no intertetion or full interaction an indicated.

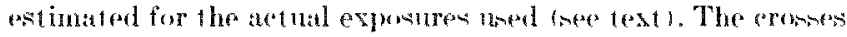
and dashed lines show the esperinental points.

\section{CYTOLOGICAL STUDIES ON CYSTEAMINE PROTECTED CHINESE HAMSTER CELLS IN VITRO}

\section{C.K. Yu and Warren K. Sinclair}

PIRPOSE AND METHODS

A preliminary investigation ${ }^{11}$ indicated that 50 m.ll "roteamine reduced rytological damage due to X rudiation at each stage of the cell cycle. The effect examined here include mitotic delay and the number and types of chromosomal aberration (including chromosome and chromatid aberrations). In order to establinh the dosc-modifying effects of cysteamine quantitatively, and to compare these with survival data, a wide range of exposures is needed.
Chinese hamster cells were synchronized by selection from a log phase population at mitosis and were irradiated at each stage of the following generation cycle: $G_{1}, S_{\mathrm{E}}, S_{\mathrm{L}}, G_{2}$. Cells were prepared at the end of the cycle for cytological examination. Mitotic delay and chromosomal aberrations were investigated.

There were two series of experiments. In one series, cells, were irradiated in the presence of $50 \mathrm{~m} . l$ cysteumine with doses from $125 \mathrm{R}$ to $3000 \mathrm{R}$. In the other series, cells were irradiated without the pro- 
tection of eysteamine at doser between $100 \mathrm{R}$ and $750 \mathrm{R}$.

\section{PROGRESS REPORT}

Mitotic delay was reduced when cells were irradiated in the presence of eysteamine, at all stages of the cycle. The calculated done-modifying factor (I)ME) was about 2.5 for all the stages, with the powible exception of $G_{2}$ which has a value of 1.9 (Table 89). Thi value is probably within the experimental error, because synchrony is poorest near the end of the eycle. By way of example, $3 \mathrm{hr}$ of mitotic delay are unually observed in cells irradiated in $S '$ with a dose of $500 \mathrm{R}$. In the presence of cysteamine, $1250 \mathrm{R}$ are recuired to produce the same amount of mitotie delay. (1)

The frequency of chromosomal aberrations was also reduced by cysteamine at all cell cycle stages. The distribution of the total breaks resulting from different type of chromo-omal aberrations was very -imilar to that obtained in the absence of cysteamine, except that the dose required was higher. An example in given in Figure 199. Chromosomal aberrations were separated into those of the chromosome type and thoe of the chromatid type. Cells were expored to $500 \mathrm{R}$ without ersteamine (upper panel) or 263.5 $\mathrm{R}$ with cysteamine (lower panell. The D)AL for total breaks was about $5.5=2$ for all the stages. However, the degree of resolution achievable between stages in more limiter than that obtained in survival studies, and small variation in DMF with cell erele ntage may not be detected.(2)

Some of the chromosomal aberrations obtained are atributed to 1-hit erent, and the others to 2-hit events. The total break- were therefore analyzer -eparately to determine the difference in DMF between the two types of aberration.

For 1-hit aberration a straight line was obtained for frequency $\mathrm{vs}$. exposure, and the DMF was about $8 \pm 1$ for all stage (Table 89). For 2-hit aber-

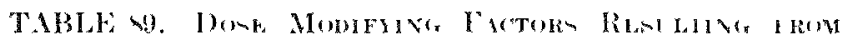

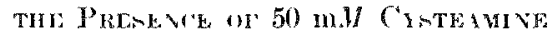

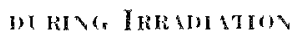

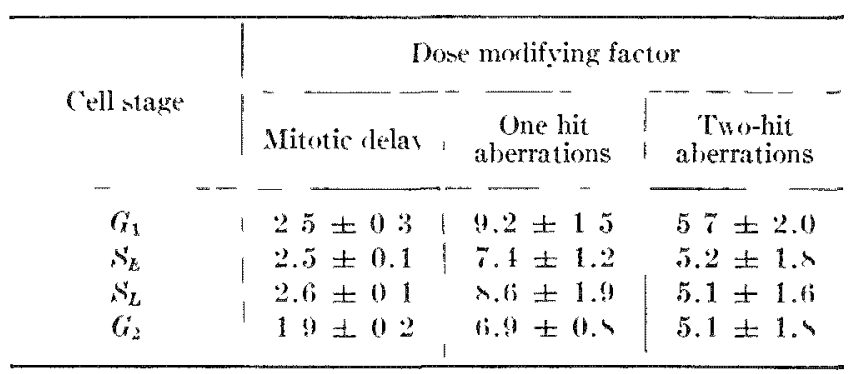

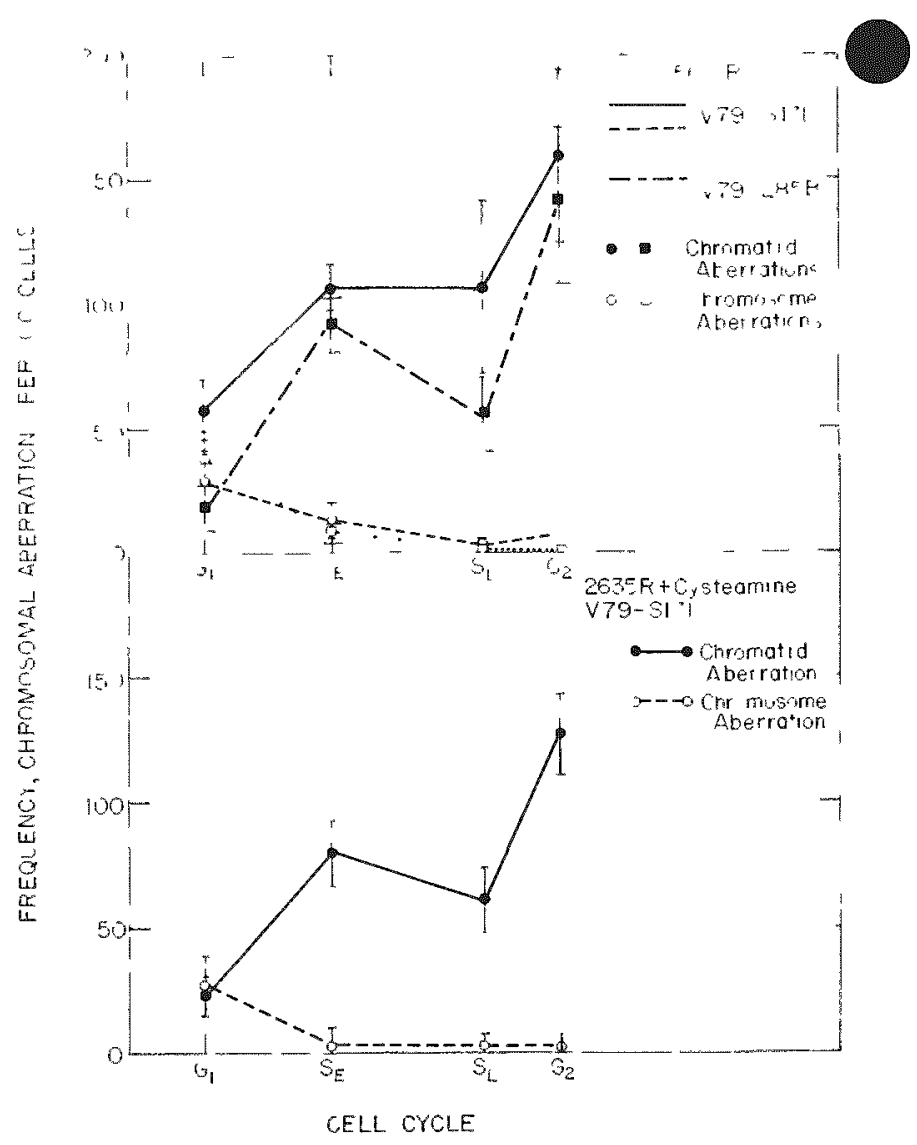

Fro. 199- Frequeney of chromosomal aberrations induced by $\mathrm{X}$ rays at various stages of the cell ercle after a dose of ton $\mathrm{R}$ (upper panel) and after $2635 \mathrm{I}$ in the presence of $6.0 \mathrm{~m} . / \mathrm{l}$ (xsteamine (lower panel).

ration-, frequency $r$. exposure yields a parabolic "urve and the DNIF was about $5 \pm 2$ (Table 89 ).

Therefort, as far as the limited resolution achiered in thi- study is concerned, the protection of cysteamine, with regard to mitotic delay and chromosomal aherrations, could be explained by simple close modifieation and does not require an explanation based on interactions between cysteamine and cellular constituents. This differs from results obtained in survival -tudies; ${ }^{(2)}$ however the difference could be due only to the limited reolution of the cytological -tudies. The principal difference between cysteamine protection for increased survival and reduced chromosomal aberrations is in the magnitude of the DMF- They are clearly different. Furthermore, the DMF for mitotic delay also is different from DAIF's obtained when either chromosomal aberrations or survival are the end points being metwured.

\section{REFERFNCES}

1. Yu, C. K. and W. K. sumelair. The effect of eyteamine on chromosomal aberrations and division delay in ("hinese 
lamster cells. Argonne National Laboratory Biolugical and Medienl Research Division Annual Report, 1968. ANL-7535, pp. 201202.
2. Ninclair, W. K. Protection by ryteamine against lethal X-rat damage during the cell crole of (hinese hamster cells. Ratiat. Res. 39, 135-154 (1969)).

\title{
POLYPLOIDY INDUCED BY X RAYS DURING THE GENERATION CYCLE OF SYNCHRONIZED CHINESE HAMSTER CELLS
}

\author{
C. K. Yu and Warren K. Sinclair
}

\section{PURPONE AND MESHODS}

Induction of polyploid cells by $\mathbf{X}$ rays is a wellknown phenomenon. Our studies have established that in Chinese hamster cells the frequency of polyploidy induced has the same dose dependence irrespective of the magnitude of ploidy. (1) The mechanism for the formation of polyploidy is believed to be endoreduplication. (1) It also has been reported from this laboratory that only chromosome-type aberrations were found in these endoreduplicated polyploird cells, particularly, in polycentric chromosomes. ${ }^{(2,3)}$ They often duplicate themselves and exhibit is "bilaterally identically symmetrical" configuration (BIs' chromosomes). This suggests that these polyploid cells are induced by $\mathrm{X}$ rays at an carly stage of the cell cycle, presumably during $G_{1}$. We have attempted to confirm this by studying the induction of polyploidy at rarious stages of the cell cycle.

V79-\$171 "diploid" Chinese hamster cells were partially srnchronized by mitotic selection and then $\mathrm{X}$ irradiated with $100 \mathrm{R}$ during the $G_{1}, S_{\mathrm{F}}, S_{\mathrm{L}}$, and $G_{\text {. }}$ stager of the following cell evele and observed at various times thereafter. In one set of experiments, cells were labeled with $10 \mu \mathrm{Ci}$ 'ml ${ }^{3} \mathrm{HTdR}$ during the irraliation and then collected at various times after synchronization for cytological examination. The material used for these cxperiments, the techniques for synchronization and irradiation, and the cytological preparations are the same as have been previously described.(4)

\section{PROGRENA REPORT}

The results of the experiment deseribed above are shown in Figure 200. Most polyploid cells observed after irradiation were "tetraploid" $(4 N$, twice the near-diploid stemline number) and "octoploid" $\left(8 N^{T}\right.$, quadruple the near-diploid stemline number). A few cells of higher ploidy also were obtained.

After $1000 \mathrm{R}$ to cells nominally in $G_{1} 137 \%$ of the oll population was labeled) about $14 \%$ of the cells ere polvpoid at $60 \mathrm{hr}$ after synchronization. At other times after synchronization, only $1 \%$ to $9 \%$ of

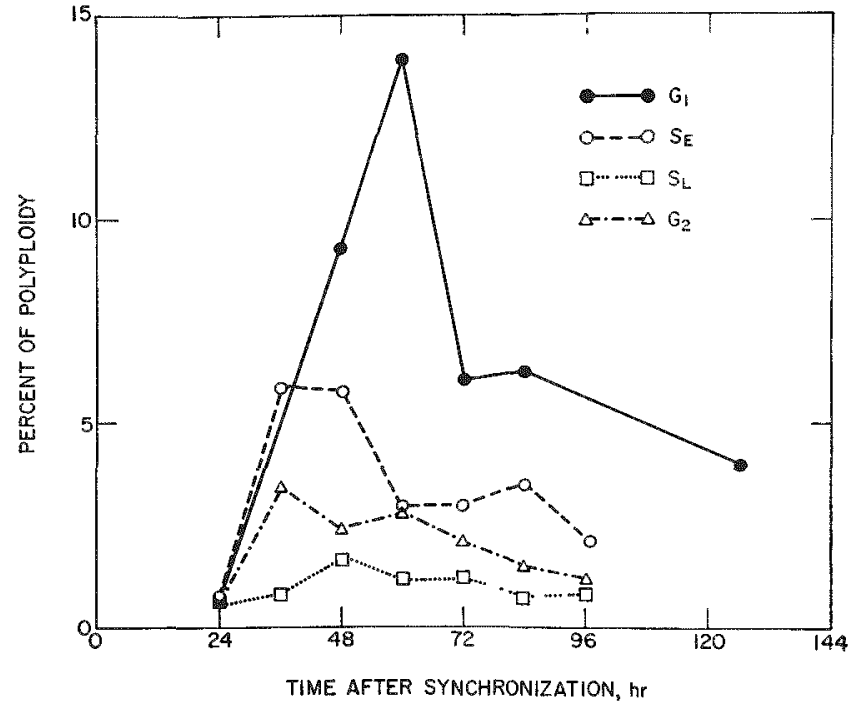

FIt. 200.- Percent of polypluidy induced by lonoll $\mathrm{X}$ ravs in partially synchronized chineste hamster cells during the eell cycle.

the cells were polyploid. A maximum of about $6^{r} \varepsilon$ polyploidy was observed for cells irradiated while nominally in $S_{E}$. This frequency of ploidy, howerer, may have resulted from contamination of $b_{1}$ cells, because only $73 \%$ of the $S_{F}$ cells were labeled at the time of irradiation. For cells irradiated in $S_{\mathrm{L}} 173 \%$ labeled) about $2^{\prime}$; were polyploid while about $4 x_{c}^{\prime}$ were polyploid for cells irradiated in nominal $G$ (41\%: labeled). It should be noted that in these cytological experiments relatively large numbers of cells are required, and consequently synchrony is only partial compared with terhniques used for survival studies. Autoradiographic studies of cells incubated with ${ }^{3} \mathrm{HTdR}$ indicated that polyploid cells were not labeled. Thus, the polyploid cells nominally observed in $S_{\mathrm{H}}, S_{\mathrm{L}_{2}}$, and $G_{2}$ were probably in $G_{1}$ when they were irradiated.

\section{REFERENCES}

1. Yu, C.K. and W. K. Minclair. Polyploidy induced by X rays in Chinese hamster cells in rito. Sichere 145, 508-510 (1964). 
2. Yu, C. K. Chromosmes of X-ray-induced giant cells in Chinese hamster in vitro. Nature 204, 1334-1335 (1964).

3. $\mathrm{Yu}, \mathrm{C}$. K. Polycentric chromosomes induced by $\mathrm{X}$ rays in giant eells of Chinese hamster in vitro. Chromosoma 18, (60) $69\left(196 i^{\circ}\right)$.
4. Yu, C. K. and W. K. Sinclair. Nitotie delay and chrom somal aberrations indueed by $X$ rays in syenelonized (hinese hamster cells in vitro. J. Nat. cancer Inot. 39, 619-0.82 (1967).

\title{
A NUCLEAR MAGNETIC RESONANCE STUDY OF THE STRUCTURE AND INTERRACTIONS OF NUCLEIC ACID DERIVATIVES IN SOLUTION. C. ASSIGNMENT AND CONFORMATIONAL PROPERTIES OF RIBOSE HYDROXYL PROTONS
}

\author{
David B. Davies and steven S. Danyluk
}

\section{PURPOSE AND ME'THODN}

High-resolution proton magnetic ronance (NIIR) studies have yielded a large amount of valuable information about the structure and interaction of base rings in nucleic acid derivatives. For example, extensive chemical shift-pH measurements(1) have established that the base and ribose groups of almost all purine and prrimidine nucleosides and nucleotides favor an anti conformation about the glycosidie ( $C-N)$ bond. N.MR measurements have also shown that bases of purine mono- and dinucleotides ${ }^{(2,3)}$ undergo both inter- and intramolecular base-stacking interactions in aqueous solution. In dinucleotides bases stacking is accompanied by a change in conformation of the ribose groups. ${ }^{(4)}$

From this work a rither good picture has emerged of the part played by buse rings in stabilizing the structure of nucleic acids (DNI, RNA, etc.) in solution. It would be most useful if the data for base rings could be combined with similar results for the ribose phosphate groups. However, such information is lacking at present and, accordingly, as the next step in our XMR study of nucleic acids, a detailed study was undertaken of the conformations and intra- and intermolecular interactions of ribose and deoxyribose groups in a variety of nucleosides and nucleotides. Since the ribose hydroxyl groups undoubtedly cxert an important influence upon the conformation of the ribose-phosphate backbone,

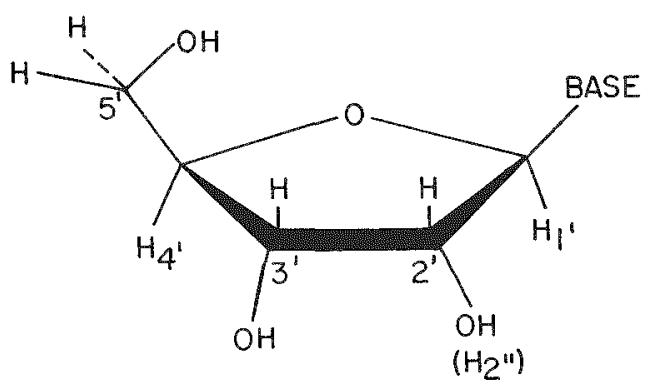

Fiti. 201.- Numbering scheme for the ribose and deoxyribose rings of the nucleosides. the initial part of this study hats been concerned with the assignment of signals for these protons. If report on this aspect of the work in the following.

\section{PROGRESA REPORT}

The ribose groups of nucleosides contain three ribose hydroxyl protons of interest. These are the () $-\mathrm{H}_{2^{\prime}},\left(\mathrm{O}-\mathrm{H}_{3^{\prime}}\right.$, and (2) $\mathrm{H}_{5^{\prime}}$ protons, rigure 201. In deoxyribose nucleosides the $\mathrm{O}-\mathrm{H}_{2}$, group is replaced by a hydrogen.

If proton exchange processes are minimized sufficiently then well-resolved multiplets, arising from spin-coupling interactions with ricinal methine prom tons, should be observed for hydroxyl protons of both ribose and deoxyribose mucleosides. Although separate hydroxyl signals were observed in an earlier study ${ }^{(5)}$ the residual $\mathrm{H}_{2}($ ) concentration in the dimethyl sulphoxide (DMSO) solvent was sufficiently high to prevent detection of fine structure in the signal.

In the present work the wolvent system relected consisted of a mixture of D.JSO $)_{-} \mathrm{d}_{6}$ and $\left({ }_{6} \mathrm{D}_{6}\right.$. Hinary mixtures of these solvents were found to give the best resolution of ribose ring and hydroxyl protons. Lxtreme precaution was taken to eliminate trace amounts of water from the solutions. All of the solvents were dried exhaustively orer molecular sieve', and the nucleosides were pumped on a high-vacuum line for extensive periods to remove adsorbed water molecules. Solutions were made up in a dry box and sealed in NMll tubes to prevent absorption of water vapor.

High-resolution speetra were measured at $30^{\circ} \mathrm{C}^{\prime}$ for $0.1 .1 /$ solutions of the eommon purine and pyrimidine nucleosides. Spect ra were recorded at $60 \mathrm{MIHz}$ with is Varian DA toI internal-lock spectrometer locked on internal tetramethylilane.

A trpical spectrum for the ribose and hydroxyl protons of adenosine is illustrated in Figure 202. In assignment of the hydroxyl proton signals was carrio out in the following manner. Comparison of the spere trum in the dried solvent system with that obtained previously in "wet" 1 ).1SO"s permitted the assign- 


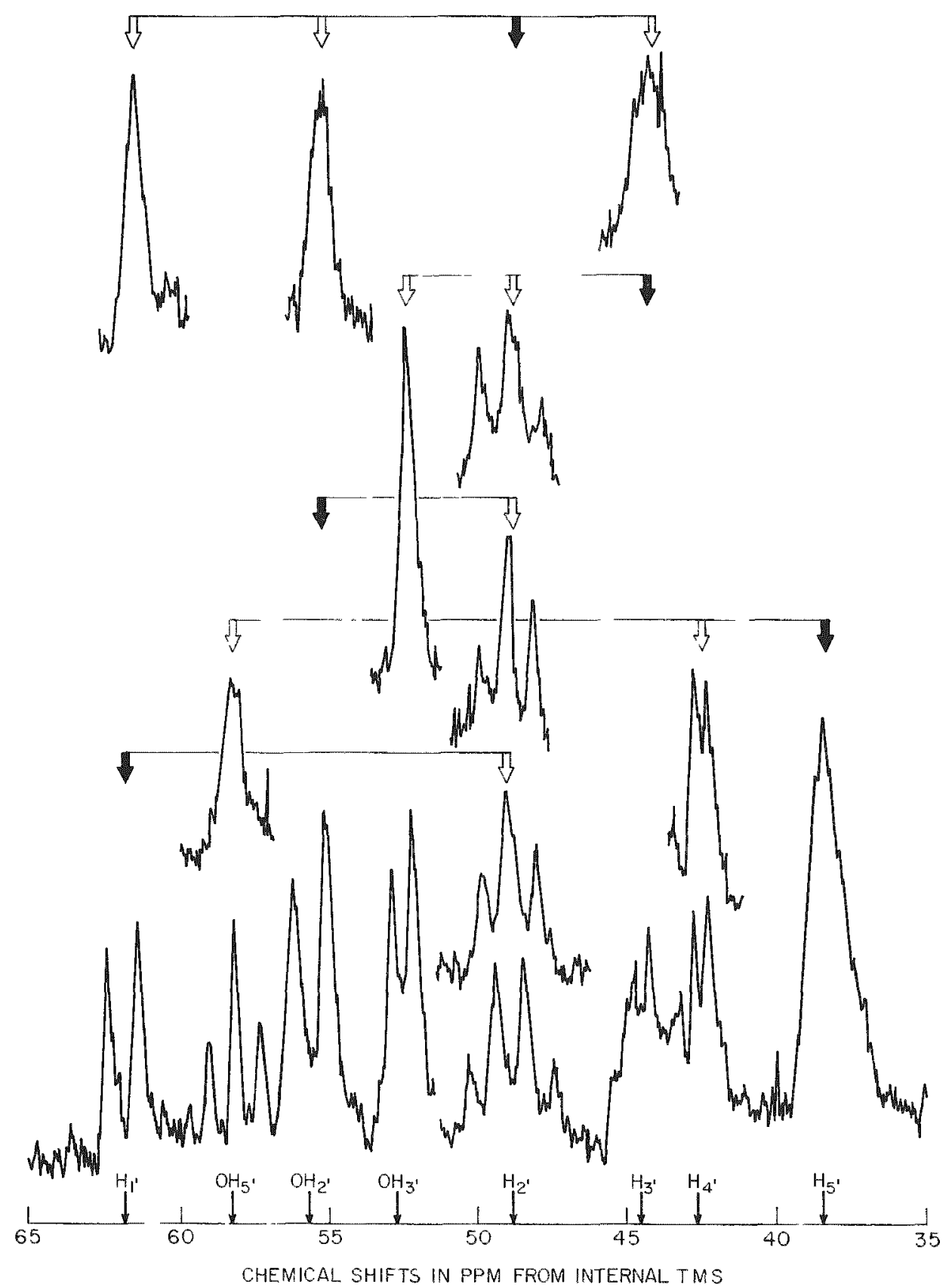

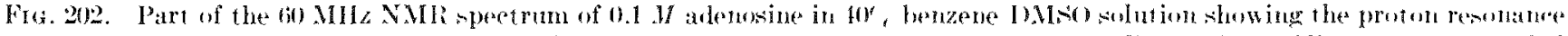

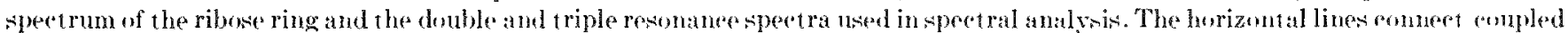
signals with the solid arrow indicating the irradiating frecueney and the apen arrow showing the observing freduene $\mathrm{y}$ in donble and triple resonance experimestis.

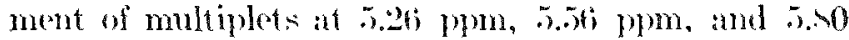
ppm to hydroxyl protons. The remaining signals in the region of the spectrum shown in Figure 202 are due to ribose ring protons.

A further amignment of the signals to individual hydroxyl groups can be made by the use of double and triple resonine techniques. For example, double and triple resonance experiments establish the coupling

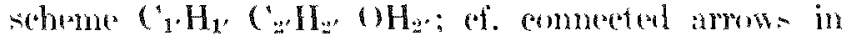
Figure 202. Hence, an ansignment of the doublet at

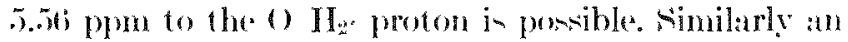
asignment may be made of the signals at 5.50 ppm and 5.26 pum to the $\mathrm{O}-\mathrm{H}_{5}$ and $\mathrm{O}-\mathrm{H}_{3}$, protons. A wignment of the hydroxyl protens for ot her modeonides was made in an analogous manter.

Since the hedroxyl multiplet patterns ware all very 


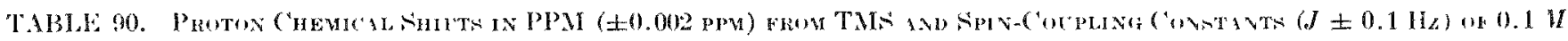

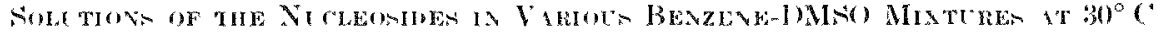

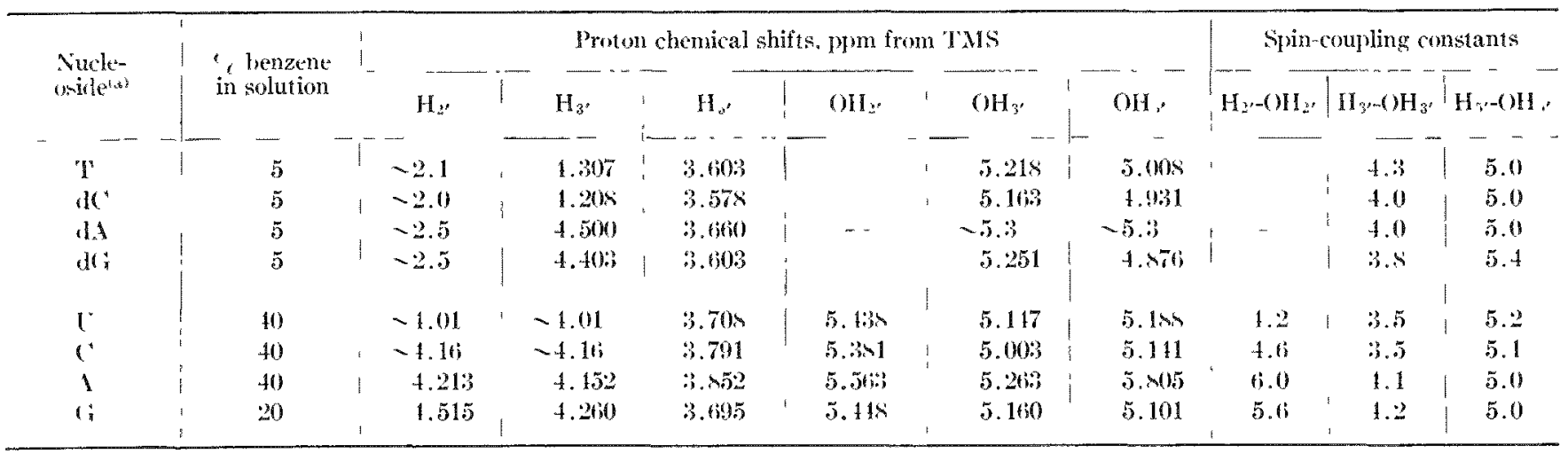

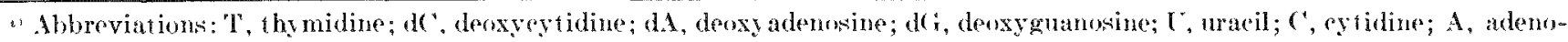
sine: li. guanosine.

clene to dirst order, the chemical shift and compling constant values were obtained directly from the spectra. A complete summary of chemical shifts and coupling constant $\mathrm{is}$ given in Table 90.

Several points may be noted regarding the magnitulen of the coupling constants. A surprising eonstancy is oberved for the $\mathrm{H}_{5^{\prime}}, \mathrm{OH}_{5^{\prime}}$ endupling constants for all the nucleosides. Noreover, the magnitude of this roupling, $.0 .0 \pm 0.1 \mathrm{~Hz}$ is close to the values observed for hydroxyl couplings in simple aliphatic aleohols, $5.3 \pm 0.2 \mathrm{~Hz} .{ }^{(6)}$ The latter value is very close to the theoretical mannitude expected for a hydroxyl group rotating freely about the (") bond.(6) Areordingly, it i- reanomible to conclude that the "it hydroxyl group of nueleosides is rotating freely about the $\mathrm{C}_{\mathrm{b}^{\prime}}, \mathrm{O}_{5}$, bond.

In eontrat with the $5^{\prime}$ hydroxyl eouplings, the $\mathrm{H}_{3}, \mathrm{OH}_{3}$ esupling constants vary for different nurensides, although all of the couplings are signifiently less than the freely rotating value. Based on the empirical relationships between $J_{\text {HCOr }}$ and the dihedral angle $\phi_{\mathrm{HCon}},{ }^{(6)}$ and assuming free rotation between gauche (2) and trams (1) conformers, it can be shown that the $\mathrm{O}-\mathrm{H}_{3}$, bond favors a gauche conformation relative of the $\mathrm{C}_{3},-\mathrm{H}_{3}$, bond.

The greater variation in coupling constants observed for the $\mathrm{H}_{2},-\mathrm{OH} \mathrm{H}_{2}$, couplings of the ribuse mucleosides reffects the eloser proximity of the hydroxyl group to the batie ring compared with the $\left(1 \mathrm{H}_{3}\right.$, group.

\section{(ONCLCSTONS}

dis part of a continuing study of the proton magnetic resonance spectra of nucleic acid derivatives, measurements were made of the ribose speetra for a number of

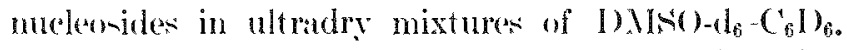
lise of this solvent system has permitted the detection of exchange-free spin-coupled multiplests for ribose hydroxyl protons for the first time, allowing the assignment of hydroxyl signals for all of the common nucleosides.

Batsed on the magnitudes of the observed coupling (oonstants it is concluded that the () $-\mathrm{H}_{5^{\circ}}$ group is freely rotating about the $\left({ }_{5},-()_{3}\right.$, bond while the ()$-\mathrm{H}_{3}$, and (1) $\mathrm{H}_{2}$, groups fatror gauche conformations relative to the $\mathrm{C}_{3}, \mathrm{H}_{3}$, and $\mathrm{C}_{2},-\mathrm{H}_{2}$, bonds respectively. Finally we note that the assignment of the hydroxyl protons opens up the possibility of a romplete analysis of the proton resonance spectra of ribose rings. Work is currently procededing in this direction.

\section{ISEF'EREN('ES}

1. I)anyluk, S. s. and F. H. Hruska. The effect of pH upon the nuclear magnetic resonanes spectra of nucleosides and muclaotides. Biorlemistey 7, 1038-104:3 (16ris).

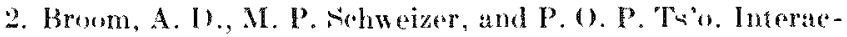
fion and association of bases and nuclessides in aquents

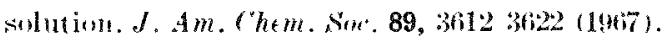

3. Hruska, F. F. and S. S. Janyluk. A nuclear magnetice resouknce study of thermal effects of hase stacking in aligonucleotides: 1pA $>$ p. Bionim. Biophys. Acla 157. $238-241(1948)$.

4. Hrusha, F. L. and $\$$. S. I manyluk. Conformational ehanges of the ribose group in dinueleoside mono- and diphosphates.

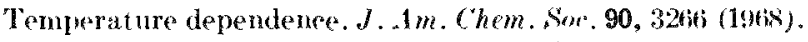

5. (atlin, L. and J. (. I)avis. (comparison of ribose and denxyribuse nucleosides by NML. $/$. Am. (hom. sar. 84, 4464-4470 $(1962)$.

6. Fraser. R. R, M. Kanfman, P. Morand, and R. Movil. sterenchemieal dependene of vicinal H-( -1$)$-H coupling constants. ('an. J. ('hem, 47, 403, 409 (1969). 
THEORETICAL CALCULATIONS OF NUCLEIC ACID CONFORMATIONS. B. CONFORMATIONAL

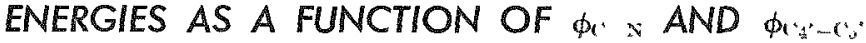

Kunio Hikithi and steren s. Danyluk

PI RPOA: AYD METHOH

In previoun worh"s, theoretical conformational energits were palculated at a function of the torion angle, $\phi_{c_{-}}$, for at variety of nuclessidem and nucleotider. There encergies were calculated on the a-sumption that the man contribution of the cotal energy arion from nonbonded dispersive type interaction. Furthermore, in order to simplify the eomputational work it was arsumed that variables other than $\phi_{i-2}$ (i.e., 4 for nudeovides; so for nucleotides) are lixed. Denpite these assumptions, excellent agreement was observed bes twren ralculated and observed torion angles for fifteren nuclessides and nuclestides.

We hatre now extended the calculations of include the effects of simultaneomst rhanging the balues of

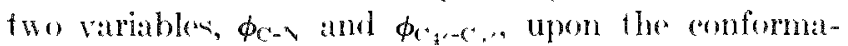
tional energien of mucleosides. The second rariable,

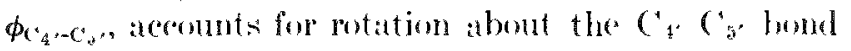
of the ribose group. Rotation about thi- bond mas be expected to influenese the eonformation of the nucleoside primarily by nonbonded interaction between the oxygen atom of the $\tilde{y}^{\prime}$-()I group and the base atome.

\section{PROMRESA RFPORT}

As in the earlier work" the nonbonded interaction energies were ealculated uning a lennard Jomes 6 12 potential function,

$$
l_{13}=d_{13} r_{13}{ }^{12}-l_{13} r_{13}{ }^{6},
$$

Where $V_{2, j}$ in the interation energy between nonbonded atom- $i$ and $j$-eparated by a distanee $r_{1 j} ; d_{13}$ and $c_{2 j}$ are constants. In a typical calculation, the atomice onordinaten obtained from eryatallographic datat were first enverted for all atoms in the molecule into a es lindrical coordinate $-y$ stem with the $Z$ axi- directed along the $X$ (' bond. The total eonformat ional energies were then calculated by summing up the interaction energies for all pairs of nonbonded atoms at different $\phi_{c^{\prime}->}$ and $\phi_{C_{1},-c_{0},}$, values. In the unal procedure,

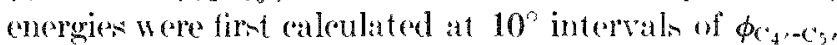
while kexping $\phi_{C_{-}-\mathrm{N}}$ fixed. Then energies were calculated it $10^{\circ}$ intervals of $\phi_{C-x}$ with $\phi_{C_{2} \cdot-C_{0}}$, fixed. Conformattional energy maps wore obtained by plotting the energy an a function of the two rotational variables.

An example of a conformational energy map obatined for the promidine nucleoside, crtidine, is given in Figure 203 ; Figure 204 illustrates the energy map

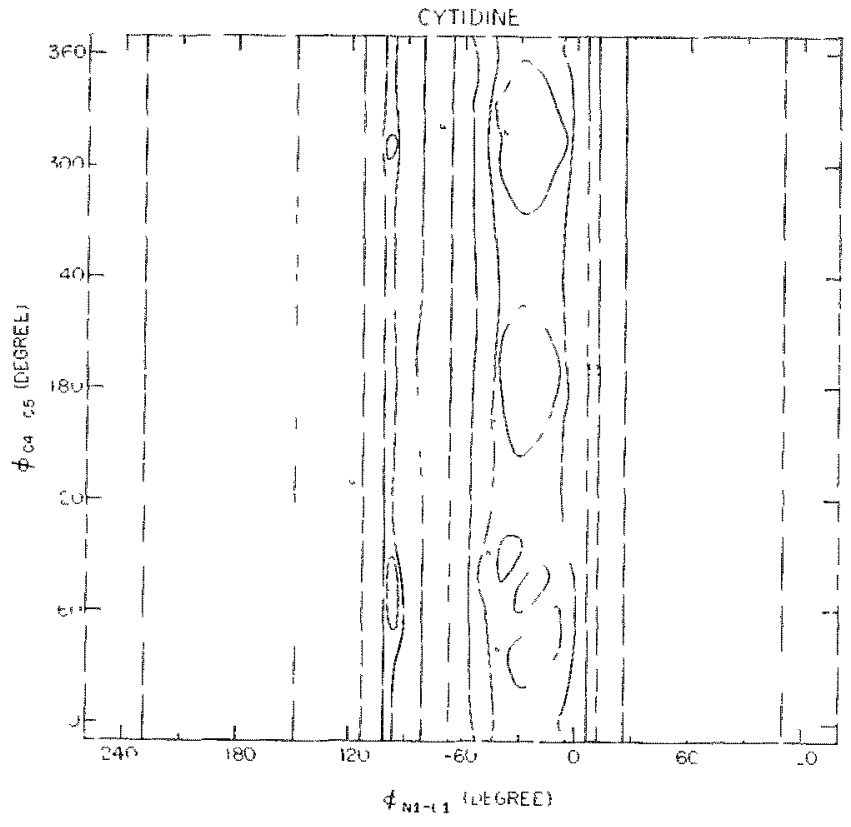

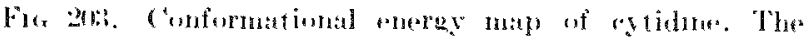

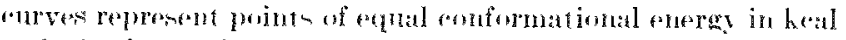

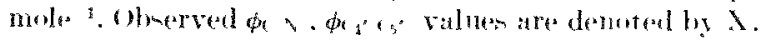

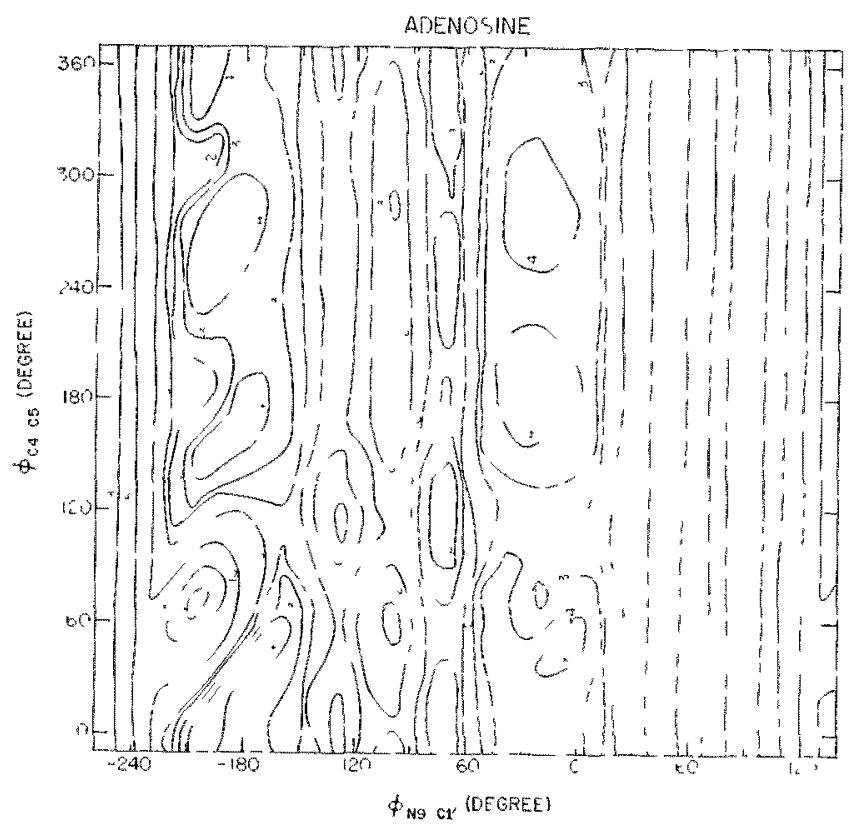

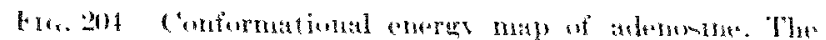

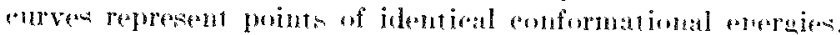

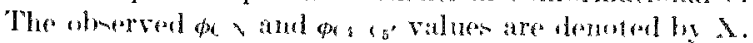


for a purine nucleoside, adenosine. In both figures the alculated conformational energies are plotted as a

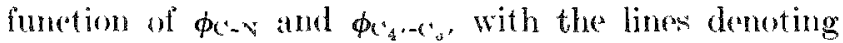
comnected isoenergetic points. The curves in Figures 203 and 204 may, therefore, be eonsidered as projections of potential energy surfaces on at two-dimensional graph.

From Figure 20:3 it is apparent that there aro a number of well-defined local energy minima in the theoretionl energy map of evtidine. Howerex, the four kowest energy minima (-3 keal mole ${ }^{-1}$ ) all lie within the $\phi_{c}-\mathrm{x}$ range of -10 to -40 . Thi is precisely the range corresponding to an anti conformation of the base and ribose grouls. The theoretical conformation about the $\phi_{C \rightarrow N}$ bond, caleulated for the case of two variables, is thus very similar to that obtained where only one variable was considered. ${ }^{19}$ Rotation of the () $\mathrm{H}_{5}$, group about the $\mathrm{C}_{1},-\mathrm{C}_{5}$, bond apparently has little influence upon the torsion angle of ertidine.

Although the lowest energy minima are all located within at narrow range of $\phi_{(-N}$ values, this is not the

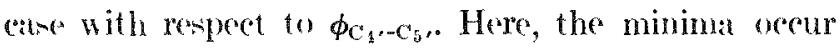
in three regions, centered at approximately $60^{\circ}, 180^{\circ}$, and $300^{-*}$. There are, therefore, theoretieally at least three pesible orientations of the $0-\mathrm{H}_{5}$, group about the $\left({ }_{1},{ }^{\circ}\right.$ bond. An analysis of molecular model structures and a consideration of the theoretion angles suggests that the three orientations correspend to gauthe, trans, and gauche forms, respectively.

The theoretical alculations thus indieate three possible inomers of equal energy for evtidine. In each isomer the bise and ribose groups are anti to each other; the (1-- $\mathrm{H}_{5}$, group), however, can exist in cither of two gauthe or one anti conformations. It is gratifying to

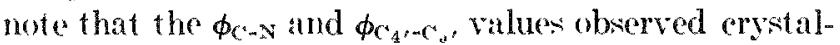
lographically's? fall in one of the lowest energy minima, i.e., at $\phi_{\mathrm{C}-\mathrm{N}}=-15^{\circ}$ and $\phi_{\mathrm{C}_{4}-\mathrm{C}_{5}}=55^{\circ}$. The crystallographic results are thus in excellent agreement with the theoretical st ructure.

The conformational energy map for adenosine (Figure 204) is much more complicated them that for crtidine, and shows at leatst six potential energy min-

\footnotetext{
* The values of $\phi_{4} a^{\prime}$ - $\left({ }^{\prime}\right.$ ' refer to the vicinal angle between the $\left(C_{3}, 0\right)$ and ()$\left.^{2}, 0\right)$ bends.
}

ima. Three of the minima correspond to structures in which the bate and ribose groups are in anti conformations, with the $\mathrm{O}-\mathrm{H}_{5}$. group in one of the gauche (2) or trans (1) conformation. The other three structures correspond to at $* y m$ conformation, with the $0 \mathrm{H}_{5}$ group again in one of the garehe or trans orientations.

The energy barriers between the syn and anti forms are ruite small, suggesting the likelihos that the nucleseside can exist as an equilibrium mixture of these forms in solution. A similar result was obtained in previous atculations. $(1,2)$ It is interesting to note that

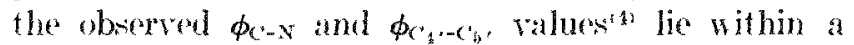
region of lowest energy, again indicating a satisfuctory correspondence between observed and anleulated structures.

\section{(O) TCLISIONG}

Theoretical calculations of nucleoside structures have been extended to include the effects of changing both $\phi_{\mathrm{C}^{-\mathrm{S}}}$ and $\phi_{\mathrm{C}_{4} \cdots \mathrm{C}_{2}}$ upon the conformational energies. The results for two nucleovides, cytidine and adenosine, have been plotted in the form of conformational energy maps. From these maps it is coneluded that the ertidine favors an anti conformation with the (1) $\mathrm{H}_{5}$, group oriented in one of the gauche (2) or trans: (1) forms. The atdenosine, on the other hand, can exist in either the syn or anti form with the $0 \mathbf{H}_{a^{\prime}}$ group again adopting a gouche or trans orientation. In both cases it is concluded that rotation of the ()- $\mathrm{H}_{5}$, group about the $\mathrm{C}_{4}-\mathrm{C}_{5}$, bond roes not ignifieantly alter the orientation of the base and ribose groups about the $C-N$ bond.

\section{REFERENCEN}

1. Hikichi, K. and S. S. Dangluk. Theoretical ealculations of uncleic acid conformat ions. A. Torsion angles of nucleotides and mucleosides. Argome National Laboratory Biologieal and Mrdical Research I bivision Annual leport, 1968. AN L7535. pp. $2028-231$

2. Hikichi, $k$. Theoretical steulations of torsion angles for nuclensides and nucleotides. Paper presented at Biophys. Soc. Atg., Los Angeles, Fohruary 1969.

$3 . S$ Furberg, $C$. S. Peterson, and (hr. liomming. An $\triangle-r a y$ strueture determination of cytidine. Acta ('ryst.18, :31:-320 (1965).

4. A. L. V. Iasehemeyer and H. M. Solhell. X-ray structure of ademsine. Acta Cryst. 18, 525-535 (1965). 
ELECTRON SPIN RESONANCE STUDIES OF $\gamma$-RAY IRRADIATED DINUCLEOTIDES AT $77^{\circ} \mathrm{K}$

\author{
William A. Bermhand and steren S.. Lanyluk
}

\section{PI RPONE AND NETHODS}

The physieal and chemical changem indured in the primary structure of nucelic acids by jonizing radiation ale still not well undertood. Previous approathen to the problem have concentrater either on changein the physical propertien of nucleie acid polymer: or on the radiation chemi-try of individual monomeric nucleic acid constituents. Although both approathe have yidded much valuable information the former sufferm from complexities inherent in de:aling with large bionolymers while the latter, thoueh yielding definitive remult for monomers, may prenent difficultien in extripolation to the polymer.

It would he most unceful to have data bridging the sal betwen these two extreme; aceordingly. the principal objectiven of this study are, 11 to identify frese radical and other species formed upon irrudiation of short-ehain oligonueleotilen (dimers, trimers, etc.1 and 2 , to correlate thene results with monomer and polymer data. The method selected for studying the free radicals is electron spin resonture (ESRi, a valuable technique in -ueh -tudies.

\section{PROARTS REPORT}

Elect ron spin resonance meanurements have been mate of the effects of $\gamma$-irradiation upon baves, $(a-a)$ nucleo-ide, ${ }^{(5)}$ :1) and nucleotides ${ }^{(10)}$ in the solid state. Irradiation of erytalline ramples at various temperatures ha- permitted the obervation of free ralicals at different stages in the seruenee of erems learling from the initial aborption of energy by electron to chemically stable radiation product.. (Generally the free radicals ob-erved at low temperatures are replateed with warming by new fres rudical product ass-umed to form at later stages in the sequence of renth. Furthermore. a correlation is often noted between free radicals produced in the -olid state and the radiolysis products in aqueous solution. ${ }^{(11)}$

Becaune the most detailed information is derived from single erystal measurements it was initially hoperl to study the effect of $\gamma$-radiation upon single crystals of dinucleotiden. However, attempts to grow single erystals large enough for ESR work were unsuccerful, and attention was, therefore, directed 10ward polycrystalline samples.

commercial samples of the dinueleotides Apd,"

* Nomenelature: Apd = adenul $3^{\prime} 5^{\prime}$-adentesine, atc. (e.ptidine, guanosine, uridine).
ApC, ApG, CpA, and $C, L$, were obtained from sigma (hemieal co. and were uned without further purificattion. Earh somple, weighing 10 to $20 \mathrm{mg}$, was dried by evacuation until dry in a cuartz tube and then sealed under varuum. The sample were then $\gamma$-irradiaterl at $7 \sigma^{\circ} \mathrm{K}$ at a dow rate of $20 \mathrm{MR}$ hr for at total dow of 13 MR. Paramengetic centers produced in the quartz tubes were amneales out of the vacant part of the tube while maintaining the ample part at $77^{\circ} \mathrm{K}$. The simple wat then transferred to the annealed part of the tube at $76 \mathrm{~K}$, and the tube was placed in a Tarian dewar fla-k containing liquid nitrogen. The dewar flakk and sample were inerted in a Varian multipurpone "avity, and ESli menctrat were recorded at X-band frecguencien with a modified Varian 4.500 ESIR yectrometer.

An example of a typical nipectrum of a $\gamma$-irradiated dinurleotide, that for $A C^{\circ}$ at $77^{\circ} \mathrm{K}$, in given in Figure 20.56h. The spectrum consint of an inteme. relationly broat ignal centered near the $y^{-}$ value for diphenyl pieryl hydrazyl (DPPHI. and a much weaker doublet, $\mathrm{JH}=126+5$ gauns, located in the wing- (arrowh. and centered at DPPH. Also hown for comparative purposes is the ENR npectrum for a $\gamma$-irrarliated polycryatalline sample of 3 -eytidylic acid, Fïnure $20.5(a)$.

The lack of fine structure in the central intense

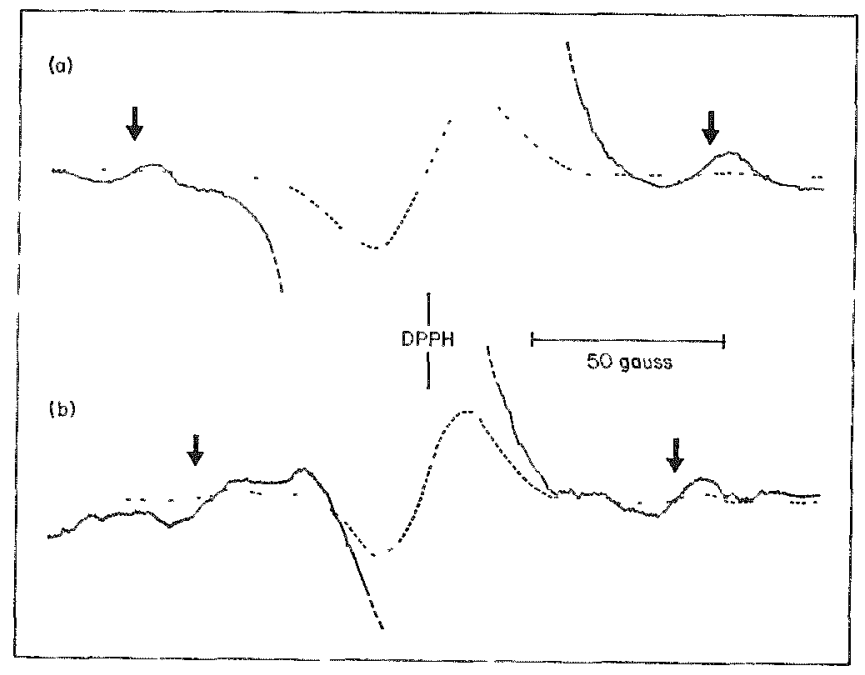

Kia. 205.- The first derivative Linll speretrum of (a) 3' eytidylic acid and (b) ApC. Samples were irradiated with ganma raye and observed at $77^{\circ} \mathrm{K}$. The magnetic field increases from left to right. the microwave attenulation is $3 \mathrm{db}$, and the solid lines represent $1 \times$ the gain of the dashed lines. 
signal for $A p{ }^{\prime}$ and $3^{\prime}-c^{\prime} y t$ tidylie asid prevents a definitive asignment of the signil to a specific tryen of free radical. The doublets, on the other hand, can be attributed to a free radical which ha unpaired spin density on the ${ }^{31} \mathrm{P}$ atom. The xistence of such a phosphorue centered free radical was proposed in a prerious stuly on single erystal of 3 -eytidylie acid where Bernhard'11 observed a doublet with a nearly inotropic hyperfine splitting of 1.50 gaus and a $g$-value sarving between 2.004 and 2.0.54. The unumually large phosphorus hyperfine splitting permit - the ob-ervation

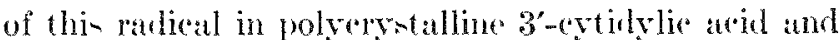
Ap '. Additional confirmation of the doublet asigntment in given by the obnerration that the signath are very difficult to power saturate. amd dexay irrexersibly upon warming to room temperature. Both of thenes propertie were aloo oburervenl for the doublet rignal in the 3 -crtidylic ardid single erystal study.'111

spectra for the ot bee dinurleotides wore similar to those of AnC. However, it was somewhat more difficult to di-tinguish the outermost doublets in $\mathrm{CpU}$ and Apd becaune of extemive overlap by the eentral browl peak.

\section{CONCLCMION}

A preliminary study has been made of the effect- of $\gamma$-irradiation upon a serits of purine and pyrimiline dinucleotides. From the FiR spectra obtatined at $77^{\circ} \mathrm{K}$ if is coneluded that $\gamma$-irrudiation produce at leant two typen of free radical. One of theme tree radiralis ean be identified as having the unpaired electron partially localized on a phomphorous atom. This free radical in enpecially interenting becaune the phosphorus atom is expected to be a primary ionization site because of it high electron density. Formation of a free radical at the phosphate group of the ribosephophate backhone of nucleic acids maty thun be one of the early events in the vrerall process of radiation damage.

In order to test -ome of the above ideas further it is exential to identify the strueture of the phosphoruscentered free radical. This can bect be accomplished by ERT studies of the appropriate single erystals of nucleotide's and dinurleotile and work in this direcm tion i- currently in progres.

\section{REH LREACLN}

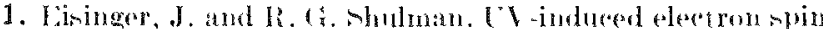

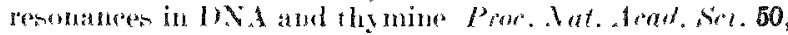

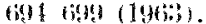

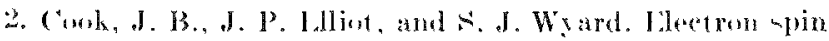

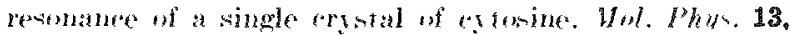
to

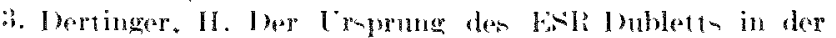

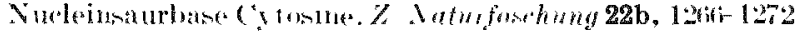
(1906).

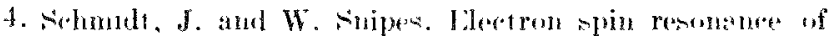

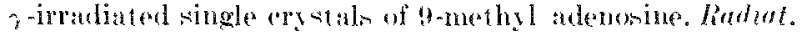
Res. 38, 271 279 (1947)).

5. Hutterman, J. and A. Muller. Frete radioale in irradiated

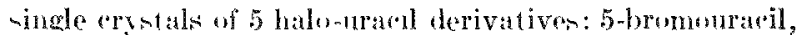

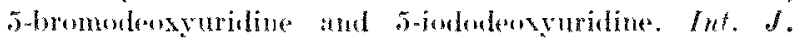
Radat. Bat. 15, 290 306 (196?).

b. B. Prudes, W. Snives, and W. Gordy. Herotron spin remo-

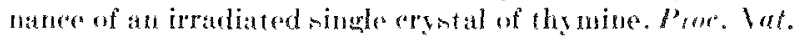

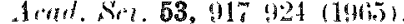

7. Dertinger, H. Mar Croprung den lati-lubletto in der Nueleinsänrebane Catomin: live linhristallesnule ber

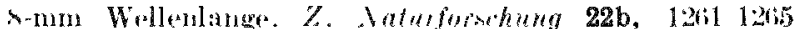
$\left(196 i^{2}\right)$.

s. coordy, W. Fresa radicale fom biological purints and py-

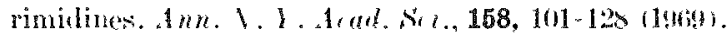

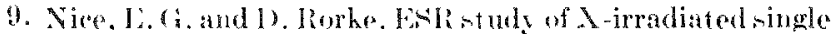

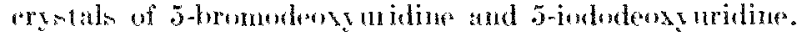
Iret. J. Liadiut. Biol. 15, 207-215 (1969).

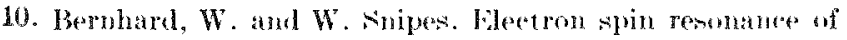

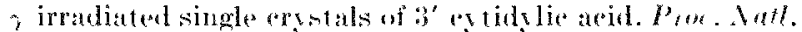

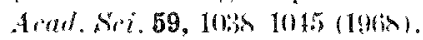

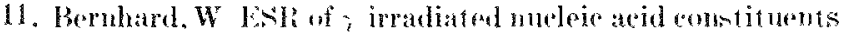
and related compoumds, Ph.ll. thesis, Pennsylvania state laversity (196is).

\section{MOLECULAR INTERACTIONS OF BIOLOGICALLY ACTIVE MOLECULES}

\section{William A. Bernhard, Stemen S. Dangluh, Datid B. Davies, and Kunio Hikichi}

As outlinen in previou reportst. 2 this -tudy is principally concerned with the determination of precise structures and conformations of biologically important moleculem in solution. The ultimate goal is to provide a sound structural basis for the interpretation of inter-and intramolecular interaction of biomolecules.

In order to arhieve thene objectiven extem-ive -peca troseopic mea-urement have been mades on a variety of biomolecules including nucleic acids, proteins. peptides, and dyes. Attention ha- been focused not only upon matronolecule biat alo upon smaller monomers and oligomer which ean sarve as model systems for the matromolecules. Variou phases of this work have been reported in the literature and in earlier annual reports. 
In parallel with the pectro-copie studies we have also been carrying out theoretical calculations of structures and conformations for selected biomolecules. Thus far theoretioal -tructures have been calculated for fourtecn mononueleosides and nucleotides. and several dinucleotides. The results of these calculations complement the speetroscopie clata in a very gratifying manner.

In the past year we have continued our experimental and theoretical studies of nucleic acid structures. In addition new studier have initiated in the arean of antibiotic strueture and interaction, and mechani-m. of raliution damage in nucleic atids. Brief summaries of weral aypets of thi work are given in following section.

\section{REI EREACES}

1. Mlears, D. J., S. S. Wangluk, K. Hihichi, and F. W. Mruska. Molectular interactions of hiologically aretive molecules. Argonne National Laboratory Biologieal and Medical Division Annual Report, 1968. ANL-7535, p. 220.

2. Blears, D, J, S. S. Manyluk, K. Hikishi, and F. F. Iruska. Melecular interartions of biologically active molecules. Argonne National Iaboratory Biological and Medieal I hivision

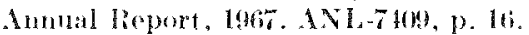

\title{
HIGH-RESOLUTION MAGNETIC RESONANCE STUDIES OF ANTIBIOTIC STRUCTURES AND INTERACTIONS, PART I. ACTINOMYCIN D: TEMPERATURE AND SOLVENT EFFECTS UPON THE N-H AND NH: GROUPS
}

\author{
Thomas A. Victor, *harles L. Bell, †rank E. Hruska, and Stern S. Danyluk
}

\section{P(RPOAE ANI) METHODN}

Antibiotios comprise an ext remely interesting class of molecules well -uited for the study of the relationship between biological structure and funetion. A great deal of information is now available, not only about the physiological effects but also about the chemical structures of different families of antibiotios. ${ }^{11}$. In opportunity is thus afforded for the study of mechanisms of antibiotic action in a wide vareety of systems.

of even grester interest is the possibility of using selected antibioties as model compounds for studying more complex biological interactions. For example, peptide antibioties which inhibit messenger RNA synthesis can serve as excellent models for studying the mechanisms of protein repressor action.

There is, however, one drawback to the realization of the full potential of antibioties as model systems. This is the lack of detailed knowledge about the conformational properties of these molecules. Although X-ray diffraction measurements have been of some use in this direction the structure and conformation in the crystal are not necessarily those most likely to be found in solution. We have, therefore, initiated a broad and comprehensive study of the structures, conformations, and molecular interactions of antibiotic molecules in aqueous and nonaqueous solutions. Among the variety of techniques to be used in this study are high-resolu-

* Visiting Respareh Associate, bepartment of Pathology niversity of Illinois Medieal center, Chicago, Illinois bofi12

$\uparrow$ Visiting Summer scient ist. Permanent address: Cniversity of Illinois Medical Center, ('hicago, Illinois 60612. tion nuclear magnetic resonance, elert ron spin rewonance, optical spectroseopy, and analytical ultracent rifugation.

In this initial study our attention has been directed toward the class of antibioties which acts primarily as RXA polvmerate inhibitors. of these the most important member is actinomycin D, one of more than thirty actinomycins isolated thus far from tetinonuyetes mieroorganisms. Aetinomyein 1$)$ has been the focus of considerable research work in the past 2.5) years, not only berease of its lumor-inhibiting ability, but also more recently becaluse of the similarity of its artion to that of protein represors. In this communication we report on some of the results obtained from preliminary high-resolution XMIR studies of actinomyin $I$.

\section{PROGLESS REYTY}

In many respect- antibioties are ideal biological molecules for study by high-resolution N.MR techniques. The average antibiotic molecule is small encugh ( I.W. $1000: 2000)$ to minimize line-broadening afferts which plague the spect ra of proteins and nucleic acids, yet is large enough that one might expect to find some of the regular structural features (secondary and tertiary structures) present in larger biomolecules. If this is the case then complete analysis of the highresolution proton speetra of moderately large biological molecules may become a reality. This has proved to be the ense for actinomycin I) (A('I)) (Figure' 206). In the following we summarize the assignment of the $\therefore \mathrm{H}, \mathrm{NH}_{2}$ and phenoxazinome ring proton signals of 


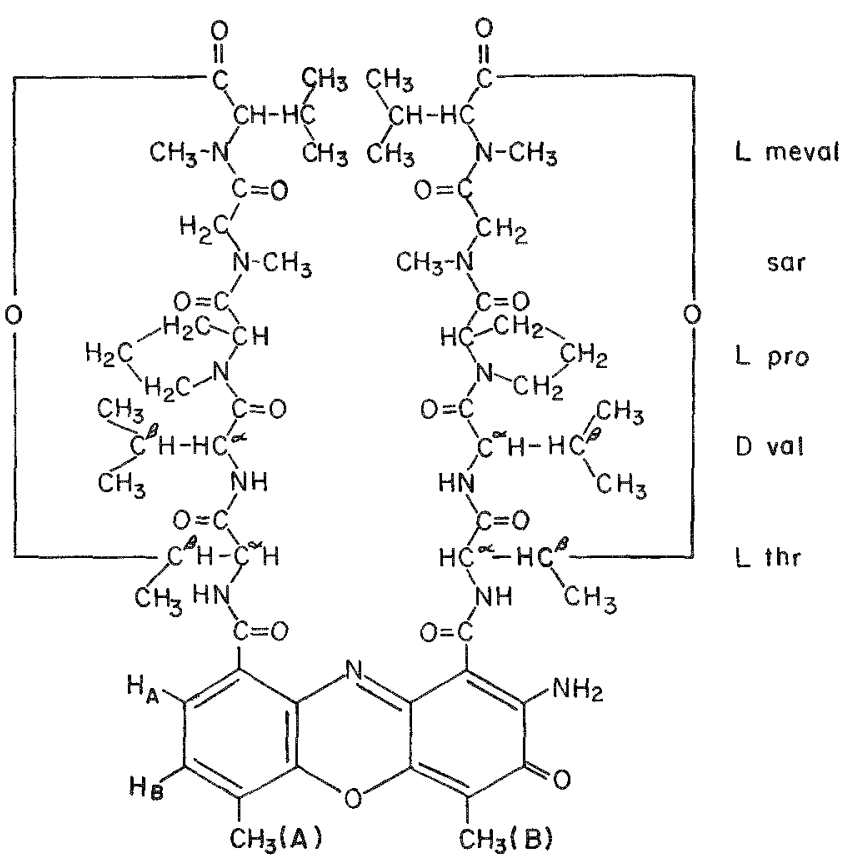

Fic. 206.- - Strueture of actinomyein $D$ in the pentapeptide form. Abbreviations: meval, methyl valine; sar, sareosine; pro, proline; val, valine; thr, thremine.

I('D) and the effects of solvent and temperature upon the signats.

An illustration of the low-field region of the proton single resonanee spectrum for $\mathrm{ACI}$ ) in $(1)(1)_{3}$ at $33^{\circ} \mathrm{C}$ is given in lëgure 207.1 . This region [415 to 49.5 egeles! sece relative to internal TIIS (tetramethylsilane)] is expected to include, $\mathrm{X}-\mathrm{H}, \mathrm{NH}_{2}$, and aromatic ring proton signals. An assignment of these signals an be made on the basis of deuterium exchange, temperature, and decoupling experiments.

Integration of the A(I) signal areas in 1$)_{2}($ )-free solutions indicates the presence of eight protons in the multiplet pattern illustrated in Figures $207 \mathrm{~d}$ and $208 \mathrm{~A}$. Addition of small amounts of $1 \mathrm{~g}(\mathrm{O}$ leads to the disappearance of two sets of doublets labelled $a, b$ and $e, d$, Figure 208 , along with a decrease in signal area of the peatk at 454 cyclesisec. The rate of exphange of the doublets differs markedly, however, with the set at higher field ( $c$ and $d$ ), exchanging much more rapidly than the set at lower field. The exchange rate of both wets is much longer than the rates generally observed for $\mathrm{N}-\mathrm{H}$ protons in other organic molecules, i.e., amides. After complete exchange the residual signal

Fici. 207. - Proton resonance spectrum of $\mathcal{N} H, H_{2}$, and ring protons of $A(D)$ in $(" I)\left(1,3\right.$ at $32^{\circ}\left({ }^{\circ}\right.$. A single resonamers spectrum; B, double ressonance spectrum with the second rf field applied at a point 276 and 267 cycles see uptield from a and $b ; C$, double resonance spectrum with the second rf field applied at a point 189 and 1503 eycles see upfield frome and $\mathrm{d}$. Shifts are in cyeles sec to low field from internal TXIs. area, rigure $20 \times 1)$ is comsistent with the presences o two protons and the $\mathrm{AB}$ type pattern, $J_{\mathrm{AB}}=8.0$ gyeles seo and $\delta_{A B}=5.8$ cyeles sec is clearly due to the phemoxizinome ring protoms. The signals sureotible

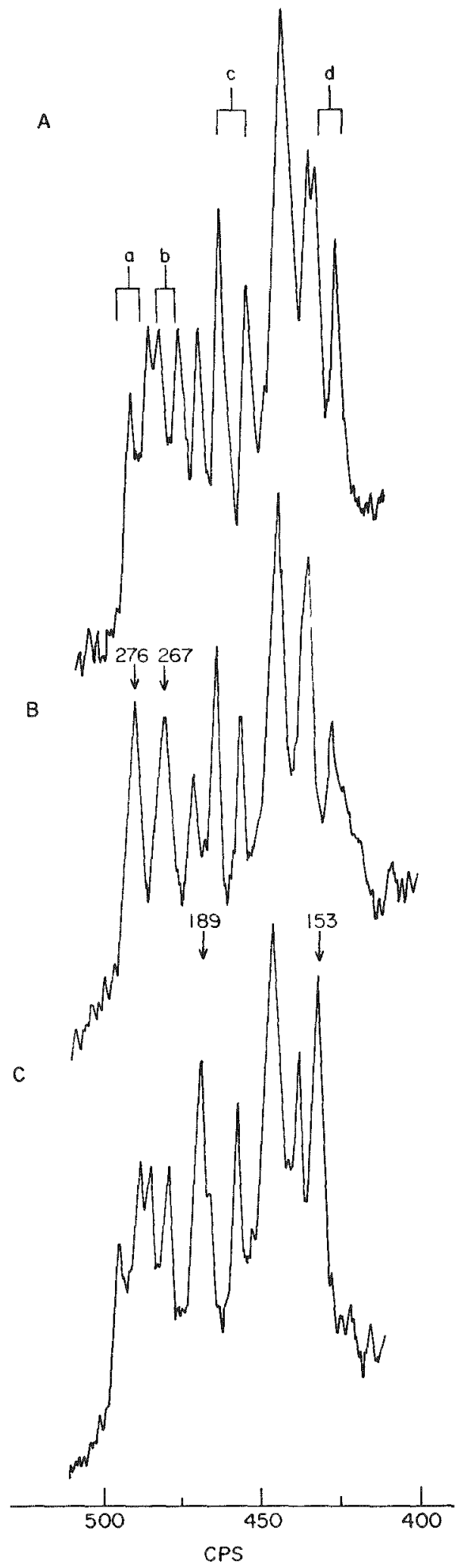


- rrea, Figure $280 \mathrm{D}$, is consistent with the presence of two protons and the $A B$ type pattern, $J_{4 B}=8.0 \mathrm{cy}$ cles sec and $o_{\mathrm{AB}}=5.5$ ercles, sec, is clearly due to the phenoxazimone ring protons. The signals susceptible to deuterium exchange are at ributed to the four X-H and two amino protons.

A more detailed assignment of the $\mathrm{V} H$ signals can be made from a consideration of spin-compling interastions. Both the threonyl (thr) and valyl (val) $>H$ proton: can couple with single vicinal methine protons. $I^{\alpha}$, on the ("x rarbon (Figure 206), giving rise to doublets for the $\mathrm{N}-\mathrm{II}$ signals. However, the $\mathrm{H}_{\text {thr }}^{\alpha}$ protoms are further coupled to the $\beta$ methine proton of

()

the ('H, (s group, while the $\mathrm{H}_{\mathrm{val}}^{\alpha}$ protons are $\coprod^{\beta}$

coupled to $\beta$ methine protons of the $\left(\mathrm{C}^{\times} \mathrm{H}_{3}\right)_{2}\left(\mathrm{e}^{\circ}\right.$ group.

$1 I^{3}$

Hince $\mathrm{H}_{\mathrm{thr}}^{\alpha}$ protons are $>1$ ppm to $\mathrm{kow}$ field of $\mathrm{H}_{\mathrm{ral}}^{\alpha}$ protons, ${ }^{63}$ if should be possible to assign the $>\mathrm{H}$ protons by appropriate decoupling experiments. "The results of such experiments show (Figure $207 \mathrm{~B},(1)$ that the a and b doublets collapse to single lines when a second rf field is applied at 267 and 266 eyeles sec upfield (i.e., 215 eycles/sec rel. TMIt), while the o and al doublets collapse when the serond of field is applied $15 \%$ and $189 \mathrm{cycles} / \mathrm{sec}$ upfield (275) cyeles see rel. TMS'). Aecordingly the a and b doublets, with of equal to 5.7 and 6.1 creles/sece, are assigned to the $(\mathrm{N}-\mathrm{H})_{\mathrm{vat}}$ protons and the $c$ and d doublets with of equal to 5. and 6.9 cycles/sec are due to the $(X-I I)_{\text {thr protons. }}$ These assignments were confirmed by additional double and triple resonance experiments on the thr and val side chatins. ${ }^{(3)}$ A further assignment of the $\mathrm{N} \cdot \mathrm{H}$ protons to individual pentapeptide rings is not possible at present. Although there has been some question as to whether the cyclic peptides are present as a decapeptide ring or two pentapeptide rings, our solvent pere furbation studies( ${ }^{(3)}$ tend to confirm the latter.

Both the $(\mathrm{N}-\mathrm{H})_{\mathrm{wal}}$ and $\mathrm{NH}_{2}$ signals shift upfield by 8 to $10 \mathrm{crcles} / \mathrm{sec}$ with increasing temperature in the range $34^{\circ}$ to $70^{\circ}\left(1\right.$ (in (1) ( $\mathrm{l}_{3}$ ), while the $(\mathrm{X}-\mathrm{H})_{\mathrm{thr}}$ signals, in contrast, shift downfield approximately 4 cyeles sece. Chemical shift for the other groups showed a negligible temperature dependence nor was there any significant change of the thr and ral $H c^{\alpha}-\mathrm{NH}$ and $H\left({ }^{\alpha_{-}}{ }^{{ }^{\beta}}{ }^{\beta} \mathrm{H}\right.$ roupling constants. In appreciable shift to 3. 3 field (6 to 40 cycles, sec) was also observed for the $(-\mathrm{H})_{\text {thr }}$ and $\mathrm{NH}_{2}$ signals in going from $\mathrm{CDC} \mathrm{J}_{3}$ to a more polar aliphatic proton aceeptor solvent such as ('I) ${ }_{3}$ OH. No comparable change was noted for the $(\mathrm{N}-\mathrm{H})_{\text {val }}$ signals or for signals of other groups. All of
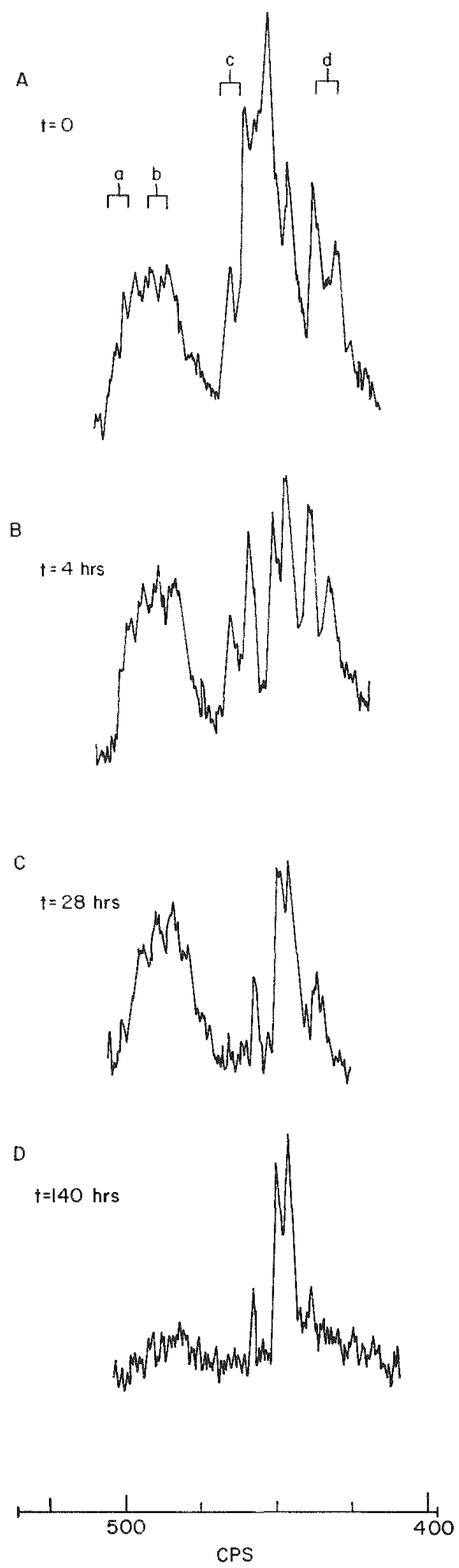

Fix. 20x. Effect of llog upon the proton resonance spectrum of $\mathrm{NH} H \mathrm{NH}_{2}$, and ring protons of $\mathrm{ACD}$ in dioxane at $32^{\circ}(\mathrm{C}, 1)_{2}()$-frees solution; the $\mathrm{X} \sim \mathrm{H}$ doublets are labelled as in Figure 207. B3, (, 1$)$, solution eontaining $\left.-55^{\prime}, 1\right)_{2}($ ) after specified time intervals. Shifts are in ares sec to low field from internal Tas. 
the signals were independent of $\mathrm{AC} I)$ concentration $(0.01 . M$ to $0.10 M)$ in the nonaqueous solvents studied.

Several points regarding the $\mathrm{A}(\mathrm{I})$ st meture ean be made from the present results.

1. From the magnitudes of the coupling constants it is very likely that the $\mathrm{HC}^{\alpha}-\mathrm{NH}$ protons favor gauche and/or trans conformations in all four thr and val residues, assuming that the coupling constant dependence upon vicinal angle is of the Karplus type. ${ }^{(4)} \mathrm{Wx}$ perimental eridence suggesting wuch a dependence has been reported very reently by Bystroy and coworker.. (5) I trans vicinal relationship is also indieated for the $\mathrm{HC}^{\mathrm{d} \alpha}-\mathrm{C}^{\beta} \mathrm{H}$ protons of the ral and thr side chains. All of these conformations are consistent with the conformations deduced theoretically for a variety of oligopeptides. ${ }^{(6)}$

2. The absence of any concentration dependence for the A(I) signals tends to rule out any significant solute-solute intermolecular hydrogen bonding ( $\mathrm{N} \mathrm{H}$ groups) or stacking (phenoxazinone rings) interactions in nonaqueous solvents. On the other hand, the temperature dependence of the $\mathrm{N}-\mathrm{H}^{*}$ and $\mathrm{NH}_{2}$ signals (in $\left({ }^{1}\right)\left({ }_{3}\right)$ and the deshielding of the $(\mathrm{N}-\mathrm{H})_{\mathrm{thr}}$ and $\mathrm{NH}_{2}$ signals in a proton acceptor solvent suggest the involvement of these groups in intra- and intermolecular (solute-solvent) hydrogen-bonding interactions. 11though a quantitative assessment of the relative rontributions for these two types of interactions is not feasible, the presener of $\mathrm{X}-\mathrm{H}$ splittings and the slow rates of deuterium exchange for these protons faror a rather strong intramolecular interaction. Furthermore, the slower exchange rate and insensitivity to proton acceptor solvents indicates that the $(\mathrm{N}-\mathrm{H})_{\text {val }}$ protons are more strongly hydrogen bonded intramolecularly than $(\mathrm{N}-\mathrm{H})_{\text {thr }}$ protons. It is interesting to note that Dreiding molecular models of the eyclic peptides show a particularly farorable possibility for intraring hydrogen bonds between $(X-I I)_{\text {a al }}$ and $\left(C^{4}=0\right)_{\text {sar }}$.

3. The observation of well-resolved doublets for the $\mathrm{X}-\mathrm{H}$ signals along with the absence of any significant temperature effect upon the magnitudes of the $\mathrm{HC}^{1 \alpha_{-}}$

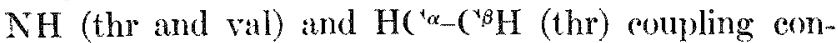
stants is indicative of a pronounced conformational rigidity for the eyclic peptide rings in nonaqueous

\footnotetext{
* The downfeld shifts of the (N H)thr signals with increasing temperature appear to be anomalous. However, such a shift rhange would arise if the $(\mathrm{N}-\mathrm{H})_{\text {thr }}$ groups become more deshielded, i.e., lie nore in the plane of the aromat ic phenoxazinone ring, with increasing temperature.
}

solvents. This rigidity is further indieated by the relatively broad line-widthst $(\sim 1$ to 2 cycles/ser) observed for the methyl signals. Nlthough this rigidity is due in considerable part to the lactone linkage, an additional stabilizing effect undoubtedly arises from intra and/or interring hydrogen bonds.

\section{CONCLITIONS}

High-resolution proton magnetic resonance spestra have been measured for the chromoneptide antibiotic actinomycin I) ( $11 . W .125 .5,86$ protons). From resulte of deuterium exchange and decoupling experiments it has been possible to assign all of the $\mathrm{N}-\mathrm{II}$ and $\mathrm{NH}_{2}$ groups and the phenoxazinone ring protons. Based on the magnitudes of the vicinal H('NH coupling constants it is concluded that these protons favor gauche conformations in all of the threonyl and valyl residues.

An extensive study was also made of the effect of temperature and solvent upon the $\mathrm{N}-\mathrm{HI}$ and $\mathrm{XH}_{2}$ chemical shifts. It is eoncluded that the $\mathrm{N}-\mathrm{H}$ protons undergo intra- and intermolecular hydrogen bonding interactions, with the former favored by valyl $\times \mathrm{H}$ protons and the latter by threonyl $N-H^{\prime}$.' Molecular models show a particularly farorable possibility for intramolecular hydrogen bonds between the valy] $\mathrm{NH}$ and sareosyl $\mathrm{C}=0$ groups.

The assignment of the $X I$ protons represents the first step in the complete assignment of the actinomyein D spectrum. In order to achieve the latter objective further deuterium exchange, decoupling, and solvent perturbation measurements are essential. Such measurements are currently in progress.

\section{REFERENC'LS}

1. (Gottlieh, 1). and P. 1). Shaw. Antibiotirs. Springer-Vorlag, New York. 1967, Vols. I and II.

2. Waksman, S. A. Actinomyein. Interseience Publishers, New York, 1968.

3. Vietor, T. A, C. L. Bell, F. L. Iruska, and S. S. I)anyluk. linpublished results.

4. Karplus, M. Contact electron spin-coupling of nuclear magnetic moments. J. ('hem. Phys. 30, 11-18 (1959).

5. Bystrov, V. P., S. L. Portuova, V. T. Tsetlin, V. T. Ivanesv, and Yu. A. Ovchinnikov. Stereochemical dependence of vicinal HCNH coupling constants in dipeptides. Tetrahedron 25, 493504 (1969).

f. Kakshiminarayanan, A. V., V. Sasisekharan and ( $\mathrm{N}$ N. Ramachandran. Amino acid enformation in the solid state. Conformation of Biopolymers, Hd. (*. N. Ramachandran. Academic l'ress, 196\%, Vol. 1, p. 61.

t The spectrometer resslution under the same operating comditions was better than 0.2 cycles sec for methyl signals of simple reference compounds. 
MUTAGENESIS BY ULTRAVIOLET AND VISIBLE LIGHT IN CONTINUOUS CULTURES

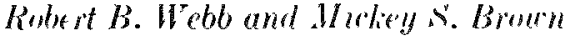

P( RPOR AND MEIHOD

Near ultratiolet $(330$ to $390 \mathrm{~mm}$ and visible $(400$ to $.500 \mathrm{~nm}$ ) light was shown to induce mutant sesintant to bacteriophage $\mathrm{T} 5$ in continuous cultures of Escherichia coli.'13) Mutegene-is wat proportional to irradiance between 125 and 1000 erg $\mathrm{mm}^{-2}$ sec $\mathrm{c}^{-1}$ and independent of growth rate between 0.1 and 0.5 rlivi-ions per hour. There was a requirement for oxygen at warelengths abore $3.50 \mathrm{~nm}$. A preliminary action -peetrum howerl a broal peak between $3.00 \mathrm{~mm}$ and $500 \mathrm{nmm.}{ }^{331}$

The purpone of this continuing inventigation is the clucidation of the mechanim of mutagene-in by near ultraviolet (CV) and visible light.

Techniques for chemontat culturen uned in this report have been described. ${ }^{3}$ : Continuou cultures of $E$. coli $\mathrm{B} \mathrm{r}$ and $E$. coll $B \mathrm{r}$, t (tryptophan-requiring) wert grown in a minimal medium (A19) containing an exeren of tryptophan $18 \mathrm{mg} 1$ when required and at limting roncentration of glucome $1100 \mathrm{mgg} / 1$. Population were maintained in balaned growth at concentration of 1 to 2 ' 10 cell ml. Mutation to reni-tance to the hacteriophage Th wa- anded by plating rells in the prenenes of excem phage on nutrient agar (Difco) supplemented with sequentered iron. streptomyein-re-i-tant mutants were andayed by pour-plating in nutrient agar in the prenenes of 12.5 $\mu g$ ml streptomyrin. All plating war done in quanlruplicate. ('olony count- were made after incubation at $37^{\circ}$ (" for $48 \mathrm{hr}$, except for as aly plate- for streptomycin resistance, which were incubated for 4 days. Radiant energy sourees were 11 low premure mereury vatpor linup (Penray $S\left({ }^{\circ}-11\right.$ ) with pin hole -hield, 2 ) Bauch and Iomb Ifigh Intensity monochromator with 1.50 -watt xenon are lamp, $312^{\prime \prime} \times 2^{\prime \prime}$ slide projector with a 200-hr 400)-watt bulh (Nawrer 550A) ued with a Baird-Atomie B1 interference filter, and 4) visible fluorescent lamps containing two 4-watt sylvania cool-white bulb- (F4T. CW).

A Schwarz vacuum thermopile standardized again-t a Nitional Bureau of Standard lamp wa uned to measure the irradianes in the near $\mathrm{CT}$ and visible rangen. A reneral Electrie germicidal meter calibrated against the schwarz thermopile was uexd to mearure the low irradiance from the 25t-nm coures.

\section{PROKRE -4 REPORT}

The induction of resi-tances to the bacteriophage "T.5

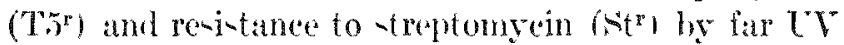

\{2.54 nmi, near CV $1330 \mathrm{~nm}$ ) and risible (400 to 750 nmy light in chemo-tat culturen of $E$. cole $\mathrm{B} \times 1, t$ is thown in Figures 209-211. At 2.54 $\mathrm{nm}$ and $330 \mathrm{~nm}$, T5r cell and $s t^{r}$ rells were asmayed in the same chemostat cultures I Figure 209 and 2101. The two mutation rytem were studied in -eparate parallel culture for 400 to $7.50 \mathrm{~mm}$ vivible light. The ratio of the rate of $T 5^{r}$ induction to the rate of $S t^{r}$ induction was 75 at 2.54 $\mathrm{nm}$ (Figure 2091, 160 at $330 \mathrm{~mm}$, and 190 at 400 to $750 \mathrm{~mm}$. Thene relation-hip appear to be reproducible, -uggesting that the mutagenic processes affecting T.; re-istance and streptomycin resistance are difierent at $2.54 \mathrm{~nm}, 330 \mathrm{~mm}$ and at 400 to $7.50 \mathrm{~nm}$.

It is evident from figures 209-211 that the mean delay of expresion's in much horter for streptomycin rei-tance than for Th re-intance. The mean delay of cxpresion for str appear to be less than one generation, whereas for Tyr it is approximately 2.5 generatiom- at $2.54 \mathrm{~mm}, 4.0$ generation- at $330 \mathrm{~nm}$, and 4.0 generations at 400 to $7.50 \mathrm{~nm}$.

The po-sible role of tryptophan in near IV and vi-ible light mutagene-i- was inve-tigated through the une of $E$. coll B r, a at rain that doen not rerpuire tryptophan or any other amino aciul. Figure 212 knows the

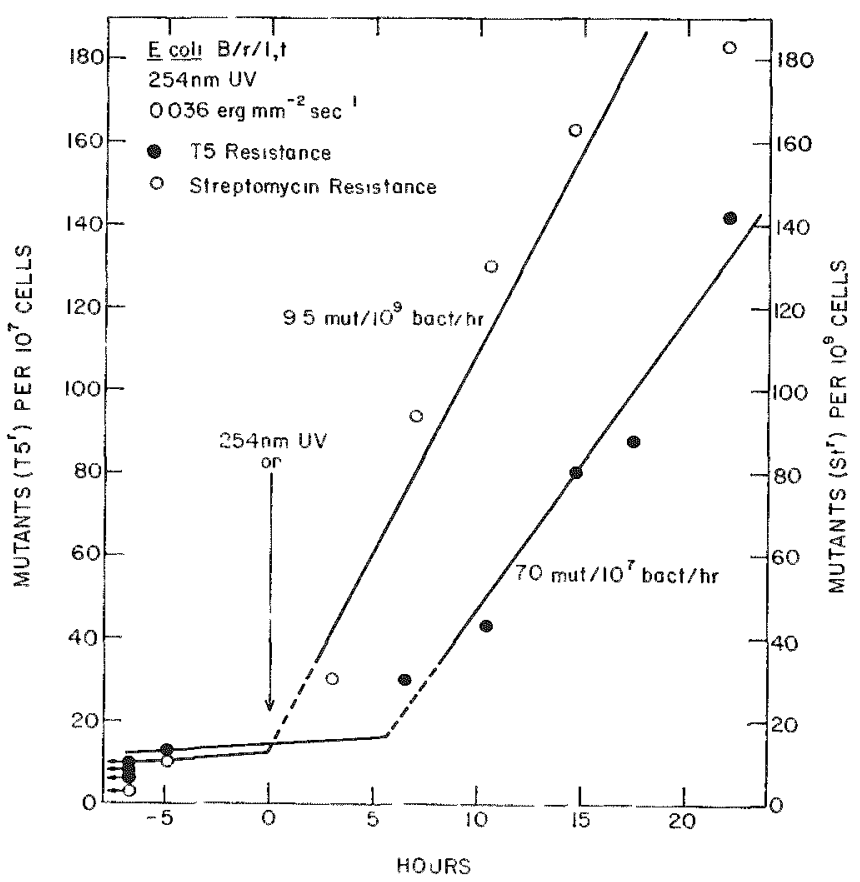

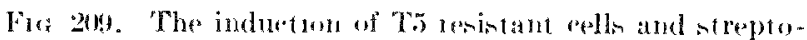
my rin resistant rells br $25 t$ num $l V$ in at chemostat culture of

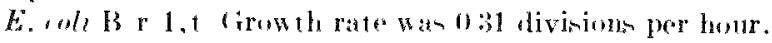




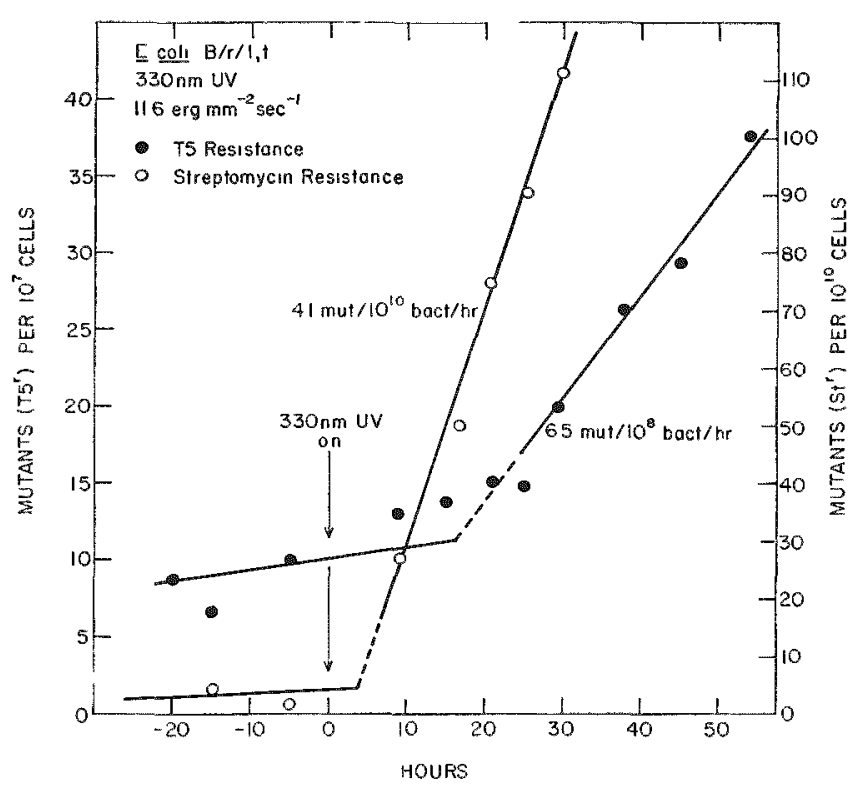

Fic. 210.- The induetion of T5 resistant cells and streptumerein resistant cells by 3300 um $l^{*} V$ in a rhemostat culture of $E_{\text {. coli }} \mathrm{B}, \mathrm{r}, 1, \mathrm{t}$. ( Arow th rate was 028 divisions per hour.

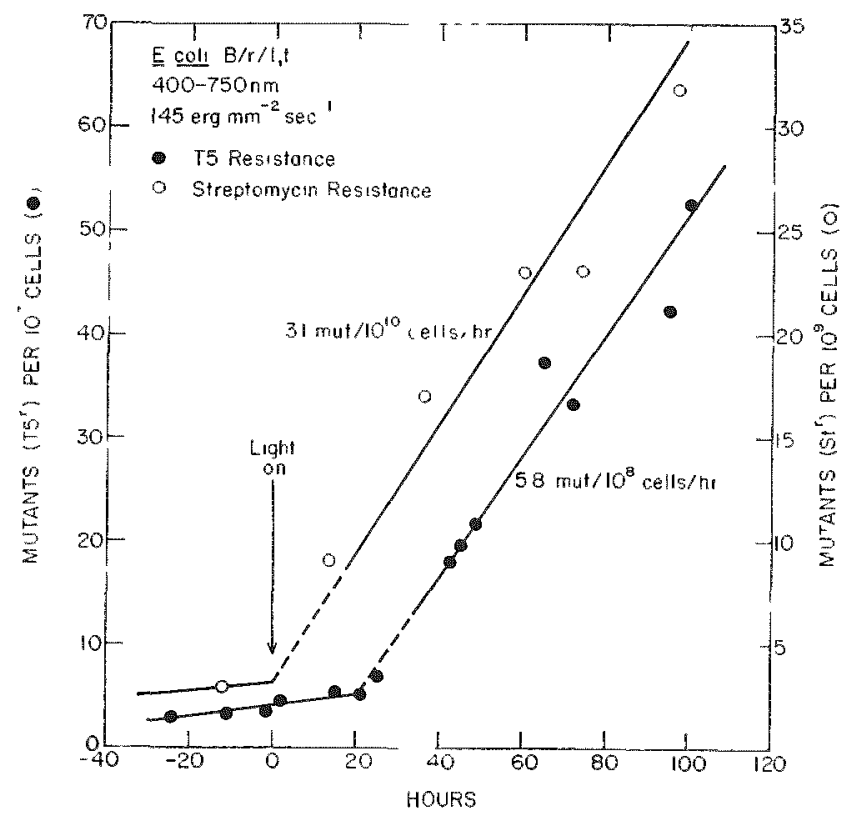

Fitx. 211. The induetion of T.5 resictant ceslls and streptoIny oin resistant (colls by 40) to 750 um visible light in two rhemostat cultures of $E$. wh $B$ r 1,1 . Cirow hate was 0.29 divisions per hour.

respone of this strain to neatr CY $(340)$ nmo and risible $(420 \mathrm{~mm})$ light. $E$. coli $B, r$ shows a much higher mutagenicity than $E$. coli $\mathrm{B}$ r, 1,1 or $k$. coli WP2 her- to both near $\mathrm{CV}$ and visible light. It is evident that exogenous tryptophan is not the chromophore for near UV or vi-ible light mutagenesis.

Blue light $(420 \mathrm{~nm})$ is somewhat more mutagenie

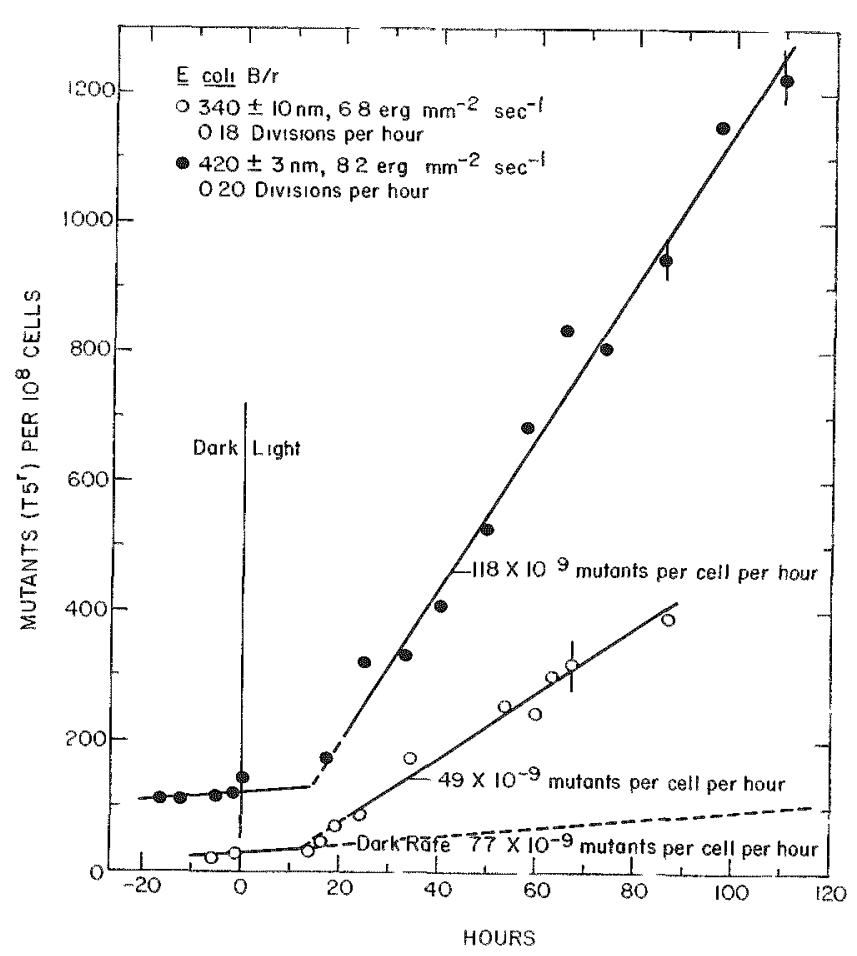

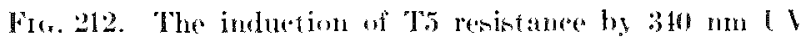
and $120 \mathrm{~mm}$ visible light in chemestat culfures of $E$. coll $\mathrm{H}_{\mathrm{r}} \mathrm{r}$. The grow th rates were 0.21 and 0.20 divisions per hour.

than near $\mathrm{CV}(340 \mathrm{~nm}$ ) for $E$. coli $\mathrm{B}$, $\mathrm{x}$. 'This result is consintent with the prelinainary action spectrum reported for $E$. coli $B$ ' $x, 1, t .^{(3)}$

\section{Coverarions}

Near UV and visible light are mutagenic for both Th resiotance and streptomycin pesistance in chemostat and Nephelontatt(t) cultures of E. coli. Mutation to T.5 resistance is induced at 7.5 times that of streptomyein renistane by far $\left({ }^{2} \mathrm{~V} 1254 \mathrm{~mm}\right.$. This ratio is somewhat higher" for 330 um IV 1160 ) and 400 to $7.50 \mathrm{~mm}$ risible light 1190$)$. The basis of these differencers in under invertigation.

dided tryptophan is not required for near UV ri-ibe: light mutageneris (Figure 212). Furthermore, the much higher mutation rate to Th resistanee hown by $E$. roli B ris a strain that does not require tryptophan or any other amino acid, show that neither near UV nor visible light mutagenesis involves a defect in the motaholic pathway of tryptophan.

\section{RETLARN(' $\mathrm{E}$}

1. Webb, R. B. and M. M Malina. Mutagenesis in Escherehut roli bs visible light. So ir we 156, 1104-1105 (1967).

2. Webb, R. B. and M. M. Malina. Mutagenesis in bacteria by visible light. Argomme National Laboratery Biologional and Mediral Researeh Diviaion Anmual Resport, 1967. AN1.-7409, p). 139142 . 
Webb, R B. and M. M. Malina. Mutagenic effects of near ultraviolet and visible radiant energy on eontinuous cul tures of Eschericha coll. "To be published

1. Noviek, A. and I. Sailard Experiments with the chemostat on spontaneous mutations of hacteria Proc Lat. Acad Sor. $36,708719(1950)$.
5. Kubitsehek, H. F. and $I I$ F Bendigkeit Mutation in rontinuous cultures. I. Dependence of mutational response upon grow th limiting factors. Untation Res. 1, 113 120 (1964).

6. Webb, $\mathrm{B}$ B. and $\mathrm{W} J$ Kisler, $\mathrm{Jr}$ Grow th and mutagenesis in the Nephelostat This report

\title{
GROWTH AND MUTAGENESIS IN THE NEPHELOSTAT
}

\author{
Robert B. Webb and William J. Eisler, Jr.
}

PI RPOSE AND METHODS

A photorell-controlled continuous culture inst rument (Nephelostat) developed at Argonne ${ }^{(\mathbf{1}, 2)}$ maintains a population density to within $\pm 2 \%$ in unrestricted growth, provides a continuous record of growth rate over -mall increment of time, has a self-contained electronic console with front panel controls, and a deteetor mechanism that provides a convenient reprodueible initial setup without optical focus problem. In the Nephelostat, particle density (ncattered light) in monitored and turbidity of the culture is held con-tant by controlling the rate that fresh nutrient medium is added to the culture. The culture rolume is held constant by an overflow -iphon.

The Nephelo-tat has been unerd in a number of invertigation- at Argonne, including cireadian rhythm studies in Tetrahymena pyriformin, (3) phy-iologicat -tudies in He-Lia cell-(") and morphologieal studien of Vocardia corallina. The The application have shown that with only minor modification anticipated in the denign of the int rument, a wide rariety of cell- can be maintained in balancel growth.

In thi inventigation, growth and mutageneis were -tudied in Nephelostat culture of bacteria an an extension of parallel studien in chemo-tat cultures." Biological techniquen in Nephelostat and rhemo-tat experiment are similar. (Chemontat are the Kubit-ehek modification ${ }^{8-9)}$ of the Novick and szilard design. (10) Growth vesels for both Nephelostat and chemo-tat technique are 23 to $24 \mathrm{ml}$ with an incide diameter of $1.5 \mathrm{~mm}$, with a capillary tube affixed to the bottom to provide aeration and stirring by bubbling air through the suspension. Both Nephelo-tat and chemo-tats are operated in individual light-tight incubator with the temperature of the growth vencel rontrolled to $3 \bar{\tau}=0.1^{\circ} \mathrm{C}$. Some of the continuou cultures utilize a refrigerated sample collector, aho

\section{- beveloped at Angonne. ${ }^{(11)}$}

Escherichio coli strain B r, B $r 1, \mathrm{t}$, WP2, and WP2 her- were used in the continuous-culture experiment. The growth medium wa M9 salt, with glucose
$1100 \mathrm{mg} /$ for chemostat and $100 \mathrm{mg}$ 1, $2.50 \mathrm{mg}$. or . $\mathrm{g} 1$ for Nephelustats and required anded amino acid. Cltraviolet light (UV') at $2.54 \mathrm{~nm}$ was - supplied by a Penray lamp (se 11) with a pin hole shield. Irradiance wa measured with a General Electric Germicirlal Moter calibrated aguinst a Schwarz vacuum thermopile, which had been calibrated againet a National Bureau of standard lamp for the 2.54-nm watrelength.

PRMAREM RFPORT

\section{Derelopment of the ilephelostat}

The ba-ie instrument hat been improved by 1 the athition of a voltage regulator to the exciter lamp rirruit making it lems emsitive to variation in the line voltugei, 21 peplacement of meehanieal meter relay with atn tectronic type of greater reliahility. 31 the arlition of an analog recorder that record the dem-ity of rell in wepen-ion, and 41 the adelitional provision of an interchinge ahle rycle timer.

spereifie modification have been made in the bate Mephelo-tat for -peceial application by different inventigator. A rompletely jackeder houning for the growth venel, nutrient inlet and atration tube, wa de-igned to hold temperature within $\pm 0.0 .5^{\circ} \mathrm{C}$ and to eliminate the need for an inculator. ${ }^{(12)}$ A hutter wa added to the hou-ine so that the culture could be illuminated for -pecific time- luring the 24 -hr evele.' 12! The cimple gravity nutrient feed $-y-t e m$ and overflow -iphon of the basie instrument wa replaced with a peristaltie pump for timsue culture studien. In thi- application the "ulture volume wa increacel to $500 \mathrm{ml}$. The ba-ie detertor and control -y-tem of the Nephelo-tat were derigned to allow for this altexnate nutrient ieed method and the incrased eult ure volume."

\section{Trouth stulies in the Nephelostat}

The growth record of a Nephelostat culture of $E$. coli B P 1.t at sereral cell concentration is shown in Figure 213. Culture of $E$. coli can be maintaines in balanced growth from $5 \times 10^{5}$ cell 'ml to approxi- 

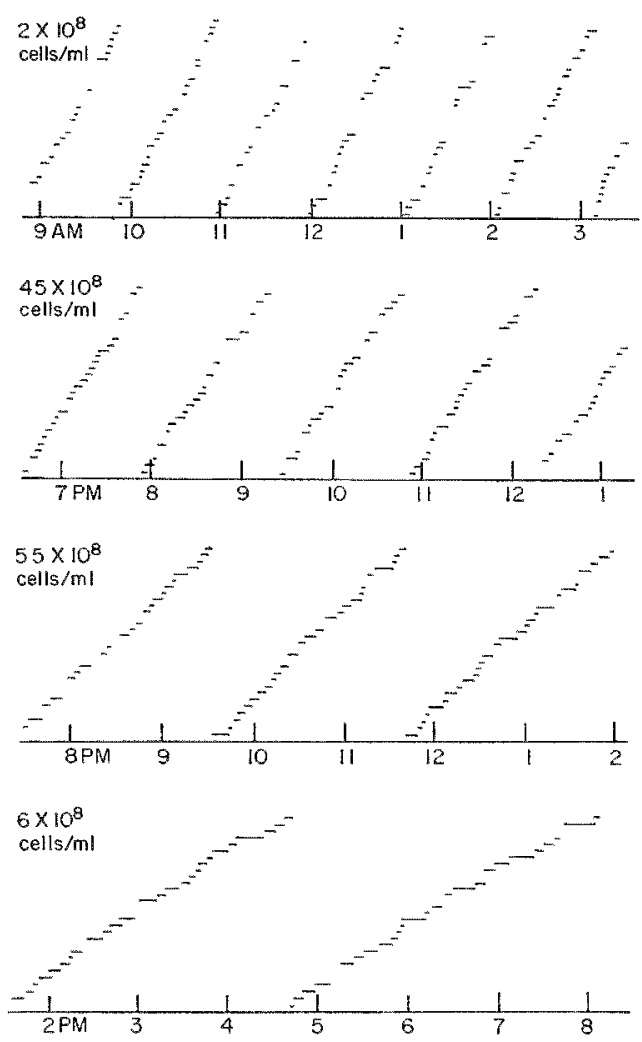

Fitr. 213. - The grow therord of a Nephelostat culture of

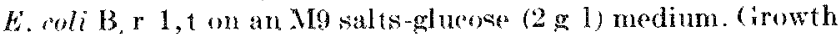
veswel was $24.5 \mathrm{ml}$ and sample volume was $0.58 \mathrm{ml}$. One cell generation is registered by 29 events.

mutely $6 \times 10^{\circ}$ cells $/ \mathrm{ml}$. The lower limit of the $\mathrm{Ne}$ phelostat, below $5 \times 10^{5}$ cells $/ \mathrm{ml}$, depends on the absence of noneellular reflective particles from the medium. The upper limit of the control system is well above the density so far achieved with any cell system in the instrument. Although batch cultures of $E$. roti on a glucose-ralts medium (e.g., .H9) can reach $2 \times 10^{9}$ cells, $m$, the maximum concentration at which this strain of $E$. coli can be mantained in balancerl growth is approximately $7 \times 10^{8}$ cells $/ \mathrm{ml}$. Ahove $7 \times 10^{8}$ cells $/ \mathrm{ml}$, the growth rate declined slowly over 2 or 3 generations, after which growth stopped completely. When the culture was diluter below $4 \times 10^{8}$ cells $/ \mathrm{ml}$, the growth rate returner to maximum (1.3 generations/hr) after a lag of 2 to 5 hr. 'The growth rate was found to be constant with $E$. coli $\mathrm{B} / \mathrm{r}, 1, \mathrm{t}$ between $5 \times 10^{5}$ cells; $\mathrm{ml}$ and $3.5 \times 10^{8}$ cells $/ \mathrm{ml}$.

A provisional explanation of these effects is the prom duction of a growth inhibitory substance which, at sufficiently high levels, induces a stationary growth phase in bacteria. In continuous cultures, this substance can approach, and exced, the concentration renuirel to induce a stationary growth phase at much lower cell coneentrations than in batch cultures. That stationary growth phase is not. induced by exhaustion of a recquired nutrient is shown by the following renults.

When an amount of glucose was present that wan limiting at approximately $2 \times 10^{5}$ cells $/ \mathrm{ml} \quad(100$ $\mathrm{mg}$ 1), the maximum growth rate of 1.30 generations hr could be maintained at cell concentrations of $90^{\circ}$, or less, of the maximum concentration. When the culture was "released" and allowed to reach maximum concentration with subserquent cessation of growth, a dilution of $10 \%$ or more, after as much as $24 \mathrm{hr}$, resulter in the immediate resumption of growth with the maximum growth rate being established within less than 10 min.

The cessation of aeration of the culture resulted in the cessation of growth within $20 \mathrm{~min}$, presumably from the shortage of carbon dioxide which is an $a b$ solute requirement of $E$. coli. Resumption of acration after as long as $24 \mathrm{hr}$ resulted in the immediate resumption of growth, with the maximum growth rate established in less than $10 \mathrm{~min}$ with no evirlenes of a lag. Therefore. the exhaustion of glucose, oxygen or carbon dioxide does not of itself induce stationary phise in E. coli.

The effect of continuou- irradiation with $254 \mathrm{~nm}$ CV on the growth rate of Nephelostat cultures of $E$. coli WP2 in a quartz growth ressel is presented in Table 91. There is only a very mall decline in growth rate in a continuous irradiance of $0.036 \mathrm{erg} \mathrm{mm}^{-2}$ ser-1. Although the irradiance is small, this intensity results in an accumulated incident dose of 145 erg $\mathrm{mm}$ = generation. An irradiance of $0.15 \mathrm{erg}^{\mathrm{mm}^{-2}}$ see $^{-1}$ resulted in a growth rate reduction of about $15 \%$. The culture appeared to be able to grow indefinitely in this irradiane of $254 \mathrm{~nm} \mathrm{CV}$. This irradiane gives an accurnulaterl incident dose of $470 \mathrm{erg} \mathrm{mm}^{-2}$ generation. A dose of $470 \mathrm{erg}^{\mathrm{m}} \mathrm{mm}^{-2}$ will inactivate $80^{\circ}$ s of a stationary phase culture of this strain. As not more than 10 s of the population was incapable of colony production, even after many hours of exposure, damage induced by low levels of 254-nm TV in $E$. coli in free growth is not cumulative. It is evident that $E$.

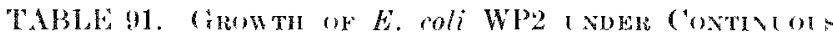
IREADI ITION WITH 254 NI $[\mathrm{V}$

\begin{tabular}{cc}
\hline Irradiance, erg mm-2 $\mathrm{sec}^{-1}$ & Crow th rate, divisions $\mathrm{hr}^{-1}$ \\
0 & 1.30 \\
$0.036 \mathrm{i}$ & 1.25 \\
0.15 & 1.15 \\
0.35 & $0^{*}$ \\
\hline
\end{tabular}

* (arowth stops after 3 or 4 mans doublings. 
coli in balances free growth can efficiently repair damage induced by 2.54-nm $\mathrm{Cr}$ at irradiane below 0.15 erg $\mathrm{nmm}^{-2} \mathrm{sec}^{-1}$.

\section{Mutagenesis in the Nephelostat}

spontaneous mutation to resistance to the bateteriophage $T$.5 in $E$. coli $B, r 1 . t$ in the chemostat 10.20 generation hrl and in the Nephelostat 11.30 generations hr) is shown in Figure 214. Although the mutation rate per hour is greater in the Xephelostat, it is comewhat les per generation. Kubituchek and Bendigkeit ${ }^{(13)}$ have shown that mutation to Th resistance (alno T6 resistance) under carbon linitation wa- proportional to growth rate. 'The' results with the Nephelontat are generally consistent with the chemostat results.

('affeine induction of T.) peristance in the Xephelostat extend the result previously reported for the chemostat (Figure 215). Although the mutation rate per hour was much higher 130 mutants per 10 bacteria per hour in the Nephelo-tat than in the chemostat 18 mutants per $10^{\circ}$ bacteria per hour , the mutation rate per generation wan approximately the same in the two systems. Figure 216 is a plot of chemontat atmd Nephelostat data for the caffeine induction of 'l5 resistance over a wide range of growth rate. It can be seen that the relationship obtained by Kubitschek and Bendigkeit for carbon-limited chemostat ${ }^{13}$ extends to the free growth charaterintic of the Nephelo-tat.

These results are consi-tent with the eaffeine induced mutational event oreurring as a mi-take during replication of DNA. Although eaffeine ha- been shown not to be incorporated in IDNA. its similarity to ade-

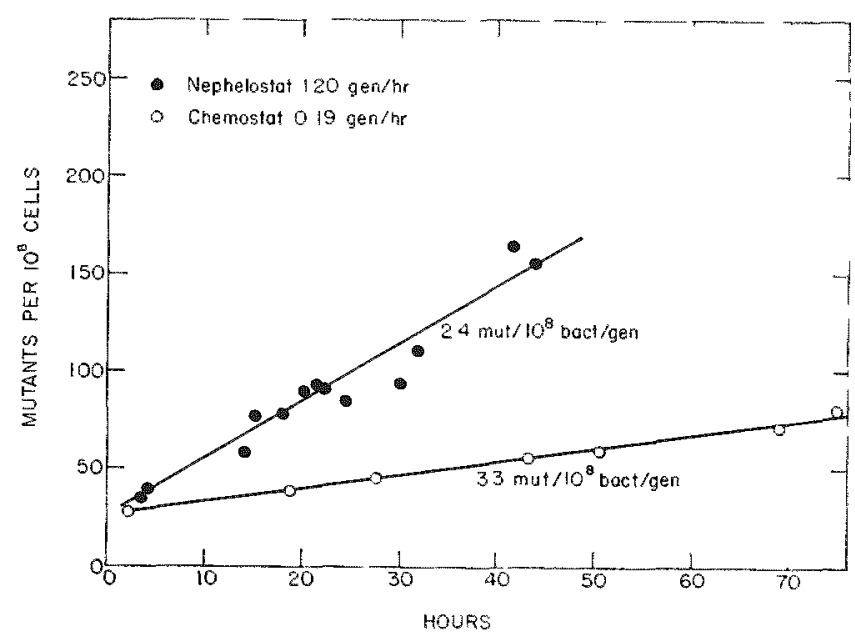

Fic. 214. - Aceumulation of spontaneous phage T5 resistant mutants in Nephelostat and chemostat cultures of $E$. coli B $r 1$, t m $M 9$ salts-ghuese medium. The chenustat medium contained $100 \mathrm{mg} 1 \mathrm{glucose}$, and the Nephelostat contained 250 mg i glucose.

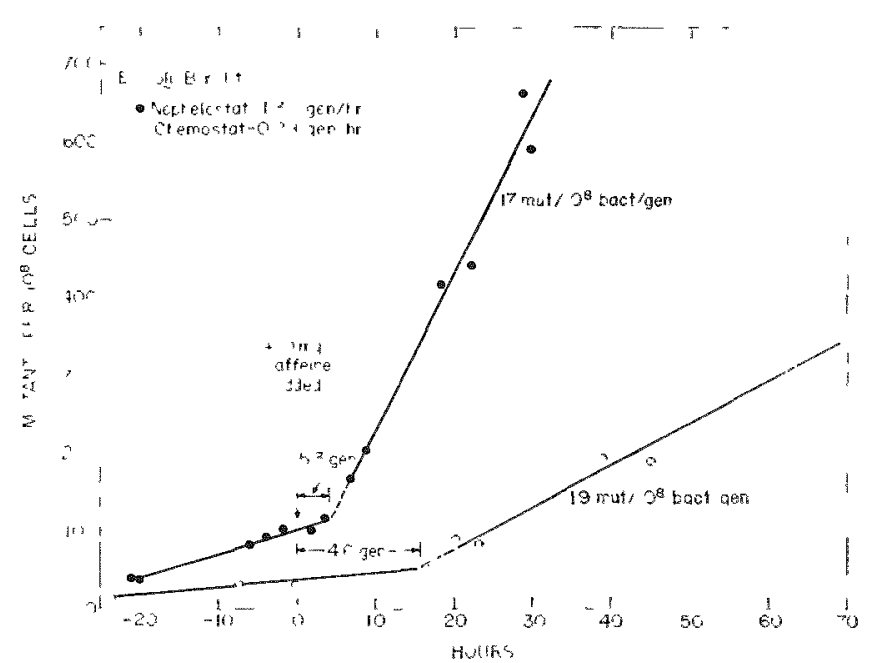

Fic. 215. -The induetion of phage Th resistant nutants by raffeine in a Nephelostat and chemostat roulture of $E$. eoli 13 i 1,1 . The ehomostat medium contained $100 \mathrm{mg} 1 \mathrm{glureses}$, and the Nephelost at medium ountained $200 \mathrm{mg} 1$ gluesese.

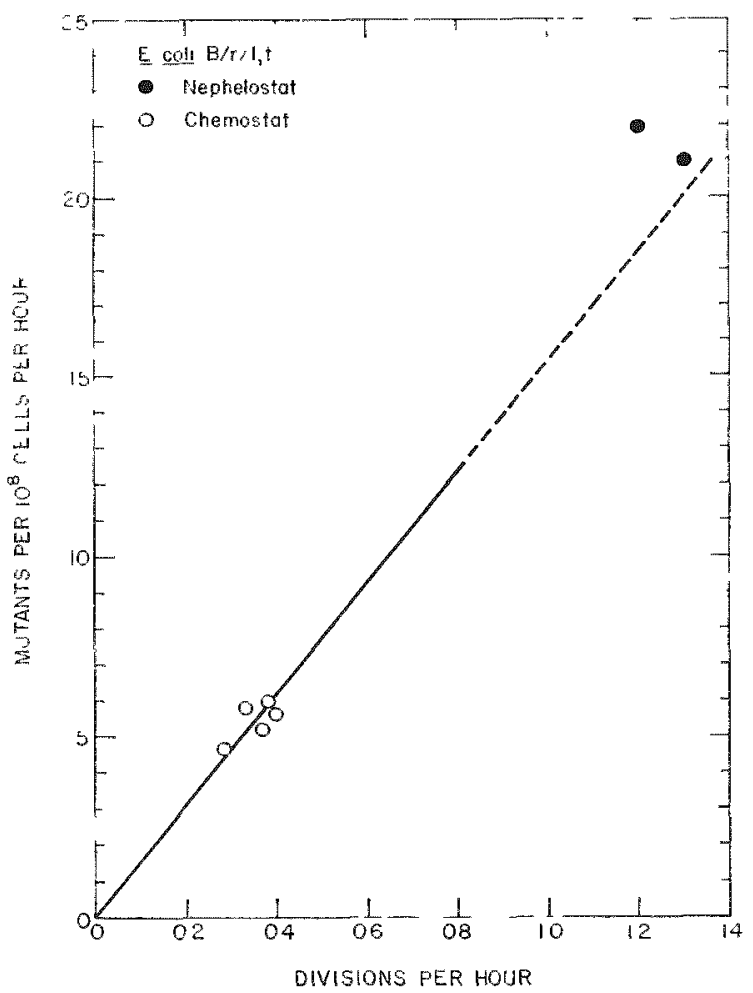

Fin: 216 the relationship between the caffeine-induerd $450 \mathrm{mg}$ l) mutation rate and generation rate in chemostat and Nephelostat cultures of $k$. onli B r 1 , t. "The line is taken from data of Kubitsehek and Bendigkeit."

nine and guanine suggest the po-sibility that caffeine interferes with precise base pairing during DNA replication.

The induction of phage T5 resistance, streptomycin resistance, and tryptophan independence by $254-\mathrm{nm}$ 


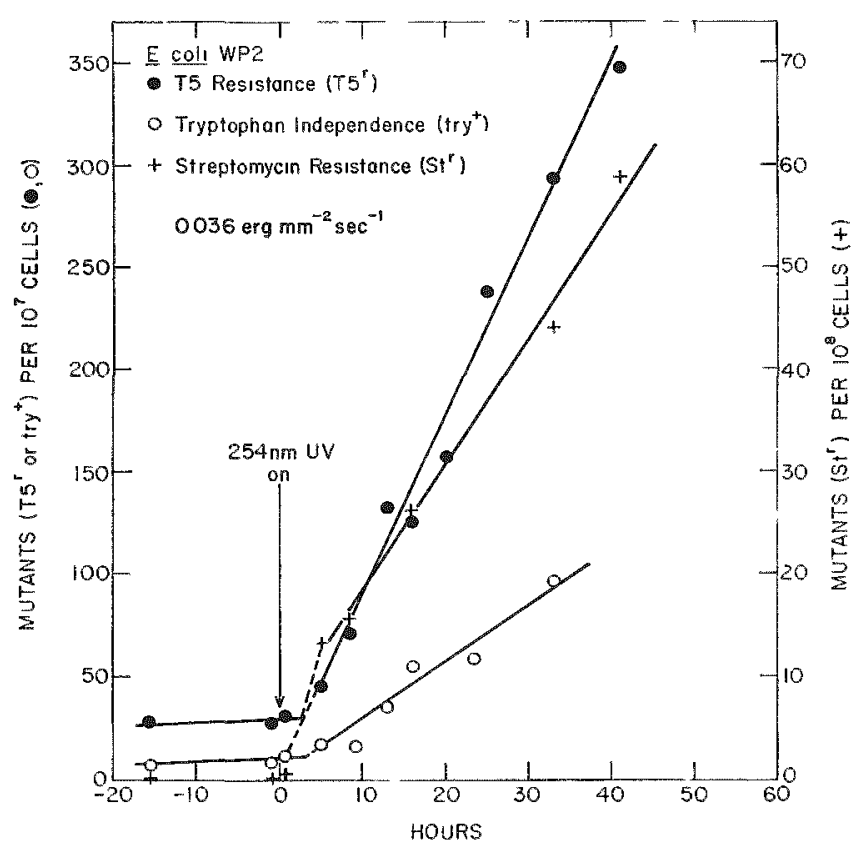

Fitx 217. The induetion of Ts resistance, streptomy cin usnistance, and tryptophan independenee in a single Nephelostat rulture of $E$ coln WP2 by 254-nm IV. ( divinions per hour.

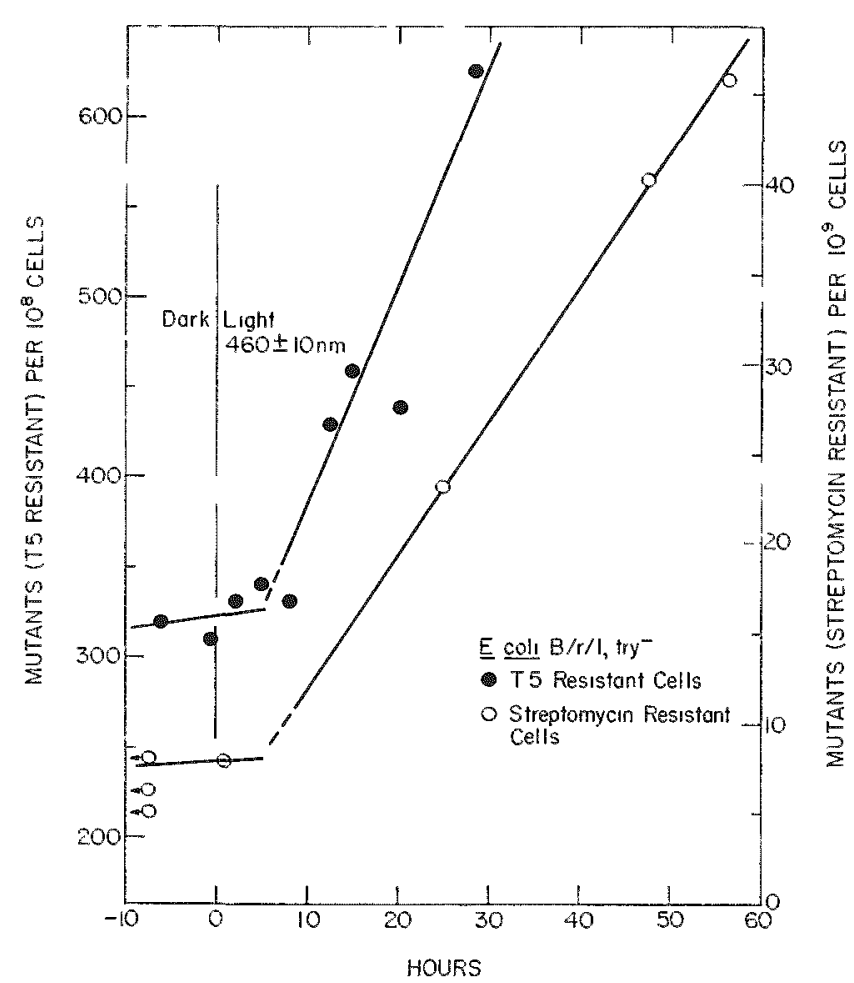

FIG. 21x. -The induetion of Th resistance and treptomyein resistance by visible light $(460 \pm 10 \mathrm{~nm})$ in a Nephalostat colture of $E$, coll $\mathrm{B}$ r $1, \mathrm{t}$ (irow $1 \mathrm{~h}$ rate was 1.25 generations per hour.
UV in $E$. coli WP2 in the same Nephelontat culture is -hown in Figure 217. The 254-nm IV mutation rater for T5 renistance and treptomycin resistance are somewhat higher under free growth in the Nephelostat than under restricted growth in the chemostat. In the chemostat, the induction of $T_{5}$ resintance by $2.4-\mathrm{mm}$ IV in independent of growth rate. ${ }^{(13)}$ Reversion to tryptophan indepentence has not been studied succenfully under chemostat conditions, as revertants have not been oberved to accumulate in ehemostat cultures. Therefore, the Nephelostat extends the range of mutant that can be studied in continuous cultureto the class typified by the reverion from tryptophan dependenes to tryptophan independence.

The induction of $\mathrm{T} 5$ resistance and streptomycin reistance by visible light $(460 \pm 10 \mathrm{~nm})$ in the Nephelo-tat in hown in Figure 218. "This renult demontrates that visible light mutagenes is is not limited to rentricted growth in the chemostat. T5 resi-tance is induced at approximately 150 timen the rate for -treptomycin resistance. This is the same proportionality oberved in chemo-tat cultures with visible light. Alos, the relationship between the two mutation rates with visible light is similar to that obtained with 254um. ('V (Figure 217).

\section{CONCLLCIONS}

The Nephelostat has been employed suceenfully in a varicty of hiological $\rightarrow \mathrm{r}-\mathrm{tem}$, by several invertigator at Argonne. It is to be expected that any organi-m that can be grown in liquid medium, exirts as isolated cells i-mall uniform clumps or short filament-1, and that can be prevented from alhering to urfices of the growth vessel, can be grown successfully in the Nepheloutat.

Mutation studies, including spontancous, caffeine, far "V" and risible light induction, in the Nephelostat have extended previous chemontat studies to much fa-ter growth rate characteristic of the Nephelostat. spontaneow mutagene-is and caffeine induction of To resistance in $E$. coli grown in at glucone-minimal salts medium remain approximately proportional to rate of cell division from very slow ehemostats to 1.3 generation per hour in the Nephelostat. Far TV mutageneis to T.5 resistance, which is independent of growth rate in the chemostat, increased by a factor of two under free growth in the Nephelontat; however, thiincreane in much less than that recyuired to give a mutation rate proportional to growth rate. Theme observations are under invertigation.

The Nephelostat affords the opportunity to -tudy three clases of mutation in the same continuous alture. This approach will be exploites in the study of 
he nature of mutation induction by far UV, near UV, visible light. and various chemical mutagens.

\section{REFERENQ}

1. Visler, W. J., Jr. and R. B. Webb. An electronically centrolled continuons culture deviee. Argonne National Iaboratory Biologieal and Medical liesearch Division Amnal litpori, 1964. ANL 46971 , pp. 29-31.

2. Hisler, W. J., Jr. and R. B. Webb. Heletronieall ront rolled rontinuous eulture device. A ppl. .h herobiol. 16, 13751380 (1968).

3. Wille, J. J. and (. F. Ehret. Light syuchronization of an cudegenous circadian rhythm of cell division in Tetrahymena. Argonne National Laboratory Biologieal and Medical hesearch l livision Annual Report, 1968. AN L -7535. pp. 208212.

1. Poraino, C. Personal communiration.

5. Clark, J. B., Cniversity of Oklahoma. Personal communication.

ti. Webb. R. B. and H. F. Kubitsohek. Mutagenir and anti- mutagenic effects of acridine orange in Escherichia woli. Biochem. Biophys. Res. ('ommun. 13, 90-94 (196:3).

7. Webb, R. B. and M. M. Malina. Mutagenesis in Escherih ia coli by visible light. Soitnce 156, 1104-1105 (196i).

\$. Kubitschek, H. K. and II. E. Bendigkeit. Jelay in thr appearance of caffeine induced Ts resistance in Escherichio roli. Genetios 43, titim 661 (1958).

9. Kubitschek, H. E. Modifieations of the rhemostat. J. Barteriol. 67, 254-255 (1954).

10. Novick, A. and L. Silarard. Faperiments with the chemost at on spontaneous mutations of bacteria. Pome. Nat. Arad. Sei. 36, 708-719)(1950)

11. Risler, W. J., Jr. Automat ie sample collector for continuous "ultures. Appl. Microbiol. 16, 13811382 (1968).

12. Fisler, W. J., Jr., C. F. Fhret, and I. Pollath. An environmental control cabines for the Nephelostat. Argonne Na. tional Lahoratory Biolowieal and Medieal Research Division Amnul Report, 1968. AN1,-7535, pp. 217220 .

13. Kubicehek, H. F., and II. F. Bendigkeit. Mutation in continums eultures. Dependenre of mutational response upon growth-limiting farturs. Wutation hes. 1, 113-120 (1961).

\title{
EFFECTS OF ULTRAVIOLET AND VISIBLE LIGHT ON A MULTIPLE REPAIR-DEFICIENT STRAIN OF ESCHERICHIA COLI
}

\author{
Wicliey s. Broun and Robert B. Webb
}

\section{PIRPOCE AND METHODS}

The sensitivity of bacteria to ultraviolet light (UV) can be greatly enhaneed by altering certain genetic markers of the cells. ${ }^{(1-3)}$ In this study, the relative sensitivities of several strains of $F$. coli to ratiant energy of different warelengths were compared. The comparison was made on the surviving fraction of cells after varying exposure times to far $\mathrm{CV}(254 \mathrm{~nm})$, near (V (365 $\mathrm{nm})$, and risible light $(460 \mathrm{~nm})$. This study $i$ - an extension of work on effects of near $T$ TV and risible light previously reported. ${ }^{1}$, a)

Three strains of Escherichic coli were used in this stuly: E. coli $\mathrm{K} 12$ AB2480 (has a genetic marker mis $-i n g$ for recombination repair $E$. coli $W P 2$, and E. coli WP2 her-. E. coli K12 AB2480 is of sperial interest because of its extreme sensitivity to $254-\mathrm{nm}$ $\mathrm{Cr}$ : the $\mathrm{D}_{37}$ of only $0.2 \mathrm{erg} \mathrm{mm}{ }^{-2}$ for this strain will produce an average of 1.3 pyrimidine dimers in the DNA of a cell of $E$. coli. ${ }^{(3)}$ For each series of experiments, the cultures used originated from a single colony isolate. For individual experiments, a suspension of cell, was made in 119 salts buffer by removing a small loopfull of bacteria from a $48-\mathrm{hr}\left(37^{\circ} \mathrm{C}\right) \mathrm{nu}-$ rient agar (Difeo) slant and aseptically adding the llk to the solution with vigorous agitation. The final concentration after a 1:10 dilution was approximately
$10^{7}$ cells ml. Asiay were carried out by making appropriate dilutions from the irradiated samples and plating $0.2 \mathrm{ml}$ of the sample onto nutrient agar plates. Plating was primarily in triplicate with an incubation period of $48 \mathrm{hr}$ at $37^{\circ} \mathrm{C}$ before colony counts were marle.

Dose-response curves were malle using three different energy sources. For the far $\mathrm{CY}^{\prime}(254 \mathrm{~nm})$, a low presure mereury lamp (Penray SC 11 ) with an added filter to reduce the long warelength $\mathrm{I} V \mathrm{~V}$ and risible light to very low levels was uned. The near LT source was a Bausch and Lomb high intensity monochromator with it 200-watt supes presure mercury are lamp. The visible light soure was a General Electric Mare 300 "metal" vapor are lamp, (300-watt) with an integral reflector. ${ }^{(6)}$ This very high intensity source was used with a condensing lens system. a 460-nm peak interference filter 1 Baird Atomic B 3 with a $20-\mathrm{nm}$ bandwirth at half-peak trankmision, and a $750-\mathrm{mm}$ infrared filter. Photoreactivation was carried out with a sawyer slide projector utilizing a .500 W quartz iodine lamp and an additional lens to reduce the field size. An interference filter (Baird Atomic B 3) was used to isolate the spectral region between 415 and $445 \mathrm{~nm}$.

Irraliane mestsurements in the near [V and visible 
ranges were made with a YsI-Kettering radiometer. The far UV was measured with a General Elcetric germicidal meter. Both energy-measuring devices were calibrated against a Schwarz vacuum thermopile which had been calibrated against a National Bureau of standards lamp.

The irradiation vessels were quartz or Pyrex tubes with an internal diameter of $1 \mathrm{~cm}$. A capillary tube war affixed to the bottom to provide stirring and aeration (or anoxia) by hubbling air (or nitrogen) through the suspension. The vessel used in the near UV photoreactivation experiment was equipped with a water jacket to maintain at temperature below the ambient. Cell suspensions, during irradiation, were maintained at either 0 to $2^{\circ} \mathrm{C}$ or 24 to $26^{\circ} \mathrm{C}$.

Dose-survival curves are approximately described by the equation:

$$
S=1-\left(1-e^{-l o b}\right)^{n}
$$

where $S$ is the surviving fraction, $D$ is the dose in erg $\mathrm{mm}^{-2} \mathrm{sec}^{-1}, l$ is the inactivation constant in units of (erg mm-2)-1, and $n$ is the "shoulder" ronstant or extrapolation ralue.

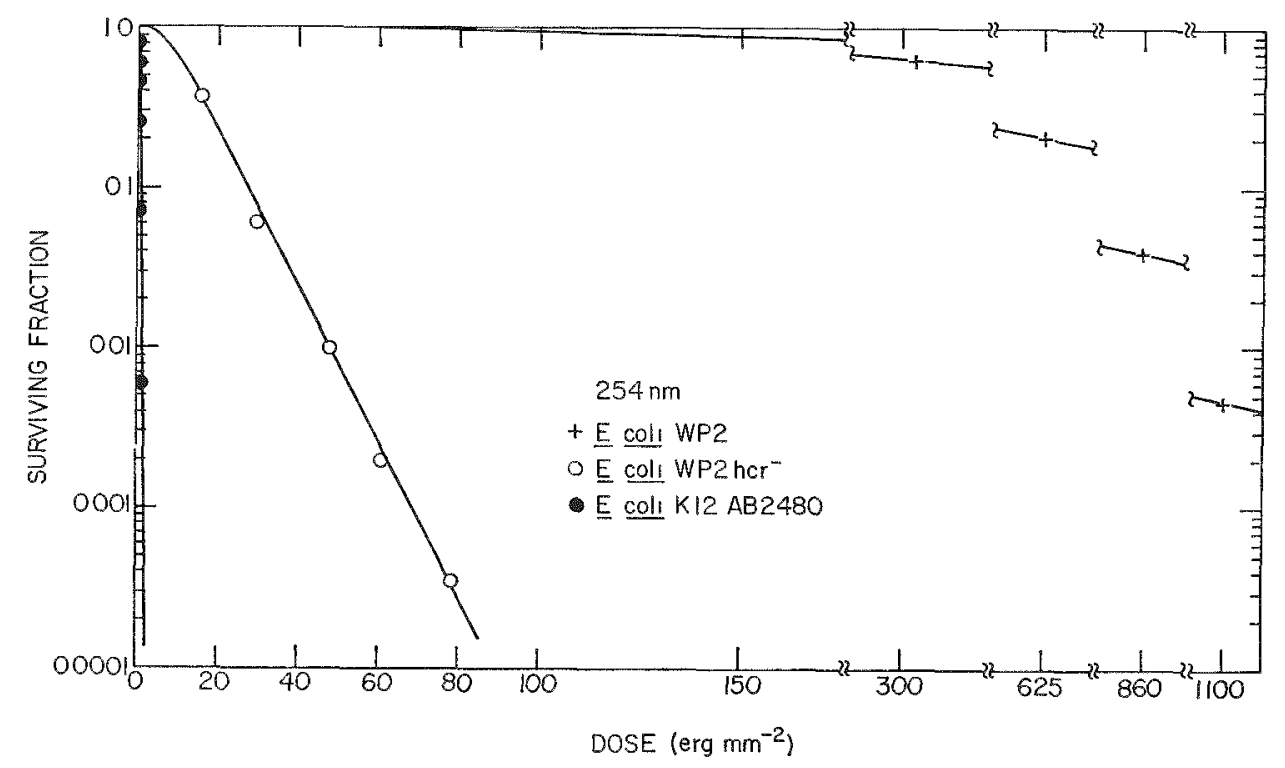

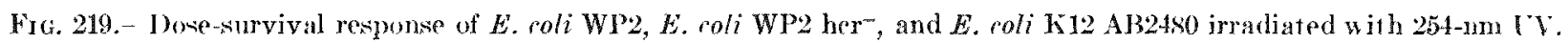

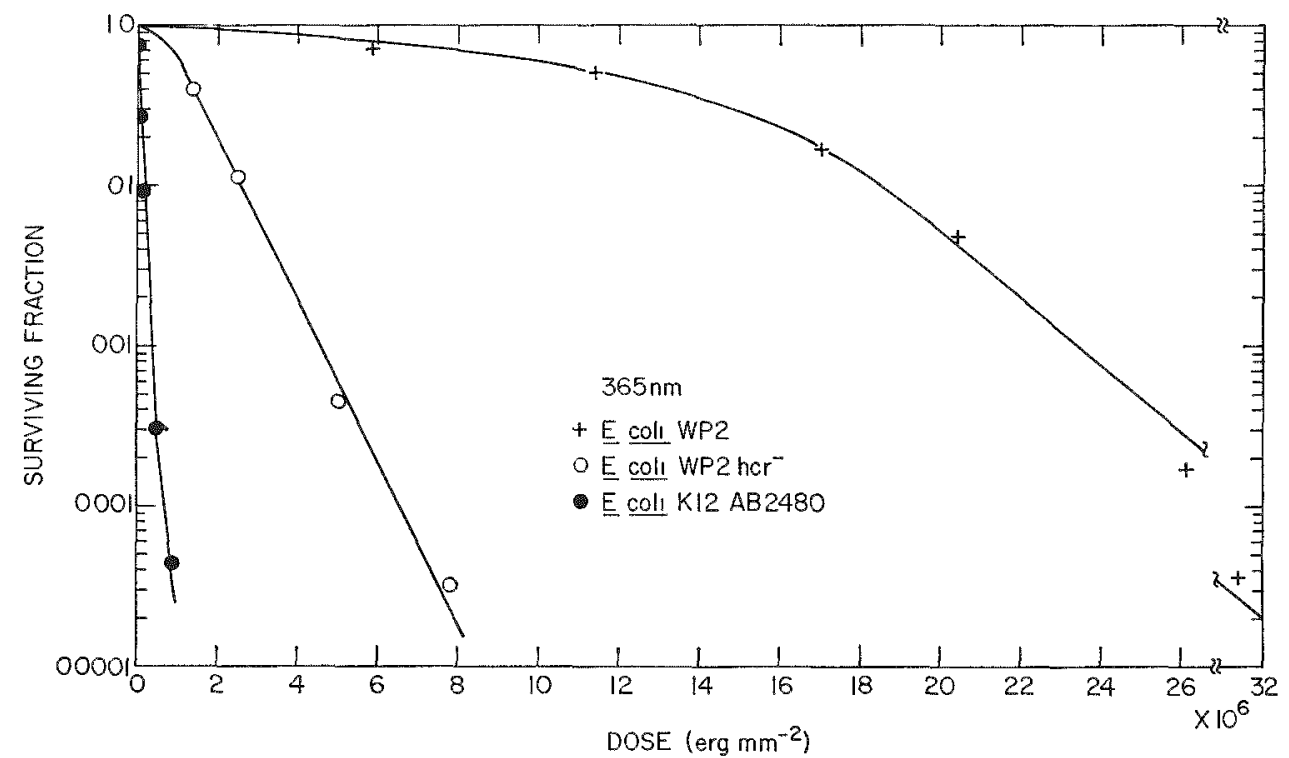

Fig. 220.- Dose-survival response of $E$. coli WP'2, $E$. roli WP2 her-, and $E$. coli $\mathrm{K} 12 \mathrm{Al} 2480$ irradiated with $365-\mathrm{nm}$ [ V. 
PRoriks REPORT

Done-response curver were made for $E$. roli K12 AB2480, $E$. coli $\mathrm{WP}^{\prime}$ and $E$. coli WP2 her- at three wavelengths: $254 \mathrm{~nm}$ (Figure 2191, $365 \mathrm{~nm}$ (Figure 220), and 460 $\mathrm{nm}$ (Figure 2211. Thene wate-

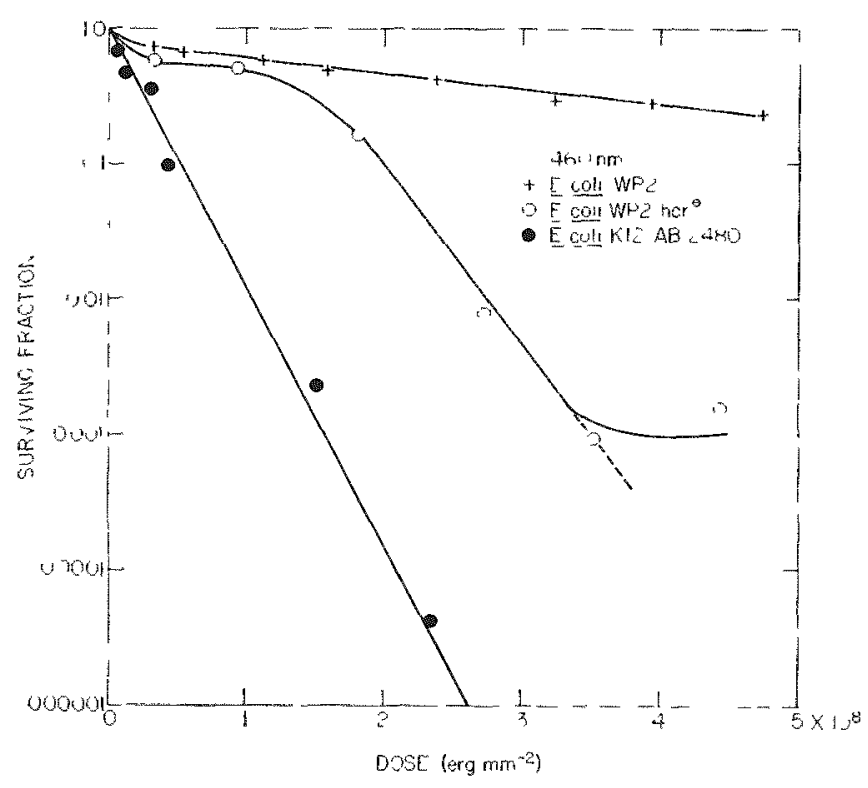

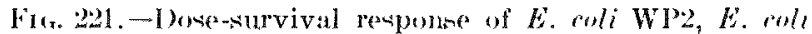
WP' her and $E$. coll K12 AB2480 irradiated with $460 \mathrm{~nm}$ vivible light. length- were chosen beteane they represent arailable band in the far $\mathrm{CV}$, near $\mathrm{CT}$, and vinible light neectrum. The pattern of semitivity appeared to be qualitatively similar at the three wavelengths among thene. -train that differ in excision repair and recombination repair capability. It is -ignificant that the curve - hape of $E$. coli K12 AB2480 remained a simple exponential at all three warelengths. $E$. coli $11 \mathrm{P} 2 \mathrm{re-}$ tained the same shoulder size $i n=200$ to 400$)$ at $254 \mathrm{~nm}$ and $365 \mathrm{~nm}$. At $460 \mathrm{~nm}$. the dat do not permit rompletion of the curve. The orerall semsitivity rhanged $b y$ a factor of more than one million from $254 \mathrm{~nm}$ to $460 \mathrm{~nm}$. $E$. coli IVP2 her showed a small shoulder $(n=1.5$ to 3.01 at $2.34 \mathrm{~mm}$ and $36.5 \mathrm{~nm}$. At $460 \mathrm{~nm}$, the shoulder size increaned to an $n$ of 1.50 .

Although the sensitivity pattern is similar among the three strains at the thres wavelength ranges, the relative spread of sensitivitie among the three strain in greater at $254 \mathrm{~mm}$, decrea-ing considerably at $36.5 \mathrm{~nm}$ and $460 \mathrm{~mm}$. The relative energy level required to obtain thres $\log _{10}$ eyclem of inactivation of E. coli K12 AB2480 at the thres warelengthe are extremely wide. For 2.54-nm $\mathrm{C}^{\mathrm{T}} \mathrm{V}$. lem than $2 \mathrm{erg}$ mm-" are repuired for 0.001 survival. For 36 ñ-nm $[Y$, approximately $5 \times 10^{5} \mathrm{erg} \mathrm{mm}^{-2}$ and for 460 -nm vinible light approximately $1.5 \times 10^{4}$ urg $\mathrm{mm}^{-2}$ are required to achiere 0.001 survival. This is a factor of

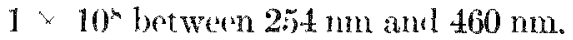

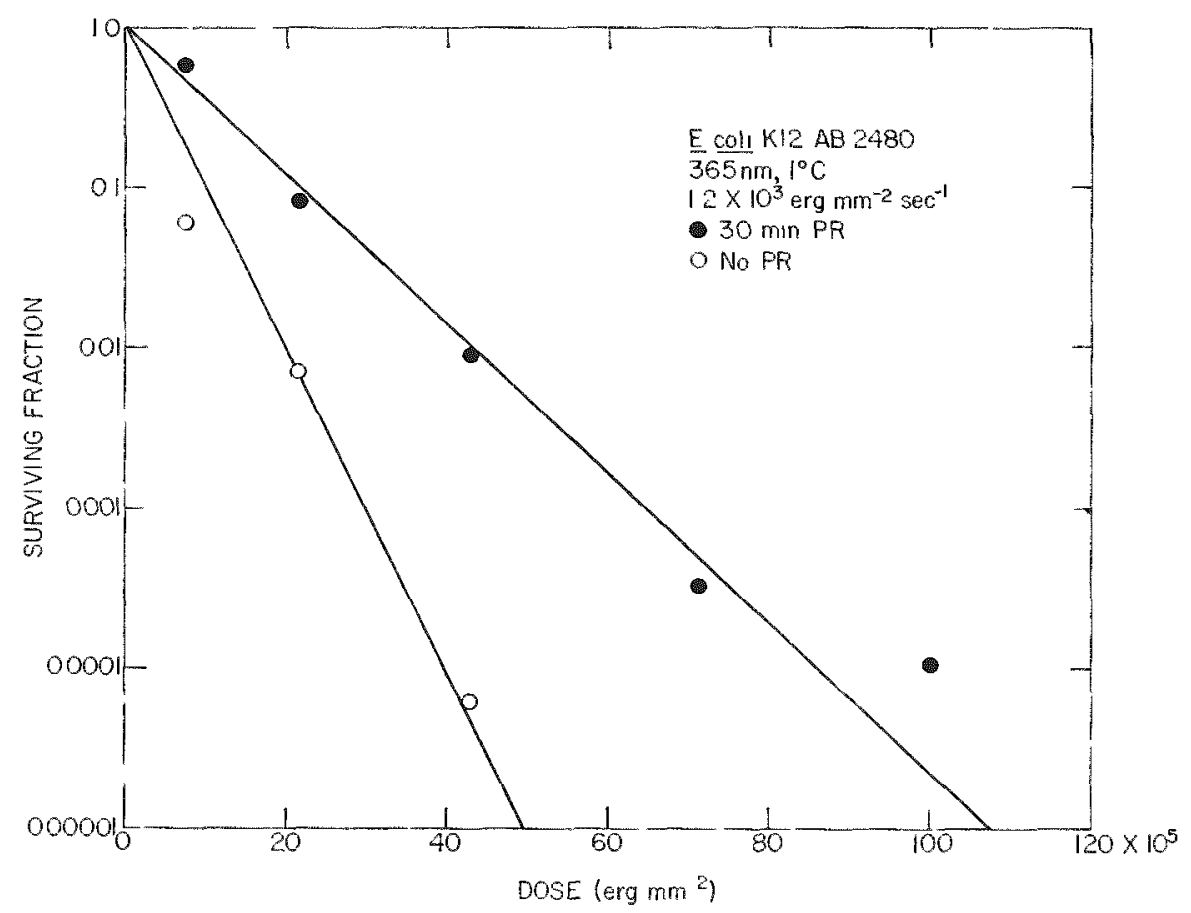

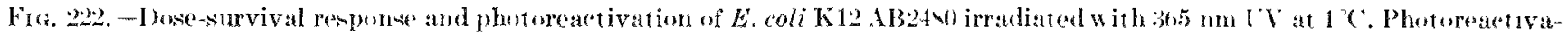
tion, 200 erg $\mathrm{nm}^{-2} \sec ^{-1}$. 


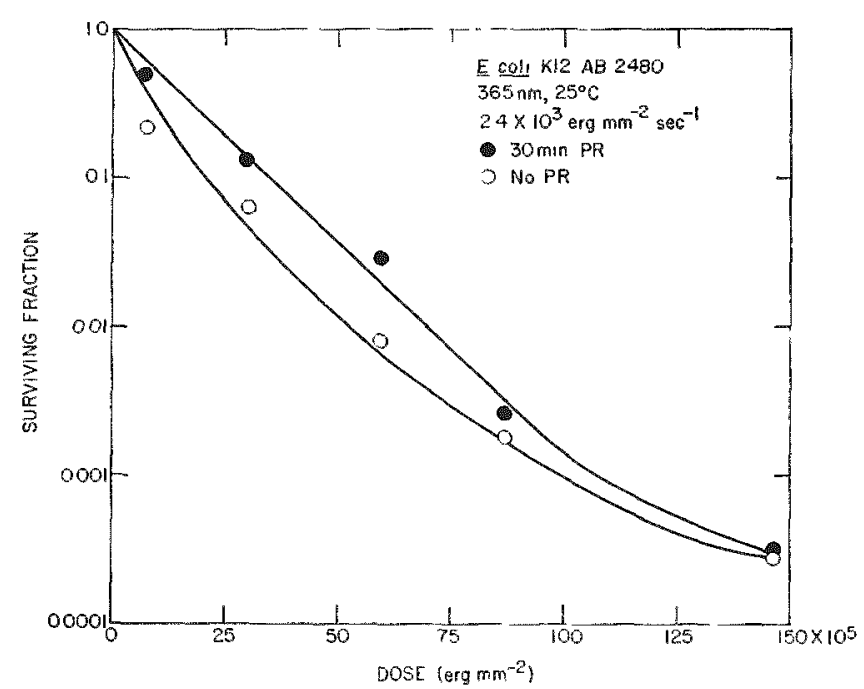

Fin. 223.- Done survival respunse and photoreactivation of

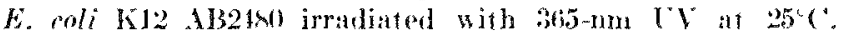
Photoreactivation, 200 erg $m m^{-2}$ sepe-

The effect of photoreativation on dumage in $E$. ali K12 AB2480 caused by near [Y $136.5 \mathrm{~mm}$ is shown to be highly significant after inactivation at $1^{\circ} \mathrm{C}^{4}$ (Figure 222), but only a small effect is seen at $25^{\circ} \mathrm{C}^{\circ}$ ( Figure 2231 . The damage is partially reversible with 30 -min exposure to $430 \pm 10 \mathrm{~nm}$ light at an irradianee of $200 \mathrm{erg}$ nmm $=$ sec ${ }^{-1}$ after inactivation

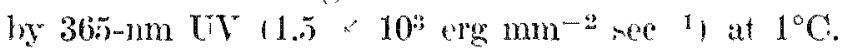
The photoreactivable sector is approximately 0.5 . Alowe the saturation irradiance for photoreativation, the $Q_{10}$ is 2.5.) The time rerpired for complete photoreactivation, at $25^{\circ} \mathrm{C}$, above cituration irradiance, is 8 min..$^{\prime \prime}$ At $1^{\circ} \mathrm{C}^{\prime}$. complete photoreactivation recuires about $90 \mathrm{~min}$. A inactivation at the highent irradiance available at $365 \mathrm{~nm}\left(1.5 \times 10^{8}\right.$ (rg $\left.\mathrm{mm}{ }^{2} \mathrm{sec}^{-1}\right)$ requires approximately $10 \mathrm{~min}$ per $\log _{11}$ cycle, it is revident that at 25c( photoreativation occurring concomitantly with inactivation would he almost complete. Therefore, very little effect would ocesur on -ubequent expo-ure to $430-1 m$ light. However, inactivation by $365-\mathrm{mm}$ IV at $1^{\circ} \mathrm{C}$ would resule in much les concomitant photoresoration rewalting in a much grater photoratstivation hy $430 \mathrm{~nm}$ light. Even so, fome photoreactiration does oecur at $1^{\circ} \mathrm{C}$, making it likely that the photoreartivable rector of 0.5 is an underestimate of the damage that can be reverned by visible light. The photoreactivable sector in $E$. coli $\mathrm{K} 12$ Al32480 after inactivation by 254-nm UV is 0.82 .

\section{COACLISION}

The greatly increased sensitivity of $E$. coli $W \mathrm{P}^{2} 2$ her and $E$. coli K12 AB2480 to 36.5-nm (iv sugest that there is a major involvement of lesions that can be repaired by both the excision repair system and the recombination repair process in the inactiration of $E$. coll by near $U$. The photorereral of $36.5-11 m$ damage implicaten pyrimidine dimers in IDNA as a major lathal lesion induced by this watelength.

The nature of lethal lesions produced by $460-\mathrm{nm}$ light is not entablished by thene results. The increased semsitivity of $E$. coli K12 \B2480 to $460-\mathrm{nm}$ light, a strain deficient in both excision repair and recombination repair, indicates that damage to DNA that can be renaired by normal -trains occurs in this strain. Thene results do not eliminate membrane damage as a major component in the lethal effect of visible light, at leat in certain strains. (s)

\section{REFLRENCES}

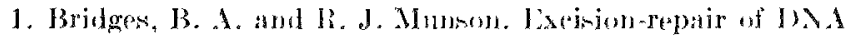

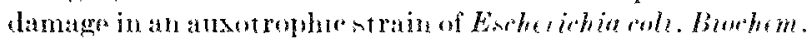

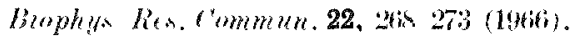

2. Zalle, M. R. and A. Ilollateder Kifecto of radiation on batetoria Radialom Biology, La. A. Hollaphder. Meritan-Hill, Jew York, 195\%, pp :36. -130.

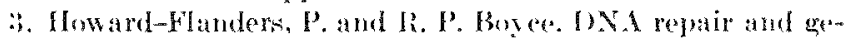
netie recombination studies on mutanto of Escherithat roh

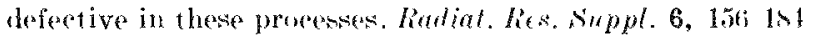
(19aiti).

4. Webb, LR. B, and M. M. Malina. Mutagenes is in Eorhe he hin mil by visible light. si it no 156, $1101110 \mathrm{~s}$ (196it).

5. Webb, R. B. and J. K. Lareua, Gygen dependene and repair of lethal affects of near ultavioles and visilhe light. Photon hem. Photobiol., in prasm.

ti. Labuim, D. A., J. R. Lorend, and W. J. Lisler, Jr. Hirk intersits vapos are lamp for hiolugieal researeh. This ren port.

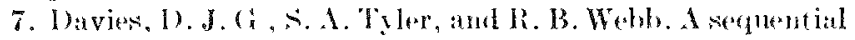
repair model of photoreatetivation in bateteria. Photom them. Photohiol, in press.

s. Mathen, M. M. and W. Li, sistrom. The funetion of the

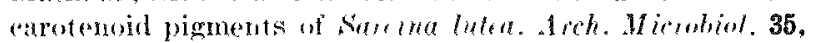
$189-115(1960)$. 

AND VISIBLE LIGHT ON CELLS

\author{
John R. Lorenz and Robert B. Webb
}

\section{PTRPOSE AND MFTHOD,}

Lethal and mutagenic rffects of long warelength ultraviolet light (CV) and visible light, with no added sensitizers, have been reported and studied by many workers; this work has been thoroughly reviewed. (1-3) The applied work in this area has proved both interesting and fruitful, particularly in the area of human dixtess associated with photosensitization le.s., xeroderma pigmentosum, porphrioia, crythema, and posibly, skin cancer). ${ }^{1,3}$, Recent hate research in this fiesd has insolved aftempts to determine the mechanisms for photosensitized mutations(5.6) and lethality.(7-10)

Our study was undertaken to continue previous rem search on the determination of the ehromophore, the lesions produed, and the pole of $1 \mathrm{NA}$ repair -y-tems in the inativation of $E$. coli by variou warelength of long rl and risible light."s)

Escherichir coli strains $1 \mathrm{~T}^{2}, \mathrm{WP}^{\mathrm{P}}$ her , $\mathrm{B}, \mathrm{Bphr}$, and K12 AB2480 were Uned in thest studien. Stationary phane cultures were produced by streaking the required strain on nutrient agar (Difeo) slants and acrobically incubating them for 48 he at $37^{\circ} \mathrm{C}$. A loop of surface growth was suspended in MI9 salt -olution without centrifugation and dilutel approximately 1:10 in $\mathbf{1 1 9}$ nedium to produes a sumension of approximately $10^{7}$ alls anl for expoure to raliation. log phase cultures were obtained direetly from a Som phelostat, ${ }^{111}$ which rontained exponentially prowing cells of the proper struin. typically growing at a conrentration of $2 \times 10^{7} \mathrm{ml}$, on $\mathrm{N9}$ salts-glucose medium at $27^{\circ} \mathrm{C}$. A typical growth rate would be 0.67 generation per homr. This supension of growing cells typically was irradiated withont washing or dilution. All suben-ions were mantained helow $27^{\circ} \mathrm{C}$ during irradiation ; occasionally, if neresary, an air blower was used for cooling.

Typically, 0.1-ml samples were taken periodioally during the irradiations, and $0.2 \mathrm{ml}$ of appropriately diluted surpensions were preat on each of four nutrient agar plates. Surviral is dofined as the ability of a cell to generate a vinible coliform colony after its incubation for $48 \mathrm{hr}$ at $37^{\circ} \mathrm{C}^{\circ}$ or $72 \mathrm{hr}$ at $25^{\circ} \mathrm{C}$. Vessels for irradiation of cultures were (fuartz for $254-\mathrm{nm}$ UT) or Pyrex (for all other wavelengths) tubes with 1side diameters of 1 cm. A rapillary tube was fused into the bottom of the tubes for the passige of hyIrated air for acobic runs or prepurified $\mathrm{N}_{2}$ ( Mathe- son (ats Products) for anaerobic runs. Cnirradiated controls were periodically run to test for death in mirradiated cultures. No control series titer was altered -ignificantly.

Short wavelength $\mathrm{CT}$, at $2.54 \mathrm{~nm}$, was supplied with a low pressure mercury lamp (Penray SC-11) with a filter to reduce the long T'T and visible output, so that $95 \%$ of the output was at $254 \mathrm{~nm} .313$ and $365 \mathrm{~mm}$ were protueed by the main line output of a 200 -wate super presure mercury lamp in a nonochromator (Batush and Lomb IIigh Intensity). One source of risible light was a quartz-iodine incandescent lamp, ung commercial side projector optics sawytr 707(2). Two simple lenas converged the beam to a uniform yot of 1 "min. The most rersatile soures of lone (T and visible light is a metal rapor are lamy) and power supply 1 ieneral Electrio) with a specially designed holder that produces an interse $1 \mathrm{~cm}^{2}$ spot of hroad yestrum light."12, With either visible light soures. the desired wavelengths were pared, and the others were rejected by ues of rombinations of $2^{\prime \prime}$ by $2^{\prime \prime}$ interference or aborption filters (Baird-Atomic, Gptirs Terhnology, and Corningl.

Irravliances below $1000 \mathrm{erg}^{\mathrm{m}} \mathrm{mm}^{-2} \mathrm{sec}^{-1}$ wers neasured with a schwarz vacuum thermopilo, standarlizel against a National Bureau of Standards lamp. The thermopile's output was neasured with a Frithley 1.5013 microvolt ammeter. Irradiances above 1000

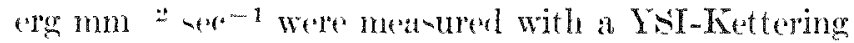
Model 6.5 radiometer calibrated against the schwark thermopile.

PRO,REM REMUR'

oxyen definitely appeatre neessary for damage to

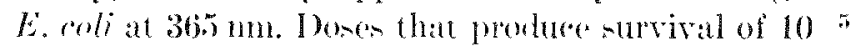
with air hubhling, typically produce less than $50 \%$ lethality when the "ells are mbbled with nitrogen."

The excision-repair -yintem appear to rearlily rerepe damage to rell- raued by 365 - $11 \mathrm{~m}$ irradiation. $E$. coli $11 \mathrm{P}^{\mathrm{p}} \mathrm{h}$ her , which differs from the will type WP2 only in the lack of the enzyme reyponsible for initiation of excision repair. is sereral times more sen-itive than WP2. ${ }^{13}$, Licuid holding recovery, a phenomenon presumably auced by acision repair during extended holding of irradiated susperesions in tubes before they are plated, has been demontrated in survival eurves of $\log$ phase cultures of $E$. coli $\mathrm{B} \quad \mathrm{r}$ hy Peak. "1"' Gxtensive trials to detect liquid holding re- 
covery after 365 -nm $\mathrm{UV}$ irradiation of stationary phase $E$. coli WP2 have fuiled in this laboratory. Peak also found an unexplained sensitization of $\log$ phase $E$. coli WP2 and $\mathrm{B} / \mathrm{r}$ to $365-\mathrm{nm}$ irradiation provided by acriflavine and caffeine. ${ }^{(10.13)}$

The recombination repair system, which also repairs DNA damage, appears to repair damage cauned by 365-nm irrudiation. Stationary phase cultures of $E$. coli strain K12AB2480, a mutant that cannot accomplish either excicion or recombination repair, are much more sensitive to inactivation than stationary phase $E$. coli WP2 her-, which is only defertive in excision repair. ${ }^{(14)}$

The third type of repair system that repairs damage to DNA, photoreactivation, appears to be active in repairing damage caused by $365-\mathrm{nm}$ irradiation. The 365-nm UV, which inactivates cells, should simultaneously photoreactivate them, beause 365 -nm light is well within the wavelength range that produces photoreactivation (330 to $440 \mathrm{~nm}$ ). Rexults secm to indicate, however, that a very small amount of photoreactivation will take place in $E$. coli IIP2 her that has been previously inartivated with $365-11 m$ light.

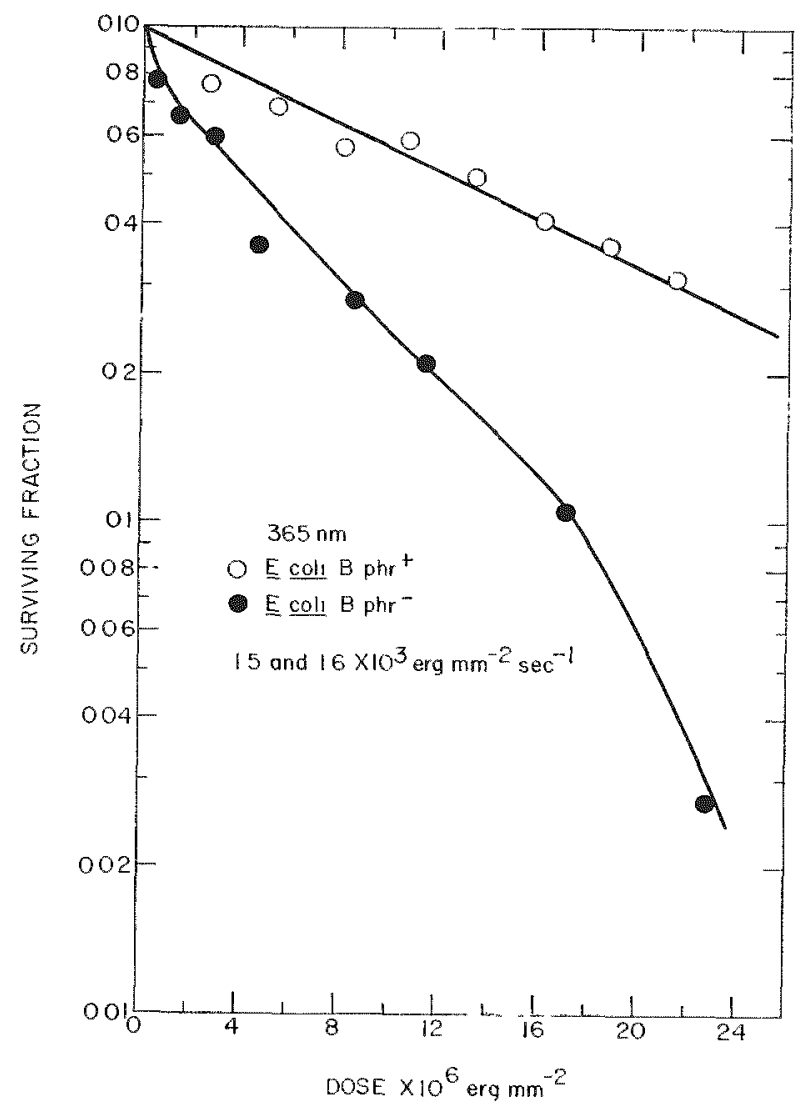

Fro. 224. - Survival of stationary phase $E$. eroli strains B (wild type) and Bphr (a photoreartivationless mutant) after irradiation with 305-nm light.
While the effect is not large, in rirtually every casce survival was slightly higher in -amples that were photoreactivated after irradiation than in those held and plated directly.

The effect is much more pronounced when stationary phate cultures of $E$. coli $B$ and Bphr- are inactivated, photoreactivated, and the effects of each compared. Bphr- differs from the wild type $B$ in that it appears incapable of photoreactivation. Survival curves, comparing the two, show that Bphr- is two or three times more sen it ive than B (Figure 224). Were it not that this amount of concurrent photoreactivation apparently takes place in all those strains which are capable of it, $36.5 \mathrm{~nm}$ would probably appear to be two or three times more lethal than it now appears to be.

Photoreativation is the one DNA repair system left wholly intact in $E$. coli K12AB2480. These cellhave considerably greater survival after inactivation with 365 -nm light at $1^{\circ}{ }^{\circ}$ when they are illuminated afterward with 430 -nm visible light. ${ }^{\text {11 })}$

\section{Lethality uith Visible Light}

Most of the damage prolued by broad spectrum vinible light 1390 to $750 \mathrm{~nm}$ i and narrow band $460-\mathrm{nm}$ light appears to be oxygen dependent. Doses of 390 to $750 \mathrm{~mm}$ visible light that produce a survival value of $10^{-4}$ in aerated sumpensions of $E$. coli WP2 her-. produce survival values greater than 0.9 in anoxic surpensions.

The excision-repair sytem appears to repair at leat some of the damage produced hy 390- to 750-nm and 460-nm visible light. Stationary phase $E$. coli WP2 her- (exeision-rep)air efeficient) is slightly. but persistently, more sensitive to 390-to $750-\mathrm{nm}$ irradiation than the repair suffeient strain $E$. coli WP2. stationary phase WP2 hor is approximately ten times more enenitive than stationary phase IIP2 when it is irradiated with $460-\mathrm{nm}$ light. In response to the ame irradiation, log phase WP2 and WP2 hershowed approximately expal semsitivities; both were approximately as ensitive as the previously mentioned stationary phase WP2 her-. When resistant stationary phase WP2 cells were alwo plated on nutrient agar plates with added acriflavine (British Drug Houses. Ltal., final concentration $5 \mu \mathrm{g}$, $\mathrm{ml}$ ), they proved to be about ten timess ats sensitive, falling into the sume range of sensitivities as stationary phase WP2 her- and log phase IIP2 and WP2 her- HFig- $^{2}$ ure 225). Acridine dyese (e.g. arriflavine) are known to inhibit the excision repair yystem. ${ }^{13}$ )

Recombination repair appears to revere damage produced at $460 \mathrm{~mm}$. At this wavelength, stationary phane $E$. coll K12AB2480 in coniderably more sent- 


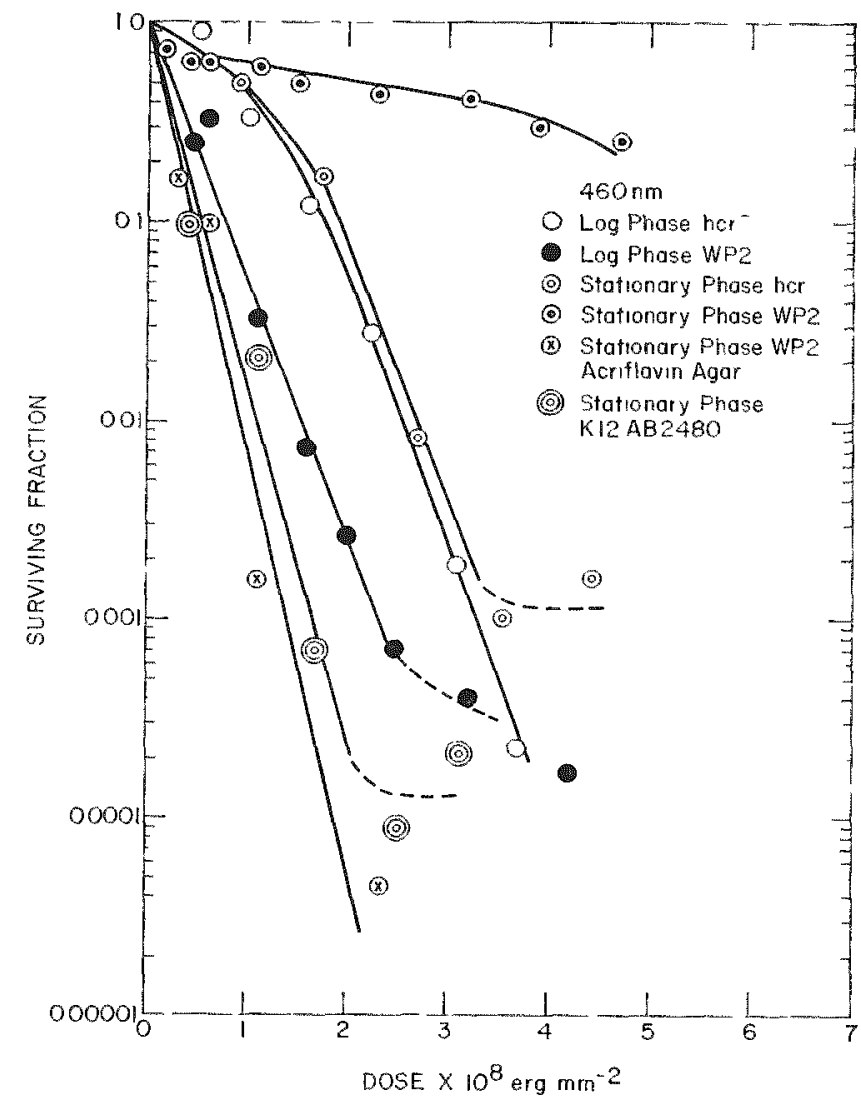

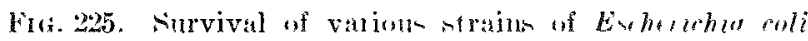
after irradiation with fol nm vishle light Bandwidth at half peak is $20 \mathrm{~mm}$. Typiral incirlent rradiane is $1 \times 10^{4} \mathrm{erg}^{\mathrm{m} m \mathrm{~m}^{-2}}$ $\sec ^{-1}$.

sitive than stationary phane E. coli WP2 her-. Alno, the K12AB2480 survival eurve has no choulder. as has the stationary phase WVP2 her-. Thewe strains ensentially differ in that K12AB2480 cannot accomplish recombination repair. while WP2 her- can (Figure 225).

It in not known whether damage produced by tisible light wavelength - can be repaired with the photoreactivation system. One problem encountered is similar to that at $365 \mathrm{~nm}$ : visible wavelengths that are within the range offective for photoreactivation (about 330 to $440 \mathrm{~nm}$ ) should photoreactivate the cell concomitantly with the inactivation produced. One approach will be to attempt to photoreactivate damage produced by visible wavelengths that are ineffective in photoreactivation, ie., above $460 \mathrm{~nm}$. Another approach which will be utilized u-es the romparison between lothality of a wild type and its photoreactivationless mutant.

\section{Letion spectrum for Lethality}

A preliminary action spectrum (Figure 226) has been obtained for lethality produced with stationary phane colturen of $E$. coli WP2 her-. The wavelengthe uned are $230.240,250,2 \pi 4,260,270,280,290,300,313$, $36.5,410,460,510.500$ to 750 , and 390 to $7.50 \mathrm{nan-}$ ometer. Lecthality is meanured in terms of the "inactivation con-tant," the -lope of the final. linear portion of each survival curve. The unit involved is (erg $m m 2^{-1}$. It can be eeen that sensitivity peaks near $265 \mathrm{~nm}$, and is relatively high. but is falling at $313 \mathrm{~nm}$. Inartivation at these wavelengths parallel the direct athorption of wath wavelength by the cell'- DNI. with oxyenen-independent formation of pyrimidine limer.

No direct abontion by DNA has been demonstrated rither for $365 \mathrm{~nm}$ or higher warelength. A large amount of the repairable damage produced $b y$ these wavelength, however, can be indirectly shown to be IDNA damage, by the une of various repairdefieient mutant. Furthermore, the damage at these longer wavelength is, to a large extent, oxygen dependent, a - hown by the dotted, anoxic curve in Figure 226. Thum, oxygen appears to be escential in the utilization of longer wavelength mergy by a claromophore which, in turn, effects the DNA damage.

DNA damage at 254, 313 , and 365 nm can be repaired by photoreactivation, a process that is quite -pecifie for the repair of pyrimidine dimers.

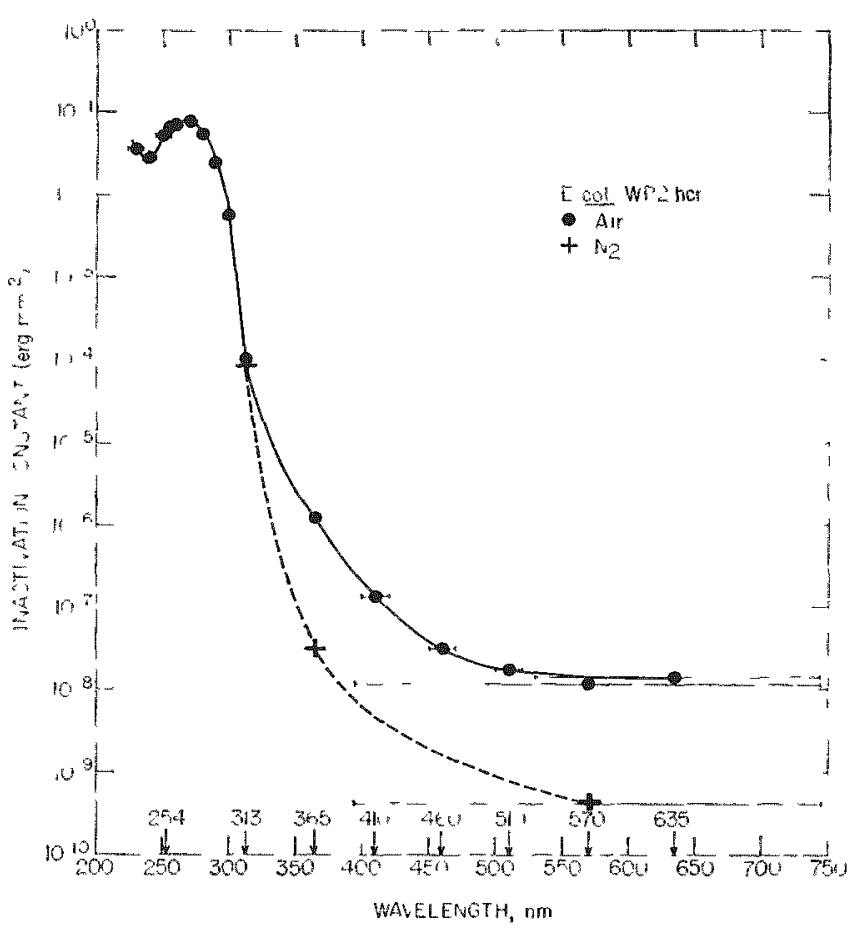

Fitr. 226, - Inactivation eonstant plot ted against wavelength for inactivation of Eshereha cols st rain WP2 her with aerohic and anarobic (dotted) irradiation. Brackets indirate width of wavelengt h hand used. 
CONTLGION

Repairable DNA damage of various repair-deficient mutants of $E$. coli was demonstrated for all warelengths studied. At warelengths of $365 \mathrm{~nm}$ and above. this damage is indirect, beatuse no absorption of these wavelengths in I)SA has bean demonstrated. Most tamizge at these longer wavelengths is also oxygen Iependent. The lata are consistent with an oxygenlependert mechanism in which an intermediate chromophore absorbs light at the longer wavelength, tram ferring the energy to DNA, forming repairable DNil damage:

The nature of the lesion or lesions produred is not known. but at latet some of the repairable damage producerl at 365 nm can be demonstrated by indirect meths to be the production of pyrimidine dimeers.

\section{RFH ERTANCES}

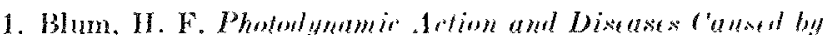
Light. Princeton ["niversity Press, Princeton. N. J., 1940.

2. Zelle, M. R. and A. Holluender. Fffeets of radiation on bate teria. Radiation Biology, Ed. A. Hollaender. Mer iraw-Hill, New York, 1955, pp. 36is $4: 00$.

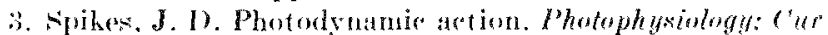

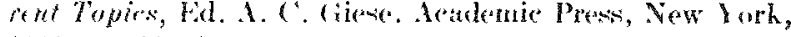
1968, pp. 3364.

4. Blum, H. F. ("areinogeresis by Tltraviolte Light, Princeton Iniversity l'ress, I'rineetom, N. J.. 1959.

5. Webh, R. B. and M. M. Malina. Mutagenesis in kischerichia cali by visible light. As some 156, 11011105 (1967).

6. Webk, R. B. and M. M. Malina. Mutagenie effects of near ultraviolet and visible radiant enerey on contimuous anl tures of $E$ socherichie enti. To be published.

7. Hopenz, J. IR. and R. B. Wobb. Inactivation of $E$. whli bs irradiation with :bes um light. Wirobial Genties Bulletin $30,12(1969)$.

8. Welh, R. B. and J. R. Lorenz. Oxygendependentes and repair of lethal efferes of near ult raviolet and visible light. Photiothem. Photolinh., in press.

9. Webb, R. B. and J. R. Luren\%. Lethal efferets of long wave length ultraviolet and visible light on cells. Argome Na tional laboratory Division of Biologieal and Medical Rereareh Anmual Report, 1646. ANI -75\%5, pp. 231235.

10. Peak, M. J. Personal communiration.

11. Kisler, W. J., and IR. B. Webh. Hectronically eontolled cont inuous eult ure deviee. $1 \mathrm{ppl}$. M icrobiol. 16, 1375 (1968).

12. Iathuis, I). A., J. R. Loren/, and W. J. Fisler, Jr. Migh intensity vapor are lamp for biologieal research. This report.

13. Setlow, R. B. Physical changes and mutagenesis. $J$. C'fll. ("ornp. Phiskiol., (Supp) 11 64, 51 68 (1964).

14. Brown, M. S. and R. B. Wekb. Heffects of ultraviolet and visible light on a multiple repair-deficient strain of Eseher ir hire coli. This report.

\section{A SEQUENTIAL REPAIR MODEL OF PHOTOREACTIVATION IN BACTERIA*}

Darid J. G. Davies, S'ylramus. A. Tyler, and Robert B. W"ebb

Fineties of photoreartivation were studied in $k$. coll WP2 her-, a strain defiedent in dark repair. Cells in aqueous sumpension were subjected to TV irrutiation, then exposed to photoreactivating light for different period. Survival cures, with samples at a minimum of six UV doses, were obtained at several periods of photoreatetivation ranging from zero to maximum. The surving fractions do not conform to a dose-reduction molel, but instear, they fit a "sequential repair"

* Abstract of paper to be published in Photochemistry and Photobiology.

fon leave of ahenee from soheol of Phamacy, Bath Iniversity of Trehnology, Bath, England. model that aswumes as a limiting condition that the number of active enzyme molecules is small. The motel used assumed: if a single enzyme molecule is active at anv one time: and 2 ) inactivating events are nullified consecutively around the DNA molecule. The mathematic of the model is derived and presented. Photoreactivation is attributed to the action of two procesies: 1) A photochemical process that is rate limiting below 1000 ergs $\mathrm{mm}^{-2}$ sec $^{-1}$ was measured at a photoreactivating irradiance of $60 \mathrm{ergs} \mathrm{nm}$ sec ". This has a rate constant of $5 \times 10^{-5}$ "erent." erg ${ }^{-1} \mathrm{~mm}^{-3}$. 2) A dark procens, measured at photoreactivating irradianes of $4000 \mathrm{aml} 6000 \mathrm{ergn} \mathrm{nmm}^{-2}$ $\mathrm{sec}^{-1}$. has a rate const ant of 2.2 "events" min"- 


\section{IGH INTENSITY VAPOR ARC LAMP FOR BIOLOGICAL RESEARCH}

Domald 1. LeBuis, John R. Lorens, and William .J. Eisles, It.

PLRPO- AND METHOD

Lethal effect of long wavelength ultraviolet light and visible light without external nen-itizers have recently been -tudied in rariou- -trains of Escherichia coli $\mathrm{B}$ and $\mathrm{B} / \mathrm{r}$. $^{(1-4)}$

Formerly. the mont practical light nouree wan a quartz-iodine lamp utilizing a commercial slide projector optices sytem. The output wan filtered and converged into an intense $1 \mathrm{~cm}^{2}$,pot. Sufficient light was prorided to produce meaningful survival surves u-ing the whole visible speetrum (390 to 750 nanometers). Howerer, denpite many modification optimizing the output, the energy arailable wam not adeguate to obtain a bandwidth narrow enough to produce a meaningful biologieal action spertrum. It was imporible to continue these studies unlew a more intenses souree of broad spectrum risible light wats found.

This report describes a light soure that provides approximately $10^{6}$ ere $\mathrm{mmm}^{-2}$ sec-1 orer the hroad spectrum visble range and permits the continuation of this line of rewearch.

PROARES REPORT

A commercially available light soures and power supply r(central Electrie Co., Nela Park, Clevelamd, Ohio) was adapted for une in biologieal researeh. The lamp is a 300-watt metallie vapor are unit, "designated Mare $300 .^{15}$

Becaue the lamp was developed for commereial projection systems, at completely new lamp holder wats designed that satisfies our experinental requirements and complien with the manufacturer's -pereifications for the lamp. Figure 227 illutrates the lamp and condensing lens mounting and the provi-ion for an adjuntable filter holder anrembly. An air blower (Alodel No. ('C3508, Dynarool Mfg. Co., Tne, Saugerties, New York), located within the enclosure, direets approximately $1,50 \mathrm{ft}^{3}$ min of cool air from the inlet upward across both the front and rear surfaces of the lamp to ensure efficient lamp operation. An air partiele filter is mounted in the inlet to minimize contamination by dust of the lamp and rondeming lens. In adjumtable aperture, corering the air inlet, controls both the air flow through the enclomre and the operating temperature.

The lamp is replaced simply by -liding it into a ack above the blower, and it - location is fised hor-

* Approsimate coost: $\$ 2500 \%$.

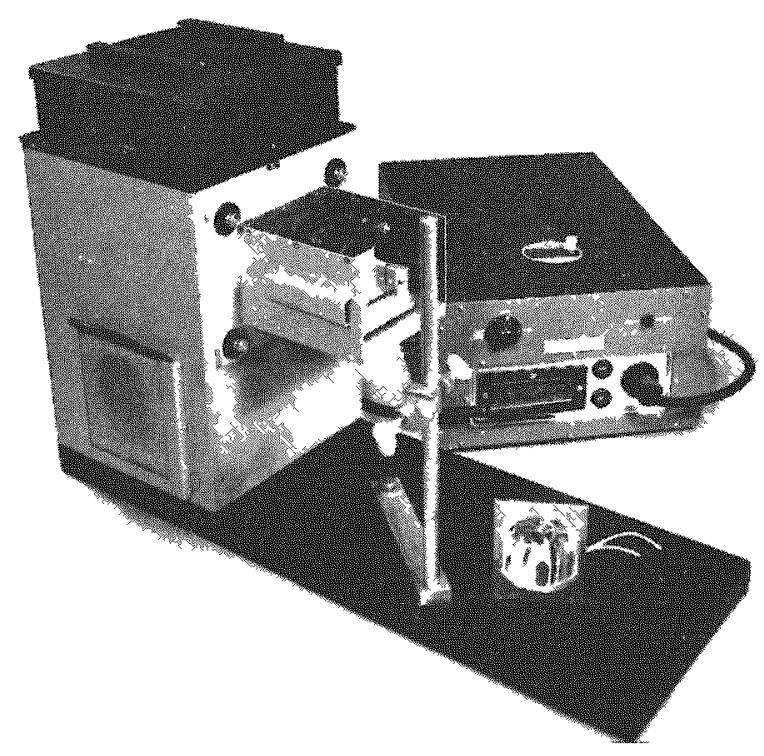

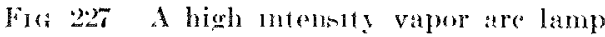

izontally by the track and vertically by it -tops. Lamp forus aljutments are never required.

Standard $2^{\prime \prime}$ by $2^{\prime \prime}$ interference filters are cavily inwerted in direct line with the condenowd light betam. The holder is adjustable to rigidly ponition one or sereral filters in combinations cho-en by the user. The object to be irradiated. for example a barterial culture. is positiones in the path of the condemed and filtered light beam.

The power supply is erpecially designed and -upplied by the manufarturer for une in stantard pro-

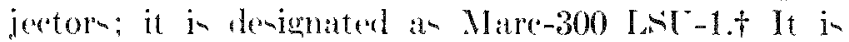
intended for installation in an enclowere and doen not include mounting and wiring of the fores panel and control circuit. The completed power supply, shown in Figure 227, provide electrical afety and adequate ventilation for the power -upply components. Figure 228 is a schematic diagram of the cont rol wiring. Thi circuit include a eries connected fan-lamp -witch that encures operation of the fan before the lamp ignites and continued operation when the lamp is disronnected. A resettable running-time meter arcumulates the total number of hour each lamp is unet. I complete ret of meehanial prints of the rytem is arailable.

The lamp's broal band ri-ible output (approximately $10^{6}$ erg $\mathrm{mm}^{-2}-\mathrm{ec}^{-1}$ in a small spots is a far-

+ Approximate oost $\$ 20000$. 


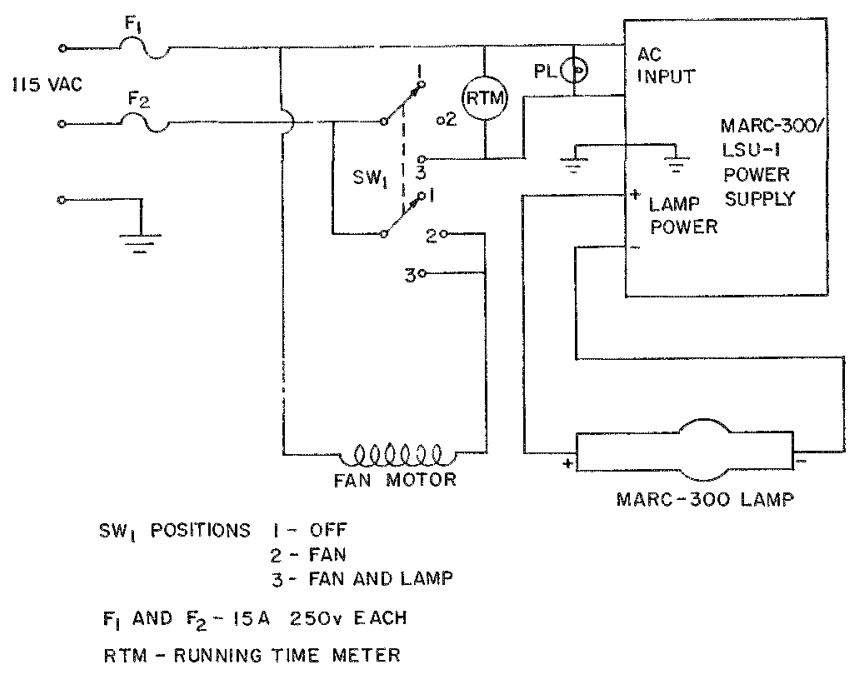

$F_{I}(x .228$. Gehematio diagram of the control cirruit

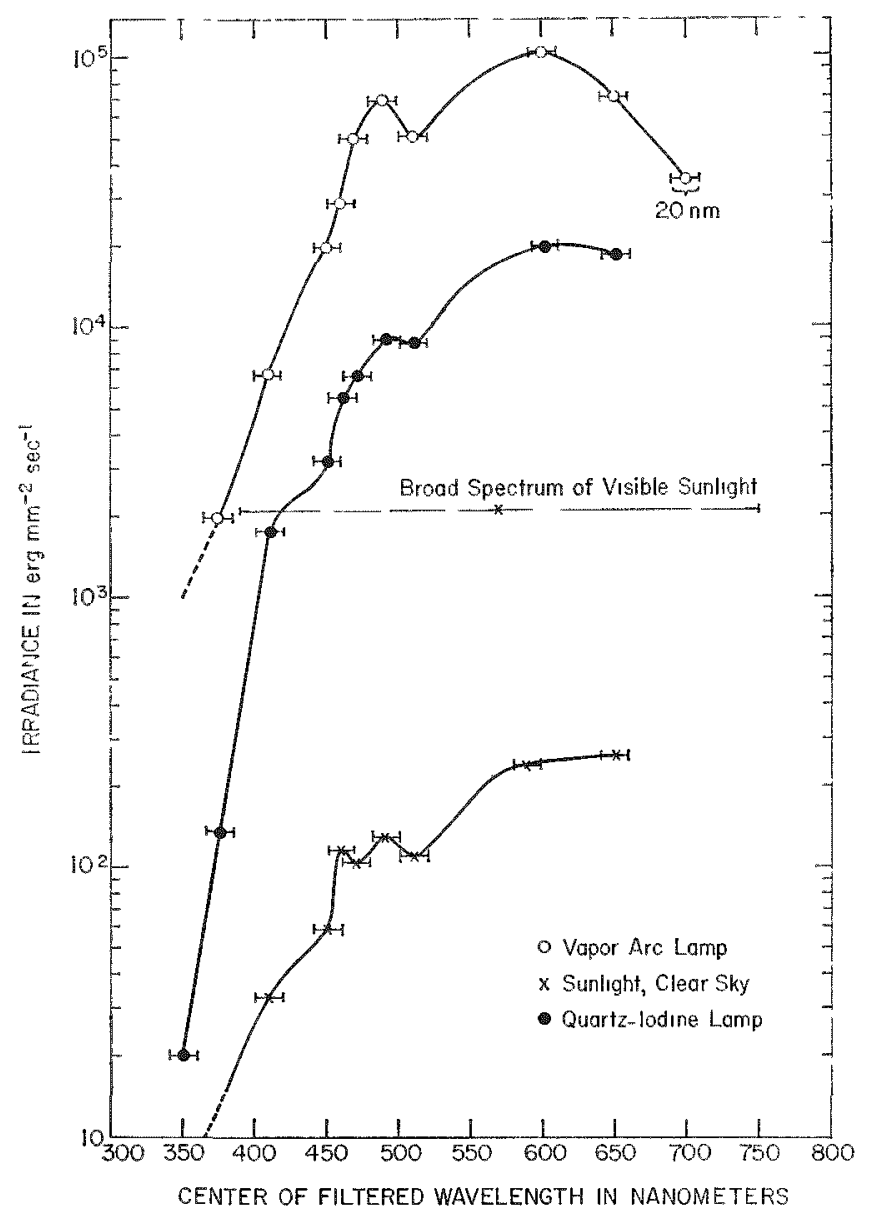

FIG. 229.-Comparison of measured irradiances

tor of 10 higher than the output of the previously used quartz-iodine light source. Figure 229 compares the output of the rapor are lamp with a quartz-iodine limp and direct sunlight over the wavelength range of 350 to $750 \mathrm{~nm}$. The sunlight measurements were made with a Schwarz varuum thermopile (standar ized against a National Bureau of Standard lamp) and a Keithley Model $150 \mathrm{~B}$ mierovolt ammeter. The lamp measurements were made on a standard $1 \mathrm{~cm}^{2}$ spot with a Y'SI-Kettering Norel 6.5 radiometer (-tandardized against the Schwarz thermopile). Ample energy is available from the vapor are source to allow the use of relatively narrow half-band width $(20 \mathrm{~nm})$ interference filters. For example, an irradiance of $7 \times 10^{4} \mathrm{erg}^{\mathrm{mm}-2} \mathrm{sec}^{-1}$ was obtained through an interference filter having a peak transmission of $55 \%$ at $490 \mathrm{~nm}$ and a hand wilth at half-peak transmission of $20 \mathrm{~nm}$. The filters uned were BairlAtomic Type B3 for 350 to $510 \mathrm{~nm}$ and Optics Technology "Varipass" (Net 60 ) for 600 to $750 \mathrm{~nm}$, with a peak transmision that varied from $35 \%$ at $350 \mathrm{~nm}$ to $65 \mathrm{c}_{r}$ at $650 \mathrm{um}$. Wuch of this energy is available in the long UV and blue visible range. "The conventional quartz-iodine lamp has very little output in this region.

\section{CONCLTEION}

The vapor are light source makes possible studies of lethality with near UV and visible light that were imposible in a reasonable exposure time with the quartz-iodine lamp. There is sufficient output to provide a fairly detailed action spectrum in the long UV and risible region; 4 to 5 eycles of bacterial killing are produced.

In addition to the rersatility and high useful output provided at a small fraction of the price of a comparable, commercially available system, the lamp and power supply are simple and hence convenient to operate.

We express our appreciation to Dr. Robert B. Webb for his helpful comments and suggestions. We also thank Mr. William R. Cole of the Central Shops Division, Argonne National Laboratory, for help in the design and construction of the apparatus.

\section{REFERENCES}

1. Wehb, R. B. and J. R. Lorenz. Oxygen dependenee and repair of lethal effects of near ultaviolet and visible lighi. Photorhem. Photobiol., in press.

2. Lorenz, J. R. and R, B. Webb. Lethal effects of long wave Ifength ult raviolet and visible light on cells. This report

3. Lorenz, J. IR. and R. B. Webh. Inactivation of $E$. coli by irradiation with $365 \mathrm{~nm}$ light. Mirrob. Genet. Bull. 30, 12 (1969).

4. Brown, M. S. and R. B. Webb. Fffects of ultraviolet and visible light on a multiple repair-deficient strain of Escherichia coli. This report.

5. Nlomski, S. I., J. ('. Sobieski, J. K. Taillon, and K. II Weber. A new high-brightness projeetion are lighting sy tem. Pror. Nat. Tech. Conf. of the Illuminating Engincering Soe., Minneapolis, Minn., 196ti. Preprint No. 22, Applieations I, pp. 1-fi. 


\section{N X-RAY CRYSTALLOGRAPHIC STUDY OF THE STRUCTURE OF CONCANAVALIN A}

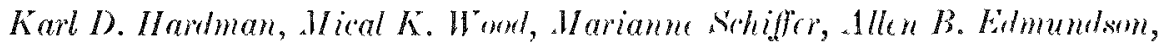

.Madonna E. Hook, Clentom F. Linsworth, and Kathryn R. Ely

PTRPOLE AND MFTHODS

In a program -tarted lant year, "1" we are attempting to solve the $\mathrm{X}-\mathrm{ray}$ cryatallographic - ructure of concanavalin A (Con A). This protein, which wa isolated from jack bean (conaralia ensiformis) bind a number of polynacehariden, including glyoogens, amylopectins, dextrans, and mamans. artive over a pH range of 5 to 7 . Berause ( on A alo bind- the polyaceharides from the surfaren of erythrocyter of varioum specien, it is clansified as a phytom hemagglutinin. It has heen found to -npyrese the im-

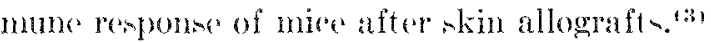

Con A has a molecular weight of $71,000^{\text {t5 }}$ and exist, as a tetramer which has four ery-tallographi"ally exuivalent subunit. (1) The tetrumer can be plit into monomers and dimer by $8 . M$ ureas. and also cau be split into dimers at a $\mathrm{pl}$ of 2.2."1) Con A has been shown to contain two carbohydrate binding ites per tetramer by eruilibrium dialysis measurements with methyl $\alpha$-D-minnopyranoside and methyl $\alpha$-D-glucopyranowide. $\left.{ }^{6}\right)$ Therefore, the binding site munt be tharel between two subunity.

Con I has been reported to rontain two divalent cations per teframer and has been irolated containing three defferent ion, ralciumn, nanganene, and

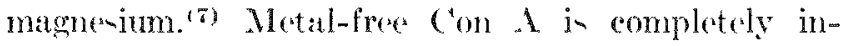
artive, (s) although nothine is currently known about what role the metal play in the binding of the carbohydrate. In addition to any of the three ion previoubly mentioned, artivity can be remtored by introduction of cobalt or zinc.'s) Studien uning disaceharides containing rariou combinations of the mannosyl and glucomyl residues to inhibit dextrun binding by con A have shown that the configurations around $43,(4$ and ( 6 in the hexome unit at the nonreducing end of the polyaceharide chain are predominant factor in it binding yecificity.

We are particularly interented in con A besaune if ha- many propertics which are similar to those found in immunoglobulin- for example, binding a variety of carbohydraten, and havine two binding site per molecule. It is thought, therefore, that determination of the three-dimemsional strueture of thin molecule might erive an insight into the functional structure of antiboly molecules. We are also interested in con-

- rmational changen of the protein molecule which are likely to be induced by the binding of varioum carbohydrate molerule. Because the molecule in made up of identical subunit, it in an excellent model for
-Hudving allosterie affect conformational changes produced when the first binding site becomes occupied. altering the binding potential of the second hinting -ite)

More generally, olving the exystallographic strueture of a protein with then interesting properties -hould help to identify parameters necen-ary for predicting thre-dimensional structure of proteins from anino acid sepuenes.

"The method of solving protrin -tructure involves the ne of at least two heary-atom derivatives that are i-omorphous with the native protein. At prosent, we are involved in the soarch for -uitahle derivativen. "This requires surveying at large number of hesy $y$-atom eompound by diffu-ing them into previou-ly prepared cry-tal-("s) Heary-atom derivatives with only -lightly altered lattice parameters, but with -ubetantial changes in diffracted inten-ities, will be u-del for further study.

PROMRH RFPOR $\mathrm{r}$

The l'idher-IBM 1130 antomated diffractometer sytem, hased on APCADE, Argonne Computer Aided Diffractometer Equipment, (1i) has hean completed and in now operating. We are using a $\mathrm{Cu} \mathrm{K}$ a soupce of $40 \mathrm{kT}$ and $16 \mathrm{~m} . \mathrm{l}$. The data collection programs

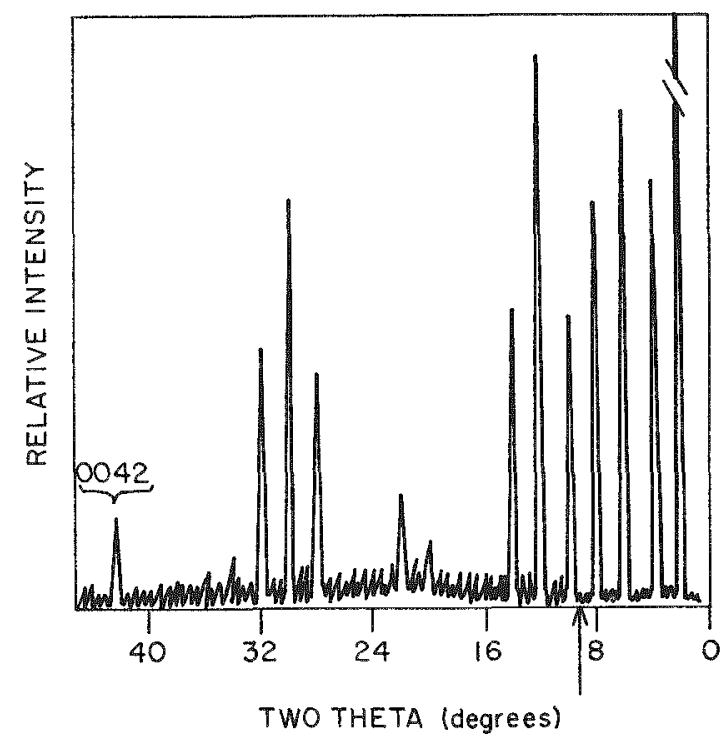

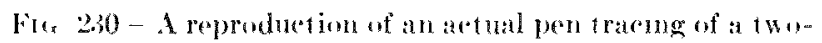

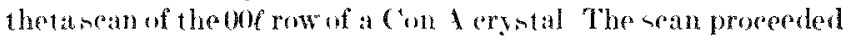
from 0 degrees (at right) to 45 degrees (left) The mot 2 refleetion is noted at about 12 degress two theta The arrow nudicaten a threofold increase in chart semsitunty at abont a degreem two thet: $a$. 
were written and modified by J. A. Scherer (Applied Mathematies Inivision. This sistem ran collect as many as 2,000 reflections per day. Programs nexensary for studies of macromolecules by X-ray cry-tallography are being written and modified.

Tests to date are eneouraging. The erystal remained aligned when data were collected for several days, indicating that vibration produred by the instrument. has little or no effect. The angle positioning is precise, and the reliability of motor driven is good. The resolving power of the instrument in regard to the two-theta angle is thown in Figure 230. The intensities are plotted rersus two theta. The intensity returned to background levels between reflections. The quality of the rrystals has been shown to be excellent for X-ray diffraction studies. Many reflections appear in the vicinity of $2 \pi$; an example, the 0042 reftection, is shown in Figure 230 at 42 degrees two theta. Figure 231 hows intensity plotted against the omega sean of the 600 reflection at two different slit width. Iine $\mathrm{A}$ shows the scan with a detector slit width of 0.04 degree, showing that the hall intensity width was not mor' than 0.0.5 degree. The mosair spread of a reflection indicates the degree of order within the erystalline lattice. Tine $B$ was another omega sean with the detector slit width of 0.2 degree (which will be the operating con-

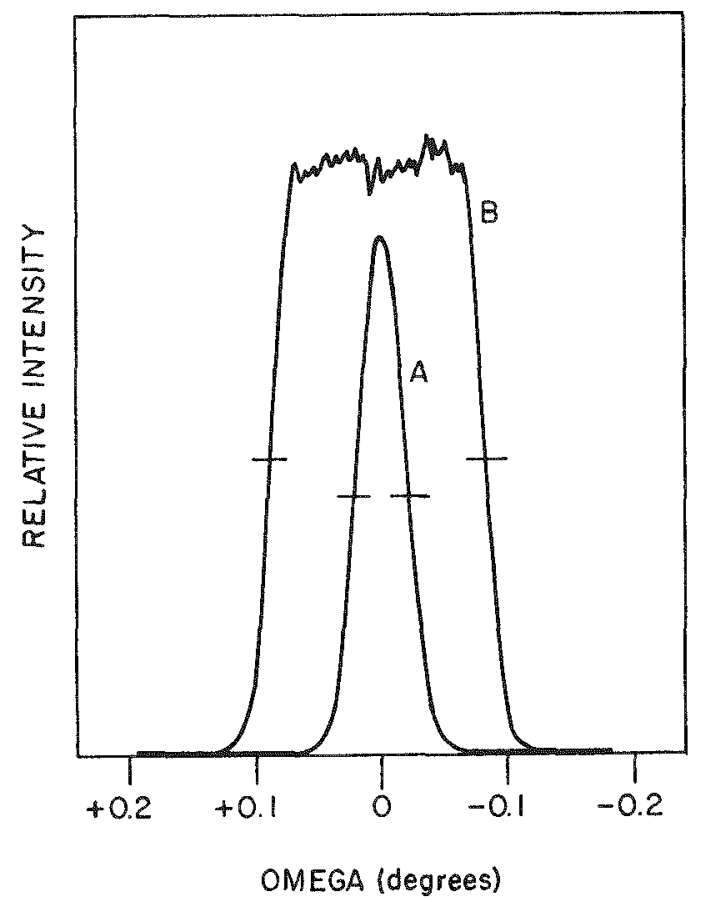

Flt. 231. - Reproductions of artual pen traeings of two omega scans over the 600 reflection. Line A shows a sean with a detector slit width of 0.04 degree indicating the mosaic spread of the crystal (see text). Line $B$ shows a sean with a detector slit of 0.2 degree used for actual data collertion.

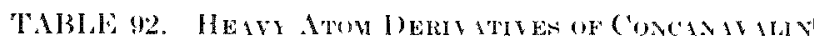

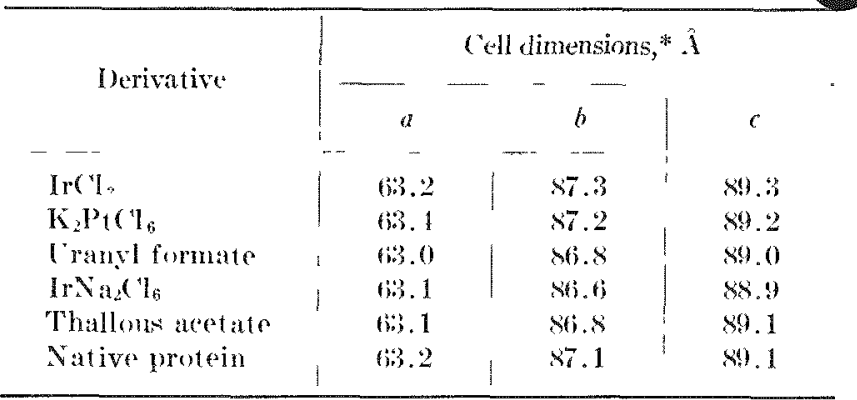

* "The standard deviations are 0.2 I for a and 0.3 I for the $b$ and $a$ dimensions.

dition for actual data collection! showing that the half-intensity wilth under thene conditions is 0.17 degree. Inder these conditions, this allowed a setting error of \pm 0.04 degree from the true omega zero which produced a count of only 2,0 lower than the maximum count.

Tahle 92 show a list of heary atom derivatives which produce minor elhanges in the crystalline lattice parameters and appear promising from preliminary precension photograph. From this list, at least two must be found which we can use to solve the phase problem. 'The iridium trichloride, platinum hexichloride, uranyl formate, and iridium sodium chloride derivatives show distinct differences in intensities from both the native erystals and one another. The thallous acetate hows some changes in intensitios from the native erystals, but they are relatively small.

\section{CONCLTSIONS}

The diffractometer system has bex'n completed and can collect data with a high degree of precision, reliability, and speet. These crystals are very well suited for diffraction studies. Some reflections correspond to interplanar distances of at least $2.15 \AA$, and the mosaic spread is no larger than 0.05 degrees. A number of promising heavy-atom derivatives have been found for attempted phase solutions.

\section{REFERENCES}

1. Hardman, K. 1). N. Kent Dalles, A. B. Edmundson, and M. E. Hook. An X-ray crystallographic study of the structure of concanavalin. Argonne National Laburatory Biological and Medical Research Division Annual Report, 1968. ANI -7535 , pp. 244-215.

2. So, L. L. and I. J. Goldstein. The interaction of coneanavalin $A$ with $\alpha$-mannans from a variety of microorganisms. J. Biol. Chem. 243, 2003 20017 (1968).

3. Markowitz, H.. D). A. Person, (A. L. ( iitnick, and R. Ritts, Jr. Immunosuppressive activity of concanavalin science 163, 476 (1969).

4. Olson, M. O. J. and I. F. Liener. Some physical and chem- 


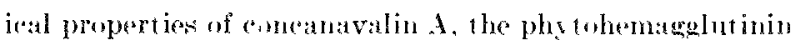

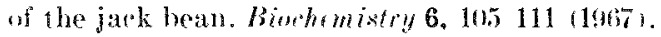

5. Olson, M. O. J. and I. E. Liener. The assomianion and dis

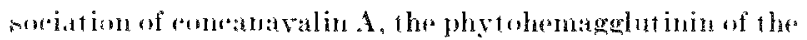

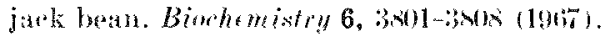

6. So, I. Is. and I. J. (xoldateiu. Protein-carbohydrata interactions. XX. On the mumber of eombining sites on con"anavalin A, the phytohemagglutinin of the jark boan.

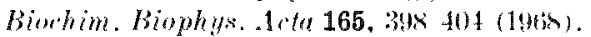

7. Yatriv. J., A. J. Kalb, and A. Levitalsi. The interation of

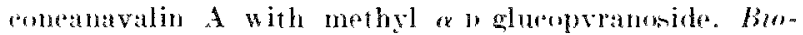

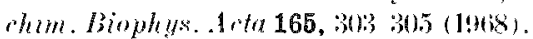

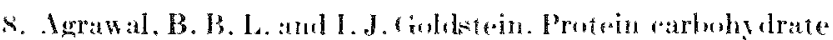

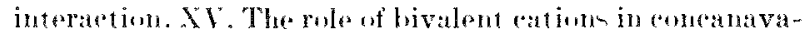

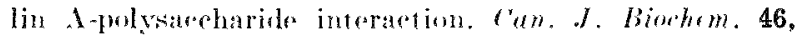
11471150 inghs.

9. Edmumbon. A. B., A. K. Halla, K. I. Hurdman, M. F. Hook, and F. A. Sheber. C'rvotallization and characterizatom of profeins sulable for study by $\mathrm{X}$ ray diffraction. Areme National laboratory Biologional and Mediral lissearch Livision, Annual liepurt, 196is. AN1.7535 pp. 212 $24: 3$.

10. Mueller, M. H., I. Heatom, and L. Amiont. I eomputer mon-

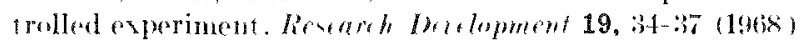

\title{
A CHEMICAL STUDY OF THE BINDING SITES OF CONCANAVALIN A
}

\author{
Karl D). Hardman, clinton F. Ainsworth, and Delwrah A. Eippte in *
}

PTKPUME AND METHODN

Thin is a new prosmam designed to complement the X-ray diffraction studies of concanavalin $\mathrm{A}$ (Con A . It consist of studving the effects of various chemical modifications of Con 1 on its activity. For a brief discusion of propertics of ('on $A$, see the previous report. This sudy is directed toward determining the mpecificity of the binding sites, the type of honds which are involved, te.g., hydrogen bourk, salt linkages between oppositely charged groups, and van der Waals interactions). and the contribution of each to the binding of the polysatecharides. Attemptr will be made to determine if the amino acid side chains which are modified are involped directly in the binding of the carbohrdrate. or whether they alter the conformation of the molecule, changing the chemical potential of the hinding sites. Broduse it appears there are two metal ions bound pere tetramer, ${ }^{11}$ and there have been whown to be two carhohydrate binding sites pere tetramer. ${ }^{2}$ the role of the metal ion is of special interest. Some of the derivatives are to be designed so that they may be uned directly in the arystallographic studies. "The location of a chemically modified site in the electron den-ity map of the protein molecule would be extremely raluable in fitting the polypeptide chain to such a map.

Some of the more likely posibilities of chemical ..... -

* ACM student from firimell college. modifiation 10 be -urvered are photooxidation and earboxymethylation of histidine thistidine is of pardicular interest bescause of powible involvement in chelating the divalent netal ions, reaction of $N^{\top}$ bromonecoinimirle and 2-hydroxy-5-nitruberzylhromide with tryptophan, aretylation and iodination of tyrosine, aterification of the carboxyl side chain, and any one of a number of reaction with amino groupo.

PROTRE- REPURT

We are survering chemiral modification of Con 1 to fiurl which ones affect binding activity. Studies under way eurrently are artoxymethylation of histidine residues and $\mathrm{T}$-hromo-nceinimile oxidation of tryptophan residus. Thene will be carried out in the presence and absence of metal and various carbohydrates. It least eleven of the twelve tryptophanper tetramer are oxidized by the $N$-bromosuecinimirle in 70: acetic acid. At present. We do not know the number of tryptophans which must be oxidized to begin affecting the binding of curbohydrates.

\section{REFERFNCES}

1. Yariv, J., A.J. Kall, and A. Levit $z$ h. The interaction of conctanavalin A with methyl ex-1-ghuropranoside. Biochim. Biophys. Ale 165, 5013 305 (1968).

2. So, I. L., and I. J. Coldstein. Protein-tarbuhydrate interaetions. XX. On the number of rombining sites on concanavalin $\mathrm{A}$. the phytohemagglutinin of the jack bean. Biochim. Biophizs. Arta 165, 3318 404 (Igtis). 


\title{
CHEMICAL AND ENZYMATIC CLEAVAGE OF CONCANAVALIN A
}

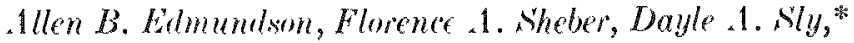

Robert It. Freund, $†$ and Bert E. Holmest

PU RPOE AND METHODS

A- purt of a program complementing the crystallographic studien l-oe preceding report-1, initial steps have been taken to determine the amino acid sequence of concantavalin A $\left(C^{\circ}\right.$ on $\left.\mathrm{A}\right)$. It is difficult to turly this protein in a conventional way, primarily beseause the con d molecule in resintant to the action of trypsin. ${ }^{11}$ Trypsin is the most specific of proteolvtic enzymen and one of the prime agent generally chonen for degradation of proteins.

The -tructural hati for the re-i-tance of Con A to trypin is an interenting problem in itself, and we are attempting to irolate peptile containing $1 y-$ -ine and arginine residue the u-ual siten of tryptio hydroly-ins. This attempt in incorporated in a more romprehemive sarch for the bent methous to cleave Con 1. Thu far the protein has been enzymatieally hydrolyzed with papain, chymotryp-in, and thermoly-in. and chemieally eleaverl with eyanogen hromide.

In an aceompanying report, Hardman et al. point out the similaritien in the typen of linding reaction in which Con $A$ and animal immunoglobuline participate. While we had no rearon to -urpecet that the two trpen of molecele would have the sme reactivitien toward enzynes, we initiated the degradative studies of ('on I with papain. with which Porter's) first hydrolyzed rabbit immunoglobulin into large fragments. Chymotrypin and thermolyin were uned beraune the amino acid compo-ition of ('on $x^{13}$ included relatively latrge number of residuen eonsidered sureptible to hredroly-i le.ge, tryptophan, tyro-ine, phenylalanine, and lencine for chymotryp-in. and phenylalanine, leurine, and i-olesucine for thermolysin). The publi-hed analy-i<(3) al-o indicated the presence of 1.2 methionine residuen pere -ubunit, a number which can be extrapolated to two resduen when oxidative lowen are taken into account. IF. hope eventually to find a denaturing agent that will fully expore thene residuen to the solvent and thereby make them arailable for attack with cranogen bromide. In the firnt trial we employed this reagent under conditions found arceptable for the Bence-olone- protein-. ${ }^{4)}$

\footnotetext{
* I AP H.s Predoctoral Thanee.
}

iche I students.
PROM THFSS REPONI

When Con A was treated with papain, the molecule was not broken into three large fragment- like the rahbit antibodien. Intear, the hydrolyate contained an incoluble fraction and any small peptiden. usually ranging from 2 to 5 residue in length. The chymotryptic digent ronsinted of a len complex mixture, but approximately half of the molecule wa reprenented by in-oluble peptides which could not be fractionated. Thermolysin aloo did not olubilize the entire Con A molecule, hut the otherwire intractable "core" wats soluble in 50\%, aretic acill. We may, therefore. be able to hydrolyze this core with an enzyme like pep-in, which is only active in acidic solution.

Among the coluble peptide were sereral with arginine or lysine residues. The composition of theme peptide were not sufficiently unusual to aplain the resi-ianee to tryp-in. The general explanation probaby incolven unfarorable orientation of the arginine and ly-ine side chain - in the three-dimen-ional structure of the protein.

con $A$ is aloo resintant to cyanogen bromide at fll 2 when denaturing agents are absent. We -urcerded in partially elearing the protein in $5.1 /$ guanidine-HC I. hut we have not a yet found a suitable rytem for the fractionstion of the products.

CUNCIAT-10\%

Inace-ibility of -it to for po-nible clearage appears to be the major obstucle in the elucidation of the amino acid serduence of roneanavalin A. The reason" for this inaces-ibility will probahly not become clear until the threedimensional structure in determined by X-ray analysis.

\section{RLFHAENCES}

1 Sumner, J $B$ and $\therefore$. F Howell. The identitiontion of the hemagghutinin of the jack bean w ith comeanavalin $1 \mathrm{~d}$ bertellol. 32, $22723 \%$ (1936).

2 Porter, R R. The hrduolysion of rablit ; globulin atrd antibodien with errstalline papain. Biorhem ff 73, 119126 (1959).

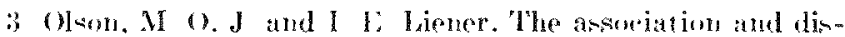
soriation of eoncanavalin 1 , the phy tohemagglutinin of the

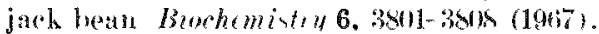

4 Edmundan, A. B , V. K. Intson, F. A. Shoher, K li. Ily,

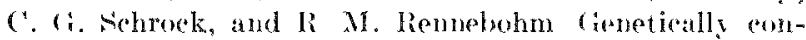
trolled variation in Benep Jones proteins. Argonne Nattional Iaboratory Biological and Medioal lieseatreh Division Annual Report, 1967 ANL-7409, pp. 123125 


\title{
A NEW PROCEDURE TO COMPARE AMINO ACID SEQUENCES OF BENCE-JONES AND OTHER PROTEINS
}

\author{
Allen B. Edmundson, Hiral K. Wood, Mariane Sihiffer, and Kathryn R. Ely
}

PUPOLF AND METHUD

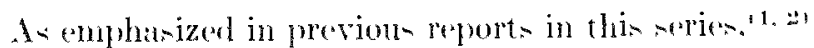
myceloma protein and $7 \mathrm{~s} y$-globulins are composed of two light and two heary chatm linked hy interdain disulfide bonds. In multiple myeloma, light chatins produred in excese are often exereted into the urine. A. urinary comstituent-, the light chains are named benceJones proteins atter their diecoverer, and their premence is pathognomonic of multiple myelomat. The Bence-tones protein - fall into two prineipal antigenipe

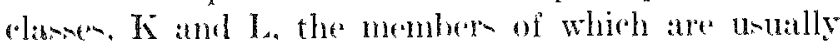
ralled $\kappa-$ and $A$-chains, pespeetively. The genetic antrol of these proteins is manifest in their amino aceil scepuences, no two of which are identiral in either the light chain or heary chain reries. Within each sperien and antigenic elas of light chain, howerer, the carboxyl halves of the molectule are relatively invariant. while the amino halven show wide variations. beven the carboxyl halve are difforent in members of other spercies or antigenic elasese.

Berane of the substantial differencer, it is diffieult to compatre the secfuenem in any sytematio way merely by incpertion. We previously devired two-dimenional projections ealled "helical wherels" to reprem stent equences in helicat segment Benee-Jones protein- appear to be largely nonhelical in ronformation. The key feature in the suceseful application of the helieal where is the oberration that apolar side chains tend to be clustered in an $n, n \pm 3$. $n \pm 4$ distribution in helieal segments. Becatuse the relative distribution of polar and apolar residues are of such structural inportance, we employed Finher'(equations' 4 to study these distributions in the $s^{\prime}-$ quence of Bence-Jones and other proteins. Our approach represents a departure from the conventional use of the equations, which are generally applied in the prediction of hystrodynamic properties from overall amino acid compositions, rather than secfuencer.

\section{Equations}

In Fin-her's approach, the polar groups ares assumed to be external, while apolar side chains were assigned to internal positions. The summed molal volumes, $I$. and $V_{i}$, for the polar $\left(F_{e}\right)$ and apolar $\left(V_{i}\right)$ residues were used to define the quantity, $p$. according to the equation $p=I, V_{i}$. The value of $p$ was compared with $p_{s}$. which is equal to $p$ in a spherieal molecule:

$$
p_{s}=-\frac{r^{3}}{(r-d)^{3}}-1 \text {. }
$$

whese $r=$ radiu of the - phere. and $d=$ thicknem of

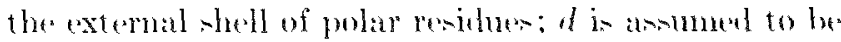
$4 \hat{\mathrm{A}}$. As it deviater from 1.0. the ration of $p$ to $p$, is a rough meanure of the "it-pherienty" of the molecule and in approximately expal to the friet ional ratio. $f f_{1 .}$ for mont proteine with molecular weights up to 47.000 . Values smatler than about $0.9-1.0$ have been associated with proteins that tend to aggrengate in -olution. The. effective p p, ratios of the ace agregate approach or exreed 1.0. Insulin and the $\alpha$ - and $\beta$-chlains of hemoglobin are exatmples of such proteins. whereat myoglobin (p) $p_{\mathrm{s}}=0.901$ exists at at monomer in solution.

\section{cilculutions:}

All ralculations of $p p$, were performed with an IB.M 1131 computer. Emphat-is wat placed on the lil

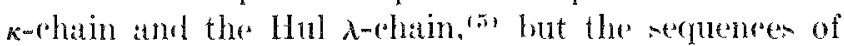
other human and nurine s-chains and human

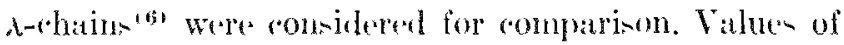
$p p_{4}$ were calculater as a funetion of chain length. and the renultin were plotted atutomatically by the computer.

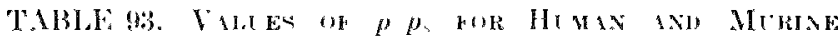
LAGHT ("HATS

\begin{tabular}{|c|c|c|c|c|c|c|c|c|}
\hline I'rotein & 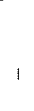 & $\begin{array}{l}\text { Entirs } \\
\text { mole- } \\
\text { cule }\end{array}$ & balf & $\begin{array}{c}\text { Gar } \\
\text { hovel } \\
\text { haifi }\end{array}$ & $\begin{array}{l}\text { First } \\
\text { quar- } \\
\text { ter }\end{array}$ & $\begin{array}{c}\text { Second } \\
\text { quar- } \\
\text { ter }\end{array}$ & $\begin{array}{l}\text { Third } \\
\text { tuar- } \\
\text { ter }\end{array}$ & $\begin{array}{l}\text { Irourth } \\
\text { guarter }\end{array}$ \\
\hline$\ldots$ & & $\ldots$ & - - & - & - & & $\ldots$ & - \\
\hline Human $k$ & & & & & & & & 3 \\
\hline Dil & & 1.20 & $0.7+i$ & $0, x$ & 0.52 & 0.11 & 0.38 & $0.3 x$ \\
\hline Ciun & & 1.20 & 0.72 & & 0.41 & 0.58 & & \\
\hline $\mathrm{Ag}$ & 1 & 1.26 & 0.76 & & 0.52 & 0.19 & & 1 \\
\hline Inoy & & 1.11 & 0.67 & & 0.45 & 0.34 & & , \\
\hline \multicolumn{9}{|l|}{ Murine $a$} \\
\hline 41 & & 1.31 & 0.76 & 1.00 & 0.49 & 0.52 & 0.335 & $1.1 x$ \\
\hline 70 & & 1.13 & 0.58 & & 0.382 & 0.12 & & \\
\hline \multicolumn{9}{|l|}{ Human $\lambda$} \\
\hline Hul & 1 & 1.25 & 0.67 & 0.70 & 0.39 & 0.70 & 0.29 & 0.91 \\
\hline $\mathrm{Bu}$ & 1 & 1.18 & $0 . \times 2$ & & 0.45 & 0.60 & & 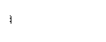 \\
\hline II a & & 1.13 & 0.75 & & 0.49 & 0.43 & & 1 \\
\hline Sh & 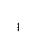 & 1.13 & 0.76 & & 0.44 & $0.5 t$ & & \\
\hline
\end{tabular}

The values were calenlated with an IBM 1131 eomputer, used in conjunetion with Fisher sequations. ${ }^{2}$. After computa tion of ratios for the entire proteins, the sequences were divided into halves and quarters, and the ealculations were repeated. Because the carboxyl halves of molecules from each type and species are relatively invariant, the results for these segments are given for only whe representative of each group. 
Similar plot- were contrueted for sperm whale myoglobin and the $\alpha$-and $\beta$-rhains of hemoglobin. ${ }^{2}$ '

To examine smaller regnents, the secquences of Bencedones proteins were divided into halres and quarters before calculation of the $p$ p ratios.

\section{PROARE- REPORT}

Values of $p p$ for the entire Bence-donen moleculer are prenented in Table 93. The wide range of 1.13 to 1.31 for thene value reflect the divereity in the overall composition of the human and nurine light rhains. The face that all ratios exced 1.0 implien that the number of polar residue- was more than atderquate to cover an apolar center.

The plots of $p, p_{\mathrm{s}}$ against chain length in the three globin, Dil $\kappa$-chain, and the Hul $\lambda$-chain, are -hown in Figure 232. The "urve for myoglohin is di-tinctly higher than those for the two chains of hemoglobin, serpite the fatet that all three globinm hate similar three-dimen-ional structures. The differences in the plot for the $k$ - and $\lambda$-type Bence-Jones proteins are even less pronounced, a finding that indieates similar distribution of polar and apolar re-idues along the polvopeptide chain. The curren al-o illustrate the importance of the chain length in the Bence-Jones proteins. A $p p_{\text {s }}$ ratio $>1.0$ was not achieved until 175 anino aced resilues were included in the calculation.

The ratios of $p p_{\text {s }}$ for halven and quarters of the light ehain moleculen are listed in Table 93. Thene vilues were uned to consider cuestions of homology of the light chains. In this approach, the result were examined for posible stable -tructures with ration $\geq 1.0$.

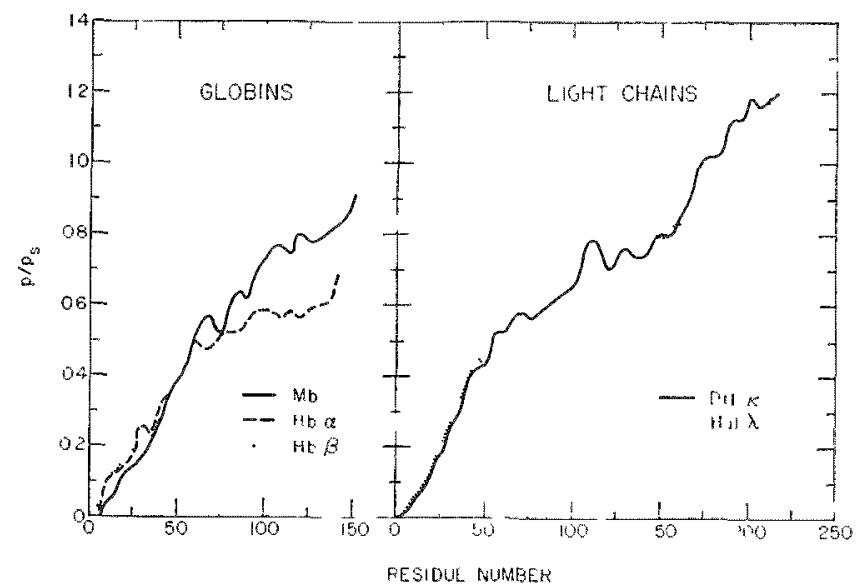

Fir. 232. ('hanges in $p p$ ratios $w$ ith increasing rhain Itrngth. The rurves for sperm whale ingoglobin (Mb) and the $\alpha$ - (IHb $\alpha$ ) and $\beta$-chaim (IIb $\beta$ ) of human hemoglobin are given in the first panel. l'lots for the In a-rhain and the Hul $\lambda$-chain are presented in the merend panel.
Comparion of sequences suggests that the two hatres of light rhain molecules are probably homolosou- "ir More tenuow arguments support an a-amption of homology in all four quartern of the molereules. Direct evidence for the primordial exintence of maller, stahle molecule of human light chain was abent, because the $p p$ values for both halven and all four quarters were below 1.0. Ration for the "pontant" carboxyl halven were clowe to values for stable strueture than those of the "Yariable" amino halven.

The anino hallee of the murine e-chatin. were in the -ame category, but the carboxyl halven did have ration greater than 1.0. surpringly, the vitue also execeded 1.0 in the fourth cquarter. Thin quarter contain - the interchain half-ry-tine resilue, the structural feature mont likely to be prenerved in the evolutionary proen.

\section{conctatsons}

The distribution of polar and apolar remidues in the Bence-Jone proteins can be conveniently compared by application of Fi-her' eruations to anino actil stquences, ats well as to compositions. (iraphie di-plays of the remult indieate that the light chain are clonele rimilar in their distribution of polar and apolar pesduen, in spite of widely diverging sequences. The ressult also support the suggestion that the ancentral prederesenor of the light ehain may have been at - mall an one-ruarter of the present molecules.

\section{RHE GRENQE}

1. Edmundson, A. B., F. Sheber, N. Nimonds, B. Bangs, and T. Johnson. Cenetir variations in Bence-Jones proteins. Argome National Laboratory Biologieal and Medioal Reo search llivision Ammal lieport, 1965. ANlatisti. pp. 1:31132.

2. Fidmundwon, A. B., N. Hutoon, and F. theber. ('omparison of the light ahain of a mycloma protein with the $\lambda$-type Bence-dones protein from the same individual. Argonne Natimal Laboratory Biological and Medieal lioneareh Division Anmual Report, te6f. ANL-7274, pp. 153154.

3. Sehiffer, M. and A. B. Edmundson. ("ie of helical whests to represent the structures of protein and to identify segments with helical potential. Biophus. J. 7, 121-135 (1966).

4. Finher, II. F. A limitung law relating the size and shape of protein molecules to their romponition. Prot. Lat. Acat.

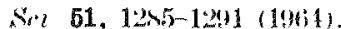

5. Fimudoon, A. B., N. K. Hutoun, F. A. Sheber, K. R. Fly, C. A. Schrock, and R. M. liennebohm. Genetically eontrolled variations in Bence-Jones proteins. Argomne National Laboratory Biological and Medieal Research llivision Annual Report, 1967. ANL-T404, Jp. 123 125.

6. Dat hoff. M. (). Ed. Atlas of Protein Sequenet and Sirurture, Immunoglobulins. The National Biomedical heneareh Foundation, Silver Spring, Maryland, 1969, pp. (1)-73 to J)-110. 7. Ihid., Globins, pp. 1)-38 to 1)-6i5. 


\title{
A CRYSTALLOGRAPHIC INVESTIGATION OF THE Mcg L-TYPE BENCE-JONES PROTEIN
}

\author{
Marianne sifhiffer, Karl I). Itardman, Mieal K. Wood, .1llen B. Eidmundson, \\ Madonna E. Honk, and Kathryn R. Ely
}

\section{PTRPONE AND METHODN}

A cryatallographic study of Benee-doner proteinshould provide direct information about the strueture of light chains, when they are not influenced by interactions with heary chains. ('rystals of both the BenceJones protein and the patrent myeloma protein fees arecompanying report were obtained from the same patient (Meg) by Dr. Hatrold $F$. Deutech at the Cniversity of Wisconsin. Dr. Deutseh kintly provided us with simples of the two proteins. and at Argonne we succeded in crytallizing them in forms - suitable for X-ray diffraction studiex.

While we are continuing to collaborate with Dr. Deutsch, we currently prepare our own samples of Bence-Jones protein from urine. After precipitation with 90 ; saturated ammonium sulfate, the protein was disolved in 0.1 $M$ Tris-H('l buffer, ph 8.0. The Bence-oonen protein wits arytallized by dialy-is against deionized water at $4^{\circ}$. For diffraction. once- or twiererystallized protein wat disolved in the Tris buffer and dialyzed in capillary tuber at $20^{\circ}$. Suitable crystals formed in 2 to 4 weeks. Diffraction pattern. were obtained with supper precesion camerats.

Wo previously have (mphasized that Bencer-lones proteins may be isolated in two stable molecular forms,

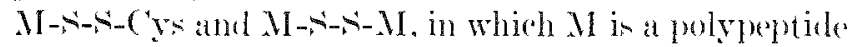
chain with a moleculat weight of $23,000.11$ "The distinction is structurally important because of the interchain disulfide hond and non-covalent interatetions between subunits in the MI-S-S-M molerules. Mloreorer. Bence-dones protein. consisting of mixtures of the two form [e.g., the Dil $k$-rhain and the (ios $\lambda$ rhain'z'], failed to cryatallize, and homogene ity in regatrd to moleculatr pecies became a factor to consider in erytallization. Major attention, therefore. Was foeuned on the identifiration of the molecular speran and the assemsment of purity of the Meg protein used in the preliminary eryatallographie studies. The moleceular peedes was identified by gel filtration at Argonne'1" and hy centrifugal analysis by Dr. Deutech at Madinon. The ancignment of the principal antigenie class and the simultaneous atsesement of purity were performed by hydrolysis with earboxypeptidare $1 .{ }^{11}$

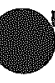

The effluent eurven for the fratetionation of disolved crystals and the supernate to the eryatals are shown in
Figure 233. The column of sepharlex $\mathrm{G}-100$ war "allibrated with the Iil $k$-chain and the Hul $\lambda$-chain.' ${ }^{\prime \prime}$ ("rytalline Meg protein migrated as a single component in the position asigned to the M-s-s-M type of nolecule in the I il and Hul proteins. This as-ignment is comsistent with the ratue of 45.500 obtained for the molerular weight by Dr. Ienterh. The pittern for the supernate shows evidenes of impurities lower in moleculat weight than the principal component.

The aberence of major impurities in the eryatals wats reffected in the produets of hrdrolysis with "atrboxypeptillase A. For eximple, 0.97 pesidue of seriue, the ("terminal renilue of human L-type but not $\mathrm{K}$-type molerule, was releated per molecular weight of 23.000 from the ample of dimolved crystals. While amino axcid- from contaminants were liberated in quantities $\leq 0.12$ residue per mole. These results were altered only slightly enerine recovery $=1.00 ;$ impuritien $\leq 0.08$ rendue per noled when the principal colum eomponent wat treated with carhoxymeptidate A. A higher level of eontamination tup to socs of the serine recovery was indicated by the quantition and types of amino acids liberated from the components in the -uperinate.

A photograph of the ergatals is - hown in Fientre 234. The rerytals. whith are colorles: and blated, ate elongated along the $b$ axis. and are bounded by $: 100$ !

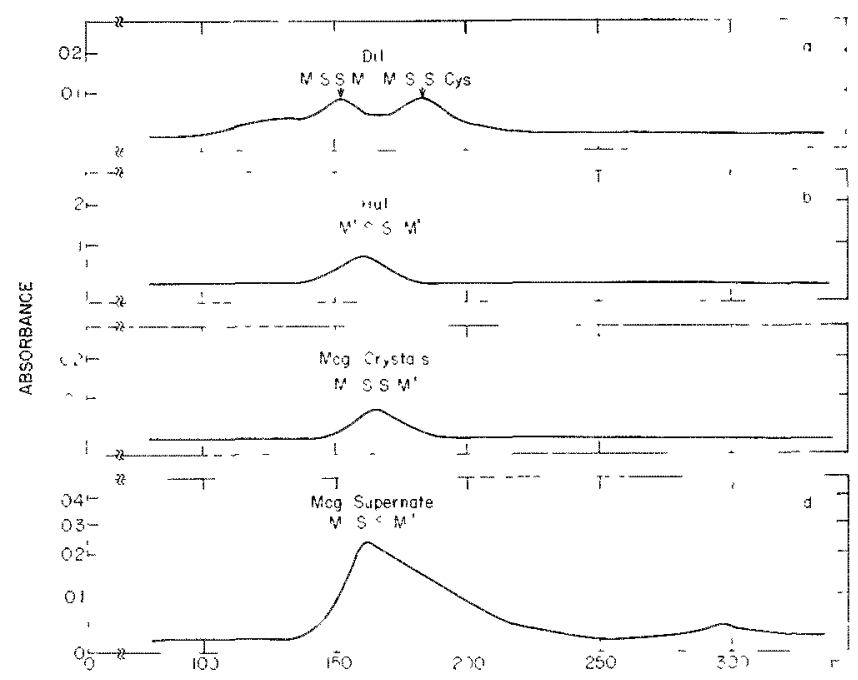

Fic. 23r. Fractionation of the loil a chain, the Hul $\lambda$-rohain, and the Mleg $\lambda$-rehain on the same column of Sephadex or 100 at $t^{\circ}$, with $0.5 \mathrm{~N} \mathrm{Na}$ ('l ats eluent. The twosamples of Meg pro toin were 1 ) dissolved (ervetals (see panel (c) and 2) the supernate from the suspension of arystalk. (see panel d) 


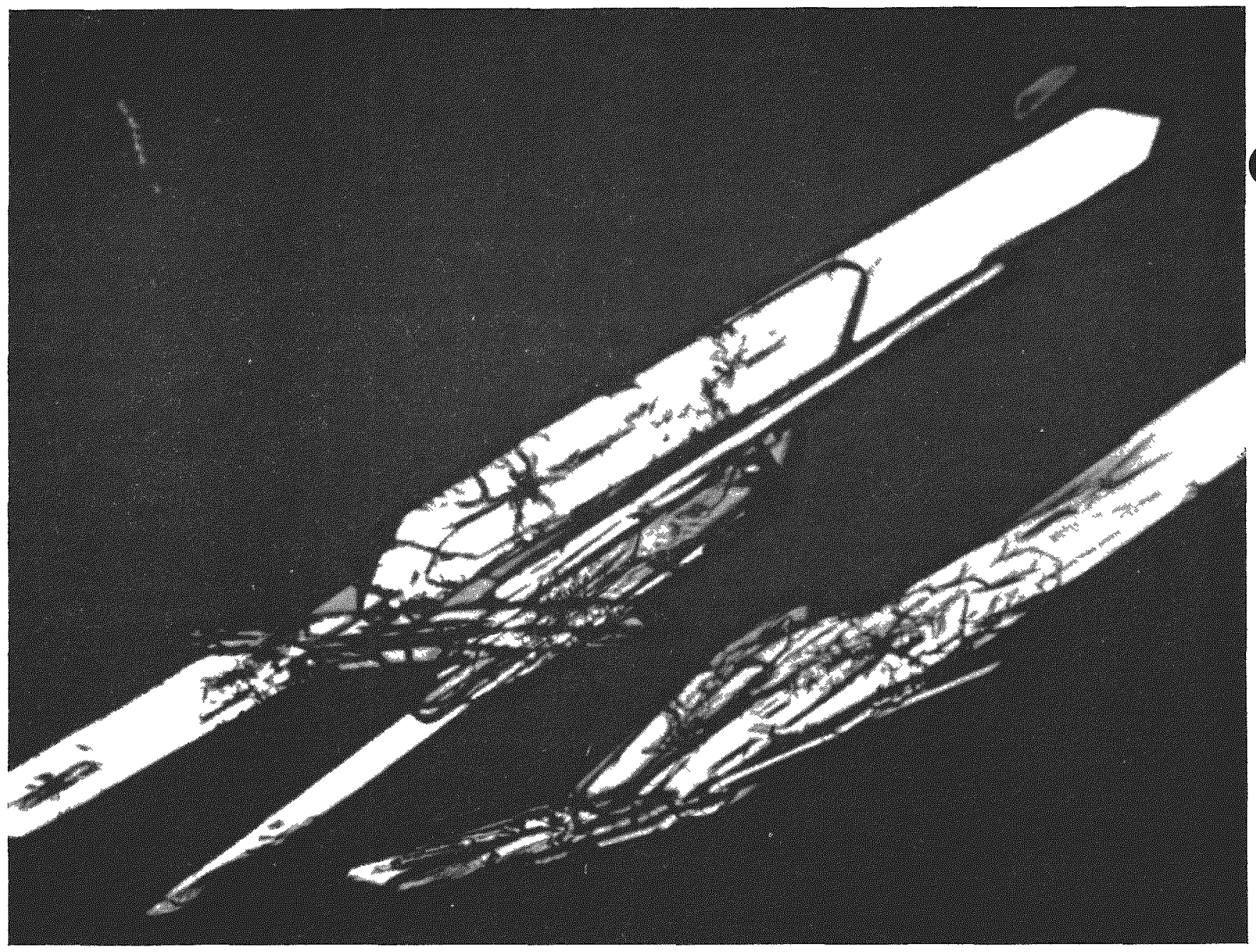

Fit, 2,34 Photograph of eryotals of the Vege Benoe Jonen protein

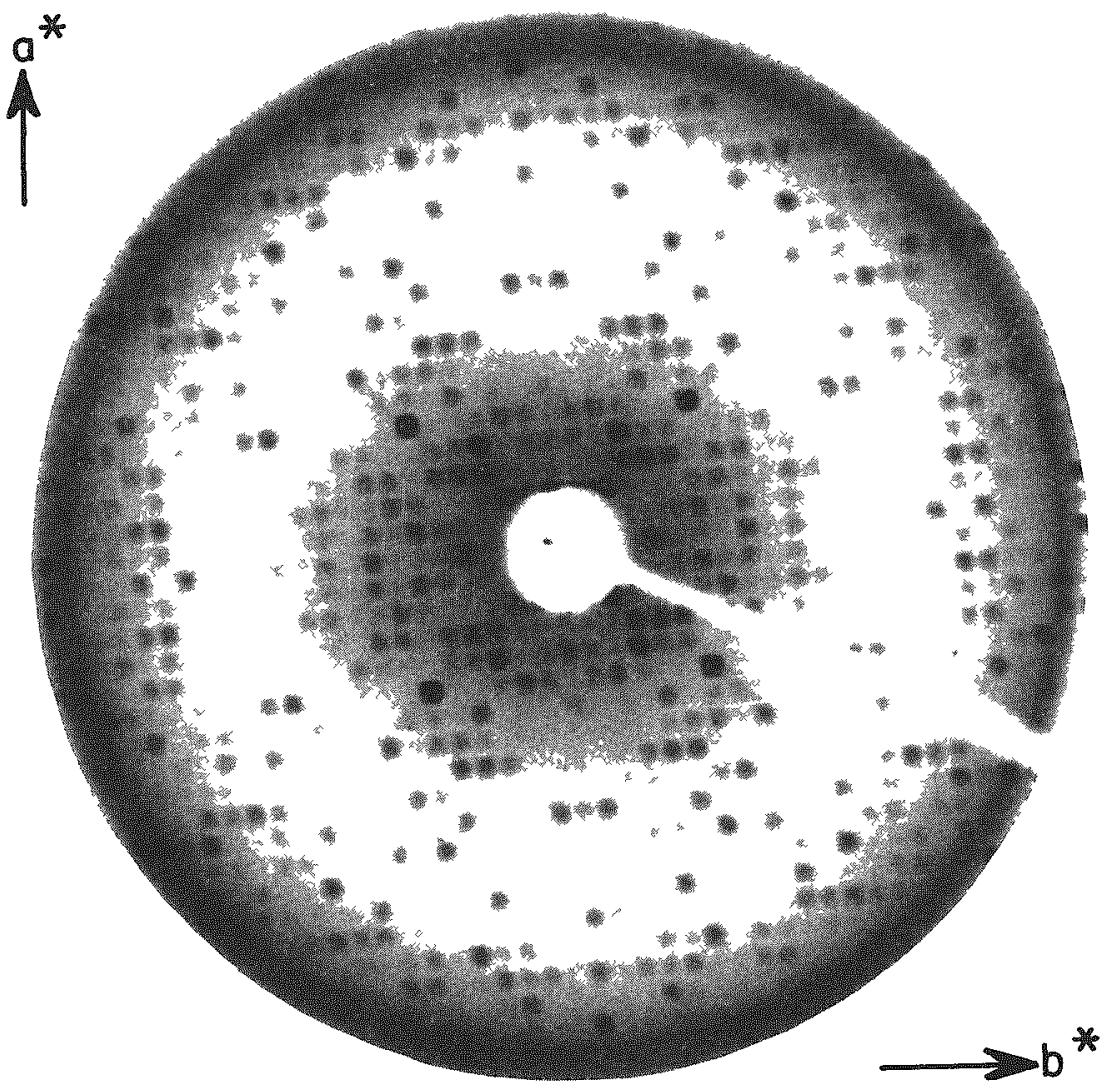

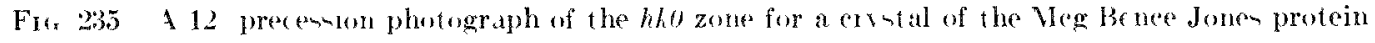


and $\{001\}$ faten. The dimensions are as latge ats $0.2 \times 2.0 \times 0.5 \mathrm{~mm}(a \times b \times c)$.

The crystals used in the diffraction experiments were fragile, but the reflection were not signifieantly dimini-hed after 12 to $18 \mathrm{hr}$ of exposure to the X-ray beam (cu $K_{\alpha}, 50 \mathrm{kV}, 18 \mathrm{mAl}$. A $12^{\circ}$ precesion photograph showing the hkl zone is presented in Figure 23\%. Other photographe contained reflections that corresponded to interplanar spacings of $2.3 \AA$.

The mmm symmetry of the three-dine ns:onal diffraction pattern indicated an orthorhombic unit eell. The following systernatic extinctions were obereved: for $h(0, h=2 n+1:$ for $0 k \%, k=2 n+1$. Therefore, the space group was lunmbiguoury identified as $P_{2} 2_{1} 2$ (No. 18 in Ref. 3 ).

The dimension of the unit cell were $a=72.6-0.2$; $b=81.9 \neq 0.2$; and $a=71.0 \pm 0.2 \AA$, and the calculated volume was $422,000 \mathrm{~A}$. The frational rolume. $I_{\text {selv. }}$ of solvent in the crystal wats estimated to be 0.46 . The number of subunits of molecular weight 23,000 in the crystallographic asymmetric unit was estimated to be two. arremonding to the M-S-S-MI limer.

CONChisions

A human L-type Bene-fone protein C.Megr wats ay-tallized from water in a form suitahle for X-ray diffrartion -twrlies. The protein was obtained in high purity l,y cryatallization alone, and further purification by gel filtration was not considered neesesary.

\section{REFERKATK}

1. Erimmdson, A. B., N. B. Simonds, F. A. Sheber, 'T. Johnsen, and B. Bancs. Ise of carboxypeptidase A for -imul taneols assessment of purity and arsignment of human Bence Jones proteins and light rhains on $\mathrm{K}$ and 1. wasses. Aroh, Brochem. Biophys. 132, 502 50s (1'6(t).

2. Edmundson, A. B., F. A. Wheber, K. R. Ely, A. B. Sinmudk, $\therefore$. K Hatson, and $J$. L. Rossiter. Charaxterization of human L-type Benee-Junes proteins ant aining arbohydrate. 1reh. Biochem. Biophys. 127, 725 710 (19tis).

3. Henry, N. F. M. and K. Lonsdale, Eds. Intemational Tables

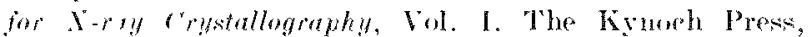
Bimingham. Fingland. 1:65, p. 104.

\section{A CRYSTALLOGRAPHIC INVESTIGATION OF THE Mcg MYELOMA PROTEIN}

Allen B. Ellmendson, Wiral K. Wood, Marianne Sichiffer, Karl D. Hardman, and Clinton F. Ainserorth

P('RP'U) AND METHCO:

A crystallographic study of the Meg myeloma protein should provide a model for considering the structural basis of antigen-binding in funetional antiborty molecules. By comparing these results with those for the Meg Bence-Jones protein, we also hope to determine what modifications, if any, oceur in the light chain structure as a remult of its heing incorporated into the larger Iger molecule. Preliminary crytallographice studies of another Ig( $\mathrm{g}$ protein a "ervoglobulin") have been reported," but the present work represents the first attempt to investigate the threesdimenional structures of both the myelomat and Bence-Jones proteins from the same patient.

"Cryoglobulins" precipitate even in the presenee of the salt in the serum when the temperature is lowered to about $4^{\circ}$. The Meg myeloma protein is a "uglobulin," which is solubls" in salt solutions, but not in witer.

To isolate the Meg protein, solid ammonium sulfate was added to the serum to bring it to 37 ; saturation. The precipitate was dialyzed at $4^{\circ}$ against $0.02 . M$ hosphate buffer, wll 7.4. After rentrifugation. the supernate was plated on at column of DEAL-erelluleres. equilibrated with the same huffer. The eluate from the columin was dialyzed against water at $4^{\circ}$. The pellet from the centrifuged sample was disolved at pll 8 in 0.1.IT Tris buffere which was 0.15 .11 in Nac'l. Crystals were obtained from both the colum eluate amel the disisolved pellet, but only thone from the latter sample were suitable for diffraction.

The diffraction techniques were similar to thone leseribed for the Meg Bences.Jones protein.

PRUARES REPORT

The Igti protein erystallized as colorlen prisms. elongated along the a axis and bounded by $; 110$ i faces. The dimennions of the prinms were at large ats $0.4 \times 0.4 \times 3.0 \mathrm{~mm} r a \times b \times 1)$. A photograth of the "rytal-is presented in Figure 236.

Precession photographs contained peflections rorreponding to interplanar spateing of $4 \hat{\mathrm{A}}$. The $\mathrm{mm}$ rymetry of the three-dimenional diffration pattem indirater an orthorhombir unit reell. The following sertematie extinetion-were observed: for $h k l, h+k$ $=2 n+1 ;$ for onl. $l=2 n+1$. The space group was, therefore unambiguonsy identilied at $(222,150.20$ in Ref. 21. The dimentions of the unit rell were: $a=88.0 \pm 0.3 ; b=111.2 \pm 0.4 ;$ and $c=186.9+$ 0.6 i: the calculated rolume was $1.829,000 \mathrm{~A}^{3}$. The 


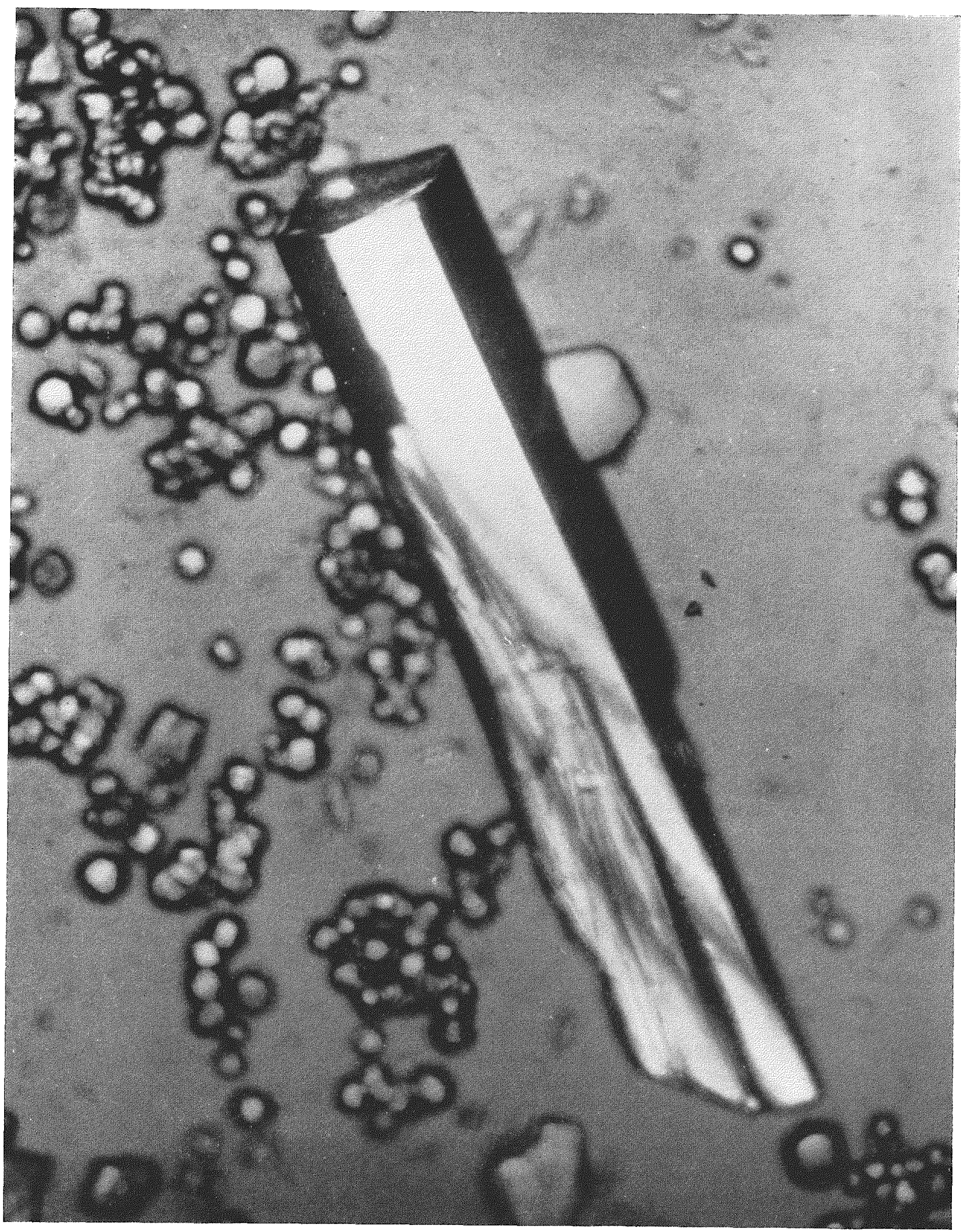

Fig. 236.-Crystal of Meg myeloma protein 
fractional rolume of solvent in the erystals wan 0.58 , a value within the normal range of 0.27 to 0.6 .5 for proteins. ${ }^{3}$ ?

There were four Ige i molecules in the unit cell. The crystallographic asymmetrie unit consinted of a halfmolecule, i.e., one light and one heary ahain with at "ombined molerular weight of 75.000 . Therefore, the' two halve of each molecule were related by at twofold rotation axis.

Our results atre similate to tho-e obtained by Terry te al.'" for eryoglobulin. For example, the fractional volume of solvent in the eryoglubulin erystals wats also 0.58 , and the anymmetrice unit was a half-molereule of the same size. The spare group (monoclinies wat different, and the crystals were subetantially nere sitive to rarliation damage than thome of the Mreg protein.
GONCLTSIONS

For the first time, both the myeloma and BenceJone protein from the ame patient (Mceg) were "rystallized in form -uitable for X-ray diffraction -tudien. (ry tallographie -inilaritie between our Meg "ruglobulin" and the "eryoglobulins" suggest that the three-dimenoional struetures of the two elitsen of immunoglobulins maty be comparable. in spite of substantial differencen in their amino arid redpuenes.

REFERLAC'LM

1. Terra. W. I)., B. W. Mat hew and I). R. Davies. (Trutallographic studies of a human immunoglubulin. Vature 220 , 239241 (196s).

2. Henry, X. F. M. and K Lansdale, Eds. International Tables

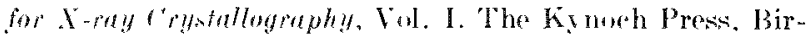
mingham, England, 196\%, p. 10 it.

3. Matthews. B. W. Solvent roment of protain eryotals. $J$. Vol. Biol. 33, 191197 (19iv).

\section{PREDICTION OF HELICAL SEGMENTS IN GLUCAGON}

\author{
. Wariame Sthiffer and dllen B. Edmundson
}

\section{PL RPOA AND MELHOD}

The ure of "he lieal whees" to prediet which segpmente in a protein have helical potential was decreribed in earlier communication-. 11. 2 "Threse other methors to prestirt helical segment- from amino acid erfuentere have heen developed.

1) Prothero: method'st in baned on the frepueney of occurrenes of ecertain pesidues in helient region-

2) Low, Lovell, and Rudko'ts studied di- through

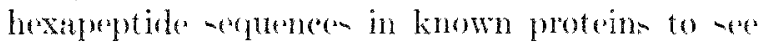
which are characteri-tio of helieal and nomhelieal resions.

31 Kotelehuek and seheragats rawify their rendues as helix-making or helix-breaking. The ir conclusion atre bated on energy ateulations of -hort range interactions, at well at empirieal eriteria to obtain a betere fit to the ditat.

For a number of protein- all methode lead to -imilar prediction, but the are are some differences in the result - Like Prothero, we tend to predict nore heliex than are actually present in large molereulex, while. Low. Lovell and Rudko. and Kotelehuek and sohepagat under-presliet. The methods haven hepetofore not been applied to moleculen -mallep that insulin. and we deeded to examine the result for the peptide hormone. glucagon, which has 29 amino ateil penidles. The $\mathrm{X}$-ray strueture of this peptide is currently being investigated by Haugen and Lipreomb, *in
IROMRE- RFPORT

The predietion- baned on the different method are presented in Table 94. "The "wheels" for the two helie:al regions we predict are thown in Figure 237. These two helices have to be wharate by our criteria, which in"lute the neerenity for hydropholie reniduen to be located on one ide of the wheed in an $n, n \pm 3, n+4$ slint ribution. These remilues, which are eircled in Figure 237, form a hyolrophobic are. One continuoum helix, encompasing remidues st through 28. would reefuire two hyrdrophobio ares on opposite silde of the wheel, at is illustrated in Figure 238.

At the Lighth International congres of ('rystallog-

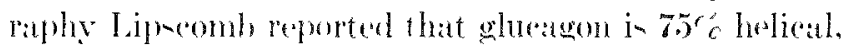
with two -eretions of helix. The ("-terminal hexapestide

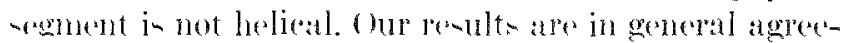
ment, although we do include five of the last six resduen in the nerond heelix predicted.

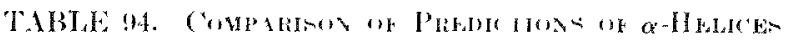

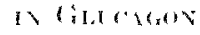

\begin{tabular}{|c|c|c|c|}
\hline Authors & Helica & erment & ', helis \\
\hline Prothero" & None & & 0 \\
\hline Lan, lovell, and Rudkis: & Vumes & & 0 \\
\hline Kotelehuek and soheraga & & $172 \pi$ & in \\
\hline Shiffer and Edmundorn 1 : & 510 & 1728 & $\$ 3$ \\
\hline
\end{tabular}


RES. $5-16$

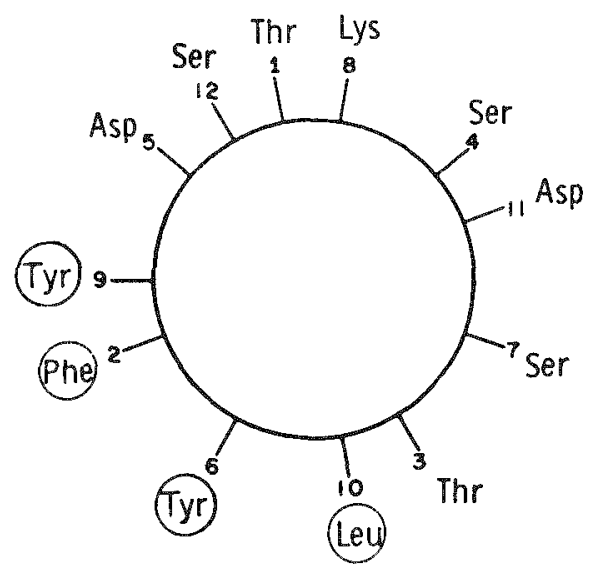

RES. $17-28$

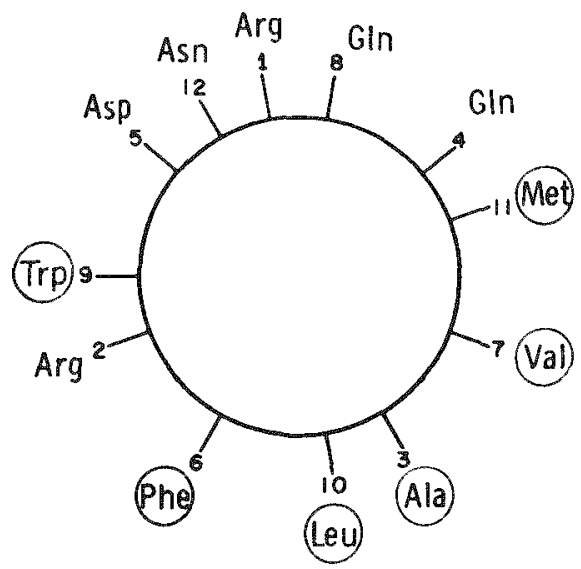

FIG. 237. Helie al wheds for glueagon. Abreviations for hydrophobic side chains are circled

RES. 5-28

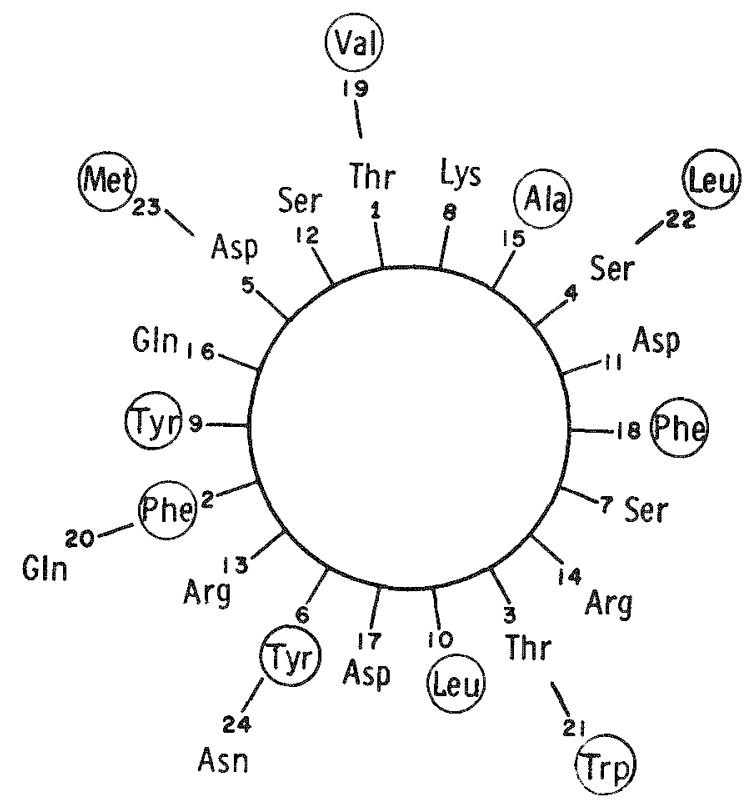

Fyo. 23x. Helieal wheel drawn under the assumption that residues 5 through $2 x$ are present in one continuous helix.

\section{CONCLUNION}

For the small peptide hormone, glueagon, the prediction of helical segments with the aid of "helical whecls" yields results that are in closer agreement with the X-ray structure than alternative methods.

\section{RFFERFINA FW}

1. Schiffer, M. and A. B. Ldmundson. Representation of threedimensional struetures of proteins by two-dimensional models: prediction of segments with helieal potential. Argonne National Laboratory Biological and Nedieal Researeh Division Annual Report, 1966. ANL-7278, pp. 273275.

2. Achiffer, M. and A. B. Edmundson. Tse of helif al wheels to represent the struetures of protein and to ident if $y$ segments with helical potential. Biophys. J. 7, 121-136 (1967).

3. Prothero, J. W. Correlation between the distribution of amino acids and alpha helices. Biophys. J. 6, 367-370 (1966t).

4. Low, B. W., F. M. Lovell, and A. I). Rudko. Prediction of $\alpha$-helical regions in proteins of known sequence. Proc. Nat. Acad. Sci.60, 15191526 (196is).

5. Kotelehuck, D. and H. A. Soheraga. 'The influence of shortrange interactions on protein conformation, II. A medel for predicting the $\alpha$-helical regions of proteins. Proc. Wat. Acad. si. 62, 1.t $21(1969)$.

b. II augen, W. P. and W. N. Lipeomb. The crystal and molerular structure of the hornome glucagon. Eighth Intemational congress of (riystallography, rolleted abstracts. XY-25, .11\%5 (1960). 


\section{MINO ACID SEQUENCING OF CATOSTOMUS CLARKI HEMOGLOBIN}

Dennis Inocers

PLRPME AND METHOD

Although the literature on -rologinal poikilotherm "polymorphism" is roluminown, theorles that axplain their origin and biological function are lacking or bated on inadequate experimental results. Fanally fen attemper have been made to correlate "noleceular polymorphisms" with envirommental parameter.

Koeth reerntly" dereribed the elextrophoretio heterogentery of the hemoglobin from ("at o-tonid fi-hes. (1) The number of migue electrophoretic hande varied frons 8 to 12 per individual. To inventigate the - ruletural bat of the oberevations, the amino acid serpeneses of the alphit and beta chation of the hemoglohin from cutostomes slakt are being inventigated. These results will be correlated with the genetio and evolutionary divergenese of the hemoglobin loci a well as morphologiral and geologieal rata and, we hope, with environmental parameter- I multivariate analy-

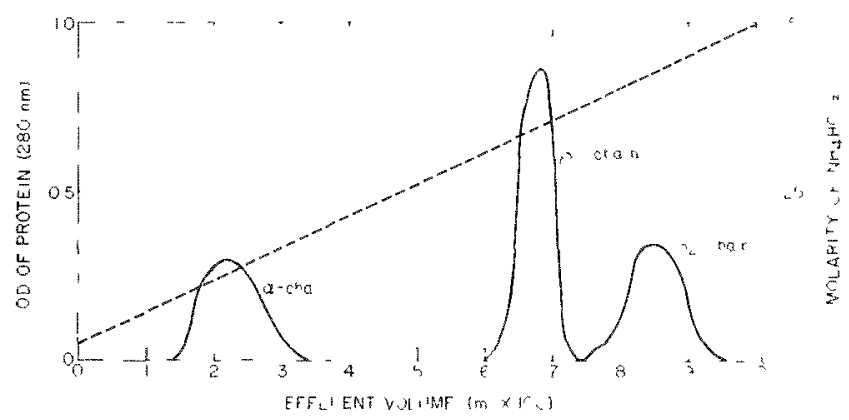

Fer. 239. Separation of a- and $\beta$ ehains wn DE.AF Sepha des $(1-25)$. The optiral denty is at $280 \mathrm{~nm}$ and is primarily at function of tryptophan and to a lester extent gy rosine and phenvialanine residues. The optieal denisty is plotted against the volume of effluent. The costerse of the $\mathrm{XH}_{4} \mathrm{H}\left(\mathrm{C}_{3}\right.$ gradient sindieated by the broken line. -is of the hnown hemoglobin secatences will be arded ond to determine the de expese of divergenese.

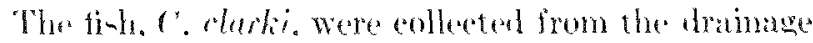
atnalo notar Phornix, Arizona. Bloorl wat obtained he carchate puncture. The arythrecten were wathed - ereral timen, then lyod, and the hemoglobin was inolated by wel filtration on sephantex $(i-100$ and $(i-200$.

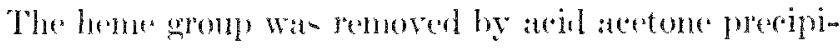
tation of the rhain.

The alphat and betal chain could not be separated by conventional proredures. athitwerl, however, by anemding ehromatourathy on I)EAE-Sepharlex A-25.

After aminoethylation of the ereteine residuen, satch chain wats hydrolyzed with trypin for $24 \mathrm{hr}$. The trypt ic pept idem were purified by ion-ex hange chromatowraphy and high-roltage electrophores. Peptides were - vbiected to amino ared atnaly-i and, if pure, to

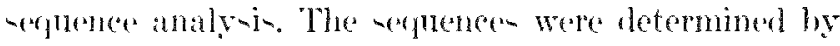

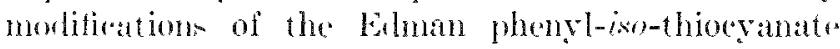
promedure.'th, it

PROMRES REPORT

Patrial separation of the intact hemoglohin has heen atecompliahed he fractionation on DEAESephadex. but complete separation ham been achiered only by clectrophore-is. Preliminary data from gel filtration indieates that all hemoglobirs have the sames molecular weight, which rule out polymerization of the hemoglobin units. Howerer. ultracentrifugetion is dexirable to eliminate doubt of polyme rization.

Excellest reparation of the alpha and beta chains was aremplished on DEAL-Sephatex (Figure 239 ). There appear to be at leant one alpha and two beta

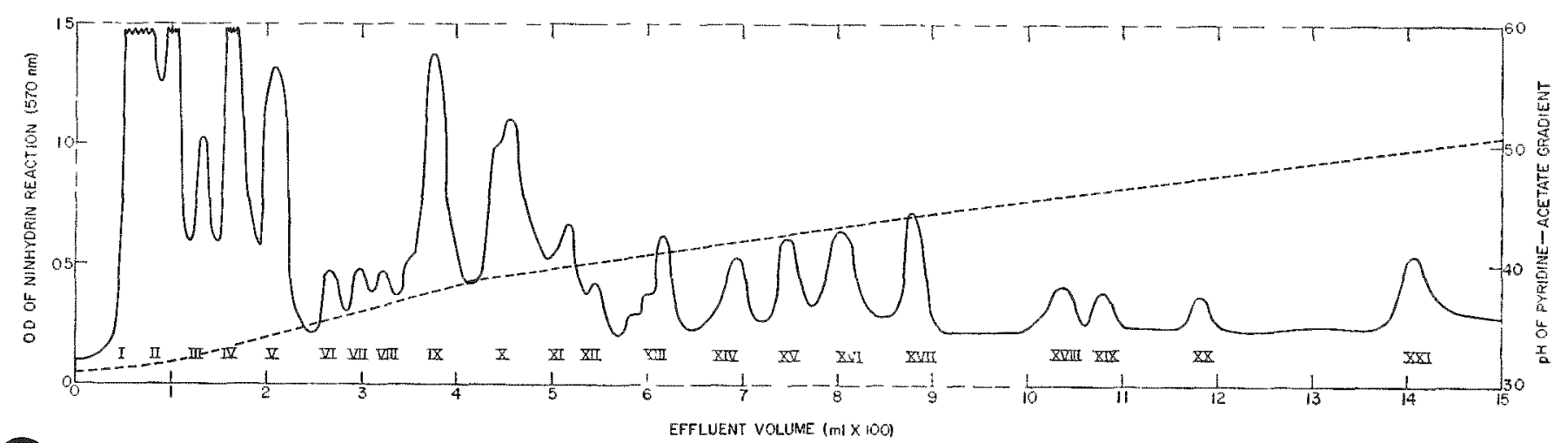

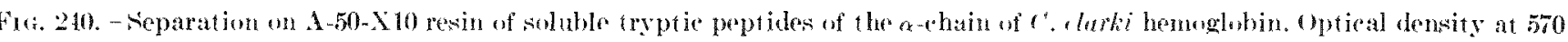
of the ninhydrin reaction is ploted againet the volume of efluent. The conte of the pridine and pH gralient is indicated hy a broken line. 
chains. The absorption of the alpha chain is smatleer than that of the beta chains. because the alpha chain contains fewer tryptophan residues.

The elution profile for the fractionation of the tryptic peptides from the alpha chain is illustrated in Figure 240. Peptider represented on this chromatogram constitute about threefourths of the alpha chain molecule. The remaining segments were in an insoluble fraction which is yet to be studied. Soluble pentides, representing approximately one-third of the beta chains, alko have been inolated and purified.

From the eompositions of the alpha chain pertiden, it was evident that the seruenee is similar to that of the earp alpha chain. ${ }^{21}$ Ferwer than $10^{\circ}$ e of the residues were involved in substitutions. No secquenees of beta chain from finh have been publinhed, but the peptiden from globins of ('. clarki appear to be substantially different from their mammalian counterparts. Several

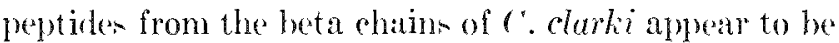
more like the human delta or gamma chains than human beta chain. It is too soon, however, to draw conclusions about divergence.

\section{CONCLCSIONS}

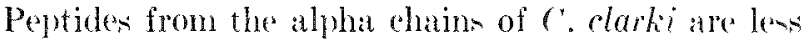
than $10^{\circ}$; different from eary alpha chains. At present. it appears that the "polymorphims" result from dif ferent alpha and beta chain combinations.

\section{REF HRFNC'W}

1. Koehn, R. K. Hemoglobins of fishes of the genus C'atastoms in Western North America. C'opeia Yo. 1,21-30 (Mareh 6, $1969)$.

2. It ayashi, H. A simple met hod for the fraetionation of globins into their $\alpha$ - and $\beta$-chains. of. Biochem. (Tokyo) 50, 70 71 (196i1).

3. Wilson, . and 1). B. Smith. Separation of the valyl-leucyl and valyl-glutanyl-polypestide chains of horse globin by fractional precipitation and column chromatography, c'an. J. Biochem. l'hysiol. 37, 405 (1959).

4. Dintzis, H. M. Assembly of the peptide chatiss of hemoglobin. Pror. Nat. Acrod. Sit. 47, 247-261 (1961).

5. Clegg. J. B.. MI. A. Naughton, and 1). J. Weatherall. An improved method for the characterization of human hemoglobin mutants: Identifie ation of $\alpha_{2} \beta_{2}^{q_{3}}$ (olu, Hemoglobin $\mathrm{N}$ (Baltimore) Vature 207, 945 957 (1965).

fi. Konigsberer, W. and IR. J. Mill. The strueture of human hemoglobin. III. The seguener of the amino arids in the tryptic peptides of the $\alpha$ chain. J. Biol. ('hem. 237, 2517-25k1 (19)62).

7. (iray, W. R. and B. A. Hartles, A fluorescent end-group reagent for proteins and peptides. Biochem. J. 89, 59P $(19+i 3)$.

S. Hilse, V. R., and ( $\mathrm{x}$. Braunitzer. Die Aminosüuresequenzz der a-Ketten der beiden Hanptkomponenten des Karpfen-

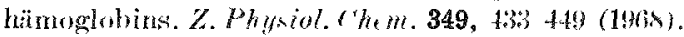

\title{
NEUTRON-GAMMA RESPONSE FOR LEAF AND COLEOPTILE GROWTH IN BARLEY
}

\author{
Norman 1. Frigrio, Thomas 1. HeCaffrey, and Joann .1. Sciler
}

L RPOAF AND MFTIODN

As part of a continuing program of cooperation with the International Atomic Energy Agency (I.A.E.A.), we have extended last year's stulies of harley seerlling growth ${ }^{11}$ into new areas in an attempt to develop an international standard for seed irralliations. In our prerious studies, we showed that the 5-daty height of barley secedlings was reprodurible to $\pm 3 r ;$, under the proper conditions and with appropriate statistical treatment, desyite the observation that height distribution were trongly skewed toward hort plants. ${ }^{11} \mathrm{RBE}$ values for $0.663 \mathrm{MI} \cdot \mathrm{V}$ neutrons or Jants neut rons were in the range 3.5 to 40 , so that the serstem showed a high differential sensitivity to nest rons.

['ing the same methork, "We now have examined the effects of growth periods and irradiation levels on the dose-effect curves and on the height distribution. in an attempt to define the parameters that must be fixed if comparable renult are to be obtained in dif-

* Inyola Iniversity, ('hicugo, Illinois. ferent laboratories. Both leaf and coleoptile remoness were considered bectuse of the supposition that coleoptiles grow primarily by elongation, and leares by rell division. Teutron and gamma rays could affect these two procesens differently, and an unhealthy coleoptile necemarily precluden a normal leaf. Thus, both - tructures were measured as a function of dose, radiation type and growth period, to determine their relative importane in the general economy of eeselling growth and their erentual effect on subseruently determined RBE values.

PROMRLAS RFPORT

Seed- were equilibrated, irratiated, and planted as before." After planting the heights of the first leaf and of the coleoptile were measured neparately at 3,4 , 5,6 , and 7 day of growth. Cuder the experimental conditions uned. growth rate wa- constant for the first leat and coleoptile grown from control and from irradiato sede. Table 95 shows the results for selected neutro and relected be co gamma irradiation doses. The re-1ults 


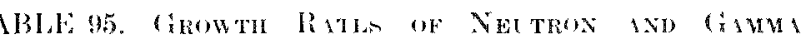

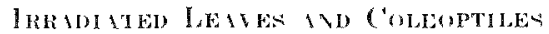

Growth period.

Coleoptiles.", of controls leaves, ', of controls dats

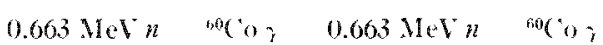

\begin{tabular}{|c|c|c|c|c|}
\hline 3 & 75 & fiti & 50 & 30 \\
\hline & 77 & fit & 52 & 18 \\
\hline & $7 t$ & bit & 18 & 39 \\
\hline & 70 & $\{i 3$ & 4.3 & $n g$ \\
\hline
\end{tabular}

$\mathrm{Mean} \pm$ or $76.0 \pm 0.764 .3 \pm 1.148 .3 \pm 3.33 .5 \pm 2.4$

Coleoptile values for seeds irradiated with 0.3 hlatd nell1rons or $20 \mathrm{kl}$ gammas; leaves with $0.9 \mathrm{~h} \mathrm{had} \mathrm{nent} \mathrm{rons} \mathrm{or} \mathrm{to}$ kR gammas. Findally eonstant grow th rates were obtained for all ut her dose values tried.

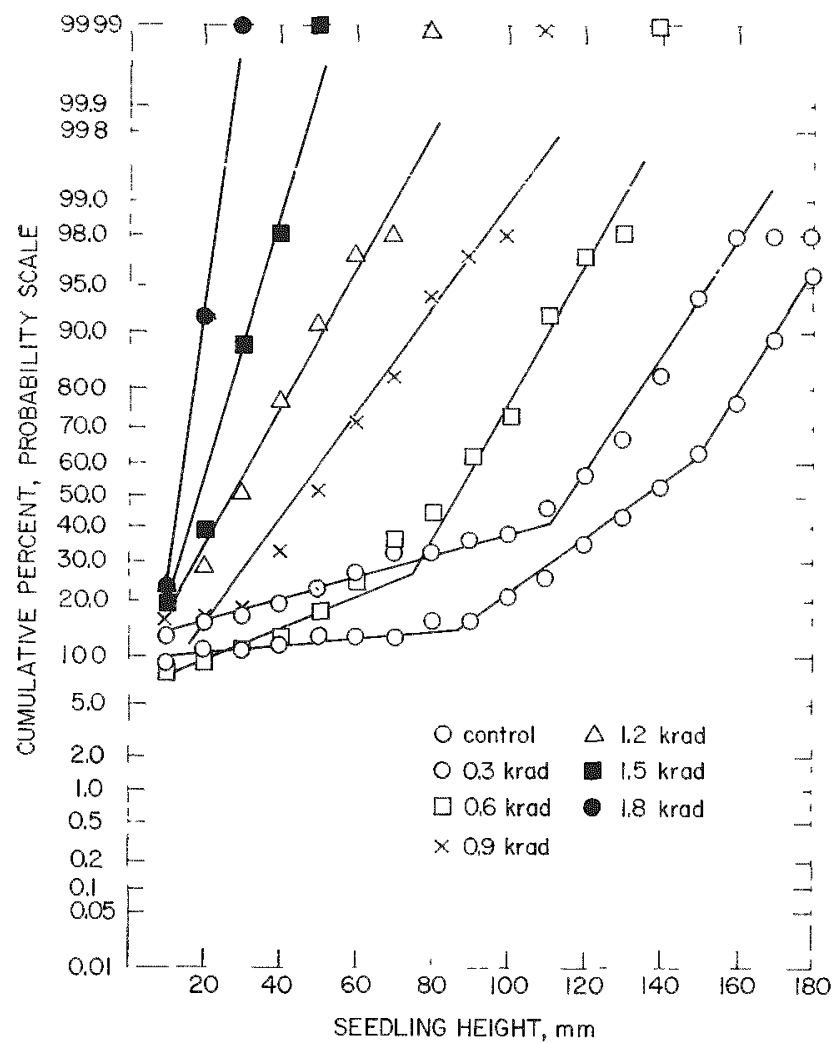

Hitr. 211. ('umulatives frequeney plotted on probahility seale agstinst seedling leaf height at ti days. follow ing expowne of seede to $6633-11$ el nesut roms.

- laggest that at single growing time would be reprenentative of the radiation effect throughout the growing period studied, as the standard deviations were within $3 \%$ in both cares. six day of growth were taken as xeprenentatives.

Frequency distributions were made for each treatment at 6 dave of growth. These are giren in Figures 241-244 as emmulative probability againt secedling height. Thi- trpe of plot atlows-everal form of analyin to be made:

11) A-traight line indieates a perfect, normal distribution. No plot thowed this behavior, as noted preriou-ly.'1,

121. In abrupt change of slope indicater a secondary dietribution. The muirradiated aede showed one -exonlary distribution in the dirertion of an abnormal number of short seedling. such short reedlings rould

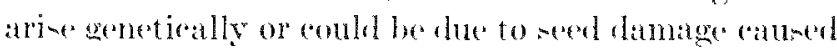
by harvesting or handling. High gatmma dosen introduend an additional serondary distribution skewed

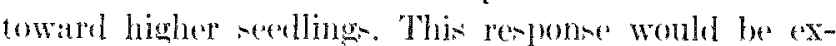
pereded from the known $Z$ microdone distributions for $\gamma$

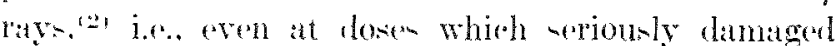

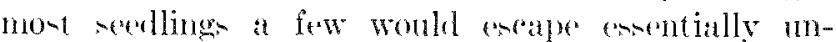
ratherd.

131 The slopes of the distribution vary inveredy with the standard deviations of the samples; the -tereper the sopes, the maller the -tandatd deviation of the -ample. Ciammat irraliation appeared to inereatse the deviation -lightly, while nentront- tended to reduce the deviation. Agting, thi was to be expereted on the ba-is of $Z$ distributions and on the known inerease of

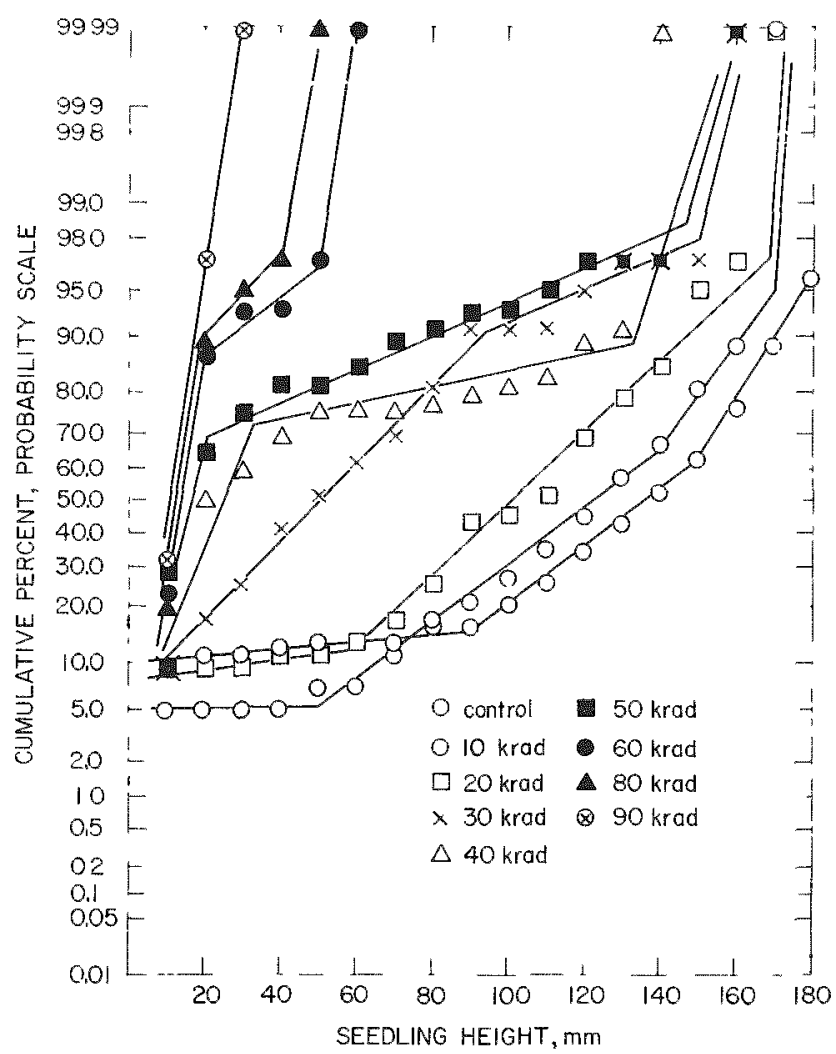

Fis. 242. ("umulative frequenes plotred on probabilits scale against seedling leaf height at 6 days, follow ing exposure of sectis to (40 $11^{60}$ gammina rass. 


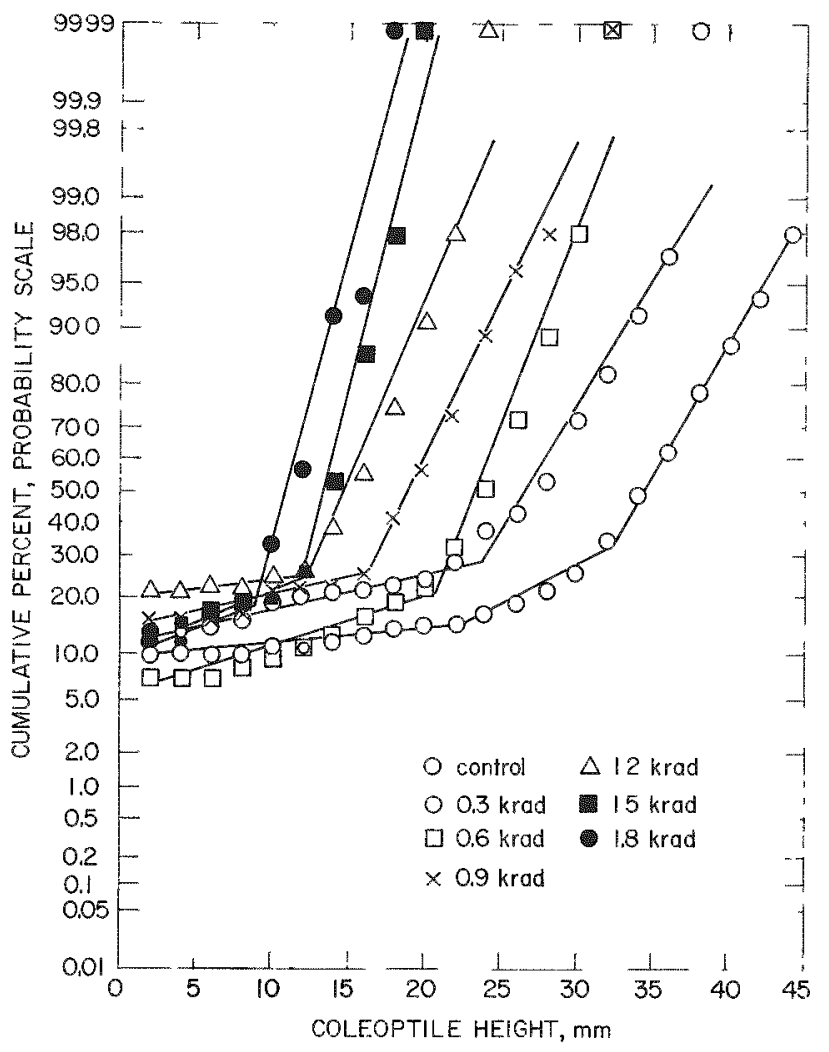

Fix. 24:3. Cumulative frequenes plotted on probabilit: scale against seedling eoleoptile height at 6 dats, follow ing exposure of seeds to 0.66i3 MIel neutromo.

-ensitivity to -mall changes in seed hydration and oxygenation for gamma rays relative to neatronr.

(4) The horizontal dinplacement of each line show the response of seedling srowth to radiation done. These are plotter in Figures 241-244.

(5) The gammatirraliated seed indieate there in at -aturation dore between 50 and $60 \mathrm{kR}$. Cp to $50 \mathrm{kR}$ there remains a proportion of seeds which reach a height near the maximum height ohserved in the control sample; but beyond $60 \mathrm{kR}$ seedling are nererely limited in height. This height at higher done is reduced to a minimum. beyond which there is little rhange with inereasing dore.

The -eedling height, an pereent of control height, was plotted on logarithmie seale (Figures 245 and 246 ). From these plots were derived the values given in Table 96. Fitting the logarithmic plot of dose responet given different extrapolation number for newtron and camma radiation. This differenee indieates that the RBE of 0.662 XIeV neutrons is a function of pereent age growth. Beeaune it in inconvenient to treat RBE an a function, the ratio of $D_{5,0}$ done for gamma and neutron irradiation was nelected by 1.A.K.A. at the batsis for RBE. For leaf growth thi- ratio is $41: 1$, and for coleoptile growth it i- $24: 1$.

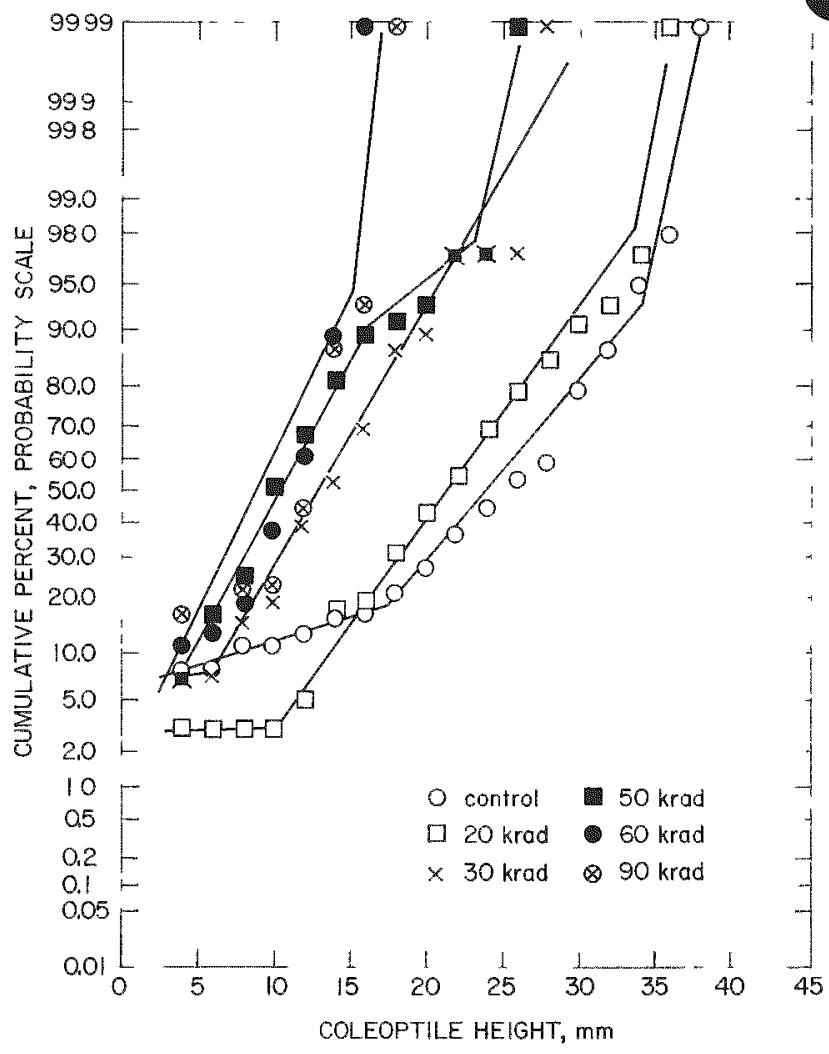

Fis: 24t. Cumulative frequeney ploted on probabilits srale against seedling colooptile height at 6 days, following evposure of seeds to Corio gatmmat rays.

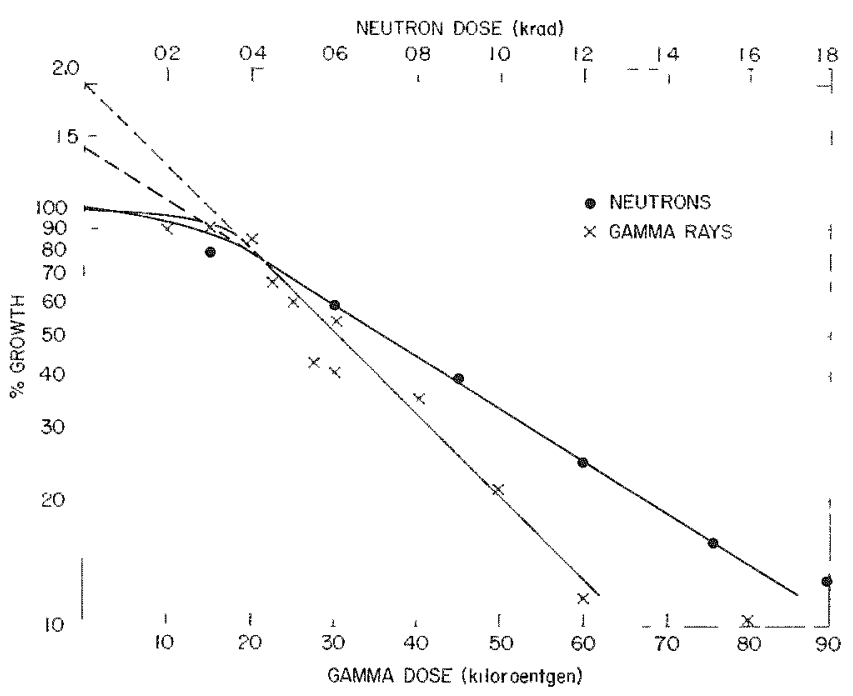

Fic: 245. Correlation of leaf height at 6 dars following gammat and noutron irratiation.

CONCLLSIONS

The ratio of $4124=1.7$ between the RBL valu for leaf and coleoptile agreen fairly well with the rat found at $14 \mathrm{MeV},{ }^{(3)} 11.0 / 5.1=2.2$. This suggests that mechanism of radiation damage are similar at these 


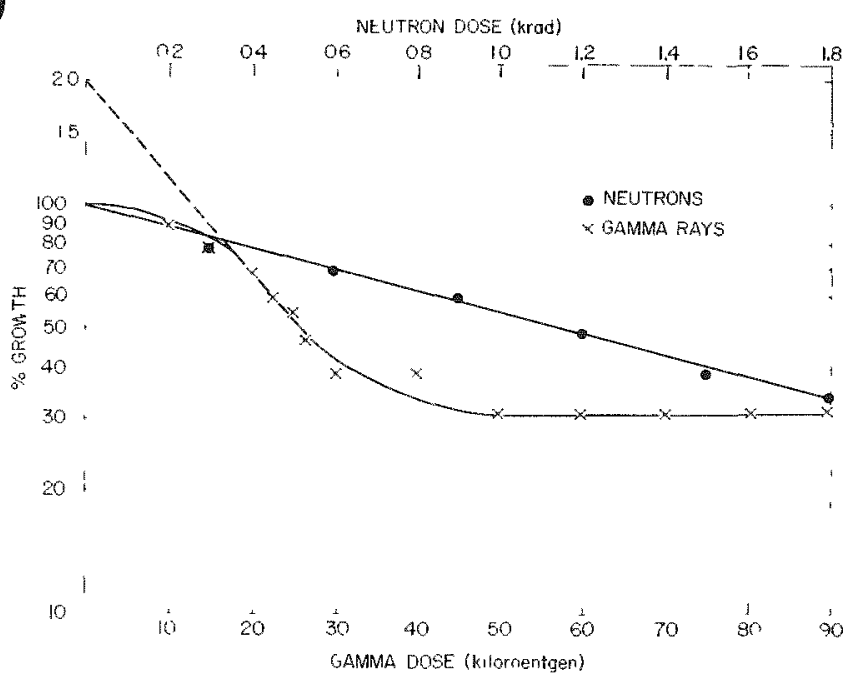

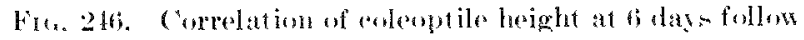
ing camma and nentron irradiation.

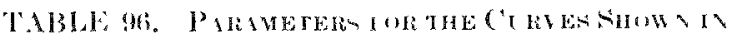
Frot ReS 215 in 246

\begin{tabular}{|c|c|c|c|c|c|}
\hline \multirow{2}{*}{$I \sin t$} & & \multirow[b]{2}{*}{1} & \multicolumn{3}{|c|}{ lokad } \\
\hline & - & & 110 & $I)_{4}{ }^{2}$ & $\mathrm{I})$ \\
\hline \multirow{3}{*}{$\begin{array}{l}\text { Istatf } \\
\qquad g \mathrm{row} t \mathrm{~h}\end{array}$} & Nentron & 1.1 & 0.7 .5 & 0.21 & 0.6 \\
\hline & Gammat & 2.0 & $: 1$ & 15 & 20 \\
\hline & liatio o $n$ & 1.1 & +1 & 62 & 33.3 \\
\hline \multirow{3}{*}{$\begin{array}{c}\text { Colexuptile } \\
\text { grow }\end{array}$} & Nevitron & 1.0 & 1.12 & 0 & $1.6 !$ \\
\hline & Ciamuma & 2.0 & $2 t i$ & $1: 3$ & Is \\
\hline & liatio; $n$ & 2.0 & 23.2 & & 10.6 \\
\hline
\end{tabular}

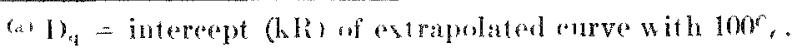

widely divergent energies, despite the incresud aver-

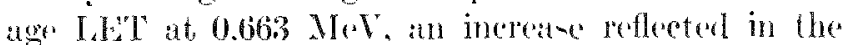
higher RBS values at the lower enereg. The exi-tenee of different RBE value for leat and roleoptile confirm the suggention that growth take plate by different meehantsms in the two -truetures. The RBE ratio of only two, howerer, suggents that much cell division must also orecur in coleoptiles, so that the differenes in growth meshani-m in not very large. Thum, roleoptileveru-leaf romparions provide only moderately senwitive setems for diserminting direet from indirect radiation damage. On the other hand, the high $\mathrm{RBF}$ value found. atul their pattern of variation with neutron energy from 34 for Janum neutron (meatn (nergy 0.25 M(N) to 41 at 0.663 MAN. to 11 at 14 MAN. is in good atgreement with the predictions of

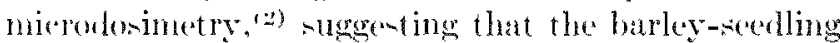
s-atem may be exeellent for -tudien of the mechaniom of RBE. In addition. the eas with which tatietically

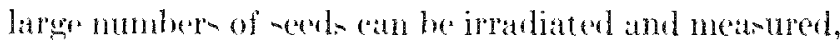
their frestom from internal energy degratation, the moderate nevtron dom recruirend, and the fact that erpivalent remult wath be olvtained at any time from as to 7 date poutirradiation resomments the barleyreedling sy-tem for general radiobiological tudies, at well it for international interemparion. With the fortheoming avalathility of modified .Janu- fis-ion farility, and of a Dynamitron monoenergetie fucility we will continue our -tudie of this syatem by examin-

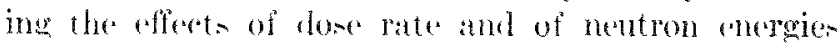
from 0.03 to 19.2 MeT on RBS and on relation leat and roleoptile growth rengoninem.

\section{REFFHEXTH}

1. Frigerio. X. A., E. G. Johnson, and J. A. Seiler. Growth

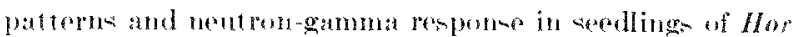
dt um. Argonne National Laburatory Biolugiond and Medieal

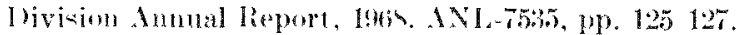

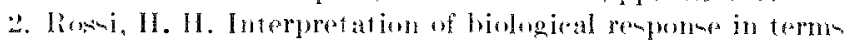
of microdosimetry. A $\mathrm{km}$. 1.Y. Ared. Sti. 161, 260 241 a1mia).

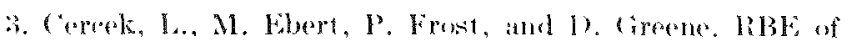

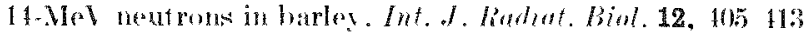
(1916i\%). 


\section{CELLULAR FINE STRUCTURE}

\section{EFFECTS OF ANTIBIOTICS ON DIFFERENTIATING CELLS. I. SENSITIVITY OF GRASSHOPPER SPERMATOGENESIS TO ACTINOMYCIN D}

Theodore $N$. Tahmosian, Rosmare L. Devine, and Betty Jan Wright

PL RPOML A YD METHOH

In the part. we eimploved ionizing radiation on callin spermatogene-i- di.e. cell undereoing growth. division, and differentiations to gain an in-ieht into ubeellular meehinimm of mitors, meioni- oratuells. differentiation, organelle production, and molecular synthesis. (1) of the mumeroun antibiotice that afferet protein s.tnthesis and, henee, well growth and derelopment, two of the mont widely uned atre artinomyen i) and puromyein. They are mont effective in celle mulersoing growth and divi-ion. (2) The effect of artinomy ein D and puromyein are being invertigated at present to clucidate thene procenen further with the expectid- tion that the inhibitory effect of thene antibiotion will yied indirest evidenee of remmal cell function. Particular attention has been given to the production of the platema membrane at the cleariage furrow." Although no differemeen in the RNA-lhhe geranules related to this membrane synthemi- have been noted. preliminary examination has -ngegented that matry of the aberratom cathed by radiatum may aloo be indured by the antibutim. Ife are dealne unw wh the experinental introduction of a rhemieat aterent in the hope of traring the aberration to it origmal catue and wite within the "oll. We appreciate that thi- foru- cutail- pecosnition

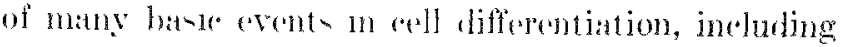

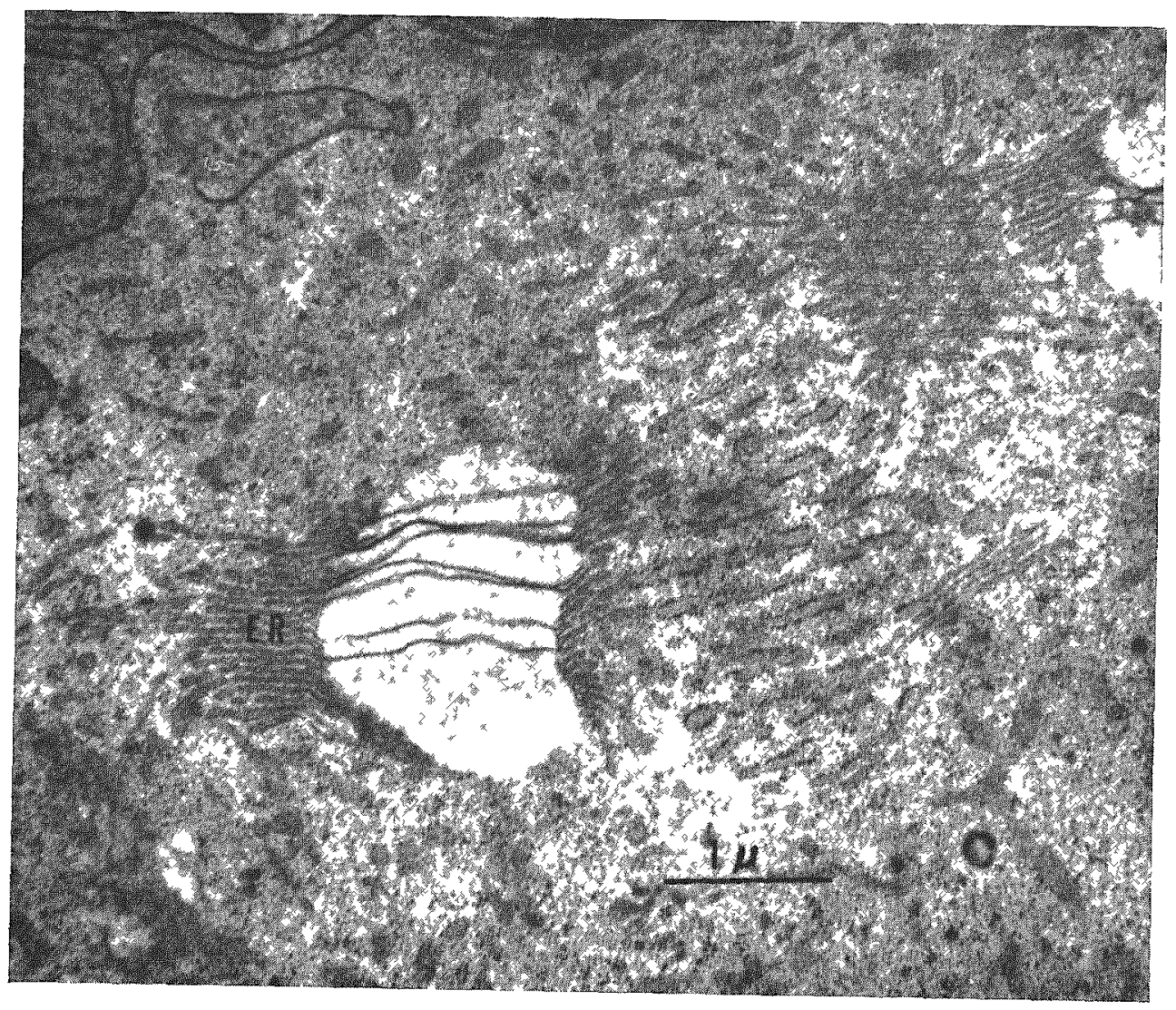

Fic. 247. A permatoey te thow an early form of myelin like figure in the smooth endopla-mio retionlum (ER) 
the preferential binding sites of the antibiotic, abnormal molecular end products, ultrastructural changes. and the identification of abnormalities due to specific rather than general blockage of the cell's metabolism. Experiments using both puromyein and actinomyein have been initiated, but to date, only the actinomyein D-treated tissue has been examined cytologically. Therefore, this preliminary report is restricted to effects of actinomycin D.

PROGRESS REPORT

The first problem has been to establish a suitable dose range of actinomycin D for the grasshopper and appropriate methods for the identification of cellular alteration due to this treatment. Last instar male gratshoppers, Melanoplus differentialis, were placel in groups of ten and maintained separately in small cages in the laboratory. Solutions of aretinomyein D, 0.25 $\mathrm{mg}$ ml, were prepared in Belar insect saline, and sub- sequent serial dilutions of this solution to provide graded dowe for injection were also made in the Belar. Each grassopper received a 0.05 -ml abdominal injection of at serial dilution, the dose atministered ranged from $0.0125 \mathrm{mg}$ to $0.0000125 \mathrm{mg}$ actinomyein $\mathrm{D}$ per animall. Two additional groups of ten grasshoppers each were kept as controls. Each grasshopper in one group received $0.05 \mathrm{ml}$ Belar and the other group was untreated.

One grashopper from each group was saterified at celected intervals of from 2 hr to 20 days post-injection. The testes were removed, disected, and fixed for elect ron mierosepy. Thick sections $(2 \mu)$ of this material, anpropriately stained with toluidine blue, ${ }^{16}$ were examined by light mirosecopy. The remaining gratshoppers during this period were ohserved to determine their -urvival and response to the treatments at the dowe ranges used. The total procedure was repeated unce.

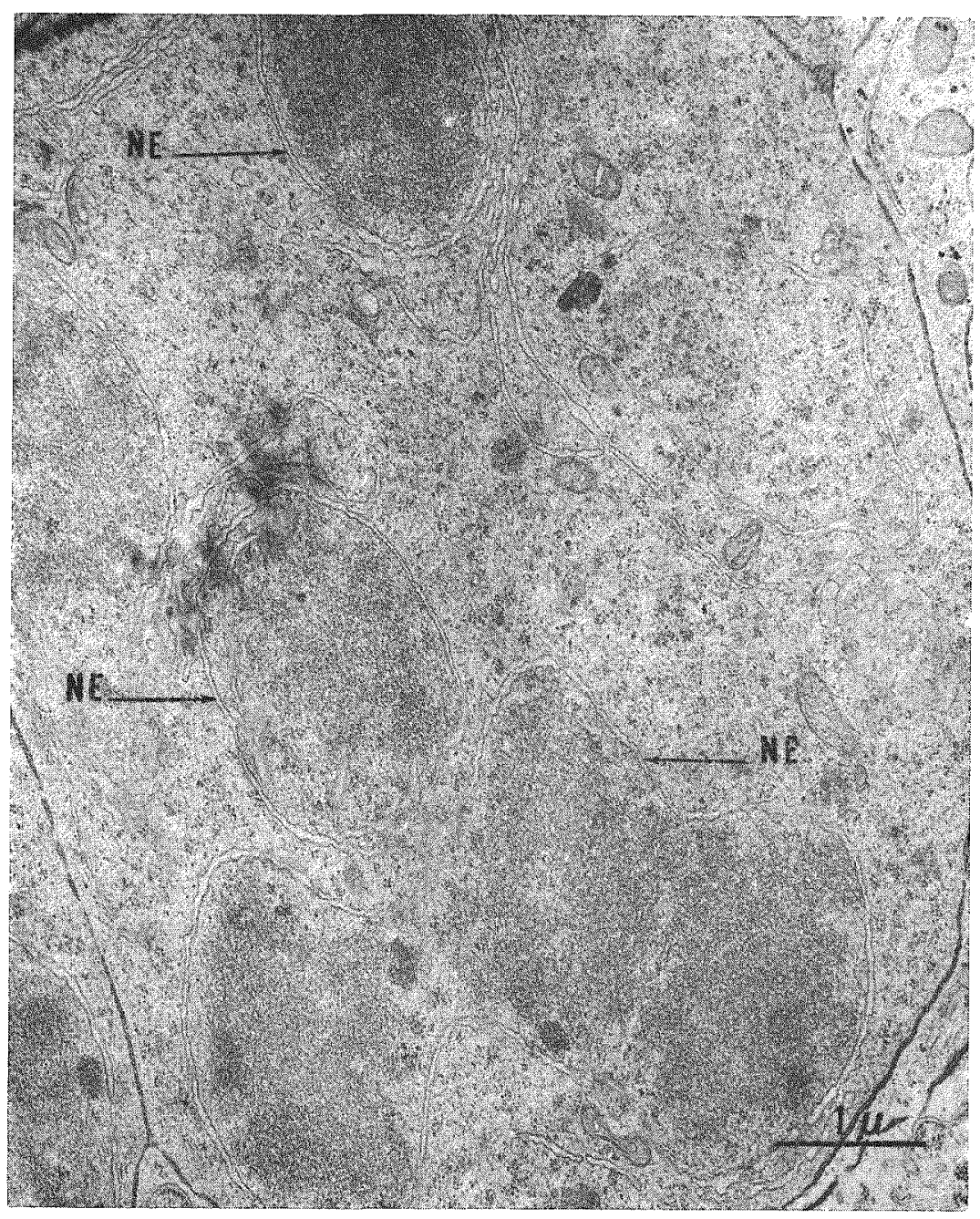

Fic. 248. One daughter cell of a telophase pair shows an abnormal regronping of ehromosomes. Nuclear envelope (NE) formation has proceded uninhibited, resulting in isolated nuclear fragments. 
All animals that received the highes dose of actinomycin $\mathrm{D}(0.012 \mathrm{mg} / \mathrm{ml})$ died by the third day poitinjection. Approximately half of all of the grasshoppers in the other groups, including the Belar saline injected control group, were alive at 7 days, and very fow deaths occurred thereafter, although the death check was continued for a month. About one-quarter of the untreated controls died during these 30 days. Although the number of girashoppers involved in this experiment is too small to be statistically significant, a trend was recognized that is a useful guide for future experiments.

Thick sections of testis. glutaraldehyde fixed ${ }^{(5)}$ and

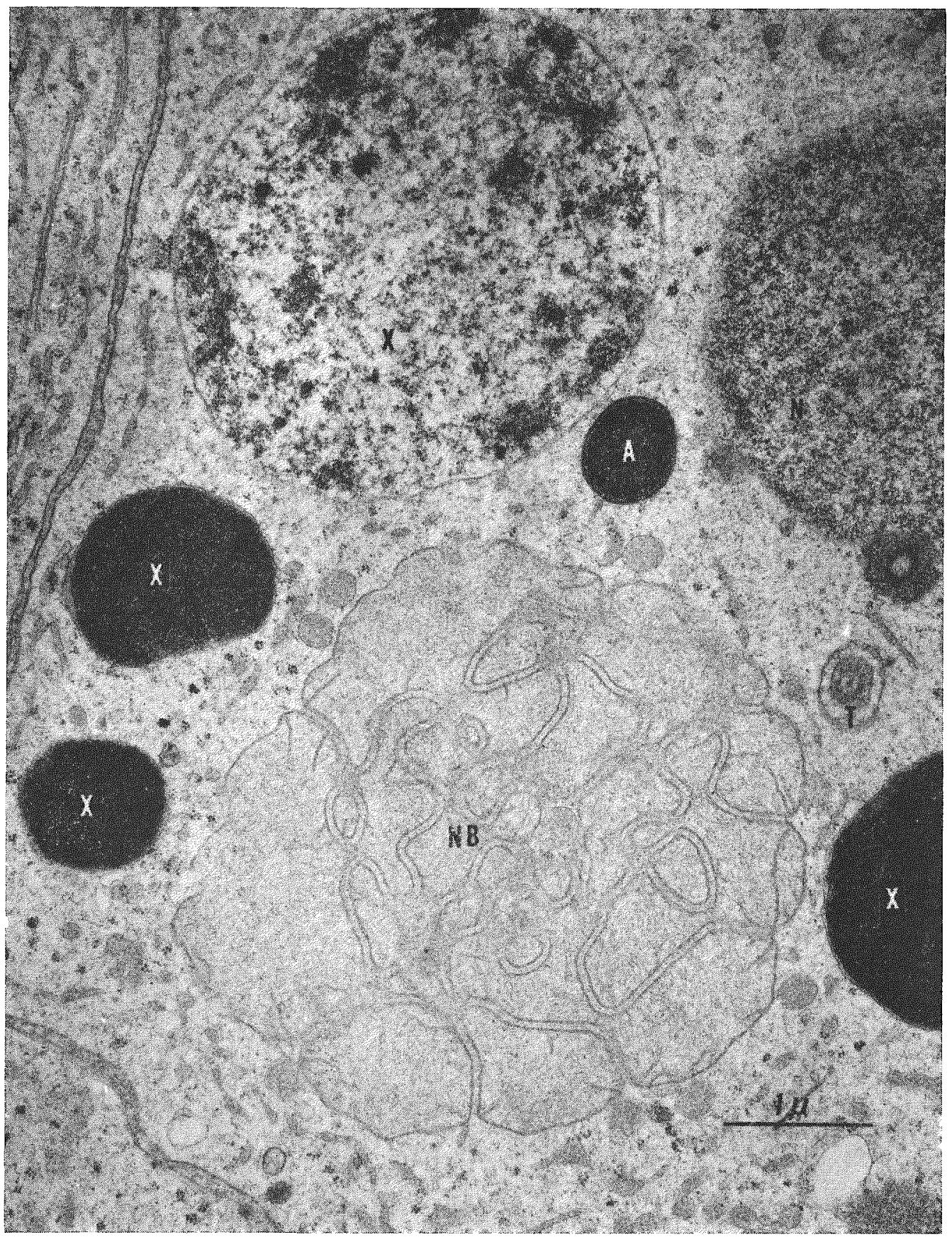

Fre. 24\%. A rung spermatid contains several abnormal bodies of uncertain origin, but suggestive of certain cell organelles. The nearly tangential nuclear segmont (N) appears normal, as does the nebenkern (NB) and tail filament bundle (T). The acrosome (A) is abnormally dark-staining within, although its size and capsule are normal. The limiting double membranes of the other dark structures $(X)$ are very similar to transversely sectioned nuclestrombranes as is the membrane of the nuclear-like upper body (X). Note the ribosomal partieles on their outer membranes. 


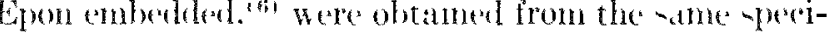

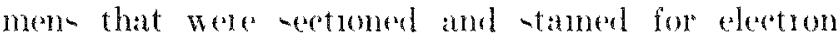

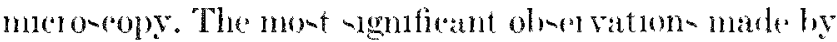

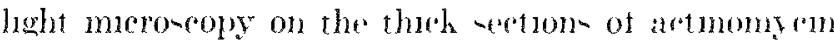
D-treated material that we de diferent from control -ertion- included. 1 , an exereste number ot cell m

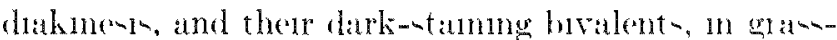
hompere taken durme the eally tme pened-atter m-

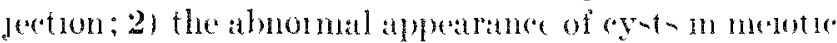

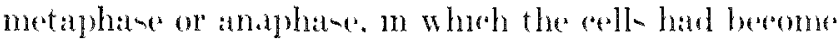

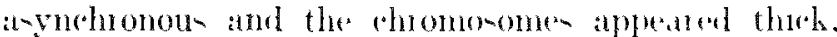

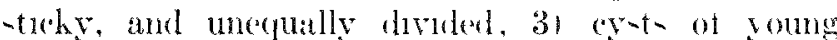
-permatide an whech numerom- latree nuela oecurred

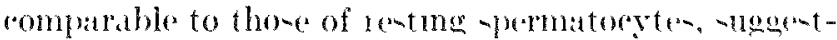
ing a failure to either undergo or eomplete deduet division; th a high moidenee of -upernumelaty tall filament- in -permated, trecpuently areompaned by "dther deep -tammg or "esploded" nehenhem bodue; and later, of a deromed number of erate per tollyele that contaned maturne. clongatme -yermated. -minlatr - sotion un the ceretron meroncope ronfimed the obervation-made by light mieroneopy i valety of ultra-truetural ahoormalitem has been noted The myelm-like figure, w-ually attrihuted to degeneratmes matrial. ocerum frequenty at all stagen a1 des lopment in the actmomyen D-mjected mate-

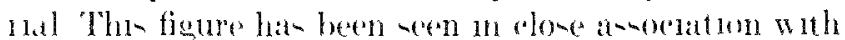
the mitochondriat and endopla-nine petweulum of teur

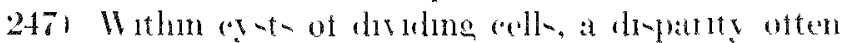
oreus among datughter ectlo In Finure 248, in ons

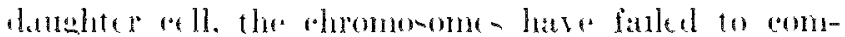

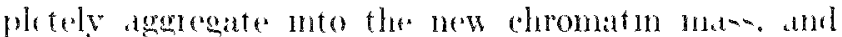

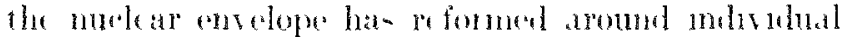

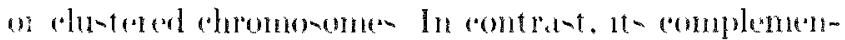
taty recll. not llwatrated. has proreded nom mally on the telophase-tage

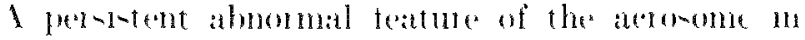

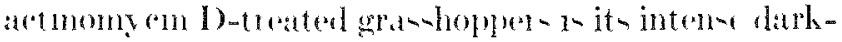
-tamed appeatrance In the -permated on Figure 249 , creral abertancere ate erodent. The dark aromomal

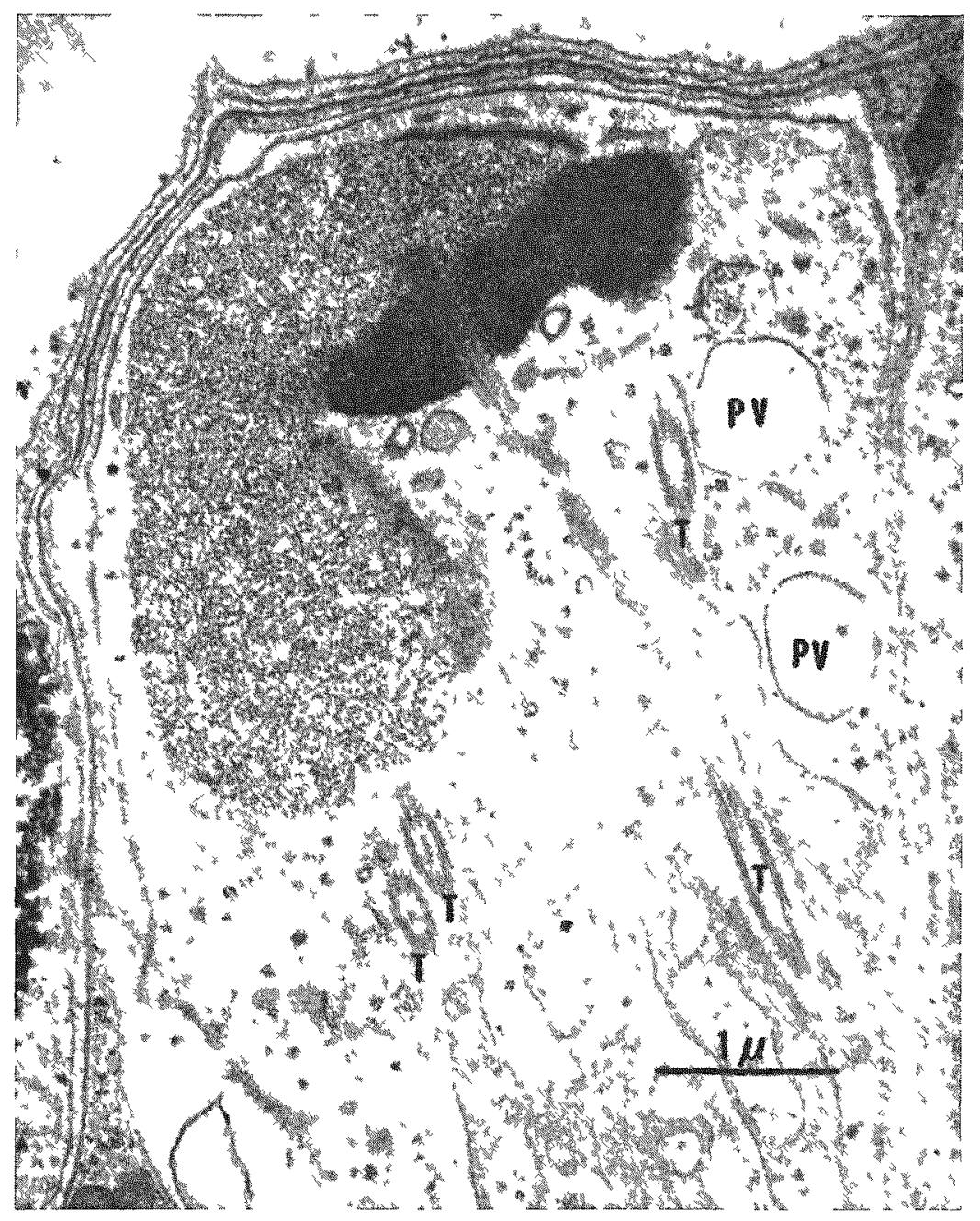

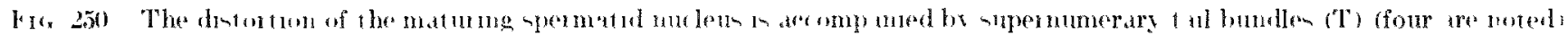

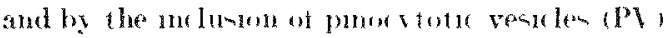




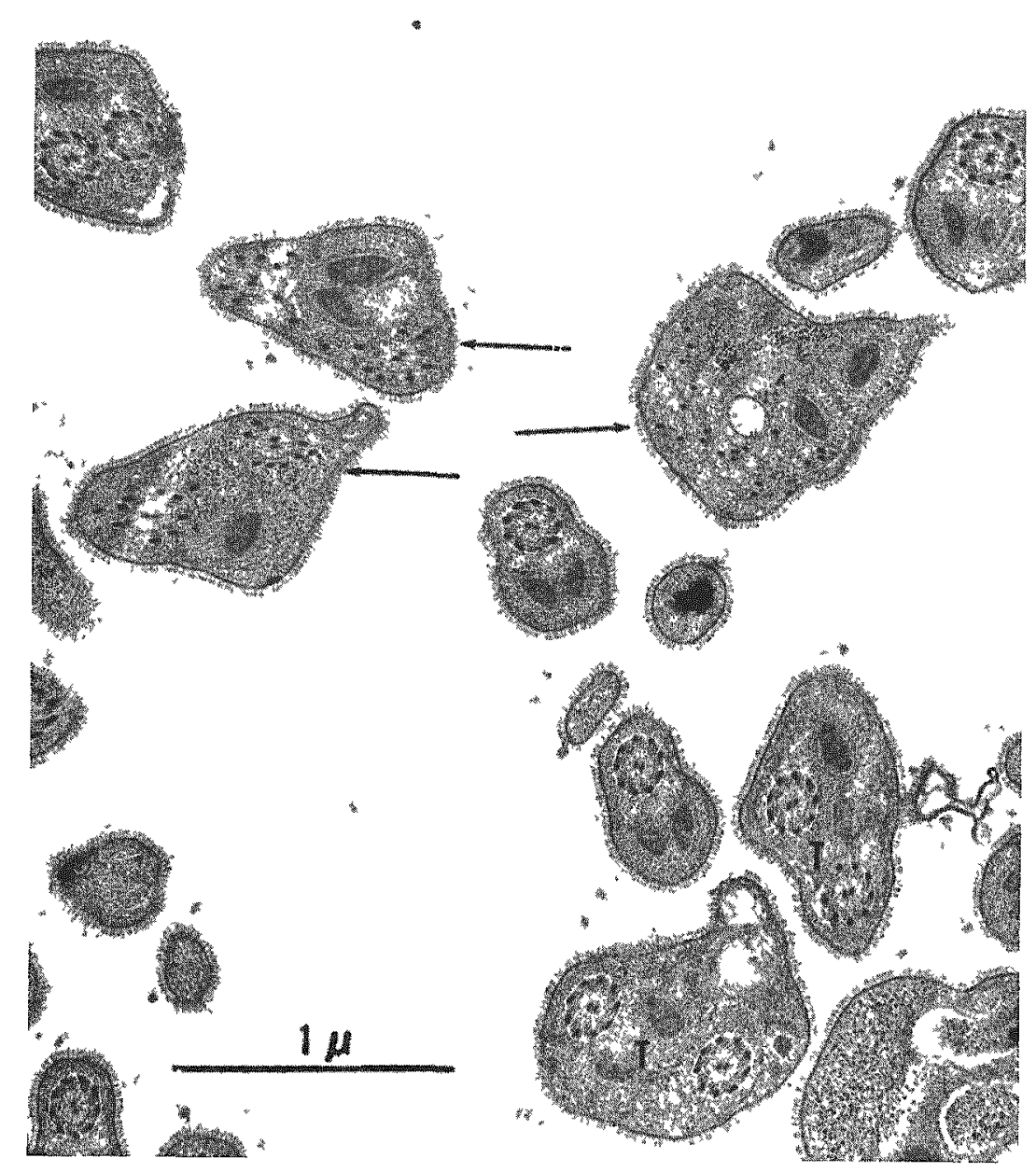

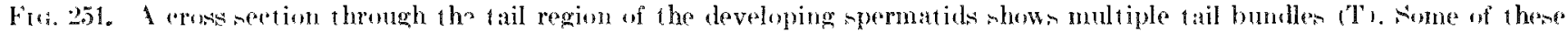
bundlas have been disoriented and have lost the ('onventional $9+9+2$ ('onfiguration (arrows).

body lie between a normal-appeating nurlede and at membrante-limited granular man that resemblen the chromatin of upermatocyten. Other darker boties surround the nebenkern. Their internal dem-ity is comparable to the acomente, but their limiting membrane iv more ahin to the chromatin-like -trueture and to normal nuelear enveloper. The tare dark bodien could be interpretenl, therefore. as vatrioun degenterate form of :bmormal nuclear bodier like tho-e hown in Figure 248 .

1)i-torted, naturing -jermatido are mumeroun I Figure 2.501. Their low of polarity is attended by supernumerary tail filanent bundlem, similar to thone frequently observed in irradiated gramhoppers. Thene bundlen typieally retain their nomal $9+9+2$ configuration, despite their multiplicity. In this actinomycin I)-treated material, however, a partial or total low of organization is not meommon l'igure 2511.

In Figure 2.52, two irregular - truetures are shown that haw been oberved in other material throughout the study. At the edl periphery are a reries of vericlewhone limiting membranes suggest a pinoeytotic origin. There vericles, whone number and size increase in the "ytoplasm of (arly spermatid in actinomycin D)treated material, are abent in controls. Pinocytosis is net nomally observed in gras hopper spermatogenesis.

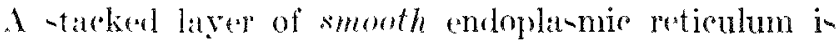
loseated arljarent to the murlear envelope, where one "xpecte to find sacked rough entoplamine reticulum. As this is the site of normal rough endoplasmis retieulum formation, thi- may repreene an interferenee of ribonome ernthesis in resone to the actinomyein I) treatment without the interruption of the membrane rntheris.

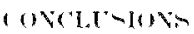

Thi- program, of neceensity, involves many fuceets of rell development. Thi prelininary report prenents progrem made in wablinhing dosage levele of actinomycin I) and satrifice timen uned to yield mea-ureable 


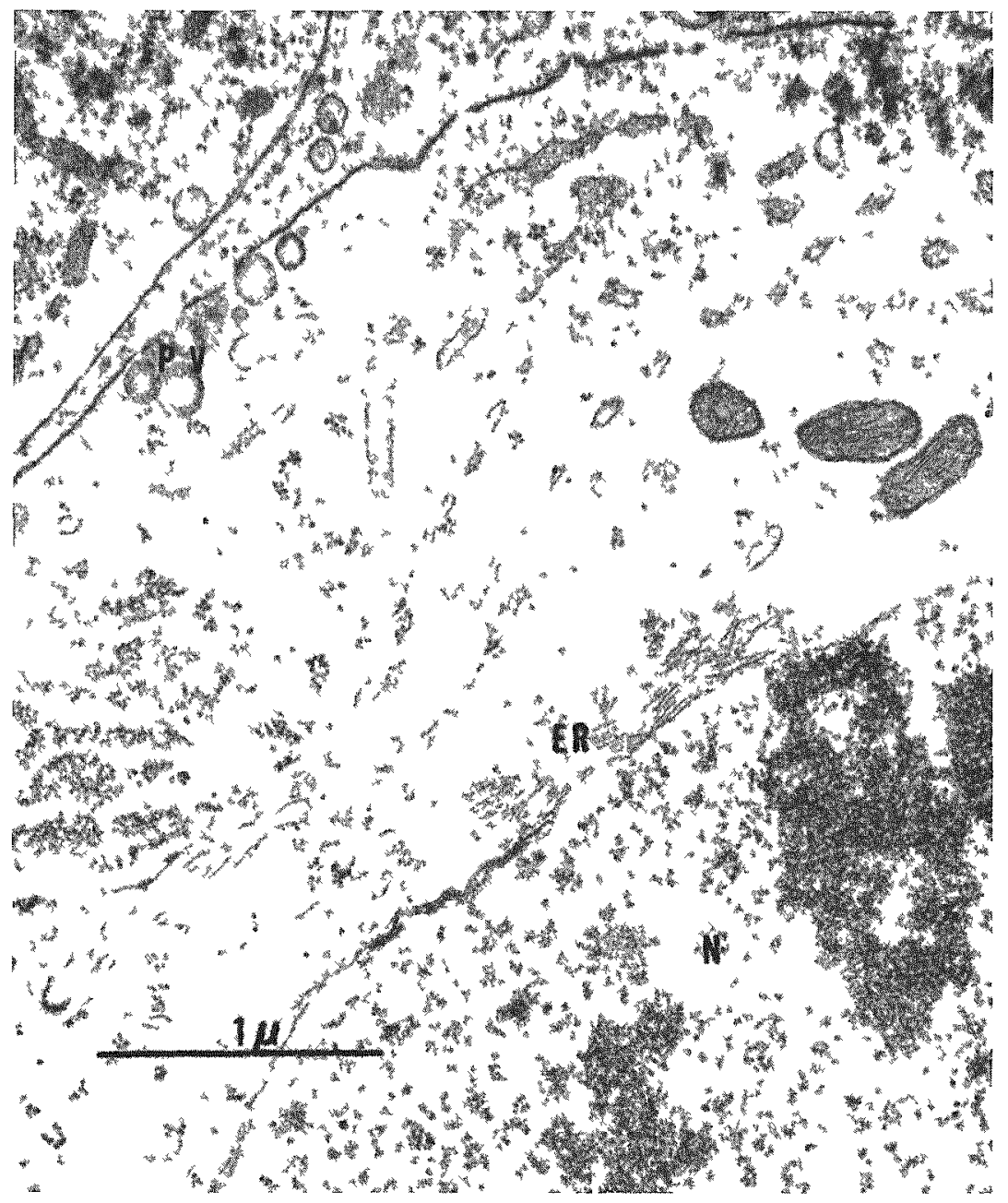

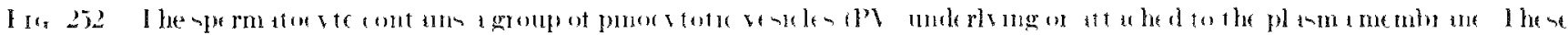

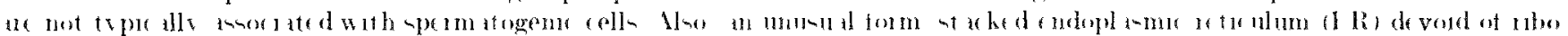

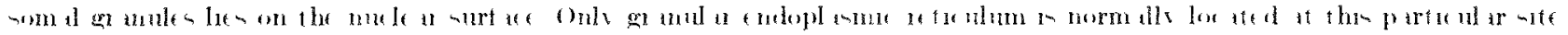

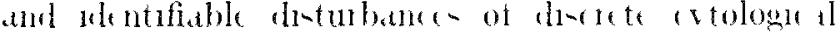
nature In the tuture we hope to determine - ite of valnedabite dwockated with de bition inom nommal or gane lla tom mation

\section{RFIFRI Y K}

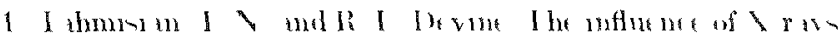

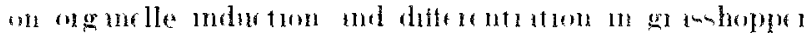

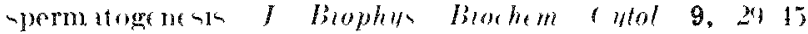
(1961)

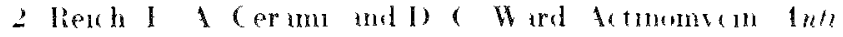

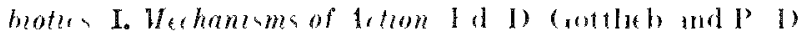

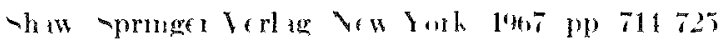

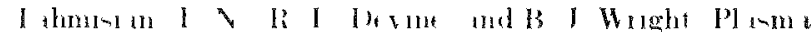

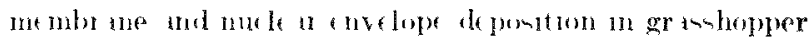

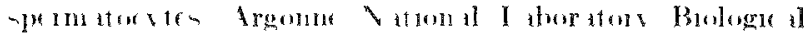

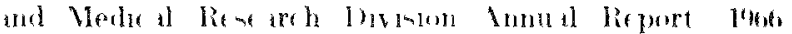
$111725,0 p 19,20$,

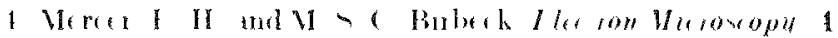

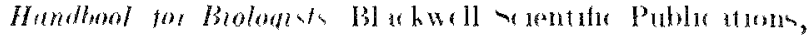

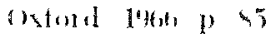

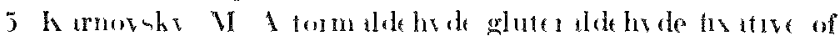

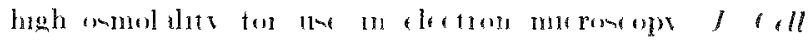
liol $27,131(1965)$

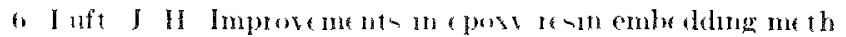

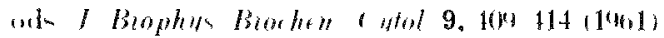




\title{
LIPIDS IN THE LIVER CELL NUCLEUS
}

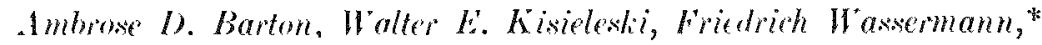 \\ and Faustina Maclieticius:
}

\section{PCRPORE AND MFTHOD}

Lipoprotein preparation- from inolated nuclei have been reported in a number of sudies." 1 " The posibility that they might be derived from the mentbrame of the nuelear envelope has been combidered, hut not definitely cotablished. In subfractionation of inolated nuclei to yidd nucleoplanmic and nucleolar

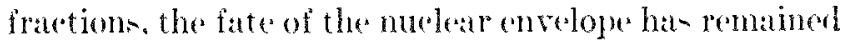
unknown。

More reententy in autoradiographic experiment- by Dr. F. Wasernann involving administration of radioartive palnitic acid to rat- grains were seen over the chromation arean of the nuclei in electron micorome sertions of liver and adlipone tim-ate" The The showed no tendeney to be locealized over the nuclear envelope. -uggenting. the refores that the nucles aborb lipid from the retoplixsm.

The prenent work is ained at elucidating the nature of the radioative material perealod by atutoratiography in the nuclei of the animals that receired the labeled palmitio acid. It is amed also at distinguishing betwen lipid anociated with the nuclear nembranes and lipid anoriated with the chromatin and the moleoli. The firt objective ha- been approached by uning thin latyer ohromatography to iolate and there meane the rationetivity in the laheled palmitic and dere ateid liberated from the rarow lipid by arid hydroly-is. "The seromd objective has betn approatehed by studying the feanibility of removing the molear membranes from inolated nucloi and then ivoluting a chromatin fraction fres of nueleolar contamination.

\section{PROMRESS RIPORT}

Followinge intragantric adminiotration, latheled palmitic acjel appears in planma chylomicrom predominantly in the form of triglyererde $1>9.5 \%$, which rapilly "nters the livere without prior hydroly-in." "s In order to determine whether the radioativity -een in the atutoratiograph wat -till prexent in palnitic or oleic ateid, and therefore legitimately to be considered in lipid, liver coll nuele from animal that had reseived palnitic acid-9,10-H" 24 he previousy wore hydrolyzed with ardel $16 \times \mathrm{NC}$ l, 16 to 20 hr. at 10.) ("). Thes hydrolyate was "vaporated to drynem nonder rexlured presure in an atmo-phere of nitrogen; the rendue wat taken up in ethanol, and the dark solid wa removed by filtration. The hulk of the nonlipin material wat

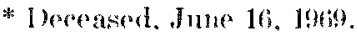

precipitated by addition of ( $\mathrm{HC} \mathrm{C}_{3}$, and the clear - upernatint was sulejected to thin layer chromatography on fiberglats paper inpregnated with siliea gel (cilman S.1: development with heptant-1.75', HAd. Lipid romponent-were visualized a- fluorement -pot-under ultraviolet light after spraying with a wlution containing rhodamine B. The fluoresent spot correyonding to palmitic and oleir acdo f isolated together in thiprocedure rontained at least $8.5^{\prime}$, of the total radioarotivity in the inolited nurleit. It appearo, therefore, that the grain- een in the autoraliographs do reprem-ent the presence of lipid in the nuclei. "The nature of thim material in being invertigated further.

In the experiment dealing with removal of the nucleat membranes, the nuelei were ivolated by the method of Blobel and Poter, and then wabled in a Tris-pota-sium ehloride-magnesium ehloride buffer

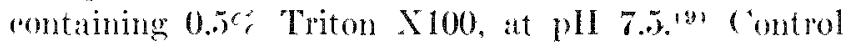
preparations received the same treatment exerpt that Triton X100 was omittel. After a ubequent wa-h in 0.34 , 4 -ucrone, the nuelei were pelleted in the antrifuge and fixed aifher" with buftered potasium permmanganate, or with ghtaraldehyde followel hy omic acid. Wrhydration, cmbedeling in Fon, aretioning, and -taining with uranyl arestate were done hy eonventional procedures.

In sections from glutaraldehrole-onnice ard fixed lires timue, the onter nembrane of the nuclear anvelope is reaty evident a Figure 2.53\%. Vindatization of the inmer membrane is often obscured by the presened of perinuelear matses of dence ehromatin, through which one sece channel leading to the porem in the nuclear enveloges. Thene perinuclear mase of ehroma-

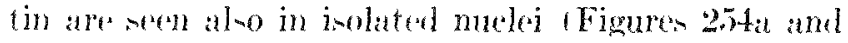
25.5at. In nuclei secetioned nearly tangentially, it ran be ren that the perinuelear dense rhpomatin actually comprises a continuol layer around the outside of the nurlere, in which the rhannel loading to the pores in the envelope appear a hole (Figure 2\%.) it. Tlis ferinuclear layer of organged chromatin may be pe-pon-ible for the fact that the nueles retain their -hapes (Pen after abletion of the nuclear membranes by Triton X100. With permanganate fixation, the chromatin is distributed more evenly, and both the inner and outer wembranes are clearly visible in the rontrol nurlei (Figure 25tat.

In the nuclei washerl with Triton X100, fixation wit whataldehrede and omic ardel reveal that the outer nombrane cortainly ha- heen penoved (Figure 2.5.5a). 


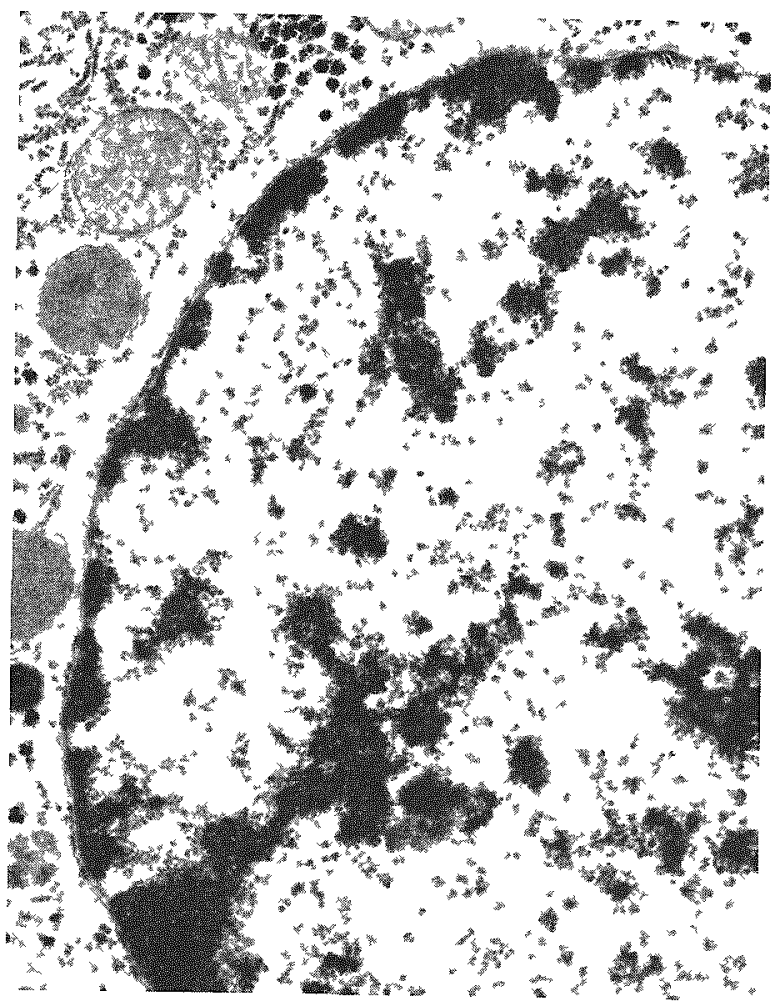

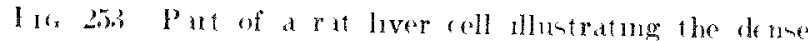

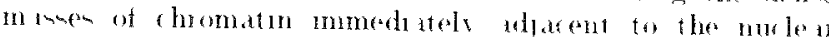

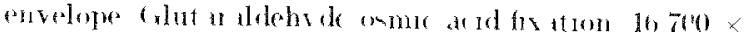

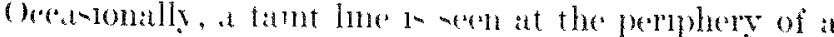

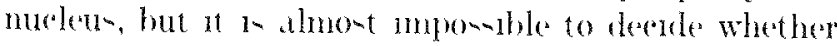
the repreente a remnant of the muer membiane, or whether it in part of the permuelear chromatm layer, wheh is etell present If ith permanganate fisation, the whomatm is nore arenly distubuted and escept for an oreatond fiant -ugegention of a peripherd line there whttre moleation that either nurlear membane remann after the expo-nes to the Triton X100 methum (F1guile 25.5)h).

In order to separate the chromatin thation from the

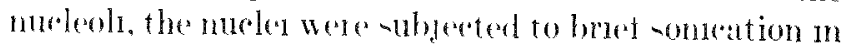

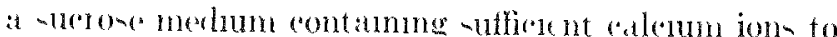
mimmaze disuntegration of the nucleole The -oncate

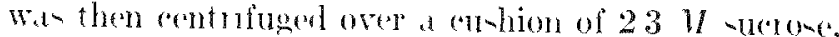

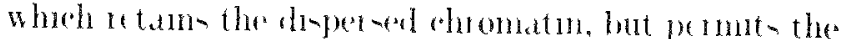

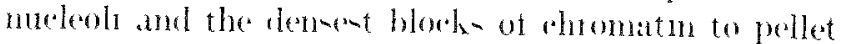
at the botton of the tube.".

In the chromatm pepald aton from nuele 1 -ublected

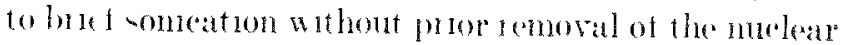

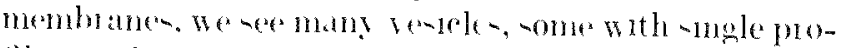
files, and wome with concentur double proble - one of

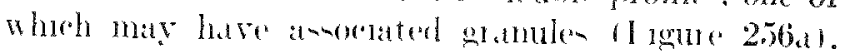
Apratently ame ate bounded by part of both mentbrame of the nuclear enrelopes and rome be only one. The nurleats membane hate been whipled into at

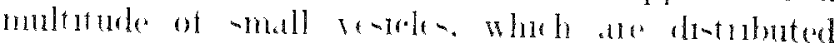

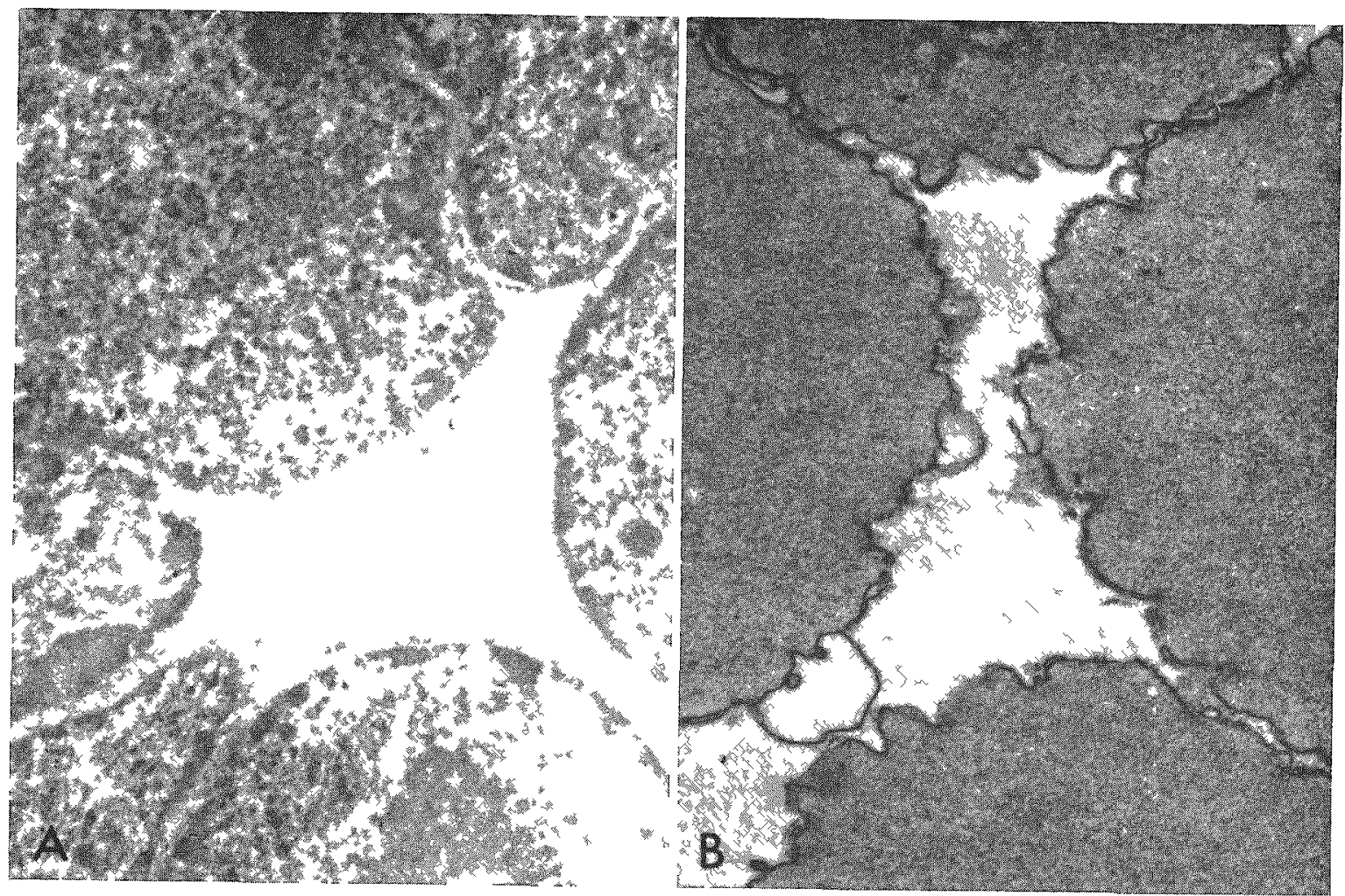

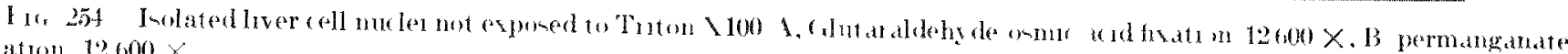
f1sation, $12,600 \times$ 

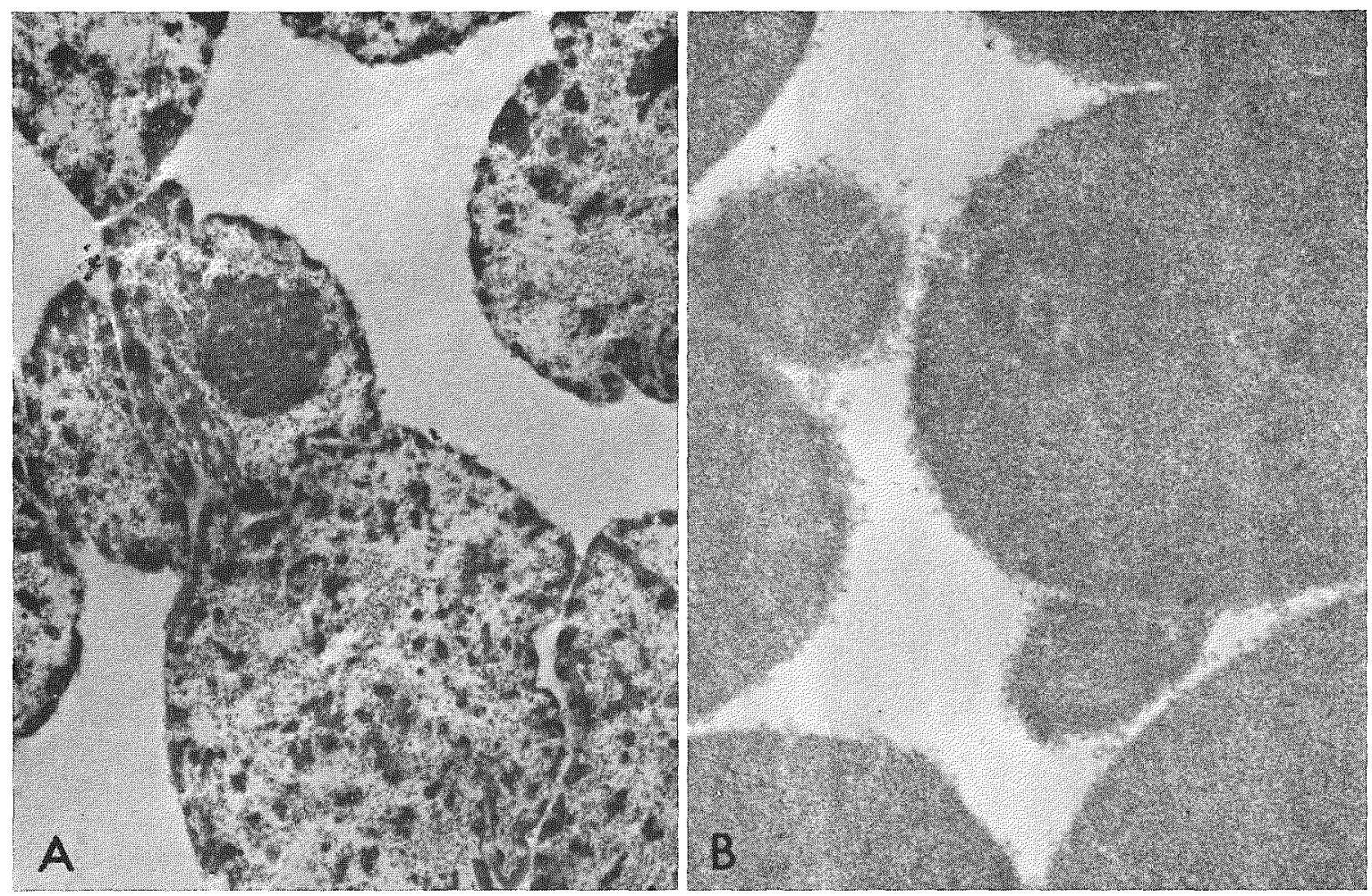

Fuc. 255. Isolated liver cell nuclei washed with Triton X100 as deseribed in text. A, Glutaraldehyde-osmie acid fixation, $4240 \times$; $B$, permanganate fixation, $12,900 \times$.

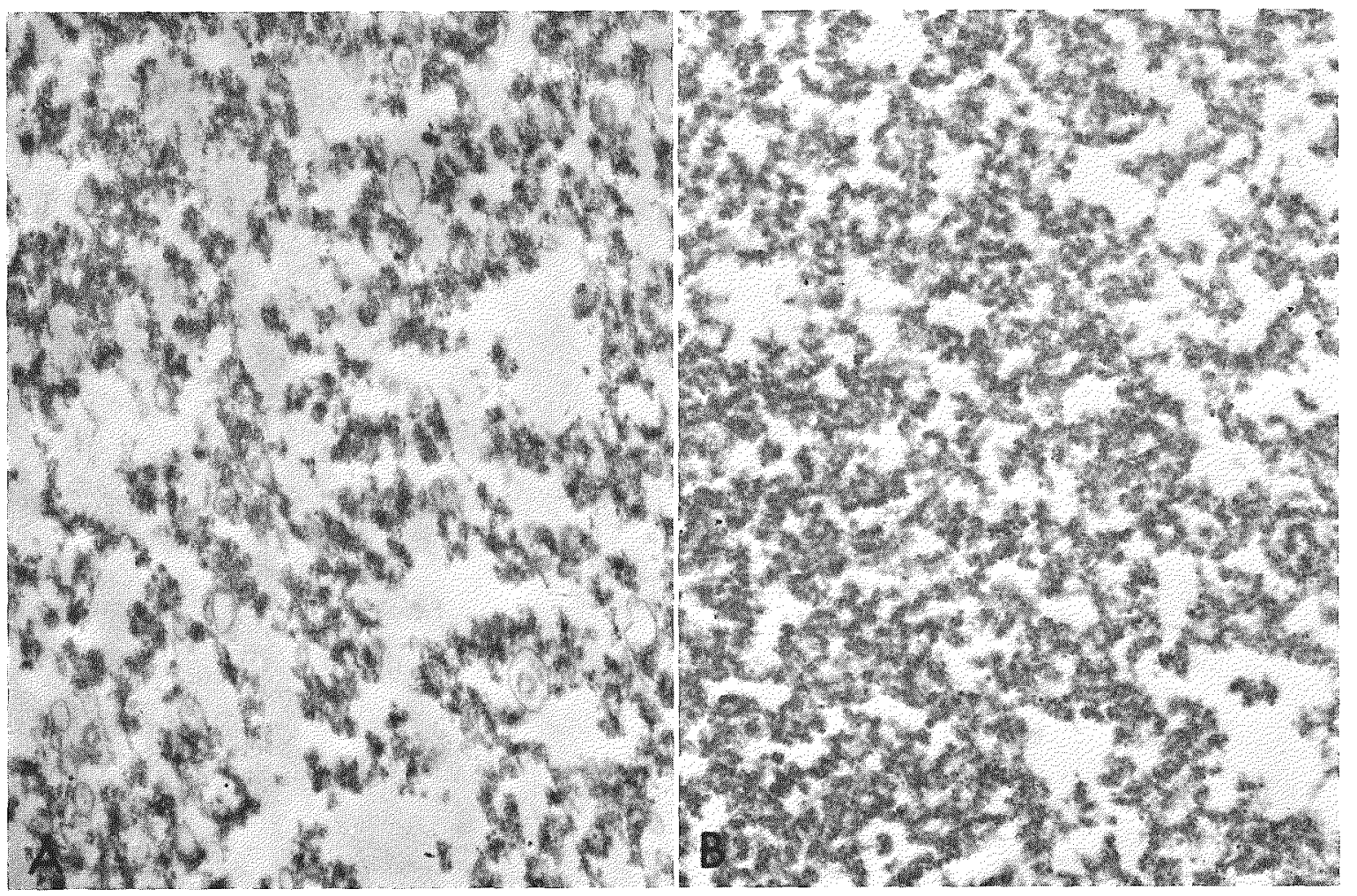

Fus. 256. Chromatin fraction from liver cell nuclei. A, Control preparation, 24.900 $\times$; B, preparation from nuclei previously exposed to Triton $\times 100,18,000 \times$. 
throughout the "hromatin. Our result show that the do not separate from it even on prolonged centrifugation. In the ehromatin from nuclei sonicated after removal of the membranen, such verieles are ext remely rare (Figure 2566$)$. In this (ant', it appear that these arise from rare intranuclear vesicles. which are produces by invagination as a result of manipulation of thes nuclei, and which then eseape removal by the wa-h in Trition X100. Nucleolar eontamination in very small in thene preparations (Figure 2,86h).

fome detergents become firmly bound to proteins and this could complicate the study of protein- from nuclei exposed to Triton X100. IIowerer. deteretion of this contamination is facilitated in this cate by the presence of a benzene ring in the strueture loctylphenylpolyethoxyethanolı. This produes a characteristic ultraviolet aborption -peetrum (Figure 25\%). which is readily disinguished from that of protein. During acid hydrolysin. nome deatrage eridently taken place at eateh of the ether linkates, an indieated hy the" pattern of spots produed in thin layer ehromitography ( Figure 2.58). Triton X100 - rareely move from the origin; with the exeeption of the one at the solvent

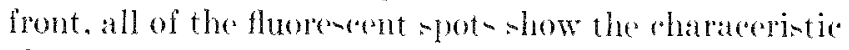
aborption peak. The hyorroly-is product from the detergent do not interfere with the recognition and i-olation of the spot containing the palmitic and oleje arde liberated by hydroly, of the lipid- 1 Figure 2.58 .

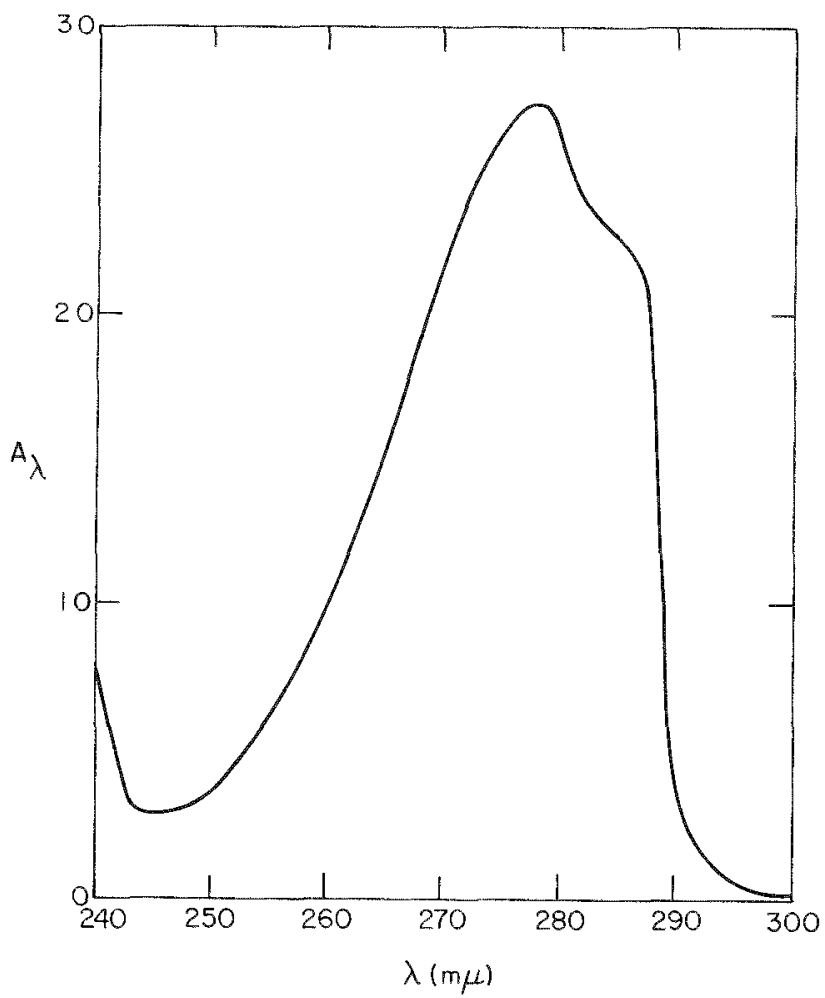

Fuc. 25\%. Tltraviolet absorption spertrum of 'Tritom $\mathrm{X} 100$ in aquesus solution.

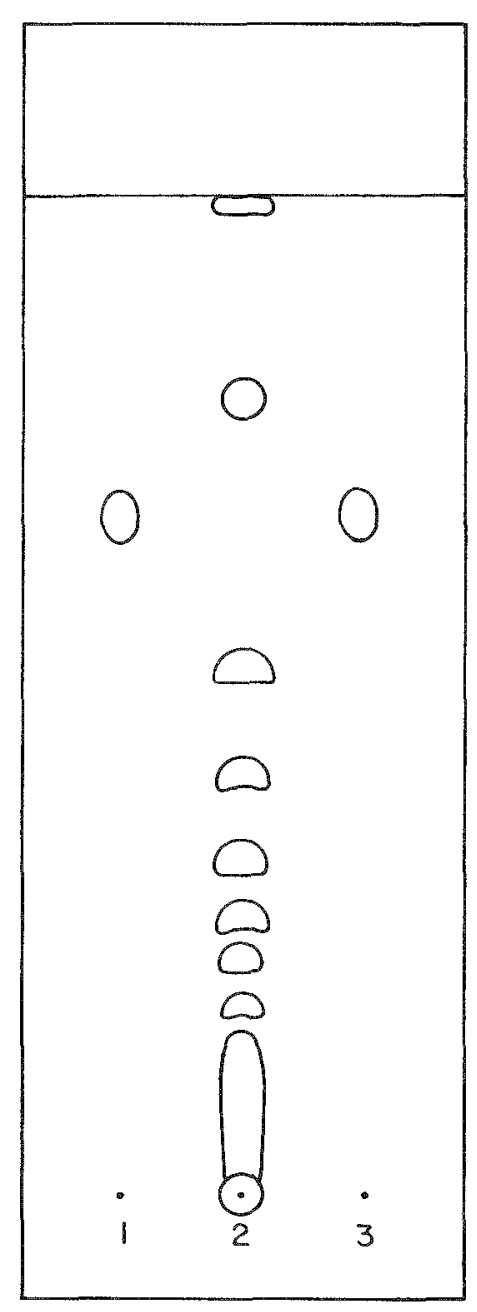

Fin. 25. Thin lager ohromatography of palmitio atrid

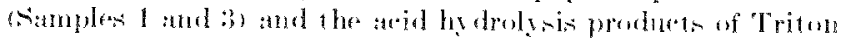
$\triangle 1100$ (Nimpla:2).

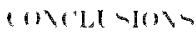

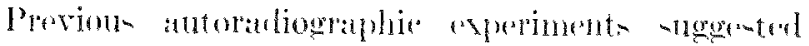
the aborption of lipid be the erell nucleus. In confirmation, the present experinernt have hown that at leat 8.5', of the total rationdetivity in the kolated

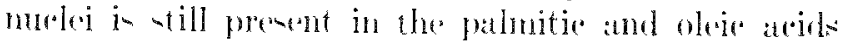
ionktad hy thin latere chromatography following exhatu-tive ard hrdrolves. The di-tribution of the labeled fatty ateid amonge the rapious clasen of lipids i- cill under incentigation.

The atutoraliographir obervation-mentionerl above fordued attention on the long-tanding need for studieaimed at dimtinguishing between lipids asoociated with the nembermen of the nurear envelopes, and lipids anowiated with the chromatin and the nucleoli. The present report demeribes the exploration of a procedure for removing the nurlear membranes with Triton X100, and then ming somication and centrifugation to isolate a chromatin fraction free of nurleolur contamination. 
It has been , hown that if the nuclear membranes are not removed before conicution, they are whipped into a myriad of mall resicles, which are distributed throughout the ehromatin.

Work in continuing on several aspects of this problem: the distribution of labeled palmitic ard amons the inolated nuclear subfractions; the nature of the protein and livid removed hy Triton X100; the incorporafion of labeled palmitic acid into chromatin during liver regeneration; and the application to our chrountin preparations of procedures previously uned to isolate nuclear lipoprotains.

\section{REFEREN'}

1. Wang, T. Y., I). T. Marer, and I. F. Thoma4. A lipeprotein of rat liver muclei. Exptl. ("all hes. 4, 102- 106 (1953).

2. linghring. V.K. and M. Laskenshi. Protein eomponents of chicken erythroevte nuelei. Bionthom. Biophys. Arin 11, $22+251(1953)$.

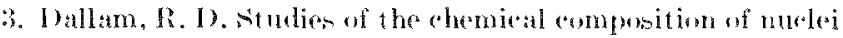

and "ytoplasmic granules. Irh. Bionkm. Biophys. 54, $2437(1955)$

f. Jackson, F., J. E. Farnharde, and R. Chalkley. A DNA. lipid protein containing material inclated from calf thymus "hromatin. Biochem. Biophlys. Res. ('omman. 33, 25.3 25ly (1968).

5. Maggio, R., l'. Siekevitz, and (x. L. Palade. Stludies on isolated nuclei. I1. Isulation and ehemical characterization of nucleolar and nucleoplasmic subfractions. I. Cell Biol. $18,29 \%-312(1963)$.

ti. Wassermann, F., A. D. Barton, and W. F. Fisieleshi, Feretron mis roseopie radioatutegraphio ohwervations suggesting absorption of lipid by the nuelews. Z. Z, Ulorseh. $95,1-8$ (ithit).

7. Mlivecrona, "T". Metabolism of ehylomicerons labeled with ("13-glveerol-H'palmitic arid in the rat. J. Lipid Res. 3, $43,4-414(1962)$.

s. Whyte, M., A. Kampe, and I). S. Comdman, Fatty acid esterification and chylomicron formation during fat ahsorption: 2. Phospholipids. J Lipid hes. 4, :322 329) (19633).

4. Blobel, (i, and V.R. Pot ler. Nuclei from rat liver: Isolation method that combinen purity w it high vield. Seciene 154,

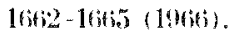


PLANT RADIOBIOLOGY

\title{
FURTHER STUDIES ON THE ORIGIN OF AUXIN IN THE URINE OF THE MOUSE
}

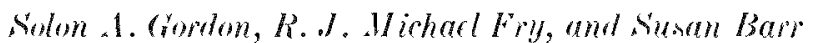

PL RPOAF, AND METHODS

Mammalian urine was one of the original cources for the isolation and chararterization of the auxin indoleacetic acid (IAA). Trine han a relatively" high conecentration of auxin. an oceurrenee that is attributed largely to the ingention of food that contain the hormone and to the metabolism of the gut flora. ${ }^{11}$ Howerer, free atuxin is found in numerom animal organ.$^{1}$ " 1 and the andin-forming enzyme complex, which converts tryptophan to IAA, aloo oceur in many vertebrate. The artivity of the enzyme is partieularly hoh in the liver, hirlney, and gonats and is -timulated by expendere of the animat to ionizing radiation. The detribution of free atuin, and the prenence of an endogenou bionsthetic pathway in the liver and kidney, suggemt that LAA in urine maght not necenarily be a produrt of the gut organi-me and that the radiation re-pone may be unrelated to these flora. Aceordingly. We are examining the auxin eeonomy of the germfres moume.

In a previou- report, "s) we thowed that IAt oe"urs in the urine of the germfree (GH) CRL:CD-1 ICR)ax moune, at conentration not materially different from thow in the urine of the conventional animal. We ato found the tryptophan-I.AA anzyme complex in cell-free homogenaten of the liver and kirhney of the CaF moune. Its sperefie actiritien in thene organ were highere than those of the conventional mouse, a difference that rould not be accounted for on the ha-in of grom protein coneentrattion. In this report. we will prement adritional data on the artivity of the tryptophan-IAd enzyme yand on the di-tribution of protein in the liver and kidney of (iF and conventional animals. We will whow that the ( $\mathrm{iF}$ animal can utilize tryptophan for the formation of lAd in live, and approximate the fratetion of the IAA serereted in the urine that can be aneribed to ingered food. The methods uned for the rulture of CiF animale, and the procedure for andy of enzyme aretivity and nitrogen di-tribution. were dereribel previously.
PROTRLE- REPOR I"

There is only one loeus of auxin activity in chromatogram of the acid fraction of urine from $\mathrm{AF}_{\mathrm{F}}$ and ronventional swi-c-Weber mire. Thi- auxin activity cormpond to the Rf of labeled IAA in the prenance of conoluter. and there is no material difference in the amounts of urinary auxin between the GF and anventional animak. Thus, the obervation madto on the ('RL:('I)-1II(R)ax mouse, (3) hold for the swin-Hellater motere.

Adritional anary of the truptophan-TAA enzyme artivition in hepatic and renal rell-free homogenatem of the (CI)-1 mou-e were rum. The result- are summarized in Tahle 97. Again, we find a relatively high titer of enzyme aretivity in the extracts of the germfree orgatls, both on timule wright and protein banes. The coefficient of rariation of enzyme titer range from 20 to soce. The higher -pereific artivitien for the eermifere preparation are not a conseculuence of lower protem leveln: the TCA-preipitated nitrogen in the liver and kilney prepatration- from the aermfrese and ronventional animal- are not iqnificantly different ITable 981. Alout two-thirds of the protein of the liver preparation reaten in the "microsomalsoluble protein" fracton; for the kidney preparation, thi fraction eontain approximately half of the protein iTable 98 ).

The int ratcellular di-tribution of protein wan asamines further. Table 99 how that there are no aignificant differenees between the two typere of animal in the protein eontent of the muclei-cell debris, the mieroumal, or the "oluble" protein fration-. The mitochondrial fretion of the conventional liver hat about one-third more protein than that of the germfree counterpart. Aedimentation analy-is of the hepatir -oluble fraction (Fienure 2.59 demon-trates no qualifation or quantitative difference in grom protein moletien between the two trape of animal.

We have hown that enzeme preparations of both the aermfres and conventional animak ean convert tryptophan to IAA in vitro. Does thi- conversion coreur in the intare aninal, viz., will the introduc- 


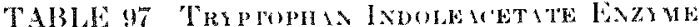

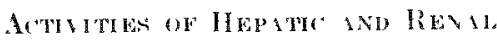
(

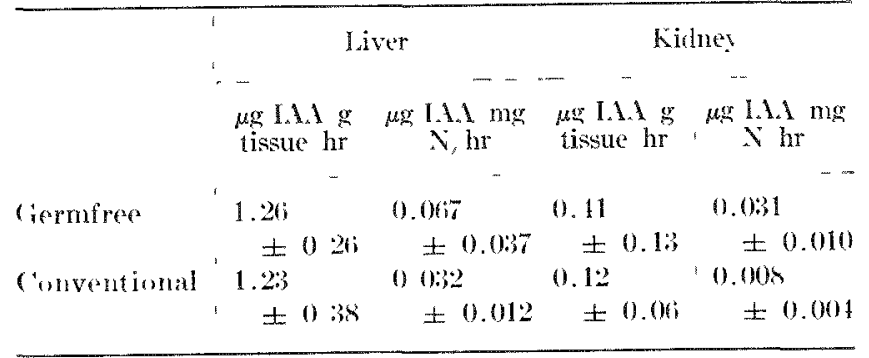

$$
n=910 \text {. }
$$

tion of labeled tryptophan result in the eppearance of labeled IAS in the urine? "17C-methylene labeled tryptophan was purified by paper chromatography and injected intraperitoneally into germfree and conventional miee $[0.25 \mu(\mathrm{i} \quad 18.8 \mu \mathrm{g})$ in $0.5 \mathrm{ml}$ physiological saline]. Pooled urine samples, collected 6 and $24 \mathrm{hr}$ after injection. were partitioned and the acid fractions chromatographed, using methanol-n-butanol-acetic acid as the solvent system. Figure 260 show the distribution of radioatetivity on the chromatogram. Activity appear at the locu of IAA on rhromatography of the urine extructs of hoth germfres and conventional mice. At $b \mathrm{hr}$ there is no material differener between the germfree and conrentional animats in the amounts of I.Ad producerl. The 24-hr samples, howerer, how significantly less activity at the IAA locu for the conventional animals. Horeover, considerable activity appeturs at the origin in the chromatograms of the extracts from the germfree animals. both at 6 and 24 hr. No activity was detected at thi- locus on the chromatograms of the extracts from conventional animals. These quantitative and qualitative disparitien between the two animals reflect difference in competitive metabolic pathways for tryptophan or one of it lerivatives.

It may be suggested from the preceding experiment (Fig. 2601 that the urinary IAA arises, at least in part, from tryptophan. But part of the urinary auxin might rome directly from ingested food. Is free IAA aborber from the alimentary tract and serereted in the urine? Because free IAA is readily inativated in arid media, partirularly in the presence of oxyen, labeled IAA dissolved in milk was intubated directly into the stomach of both CiF and conventional animals [2-1'C-IAA, 15 nC 1 i $1 \sim 7$ ng) in $1 \mathrm{ml}$ milk]. Pooled urine simples were collected

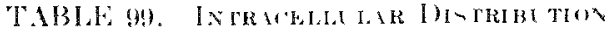
of HePligr Prothis?

\begin{tabular}{|c|c|c|}
\hline \multirow{2}{*}{ Preparation } & \multicolumn{2}{|c|}{$\operatorname{mg} \therefore g$ tissue } \\
\hline & Germfree & Conventional \\
\hline Homogenate & $211 \pm 1.0$ & $23.7 \pm 0.7 s$ \\
\hline \multicolumn{3}{|l|}{ Preeripitate } \\
\hline $1,000 \times y, 10 \mathrm{~min}$ & $112 \pm 0.37$ & $10 . x \pm 0.3 x$ \\
\hline $12,000 \times a, 30 \mathrm{~min}$ & $2.21 \pm 0.160^{n}$ & $3.01 \pm 0.2 \%$ \\
\hline $110,000>y, 00 \mathrm{mu}$ & $: 3.30 \pm 011$ & $3.02 \pm 0.14$ \\
\hline \multicolumn{3}{|l|}{ Sinpernat ant } \\
\hline $110,000 \times g, 90$ min & $1.20 \pm 002$ & $1.37 \pm 0.06$ \\
\hline Organ weights, g & $1.66 t \pm 0.16 i$ & $2.11 \pm 0.15$ \\
\hline
\end{tabular}

(.) $n=4$.

(a) $P<0.05, t$ test.

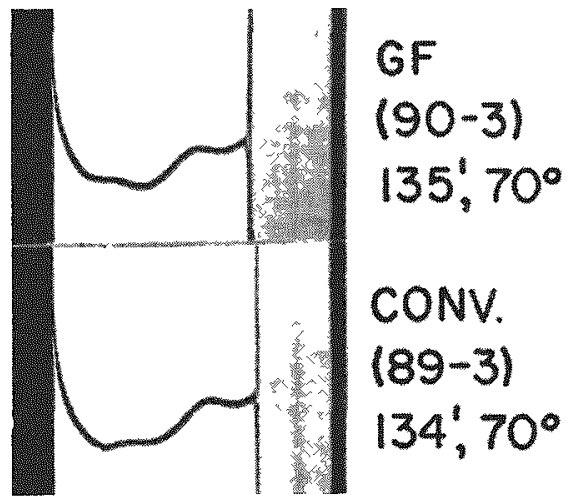

Fis. 259. Schlieren profiles during sedimentation of extrats from the livers of germfree and conventional animals. livers perf used with physiological atine to remove interfering hemoglobin and then dispersed in 3 times their weight of $0.25 M$ sucrose in 004 Tris buffer, pH 7.3 . Preparations were subjected to a preliminary eent rifugation of $30,000 \times y$ for 15 min (analytiost ult rasentrifugation bỵ Lỵe Bunville).

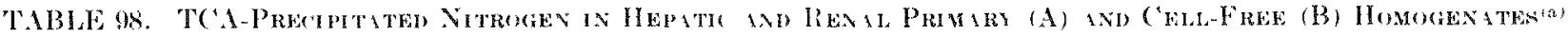

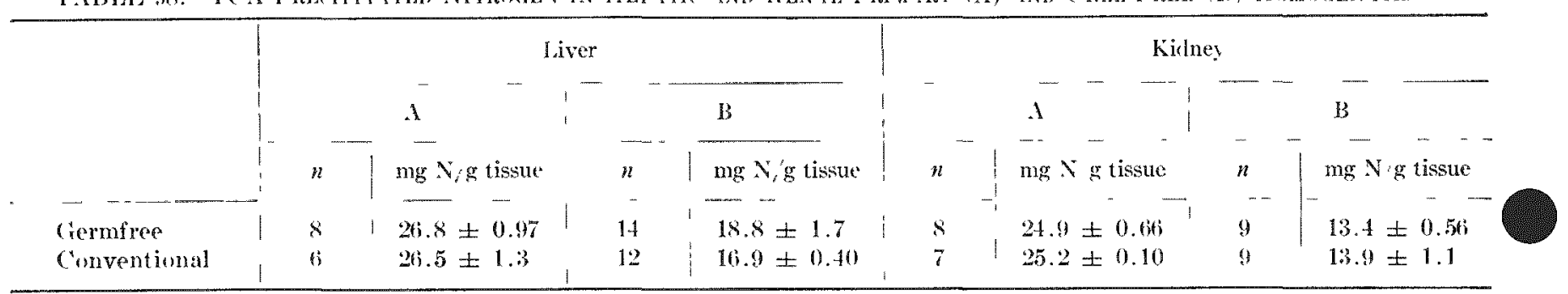

(4) $15,000 \times g .15 \mathrm{~min}$. 
at 4 and $24 \mathrm{hr}$ after intubation, fractionated, and the axid fractions chromatographed. Figure 261 shows the distribution of radionctivity on the chromatograms. Activity appear only at the loens of IAA on the chromatograms, and there is no material difference between the activitien of the GF and conventional animals, either at 4 or $24 \mathrm{hr}$. From these data. we suggest that IAS, in milk introlueed into the stomach, is aborbed and excreted as IAd in both (iF and conventional mice. ()n the baris of the total radioactivities measured, approximately 2.5 ' IAA introduced is climinated, as such, within $24 \mathrm{hr}$.

If the animal can aborb and excrete the free IAA of food, what fraction of the urinary titer arises from this souree? Mice of the size, age, and strain used, consume about $5 \mathrm{~g}$ of the auterlaved Iab-Blox supplied to them. BY wher extraction, chromatography. and bioasay of the rhromatogram, we find that the average amount of free IA.I in one day's foor consumption in, conservatively, about 2.5 $\mathrm{ng}$. From the intubation experiment we have noted that (a. 25r of ingested LAd appears in the urine in $24 \mathrm{hr}$. ()n this basis, on the order of $6 \mathrm{ng}$ of IAA in the urinary output for one day could be arecomted for as originating in the free IAA of the fool. However. the urinary exeretion of IAA in one day, as determined by chromatographic resolution and hioasay, is at. 2.5 $\mu \mathrm{g}$. Thus, the total amount of LAd excreted daily is at least 400 timen that present as such in the food. We suggerest that the ingested frese IAA camnot account for the amount of IAd prenent in the urine of either the (AF or conventional moune. The difference mut arise, therefore, by conversion of some IAA precursor in the animal.

If the mouse can aborb 1A.t intubated into the alimentary trart, what concentrations of auxin occur in the intestinal contents? Wre would antipipate that the intertine of the conventional animal rontain. free IAA, but had no basis for asouming a like ocrurrence in the (iF moune. Aceordingly, intact intestines were removel from both types of animal and divided into three segments: the upper and lower small intestine, and upper larese intestine. The contents of each sexment were rapilly washed out with $0.01 .1 /$ phosphate buffer, pII 8.0, acilified, extracted with ther at $3^{\circ} \mathrm{C}$ and the acid fraction of the extract chromatographed. The results of bioassays of the IAA locus on the ehromatogram are summarized in Table 100. Typically, the careum of the GF animal is enlarged. This is refferted by the 20 -fold greater dry matter eontained within this segment in the (if mouse. It is not unlikely that bacteria contribute to the relatively high concentration of $\mathrm{IAA}$ in the caecum of the conventional animal; however,

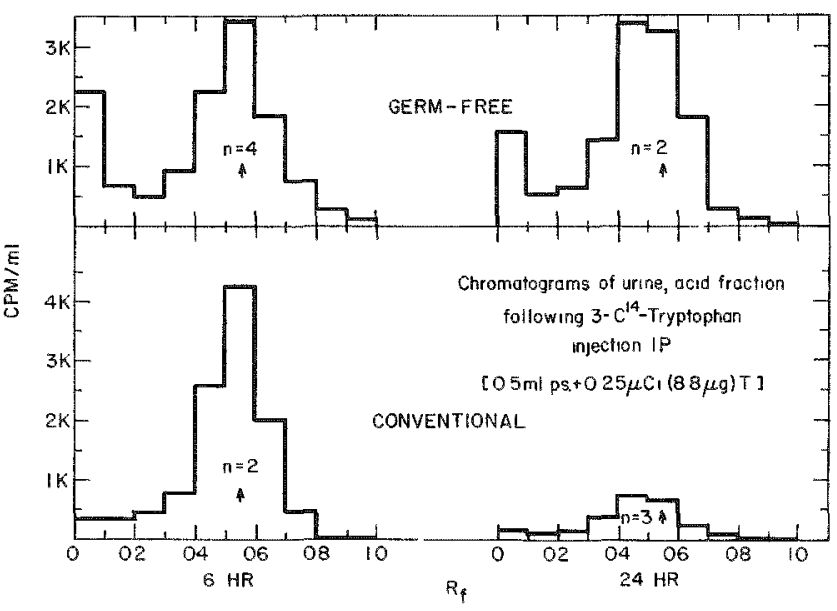

Fra. 2to). Instribution of radionetivity on chromatograms of urine, acid fraction, following intraperitoneal injection of 3-112-tryptophan. The arrow represent the hif of I.A. in admixture.

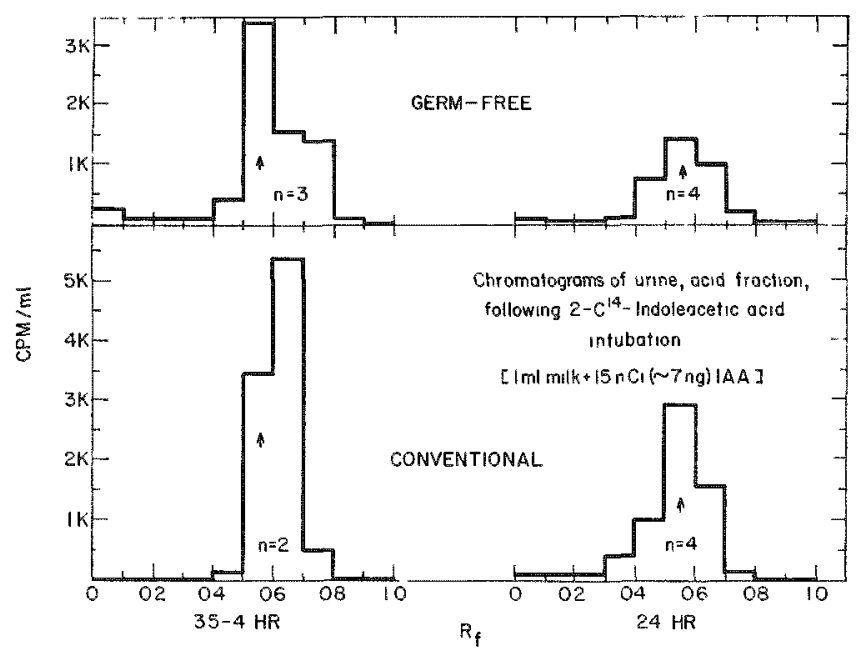

Fitr, 261. Distribution of radionetivity on chromategrans of urine, acid fraction, follow ing intulation of $2{ }^{1:(}-1.1 .1$.

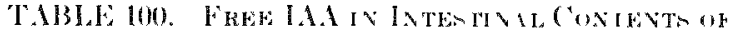

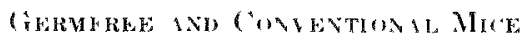

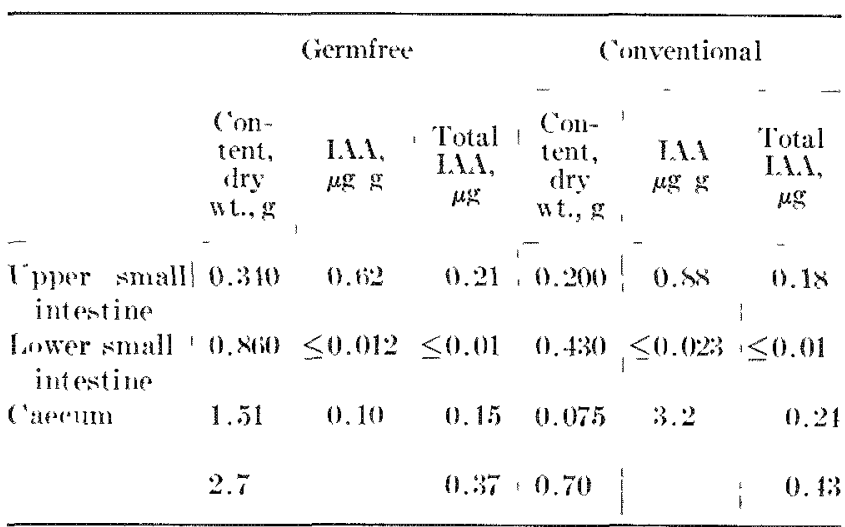


the greater amount of matter within this segment in the GF moure tends to equalize the total contrint of caecal IAd between the two typers. The nummerd intestinal contents of IAA for the (iF and conventional mouse are inuilar. Thue noncumulative samplings, with IAA lerels at leat an order of nagnitule greater than those found in a daily food intake, indirate that concersion of IAA precursors to IAA takes place in. or at leat winds up in, the gut. Bacteria are not obligate to this process. though it is probable that the large concentration of $I A A$ in the conventional caterm is of baterial origin. We ammot explain why the ileum of the conventional animal, which presmably posemen a bacterial flori, has so low a level of IAA.

\section{CONCLTESTONS}

1. We find auxin, presumahly IAA on the ba-is of chromatographir resolution and biological activity, in the urine in two strains of (iF mile. It concentration in not materially different from that of the tuine of comparable conventional animal.

2. The tryptophan-to-TAA cuayme complex oecurs amel is artive in ritro in engyme preparation of the liver and kidney of $\mathrm{CF}^{3}$ mice. The activities in the GF organs equal or exceed those of conventional controls.

3. Labeled tryptophan introdued into the peritoneal cavity of both $\mathrm{GE}$ and conventional animals gives rise to labeled IAA in the urine. We suggest that both GF and conventional animals not only can, but do ronvert the amino acid to the stuxin. Emegenous bateteria are not obligate in the process.

4. The intubation of labeled IAA. as well as a way of the free atuxin content of fourl. indicate that rome of the urinary IAA could come from ingested free IA and be absorbed as such from the alimentary tract. Quantitatively, however, ingestion of free IA. ran account for only a smatl fraction of the amount that appears in the urine.

5. Away of free 1.1.1 in the gut contents suggent that IAI formation takes place in the intestine, that haveria are not mandatory for this produrtion, and that it is probatble that part of this IA.A is absorbed and relared renally. Wo suggest, therefore, that the major fraction of the urinary IAA of the moune arises from endogenous enzymes intrinsic to that animal. The function of tryptophan as a substrate in this conversion is in no sense incompatible with a like function of other potential precursors of IAA, ingented or chdogenous. We also suggest that microorganioms, in situ or invanive, may not be mandatory for the artivation of the auxin-producing antzame in the $\mathrm{X}$-irraliated moure.

\section{REFWREN('ES}

1. Went, F. and K. V. Thimann. Phytohormones. Nacmillan ('o., New Yort, 1933\%.

2. Cordon, S. A. and H. Buess. Observations on the physiologgy and radiation response of anin formation by animal tissuss. Trans. A. Y. Acad. Ari. 144, 136145 (1976).

:. Cordon, S. A., R. J. M. Fry, and S. Barr. On the origin of auxin in the urine of the monse. Argonne National Laboratort Biological and Medical liestearch Division Annual Report, 196\%. AN1, -7535, pp. 312313.

\title{
GROWTH AND CYTOLOGICAL EFFECTS OF LIGHT ON HAPLOPAPPUS IN SUSPENSION CULTURES
}

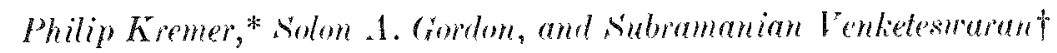

\section{PLRPOAE AND METHODS}

Previous studies here have shown that a ligh incidence of chromosome aberration oceurs in pig kidnetre cells that were expowed to far-red light leat. 730 nml. The atherrancies are similar to those caluest by ionizing radiation. We were curious ats to whether plant wels grown in the almence of light exhibited analogous photonemitivities. Accordingly, we are determining the effects of white and far-red light on the growth and eytology of plant rells grown in

* Marmion College, Aurora, Illinois.

t Cniveraity of Houston, Hobston, Texas. supenion rultures. The present report describer -everal of the preliminary results.

Indifferentiating cells of Haplopappus gracilis $(2 n=4)$ were grown under continuous agitation using a modification of the medium of Lriksson. (1) Inocula and suspensions for irratiation were made of mixtures of single cells and small colonies of lexs than 10 rells by preliminary filtration through $110-\mu$ menth nylon bolting aloth. Ahout two-thirds of the cell in the filtrate were single.) Exposures gencrally involver $5 \mathrm{ml}$ of cell when-ion containing from 500 to 2000 cell-, $m$ of medium, spread by settling to a relatively uniform layer. White light was obtained 


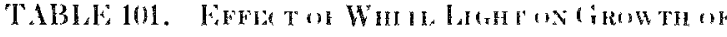
Haplapappus ("Hotan"

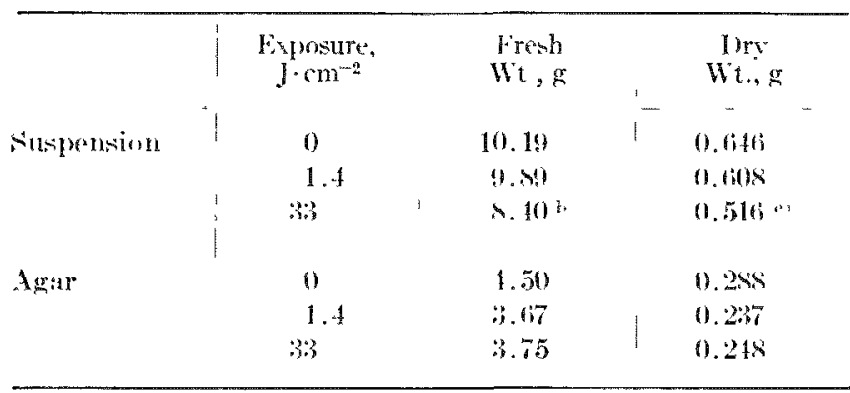

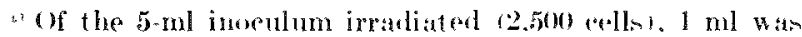
plated on agar and the remainder uned for suspension ent ture. Gow heriol:3 weeks at 25 (", five replicaten.

in Differenese signifieant at the $2^{\prime}$, level.

(e) Iifferenese simnifieant at the $l^{\prime}$, level.

from a tungsten halide incindencent lamp filtered by infrared reflecting glas. An interferenes filter, $\lambda$ max. $730 \mathrm{~mm}, 1.5 \mathrm{~nm}$ III blocked to "infinity", was added to obtain far-red light. Phased populations were obtained he ketping cell suspensions at $4^{\circ} \mathrm{C}$ for $6 \mathrm{hr}$ before inceulation. For reell rounts and eytological obervation, cells were suspended in $1:, u$ sucrose solution containing 0.002.5's colcemid for 2 hr, fixed in Newcomer's reagent, and then stained with aceto-orcein. Permanent mounts were mate of squarh preparations. Cell count- were mate by hema- cytometer, gentrally atter materation of the stained cells in dilute nitric-chromic anderle $F$ and $l$ tent were und for variane analysis.

\section{PRORHW- RI:PORT}

Table 101 show the eflect of single exponures of white light on the suberpluent growth of Haplowapmos: redls. Total erell weight. Woth in stepemsion and agar rulture, is rodured by previon irradiation of the "ells. The examine the efferet of -ingle exposures to white light on colony size and on ploidy, unphased inorulat of filtered altures were axpored to white light at four lexvels of indident antergy. The influrinee of thene axposuren on cell number, type of rolony and ploidy is shown in Table. 102. Kxeept in one instances. expowere to white light did not materially derestere the number of ingle cells produed in the $: 12-p e+4$ ion eulures. The exreption was at the 10-joule level for the 7-day growth perior of Experiment II. In all threes experiments, there wat atetually an increane in the number of -ingle rolk atnd number of colonien in the cultures irracliated at the 0.1-joule level. However, the number of colonies formed after one week of growth was materially dereated by the greater exposuren. This impoiment alletere to be transient, for there is no significant rfiect of illumination on colony number after a 1 thday growth period. The decreatie of rolonics at the

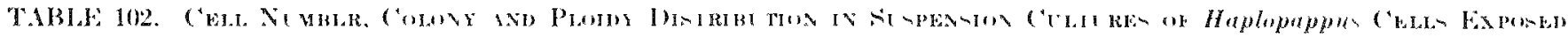
TW WhTE IIMHT"

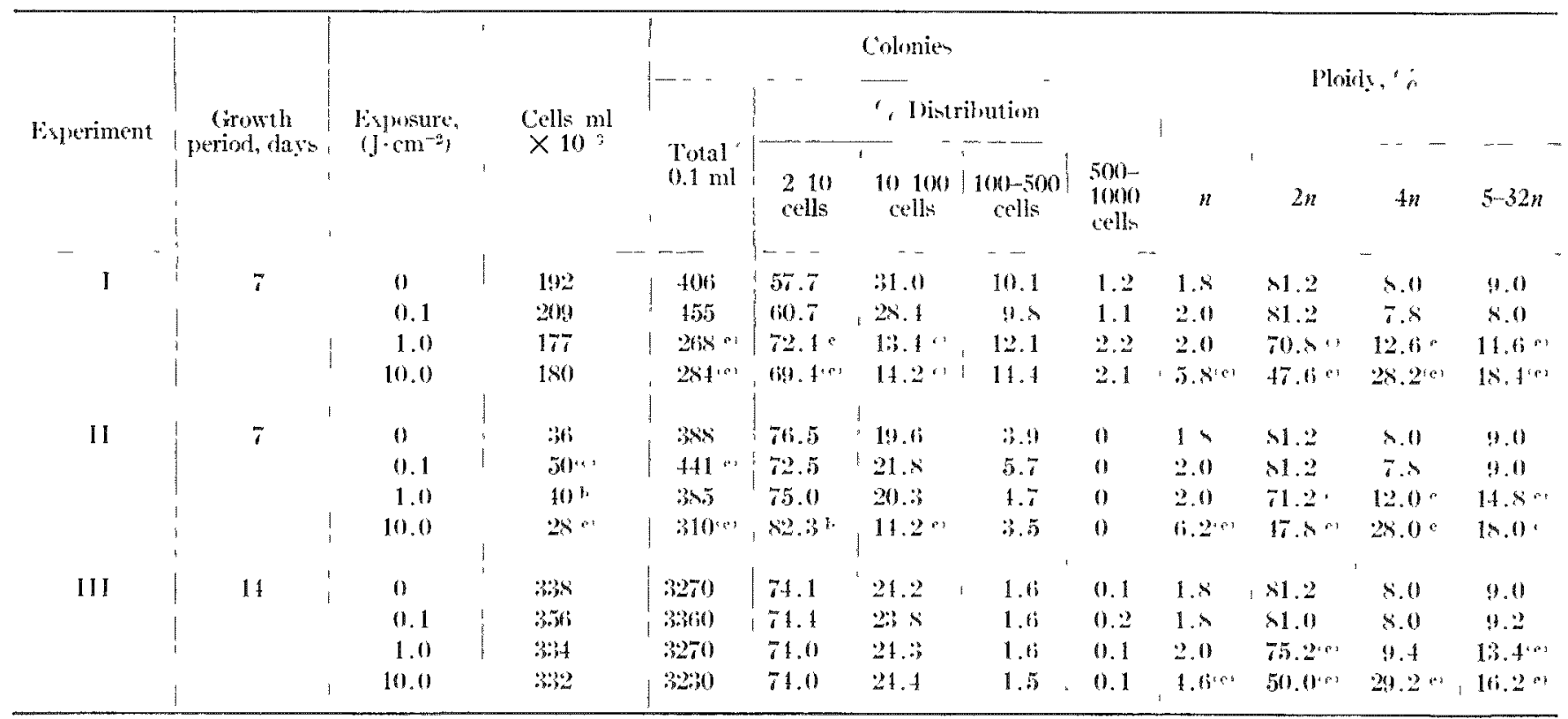

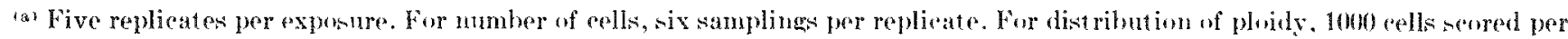
replicate.

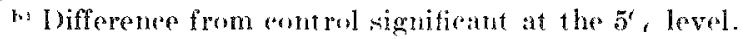

e I bifferenee from cont rol significant at the $l^{\prime}$, lovel. 


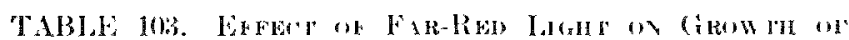
Haplopappure ("HoLA'"

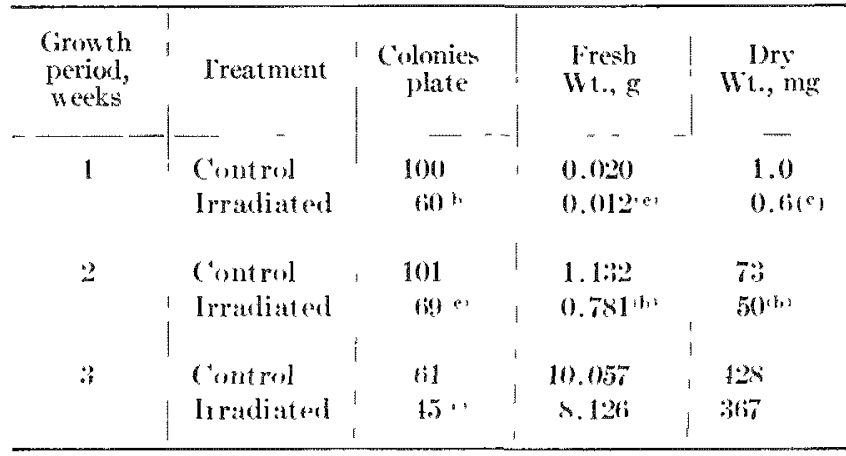

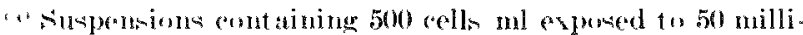

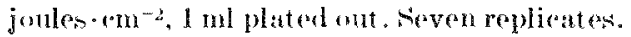

ba Jifferences from cont rol signitiont at the $1^{\prime}$, level.

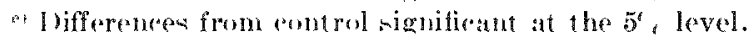

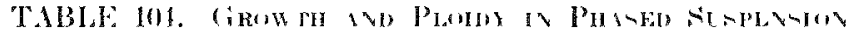

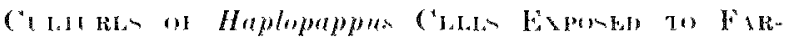
Rit) IAGH

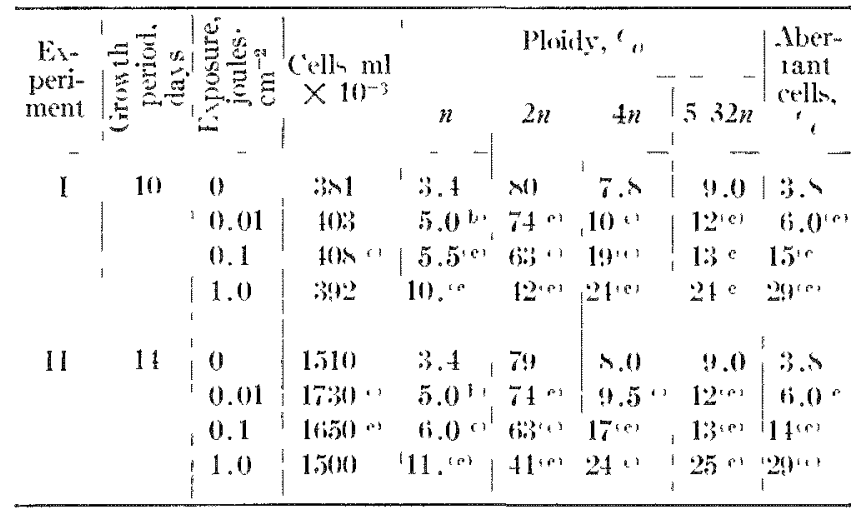

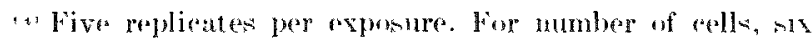
samplunge per replieate. For distribution of ploids and fran

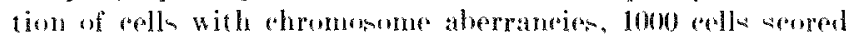
per replicate.

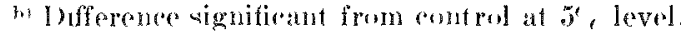

- [Differenese signifir:ant from ront rol at $1^{\prime}$, level.

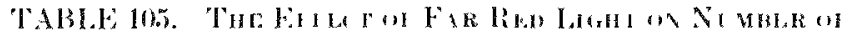

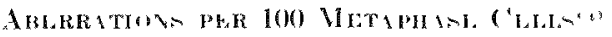

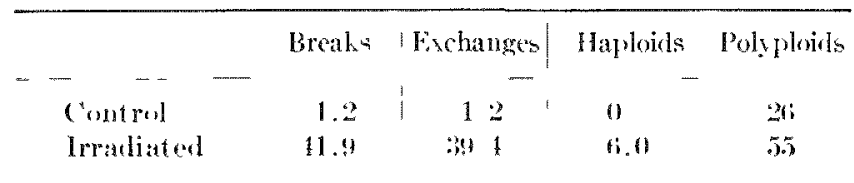

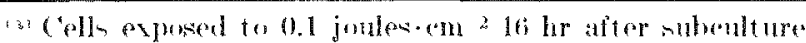
and roored approsimatels 10 hr after irradiation

higher energy levele oberened at 7 days wan arerompanied by a hift in the mean population per colony from the 10- to 100-cull clans to the 2- to 10-cell category. Again. no material differences appeared at 14 days for the di-tribution of colony populations. Finally, ploidy within the population wa altered strikingly by white light at the 1 - and 10 - joule level. There are highly significant increase in the frecfuency of polyploid cells, and at the highent energy a ignifieant riee in haploid population.

Surpensions of eclls were expoed to far-red light (50) millijoulen. $\mathrm{cm}^{-2}$ ) and then plated out to determine the effect of this spectral region on growth IT:able 1031. Significant redurtions were observed in both the number of colonies per plate and their fren and dry weights. (ultures were then expered to far-red light in the range of 0.01 to 1 joulem. $\mathrm{cm}^{-2}$, and grown in sunpension for 10 or 11 day" 1 Table 1041. Again, an increate in cell number wan observed at the lower expoures. However, farred light at all levelo proger-ively thifted the chromosome number from the diploid to the haploid and polvploid. Accompanying this hift of ploidy was a significant enhancement in the incirlence of cells with chromo-ome aberancien. The effect of far-red light in rausing ehromosome aherration is characterizerl more explicitly by the analyses thown in Table 105.

1. hown in Figure 262, ehilling effectively phanes cell division in Haplopappes -uppensions. The rell cycle in ea. 20 hr. Erikonon'11 has shown that Ilaplopapmes in suypen-ion eulture, with a rell cycle of 22 I 3.8 lur. hat the follow ing stage durations of

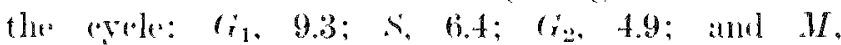
1.t hr. Thu, we cin infer that our expo-ures to fatrered light were given at about the middle of the

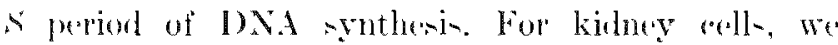
have hown':- that thin is the most rensitive period for the induction of ehromesome aberrations by far-red light, and it i- not unliknly that similar timedependent differences in semitivity hold for plant cetle. It would be of interent to determine if syuthein of IINA in Itoplopappus in impaired by far-red

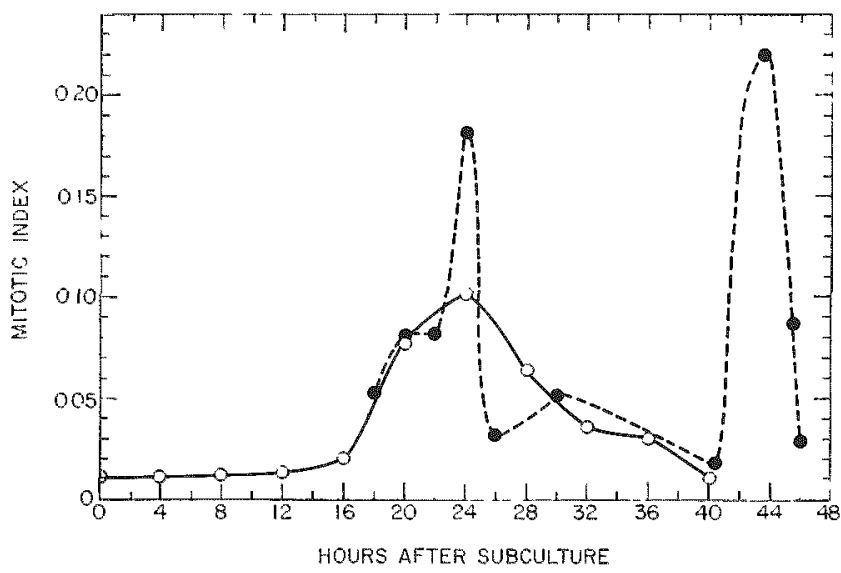

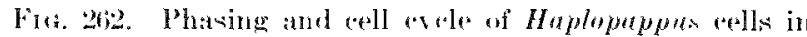

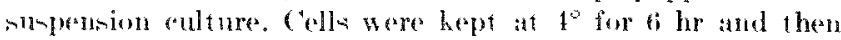
grow nat 23.5 . 


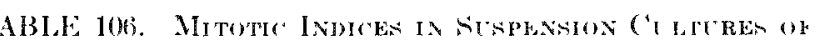

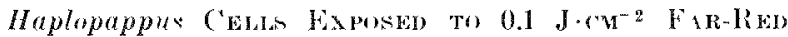

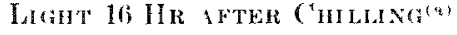

Grow the period, hr

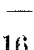

16

24

26

27

34
Mitotic index

$\begin{array}{cr}\text { Control } & \text { Irradiated } \\ - & \\ <0.01 & <0.01 \\ 0.40 & 0.08 \\ 0.20 & 0.30 \\ 0.20 & 0.40 \\ 0.10 & 010\end{array}$

to Fuch datum represents 1000 eells in mitusis.

light. an impairment demonstrated for kidney cell- in monolaver rulture."3) An action spectrum for the cytologicat responsen of Haplopappus to illumination would he of aid in the identification of the photoreceptor infolved.

Finally. irradiation of phand pig kidney eell population at $x$ delayed the time at wheb maximum aberration freruencies, induced by $\times$ radiation, were observed. 2 From this, it rould be inferred that far-red radiation eauses a pha-e wift in the cecll cycle. This is consistent with the observations of Wolff and Luippold't. an, who found that far-red light produced a phase delay in the cell divinion ryeles of the root tips of $\mathrm{I}$ irradiated ricia fuba. The influence of far-red light alone on the mitotic index at several times after irratiation of phased Haplopappus rells in suppension aulture was, therefore. determined. The data of Table 106 suggest that exposure to far-red light aloo produces a phase delay in the rell revele of Heplopappus that has not been axposed to $\mathrm{X}$ rardiation.

REF HREACI:

1. Crikson. T. Nindies on the grow th reguirements and grow th measurements of cell cultures of Haplopappes gracles. Phymiol. Plathatum 18, 4 th $94: 3$ (1965).

2. Gordon, S. A.. A. N. Strond. N. A. Munro. and C. H. C'hen. The induetion of ehromosome aberrations of pig kidney wells by far-red light. Argome National Laboratory Biological and Medieal lieseareh Divioion Annual Report. 1961. ANL,tig91, Np. 122 125.

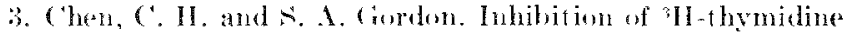
incorporation in pig bicher cells by far-red light. Argonne Sanional Laboratory Biological and Medieal Research

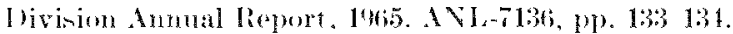

4. Wolff, s. and II. E. Lainpold. Mitot ie delay and the apparent synergism of far red radiation and $x$ rats in the product ion of chromosomat aherrations. Photochem. Photobol. 4, 1839 $41.5(196,5)$.

5. Ma, T. II, and S. Wollf, Far rod indueed mitotide delat and the apparent increase of $X$-ray indueed chromatid aberra-

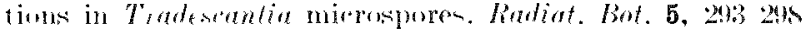
(1616is).

\section{LIGHT AND RIBULOSE-7, 5-DIPHOSPHATE CARBOXYLASE ACTIVITY IN ETIOLATED PLANTS}

\section{Ilerrill Gas:man, , Solon .1. Gardon, and Jane when-.Miller}

\section{PTRPOLE AND METHID}

The enzyme ribulome-1., stliphomphate carboxylate" catalyzes the condensation of carbon dioxide with ribulo-e-1.5)-diphouphate. This enzyme, which is located in the plastids of higher plants, is responsbe for the converion of carbon dioxiles to cirrbohytlraten. The enzyme comprien a large portion of the -oluble protein in the platid. the -o-ealled "Fraction I" protein. Etiolated rark-grown! rom, ant. and bean plants contain high levels of this enzyme in their learem.

It was reported recently that a 3 -min irratiation of etiolated corn leaver renulted in a 20- to 60 " increate in the level of thi- enzame orer unirratliatent control-" "The speed of thi; response together with its reported insemsitivity to short preineubation of he leaver with chlorampheniend. sugerented that the

\footnotetext{
* Eniversity of lllinois, ( hiveagn ("ircle".
}

illumination might ratue an activation of the enzarme in eontraint to de nowo rntheri- The experiments retorted here were initiated to dotermines firt. whether this artivation doen oreur rapidly after illumination, and. if so, what the secetral response rhatateteri-tide are. And exomd, whether the change

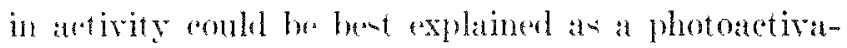
tion of the enzyme an appored 10 syntheris of new enzyme. A -peetral repones might indicate the natture of the photoreseptor involveel and whether photoatrotivation of this platid enzyme could partiripate in plant phototropism or photomorphogenesis.

Arena sativa cr. Vietory I and Phasenlus rulyaris var. Red Kirdney were grown in total darknem for rarying periods up to cight day. Illumination, when required. was provided hy at greten'al safelight. Exrisent roleoptiles, or leatren. Were flocted on $2 \%$ sucrone on filter diers in 4-em Petri dishes. Approximately $200 \mathrm{mg}$ f frem weight of ti-nes were placed 
in each dish. Experimental treatments involved irradiation with either white light (quartz-halogen tungsten filament lampl or monochromatic light obtained by insertion of an interference filter $1660 \mathrm{~nm}$, $15 \mathrm{~nm}$ H.W.' between the above source and the samples.

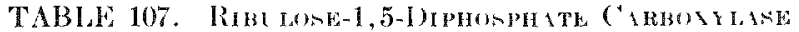

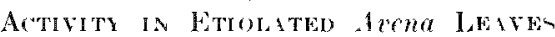

\begin{tabular}{|c|c|c|}
\hline Treatment & & $\begin{array}{c}\text { umoles } \mathrm{CO}_{2} \text { fixed } \mathrm{mg} \\
\text { protein hr }\end{array}$ \\
\hline - - - & & $\ldots \ldots$ \\
\hline C'nirradiated control & 3 & $2.26 \pm 0.20$ \\
\hline $15-\mathrm{sec}$ white light, $000 \mathrm{~mW} \mathrm{~cm}^{2}$ & 3 & $2.28 \pm 0.20$ \\
\hline $\begin{array}{l}\text { 45-sec white light, } 900 \mathrm{~mW} \mathrm{~cm}^{2}+1 \\
\text { hr dark }\end{array}$ & & $2.11 \pm 0.11$ \\
\hline
\end{tabular}

TABLE 108. DOSE RESPONAS OF RIB LOSE-1,5-THPHOSPHITE C'IRBOSYLASE ACIVITY CPON IRBSDITION OR ETIOLTED Phasealus LeAres WITH WHITE light

\begin{tabular}{|c|c|c|}
\hline \multirow{2}{*}{ Irradiance, $100 \mu \mathrm{W} \cdot \mathrm{cm}^{-2}$} & \multicolumn{2}{|c|}{$\mu$ moles $\mathrm{CO}_{2}$ fived mg protein, $\mathrm{hr}$} \\
\hline & $\begin{array}{l}\text { Esperiment } 1 \\
(7 \text { days old })\end{array}$ & $\begin{array}{l}\text { Esperiment } 2 \\
\text { (8 days old })\end{array}$ \\
\hline Cuirradiated & .20 & ؛ $01+\overline{0}$ \\
\hline $1 \times 10^{3} \mathrm{ergs} \cdot \mathrm{cm}^{-2}(1 \mathrm{sec})$ & $\begin{array}{l}2.38 \pm 019 \\
2.61 \pm 0.25\end{array}$ & $\begin{array}{l}2.91 \pm 0.36 \\
3.39 \pm 0.23\end{array}$ \\
\hline $10 \times 10^{3} \mathrm{ergs} \cdot \mathrm{em}^{-2}(10 \mathrm{sec})$ & $2.62 \pm 0.12$ & $2.97 \pm 0.12$ \\
\hline $100 \times 10^{3} \mathrm{ergh} \cdot \mathrm{cm}^{-2}(100 \mathrm{sec})$ & $2.60 \pm 0.74$ & $3.18 \pm 0.49$ \\
\hline 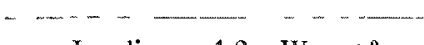 & -- & -- \\
\hline Irradiance, $1.2 \mathrm{~mW} \cdot \mathrm{cm}^{-2}$ & 1 & \\
\hline$-\cdots$ & & \\
\hline Inirradiated & $2.57 \pm$ & $=0.49$ \\
\hline $0.72 \times 10^{6} \mathrm{ergs} \cdot\left(\mathrm{m}^{-2}(5 \mathrm{~min})\right.$ & $2.78 \pm$ & $=0.20$ \\
\hline $1.41 \times 10^{6} \mathrm{ergs} \cdot\left(\mathrm{m}^{-2}(10 \mathrm{~min})\right.$ & $2.89 \pm$ & $=0.39$ \\
\hline $2.16 \times 10^{6} \mathrm{ergs} \cdot\left(\mathrm{mm}^{-2}(15 \mathrm{~min})\right.$ & $2.87 \pm$ & $=0.65$ \\
\hline
\end{tabular}

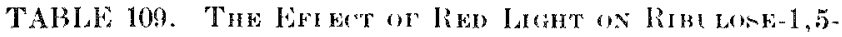

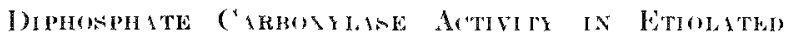
Phasculus LADEA

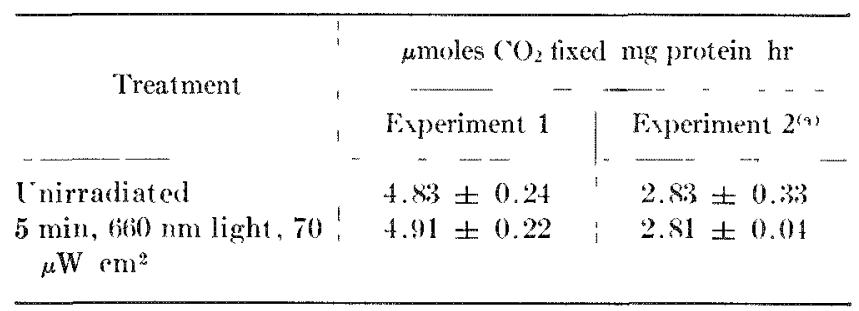

(a) lacking glut at hione during extraction and ineubation.

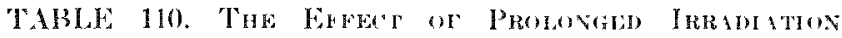

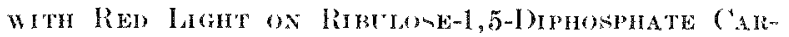

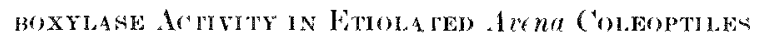

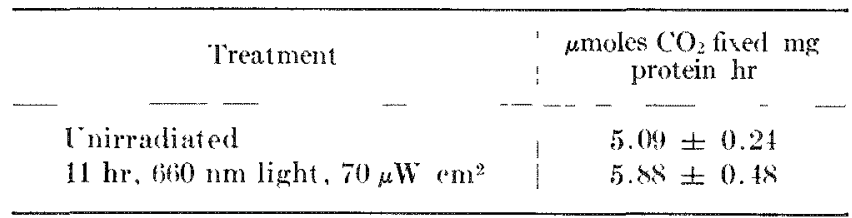

Extraction of the enzyme and all subsecpuent pro redures were carried ont at 0 to $2^{\circ} \mathrm{C}^{\circ}$ under the safelight. The stmples were macerated in a glass mortar with a small amount of sand plus a solution of 1 part of $0.1 . M$ Tris-s() 5 , bufier, pH $7.4,101$ part of $0.01 M$ glutathione. The extracts were centrifuged at $20.000 \times g$ for $20 \mathrm{~min}$ and the preeipitates were direarded. An aliquot of the supernatant was diluted 1:101 with the extraction solution and used for ansay of enzyme activity. The remainder of the supernatant war used for the determination of total protein colorimetrieally by the Biuret procedure, ${ }^{131}$ with bovine serum albumin as a standard.

Ribulone-1.5-diphomphate "arboxylane activity was measured by incubating a $0.5-\mathrm{ml}$ reaction mixture of the following at $30^{\circ} \mathrm{C}:$ b-ribulose-1,5-rliphorphate [harium alt of Sigmat Chemical converted to the solium salt by the method of Rabin and Trown't'], $0.2 \mu$ moles; $\left.\mathrm{NaH}^{14} \mathrm{C}^{\mathrm{C}}(\mathrm{O}), 0.5\right) \mathrm{m}(\mathrm{i}$ m.M, $10 \mu(\mathrm{i}: 0.25$

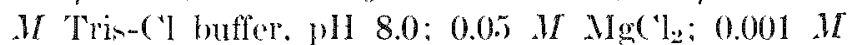
EDTA stock solutions. $0.1 \mathrm{ml} ; 0.025 .1 /$ glutathione, $0.1 \mathrm{ml}$; enzyme protein. Reaction rates were lincar to at leas $750 \mu \mathrm{g}$ of protein $\mathrm{ml}$ of reaction mixture luring incubation periods to $10 \mathrm{~min}$. The restetion was stopped after 5 or $10 \mathrm{~min}$ by acidifying a 0.1 ml aliquot with $0.1 \mathrm{ml}$ of $0.5 \times \mathrm{H}(1.0 .1 \mathrm{ml}$ of this acidified mixture was placed on a 2 -cm filter paper di-k and dried overnight in a hood. The disks were then placed in seintillation vials, and $0.5 \mathrm{ml}$ of water was adderl to elute the labeled products from the paper. Fifteen $\mathrm{ml}$ of seintillation fluid $(4 \mathrm{~g}$ $\mathrm{PP}(), 0.05 \mathrm{~g} \mathrm{P}() \mathrm{P}(\mathrm{P}, 120 \mathrm{~g}$ naphthalene, dioxane to 1 liter were added, and the samples were rounted. ${ }^{14}$ ('-toluene then was added as an internal standard to determine counting efficieney, which was u-ually 80 to 83 ir.

\section{PROGREN RWPORT}

The influence of illumination on artivity of the leaf carboxylase was determined under the following experimental conditions: a, Leena, enzyme activity measured immediately and 1 hr after irradiation with white light (Table 107); b, Phaseolus, domage-remponse to white light (Table 108): r. Phascolus, exposed to red light for 5 min (Table 109); d, Alema, exposed to red light for $11 \mathrm{hr}$ (Table 1101 .

The results presented in Tables 107 to 109 , listing mean specifie atetivities with their 95; confidence limits, show no significant efferts of white or red light on activity of the carboxylase. These experimente inrolved exposures and assay within $1 \mathrm{hr}$ after the beginning of irradiation. Because plastid derelopmen in initiated by the activation of phytochrome. the effect of prolonged irraliation with red light was 
atermined. A stimulation of aetivity, signifieant at the s', level, took place lTable 1101. An enhancement of artivity of this carboxylane upon prolongerd irraliation of etiolated leaven hat been previously

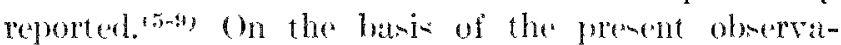
tions, we suggest that stimulation of artivity of rubulone-1,5-diphosphate carboxylas-2 by light is not a direst photoactivation but oecurs at a comesquenese of the biongnthetio events arempanying photoinlueed development of the platid.

It haw heen suggenter that the photomorphogenetio activation for which phytorhrome in the photoar"eptor are mediated viat at change in redox potential.

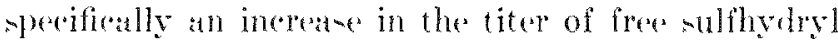
groups. "1"1 "Thu the lack of immediate effect of light chenerved here could be aterounted for an a matking of photoartivation by the prenemer of exem - SII in the medium ureal to dieperese the enzyme. It is of interest. therefore, that ure of a merlium without glutathione before and during illumination doen not remult in detertable photoactivation (Table 1091. Wa infer that a direct photoactivation of the enzane wat not replated, and hence ob-ured. by chemoreducetive atctivation in uniratliated tisues.

\section{REFLRENCES}

1. ('hen, S. I). MeMahon, and I. Bogorad. Larly effects of illumination on the activity of some photosynthetie enz.tues. Plant Physiol.42, 1 5) (196io).
2. Shen Millor, J, and 5 . A. Comblon. Hormunal relations in

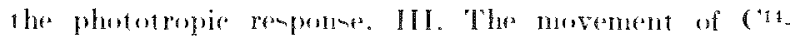

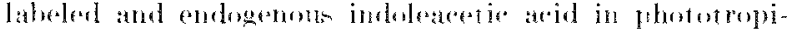

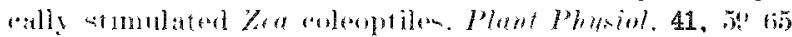
ilmitis.

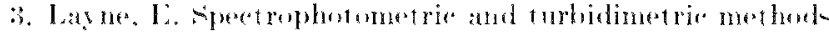
for meaturing proteins. Wothoth of Enatmologm. Fal. \&. P.

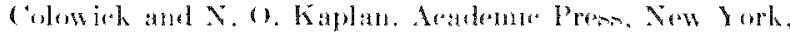
i.1. III, 19.5\%) pp. 116 tojl.

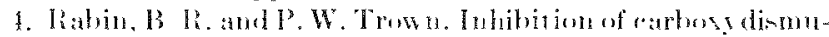

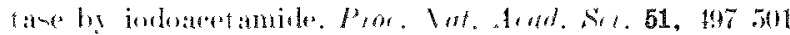
(196in).

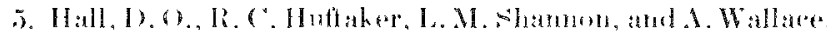

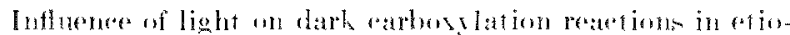

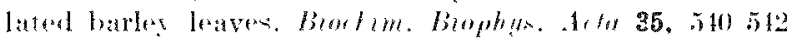
$(194)$.

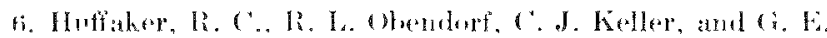

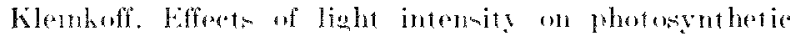

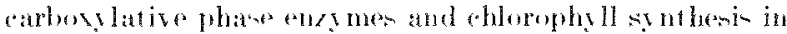

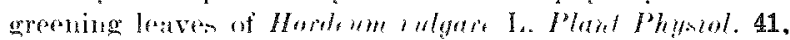
!13:140 (196iti).

7. Margulies, M. M. Hefferet of rhlerampheniersl on light

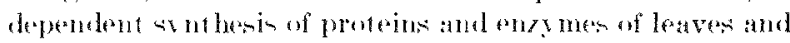

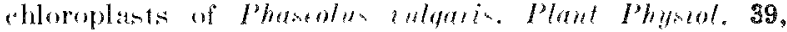
57 5) $50.5(19041)$.

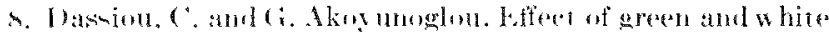

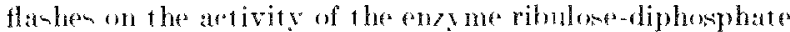

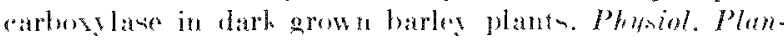

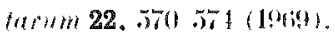

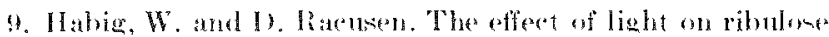
diphonphate "arbosylase in corn leaves. cast. . Botany 47. $10.5110 .51(19169)$.

10. Klein. R. M. and P. C. Kdsall, substutution of redox ohemi"als for radiation in phyterehrome-nediated photomorphes gencsis. Plont Phusiol. 41, !1!19.52 (196ri).

\title{
RESPIRATION MEASUREMENTS DURING FLOWER INDUCTION IN XANTHIUM
}

\author{
IVilliam ('horney, (iemrge Kostal, Lomis Decker, and Richard R. Wedolph
}

\section{PLRPOSF ANO METHOLN}

The discorery of the circadian flowering rhythm in fanthinm"l provides a unique tool for the invertigation of the chemistry and physiology of the flowering prosers.

(l) immediate interent was the posible direct correlation between respiratory metabolism in Xanthium and its obsered erelic flowering pattern. To farilitate these repiration measurements and more closely assess the behavior of the portion of the plant subject to floral induction and initiation, apical cuttings were employed. Prior to such use, it hat been establi-hed that cutting- -imilar to those used in the reppiration measurements responded as did whole lint - with respect to a circadian flowering rhythm. Cutting were made hy excising plant tip a few centimeter below the three-fourths fully expanded leaf at the sixth nork. All leaves greater than $1 \mathrm{~cm}$ in length, exerent the one at the sixth norle, were al exciend and the cutting were plated in quartz sand saturated with one-fifth itrenceth Iloaglanl' nutrient -olution. From the 8 th through the 80 th

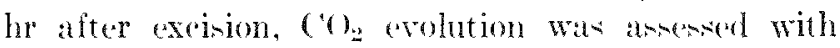
an infrared gac analyzer, which served an the sen-ing element of at ronstant flow remirometer.' ${ }^{2}$

\section{PROWRKA RFPORT}

Naximum flowering in Sonthimm rottings and intact plants orcurred during the 14 th, $41 \mathrm{st}$, and 68 th hr after the start of the dark perion. Maximum in respiration raten were oberped during the 1,5th, 20 th. $301 \mathrm{~h}$. 43rd, and 6.5th hr of the $72-\mathrm{hr}$ experimental period. Whether the appitrent coincidence of flowering maxima and peppiration maximat in of direct biological signifieanees is cluentionable, becaluses the 
plants kept under low-light conditions, which wholly inhibit flowering, exhibited repiration maxima of the same magnitude and at the same times as plant which were kept in complete darkness.

\section{COYCLTSIONS}

We conclude from there results that the flowerinduction process has little effect on the overall plant rempiration rate. This further suggests that though the thysiological consequences of flower induction are substantial, large quantitative changes in plant me- tabolism neither preceder, ateompanies, nor in mediately follow the initiation of this dark induced transition from the vegetative to the flowering state.

\section{REFERFNCES}

1. ('horney, W., E. Rakosnik, Jr., M. II. Dipert, and R. R. Dedolph. Rhythmie flowering eyele in Xanthism. Argonne National Laboratory Biologioal and Medical liesearch Division Amulal Report, 1965. AN1 -7535, pp. 317318.

2. Iilley, I). R., I). H. Dewey, and R. R. Dedolph. Automated system for detemining respiratory gas exchange of plant materials. $J$. Am. Soc. Hort. Sor. $94(\mathbb{N} 0.2), 138141$ (19m).

\section{THE SOURCES OF LEAD IN PERENNIAL RYEGRASS AND RADISHES*}

Richard R. Dedolph, Gary Ter Haur, † Richard Holtzman, $\$$ and Henry Lucas, Jr.

Experiments designed to arsess the relative importanee of air, water, and soil as sources of lear in perennial ryegrass and radishes showed that only air and soil were significant sources. Subseduent experiments reaffirmed that both grass and radish leares

* Abstract of a paper to be published in the Mareh 1970 issue of Environmental sience and Technology as a purtion of the American Chemieal Society Armposium, Air Quality and Lead, held in Minneapolis, April $1+15,1969$.

t Hoyl Corporation, Research laboratories, Ferndale, Michigan.

\$Radiologieal Physies Division, Argonne National Laboratory. derived 2 to $3 \mu$ of lead per gram dry weight from noil sourees. Leaf load lerels in exces of this were derived from, and quantitatively related to, atmospheric lead concentration. Lead levels in radish roots were less than or equal to soil-derived leaf lead lexels. The lead concentration in this edible portion of the radish plant was apparently unaffected by rariations in lead concentrations in either soil or air. Collertively, these data would not upport a contention that the food of prehistoric man contained only a smatl fraction of the lead in the food of contemporary man, unless one assumes that prehistorie man as iduously esehewed plants as a food source.

\section{THE CONCENTRATION OF RADIUM, THORIUM, AND URANIUM BY TROPICAL ALGAE*}

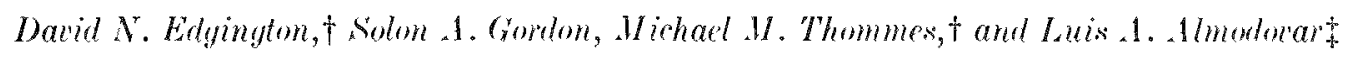

Samples of twenty rpecies of marine algae were collected between 1961 and 1968 from the roatal waters of Puerto Rico. In eollection, emphasis was placed on areas related to the location of the reactor on the wert coast of the inland, before and after it went "eritical." The algae were analyzed for total organic material, protein nitrogen and calcium, and radium-226, thorium-232, and uranium-238, naturallyorcurring alpha particle emitters. From these analyser it is suggested that the concentration of radium, thorium, and uranium by tropiral marine algae may be controlled by two mechanims: 11 ion exchange or

* Abstract of a paper to be published. I more detailed discussion appears in the Anmual leeport of the Radiological Phrsies Division, July 1966 June 1969 (ANL-7615).

+ Radiologieal Physies Inivion, Argone National Laboratory.

+ Department of Marine Biolugy, Iniversity of Puerto lieo. coprecipitation of the ion with the calleium carbonate matrix, or 2) complex formation with either the protein nitrogen or some other component of the organic fratction.

('oncentration of radium land possibly thorium) appesars to occur by both mechanisms, the dominant one depenting upon the phyla. For the Rhodophyceae and the highly raleified chlorophyosese it is the former. and for the Phacophyceate the lattere concentration of uranium oecure by the firt mechanism. This differences in behatrior is consistent with the chemiral forms of the ions of these elements in reawater. The analytical data contribute to the characterization of the background level of radiation in the marine algate of the littoral waters of Puerto Rico. They alio contribute to our unde -tanding of mechani-ms of biological concentration of actinide elements. 


\section{GROWTH AND DEVELOPMENT OF PLANTS IN COMPENSATED GRAVITATIONAL, MAGNETIC, AND ELECTRICAL FIELDS}

\section{OBSERVATIONS ON THE INTERACTION OF GRAVITY AND IONIZING RADIATION ON NUCLEI IN THE ROOTS OF VICIA FABA}

Svolon .1. Combon and Evelyn M. Buess

\section{PTRPOME}

A an index of the influence of gravity on radiation response, we are examining the effect of gravity compensation by clinomtat on the component- and morphology of the nucleur. We have found th that the mean DNA content of interphase nuclei in the root of X-irradiated Ficia faba -cedling is not materially affected by gravity compensation. Howerer, compen-ation shiftel the temporal perionlicities of nuclear volume and mitotic frexuency and enhanced the incidence of micronucles. (xravity compenation also increasen the dimensional ymmetry of the nucleas in the root- of unirradiated seedlung-

The present report decerben a continuance of the above invertigation along the following two lines. First, the number of elinostat-previously arailable did not permit a sinultaneous tent of the effect of gravity compensation on irradiated and unirradiated plants. Arditional clino-tat were con-trueted to allow test of this matrix. Fecond, there are uncertaintien about the ralidity of the ningle-wavelength technique for the microspectrophotometry of hound $d y{ }^{(3,4)}$ the methorl we uned for the extimation of DNA." We have, therefore, shifted to the two-wavelength methol" ${ }^{13}$ for the photometry of the nuclew, with the following procedural extension: Two nuclear stains were u-ed to differentiate botween the root tipe from two experimental treatment - that were combined a a single squath preparation. Thi procedure wat introduced because we have evidencese that variations in premare in the squash technique exert a strong influence on meanured dimensions of the nuclets. We will present here weral preliminary generalizations on the effect of gravity compensation and radiation on nuclear rolume, DNA, and symmetry.

\section{PROC:RTS REPORT}

Seeds of Ficia faba (Azoren) were dusted with Cerean-M and soaked in -terile distilled water at $4^{\circ} \mathrm{C}$ for $24 \mathrm{hr}$. After removal of the sed coat, the

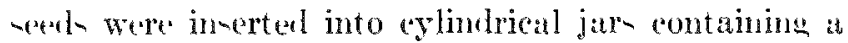
hydratol mixtune of remirulite and styrofoam at a -upporteve medium. 'The -eeds were orituted within the medium no that the initial dirertion of the emergind root and thoot followed the longitudinal : $1 \mathrm{x}-\mathrm{n}$ of the jar, the axi of rotation. The jar were clamper to multiple-unit clinowat of our demen (Figure $26 \%$ ). (Be group was rotated at 2 rpm on horizontal axen of rotation. another wa-imilarly rotated on rertical axe a a control. Plants were grown in the dark for $8 d a y-a t 2^{\circ} C^{\circ}$.

Eight ray-after plantung. half of the compenated and halt of the vertical, rotated sedling were wpous in situ to $100 \mathrm{R} \times$ radiation 1 HIV $1.6 \mathrm{~mm}$ ("u), the remaining halven -erving at unirradiated controk. Po-ition of the atedling on the clinostat were chonen on the has of previou phantom do-imtry so that exposures differed from one another by no more than $5 \%$. Rotational motion wa- mantained during the eight days before, during, and after $X$ irradiation. At variom time after irradiation. three jars from each treatment were welected for analy-in. strudling were not expo-exl to light after phanting fxcept for $X$ irradiation and ampline, at which time green light at an irraliance level barely -ufficient to allow manipulation wa used. (mly serondary roots were taken for analvin. Thene were treated with colchicine $10.2 \%$ in $1 c^{\prime}$ sucromel for $2 \mathrm{hr}$. They were then fixed in a modified Ford's reagent. cleared, and tained with either Fenlgen lenco-hatere furh-ins or toluidine blue. (nemenillimeter tips, cut under a dimestion micro-cope, were taken for -quah preparation and permanently nounted in Fuparal. Two -tain were uad to identify tisues from two treatments spuathed on the same slide. This procedure fermited the nurlei from tho experimental treatment - to be distinguinhed by color and yet be exponed to approximately the same squash pressure. Fisure 264 -how the aborption spectrat of interphase nuclei stained with the Feulgen and toluidine blue reagent- Aborbancies for the two-wavelength andy- 


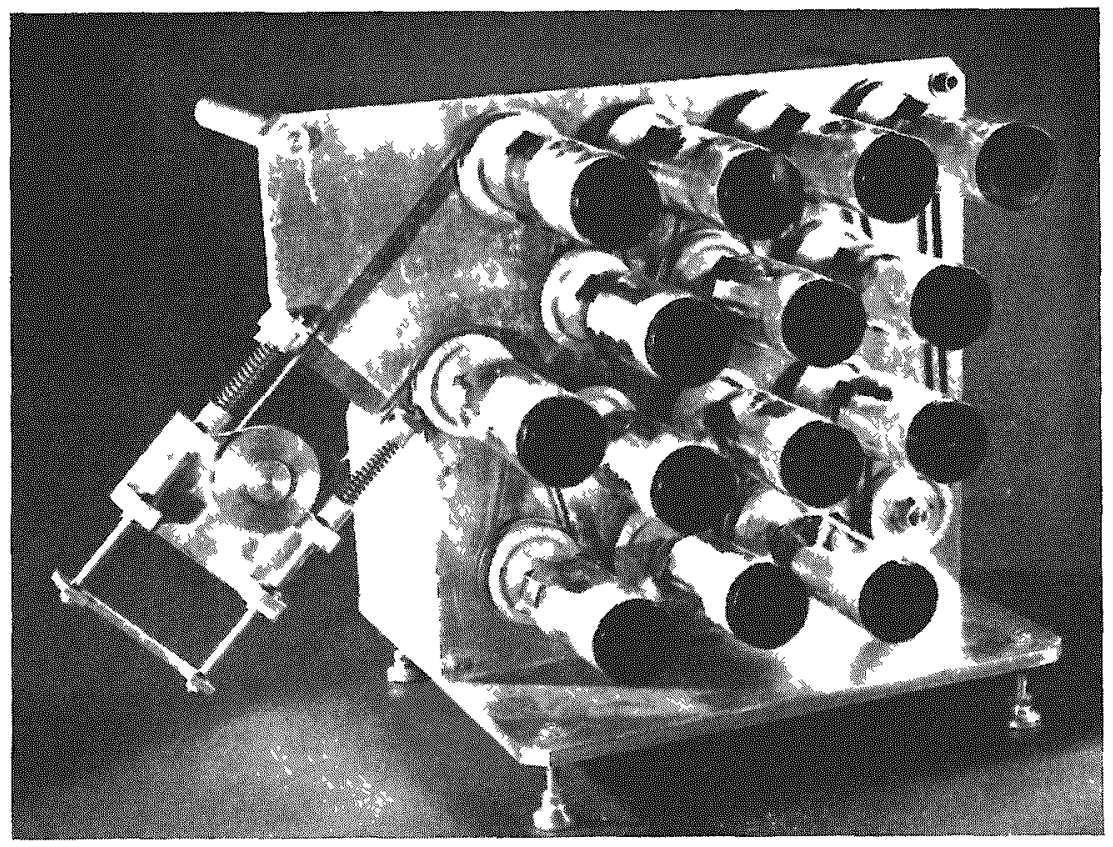

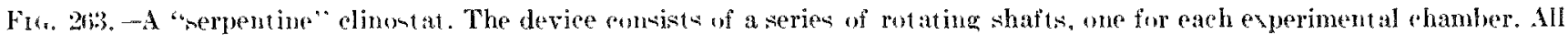
shaft rotate in synchrong since theor drive pulleys are compled to the motor by an endless belt.

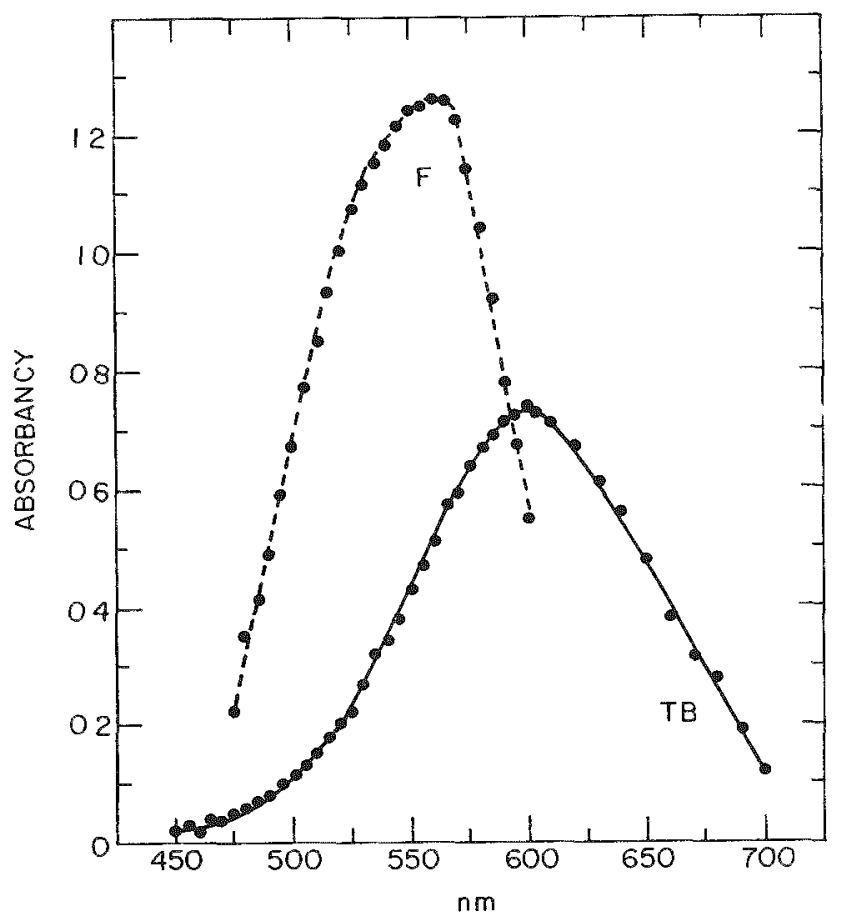

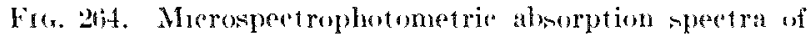
the interphase nucleum in secondary ront of lato fabr. F. Fenlgen st ained; TB, toluidine blue.

sis were obtained at 560 and $497 \mathrm{~nm}$ for Feulgenstained nuelei and 600 and $544 \mathrm{~nm}$ for those stained with toluidine blue.

For spectrophotometry and the determination of nurlear dimen-ions, horizontal seans were made across the - lide at the one-third, one-half, and two-thirds width. At each $1-\mathrm{mm}$ position of the scan, the interwhane nucleun clonest to the center of the field was chosen. Two dimemion of the nucleus were measured-the major or maximum diameter and the minor diameter at the midpoint of, and normal to, the major diameter. (The ratio between the major and minor diameter' was considered as an index of ymmetry. seanning wa- continued until a total of 20 nuclei were obtained for each root tip. Five root tip were analyzed per experimental treatment at each sampling time. All slides were blind-colled to minimize bias.

The datat on the effect of gravity treatment and $X$ radiation on nuclear volume, DNA, and symmetry were subjected to analyos of rariance. The analy-1" showed highly -ignificant interaction between treatment and time for volume and DNA, but not for ymmetry. An evaluation of these interactions will be presented in a forthcoming study. Here we will deal solely with the effects of gravity and radiation on the sampling secquence as a whole.

Becau-e we have observed that nuclei become progremively more elongate with distance from the root tip. volumes were computed assuming that the nuclei were pheres, oblate spheroids, and prolate spheroids. Tatblem 111 and 112 how ementially no difference in volume ration related to these geometric an-unntion. It may be inferer that the shape of the nuclei in the terminal $1 \mathrm{~mm}$ of these secondary 


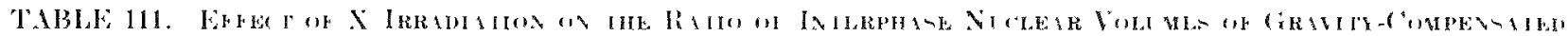

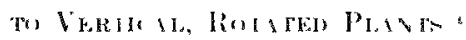

\begin{tabular}{|c|c|c|c|c|c|c|c|c|c|c|c|c|c|c|}
\hline & & & & & & & & ling 11 & $h r$ & & & & & \\
\hline & & - & - & 1 & - - & $\cdots-\ldots$ & - & - & & - & - & - & - & \\
\hline & & $t$ & 6 & & 8 & 12 & 16 & 20 & 24 & 28 & 32 & 30 & Metan & $i n \stackrel{i}{=}=50$ \\
\hline$\therefore--$ & & & & & - & --- & - & & -. & & & & $\cdots$ & - \\
\hline Irradiated & $A$ & 1.20 & $1.0: 3$ & & 1.52 & $1 \mathrm{sit}$ & 1.20 & $1.1 \mathrm{~m}$ & 119 & l.ibit & $1.0 \% 1$ & 1.10 & $1 .: 32$ & $0.015 \mathrm{~s}$ \\
\hline & $B$ & 1.20 & 101 & & 1.51 & 1.90 & 1.20 & 1.07 & $1.1 \mathrm{x}$ & 1.:Bs & 1.33 & $1, \ldots$ & $1 .: 31$ & $0.1 \%$ \\
\hline & $c^{\prime}$ & 1.20 & 1.08 & & 1.51 & 1.78 & 1.20 & 1.09 .1 & 121 & 1.34 & $12 t i$ & 1. 14i & $1 .: 22$ & $0.05 \%$ \\
\hline Inirratiated & 1 & 10.59 & 0.82 & 1 & 0.72 & 050 & 0.76 & 0.78 & 1) $\mathrm{ns}$ & 0.71 & 073 & 0.75 & $0.7: 3$ & 0.0121 \\
\hline & B & 0.619 & 0.81 & & 0.73 & 0. 1: & 0.76 & 076 & $0 . t i 1$ & $0.7 ; ;$ & 1172 & 0.71 & $07: 3$ & 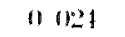 \\
\hline & $0^{\circ}$ & 0.54 & $0 . \$ 1$ & 1 & $0.7: 3$ & 0.54 & $0.7 t i$ & $0 . \times 11$ & $0 \mathrm{lis}$ & 0.75 & 0.7 .5 & 0.75 & 0.75 & $0013+4$ \\
\hline
\end{tabular}

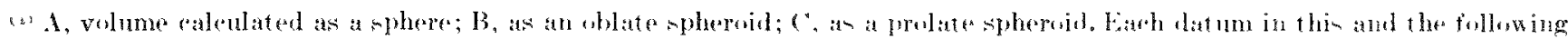

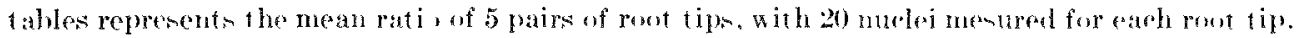

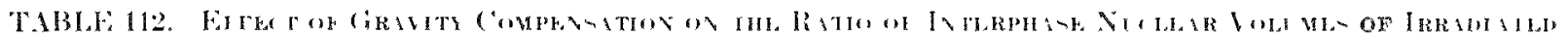

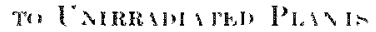

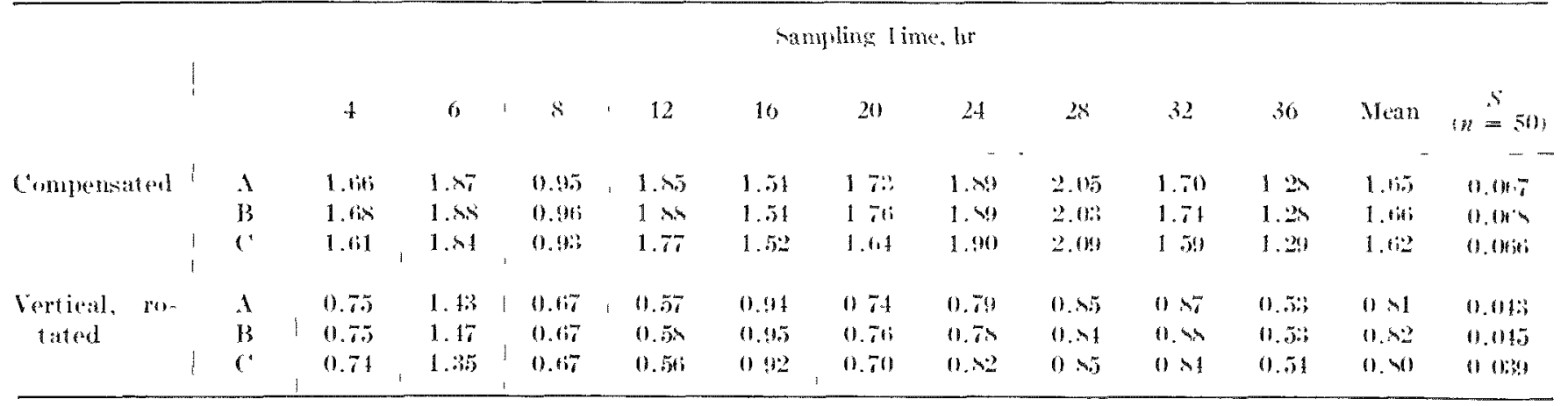

roots is approximately -pherical. ( W' will comment further, below, on these srmmetries.)

Each datum in Table 111 is a ratio deseribing the effect of gravity compenstion. The ration for unirraliated plants are consistently les than 1 . with a mean of 0.73. Considered as a hinomial distribution, the chance probability of this ronsiteney is les than $0.1^{c}$. Or, with student is $t$ statistio as at reriterion of a null hypothe-is, the difference hetween 0.73 and 1 is highly significant $(P<0.001)$. (irarity compermation, alone, decreanes the nucleatr volumes. A similar decorase. with a libe significance probability is elieited by $x$ radiation alone rTable 112. vertical, rotated mean of $0.81 \%$. Irradiation of the plant reverese rompletely the effect of compenation on nuclear volume (Table $111,1.32 \mathrm{w}, 0.73, \mathrm{P}<$ 0.0011 , and a compensition produces a similar action on the effect of $\mathrm{X}$ radiation on nuclear volume $1 \mathrm{Ta}-$ ble 112, 1.6.) rs. 0.81, $\mathrm{P}<0.0011$. $\mathbb{W}$. eonclude that there is a trong invere interaction between the effects of gravity compenation and $X$ rays on the volume of the nureleus in the tip cell of the secondary root.

Data on nurlear DNA are summarized in Table-
113 and 114. Ciravity rompensation, alone. has no -ignificant effecet on the mean D)X.1 rontent of the

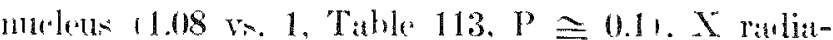
tion. alone. likewire has no material effect on netan 10NA levelo $11.05 \mathrm{~km}$ 1, Table 114, $\mathrm{P}>0.1 \%$. Thro above lack of influener of compensation in not altered by irradiation $11.01 \cdots 1.08$, Table $113, \mathrm{P}>$ 0.11, whith substantiates our previou- obervations that the mean DS. content of interphase nueles in X irraliated plant is not materially changed by rompen-ition."1) On the other hand, analysi of the data repreented by Table 114 indicatem that componsation increasen the ratio between mean DN.t leverel of irradiated to unirradiated plant he about 10 'c

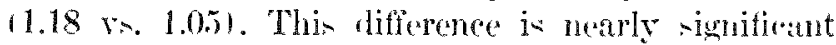
at the $\pi$, level, hat on the null hypotheris, $1.18 \mathrm{vs}$. 1 is highly signifieant. $\mathrm{P} \cong 0.002)$. The impliation here of interaction might be eomsidered estuivoeal in riew of the indicaterl alwence of interartion betwrees aravity and radiation in Table 113.

The dats on symmetry indice are -ummarized in Table- 11.5 and 116. We have shown that eratvity "ompenstion hring the symmetry index of the

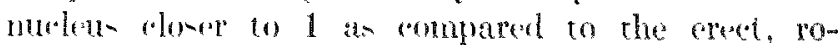




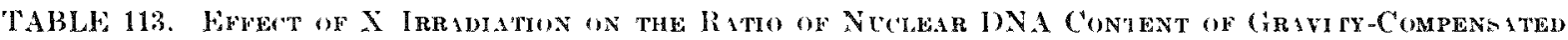
To VERTIPlL, ROTITED PlaN'T

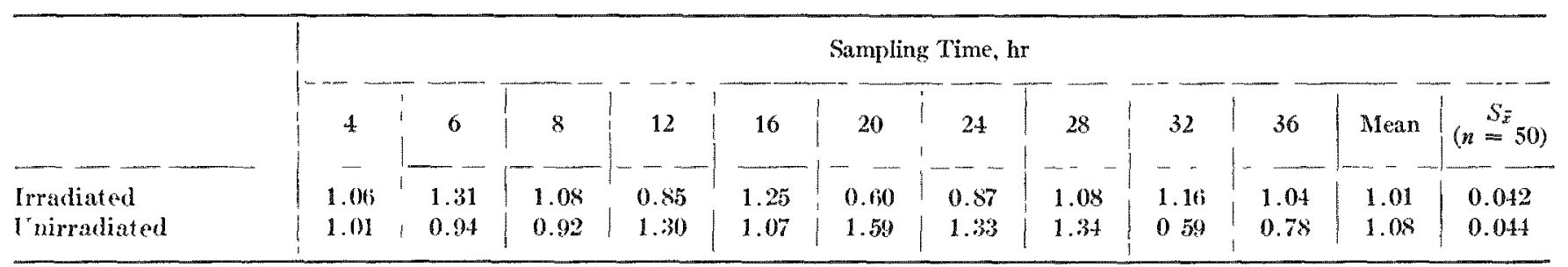

TAlBLF 11\%. FFFET OF GRIVIIY COMPENSITION ON RHE RITIO OF NUCLEIR INA CONTENT OF IHR UDI ITUD TO I'NIRRIDITED PLANTA

\begin{tabular}{|c|c|c|c|c|c|c|c|c|c|c|c|c|}
\hline & \multicolumn{12}{|c|}{ Sampling Time, $\mathrm{hr}$} \\
\hline & $\begin{array}{l}4 \\
4\end{array}$ & 6 & 8 & 12 & 16 & 20 & | 24 & 28 & $1 \quad 32$ & 136 & Mean & $\left\{\begin{array}{c}S_{\bar{x}} \\
(n=50)\end{array}\right.$ \\
\hline Compensated & 1.05 & 1.34 & 1.55 & $---\overline{1}$ & 1.22 & 0.65 & 0.82 & 0.89 & 1.70 & 1.32 & 1.18 & 0.053 \\
\hline Vertical, rutated & 0.84 & 0.85 & 1.14 & 1.38 & 1.06 & 1.70 & 1.01 & 0.90 & 0.79 & 0.84 & 1.05 & 0.052 \\
\hline
\end{tabular}

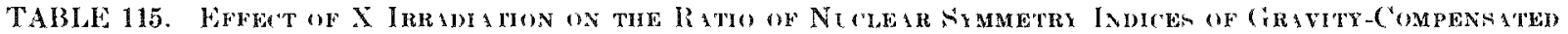

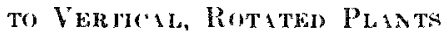

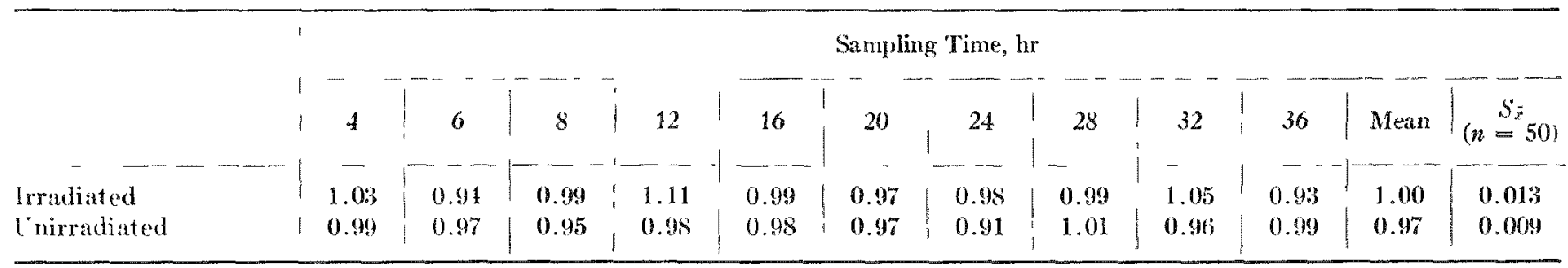

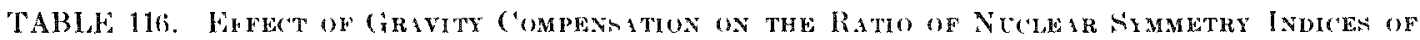

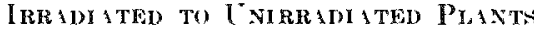

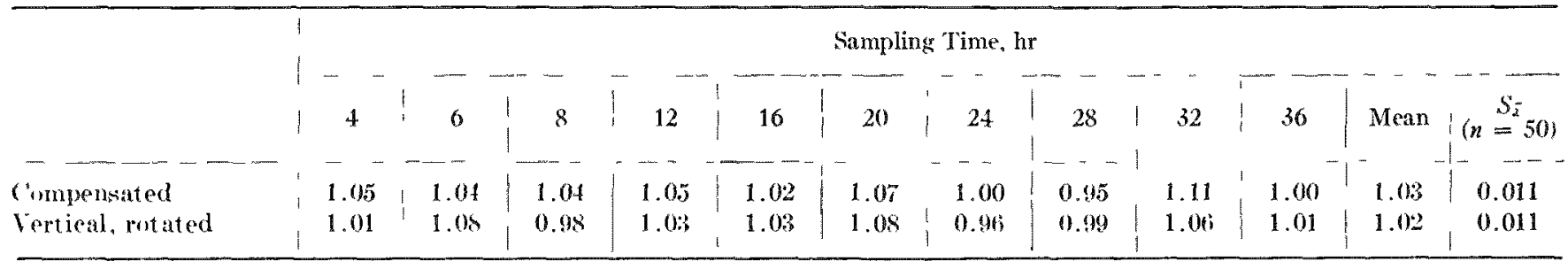

tated plant. (2) This effect of compenation is reflected in the mean ratio of unirradiated compensated to vertical rotated plants 10.97 , Table 1151 . The mean is significantly less than 1 (P $<0.01)$. A raliation. alone, raines, but not ignifieantly, the ratio of symmetry indices (Tathle 116). Compensation adds to this effect of radiation, making the mean ratio of nymmetry indices, 1.03, statistically different from 1 $(\mathrm{P} \leq 0.01)$. Thene differences are -mall, and perhatps not biologically significant. We suggest that the more sherical nuclei in $1-\mathrm{mm}$ root tips than in the 2 -mm tips used previously $y^{(2)}$ tend to minimize the effect of gravity compensation on nuclear symmetry.

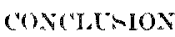

The effects of gravity compensation and $X$ radiation on the volume, DNA, and symmetry of the nuclei of licia faba roots were analyzed. Mean nuclear volumes were diminished both by gravity compensation and by $\mathbb{X}$ radiation. Irradiation of the plant reverned completely the effect of compensation on mean volumes, and compensation had a similar effect on the action of radiation. INA content of interphase nuclei (as indexed by microspectrophotometry of bound dyel were not materially affected by either radiation or compensation. However, compensation increated the mean DNA contents of the muclei from 
Irradiated plants. We find again that nuclei are more spherical in gravity-compensated plant than in their erect controls. Though irradiation did not materially affect the nuclear symmetry, it diul enhanee signifieantly the effect of compensation. In summary. there is a strong interaction hetween the effects of gravity compensation and $\mathrm{X}$ rays on the rolume of the nucleus, and an indication of interaction between these two treatments upon nuclear symmetry and DNA level.

\section{RFY ERENCES}

1. Gordon, S. A. and F. M. Buess. (iravity rompensation and intracellular periodieities in $\mathrm{X}$ irradiated toma seedlings.
Argonne National Iaboratory Biologieal and Mediral Research bivision Annual Report, 1967. ANL-7409, pl. 100-102.

2. Cordon,.. A. and L. MI. Buess. A note on the effert of gravity compensation on nuclear symmetry in Vicia faba. Argone National Laboratory Biologieal and Medieal Research Ilivision Anuual Repurt, 1464. ANL-7535, pp. $322-323$.

3. Nwift, H. and E. Raseh. Microspeetrophotometry with visible light. Phystcal Tochniques in Biologeal Researeh. Fid. (t. Oster and A. Pollister. Academic Press, New York. 1956 , pp. 3533400.

1. Nortimer, Is. Absorption evtophotometry: comparative methodology for heterogenerous objects, and the two-w avelength method. Introtuction to Quatitative Photochemistry. Ed. (A. L. Wied Aradenic P'ress. Nen York, 1966, pp. 201214.

\section{RECIPROCITY IN THE ACTIVATION OF GEOTROPISM OF OATS GROWN ON CLINOSTATS}

\author{
Jane shen-lliller
}

\section{PIRPUSE AND METHOD:}

The activation of geotropism of the normal plant hits been shown to follow, within limits, a reciprocal relation between force, $f$, and time, $t, f \times t=k$ (constant $1.1,21$ We define the time, $t$, at which activation of geotropism oreurs in response to a constant force as the presentation time, the force-time product, $k$, as the presentation stimulus, and the reponse elicited by the presentation stimulus as the presentation response. We emphasize that this invertigation is restricted to the study of reciprocity in the activation of geotropism.

Rutten-Pekelharing ${ }^{1)}$ demonstrated that reciprocity oceurs in the geotropic presentation rexponse of the oat coleoptile and garden-cress root. Whe found a $k$ of 250-300 $g$ see, depending on temperature. More recently, Johnsion's' ralculated a $k$ of $240 \mathrm{~g} \cdot \mathrm{sec}$ for oat seedlings grown in $22.5^{\circ} \mathrm{C}$. Using a different apuroach, by testing various acceleration, we foumd a presentation reponse for continuous $\mathrm{ex}$ posure (cat. $68 \mathrm{hr}$ ) to $0.0014 \quad g$, with a $l \cdot t$ proluct of approximately $340 \mathrm{~g} \cdot$ rec. $^{(3)}$

The aim of the present study is to detemine, firs, if the reciprocity relation holds for the gerotropism of oat coleoptiles grown in simulated "weightless" condition fi.e., under gravity compensation by horizontal clinostats of the serpentine type 141 . Second, if reciprocity does hold, is the prod- ct constant, $k$, similar to that for plant grown in normal orientation.

This study was carried out in two phanes ifor method of plant growth, gravity stimulation, and curvature measurement, see Reference 5). In the firnt phase. agar was uned as the growth medium, and Johnwon's(2) extrapolation method was employed iprenentation time extrapolated from the linear relationship, renponse to a constant foree $=a+b$ log times). I total of seven accolerations between 0.08 and $3.0 \mathrm{~g}$ were tested. Each acceleration was repeated about five times, with an average total of 780 plants per acceleration. In the second phase, both sand and agar were uned as growth media, and the stimulation times inclucled rery short intervals. i.e., $0.15 \mathrm{~min}$. Tnder the renditions the response curve shows two distinct rate constants, a low rate for the short stimulation times, and a higher rate as stimulation time is lengthened (Figure 265). The intersection of the two rate segments (I and II) of the response curve was consilered to be the presentation time. Curvature measurements were made from blindcoded hadowgraphs. All experiments were carried out at $27.2 \pm 1^{\circ}\left(^{\circ}\right.$. All curves were fitted by the method of leat reluater.

PROCREAS REPORT

If the prenentation reponses of geotropiem follow a reciprocity relationship between $f$ and $t$, the product of the two variables will be a constant.

$$
f \times t=k
$$

or.

$$
\log t=\log t h+(-1)(\log t) .
$$




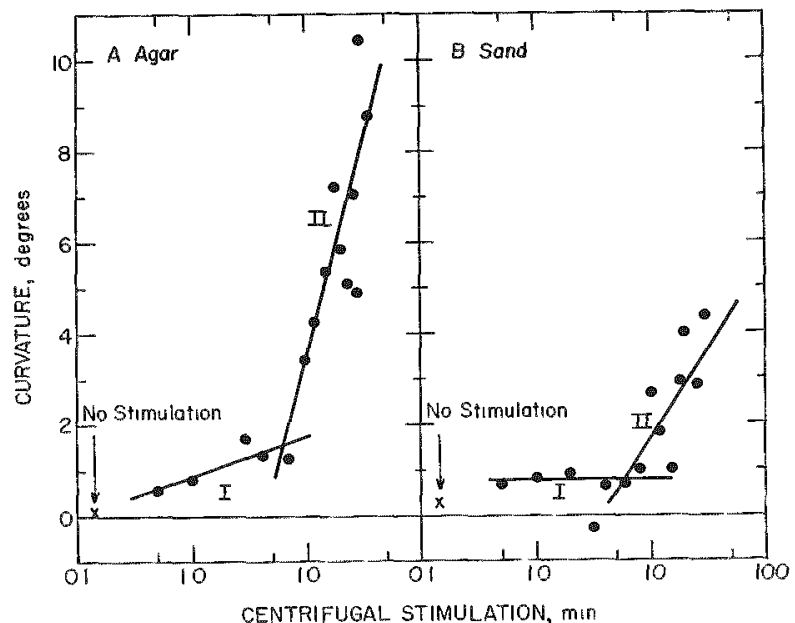

Fias. 265. Cientropice responiate curven of gravity arompentsated oat coleontiles; - timulus acceleration $0.2 g$.

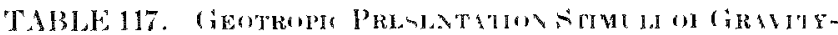

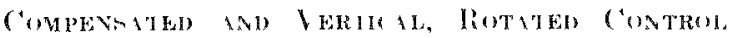

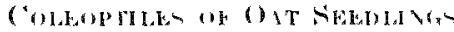

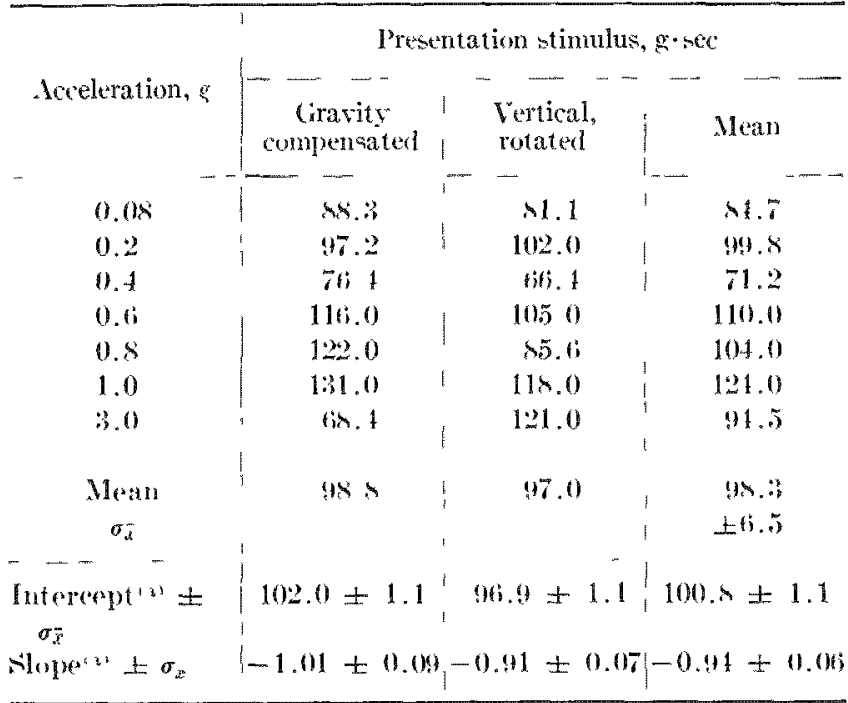

to lerived from the leat stgutres fit of $\log$ presentation time va. log acceleration.

Equation (2) describes a linear function of the logtranform with intercept equal to the logarithm of $k$ and a slope of -1 . We will show that the experimental duta follow closely this relation hip.

Using Jolnsson's extrapolation method, the prenentation stimuli calculated for gravity-compensated and vertical, rotated reontroll wat coleoptiles are not ignificantly different at the 0.0 . level of student's $t$ divtribution ITable 117). The datal of the two treatments were, therefore, grouped and plotted in Figure 266 as log presentation time rs. $\log$ arceleration. The linearity and the slope, -0.94 with a standard error of \pm 0.06 . indicates the compatibility of the datta with the ariterion for reciprocity. The intereept, $100.8 \pm 1.1$, is not ignificantly different from the

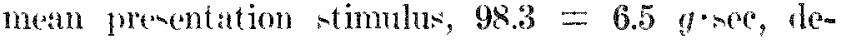
rived from the data tabulated in Table 117. When the presentation stimuli of the vertical, rotated and stationary treatments were compared, $93.9 \pm 20$ and

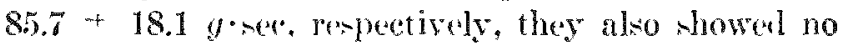
signifieant difference. It may be inferred that gravit y" compermation doen wot alter the semitivity of the phy-ical perception of gravity hy the oat coleoptile. Moreover, the linear relation-hips between presentation time and acceleration on log-log plots. with their slopem of relore to -1 . indicate that the reriprocity rule is followed not only by normal plants 1,2 but aloo hy gravity-compensated and vertiral, rotated oat stestlinge.

The ralidity of uning the extrapolation method for the determination of $t$ conld be critieized on the ba-is that there is no clear evidence for a dircrete throhold in the "all or none" or "triggering" sene in plant geotropism. ${ }^{(3)}$ As pointed out undere Nethors, when the stimulation times ware bricf, a two-rate reyoune curve (Figure 26.5. curve segment I \& II; Table 118) wan obtained. Table 118 ,how that the Alopen of segment I and II for the compensated plant are not ignificantly different from their comparable slopes for the vertieal, rotated plant. (A similarity between the fwo gravity treatments in aho shown in Table 1191. The , lopes (reflecting mannitude of response) for segment II are greater when

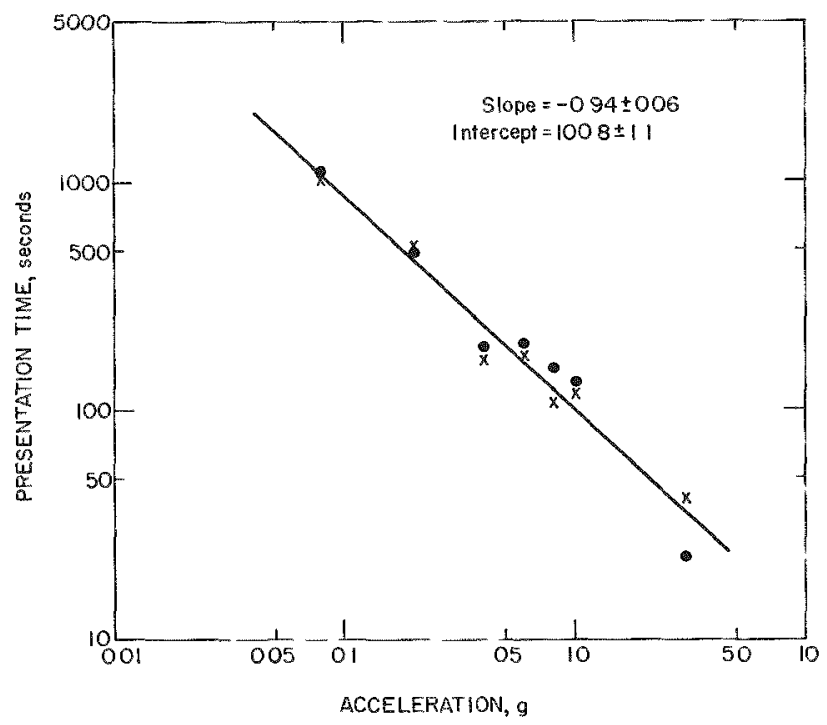

Fur. 2oti. Relationhip between presemution time and arealeration (calculated) in the presentation renponsex of seotropiom of gravity-rompensated, and retieal, rotat control, $x$. oat colespliles. Presentation times calculat bedy parapelation. The regression line is derived frem the means of the two treatments: $n=7$ sol asedlings per arceleration. 
agatr in uned at the growth metium. Howerer, the coleoptilen grown in and are significantly more semsitive in geotropic artivation than tho-s grown in agar iTable 1191, the presentation stimulua being $61.3 \pm 2.9$ and $84.8 \pm 6.3 \mathrm{~g} \cdot$ rexe, rempertirely. Tht $f$-t relationships for the two media are shown in Figure 267. The slope are $-0.96 \pm 0.06$ for sand, and $-0.91=0.08$ for agar. The indicate once again the exintence of reciprocity.

The intercepts tabulated in Table 119 are lower for the $C$ than for the $R$ treatment. They are rignificantly different when asatr wat the growth merlium, indicuting that gravity compensation might enhance the sensitivity of gravity pereeption by the oat coleoptile. We must point out, however, first, the experinents with agar a the growth medium

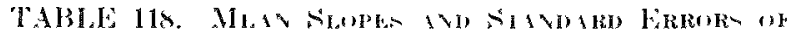

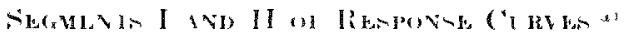

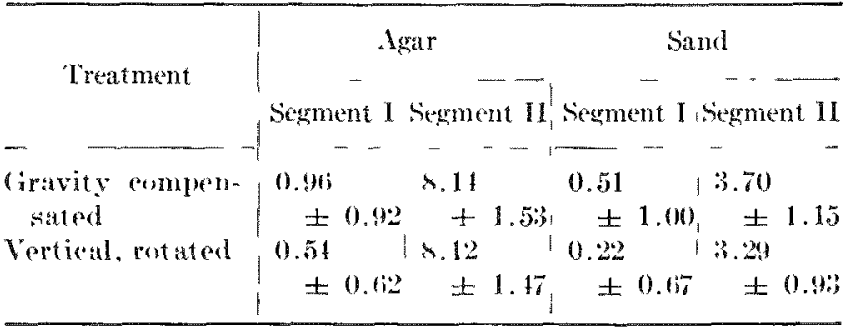

ise Figure 265.

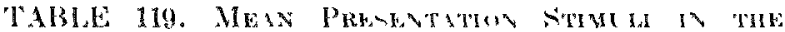
G A $1 \mathrm{NI} S \mathrm{~S} N \mathrm{~B}^{\prime}: 3$

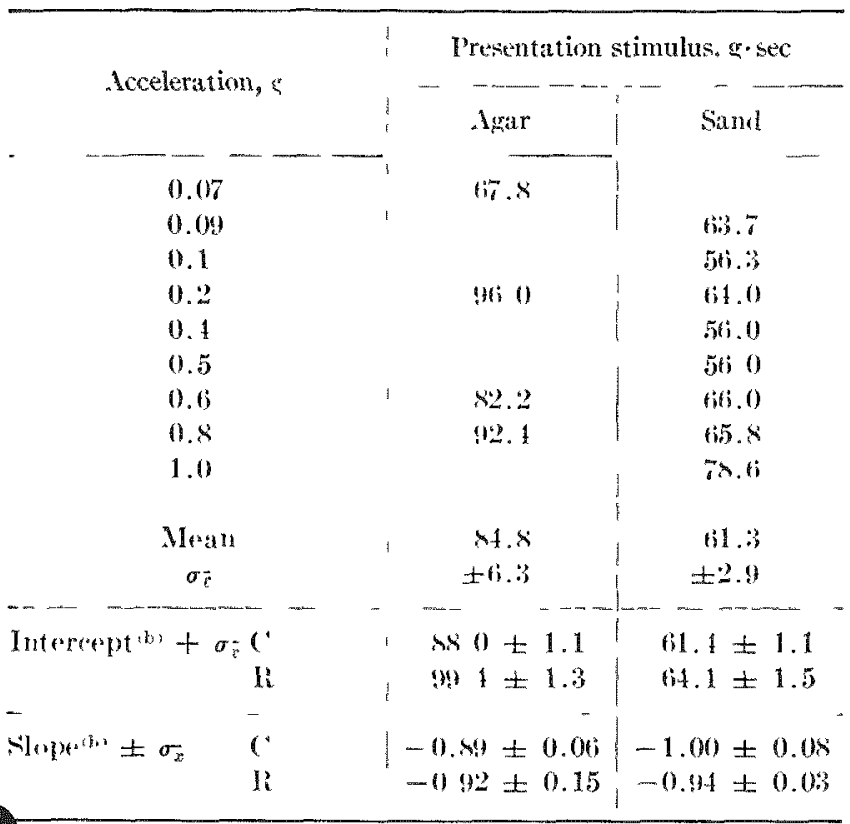

is: Dat a for compensated and rotated plants errouped.

(b) l lerived from the leant sutures fit of log prenent ation time versus log acceleration. $(\because$ gravity compensation; $R$, vertical rotation.

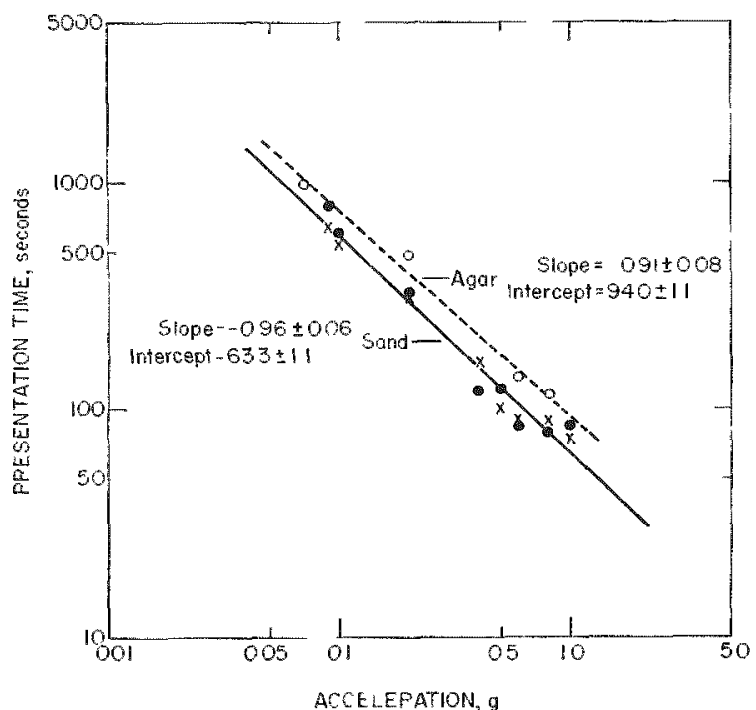

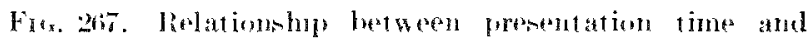

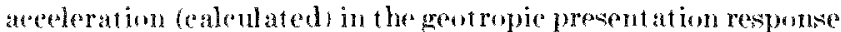
of eoleoptilen. Presentation times ralculated by intersection. 'The regression lines are derived from the meats of the eompensated. and rotated. . treatment for atnd, and the moan, $O$, of the two treatmente for agar. Each acecleration was repeated ra. $t$ times for sand and one for atgar.

involver only one test at each acceleration, with only four accelerations tested. Second, there was no significant difference between the $C$ and $R$ treatment when sand was the medium. or when the extrapolation method (Table 118) with agar as the mem dium was used for the determination of presentation stimulus. Becaune of thene considerations, we feel that the validity of the difference between the $C$ and $R$ treatment for agar in Table 119 is quentionable.

\section{CONCLCSTON}

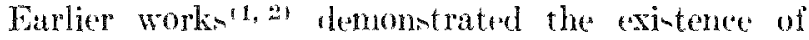
reciprocity between preantation time and force in the prementation repones of geotropism. Wr find this relationship also hold for plants grown under continuous gravity compensation. The ensitivity of gravity perception is not changed by the gravity treatment during growth, but is affected by the growth medium and temperaturete.2. Secedlings grown in sand are more sensitive than those grown on agar to physical timulation by sravity. However, the rate at which subeduent geotropic curvature develom in lower for sedellings grown in sand.

The prenentation stimulus derived from the present tudy is less than those calculated by RutenPokelharing(2) and by Johnson'21. This could be a con-erpuence of differences in temperature and modium. Howerer, the preentation times derived from the two methods of approximation. extrapolation 
and intersection, appear not to differ significantly. Although both methods show the existence of reciprocity in the presentation reponse of geotropism, the method of intersection appears to be more appropriate for the entimation of presentation stimuli, since it is based on observed data rather than on extrapolation.

\section{REFERENCES}

1. Rutten-Pehelharing, ('. J. Intersuchungen uber die Perm zeption des schwerhraftreizes. Rér. des traux. bot. nécrl. 7. $241344(1910)$.
2. Johnswon, A. Investigations of the resoiprocity rule by means of geotrupic and geodectric moasurements. Physiol. Plan. tarum 18.945 967 (19465).

B. Shen-Miller, J., R. Hinchman, and s. 1. Cordon. Thresholds for georesponse to accelcrations in gravity-compensated Avena seedlings. Plant Physiol. 43, 33s 344 (1968).

4. Cordon, s. A. and F. M Buess. Ohservations on the interartion of gravity and ionizing radiation on nucles in the poots of Vicia faba. This report.

5. Shen-Miller. J. and I. Morris. Reeriprocity in the geatropic response of gravity-compensated Ave na eoleoptiles. Argomne National Lahoratory Biologioal and Medical lieseareh Division Anmual lieport, 196iT. ANI 4 -709, pp. 102-104.

\title{
PARTICIPATION OF GOLGI APPARATUS IN GEOTROPISM
}

\author{
Jane shen-1hiller and Ray Hinchman
}

DTKPOA AND METIIODN

Geotropism is a result of differences in cell elongattion, differences in eell wall extension and aceretion, in tisues proximal and distal to a gravity stimulus: Organelle that can be directly associated with expamsion of the cell wall are the endoplamice peticulum, the Golgi apparatus or dictyonomes, and the vesicles $a=$-ociated with both organelles.(1) Material is anded to the wall from vesicles which, in some celle, appear to be derived directly from the Golgi apparatur. 2 ' The rate of Colgi venicle production, and the time required for a reciele to trarerne the ('topla-m to the cell membrane and wall, (3) are compatible with the appearance of visible curvature in geotropiem.

What role coull the (xolgi apparatu play in plant geot ropism? It could have the role of a nensor. (iriffithe and Audus' found a small but ignifieant displacement of the colgi upon geostimulation of roots of ricia faba. They considered the displacement to be too small and too inconnistent to form a ralid basi for speculation. We will present data that make the Golgi apparatum a possible contender for the role of a geonensor. (On the other hand the (iolgi apparatus could function in the physiological implementation of geotropiom. Cotropic stimulation result in a change of auxin distribution within an organ. The increased auxin concentration on the lower half of a cell could bring about at activation of Colgi apparatus in that part of the cell. The artivation of Crolgi apparatur by anxin is supported by the thesis work of siegesmund ${ }^{(5)}$ with tobaceo cells in eulture; more Golgi venclen were formed in those cells when auxin was added to the medium.

Activation of the crolgi in manifent a- an increased production of vesicles by the (rolgi. (1) The increated vesicle production could reult in an increated rate of auxin transport. Although there is no direct evidence of veciele effect on allxin transport. unpublished work of Thornton't) , hows that phototropie stimulation of Phycomyces sporangiophore reduces significantly the number of resieles. We have found that phototropic stimulation of the oat coleoptile inhibit: materially the basipolar transport of auxin. (i) We coukd infer from this that verieles might be inrolvel in auxin transport. Further, recent works of lavold and Lam $^{(b)}$ and Hertel and Flory ${ }^{(9)}$ show that pretreatment of timsues with auxiu enhancess the subsequent transport of auxin. Thum, a feed-bark interactive enhancentent between (iolgi renicle production and anxin tranpport does not seem unreatsonable. With these considerations in mind, we undertook to examine changes of the (iolgi apparatus in oat coleoptiles after various periods of gravity st imulation, uning elect ron microwropy.

After geostimulation the tip $1 \mathrm{~mm}$ of the coleoptile ti-neses was divided into upper and lower halves with renpect to gravity and fixed in $2 \%$ KMnos. The timan were anberded in buon remin and sectioned. All tisues were blind-coled to minimize subjestive bias. In preliminary seanning, we scored the numher of (iolgi bodies and their activity in the top and bottom halves of eells in the upper and lower region of a coleoptiles segment.

PROMRFIS REPORT

We have arbitrarily segregated the Golgi apparatus into the following three states: the inactive $(N)$, thowe of intermediate activity (I), and the active (A) (Figure 268). It is obriou that the $\mathrm{N}$ are -maller in 

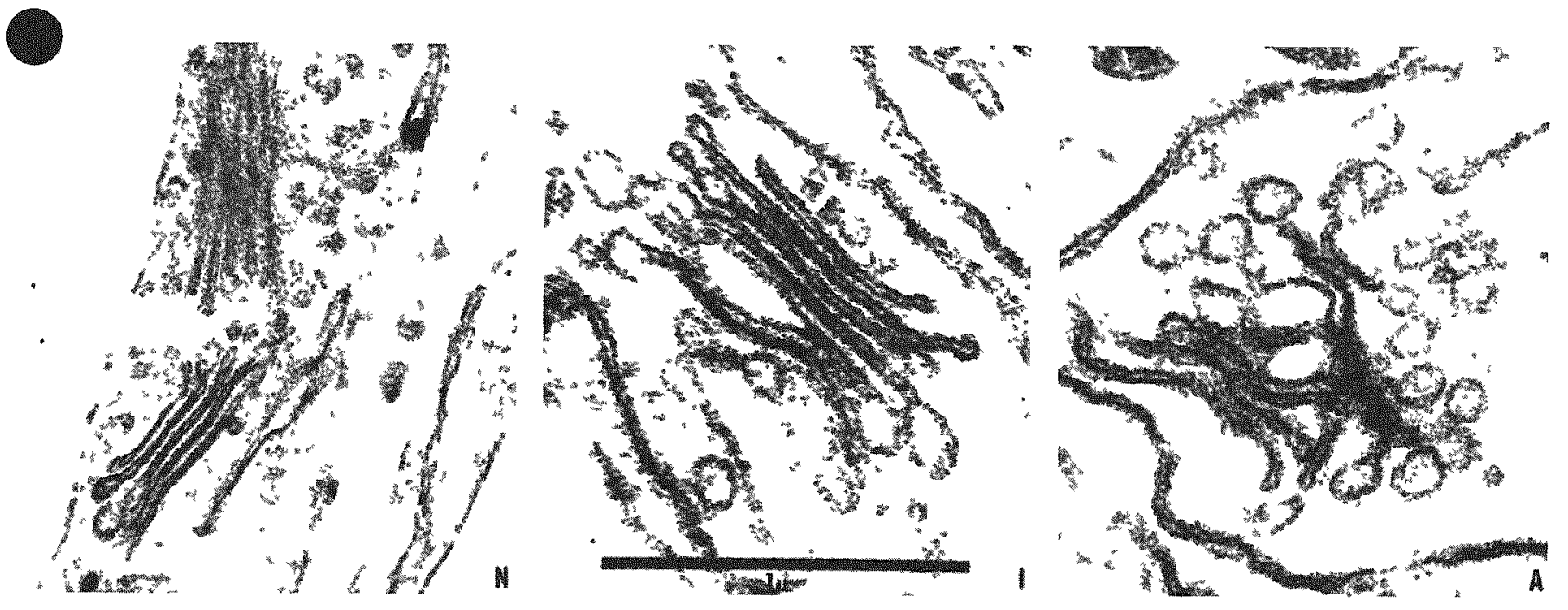

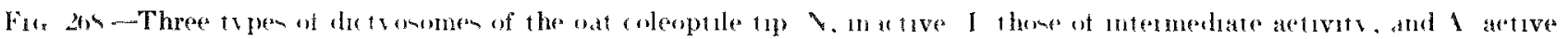

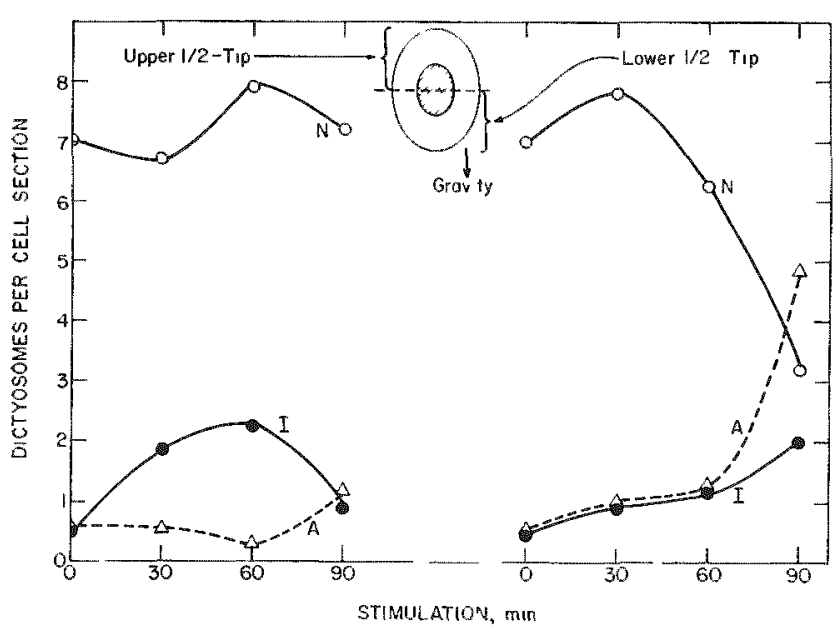

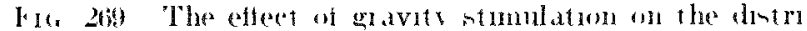

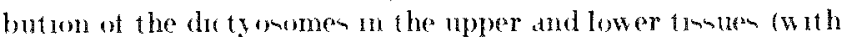
rempect to graviti) of coleoptale tup $(1 \mathrm{~mm})$ it oath $(n=25$

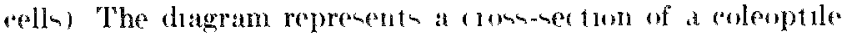
tup Linartive. I, thome of miternediate activitr, and 1 , the :antivis

$-2 x^{2}$ both in theknem and diameter of the erternat: $0.78 \mu(\mathrm{N})$ in diameter at compared to $1.3 \mu$ (I). The activity of the Golgi is determined by their veriele production. Theres is almost no production in the $X$, some in the I, and much in the $\mathrm{A}$.

Figure 269 -how the distribution of total dictyosomen per cell section in the coleoptile tip. In the upper trune there were alway more $X$ detyonomen at the variou stimulation times. The $I$ increaren atud then decreasen, the $A$ mereasen -lowly with mcreang -tmulation. The distribution of detyoomen in the lower ti-ue in defferent from that on the upper. The $\mathrm{N}$ decreasen teadily at longer stimulation times, and the A show a teady increare. Table

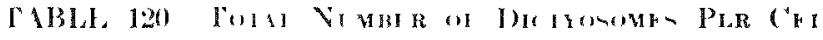

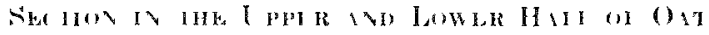

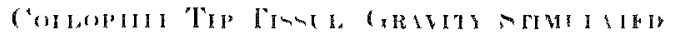

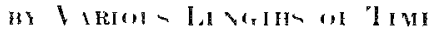

\begin{tabular}{|c|c|c|}
\hline & \multicolumn{2}{|c|}{ lotal to of dxatromes } \\
\hline & I pper thsue & lower tissue \\
\hline 0 & $\varangle 0$ & $\checkmark 0$ \\
\hline :i1) & 41 & 17 \\
\hline (6) & 100 & 6 \\
\hline$m$ & 1) 1 & 100 \\
\hline
\end{tabular}

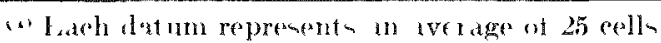

120 indieater exentially no differener in the total number of duetyoumen per cell section between the upper and lower t1-uen at the varion- tmulation timen. It mu-t be pointed out that we did not have comparable rertical control- for the different timulation tmes. Thu it is powible that nongeostimulated celln aho inerease in dietyonome number with times.

Fioure 270 thow - the distribution of dietyonomebetween the top and bottom half of a cell. The bottom half alway has more than the top, both in the upper and lower tiwuen. The inerease in the bottom rould be a re-ult of production of new dertyonomen or a tramefer of dietyonomes from the top to the bottom, or perhatp both. 'The quention of tran-fer or production ha to be settled more rigorou-ly before the Golgi appatratu can be -eriou-ly propoed as a geonem-or. Figure 271 how the dentribution of active dictyonome between the top and bottom halfcell- The bottom has more active dictyonomen than the top. Thi differenee is more strikmo in the lower tiwuth than in the upper. 


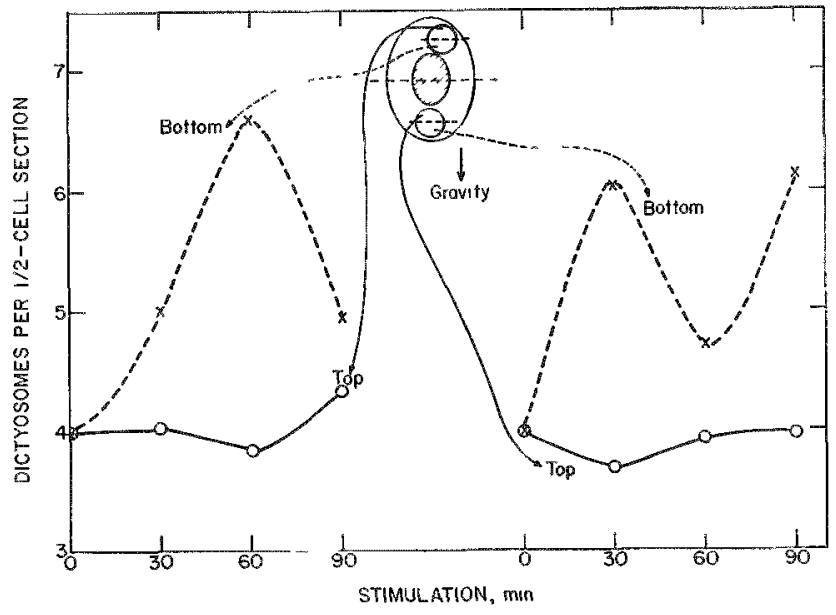

Fic: 270.- The efferet of gravity stimulation on the distribution of dietyosomes in the top and hot tom half-cells in the upper and lower tissues of oat colcoptile tips $(n=25$ cells).

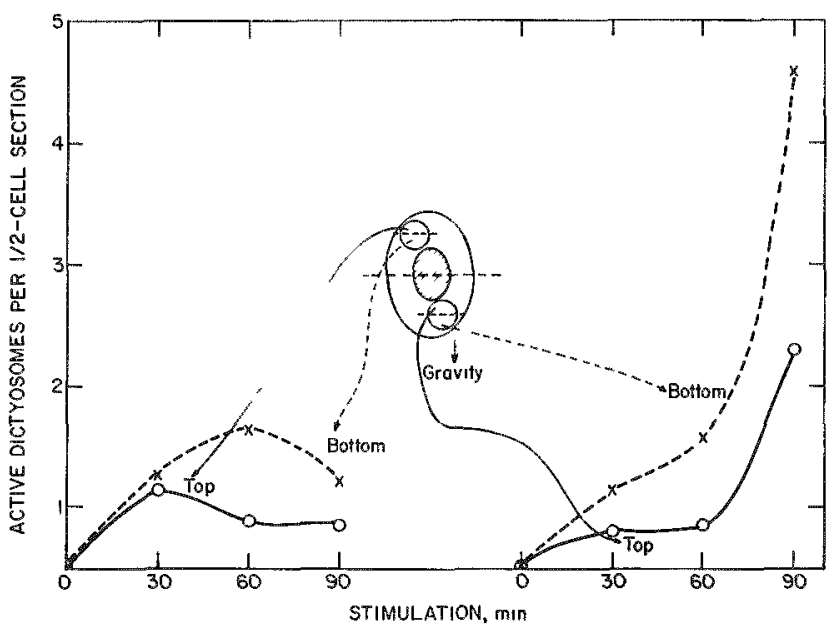

Fit. 271. - The effect of gravity stimulation on the distribution of active dictyosomes in the lop and bottom half-eclls in the upper and lower tissues of the oat colepotile tip $(n=25$ (rells).

\section{CONCLUSION}

In geotropic curvature, the cells in the lower tirsues clongate more than those in the upper. Our data -how that the hottom half of a cell has both more dictyosomes and more active dictyonomes than the top after geotimulation. The difference in the number active dietyonomes is greater in the lower tissue than in the cells of upper. These preliminary obmervations suggest that activity and the localization of activity of the (rolgi apparatus are correlated with the direstion of the grutritational field, and that the morphologieal changes in this organelle oceur with time constants not incompatible with the appearance of geot ropism.

Since the latent period hetween gravity stimulation and the appearance of risible curvature in relattively short, ea. $15 \mathrm{~min}$, we are obtaining data for -timulation periods between zero and $30 \mathrm{~min}$, to check if both (rolgi distribution and activation can be correlated kinetically with the georesponse. Since geotropism is a consequence of altered auxin distribution, we plan to determine 11 if auxin affects vesicle production and 2 if the rate of auxin transport is related to the number of wicles. If both phenomena occur, their sequence in geotropism still remains to be determined. Both proceses could well be feedback related.

\section{REFERENCES}

1. Mollenhaver, II. H. and J. I). Mooré Colgi apparatus and plant secretion. Ann. Rev. Plant Physiol. 17, 27-4t (1966).

2. Pickett-Heaps, J. I). The use of radioautography for investigating wall seretion in plant cells. Protoplasm 64, 4 66 (196is).

3. Sohnepf. F. Quantitative Zasummenghange zw isehen der Fekretion des Fangshleimes und den Crolgi-strukturen bei Drowophyllum lustanicum. Z. Naturforsch. 16(b), 605 ti10 (1961).

4. ('ritfit ha, H. J. and 1.J. Audus. Grganelle distribution in the statocyte eells of the root tip of Ficin faba in relation to gentropic stimulation. If 1 h hytol. 63, 319-3393 (196it).

5. Niegesmund, K. A. Studies of the effects of indoleacestic acid on the fine structure of "ult ured tobacen parenchy ma ('ells. Phl) thesis, Cniversity of Wisconsin (1960).

f. Thornton, R. M. The use of eleetron microseropy in the study of photototropism. Fifth Int. Congr. on Photoliology, Hanover, New Hampshire (196is).

7. Shen-Miller, J., P. Cooper and s. A. Gordon. Phototropism and photo-inhibition of basipolar transport of anxin in oat roleoptiles. Plant Physiol. 44, $491496(1969)$.

৯. Leopold, A. C. and S. L. Lam. The auxin transport gradient. Physiol. Plantarum 15, 631 b3s (1962).

9. Hertel, R. and R. Flory. Anxin movement in corn coleop(iles. Planta 82, 123-14t (196s). 


\section{PTRPOSE AND MLTHOD}

Though the oat sexdling (1,ena sativa) has beren und extemively in plant physiological remearch, there is relatively little detailed cytological information about the arly stages of its germination. Our preliminary observations indicate that rerg rombs oat coleoptilen lless than $2 \mathrm{~mm}$ longl do not repond to geotropir timuli. Because of the possible role of the coleoptile amyloplast in geotropic jesponse, we have begun an inventigation of the starch economy of the young oat seedling. More specifically, we are letermining patterm of -tarch mobilization from endo-perm reserves to coleoptile amyloplant, examining in particular interactions at the endosperm-tmbryo interfaces.

'This report dencribes a number of cytological observations on the arly sages of germination in Arena, and focuse on the location, morphology and "ridence of mobilization of tareh.

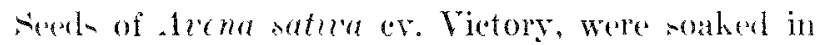
tap water at room temperature for $2 \frac{1}{2}$ hr, ilrained. and placel at $2^{\circ} \mathrm{C}$ for $18 \mathrm{hr}$. At the end of the cold treatment, some of the reds were fixed in warm FPA formalin, propionic acill, alcohol) under vacunm 10-hour samples). The remainder were placed on moint filter papere in the dark at $25^{\circ} \mathrm{C}$. After 24 hr. seerk that had germinated were selected under dim green safe-light. Soms of these germinants were fixed a above (24-hr sample-. The remainder were planted in moist quartz and and allowed to grow for $48 \mathrm{hr}$, at which time they were also fixed 172-hr samples). Fixed specimens were dehyolrated, embedeled in Ti-uemat, sectioned, and tained with a quadruple stain (Mayer's acid hamalum, safranin, fa-t green and orange (a), acid fuchin. or IKI.

\section{PROMRLA REPORT}

The two major parts of the oat exed, or caryopsiare the endoperm and the embryo 1 Figure 27241. At zero hour, there is a might incerese in size of the embryo. primarily due to inhibitional welling. At $24 \mathrm{hr}$, the shoot is less than 2 mum long and the single primary root can he up to $5 \mathrm{~mm}$ in length. At $72 \mathrm{hr}$, the shoot is 10 to $15 \mathrm{~mm}$ long and the 4 or 5 root - vary from 2 to $30 \mathrm{~mm}$ in length.

The aleurone lager is the outermont ti-sue of the romporm. and in oats is 1 to 2 cell thick (Figures 272 b, and Figure 273a, bl. I number of physiological tudio have shown that barley aleurone cell

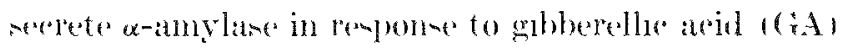
sereted by the arutellum.t) The $\alpha$-amylate breaklown the tarch of the undo-perm and convert it to - oluble carbohydrates that are absorbed by the scutellum.

The aleurone cell are donely rytoplamic and have thick coll wall. "The cells are packed with aleurone grain, a characteristic feature. In the aluront" "ells of oats, a gratual increase in the size of the aleurone grain with time wan found, with the maximum size reached in the 72 -hr amples (Figures $273 a$ and bl. I marked erowion and lymis of the walls of the aleurone cell of the $72-h r^{2}$ sample was obrerved. Palege's reportel sinilar changen in isolated barley alcurome troated with (A.t.

In aats, only a portion of the aleurone layer appear to be active as indicated by increased alenrone grain -ize) at a given time during germination. The alewrone cells nearent the satellum are activated firt, and activation procesd from the embryo and of the erain to the ohalazal end. By the time the alexpone cells at the chalazal end of the seed are activated, many of lhowe nearest the scutellum are lysed and emopty.

The endo-perm of the mature, ungerninated oat sext is completely cellular and the major storage product is starch. After imbibition 10 hour), the endoperm is till collular. In Figure 272b, several endosperm coll, which rontain utareh plastids lamrloplasts are visible. Theme contain from one starch grain to several hundred polyherlral gramula a a compound grain.

It $24 \mathrm{hr}$, extensive breakdown of the endomperm cell ha taken place. Most of the taroh in in the form of free granula and theres is 110 evidenes of cell wall- extopla-m or anyloplant membranm i Figure 27201. It $72 \mathrm{hr}$ the entumperm starch is greatly depleted and the granula that remain are noticeably -maller due to (nzvinatic prosion (Figure $272 \mathrm{~d})$. Even at thi stage. there mar be a fow intact endosmerm cell at the chalazal end of the aeed. indicating the progremive nature of the endo-perm disolution.

The -cutellum is an elongate theld-waped structure that is part of the embryo, has a well-developed valeular bundle. and in in contart with the starehy endo-perm (Figure 272a). All endo-perm metabolites tran-located to the embryo axi- muat move through the coutellar inferface. Thus, it appear the scutellum han a dual function: the secretion of G.A 


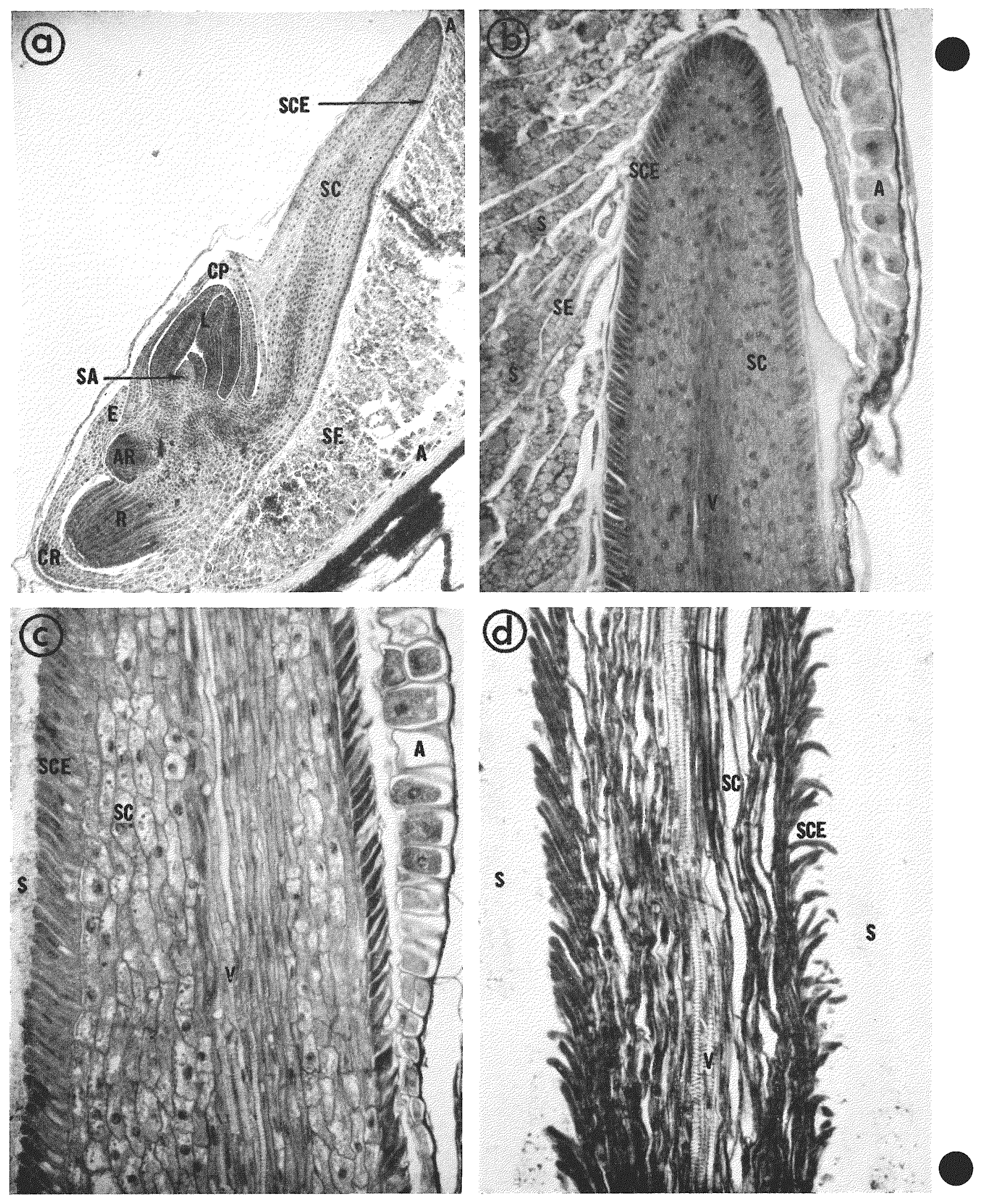

Frg. 272.-. Changes in oat scutellum during germination: a, embryo end of uat seed showing embryo and part of endosperm ( $X$ 44); b, oat seutellum, $0 \mathrm{hr}$; $\mathrm{c}$, oat scutellum, $24 \mathrm{hr}$; d, oat seutellum, $72 \mathrm{hr}(\mathrm{b}, \mathrm{c}, \mathrm{d}, \times 158$ ). A, aleurone layer; AR, adventitious root; $\mathrm{CP}$, coleoptile; CR, coleorhiza; E, epiblast; $\mathrm{T}$, leaf (first); $\mathrm{R}$, radicle; S, endosperm starch grain(s) or granula; SA, shoot apex; SC, seutellum (cortex); SCE, scutellum epithelium; $\mathrm{SE}$, cellular starchy endosperm tissue; $\mathrm{V}$, vascular bundle of seutellum. 

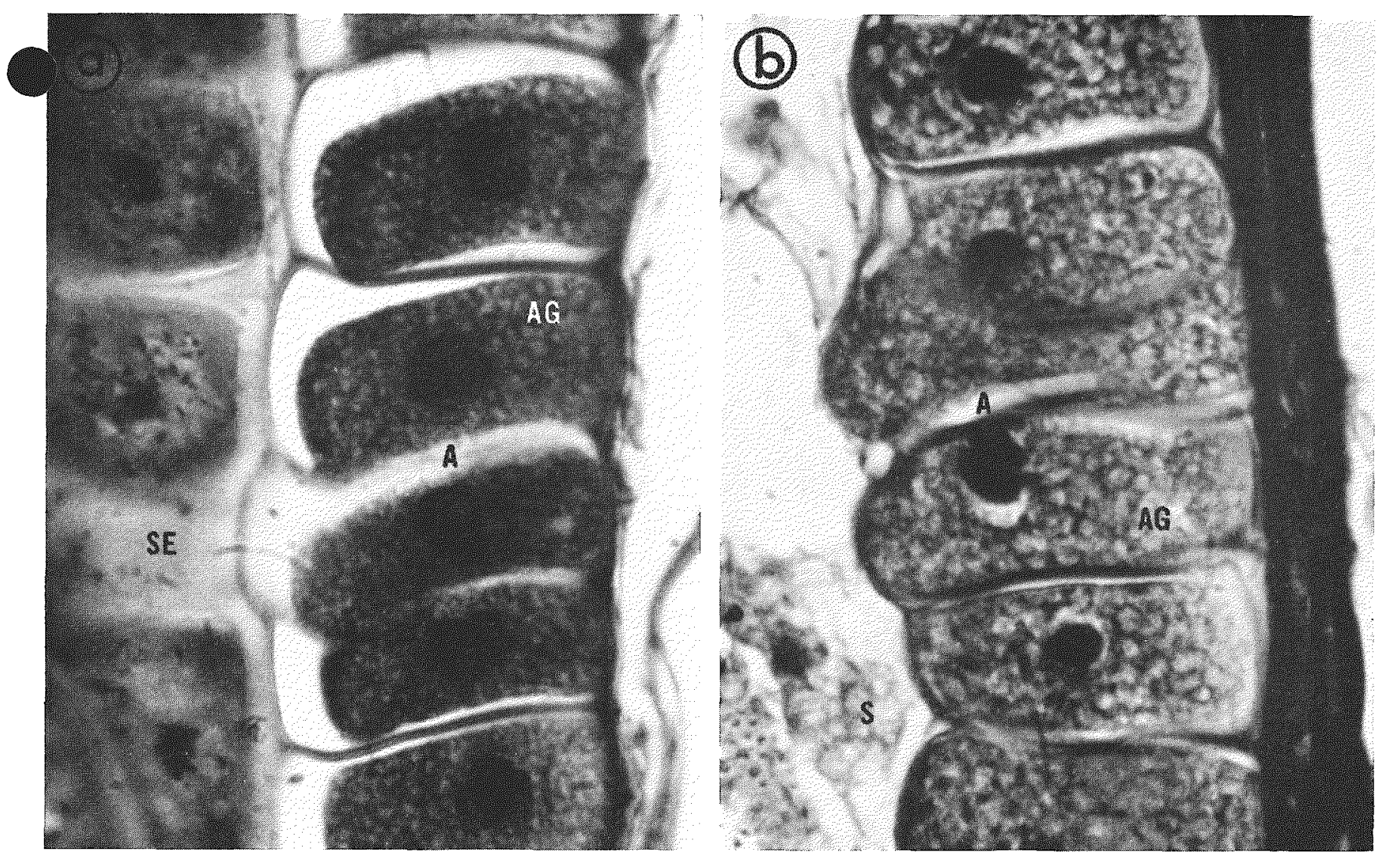

1.C
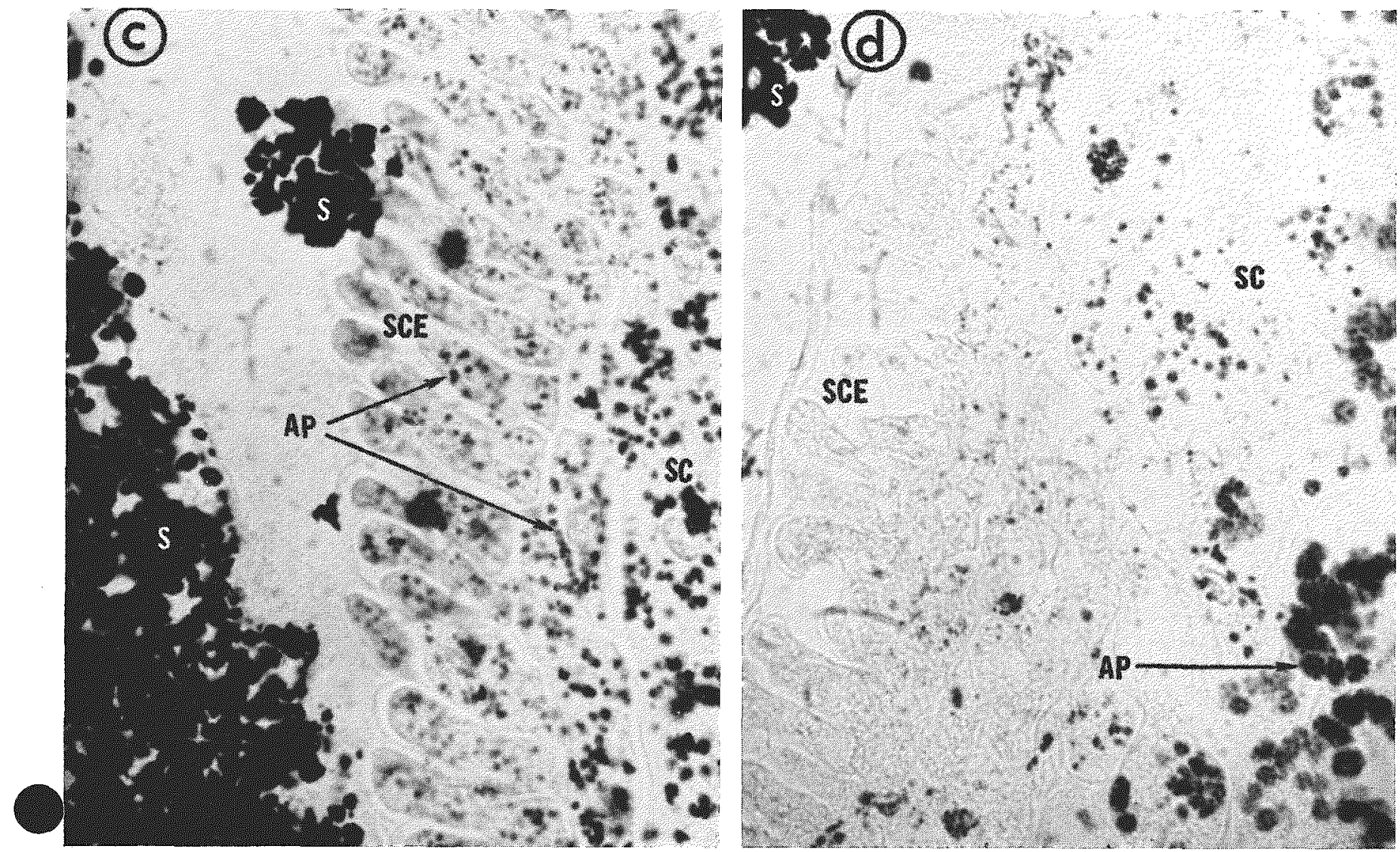

. 

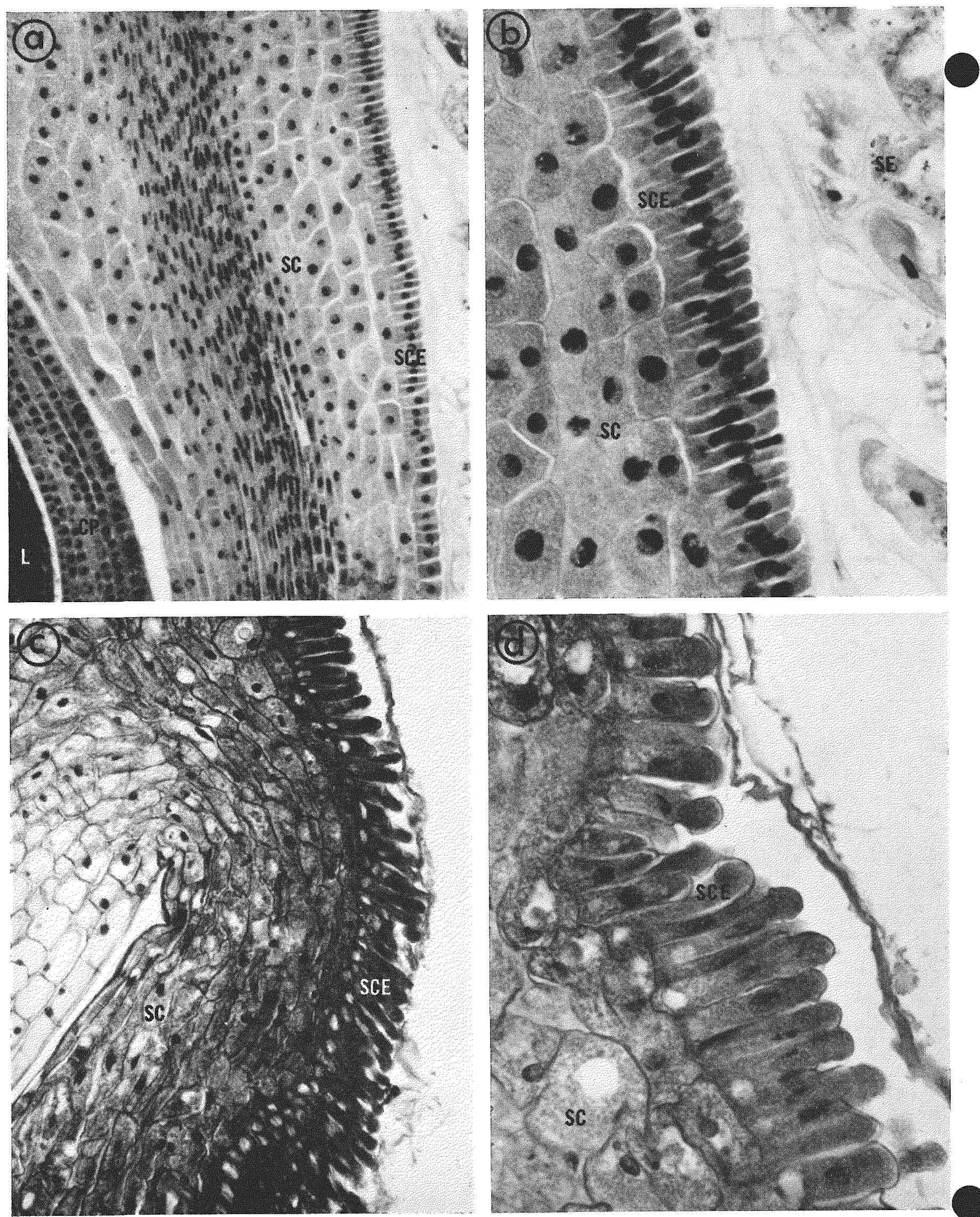

Fir. 274.-. Changes in oat seutellum epithelium during germination: a, portion of seutellum (0 hr) showing unexpanded epithelial Laver $(\times 158)$; b. higher magnifieation of same area $(X 100) ; c$, portion of scutellum ( $72 \mathrm{hr}$ ) showing expanded, villi-like epithelium $(X 15 x)$; $d$, higher magnification of same area $(X 400)$. SC, scutellum (cortex); sCE, scutellum epithelium; sE, cellular starchy endosperm. 
and absorption of the produets of stareh hydrolysis. To accomplish these functions effectively, the seutellum undergoes considerable expansion and develops villi-like cells from the epithelial layer.

At 0 hour, the cells of the seutellum are compact and densely cytoplarmic; the epithelial layer is unexpanded (Figures 272b and 274a and bl. At $24 \mathrm{hr}$, the seutellum has expanded to more than double its size at 0 hour and extend half the length of the endosperm area. The cortical cells hare become vacuolate and contain many small amyloplasts and nonstarch inclusions (Figures 272c, 273e). The cells of the epithelial layer are expanding and becoming long and cylindrical. At $72 \mathrm{hr}$, the scutellum cortex cells are very long and appear to be degenerating. Those near the base of the scutellum contain many large amyloplasts (Figure 273d). The epithelial rells are even more expanded and extended at this time (Figure $272 \mathrm{~d}$ and $274 \mathrm{c}$ and $\mathrm{d}$ ).

At 0 hour, no starch is found in the embryo stained with IKI. At $24 \mathrm{hr}$, there are numerous amyloplasts throughout the scutellum and embryo axis. The stareh that appears in the embryo after germination is markedly different, in form and appearance, from the endosperm starch. The endosperm stareh, at all sampling times, has a much darker IKI reaction. The endoyverm starch, prior to germination, is contained in amyloplasts in the form of very large compound grains. After germination, this stareh is found free in the endorpermal space as polyherlal granula, which become progressively smaller, probably by enzymatic erosion.
The stareh grains in the cells of the embryo arts -maller and usually oreur in numbers of eight or less per amyloplast. The grains in the larger amyloplasts are often cuncate in shape, arranged around a center with areas of nonstaining matrix between the grains (Figure 273d, arrowl. Numerous starch grains were oberrved. even in the epithelial cells of the scutellum at $24 \mathrm{hr}$, but no stareh was found in the epithelial cells at $72 \mathrm{hr}$ (Figure $273 \mathrm{c}$ and d). It may be suggented that. during germination, the stareh of cndoperm origin is molilized and deposited several times hefore it i- utilized in the embryo axis.

\section{CONCLTSION}

The cellular endorperm of the oat seed breaks down soon after germination. and its reserve starch is hydrolyzed and translocated rapidly to amyloplasts throughout the embryo. The scutellum and embryo axis rontain no stareh or amyloplasts at the time of germination. The lack of geotropic sensitivity estry in germination posibly is correlated with the abwence of this polysaceharile organclle. During germination, the scutellum expand and develops a villilike epithelial layer. The development of geotropic sthitivity of the very young oat coleoptile will be examined in subsequent studies.

REFLRENCEN

1. Paleg. La. (i. Phrsiologional effects of gibberellins. Ann. Re Plant Physiol. 16, 291 322 (1965).

2. Paleg. L. and B. Hyde. Physiologieal effects of gibberellic acid. VII. Electron microseopy of barley alemone cells. Plant. Physiol. 39, (itis) tixo (1964).

\section{INFLUENCE OF AUDIOFREQUENCY SOUND ON THE GROWTH OF THE OAT SHOOT: FURTHER OBSERVATIONS}

Richard A. MePhersort * and Solon A. (rordon

\section{PURPOSE AND METHODS}

Several plant species flown in soviet and Americun place flights were found to have more chromosome or ertological aberrations than their ground-based counterparts. These differenees have been attributed to unique vibrational stresses. It is possible that organisms in free fall will respond to vibrational acecleration in fashions qualitatively and quantitatively different from those under terrestrial conditions. It is of interest, therefore, to determine how grarity-compensated plants respond morphologically and rytologically to vibration.

\footnotetext{
* Student Aide.
}

As a first step, we examined ${ }^{(1)}$ the effect of acoustic vibration on elongation rates of static oat shoots grown in normal orientation. A reduction in coleoptile growth rate was obscrved when seedlings were exposed to wide range $(50$ to $10 \mathrm{kHz})$ white noise. Moreover, the effects of 500-hertz bands within this range shifted from growth depression to growth acceleration as the frequency rose, with an indication of bimodality at octave separation. Though the differencess observed were significant statistically. we were troubled about the validity of the correlation: drawn from the data. Rexonance excitation of biologieal struetures by audiofrequencies of 1 to $5 \mathrm{kHz}$ snggests dimension of the order of 100 to $20 \mathrm{~cm}$. For 
the oat seedling. renonance of the shoot might be expecterl at the 5th or 6th harmonie, and of cells in the range of the 13 th to 15 th harmonic. It reemed improbable that biologically detectable power at these harmonic levels was generated by the equipment used. Accordingly, we have re-examined the effect of both wide- and narrow-band acoustic vibration on the growth of the young oat hoot, paving particular attention to test chamber and temperature effect.

The methods were doseribed previously. (1) Essentially, they involve growing oat seedlings, whose mesorotyl had been inhibited by brief exposure to red light, in the dark for three days. During the lant $19 \mathrm{hr}$ of this period, they were exposed to white noise in "anechoie" chambers constructed of styrofoam. The influence of the experimental treatment on growth rate was determined by measurement of organ increments in length on shadowgraphs taken at the beginning and end of the experimental treatment. Phototropically inactive green light was ured for photography.

\section{PROGRHES REPORT}

Seedlings were exposed to wide- and narrow-hand white noire, at about 40 to 45 dh above background level. The experiments were designed on latin square matrices to permit evaluation of the influenee of location effect, npecifically, the influence on growth rate of the Styrofoam chamber itself and the influence of small differencen in temperature. With this experimental design, we find no signifieant retardation or enhanerment of growth of the eleoptile under the influence of either wide-band acoustic noise in the freculency range of 50 to 10,000 hertz, or narrow bands $1-4$ db at $20 \%$ each side of midfrequency. dropping $24 \mathrm{db}$ per octarel at $500,1,000,2,000$, or 4,000 hertz.

Nignificant enhaneoments in the growth rate were obtained when the seedlings were exposed to widerange noine at $70 \mathrm{~d}$ b above background. Howerer, the acoust ir driver became quite warm in the generation of these power level. Tests of the temperature in the experimental chambers in the $70 \mathrm{db}$ field $1130 \mathrm{db}$ against reference sound pressure of $2 \times 10^{-4}$ dynes. $\left(\mathrm{m}^{-2}\right.$ ) showed a gradual rise in air temperature over a 7 -hr period, stabilizing at $1.4^{\circ} \mathrm{C}$ above the room temperature of $23.3^{\circ} \mathrm{C}$. We know that the rate of coleoptile extenion increases with temperature in this temperature range, although the exact relationship has not been determined. Thus, it seems: likely that the increase in growth $\left.(6.5)^{c}\right)$ observed at the 130-dh sound level- occurred, wholly, or in part, as a consecuence of the rise in temperature.

Asiming, for the ranges of temperatures, $T$, and velocity of growth, $v$, encountered, that $v=K T$, it ean be hown that the coefficient of velocity inereares

$$
\kappa=F\left[\begin{array}{c}
r_{1} l_{1}+r_{2} t_{2} \\
t_{1} \Delta T_{1}+t_{2} \Delta T_{2}
\end{array}\right],
$$

where $F$ is the fractional increase of growth occasioned by a temperature increase during a period wherein thes growth can be charactcrized with respect to time, $t$, by two successive linear rate constants. ${ }^{2}$ ') Areraging the areas under the temperature eurves that correspond to $v_{1} t_{1}$ and $v_{2} t_{2}$, and using the observed $F$ of $6.5^{2} s$, the coefficient of velocity increase with temperature wan approximated as 0.038 $m m \cdot h r^{-1}{ }^{\circ} C^{-1}$. It would be of interest to test this approximation for the effect of temperature on growth rate of the colcoptile by direct examination of $v=$ $f(T)$.

\section{CONCLCATON}

No rigorou inference maty be drawn at this time concerning the effect of white noise, in the range of 50 to 10,000 hertz at sound levels up to $130 \mathrm{db}$ ahove aural threshold, on the elongation of the Avena coleoptile. In the experiments dereribed, cell division in the coleoptile terminated soon after the plants were placed in the acountic field, and organ elongation then derived solely from cell expansion. We suggest that it may be uneful to examine the influence of acoustic vibration on organs in which cell division is continuouly involved in the growth process, viz., the oat shoot immediately after germination, the root, or the hoot under a functioning apical meristem. The magnitude of the effect (if any) of sound on coleoptile elongation in the system examined is small with respect to the influence of temperature and chamber components. Fuder these circum-tances, the une of the tewt organism as its own control might be informative-riz., does introluction of noise in a period of constant growth rate alter the rate constant?

\section{REFERFNC'}

1. Gordon, S. A. and R. Marksteiner. Influenee of audiofrequency sound on the grow th of the oat shoot. Argonne National Laborator Biological and Medical Researeh Division Annual Report, 1968. ANL-7535, pp. 321322.

2. NePherson, Richard A. and S. A. (rordon. A note on the growth rates of the Acena coleoptile. This report. 
THE EFFECT OF THE LENGTH OF THE PERIOD OF PREPLANTING IMBIBITION ON SUBSEQUENT GROWTH AND GEORESPONSE OF OAT SEEDLINGS

\author{
Louis H. Declier, Edward Rakesnili, Jr., and Richard R. Dedolph
}

PIRPOAF AND METHODS

To obtain more uniform populations of oat seedlings for experimental work, sceds are mistomarily soaked in warm tap water for about $2 \mathrm{hr}$ prior to planting. It has been reported that holding soaked oat reed under moist conditions overnight in a refrigerator at $5^{\circ} \mathrm{C}$ "rewulted in more uniform germination and growth of seedlings." (1)

To test this, oat seeds (Avena sativa er. Vietory 1) were roaked for $2 \mathrm{hr}$ at $25^{\circ} \mathrm{C}$ and then held under moist conditions at $5^{\circ} \mathrm{C}$ either for an additional $20 \mathrm{hr}$ (long imbibition treatment, or for only $2.5 \mathrm{hr}$ (short imbihition treatment). The seeds from these two treatments were then planted in moist quartz sand (about $15 \mathrm{c}$ water by weight). Seedlings were grown at $25^{\circ}$ ( for about $69 \mathrm{hr}$. Red light (G.E. Ruby Red, $\left.1 \mathrm{mWr} / \mathrm{cm}^{2}\right)$ was used during the first $50 \mathrm{hr}$ to inhibit the growth of the mesocotyl. Growth was otherwise in darkness, except for brief periods under the same. red lights during manipulation- neesessary for geotropic stimulation.

Shortly before harvest, one-half of each preplanting imbibition treatment class was subjected to a $1.0 \times g$ unilateral stimulus for $40 \mathrm{~min}$. After the $40-\mathrm{min}$ stimulation period, plants were rotated on a clinostat $(2 \mathrm{rpm})$ for an additional $40 \mathrm{~min}$ to permit curvature development. They were then sharlowgraphed to asseris coleoptile curvature, harvested, separated as to tops and roots, weighed, and reshadowgraphed for length measurements.

\section{PROGRENS REPORT}

No significant $(5 \%$ level) increase in germination attributable to imbibition period was found with high level of germination apparent in both the long and

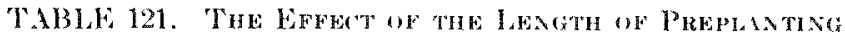

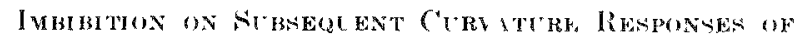

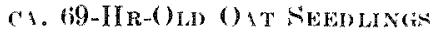

\begin{tabular}{|c|c|c|}
\hline \multirow[t]{2}{*}{ Treatment } & \multicolumn{2}{|c|}{ Curvature, deg } \\
\hline & 22-hr period & 4.5-hr period \\
\hline$-\ldots-\ldots-$ & $-\ldots$ & $-{ }_{-}^{-}$ \\
\hline 0.0 -min stimulation & $2.68 a$ & $1.72 a$ \\
\hline 40.0-min stimulation at $1.0 \mathrm{~g}$ & 29.96 & 30.880 \\
\hline Mean rurvature & $1 \mathrm{fi} .3 a$ & $16.3 n$ \\
\hline$n=30$ & ? & I \\
\hline
\end{tabular}

Means within rows, not followed by a common letter are signifieantly different at the $\mathrm{s}^{\mathrm{s}}, \mathrm{e}$ level.

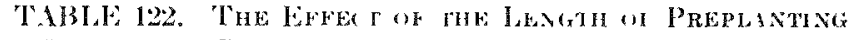

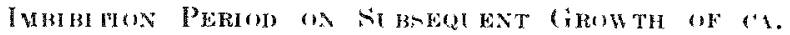

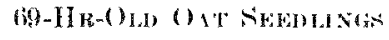

\begin{tabular}{|c|c|c|}
\hline Merasurement & 22-hr jerion & 4.5-hr period \\
\hline - & - & $-\ldots$ \\
\hline Letugth of tops, mn & $32.9 a$ & $2 x \cdot \times b$ \\
\hline I dength of ronts, $\mathrm{mm}$ & $1334.0 \mathrm{~kg}$ & $131.5 b$ \\
\hline Weight of tops, g & 0.1 .4720 & $0.1322 b$ \\
\hline $\begin{array}{l}\text { Weight of roots, } g \\
n-t 0\end{array}$ & 0.1 tisia & $0.1603 a$ \\
\hline
\end{tabular}

Jeans within rows, not followed by a common letter are signifieantly different at the $5^{\prime}$, level.

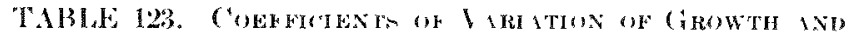

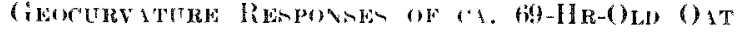

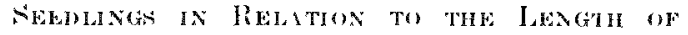
PREPLANING I URI BITION P'ERIOH

\begin{tabular}{|c|c|c|c|}
\hline Plant response & : & $22 \mathrm{hr}$ period & 4.5-hr period \\
\hline$=--\infty-$ & , & $-\quad \ldots$ & $-1 \ldots-\cdots$ \\
\hline ('urviture, deg & & 24.8 & 87.8 \\
\hline length of tops. mm & & 3.3 & 2.9 \\
\hline length of roots, mm & & 50 & 4.0 \\
\hline Weight of tops, gg & & 18.0 & 10.7 \\
\hline $\begin{array}{l}\text { Weight of ronts, gr } \\
n=60\end{array}$ & & 21.4 & 14.0 \\
\hline
\end{tabular}

short imbibition treatments, 96.2 and $98.3 \%$, respectively. The magnitude of geotropir curvature of plants was, imilarly, not signifieantly influened by the length of the period of preplanting imbibition (Table 1211 , although the period of stimulation showed the "xpected differences in eliciting eurvature.

The longer period of preplanting imbibition, however. did tend to produce significantly larger plants (Table 122 ).

These differences in subsequent growth attributable to period of preplanting imbibition are explicable on a basis of a significantly $\left(1 \%_{0}\right.$ level) greater uptake of water by the seeds permitted to continue imbibition orer the longer time period as contrasted to the horter period $129 \mathrm{vs}$. $19 \%$ of initial weight, respectively). The more fully imbibed seeds likely had progresed further into the initial stages of germination than the less fully imbibed seeds and consequently may have been somewhat older physiologieally at the time they were planted.

When coefficients of variation were calculated for the various means, it was apparent that the long preplanting imbibition period resulted in a more uniformly responding population only when the curva- 
ture responise wits considered. If growth, either as length or weight, was measured, the longer preplanting imbibition period resulted in a less uniform nopulation (Table 123). Tents of homogeneity of variance further showed that the difference in uniformity of the populations of plants grown from seeds that received the two different periods of preplanting imbibition wan great enough to render direct compari-ons of mean curvatures, weights, or lengths from these two treatments by analysis of variance methods not rigorous.

\section{CONCLTSION}

The tenet ${ }^{(1)}$ that a long (20 hr) low temperature $\left(5^{\circ} \mathrm{C}\right)$ preplanting imbibition period for oat seeds results in more uniform germination and growth must be rejected on a basis of these data because this treatment resulted in a seedling population less uniform in weight and length than seedlings derivel from seeds that received a short $(2.5 \mathrm{hr})$ treatment period under these conditions. The length of the period of preplanting low temperature imbibition had no effect upon germination.

Seedlings grown from seeds that received the long, low temperature preplanting imbibition, howerer, were more uniform in their curvature responses to geo-timulation and attained greater average lengths and weights than corresponding seedlings grown from secd that received the shorter treatment period. Consirleration of population uniformities suggested that without appropriate tran-formations, statistical differences between mean lengths, weights, and curvatures could not be rigorously assessed by tests that required homogeneity of error variance.

\section{REFERENCE}

1. Shen-Miller, J. and 5 . A. (ordon. Gravitationtl compensition and phototropic response of oat eoleoptiles. I'lant Physiol. 42(3), 352-360 (1967).

\title{
A NOTE ON GROWTH RATES OF THE AVENA COLEOPTILE
}

\author{
Richard A. Mcl'herson* and solon A. Crordon
}

\section{PIRPOSF AND METHODS}

Knowledge of the growth rate of the dena colcoptile during the latter portion of its ontogeny became desirable in a study of acoustic vibration and growth. (1) Accordingly, the elongation rate of the etiolated coleoptile was determined by hourly measurement of height inerements for a 24 -hr period, beginning two days after seed imbibition.

Seeds were soaked for $2 \mathrm{hr}$ in warm tap water and then stored in the dark at $4^{\circ} \mathrm{C}$ for ca. $19 \mathrm{hr}$. They were then aligned on moist sharkskin filter paper on Tueite bars and exposed to red light for $24 \mathrm{hr}$ at $25^{\circ} \mathrm{C}$. Each seed was planted individually in a motal cup and grown in the dark at $26.7^{\circ}$ for $27 \mathrm{hr}$ in one experiment, $31 \mathrm{hr}$ in another, corresponding to 51 and 5.) hr of growth after the imbilition at low temperature. At this point, photography of the heights of the coleoptiles was initiated and continued at hourly intervals. Green light, $\lambda \max .560 \mathrm{~nm}, 1^{c}$; width $40 \mathrm{~mm}$, phototropically inactive at the exposure lerels employed, was used for photography. Growth was computed by measuring ineremental differences in height as a function of time. Parallel runs of seedlings were photographed only at the beginning and end of the 24-hr growth period, or at either 6- or 10-hr intervals.

* student Aide
The hoight increments were slightly less for the plants photographed hourly. However, the relation between growth increments and amount of photographic manipulation was not monotonic, and the rate changes in the plants photographed at 6-hr intervals were qualitatively similar to those photographed hourly.

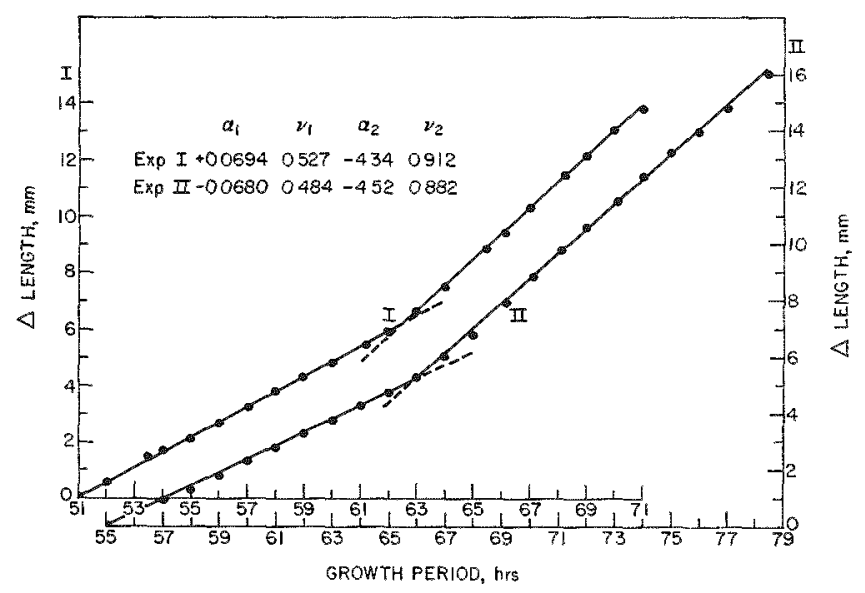

Fro. 275. - Height increments of the intact etiolated Alena coleoptile during the third day of growth. I and II are the grow th curves of separate experiments. Initial rates a intercepts are represented, respertively, by $v_{1}$ and $\alpha_{1} ; v_{2}$ and $\alpha_{2}$ are the eonstants for the later portions of the curves. 
'RURER- REPUR $\mathrm{l}^{\prime}$

The inerements of growth ineasured over the third day of colcoptile elongation are shown in Figure 27\%. Within each experiment, regrensions were computed for the two growth phanes (breaking at $11 \mathrm{hr}$ ) reparately and then for the entire time period 1.51 or $5.5 \mathrm{hr}$ to termination). In each instance, two constant rates fit the data better than a single quadratic curve at a chance probahility of les than $0 . x^{c} c$. The velocity ronstant for the firt growth phase is about $0.5 \mathrm{~mm} \cdot \mathrm{hr}^{-1}$, for the second about $0.9 \mathrm{~mm} \cdot \mathrm{hr}^{-1}$.

Ife find the eurve describing the growth rate of the intact coleoptile, of interest in two respect. First, they are qualitatively di-similar to published data on the growth rates of Avenu coleoptilen at difierent age ; ${ }^{(2)}$ the latter show an almost contant increase of growth rate from about the 1.5th to the 65th hr after soaking; the rute decrease- progren-ively after $70 \mathrm{hr}$.

Second, it is known that cell divi-ions accompany elongation of the parenchyma cells up to a coleoptilo length of about $1 \mathrm{~cm}$; thereafter, growth is entirely by cell clongation.'3) The length of the organ at this developmental change corresponds to the length of the coleoptiles at the intersection of the two growth eurves (Figure 275). It mav be suggested that the two processes, cell division and clongation. compete for a fartor limiting to organ txtension.

This factor could well be gibberellin. There in evi- dence that, in harley, the reutellum is the ite of gibberellic acid ( $\left(x_{d}\right)$ origin in the early atages of germination. (") The production of GA by the scutellum terminate near the third ray of germination; the scedling axi then taken over with tha, apparently de nove, synthesis of $G A .^{(4,5)}$ It in likely that a -imilar phenomenon oceur in the oat, and it would be of interent to determine whether the change in growth rate we oberre could be correlater with thi- transition of G.A production. Possibly aho related to these GA and growth phenomena is the ob-ervation thut at approximately transition time, amyloplast nunber and ize rise markedly in the scutellum of the oat. ${ }^{(6)}$

\section{RTFERFNQES}

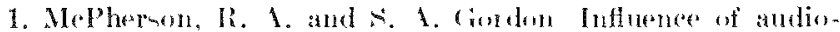
frequener soumd on the grom the of the wat heort: Further obstratum. Thim report.

2. Wont. H. and K. I. Thmmann. Phytohomones Mardillan and Co., New York, 1967, p. 5!1, Vig, 2i

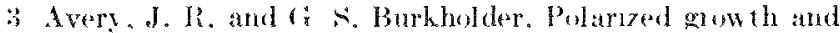
cell studies on the deena conlenptrle Bull. Tormel Bot. Club $63.115(19 t i 2)$.

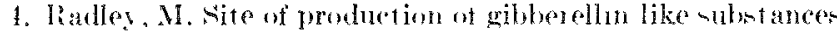
in germuating barler embryos. Planta 75, lit 171 (1967).

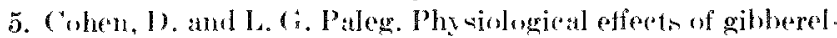
lice arid. \. The releate of gabberellin hafe nhotances by germindting baley embryos. Plant Phused 42, 124t-129ti (19tion).

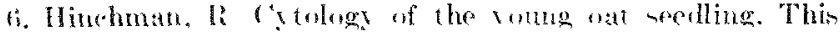
revort. 


\section{EDUCATIONAL ACTIVITIES IN COOPERATION WITH THE ARGONNE CENTER FOR EDUCATIONAL AFFAIRS}

\section{SUMMER INSTITUTE IN RADIOBIOLOGY, JUNE 16-AUGUST 1, 1969}

As a part of a national effort to further the education and training of seience teachers, Argonne National Laboratory offered a reven-week yrogram of instruction for college teacher of biology. Prospective participants were informed about the nature of the program through the distribution of a directory of -ummer programs ly the National Science Foundation and a brochure sent out by Argonne's Center for Educational Affair (CEA).

The institute was a cooperatire effort by several participating orgunizations. As in previous years the initial proposal was sponsored by the Associated Colleges of the Chicago Area (ACCA)* and the leeture and lahoratory components of the program were offered by Argonne staff memhers in sereral dirision. The 1)ivision of Biology and Medicine (BIMI) provided lecture hall facilities and the majority of lectures, whereas the CEA used their instructional laboratories for individual and group inatruction in laboratory techniques and the operation of instruments.

The program was organized and coordinated by

* Aurora, Coneordia, Elmhurst, (ieorge Williams, Judeon, late Forest, Lewis. Mundelein, North central, North Park, olivet Nazarene, Romary, St. Dominic, st. Franeis, St. Procopius, At. Xavier. Trinity Christian, and Wheaton.
Raymond II. Brandt who served an A-ociate Dirertor of the summer In-titute. Major emphasis in the serien of lectures was given to hasic aspect of radiation and the effects of radiation on hiological systems. Additional topice in molecular biology were also inchuded. The sequence of topie ranged from molectular and cellular biology to the organism, population, and econytem levels of organization.

Twenty-one college teachers took part in the program. of thene, six were from two-year collegen and fifteren from four-your colleges or universities. Participant and their respective institutions and geographic locations are indicated in the accompanying photograph.

One of the major objectives of this particular institute program is to bring biology teachers from academir environments where teaching has primary emphasi- to an institution where research is of primary importance. It in believed that through the experience of rontact with person, engaged in active seientific research the teacher will be better informed about recent development, in biology. In ardition. he mav be stimulated to initiate or continue a modest research program on his own campus and be in a better poition to guide students in limited research projects.

Professor of Biologe and (hairman of the seienee I)ivision at Wheaton college, Wheaton, lllinois. 


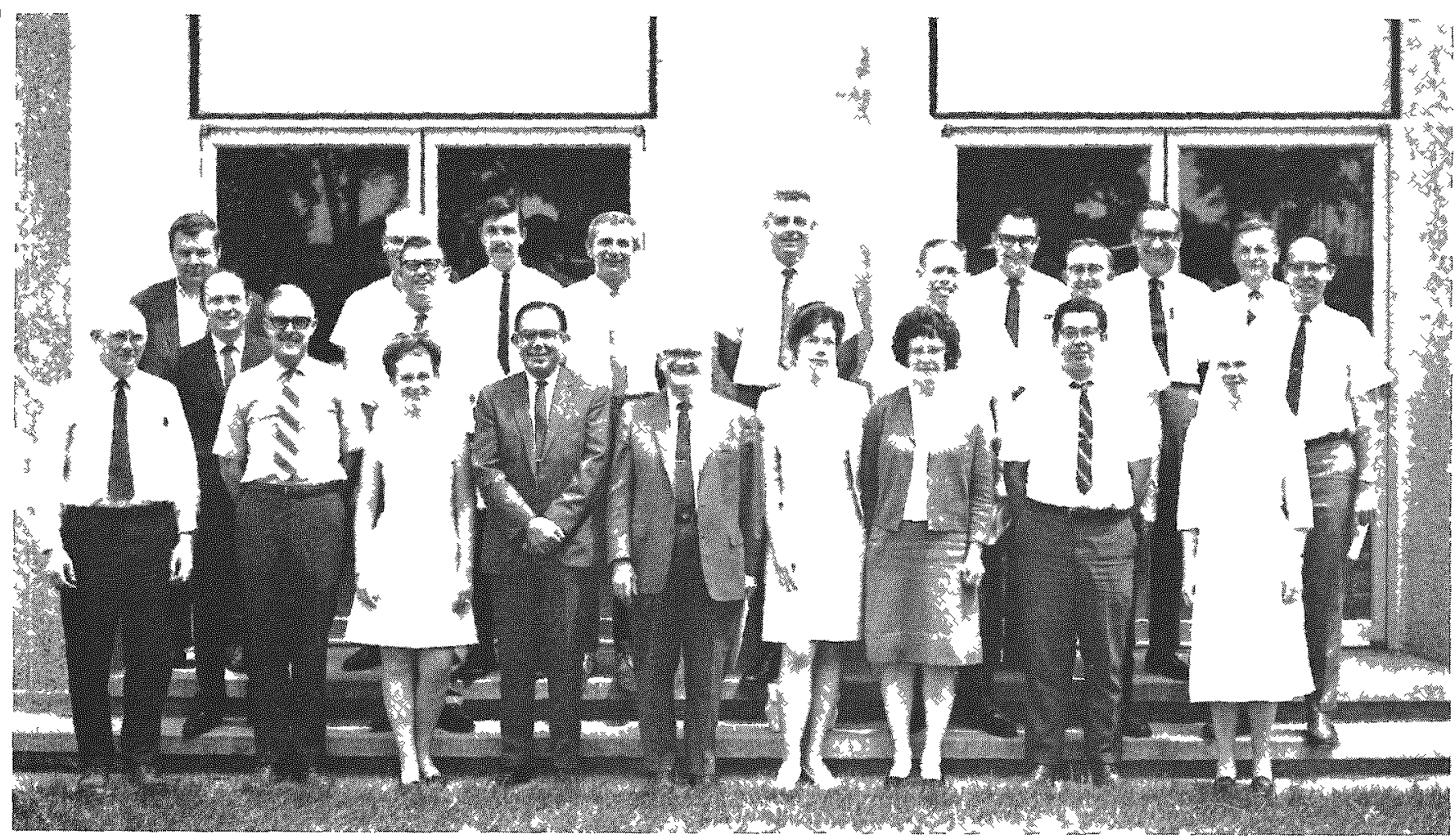

I II, 276

Irelentual

I tont hiou

Jerome $B$ und

Orts Orr

Vin I In I ochowirh

Must it i $>$ ined

lex Bitrth t

liuth IIt litiom

II us Vemme I

lio $a$ ph oteto

Be it a hnop lle 1

Halle km

lit imond bit and

voble Ruberto

He nru lorian

('hemete I thder lat

I Jom Ifendirek

Ist nit $\backslash \mathrm{i}$ irtin

Barl $R(b)$

Lowum I thh uel

(linton II uk

Willi im Wille 1 -

Arthu W ignes

Dale I arlor

(rle nu Petergohn

(x) vorre
In tituh "

Irgonne \tional I ibornom

Mresonum or (llege

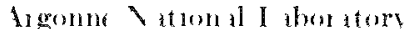

It II ix hithate-t olloge

Voith Puh (allegt

Vunkegon o ommunts c allege Hrapho ( allege

I nivesuts of Vieh tl hint

-pringfie ld o olle ge

Whe itom t alle $x$

(amphe llaville ( ollest

college of Dul' age

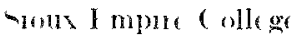

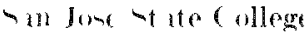

() 1010 do ( ollege

W whburn I meverats

Whe etent alle get

Wh $\rightarrow$ I I niverati

Jolut $\mathrm{Jr}$ ( ollege

Millikin I nuve rats

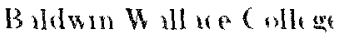

Dentand I nuverelts
Digoime II

Joplin VI

IIg Hill III

Hith Kith

( har rgo III

Munkegon Muh

Nilwe anhe Wre

I lunt Vhe h

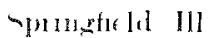

Whe aton 111

(impl)elluvill h:

viperville III

How unden low

aril Jone ( thit

I I Junt * ( a 10

lopel $\neq$ hin

Whe aton III

()hhich ith

Jollet III

Def itur Ill

Btic a Oho

(n) morlte Ohn, 


\section{SYMPOSIUM ON THE EVOLUTION OF THE IMMUNE RESPONSE- OCTOBER 20 TO 22, 1969}

Bernard $\mathrm{Y}$. Jander, Chaimem

The 4th annual ACA-ANL Biology Aymposium examined the evolution of the immune response. There - ymposia are aimed at graduate tudents in the $1 \mathrm{~L}$. member univer-itier. Nymposium topien are selected from sulject identified with promise for future grow th where new investigators can find many stimulating problems. Evolution of vertebrate inmunity wa discussed in depth at molecular, cellular, and organi-nic levels. The present aketehy knowledge of invertebrate immunity was examined in compari-on with that of vertebrates. Three hundred eighty registrant- at tended the symposium. Sixty pereent of these were graduate -tudento from $1 \mathrm{C}^{\mathrm{T}} \mathrm{I}$ member univer-ities. The remainder included staff and students from $A X L$ and staff from AUA member unirersition.

\section{THE PROGIRAM}

Honday, Uctober 20

Welcoming Address

R. B. Dufficld, Director, Argome National Laborattory

Introduction and Announcements

B. Jaroslow, Argonne National laboratory

1. REGLLATIUN UF GAMMA GHOBL LIN SYNTHESI

R. Is. Heker, Chaiman, Argonne National Lakoratory

Genetics of Antibodies

(). Smithie, The University of Wisconsin

Quantitative studies of Idiotypic Antibodies

A. Nisonoff, University of Illinoir, Medical School

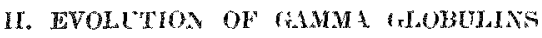

J. J. Cebra, Chatirman. The John Hopkin Tniverwity

Antibody complenentarity and Light chain st rueture

E. A. Kabat, Columbia C'niversity

The Genetic Basio for Antibody Diversity

L. Hood, National In-titute of Health

Physical and Chemical Propertien of the Immunoglobulins

A. B. Edmundon, Argome National Laboratory
Tetalay, actuber 21

11. MOLATYOA OF PHRTEBRATE HML ATY

D. Talmage, ('haiman, Lniver-ity of colorado

Phylogenetic Development of Lxmphoid System, Inmunoglobulin and Immune Rerpones

l. A. Coorl, Cniversity of Minnesotat

Erolution of Vertebrate Inmunoglobulins

B. Papermaster, Rowwell Park Memorial Institute

Evolution of the Complement system

H. (iewurz, Cniversity of Minnemota

IF. TRAMAPLANCATION IMMLATY

R. T. Smith, ('hairman, Iniversity of Florida

Evolution of Immune Responsivenem in Ectothermic Vertebrater

W. H. Hillemann, Cniveresty of California

Serological and Cellular A Apect of Immunity in sevcral Marine Invertebrates

F. B. Bang, The John Hopkin University

Correlations of Radiation Sensitivity with Immunologic Remponivenens in Phylogeny

J. Fintad, Iniversity of Minnesota

INTHRDIACIPLINART LECIYRE

J. Thomon, (hairman, Argonne National Laboratory

Biological Benefits of Technology

D. W. Bronk, The Rockefeller Tniver-ity

Wedne sday, Oetotore 22

r. NON-TER CEBRATE IUNT NTT

J. Cushing, Chairman, Iniversity of California

(ell r.. (ell in the Cockrouch

(. .J. Dawe, National Tustituten of Health

Ilumoral Immunity in Insects

I. Stephen Chadwiek. Queen'- Ciniversity

1)ienase Immunity in Plant

I. Paxton, Tiniversity of Illinois 


\section{PUBLICATIONS}

JOCRNAL ARTICLF

Barton, 1. D. and A. K. Laird. Analysis of allometric and non-allometric growth. Growth 33, 1-16)(1969).

13ell, C. 1., S. S. Danvluk, and T. P. Schaefer. Signs of spin-spin coupling constants between aldehydic and ring protons in 2,6-dinitrobenzaldehyde. Evidenee for a hyperconjugative contribution to $\mathrm{J}_{\mathrm{p}}{ }^{\mathrm{H}, \mathrm{MH}}$. ("an. J. ( $/ \mathrm{cm} .47,3.529-3.393)(1969)$.

Brennan, P'. C., T. F. Fritz, and R. J. Flynn. Role of Pasteurella pneumotropira and Mycoplasma pulmonis in murine pneumonia. I. Bacteriol. 97, 3377-349 (1969).

Brennan, P. ( . and R. X. Feinstein. Relationship of hydrogen production by Mycoplasma pulmonis to virulence for catalase-deficient mice. I. Bacteriol. 98, $1036-1040(1969)$.

Brennan, P. C., T. F. Fritz, and R. J. Flynn. Murine pneumonia. I review of the etiologic agents. lab. Animal care 19, 360-371 (1969).

Brues, A. M. Strontium motabolism book review. Health Phys. 16, 241 (1969).

Copeland, J. C. Regulation of chromosome replication in bacillus subtilis. Effect of amino acid starvation in Strain 168. . . Barteriol. 99, 7:30-736 (1969).

Copeland, J. C. and J. Marmur. Identification of conserved genetic functions in bacillus br use of temperature-sensitive mutants. Bacteriol. Ror. 32, $302-312(1969)$.

Daniels, H. W., P. A. Sustarsic, and J. F. MeClellan. Giant amoebae from colorado identified by transplantation tolerance. I. Protozool. 16, 182-184 (1969).

Daniels, E. W., J. M. MeNiff, and D. R. Tkberg. Nucleopores of giant amoebae, Pelomyxa carolinensis. Z. Zellforseh. 98, 357-366) (1969).

Danyluk, S. S., C. I. Bell, and T. P'. Schaefer. I.ongrange spin-spin coupling constants between ring protons and aldehydic protons in some parasubstituted benzaldehydes. Can. J. ('hem. 47, $4005-4010(1969)$.

Dilley, D. R., D. H. Dewey, and R. R. Dedolph. Automated svstem for determining respiratory gas exchange of plant materials. $\% .4 \mathrm{~m}$. Sor. Hort. '́ci. 94, 138-141 (1969).

Ecker, R. F. and C. Kokaisl. Synthesis of protein, ribonucleic acid, and ribosomes by individual bacterial cells in balanced growth. J. Bacteriol. 98, $1219-1226(1969)$.
Fdmundson, 1. B3., У. B. Nimonds, IV. 1. Nheber, T. Johnom, and B. Bang. Cif of carboxypeptidase 1 for simultanowus asiesoment of purity and asignment of human Bence-Jones proteins and light ehains to $\mathrm{K}$ and $\mathrm{l}$ classes. Aroh. Biochim. Biophys. 132, $.502-50 \mathrm{~s}(19099)$.

Feinstein, R. ․, J. B. Iroward, and J. T. Faulhaber. Catalase levels and radiation resistance in thres species of wild duck. Int. .J. Ratiat. Biol. 15, 341$346(1969)$.

Fichtolius, K. F. Ihadiosensitivity of the lymphocetes within the gut epithelinm. Arta Pathol. Nicrobiol. sirand. 75, 27-302(1969).

Frigerio, X. A. and M. J. Thaw. I simple method for determination of glutaraldehvile. J. Histochem. rytochem. 17, 176-1si (1969).

Frigerio, X. A. Preparation and properties of erwtalline permanganic acid. I. .1m. (hom. אor. 91, 6200-6201 (1969).

Hubbard, I. B. and H. P. Jolly. 1d $d_{\gamma_{2}}-1 f_{7_{2}}$ energy splitting at ( ${ }^{40}$. I'hys. Rov. 178, 17\$3-178x (1969).

Hubbard, I. B. and I. S. Williamson. Gamma-ray doses for all points in spheres and cylinders with uniformly distributed sources. Phys. Ihed. Biol. 14, $2.5 .5-267(1969)$.

Jaroslow, B. X., D. E. Smith, M. A. Williams, and $\$$. 1. Tyler. Survival of hibernating ground squirrels (citellus tridecemlineatus) after single and fractionated doses of cobalt-60 gamma radiation. Radiat. Res. 38 , $379: 388(1969)$.

Kispar, L. V. and W. l'. Forris. Fixation of cesium-1:37 by urinary calculi. Heath Phys. 16, 798-800 (1969).

Klein, P. D. and P. A. Szezepanik. Local solvent structure as a factor in secondary isotope fractionation phenomena of labeled amino acids on ion-ex(hange columns. /. ('hromatug. 42, 49)-502 (1969).

Krall, J. F. The ruticle and epidermal rells of Dero obtusa (family Naididae). I. Lltrastruct. Res. 25, $\times 4-93(1969)$.

Lrisch, R. I\% DNA synthesis by antibody-forming cells during the primary immune response. Vature 222 , $1295-1296(1969)$.

Kubitsehek, H. F. Growth during the bacterial cell crole. Analysis of rell size distribution. Biophys. I. 9, 792-809(1969).

Laird, A. K., A. D. Barton, and S. A. Tyler. Growth and time. An interpretation of allometry. (rowth 32 , $347-354(1969)$. 
Lindenbaum, A. and (. I. Lund. Aphat connting by liquid scintilation spectrometry. Plutonium-239 in animal tissurs. Radiat. Res. 37, 1:31 140 (1969).

Lindenbaum, $A$. and .I. II. Smoler. High-resolution autoradiography of intracellular plutonium. Scitrece $165,192194(1969)$.

Morris, D. 1). and M. F. Laop. Stimulus eontrol of prey attack in naive rat snakes. A stecies duplica tion. Psychon. Sci. 15, 141-142 (1969).

Morris, D. D. and R. X. Fainstein. Mechanism of mouse awareness of $\mathrm{X}$ radiation. Nature 222 , tiss$689(1969)$.

Ortiz-(ortiz, L. and B. N. Jaroslow. Synthesis of R N A by normal mouse splean eclls after stimulation with antigen in vitro. Nature 221, 115)3 11.5t (1969).

Peraino, C., L. ( ${ }^{\prime}$. Bunville, and 'T. X. Tahmisian. Chemical, phyical, and mompological properties of ornithine aminotransferase from rat liver. $J$. Biol. ("hem. 244, 2241-2249 (1969).

Rahman, T. F., E. A. Cemy, and ('. Peraino. Studies on rat liver ribonucleases. IV. Liver ribonucleases in developing, 2-acetylaminofluorene fed and partially hepatectomized rat. Biochim. Biophys. Asta 178, $(28-73)(1969)$.

Lahman, X. F. and F. 1. Cerny. Studies on rat liver ribonucleases. III. Further studies on heterogeneity of liver lysosomes-intracellular localization of acid ribonuclease and acid phosphatase in rats of various ages. Biochim. Biophys. deta 178, 61-67 (1969).

Romenthal, M. W., J. J. Rusell, E. S. Morotti, and A. lindenbaum. Fiffective dose of DTPA, spaced at 3-day intervals, in removal of skeletal plutonium. Health Phys. 16, s06 (1969).

Ficher, C. A. and M. Miller. Inereaned rewistanes of immature red cells of rat and doge to osmotic lysis. of. ('ell. Physiol. 73, 2.51 260)(1969).

Schaefer, T. J. and t. S. Danyluk. The sign of the long-range spin-spin coupling constant between ${ }^{19} \mathrm{~F}$ : and the aldehydic ${ }^{1} \mathrm{H}$ in $p$-fluorobenzaldehyde.

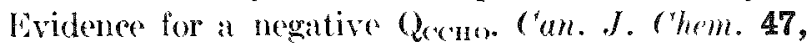
$+289+2991(1969)$.

Schaefer, T. P., S. S. Danvluk, and ( . L. Bell. Signs of proton-proton and proton-fluorine spin-spin eoupling constants in 2-fluoro-3-methylpyridine. sigma and pi contributions to coupling in a nitrogen heterocycle. ("all. J. rhom. 47, 1.50\%-1.514(1969).

Schlenk, F. and ('. R. Zydek-( wick. Stability of the glycosidic bond of S-adenosvlsulfonium compounds toward acid. Arch. Biochem. Biophys. 134, 414-122 (1969).

Schuster, I. I. and (i. Svihla. Ribonucleoproteincontaining vesicles in avsts of Saegleria gruberi. I. Protozonl. 15, 752-7.58 (1969).

Shapiro, S. K. and D. I. Hhninger. Biosynthesis of adenosymethionine from adenosylhomocysteine in 'andida utilis. Binchim. Biophys. Leta 177, (it 75 (1969).

Shen-Miller, J., P'. ('ooper, and s. A. Crordon. Photom tropism and photoinhibition of the basipolar transport of auxin in oat moleoptiles. I'lant Physiol. 44, $491-+96(1969)$.

sinchir, W. K. Protection by rysteamine against lethal $\mathrm{X}$-ray damage during the cell cycle of (hinese hamster cells. Radiat. Res. 39, 13.5 154 (1969).

Sinclair, W. K. and D. W. Ross. Modes of growth in mammalian cells. Biophys. . . 9, 10.56-1070 (1969).

Simith, I. D. and R. L. Feker. Role of the oocrte nucleus in physiological maturation in Rana pipiens. Derelop. Biol. 19, 281:309 (1969).

Stearner, S. P. and E. J. B. ('hristian. Farly vascular injury in the irradiated chick embryo. Effect of exposure time. Radiat. Rs. 38, 15; 160 (1969).

Stroud, A. N., I. M. Welter, D. A. Resh, D. A. Habeck, A. V. Crewe, and J. Wall. Scanning electron microsropy of cells. Science 164, si30-\$32 (1969).

Sihla, (: Isolation of radioactive fallout particles for microscopical examination. Microscope 17, 2.5 28 (1969).

Sivibla, G., J. I. Dainko, and F. Schlenk. Tltraviolet micrography of penptration of exogenous eytochrome c into the yeast eall. J. Bucteriol. 100, 498-,504 (1969).

Szysako, A. H., B. L. Prazak, ('. F. Fhret, W. J. Eisler, and J. J. Wille. A multi-unit sampling sytem and its use in the characterization of ultradian and infradian growth in Tetralymena. I. Protozool. 15, 7s1-7s; (1969).

'Tahmisian, 'T. N. Biological nacomolecules: Some" methods used to prepare specimens of various proteins for electron microscopy. Wicron 1, 40-45) (1969).

Taliaferro, W. I1. and L. (i. Taliaferro. Efferts of radiation on the initial and anamnestic IgM hemolysin response in rabbits. Antigen injection after $X$ raxs. I. Immund. 103, 5.59-5)(69 (1969).

Thompson, J. F., S.. L. Nance, and K. J. Beetham. Radiation effects on cold-induced growth response of interscapmlar brown fat. Radiat. Res. 38, 5. - (it (1969).

Thompson, J. F., D. A. Haberk, S. L. Nanee, and K. L. Beetham. Fltrastructural and biochemical changes in brown fat in cold-exponed rats. J. Cell. Biol. 41, $312-334(1969)$.

Victor, 'T. A., H. H. Hruska, K. Hikichi, S. S. Ianyluk, and C. I. Bell. Nuclear magnetic resonance study of the structure and interaction of actinomycin $D$. 'Temperature and solvent effects on the $\mathrm{N}-\mathrm{H}$ and $\mathrm{NH}_{2}$ groups. Nature 223, 302-303 (1969).

Vogel, H. H., A. Hasegawa, and R. I. Wang. Comparative protection by a combination treatment in 
mice irradiated with fission neutrons or X-rays. Radiat. Res. 39, 57-67 (1969).

Wassermann, F. and J. A. Yaeger. The matricen of mineralizable tissues. Int. Dental .J. 19, $308-34: 3$ (1969).

Wastermam, F., A. D. Barton, and W. E. Kisielenki. Filectron microseopic radioautographic observations suggesting absorption of lipid by the nucleus. $Z$. Zollforsch. 95, 1-S (1969).

Wille, J. J. and ('. F. Ehret. ('ireadian rhythm of pattern formation in populations of at free-swimming organism, Tetrahymena. J. Protosol. 15, 7s9-792 (1969).

Wille, J. J. and (. F. Ehret. light suchronization of an endogenous circadian rhythm of cell division in T'etrahymena. J. Protozos. 15, 78.5-7\$9 (1969).

Yatvin, M. B., I. l. Mitchen, A. L. Wiles, and H. H. Vogel. Polyribonome reduction and recovery following neutron exposure of regenerating liver. Biochem. Biophyse. Arta 169, 5i36-.039 (1969).

Zappia, V., ('. R. Zydek Cwick, and If. Schlenk. The neceificity of sidentent-L-methionine sulfonium steroisomers in some enzyme rytems. Biochim. Biophyse defa 178, 15.) 1s. (1969).

\section{Books}

Bond, V. P., J. W. (Mborne, N. I wesher, ('. ('. Lashbaugh, and $\mathrm{S}$. Horney. Mechani-m of intestinal radiation death (panel disassion). Gatroints stinal Radiation Injury, Proe. Symp., Richland, Nept. 1966, Ed. M. F. Sullivan. Excerpta Medica Foundation, Amster. dam, 1962 , pp. 3.83 373.

Fry, R. J. M., 1. B. Reikin, IV. Käiele,hi, A. Sallere, and F. Staffeldt. Radiation effects and cell renewal in rodent intestine. ('omparative Cellular and Species Radiosensitivity, Ed. V. P. Bond and T'. Siggahatra. Igaku Shoin Ltd., Tokyo, 1969, pp. 20.5-270.

Gordon, S. A. and J. Shen-Miller. Auxin relations in phototropism of the coleoptile. A re-examination. Biochemistry and Physinlogy of I'lant (imoth substanes, lidl. F. Wightman and (i. Setterfield. The Runges Press, Ltdl., ottawa, 196s, pl. 1997-110s.

Krisch, R. E. and M. R. Zelle. Biologieal effects of radioactive decay. The role of the transmutation effect. Ideranes in hodiation Biology, Fd. L. (i. Augentein, R. Manon and M. Zelle. Arudemic l'ren, New York, 1969, pp. 177-21:3.

Kubitseheh, H. I. ('ounting and vizing microorganisms with the (oulter conuter. Mothods in .Mierobiology, Ed. J. R. Norrio and D). W. Ribbonn. Academic J'res, I ondon, 1969, pp. .59:3 610.

Laird. A. K. Drnamien of growth in tumors and in normat organioms. Human Tumor rell Kinetirs. Monograph :30, Nitl. ('incer Inst., Wishington, D. (‥ 1966, pp. 1.5 2 .

Lamerton, L. F., G. W. Barmden, A. M. Bruen, (i. II. Dolphin, J. Nuller, I $\therefore$. E. Smith, and J. Vaughn. Radiowenstivity and special distribution of done. ICRP P'ubliration 11, Permagon Prom Ittd., London, 1969.

Romenthal, X. W. and A. Lindenbatum. Oeteosareomas as related to timene di-tribution of monomerice and polymerice plutonium in miese. Delayed Effects of Bene-s'teling Rodionuelides, HA. C. W. Mars at al.

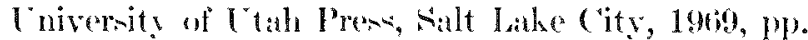
$371-3 \mathrm{sit}$.

Finclair, IV. K. X ray survival of mammalian cell in culture. Comperatio lellular and Sipecies Radiosensitirity, Fd. V. P'. Bond and 'l'. Sugahtarat. Igaku shoin I,td., Tokin, 1969, pp. 6i, -7s.

sinclair, W. K. Radiological dosimetry. hadintion Dosimetry, Ed. F. II. Attix and E. Torhilin. Academic Presin, Vew York, 1969, Vol. III, pp. tilf 67t).

Taliaferre, W. H. and L. A. Stauber. Immunology of protozoan infections. Restareh in Protosoologyle lid. TZE-T. (hen. Pergamon Pres, Oxford, 19kis, Vol. : pr. 506 . 56 is. 


\title{
STAFF OF THE BIOLOGICAL AND MEDICAL RESEARCH DIVISION
}

\author{
ADUINTSTRATION
}

Anderun, Allen II. (A-sistant Director)

Brues, Austin .I. (Acting A Arociate Direetor)

Flynn, Robert J. (Aci-tant Director, Animal Facility)
Harri-on, James W. ( lixecutive Assistant)

Thomson, John li. Adeting Iireector I

Wolfgang, Robert IF. (Editor)

\section{PERIIANENT NTLAF}

Ainsworth. W. John (Amociate Biologint)

Ain-worth, ('linton F. (sicientific Amistant)

Allen, Katherine (A-ristant Biologi-t)

Auerbach, Harry (A-ociate Statistician)

Barr, Sunan H. iscientific Awivtant)

Barton, A. Donald (Associate Biochemist)

Blomquist, Jeanne A. (Programmer)

Bremnan, Patricia C. (Assi-tant Biologist)

Brown, Mickey s. A(Acientific Assistant)

Brues, Austin MT. (Senior Biologist)

Buess, Evelyn (Scientific Am-istant)

Bunville, Lvle G. (Assistant Chemict)

Camden, Ronald W. (A-istant Veterinarian)

Cerny, Hlizabeth (Acientific Assistant)

Chladek, Dorothy (Scientific A sistant)

Chorney, William (Assistant Biologist)

Christian. Fmily J. (scientific A-sistant)

Chubb, G. Theodore (Scientific Assistant)

Cooke, Fugenia M. (S.cientific Imistant)

Coombs, Barbara A. (Solentific Asi-tant)

Copeland, Jamen C. (A-i-tant (Geneticist)

Cwick, Cynthia R. (Scientific Assintant)

Dainko. Julia $I_{\text {. }}$ (Acientific Assistant)

Daniels, Edward W. (A-ocociate Biologi-t)

Danyluk, Steven S. (Anoriate Chemint)

Decker, Louis H. (Scientific Assictant)

Dedolph. Richard R. (A wociate Plant Phr-iologist)

DeRoche, (reorgia M. Iscientifie As-istant)

Devine, Rosemarie I. (sicientific A-sistant)

Dipert, Merlin II. (As-intant Mathematician)

Dohra. William A. (Neientifie A - istant)

Doyle, Donald F. (Scientific Amictant)

Drick, Sandra A. Acientific A-nittant)

Eeker, Richurd E. (Amociate Biologint)

Edmundson. Allen B. (Awociate Biochemi-t)

Ehrot, Charles F. (Senior Biologist)

Ei-ler, William J. (Engineering Speciali-t)

Ellwanger, Paul W. (Acientific Ascistant)

Fily. Katherine A. (Necientifie A-si-tant)
Faulhaber, Joamn T. (Scientifie Am-intant) Feinatein, Robert X. (Aenior Biochemint) Flynn, Robert J. (Senior Veterinarian) Frigerio, Norman A. A-ociate Biochemint) Fritz, 'Thomas E. (A-ociate Feterinary Pathologint) Fry, R. J. Michael LAmociate Phyiologist) (Gliner, Jane K. A-Amociate Technical specialist) Gordon. Nolon A. (Nenior Plant Phymiologint) Grahn. Douglan (Axenior Biologiet) Grube. Donald D. Istientific A mistant) Hardman, Karl D). (Amistant Biochemist) Hinchman, Ray R. (sicientifie A $-i$-s ant) Itolmblad. Gordon I. (A.cientific A-istant) Hook, Aladoma E. Ascientific A-intant) Howard, Judith B. iscientific A-ui-tant) Iruebner, Leonid (s. (Acientifie A-ristant) Hulesch. Jane S. (Ncientific Awistant) Huton, Nancy K. Wrentific Is-istant) Janu-zyk, Rita M. (Noientifie Assi-tant) Jaro-low, Bernard N. 1.1-notiate Immunologist) Jordan, Donn L. (A-istant Biologist) Kampar, Lillian A. Ascientific A- A-istant) Keenan, William (i. Neientific Asi-tant) Tickel, Warne T. (Scientific A-i-tant) Kisielent, IValter E. (Anociate Chemist) Klein, Peter D. (A sociate Biochemist) Kokail, Cloria A. (Nocientific A-ivtant) Fontal, ('eorge (As-intant Technical specialist) Fret $\%$, Norbert D). (sicientific A-sistant) Krisch, Robert E. (1-nistant Biophysicist) Kubit nehek, Herbert F. (A-ociate Physicist) Lea, Ruth A. (Srientific Am-intant) Lindenbaum, Arthur (A-ociate Biochemi-t) Long. Melvin D. Iscientific Asistant) Torenz, John R. (Seientific A-wi-tant) Mackeviciun. Fan-tina V. (Ncientific Assistant) Miller. Carol I. (Neientifie A-nistant) Miller, Jane Shen (Assi<tant Botanist) Miller, Marietta (A-intant Biologint) 
Moreton, Marilyn F. (seientific Assistant) Moret ti. Flizabeth s. (Nelentifie A sintant) Morris, Dale D. (A-nistant Biologint) MeNiff, Judith M. (Nedentifie A-istant) Nance, sharron L. Seientifie A-intant Norris, William P. (A-mociate Biochemist) OMalley, Mary P. Ascientifie A-intant) Pearon, Donald I. (scientific Asuitant) Peraino, Carl (A-istant Biochemint) Polk, Patrick LI. (Scientific Awstant) Poolc, Calvin M. (Amoriate Veterinarian) Prapuolenis, Aldona M. Iscientific A-ni-tant) Ramter, Grace B'. (Scientifie A-istant) Rahman. Yueh-Hih ( 1 wintant Brologint) Rehfeld, Carl E. (A-ociate Veterinarian) Reishin, Allan B. (A-nistant Biologist) Robbin-, Nartha H. (Neientifie Aar-tent) Ro-enthal, Mareia II. (Amociate Brologirt) Rusell, John J. Aseient ifie Awi-tant) sicher, (reorge A. (A'nior Biologint) sallese, Anthony R. (Neientific A-bistant) Sampson, Martin .J. (Ncientifie A-ci-tant) Sander-on. Margaret II. (A-iutant Biologint) schiffer, Marianne 'T. (A-nistant Biochemisb) schlenk, Fritz (Aenior Biochemet) Shapiro, Stanley K. (A-ociate Bio(hemist) Sheber, Florence A. (Acientific Amistant) shotola, M. Anita (seientifie Assi-tant) Simkin- Richard (C. Iseientific An-i-tant) sinclair, Warren $\mathbf{K}$. (Senior Brophyient) Smith, L. Denni (A-nociate Biologi-t)
Smyth, Marguerite A. Nicientific Amintant Soucek. Stephanie L. (Nerentifie A-..i-tant) Staffeldt, Liverett F. (scientifie A-intant) stearner, S. Phyllin (A-Amociate Biologist) suhrbier. Katherine M. Meientifie Anistant) sutton, llarold (i. (A-intant Biologint) svihla, George A Amociate Biologri-t) swick, Robert W. Adsoriate Biorhemist) Szozepanik, Pat ricia A. (Scientilic A-istant) Tahmi-ian, Theodore $\mathrm{X}$. (senior Biologint) Taliaferro, II Ilistm I1. Asenior Biologi-t Emeritur) Thom-on, John F。 (Ácnor Biologit) Tollak-en, sandra L. Fecientific A-si-tant)

Tolle, David V. (Acientifie A-istant)

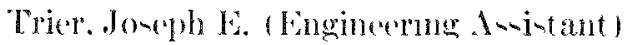
Trureo, Ernesto (A- Aroriate Mathematerian) Tyler, Fylvanu A. (A-rociate Mathematician) Van Bonkirk, John L. IScientifie A--intant)

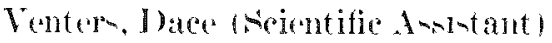
Wa-remann, Friedrieh (senior Biologirt Lmeritus) IV ebl, Robert B. 1.1 -o(diate Bacteriologi-t) Wheber. Charlotte L. (Aceientifie Amistant)

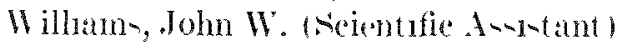
William-, Marilyn A. (Scientifie A-istant) Willamon, Erank s. A Awociate Phy-ient) Wolfeans, Robert W. (Asmociate Biologist) II right, Betty J. (Aecientifie A-nistant) Yu, Chi-Kang (Aristant Cytologint) Zardylak, Arlene H. Afecentific A-sintant Kelle. Max li. (senior (teneticist) Zeman, Ruth ('. secientific A-siotant)
Bacehetti, silvia (Vi-iting sicientist) Barnett, Audrey J. (Viniting Scientret) Bell, Charles I. (Resident Asociate) Berneruber. (Ot to WI. (Pottloctoral Appointee) Bernhard, William A. (Postdoctoral Appointee) (hapman, George E. ( Po-tdoctoral Appointec) Coley, Ronald F. (Pontdoctoral Appointec) Davies, David B. (Poutdortoral Appointee) Egan, Nancy Li. (Reident Aroriate) Erickwon. Robert J. (Postiloctoral Appointee) Freedman, Michatel I. (Pontloctoral Appointee) Gatman, Merrill I. (Rencarch A-nociate)
TEMIPORARY STAFF

Iran, Antun (Visiting heienti-t)

Hakichi, Kunio (Viviting scientivt)

Killich, Kathleen A. (Pontroctoral Appointee)

Me.Ardle. Fugene WV. (Remeareh Amociate)

MeDowell, Richard F. (Rewident A-nociate)

Power, Demi- A. (Re-illent Asociate)

Rom, Demi- W. (Resident student Isociate)

Taliaterro, Luey C. (Remident A-ociate)

Victor, Thomas A. (Renearch Amociate)

Wood, Mical K. (Posteloctoral Appointee)

lang, Tracy C. (Pont doct oral Appointee) 
-

- 


\section{Author Index}

Ainsworth, Clinton $\mathrm{F}^{\prime}, 275,277,283$

Ain-worth, E. John 91

Allen. Katherinf H. 154

Almodovar. Luis A. 312

Auerbach. Harry 115. 119

Barehetti, silvia 128, 238, 240

Barr, Sunin 303

Barton. Ambrose D. 298

Bell, Charles L.255

Bernhard. William A. 253, 254

Brennan, Patriciat C. 55, 58,64.65. 99, 133

Brothwell, Peter J. 69

Brown, Mickey S. 259, 265

Brues, Auxt in M. 115, 119

Buchal. Robert N. 70

Bues. Fielyn M. 313

Bunville. Ixyle Ci. 209

(amden, Ronald W. 55, 57.58.5\%,61.62

Cerny, Elizabeth 1.219, 220

Cheng, Frank Y. 146

Chladek, Dorothy I. 96

Choruey, William 88, 311

Chrivtian. Fmily J. B. 30,39

Colr. William 126

Coley, Ronald F. 150

Coombs, Barbara A. 175

Copelund. James C. 176,180

Dainko. Julia 1. 200, 212

Dammin, Gustave J. 110

Daniels, Edward W. 192, 195

I)anyluk, Strven S. 248, 251, 253, 251.255

Daxies, Darid B. 248, 254

Daries, Darid J. (4. 272

Derker. Louis H. 311, 329

Dedolph, Richard R. 88, 311, 312.324

DeRorhe. Georgit M. 115. 119

Devine. Rosemarie I. 110.292

Dipert, Merlin H. 86. 88, 216

Dovle. Donald F. 96

Edgington, Darid N. 312

Edmundson. Allon B. 275.278.279.281. 283.285

Fislor. William J. 128, 214, 216, 261, 273

Ely, Kathryn R. 275. 279, 281

Fipstein. Deborah A.27\%

Erichron. Robert J. 180

Faulh:1 ber, Joam 'T. 17, 18, 20. 158

Foinstein, Rohert X. 16, 1\%, 18, 20.5\%, 158, 160

Finney. Ann 174

Flynn, Robert J.55, 57, 58, 59, 62,64

Freedman. Mirhatel L. 162.171

Freund. Robert W. 278

Frig 4 rio. Norman A. 50. 135, 138, 139. 111. 146. 148, 150.288

Fritz, Thomas F. 55. 58, 64. 102, 104. 107, 108. 110

Try. R. J. Michael 1. 10.11. 14, 69. 131. 133. 154. 308

Gasmm. Merrill 309

Glon. Xorman 139
Gordon, Solon 1.303,306, 309, 312, 31\%, 327.330

(Grahn, Douglas 1. 151. 156

(irube. Donald 1). 115.110

Hitn, Ant un 242,244

Hardman. Karl D. 275, 277, 281, 283

IIrster. William J. 110

Hikirhi, Kunio 251. 254

Hinchman, Ray 320,323

Holmes. Bert E. 278

Holtzman. Richard 312

Ilook. Madonna E. 275, 281

How ard. Judith B. 18, 20, 158

Hruska, Frank E. 255

Hulwalh. Jane 154.156

Jaruslow. Bernard N. 9, 17, 39, 12,334

Kichels, Wayne T.175

Kisinleski, Walter E. 11, 14, 152, 298

Klein, Petor D. 212, 214, 216,217

Kostal, Gorge 311

Kremer. Philip 306

Kretz. Norhert D. 102.108

Rriwch, Robert E. 171, 174. 175

Kubitohek, Herbert F. 162, 163, 165. 167. 168, 170, 174

I. Rit. Ruth A. 156

Le Buis, Donald A. 273

lindenbetum, Arthur 186, 191

Lonewell. Arlene C. 195

Lorenz, John R. 269, 273

Lurien, Henry, Jr. 312

Mutekericius, Fatustina 298

Maclaren, M. Donald 69

Marchi, Mark $I_{i}, 146$

Mucaffere, Thomas T. 288

M. Viff, Judith M. 192, 195

MrPherson, Richard A. 327, 380

Miller. Marietta 9

Moretti. Elizabeth s. 186

Morris. I ale D. 16

Sinner, sharron I. 209

Norrix, William P. 93, 44, 95, 102, 101. 108, 110

OHary, William M. 21\%

()rtiz-1)rtiz, librudo 42

Peraroson. Donitd T. 96

Peraino. ("arl 128, 129, 131, 133, 160, 205, 219, 220

Phillyp. Datrid L. 70

Polk. Patrick H. 96

Poole, (ats in M1.55.57.59,62.64. 91.95

Pontr. I Jennis $28 \%$

Rahman, Yueh-Frh 219. 220. 224. 225. 226

Rakonnik, Edward, Jr. 329

Relifeld. Corl H.96. 110

Reishin. Allan P. 11. 59. 121

Rhoud Harolds. 146

Roblins, Martha 39,12 
Rownthal. Alareia W. 186

Row Dennis W. 229

Rusuell, John J. 186

Rust, John H. 1

Sitro. Pitul 217

Sacher, Geopere $1,1,47,49,67,69$

Sillese. Anthony R. 11, 121

Simuson, Martin J.50.139, 111

Sinderson, Margaret H. 22

Nehiffer, Mitritune' 275, 279, 281.283,285

silhenk, Fritz 200, 201, 203, 212

Seiler, Jounn 1. 148, 288

Wheter, Florene' 1.278

when-Miller. Jano $309,317,320$

Sherwin. Louike C. 148

Simkin Richard ( . .58, 6.).99

Finclair, Warren K. 229, 232. 233. 234, 236, 238, 210, 242, 244, 245, 248

Sli, Dax le d.278

simith. Quenton T. 191

smyth, Marsuerit" ^1.186

Staffeldt, Exereft 14.52.131

stalling, susan A. 39,42

stearner. s. Phyllis 22, 30, 35, 39

sulrbier. Katherine 126

sutton. Farold 126

sinhlit, (feorge 210, 212

Swiek, Rohert W, 133, 205, 206, 209

Saczepanik, Patricia A, 211, 217

Tahminizn, Throdore N. 110,292

Taliaferen, luer (arture 44
Taliafurro, William H.44

Tay lor. Jamew 1. 101

Ter Haar, Gary 312

Thommes, Michael M. 312

Thom 0 . John F.209

Tollaksen, Siandra I. 209

Tolle. Dar id V. 58, 64. 102, 110

Trueco. Ernesto 69, 70, 72,75, 80

Tylex, Ny lyanum 1. 86, 102,272

Van Boshirk. John F. 59.61

Van Deenen, Isturent I. M. 224

Yenkofeswaran, subramanian 306

Vorhagen. Jan 221

Victor, Thoman 1.25

Wit-ofrmann. Friedrich 298

Webb. Rohert B. 259, 261. 265, 269, 272

Weber, Charlot te I. 10.11

Wiel, Dirk T, M. v.d. 221

Willizms, John W. 102, 108

Williamon. Frank $\$ .89$

Wood, Miral K. 275. 279, 281,283

Woodle, Ditn E. 200

Wright. Betty Jean 110, 292

Yang. Traey Chui-Han 17, 19,50,52

Yu, C. K. $242,245,247$

Zatpria. Vintenzo 20:

Zalle, Max R. 10t

Kernin, Ruth C. 102, 107, 108, 110

Kucdoli-Cw ick, Crnthia R. 200. 201 